Universidad deValladolid

PROGRAMA DE DOCTORADO EN EUROPA Y EL MUNDO

ATLÁNTICO: PODER, CULTURA Y SOCIEDAD

TESIS DOCTORAL:

\title{
LA ALIMENTACIÓN Y CUIDADOS DE LOS LACTANTES EN EL HOSPICIO PROVINCIAL DE VALLADOLID ENTRE 1900 y 1930
}

Presentada por MaÁNGELES BARBA PÉREZ para optar al grado de

Doctora por la Universidad de Valladolid

Dirigida por:

MAGDALENA SANTO TOMÁS PÉREZ

$M^{a}$ CONCEPCIÓN MARCOS DEL OLMO

2017

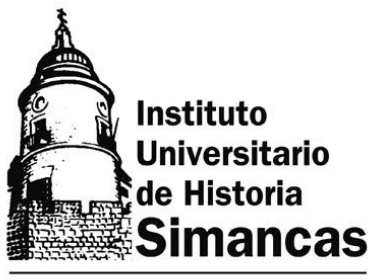

Universidad de Valladolid 



\section{"Solo quisiera saber para apurar mis desvetos (dejando a una parte, cielos, el delito de nacer), qué más os pude ofender \\ para castigarme más ¿No nacieron los demás Pues si los demás nacieron, ¿qué privitegios tuvieron \\ Que yo nogocéjamás \\ Pedro Calderón de la Barca La vida es sueño}

"No hay causa que merezca más alta prioridad que la protección y el desarrollo del niño, de quien dependen la supervivencia, la estabitidad y el progreso de todas las naciones y, de hecho, de la civitización humana".

Plan de Acción de la Cumbre Mundial a favor de la Infancia 30 de septiembre de 1990. 



\section{AGRADECIMIENTOS}

Gracias a todas las personas que de alguna manera me han ayudado a llegar al final. Este trabajo, que ha supuesto un importante esfuerzo personal, jamás se hubiera logrado sin ellas, sin su afecto, sin sus ánimos o sin su ayuda.

Gracias a Miguel, a Fernando y a Pablo por su enorme apoyo y por hacerme la vida más fácil; a toda mi familia y en especial a mis padres, que lo han dado todo por sus hijos. Gracias por vuestro cariño incondicional y perdón a todos por el tiempo que os he robado.

Gracias a mis directoras, a Malen que siempre ha sido una amiga y un estímulo muy importante, que me ha ayudado a seguir cuando he estado a punto de tirar la toalla, y a Conchita que me acogió con los brazos abiertos sin conocerme. A las dos gracias por sus inestimables consejos, por su tolerancia conmigo y por estar ahí hasta el último momento.

A mis compañeros y amigos; a Lucía y Mariví siempre dispuestas a ayudarme y a animarme; a todos gracias por vuestros ánimos y vuestra paciencia.

Al personal del Archivo provincial de la Diputación de Valladolid que tan amablemente se han portado siempre conmigo, desde el principio, facilitándome en todo lo que han podido el trabajo; a Ángel, Guadalupe, Vicente, Pilar y a todos en general.

Que nadie se moleste si no le menciono, no sigo por no correr el riesgo de olvidar a alguien. De corazón, gracias a los que se alegran conmigo 

ÍNDICE GENERAL

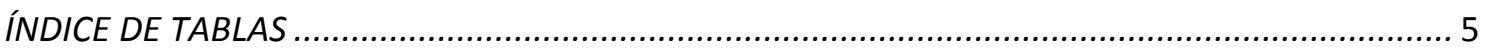

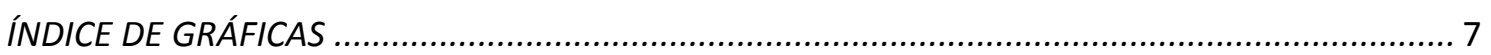

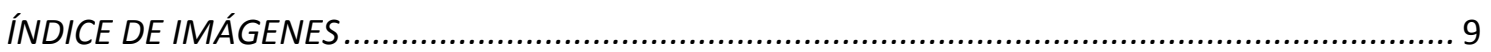

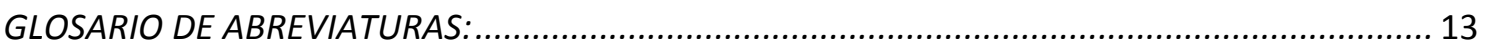

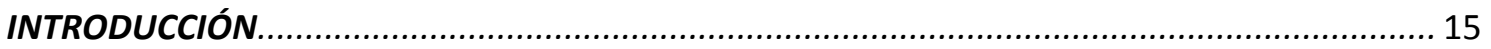

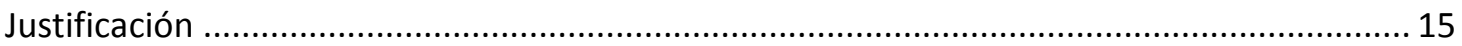

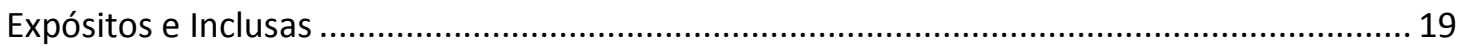

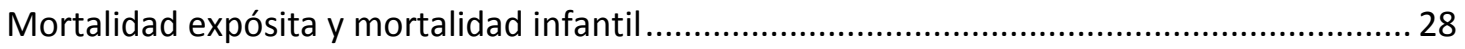

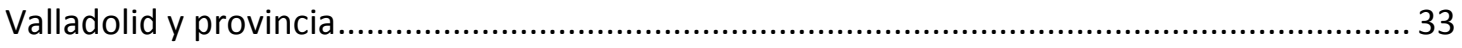

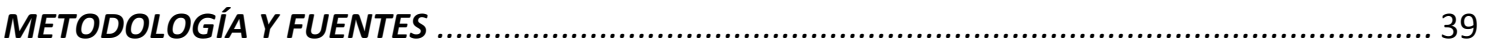

OBJETIVOS

Capítulo 1: FUENTES DOCUMENTALES: FONDOS DEL ARCHIVO DE LA DIPUTACIÓN

PROVINCIAL DE VALLADOLID SOBRE LA ACOGIDA DE MENORES...................................... 49

1.1. Correspondencia de acogida de menores............................................................. 54

1.2. Prohijamientos y adopciones de menores ........................................................ 57

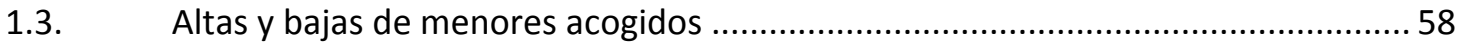

1.4. Libros de registro de entradas de menores acogidos. ............................................ 59

1.5. Libros de registro de salida de menores acogidos ............................................... 80

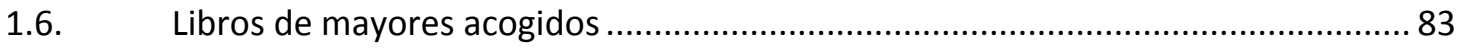

1.7. Registros de Maternidad de los centros de acogida de menores........................... 88

1.8. Libros de registro de amas de cría ......................................................................... 91

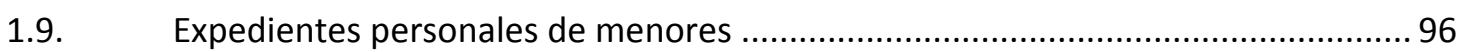

1.10. Registros de existencias de los centros de acogida de menores .......................... 103

1.11. Comunicaciones e informes de acogida de menores............................................ 114

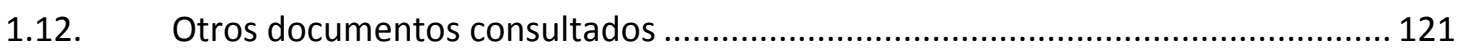




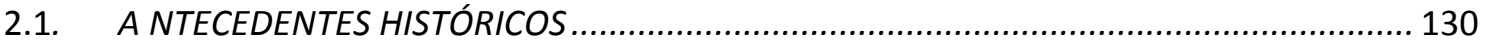

2.1.1. El Hospicio de Pobres y la Real Casa de Misericordia de Valladolid ..................... 130

2.1.2. La Casa de Expósitos de Valladolid..................................................................... 134

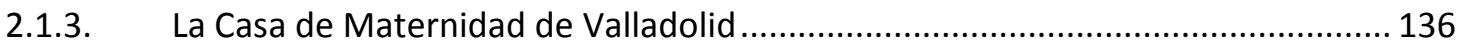

2.1.4. Fundación del Hospicio Provincial de Valladolid................................................. 137

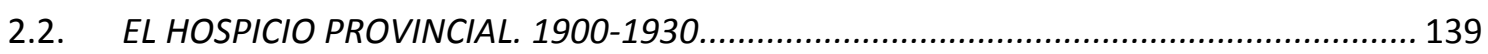

2.2.1. Financiación del Hospicio Provincial ................................................................... 140

2.2.2. La Casa de los Benavente, el edificio y sus instalaciones...................................... 148

2.2.3. Personal y gobierno del Hospicio ......................................................................... 163

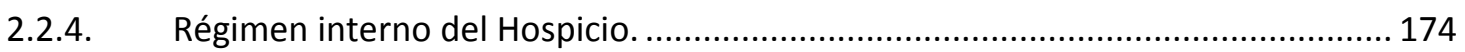

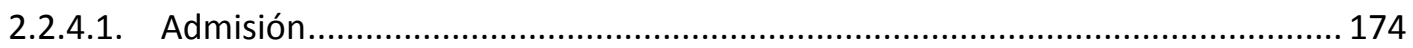

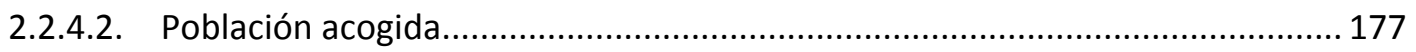

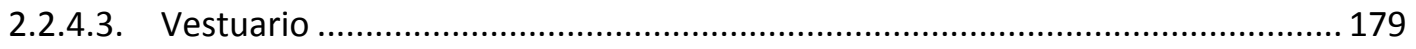

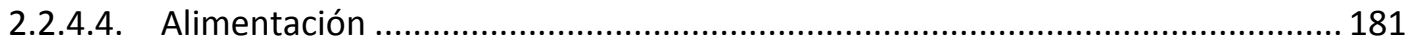

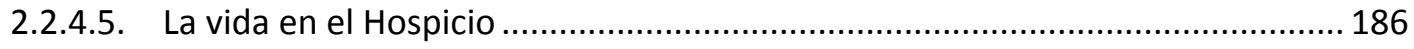

2.2.4.6. Salida del Hospicio y baja definitiva .................................................................. 190

Capítulo 3: LA INCLUSA DEL HOSPICIO PROVINCIAL DE VALLADOLID ................................ 195

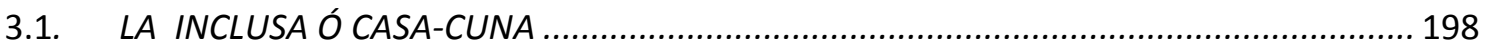

3.2. POBLACIÓN DE LA INCLUSA. MOVIMIENTO DE LACTANTES Y NIÑOS DE DESTETE..... 203

3.2.1. Ingresos anuales en la Inclusa............................................................. 207

3.2.2. Salidas y bajas de la Inclusa.................................................................. 220

3.2.3. Número de acogidos en la Cuna ................................................................ 222

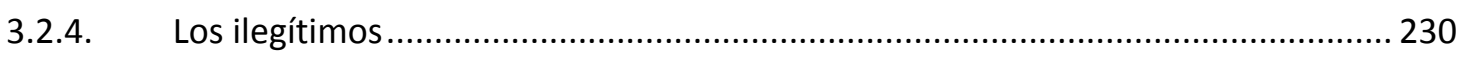

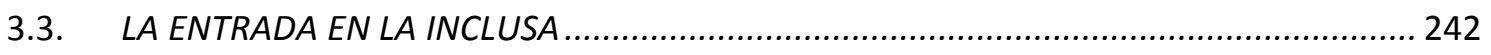

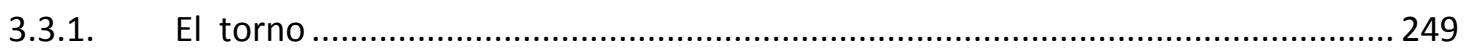

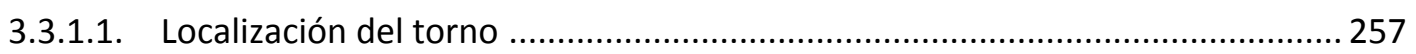

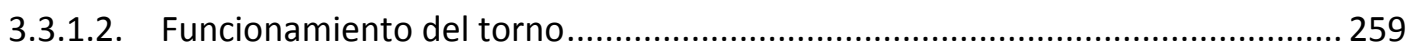

3.3.1.3. Los expósitos, señas de identidad .................................................... 274 


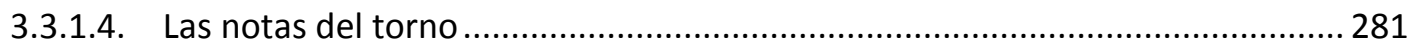

3.3.1.5. Marcas, recuerdos y señales de identificación ................................................. 296

3.3.2. Vía oficial de ingreso en la Inclusa. Comisión Provincial de la Diputación y

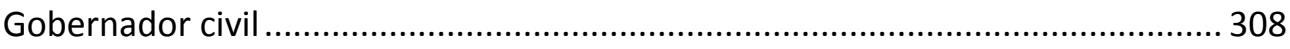

3.3.3. Los expósitos de los pueblos de la provincia ...................................................... 321

3.3.3.1. Lugar de origen de los niños de la Inclusa de Valladolid.................................... 331

3.3.4. La Maternidad del Hospicio Provincial de Valladolid ............................................... 337

3.3.5. Los niños nacidos en el Hospital Provincial de la Resurrección ............................. 362

3.4. CONDICIONES DE VIDA Y CUIDADOS DE LOS NIÑOS DE LA INCLUSA ........................... 367

3.4.1. Identidad e identificación de los incluseros ....................................................... 374

3.4.1.1. El nombre de pila de los expósitos................................................................... 380

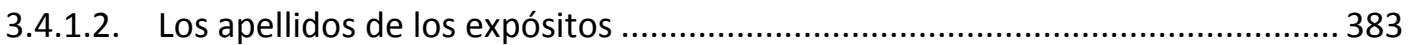

3.4.1.3. Identificación y registro para el control de los incluseros.................................... 392

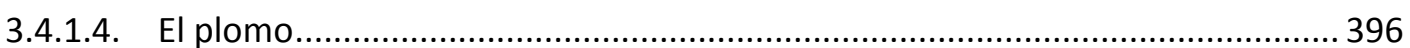

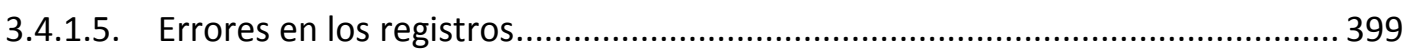

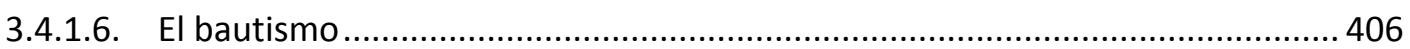

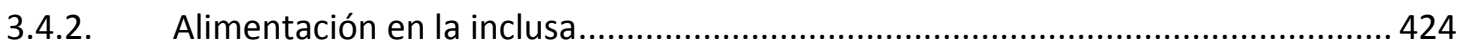

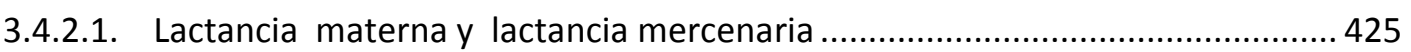

3.4.2.2. Las nodrizas internas, un grave problema para la Inclusa ................................ 433

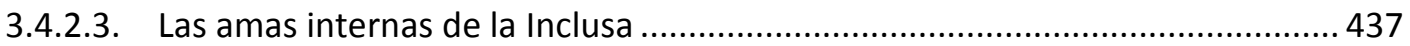

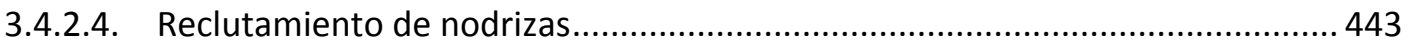

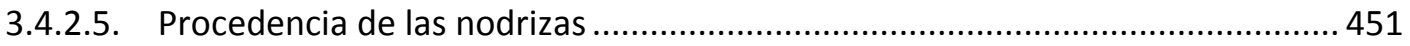

3.4.2.6. Patrón de comportamiento de las refugiadas ................................................. 453

3.4.2.7. Productividad de las nodrizas internas ........................................................... 456

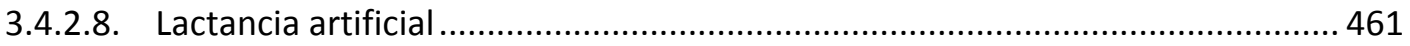

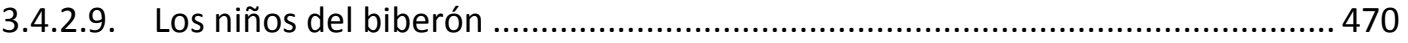

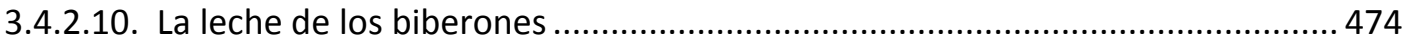

3.4.2.11. La alimentación complementaria y el destete .................................................. 477

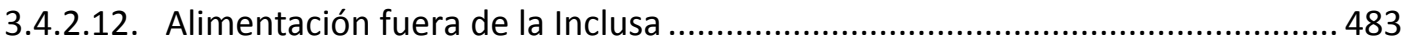

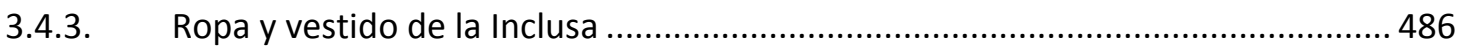

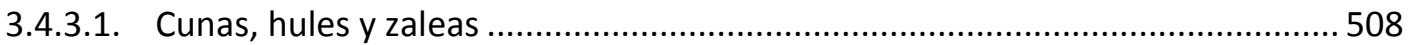

3.4.4. Higiene y salud de los niños de la Inclusa ............................................................ 510

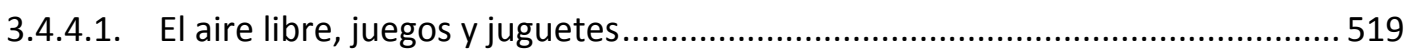

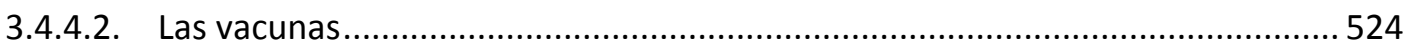

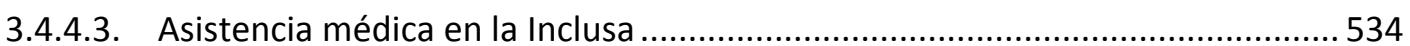




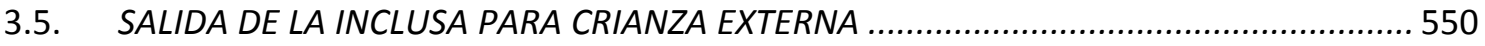

3.5.1. Los niños de la Inclusa reclamados por su familia ............................................... 555

3.5.2. El prohijamiento administrativo de los niños de la Inclusa.................................... 561

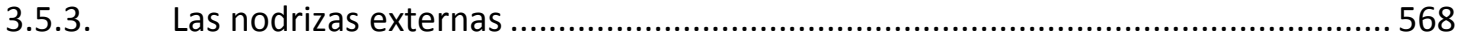

3.5.3.1. Requisitos exigidos a las nodrizas externas ...................................................... 573

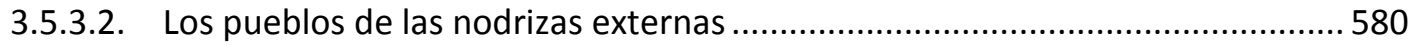

3.5.3.3. Devolución e intercambio de expósitos .......................................................... 583

3.5.3.4. Salarios, cartillas de cobranza y comisionados ................................................. 590

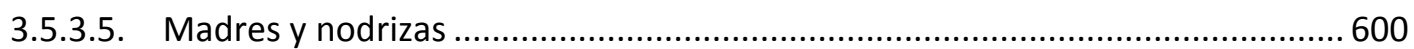

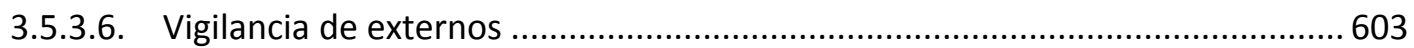

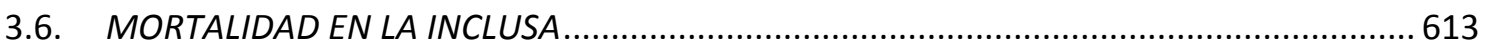

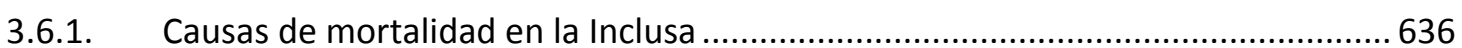

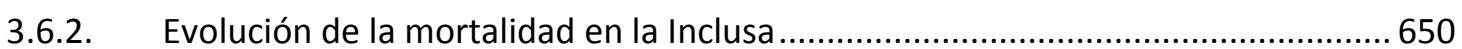

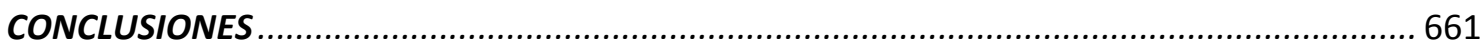

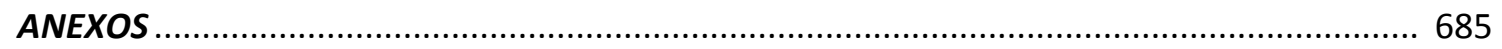

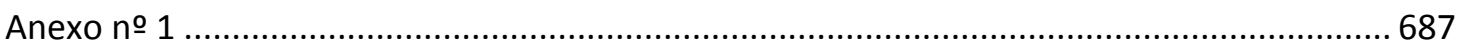

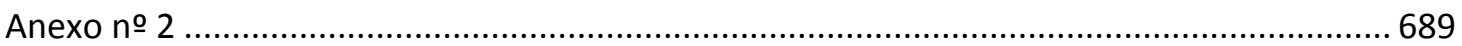

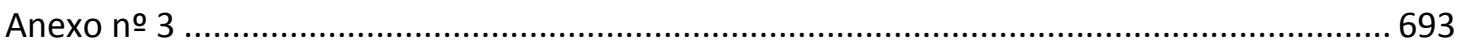

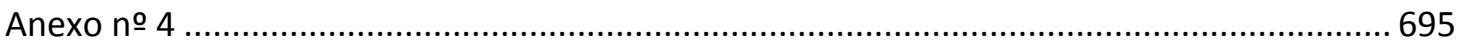

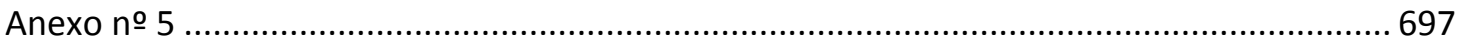

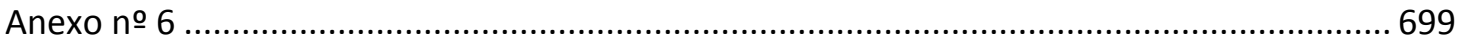

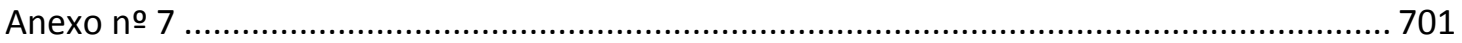

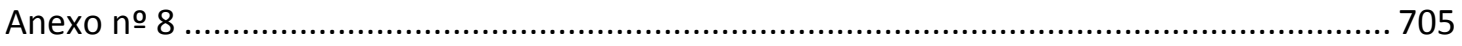

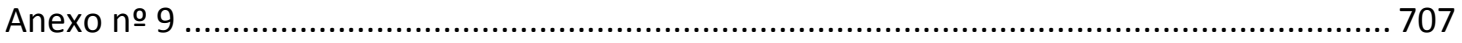

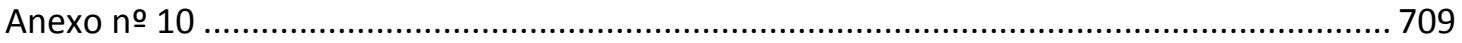

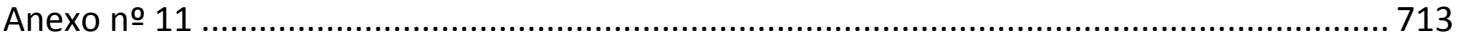

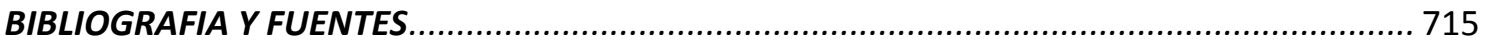




\section{ÍNDICE DE TABLAS}

\section{El Hospicio Provincial de Valladolid}

TABLA 2-1: Presupuestos medios de la Diputación y promedio de los Gastos de Beneficencia y del Hospicio por décadas

TABLA 2-2: Presupuestos de gastos del Hospicio Provincial de Valladolid 1901- 1930

TABLA 2-3: Salarios percibidos por los empleados del Hospicio Provincial de Valladolid en el período 1903- 1906, en 1925 y 1928

TABLA 2-4: Niños ingresados anualmente en el Hospicio Provincial por departamentos

TABLA 2-5: Promedio mensual de población interna y externa en el Hospicio Provincial de Valladolid. Quinquenio 1917- 24

TABLA 2-6: Producción diaria de leche en la vaquería del Hospicio Provincial de Valladolid

TABLA 2-7: Reproducción literal del listado que se encuentra en la Memoria de 1908 sobre la ocupación de las niñas mayores de 17 años

\section{La Inclusa del Hospicio Provincial de Valladotid}

TABLA 3-1: Edad de ingreso de los niños, años 1906, 1909 y 1912

TABLA 3-2: Ingresos anuales por grupos de edad en la Cuna provincial y porcentaje sobre los nacimientos de la provincia de Valladolid

TABLA 3-3: Porcentaje de niños que salen para crianza externa y mortalidad entre los niños que no salen de la Inclusa

TABLA 3-4: Total de niños menores de 5 años a cargo de la Inclusa: internos + externos

TABLA 3-5: Movimiento de niños < de 5 años del 1 de enero al 31 de diciembre de 1905 en el Hospicio Provincial de Valladolid

TABLA 3-6: Movimiento de niños < de 5 años del 1 de enero 1908 al 31 de diciembre de 1908 en el Hospicio Provincial de Valladolid.

TABLA 3-7: Niños menores de 5 años asistidos por el Hospicio Provincial de Valladolid

TABLA 3-8: Movimiento de expósitos en la Cuna de Valladolid entre 1915 y 1930

TABLA 3-9: Legitimidad de los niños del Hospicio Provincial de Valladolid. Años 1905, 1908 Y 1912

TABLA 3-10: Nacimientos en la provincia de Valladolid en 1905 y 1908

TABLA 3-11: Clasificación de los nacidos vivos y muertos según su legitimidad. Fuente: Movimiento Natural de la Población de España. Año de 1905

TABLA 3-12: Relación entre el promedio de los nacidos en el sexenio 1900-05 y los totales de mujeres a fines de 1902. Fuente: Movimiento Natural de la Población de España. 1905

TABLA 3-13: Porcentaje de ilegítimos sobre el total de nacimientos (vivos y muertos). Comparativa entre Valladolid y otras provincias del territorio nacional. Año 190

TABLA 3-14: Población y natalidad estimada y porcentaje de ilegítimos entre diferentes provincias del territorio nacional. Año 1905

TABLA 3-15: Porcentaje de ilegítimos sobre el total de nacimientos (vivos y muertos). Comparativa entre Valladolid y otras provincias del territorio nacional. Año 1908 
TABLA 3-16: Distribución mensual y por franjas horarias de las exposiciones en el torno de Valladolid

TABLA 3-17: Origen de los niños echados en el torno según refieren las notas o los documentos dejados con ellos en la Inclusa de Valladolid en el período 1900- 1913

TABLA 3-18: Relación de las mujeres que podrían haber reingresado en la Maternidad con las fechas de nacimiento de los niños registrados en los Libros de Exposiciones y su no de folio ...... 338

TABLA 3-19: Mujeres ingresadas en la Maternidad del Hospicio. 1907- $1913 \quad$........................ 356

TABLA 3-20: № de niños bautizados cada día en algunos meses seleccionados .......................... 418

TABLA 3-21: Salario de las nodrizas internas de la Inclusa de Valladolid (en pts/mes). Número de nodrizas internas contratadas anualmente por la inclusa de Valladolid 442

TABLA 3-22: Número de niños por nodriza en las inclusas españolas en 1918 458

TABLA 3-23: Tiempo de lactancia de los niños de la nodriza Sofía Guerrero en la Inclusa 459

TABLA 3-24: Niños de estancias entre 5 y 36 días sin ama. Año 1905

TABLA 3-25: Estancias cortas en la Inclusa ( $\leq 1$ mes) antes de la primera salida en los años 1901-05-06-08-09-12-13

TABLA 3-26: № de niños que volvieron con sus padres en cada año, legítimos e ilegítimos y dudosos. Distribución según vía de entrada en la Inclusa

TABLA 3-27: Nodrizas internas y externas contratadas anualmente por la Inclusa

TABLA 3-28: № de nodrizas externas que tuvieron los niños de la Inclusa de Valladolid en el período 1900- 13 y $n$ o de niños que fallecieron con ellas según el $n$ ㅇ de orden de las criadoras

TABLA 3-29: Salario de las nodrizas internas y externas de la Inclusa de Valladolid en pts./mes

TABLA 3-30: Defunciones por grupos de edad y año de los expósitos de la Inclusa provincial de Valladolid

TABLA 3-31: Tasas de mortalidad infantil de la Inclusa provincial y de la población general 623

TABLA 3-32: Mortalidad infantil de las inclusas provinciales de Valladolid y Navarra y de sus capitales (en \%o) y tasas en el grupo de edad de $0-7$ años

TABLA 3-33: Fallecidos sin salir de la Cuna

TABLA 3-34: Principales causas de mortalidad por orden de incidencia y por grupos de edad, según la nomenclatura utilizada para la época por el Instituto Geográfico y Estadístico ...... 637

TABLA 3-35: Ingresos y defunciones en la Cuna en el quinquenio 1914- 1918

TABLA 3-36: "Resumen comparativo en el último quinquenio. Promedio Mensual". Fuente: Presupuesto General de Ingresos y Gastos de la Diputación Provincial de Valladolid para el año económico de 1922- 23. Memoria. 651

TABLA 3-37: Mortalidad de los expósitos de la Cuna Provincial 651 


\section{INNDICE DE GRÁFICAS}

\section{La Inchusa del Hospicio Provincial de Valladotid}

GRÁFICA 3-1: Ingresos en la Casa -Cuna del Hospicio Provincial de Valladolid por años en el período 1900-13, menores de 5 años. Ingresos Efectivos e Ingresos Totales

GRÁFICA 3-2: Distribución por edad al ingreso de los niños y año. Valores absolutos y comparativa porcentual de la edad al ingreso

GRÁFICA 3-3: Ingresos anuales efectivos en la Cuna, distribución por grupos de edad

GRÁFICA 3-4: Niños que ingresaron en su primer mes de vida en la Cuna. Años 1905. 1906, 1909 y 1912. Distribución porcentual por grupos de edad

GRÁFICA 3-5: Distribución por sexo y año de los ingresos de la Cuna. 1900- 1913

GRÁFICA 3-6: Comparativa por años entre el porcentaje de varones y de mujeres que nacían en la provincia de Valladolid y los que ingresaban en la Inclusa.

GRÁFICA 3-7: Ingresos por meses en la Cuna para el periodo 1900- 1913

GRÁFICA 3-8: Destino de los niños que ingresaron en la Cuna. 1900- 1913

GRÁFICA 3-9: Distribución de los niños ingresados en la Casa Cuna según la vía de entrada 249

GRÁFICA 3-10: Utilización horaria del torno. Distribución de las exposiciones 269

GRÁFICA 3-11: Uso del torno por estaciones y horas. Distribución de las exposiciones 270

GRÁFICA 3-12: Entradas por el torno en los diferentes meses del año en el periodo 1900-1913. Promedios mensuales y porcentajes sobre el total

GRÁFICA 3-13: Exposiciones en el torno /total ingresos. 1900-13

GRÁFICA 3-14: Edad al ingreso de los expósitos del torno. 1900-1913 276

GRÁFICA 3-15: Edad de ingreso de los niños expuestos en el torno de la Inclusa provincial, años 1901, 1905, 1906, 1908, 1909 y 1912

GRÁFICA 3-16: Distribución según legitimidad y sexo de los niños del torno 1900- 1913

GRÁFICA 3-17: Ingresos a través de la Diputación Provincial. Distribución en valores absolutos y en tantos por ciento 1900-13

GRÁFICA 3-18: Comparativa entre el número de niños ingresados a través de la Diputación Provincial de Valladolid en el período 1900-1913 y los expósitos provinciales

GRÁFICA 3-19: Distribución por edad y por sexo de los ingresados a través de la Diputación 319

GRÁFICA 3-20: Distribución según legitimidad y sexo de los ingresados a través de la Diputación. 1900- 1913

GRÁFICA 3-21: Origen de los niños que ingresaron por la vía oficial. 1900- 1913 320

GRÁFICA 3-22: Expósitos de los tornos y pueblos de la provincia. 1900- 1913

GRÁFICA 3-23: Origen de los niños de la provincia de Valladolid que ingresaron a través de la Diputación en el período 1900-1913, excluyendo la capital

GRÁFICA 3-24: Origen conocido de los niños que ingresaron en la Inclusa provincial en el período 1900-1913, excluyendo los nacidos en la Maternidad y en el Hospital Provincial

GRÁFICA 3-25: Sexo de los niños nacidos en la Maternidad, vivos y muertos. 1900- 1913

GRÁFICA 3-26: Edad de salida para crianza de los niños de la Maternidad. 1900-1913 359

GRÁFICA 3-27: Edad de salida de la Inclusa de los niños de la Maternidad. Comparativa entre el período $1900-1910$ y 1911- 1913, después del cambio de Reglamento 
GRÁFICA 3-28: Niños nacidos en el Hospital Provincial ingresados en la Inclusa 1900-13 365

GRÁFICA 3-29: Tiempo de estancia en la Inclusa de los niños antes de su primera salida 1900-13 551

GRÁFICA 3-30: Niños fallecidos, internos y externos, menores y mayores de 5 años, y supervivientes. 1900 y 1913

GRÁFICA 3-31: Comparación y distribución por sexos de los niños ingresados en la Cuna y los fallecidos entre 1900 y 1913

GRÁFICA 3-32: Defunciones de expósitos por grupos de edad, internos y externos 1900-1913 621

GRÁFICA 3-33: Fallecidos dentro de la Cuna y con las nodrizas externas. 1900- 1913 625

GRÁFICA 3-34: Comparativa entre los fallecidos dentro y fuera del establecimiento, el número total de defunciones y el total de ingresos anuales. 1900-1913

GRÁFICA 3-35: Porcentaje de expósitos fallecidos con las nodrizas, calculado sobre el total de ingresos y sobre el total de salidas para crianza externa anuales y comparado con la mortalidad infantil provincial (en \%). 1900- 1913

GRÁFICA 3-36: \% de fallecidos y supervivientes de la Cuna. Distribución de los niños ingresados en la Cuna Provincial entre 1900 y 1913

GRÁFICA 3-37: Distribución estacional de las defunciones de la Cuna Provincial 1900-13

GRÁFICA 3-38: Promedio de las defunciones mensuales dentro y fuera de la Cuna 1900-13

GRÁFICA 3-39: Porcentaje de defunciones mensuales dentro y fuera de la Cuna entre 1900 y 1913 respecto al total de fallecimientos de cada grupo

GRÁFICA 3-40: Causas de mortalidad en la Cuna. 1900- 1913

GRÁFICA 3-41: Causas infecciosas de mortandad en la Cuna excluida la Sífilis entre 1900-13

GRÁFICA 3-42: Causas infecciosas de mortandad en la Cuna- 2, incluyendo la Sífilis Congénita, entre 1900 y 1913

GRÁFICA 3-43: Comparativa entre las principales causas de mortalidad en la Cuna provincial y a las nacionales para el grupo de edad de menores de 5 años 1900 y 1913 


\section{ÍNDICE DE IMÁGENES}

PORTADA: A Mother depositing her child at the Foundling Hospital in Paris. Harry Nelson O'Neil 1817-84 CONTRAPORTADA: Palacio de los condes de Benavente, sede del Hospicio Provincial de Valladolid. Autor y fecha desconocidos. Fondo fotográfico del Archivo Municipal de Valladolid

Introducción

Imagen 1: Buzón para recoger niños en una ciudad centroeuropea 15

Imagen 2: Inclusa de Madrid. Sala del torno. Francisco Ortego. 1861 26

Imagen 3: Esquela infantil publicada en El Norte de Castilla 21- 01- 1902 30

Imagen 4: Reparto de lotes de comestibles entre los pobres de la ciudad. Fuente: DÍAZ J.: Álbum de Valladolid. 2010

Fuentes documentales. Fondos del ADPVA de Valladolid

Imagen 1-1: Libros de Exposiciones. ADPVA

Imagen 1-2: Carta dirigida al Cura párroco de Cantalejo requiriendo información de los niños y contestación en el interior del folio 56

Imagen 1-3: Página del libro Defunciones 1908, folio no 12

Imagen 1-4: Libro Defunciones 1913, folio no 11 59

Imagen 1-5: Página del libro Años 1906 y 1907, 1908. Junio 1908 61

Imagen 1-6: Entradas y salidas de los niños de la Inclusa Años de 190919101911 63

Imagen 1-7: Portadas y lomos de los Libros de Exposiciones 65

Imagen 1-8: Pólizas que aparecen sucesivamente en los libros partir de 1901 66

Imagen 1-9: Sello del Hospicio y firma del Director en los Libros de Exposiciones a partir de $1909 \quad$...... 67

Imagen 1-10: índices de los Libros de Exposiciones 10 tomo de 1901 y de 1913 .67

Imagen 1-11: Fos 136 y 321, 1911. Sellos diferentes con el mismo no de filiación 68

Imagen 1-12: Libro de Exposiciones de 1907 69

Imagen 1-13: Folio 74 de 1909. Niña expuesta en el torno 75

Imagen 1-14: Folio no 205 del 1 o tomo del Libro de Exposiciones de 1912 78

Imagen 1-15: Folio no 369 del Libro de Exposiciones del Año 1911, 20 Tomo 79

Imagen 1-16: Folio no 179 del Libro de Exposiciones del Año 1911, 10 Tomo

Imagen 1-17: Folio 401 del libro de Salidas de menores 1900 con una nota en una papeleta que comunica el fallecimiento del niño

Imagen 1-18: Página 74 del Libro 16 de Mayores 1906 -1911

Imagen 1-19: Folio № 3 del Libro 16 de Mayores acogidos 1906-1911

Imagen 1-20: Página 148 del libro Entradas y salidas de los Niños de la Inclusa Años de 190919101911 en la que figura Ecequiela Pastor Olmos como ama lactante

Imagen 1-21: Folio no 389 del Libro de Exposiciones de 1909 en la que figura Ecequiela Pastor Olmos como madre de la niña inscrita y refugiada en el asilo

Imagen 1-22: Página no 176 del libro Entradas Maternidad 1906, 907, 1908 en la que se registra a Ecequiela Pastor Olmos 
Imagen 1-23: Fo 299. 1909 Libro de cuentas corrientes con las amas externas. Lactancias _........ 91

Imagen 2-24: Fo 20. 1909 Libro de cuentas corrientes con las amas externas. Lactancias _

Imagen 1-25: Registro especial de cartillas de Lactancia y Destete 1910-1913 …...................... 92

Imagen 1-26: Recibo de la contaduría para cambio de cartilla y pago de cuota $\quad$........................... 93

Imagen 1-27: Justificante de devolución del niño para dar de baja a la criadora $\quad$............................ 94

Imagen 1-28: Papeleta con certificación de vida del niño y autorización de cobro. Año $1906 \quad$......... 94

Imagen 1-29: Nueva Libreta de crianza externa, cartilla $\mathrm{n}$ - 94, 1914

Imagen 1-30: Cartilla para niños de lactancia en los pueblos pertenecientes al Hospicio _........ 96

Imagen 1-31: Carpeta de Expediente Personal. Exposición 1911. Fo 269

Imagen 1-32: Folio cortado, con el registro de un fallecimiento en la enfermería del asilo $\quad$............... 102

Imagen 1-33: Certificación del Libro Recibos 1921- $1922 \quad$........................................................... 103

Imagen 1-34: Hospicio Provincial - Almacén- Diario de entradas de suministros. Año $1915 \quad$.......... 104

Imagen 1-35: Cuaderno de compras 1909- $1917 \quad$......................................................... 104

Imagen 1-36: Libro de la Vaquería 1928 -1933

Imagen 1-37: Estadística de gastos 1903, 1906. Camas, ropas vestuarios y útiles de cocina $\quad$............. 106

Imagen 1-38: Presupuesto para Nodrizas y Hermanas de la Caridad en 1906. Estadística general de gastos 1903, $1906 \quad$......................................................... 108

Imagen 1-39: Anuncio en prensa de 1926 de la Pomada de la Viuda Farnier $\quad$.......................... 113

Imagen 1-40: Sobre de Larosán Roche. Museo Farmacia Ferrer ..................................................... 113

Imagen 1-41: Niños ingresados en el Hospicio para su lactancia durante el año 1905 ........................... 115

Imagen 1-42: Estadística demográfica sanitaria del Hospicio, primer trimestre del año $1932 \quad$........... 116

Imagen 1-43: Proyecto de Edificio para Escuela y ampliación de dormitorios. Santiago Guadilla. 1911

El Hospicio Provincial de Valladolid

Imagen 2-1: El palacio del conde de Benavente desde el Espolón nuevo, hacia 1836. V. Carderera..... 127

Imagen 2-2: Hospicio Provincial de Valladolid. Autor Pacheco. (1900) 129

Imagen 2-3: El edificio del Hospicio Provincial en las primeras décadas del siglo XX. Fuente: URREA J.: Arquitectura y nobleza: casas y palacios de Valladolid. 1996

Imagen 2-4: Izda: plano del antiguo palacio de los Condes de Benavente. Dcha: plano actual $\quad$..... 150

Imagen 2-5: Plano de la Distribución en planta principal de las Galerías de Poniente y Norte Reformas en las salas anejas a la Enfermería. (ADPVA, s.a., s.f.) $\quad$.......................... 152

Imagen 2-6: Lavatorios del Hospicio. (ADPVA, s.a., fecha probable 1911) _........................ 157

Imagen 2-7: Dormitorio de niños del Hospicio. (ADPVA, s.a., fecha probable 1911) .......................... 186

Imagen 2-8: Dibujo de la escuela del Hospicio. (N.C. 1904) $\quad$.............................................................. 187

Imagen 2-9: Taller de tejidos del Hospicio. ADPVA, s.a., fecha probable $1911 \quad$......................... 189

\section{La Inclusa del Hospicio Provincial de Valladotid}

Imagen 3-1: Sala de Cunas del Hospicio Provincial. ADPVA Valladolid (fecha probable 1911) .......... 195

Imagen 3-2: Plano de los dormitorios de niños y amas de la Inclusa. Santiago Guadilla, $1910 \quad$...... 200 
Imagen 3-3: Estado demostrativo del movimiento de acogidos del Hospicio Provincial. 1906. Recoge el movimiento durante el año 1905

Imagen 3-4: Nota pegada al folio no 14 del Libro de Exposiciones de 1913

Imagen 3-5: Palacio de los Condes de Benavente. Postal de la Colección de fotografías de Castilla y León de la Fundación Joaquín Díaz (va 0977), s.a. Sin datar.

Imagen 3-6: Palacio de los Condes de Benavente. Fotografía actual

Imagen 3-7: Papeleta de exposición fo 363, 1912. Niño "colocado en la Sala de los bautizados"

Imagen 3-8: Reverso de la papeleta de exposición. Expediente del folio no 269, año $1911 \quad$...... 262

Imagen 3-9: Papeleta para comunicar nodriza y bautismo. Expediente fo 46- 1912 263

Imagen 3-10: Papeleta asignando a un niño a "la sala de los colocados". Fo 346, 1904 264

Imagen 3-11: Mapa de Valladolid provincia, pueblos más alejados y distancia a los tornos 321

Imagen 3-12: Localidades desde donde se trasladaron expósitos a la Inclusa de Valladolid 1900-13 ... 329

Imagen 3-13: Distribución territorial de los lugares de origen de los expósitos 330

Imagen 3-14: Pueblos de origen de los expósitos del torno de la Inclusa Provincial, porcentaje de niños por zonas. № de localidades y $\mathrm{n}$ - de expósitos que nacieron en ellas

Imagen 3-15: Lugares de origen de los expósitos de la provincia de Valladolid, los expuestos en los pueblos y en los tornos de la capital y las dos Medinas

Imagen 3-16: Distribución de los lugares de origen de todos los niños de la provincia de Valladolid ingresados en la Inclusa provincial por las distintas vías posibles entre 1900-13 ......... 336

Imagen 3-17: Inscripción del fo 152 del libro Entradas Maternidad 1906907 y 1908 ......................... 353

Imagen 3-18: Plomo de identificación del Hospicio Provincial de Valladolid

Imagen 3-19: Inscripción del 10 de Abril de 1907 correspondiente al fo 126 en el Libro de Entradas de 1907- 1908 de la Inclusa

Imagen 3-20: Fo 126 del Libro de los niños que salen para lactancia de 1907 donde se registran los pagos a la nodriza

Imagen 3-21: Jeringa para el bautismo uterino 409

Imagen 3-22: Capilla del Hospicio Provincial. El Financiero Hispano Americano. Extraordinario Valladolid 1911, p 72

Imagen 3-23: Papeleta con la firma del capellán como director en funciones

Imagen 3-24: Sacaleches (Fuente: E. SUÑER). y sacaleches atmosférico de Hartmann

Imagen 3-25: Traje de nodriza, modelo pensado para dar de mamar con recato. Fuente: Suñer E.: La salud del niño

Imagen 3-26: Virgen de la leche. S. XV, taller de Diego de la Cruz. Museo de Burgos 448

Imagen 3-27: La cabra nodriza. Revista higiene de la infancia 1891 464

Imagen 3-28: Biberón fabricado por la casa inglesa Allen\&Hanburys a partir de 1894 466

Imagen 3-29: Anuncio de Harina lacteada Nestlé. N.C. 10- 7- 1913, p 5

Imagen 3-30: Anuncio de BANARINA. La Vanguardia 27- 04 - 1921, p 21

Imagen 3-31: Taller de tejidos del Hospicio Provincial de Valladolid. Archivo de la Diputación Provincial de Valladolid. Sin datar (fecha probable 1911)

Imagen 3-32: Ropas de los bebés. Fuente: SUÑER E.: La salud del niño 494

Imagen 3-33: Niños enfajados. Ospedale Santa María degli Innocenti de Florencia 496 
Imagen 3-34: Familia de Campaspero 1907, niño con gorrito y faldón. Fuente: Campaspero. Las imágenes de nuestra vida. 1900-1980

Imagen 3-35: Niño de año y medio vestido de corto década de los 20. $1926 \quad$........................... 500

Imagen 3-36: Niña de de luto, edad 3- 4 años. Fecha probable 1933-4 ........................ 504

Imagen 3-37: En el Hospicio. N.C. 6-1- 1904, portada

Imagen 3-38: Una visita a la Inclusa la tragedia del niño expósito. El Nuevo Mundo $1927 \quad$................ 507

Imagen 3-39: Ropero del Hospicio. ADPVA. Sin datar (fecha probable 1911) $\quad$......................... 509

Imagen 3-40: Anuncio de Polvos Antisépticos Calber. N.C. 1914

Imagen 3-41: Anuncio de Polvos Calber en ABC. $1916 \quad$.......................................................... 516

Imagen 3-42: Lactante vestido de corto montado en caballito de madera. $1927 \quad$........................ 519

Imagen 3-43: Juguetes de principios del siglo XX Fotografías cedidas por Pilar Ponce ........................ 521

Imagen 3-44: Carretones populares

Imagen 3-45: Pollera. Museo de las Artes, Industrias y Tradiciones populares de Barcelona $\quad$........... 524

Imagen 3-46: La viruela El Norte de Castilla, 24-11-1902 $\quad$........................................................ 531

Imagen 3-47: Papeletas del Hospicio para el reconocimiento médico. Expediente fo 269 del Libro de Exposiciones de 1911

Imagen 3-48: Envase de aceite de ricino

Imagen 3-49: Anuncio de Agua de Carabaña. El Sol 2-05-1924, p 2

Imagen 3-50: Incubadoras en la Exposición Panamericana de Buffalo en 1901. Fuente: The PanAmerican Exposition Illustrated

Imagen 3-51: Solárium artificial en la Casa Provincial de Maternidad y Expósitos de Barcelona. Fuente: Exposición Josep Brangulí Barcelona 1909-1945. Archivo Nacional de Cataluña ........... 549

Imagen 3-52: Báscula pesabebés de la época 549

Imagen 3-53: Folio del Libro de Amas de 1901 en el que se iban anotando los pagos que se hacían a las nodrizas externas

Imagen 3-54: Localidades de las nodrizas externas de la Inclusa de Valladolid. 1900- $1913 \quad$............ 582

Imagen 3-55: Libreta de crianza externa. Nuevo modelo de cartilla implantado en $1913 \quad$................... 593

Imagen 3-56: Lista de cartillas que cobra el comisionado Celedonio Martín $\quad$.......................... 596

Imagen 3-57: La cuna vacía, Manuel Ocaranza 1871

Imagen 3-58: Niño de dos meses fallecido en la Inclusa (fo 37 LE 1913)

Imagen 3-59: Niña raquítica fallecida. Fuente: BUXÓ P. Enfermedades de los niños de pecho. Lámina XVI

Imagen 3-60: Sustitución del torno de la Inclusa. El Norte de Castilla, viernes 15-05-1936

Imagen 5: Entierro de un párvulo. 1887. Fuente: Valladolid un siglo de cuestión social (1840-1940). Valladolid. Grupo Pinciano. 1995, p 281 (s.a., s.f.)

Imagen 6: Palacio de los condes de Benavente. Patio. Fuente: Colección Fundación Joaquín Díaz/ Libro Valladolid hace 100 años. (va 1697) (s.a.)

Imagen 7: Palacio de los Benavente, esquina san Quirce. Fuente: MUVA. Año 197? ........................... 717 


\section{GLOSARIO DE ABREVIATURAS:}

- ADPVA: Archivo de la Diputación Provincial de Valladolid

- AHPVA: Archivo Histórico Provincial de Valladolid

- AMVA: Archivo Municipal de Valladolid

- Art: artículo

- Fo: folio

- INE: Instituto Nacional de Estadística

- LE: Libro de Exposiciones

- N.C.: diario El Norte de Castilla

- pts: pesetas

- RAE: Real Academia de la Lengua Española

- R.C.: Registro Civil

- Regl: Reglamento

- $\quad$ R.N.: Recién nacido

- R.O.: Real Orden 


\section{INTRODUCCIÓN}

\section{JUSTIFICACIÓN}

De repente un día me sorprendió en los medios una noticia extraordinaria, decía que en una ciudad centroeuropea habían colocado una especie de buzón para depositar niños abandonados; con este procedimiento se respetaba la identidad de la madre y se quería evitar el abandono en lugares como portales, parques o contenedores. Sorprendente sin duda, pero no novedoso, como dijo el presentador que dio la noticia haciendo gala de ignorancia histórica, inmediatamente pensé en los tornos de las inclusas. ¿La historia se repite?

En todas las sociedades los niños han constituido el grupo más vulnerable y el más afectado por las catástrofes naturales o provocadas, entre otras causas por su indefensión, su falta de recursos y por haber sido tradicionalmente considerados "cosa de mujeres", relegadas así mismo socialmente y por ello víctimas también fáciles. Dice DeMause que la Historia de la infancia es "una pesadilla de la que hemos empezado a despertarnos hace muy poco" ${ }^{\prime 1}$; el abandono y el infanticidio, los expósitos, el torno y las inclusas forman parte de ella.

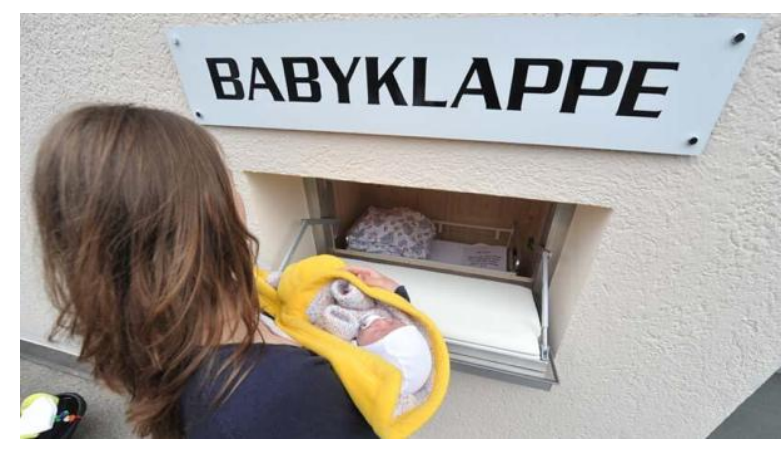

IMAGEN 1: La historia se repite: buzón para recoger niños de forma anónima en una ciudad centroeuropea. Imagen tomada del diario digital La Voz de Galicia ${ }^{2}$

Aunque con dimensiones y características muy diferentes estos buzones la recuerdan, en cinco años de funcionamiento en la ciudad de Hamburgo, pionera en esta iniciativa, se recogieron 22 bebés. Hoy día en nuestro medio no dejan de ser algo anecdótico, pero es

\footnotetext{
${ }^{1}$ Sigue diciendo: "Cuanto más se retrocede en el pasado, más bajo es el nivel de la puericultura y más expuestos están los niños a la muerte, la violencia, el abandono". DEMAUSE LI.: La evolución de la Infancia. En DEMAUSE LI.: Historia de la infancia. Madrid. Alianza Universidad. 1982, pp 15- 92. (1a edición en inglés 1974). Lloyd DeMause junto con Philippe Ariès son los historiadores más representativos del estudio de la infancia, Philippe Ariès se considera pionero con la publicación en 1960 de una obra considerada hoy un clásico: El niño y la vida familiar en el Antiguo Régimen.están los niños a la muerte, la violencia, el abandono".
} 
terrible que todavía tengamos que asistir a noticias sobre niños que aparecen, a veces muertos, echados, como se decía antaño, en cualquier sitio cuando disponemos de unos servicios sociales capaces. En España en 2005 se encontraron 24 bebés abandonados, 7 de ellos fallecieron ${ }^{2}$; se podría haber evitado si la madre hubiera solicitado ayuda social. Tanto a nivel nacional como en nuestra comunidad, Castilla y León, cualquier mujer puede acudir hoy a un centro hospitalario a parir y entregar a su hijo en adopción si así lo desea sin problemas ni penalización legal, los servicios de asistencia social se hacen inmediatamente cargo del niño.

Sé bien de lo que hablo porque lo vivo en mi actividad profesional; soy enfermera pediátrica, profesionalmente mi trabajo asistencial se desarrolla en una unidad neonatal donde de vez en cuando ingresan niños para adopción, así figura en el motivo de ingreso de su ficha clínica. Son pocos, 76 niños en un intervalo de veintiséis años (1990- 2016) en el Hospital Clínico Universitario de Valladolid, que representan el 0’21\% del total de los nacimientos registrados en dicho centro para este período; muchos años, como el pasado de 2016 no ingresó ningún niño por este motivo, casi la mitad (36) lo hicieron hasta 1996 y después de un periodo de mínimos, se notó un incremento con la crisis económica reciente, con 9 niños en 2013 y 5 en 2014 (ANEXO 1). Cuando una mujer comunica en la sala de maternidad su intención de dejar al hijo en adopción se avisa a la trabajadora social del centro y al nacer se ingresa al bebé en la unidad neonatal para cuidarlo, valorar su estado de salud y hacer un informe pormenorizado. La sección de Protección a la Infancia de los Servicios Sociales de la Junta de Castilla y León, después de entrevistarse e informar a la madre, declara al hijo en desamparo y asume su tutela. Se da un plazo a la mujer de seis semanas para confirmar su decisión de renunciar a la patria potestad y hasta ese momento, una vez que sale del hospital, el niño será cuidado por una familia de acogida temporal o en una casa de los servicios sociales mientras se tramita su adopción con la familia adoptiva definitiva.

\footnotetext{
${ }^{2}$ Imagen tomada de BALADO F.: Abandone aquí a su bebé y no en un contenedor de basura. La Voz de Galicia. 1807- 2015. Disponible en: http://www.lavozdegalicia.es/noticia/sociedad/2015/07/17/abandone-bebe-contenedorbasura/00031437156064133308747.htm

"Los «babyklappe», cuya traducción al español es "buzón para bebés», son una especie de cuna acondicionada para los recién nacidos e instalada en el exterior de algunos hospitales para que las madres que así lo deseen puedan entregar a sus bebés de una forma anónima y segura. Esta idea surgió en Hamburgo en el año 2000 con el fin de reducir infanticidios y de ahí se extendió a Berlín, Austria, Bélgica, Suiza e incluso Sudáfrica. En el país austriaco cumplieron el pasado año su décimo aniversario, ya que surgieron en 2001 a raíz de la modificación de una ley que despenalizó el abandono de niños en estos "nidos" y permitió a las mujeres dar a luz de una forma totalmente anónima. Desde entonces, 15 hospitales han puesto en marcha estos "buzones» y hasta el año pasado habían sido depositados allí un total de 29 niños". PALACIOS L.: Los babyklappe: Así lucha Austria contra el infanticidio. ABC. Es. Sociedad. Madrid, 29- 01- 2012. Disponible en: http://www.abc.es/20120129/sociedad/rc-babyklappe-luchaaustria-contra-201201290913.html

"Cada año en Alemania se registran entre 30 y 40 infanticidios. Entre 30 y 50 niños son abandonados en parques y contenedores, la mitad muere". MORENO U.: Drama. Frente a los bebés abandonados necesitamos el buzón bebé. Suplemento de El Mundo, no 542, 19- 03- 2006. Disponible en: http://www.elmundo.es/suplementos/cronica/2006/542/1142722802.html
} 
Soy también docente en el campo de la enfermería pediátrica e intento transmitir a mis alumnos y alumnas mi pasión por la infancia y su cuidado; cuando comentamos la noticia y el fenómeno histórico no sabían lo que es una inclusa o un expósito, para ellos también resultó novedoso y sobre todo increíble qué cientos de niños fueran abandonados todos los años en un lugar como Valladolid; este desconocimiento viene a demostrar cuan frágil es la memoria histórica, pues hablamos de hechos acaecidos hace nada, de los que sus abuelos han sido testigos. Conocer la historia puede ayudar a no repetir y corregir errores, a encontrar soluciones y en definitiva a mejorar socialmente. Además soy antropóloga, me interesan extremadamente todas las cuestiones relacionadas con la forma de vida del ser humano en cualquier momento y lugar y como tal soy amante y aficionada de la Historia; así que lo vi claro, no dudé ni un momento cuando me planteé hacer una tesis, el tema no podía ser otro que los niños abandonados en aquellas inclusas afortunadamente hoy inexistentes, preferiblemente los más pequeños, los lactantes. Entendemos por lactantes, desde el punto de vista pediátrico, los niños menores de dos años, que por sus características tanto físicas como psico-sociales, diferentes y diferenciadas del resto de la población infantil, son los más frágiles y más dependientes de los cuidados maternales. Había que acotar tiempo y lugar; para la localización espacial mi corazón se dividía entre Salamanca mi ciudad natal tan querida y añorada y Valladolid mi ciudad de residencia desde hace tantos años, más de la mitad de mi vida, naturaleza de mis hijos, mi ciudad también muy querida. La elección no era fácil, así que la decisión al elegir Valladolid ha sido puramente pragmática, para mayor facilidad en el desarrollo del trabajo. En cuanto a la elección temporal, me situé hace 100 años, en una época en que la Pediatría ya se había desarrollado pero sin llegar al avance que supondría la aparición de los antibióticos $(1928)^{3}$, y en la que existía interés médico, social y político por la infancia; también influyó mucho en esta decisión que con la búsqueda bibliográfica previa detecté que la mayoría de los trabajos sobre expósitos en España se sitúan en épocas anteriores y hay muy pocos sobre las primeras décadas del siglo XX.

El tema del abandono infantil y las cuestiones con él relacionadas, expósitos, inclusas y nodrizas especialmente, han sido ampliamente estudiados por los historiadores. El profesor Julio Valdeón defendió "en el ámbito de lo que entendemos por "historia»... la necesidad de la interdisciplinariedad", "el acercamiento creciente entre la historia y otras disciplinas" para poder crear "una "historia total», en la que quepan todas las facetas que conciernen a la vida

\footnotetext{
${ }^{3}$ La era de los antibióticos comienza en 1928, cuando Alexander Fleming descubrió la penicilina, aunque ya existía el salvarsán, "arsénico que salva", descubierto en 1909 por Paul Ehrlich para tratar la sífilis.
} 
en sociedad de los seres humanos", lo que dice, contribuye "a reivindicar la cultura popular, entendida como parte integrante esencial del discurso histórico" ${ }^{4}$. Este estudio se realiza desde un enfoque antropológico y enfermero, que ya se ha querido reflejar en el título, sin olvidar el obligado aspecto histórico. Pretende desvelar la pequeña historia (Microhistoria) de los expósitos de Valladolid en su más tierna infancia, quiénes eran, qué cuidados recibían, cómo vivían y morían, en las primeras décadas del siglo XX; un siglo de cambios y contradicciones que ha revolucionado a la humanidad con sus avances científicos, especialmente en materia de salud. La alimentación en las inclusas y el nodrizaje, por resultar un tema indudablemente muy atractivo, se ha tratado abundantemente; sin embargo este trabajo quiere ir más allá y abordar de forma amplia el tema de los cuidados que recibían estos niños que se encontraban bajo la tutela de una institución pública que debía garantizar su bienestar. Hablar de cuidados es hablar de enfermería, cuidar es la esencia de esta profesión, cuidar en el más amplio sentido de la palabra, con un enfoque holístico que comprende aspectos biológicos, sociales, psicológicos, culturales y espirituales.

Además de la aportación que supone la utilización de un enfoque interdisciplinar, avalan la relevancia de este trabajo su novedad por su ámbito específico de estudio; el temporal porque el periodo cronológico elegido es de los menos abordados por la historiografía sobre los expósitos y el local porque la Inclusa Provincial de Valladolid está poco documentada. Dice Lola Valverde Lamsfus sobre el estudio del fenómeno de los expósitos, que se necesita más investigación sobre las diferentes inclusas que funcionaron, que las "características generalizadas (número de abandonos, elevados índices de mortalidad y niños legítimos abandonados) no deben ocultarnos que profundos y detallados estudios de cada Inclusa y la ulterior comparación que se establezca entre ellos nos harán avanzar en la comprensión del problema que hoy por hoy sigue conservando incógnitas, no fácilmente desvelables dado el carácter clandestino del abandono"5. En este sentido este trabajo puede aportar datos nuevos para el contraste dado que es el primero que aborda un estudio profundo y global de la Inclusa de Valladolid en las primeras décadas del siglo XX. La mayor parte de la documentación que se ha manejado en el Archivo de la Diputación Provincial no se había consultado nunca para investigación.

\footnotetext{
${ }^{4}$ VALDEÓN BARUQUE J.: Reflexiones sobre la cultura popular en la Edad Media. Edad Media: Revista de Historia, no 1, 1998, pp 15-28

${ }^{5}$ VALVERDE LAMSFUS L: Legitimidad e ilegitimidad. Evolución de las modalidades de ingreso en la Inclusa de Pamplona, 1740-1934. En: Enfance abandonnée et société en Europe, XIVe- XXe siècle. Actes du colloque international de Rome. Roma: Publications de l'École Française de Rome, 1991. Volumen 140, no 1, p 1169
} 


\section{EXPÓSITOS E INCLUSAS}

El abandono de niños ha sido una constante en la historia de la infancia, practicado por todas las sociedades desde los tiempos más remotos de la humanidad ${ }^{6}$. Abandono e infanticidio han constituido en la sociedad occidental las dos caras de una misma moneda: la carencia de medios eficaces para el control de la natalidad unida a la falta de recursos para criar a un hijo probablemente no deseado y, sobre todo, a la necesidad de ocultar la vergüenza de un hijo ilegítimo en una sociedad moralmente estricta y con una concepción muy concreta de la familia, de las redes de parentesco y del sentido del honor. La mentalidad que ha persistido durante siglos en la sociedad occidental hizo a la mujer depositaria del honor familiar, más concretamente del honor de los varones de la familia; se la exigía contención sexual, siempre dentro del marco de una unión legítima, de manera que cualquier nacimiento fuera del matrimonio implicaba deshonor y vergüenza para ella y su entorno. La forma más sencilla de ocultar la prueba de la deshonra era deshacerse de la desgraciada e inocente criatura por diferentes medios, desde el infanticidio hasta el abandono pasando por la entrega a otros para su crianza, casi siempre previo pago. Aunque la mujer estuviera dispuesta a afrontar la vergüenza de criar a un hijo ilegítimo, las posibilidades de salir adelante eran muy reducidas, por no decir que nulas; quedaba en una situación de marginalidad social para todos los efectos y generalmente ni siquiera podía contar con el apoyo de su familia, que solía ser la primera en repudiarla como una salida "honrosa" ante los ojos del resto de la sociedad. Para una mujer soltera, "cargar" con un hijo le cerraba prácticamente las puertas a las pocas opciones laborales disponibles y a la posibilidad de un futuro matrimonio. No es de extrañar que se haya dicho que los niños expósitos eran "producto de embarazos privados en los cuales las mujeres enfermaban nueve meses, para después del parto recobrar su virginidad"7.

La magnitud del problema histórico en la cultura occidental se pone de relieve con la aparición de las primeras leyes romanas y los primeros asilos para recoger niños abandonados, en una sociedad que aceptaba el abandono como algo normal, que disponía de las Columnas Lactarias, donde se abandonaban a su suerte los niños que no habían sido reconocidos por el

\footnotetext{
${ }^{6}$ HARRIS M., ROSS E.B: Muerte, Sexo y Fecundidad. La regulación demográfica en las sociedades preindustriales y en desarrollo. Madrid: Alianza Universidad. 1991, p 246

${ }^{7}$ MONIEC S.: El universo simbólico entorno de la sociedad de la beneficencia en la política social argentina. Revista de trabajo social Perspectivas. Año XIII, no 19. Santiago. 2008, p 23, citando a COWEN P.: Nacimientos, partos y problemas de la primera infancia fines del siglo XVIII, primeras décadas del Siglo XIX.
} 
pater familias. En la Alta Edad Media se crearon en Europa hospitales que recogían niños junto a pobres, peregrinos y enfermos; en el año 787 Dateo de Milán fundó la primera Inclusa conocida del occidente medieval. En el siglo XV se fundó en Florencia I'Ospedale di Santa María degli Innocenti, que sería modélico al iniciar un sistema similar al acogimiento en el que las familias que recibían niños se comprometían a tratarlos como hijos y a enseñarles un oficio $^{8}$.

En España también aparecieron instituciones para recoger y criar huérfanos y expósitos. En Segovia se sabe de la existencia en el siglo XIII del Hospital de Sancti-Spíritu y del Hospital de Pobres y Expósitos, o de "Refitolería" que alojaba, vestía y atendía a pobres y criaba a los niños abandonados en la puerta de la iglesia ${ }^{9}$. La primera Casa de Expósitos como tal, sólo para niños, que está documentada es el Hospital de la Piedra u Hospital de la Santa Cruz de Toledo construido por orden del cardenal Mendoza en 1504. Un antecedente

\footnotetext{
${ }^{8}$ Los romanos, colocaban al recién nacido en el suelo y el padre debía cogerlo en brazos y elevarlo como señal de reconocimiento, si no lo hacía así el niño era abandonado. Philippe Ariès interpreta este gesto de elevar al niño como una especie de procedimiento de adopción; las adopciones eran muy frecuentes en la antigua Roma, pesaban más los vínculos electivos que los lazos familiares. La Columna Lactaria se llamaba así porque en ella se ofrecían las mujeres como amas de cría, se encontraba en la plaza del mercado de verduras y también allí se depositaban los expósitos. Los niños abandonados en general tenían muy malas perspectivas de futuro, o morían o se quedaban como propiedad de quien los encontraba, que muchas veces los vendía o los trataba como esclavos, solamente unos pocos tenían la suerte de ser recogidos por alguien que los criaba como hijos. El abandono de niños era tan frecuente en Roma que el emperador Augusto creó un subsidio para quienes los criaran en casa y Graciano en el siglo IV publicó un edicto que castigaba a los que abandonaran a sus hijos. Trajano en el siglo II fundó en el Monte Celio de Roma un asilo a cargo del Estado conocido como Puerii Alimentarii, que llegó a acoger a 5.000 expósitos que de adultos eran alistados en las legiones; más tarde, Antonino Pío crearía una institución similar para niñas. El arzobispo Dateo fundó un hospicio bajo la advocación de San Ambrosio para recoger y criar niños de hasta ocho años que también acogía madres solteras encargadas de cuidarlos. En el siglo XI se fundó la orden del Espíritu Santo para crear asilos para huérfanos y expósitos bajo el patrocinio de Inocencio III, se dice que afectado por la visión habitual de niños flotando en las aguas del Tíber. L'Ospedale Santa María degli Innocenti se fundó en 1451, construido con fondos de un gremio de comerciantes de seda de Florencia, es famoso desde el punto de vista artístico porque lo construyó Brunelleschi y por los famosos medallones de niños enfajados de Andrea dela Robbia que adornan su fachada. Estas iniciativas a favor de los niños abandonados ponen de manifiesto cierta sensibilidad hacia la cuestión y hacen sospechar que debía tratarse de un problema social realmente importante.

DEMAUSE LI: Historia de la Infancia, pp 51-52; LÓPEZ PIÑERO J.M., BRINES SOLANES J.: Historia de la Pediatría. Albatros. Valencia 2009, p 31; MORALES J.L.: El niño en la cultura española: (ante la medicina y otras ciencias; la historia, las letras, las artes y las costumbres). Tomo I, Biografías, obras benéfico-sociales, legislación, p 53 y 393 ; SANTO TOMÁS PÉREZ M.: Historia de la Enfermería. Enfermería Fundamental. Editorial Masson. Barcelona 1995; DONAHUE M.P.: Historia de la Enfermería. pp 177-178; RUIZ GÓNZALEZ M.D., MARTíNEZ BARELLAS M.R., GONZÁLEZ CARRIÓN P.: Expectativas de la Enfermería de la Infancia, en RUIZ GÓNZALEZ M.D. y col: Enfermería del niño y el adolescente.Tomo I. Ediciones D.A.E. Madrid 2009, pp 16- 29; WOLF S: Los Pobres en la Europa Moderna. Barcelona: Editorial Crítica. 1989 p 258.

${ }^{9}$ No se sabe con exactitud cuando se fundó el Hospital de Sancti-Spíritu, pero se conoce de su existencia porque en 1257 Alfonso X le otorgó privilegios "por estar muy pobre"; también se conocen distintos pleitos que tuvieron lugar en el siglo XVI en los que se dice que "tenía por misión criar y amparar a los niños desamparados de sus padres, que nombran Expósitos" El Hospital de Pobres y Expósitos se creó en el "refitorio", lugar destinado anteriormente para dar de comer a los pobres. GARCÍA ESTEBAN A.: De los Centros de Acogida a las Instituciones Sanitarias. Evolución de la Política Socio-Sanitaria en la ciudad de Segovia: Siglos XV-XIX. Diputación de Segovia. 2002, pp 43-45 y 76-77.
} 
interesante es el Hospital d'En Guitard de Barcelona, que en el siglo XV disponía de didas, mujeres "de reputación honesta y buenas costumbres" encargadas de cuidar a los expósitos ${ }^{10}$.

Con el término EXPÓSITO se hace referencia a los niños abandonados "a quienes desamparase la fiereza y desamor de sus padres, exponiéndolos a diversos peligros"11; se les decía también "echados" o "precipitados" ${ }^{12}$. Los diccionarios históricos de la Lengua Española muestran la evolución de este concepto; manteniendo la esencia, las definiciones que nos ofrecen a lo largo del tiempo son interesantes por los datos que aportan a mayores, que tienen mucho que ver con la mentalidad y el concepto social de cada época. El término aparece en los diccionarios por primera vez en el Tesoro de la Lengua Castellana o Española de Covarrubias de $1611(p 784,1)$ :

\begin{abstract}
"EXPOSITO, el niño que ha sido echado de sus padres, ó de otras personas en los câpos o en las puertas de los templos desamparándolos a su ventura: y de ordinario son hijos de personas que padecerian sus honras o sus vidas si se supiesse cuyos son. A otros los han mâdado echar a las fieras sus mesmos aguelos o matarlos: y los que llevavan comissión desta crueldad por no executalla en todo y por todo, ensangrentando sus manos en los inocentes, se los dexavâ en los montes, y en las cuevas: y de ordinario los criavan pastores allegándo les a las tetas de las cabras, y de las ovejas. Y de aquí ha nacido tàta variedad de criança en los expositos, sustentados de las cabras, de las ciervas, de las ovejas, de las vacas, de las yeguas, de las perras, de las lobas, de las ossas, de las serpiêtes, de las abejas, de las palomas, de los cuervos, \& c." [sic]
\end{abstract}

Esta definición coincide en su relato con lo que escribiera Pedro Salazar de Mendoza, sobre el Hospital de la Piedra o de la Santa Cruz de Toledo

\begin{abstract}
"No se puede encarecer el beneficio que ha recebido España con la fundación de este hospital, principalmente en la criança de los niños expósitos. Ha sido singular remedio contra las crueldades de sus padres. Vianse antes muchos hijos arrojados en el campo a las fieras, y a las aves, ahogados otros en los ríos, arroyos, y en los poços. Otros enterrados en muradales, y otros hechados en lugares sucios. Los más piadosos los ponían a las puertas de las yglesias, donde se los comían, y despedaçavan los perros, y otros animales... Hanse labrado a exemplo de este hospital, otros muchos en todo el Reyno: de manera que
\end{abstract}

\footnotetext{
${ }^{10} \mathrm{El}$ Hospital d'En Guitard, se fundó en Barcelona en 1024. En las Ordinacions de 1417 (conservadas en el Hospital de la Santa (ruz) habla de las didas, mujeres responsables de atender a los niños internos, sanos y enfermos, y de controlar a los que se criaban fuera del hospital. La dida tenía que ser "Mujer de reputación honesta y buenas costumbres, que tuviera una especial atención a los niños, es decir, que los cuide y los mantenga limpios". Se conservan también los Libres d'infants $i$ didas del hospital, un registro donde se encuentran anotados todos los datos de los niños acogidos: RUIZ GONZÁLEZ M.D. y col.: op.cit. . pp 21-22.

${ }^{11}$ SALAZAR DE MENDOZA P.: Crónica de el gran Cardenal de España don Pedro Gonçalez de Mendoça, Arçobispo de la muy Santa Yglesia Primada de las Españas. Toledo, imprenta de doña María Ortiz de Saravia. 1625, p 381. Copia digital disponible en Biblioteca Digital de Castilla y León: https://bibliotecadigital.jcyl.es/es/consulta/registro.cmd?id=13377

12 PRECIPITAR, entre sus acepciones, en sentido figurado significa "Exponer a uno a una ruina espiritual o temporal" RAE 1899 Diccionario de la lengua castellana por la Real Academia Española. 13a edición. Madrid, pp 805,1
} 
apenas ay oy buen lugar en él, en que no aya comodidad y abrigo, para recoger estos niños y criallos ${ }^{13}$ [sic]

El Diccionario de Autoridades de la RAE de 1732 ( 1 690, 2) suaviza un poco al menos lo referente al destino de estos infelices y ya habla de Casas de acogida para ellos:

"EXPOSITO, TA. adj. en lo literal significa echado y puesto al público, pero comúnmente se toma esta palabra por el niño o niña que han sido echados de sus padres, ó por otra persona á las puertas de las iglesias, de las casas o de otros parajes públicos ó, por no tener con qué criarlos, ó porque no se sepa cuyos hijos son. En diferentes Ciudades hai Casas y Hospitales públicos, erigidos para recoger y criar estos niños, los cuales se llaman de los Espositos. En Toledo le intitulan de la Piedra, por la que está destinada en un nicho para que allí los pongan, y en Madrid se llama la Inclusa. Del latín expositus" [sic]

Esta definición se va abreviando y desde el Diccionario de 1884 ( p 480, 2) en las sucesivas ediciones hasta 1970 aparece como:

\section{"Dícese del niño recién nacido expuesto en un paraje público"}

Desde la edición de 1970 (p 599,1) permanece la definición actual:

"Dícese del que recién nacido fue abandonado o expuesto, o confiado a un establecimiento benéfico"

Vemos pues, que a lo largo del tiempo se conserva la idea del niño abandonado por sus padres en un lugar público. Es especialmente dura la definición de Covarrubias que añade además la idea de "deshacerse" de él por la condición de ilegítimo y el aspecto anecdótico de la crianza con el relato de los animales empleados para ello que incluye serpientes, abejas, palomas y cuervos. Se pasa a la idea de recoger a los niños abandonados en casas creadas a propósito, lo que demuestra cierta sensibilidad social respecto al tema, y a la ilegitimidad se añade, como causa del abandono, la pobreza. Finalmente, el abandono se produce en los propios establecimientos benéficos o en lugares dispuestos para ello, ya no se deja al niño " $a$ su ventura", como decía Covarrubias, esperando que con suerte alguien lo quiera recoger, se abandona con la certeza de que va a ser "cuidado".

Los hospitales donde se acogieron los niños abandonados recibieron diferentes nombres, Casa de Expósitos, Casa Cuna, Casa de la Piedra ${ }^{14}$ y finalmente se generalizó el de

\footnotetext{
${ }^{13}$ SALAZAR DE MENDOZA P.: op.cit. , pp 399- 400

${ }^{14}$ El nombre de Casa de la Piedra hace referencia a la "piedra" o "cuna pétrea", normalmente de mármol, que se colocaba en algunas iglesias, como reminiscencia de las columnas lactarias, para depositar en ellas a los expósitos. MORALES J.L.: op.cit., pp 380 - 381. En la biografía que escribió Pedro Salazar de Mendoza, sobre su tatarabuelo el
} 
INCLUSA; como tal aparece con sus equivalentes en los diccionarios de la RAE desde 1734 definido como: "La Casa u Hospital donde se recogen y crían los niños expósitos". En el siglo XIX desaparece el concepto Hospital como casa de acogida, se incluye el origen del término Inclusa y aparece la definición que se mantiene actualmente ${ }^{15}$ :

INCLUSA. (Del nombre de Nuestra Señora de la Inclusa, dádo á una imagen de la Virgen que en el siglo XVI se trajo de la isla de L'Écluse, en Holanda, y que fue colocada en la Casa de Expósitos de Madrid). Casa donde se recogen y crían los niños expósitos [sic]

"La inclusa de Valencia era denominada con el ilustrativo apelativo de la Casa del Pecado" ${ }^{16}$ haciendo alusión al origen ilegítimo de los niños que recibía. Las principales víctimas de abandono e infanticidio durante siglos fueron los "desechados", como les llama el Fuero Real de Alfonso $\mathrm{X}$, donde ya se condena la exposición de niños castigando con la "muerte a quien echase a un niño sin que haya nadie que lo tome para criar y muriese ${ }^{\prime 17}$. Las inclusas se crearon para recoger a los ilegítimos, considerados hijos del pecado, "de la infamia, del vicio o de la deshonra", o como inhumanamente se les llegó a llamar "hijos de la escoria y hez de la república", la vergüenza de las familias y el desecho y de la sociedad, por eso eran los que más riesgo tenían de ser abandonados o incluso eliminados de forma violenta ${ }^{18}$. Carlos IV, en la Novísima Recopilación que se publicó en 1805, legitimó el estado de los bastardos de padres

cardenal Mendoza fundador del Hospital de la Santa Cruz, dice que "Para recogellos, está hecho un abrigo de madera, con alguna ropa, en un pilar de la santa iglesia de Toledo, enfrente de la capilla de San Pedro, acomodado para qué los hechen allí y los lleven al hospital. Las guardas de la iglesia eclesiasticos y seglares, requieren de cuando en cuando esta estancia, que es llamada la Piedra, y en hechandole alguno, le llevan al hospital para que se vista y crie con los demás" [sic]. SALAZAR DE MENDOZA P.: op.cit., p 400.

Piedras con la misma función se encuentran por ejemplo en el zaguán de la Catedral de Segovia o en el atrio del santuario de Nuestra Señora de la Carballeda en Rionegro del Puente (Zamora). En HERNANDO GARRIDO J.L.: Los niños expósitos en tierras de Zamora durante el Antiguo Régimen. Revista de Folklore. Fundación Joaquín Díaz; edición digital no 364; pp 4 -16.

${ }^{15}$ Definiciones tomadas del Diccionario de Autoridades de 1734 ( $\mathrm{p}$ 241, 2) y Diccionario de la Lengua Castellana por la Real Academia Española. 13a edición. Madrid. 1899, p 550, 3. La etimología que aparece en los diccionarios a partir de 1899 se ajusta a la que dio Daniel De Cortázar en su Discurso de recepción en la RAE, Madrid, 1899, (pp. 42-43). Según una larga tradición, recogida por muchos autores, como Paula Demerson o Antonio R. Jiménez, un soldado trajo de los Países Bajos de la ciudad de Enkhuissen un cuadro de la Virgen de la Paz que Felipe II donó a la cofradía de Nuestra Señora de la Soledad y de las Angustias de Madrid. Dicha cofradía fundó en 1572 la Inclusa de Madrid y colocó allí el cuadro de la Virgen de Enkhuissen; debido a la dificultad para pronunciar el nombre éste fue derivando a Écluse y posteriormente a Inclusa

${ }^{16}$ HERNANDO GARRIDO J.L.: op. cit., p 5

${ }^{17}$ Titulo XIII del Libro IV del Fuero Real (1252- 1255); se titula "De los desechados e de los que desechan" y regula la situación de los menores abandonados. En él se trata también de los derechos sobre el niño abandonado y se recoge la figura de la adopción como una modalidad de filiación que imita a la natural y que tiene como objetivo, aparte del de protección, convertir al adoptado en heredero, por tal motivo solamente permite "recibir por fijo" a quien "por edad le pudiere hablar por fijo" y prohíbe adoptar a los religiosos, los castrados y las mujeres, salvo que tengan autorización real o sean mujeres que han perdido un hijo al servicio del rey. SEVILLA BUJALANCE J.L.: LOS niños expósitos y desamparados en nuestro Derecho histórico. Córdoba, 2001, p 64- 69.

${ }^{18}$ PÉREZ MOREDA V.: La infancia abandonada en España (Siglos XVI-XX) Discurso de ingreso en la Real Academia de la Historia (8 de mayo de 2005). Madrid. 2005, p 38- 39. Los calificativos "hijos de la escoria y hez de la república" los recoge de FERNÁNDEZ NAVARRETE, 1626 
desconocidos en un intento por desterrar la situación de desigualdad que les marginaba legal y socialmente. El Código de las Partidas ya planteó la posibilidad de legitimar a los expósitos, pero debía ser a petición del padre, lo que de entrada excluía a los de padres desconocidos. Carlos IV estableció una legitimación general, pero clasista, como corresponde a la época; en ella se justifica darles un trato de igualdad penal respecto a los legítimos por la posibilidad de que pudieran ser hijos de ilustres, esto es tanto como reconocer que en muchos casos así era; también se castiga llamarles ilegítimos, bastardos, bordes u otros términos peyorativos:

"ordeno y mando por el presente mi Real decreto... que todos los expósitos de ambos sexos..., así los que hayan sido expuestos en las inclusas o casas de caridad, como los que hayan sido o fueren en cualquier otro paraje y no han padres conocidos, sean tenidos por legitimados por mi Real autoridad, y por legítimos para los efectos civiles ... y declarando como declaro que no debe servir de nota de infamia o menor valor la qualidad de expósitos..." [sic]

"Y mando, que los Justicias de estos mis Reynos y los de Indias castiguen como injuria y ofensa a qualquier persona que intitulase y llamase a expósito alguno con los nombres de borde, ilegítimo, bastardo, espúreo, incestuoso o adulterino; y además de hacerle retractar judicialmente, le impongan la multa pecuniaria que fuere proporcionada a las circunstancias... Finalmente mando, que en lo sucesivo no se impongan a los expósitos las penas de vergüenza pública, ni la de azotes, ni la de horca, sino aquellas en que en iguales delitos se impondrían a personas privilegiadas, incluyendo el último suplicio; pues pudiendo suceder que el expósito castigado sea de familia ilustre, es mi Real voluntad, que en la duda se esté por la parte más benigna..." [sic $]^{19}$

A pesar de este reconocimiento legal, solamente con efectos civiles, la ilegitimidad siguió siendo una condición social relevante y diferenciada, incluso avanzado el siglo XX; por ello no es de extrañar que cuando en 1870 se publicó la ley de Registro Civil en su artículo 48 punto 70 exigiera la inscripción del carácter legítimo o ilegítimo del niño; "ciertamente que este criterio era general en su época", como afirma Diego Espín Cánovas ${ }^{20}$.

\footnotetext{
${ }^{19}$ Novísima Recopilación de las Leyes de España, dividida en XII Libros. mandada formar por el señor Don Carlos IV. Impresa en Madrid Año 1805. Libro VII, Título XXXVII, Ley IV. Los expósitos sin padres conocidos se tengan por legítimos para todos los oficios civiles, sin que pueda servir de nota la qualidad de tales. Madrid 1985

${ }^{20}$ La Ley del Registro Civil de 1870 en su artículo 48 establece las circunstancias que debe expresar la inscripción del nacimiento, en su punto 70 incluye "la legitimidad e ilegitimidad del recién nacido, si fuese conocida". Promulgada el 20 de junio de 1870 "con el carácter de provisional", como afirma la propia ley, este artículo estuvo en vigor hasta que fue derogada por Decreto en 1932 desarrollando el principio de igualdad de derechos de los ilegítimos con los legítimos proclamado por la Constitución de 1931, que prohibió expresamente consignar la legitimidad o ilegitimidad en el Registro civil (art. 45). El Decreto de 1932 sería derogado por ley en 1941, recobrando su vigencia el precepto anterior hasta que la Ley de 1957 volvió a prohibirlo, ésta se mantiene vigente con modificaciones. Cfr. SEVILLA BUJALANCE J.L.: op.cit.; ESPÍN CÁNOVAS D.: La Constitución de 1869 y la legislación civil española hasta 1874 Revista de estudios políticos, № 163, 1969, pp. 117-13; BARÓ PAZOS J.: La codificación del derecho civil en España (1808-1889) Santander. Universidad de Cantabria. 1992, p 190-194.

La actual Ley 20/2011, de 21 de julio, del Registro Civil, modifica en su Título VI la inscripción de nacimiento "En cuanto a la filiación, se elimina toda referencia a la no matrimonial con plena equiparación a la matrimonial". Título VI. Capítulo primero. Artículo 49. Contenido de la inscripción de nacimiento y atribución de apellidos. BOE. Viernes 22 de julio de 2011. Disponible en: http://www.boe.es/boe/dias/2011/07/22/pdfs/BOE-A-2011-12628.pdf
} 
Desde finales del siglo XVIII se produjo, en palabras de Vicente Pérez Moreda, un aumento "formidable" e "imparable" de los expósitos ${ }^{21}$, proporcional a la aparición de establecimientos para su acogida. Esto dio lugar a un debate conocido y recurrente, y que todavía hoy persiste. Frente a la idea de que la proliferación de inclusas motivó el aumento de expósitos, "Veremos los pobres crecer siempre en proporción de las fundaciones hechas para socorrerlos"122, se contrapone la que considera que las inclusas cumplieron una función y evitaron abandonos más inhumanos e infanticidios constituyéndose en una forma menos cruel de rechazo "de la infancia indeseada, "una alternativa al aborto, al infanticidio o a la muerte diferida", pero casi segura, en aquellos casos anteriores de abandono salvaje de las criaturas $^{\prime 23}$. El canónigo D. Juan Bautista Sacristán y Galiano, cuando redactó en 1806 las "Ordenanzas para el gobierno y dirección de la Real Casa de Misericordia y Expósitos de la ciudad de Valladolid", empezó escribiendo: "Estos Establecimientos tan precisos a la humanidad, y sin los que ha acreditado la experiencia se han seguido gravísimos perjuicios á las Sociedades..." ${ }^{24}$ [sic]. En todo caso, el verdadero problema de fondo era la miseria, junto a una mentalidad tolerante con estas cuestiones, de tal forma que, aunque la proliferación de inclusas pudo favorecer el aumento de expósitos, comparto la opinión de los que piensan que no podemos asegurar que los niños que se entregaron a las inclusas no hubieran sido abandonados igualmente en cualquier otro lugar. El incremento enorme de expósitos se atribuyó por una parte a la colocación de los tornos en las inclusas, que ofrecían clandestinidad, y por otra y relacionada con la primera, al ingreso de hijos legítimos, temas que pasaron también a formar parte de la polémica.

El torno se convirtió en el siglo XIX en un elemento emblemático de las inclusas para acabar siendo motivo de controversia y desaparecer finalmente en las primeras décadas del siglo XX. El miedo a la deshonra y a sus consecuencias era el motivo principal del abandono de los hijos ilegítimos; era necesario "ocultar la vergüenza" de estas mujeres para evitar el rechazo social y familiar en una sociedad esclava de la "honra" que condenaba los pecados de la carne. Si deshacerse del hijo era la solución, los tornos de las inclusas vinieron a ofrecer anonimato a la "madre pecadora" preservando su reputación y la de su familia, la clandestinidad que garantizaban intentaba así evitar los abandonos en lugares inhóspitos y los

\footnotetext{
${ }^{21}$ PÉREZ MOREDA V.: op. cit., pp 33- 34

${ }^{22}$ Conde de Cabarrús citado por PÉREZ MOREDA V.: op.cit, pp 34-35

${ }^{23}$ PÉREZ MOREDA V.: op. cit., p 51

${ }^{24}$ Ordenanzas para el Gobierno y Dirección de la Real casa de Misericordia, y Expósitos de la Ciudad de Valladolid dispuestas por el Doctor Don Juan Bautista Sacristán y Galiano... 1806, Ordenanzas Generales para el Departamento de Expósitos, p 89.
} 
infanticidios de los bastardos. Aunque los primeros tornos se remontan al siglo XII, su uso se extendió sobre todo por el Sur de Europa en el siglo XVIII, promovido por instituciones eclesiásticas y políticas. En España se despenalizó el abandono de niños en el torno, pero no la exposición en otros lugares, en 1796, ya se había hecho unos años antes en Portugal. Napoleón en 1811 decretó la implantación de tornos en Francia; como consecuencia se produjo un aumento tan espectacular de los abandonos que a partir de 1826 empezaron a cerrarse y desaparecieron en 1860. La supresión de los tornos se acompañó a su vez de un descenso marcado, aunque no homogéneo, del número de niños abandonados. El mismo proceso ocurrió en los países europeos que habían implantado el torno, el anonimato que brindaba se convirtió en un elemento facilitador y favorecedor del abandono, de manera que aumentó de forma tan importante la entrada de niños legítimos que en algunas inclusas llegaron a superar el $50 \%$ de las exposiciones. El incremento significativo de la demanda asistencial debido a este uso considerado abusivo, provocó que en la segunda mitad del siglo

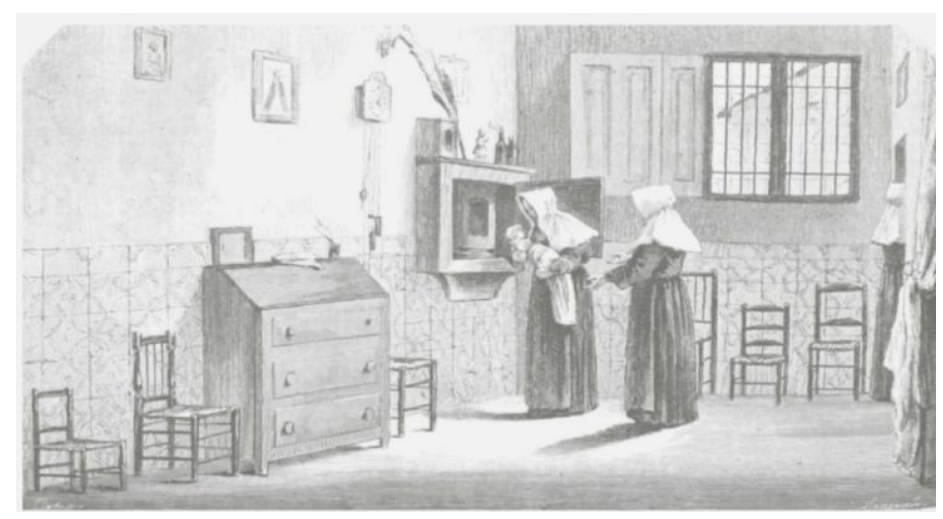

Imagen 2: Inclusa de Madrid. Sala del torno. Francisco Ortego. El Museo Universal. Madrid 16 de junio de 1861. Número 24, año V; p 188
XIX se fueran cerrando los tornos y se restringieran los criterios de admisión para evitar el ingreso de los legítimos. No todas las inclusas notaron de la misma manera el cierre del torno en cuanto al número de exposiciones, ya que su ámbito social era muy heterogéneo; en algunos

centros simplemente cambiaron las formas y en vez de usar el torno, se dejaba al niño en la puerta y como mucho se tiraba de la campana o se voceaba para avisar de su presencia ${ }^{25}$.

El proceso en España siguió un ritmo diferente; aunque también se experimentó un aumento de niños legítimos se culpó a la situación económica y la supresión del torno se retrasó hasta la década de los treinta del siglo XX, después de años de polémica entre las tesis

\footnotetext{
${ }^{25}$ PÉREZ MOREDA V.: op. cit.; REVUELTA EUGERCIOS B.A.: Los usos de la inclusa de Madrid, mortalidad y retorno a principios del siglo XX (1890-1935). Madrid, 2011, pp 108; VALVERDE LAMSFUS L: Legitimidad e ilegitimidad. Evolución de las modalidades de ingreso en la Inclusa de Pamplona, 1740-1934. En: Enfance abandonnée et société en Europe, XIVe- XXe siècle. Actes du colloque international de Rome 1987. Roma: Publications de l'École Française de Rome, 1991. Volumen 140, no 1, p 1.188. En Portugal se abolió el torno en 1867, en Italia los de las ciudades más importantes se suprimieron en las décadas 60 y 70 y quedaron abolidos en 1923 Bárbara Revuelta recoge datos estimados sobre los ingresos de legítimos en las inclusas de algunas ciudades europeas, para Milán concretamente el $62 \%$ de los ingresos eran legítimos (citando a HUNECKE: I trovatelli di Milano: Bambini esposti e famiglie espositrici dal XVII al XIX secolo) y a finales del siglo XVIII cita para Madrid cifras del $50 \%$.
} 
que lo rechazaban por el abuso que se hacía de él y las que lo defendían por su capacidad disuasoria de infanticidios. Con la desaparición del torno desaparecía el anonimato y las madres tendrían que entregar al niño en una oficina de recepción y aportar sus datos.

Una polémica asociada a la del torno es la del ingreso de hijos legítimos. La situación generalizada de pobreza, en el que Montanari llamó "el siglo del Hambre"26 llevó en España a la recomendación por parte de muchos prelados de admitir en las inclusas "hijos de pobres casados", aceptada en el R. Decreto de $1794^{27}$. Recoger a estos niños, que por las condiciones de miseria de su entorno tenían pocas posibilidades de supervivencia se consideró inicialmente un acto de caridad, sin embargo, se fue generando una actitud de rechazo debido a la altísima mortalidad que tenían las inclusas. Aparte de la cuestión económica, también importante porque las instituciones no disponían de fondos suficientes para atender tanta demanda como se generó, restringir el ingreso pasó a ser otra forma de entender la caridad ya que documentos de la época reconocían que "se mueren quantos niños aquí se depositan a causa de la miseria" y consideraban un mal menor preferible que se quedaran con sus madres a pesar de la pobreza, puesto que "mal o bien puede vivir la infeliz criatura a sus pechos"28. Algunas inclusas más progresistas como las de Pamplona y Pontevedra establecieron un sistema de ayudas económicas a madres pobres consiguiendo una disminución significativa del número de legítimos abandonados. Es una política que no pudo extenderse por la falta de recursos de estas instituciones, que a duras penas cubrían muchas veces los gastos de atención a los niños acogidos, lo intentaron Casas como la de Oviedo, que pronto se vio desbordada por el número de solicitudes y no pudo hacer frente a los pagos comprometidos ${ }^{29}$.

\footnotetext{
${ }^{26}$ MONTANARI dedica un capítulo de su libro al siglo XVIII, al que llama "el siglo del hambre". MONTANARI M.: EI hambre y la abundancia. Historia y cultura de la alimentación en Europa., Barcelona. Ed Crítica, 1993

${ }^{27}$ PÉREZ MOREDA V.: op. cit. p 40- 41

${ }^{28}$ SÁNCHEZ FERNÁNDEZ L.V., COBO BARQUÍN J.C., RADHAMÉS HERNÁNDEZ M.: Marginación y pobreza desde la cuna: el niño expósito en el Concejo de Siero, Asturias (1800-1936) p 142

${ }^{29}$ VALVERDE LAMSFUS L.: op.cit., pp 1.178; RODRÍGUEZ MARTín A.M.: Una estrategia de supervivencia femenina: Las nodrizas sin retribución de la inclusa de Pontevedra, 1872-1903, Minius Historia, Arte y Xerografía, no. 15, 2007, p 240; MARTÍNEZ GÓMEZ-SIMÓN L.M.: Las instituciones de atención social al menor en la ciudad de Albacete. Albacete. Instituto de Estudios Albacetenses "Don Juan Manuel" de la Diputación de Albacete, 2002; SÁNCHEZ FERNÁNDEZ L.V., COBO BARQUÍN J.C., RADHAMÉS HERNÁNDEZ M.: Marginación y pobreza desde la cuna: el niño expósito en el Concejo de Siero, Asturias (1800-1936). Revista de Demografía Histórica, XXXI, II, 2013, pp. 131-165
} 


\section{MORTALIDAD EXPÓSITA Y MORTALIDAD INFANTIL}

Es un fenómeno bien conocido, y sobre el que se ha escrito mucho, el de la alta mortalidad de los expósitos ${ }^{30}$, muy superior a la del resto de la población infantil, que hizo a las inclusas merecedoras de calificativos como "morideros" ${ }^{31}$ o "sepulcro de niños" ${ }^{32}$, con valores que llegaron a alcanzar casi al $100 \%$ de los acogidos en muchas de ellas sobre todo en el siglo XIX, que Álvarez Santaló ha calificado como "auténticamente asesino" en su estudio de la CasaCuna de Sevilla, de la que diría que "era un sistema organizado de infanticidio"33. El informe que hizo Antonio de Bilbao en $1789^{34}$ sobre el estado de las inclusas españolas fue demoledor y sirvió de alarma sobre la situación y la tremenda mortalidad de los expósitos en ellas acogidos, el título ya es significativo Destrucción y conservación de los expósitos. A raíz de este escrito, en una circular de marzo de 1790 el Consejo de Castilla solicitó información a los obispos del país sobre las Casas de expósitos ubicadas en sus jurisdicciones, quienes vinieron a confirmar lo que denunciaba Bilbao, salvo honrosas excepciones como la Casa-Cuna del monasterio de Guadalupe ${ }^{35}$. La causa de esta mortalidad se relacionaba directamente con la miseria, la que padecían en las Inclusas y la que ya venían arrastrando antes de llegar a ellas

"El expósito, en un régimen demográfico como el del tiempo que nos ocupa, cataliza todos los factores favorables a la mortalidad infantil y, además, los que acompañan a la criatura desde su concepción, durante la gestación que había que esconder o disimular, a la hora del nacimiento, generalmente clandestino, hasta los avatares connaturales a la exposición: abandono en lugares

\footnotetext{
${ }^{30}$ Han tratado este tema entre otros: EGIDO T.: Aportación al estudio de la demografía española: los expósitos de Valladolid (siglos XVI- XVIII), Santiago de Compostela 1975; URIBE-ECHEVARRIA FLORES A.: Marginalidad "protegida": mujeres y niños abandonados en Navarra 1890-1930. Bilbao, 1996; DEMERSON P.: La Inclusa de Madrid, Historia 16, 90. 1983.; REVUELTA EUGERCIOS B.A.: op.cit.; VALVERDE LAMSFUS L.: Entre el deshonor y la miseria. Infancia abandonada en Guipúzcoa y Navarra. Siglos XVIII y XIX, Bilbao 1994; ÁLVAREZ SANTALO L.C.: Marginación social y mentalidad en Andalucía occidental: Expósitos en Sevilla (1613-1910), Sevilla 1980; FERNÁNDEZ UGARTE M.: Expósitos en Salamanca a comienzos del siglo XVIII, Salamanca 1988; VALLECILLO CAPILLA M.: Política demográfica y realidad social en la España de la Ilustración. La situación del niño expósito en Granada (1753- 1814), Granada 1990; CORTÉS CORTÉS F., CORTÉS GORDILLO M.I.: Expósitos en la Extremadura de los tiempos modernos, Badajoz 1997; GÓMEZ RUIZ T.: El Hospital Real de Santa María Magdalena y la Casa de Expósitos de Almería, Almería 1997; TARIFA FERNÁNDEZ A.: Pobreza y asistencia social en la España Moderna. La cofradía de San José y niños expósitos de Úbeda (siglos XVII y XVIII), Jaén 1994; SÁNCHEZ DE LA CALLE J.A.: La mortalidad infantil en Plasencia durante los siglos XIX y XX: hacia una historia de la casa cuna y el hospicio, Plasencia 1998; VIDAL GALACHE F., VIDAL GALACHE B.: Bordes y bastardos. Una historia de la inclusa de Madrid, Madrid 1995.; RODRÍGUEZ MARTíN A.M: op.cit., 2001; PÉREZ MOREDA V.: op.cit.

${ }^{31}$ MARCOS MARTín A.: De esclavos a señores. Estudios de Historia Moderna. Valladolid 1992, pp. 43-58

${ }^{32}$ Término que utilizan Florentina y Benicia VIDAL GALACHE en Bordes y bastardos. ..., p 103. La principal causa de mortalidad en la inclusa de Madrid en la primera mitad del siglo XIX fue la "extenuación" provocada por el hambre, el frío y la falta de cuidados, pp 103- 107.

33 ÁLVAREZ SANTALÓ L.C.: op.cit, pp 160- 166.

${ }^{34}$ DE BILBAO A.: Destrucción y conservación de los expósitos: Idea de la perfección de este ramo de policía: Modo breve de poblar la España y testamento. Antequera 1789. Disponible la Segunda Impresión, Málaga 1790 en : https://books.google.es/books/about/Destrucci\%C3\%B3n_y_conservaci\%C3\%B3n_de_los_exp.html?id=FqbInoiTj2s C\&redir_esc=y

${ }^{35}$ TESTÓN NÚÑEZ I., SÁNCHEZ RUBIO M.R., BLANCO CARRASCO J.P.: "Mi padre y mi madre me abandonaron, pero el Señor me acogió" expósitos y lactancia mercenaria en la Puebla de Guadalupe. Valladolid. 2004
} 
inhóspitos, muchas veces en días (más en noches) gélidos o abrasadores, entrega a nodrizas pobres y depauperadas ${ }^{\prime 36}$

"Aún así, el hecho de llegar a la Inclusa vivos ya suponía una mínima esperanza de supervivencia que no tenían aquellos que eran abandonados sin idea de que fueran recogidos 137

El interés por los expósitos y su tremenda mortandad, no fue solamente una cuestión moral, este asunto se convirtió también en un tema de preocupación política y económica, había que cuidarles para que "estos inocentes desgraciados no perezcan al rigor de una exposición inclemente... vivan según las reglas del Evangelio, y se hagan fructuosos, y útiles a la Patria", o, dicho más directamente, porque " podrán ser útiles al Estado, y gloria para la Nación" ${ }^{\prime 38}$. La Novísima Recopilación de las Leyes de España... mandada formar por el Señor Don Carlos IV en 1805 se ocupa en su Título XXXVII De los expósitos; y de las casas para su crianza, educación y destino y muestra también estos criterios utilitaristas

\begin{abstract}
"Mandamos, que no pueda haber estudios de Gramática en los hospitales donde se crían niños expósitos y desamparados, y que los administradores y superintendentes tengan cuidado de aplicarlos á otras artes, y particularmente al exercicio de la marinería, en que serán muy útiles por la falta que hay en este Reyno de pilotos...

Los Rectores ó administradores de las casas de niños expósitos... pongan el mayor cuidado en que... se les dé la debida educación y enseñanza para que sean vasallos útiles... y enseñen oficios y destinos convenientes á ellos mismos y al Público" [sic]
\end{abstract}

Afirma Vicente Pérez Moreda que en la política asistencial ilustrada dirigida a la infancia, que llama abandonada, tanto para el clero como para las autoridades civiles primaban intereses e iniciativas utilitaristas y poblacionistas" ${ }^{39}$, sin dudar de que "los objetivos filantrópico de la salud y la supervivencia del niño" irán prevaleciendo cada vez más claramente dando como resultado actuaciones legislativas, como la ley de Protección a la Infancia de 1904, e iniciativas prácticas en las que junto a la clase política se implicaron médicos, intelectuales y filántropos que con más o menos éxito intentarían en el siglo XX mejorar las condiciones de vida de los expósitos y combatir su elevadísima mortalidad intentando implantar un nuevo modelo de Inclusa.

\footnotetext{
${ }^{36}$ EGIDO T.: Aportación al estudio de la Demografía española: los niños expósitos de Valladolid (siglos XVI- XVIII), en actas de las I Jornadas de Metodología Aplicada de las Ciencias Históricas III. Universidad de Santiago de Compostela 1975, pp 333- 345

${ }^{37}$ VIDAL GALACHE F., VIDAL GALACHE B.: op.cit, p 103.

${ }^{38}$ Citas recogidas por PÉREZ MOREDA V. en La infancia abandonada en España (siglos XVI-XX), Madrid, 2005 que corresponden a las Ordenanzas del Real Hospital de Oviedo, 1752 y la circular de Diogo Inácio de Pina Manique de Mayo de 1783, en pp 24 y 33

39 PÉREZ MOREDA V.: op, pp 23- 25
} 
El interés por la infancia que se empezó a despertar en la Ilustración y la preocupación por la elevadísima mortalidad infantil, llevó a considerar este asunto como un problema social principal en los siglos XIX y XX. En las primeras décadas del siglo XX, tanto las autoridades médicas como políticas van a utilizar discursos economicistas y nacionalistas en su lucha contra este problema; rebajar la mortalidad infantil se convertiría en una cuestión de estado, de ello dependía el desarrollo económico y el progreso del país, la mejora de la raza y, en definitiva, la grandeza de la nación. Se valoraban las muertes infantiles en términos de pérdidas económicas y de riqueza social, de futura mano de obra y de potencial intelectual que podría engrandecer el país. El doctor Martínez Vargas ${ }^{40}$ en su discurso titulado En defensa de la raza planteaba la necesidad de aumentar la natalidad y disminuir la mortalidad infantil en España, bajo la idea

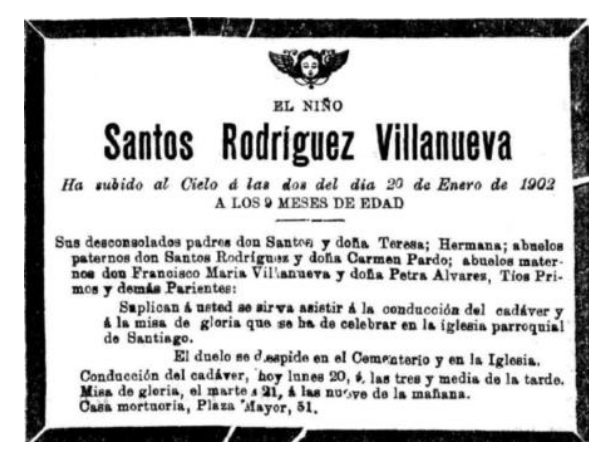

IMAGEN 3: Esquela infantil publicada en EI Norte de Castilla el 21- 01- 1902 en la portada. Esquelas de este tipo, que serían de niños de clases sociales favorecidas, eran habituales en la prensa diaria.

de que las naciones poderosas necesitan mucha población para su engrandecimiento; ya había calculado que las pérdidas ocasionadas al país por las 200.000 muertes anuales de niños menores de 5 años ascendían a 142.800.000 pesetas. Los mismos datos recoge el profesor Enrique Nogueras, catedrático de Enfermedades de la Infancia de la Facultad de Medicina de Valladolid en 1922, además, "En América han calculado que el aumento de un solo año de vida por persona equivale al aumento de cien millones de dólares en la riqueza nacional ${ }^{\prime 41}$. En 1917 el señor Navarro Salvador del Consejo Superior de Protección a la Infancia situaba la pérdida de 300.000 niños, incluyendo mortinatos y abortos, entre 300 y 600 millones de pesetas ${ }^{42}$.

\footnotetext{
${ }^{40}$ Andrés Martínez Vargas fue catedrático de Pediatría en Granada y Barcelona, reconocido a nivel nacional e internacional por el impulso que dio a la Pediatría en España y por su preocupación por la infancia y por rebajar su mortalidad, se le considera pionero de la Pediatría Social. Fue promotor de obras sociales en favor de la infancia, como la Escuela de Madres o el Instituto Nipiológico (del griego nêpios= el que no habla, dedicado a los niños más pequeños para reducir su mortalidad), fundó la Asociación Española de Pediatría en 1912 y promovió los primeros congresos nacionales de la especialidad. Dio el discurso En defensa de la raza en la inauguración del curso académico de 1918-19 en Barcelona; los datos sobre el coste de la mortalidad infantil los presentó en su conferencia inaugural del primer congreso Español de Pediatría en 1914 en Palma de Mallorca.

${ }^{41}$ Las conferencias de extensión universitaria. Las enfermedades evitables y la asistencia social del niño de pecho, por el doctor don Enrique Nogueras. N.C. 21- 02- 1922, p 4

${ }^{42}$ Citado por ECHEVARRIA FLORES A.: Marginalidad "protegida": mujeres y niños abandonados en Navarra 18901930, Bilbao, 1996, p 15.
} 
En este marco de preocupación general hay que considerar el interés por la alta mortalidad de los expósitos, muy por encima de la del resto de la población infantil, que ya era de por sí muy elevada.

La tasa de mortalidad infantil (menores de doce meses fallecidos por cada mil recién nacidos vivos en un año) en España a principios del siglo XX, aún siendo elevadìsima, había descendido de forma importante respecto al XIX, cuando las tasas eran superiores al $200 \%$ o (204,4\%o en 1890), y seguiría esa línea descendente progresiva, con picos como el de 1918 coincidiendo con la pandemia de gripe española, hasta llegar al 117\% en 1930; durante la Guerra Civil las tasas aumentaron pero sin llegar a alcanzar a las previas a $1925^{43}$. Valladolid se encontraba entre las provincias con mortalidad infantil más elevada del país, con índices del $254^{\prime} \%$ en 1901 y del 170\%o en 1930 (la segunda del país en los dos años) ${ }^{44}$. Refiere Antonio Arbelo las dificultades para realizar un estudio adecuado de la mortalidad en la infancia en España en las cuatro primeras décadas del siglo XX ${ }^{45}$ por la forma en que la Dirección General del Instituto Geográfico y Estadístico recogía los datos infantiles con criterios diferentes de unos años a otros y utilizando indicadores distintos de los actuales. El resumen estadístico de 1902 da una tasa nacional del 180'52\% y reconoce "Ia gran mortalidad de la infancia, de cada 1.000 defunciones $246^{\prime} 48$, casi la cuarta parte del total, fueron niños menores de 1 año y 441.42, ó sea, más de dos quintas partes, de menores de cinco" ${ }^{\prime 4}$. El resumen de 1923 sigue afirmando que "Las cifras ponen de manifiesto la enorme mortalidad de los menores de un $a \tilde{n} o^{\prime \prime 4}$.

Estos datos de mortalidad infantil, ya de por sí altísimos, se quedan cortos porque no incluyen a los fallecidos en las primeras 24 horas de vida. 100 años después, los últimos informes del INE para 2015 refieren una tasa de mortalidad infantil en España del 2'67\%o, la provincia de Valladolid se sitúa en la media nacional con el 2'62\%. Otro dato también muy demostrativo del cambio es la esperanza media de vida al nacimiento, la de la población

\footnotetext{
43 ARBELO CURBELO A.: La mortalidad de la infancia en España (1901-1950), Centro Superior de Investigaciones Científicas. Instituto Balnes de Sociología. Dirección General de Sanidad. Madrid, 1962; pp 266- 268. Arbelo señala dos crisis demográficas en España en nuestro período de estudio, la primera en 1896-1898, relacionada con las guerras coloniales, con el pico máximo de recuperación en 1903 debido a una alta natalidad, y la segunda en 19181920, relacionada con la epidemia de gripe que ocasionó alrededor de 320.000 muertes, de las que casi un $10 \%$ fueron menores de un año, y una crisis de nupcialidad porque la mayoría de víctimas eran jóvenes. Una tercera crisis corresponde a la Guerra Civil y la postguerra.

${ }^{44}$ Valladolid en 1901 es la segunda provincia española con la mortalidad más alta (25402\%o), después de Cáceres (277'19\%), le siguen Zamora y Burgos con el 243\%; Baleares con el 10141\%o tuvo la más baja. En 1930 Cáceres $(175 \%$ ) y Valladolid $(170 \%$ ) repiten posición, le siguen Palencia $(163 \%$ ) y Zamora $(162 \%$ ). Baleares se mantiene con la más baja (64\%) ARBELO CURBELO A.: op.cit., pp 315- 319

${ }^{45}$ ARBELO CURBELO A.: op.cit., Introducción, p XVIII

${ }^{46}$ Resumen de los hechos registrados en 1902. Defunciones Movimiento Natural de la Población. Fondo documental. INEbase Historia. Disponible en: http://www.ine.es/inebaseweb/pdfDispacher.do?td=205766\&ext=.pdf

47 Movimiento Natural de la Población. Fondo documental. INEbase Historia. Disponible en: http://www.ine.es/inebaseweb/pdfDispacher.do?td=206437\&ext=.pdf
} 
española en 1900 era de 34,76 años, (33'85 en varones y 35'70 en mujeres), en 1930 pasó a $49^{\prime} 97$ ( $48^{\prime} 38$ en varones y 51'60 en mujeres). Actualmente es de 83'25 años (80'41 para los varones y $86^{\prime} 10$ años para las mujeres); nada que ver con las cifras de hace un siglo ${ }^{48}$.

Las principales causas de mortalidad infantil durante las tres primeras décadas fueron las diarreas, con una diferencia considerable respecto a las demás, a continuación las bronquitis agudas e infeccciones respiratorias y en tercer lugar "la debilidad congénita y los vicios de conformación", también muy separadas del resto ${ }^{49}$. El hecho de que las diarreas constituyeran la causa principal de muerte significa que estaban interviniendo factores de tipo ambiental y social varios, fundamentalmente de tipo alimenticio e higiénico, desde condiciones generales como el abastecimiento de agua y los saneamientos a las condiciones higiénicas del entorno familiar más próximo. La medicina higienista de principios del siglo XX señalaba causas de tipo físico y moral como responsables de la alta mortandad infantil: la miseria, la ignorancia de las madres y dentro del discurso moralista y maternalista dominante, la falta de moral que asociaban por una parte a las malas costumbres de las clases populares y por otra a la "alimentación viciosa", como llamaban algunos a la lactancia mercenaria, y a la negación de las mujeres a lactar a sus hijos. Los tres pilares de la Higiene Social eran "Higiene, Educación y Moral... higienizando moralizamos, moralizando higienizamos, haciendo uno y otro educamos ${ }^{\prime 50}$. El doctor Tolosa Latour, uno de los principales impulsores del movimiento proteccionista de la infancia en España y de la Ley de Protección de 1904 y director de la revista Pro-Infantia diría que "Instruir a la mujer es la suprema aspiración de la higiene contemporánea" ${ }^{51}$

\footnotetext{
${ }^{48}$ La tasa global de mortalidad infantil de España en 2015 fue del $2^{\prime} 67 \%$, (2’88 \%o en varones y $2^{\prime} 45 \%$ on niñas). En la provincia de Valladolid la tasa global fue del $2^{\prime} 62 \%$, (2'38\% en varones y $2^{\prime} 87 \%$ en niñas). Quedan muy lejos las tasas de las primeras décadas del siglo XX. En cuanto a la esperanza media de vida a los 5 años de edad, es decir los años que se pueden sumar a los 5 ya vividos se situó en $42^{\prime} 38$ en 1900, y 55'49 años en 1930. Esto significa que una vez superados los primeros 5 años de vida, las posibilidades de supervivencia de los individuos aumentaba de forma importante. GOERLICH GISBERT F. J., PINILLA PALLEJÁ R.: Esperanza de vida en España a lo largo del siglo XX. Las tablas de mortalidad del Instituto Nacional de Estadística. Bilbao. Fundación BBVA. 2006, pp 23- 26

49 Para hacernos una idea, un año como 1910, de un total de 96.594 niños menores de 12 meses fallecidos, sin contar los de las primeras 24 horas de vida, más de un tercio (28.153) lo fueron por diarreas, 16.017 por debilidad congénita y vicios de conformación y 15.889 por bronquitis aguda y neumonías. A mucha distancia siguen, meningitis y otras infecciones como coqueluche (tosferina) y sarampión. ARBELO CURBELO A.: op.cit., p 335 Se llamaban vicios de conformación a las malformaciones y deformidades congénitas y se entendía por debilidad congénita cuando el neonato "tiene sus órganos y aparatos incompletamente desarrollados... un niño no acabado, de escaso peso y de funciones incompletas (inmaduro)". BOIX BARRIOS J.: Manual de puericultura, 1941, p 251 -252 ${ }^{50}$ BOROBIO P.: La Educación y la Higiene. Pro-Infantia, no 77, 1915. Citado por URIBE-ECHEVARRIA FLORES A.: op.cit., p 24. El boletín Pro-Infantia, editado por el Consejo Superior de Protección a la Infancia y Represión de la Mendicidad que se constituyó a partir del Reglamento de 1908 de la ley de Protección a la Infancia, tomó por objetivo educar a la población general y particularmente a la mujer y divulgar "los mandamientos" higiénicos y morales necesarios para la buena crianza de los niños.

${ }^{51}$ Discurso inaugural del primer Congreso de Higiene Escolar de 1912. RUIZ RODRIGO C., PALACIO LIS I.: Higienismo, Educación ambiental y previsión escolar (Antecedentes y prácticas de Prevención social en España (1900-1936). Valencia 1999, p 109
} 
Si la mortalidad infantil se considera un indicador muy fiable de la situación sociosanitaria de una población, podemos contemplar la de los expósitos como un reflejo fiel y objetivo de sus condiciones de vida, particularmente en lo que se refiere a los cuidados básicos higiénico-sanitarios y alimentarios.

\section{VALLADOLID Y PROVINCIA}

España empieza el siglo XX intentando superar la profunda crisis social y política ocasionada por las guerras y las consecuentes pérdidas coloniales de 1898. En pleno periodo de restauración borbónica, con un régimen liberal parlamentario, Alfonso XIII alcanza la mayoría de edad en 1902, y recoge un país atrasado y bipartidista en el que dos grupos políticos, liberales y conservadores, se alternan en el poder de forma pactada y, sobre todo, una nación con serios problemas sociales. El resurgir del nacionalismo, el terrorismo anarquista, las huelgas generales promovidas por un movimiento obrero cada vez más potente, entre otros, someten al país a crisis sucesivas potenciadas por la guerra de Marruecos. El descontento político y social creciente conduce al golpe de estado de Primo de Rivera en 1923 y a la implantación de su dictadura militar con el apoyo real. Aunque inicialmente parece resolverse la situación con mano de hierro, el régimen dictatorial va ganando cada vez más opositores entre los intelectuales y la sociedad en general y acaba perdiendo el apoyo del ejército y del rey. La crisis mundial de 1929 agudiza la depresión económica española y cuando Alfonso XIII intenta restablecer la monarquía constitucional ya era tarde, había perdido el apoyo social y los grupos republicanos y de izquierdas habían ido adquiriendo fuerza y consiguieron ganar las elecciones municipales de 1931; el rey abandonó el país y el 14 de abril de 1931 se proclamó la Segunda República.

Desde el punto de vista económico, es un país deprimido con una política de tipo intervencionista y en el que predomina el sector agrario, sin modernizar y en poder de una oligarquía de grandes propietarios. La industria es escasa y se centra en Cataluña, País Vasco y Madrid, y el país apenas tiene presencia en el comercio internacional, salvo en la etapa de la Primera Guerra Mundial, que no supo aprovecharse para dar continuidad a la ventaja que supuso mantenerse al margen. La mayoría de la población española inicialmente era rural, pero se van a producir migraciones hacia las grandes ciudades, donde por un lado irá creciendo la clase obrera y por otro, se va a desarrollar la clase media a expensas de 
profesiones liberales, funcionarios y comerciantes. La brecha social entre las clases más acomodadas y una masa obrera cada vez más pobre se fue agudizando. La población española desde 1900 hasta 1930 creció un 27'18\% (de 18.618 .086 a 23.677 .794 habitantes de hecho)

La provincia de Valladolid se caracteriza a principios del siglo XX por un predominio de la población rural, empleada fundamentalmente en el sector primario, y de localidades de menos de mil habitantes; solamente la capital tenía más de 10.000, no existiendo ciudades de rango intermedio, únicamente los municipios de Medina del Campo, Nava del Rey y Medina de Rioseco superaban los 5.000 vecinos $^{52}$. La población provincial apenas se incrementó en 23.000 habitantes en las tres primeras décadas pasando de 278.561 habitantes en $1900^{53}$, muy por debajo de las vecinas Burgos, León y Salamanca que por entonces superaban los 300.000, a 301.571 en 1930 (incluyendo la capital en los datos provinciales). La capital vivió un aumento demográfico significativo a lo largo de la segunda mitad del siglo XIX, pasando de 20.000 habitantes previos a más del triple en 1900 (68.789 según el Censo de Población), debido a los movimientos migratorios que llegaron "atraídos por su potencial económico y empujados por las graves dificultades del entorno agrario" ${ }^{54}$. El crecimiento siguió en el siglo XX, la ciudad absorbió buena parte del incremento total de población de la provincia que alcanzó los 91.089 habitantes en 1930, la capital sola tuvo un incremento similar al total provincial. La población infantil siguió el mismo patrón, no aumentó significativamente en las tres primeras décadas, pero en la capital pasó de 6.715 menores de 5 años en 1900 a 8.614 en 1930 y en la provincia tuvo un incremento similar de 33.482 a 35.755 respectivamente. No se modificó el patrón demográfico, que siguió siendo el típico de tipo antiguo con una mortalidad general muy elevada, en torno al 30 por mil, encontrándose tanto la capital como la provincia entre las más altas de España; la esperanza de vida al nacimiento a principios de siglo se situaba en $30^{\prime} 8$ años, por debajo de la media nacional, como corresponde a una mortalidad infantil también muy alta, como vimos anteriormente ${ }^{55}$

\footnotetext{
52 FUNDACIÓN BBVA La población de Valladolid. Cuadernos fundación BBVA. elVle, no 49. Madrid. 2007, p 5

${ }^{53}$ El primer Censo oficial español de 1857 que nos ofrece el Fondo documental del INE muestra una población de hecho para Valladolid capital de 41.548 habitantes y para la provincia de 234. 617. El último censo del siglo XIX se realizó en 1897 y en él se recogen 68.746 habitantes de hecho en la ciudad y 276.366 en la provincia, es decir, que más de la mitad del incremento de la población provincial tuvo lugar en la capital. Datos disponibles en INEbase, Censo de población 1857, Valladolid : http://www.ine.es/inebaseweb/pdfDispacher.do?td=192679\&ext=.pdf Censo de población 1897, Valladolid :http://www.ine.es/inebaseweb/pdfDispacher.do?td=194239\&ext=.pdf ${ }^{54}$ MAZA E.: Pobreza, Trabajo y Sociabilidad. 1999, p 860

55 Datos demográficos tomados de: MARTín JIMÉNEZ I.: La sociedad vallisoletana en los albores del siglo XX. Comportamientos ante los hitos vitales. Valladolid. Diputación provincial de Valladolid. 2004, pp 8- 12; FUNDACIÓN BBVA La población de Valladolid. Cuadernos fundación BBVA. elVle, no 49. Madrid. 2007, pp 3- 13 y Fondo documental INEbase Historia: Censos de población por edad de Valladolid de 1900 y 1930. Disponibles en: http://www.ine.es/inebaseweb/libros.do?tntp=71807 y Movimiento Natural de la Población. Disponible en: http://www.ine.es/inebaseweb/libros.do?tntp=205002
} 
Valladolid se convirtió en la localidad más poblada de la región castellana ${ }^{56}$, las oleadas migratorias que fue recibiendo se asentaron sin muchos problemas en una ciudad de estructura alargada y sin demasiadas barreras naturales; la expansión, desordenada e incontrolada, empeoró aún más las malas condiciones higiénico-sanitarias de la ciudad. La insalubridad no era un problema reciente en Valladolid, hay testimonios muy anteriores que la califican como "la más sucia tierra de toda España, de más lodos, peor naturaleza y olor más pestilente que se puede imaginar, con lo que se hace insufrible y aborrecible" ${ }^{\prime 57}$. Hasta 1907 no se iniciaron las obras de saneamiento y alcantarillado de la ciudad, proyectadas desde $1890^{58}$; en 1913 el alcantarillado no cubría toda la ciudad, se había construido un nuevo cauce para el río Esgueva pero estaba pendiente su desvío y sus ramales, "que fueron siempre colectores de inmundicias y constante peligro de infección e inundación" cruzaban la ciudad; las aguas sucias vertían sin depurar "en el río Pisuerga a las puertas mismas de la población"; las aguas del canal del Duero, que abastecían la ciudad, no eran potables "desde el punto de vista bacteriológico", aunque por suerte la población contaba con algunas fuentes de aguas limpias y válidas para el consumo como la del manantial Argales ${ }^{59}$ y en el casco urbano había corrales y

En 1911 por primera vez el Instituto Geográfico y Estadístico de España presenta en las estadísticas nacionales cifras relativas de mortalidad, Valladolid con 27,67 fallecidos por 1.000 habitantes fue la $5 \underline{a}$ provincia con la mortalidad más alta y siguió en la misma posición en 1930 con una tasa similar, en cuanto a la capital ocupó el 6 y 5 lugar con tasas del 32'35 \% y 27'24 respectivamente. Movimiento Natural de la Población. INEbase Historia

${ }^{56}$ Según el censo de 1900 Valladolid capital era la ciudad castellana más poblada con mucha diferencia, doblando a la siguiente que era Burgos y casi multiplicando por diez a Soria con 70.951 habitantes de derecho (presentes y ausentes), de ellos 34.555 varones y 36.396 mujeres, y 68.789 habitantes de hecho (presentes y transeúntes). La población de hecho de las demás capitales de las provincias de Castilla y León era la siguiente: Burgos 30.167, Salamanca 25.090, Zamora 16.287, Palencia 15.940, León 15.580, Segovia 14.547 y Soria 7.151 habitantes.

En 1900 la provincia de Valladolid contaba con 11 Partidos Judiciales y 237 Ayuntamientos y el censo de 1900 contabiliza un total de 283.045 habitantes de derecho (presentes y ausentes), de ellos 139.744 varones y 143.301 mujeres y 278.571 habitantes de hecho (presentes y transeúntes). Le superaban León con 386.083, Burgos con 338.828 y Salamanca con 320,765 , por debajo, con menos habitantes estaban Zamora con 275.545, Palencia con 192.473, Segovia con 159.243 y Soria con 150.462. Censo de la población en 1900. Tomo I: Detalle por Provincias. Resumen general por Provincias y por Capitales de Provincia, pp 323 y 324. Disponible en:

http://www.ine.es/inebaseweb/pdfDispacher.do?td=69595\&ext=.pdf:

57 MAZA E.: op.cit, pp 861 citando a PINHERIRO DA VEIGA T. en: Fastiginia o Fastos geniales, "Tercera parte. Pincigrafía o Descripción e Historia natural y moral de Valladolid". Obra en tres partes escrita en 1605 y ampliada en 1607 y 1620

${ }^{58}$ El ingeniero Recaredo Uhagón responsable del proyecto en una entrevista publicada en El Norte de Castilla en 1910 decía que "Principiaron [las obras] en 5 de agosto de 1907 y deben concluirse con arreglo a contrato el 5 de Agosto de 1912". ALLUÉ R.: El saneamiento de Valladolid. Las obras de alcantarillado. N.C. 22- 01- 1910, portada.

${ }^{59}$ DURÁN R.: La geografía médica de Valladolid. N.C. 21-10-1913 p 3. El doctor Román Durán era inspector provincial de Sanidad y presentó estos datos en el IX Congreso Internacional de Hidrología, Climatología y Geología. Un análisis bacteriológico de 1911 determinó un crecimiento de 10.800 bacterias por centímetro cúbico, "con una flora bacteriana... rica en especies por su número y calidad... [algunas] de difícil diagnosis por ser especies nuevas". Campaña sanitaria. Las aguas de Valladolid. N.C. 6-08- 1911 portada 
establos, que además ni siquiera reunían las condiciones higiénicas que exigían las ordenanzas municipales ${ }^{60}$. Con estas condiciones no son de extrañar sus tasas de mortalidad.

Al comienzo del nuevo siglo Valladolid era una provincia eminentemente agrícola y atrasada. Su tasa de actividad era del $36^{\prime} 7 \%$ de la población total, por debajo de la media regional y nacional (40'3 en Castilla y León y 46'9 en España); era especialmente baja la tasa de la población femenina, solamente el $10 \%$ de los activos de la provincia eran mujeres frente al $23^{\prime} 5 \%$ regional y el $19^{\prime} 1 \%$ nacional. El $66^{\prime} 8 \%$ de la población se ocupaba en la agricultura; el $11^{\prime} 9 \%$ en la industria y la construcción, concentradas sobre todo en la capital y el $21^{\prime} 3 \%$ en el sector servicios, el único en el que predominaban las mujeres con más del $80 \%$. Más de la mitad de la población provincial era analfabeta en 1900 (506\%), aunque en este aspecto estaba bastante mejor que la media nacional que superaba el 66\%; en el reparto por sexos la población femenina salía claramente perjudicada con una diferencia de más de 20 puntos $^{61}$. Este predominio del analfabetismo femenino es relevante en relación con la mortalidad infantil, no en balde la educación de las mujeres se convirtió en la época en una cuestión de preocupación médica y pediátrica principal ${ }^{62}$.

Valladolid capital no se podía considerar un núcleo industrial, ni una ciudad moderna. Era una ciudad provinciana en la que predominaban los sectores agrario y de servicios (hasta el punto que el servicio doméstico acaparaba un $39 \%$ de la población activa en los años veinte ${ }^{63}$ ) y llamaba la atención el "crecido número de pobres que, a todas horas del día, interrumpen el paso en las aceras con su marcada e intempestiva petición" ${ }^{\prime 64}$. No es de extrañar porque, por entonces, el índice de pobreza en la ciudad era escandaloso; distintos autores, entre ellos Elena Maza, calculan que "la tercera parte del vecindario son pobres oficiales, en su mayoría braceros y jornaleros" a los que añade otros tantos trabajadores que vivían en la pobreza aunque no se consideraran "pobres oficiales", en total estima "la friolera de 40.000 personas, casi dos tercios del vecindario con serios apuros para bandear la lucha diaria por la

\footnotetext{
${ }^{60}$ Por la salud pública. Campaña de higiene. N.C. 18-08-1913, portada

${ }^{61}$ FUNDACIÓN BBVA: La población de Valladolid. Cuadernos fundación BBVA. e IVle, serie Población, no 49. Madrid. 2010, p p 7-11

62 Pediatras tan eminentes como el anteriormente mencionado doctor Martínez Vargas fundaron Escuelas maternales y centraron sus esfuerzos en la educación de las mujeres en cuestiones como la higiene y la alimentación relacionadas con la prevención de la salud como la medida más eficaz para luchar contra la mortalidad infantil. El tema de la educación de la mujer adquirió tal relevancia que afirma Consuelo Flecha que fue objeto de muchas tesis doctorales de la época, entre ellas las de las dos primeras doctoras en Medicina españolas, Dolores Aleu y Martina Castell, que plantearon en sus discursos doctorales la "educación de las mujeres como uno de los requisitos del progreso y bienestar social". FLECHA GARCÍA C.: La educación de la mujer según las primeras doctoras en Medicina de la Universidad Española. Año 1882. Acta Hisp. ad Med. Sci. Hist. Illus. 1999. Vol 19, pp 247 y 253

${ }^{63}$ MAZA E.: op.cit, pp 863, citando a SERRANO RUIZ M.: Un proceso de desarrollo urbano. Valladolid 1900- 1965

${ }^{64}$ Ibídem pp 37- 49
} 
supervivencia"65. En 1914 la prensa local se quejaba de que "las calles de nuestra capital están convertidas en una lamentable «corte de los milagros». Los mendigos callejeros han invadido la ciudad y campan por sus respetos asediando al transeúnte, entrando en los comercios, subiendo a las casas, metiéndose en todas partes"66 Tanta pobreza, tan solo en la capital tenía que desbordar necesariamente a las instituciones dedicadas a la ayuda social.

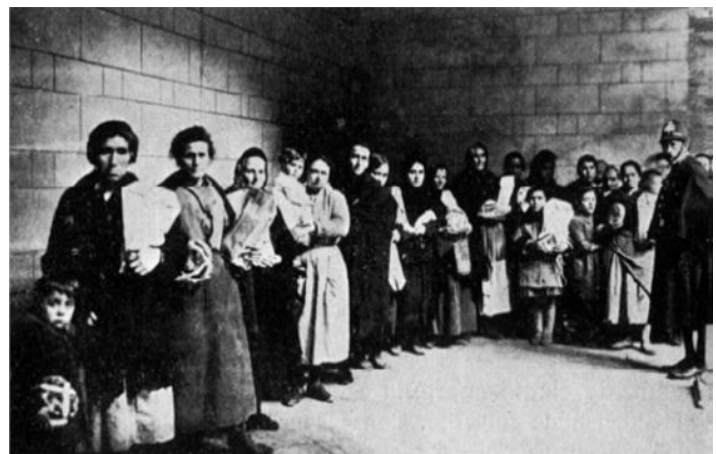

IMAGEN 4: Reparto de lotes de comestibles entre los pobres de la ciudad, 6 de marzo de 1928. Fuente: DÍAZ J.: Álbum de Valladolid. 2010, p 50

\footnotetext{
${ }^{65}$ Ibídem, p 866. Estimaciones que hace Elena Maza para una población de 74.262 vecinos en la capital y casi 280.931 en la provincia. Ibídem $\mathrm{p} 880$

${ }^{66}$ La mendicidad callejera. N.C. 14- 10-1914, p 3
} 


\section{Metodología y fuentes}

Pretende este trabajo un enfoque interdisciplinar que combine las Ciencias Sociales desde la perspectiva histórica y antropológica y las Ciencias de la Salud desde una perspectiva fundamentalmente enfermera, centrada en los cuidados, y pediátrica ya que es el niño expósito, y especialmente el lactante, el protagonista de este estudio.

Abordar esta investigación ha supuesto la utilización conjunta del método cualitativo y cuantitativo. La posibilidad de conjugar la orientación cualitativa con la cuantitativa, admitida cada vez más desde mediados del siglo $X X$, supone ir haciéndose preguntas e ir respondiéndolas a medida que se va avanzando en la investigación, y además cuantificar siempre que el estudio lo requiera aquellas cuestiones que transformadas en datos y cifras puedan aportar información relevante y claridad al conjunto del estudio o a una parte concreta de él. Las preguntas, planteadas como hipótesis de trabajo, van a ir adquiriendo consistencia en forma de respuestas o se van a ir rechazando en el caso de resultar inoperantes o de que su aportación resulte de escasa trascendencia. En cualquier caso, se consigue ir avanzando en el proceso de investigación, un proceso que en ambos casos, método cuali-cuantitativo, requiere una observación estructurada y pormenorizada, tanto de las fuentes en sí como de lo que ellas aportan.

Se realiza por tanto estudio histórico siguiendo metodología analítico-sintética basada en la búsqueda de información en fuentes primarias y secundarias y apoyada en una búsqueda bibliográfica. La Heurística o búsqueda, localización y recopilación de fuentes documentales ha supuesto para este trabajo, cómo trabajo histórico que es, junto con la crítica que de ellas se ha realizado y su interpretación, su eje vertebrador, permitiendo llegar a establecer las respuestas que dan por finalizada la investigación.

No podemos dejar de lamentar dos limitaciones importantes encontradas en relación con estas fuentes, por una parte la impuesta por la normativa legal que ha imposibilitado abordar el estudio completo hasta las fechas pretendidas inicialmente y por otra, a pesar de su abundancia, la limitada información, para nuestra satisfacción, que proporcionan sobre la vida real y cotidiana de la población que nos interesa y que nos deja el regusto de querer saber 
más. Ha habido muchas preguntas de las que partíamos inicialmente y otras que nos hemos ido planteando a medida que avanzábamos en el trabajo que hemos tenido necesariamente que dejar sin respuesta. Además de la referida a lo cotidiano, se echa en falta en particular más información sobre los grupos de mujeres que van apareciendo en la investigación y que rodean a los expósitos, las proveedoras de sus cuidados, las monjas que se encargaban del Hospicio, pero sobre todo las madres de los expósitos y sus nodrizas. Se trata de un grupo numeroso de mujeres, fundamentalmente del ámbito rural, aunque también del ciudadano, mujeres de provincias llegadas a la capital para trabajar o para ocultar su embarazo; desvelar sus circunstancias vitales permite comprender mejor el mundo expósito. Nos habría gustado saber más sobre las nodrizas de la Inclusa, casi todas madres de incluseros, mujeres que después de parir un hijo y alimentarle durante un tiempo tenían que ver como se lo llevaban mientras ellas se quedaban amamantando a los hijos de otras madres que se encontraban en circunstancias similares a las suyas. Sobre las nodrizas externas, saber qué las motivaba, qué aportaban al sustento económico familiar, descubrir algo más sobre el mercadeo y las especulaciones que sufrieron ellas y los expósitos y qué papel jugaron sus esposos. Y para todas en general, definir mejor su perfil, la visión social que existía de ellas y el rol social y profesional que desempeñaban.

Hemos chocado con frentes inexpugnables que no han permitido abordar el estudio desde la metodología de Género que en principio se quería utilizar y hemos tenido que conformarnos con reflexionar acerca de algunos datos o de su ausencia con el fin de visibilizar en lo posible al género femenino en estos años y en el mundo expósito. En este sentido, aunque en las referencias a pie de página se han utilizado iniciales por una cuestión de brevedad, en la bibliografía las hemos recogido con el nombre completo.

La localización de fuentes primarias documentales e iconográficas se ha realizado en el Archivo de la Diputación Provincial de Valladolid (ADPVA), el Archivo Municipal de Valladolid (AMVA), la Biblioteca Digital de Castilla y León y la Biblioteca de Castilla y León-Biblioteca Pública de Valladolid, donde se ha consultado la Hemeroteca del diario local El Norte de Castilla. También se han consultado los libros de Bautismo y de Defunciones de la Parroquia de San Nicolás a la que pertenecía el Hospicio. En las páginas web del Fondo Documental del INE se han hecho consultas en sus secciones de los Anuarios Estadísticos de España, Censos de Población y Movimiento Natural de la Población, para el periodo 1900-1930, sobre estas consultas hay que decir que se ha descubierto una errata en el Movimiento de la Población de 
1903, en el que se han cargado documentos del año 1904, que se encuentra repetido. Se ha comunicado al INE por correo electrónico en el año 2015 y nos ha respondido dándose por enterado, pero a fecha de hoy no se ha corregido. Se han utilizado además entrevistas personales a personas nacidas antes de 1935 de la provincia de Valladolid, como fuente de información directa o fuentes orales.

Se intentan localizar fuentes en otros archivos locales y vía Internet, sin éxito. En cuanto a los archivos locales tanto en el Archivo Histórico Provincial de Valladolid (AHPVA) como en el Archivo Diocesano me remiten al ADPVA para las fechas que abarca el estudio. Se ha hecho una búsqueda en la web de los Archivos de Castilla y León en el "Buscador de fondos documentales $^{\prime \prime 67}$ utilizando como palabras clave: hospicio, orfanato, inclusa, casa-cuna, expósito huérfano y nodriza sin resultados válidos. En el AHPVA para los términos Diputación y beneficencia aparece únicamente la documentación sobre la Junta Provincial de Beneficencia de Valladolid, que se descarta para consulta ya que en el período que contempla el estudio era una entidad dependiente del Ministerio de la Gobernación que funcionaba al margen de la Diputación para "gestionar las fundaciones sin patronos", por tanto sin relación directa con el Hospicio Provincial de Valladolid ${ }^{68}$.

La búsqueda iconográfica ha sido muy frustrante por infructuosa, apenas hay documentos gráficos sobre el Hospicio de Valladolid para la época estudiada, salvo unas pocas fotografías sin datar que se conservan en el ADPVA y alguna aislada en el AMVA, la Fundación Joaquín Díaz y fuentes impresas como El Financiero Hispano Americano. Extraordinario Valladolid. Año 1911 y alguna otra publicación sobre Valladolid.

La búsqueda de fuentes primarias documentales se ha centrado fundamentalmente en el Archivo de la Diputación Provincial de Valladolid (ADPVA) donde se consulta la documentación disponible sobre el Hospicio Provincial de Valladolid concretamente sobre su departamento de Menores para el período 1900- 1930 y documentos relacionados. Se solicitaron los permisos pertinentes para la consulta y realización de fotografías, que se concedieron de acuerdo a la limitación temporal fijada por la normativa legal sobre protección de datos en Castilla y León. En virtud de la Ley 6/1991 de 19 de abril de Archivos y Patrimonio

\footnotetext{
${ }^{67}$ Disponible actualmente a fecha de abril de 2017 en: http://www.archivoscastillayleon.jcyl.es/web/jcyl/ArchivosCastillaYLeon/es/Plantilla66y33/1284336673042/_/_ ${ }^{68}$ Las Juntas Provinciales de Beneficencia se crearon en virtud de la Ley General de Beneficencia de 1849 para "el control e inspección tanto en la gestión de los establecimientos públicos como de las actuaciones, bienes y recursos de las instituciones benéficas de fundación particular. ...fueron suprimidas en 1868, pasando sus funciones a las Diputaciones y se volvieron a crear en 1873... se encarga de gestionar las fundaciones sin patronos...". Junta Provincial de Beneficencia, Reseña. AHPVA.

http://www.archivoscastillayleon.jcyl.es/web/jcyl/ArchivosCastillaYLeon/es/Plantilla100DetalleFeed/125386140135 5/FichaISAD/1259394842613/Archivo
} 
Documental de Castilla y León y normativa de desarrollo, Articulo 21, sólo se han podido consultar documentos con datos personales con una antigüedad superior a 100 años, mientras que en la normativa nacional el límite es de 50 años $^{69}$

"La consulta pública de los documentos que integren el Patrimonio Documental de Castilla y León conservados en los archivos públicos y privados de uso público se regirá por las siguientes normas: ...

b) Cuando los documentos, contengan información de cualquier índole cuyo conocimiento puede afectar a la seguridad de las personas físicas, a la averiguación de los delitos, a su honor, a la intimidad de su vida privada y familiar o a su propia imagen, no podrán ser consultados públicamente sin que medie consentimiento expreso de los afectados o hasta que hayan transcurrido cincuenta años desde su fallecimiento, si la fecha es conocida, o, en caso contrario, cien años a partir de la fecha de los documentos."

Como sea que la mayor parte de la documentación conservada refiere datos de índole personal, esta Ley ha limitado la consulta de este tipo de documentos hasta el año 1913, procediéndose al vaciado sistemático de fuentes disponibles en el Archivo de la Diputación Provincial de Valladolid en su sección Acogida de Menores para el periodo 1900-1913, ampliado hasta 1930 en documentos impersonales sin limitación legal de consulta. Se han revisado 71 libros de Registro, 24 expedientes, 5 carpetas, más planos, cartas y documentos sueltos; a los que hay que añadir documentos impersonales sin limitación legal de consulta como los presupuestos generales de la Diputación de todo el período desde 1900 hasta 1930. La pretensión es obtener una visión lo más amplia y certera sobre las cuestiones relacionadas con los cuidados que los lactantes recibían en la Inclusa provincial en este periodo.

\footnotetext{
69 Ley 6/1991, de 19 de abril, de Archivos y Patrimonio Documental de Castilla y León, publicada en el BOCYL no 91/1991 el 15 de mayo de 1991 y en el BOE no 134/1991el 5 de junio de 1991. Disponible en: http://www.boe.es/boe/dias/1991/06/05/pdfs/A18316-18321.pdf La Ley 16/1985 del 25 de junio de 1985 del Patrimonio Histórico Español en su Artículo 57 dice:

"c. Los documentos que contengan datos personales de carácter policial, procesal, clínico o de cualquier otra índole que puedan afectar a la seguridad de las personas, a su honor, a la intimidad de su vida privada y familiar y a su propia imagen, no podrán ser públicamente consultados sin que medie consentimiento expreso de los afectados o hasta que haya transcurrido un plazo de veinticinco años desde su muerte, si su fecha es conocida o, en otro caso, de cincuenta años, a partir de la fecha de los documentos.

Según se recoge en Sentencia 38/2013, de 14 de febrero de 2013 del Tribunal Constitucional sobre el Recurso de inconstitucionalidad 2081-2005. Interpuesto por el Presidente del Gobierno de la Nación en relación con el artículo único de la Ley de las Cortes de Castilla y León 7/2004, de 22 de diciembre, que da nueva redacción al art. 47 de la Ley 6/1991, de 19 de abril, de archivos y patrimonio documental de Castilla y León publicada en el BOE» núm. 61, de 12 de marzo de 2013 los Archivos Provinciales son de titularidad estatal y los Archivos de las Diputaciones Provinciales son de titularidad autonómica.

"Por lo que se refiere a las competencias de la Comunidad Autónoma de Castilla y León en materia de archivos, su Estatuto de Autonomía estableció en el art. 32.1 .13 que tiene competencia exclusiva en materia de "museos, bibliotecas, hemerotecas, archivos y otros centros culturales y de depósito de interés para la Comunidad y que no sean de titularidad estatal».
} 
Para sorpresa y satisfacción personal, en la primera visita al ADPVA su Jefe de Servicio advierte que es la primera vez que en este archivo se investiga el tema que ocupa esta tesis y que se consulta la mayoría de la documentación que se va a manejar. Sin duda este ha sido un aliciente importante para esta investigación, además de comprobar, tras la consulta bibliográfica necesaria para situar y referenciar el tema, que no existe ningún trabajo similar sobre la Inclusa de Valladolid y que, aunque hay muchos estudios sobre expósitos e inclusas españoles, muy pocos se sitúan en el marco temporal elegido para este trabajo, por lo que se va a aportar información nueva para ampliar el conocimiento sobre estos establecimientos en la España de las primeras décadas del siglo XX.

Dada la variedad y cantidad de la documentación consultada en el ADPVA se ha dedicado un capítulo aparte a su análisis.

En el AMVA se hace la búsqueda en la web disponible para fondos documentales, en las bases de datos "HISTÓRICO" y "FOTOGRAFÍAS 70 utilizando como palabras clave: hospicio, inclusa y diputación y sobre los resultados se hace una selección de 9 documentos de interés por su temática y fecha, además de algunas fotografías del Hospicio, aunque solamente una de ellas corresponde al período de estudio.

Se consulta además la hemeroteca de El Norte de Castilla en la Biblioteca de Castilla y León-Biblioteca pública de Valladolid, ubicada precisamente en el edificio que fuera el Hospicio Provincial de Valladolid, el palacio de los condes de Benavente. Cuando se inicia la consulta todavía no se había completado la digitalización del diario y se encontraba microfilmado, por lo que se hace una búsqueda diaria a partir del 1 de enero de 1900 con un lector de microfilm. Es un sistema lento y muy laborioso que exige la inversión de mucho tiempo, pero que permite localizar asuntos interesantes que de otra manera habrían pasado desapercibidos; además del tiempo y el esfuerzo invertido tiene el inconveniente de que con frecuencia la lectura es muy dificultosa. Se hace una búsqueda lo más ágil posible por titulares relacionados con hospicio, infancia, infanticidio, pediatría, expósito, huérfano, nodrizas, sanidad, salubridad, epidemias y vacunas; la biblioteca proporciona fotocopias de las secciones que puedan ser de interés, aunque tampoco siempre se consiguen con suficiente nitidez.

70 http://www.valladolid.es/es/temas/hacemos/fondos-documentales-acceso-bases-datos/acceso-bases-datoscolecciones-documentales 
Finalmente se puede completar con la consulta de la hemeroteca digital de El Norte de Castilla en el AMVA para el período 1895-1931, en la que se hacen búsquedas por fecha, sobre cuestiones de interés detectadas con el sistema anterior que resultan de difícil lectura, aunque no siempre se obtiene el resultado deseado, y por palabras clave utilizando los términos: hospicio, inclusa, expósito, huérfano, infancia, infanticidio, pediatría, nodriza, epidemia, salubridad, higiene, sanidad y vacunas. Solamente para hospicio se localizan 2.837 entradas. Al tratarse de documentos escaneados cuyo original podía no encontrarse en buen estado, no siempre se localizan los términos de búsqueda, por lo que los dos sistemas se han complementado mutuamente. El Archivo proporciona en PDF las páginas de interés solicitadas. El Norte de Castilla era el periódico local más importante de la época, con la ventaja de que es el único que actualmente está digitalizado; su consulta se ha considerado suficiente por su relevancia.

Finalmente, para complementar la información obtenida del análisis de la documentación y para poder comparar y valorar adecuadamente los cuidados en la Inclusa y la situación de los expósitos que se criaban fuera de ella, me pareció de interés conocer cómo se cuidaba a los lactantes en la época de estudio y en la provincia de Valladolid, suponiendo que se compartirían mentalidad y costumbres, salvando las diferencias sociales, en un mismo entorno geográfico y temporal en aspectos como la alimentación, el vestido o los cuidados higiénico-sanitarios.

No sería correcto analizar la información conseguida solamente desde la mentalidad y conocimientos actuales, podríamos caer en una crítica inmerecidamente injusta. Lo más fácil habría sido recurrir simplemente a la documentación existente sobre el tema, pero prefería ceñirme al entorno de la provincia de Valladolid ya que en la época había usos y tradiciones locales que podían ser muy diferentes de unos lugares a otros, por lo que me pareció más interesante recoger testimonios vividos directamente. Me planteé por tanto la utilización de fuentes orales, realizando entrevistas a personas que pudieran dar información de primera mano sobre cómo se criaban los lactantes por entonces, sabiendo de la dificultad que supone el tiempo transcurrido y la edad que necesariamente deberían tener los entrevistados. Se diseñó una entrevista abierta dirigida preferentemente a mujeres nacidas antes de 1935; a mujeres porque tradicionalmente son las que han cuidado a los niños y podían ofrecer más información, como de hecho se ha comprobado, aunque no se han descartado hombres que han participado y han aportado también testimonios importantes (ANEXO 10). Así mismo se 
han considerado las aportaciones que han hecho algunas personas de menor edad desde los recuerdos "oídos" en su entorno familiar y social. A los entrevistados se les ha solicitado que cuenten lo que recuerden sobre la crianza de los lactantes, ya sean hermanos, familiares o vecinos, cuando ellos eran pequeños. Pasé personalmente la entrevista primero a 5 personas para validarla y corregir fallos y posteriormente la planteé como una tarea dentro de la asignatura de Enfermería en la Infancia y la Adolescencia de la Facultad de Enfermería de la Universidad de Valladolid en el primer semestre de 2014. Se dio la opción de realizar la entrevista individualmente o en grupos de dos o tres estudiantes como máximo, en total eran 137 matriculados en la asignatura. Se entregaron 69 entrevistas, la mayoría realizadas a personas del entorno familiar o social de los estudiantes y alguna en residencias de la tercera edad, se descartaron de entrada 6 porque el lugar de crianza estaba muy alejado de la provincia de Valladolid. La mayoría de las entrevistas se realizaron a un solo entrevistado, hay 14 que son grupales y que resultan enriquecedoras porque el grupo refuerza y corrige los recuerdos individuales. La principal dificultad ha sido precisamente la edad de los participantes por los problemas de lucidez mental frecuentes en la vejez, que obligan a descartar los testimonios, y por la posible confusión y mezcla de recuerdos; con frecuencia los entrevistados combinan los de su niñez con los que tienen sobre la crianza de sus propios hijos. Se ha comparado y valorado la información obtenida y descartado cuando han surgido dudas respecto a su fiabilidad.

Como se ha dicho, la fuente principal de este trabajo es la documentación sobre la Inclusa conservada en el ADPVA. La información sobre los expósitos se encuentra repartida entre unos pocos expedientes personales y los numerosos libros de registro que utilizaba el Hospicio, de Entradas y Salidas de Menores, de Maternidad y de Amas y sobre todo en los llamados Libros de Exposiciones, dos por cada año con un promedio anual de 430 folios.

Para recoger y gestionar la ingente información que ofrecen los libros para los 14 años de consulta legalmente permitida sobre los expósitos y sus nodrizas, se han empleado hojas de cálculo de Excel, por su sencillez de manejo, porque admiten un número ilimitado de campos y sobre todo porque permiten hacer modificaciones sobre la marcha añadiendo otros nuevos cuando es conveniente; además de ofrecer la posibilidad de elaborar gráficos a partir de los datos. Se han utilizado dos tipos de tablas para recoger los datos anuales sobre los expósitos.

La primera más sencilla y de manejo más ágil contiene los campos siguientes: 


\begin{tabular}{|l|l|l|l|}
\hline No de folio & Sexo & Vía de Entrada & Edad \\
\hline Horas de vida (torno) & Legitimidad & Mes de Ingreso & Hora de Exposición \\
\hline Localidad de origen & Lactancia/Destete & Salida para crianza & Edad salida \\
\hline Estancia en Inclusa & № de Amas externas & Devuelto a familia & Prohijamiento \\
\hline Fallece (en asilo/fuera) & Edad defunción & Mes defunción & Causa \\
\hline Observaciones & & & \\
\hline
\end{tabular}

La segunda, ampliada, recoge además los siguientes datos:

\begin{tabular}{|l|l|l|l|}
\hline 1을 Apellido & 2을 & Nombre & $\begin{array}{l}\text { Fecha de nacimiento } \\
\text { (completa) }\end{array}$ \\
\hline $\begin{array}{l}\text { Fecha de ingreso } \\
\text { (completa) }\end{array}$ & Torno: Nota & Torno: Ropa & $\begin{array}{l}\text { Bautizado (Si/en } \\
\text { Asilo) }\end{array}$ \\
\hline Lactancia (Ama/Madre) & Alta: Óbito/Crianza & $\begin{array}{l}\text { Salida: Fecha } \\
\text { completa }\end{array}$ & $\begin{array}{l}\text { Fecha de defunción } \\
\text { (completa) }\end{array}$ \\
\hline $\begin{array}{l}\text { Origen de los apellidos } \\
\text { (padres/nota/asilo/pueblo) }\end{array}$ & Localidad madre & Edad madre & Devuelto a la Inclusa \\
\hline
\end{tabular}

Se elabora otra tabla para recoger la información de cada año sobre las nodrizas internas y externas en la que se incluye los siguientes datos:

\begin{tabular}{|c|c|c|c|}
\hline Nodrizas Internas: & $\underline{\text { Niño }}$ & $\underline{\text { Nodrizas Externas }}$ & $\begin{array}{l}\text { Devuelto a } \\
\text { madre/familia: Fecha }\end{array}$ \\
\hline Nombre & Nombre & № de nodrizas & $\begin{array}{l}\text { Fallece en pueblo: } \\
\text { Fecha }\end{array}$ \\
\hline Madre (si/no) & № folio del niño & Nombre 1a & Prohijado \\
\hline Inicio lactancia & Edad ingreso & Localidad $1 \underline{a}$ & Devolución Fechas \\
\hline Fin lactancia & $\begin{array}{l}\text { Causa fin lactancia } \\
\text { (Sale/Fallece/Madre) }\end{array}$ & Nombre 2 a (y otras) & Vuelve a salir: Fecha \\
\hline Duración & Edad fin lactancia & Localidad $2^{a}$ (y otras) & Fallece en asilo: Fecha \\
\hline
\end{tabular}

Se elaboran tablas para cada año estudiado y luego tablas finales por campos para analizar y comparar los datos de todos los años y obtener valores globales y disgregados por categorías. Con la misma aplicación Excel se realizan los gráficos que acompañan el trabajo en un intento de hacer más visual la abundante información que en ocasiones manejamos. 


\section{OBJETIVOS}

Este trabajo se quiere centrar principalmente, como dice su título, en el estudio de los lactantes de la Inclusa del Hospicio Provincial de Valladolid en las primeras décadas del siglo $\mathrm{XX}$, describir los cuidados que recibían, el tipo de alimentación, primordial siempre y especialmente en esta edad, pero además todos los cuidados en general, desde un punto de vista enfermero. Hablar de cuidados es hablar de enfermería, cuidar es la esencia de esta profesión, cuidar en el más amplio sentido de la palabra, con un enfoque holístico que abarca aspectos biológicos, sociales, psicológicos, culturales y espirituales.

A partir de este planteamiento general, y con ese sentido global e integrador, se pretende conocer sus orígenes, quiénes eran y de dónde procedían, cómo llegaban a la Inclusa y por qué, cómo se les recibía y qué tipo de atención se les prestaba desde su llegada. En el tipo de atención interesan tanto los cuidados que atienden a sus necesidades físicas, las que tienen que ver con la subsistencia y la salud, alimentación, higiene, vestido o asistencia de tipo sanitario, como a las psíquicas y espirituales, afecto, identidad, religión. Por tratarse de lactantes no incluimos la necesidad de educación, aspecto estudiado ampliamente en algunos trabajos de corte educativo existentes sobre el Hospicio ${ }^{71}$.

Conocer el entorno en que se tenían que desenvolver desde su entrada a la Inclusa es también importante para descubrir y entender sus condiciones de vida, eso incluye conocer no solo el medio físico, sino, sobre todo el humano, particularmente a las mujeres proveedoras directas de su cuidado, porque no pueden ser sino mujeres sus cuidadoras. En este sentido necesariamente tenemos que estudiar el mundo de las nodrizas, cuidadoras de los niños, dentro y fuera de la Inclusa. El nodrizaje es un tema íntimamente unido al de la alimentación y cuidado de los expósitos, que este trabajo quiere abordar de forma lo más amplia posible. Conocer la procedencia de las nodrizas, sus características, condiciones de vida, las exigencias de su contrato con la Inclusa y su implicación en la crianza de los expósitos, niños que no olvidemos, se encontraban bajo la tutela de una institución pública que debía garantizar su bienestar.

Interesa conocer todas sus vicisitudes de vida y eso incluye su muerte. Un aspecto importante en el estudio de los expósitos es el de su mortalidad; en este trabajo se pretende

\footnotetext{
${ }^{71}$ CANO GONZÁLEZ R.: La Diputación Provincial de Valladolid: campos de asistencia educativa y establecimientos dedicados a la infancia (1812-1900). Madrid. UNED. 1994; CANO GONZÁLEZ R., REVUELTA GUERRERO C.: Educación y enseñanza en la Casa Hospicio de la Diputación Provincial de Valladolid (1723- 1900). Badajoz. 2007
} 
determinar la de los niños de la Inclusa Provincial de Valladolid y sus causas y analizarla lo más detalladamente posible. Queremos establecer cuántos, cómo, cuándo, dónde y por qué morían; conocer sus coeficientes y valorarla en relación con distintos factores como el sexo, la edad, la estancia en la Inclusa o la ilegitimidad. Pretende este trabajo determinar las causas especificas de la mortalidad pocas veces analizadas en este tipo de estudios ${ }^{72}$, compaginando los criterios médicos de la época con los actuales.

Aunque el planteamiento inicial iba dirigido a los lactantes y a las tres primeras décadas del siglo XX, como dice el título, se ha tenido que corregir sobre la marcha en función de las necesidades de investigación que han ido surgiendo y sobre todo de las limitaciones que se han encontrado, principalmente en relación con la obtención de información. La primera importante de tipo legal, la limitación temporal. Sin perder de vista el periodo predeterminado, poder consultar solamente hasta el año 1913 ha sido un inconveniente pero seguramente también una ventaja. Esta limitación me ha permitido hacer un estudio mucho más profundo, que es probable que no hubiera podido hacer de forma tan intensa de haber conseguido acceder a todo el período. Lo que se ha perdido en amplitud temporal se ha ganado sin duda en profundidad.

Sin perder de vista que el centro de atención de este trabajo son los más pequeños, los lactantes, no he podido eludir el interés, ni tampoco he querido evitar recoger información, sobre el siguiente grupo de edad, ya que los departamentos de lactancia y de menores hasta 5 años estaban unidos administrativamente y muchas veces los documentos consultados no los diferencian. Pero, sobre todo, esta información no se ha rechazado y se ha buscado por su valor en cuestiones como la relacionada con la mortalidad de esta población. Por otra parte, siendo estrictos con el término, la división que se hacía en la Inclusa suponía que los niños menores de dos años, que desde el punto de vista pediátrico consideramos todavía en el grupo de edad que llamamos del lactante, se repartían entre los dos departamentos.

Teniendo en cuenta la importancia que tienen las mujeres en el cuidado de los niños y muy especialmente de los lactantes, nos proponemos conocer lo más posible sobre las mujeres relacionadas con los expósitos, madres y nodrizas. Se ha recogido toda la información disponible sobre ellas, lamentablemente muy escasa pero tan interesante que ha planteado preguntas que no se han podido resolver en su totalidad, me hubiera gustado poder definir mejor el perfil de estas mujeres, pero los datos sobre ellas casi siempre se pueden ver solo entre líneas. Lo que me falta lo dejo como una cuestión pendiente de estudio por su interés.

\footnotetext{
72 REVUELTA EUGERCIOS B.A.: op.cit., pp 420- 421
} 
Capítulo 1

\section{FUENTES DOCUMENTALES: FONDOS DEL ARCHIVO DE LA DIPUTACIÓN PROVINCIAL DE VALLADOLID SOBRE LA ACOGIDA DE MENORES}

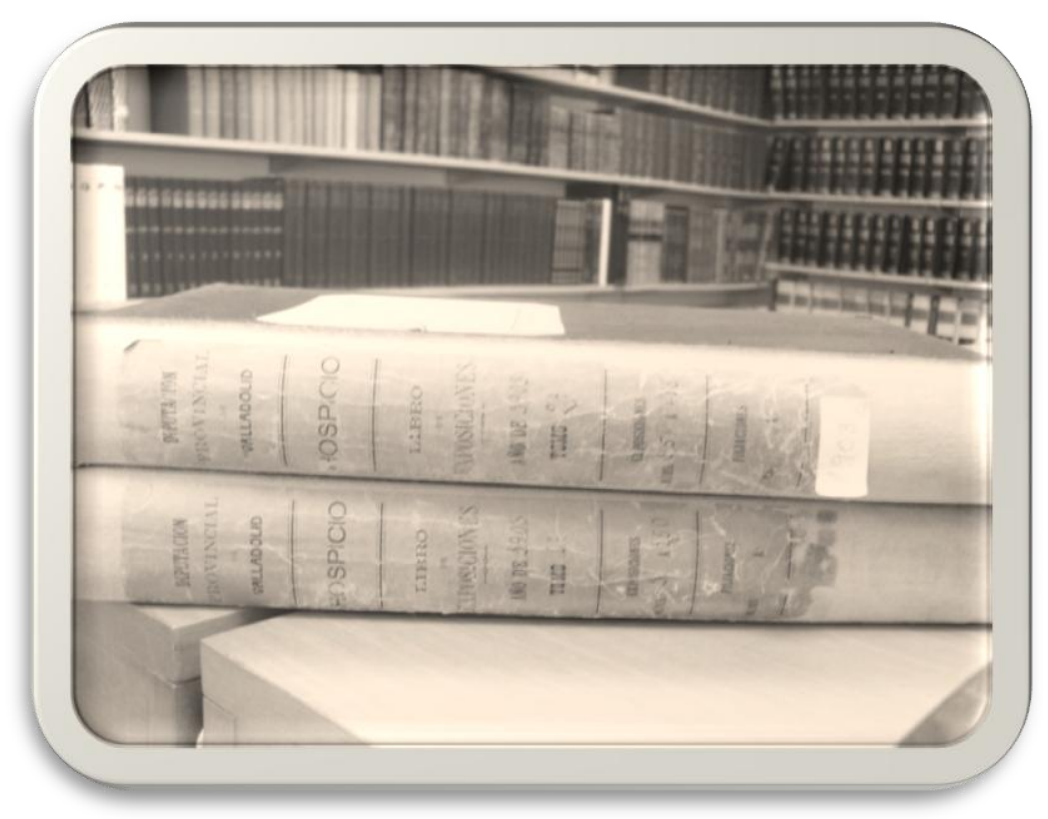

Imagen 1-1: Libros de Exposiciones. Sala de consulta del Archivo de la Diputación Provincial de Valladolid. 


\section{ÍNDICE DEL CAPÍTULO}

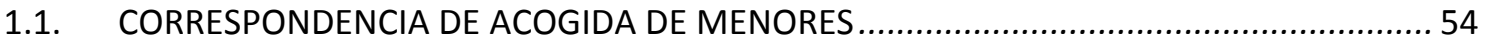

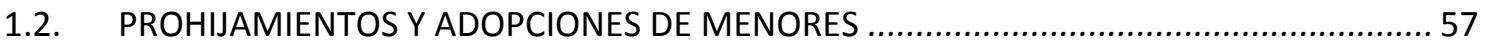

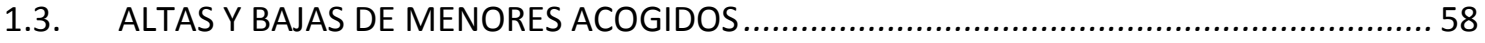

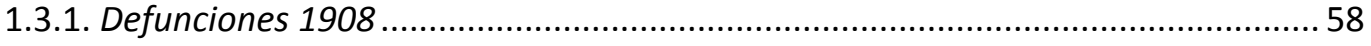

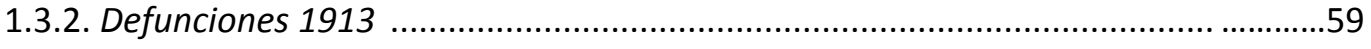

1.4. LIBROS DE REGISTRO DE ENTRADAS DE MENORES ACOGIDOS................................... 59

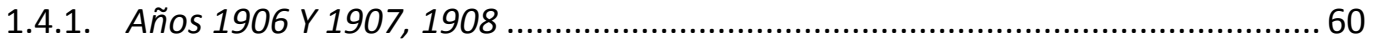

1.4.2. Entradas y Salidas de los niños de la Inclusa Años de 190919101911. Inclusa Niños Dbre 1911 Año 1912 Año 1913 Fin................................................................62

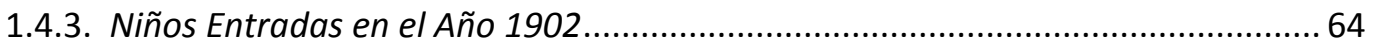

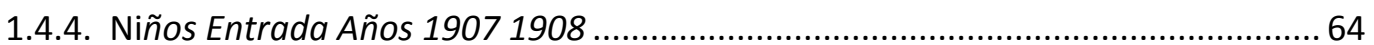

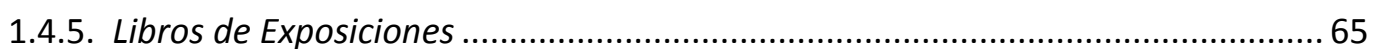

1.5. LIBROS DE REGISTRO DE SALIDA DE MENORES ACOGIDOS .......................................... 80

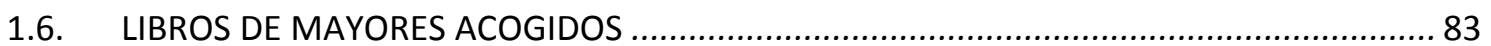

1.7. REGISTROS DE MATERNIDAD DE LOS CENTROS DE ACOGIDA DE MENORES ................ 88

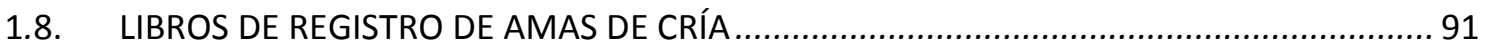

1.8.1. Libros de Cuentas con las Amas Externas...................................................................91

1.8.2. Registro Especial de Cartillas de Lactancia y Destete Años 1910,

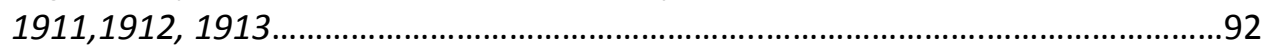

1.8.3. Justificantes de Pago por Crianza Externa ………...................................................93

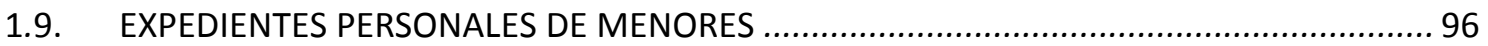

1.10. REGISTROS DE EXISTENCIAS DE LOS CENTROS DE ACOGIDA DE MENORES ................. 103

1.11. COMUNICACIONES E INFORMES DE ACOGIDA DE MENORES …................................ 1145

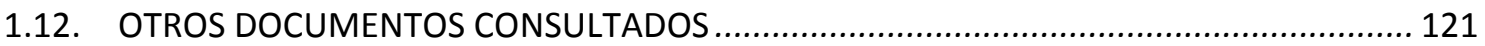




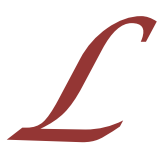

a investigación se ha centrado principalmente en el Archivo de la Diputación Provincial de Valladolid ${ }^{73}$ como organismo responsable del Hospicio Provincial, en el cual se encontraba la Inclusa Provincial en la época de estudio.

El Fondo del archivo dispone de 3 secciones:
a) Archivo Central
b) Obras Pías
c) Depósito de Documentación Histórica Municipal de Castroverde de Cerrato

En la sección de Obras Pías se recogen todos los fondos que pertenecían a la Real Casa de la Misericordia cuando pasó a constituir el Hospicio Provincial el 5 enero de 1847 al fusionarse con la Casa de Maternidad y la Casa de Expósitos. Por las fechas se sale del motivo de esta investigación ${ }^{74}$. Interesa para este trabajo por su contenido la sección del Archivo Central y en concreto la subsección Archivo Histórico ${ }^{75}$ en la que se recoge documentación producida entre 1807 y 1940, más alguna otra fechada hasta 1972 que se ha considerado de interés para su conservación, la restante se encuentra en el Archivo Administrativo.

Una vez solicitado y concedido el permiso para la consulta de fondos, en la primera visita el Jefe de Servicio del Archivo de la Diputación Provincial de Valladolid nos hace constar que es la primera vez que en este archivo se investiga el tema que ocupa esta tesis. Así mismo

\footnotetext{
${ }^{73}$ El Archivo de la Diputación Provincial de Valladolid está ubicado en el Centro Asistencial "Dr. Villacián" en la calle Adolfo Miaja de la Muela s/n de Valladolid

${ }^{74}$ "Entre 1786 y 1806, se agregaron a la Real Casa de la Misericordia las Obras Pías (cofradías y fundaciones) existentes en la capital y los pueblos del Arzobispado de Valladolid. Parte de los bienes agregados lo constituían sus archivos. En virtud de la Real Orden de 22 de octubre de 1846, el Consejo Provincial, en sesión del 5 de enero de 1847, acuerda fusionar la Casa de Maternidad, la Casa de Expósitos y la Casa de Misericordia en un único establecimiento que se denominaría Hospicio Provincial. De esta forma, los fondos de la Real Casa de la Misericordia y sus archivos agregados pasaron a formar parte del Archivo de la Diputación Provincial de Valladolid". Información ofrecida por el propio archivo y disponible en su página web: disponible en:

http://www.diputaciondevalladolid.es/diputacion/modulo/archivo-provincial/informacion-general/119067/

${ }^{75}$ La página Web del Archivo de la Diputación se ha modificado recientemente. La información de la subsección del Archivo Histórico, perteneciente al Archivo Central está disponible en: http://www.diputaciondevalladolid.es/diputacion/modulo/archivo-provincial/informacion-general/119065/
} 
advierte que, en virtud de la Ley 6/1991 de 19 de abril, de Archivos y Patrimonio Documental de Castilla y León y normativa de desarrollo, Articulo 21, la documentación que contenga datos personales sólo podrá ser consultada si tiene una antigüedad superior a 100 años $^{76}$.

"La consulta pública de los documentos que integren el Patrimonio Documental de Castilla y León conservados en los archivos públicos y privados de uso público se regirá por las siguientes normas: ...

b) Cuando los documentos, contengan información de cualquier índole cuyo conocimiento puede afectar a la seguridad de las personas físicas, a la averiguación de los delitos, a su honor, a la intimidad de su vida privada y familiar o a su propia imagen, no podrán ser consultados públicamente sin que medie consentimiento expreso de los afectados o hasta que hayan transcurrido cincuenta años desde su fallecimiento, si la fecha es conocida, o, en caso contrario, cien años a partir de la fecha de los documentos."

El acceso a este tipo de fondos siempre está legalmente restringido, ya que afecta al derecho a la intimidad, el honor y la propia imagen, derecho reconocido por la Constitución Española de 1978 en su art. 18.1 y a nivel internacional por la Declaración Universal de los Derechos Humanos de 1948 o el Convenio Europeo de los Derechos Humanos de Roma de 1950. La ley de Patrimonio de 1985 restringe la consulta pública de este tipo de documentos, siempre que no exista consentimiento de las personas afectadas, a un período de 25 años a partir del fallecimiento del interesado o de 50 años desde la fecha de creación del documento en cuestión, pero los Archivos de la Diputación son de titularidad autonómica y por tanto, competencia de la Comunidad Autónoma de Castilla y León ${ }^{77}$. La gran mayoría de la documentación consultada refiere datos de índole personal, por lo que la normativa autonómica ha limitado la consulta de estos documentos hasta el año 1913.

\footnotetext{
76 Ley 6/1991, de 19 de abril, de Archivos y Patrimonio Documental de Castilla y León, publicada en el BOCYL no 91/1991 el 15 de mayo de 1991 y en el BOE no 134/1991el 5 de junio de 1991. Disponible en: http://www.boe.es/boe/dias/1991/06/05/pdfs/A18316-18321.pdf

77 La Ley 16/1985 del 25 de junio de 1985 del Patrimonio Histórico Español en su Artículo 57 dice:

"c. Los documentos que contengan datos personales de carácter policial, procesal, clínico o de cualquier otra índole que puedan afectar a la seguridad de las personas, a su honor, a la intimidad de su vida privada y familiar y a su propia imagen, no podrán ser públicamente consultados sin que medie consentimiento expreso de los afectados o hasta que haya transcurrido un plazo de veinticinco años desde su muerte, si su fecha es conocida o, en otro caso, de cincuenta años, a partir de la fecha de los documentos.

Según se recoge en Sentencia 38/2013, de 14 de febrero de 2013 del Tribunal Constitucional sobre el Recurso de Inconstitucionalidad 2081-2005, interpuesto por el Presidente del Gobierno de la Nación en relación con el artículo único de la Ley de las Cortes de Castilla y León 7/2004, de 22 de diciembre, que da nueva redacción al art. 47 de la Ley 6/1991, de 19 de abril, de archivos y patrimonio documental de Castilla y León publicada en el BOE» núm. 61, de 12 de marzo de 2013, los Archivos Provinciales son de titularidad estatal y los Archivos de las Diputaciones Provinciales son de titularidad autonómica.

"Por lo que se refiere a las competencias de la Comunidad Autónoma de Castilla y León en materia de archivos, su Estatuto de Autonomía estableció en el art. 32.1.13 que tiene competencia exclusiva en materia de "museos, bibliotecas, hemerotecas, archivos y otros centros culturales y de depósito de interés para la Comunidad y que no sean de titularidad estatal».
} 
La documentación del Archivo de la Diputación Provincial de Valladolid perteneciente al Hospicio Provincial para la época de estudio se encuentra en la subsección Archivo Histórico en la sección de Bienestar Social. Según el listado proporcionado por el propio archivo al comienzo de la investigación, con el que se ha trabajado para este estudio, en la serie 2.1. Acción Social se encuentra catalogada la siguiente documentación ${ }^{78}$ :

2.1.2. Acogida de menores: incluye 19 series:

2.1.2.1 Correspondencia de acogida de menores

2.1.2.2 Comunicaciones e informes de acogida de menores

2.1.2.3 Libros de registro de entradas de menores acogidos

2.1.2.4 Altas y bajas de menores acogidos

2.1.2.5 Expedientes personales de menores

2.1.2.6 Prohijamientos y adopciones de menores

2.1.2.7 Partes de movimiento de menores

2.1.2.8 Tribunales

2.1.2.9 Libros de registro de cartillas de ahorro de menores acogidos

2.1.2.10 Expedientes de devolución de cartillas de ahorro a menores acogidos

2.1.2.11 Becas a menores acogidos

2.1.2.12 Libros de registro de amas de cría

2.1.2.13 Expedientes de actividades y talleres de los centros de acogida de menores

2.1.2.14 Actas de los órganos de gobierno de los centros de acogida de menores

2.1.2.15 Registros de existencias de los centros de acogida de menores

2.1.2.16 Registros de visitas de los centros de acogida de menores

2.1.2.17 Registros de maternidad de los centros de acogida de menores

2.1.2.18 Libros de registro de salida de menores acogidos

2.1.2.19 Libros de mayores acogidos

Se descarta la consulta de algunas series, como las referidas a becas y a cartillas de ahorro de los menores que no tratan asuntos relacionados con la crianza de los lactantes, tema de esta tesis.

\footnotetext{
78 Se registran aquí las secciones según el listado que proporcionó al comienzo de la investigación el propio Archivo, que es el que se ha manejado durante la investigación. Es más amplio y el código de las series no coincide exactamente con el que figura actualmente en los catálogos de la subsección de Bienestar Social del Archivo Histórico y del Archivo Administrativo de la Diputación que están disponibles en las nuevas páginas web del Archivo.
} 
En algunas series no se encuentran documentos de la época de estudio. Los documentos que se incluyen en la serie TRIBUNALES están fechados a partir del año 1970, las ACTAS DE LOS ÓRGANOS DE GOBIERNO DE LOS CENTROS DE ACOGIDA DE MENORES Se conservan desde el año 1980 y los REGISTROS DE VISITAS DE LOS CENTROS DE ACOGIDA DE MENORES tienen fecha posterior a 1965. La serie PARTES DE MOVIMIENTO DE MENORES sólo contiene dos registros que corresponden a un libro de $1884-88$, anterior a la época de estudio, y otro de 1918, fuera del tiempo permitido por ley para consulta.

\subsection{Correspondencia de acogida de MENORES}

Es una serie que contiene cinco carpetas, pero solamente una corresponde a la época de estudio. Se trata de una carpeta ${ }^{79}$ que contiene una serie de cartas con su correspondiente respuesta; salvo una de ellas que es personal y va dirigida a una de las Hermanas de la Caridad, el resto es correo oficial. Están escritas en papel con membrete del organismo emisor, en un folio doblado y en su interior se encuentra la respuesta en lo que parece un borrador de la misma. La mayoría es correspondencia entre el arquitecto provincial, o su ayudante, el director del Hospicio, la Comisión de la Diputación y el Gobierno Civil referente a obras que hay que acometer en el asilo y sobre las que se presenta el presupuesto, se solicita aprobación y se comunica la decisión de la Comisión. Son 15 cartas que van de febrero de 1902 a mayo de 1905 y que ponen de manifiesto el mal estado del edificio y su falta de acondicionamiento. En correspondencia de febrero de 1902 se comunica el desplome del techo de la zona de la enfermería y se aprueban las obras necesarias. En agosto de 1903 se aprueba el presupuesto para apuntalar y arreglar una columna del patio. Se solicita material para abrir una puerta a las Moreras (enero 1902), aprobación para realizar arreglos en las habitaciones del capellán y el director del asilo (febrero- octubre 1902) y en las cocinas de los asilados (marzo 1904). Encontramos además correspondencia sobre arreglos en el alcantarillado (enero 1902), construcción de un pabellón nuevo y construcción y arreglos de retretes, lavatorios y baños e instalación de inodoros que no existen para los asilados, todo ello en 1904. El 10 de octubre de 1904 el ayudante del arquitecto provincial escribe:

\footnotetext{
${ }^{79}$ Signatura: caja 2449, expediente 30481
} 
"Próximas á terminarse las obras que se ejecutan en el Hospicio provincial con destino a lavatorios, cuartos de baño y otras dependencias, tengo el honor de exponer a V.E.la aprobación de un presupuesto por cantidad de 1750 pesetas para colocación de cañerías de conducción de aguas como complemento de dichas obras" [sic]

La comisión aprueba el día 24 de octubre el presupuesto de obra tras el informe de los visitadores que se envían al Hospicio:

"Los visitadores... tienen el honor de informar que las obras que se indican son de absoluta necesidad... siendo de urgencia la ejecucion de las mismas por razon de higiene" [sic]

En la carpeta se encuentra también correspondencia sobre tres asuntos relacionados con la escuela del asilo. Hay una carta fechada en 1884 que comunica el inicio de las clases nocturnas de adultos, otra del 5 de marzo de 1903 en la que el Gobernador pide la relación de los niños que asisten a las escuelas del Hospicio para elaborar el censo escolar y una solicitud del maestro del Hospicio en octubre de 1901 de material escolar. Esta carta del maestro resulta interesante, primero porque en ella hace una relación de todo el material que se necesita; se conservan los documentos de todo el proceso, aprobación de la Comisión tras el informe de los visitadores, conforme en la misma nota y carta al gobernador civil para comunicarle el acuerdo. En segundo lugar porque dentro de ella se encuentra un pliego doblado de la escuela etiquetado como "Libro de matrícula y clasificación" que en su cara interna a doble página contiene una tabla para anotar los datos y el expediente escolar de los niños escolarizados. Las columnas recogen nombre del niño y localidad de origen, nombre y oficio de los padres, fecha de entrada y salida de la escuela y del centro. Bajo el epígrafe "Clases generales de la Enseñanza" se incluyen cinco columnas tituladas Doctrina Cristiana e Historia Sagrada, Lectura, Escritura, Aritmética, Gramática y hay dos más sin etiquetar; en cada una de ellas incluyen a su vez 8 columnas que corresponden a las Secciones numeradas desde la $1 \stackrel{a}{a}$ a la $8 \stackrel{a}{a}$.

Además de esta correspondencia, lo más interesante para este trabajo son dos cartas fechadas el 6 de febrero de 1906 y dirigidas a los párrocos de Corrales del Vino y de Cantalejo solicitando información sobre los asilados que se encuentran en su localidad. Se trata de un folio plegado que tiene impresa una plantilla con el texto de la carta y en la que sólo hay que rellenar la fecha y la localidad.

"Siendo de imprescindible necesidad para esta Dirección conocer el estado y situación en que se hallan los asilados de este Establecimiento que por cualquiera causa se autorizara su salida, he de merecer de V., en bien del servicio benéfico, se sirva manifestarme el que tengan los niños que en esa localidad residan; esperando de su celo me informe á la mayor brevedad de 
cualquier incidente que ocurra, lo cual recibiré con la mayor reserva, agradeciéndole en nombre de la Excelentísima Diputación cuantos datos me facilite.

Dios guarde a V. muchos años Valladolid a.

Sr Cura párroco de. " [sic]

En la cara interna del folio hay una tabla de cuatro columnas para los datos a rellenar con las etiquetas:

$$
\begin{aligned}
& \text { "Nombre de la Nodriza" } \\
& \text { "Idem del Niño" } \\
& \text { "Vive" } \\
& \text { "Falleció y en qué dia". }
\end{aligned}
$$
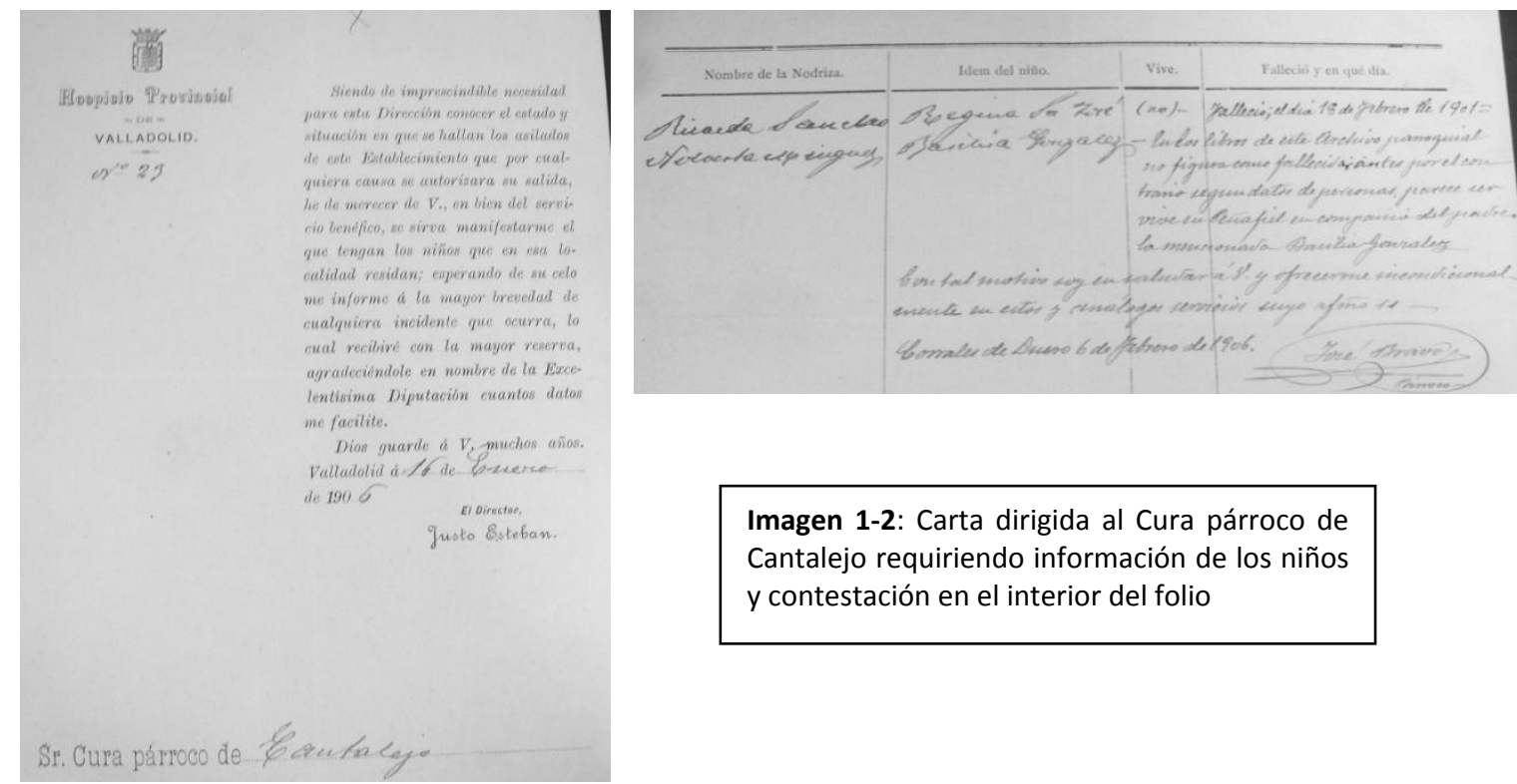

Imagen 1-2: Carta dirigida al Cura párroco de Cantalejo requiriendo información de los niños y contestación en el interior del folio

Las dos cartas contienen la respuesta, muy escueta, de los párrocos. En Corrales del Vino, de los dos niños acogidos uno falleció en 1901 y el otro "según datos de personas, parece ser vive en Peñafiel en compañía del padre". En Cantalejo se refieren 6 niños, en 5 se escribe "vive" y en uno "se ignora por no tener noticias de ello". En estos informes no se dice nada acerca del estado en que se encuentran los niños, por lo que es de suponer que realmente estos controles sólo servirían para constatar que el niño seguía con el ama que está cobrando por la crianza. Por lo que podemos comprobar por estas cartas, no parece que el control de los niños ni de las amas fuera muy eficaz. En algunas inscripciones de los libros de registro de menores encontramos anotaciones en las que después de años se averigua que el niño ha fallecido o que ha cambiado de ama o ha vuelto con los padres. Por ejemplo en el folio 449 de 1909:

"En abril de 1916, remitio el Sr Juez de dicho pueblo (Villanueva de Duero) Certificación del RC en que consta que falleció en 9 febrero 1910" [sic] 


\subsection{Protijamientos yadopciones de MENORES}

Esta sección contiene más de 200 documentos, pero sólo uno corresponde a la época de estudio, del año 1918, y no se puede consultar por la limitación de acceso (menos de 100 años) impuesta por la Ley 6/1991 de Archivos y Patrimonio Documental de Castilla y León. El primer documento recogido data de $1621^{80}$. Se trata de una escritura pública de prohijamiento, es un documento que tiene impresa una plantilla con espacios para rellenar algunos campos como el nombre de los interesados. El más próximo en el tiempo a nuestro estudio es un documento de $1877^{81}$ en el que un mesonero solicita una niña de 14 a 16 años para criada y que se transcribe aquí íntegramente porque hace referencia a una actuación que va a continuar en el tiempo y que persiste en la época de interés, en la que los niños alojados en el orfanato a partir de cierta edad son cedidos al servicio de personas que lo solicitan.

"Sr. Presidente de la Diputación Provincial de Valladolid

Agapito Velasco de estado casado y de oficio mesonero á V.S. como mejor proceda expone: Siendome preciso una criada para los oficios propios de su sexo, he creido conveniente dirigirme á $V$. S. con el fin si es posible el concederme sacar una joven de catorce o diez y seis años del hospicio con el fin ya expresado.

A V.S. suplica se digne concederme dicha petición que no dudo alcanzar de esa gran vondad y rectitud que le caracteriza á V.S.

Dios $g^{u}$ á V. S. muchos años para bien de sus administrados.

San Miguel del Arroyo á 27 d Mayo de 1877" [sic]

En otros libros del período estudiado encontramos registros que demuestran que efectivamente este procedimiento se mantiene y se solicitan niñas y niños para compañía, para el servicio doméstico o para realizar distintos trabajos. El orfanato establece el salario que cobran cuando trabajan. Como ejemplo, en el Libro de mayores acogidos 1906-1911 en el folio 96 encontramos una anotación hecha en 1916 referente a un muchacho que en esas fechas contaba con 16 años:

"En 1o de Agosto de 1918 [sic], cumpliendo orden del Sr Vicepresidente de la Comisión provincial, fue entregado para destinarle al comercio a Don Aniceto García Ruiz, vecino de Castrojeriz (Burgos)..."

\footnotetext{
${ }^{80}$ Signatura: caja 2449, expediente 30489

${ }^{81}$ Signatura: caja 2449, expediente 30492
} 
$Y$ en el mismo libro en el folio 93 se entrega un muchacho de 18 años, que unos meses después, en octubre, reingresa en el asilo y en el mismo día se le concede la emancipación a petición propia, no constando su destino posterior.

“En 17 de Junio de 1920, cumpliendo orden del Sr Vicepresidente de la Comisión provincial del dia de hoy fue entregado para dedicarle a la labranza a Eulogio Gallego Salinero, labrador, vecino de Peñafiel firmando esta diligencia en prueba de conformidad" [sic]

\subsection{Altas y bajas de menores acogidos}

Es una serie que conserva libros de defunciones; sólo dos se pueden consultar y corresponden uno al periodo 1908-1910 y otro al año 1913.

1.3.1. El libro “DEFUNCIONES $1908^{\prime \prime 2}$ recoge las órdenes de enterramiento de los niños fallecidos en el Hospicio firmadas por el capellán. Los folios del libro están impresos por las dos caras con una plantilla que se rellena con la fecha de la orden; el nombre y la edad del niño; la localidad de origen y el nombre de los padres si se conoce, de lo contrario se pone hijo de padres desconocidos; la fecha, hora y causa del fallecimiento según el certificado médico de

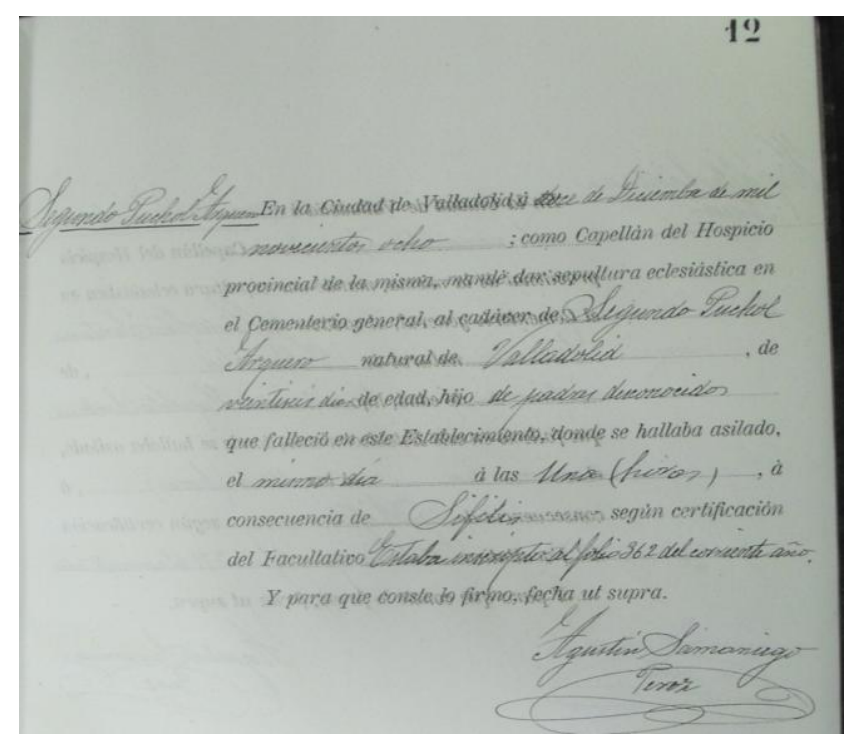

Imagen 1-3: Página del libro Defunciones 1908, folio no 12

\footnotetext{
${ }^{82}$ Signatura: caja 1225. expediente 7757
} 
defunción y el año y el folio del libro de registro de entradas en que está inscrito. En el margen izquierdo, mucho más amplio, se escribe el nombre del niño para hacerlo más visible. Están numerados los folios, no las páginas, y se recogen registros desde el 22 de octubre de 1908 hasta el 29 de junio de 1910, en total hay 210 folios, 420 registros, alguno anulado mediante un sello, aunque no se hace constar la causa de la anulación, son registros que están incompletos, probablemente se trata de errores.

Se comprueba, comparando los libros, que los datos coinciden, salvo excepciones que pueden ser errores de transcripción, con los registros del Libro de defunciones 1906-1909, que por su aspecto debía ser el que se rellenaba en la Inclusa para pasar después la información a la oficina administrativa del Hospicio.

1.3.2. El libro "DEFUNCIONES 1913" ${ }^{83}$ está todo él manuscrito y recoge de forma

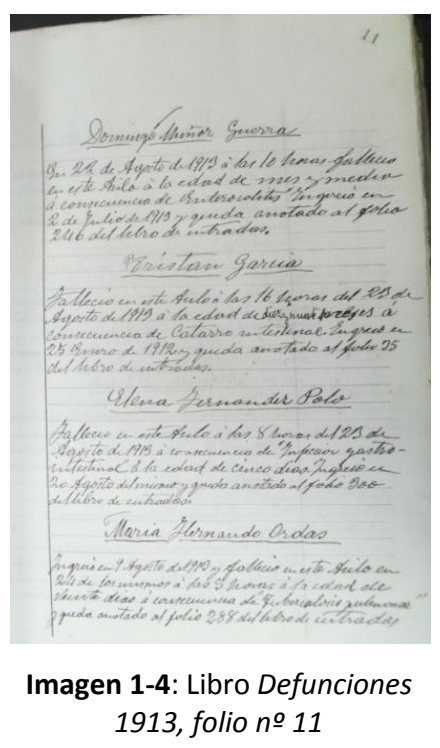

1913, folio no 11 consecutiva y por orden cronológico los fallecimientos en el asilo desde el 8 de junio hasta el 12 de octubre de 1913, como consta en la etiqueta de la portada. Están numerados los folios, pero se escribe por las dos caras. Se anotan sólo los datos básicos de los niños fallecidos: nombre, edad, fecha, hora y causa del fallecimiento, fecha del ingreso en el asilo y folio y libro donde está inscrito:

"Elena Fernandez Polo. Fallecio en este Asilo a las 8 horas del 23 de Agosto de 1913 a consecuencia de «Infeccion Gastrointestinal». Ingreso en 20 Agosto del mismo y queda anotado al folio 300 del libro de entradas" [sic]

\section{4.}

\section{LIBROS DE REGISTRO DE ENTRADAS DE MENORES ACOGIDOS.}

Esta serie conserva 169 libros, el primero, cronológicamente, de 1840 y el último de 1985. La mayoría corresponden a los denominados por el Hospicio Libros de Exposiciones, de los que

\footnotetext{
83 Signatura: caja 1201, expediente 7672
} 
encontramos hasta 1889 un tomo por año y a partir de 1890 y hasta 1939 , inclusive, dos tomos anuales.

A partir de 1939 los archivos conservados tienen continuidad hasta 1971, con dos libros de 1940 y 1941 respectivamente, uno para el período 1942- 49, siete del 1950 al 67 y un libro de 1950 a 1971; finalmente se encuentra otro de 1984-5.

Hay otros nueve libros sin descripción en el catálogo, cuatro desde 1915 a 1927 y cinco anteriores de registros de entradas y salidas y con un aspecto que hace pensar que no se trataba de libros oficiales, pues carecen de pólizas, sellos y firmas, y que podían ser utilizados para control en el departamento de la Inclusa; los datos que recogen estos libros se encuentran también en los de Exposiciones, que seguramente estarían en la oficina del Hospicio. En la documentación del orfanato consultada vamos a encontrarnos con la misma información repetida en libros diferentes. Entre estos libros, hay uno descrito en el catálogo del Archivo como "Defunciones" y en cuya portada en una etiqueta del Hospicio solamente pone "Años 1906 y 1907 1908" [sic]. A pesar de la descripción del Archivo se trata de un libro de registro de entradas y salidas que recoge las fechas de ingreso y de salida de los niños, del fallecimiento y del nombre de la nodriza encargada del niño en la Inclusa. Los libros etiquetados por el Hospicio como "Entradas y Salidas de los Niños de la Inclusa Años de 1909 1910 1911" e "Inclusa Niños Dbre 1911 Año 1912 Año 1913 Fin" tienen características similares. Los otros dos libros están etiquetados como "Niños Entradas en el Año 1902" y “Niños Entrada Años 1907 1908" y son parecidos en su contenido a los Libros de Exposiciones.

Al tratarse de libros con información personal sólo se pueden consultar los tomos de 1900 a 1913, Se consultan todos ellos, en total treinta y un libros: los dos tomos anuales de los Libros de Exposiciones de todos los años y los otros cinco de registros de entradas y salidas mencionados anteriormente. Los cinco son libros similares en su estructura y contenido y que no parecen oficiales porque carecen de pólizas, sellos y firmas.

1.4.1. El libro "AÑOS 1906 Y 1907, 1908" ${ }^{\prime 84}$ contiene registros desde el 11 de septiembre de 1906 hasta el 19 de enero de 1909 y está todo él escrito a mano, incluida la tabla en la que se recogen los datos. Los folios están sin numerar y se escribe por las dos caras. En cada página se encuentra una tabla con siete columnas, en la parte superior se escribe en el centro el año y sobre la primera columna el mes.

\footnotetext{
${ }^{84}$ Signatura: caja 1213, expediente 7736
} 
La primera columna de la tabla se titula "Espo" en unas hojas y "Esposi" en otras y en ella se anota en cada fila un número que parece corresponder al día del mes. Esta etiqueta debe referirse a Exposición porque se ha podido comprobar por los Libros de Expósitos que el número coincide con la fecha de ingreso del niño en la Inclusa. En algunas filas, hay escrito lo que parecen iniciales o abreviaturas. Los registros en los que solamente consta el día del mes se puede comprobar que se corresponden con niños expuestos en el torno o que ingresan a través de la dirección del asilo. Las iniciales parece que hacen referencia al lugar de procedencia del niño, como también se ha podido constatar en los Libros de Expósitos.

"SG": son las iniciales de Sala General, que se refiere a la sala de Maternidad de la Inclusa donde daban a luz las mujeres acogidas.

" $R^{\text {do": }}$ aparece en niños que se ha podido comprobar en los libros de expósitos que nacieron dentro del establecimiento y cuya madre figura en ellos como "refugiada en el asilo". Suponemos que significa "reservado/a" y que se refiere a una parte de la sala de maternidad. En el libro de la Maternidad de 1863, en un apartado denominado "Sala" se encuentran dos tipos de anotaciones "General", que también figura como "Gräl", y "Reservada" o "Res"da". Así mismo, en la memoria de "Niños ingresados en el Hospicio Provincial para su lactancia durante el año 1905" encontramos que se contabilizan las mujeres ingresadas en la maternidad "En sala reservada" y en la Memoria de 1908 se diferencia las mujeres ingresadas en la Sala General y en la que aquí llama la "Sala Particular".

" $H$ ": hace referencia al Hospital provincial de la Resurrección y " $\boldsymbol{M}^{\text {mo" }}$ al manicomio, como también podemos comprobar con los libros de registro de expósitos.

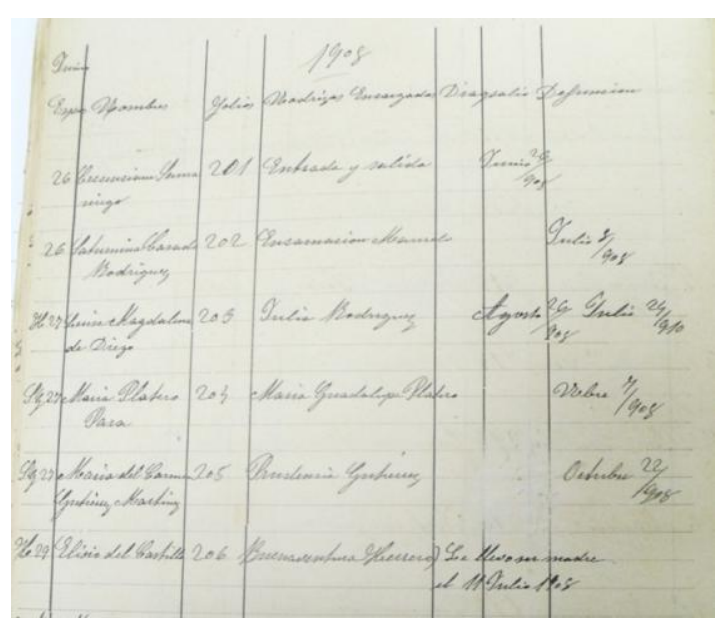


En la segunda columna, "Nombres", se recogen los nombres completos de los niños con los dos apellidos, normalmente, y en algunos por debajo y entre paréntesis se ha escrito" (confirmado...)" con la fecha en que ocurrió.

En la tercera columna se registra el número del "Folio" que ocupan los niños en el Libro de Exposiciones, de registro de entradas de menores.

La cuarta columna, "Nodrizas Encargadas" se utiliza para anotar el nombre de la nodriza que amamanta al niño dentro de la Inclusa. Se detecta que algunas nodrizas que aparecen aquí no se encuentran en los libros de Registro de Entradas, puede ser que en algún momento se hiciera un cambio no registrado en los libros o puede deberse a un error de transcripción, ya que los mismos datos se van registrando en varios sitios. En los niños que por edad no necesitan lactancia, y que por tanto no requieren ama de cría, se anota "Destete" y en algunos que no permanecen en el asilo se anota "Entrada y salida" cuando se produce en el mismo día, como en el registro que corresponde al folio 201 de 1908.

Las dos últimas se etiquetan como "Dia que salió" [sic], para anotar el día en que el niño sale de la Inclusa con un ama externa y "Defunción", para registrar la fecha del fallecimiento dentro de la Inclusa, no se anota en los niños que fallecen fuera del asilo. Cuando aparece la fecha en las dos columnas quiere decir que el niño en algún momento fue devuelto al asilo y falleció en él. Cuando un niño se entrega a sus padres se hace constar en el registro.

1.4.2. Los libros etiquetados como "ENTRADAS Y SALIDAS DE LOS NIÑOS DE LA INCLUSA AÑOS DE 190919101911 "স85 e "INCLUSA NIÑOS DBRE 1911 AÑO 1912 AÑO 1913 $\underline{F I N}^{86}$ son continuación del anterior, el primero abarca desde el 1 de enero de 1909 hasta el 30 de noviembre de 1911 y el segundo desde el 1 de diciembre de 1911 hasta el 29 de septiembre de 1913. Se empieza anotando en el primer libro un solo niño en cada página, pero a partir del folio 28 se anotan tres niños. Los dos libros están completos y son idénticos en su formato y similares al libro anterior pero con la tabla ya impresa con 11 columnas etiquetadas como:

- "ENTRADA" incluye las tres primeras columnas, para anotar "Año", "Mes" y "Día"

\footnotetext{
${ }^{85}$ Signatura: caja 409, expediente 3979

${ }^{86}$ Signatura: caja 441, expediente 4092
} 


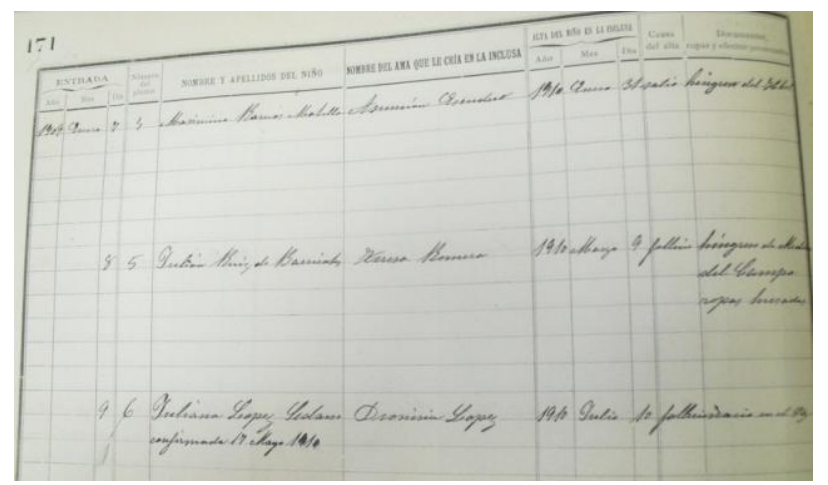

Imagen 1-6: Página 171 del libro "Entradas y salidas de los niños de la Inclusa Años de 19091910 1911"

- "Número del plomo": se anota el número del folio que ocupa el niño en el libro de Expósitos correspondiente

- "NOMBRE Y APELLIDOS DEL NIÑO"

- "NOMBRE DEL AMA QUE LE CRIA EN LA INCLUSA"

- "ALTA DEL NIÑO EN LA INCLUSA", también con columnas para "Año", "Mes" y "Día"

- "Causa del alta": se anota "Salió", para los niños que van a criarse con una nodriza externa, o "Falleció", seguido de la fecha, solamente cuando los niños fallecen en el asilo, comprobamos por los libros de Expósitos que no se registra en los niños fallecidos fuera.

- "Documentos, ropas y efectos presentados" es la última columna y en ella se registra la vía de entrada en la Inclusa y el estado de las ropas que lleva el niño al ingreso con las anotaciones "trapos", "husadas" y "en buen huso" [sic]. Para el ingreso se utilizan las anotaciones:

- "entro por el torno" [sic], en cuyo caso se registra fecha y hora

- "nacio en el SG" ó "nacio en el Rdo" [sic]. Se comprueba en los libros de Expósitos que corresponden a niños nacidos en la Maternidad del asilo por lo que deben referirse a la sala general o la reservada.

- "hingreso del $H^{\text {talı }}$ [sic] para los niños nacidos en el Hospital provincial de la Resurrección

- "entro por la dirección" ó "entro por la oficina" [sic], por los Libros de Exposiciones se comprueba que se refiere a niños que ingresan por mediación de la Diputación o el Gobierno Civil y

- cuando traen a los niños al asilo desde algún pueblo de la provincia se anota la localidad de procedencia, "hingreso de Medina del Campo" [sic]. En algunos casos esto se escribe a continuación de "entro por la dirección" [sic] porque pasan primero por la oficina con los certificados correspondientes. 
En estos libros se puede comprobar de forma sencilla la mortalidad en el asilo y el número de niños que cuidan las nodrizas internas.

1.4.3. El libro "NIÑOS ENTRADAS EN EL AÑO 1902" ${ }^{87}$ está todo él escrito a mano en hojas rayadas, en cada página se registra un niño. A diferencia de los anteriores los datos se escriben a renglón corrido y en cuanto al contenido de los registros es más completo y similar al del libro oficial de Exposiciones. Debajo de la fecha se anota el no del folio y un resumen de la inscripción con la forma de ingreso, el nombre del niño, las ropas que viste a su llegada, si es un niño del torno y lleva una nota se transcribe su contenido, el nombre de la mujer que le lacta en la Inclusa y la fecha de salida, o de fallecimiento en su caso, con el nombre de la localidad y del ama que se lo lleva. Si fallece en el asilo se anota la fecha, pero aquí no se recoge la causa, tampoco si se produce fuera del asilo con las amas. Se registra, además, si llega ya bautizado o lo fue en el asilo y, si es así, en qué fecha; este dato se ha suprimido en los libros de años posteriores y en su lugar hemos visto que se anota si el niño se ha confirmado y en qué fecha.

“Enero $4 \quad 1902$

folio 5 entro por la oficina un niño bautizado se llama Gregorio Herrero ropas trapos. Le lacta Juana Gomez fallecio el 17 Enero 1902 t" [sic]

En el tomo 1으 del Libro de Exposiciones de 1902 se recoge el registro completo

"Gregorio Herrera".

En cuatro de Enero de milnuevecientos dos, fue entregado en este Asilo por Prudencia Herrera, vecina de Brahojos de Medina, con comunicacion del Alcalde de dicha localidad, expediente de pobreza, partida de bautismo e inscripcion del Registro Civil, de dicho Brahojos de Medina, domde dice ser hijo natural de Francisca Herrera.

Bo en Brahojos de Medina en 1ㅇ de Enero de 1902.

Le lacta Juana Gomez.

Fallecio 17 Enero de 1902 á consecuencia de catarro bronquial t" [sic]

1.4.4. El libro “NIÑOS ENTRADA AÑOS 1907- $1908^{\prime 89}$ es similar al de 1902, la única diferencia es que en cada página recoge dos inscripciones. En definitiva es casi la misma información de los Libros de Exposiciones y que volvemos a encontrar más esquematizada, y fácil de consultar, en forma de tabla en el libro "Años 1906 y 1907, 1908", ya visto.

\section{"Agosto 5 Año 1908}

Folio 247 entro por la oficina una niña bautizada con el nombre de Micaela

Rodríguez Per... ropas trapos tiene un lunar grande en el muslo derecho Falleció el 6 Sbre 1908 t" [sic]

\footnotetext{
${ }^{87}$ Signatura: caja 1938, expediente 16992

${ }^{88}$ La transcripción de los apellidos es correcta, en un libro figura Herrero y en el otro Herrera

${ }^{89}$ Signatura: caja 1938, expediente 16993
} 
Libro de la Inclusa "Niños Entradas años 1907-1908”

1.4.5. LOS LIBROS DE EXPOSICIONES consultados están todos ellos encuadernados igual. En la portada tienen una etiqueta escrita a mano con el año y el tomo correspondiente, 1ㅇ o 2ㅇ, y el número de folios que contiene el libro, que se corresponde con el número de inscripciones. En el lomo tienen impreso el lema: DIPUTACIÓN PROVINCIAL - VALLADOLID HOSPICIO - LIBRO EXPOSICIONES - AÑO DE... - TOMO ... - EXPOSICIONES NÚMS ... A... FILIACIONES NÚMS ... A... estos últimos datos se completan a mano. Tienen en la parte inferior una etiqueta con el año.
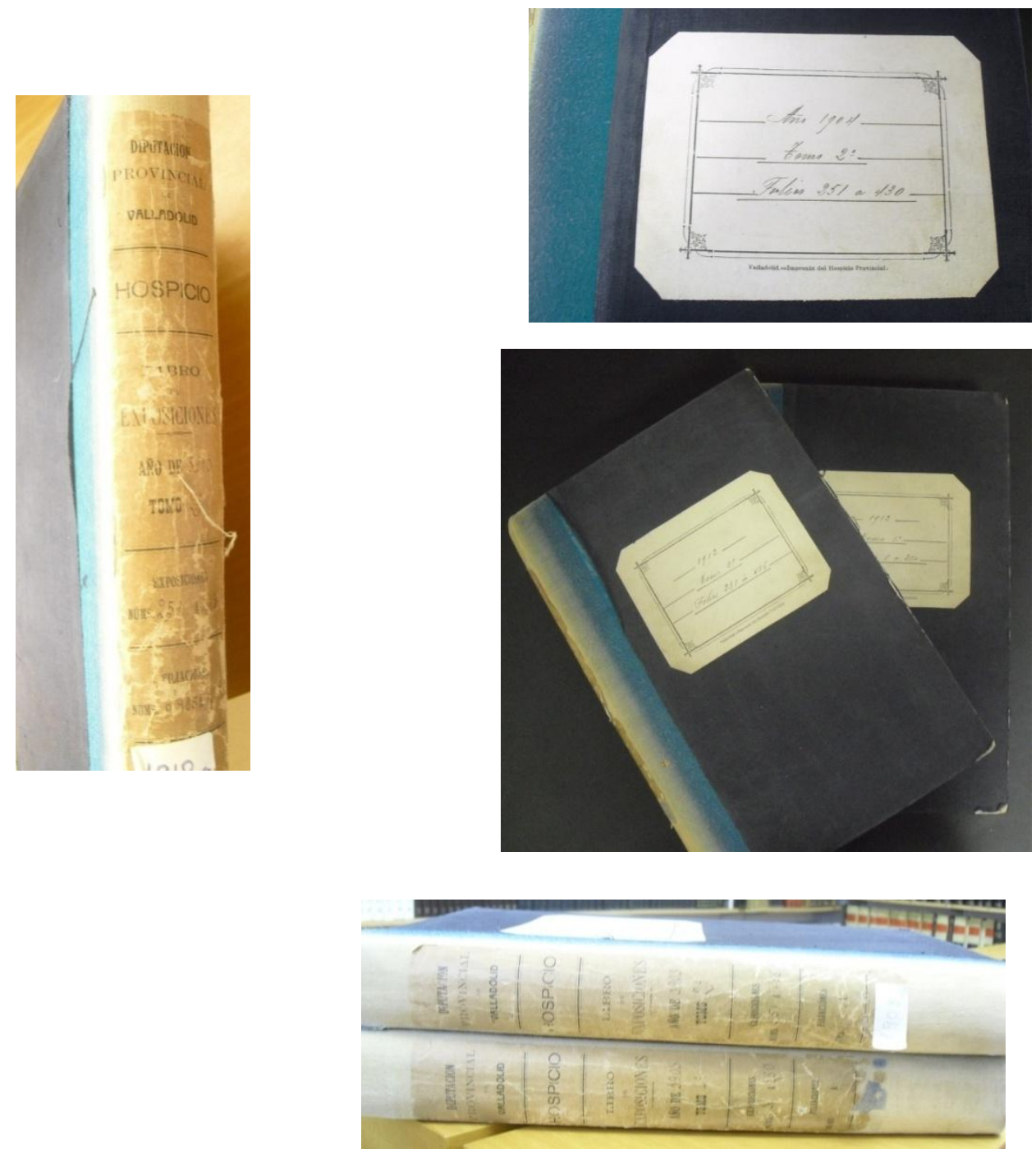

Imagen 1-7: Portadas y lomos de los Libros de Exposiciones 
Son libros que, por su aspecto, parece que tienen carácter oficial y que debían encontrarse en las oficinas del hospicio. Están formados por pliegos timbrados con pólizas del Estado de $12^{a}$ categoría de 10 céntimos, excepto los libros de 1900 que están sin timbrar. A partir de 1909 cada inscripción lleva el sello de la dirección del Hospicio y la firma del director, que no aparece anteriormente y que tampoco se encuentra en ninguno de los libros comentados anteriormente y que hemos considerado de control de la Inclusa.

Imagen 1-8: Pólizas que aparecen sucesivamente en los libros partir de 1901

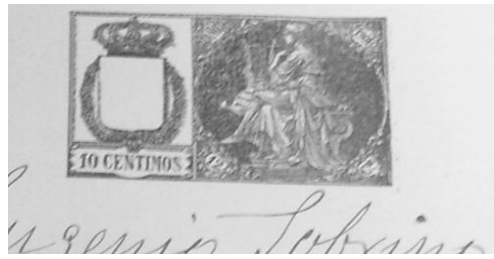

1901
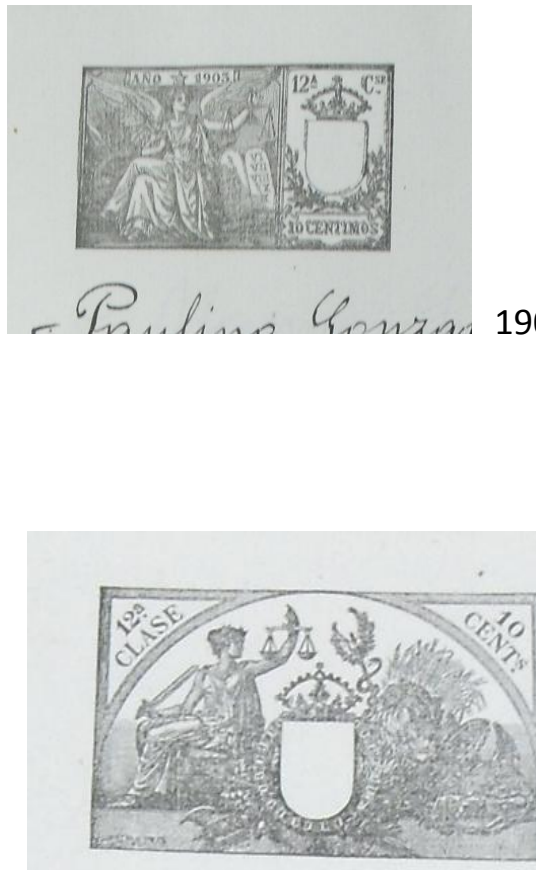

$1904-5$

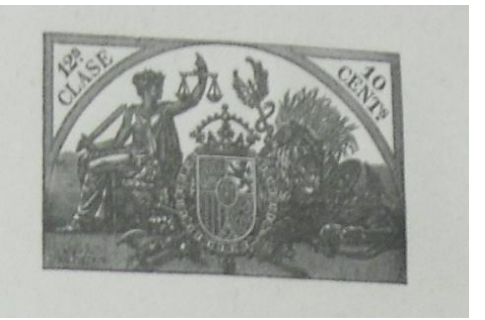

1906-09

Desde 1910

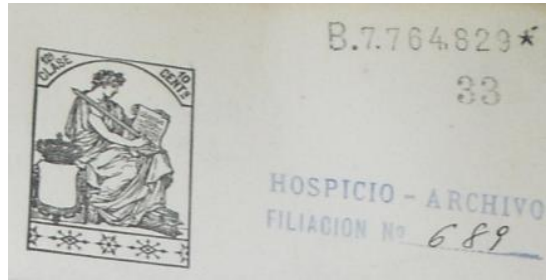




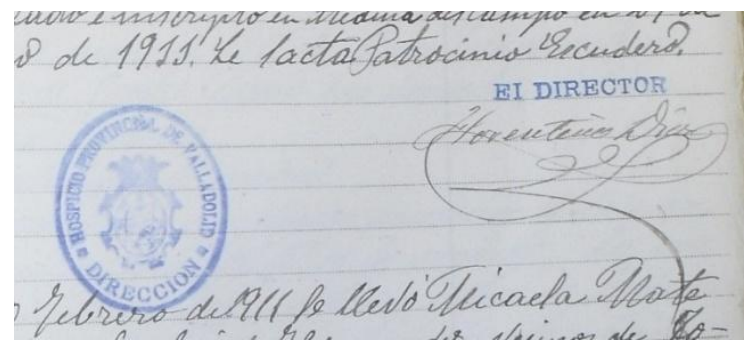

Imagen 1-9: Sello del Hospicio y firma del Director que figura en los Libros de Exposiciones a partir de 1909

Todos los Libros de Exposiciones consultados tienen el mismo formato, que se emplea también en los libros de mayores. Se ha hecho una revisión exhaustiva de todos ellos, hoja por hoja, y se han recogido los datos en una tabla de Excel elaborada para poder procesarlos.

Las primeras hojas, a modo de índice, están marcadas y ordenadas por orden alfabético. En ellas se anota el nombre completo de los niños que ingresan en la Inclusa y el número del folio en el que se encuentran inscritos dentro del libro. Se ordenan por la letra inicial del nombre de pila. Los niños fallecidos están señalizados con una " $M$ ", una " $f$ " o una cruz al margen, según el libro, aunque podemos comprobar que en muchos casos no se ha anotado, por lo que no sirve, aunque en principio podía parecerlo, para calcular la mortalidad de los asilados en la Inclusa; de todos modos, ya a simple vista nos permite hacer una valoración muy desfavorable.

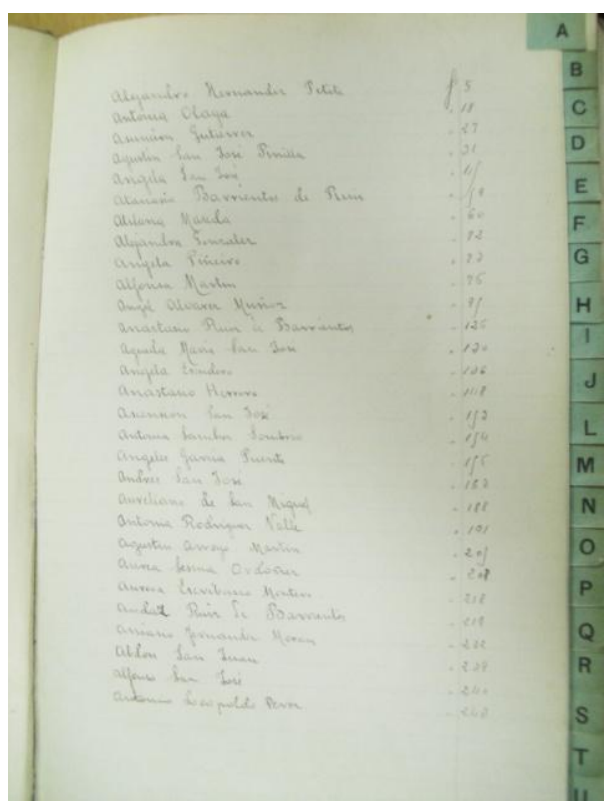

Imagen 1-10: Índices de los Libros de Exposiciones 1을 tomo de 1901 y de 1913

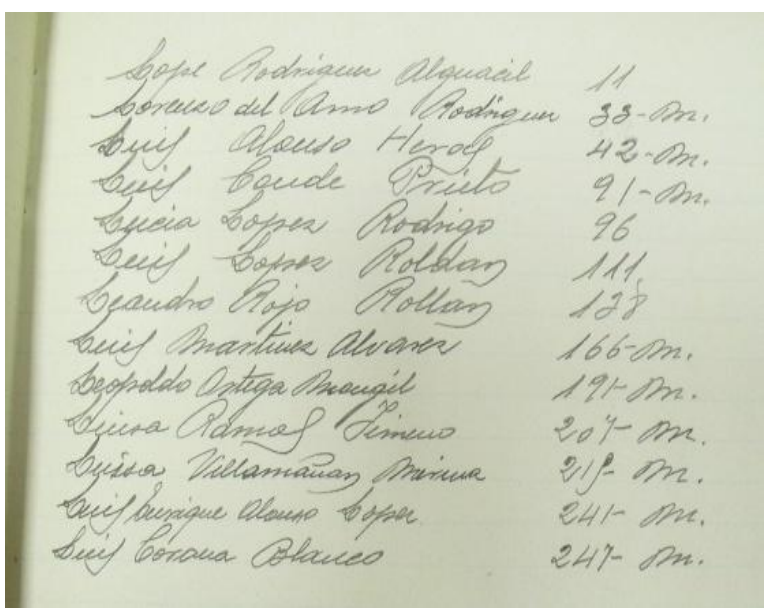

A partir del índice, se numeran todos los folios, no las páginas. En cada libro se incluyen 250 folios numerados y se utiliza uno para cada inscripción. Cada año ocupa dos tomos, el primero se completa siempre y en el segundo los folios continúan la numeración, es 
decir, empiezan a numerarse a partir del 251 y se anotan registros hasta el último día del año en curso. El número del folio y el año de exposición se recogen en todos los documentos que hacen referencia al niño.

A partir del 10 tomo de 1908 en todos los folios encontramos un sello estampado en la parte superior con el número de filiación. Este número es diferente e independiente del número del folio y constituye una serie indefinida y continua que sobrepasa los años, mientras que cada año todos los libros de expósitos empiezan por el folio no 1 y por tanto coinciden los números y es necesario añadir siempre el año cuando se utiliza esta referencia. Antes de 1908 sólo encontramos el sello con el no de filiación en algunas inscripciones aisladas, hay más sellos en cada año que avanza.

El número de filiación se supone que es personal e individual y que podría corresponder con el número del expediente personal del niño. Sin embargo, en los libros consultados no se ha encontrado un listado que permita la relación de los números de filiación con los niños a los que corresponden y hemos comprobado coincidencias de niños diferentes con un mismo número escrito, eso sí, en sellos de aspecto diferente. Quizás, por esto, en los documentos, tanto oficiales como oficiosos, referidos a los asilados siempre se recoge el folio y el año de la exposición como dato identificativo del niño; probablemente es la manera más fácil de acceder a su historial. Al revisar los expedientes personales disponibles podemos ver que, efectivamente, en todos consta en la portada de la carpeta que los contiene el no de filiación y, junto al nombre del niño, el libro (año) y no de folio.

Hay dos tipos distintos de sellos con el no de filiación y se constata que siguen numeraciones diferentes e independientes, tampoco se respeta siempre el orden en la secuencia, sobre todo en los libros de los primeros años. En los expedientes personales disponibles en el Archivo se utiliza el sello circular.

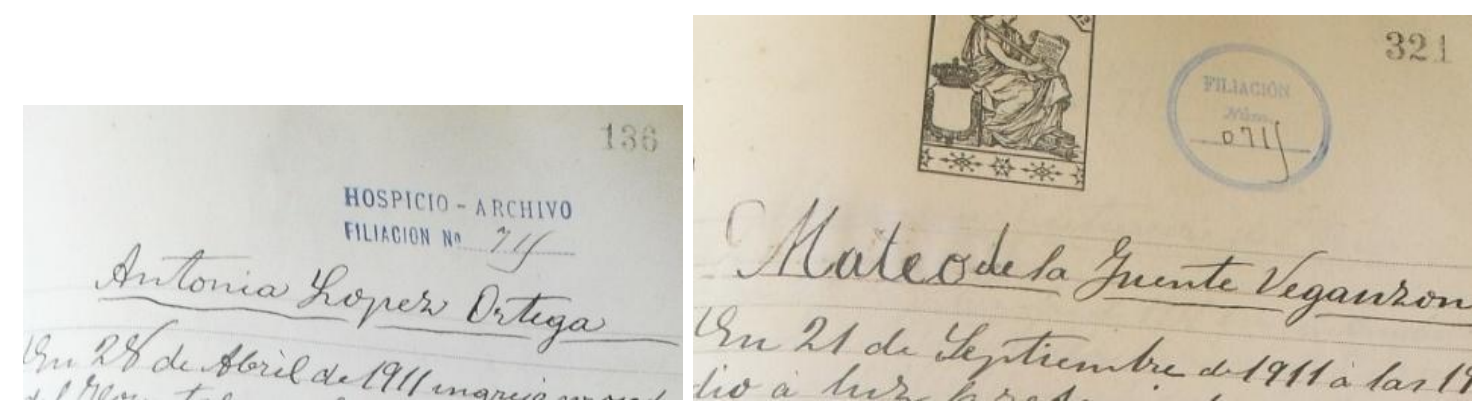

Imagen 1-11: Folios 136 y 321 de 1911 con sellos diferentes, los dos sellos tienen el mismo no de filiación, el 715

En cada folio se recoge: 
a) Nombre del niño, en el encabezado del folio. Generalmente se anotan los dos apellidos, aunque en algunos registros sólo aparece uno, debe ser el que consta en el momento del ingreso. Los niños expuestos en el torno y los nacidos en la Maternidad del Hospicio y del Hospital Provincial son bautizados en el propio asilo, aunque los del Hospital ya llegaban con la inscripción en el registro civil y por tanto con nombre. Cuando en el torno se deja una nota junto al niño con algún dato de identificación, se respeta, salvo pocas excepciones, y se mantiene el nombre y los apellidos que figuran en ella. Los niños que traen desde pueblos de la provincia vienen bautizados e inscritos en el registro civil con nombres y apellidos elegidos en la propia localidad cuando los padres son desconocidos. A los hijos ilegítimos les ponen los apellidos de la madre, incluso en algún caso en que consta el nombre del padre.

"Francisco Suarez Menendez

En 29 de enero de 1910 a las 17 horas le dio a luz la refugiada en este Hospicio Soledad Suarez Menendez.

Se dio parte al Registro Civil en 1 de febrero de 1910.

Bautizado en este Asilo en 31 de enero de 1910" [sic]

Folio o 32 del 10 libro de 1910. Falleció en el mes de mayo

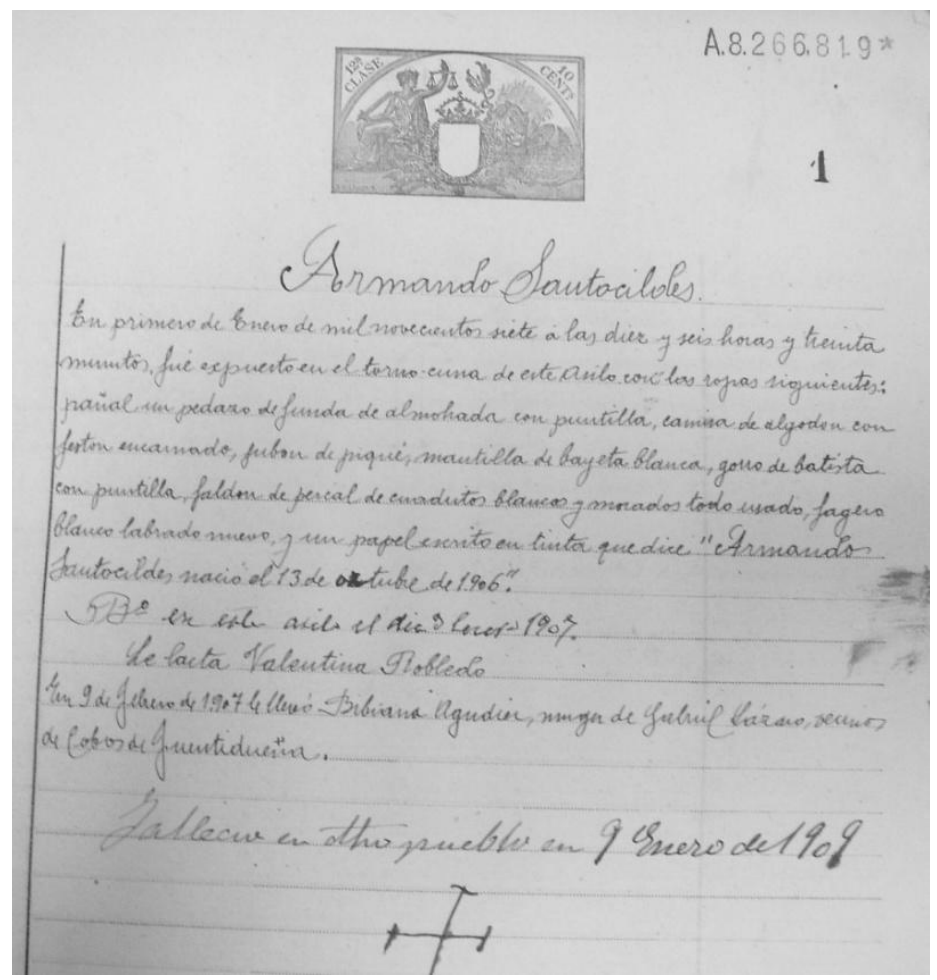

Imagen 1-12: Libro de Exposiciones de 1907, tomo 1‥ Folio no 1

b) Fecha de ingreso y vía de entrada. Después del nombre, se anota el día, la hora y la forma del ingreso. El ingreso podía hacerse por el torno, desde la Maternidad de la Inclusa o a través de la dirección del Hospicio. 
En los ingresos por el torno del asilo se registra siempre la fecha y hora de la exposición, toda la ropa y cualquier objeto que porte el niño con sus características: color, material, estado de conservación y adornos, bordados, etc; en definitiva, todo lo que pueda servir para una posible futura identificación. Cuando se deja una nota con el niño, se transcribe literalmente su contenido.

\section{"Emilio Gutiérrez Sanz}

En 6 de Enero de 1911 a las 1 y 15 minutos fue expuesto en el torno de este Hospicio con un papel que dice «Deseo que se le ponga al niño el nombre de Emilio Gutiérrez Sanz nacido el 5 de Enero de 1911 a las once de la noche= desearia le cuidasen lo mejor posible» Traia puestas las ropas siguientes, pañal de hilo, camisa de algodon con tira bordada y entredos, jubón con tira, dos gorros id mantilla de bayeta blanca, fajero labrado, toquilla de lana blanca grande, todo en buen uso" [sic]

Folio no 6 del 1ㅇ libro de 1911. Falleció en el mes de marzo.

\section{"Perfecta Torres}

En 14 de Enero de 1901 y hora de las doce y treinta minutos, fue expuesta en el torno de este Asilo con unos trapos y un papelito que dice: nació una niña lo pondrán Perfecta Torres, nació el 14 de Enero de $191^{90}$ Valladolid" [sic]

Folio no 11 del 1ㅇ libro de 1901. Falleció en el mes de agosto.

Hay algún caso en que en lugar de dejar al niño en el torno, lo entregan personalmente, "por la puerta". En el libro de la Inclusa "Niños Entradas años 1907 $1908 "$ se anota

\section{"Agosto 5}

Folio 244 entro por la puerta una niña sin bautizar la encontraron tirada á las moreras envuelta en un pañal de hilo en buen huso..." [sic]

Los niños nacidos en la Maternidad del Hospicio se dice que son hijos de "refugiadas en el asilo" y, salvo pocas excepciones, llevan los apellidos maternos, hemos de suponer que en su mayoría se trataría de mujeres solteras. De las madres, sólo se recoge en los libros, tanto de la incl Inclusa usa como de Exposiciones, el nombre sin ningún dato más, ni identificativo ni sobre su estado social:

"Maria de Lurdes Vergara

El dia 11 de febrero de 1907 a las 3 la dio a luz la refugiada en este asilo Gregoria Vergara..." [sic]

Folio no 57 del 10 libro de Exposiciones de 1907. En el libro de la Inclusa "Niños Entradas años 1907 1908" no se anota el nombre de la madre

\footnotetext{
${ }^{90}$ Transcripción literal, se refiere sin duda a 1901; teniendo en cuenta que copiaban fielmente el contenido de las notas del torno, seguramente así estaría escrito en la de este niño
} 
"Febrero 11

Folio 57 nacio en el SG (sala general de la maternidad) una niña que se la bautiza en este Establecimiento con el nombre de Maria de Lordes Vergara Vergara ..." [sic]

Los demás niños entran, según dice en los libros de la Inclusa, "por la oficina", o lo que es lo mismo, "por la dirección"; son los que ingresan a través de la Diputación, pero que podían llegar a su vez por distintas vías.

La vía de entrada reglamentaria sería mediante acuerdo de la Comisión

Provincial de la Diputación previa solicitud, en cuyo caso se disponía normalmente de todos los datos y la documentación referente al niño requerida para la tramitación del ingreso y se recoge en los registros del libro:

"Longinos Rodriguez Diez

En cinco de enero de mil novecientos siete ingresó en este asilo por acuerdo de la Comisión Provincial con partida de bautismo del Sr cura Párroco de Sn Andrés donde dice ser hijo legitimo de Enrique y de Librada..." [sic]

Folio no 5 del 10 Libro de Exposiciones de 1907. Falleció en el mes de abril "folio 5 entro por la oficina un niño bautizado con el nombre de Longinos Rodriguez Diez y nueve meses ropas trapos..." [sic]

Anotación del 5 de enero de 1907 del libro “Niños Entradas años 1907 1908”

Muchos niños ingresan por "orden del Presidente" o del Vicepresidente de la Diputación, es de suponer que se trate de una vía de urgencia para casos que no pueden esperar a la tramitación del ingreso y la reunión de la Comisión.

"En 21 de febrero de 1911 ingresó por Orden del Sr Vicepresidente de la Comisión provincial con certificación del Registro civil donde consta que nació el 11 del corriente y és hijo natural de Maxima Martinez Rebollo de 19 años de edad y domiciliada en dicha Villa de Melgar de Arriba..." [sic]

Folio no 64 del 1ㅇ Libro de Exposiciones de 1911.

De hecho, nos encontramos con algunos casos de niños que son expuestos en el torno con parte de la documentación antes de formalizar la solicitud de ingreso

"En 7 de febrero de 1909 á las 10 horas fue expuesto en el torno de este Establecimiento con un expediente incompleto de los exijidos para ingresos..."

Folio no 55 del 1ㅇ Libro de Exposiciones 1909

Así mismo, el Gobernador Civil podía solicitar, o dar la orden de ingreso, aunque era poco habitual. Tanto en esta situación como en la anterior, hasta que la Comisión provincial daba el visto bueno, se consideraban ingresos provisionales

"En 19 de Enero ingresó provísionalmente en este Asilo por orden del Sr Gobernador Civil de esta provincia en comunicacion que dice: que este niño 
nacio en esta Ciudad que tiene 3 años y que és huerfano de padre y madre. Es hermano de los que ocupan los folios 267, 268 y 269 del libro 16 de mayores..."

Folio no 30 del 1ㅇ Libro de Exposiciones 1909

También ingresaban niños desde el Hospital Provincial de la Resurrección, la mayoría eran recién nacidos entregados por sus madres, pero había casos de niños de cualquier edad que entraban en el asilo cuando la madre ingresaba y/o fallecía en el hospital y no tenían más familia o el padre no se hacía cargo de ellos. El traslado al hospicio lo hacía en los primeros años "una portera" de dicho Hospital y posteriormente la que entregaba al niño sería "una enfermera", según consta en los libros. Todos estos niños llevaban un informe del Director del Hospital comunicando la inscripción en el Registro civil y sus datos y circunstancias familiares. Curiosamente, en estos casos sí se registran en los libros los datos de la madre, incluido su estado civil, mientras que en las mujeres "refugiadas" en el Asilo no se anotaban, puede ser que constaran en otros Libros de la Maternidad.

"Tomasa Morales Alvarez

El dia 11 de febrero de 1907 fue entregada por una enfermera del Hospital Provincial de la Resurrección con papeleta del Sr Director del mismo donde dice que ha sido inscripto en el Registro civil y que es hija de Encarnacion, soltera de 24 años de edad natural de Oviedo..." [sic]

Folio no 59 del 1ㄴ Libro de Exposiciones de 1911. En el libro de la Inclusa "Niños Entradas años 1907 1908" se anota:

"Febrero 11

folio 59 entro por la oficina una niña sin bautizar hingreso del Hospital se la bautizo en este Establecimiento ..." [sic]

Los niños abandonados en los pueblos de la provincia y en los tornos de Medina del Campo y Medina de Rioseco se trasladaban a este asilo. El traslado lo hacía la mujer responsable del torno o, donde no había torno, una mujer del pueblo que entregaba al niño en la oficina con los certificados de bautismo y del Registro Civil; es por esto que en algunos libros pone para este tipo de ingresos que "entró por la oficina" o "por la dirección" pero se anota después el nombre de la localidad de origen. En el libro de Expósitos siempre se recoge el nombre de la mujer que hace la entrega, el pueblo de origen y el lugar donde el niño fue expuesto, "aparecido" como dice en algunos certificados, y que suele ser el torno en el caso de las dos Medinas y la ventana o la puerta de alguna casa en otros pueblos. En Medina del Campo los primeros años revisados hasta finales de 1902 la encargada del torno era Joaquina Vaquero, después 
pasaría a ser Isidora, de apellido Giménez, Jiménez ó Jimeno, según encontramos en distintos registros, viuda como consta en alguno de ellos, y a partir de 1911 seria Vicenta Tremiño.

"Julian Barrientos de Ruiz

El dia 18 de Marzo de 1907 fue entregado por Isidora Gimenez, vecina de Medina del Campo con partida de bautismo y certificación del Sr Juez Municipal donde dice que es hijo de padres desconocidos" [sic]

Folio no 105 del 10 Libro de Exposiciones de 1907. En el libro de la Inclusa "Niños Entradas años 1907 1908" no se anota el nombre de la mujer, pero sí las ropas que lleva el niño:

“Marzo 18 Año 1907

folio 105 entro por la oficina un niño bautizado con el nombre de Julian Barrientos de Ruiz hingreso de Medina del Campo $P^{\text {cia }}$ Valladolid de ropas trapos..."

[sic]

\section{"Antonio Ruiz Botran}

En 14 junio 1914 fue entregado por Vicenta Tremiño mujer encargada del torno de Medina del Campo con oficio del Alcalde, partida de bautismo y certificación del Registro Civil donde consta que fue expuesta en aquel torno en el dia anterior y que es hijo de padres desconocidos" [sic]

Folio no 223 del 10 libro de Exposiciones de 1912. Falleció en octubre.

La responsable de los traslados de Medina de Rioseco fue durante todos los años revisados Emilia Matobella

"Francisco Brabo

En 31 de Enero de mil novecientos le entregó en este asilo Emilia Matobella, vecina de Medina de Rioseco con partida de Bautismo e inscripción en el R.C. donde dice ser hijo de padres desconocidos" [sic]

Folio no 51 del 1은 Libro de Exposiciones de 1900.

Cuando se trata de niños abandonados en otros pueblos la entrega con frecuencia la hace la mujer de la casa en la que "apareció" al niño.

"Francisco de San Miguel Torquemada

En 3 de abril de 1909 ingreso en este Asilo siendo entregado por Francisca Val Garcia vecina de Villalón, con diligencia de la Alcaldia partida de bautismo y certificación del Sr Juez Municipal de referida Villa donde dice que este niño fue hallado en el portal de la casa de la misma que la entrega á las 8 de la noche del 1 de los corrientes y que és hijo de padres desconocidos." [sic]

Folio no 128 del 10 Libro de Exposiciones de 1909. Falleció en el mes de mayo.

c) Datos de filiación: Nombre de los padres y localidad de residencia, si se conocen en el momento del ingreso. Se anota el nombre de los dos cuando el niño es hijo legítimo, 
de lo contrario, suele escribirse solamente el nombre de la madre. Siempre que se sabe se indica si se trata de un hijo legítimo, ilegítimo o natural.

"Angela Asensio

En 4 de enero de 1904 ingreso en este Asilo por acuerdo del Sr Vicepresidente de la Comision Provincial, con partida de bautismo de Villavicencio de los Caballeros, donde dice ser hija natural de Domitila Asensio." [sic]

Folio no no 1 del 1ㅇ Libro de Exposiciones de 1904. Falleció al año siguiente

En los libros de menores revisados se puede observar que, habitualmente, solo se anotan los datos de los que tienen constancia en el momento del ingreso y, aunque puedan conseguir la filiación completa de los niños expuestos a través de la partida de bautismo o de los datos del Registro Civil, no se suelen corregir después.

"En 7 de Marzo de 1910 a las 17 horas y 30 minutos fue expuesto en el torno de este establecimiento con un papel que dice «Esta niña esta bautizada en la parroquia de San Martin y se llama Maria Esperanza Castaño Espeso= hoy 7 de marzo de 1910-(en lápiz) nació el 27 de febrero ultimo...»

Bautizada en Valladolid (San Martin) Inscripta en Valladolid (Audiencia) en 1 de Marzo de 1910" [sic]

Folio no 97 del 1ㅇ Libro de Exposiciones de 1910.

A pesar de confirmar la inscripción en el Registro Civil de la niña no se añade ningún dato sobre los padres en el libro.

Intentan confirmar si el niño ha sido bautizado y/o inscrito en el Registro Civil. En el folio de inscripción de un niño expuesto en el torno con una nota con su nombre completo, encontramos grapada una papeleta con el nombre del niño que dice

"de un mes prosimamente de edad expuesto en este torno se precisa saber dia de su nacimiento y parroquia del domicilio de su nacimiento" [sic]

Folio no 14 del 1o Libro de Exposiciones de 1913.

En un expósito que se dejó en el torno con una nota escrita por el párroco, le piden informes

"Isidoro Tomas de San Jose

En 8 de Abril de 1910 a las 9 horas y 40 minutos fue expuesto en el torno de este Asilo con un papel que dice «En la Iglesia parroquial de mi cargo fue bautizado el seis de los corrientes un niño Ilamado Isidoro = Aguilar de Campos Abril $7 / 910=$ El Parroco $=$ Ceferino Zamora $=$ rubricado. Hay un sello que dice "parroquia de Santa Maria de Aguilar de Campos»

Nota: Habiendose oficiado al Sr Cura párroco de Aguilar de Campos para que suministre mas antecedentes de este muchacho, en 12 de los corrientes contesto que este niño Isidoro tiene solo madre conocida de quien es hijo natural y se llama Placida Tomas de San Jose habiendo sido inscrito en el Registro Civil de Aguilar de Campos en concepto de hijo natural en cuatro de los corrientes" [sic] 
Folio no 133 del 10 Libro de Exposiciones de 1910.

En el libro se inscribe este niño con los apellidos de la madre, que constan en el Registro Civil. Es excepcional encontrar este tipo de anotaciones, además, como se ha dicho anteriormente, no se suelen añadir los datos de los padres, como hacen aquí con el nombre de la madre, cuando se confirman los registros oficiales.

En algunos casos sabemos algo más cuando los niños son entregados a sus padres, porque siempre se anotan los datos de la persona que recoge al niño.

Cuando ingresan varios hermanos también se hace constar en el registro y se recoge el folio donde están inscritos los otros.

"En 29 de enero de 1910 ingresó por acuerdo de la Comisión provincial y con certificación del Registro Civil donde consta que nació el dia 28 de abril de 1906 y que es hijo legitimo de Selencio y Felisa. Es hermano del que ocupa el folio anterior y el 332 y 333 del libro 16 de mayores". [sic]

Folio no 31 del 1ㅇ Libro de Exposiciones de 1910

d) Fecha del bautizo y/o de la inscripción en el Registro Civil, y localidad o parroquia en el caso de la ciudad de Valladolid. Los niños que nacen en la maternidad y los

Imagen 1-13: Folio 74 del Libro de Exposiciones de 1909. Niña expuesta en el torno, se anota la fecha del bautizo en el asilo, de la inscripción en el registro civil y el nombre de la nodriza interna. Sello de la dirección del Hospicio y firma del director

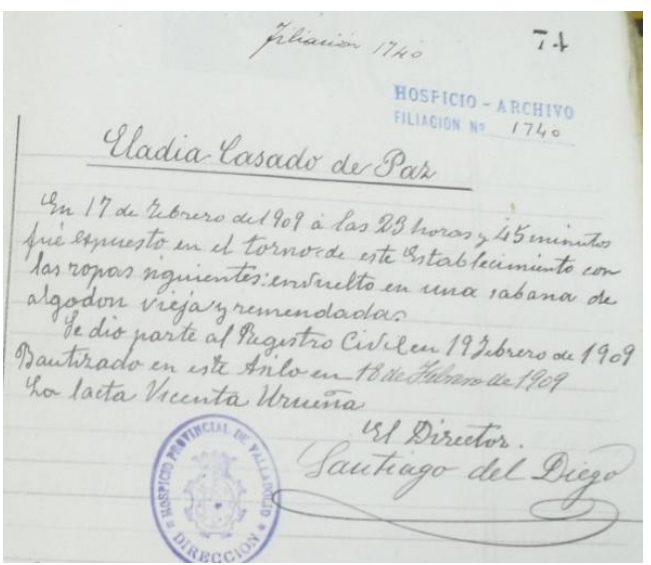

expuestos en el torno sin bautizar se bautizan en el asilo, y así se hace constar en el libro junto con la fecha en que se da parte al Registro Civil. En muchos casos, en la nota que acompaña al niño se advierte si está o no bautizado, desde el orfanato se debían hacer indagaciones para comprobarlo entre las parroquias, como vemos en la cita recogida anteriormente del folio 133 del 1ㅇ libro de 1910. También se bautiza en el asilo a los niños del Hospital, aunque éstos ya llegan inscritos en el Registro Civil.

e) Nombre de la nodriza que le lacta en la Inclusa. Los hijos de mujeres "refugiadas en el asilo" son lactados por su propia madre durante la estancia del niño en la Inclusa, Hasta 1907 en todos estos casos encontramos anotado el nombre de la mujer que 
lacta y siempre coincide con el de la madre. A partir del segundo tomo de 1907 se deja de anotar el nombre de la mujer lactante cuando se trata de una asilada, pero por los libros de registro de la Inclusa comprobamos que sigue siendo siempre la madre; de hecho, en algún registro aislado se anota y sigue coincidiendo y encontramos otros en los que en vez del nombre se ha escrito que "Le lacta la madre" como en el folio 157 de 1908 ó el 206 de 1909.

Cuando al ingreso el niño ya no está lactando en ocasiones se indica Destete, pero normalmente en estos libros no se anota nada, si se refleja en los libros de registro de niños de la Inclusa.

f) El sello de la dirección del establecimiento y la firma del director. Como ya se ha mencionado, empiezan a ponerlos a partir de 1909. Podemos ver que en 1909 el director era Santiago del Diego, a partir de 1910, Florentino Díez

g) A continuación se anotan las salidas del asilo o, en su caso, el fallecimiento. Cuando el niño sale con una "criadora", se anota el nombre de la mujer y su localidad, siempre se acompaña del nombre del marido y cuando se trata de una viuda se especifica. Si el niño vuelve al asilo se anota la fecha, pero no suele reflejarse la causa de la devolución, ocasionalmente encontramos alguna anotación del tipo "por no poder criar", porque ha terminado el período de crianza, o "por reclamación", cuando lo solicita la familia del niño, pero es muy poco habitual encontrar explicaciones de éste u otro tipo. Se anota de la misma manera cada vez que el niño sale o vuelve al asilo.

La vuelta con los padres, o en algún caso con otro familiar, era aprobada por la Comisión de la Diputación. Se registra la fecha y a quien se entrega, muchas veces sólo se anota el parentesco con el niño sin el nombre. Quien recoge al niño debe firmar en el libro a modo de recibo, o alguien en su nombre, en muchos casos encontramos que "no firma por no saber".

“En 21 de Septiembre de 1909 le llevó Josefa de la Fuente mujer de Nicolás Rojo vecinos de Langayo Devuelta el 31 Marzo de 1910

En 10 abril de 1910 le llevó... Devuelta el 11 de Mayo de 1910

En 13 de Mayo de 1910, cumpliendo acuerdo de la Comisión provincial de 23 de Abril último, fue entregada a su Madre, vecina de esta Capital No firma por no saber". [sic]

Folio no 164 del Libro de Exposiciones de 1909, Tomo 1ㅇ. 
"En 11 de Marzo de 1908 le llevo Maria Encarnacion Prieto mujer de Agustin Roque vecinos de Peñafiel Devuelta por reclamación en 11 Enero de 1910 y el mismo dia fue entregada a su padre Domingo Alvarez vecino de La Seca y para su conformidad y recibo se firma" [sic]

Folio no 76 del Libro de Exposiciones de 1908, Tomo 1‥

Una vez cumplido el período de crianza, los niños mayores pueden ser entregados a quien lo solicite y previo acuerdo de la Comisión de la Diputación, en el libro se especifica a quien se entrega el niño y para qué fines, en la mayoría de los casos encontramos que salen "para compañía de matrimonio", pero también en algunos se dice que van a aprender un oficio, o a trabajar, sobre todo en el servicio doméstico en el caso de las chicas, incluso en algún registro se anota el sueldo acordado.

"En 22 de junio de 1920, cumpliendo acuerdo de la Comisión provincial en sesión del día de hoy fue entregado para enseñarle el oficio de hortelano a Eusebio García Sanz, vecino de Peñafiel; firmando esta diligencia en prueba de conformidad y recibo" [sic]

Folio no 85 del Libro de Exposiciones de 1909, Tomo 1‥ El niño tenía en ese momento 13 años

Algunos niños se quedan con los criadores, sin remuneración, una vez cumplido el tiempo de crianza y se anota que son "prohijados" o, más frecuentemente, que "pasan a $3 \underline{a}$ situación", junto con la fecha; normalmente ya no vuelven al asilo, aunque en algún caso son también devueltos.

“... 1915 En esta fecha y habiendo cumplido el periodo de cobranza se presento en esta dirección la criadora Maria Hervada manifestando que se quedaba el niño con caracter de prohijado" [sic]

Folio no 137 del Libro de Exposiciones de 1909, Tomo 1ㅇ.

"1915. 03. 13. Cumplió periodo destete y pasa a 3ํㅗ situación"

Folio no 19 del Libro de Exposiciones de 1909, Tomo 1ㅇ․

En la mayoría de los registros no dan tantas explicaciones, simplemente anotan "prohijado" о "3모 situación".

Una vez cumplida la edad, el asilado podía solicitar la emancipación, que tenía que ser aprobada en sesión de la Comisión provincial. Se registra la fecha de la aprobación y de la salida con la firma del emancipado. 
Hay folios en los que después de la salida del niño del asilo ya no se hacen más anotaciones, no aparece ni el retorno al Hospicio ni el fallecimiento. Puede tratarse de niños dados de baja que no reingresaron porque se quedaron con las criadoras o porque volvieron con su familia sin que se notificara; o porque fallecieron, aunque el fallecimiento siempre se registraba en este libro, incluso cuando ocurría fuera del asilo en edades avanzadas; pero en algunos casos se ha podido comprobar que simplemente no se han pasado los movimientos del niño a su folio de registro. Comparando estos libros con los de Mayores, comprobamos que habitualmente se registran aquí todos los cambios hasta que el niño se da de baja, aunque haya pasado a los libros de mayores y también se recojan allí estos datos; hay en estos libros registros de muchachos que tienen más de 20 años.

Cuando el niño fallece se anota si ocurre "en el Asilo" o "en el pueblo". Cuando fallece en el Asilo se recoge fecha, hora y causa de la muerte. Si fallece fuera, sólo se suele recoge la fecha, a veces mucho después de haber ocurrido, pocas veces encontramos la causa. Siempre se dibuja debajo una cruz, normalmente bien visible.

"Falleció en este Asilo el dia 11 Agosto 1905 á consecuencia de Atonia gastrointestinal" [sic]

Folio no 148 del Libro de Exposiciones de 1905, 1 tomo.

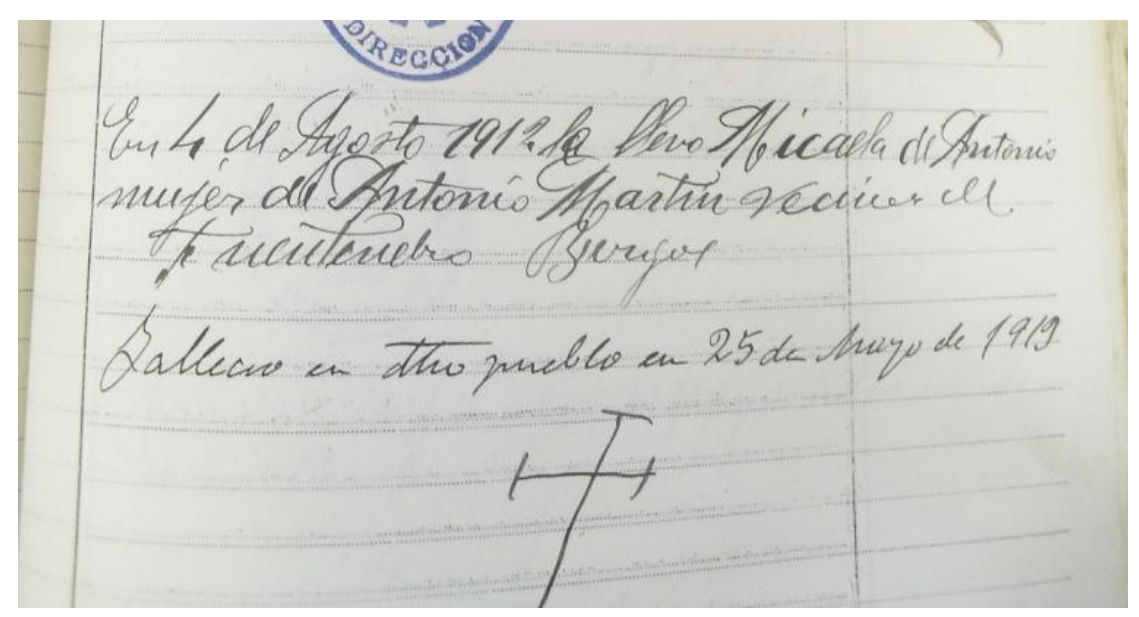

Imagen 1-14: Folio no 205 del 1 o tomo del Libro de Exposiciones de 1912

"En 4 de Agosto 1912 la llevo Micaela de Antonio mujer de Antonio Martín vecinos de Fuentenebro Burgos

Falleció en dicho pueblo en 29 de Mayo de 1913" [sic]

Folio no 230 del Libro de Exposiciones de 1912, 1 tomo. 
h) En todos los libros encontramos algunos folios en los que en lugar del nombre se ha escrito "Niño muerto" ó "Niña muerta". Son niños fallecidos en la Maternidad, hijos de mujeres asiladas. Se anota en el libro la fecha y hora del parto, el nombre de la madre y cuando se da parte al Registro Civil.

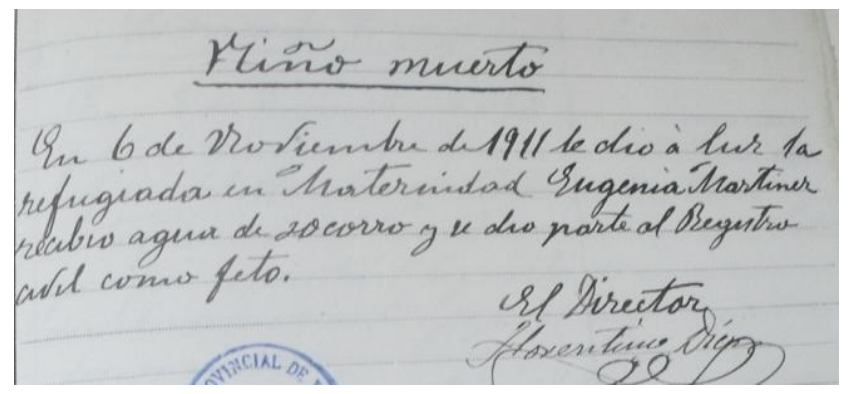

Imagen 1-15: Folio no 369 del Libro de Exposiciones del Año 1911, 2ํTomo

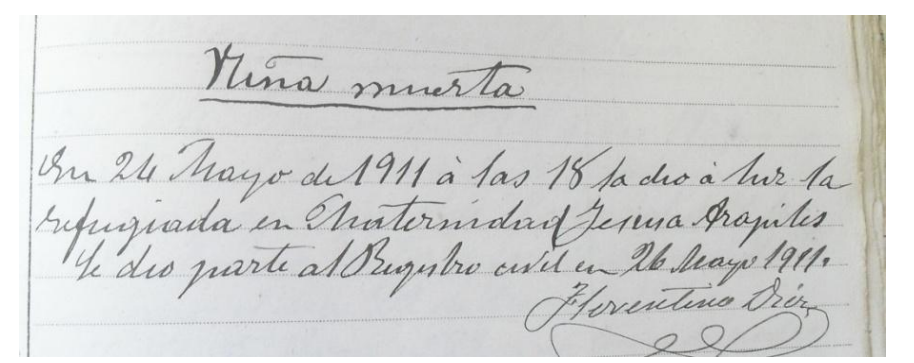

Imagen 1-16: Folio no 179 del Libro de Exposiciones del Año 1911, 1ㅇTomo

Puede tratarse de niños que nacen muertos o que fallecen en los momentos posteriores al parto, no se especifica en los registros de estos libros, en todo caso, al no tener nombre hemos de pensar que habrían fallecido en las primeras 24 horas de vida, pues según el artículo 30 del Código Civil vigente en la época, y modificada recientemente en 2011, sólo se considera nacido el niño después de transcurridas 24 horas desde el nacimiento. Aunque se da parte al Registro Civil, estos niños no se inscriben en la sección de Nacimientos sino en el llamado "Legajo de abortos"91, así, en

\footnotetext{
${ }^{91}$ Según el artículo 30 del Código Civil, publicado el 24 de julio de 1889 que entró en vigor el 16 de agosto del mismo año:" Para los efectos civiles, sólo se reputara nacido el feto que tuviere figura humana y viviere veinticuatro horas enteramente desprendido del claustro materno", esto supone que los niños que morían en las primeras 24 horas eran considerados como abortos hasta la modificación de este artículo en el año 2011. La inscripción en el Registro Civil de estos niños se hacía aparte del Libro de Nacimientos, en el llamado Legajo de abortos, donde se archivaban las certificaciones correspondientes para poder autorizar la inhumación. La Ley de 8 de junio de 1957, sobre el Registro Civil en su artículo 74 dice todavía al respecto que "El fallecimiento, antes de las veinticuatro horas del nacimiento, constará igualmente en el acta, que será incorporada, con los documentos complementarios, al legajo de abortos; si ocurre en circunstancias distintas del nacimiento, se acreditará con la declaración y parte pertinente que, con el acta de nacimiento, se llevarán a dicho legajo". La Ley 20/2011, de 21 de julio, del Registro Civil modificó el artículo 30 del Código Civil (Libro Primero, Título II, Capítulo I) que actualmente dice: "La
} 
algún registro podemos leer que se comunica el nacimiento al Registro Civil en calidad de "feto", como en el folio № 369 del Libro de 1911, 2ㅇ Tomo. En este folio se dice además que se dio "agua de socorro", es decir que se hizo un bautismo de urgencia, por lo que cabe pensar que el niño debió nacer con vida, pues en otros casos, como el de la imagen del folio no 179 de 1911 (IMAGEN 1-16), no se hace constar este punto y, sabiendo la importancia que se daba al bautismo, las Hermanas de la Caridad encargadas de la Inclusa en caso de administrarlo no lo dejarían sin registrar.

\subsection{LIBROS DE REGISTRO DE SALIDA DE MENORES ACOGIDOS}

Son una serie de libros en los que se registra el ama externa de cada niño que sale para crianza y los pagos que se le hacen. Son similares a los LIBROS DE CUENTAS DE LAS AMAS EXTERNAS, volvemos a encontrarnos con información duplicada en distintos libros, que además veremos que está incompleta en muchos casos. Hay un libro por año, aunque de la época de estudio legalmente permitida faltan los libros de 1908, 1910, 1911 y 1912. Se consultan los diez libros existentes.

Estos libros tienen los folios numerados y cada folio corresponde a un niño. El número del folio en este libro coincide con el que el niño ocupa en el de Exposiciones del año correspondiente.

\footnotetext{
personalidad se adquiere en el momento del nacimiento con vida, una vez producido el entero desprendimiento del seno materno.". Además, en la Disposición adicional cuarta, Constancia en el Registro Civil de los fallecimientos con posterioridad a los seis meses de gestación dice: "Figurarán en un archivo del Registro Civil, sin efectos jurídicos, los fallecimientos que se produzcan con posterioridad a los seis meses de gestación y no cumplieran las condiciones previstas en el artículo 30 del Código Civil, pudiendo los progenitores otorgar un nombre."

La exigencia de un plazo de vida extrauterina para adquirir la condición de ser vivo en nuestro país viene del Fuero Juzgo, del siglo XIII, que en su libro IV, leyes XVIII y XIX del título III exige para que un recién nacido tenga derechos sucesorios que "recibiere baptismo e visquiere $X$ días"[sic], este plazo de diez días se reduciría posteriormente a veinticuatro horas en las Leyes de Toro de 1505, que en la número XIII dice que "Por evitar muchas dudas que suelen ocurrir cerca de los hijos que mueren recién nascidos, sobre si son naturalmente nascidos o son abortivos, ordenamos y mandamos que el tal hijo se diga que naturalmente es nascido, quando nasció vivo todo, y que a lo menos después de nascido vivió veinticuatro horas naturales y fue baptizado antes de que muriese; y si de ora manera nascido murió dentro del dicho término o no fue baptizado, mandamos que el tal hijo sea habido por abortivo y que no pueda heredar a sus padres, ni a sus madres ni a sus ascendientes". La Ley de Matrimonio Civil de 1870 retiraría el requisito del bautismo para adquirir la condición de personalidad civil y lo cambiaría por el de tener figura humana a raíz de la libertad de culto sancionada en la Constitución de 1869, y así se recogería en el artículo 30 del Código Civil.
} 
El formato de los folios es el mismo en todos ellos. En la parte superior se registra el año de la exposición y la fecha del bautizo y debajo: nombre del ama y de su marido, localidad, tipo de crianza de leche o destete, nombre del niño, con frecuencia sólo se anota el nombre de pila, y la fecha de exposición. A continuación y por las dos páginas hay una tabla con tres columnas: En la primera denominada "MOVIMIENTO" se anota la fecha de la salida y los cambios de ama y de situación; en la segunda, "PAGOS", se van anotando las fechas de pago y el período remunerado y en la tercera, "Pesetas" la cantidad abonada a las amas en pesetas y céntimos.

La información que ofrecen es muy escueta, ni siquiera suele anotarse la fecha de finalización del contrato ni la causa. Tampoco se registra siempre la devolución al asilo o a los padres, el prohijamiento o el fallecimiento del niño, sobre todo en los primeros años, simplemente se dejan de realizar anotaciones; en cambio, estos datos sí suelen registrarse en los Libros de Exposiciones. A partir de 1903 los registros son más completos, aunque no todos. En el libro de 1900 sólo se anotan dos devoluciones al asilo - de los niños que ocupan los folios no 377 y 486- y otras cinco con cambio de ama - nos $138,240,340,405$ y 454-, pero si comparamos con los registros del Libro de Exposiciones podemos comprobar que faltan de anotar muchas; así, por ejemplo, el niño del folio 10 fue devuelto y entregado a nodrizas en dos ocasiones y finalmente entregado a su madre, los de los $n^{\text {os }} 11$ y 12 se devolvieron por "haber cumplido la edad", el del no 13 tuvo 3 amas o el no 48 fue devuelto a la edad de 7 años y en el libro de salidas constan pagos hasta esa edad sin ninguna anotación final que advierta de su vuelta al asilo.

En el folio no 364 de 1901 se registra la salida de una niña el 17 de diciembre y un único pago por el resto del mes, no hay más anotaciones.

\begin{tabular}{|l|l|r|r|}
\hline MOVIMIENTO & PAGOS & \multicolumn{2}{|l|}{ Pesetas } \\
\hline Salió 17 diciembre 1901 & En 22 enero por 13 días Dbre & 5 & 41 \\
\hline
\end{tabular}

En el folio correspondiente del libro de entradas se comprueba que falleció en el pueblo del ama el día 1 de enero de 1902, por lo que sólo se pagó por los días de crianza.

En 17 de diciembre de 1901, la llevó Magdalena Requejo, muger de Juan Fuente, vecinos de Fuente-Soto (Segovia) Falleció en Fuentesoto en 1o de enero de 1902 [sic]

En el folio no 138 se registra un niño que según el libro de entradas pasó por tres amas diferentes y falleció con la última, en este libro sólo aparecen el ama primera, cuyo nombre se 
escribe en el encabezamiento de la página y la segunda, que, aunque aquí no dice nada, según el otro libro "le devolvió en el mismo día porque decía que estaba enfermo".

Se encuentran entre los libros algunas papeletas sueltas que a veces aportan datos de interés. En el folio no 355 del libro de 1900, por ejemplo, encontramos un recorte de papel donde está anotada la fecha de devolución al asilo y en el no 401 otra con el fallecimiento del niño, ocurrido unos días después de la salida del asilo, no consta que se haya abonado ninguna cantidad, pero están anotadas las fechas de pago,

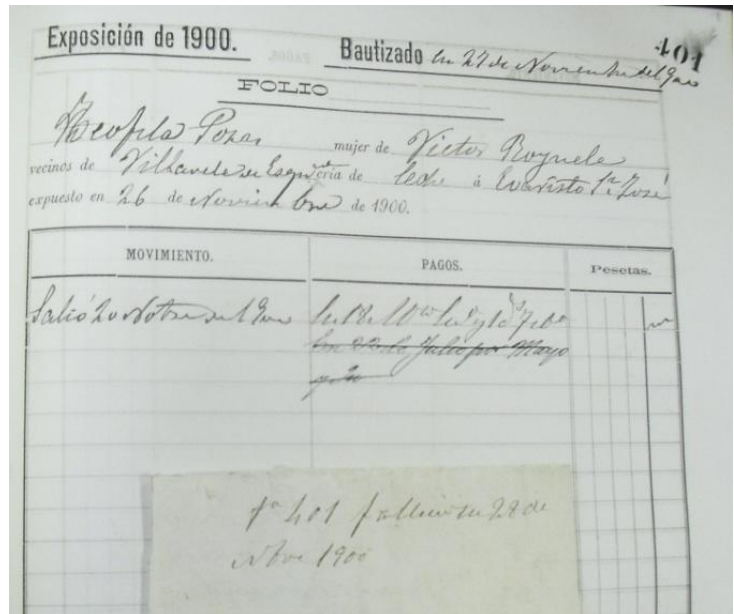

Imagen 1-17: Folio 401 del libro de Salidas de menores 1900 con una nota en una papeleta que comunica el fallecimiento del niño

puede ser que el pago estuviera previsto pero no se hiciera al comprobar el fallecimiento.

Los folios en blanco corresponden a niños fallecidos en el asilo que no llegan a salir, nos permiten comprobar a simple vista la elevada mortalidad en la Inclusa y su temporalidad, por ejemplo en los meses de junio y julio de 1901 es llamativo el número de hojas en blanco que hacen sospechar de la existencia de una epidemia severa en el asilo. En efecto, consultando el correspondiente libro de registro de entradas de menores comprobamos un elevado número de fallecimientos por "catarro intestinal" y causas similares.

La mayoría de los niños salen para lactancia; los que salen de la Inclusa directamente para "destete" son muy pocos, son niños que ingresan con unos meses y que ya han superado el periodo de lactancia y hay algún caso anotado de niños que la habían abandonado previamente al ingreso a pesar de que por edad podrían seguir lactando. Se observan pocos cambios de ama y en muchos casos se deben al cambio de contrato de lactancia a destete, aunque es algo que podemos suponer por la edad del niño porque tampoco suele escribirse el motivo del cambio. 
Esta serie tiene cuatro libros pertenecientes al período de consulta permitido que abarcan desde 1888 hasta 1911 completo. Cada libro recoge varios años, entre 3 y 6 años, no se puede consultar el siguiente libro porque registra hasta 1915. Se inscriben los niños del orfanato que tienen más de 5- 6 años. Aunque exceden la edad de estudio, el niño lactante, se consultan para comparar datos y en busca de otros nuevos; por eso sólo se revisa el Libro 16 de Mayores, que contiene registros desde 1906 a $1911^{92}$, niños en su mayoría nacidos a partir de 1900. Muchos de ellos ingresaron en la Inclusa en las primeras semanas de vida y pasaron a la sección de mayores al llegar a la edad de 5 - 6 años, una vez finalizada la etapa de crianza, que comprende lactancia y destete. El formato de estos libros es similar al de los libros de registro de menores. Las primeras páginas, a modo de índice, están ordenadas y marcadas por orden alfabético, en ellas se anotan los niños ingresados con el nombre completo ordenados por el nombre de pila y con el número del folio en el que están inscritos. A partir del índice en este libro se numeran todas las páginas y se utiliza una para cada niño inscrito. Como ocurre con los libros de menores, el sello y la firma del Director del Hospicio no aparecen hasta los registros de 1909.

En cada registro se recoge

a) Número de filiación, escrito a mano y en un sello del archivo del Hospicio, cuando el niño lo tiene asignado, que no es siempre. Los niños fallecidos y los que salen pronto del establecimiento no tienen un número de filiación en este libro

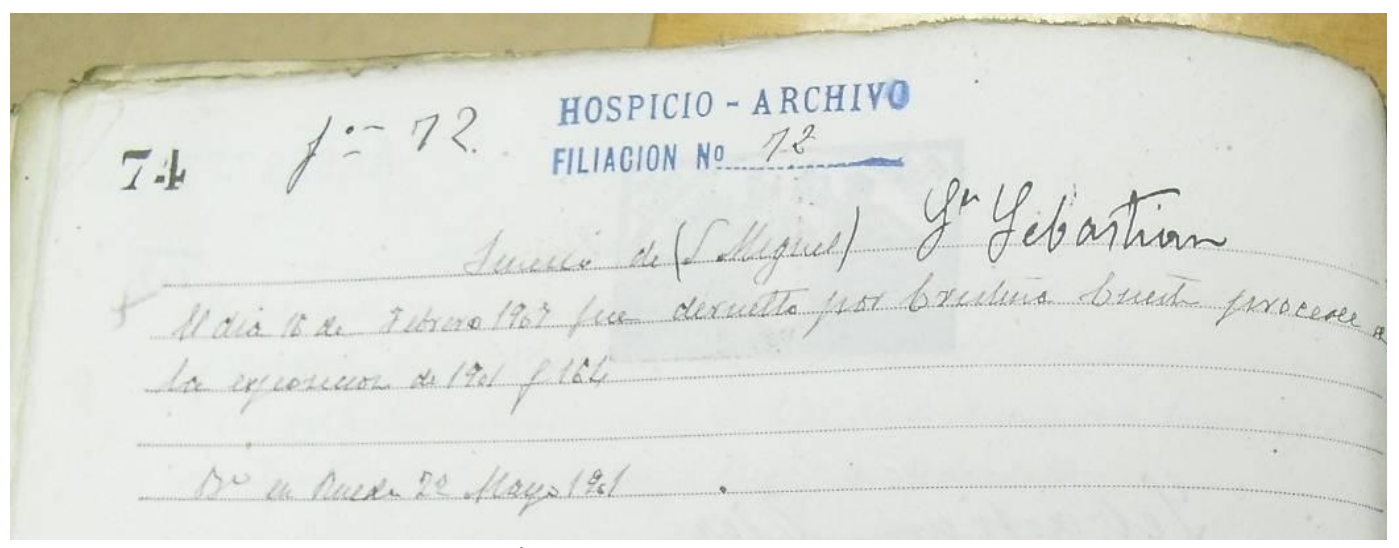

Imagen 1-18: Página 74 del Libro 16 de Mayores 1906 -1911

\footnotetext{
92 Libro de Mayores acogidos 1906 -1911. Signatura: caja 01869, expediente 16474
} 
b) Nombre completo del niño, normalmente se escriben los dos apellidos, ocasionalmente ocurre como en la imagen que corresponde al folio no 74 y sólo figura uno de ellos, San Sebastián, apellido característico de un niño expuesto (IMAGEN 1-18).

c) Fecha de ingreso en el departamento de mayores y vía de entrada. En la mayoría de los casos los niños ya estaban a cargo del asilo y pasaban desde la Inclusa al departamento de "Mayores" o entraban desde el exterior cuando los devolvían las nodrizas externas. Se anota el día que entró en la Inclusa y el folio que ocupa en el libro de entrada de menores, en el que también se registra el paso con anotaciones del tipo "pasa al libro de mayores por cumplir la edad"

"Isidro Baena Gutierrez

Procede de la exposición del mil nuevecientos tres pasa a este libro por haber cumplido la edad fo 208 en 903

Inscripto en Simancas 16 Mayo 1899" [sic]

Folio no 9 del 1은 Libro de mayores acogidos 1906 -1911. № de filiación 86

Cuando se trata de niños criados fuera del orfanato que son devueltos, se anota la fecha de devolución y el nombre de la nodriza.

"El día 18 de febrero fue devuelto por Cristina Cuesta procede de la exposición de 1901 folio 164" [sic]

Folio no 74 del Libro de mayores acogidos 1906-1911

Tampoco en este libro suele registrarse la causa de la devolución, a veces se anota que el niño ha cumplido la edad, o "cumplido la edad de destete" es decir la edad marcada como límite para los contratos de crianza externa.

"Devuelto en 2 de julio de 1907 por haber cumplido la edad procede de la exposición de 1902 folio 74.

Bo (bautizado) en Medina del campo en 28 febrero de 1902" [sic]

Folio no 103 del Libro de mayores acogidos 1906-1911. Tiene no de filiación 77

Los niños que ingresan por primera vez en el asilo y entran directamente en este departamento lo hacen habitualmente por acuerdo de la Comisión provincial. En algunos casos; que probablemente sean situaciones especiales, graves o de urgencia para el niño; ingresan por orden directa del Presidente o Vicepresidente de la comisión, o incluso del propio Gobernador Civil, como ocurre en el folio no 113, que debía tratarse de un niño que ingresó enfermo, no figura número de filiación y no se recogen, al menos en este libro, el nombre y domicilio de los padres

"En 13 de Agosto de 1907 ingresó por orden del Sr Gobernador Civil de la provincia con carácter provisional 
Falleció en este asilo en 20 de Agosto de 1907 a consecuencia de Periencefalitis difusa" [sic]

d) Nombre de los padres y localidad de residencia. Se escriben cuando se trata de ingresos nuevos, en los ingresos antiguos estos datos se encuentran en los registros de menores. También en estos libros, siempre se indica si el niño en cuestión es hijo legítimo, ilegítimo o natural y se utiliza más el término "hijo natural".

Con frecuencia ingresan varios hermanos y en ese caso se refleja así en el registro de todos y cada uno de ellos y se anotan los folios que ocupan.

"En 2 septiembre de 1907 ingresó por orden del Sr Vicepresidente de la Comisión provincial con partida del R C (registro civil) de Pedrajas de San Esteban donde dice que es hijo legitimo de Frutos y Julia y es mano [sic] de los que ocupan los folios 122 y 123 y 275 del libro de entradas de 1907.

Inscrito en Pedrajas de San Esteban el 27 octubre de 1887" [sic]

Folio no 121 del Libro de mayores 1906-1911. En los folios que indica se encuentran registrados los hermanos.

e) Fecha y lugar del bautismo o de la inscripción en el Registro Civil. En los niños que fueron expuestos en el torno se anota además la fecha de la exposición y el folio en que está registrado como hemos visto en las citas anteriores.

"En 22 Septiembre 1907 fue devuelto por Eugenia Pecharroman procede de la $\operatorname{Exp}^{n}$ (exposición) 1901 folio 113

Bo (bautizado) en este Asilo 5 Abril 1901

Falleció en este Asilo a las 15 horas del 27 de Abril de 1908 a consecuencia de Tuberculosis Pulmonar" [sic]

Folio no 139 del Libro de mayores acogidos 1906-1911. No tiene no de filiación

A pesar de que el niño ha pasado a este libro, todas estas anotaciones se hacen también en el Libro de Exposiciones, o de registro de menores. En efecto en el folio 113 del Libro de 1901 está inscrita esta niña y podemos leer:

"En 11 de Abril de 1901 le llevo Eugenia Pecharroman mujer de Jose Peña de Castroserracin

Devuelta en 22 de Septiembre de 1907. Pasa al Libro 16 fo 109 por haber cumplido la edad

Falleció en este Asilo en 27 de Abril 1908 a consecuencia de Tuberculosis pulmonar" [sic]

f) Fecha de salida del asilo y circunstancias en que se produce: puede ser por fallecimiento, fuga del establecimiento, por devolución a los padres, para compañía, para trabajar o por emancipación. Se registran, igual que en los libros de menores, 
todos los reingresos en el asilo y las nuevas salidas indicando el nombre de quién les devuelve. No suele explicarse habitualmente el motivo de la devolución.

Cuando estos niños y niñas, ya considerados "mayores", se entregan para compañía o para trabajar, en el libro se anota, junto a la fecha de salida, el nombre y la localidad de residencia del solicitante que será responsable del niño, o la dirección si reside en la ciudad.

"1916-01-28 [sic] Cumpliendo orden del Sr Vicepresidente de la Comisión Provincial fue entregado para el oficio de herrero y carretero [un niño de 15 años]..."

Folio no 74 del Libro de mayores acogidos 1906-1911. Número de filiación 72.

Aunque todos los datos sobre los movimientos de los niños se escribían normalmente también en los Libros de entradas de menores, en este caso no se añadió esta información. El último dato registrado en el folio no 164 de 1901 es su devolución después del período de crianza y el paso al libro de mayores:

"En 14 de Junio de 1901 le lleva Cristina Cuesta mujer de Juan Lopez de Hinojosa.

Devuelto el 16 de Febrero 1907 pasa al Libro 16 fo 74" [sic]

Esto nos hace suponer que en casos similares, en los que no se continúan los registros de los Libros de Exposiciones, puede deberse a que no se han completado con los datos recogidos en los Libros de Mayores.

En marzo de ese mismo año el muchacho del registro anterior se escapó y retornó voluntariamente al asilo, esto no era muy normal, solían desaparecer, de hecho también hay fugas del asilo

"Se escapó descolgándose por una ventana y no se volvió a saber nada de él. Se puso en conocimiento de los Sres Gobernador, Vicepresidente y Visitador"

Folio no 89 del Libro 16 de mayores acogidos 1906-1911.

La emancipación la puede solicitar el propio asilado, o bien se produce de manera forzosa a partir de los 20 años. Es la Comisión provincial la que decide.

"Isidro Baena Gutierrez

Inscripto en Simancas 16 Mayo 1899

1916. En 20 de Junio y accediendo a lo solicitado por él, la comisión provincial le concedió la emancipación del establecimiento y como justificante firma la presente diligencia"

Folio no 9 del 10 Libro 16 de mayores acogidos 1906 -1911. № de filiación 86. 
Los asilados que realizaban estudios permanecían en el orfanato hasta su finalización, el más frecuente era el de Magisterio y la Diputación se hacía cargo de todos los gastos

“... Bautizado en la Nava del Rey el dia 25 Agosto 1891. En 19 de Enero de 1910 y cumpliendo acuerdo de la Comisión provincial de fecha 18 del corriente, salió este asilado de este Establecimiento después de tener consignadas las cantidades precisas para el titulo de Maestro Superior cuyos estudios siguió a costa de la Excm Diputación Provincial" [sic]

Folio no 11 del Libro 16 de mayores acogidos 1906-1911. Sin no de filiación.

En cuanto a la mortalidad, en este departamento del asilo es menor que en el de los niños menores de 5 años, pero sigue siendo alta. Se anota fecha, hora y causa del fallecimiento y se dibuja también debajo una cruz bien visible

"El dia 30 de Junio de 1906 fue devuelta por Buenaventura Velasco procede de la exposición de 1903 folio 207

Inscripta en Simancas 16 enero 1901

Fallecio en este asilo a las 17 horas del 19 de Noviembre de 1911 a consecuencia de "Congestion cerebral»" [sic]

Folio no 3 del Libro 16 de mayores acogidos 1906-1911. En el Libro de 1903 está inscrita esta niña y también se recoge la vuelta al orfanato y el fallecimiento:

"Devuelta el 30 de Junio 1906 pasa al libro 16 al 3

fallecida en el asilo 1911 -11-19"

[sic]

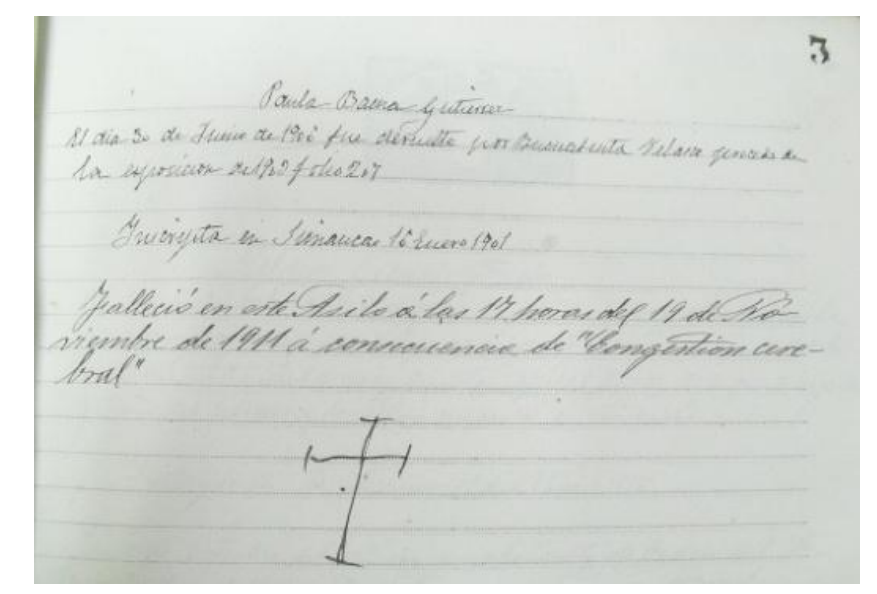

Imagen 1-19: Folio no 3 del Libro 16 de mayores acogidos 1906-1911. 


\subsection{REGISTROS DE MATERNIDAD DE LOS CENTROS DE ACOGIDA DE MENORES}

En esta serie se conservan 16 libros sobre el período de estudio, pero sólo se ha podido consultar el que recoge datos de los años 1906 a 1913, etiquetado por el Hospicio como "Entradas Maternidad 1906, 907 y 1908"93, los demás se salen del periodo de consulta permitido. Se revisa también un libro anterior con la etiqueta " $\underline{\text { Hospicio }} \underline{\text { Provincial Maternidad }}$ Año de 1863" ${ }^{\prime 94}$ que contiene registros desde 1863 a 1869 para comparar información y constatar los cambios habidos con el paso del tiempo. Son libros de control de las mujeres que ingresan y dan a luz en la maternidad del Hospicio, el gasto que genera su estancia y el sueldo que perciben por lactancia para la Inclusa, aunque podemos comprobar que no todas se quedaban a lactar. Los dos libros son similares en cuanto a estructura y contenido, con la diferencia de que en el de 1906 los datos se recogen en una tabla que ya está impresa y en el de 1863 está hecha a mano. Los libros están escritos por las dos páginas, todas están numeradas y en el de 1906 sólo se registra una mujer en cada una de ellas. El libro de 1863 está completo pero el de 1906 sólo tiene anotaciones hasta la página 197 con los ingresos habidos en la maternidad desde el 4 de octubre de 1906 hasta el 5 de septiembre de 1909, en total 176 inscripciones, y en la página 178 encontramos el titular a grandes letras y a página completa "Año 1909 Ingreso de Nodrizas" y a partir de aquí cambia el tipo de registro y pasan a inscribirse solamente las nodrizas internas de la Inclusa, mujeres que ingresaban para lactar y que no procedían de la sala de maternidad. Cada nodriza tiene asignado un número de folio empezando por el 1, que está escrito sobre el número de página; en total hay 15 mujeres que ingresan en la Inclusa desde el 5 de mayo de 1909 la primera hasta el 31 de marzo de 1913 la última inscrita en el folio numerado como 15. En estas inscripciones en el apartado "sala" vemos anotado: "Nodriza", "Nodriza interna", "Ama interna", o "Inclusa".

En la tabla, para las mujeres de la maternidad, se anotan los siguientes campos:
a) "Número de orden"
b) "NOMBRES": de las mujeres
c) "Naturaleza": localidad de origen
d) "Día de entrada": en la sala de maternidad

\footnotetext{
${ }^{93}$ Signatura: caja 929 , expediente 7142

${ }^{94}$ Signatura: caja 1228, expediente 7771
} 
e) "Sala"

f) "Día del parto"

g) "Día en que pasó a lactar", entendemos que para la Inclusa.

h) "Día de salida o paso al libro de amas internas": en todos los registros comprobamos que anotan siempre el día de salida del asilo, de la Maternidad o de la Inclusa, pues en el caso de las mujeres que se quedan a lactar encontramos anotados los pagos que reciben por lactancia hasta su marcha.

i) "Precio de estancias", se refiere por lo que vemos en el primer libro al coste diario de su estancia en la Maternidad

j) "Importe de las estancias. Pesetas. Cts.": para el total

k) "OBSERVACIONES"

A continuación se encuentra anotada la liquidación de la cuenta que ha generado la mujer, a su favor o a pagar. Se calcula el gasto de su estancia en el establecimiento dependiendo de la sala y, cuando pasaba a lactar a la Inclusa, el sueldo que debía percibir por la lactancia, la que no se quedaba a lactar tenía que pagar el importe íntegro de su estancia.

Es más completo en cuanto a detalles el libro de 1863-69, aunque comparando los dos no parece que hayan cambiado los procedimientos solamente los costes y la moneda, que pasó de reales a pesetas. En este primer libro se recogen todos los pagos que hacen las mujeres y los que dejan pendientes y por él podemos saber en concepto de qué pagaban o se libraban de pagar. En el folio 8 en una mujer inscrita dejó a deber en

\section{“... total 56 reales}

que pierde la casa por haber salido por enferma segun la certificacion del Profesor de Medicina de la misma" [sic]

Una segunda mujer se quedó a lactar y al hacer la liquidación resultó una

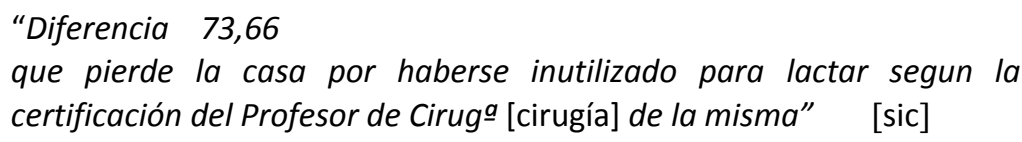

Estos libros, y en particular el de 1863, han ayudado a entender el significado de las abreviaturas del tipo $S G$ ó $R^{d o}$ que iba encontrando en otros libros y que solamente por el contexto no eran comprensibles. En todos los registros del libro de 1906-9 en los que se ha rellenado el apartado "Sala" figura "General" o abreviaturas del tipo "Gral" ó "SGrl". En el libro de 1863 encontramos además asientos en los que pone "Reservado" o abreviaturas como " $R^{\text {do" }}$ y a continuación una columna etiquetada "Importe de la Est ${ }^{a}$." (Estancia); en el folio 12 de este libro referido a la sala se ha escrito "secreta". 
En la página 148 del libro "Entradas y salidas de los Niños de la Inclusa Años de 1909 1910 1911" aparece Ecequiela Pastor Olmos como ama lactante del niño inscrito en el folio 389 de 1909; en la última columna podemos leer: "nació en el SG".

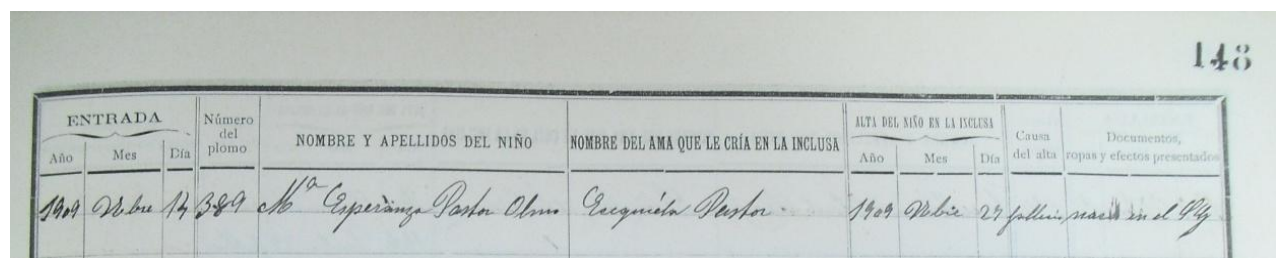

Imagen 1-20: Página 148 del libro "Entradas y salidas de los Niños de la Inclusa Años de 190919101911 " en la que figura Ecequiela Pastor Olmos como ama lactante

El registro del libro de Exposiciones no aclara nada al respecto. En el 20 tomo de 1909 en el folio 389 figura la misma Ecequiela solamente como "refugiada en este Asilo" y madre de la niña inscrita en él que lleva sus dos apellidos.

Imagen 1-21: Folio no 389 del Libro de Exposiciones de 1909 en la que figura Ecequiela Pastor Olmos como madre de la niña inscrita y refugiada en el asilo

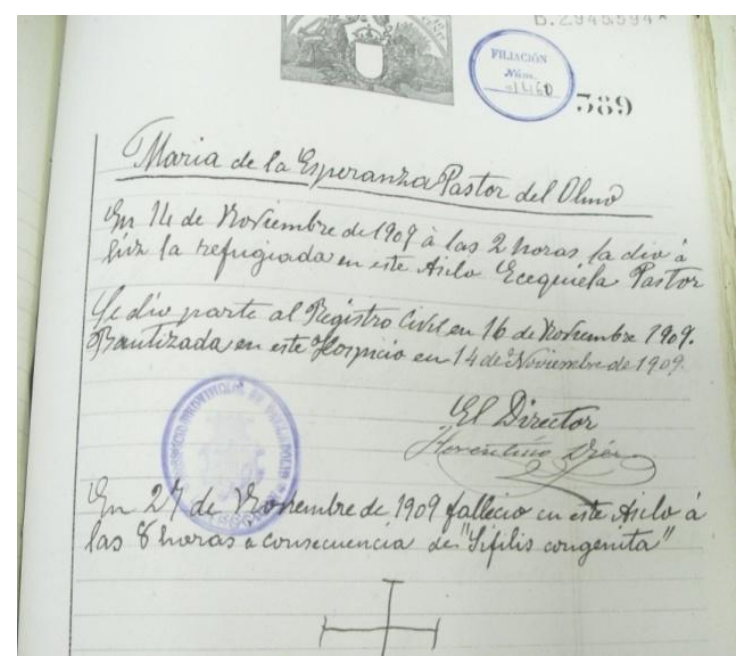

El libro de entradas de la maternidad nos aclara el significado de las siglas SG. En la página 176 encontramos el registro de Ecequiela Pastor Olmos, que ingresó el 5 de septiembre de 1909 en la sala "General" y dio a luz el 14 de noviembre; en OBSERVACIONES dice "Recogida enferma en las Moreras y entrada por la Autoridad Municipal"

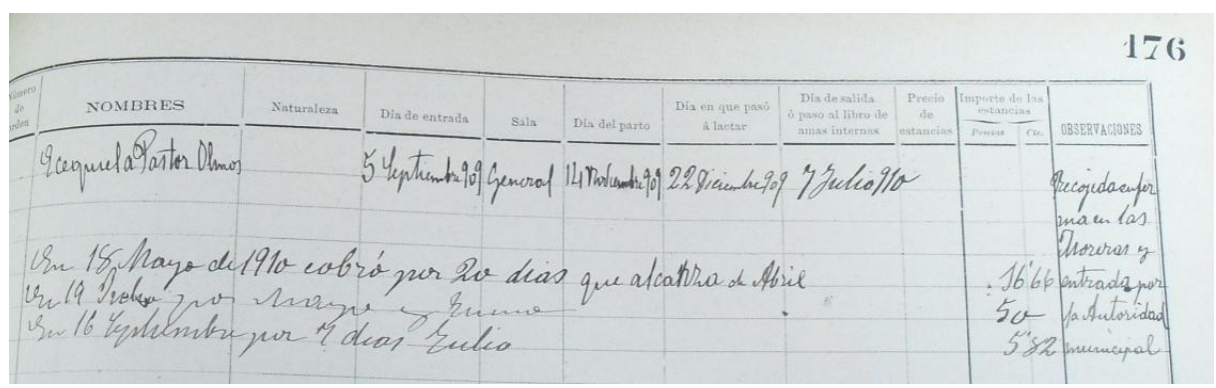

Imagen 1-22: Página № 176 del libro "Entradas Maternidad 1906, 907, 1908" en la que se registra a Ecequiela Pastor Olmos 


\section{8 .}

\section{LIBROS DE REGISTRO DE AMAS DE CRÍA}

En esta serie encontramos para el período de consulta permitido dos libros etiquetados como "Libro de cuentas corrientes con las amas externas. Lactancias" correspondientes a los años $1909^{95}$ y $1910^{96}$, un libro con la etiqueta "Registro especial de cartillas de Lactancia y Destete Años 1910, 1911,1912, 1913"97 y 6 expedientes descritos por el archivo como "Justificantes de pago por crianza externa". Hay además 6 libros de cuentas, fuera del periodo de estudio, dos de ellos con la descripción "Pagos de lactancia", de 1847 y 1863 y un libro titulado "Amas internas procedentes del Hospital Provincial" que no se puede consultar porque es de 1923 a 1948.

1.8.1. Los LIBROS DE CUENTAS CON LAS AMAS EXTERNAS tienen folios numerados y cada registro ocupa una doble página, una con el DEBE y la otra con el HABER. En el encabezamiento se pone en la primera línea el nombre del ama externa y a continuación el de su marido, o se indica que la mujer es viuda en su caso, y a continuación se anota el nombre del niño, el año de exposición y el folio, si se entrega al ama para lactancia o destete, la fecha de entrega y la localidad del ama.

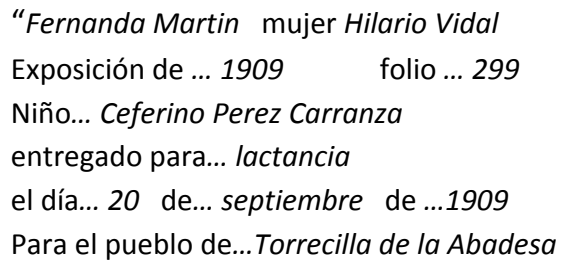

En la tabla impresa por debajo de este encabezamiento se van anotando los pagos que se hacen a la nodriza, la fecha, el concepto y la cantidad. Los pagos se hacen cada dos meses, a mes vencido y si no se cumple el mes completo se paga la parte proporcional. Aunque lo más visible es el nombre del ama en realidad cada folio completo corresponde a un niño y el no de folio de este libro coincide con el que el niño ocupa en el libro de exposiciones, de manera que, cuando pasa por diferentes amas, se anota el cambio, el nombre de la nueva nodriza, de

\footnotetext{
${ }^{95}$ Signatura: caja 689, expediente 6752

${ }^{96}$ Signatura: caja 1158, expediente 7486

${ }^{97}$ Signatura: caja 1260, expediente 7863
} 
su marido y la localidad y se siguen registrando en el mismo folio las cuentas con las criadoras sucesivas. En algún margen se escribe de forma bien visible la fecha de inscripción del niño en

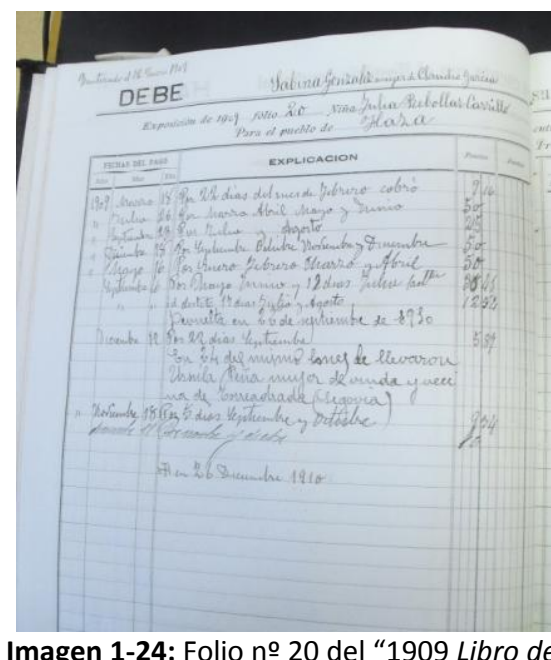

cuentas corrientes con las amas externas. Lactancias"

el registro civil, así se controla su edad para el cambio de lactancia a destete y el fin del periodo de crianza. Se paga más por lactancia que por destete, a pesar de que resulta mucho más barato criar al niño a pecho. Asimismo, cobran más las nodrizas de los pueblos que las de la capital, en pueblos se pagan 25 pesetas por lactancia cada dos meses y 16 por destete y en la capital 20 y 13 pesetas respectivamente. Aunque hemos dicho que se anotan los cambios de ama, no siempre se registra el motivo del cese de los pagos. En algunos folios se recoge el fallecimiento del niño o su devolución al asilo o a sus padres, pero, como en otros libros, lo más frecuente es que se dejan de hacer anotaciones sin ninguna explicación.

1.8.2. El libro titulado "REGISTRO ESPECIAL DE CARTILLAS DE LACTANCIA Y DESTETE

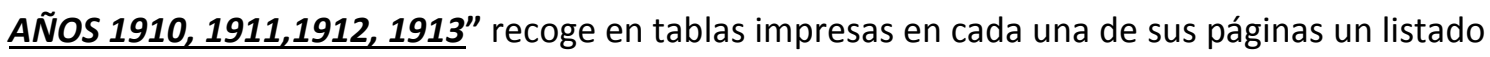
de las nodrizas externas y controla las libretas de crianza. Cada registro tiene un "Número de orden" que se anota en la primera columna, el libro empieza por el 267 y en 1911 reinicia la serie desde el no 1. Después del no, en las siguientes columnas se anota la "CLASE" de crianza: lactancia o destete, el "NOMBRE DEL ASILADO", "NOMBRE DEL AMA", "PUEBLO", "PROVINCIA", "Número de la cartilla" y la última columna se destina a "OBSERVACIONES".

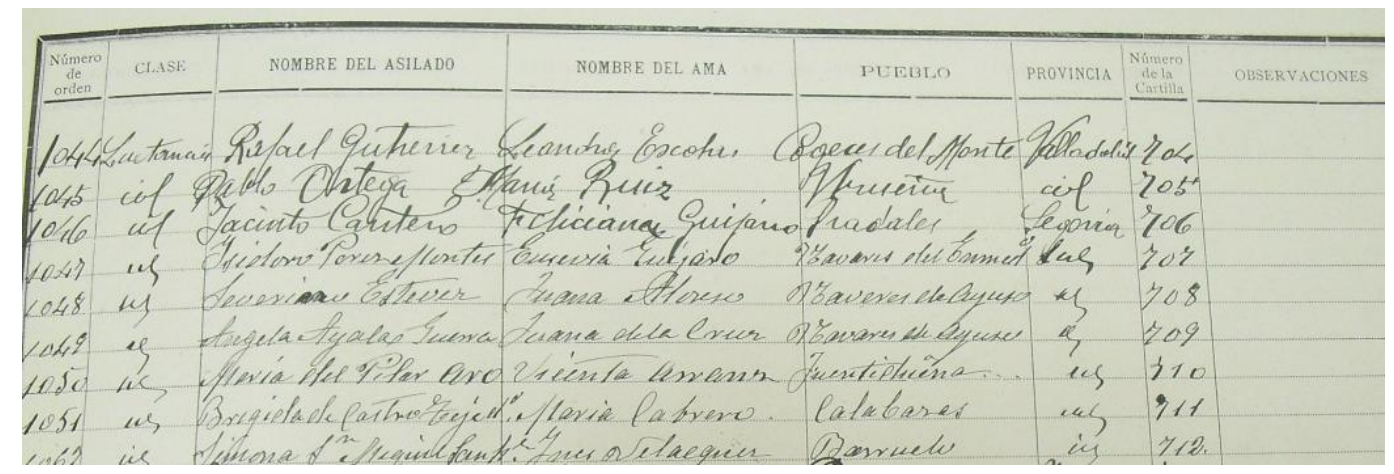

Imagen 1-25: Registro especial de cartillas de Lactancia y Destete Años 1910, 1911,1912, 1913 
Como podemos ver, entre los datos no figuran fechas, tampoco se recogen ni el no de filiación ni el folio de exposición del niño. En algunos registros de las últimas hojas en la columna "OBSERVACIONES" se ha escrito en lapicero una fecha y en unos pocos, además, el año del libro de exposición y el no de folio; consultando este libro podemos comprobar que la fecha anotada corresponde a la de salida del Hospicio. Ni el no de orden ni el de la cartilla corresponde a los asignados al niño, son series independientes, también se sigue una numeración diferente para las cartillas de lactancia y de destete, en el no de orden 566 está registrada la cartilla de lactancia no 853 y en el registro siguiente la libreta de destete no361. En 1913 se empiezan a utilizar cartillas nuevas y se inicia la serie desde el no 1, no se diferencia la numeración de lactancia y destete porque se implanta una libreta única para toda la crianza, en "OBSERVACIONES" se anota "Nueva". Según consta en una anotación hecha en el libro, el 29 de septiembre se canjearon 585 libretas antiguas por las nuevas. Con las anteriores utilizaban cartillas diferentes y se cambiaban al pasar de lactancia a destete.

El no de orden corresponde al de la inscripción en este libro. Consultando los Libros de Exposiciones vemos que se van anotando las lactancias según van saliendo los niños del Hospicio. Así por ejemplo entre las primeras anotaciones encontramos anotados con los números 269 y 270 a los niños Pedro González del Valle y Catalina Ligos Ligos que ocupan los folios 412 y 420 de 1909, nacieron el 4 y el 10 de diciembre respectivamente y salieron del asilo el 4 de enero; el no 274 es un niño, David Martin, que ocupa el folio 448 de 1909, nació el 29 de diciembre y salió el 14 de enero. Los niños que ingresaron entre ellos, unos salieron más tarde y los encontramos registrados más abajo y otros en diciembre y estarían por tanto registrados en el libro de 1909. En el resto no se anota ni siquiera el año, en la primera página del libro se ha escrito en el margen superior a grandes letras "1o de Enero del año1910" y posteriormente encontramos escrito con las mismas características "1911", pero 1912 y 1913 aparecen escritos en la columna de "OBSERVACIONES" en uno de los registros y están poco visibles.

1.8.3. En los "JUSTIFICANTES

\section{DE PAGO POR CRIANZA EXTERNA"}

encontramos, agrupadas por años, una serie de carpetas de la Contaduría de la sección de Beneficencia de la Diputación Provincial de Valladolid que contienen

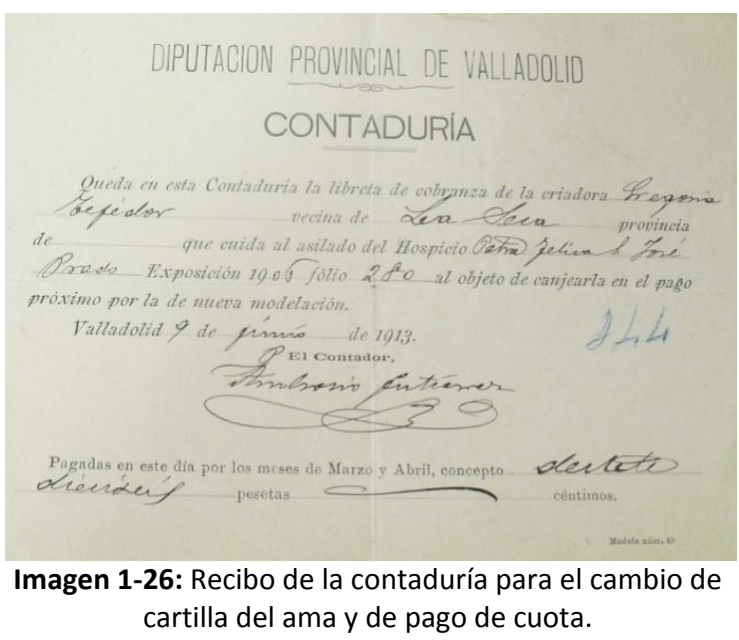


papeletas del Hospicio relacionadas con estos pagos. El archivo Justificantes de pago por crianza externa de $1906^{98}$ contiene 9 carpetas, el de $1907^{99}$ otras 9 , una el de $1908^{100}, 3$ el de $1909^{101}, 4$ el de $1910^{102}$ y una el de $1911^{103}$. Cada carpeta corresponde a un niño, figura su nombre, número de filiación, el año de exposición y el no de folio. El contenido de todas estas carpetas es muy similar. Encontramos las papeletas que presentaban las nodrizas para el cobro de las cuotas correspondientes; llevan el membrete “DIPUTACIÓN PROVINCIAL DE VALLADOLID CASA DE EXPÓSITOS Y DESAMPARADOS" y en ellas el Juez municipal de la localidad de la nodriza certifica que el niño vive y está con ella. En algunas se hacen anotaciones a mano con las cantidades satisfechas y el periodo cobrado o indicando la fecha en que el niño ha sido devuelto o en la que corresponde hacerlo cuando está próxima. Por el reverso hay una AUTORIZACION del ama para que pueda cobrar la cuota bimensual

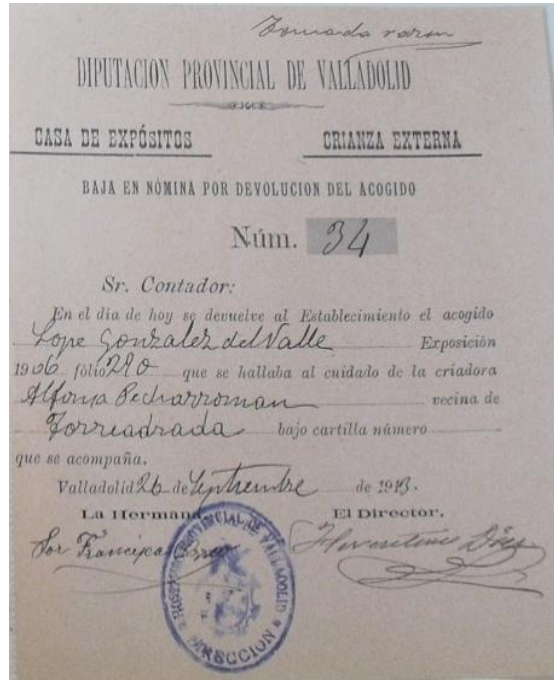

Imagen 1-27: Justificante de devolución del niño para dar de baja a la criadora otra persona, la puede firmar ella o un testigo.

Hay algunas papeletas con el membrete de la CONTADURIA de la Diputación fechadas en junio de 1913 como justificantes para el cambio de la "libreta de cobranza de la criadora" por una de nueva remodelación, sirven también como recibo por el cobro de una cuota anotándose período, cantidad y concepto, lactancia o destete
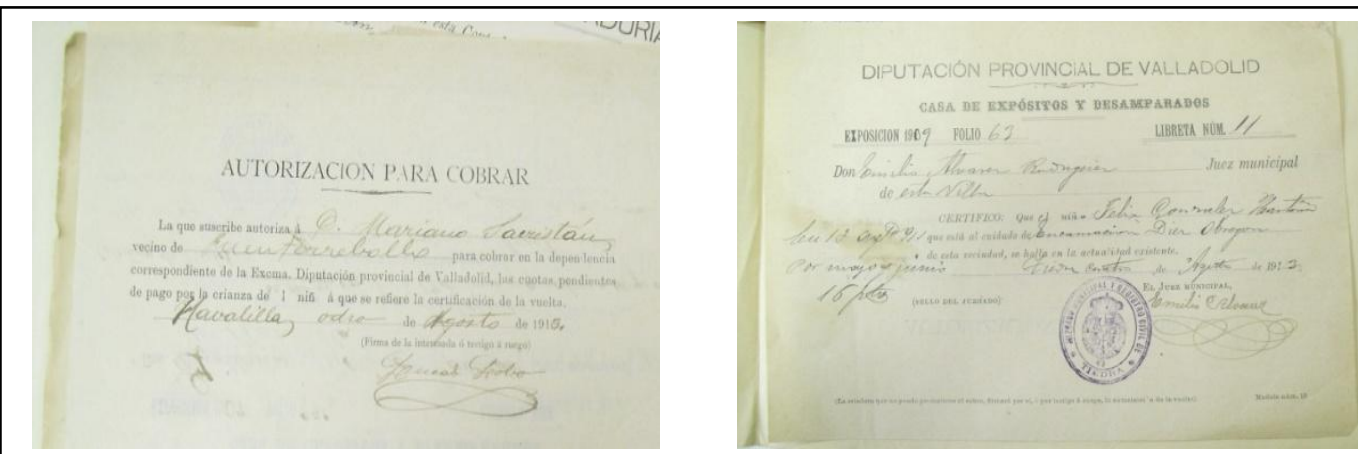

Imagen 1-28: Papeleta con la certificación de vida del niño y la autorización de cobro. Año 1906 folio 290

\footnotetext{
${ }^{98}$ Signatura: caja 2450, expediente 30505

${ }^{99}$ Signatura: caja 2450, expediente 30506

${ }^{100}$ Signatura: caja 2450, expediente 30507

${ }^{101}$ Signatura: caja 2450, expediente 30508

${ }^{102}$ Signatura: caja 2450, expediente 30509

${ }^{103}$ Signatura: caja 2450, expediente 30510
} 
También encontramos las papeletas, de color rosa, de baja en nómina de la criadora por devolución del niño. Son justificantes firmados por el director y una Hermana de la Caridad comunicando la vuelta del niño al establecimiento al Contador de la Diputación, se anota junto el nombre del niño el año y folio de exposición, el nombre de la criadora y su localidad y el número de la libreta de crianza.

Todas las papeletas conservadas llevan fecha de 1913-14, aunque corresponden a expedientes de niños ingresados en distintos años y que están ya en período de destete.

En una de las carpetas, de 1908, encontramos una cartilla o LIBRETA DE CRIANZA EXTERNA de las nuevas, que se empezaron a utilizar a partir de 1913 , es para una niña nacida en 1910, que está ya en destete, y los pagos registrados comienzan en septiembre de 1913. Las cartillas estaban numeradas con una serie propia, que no tenía relación ni con el no de filiación ni con el del folio de exposición. En la portada de la cartilla va el número bien visible en la parte superior y a continuación los datos del niño: nombre, año y folio de exposición, fecha de inscripción en el registro civil, las fechas de finalización de la Lactancia y el Destete y finalmente la fecha de expedición de la cartilla. En la parte interior se recogen los "Artículos del Reglamento del Hospicio" referentes a la crianza externa; artículos 331, 334, 337, 339, 341, 342 y 343. Siguen tres "ADVERTENCIAS IMPORTANTES" y la "DILIGENCIA DE SALIDA" donde se registra la primera salida del niño del Hospicio y el número de la libreta, además de volver a poner la exposición el folio y la inscripción en el registro civil. A continuación, en la página siguiente hay cinco apartados para registrar posibles cambios de ama, se anotan los nombres y la localidad. En las tres páginas siguientes se inserta una tabla para registrar la CUENTA DE COBRANZA, la primera parte para anotar las cuentas por LACTANCIA y a continuación el DESTETE. Se anota en cada registro la fecha de cobro, el concepto y la cantidad.

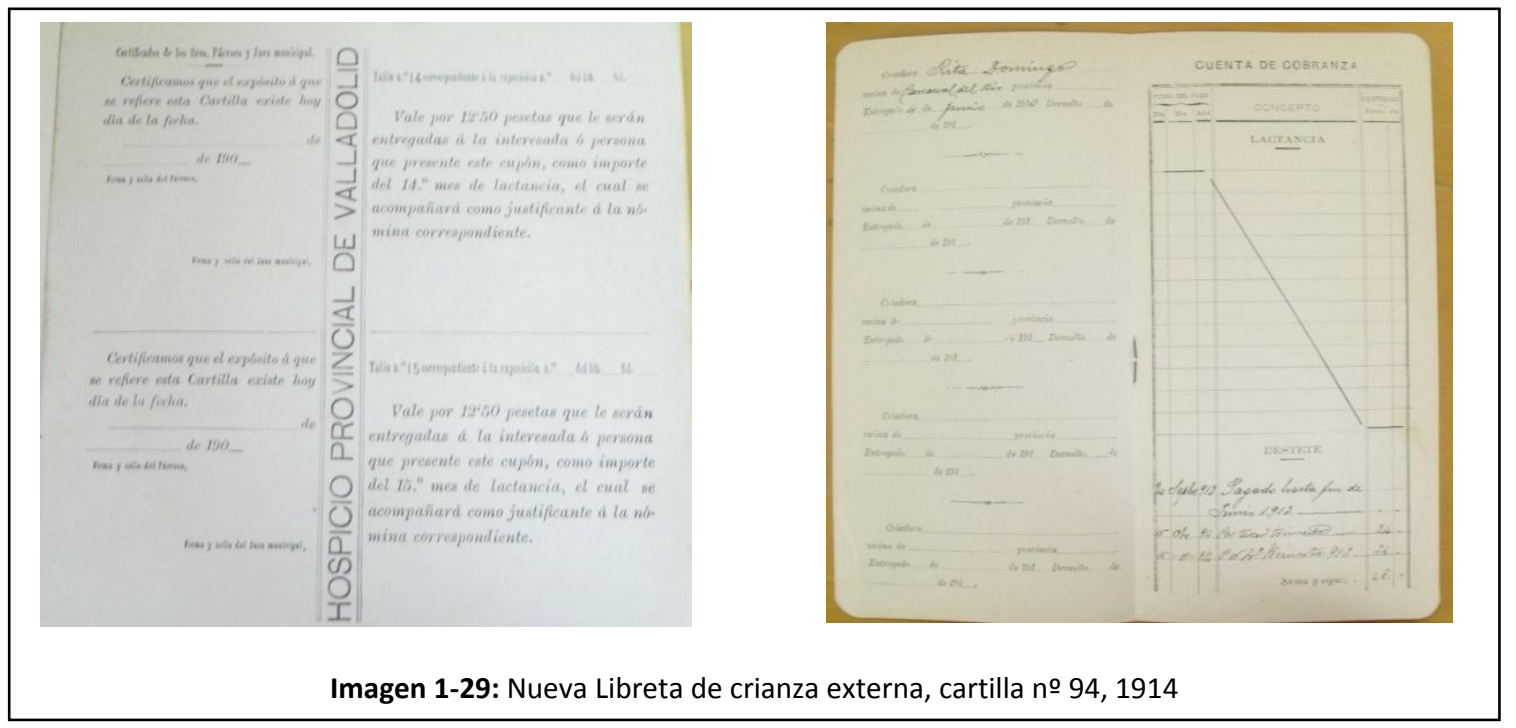


En el Libro de registros de salidas de 1907 se ha encontrado una cartilla antigua de lactancia. Es una libreta impresa en la imprenta del propio Hospicio, como muchos de los libros y documentos que utilizan, y en cuya portada bajo el membrete de la Diputación Provincial figura el lema "Cartilla para niños de lactancia en los pueblos pertenecientes al Hospicio provincial". En el interior, tras los datos de identificación del niño (nombre, no de folio, fecha de exposición y de salida) y el nombre de la mujer y de su marido y la localidad, aparece el artículo 91 del Reglamento del Hospicio que advierte a la nodriza de la obligación de justificar la devolución de los niños para percibir el pago correspondiente. Este artículo pertenece al Reglamento de 1889, que seguía vigente en 1906, fecha de esta cartilla, en las cartillas nuevas se aplica ya el Reglamento de 1910. A continuación hay 15 talones para el cobro de las correspondientes mensualidades a razón de 12,50 pts mensuales. Cada talón se acompaña de un cupón que se arranca como justificante del pago y un resguardo que queda en la cartilla y en el que el Cura párroco o el Juez municipal certifican que "el expósito... existe hoy día de la fecha"

No se ha encontrado ninguna libreta de destete.
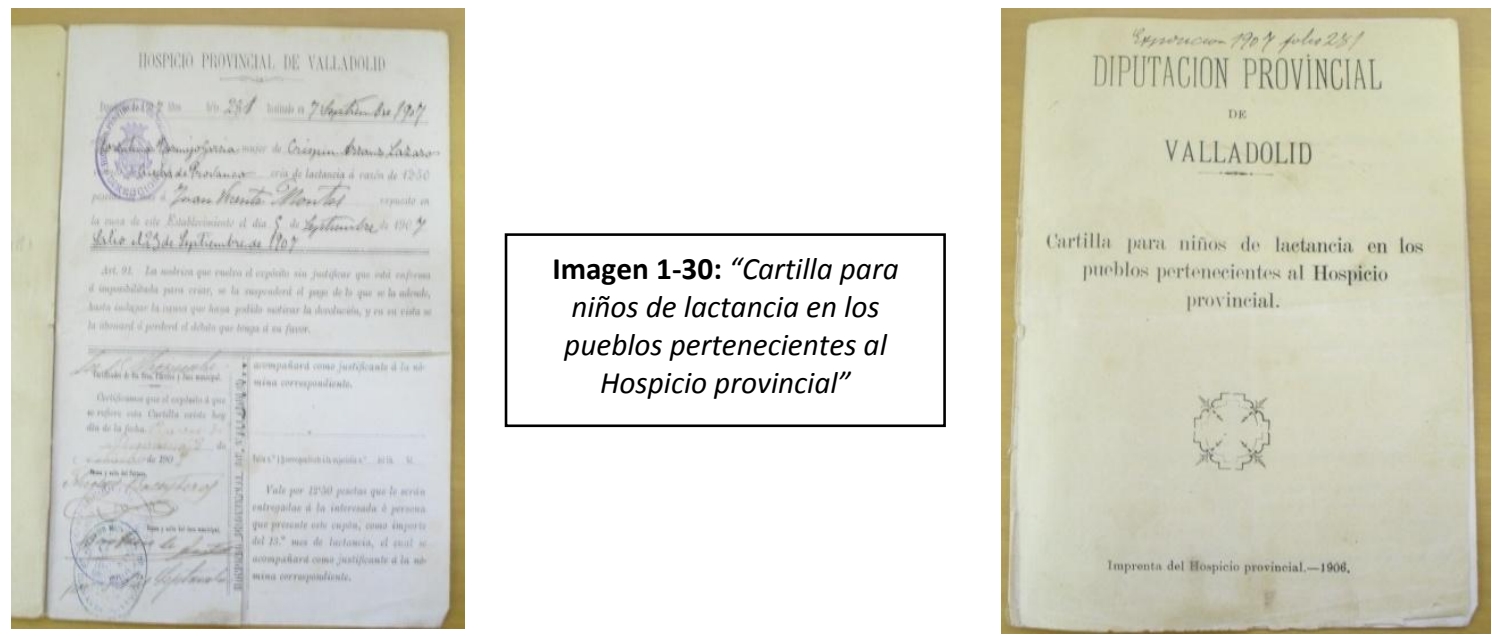

\subsection{EXPEDIENTES PERSONALES DE MENORES}

En esta serie se conservan 219 expedientes, la mayoría fueron abiertos a partir de 1910 y pueden consultarse 24, teniendo en cuenta la fecha límite de cierre de 31/12/1913. Muchos de los expedientes, 17 de los 24 revisables, recogen sólo períodos de un año. Se 
comprueba que la fecha de inicio de los expedientes no coincide con la de ingreso en el Hospicio, así, en el listado figuran con fecha 1 de enero de 1901 tres niños que no se corresponden con el único que ese día ingresó en el orfanato, según figura en el libro de entradas de ese año.

El expediente de cada niño se guarda en una carpeta de papel en la que bajo el membrete de DIPUTACIÓN PROVINCIAL DE VALLADOLID. HOSPICIO PROVINCIAL-CENSO, se anota el año de la Exposición, el número del Folio, el nombre del Asilado y el número de Filiación, además lleva el sello donde también se registra dicho número. A pesar del nombre de la serie no encontramos ningún expediente completo, es decir, con toda la información que podríamos esperar de cada niño desde su ingreso en el asilo hasta su baja. Dentro de cada expediente hay documentos sueltos y diferentes, normalmente, los que corresponden a cuestiones similares están pegados o atados con bramante, por ejemplo encontramos la papeleta del hospicio con el nombre del ama interna unida a los certificados de buena conducta de las amas externas, que es la documentación más frecuente. Se comprueba que todos los niños están registrados en los Libros de Exposiciones correspondientes y que coinciden los datos en ambos sitios.

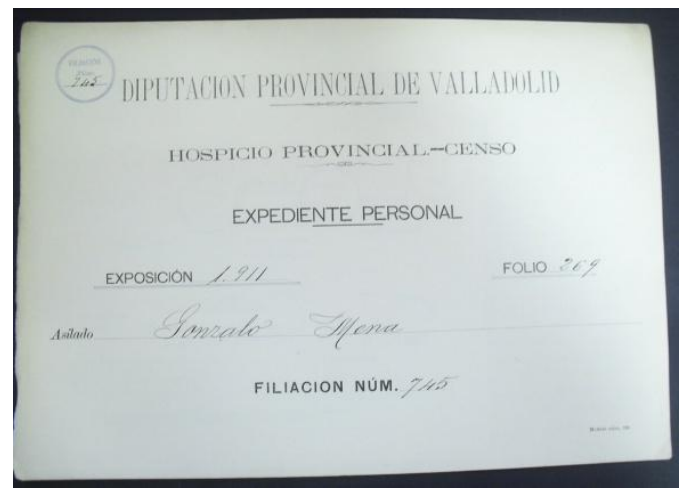

Imagen 1-31: Carpeta de Expediente Personal. Exposición 1911. Folio no 269. № de filiación 745

a) El expediente de la asilada de la Exposición de 1909, folio $127^{104}$ es uno de los más completos, muchos de los documentos que contiene se repiten en los demás expedientes:

- Una carta con timbre de la secretaría de la comisión provincial con fecha de 3 de abril de 1903 dirigida al director del Hospicio aceptando la solicitud de ingreso hecha por el abuelo de la niña, que argumenta que la madre es soltera y no tiene leche ni recursos para criarla.

- Certificado de la inscripción en el Registro Civil firmada por el juez municipal

\footnotetext{
${ }^{104}$ Signatura: caja 2224, expediente 24442
} 
- Papeleta de la Dirección del Hospicio con la orden dirigida a la Sa Superiora de ingresar a la niña en la "Sala de los Bautizados". En la parte de atrás figura el nombre del ama interna.

- Papeleta del Hospicio firmada por el médico con el resultado del reconocimiento realizado al ingreso. En la papeleta hay un apartado para anotar SEÑAS PARTICULARES, en la que está anotado el peso y DEFECTOS DE CONFORMACIÓN, que en esta niña pone "ninguno"

- Papeleta del Hospicio con el nombre de la nodriza interna y la fecha del ingreso. Está pegada a un certificado de buena conducta del ama externa y de su marido, firmado por el alcalde del pueblo de éstos, y que en la parte inferior tiene el visto bueno del médico del asilo, que escribe y firma: "Buenas condiciones para lactar"

- Papeleta con la devolución por la primera criadora el 2 de enero de 1910, no consta el motivo. Está pegada a una carta manuscrita por el Cura párroco de San Cebrián certificando la "buena conducta moral, social y religiosa" de la segunda ama.

- Papeleta de cobro de la nodriza externa con certificado de vida de la asilada con fecha de 31 de diciembre de 1913.

- Recibo de la contaduría del Hospicio por la cartilla de crianza para sustituirla por un modelo nuevo

- Resguardo de color rosa de "baja en nómina por la devolución del asilado"

- Libreta nueva de crianza externa con anotaciones en el periodo de destete y con la fecha de finalización, marcada al cumplir los 6 años en abril de 1915; el período de lactancia está tachado, se encontraría registrado en una cartilla de las antiguas.

b) El Expediente de 1905, Folio $n=158^{105}$ contiene los siguientes documentos:

- Certificado de Bautismo manuscrito y firmado por el Capellán del Hospital General de la Purísima Concepción de Medina del Campo, se trata de una "niña expuesta en el torno" [sic].

- Acta de nacimiento y de inscripción en el Registro Civil de Medina del Campo, en ella se relata cómo fue encontrada la niña.

\footnotetext{
${ }^{105}$ Signatura: caja 2199, expediente 21740
} 
- Carta del alcalde comunicando el traslado al Hospicio acompañada por Isidora Giménez Delgado.

- Papeleta de asignación de la nodriza interna pegada al certificado de buena conducta del ama externa y de su marido, firmado por el juez municipal del pueblo, con el visto bueno del médico del asilo.

- Papeleta de devolución por la criadora pegada al certificado de buena conducta de una mujer viuda que quiere solicitar a la niña para destete

c) El Expediente de 1911, Folio no $269^{106}$ contiene:

- Papeleta del Hospicio de Exposición en el torno firmada por la Superiora. En el reverso se anotan las ropas que llevaba el niño y el nombre del ama adjudicada. Lleva pegada una nota con el nombre y el sello de filiación avisando que está "Bautizado".

- 2 papeletas de revisión médica, una de ellas pegada a las dos anteriores, con el mismo números de filiación y "número de plomo" pero que no coinciden en los datos de la exploración clínica.

- Carta del Juzgado de instrucción de Primera Instancia solicitando señas y estado de salud del niño para el sumario que se está instruyendo sobre él porque fue encontrado por dos guardias en la puerta del hospicio.

- Papeleta de la nodriza interna con la nota al margen: "Bauticé hoy 12 de Agosto de 1911 condicionalmente" [sic] al niño firmada por el párroco. Está pegada al certificado de buena conducta del ama externa con el visto bueno del médico del asilo para lactar.

d) El Expediente de 1906, Folio no $344^{107}$ contiene: Carta del alcalde de Medina del Campo, certificado de Bautismo y Acta de inscripción en el Registro Civil. Papeletas de ingreso en la "Sala de los Bautizados" y del ama interna con el certificado de buena conducta del ama externa y el visto bueno para lactar del médico del asilo. Papeleta de devolución por la criadora pegada a una carta de la Comisión comunicando el acuerdo de "entregar un asilado del hospicio de 10-12 años de edad" [sic] a un labrador de Peñafiel.

\footnotetext{
${ }^{106}$ Signatura: caja 1284, expediente 8522

${ }^{107}$ Signatura: caja 1281, expediente 8416
} 
e) En el Expediente de 1908, Folio no $128^{108}$ podemos ver el Certificado de Bautismo del Capellán del Hospital de Medina del Campo, el Acta de inscripción en el Registro Civil, la carta del alcalde comunicando el traslado del niño, la papeleta de ingreso en la "Sala de los Bautizados", la papeleta de la nodriza interna pegada al certificado de buena conducta del ama externa con el visto bueno del médico del asilo y una Libreta nueva de crianza externa con anotaciones de 1912 en el periodo de destete.

f) En el Expediente de 1911, Folio no $229^{109}$ encontramos la papeleta del Hospital Provincial de la Resurrección con los datos de la madre pegada a la del reconocimiento médico y la papeleta de la nodriza interna pegada al certificado de buena conducta del ama externa con el visto bueno del médico del asilo.

g) En el Expediente de 1912, Folio no $28^{110}$ hay una papeleta de la maternidad del Hospicio con el nombre de la "Refugiada", el sexo del hijo y la fecha y hora del parto; la papeleta del Hospicio con la fecha del bautizo firmada por el capellán y el nombre de la nodriza interna, que es la propia madre y, pegada a ella, el certificado de buena conducta del ama externa y el visto bueno para lactar.

h) En el Expediente de 1912, Folio no $29^{111}$ encontramos la carta del alcalde de Tiedra con fecha 19 de enero de 1912 comunicando el traslado de un niño recién nacido "aparecido en el humbral de la puerta de la casa" [sic]. Cosidos con bramante están el certificado de bautismo y el de la inscripción en el Registro Civil. También están la papeleta del Hospicio con la orden de ingreso en la "Sala de los Bautizados" y la que registra el nombre de la nodriza interna pegada al certificado de buena conducta del ama externa y de su marido y el visto bueno para lactar del médico del Hospicio.

i) El Expediente de 1912, Folio no $46^{112}$ contiene la papeleta del Hospital Provincial de la Resurrección fechada el 5 de febrero de 1912 con los datos del niño trasladado y de su madre, pegada a la orden de ingreso en la "Sala sin Bautizar". También tiene la papeleta del Hospicio con el nombre de la nodriza, en la que se indica en un punto que está sin bautizar y en una nota al margen el capellán firma el bautizo al día siguiente del ingreso. Está pegada al certificado de buena conducta del ama externa y su marido con el visto bueno para lactar del médico del hospicio.

\footnotetext{
${ }^{108}$ Signatura: caja 2224, expediente 24392

${ }^{109}$ Signatura: caja 1284 , expediente 8520

${ }^{110}$ Signatura: caja 1279 , expediente 8313

${ }^{111}$ Signatura: caja 1279, expediente 8312

112 Signatura: caja 1279, expediente 8311
} 
j) El Expediente de 1912, Folio no $263^{113}$ tiene una papeleta del Hospicio de registro de la exposición en el torno, con las ropas que llevaba el niño y el nombre de la nodriza interna escritos al dorso. Cosidos con bramante, el certificado de bautismo y el de inscripción en el Registro Civil y, aparte, la papeleta del Hospicio con el nombre de la nodriza interna pegada al certificado de buena conducta del ama externa y de su marido con el visto bueno para lactar.

k) En el Expediente de 1912, Folio no $331^{114}$ podemos ver la carta de la Comisión comunicando el ingreso de la niña, solicitado por los padres por carecer la madre de leche y de medios para mantenerla; el Acta de la sección de Nacimientos del Registro Civil; la papeleta de ingreso en la Sala de Bautizados; la de la nodriza interna pegada al certificado de buena conducta "moral y política" del ama externa; 2 papeletas de cobro del ama externa con la autorización en el reverso a una tercera persona; otra de la contaduría para el canje de cartilla y la libreta de crianza externa con pagos hasta noviembre de 1913. Se encuentra además la papeleta rosa de baja en nómina de la criadora, el recibo por la devolución de la cartilla con el último pago y la papeleta de devolución de la nodriza con una nota firmada por el médico respecto al fallecimiento de la niña en el reverso

I) El Expediente de 1913, Folio no $75^{115}$ tiene la carta de una mujer viuda solicitando el ingreso de sus hijos, entre ellos el interesado, la resolución de la Comisión Provincial y el certificado de la inscripción en el Registro Civil. También están la papeleta de ingreso en la sala de bautizados para destete, el niño tiene 3 años, el certificado de buena conducta del ama externa, con garantía de que tiene medios suficientes para mantener al niño y papeletas de cobro del ama y del cambio de cartilla.

Hay 6 expedientes que pertenecen a niños registrados en los Libros de Mayores, denominados con las siglas LM y con el número del libro a continuación:

a) Expediente de 1904 del LM 15, folio no $8^{116}$. Contiene la carta de la Comisión comunicando el ingreso de la niña, huérfana de 9 años, solicitado por su tío; el certificado de nacimiento y la papeleta de ingreso en el hospicio. Hay dos cartas más de la Comisión para comunicar al hospicio en una la entrega a un matrimonio de una

\footnotetext{
${ }^{113}$ Signatura: caja 1279 , expediente 8310

${ }^{114}$ Signatura: caja 1285 , expediente 8576

${ }^{115}$ Signatura: caja 1279 , expediente 8312

${ }^{116}$ Signatura: caja 1278 , expediente 8279
} 
niña de 12 años "para criarla y educarla", y en la otra el reingreso de la muchacha con 21 años y su baja definitiva en el asilo por la edad.

b) Expediente de 1906 del LM 15, folio no $161^{117}$. Contiene la carta del Gobierno Civil solicitando el ingreso provisional de una "joven muda... (que) carece hoy de familia por estar detenida y complicada en un robo de alhajas de esta capital y ser conveniente que se halle en un lugar de refugio y asegurada su vida de cualquier asechanza que contra ella pudiera intentarse". Junto a ella hay una serie de cartas y notas internas para comunicar las salidas y vueltas de la muchacha al juzgado.

c) El Expediente de 1908 del $L M$ 16, folio no $244^{118}$ corresponde a una niña de 8 años. En él encontramos la carta de la Comisión aceptando la solicitud hecha por su madre por falta de recursos, la nota de entrada en el hospicio y el certificado del Registro Civil, donde consta que es hija ilegítima. Además hay otras tantas cartas de la Comisión Provincial para comunicar la entrega de una niña de 14-16 años "para compañía (de un) matrimonio por carecer de familia", la devolución de la niña, por el fallecimiento de la mujer, y una nueva entrega al mismo que la devolvió un año después. También está el certificado de buena conducta del matrimonio y la papeleta de la devolución

d) En los expedientes de los niños inscritos en el $L M$ 16, folio $n$ o $316^{119}$; $L M$ 17, folio $n$ o $68^{120}$ y LM 17, folio no $112^{121}$ encontramos documentos similares a los anteriores sobre el ingreso, certificados del Registro Civil y entrega de niños "para compañía".

Hay dos carpetas más que contienen un único documento. En la primera ${ }^{122}$ hay una cuartilla de la Comisión provincial con el acuerdo de aceptar la solicitud del padre de un asilado para devolverle a su hijo después de ocho años internado. En la otra ${ }^{123}$ se guarda una hoja cortada de lo que podría ser un libro de registro de defunciones de la enfermería en la que consta el fallecimiento de una

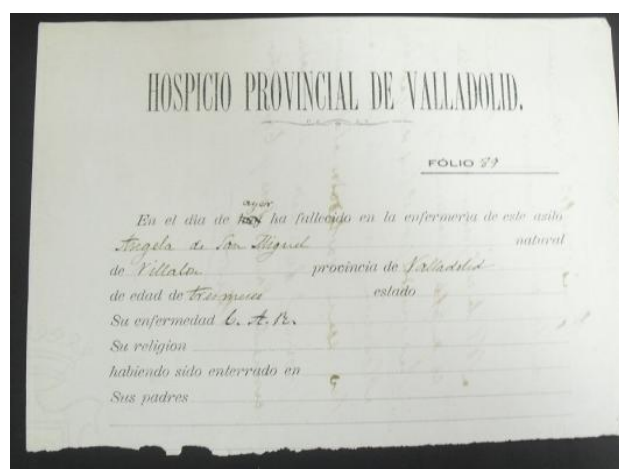

Imagen 1-32: Folio cortado, con el registro de un fallecimiento en la enfermería del asilo niña de 3 meses, no aparece la fecha. Se trata de un

\footnotetext{
${ }^{117}$ Signatura: caja 2224, expediente 24390

${ }^{118}$ Signatura: caja 2224, expediente 24386

${ }^{119}$ Signatura: caja 2224, expediente 24380

${ }^{120}$ Signatura: caja 2224, expediente 24417

${ }^{121}$ Signatura: caja 2224, expediente 24417

${ }^{122}$ Signatura: caja 5419, expediente 53876

${ }^{123}$ Signatura: caja 6594, expediente 66378
} 
folio numerado, con el membrete del Hospicio y una plantilla impresa para los registros; es diferente de los folios del libro de defunciones de 1908 que es el único de estas características que se conserva. En el reverso, manuscrito, lo que parece el borrador de una carta al Vicepresidente de la Comisión solicitando el ingreso en el manicomio de una asilada por indicación del "Profesor Médico del Establecimiento"

\subsection{REGISTROS DE EXISTENCIAS DE LOS CENTROS DE ACOGIDA DE MENORES}

Debido a sus características, no existe limitación temporal para la consulta de la documentación de esta serie, por lo que se ha podido acceder a todos los archivos pertenecientes a la época de estudio, en total 19; salvo uno de 1863- 64 que también se consulta, el resto de los libros conservados están fechados a partir de 1958. Son libros de contabilidad, de control de compras, de suministros y de facturas; unos tienen aspecto más oficial, podían llevarse en la oficina del Hospicio y otros parece que podrían utilizarse para control del almacén.

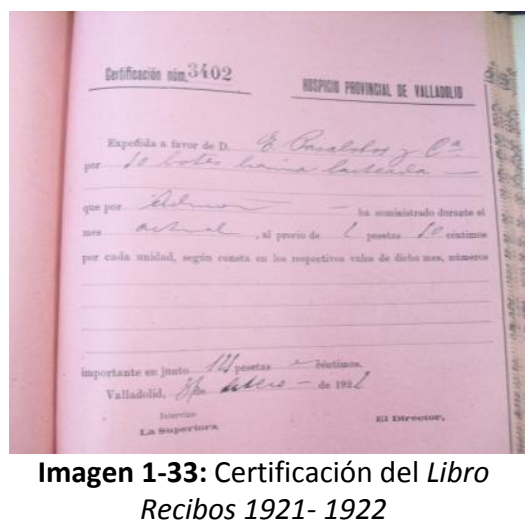

Hay 5 libros en el Archivo con la descripción "Recibos" o "Suministros" de los años $1901^{124}, 1921^{125}$, que en realidad contiene recibos de los años 1924 y 1925, Suministros de $1921-1922^{126}, 1924^{127}$ y $1926-1927^{128}$. Todos recogen los resguardos de las certificaciones de todas las compras hechas en estos años, ordenadas por fechas, firmadas por el Director y la Superiora y con el visto bueno del Diputado Visitador. Parece que a los proveedores se les debía entregar la otra parte de los recibos, en la que el director certifica la entrega del material y su precio, y que la tendrían que presentar para el cobro en la Contaduría de la Diputación. Las compras habituales se hacían por concurso

\footnotetext{
${ }^{124}$ Signatura: caja 476 , expediente 4196

${ }^{125}$ Signatura: caja 450 , expediente 4124

${ }^{126}$ Signatura: caja 480, expediente 4218

${ }^{127}$ Signatura: caja 450, expediente 4125

${ }^{128}$ Signatura: caja 480, expediente 4219
} 
o subasta, los gastos extras, como los que aparecen por "catres nuevos de hierro" o "36 docenas de cucharas de peltre ${ }^{129 "}$ en 1901, tenían que ser aprobados "por acuerdo de la Comisión provincial".

Se conservan libros de contabilidad de algunos años sueltos y entre ellos un cuaderno de aspecto casero de $1909-17^{130}$ que no tiene ninguna etiqueta identificativa ni hojas impresas, todo está escrito a mano y recoge los gastos diarios del Hospicio, con la fecha, el producto y el precio.

El libro etiquetado "Hospicio provincial - Almacén- Diario de entradas de suministros. Año $\mathbf{1 9 1 5}^{131}$ recoge también la relación de gastos diarios pero con el formato de un libro de contabilidad en hojas impresas para anotar entradas y salidas, conceptos, fecha y costes.

Hay otros diez libros de control de gastos por partidas etiquetados como:
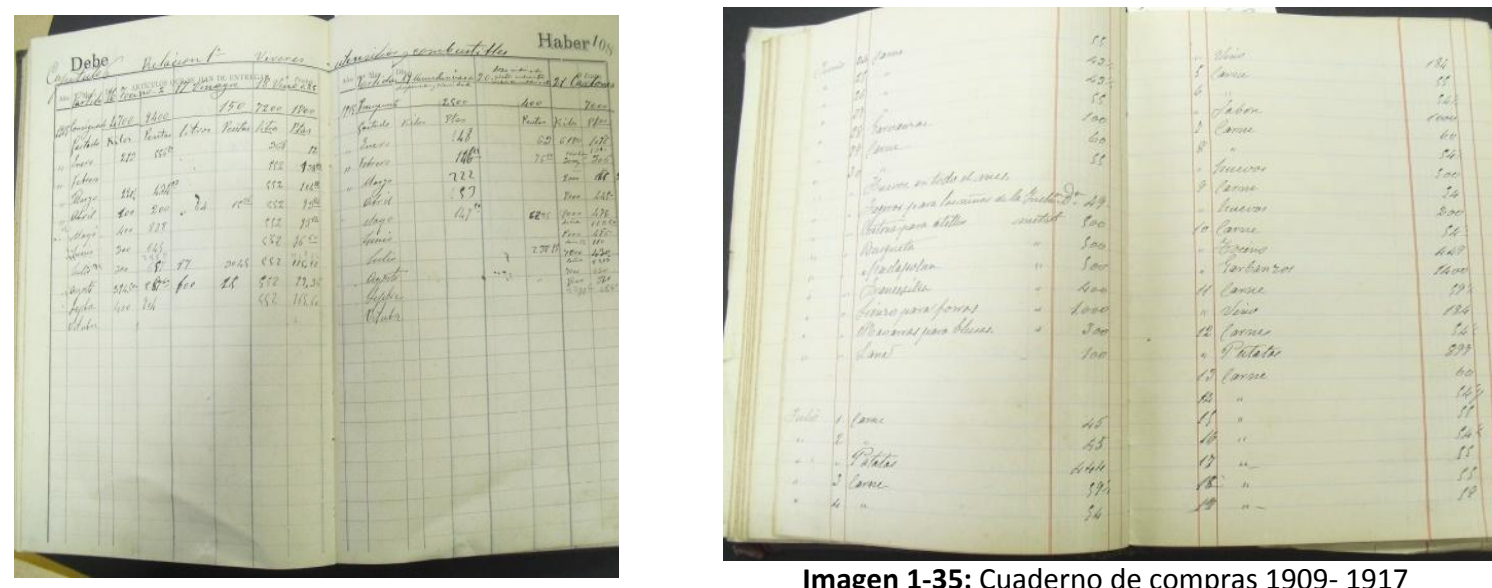

Imagen 1-35: Cuaderno de compras 1909- 1917

Imagen 1-34: Hospicio provincial - AlmacénDiario de entradas de suministros. Año 1915

- “1902-03"132

- “Presupuesto Año 1909"133

- "Mensual de cuentas. Año de 1913 Oficina"134

- "1915 - Hospicio-Almacén-"135

- “Libro de Certificaciones Año de 1918-19"136

\footnotetext{
${ }^{129}$ PELTRE: “aleación de zinc, plomo y estaño". Enciclopedia ESPASA, tomo 43, p 114

${ }^{130}$ Signatura: caja 659, expediente 6704

${ }^{131}$ Signatura: caja 1231, expediente 7782

${ }^{132}$ Signatura: caja 667, expediente 6717

${ }^{133}$ Signatura: caja 928, expediente 7140

${ }^{134}$ Signatura: caja 1260, expediente 7864

${ }^{135}$ Signatura: caja 667 , expediente 6718
} 
- "Hospicio provincial Registro de Certificaciones Año económico de 1919- 20"137

- “Hospicio provincial Registro de Certificaciones Año económico de 1921- 22"138

- "Hospicio provincial Registro de Certificaciones Año económico de 1922- 23"139

- "Hospicio provincial Registro de Certificaciones Año económico de 1923-24"140

- “Hospicio provincial Registro de Certificaciones Año económico de 1924 al 1925"141.

En todos ellos se anota una partida en cada hoja con el presupuesto aprobado para el año y los pagos realizados, con la fecha, el nombre del proveedor y el número de la certificación o justificante del pago.

Un libro etiquetado como "1928", recoge la contabilidad de la Vaquería ${ }^{142}$ en los años 1928 -1933. En cada hoja, se registra un mes completo con las entradas y salidas de los distintos tipos de pienso: salvado hoja, tercerilla, paja, alfalfa y heno. Se anota su consumo diario y en la paja se diferencia entre la que se utiliza para Pienso y para Camas. En las columnas destinadas a "Productos" se registran los litros de leche recogidos por la mañana y por la tarde, los carros de Basura y las "Reses nacidas en el establo". Cada hoja debía contar con la firma del vaquero, que no aparece en ningún registro, y el visto bueno del director, que firma en todas. Hay aparte un

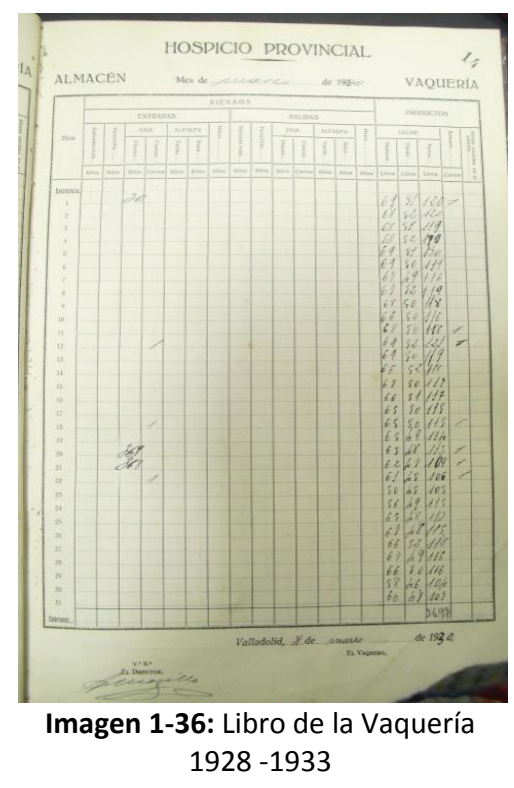
expediente denominado "Productos de Vaquería del Hospicio" de $1926^{143}$ que contiene algunas hojas sueltas de registro donde constan los "NOMBRES DE LAS RESES" y los litros de leche que producen en el ordeño de la mañana y de la tarde y el total. En ese momento tienen 10 vacas, cada una con un nombre propio (Cierva, Estrella, Montañesa, Rata, Bonita, Lucera, Mariposa, Perla, Rubia y Preciosa), un toro (Arrogante) y una ternera. Anotan las que están próximas a parir o recién paridas y quedan para ordeñar de 4 a 6 vacas consiguiendo entre 86 litros diarios a primeros de julio con seis vacas disponibles y 59- 60 litros a finales de octubre con el ordeño de sólo 4 de las diez vacas. Firma cada hoja de registro diario la Hermana Superiora Sor Ignacia Domínguez.

\footnotetext{
${ }^{136}$ Signatura: caja 6265, expediente 61890

${ }^{137}$ Signatura: caja 1226, expediente 7763

${ }^{138}$ Signatura: caja 920, expediente 7115

139 Signatura: caja 1333, expediente 10650

${ }^{140}$ Signatura: caja 1328, expediente 10614

${ }^{141}$ Signatura: caja 1328, expediente 10613

${ }^{142}$ Signatura: caja 441, expediente 4091

${ }^{143}$ Signatura: caja 2449, expediente 30487
} 
El libro que lleva la etiqueta "Hospicio provincial de Valladolid. Estadística general de gastos 1903, 1906"144 recoge, como dice en su primera página la "Estadística de suministros y enseres que se han consumido en dicho Establecimiento en 1903", aunque luego se añadieron las cuentas de los ejercicios siguientes hasta 1906 completo. Contiene la relación de los gastos mensuales; compras, gastos de personal, de culto..., incluidos los extraordinarios e imprevistos. Este libro recoge todos los artículos que adquiere el Hospicio en estos años y es representativo para todo el período, pues, salvo los gastos extraordinarios e imprevistos, los artículos se repiten en todos los libros. En este libro se registran los gastos por partidas, con su presupuesto anual, el ordinario y en algunos casos un " $P^{\text {to }}$ adicional", y el gasto mensual. Se anotan los títulos de cada sección del presupuesto en el margen superior de las hojas y cada artículo en una columna, se recogen tal y como aparecen en el respectivo Presupuesto General de Ingresos y Gastos de la Diputación Provincial de Valladolid,.

En el apartado titulado "Víveres, utensilios y combustibles" se incluyen en distintas columnas los gastos de: "Pan de 19", "Pan de 2q" , "Carne de vaca", "Tocino salado", "Aceite común", "Garbanzos", "Judías", "Arroz", "Bacalao", "Huevos" de gallina (como se añade en otros libros), "Sardinas", "Pimentón flor", "Sal", "Chocolate", "Bizcochos", "Patatas", "Vino común", "Pasta para sopa", "Azúcar" y dos columnas para "Menudencias, postres Hijas de la

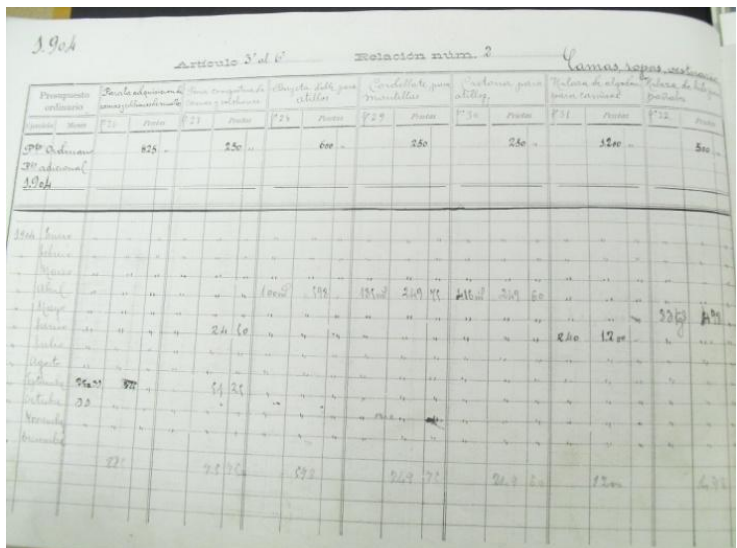

Imagen 1-37: Estadística general de gastos 1903, 1906. "Camas, ropas vestuarios y útiles de cocina"
Caridad y extraordinarios" y "Para loza, platos, jarros, vasos y cubiertos de madera y de metal". Todos estos artículos se repiten en los ejercicios de 1903 a 1905, en 1906 hay algunas diferencias: se anotan garbanzos de 1aㅡ y de 2a , sal molida o en grano, se añade "Bizcochos y Azucarillos ${ }^{145 " ~ y ~}$ "Sardinas ó Pescado fresco" y aparecen los gastos en "Vinagre". En el apartado

de la Loza vemos que se empieza a comprar vidrio, "Loza y vidriado de todas clases, platos, vasos, jarras, cubiertos de madera y de metal, cubos de madera o de hierro", en él se incluye en el libro de certificaciones 1918-19 la compra de "orinales de distintos tamaños". Como podemos comprobar no hay gastos para leche ni para frutas y verduras. El Hospicio contaba

\footnotetext{
${ }^{144}$ Signatura: caja 1328, expediente 10615

145 AZUCARILLO: "pan de azúcar esponjado á manera de pana, que sirve para refrescar con agua". Zerolo Elías. Diccionario Enciclopédico de la Lengua Castellana. París 1895 p 312. El Diccionario de la RAE de 1899 en su p 117 lo define como: "porción de masa esponjosa que se hace con almíbar muy en punto, clara de huevo y zumo de limón. Empapado con agua ó deshecho en ella sirva para endulzarla ligeramente y templar su crudeza.
} 
con vaquería propia, pero no podemos asegurar que tuviera huerto, los gastos de su mantenimiento no se encuentran en los libros, sólo consta en el ejercicio de 1904 un asiento de 250 pesetas en concepto del "Pago del arriendo de una huerta pa el Establecimiento" [sic].

En combustibles se anotan los gastos de "Carbón mineral y de cok"146", "Carbón de encina", "Leña de encina" y hay una columna para "Alumbrado de todas clases, aparatos $e$ instalaciones que fuesen necesarios".

En el apartado de "Camas, ropas vestuarios y útiles de cocina" se incluye, además de las compras de camas y cunas, un apartado para la "Compostura de camas y colchones" y en diciembre de 1905 se registran "2 cunas incubadoras" por un valor de 500 pesetas. Desde 1904 se hacen compras de colchones de muelles; aunque la mayoría se debían elaborar en el propio Hospicio pues hay registros de "Lana para colchones", "Cutí147 para jergones" y en Gastos Generales se anotan todos los años las compras de "Paja larga ó de maíz para colchones y jergones" además de "Hules ${ }^{148}$ para las cunas de los niños de la inclusa" y para las camas, "Zaleas ${ }^{149 ",, ~ " M a n t a s ~ d e ~ l a n a " ~ d e ~ d i s t i n t o s ~ p r e c i o s ~ q u e ~ p o d r i ́ a n ~ s e r ~ d e ~ c u n a s ~ y ~ c a m a s ~ y ~}$ "Cretona ${ }^{150}$ para colchas". Hay compras de diferentes tipos de telas para la confección de ropa: "Hilaza de algodón para camisas" e "Hilaza de hilo para pañales", "Bayeta ${ }^{151}$ doble para $a^{a t i l l o s}{ }^{152 ",}$ "Cordellate ${ }^{153}$ para mantillas", "Cretona para atillos", "Muselina ${ }^{154}$ de lana para mantillas ${ }^{155}$ ", "Lienzo y percalina ${ }^{156}$ para forros", "Fortuna para atillos" y para gorros y camisas, "Bion para bombachos y blusas", "Patent cuadritos para pantalones de asilados", "Navarra

\footnotetext{
${ }^{146}$ COK= COQUE: "Substancia carbonosa sólida, ligera, gris y lustrosa, que resulta de la calcinación de la hulla en vasos cerrados ó en montones cubiertos de tierra, y produce, al quemarse, gran cantidad de calor." Diccionario de la RAE. Madrid 1899, 13a edición, p 269

147 CUTí: "Tela de lienzo rallado o con otros dibujos que se usa comúnmente para cubierta de colchones". Enciclopedia ESPASA, tomo 3, Apéndice 1931, p 1104

148 HULE: "Tela pintada al óleo y barnizada que por su impermeabilidad tiene muchos usos". Diccionario de la RAE, Madrid 1899, 13a edición, p 540

149 ZALEA: "Cuero de oveja o carnero curtido de modo que conserve la lana, sirve para preservar de la humedad y el frío... se emplean como protectoras de los colchones debajo de la sábana con la lana hacia arriba en invierno $e$ invertida en verano para que no dé tanto calor". Enciclopedia ESPASA, tomo 70, 1930, p 906

${ }^{150}$ CRETONA:"Tela comúnmente de algodón, blanca o estampada". Diccionario de la RAE, Madrid 1899, 13a edición, p 283

${ }^{151}$ BAYETA es la "tela de lana floja y poco tupida", según el ESPASA tomo 7, p 1301

152 Aunque lo veamos escrito en la mayoría de los asientos así, se refiere a HATILLOS o HATOS, que el ESPASA de la época en la página 796 del tomo 27 define como "ropa y pequeño ajuar que uno tiene para el uso preciso y ordinario".

${ }^{153}$ CORDELLATE, el ESPASA en la página 543 en el tomo 15 lo define como "tejido basto de lana cuya trama hace cordoncillo".

${ }^{154}$ MUSELINA es una "tela de algodón fina y poco tupida". Enciclopedia ESPASA tomo 37, p 543

${ }^{155}$ MANTILLA en su segunda acepción: "Cualquiera e las piezas de bayeta u otra tela con que se abriga y envuelve por encima de los pañales a los niños desde que nacen hasta que se sueltan a andar". Diccionario de la RAE, Madrid 1899, 13a edición, p 633.

${ }^{156}$ PERCALINA: "Percal de u solo color que sirve para forros de vestidos y otros usos". Diccionario de la RAE, Madrid 1899, 13a edición, p 764.
} 
para blusas", "Francesilla" y "Terliz ${ }^{157}$ para delantales", "Algodón para medias", "Vicuña para abrigos de niñas", "Paño para remendar" "Paño para trages de los asilados" [sic]; entre otras telas. Se compran pocas prendas confeccionadas, sólo figuran "Pañuelos moqueros", "Pañuelos para la cabeza", "Toquillas para las asiladas" y "bufandas finas". Se compran alpargatas de distintas medidas y diferentes materiales, "suela, baqueta ${ }^{158}$, badana... y otros para la confección de calzado para los asilados" [sic]. En este apartado también se incluye en 1905 la compra de 16 docenas de "Fajeros para los niños de la inclusa" con un presupuesto anual de 100 pts, que pasaría a 41 docenas y 250 pts, en 1906.

Casi todas las prendas de vestir, el calzado y las ropas de casa se elaboran y/o se arreglan en el Hospicio; además de los materiales anteriores, en el apartado de "Gastos Reproductivos" encontramos "Los Jornales del Maestro Zapatero" , "...del Maestro Tejedor" y "...del Maestro Sastre" y las "Herramientas y otros útiles para el taller de Zapatería", "...del oficio de Tejedor" y "Material para la sastrería"; en 1904

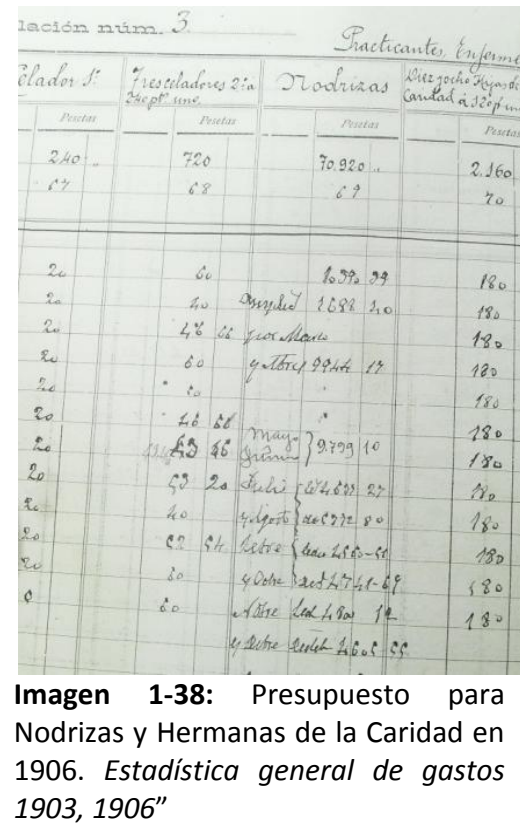
se adquiere una máquina de coser por 300 pesetas; en el libro de 1925 encontramos la compra de otra por 600 pts. También aparecen los gastos de jornales, materiales $y$ herramientas de carpintería, albañilería y de la imprenta, que incluyen el material, los gastos contributivos y los jornales de un "...cajista temporero" y "Para gratificar a los asilados que asistan a la Imprenta".

$$
\text { En el apartado titulado "Empleados, }
$$

administrativos y facultativos" se registran los sueldos del "Director" y de un "Médico" y en 1906 se añaden un "Profesor médico con derecho a ocupar este destino según RD de 25 de mayo de 1905" y un "Auxiliar" para la administración. Aparte se anotan los jornales de "Practicantes, Enfermeros y sirvientes" 159 , en 1906 figura un "Practicante", un

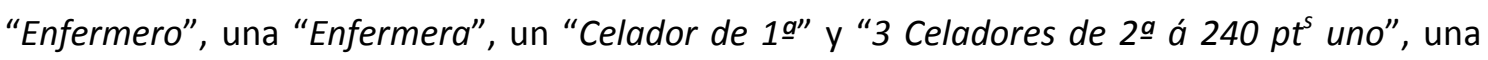
"Criada demandadera", "Dos lavanderas á 180 pt ${ }^{a s}$ una", antes de 1906 sólo había una y el "Portero", que vivía con su familia en un local a la entrada del Hospicio. Se encuentra además

157 TERLIZ: "Tela fuerte e lino o algodón, por lo común de rayas o cuadros y tejida con tres lizos". Diccionario de la RAE, Madrid 1899, 13a edición, p 954. En la p 607 define LIZO: "Hilo fuerte que sirve de urdimbre para ciertos tejidos".

${ }^{158}$ Se refiere a la VAQUETA, que según dice el ESPASA es un material de "cuero de ternera curtido y adobado ... (con el que) se hacen palas para el calzado", son "cueros fuertes y flexibles ... (que) se obtienen de pieles de ternera ... y ahora también de otros animales" tomo 66, 1929, p 1477

${ }^{159}$ Ver TABLA 3-3 
una "Gratificación a la persona que corta el pelo a los asilados" de 200 pts, aunque en 1903 fue de 300 pts, y otra de 25 pts anuales “... al Sepulturero", que se mantiene así en todo este período y que debía ser por el enterramiento de los niños fallecidos, ya que en la partida de Gastos Generales hay un presupuesto de 250 pts para "Funerales de las Hijas de la Caridad".

En esta partida se registran también los sueldos de las "Nodrizas" y de "Dieciocho Hijas de la Caridad a 120 pts [anuales] una", con anterioridad a 1906 eran 17 hermanas. Suponemos que es el presupuesto global para todas las amas porque en el libro de 1863 vemos anotados por separado los gastos en nodrizas internas y externas. Sólo está anotado el total y los pagos bimestrales, que coinciden con los períodos de pago de las amas externas. Hay dos asientos para cada período bimestral; la letra es de difícil lectura, pero parece que pone Leche y Destete.

En Gastos Generales encontramos desde 1903 pagos de 145 pts anuales por el "Servicio Telefónico", 1200 pts por "Dotación de Agua" corriente más 100 pts por "Reparación y conservación del filtro" (del agua), 1500 pts por "Legía, jabón ó $1^{a s}$ materias $p$ a la fabricac" [sic](para la fabricación). También aquí se incluye "la adquisición de instrumentos de cirugía" y el "material para enfermería y curas" en el que se refieren los pagos por algodón, aceite de hígado de bacalao y "solárium" y en 1906 encontramos por primera vez en este libro "tetinas y biberones" con un presupuesto de 250 pts. En 1903 aparece la primera compra de "Harinas lacteadas para los niños de la Inclusa"; se hizo un presupuesto inicial de 500 pesetas que se tuvo que ampliar con un presupuesto adicional para un gasto total de 962,50 pts, 400 botes en total en este año

En "Cargas del Establecimiento" aparecen los pagos de seguros de incendios, en algún otro libro dice "seguros y contraseguros de incendios", además de impuestos, limosnas y misas. Hay un apartado para "Culto y clero" en el que se recogen los gastos de las celebraciones del asilo, como la fiesta del patrono. Es interesante el apartado de Educación, llamado en el libro de 1863 de "Gastos de Cátedra y objetos de educación", en el que además de los jornales a los maestros y los gastos de material educativo se incluyen los gastos "Para pagos de matrículas a los asilados que sigan carreras" y en algunos años como en 1921 encontramos asientos del tipo "libros para una asilada que hace Magisterio". En el libro de certificaciones 1918-19 entre los gastos para el colegio diferencia las partidas de "menaje para niños" en el que aparecen mapas, libros, cartillas, etc y "menaje para niñas", que no tiene más anotaciones; en otros libros también se anotan por separado, en el de 1919 figuran la escuela "de niños y adultos" y la "de niñas y párvulos". 
Podemos comprobar que se mantienen los mismos artículos de unos años a otros, salvo gastos extraordinarios, que suelen ser obras, arreglos o compras de utensilios especiales como las máquinas de coser o una nevera, que se adquirió en 1927. Además, hay poca diferencia en cuanto a la relación de compras y gastos con el libro de 1863, excepto en cuestiones como el agua, pues en este libro todavía hay asientos por "acarrear el agua para los acogidos" a 6 reales diarios, por "dos arrobas de velas de sebo" y "lamparillas para el alumbrado", mientras que en 1900 ya se paga por el suministro de agua corriente y por el "alumbrado de todo tipo e instalaciones", en el libro de 1913 dice expresamente por "energía eléctrica" y en 1915 se anota un asiento de "Bombillas".

En el cuaderno de contabilidad de $1909-17$ se anotan los gastos diarios y comprobamos que efectivamente coinciden con los que aparecen en los libros de contabilidad por partidas de los mismos años. La mayoría de las compras son de productos de alimentación y se mantiene el listado que hemos visto en el libro de 1903-06 con pocas variaciones. Aquí vemos que se empieza a comprar "sal para la panadería" en mayo de 1911, por lo que es de suponer que empezó a funcionar por entonces y surtía suficientemente al hospicio porque después ya no aparecen compras de pan. En el libro "Mensual de cuentas. ... 1913" y en los posteriores no figura el pan, ni de primera ni de segunda, pero encontramos asientos por "efectos de panadería": harina, sal, aceite, combustible ramera, cestos... todos los años.

Llama la atención que la lista de productos de alimentación es muy corta y se repiten con muy pocas variaciones en todos los libros, por ejemplo, en 1915 junto al chocolate se empieza a comprar café. Las compras de fruta son muy escasas y sobre todo se hacen en diciembre, coincidiendo con las fechas navideñas. Con productos como el "turrón y otras fruslerías" [sic], encontramos cascajo surtido, avellanas, almendras, nueces, castañas y manzanas. Hay alguna partida aislada de naranjas, aunque no todos los años, en 1915 y 1916 no figura la compra de fruta. En los libros que recogen los presupuestos por partidas encontramos las frutas consideradas como "Gastos Extraordinarios", como en el libro de 1909, o incluidas en el apartado de "Menudencias de despensa", como en el "Mensual de cuentas...1913". En este apartado aparece también la compra de otros productos que no eran usuales como "80 $\mathrm{Kg}$ de pescadilla" en enero de ese mismo año, el pescado que se compra de forma habitual es el bacalao y algunas partidas de sardinas. Tampoco se compran verduras, sólo las patatas están incluidas en la lista de productos corrientes. En el libro de certificaciones de 1924 -1925 en "Extraordinarios de enfermería", con un presupuesto de 1500 pesetas, 
aparecen pescados, limones, vino, galletas, sesadas, bizcochos, azucarillos y "específicos ${ }^{160} y$ jarabes" y en "Extraordinarios Navidad" se anotan naranjas, manzanas, cascajo, nueces, castañas, longanizas, turrones y vino blanco. En todos los libros aparece entre los gastos corrientes el vino, más de 6.000 litros se compraron algunos años, especialmente en la primera década.

En 1901 se compraron, "por acuerdo de la comisión", "100 Kilogramos de azúcar para la papilla de los ninos" [sic] a un precio de 1'30 pesetas el kilo y en 1903 encontramos la primera compra de "Harinas lacteadas para los niños de la Inclusa", se hizo un presupuesto inicial de 500 pesetas que se tuvo que ampliar con un presupuesto adicional para un gasto total de 962,50 pts por 400 botes; a partir de entonces figura en todos los libros junto con otros productos dietéticos infantiles: "Para harina lacteada, lactosa, azúcar de leche para los niños de la Inclusa". También algunos años en este apartado se incluye harina de arroz y en 1922- 23 y 24 la compra de harina de plátano. En el libro de 1924- 1925 aparece por primera vez, el 31 de octubre de 1924, la adquisición de "1 caja de leche condensada" por 77 pesetas, "48 botes" y otros tantos en enero, además de tapioca y sémola en una partida presupuestada con 25.800 pesetas denominada "Para Amas lactantes internas, harinas, etc....". En 1926 hay recibos por $4 \mathrm{~kg}$ de maicena, 6 de sémola y 3 botes de miel, en compras hechas por la administración, es decir que debían ser directas sin concurso previo. Estos datos reflejan cómo se fue diversificando la dieta de los lactantes, aunque que no podemos decir a partir de qué edad incluían todos estos productos.

En 1901 encontramos también la compra, "por acuerdo de la comisión" de "12 docenas de fajeros" para los recién nacidos a 7 pts la docena, lo que quiere decir que en este año eran gastos no previstos en el presupuesto ordinario. A partir de entonces, los "Fajeros para los niños de la Inclusa" aparecen todos los años con compras en torno a 50 docenas anuales.

Las diferentes telas para la confección de ropas y los materiales para confeccionar y reparar calzado aparecen también en todos los libros. Además hay pagos por "alpargatas de distintas medidas" y algunos años, como en 1909, con un presupuesto de 1200 pts "Para la confección de borceguíes ${ }^{161}$ de niños y botas de niñas" se paga por la compra y hechura de 692 pares. Además de las máquinas de coser ya mencionadas, en septiembre de 1910 se adquirió un telar mecánico.

\footnotetext{
160 ESPECÍFICO: "Medicamento eficaz para curar una enfermedad determinada". Diccionario de la RAE, Madrid 1899, 13a edición, p 424

161 BORCEGUI: "especie de calzado o botín que llega hasta más arriba del tobillo, es abierto por delante y se ciñe ordinariamente con un cordoncillo que pasa por los agujeros de ambas partes." Enciclopedia ESPASA, tomo 9 , p 90
} 
Entre los materiales de la enfermería encontramos en 1903 la compra de $2 \mathrm{Kg}$ de sal de amoniaco y, en la partida de "Imprevistos", 36 "tubos vacuna nueva" en septiembre y otros 6 en diciembre, se refiere a la vacuna de la viruela. En los libros siguientes aparece un apartado "Para enfermería, tetinas, biberones, ligadores y otros análogos", en él encontramos en 1909 pagos por"300 frascos cristal y 100 tapones goma roja" que serían para biberones y "el arreglo de un aparato esterilizador". En el libro de Recibos de 1924 hay resguardos por las compras de 75 "botellas biberón" a 1 pta la unidad y por "6 docenas de tetinas" para biberones "al precio de 6 pesetas" la docena. En 1921 en los gastos de enfermería consta la compra de "6 caloríferos $^{162 "}$ a 2,75 pts y hay una partida presupuestada con 500 pesetas para "Esterilización de la leche con destino a la Cuna", que también aparece en el libro siguiente de 1923- 24, aunque no sabemos si se hizo el gasto porque en ninguno de los dos libros se han anotado pagos; en muchas de las partidas no llega a gastarse el total de lo presupuestado. Los gastos de farmacia se suelen anotar referidos con conceptos generales, pocas veces se detallan los artículos incluidos, son habituales las anotaciones del tipo "harina lacteada, salicilato, etc"[sic]. Entre ellos encontramos en los libros de 1921 y de 1924 -25 un asiento por "Salicilato y Larosan Roche ${ }^{163 "}$. En el libro de 1863 en gastos de "Botica" se anota "un frasco de pomada de la viuda de Farnier ${ }^{164 ",}$, aunque no vuelve a aparecer como tal podía seguir utilizándose en

\footnotetext{
162 Puede referirse a calientapiés. En el Diccionario de la Lengua Española de 1899, 13a edición, página 177, la tercera acepción de Calorífero es: "caja metálica que, llena de agua caliente, sirve para calentar los pies.". El Diccionario de la Lengua Española 1933- 1936, página 536, esto mismo lo define como "calientapiés"

${ }^{163}$ Larosan Roche se utilizaba como antidiarreico. En la Revista de Pediatría Chilena de 1930 se anunciaba contra las diarreas: "Las diarreas de los niños de cría son debidas algunas veces a microbios, pero en la mayoría de los casos son debidas a una desviación patológica del proceso digestivo, esta desviación determina sea la atrepsia (pedatrofia, descomposición de los autores alemanes) sea la intoxicación alimenticia... Nada vale desde luego lo que la leche de mujer, pero en los numerosos casos en que no se puede recurrir a ese modo de amamantamiento es preciso ... suprimir de la alimentación el suero (de vaca) nocivo, disminuir los azúcares y añadir caseína. A estas indicaciones respondía la leche albuminosa que se ha utilizado con éxito contra las diarreas infantiles; pero es muy difícil de preparar, su costo es muy elevado; es desagradable de tomar y provoca, a menudo, fenómenos de intolerancia. ... ". Sobre sus indicaciones y forma de uso dice: "1. Diarrea verde (infecciosa coleriforme, atrepsia, etc) A. durante 6, 12, 18 o 24 horas dieta hídrica absoluta... B. durante 3 a 6 días... se toma alternativamente y cada hora una cucharadita de las de sopa de mezcla Larosan Roche... C. ... medio biberón o medio vaso de mezcla no azucarada, hasta que las deposiciones fueren consistentes; una vez obtenido este resultado se puede azucarar la mezcla... no debe exceder de un litro de mezcla en los niños de cría de menos de 6 meses; hasta es bueno algunas veces disminuir la leche y aumentar el agua hervida. En general el tratamiento dura 6 a 8 semanas y da excelentes resultados. ... 2. Diarrea simple (de dentición, de destete... Es suficiente... la mezcla de Larosan, azucarada o no,... de 1 litro a litro y medio al día 3. Diarreas tóxicas de los niños después del destete. En estos enfermitos la cantidad puede ser aumentada... por un litro de mezcla, hervida o no, se puede meter de 2 a 4 cucharadas de las de sopa de Larosan Roche... Dosis: de un litro y medio a dos litros al día". VARGAS CATALÁN N. A.: Historia de la Pediatría chilena. Crónica de una alegría, 2002, pp 451- 452.

La imagen del Sobre de Larosan Roche es del "Museo Farmacia Ferrer". Imagen disponible en: "Museo Farmacia Ferrer": http://museofarmaciaferrer.com/?page_id=1081

${ }^{164}$ Se trata de una pomada oftálmica cuya composición debió ser secreta durante mucho tiempo. En el libro de Ruiz R. Apéndice y formulario del restaurador farmacéutico, publicado en Madrid en 1851, que contiene, según dice en su portada, "más de 420 fórmulas de preparaciones farmacéuticas" en la página 291 habla de ella y dice: "Esta pomada es un secreto hasta el día, pero en el sentir de muchos prácticos debe ser una cosa análoga á la pomada del Regent del codex, que se compone de 18 dracmas de manteca lavada con agua de rosas, 6 granos de alcanfor, 1 dracma de precipitado rojo y otro de sal de Saturno. Sus efectos por lo menos no discrepan de los de la otra, sin embargo que se conserva mejor la de la viuda de Farnier que la de Regent"
} 
esta época al ser un remedio muy conocido frente a las conjuntivitis que todavía se comercializaba.

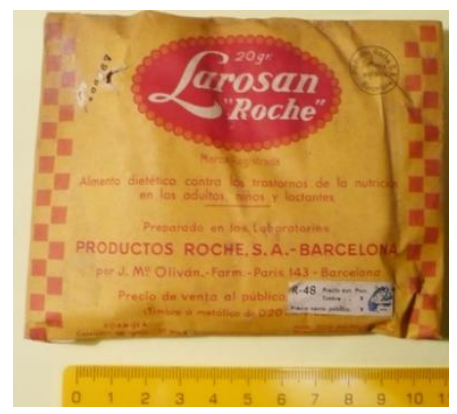

Anuncio en prensa de 1926 de la Pomada de la Viuda Farnier

Sobre de Larosan Roche. "Museo Farmacia Ferrer"

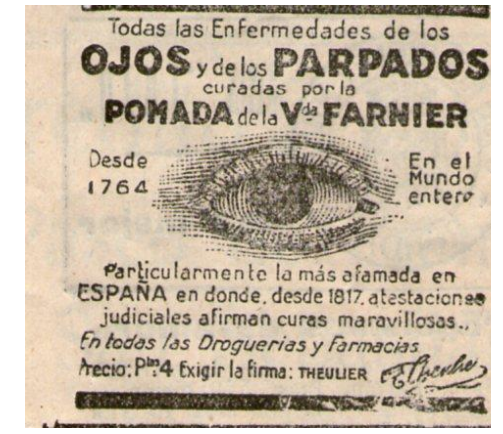

En "Gastos Extraordinarios" encontramos la compra en septiembre de 1909 de "una incubadora para recién nacidos" por 1500 pesetas y, en una nota aparte escrita antes de la primera hoja contable, de "un pesa niños". En 1915 se adquieren 6 cunas a 19 pesetas cada una. También aparecen cc Imagen 1-39 ocasionados "por los baños tomados en el río Pisuerga por los asilados", que se pagan a "Ia Sra Viuda de Peña" en 1913; en el libro de 1863 hay pagos por "baños de Mar y minerales de las Hermanas y 14 acogidos en la temporada de verano". En marzo de 1927 se adquiere " 1 nevera" por 470 pts. En el libro de Recibos de Imagen 1-40 ;guardo por la compra de "unas gafas" por 12 pesetas como gasto extraordinario en marzo, no especifica si son para algún asilado. En 1926 se compran "dos vacas de leche" por 250 pts y "3 sacaleches atmosféricos" a 4,10 pts en mayo de 1927.

Son muchas las obras y arreglos que se realizan en este período, entre otros se registran en los libros: la apertura de una puerta accesoria al paseo de las Moreras en 1903; la compra de tres pararrayos y un baño, aunque se presupuestaron dos, "para el nuevo local del departamento de Maternidad" y el "arreglo de patios y excusados" en 1913; la "Colocación de estufas en distintos departamentos y arreglos de las mismas" en 1921; la "reparación en la

En una hoja a modo de prospecto de 1920 dice que cada 100 gramos de la pomada, contenía 6,04 gramos de óxido rojo de mercurio, 5,02 gramos de acetato de plomo y 88,94 gramos de manteca lavada al agua de rosas. También asegura que es un remedio de gran efectividad en todas las afecciones inflamatorias de los ojos y párpados, así en iritis, conjuntivitis, cataratas originadas por el sarampión o la viruela, del mismo modo en la epifora, queratitis, nubes o albugos. En 1870 se anunciaba en El Norte de Castilla: "Gran servicio en todas las afecciones de los ojos y de las pupilas, un siglo de experiencias favorables prueban su eficacia en las oftalmías crónicas y purulentas (materiosas) y sobre todo en la oftalmía dicha militar". Tomado de: LÓPEZ DE LETONA C. La pomada antioftálmica de la viuda Farnier.. Archivos de la sociedad española de oftalmología. N. 6 - Junio 2000

Anuncio en prensa de 1926. Imagen disponible en: http://www.todocoleccion.net/pomada-viuda-farnier-anunciopublicidad-prensa-retal-revista-papel-ano-1926 x31950036http://museofarmaciaferrer.com/?page_id=1081 
máquina de hacer jabón" en diciembre de 1924; la "Ampliación y reforma en la instalación de la calefacción de la Inclusa" el 31 de enero de 1925 y la "reparación de la calefacción de la Inclusa" en 1926. Se realizaron también "Obras de reforma en la Maternidad" con un presupuesto de 10.000 pesetas en 1924 y en julio de 1927 hay un pago por "pintar un mostrador y una mesita en la Gota de Leche". En 1901 hay dos pagos, por acuerdo de la comisión, por 100 cristales en julio y por colocar 144 en septiembre; parecen muchos para reponer y no constan nuevas obras por lo que podemos suponer que podrían haber servido para acristalar ventanas que carecieran hasta entonces de acristalamiento. En el Libro de Existencias $1863-64{ }^{165}$ figura la compra en junio de 1864 de "cristales nuevos para las ventanas nuevas de las salas de destete y dormitorios de niñas" y más abajo hay asientos para las obras de las ventanas

"En id (30 de junio) á Eugenio Mendes Maestro herrero por once antepechos de hierro para las ventanas referidas á ochenta reales uno"

“... por importe de cinco ventanas nuevas con herraje para la enfermería, salas de destete y dormitorios de niñas á 317" reales

Folio no 66 asientos 670 y 675 del Libro de Existencias 1863-64

En el libro de Suministros de 1921-22 además de los recibos por compras habituales como "100 mts de lienzo para pañales", "12 docenas de fajeros", botes de harina lacteada a 2,50 pesetas cada uno; aparecen "bombillas, etc" [sic] por 129,50 pesetas y "2 pedestales blancos, etc (inodoros)" [sic] por 146 pesetas en febrero de 1922.

En "Gastos imprevistos" en el libro de certificaciones de 1924 aparece una partida presupuestada con 249,75 pesetas para "diferentes juguetes", es la única de este tipo que se ha encontrado en todos los libros.

\subsection{CoMUniCACIONES E INFORMES DE ACOGIDA} DE MENORES

Contiene 66 documentos, sólo 14 interesan por su temática y fecha y se consultan exhaustivamente, se incluyen algunos que, aunque se salen temporalmente, se han considerado de interés:

$\overline{{ }^{165} \text { Signatura: caja 962, expediente } 7200}$ 
- Niños ingresados en el Hospicio Provincial para su lactancia durante el año $1905^{166}$.

La carpeta contiene un pliego con la estadística global de los "Niños que han ingresado en el Establecimiento para su lactancia durante el año 1905" y "Su estado actual". Recoge el número de "Ingresados. Nacidos en el Establecimiento. Idm sin vida. Expuestos en el torno. Ingresaron por acuerdo de la Comisión Provincial. Hijos naturales. Idm de padres desconocidos (e) Idm de legítimo matrimonio" [sic] y en cuanto al "estado actual" de los niños se anotan los "Existentes hoy en el Establecimiento. Para su lactancia fuera del Establecimiento. Devueltos a sus padres. Fallecidos (y el) Total". [sic]

- Estado demostrativo del movimiento de acogidos del Hospicio Provincial. $1906^{167}$. La carpeta contiene un pliego que completa el documento anterior con los datos totales de ingresos y salidas de los asilados por departamentos durante el año 1905: "Maternidad", "Lactancia", "Destete; mayores de...meses y menores de cinco años" [sic]. y "Mayores de cinco años".

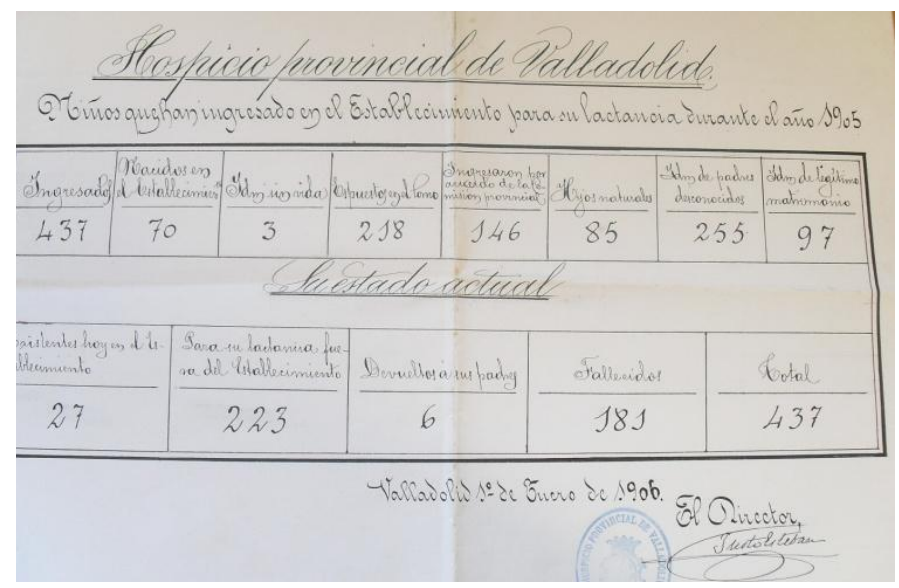

- Informe sobre necesidades y mejoras del Hospicio Provincial. $1906^{168}$. Se trata de un informe del Director del Hospicio dirigido al vicepresidente de la Comisión provincial con las necesidades del hospicio y una propuesta de mejoras para, entre otras cosas, reducir la altísima mortalidad infantil, muy superior, dice, a la de los hospicios de las provincias adyacentes

- Memoria. 1908 $^{169}$. Memoria con los "Estados de personal" del hospicio que refiere los movimientos de los niños asilados con datos sobre la forma de ingreso y salida, origen,

\footnotetext{
${ }^{166}$ Signatura: caja 4872, expediente 43325

${ }^{167}$ Signatura: caja 4872, expediente 43334

${ }^{168}$ Signatura: caja 4872, expediente 43333

${ }^{169}$ Signatura: caja 2449, expediente 30483
} 
ocupaciones, mortalidad y sus causas y su situación al cierre del informe. Incluye un recuento de todo el personal del orfanato a fin de año, incluidas las nodrizas, las hermanas de la Caridad y los trabajadores.

- Estadística de la población existente en los servicios asistenciales. $1911^{170}$. Contiene una carta de un representante del Instituto Geográfico y Estadístico solicitando datos de los establecimientos de Beneficencia para "redactar el capítulo de Beneficencia y Sanidad Española" y las respuestas. El Hospital Provincial ofrece los datos de su población por sexos y de los "Gratuitos" y "Pensionistas". El Hospicio Provincial aporta los datos totales y por sexo de la Inclusa y del Hospicio y los de las mujeres "Gratuitas" y "Pensionistas" de la Maternidad Provincial.

- Informe del número de acogidos entre 1914 y $1918^{171}$. Presenta la relación de acogidos en estos años por sexo y por departamentos y el número de fallecidos en el asilo.

- Memoria suscrita por los médicos del Hospicio Provincial relativa a la mortalidad de niños del establecimiento. $1920^{172}$. En cuartillas escritas a máquina se recoge la estadística de mortalidad del centro, que califica de trágica, hace una valoración, analiza las causas y presenta propuestas para aliviarla.

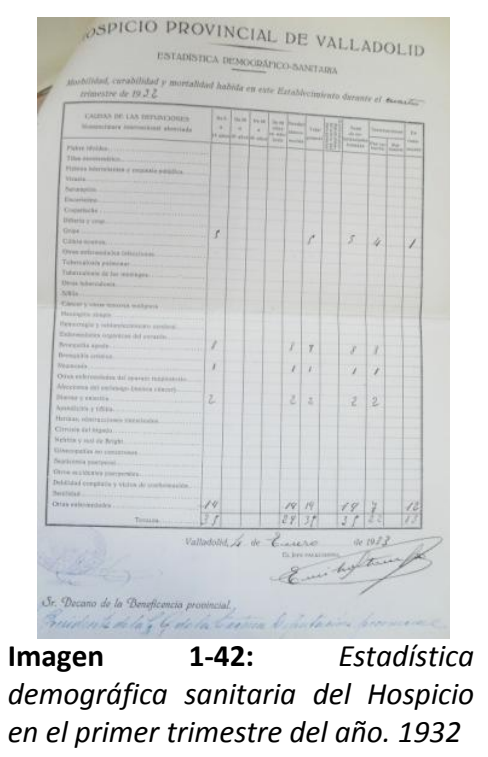

- Estadística demográfica sanitaria del Hospicio en el

primer trimestre del año. $1932^{173}$. Estadística del movimiento de enfermos del orfanato, para los niños mayores de 5 años. Recoge un listado de diagnósticos con el número de fallecidos, de enfermos en tratamiento, tratados y trasladados al hospital y el número de altas.

- Estadística demográfica sanitaria 1932-1934 $4^{174}$. Estadística con las mismas características que la anterior de 1932 acompañada de cartas manuscritas solicitando a la Comisión provincial mejoras en el Manicomio y en el Hospicio.

\footnotetext{
${ }^{170}$ Signatura: caja 1619 , expediente 12606

${ }^{171}$ Signatura: caja 4051, expediente 38001

${ }^{172}$ Signatura: caja 4025, expediente 37809

${ }^{173}$ Signatura: caja 565, expediente 5776

${ }^{174}$ Signatura: caja 1619, expediente 12607
} 
- Elaboración de pan. $1911^{175}$. Dentro de la carpeta así nominada se conservan una serie de cartas entre la Comisión provincial por un lado y el Hospicio, el Hospital y el Manicomio por otro, para valorar la calidad del pan elaborado por el hospicio y compararlo con el pan comprado a los contratistas, con la opinión general de que el pan del Hospicio es mucho mejor.

- Productos de vaquería del hospicio provincial. Julio- octubre. $1926^{176}$. Se encuentran unas cuantas hojas sueltas en las que se registra diariamente la cantidad de leche ordeñada en la vaquería del orfanato y los animales que tienen anotando las vacas próximas a parir y las recién paridas así como el número de terneros.

- Memoria. $1871^{177}$. Titulada Memoria sobre la fundación del Hospicio Provincial de Valladolid, sus vicisitudes, estado actual, medios que podían adoptarse para mejorar todas sus rentas, reivindicar todos sus derechos perdidos y aumentar los créditos con que hoy cuenta el mencionado Establecimiento. Dedicada á la Excma. Diputación Provincial por Dn Ignacio María Bueno, su apoderado general para la liquidación y gestiones necesarias hasta lograr el cobro de toda clase de créditos pertenecientes a todos los Establecimientos de Beneficencia Provincial. Año de 1871. Recoge la relación de rentas que percibe y las que debería percibir el Hospicio. Algunas están ya catalogadas como "incobrables" y otras de "dudosa cobranza". Se incluyen las aportaciones de las cofradías, las rentas del Estado y las rentas por Tabaco junto con las aportaciones y fincas de la casa de la Misericordia

- Memoria estudio del orfanato provincial. 1944- $1948^{178}$. El título completo que aparece en la portada del documento es "Memoria-Estudio del Orfanato Provincial de Valladolid. 1944- 1948". Comienza con una reflexión sobre el abandono de niños y sobre este tipo de establecimientos, reconociendo el desinterés social por los niños acogidos y el abandono al que se han visto sometidos estos centros a pesar de su necesidad. A continuación recoge las estadísticas sobre el movimiento de población y las estadísticas sanitarias del hospicio en este período, las actividades realizadas por los niños, entre ellas las de los actos religiosos y culturales, las obras y cambios realizados y la relación de gastos calculando el gasto diario de cada asilado en 2'90 pesetas en 1944, 5'047 en 1946, 6'25 en 1947 y 7'007 pts en 1948.

\footnotetext{
${ }^{175}$ Signatura: caja 2450 , expediente 30511

${ }^{176}$ Signatura: caja 2449, expediente 30487

177 Signatura: caja 307, expediente 3668

${ }^{178}$ Signatura: caja 7593, expediente 10
} 
- Reglamento del Orfanato provincial. $1945^{179}$. A pesar de que el Archivo ha catalogado este documento con este título, se trata realmente de una carta en la que se propone una modificación del "Reglamento interior del Orfanato provincial por estar algún tanto anticuado y ser necesario adaptarlo a la legislación actual" en los puntos que se refieren a los pagos a las nodrizas internas y externas.

\section{- MORTALIDAD EN LA SALA DE MATERNIDAD. 1922}

Entre los expedientes de la serie Comunicaciones e informes de acogida de menores destaco por su interés este titulado Mortalidad en la Sala de Maternidad $1922^{180}$, una carpeta con cartas escritas entre 1922 y 1924 que muestran la preocupación por la elevada mortalidad de la Inclusa y el intento de reducirla mediante un acuerdo entre la Diputación y la Facultad de Medicina, similar al que ya tenían en el Hospital provincial, por el que los catedráticos de la Facultad se harían cargo de la asistencia médica y la Diputación controlaría la parte económico-administrativa. La correspondencia recoge la evolución del proyecto y las dificultades para llevarlo a cabo en los siguientes documentos (ver ANEXO № 7):

a) Carta oficial de la Comisión provincial fechada el 29 de julio de 1922 y dirigida a la Excelentísima Diputación proponiendo un acuerdo urgente con la Facultad de Medicina a fin de hacerse cargo sus profesores de la asistencia de los departamentos de Maternidad e Inclusa. Documento muy interesante que reconoce la "aterradora" mortalidad infantil y propone este proyecto como una estrategia para reducirla.

b) En cuartilla manuscrita se recoge la aprobación de la propuesta en la sesión de la Comisión provincial del 2 de agosto de 1922

c) Dos cuartillas, una manuscrita con fecha 5 de agosto y su transcripción mecanografiada el 14 del mismo mes, en las que se comunica al Gobernador civil el acuerdo aceptado por ambas partes, Diputación y Facultad de Medicina, el día 2 y se pide que lo transmita al ministro de Instrucción Pública para su aprobación.

d) Una octavilla mecanografiada que recoge la memoria, o parte de ella, de la sesión de la Comisión Provincial celebrada el 30 de septiembre de 1922 en la que se refiere la visita al Hospicio de tres diputados y de los catedráticos de Pediatría y de Obstetricia para

\footnotetext{
${ }^{179}$ Signatura: caja 7635 , expediente 9

${ }^{180}$ Signatura: caja 2449, expediente 30486
} 
presentarlos al personal del Hospicio y a las Hermanas de la Caridad y los acuerdos que en ella se adoptaron

"... como Profesores encargados de la asistencia de la Maternidad e Inclusa conforme y en cumplimiento del acuerdo adoptado... [en el transcurso de esta visita] se indicó la conveniencia de que su visita [se refiere aquí al reconocimiento médico de las salas de Maternidad] fuera acompañada de los alumnos de la asignatura para que estudiasen los casos clínicos que en dicho departamento puedan presentarse. ... [y se] acordó que desde luego se autorizara... también se acuerda dirigir oficio a los referidos Sres Médicos para que desde primero de curso se encarguen de la asistencia de dichos departamentos...

Así mismo se acuerda oficiar a los Médicos provinciales del Hospicio para que cesen en la visita a dichos departamentos quedando a su cargo la de la asistencia a los niños y niñas que no pertenezcan a ninguno de los citados departamentos"

e) 6 borradores manuscritos de cartas fechadas el 4 de octubre de 1922 y dirigidas al Director del Hospicio, al Decano de la Facultad de Medicina, al catedrático Isidro de la Villa, al catedrático Enrique Nogueras y a los médicos del Hospicio, los doctores Jerónimo Gavilán y Evaristo Millán. Comunican el acuerdo entre la Diputación y la Facultad de Medicina para "... que desde el 1ㅇ del corriente mes de octubre se encarguen de la asistencia técnica [y, más adelante, dice que gratuita] de los departamentos de Maternidad e Inclusa de su Hospicio los Profesores de la Facultad de Medicina que tengan a su cargo estas enseñanzas...". Todas vienen a decir lo mismo. Al doctor Nogueras le comunican que se aprobó su propuesta de hacer la visita acompañado por los alumnos de la asignatura. A los médicos del Hospicio les comunican la puesta en marcha del acuerdo desde el primero de octubre y que pasarán a ocuparse únicamente "... de la asistencia a los niños y niñas que no pertenezcan a ninguna de estas secciones". Una sexta carta escrita el 5 de octubre se dirige al Diputado Constancio Alonso para comunicarle el acuerdo y los diputados que van a constituir la comisión mixta, "que establezca y concrete las bases el alcance y condiciones" del contrato de colaboración junto con los que nombre la Facultad.

f) Un folio mecanografiado con la memoria de la sesión de la Comisión provincial del día 30 de agosto de 1923 reitera la preocupación por la alta mortalidad de la Inclusa y denuncia que los profesores de la Facultad de Medicina la tienen desatendida.

"... que tiene también noticia que los Médicos de la Facultad que se hicieron cargo de este departamento han estado fuera de Valladolid y es preciso que se les haga entender que tan importante servicio no puede quedar abandonado ... ... se acuerda recordar al Sr Decano de la Facultad de Medicina la conveniencia de designar los señores Profesores ... advirtiéndole que de no hacerlo en un plazo prudencial se entiende que desisten de prestar los servicios médicos que se les tenía encomendados" 
g) En un folio plegado y mecanografiado contesta el profesor de Obstetricia de la Facultad de Medicina el día 18 de septiembre de 1923 que se ha ocupado

“...de elegir locales para mejorar el servicio actual, que no reúne ninguna de las condiciones necesarias. Además en reciente viaje por el extranjero ha adquirido material, sobre todo de esterilización, que falta en absoluto para la maternidad. Atendiendo sin embargo su deseo, comunicaré al Sr Decano... su oficio e inmediatamente nos pondremos de acuerdo con la comisión nombrada por $V$. $S$. para remediar la mortalidad infantil"

h) Carta fechada el 5 de octubre de 1923 escrita a mano en un folio plegado y que parece correo interno de la Diputación enviada desde el negociado probablemente al presidente. Recuerda el acuerdo del 2 de agosto de 1922 "para mejorar, ampliar y reorganizar (los) departamentos (de Maternidad y Pediatría) de nombrar una comisión de Sres Diputados y Catedráticos que procediesen a redactar las bases de un contrato" y comunica la respuesta de la facultad del 18 de septiembre y "el estado del asunto por si estima oportuno designar el vocal que sustituya al que ha cesado y pueda completar la comisión que haya de entenderse con la de la facultad".

i) En marzo del año siguiente todavía coleaba este asunto. Una cuartilla mecanografiada y que debió estar grapada a algún documento recoge la resolución de la Comisión Provincial de requerir de nuevo al decano de la Facultad para que designe la comisión que debe negociar con la Diputación las bases del acuerdo

"Comisión Provincial. Sesión del día 31de marzo de 1924

Se acordó insistir nuevamente cerca del Sr Decano de la Facultad para que designe la comisión que en unión de la Diputación acuerden las bases que han de determinar los servicios de Maternidad e Inclusa cuya parte técnica se encomienda a catedráticos de dicha Facultad"

En la parte inferior del documento escrito a manos dice: "Cumplido el 1 Abril"

j) Finalmente, hay una carta mecanografiada en un folio de la Diputación provincial dirigida a los directores del Hospital Provincial y del Hospicio muy interesante, que recoge las decisiones adoptadas en la sesión del 3 de agosto de 1923 y aprobadas por la Comisión Provincial el 4 de septiembre. En ella se les comunica el acuerdo de unificar los reglamentos de las maternidades del Hospicio y del Hospital Provincial en cuanto a las condiciones que se debían exigirse a las mujeres atendidas en ellas, y se designa a un diputado para atender los temas de la Maternidad y la Inclusa. Es un documento que manifiesta, aunque de forma sucinta, la altísima mortalidad infantil en la época en relación con la lactancia artificial y la explotación que sufrían muchos de 
los niños criados con nodrizas externas, utilizando estos argumentos para justificar el interés por obtener nodrizas internas a través del compromiso de todas las mujeres gestantes asiladas en las maternidades de los dos centros dependientes de la Diputación de lactar a los niños de la Inclusa, ya que hasta ese momento solamente tenían obligación las refugiadas de la Inclusa (ANEXO 8):

"Acordado por la Diputación Provincial la unificación de las maternidades instaladas en el Hospicio y Hospital Provincial, se hace necesario unificar la reglamentación para el ingreso y estancia de las embarazadas que acudan á los referidos establecimientos.

Actualmente las gestantes que ingresan en el Hospicio adquieren el compromiso de lactar a los niños del establecimiento durante un tiempo igual al que han estado asiladas; y las que permanecen en el Hospital se ven libres de este compromiso, ...

La espantosa mortalidad de la lactancia artificial, la explotación ejercida con muchos niños sometidos a la lactancia externa nos obligan a procurar los medios para que la Inclusa disponga del mayor número posible de amas de cría...

Palacio de la Diputación de Valladolid a 3 de agosto de 1923 Comisión Provincial. Sesión 4 sepbre 1923

Aprobada, y que se comunique al Hospital a los efectos procedentes (en una esquina) Transcrito á los directores del Hospital y Hospicio el $7 \mathrm{Ag}$

\subsection{Otros documentos consultados}

12.1. Se han solicitado planos del Hospicio y fotografías. Se revisan y fotografían todos los planos conservados referentes al hospicio. En cuanto a fotografías no disponen más que de unas pocas no catalogadas, algunas de ellas publicadas en la Memoria de la Diputación.

En la sección de Bienestar Social se encuentra una carpeta con la solicitud del Director del Hospicio dirigida al Presidente de la Diputación para la construcción de un "Pabellón para instalar estufa de desinfección y depósito de cadáveres en el Hospicio Provincial"181, los planos, firmados por el arquitecto provincial Santiago Guadilla en 1911, los presupuestos detallados y la aprobación de la Comisión, en lo que parece ser un borrador de la carta.

${ }^{181}$ Signatura: caja 245 , expediente 2769 
Se conservan así mismo:

- Plano de las salas de cunas, situadas en la planta principal y de los dormitorios de las amas, en la primera planta ${ }^{182}$, firmado por Santiago Guadilla en 1910.

- Distribución en planta principal de las Galerías de Poniente y Norte ${ }^{183}$. Incluye los planos de la enfermería FPOSPICIO PRovinctale PROYECTO DEEOIPTCIO ESCURLA Y GMPAIGCLON DE DORMTTOR OS Ka .

con la distribución existente y el nuevo proyecto. También se ve el plano de la Panadería en un terreno cedido por el Ayuntamiento que da al paseo de las Moreras. No aparece autor ni fecha, es de suponer que se trate del mismo arquitecto provincial autor de los demás planos y puede ser de 1911 en adelante, porque la panadería del hospicio, que ya se ve junto a la tapia, se construyó en ese año, como se puede ver en la carta de solicitud del Pabellón para instalar estufa de desinfección.

- Proyecto para la construcción de un edificio para Escuela y Ampliación de dormitorios" ${ }^{184}$, firmado por Santiago Guadilla en 1911.

- "Croquis de la tapia y del edificio proyectado en el terreno cedido por el Excmo Ayuntamiento en las Moreras" ${ }^{185}$. Planos de las fachadas a las Moreras y laterales, en los que se ve que se conservan el arco de la puerta y parte de la tapia ${ }^{186}$. Un Proyecto de un pabellón en el patio de niños ${ }^{187}$ del 25 de mayo de 1903 y un proyecto de reforma de la cocina del Hospital Provincial de 1934

12.2. Entre los libros se han encontrado, hojas, papeletas y documentos sueltos que en muchos casos han resultado muy interesantes a la hora de aportar información nueva. Es el caso de unas hojas sueltas aparecidas entre el libro de entradas de 1902 con listas de mujeres y lo que parecen cantidades. En una de las hojas dobladas las anotaciones son del tipo de:

\footnotetext{
182 Signatura: caja 245, expediente 2768

183 Signatura: caja 245, expediente 2766

184 Signatura: caja 245, expediente 2747

185 Signatura: caja 245, expediente 2767

186 Signatura: caja 245, expediente 2739

187 Signatura: caja 245, expediente 2732
} 
"Luisa García por Marzo y Abril 35

Anastasia Ledo por 8 dias Febrero Marzo y Abril 39 - 64

Cecilia Gomez por 18 Abril $10-44$

María Olalla por 10 Marzo y Abril $23-30$

Leonor Franco por 8 dias Abril y Marzo $\quad 22-14$

Francisca Serrano por 3 dias Abril 1 - 74..."

[sic]

Debajo de la lista se suma todo y se añaden lo que pueden ser 90 céntimos de "Sellos", junto al total parece que dice "Pagado". Es un borrador que tiene más anotaciones y sumas. La pista del significado de este listado nos la da otro folio que parece arrancado de un cuaderno con un encabezado que dice:

"Nómina de los haberes satisfechos a las mujeres que cuidan niños de lactancia del Hospicio Provincial correspondientes a los meses de Septiembre y Octubre últimos"

y que a continuación tiene una lista de mujeres similar a la anterior con el tiempo de cobranza y la cantidad a pagar, o pagada, en pesetas y céntimos para cada una. En la mayoría se anotan los dos meses completos que se indican arriba, que suponen un sueldo de 35 pesetas, cuando figuran otras fechas la cantidad es proporcional a los días de pago. No pone el año y aunque cabe pensar que pertenecen a 1902, no se puede dar por seguro, ya que muchas veces estos documentos que se encuentran sueltos son de fechas diferentes a las del libro en que aparecen. Algunas mujeres figuran en estas dos listas y en otra encontrada que está escrita en un trozo de papel cortado y en la que sólo se ven los nombres, las cantidades y la suma total, incluyendo los sellos, pero no aparece ninguna fecha ni pistas sobre ella.

Se busca a estas mujeres en el libro de 1902, entre las que dan a luz en la maternidad del hospicio o del hospital y se encuentran casi todas las de las tres listas como "refugiadas" en el asilo. Sólo una de ellas dio a luz en el hospital, María Guinaldo, madre del niño del folio no 120. Como las mujeres de la lista de abril pueden haber parido unos meses antes, se continua la búsqueda en el libro de 1901 y se encuentran otras tres de ellas: Francisca de la Cruz (fo 334 de 1901) que tiene en la lista anotados para cobro sólo 7 días de marzo, debe ser final de contrato porque dio a luz el 10 de noviembre de 1901 y lactó a su hijo hasta el 11 de diciembre; Felipa Bermejo, que dio a luz una niña muerta el 10 de octubre de 1901 (fo no 299) y Petra Barba (fo 278,1901$)$ que lactó a su hijo del 19 de septiembre al 23 de noviembre.

Hay una mujer sobre la que caben dudas, la llamada Luisa García que cobra marzo y abril completos y que luego ya no figura en las otras listas; para encontrar una asilada con ese nombre ha sido necesario retroceder hasta el folio 257 del libro de 1900, donde vemos que dio a luz el 27 de junio y lactó a su hijo hasta el 11 de julio; podría ser la misma, no podemos descartarlo porque hay mujeres que pueden mantener la lactancia más de dos años. 
La única que no se ha encontrado es Baldomera Barrios, una mujer que está anotada en la lista de abril- marzo en el margen inferior con " 2 ' 32 " pesetas, que podrían ser por principio o por final de contrato, no aparece en las otras listas y no se ha encontrado ni en el libro de 1902, ni en los de 1901 ni 1900, podría ser un ama contratada.

No todas las mujeres asiladas que dan a luz en los meses previos a las listas figuran en ellas; así, por ejemplo, en los primeros meses del año 1902, hasta finales de abril, encontramos en estas listas a las madres de los niños registrados en los folios no $7,8,10,42,50,56,57,61$, $69,80,91,101,106,146,147,151$. En las mismas fechas, dan a luz pero no están en las listas las mujeres de los folios no 12, 15, 36, 45, 60, 63, 70, 92, 93, 94, 99, 134, 138, 156, 158 y 161.

La lista que no tiene fechas podría corresponder a noviembre y diciembre de 1902, se presume por las fechas de su parto y de lactancia de sus hijos. Aquí encontramos a María García (folio no 310 de1909), que da a luz el 29 de septiembre, lacta a su hijo hasta el 26 de octubre y sólo figura en esta lista para cobrar medio mes, 8’75 pesetas; en la lista de septiembre- octubre no está incluida. Aparece otra María García en el folio 113, madre de un niño nacido en marzo en el hospital, pero se descarta al no encontrase en las otras listas que parecen anteriores porque hay otras mujeres que sólo se encuentran aquí y que por las fechas de parto no pueden estar en las otras hojas como Marciana Espeso (fo 317 de 1902), que dio a luz el 4 de octubre, lactó a su hijo hasta el día 26 y tiene marcado para cobro lo correspondiente a un mes, 17'50 pesetas; Maximina Moral (folio 337), que lactó a su hijo entre el 26 de octubre y el 20 de noviembre y tiene anotado lo correspondiente a mes y medio, o las que aparecen en los folios 346, 356 y 366 que dieron a luz en noviembre. También está solamente en esta lista Enedina Bello, que da a luz el 14 de agosto y lacta a su hijo hasta que fallece por sífilis congénita el 1 de septiembre (folio no 262 de 1909) y tiene anotado para cobro lo correspondiente a medio mes, 8'75 pesetas; en la lista de septiembre- octubre no aparece aunque la encontramos lactando al niño del folio 270 que falleció el 23 de septiembre.

12.3. Memoria $1950^{188}$ : aunque se sale de fecha se consulta para comparar. Resulta curiosa su lectura por el tipo de lenguaje grandilocuente empleado, propio de documentos oficiales de la época. Alaba la importante labor y el gasto de la Diputación en los establecimientos benéficos de la provincia: “... los servicios benéficos están bastante bien atendidos, lo que lleva consigo... la inversión de una cantidad crecida del presupuesto..." y en particular en el Orfanato:

\footnotetext{
${ }^{188}$ Signatura: caja 448 , expediente 4118
} 
" Hoy día, una corriente intensa de reforma, producida por la natural evolución de la vida, va impulsando a corazones generosos la reivindicación de estos Centros, convencidos de que la infancia en ellos acogida puede constituir la regeneración de las clases humildes, el porvenir de la nación y la fuerza de sus destinos.

La Diputación Provincial... con un interés y celo desmedidos sujetos a la premura económica de su presupuesto, va implantando en este centro mejoras sensibles en una labor silenciosa y profunda.

La Corporación se dio perfecta cuenta de la importancia de la educación del hombre en su niñez, y por eso no dudó en su labor, dispuesta a modelar esas almas jóvenes y a grabar en ellas los sanos santos ideales, origen y base de una Patria fuerte y sana..."

Quiere dar una visión optimista del orfanato, contra lo que vemos en las memorias anteriores. Afirma que en 1950 se han atendido 622 niños en el asilo, con un precio por estancia de 8 pesetas diarias y presume de un descenso importante de la morbilidad y de que "no ha habido entre los acogidos casos de muerte dentro del establecimiento", no dice si han ocurrido fuera o en el Hospital provincial. 
Capítulo2

\section{EL HOSPICIO PROVINCIAL DE VALLADOLID}

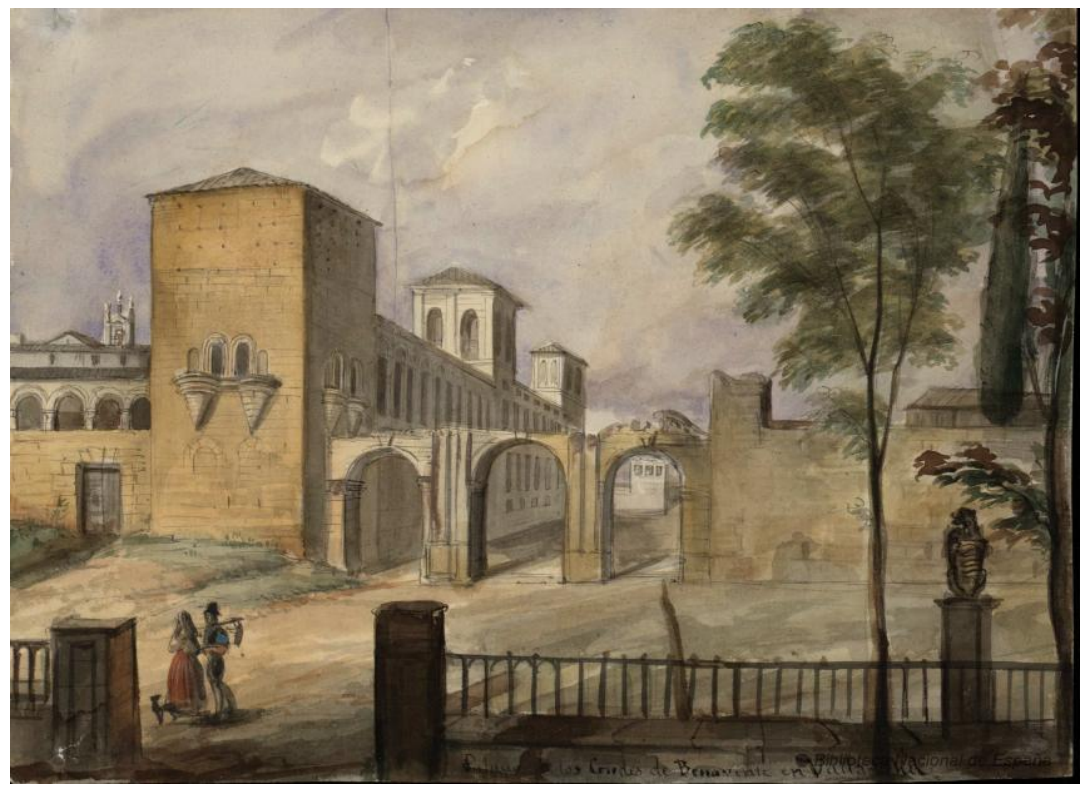

Imagen 2-1: El palacio del conde de Benavente desde el Espolón nuevo, hacia 1836. Valentín Carderera. Madrid. Biblioteca Nacional de España. El torreón que aparece en primer plano desapareció en 1842. Imagen disponible en la Biblioteca Digital Hispánica 


\section{ÍNDICE DEL CAPÍTULO 2}

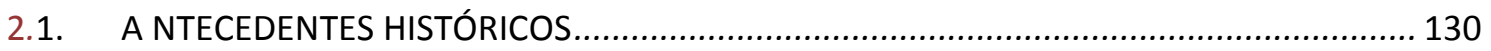

2.1.1. El Hospicio de Pobres y la Real Casa de Misericordia de Valladolid ..................... 130

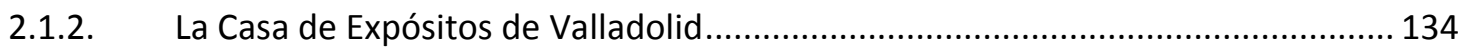

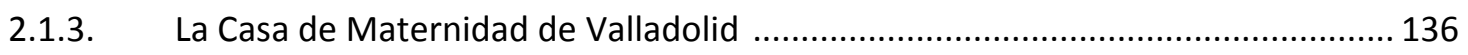

2.1.4. Fundación del Hospicio Provincial de Valladolid.................................................. 137

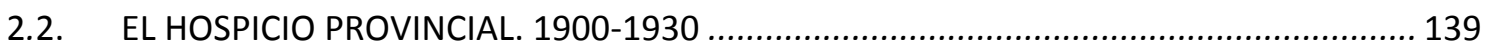

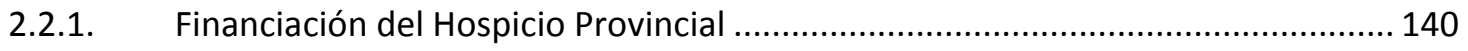

2.2.2. La Casa de los Benavente, el edificio y sus instalaciones ..................................... 148

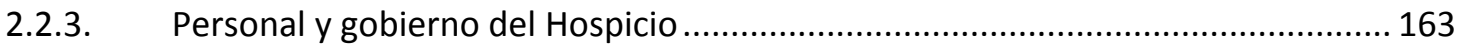

2.2.4. Régimen interno del Hospicio....................................................................... 174

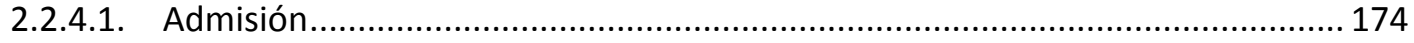

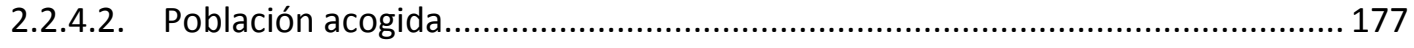

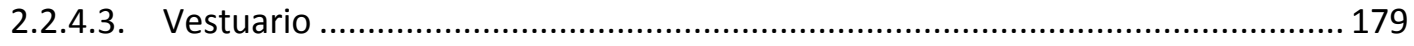

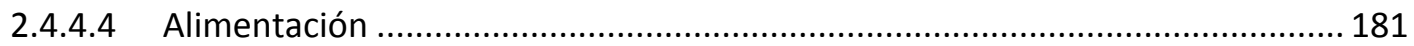

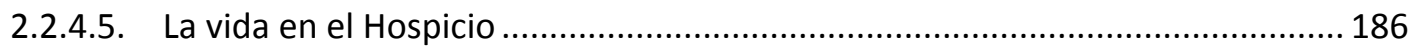

2.2.4.6. Salida del Hospicio y baja definitiva ............................................................... 190 


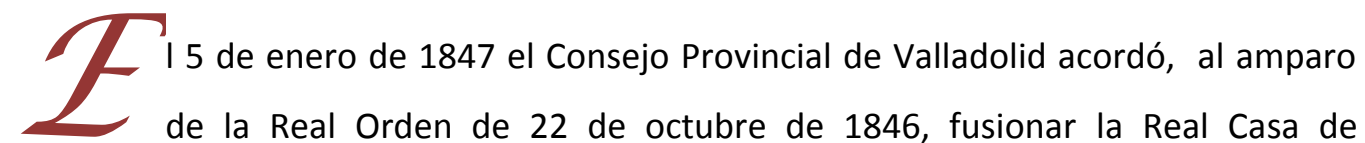
Misericordia, la Casa de Expósitos y la Casa de Maternidad en un único establecimiento denominado Hospicio Provincial de Valladolid. Quedó instalado en el palacio de los Condes de Benavente ${ }^{189}$, ubicado en la plaza de la Trinidad, conocida anteriormente como Plazuela del Hospicio, junto a la iglesia de San Nicolás, esquina a la calle San Quirce. El edificio ya servía por entonces de sede a su precedente, la Real Casa de Misericordia ${ }^{190}$, fundada en 1783 por R. O. de 29

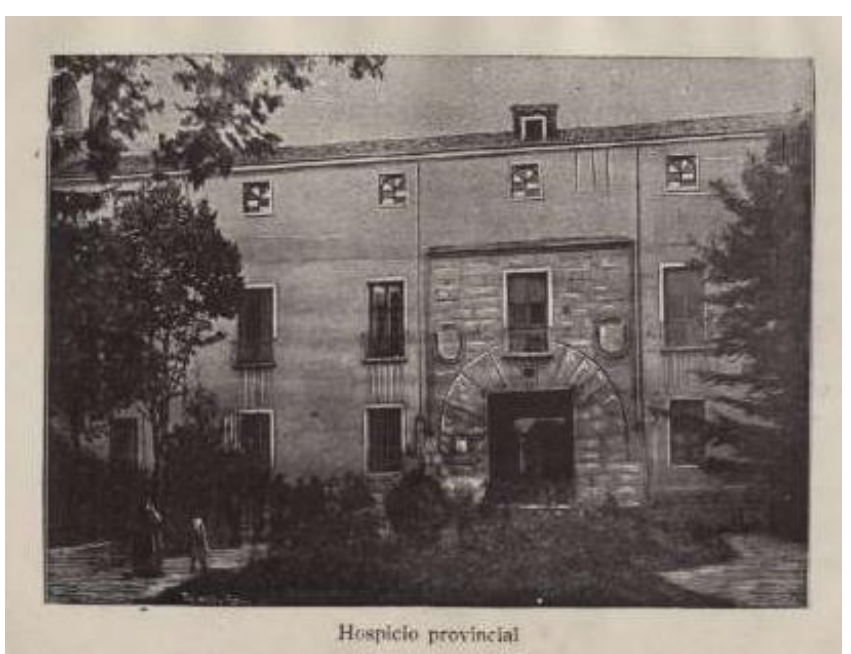

Imagen 2-2 Hospicio Provincial de Valladolid. Autor Pacheco. Fotografía publicada en Valladolid: sus recuerdos y sus grandezas (1900). Disponible en: Biblioteca Digital de Castilla y León,

de enero para sustituir a su vez al antiguo Hospicio de la Junta de Comercio de Valladolid, que tuvo que cerrarse por falta de recursos a pesar de ser muy necesario para la ciudad.

\footnotetext{
${ }^{189}$ El palacio de los Benavente se empezó a construir en 1515, sufrió dos graves incendios, en 1667 y 1716, algunas transformaciones y cambios de uso, siendo actualmente Biblioteca Pública de Castilla y León. Se construyó en los terrenos que adquirió D. Rodrigo Alfonso Pimentel, IV conde y I duque de Benavente el 4 de mayo de 1475 por 240.000 maravedís, "en la calle de la puente" al noroeste de la ciudad de Valladolid. La construcción se inició en 1516 y concluyó en 1520 tras algunos avatares ocasionados por el temor de que el edificio pudiera ser una fortaleza de tipo feudal, en una época en la que los Reyes Católicos habían dispuesto derribar todos los edificios o elementos de estas características. Fue, según Jesús Urrero, el palacio más grandioso del Valladolid del siglo XVI, quizás por ello sirvió de sede de las Cortes Generales en 1555 y de residencia real de Felipe II en 1559 y de Felipe III en 1601, naciendo en él las infantas Doña Ana Mauricia, que casaría con Luis XIII de Francia, y Doña María. En 1799 fue adquirido por el Ministerio de la Guerra y posteriormente pasó a ser sede del Hospicio. El arquitecto Pedro García González dirigió las obras de acondicionamiento. El palacio en su parte posterior tenía un torreón, galerías con vistas al río Pisuerga y un jardín que comunicaba con el "Paseo de Las Moreras". Dice Juan Agapito y Revilla que el paseo recibió este nombre en 1863 y era conocido anteriormente como el "Espolón nuevo" y al tramo de la calle San Quirce que correspondía al palacio se le conocía como "arcos de Benavente" por la arcada que tenía el palacio hacia esta calle. Se derribó el torreón, se vendió parte del jardín y se destruyeron sus galerías y paseos, pero conservó su estructura inicial.

Cfr. URREA J.: Arquitectura y nobleza: casas y palacios de Valladolid. Valladolid. 1996, pp 41-45; AGAPITO Y REVILLA J.: Las calles de Valladolid. Noménclator histórico. Valladolid.. 1937, PP 228- 29

Sobre el palacio de los Benavente y el Hospicio Provincial de Valladolid también en PALOMARES IBÁÑEZ J. M.: La asistencia social en Valladolid. El hospicio de pobres y la Real Casa de Misericordia (1724-1847), Valladolid, 1975, p.136; MARTÍN GONZÁLEZ J.J.: Monumentos civiles de la ciudad de Valladolid, Valladolid, 1983, pp. 81-84; DE LAS CASAS I., DE LAS CASAS M., LORENZO J. L: Rehabilitación del palacio de los condes de Benavente. Valladolid. BAU, (Revista del Colegio oficial de arquitectos de León, colectivo de arquitectos de Castilla y León Este y Colegio oficial de arquitectos de Castilla-La Mancha), 1, pp. 49-64; GARCíA CHICO E.: El palacio del conde de Benavente, Boletín de la Real Academia de la Purísima Concepción de Valladolid, 1946, pp. 1330.

${ }^{190}$ Cfr. PALOMARES IBÁÑEZ J.M.: La asistencia social en Valladolid: el Hospicio de Pobres y la Real Casa de Misericordia (1724-1847). Valladolid 1975, pp 86-89, 130-136
} 


\subsection{ANTECEDENTES HISTÓRICOS}

\subsubsection{EL HOSPICIO DE POBRES Y LA REAL CASA DE MISERICORDIA DE VALLADOLID}

El Hospicio promovido por la Junta de Comercio de Valladolid abrió sus puertas el 10 de abril de 1723 en un edificio alquilado al duque de Híjar, situado en lo que es hoy la plaza de Santa Brígida. Desde sus inicios tuvo serios problemas económicos que amenazaron su supervivencia hasta que finalmente, en 1737, la Junta fue suprimida debido a su mala gestión, dejando al Hospicio endeudado y sin ingresos suficientes; sólo contaba por entonces con las limosnas voluntarias de los ciudadanos de Valladolid y con una donación de la Ciudad de cuarenta mil reales anuales, que no alcanzaban para mantenerlo ${ }^{191}$.

En 1752 el obispo Martín Delgado, preocupado por erradicar la mendicidad que había aumentado en la ciudad, consiguió poner en marcha el Hospicio de Pobres bajo la dirección de una Junta de carácter benéfico- religioso, la "llustre y piadosa Congregación de Nuestra Señora de San Lorenzo". El Hospicio de Pobres contaría desde entonces con los 40.000 reales municipales anuales más una limosna de 1.000 reales mensuales suscrita por el mencionado obispo $^{192}$.

Uno de los fines del hospicio, dice Palomares (1975, p 71), era "transformar en personas útiles a los ociosos de la Ciudad incorporándolos al trabajo" ${ }^{193}$, de ahí el interés desde

\footnotetext{
${ }^{191}$ Ibídem, p 19-29

192 Ibídem, p 68. El obispo Martín Delgado además le legó 48.000 reales cuando falleció en 1753

193 El tema de la pobreza y de la asistencia social en Castilla y León ha sido ampliamente tratado por MAZA ZORRILLA E.: Asistencia social en Castilla-León, 1990; Valladolid: sus pobres y la respuesta institucional (1750-1790), 1985; Pobreza y asistencia social en España, siglos XVI al XX. Aproximación histórica, 1987; Pobreza y beneficencia en la España contemporánea (1808-1936),1999; Pobreza, trabajo y sociabilidad (siglos XIX- XX), 1999 y por CARASA SOTO P.: Pobreza y asistencia social. 1992; "Historias de la beneficencia en Castilla y León: poder y pobreza en la sociedad castellana", "Crisis del Antiguo Régimen y acción social en Castilla", "Beneficencia y "cuestión social» una contaminación arcaizante", "La historia y los pobres: de las bienaventuranzas a la marginación", "Cambios en la tipología del pauperismo en la crisis del antiguo régimen", "De la caridad a la beneficencia", "Lo privado y lo público en el sistema asistencial, el triángulo Iglesia-Ayuntamiento-Estado en la beneficencia española", "Pobreza y beneficencia en Castilla en el siglo XIX", "Los peligros de la pobreza, los valores del liberalismo y las soluciones asistenciales burguesas", "Las clases populares urbanas y el mundo de la pobreza en Castilla", "Beneficencia en Castilla y León, transformaciones del sistema hospitalario (1750-1900)"; entre otras. .

En el siglo XVIII se produce un cambio de mentalidad respecto a la valoración de la pobreza y la asistencia social, fruto del pensamiento ilustrado. La pobreza, en palabras de Elena Maza, "se convierte en un problema social y político, en un peligro y pesada carga para el Estado. No se trata... de proteger al pobre, sino a la sociedad del pobre" (MAZA E.: Asistencia social en Castilla-León, 1990, p 968). La caridad de carácter religioso se considera indiscriminada, desigual e ineficaz y despilfarradora, se entiende que fomenta la pobreza y la mendicidad y surgen fuertes ataques a las cofradías que regentan las instituciones que la practican. Frente a este tipo de caridad se propone la integración social mediante el trabajo; se considera que la pobreza hay que encerrarla, reprimirla y
} 
la primera Junta por contar con fábricas, talleres para la fabricación de tejidos que deberían ser también una fuente de ingresos, pero que solamente funcionaron bien durante unos años en esta segunda etapa, hasta $1764^{194}$. Los ingresos vuelven a ser insuficientes por el aumento de pobres en la ciudad ${ }^{195}$, los 40.000 reales de asignación anual no siempre llegan y provocan litigios entre el Hospicio y el Municipio. La Real Cédula 14-8-1768 ordenaba la fundación en cada capital de un hospicio de pobres y de una casa de expósitos con una dirección común, aunque se localizaran en centros diferentes. Amparándose en ella el Hospicio pretende unirse a la Casa de Expósitos, más saneada económicamente, para resolver sus problemas, argumentando que tiene que hacerse cargo de los niños que por edad salen de dicha Casa. Tras un largo proceso, en 1776 por una Real Orden (R.O.) de 1 de junio se crea una Junta única para dirigir la Casa de Expósitos, el Hospicio de Pobres y los Niños Doctrinos de San Blas ${ }^{196}$. Se trasladaron los expósitos al Colegio de San Blas y se cerró el Hospicio de Pobres en $1777^{197}$, parece que con intención de trasladarlo también, sin embargo se mantuvo cerrado durante diez años.

Tras el cierre, cada vez se hace más patente la necesidad de un hospicio en Valladolid para aliviar a la ciudad de la gran cantidad de pobres que por ella deambulan. La R. O. de 29-1$1783^{198}$ nombró la Junta General del Hospicio como órgano rector de un nuevo

rehabilitarla y se convierte en una cuestión de Estado. Esto se refleja en la producción de una abigarrada normativa legal que intenta reconvertir la caridad popular, entre otras cosas para un mejor control social de sectores marginales de la sociedad. Se agregan, desamortizan y reconvierten fundaciones e instituciones dispersas de caridad particular y se concentran los recursos. Los hospicios serán las instituciones encargadas del internamiento de población marginal, concebidos como instrumentos de "profilaxis social" de carácter más corrector que asistencial (MAZA E.: op.cit., p 973; CARASA P.: op.cit., p 80). Centros disfuncionales en su mayoría, de escasa operatividad, con graves problemas económicos y condiciones higiénicas deplorables, "una mancha de aceite que se expande lentamente por la geografía nacional" (MAZA E.: op. cit., p 973). Destacan estos autores que precisamente donde más deficiencias se producen es en la atención a la población infantil y buena muestra de ello es la altísima mortalidad de los niños expósitos que llegaba al 60-70\% de los incluseros, como muestra el informe de los prelados de 1790 (MAZA E.: op. cit., p 978). Según el censo de Floridablanca de 1787 Castilla y León contaba con 12 Casas de Expósitos, una en Valladolid que atendía por entonces a 27 niños con una única persona a su cargo, y 22 hospicios, también uno en Valladolid con 53 niños; la población infantil total entre casas y hospicios representaba el 38,55 del total de asistidos (MAZA E.: op.cit., p 975- 77). A pesar del interés del Estado por esta cuestión, no se implica económicamente; la principal fuente de financiación de las instituciones asistenciales seguirá siendo la caridad y las limosnas y la mayoría de los establecimientos de carácter benéfico seguirán a cargo de particulares o de la Iglesia, con mínima presencia estatal; su gestión se pone en manos de juntas y de organizaciones parroquiales o diocesanas.

${ }^{194}$ PALOMARES J. M.: op.cit., 1975, p75

${ }^{195}$ El panorama social es terrible, lo refleja bien el motín popular que se produce en Valladolid en 1789 con ocasión de la grave crisis originada por las malas cosechas. Se elaboró un padrón para calcular el número de personas que requerían asistencia y se contabilizaron 10.885 "vecinos necesitados", el 51,59\% de la población. Aunque son cifras referidas a un año que no es normal, lo cierto es que las crisis de subsistencia eran habituales por una u otras causas, lo que suponía una fuerte demanda asistencial, además, Valladolid era una ciudad que atraía a los desposeídos, entre otras razones por tener fama de caritativa y limosnera. Cfr.: MAZA E. 1990, p 972

${ }^{196}$ Ibídem, p 88

${ }^{197}$ PALOMARES J.M.: op.cit., 1975, pp 37-38

198 Ibídem, p 93 
establecimiento que recibirá el nombre de "Real Casa de Misericordia"199. Se instaló en la casa de Híjar aprovechando las instalaciones existentes y los antiguos talleres, en 1784 se adquirió el edificio en propiedad y se iniciaron obras de rehabilitación. En 1786 se nombró al administrador y el 1 de agosto empezó a recibir a los primeros pobres, iniciándose una nueva etapa en la que será, en palabras de Palomares, "el centro neurálgico de la beneficencia vallisoletana"200; aunque no por ello se verá libre de problemas, por el contrario, pasará por diferentes vicisitudes fruto de la inestabilidad política, social y económica tanto local como nacional. La Casa de Misericordia dejó de ser una institución benéfico-religiosa para vincularse a la administración central como un organismo laico, pero siguió financiándose con limosnas, con sus rentas y con el producto de sus fábricas, sin ninguna participación estatal, como era habitual en la época para los establecimientos benéficos ${ }^{201}$.

Por R.O. del 6-enero-1799, la Real Casa debía trasladarse al palacio de los Benavente, comprado por el Ministerio de la Guerra, quedando la casa de los Híjar como cuartel. En junio del mismo año se iniciaron las obras de reparación y acondicionamiento del palacio, que se prolongaron más de tres años debido al mal estado en que se encontraba, y se abrieron sus puertas ya convertido en hospicio y todavía en plena reforma el 15 de enero de $1801^{202}$.

La R.O. de 1798 extinguió las Juntas provinciales de los "Reales establecimientos de Hospicio y Expósitos" de Valladolid y nombró "Visitador y Director de la Casa de Misericordia" al canónigo vallisoletano D. Juan Bautista Sacristán y Galiano, quien puso en marcha el establecimiento en su nueva ubicación y redactó las "Ordenanzas para el gobierno y dirección de la Real Casa de Misericordia y Expósitos de la ciudad de Valladolid"; aprobadas impresas y puestas en vigor en $1806^{203}$, regulaban toda la vida del Asilo y se consideraron modélicas en su momento. Las Ordenanzas empiezan con una breve declaración de intenciones, en la línea del pensamiento ilustrado de la época que señala la pobreza como un problema social y una

\footnotetext{
${ }^{199}$ Dice Palomares citando a Jimenez Salas que las denominaciones de Hospicio y Real Casa de Misericordia se usan en el siglo XVIII en muchos centros benéficos para referirse a asilos "de alguna clase de pobres". Ibídem, p 121

200 Ibídem., p 122

${ }^{201}$ Cfr. MAZA ZORRILLA E.: Asistencia social en Castilla-León, 1990.

202 La Real Casa de Misericordia ocupó la casa de los condes de Híjar primero en régimen de alquiler y luego en propiedad hasta el 15 de enero de 1801 cuando se trasladó al palacio de Benavente. Ese mismo día se realizó una especie de inauguración muy modesta y prácticamente desapercibida para la ciudad pues simplemente se rezó una Salve y se ofreció un refresco a los obreros que trabajaban en el palacio de Benavente y las obras continuaron después de su ocupación.

${ }^{203}$ Aprobadas por Real Orden el 1 de febrero de 1806: Ordenanzas de la Real Casa de Misericordia de Valladolid. Ordenanzas para el gobierno y dirección de la Real Casa de Misericordia, y Expósitos de la ciudad de Valladolid, dispuestas por el doctor don Juan Bautista Sacristán y Galiano, del consejo de S. M. Inquisidor de provincia, doctoral de su santa iglesia catedral, director único, y juez conservador por S. M. de dichos establecimientos, y electo arzobispo de Santa Fe de Bogotá.
} 
cuestión de Estado y atribuye a la asistencia social un fin protector y rehabilitador en busca de la integración social mediante el trabajo:

"Las Casas de Misericordia, establecimientos tan útiles al Estado, se han erigido para socorrer la verdadera pobreza, educar christianamente, y habilitar á los jóvenes huérfanos desamparados en las artes, proporcionándoles oficios y ocupación que les haga útiles en la sociedad, y al mismo tiempo para que sirvan de freno á la mendicidad voluntaria, que es causa de infinitos perjuicios en ella. Una casa pública de piedad..." [sic].

El 21 de octubre de 1836, al amparo de la ley de Beneficencia del mismo año (8 de septiembre) que restableció la anterior del 6 de febrero de 1822, la Casa de Misericordia pasó a depender de la recién creada Junta Municipal de Beneficencia de Valladolid ${ }^{204}$, junto con la casa de Expósitos y los demás establecimientos benéficos de la ciudad; incluida la Casa de Beneficencia, asilo de mendicidad fundado en 1818 para auxilio y acogimiento de los pobres. Esta Junta tampoco consiguió sanear la economía de la Casa de Misericordia, a pesar de contar con importantes rentas proporcionadas por las agregaciones de Cofradías y Obras Pías dispuestas por ordenanza real. ${ }^{205}$.

La Junta Municipal retomó la antigua idea, no lograda aún, de unir la Casa de Misericordia con la de Expósitos y, además, la recién creada Casa de Maternidad. Inició gestiones para la fusión de los tres establecimientos y para conceder su administración a las Hermanas de la Caridad, que tenían fama de ser muy eficaces y muy rentables. Al amparo de la ley de Beneficencia de 1849 (R. O. del 27 de junio) se creó la Junta Provincial de Beneficencia de Valladolid y el Hospicio pasó a depender de ella. ${ }^{206}$

\footnotetext{
${ }^{204}$ La Ley de Beneficencia se promulgó durante el Trienio Liberal en un intento de regular la Beneficencia pública. Atribuyó a las Juntas Municipales presididas por los alcaldes la supervisión de los establecimientos asistenciales y a las Juntas parroquiales de Beneficencia las labores de apoyo fuera de ellos, como recolectar limosnas o recoger expósitos y desamparados y, como novedad, la asistencia a domicilio. Dispuso que todas las capitales debían contar con Hospitales Públicos en número no superior a cuatro y con capacidad para 300 enfermos como máximo, separados por sexos, edad y tipo de dolencias y con la posibilidad de contar con salas de pago independientes. Las Casas de Maternidad debían atender tanto a las mujeres embarazadas sin recursos como a los niños hasta los seis años, recogiendo las funciones de las Casas de Expósitos. Las Casas de Socorro asumían las funciones de las antiguas Casas de Misericordia dedicadas a la asistencia de niños huérfanos mayores de seis años y de adultos pobres. Cfr. MAZA ZORRILLA E.: Valladolid: sus pobres... 1985.

La Real Casa de Misericordia cambió en esta etapa temporalmente su nombre por el de "Casa de Beneficencia de la Provincia", apenas utilizado.

205 La R. O. de 1783 dispuso la inspección de las numerosas Cofradías, Hermandades y Congregaciones de la ciudad, se suprimieron todas las que no cumplían sus reglamentos o no estaban en regla y se destinaron sus rentas, derechos y privilegios a la Casa de Misericordia. Se agregaron 61 cofradías en este momento y otras 209 en 1800. Sobre la agregación de Obras Pías a la Casa de Misericordia, además de las obras citadas de PALOMARES, MAZA y CARASA, puede también consultarse ALCALDE MARTíN- CALERO C.: Agregación de las obras Pías de Valladolid y su obispado a la Real casa de Misericordia, 1783 y 1805.

206 El nuevo ordenamiento diferencia y delimita la Beneficencia la privada y la pública y dentro de ésta define tres niveles: general, provincial y municipal, con sus respectivas juntas. El Reglamento del 14 de mayo de 1852 desarrolla de forma detallada los tipos de beneficencia y sus características en cuanto a gobierno, administración y otras particularidades: "Son establecimientos provinciales de beneficencia... los hospitales de enfermos, las casas de misericordia, las de maternidad, las de expósitos, las de huérfanos y desamparados...". Cfr. MAZA E., 1985, p 288
} 


\subsubsection{LA CASA DE EXPÓSITOS DE VALLADOLID}

La Cofradía de San José "viendo el daño que las malas mujeres hacían en echar los niños en los ríos, muladares y otras partes", fundó en 1540 el Hospital de San José y Niños Expósitos frente a la iglesia de San Lorenzo bajo la protección de San José para evitar infanticidios y recoger, criar y educar a los niños abandonados en Valladolid y alrededores. Para financiar el asilo, que por entonces atendía a más de 130 expósitos, la cofradía en 1574 inició la representación de obras teatrales en el corral del hospital, conocido como Patio de Comedias, consiguiendo que Felipe II le concediera el monopolio del teatro en la ciudad ${ }^{207}$. Durante años el teatro junto con otros censos que tenía la cofradía, entre ellos uno de la diócesis $^{208}$, permitieron a la Casa de Expósitos mantenerse sin demasiados problemas económicos, a diferencia de lo que le ocurría al Hospicio. Cuando perdió las rentas del teatro, consiguió de Fernando VI y luego de Carlos III el muy rentable arbitrio de dos maravedís por cántaro de vino consumido en toda la provincia (que perdería en 1847 cuando el establecimiento fue declarado provincial). En 1757 la Real Orden del 15 septiembre cesó a la cofradía de San José y a partir de entonces la casa de Expósitos fue regentada por sucesivas Juntas $^{209}$. En 1778 se dispuso el traslado al Hospital de San Blas ${ }^{210}$, hoy desaparecido, que por entonces estaba en plena decadencia y mantenía una actividad asistencial mínima.

Extinguidas las Juntas provinciales de los "Reales establecimientos de Hospicio y Expósitos" de Valladolid y nombrado director de ambas Casas D. Juan Bautista Sacristán y Galiano, los expósitos se mudaron al palacio de los Benavente. En 1806 el nuevo director

\footnotetext{
${ }^{207}$ Cfr. FERNÁNDEZ MARTIN L.: Construcción de nueva planta del antiguo teatro de Valladolid 1609- 1610. Castilla: Estudios de literatura, № 20, 1995, págs. 105-124. La cofradía construyó el edificio del teatro y lo regentó hasta mediados del siglo XVIII y percibía por ello una parte de la venta de entradas

${ }^{208}$ Cfr. PALOMARES J.M.: op. cit. 1975, p 33: En la época del mencionado obispo Martín Delgado, las rentas anuales de la diócesis de Valladolid ascendían a 16.000 ducados, de los cuales 900 se dedicaban a pensiones a favor de la Casa de Niños Expósitos y del Colegio de Irlandeses de Salamanca.

${ }^{209}$ MAZA ZORRILLA E.: Valladolid: sus pobres... 1985. Véase el apartado Establecimientos dedicados al mundo de la infancia, pp 66- 76

210 Ibídem: La Junta común que debía hacerse cargo de la Casa de Expósitos, el Hospicio de Pobres y los Niños Doctrinos de San Blas según la R.O. de 1 de junio de 1776 dispuso el traslado de los expósitos y se desentendió del Hospicio. El Colegio de la Misericordia de San Blas, como también se llamó, se encontraba situado en la esquina de las actuales calles de San Blas y Felipe II. Lo regentaba la Cofradía de la Misericordia desde el siglo XVI, cuando consta documentalmente su funcionamiento, y acogía niños de entre 6 y 14 años para su crianza y educación, en la que ponían especial empeño, de ahí el nombre de "Doctrinos" o "Niños de la Doctrina de San Blas". También se llamaban "Doctrinos" a los Niños del Colegio del Amor de Dios, fundado por la Compañía de Jesús en 1613, que se localizaba en la actual calle de María de Molina. Las niñas huérfanas de 6 a 12 años de Valladolid y su provincia, siempre que procedieran de familias de probada honradez, eran recogidas en el Colegio de Niñas Huérfanas y Nobles, establecimiento que desde el siglo XVI ha persistido hasta el XX y que tuvo distintos emplazamientos hasta ubicarse finalmente en el paseo de Zorrilla, entre las calles Espíritu Santo y Gregorio Fernández.

Los emplazamientos de los distintos edificios se pueden encontrar en la página web:

http://www.valladolidweb.es/index.htm
}

Página 134 
dirigió una carta al Sr Colector general de Expolios y Vacantes para solicitar la aprobación de las "Ordenanzas para... la Real Casa de Misericordia y Expósitos..." , los expósitos estaban ya alojados en el palacio ${ }^{211}$ :

\begin{abstract}
"Por Reales órdenes, que en el año de 1798 se me comunicaron por la primera Secretaria de Estado, tuvo á bien S.M. nombrarme para la Dirección y Judicatura de conservaduría de los Reales establecimientos de Hospicio y Expósitos de esta Ciudad,..., extinguiendo las dos Juntas á cuyo cuidado habían estado hasta entonces.... Después de haber conseguido... reunir ambos Departamentos en la Casa que fué de los Condes de Benavente, ..., aunque a costa de gruesas cantidades, se han mejorado y extendido los servicios de ambos ramos, triplicando los Hospicianos y pasando de ciento los Expósitos, que anualmente se reciben de más..." [sic]
\end{abstract}

A partir de la página 89 de las Ordenanzas Generales... se desarrollan las que corresponden al Departamento de Expósitos, "Esos establecimientos tan precisos á la humanidad, y sin los que ha acreditado la experiencia se han seguido gravísimos perjuicios á las Sociedades...". En ellas se advierte que la Casa de Misericordia y la de Expósitos son departamentos que "aunque baxo [sic] una misma dirección, para evitar toda confusión, se han de administrar y gobernar con total separación é independencia...; por manera que se han de conservar todos sus fondos [de la Casa de expósitos]". Insiste además en la separación física de los dos establecimientos: "Este departamento estará totalmente separado de el de pobres de el Hospicio, y aunque la entrada principal ha de ser la misma que para éste..." [sic] pasa a hacer una relación de todas las estancias de que debe disponer:
"tendrá una sala grande con destino á la lactancia y cocina inmediata á ella para los usos precisos de amas, y secar ropas de los niños en los tiempos, que no pueda verificarse de otro modo: otra de destete en la que estarán aquellos á quienes se quite el pecho, ó recibiéren algo grandes, permaneciendo en ella hasta tiempo, en que se les destine á el Hospicio; en esta pieza habrán de ponerse los baules ó cajones en que las amas custodian sus ropas, y pongan las de diario uso de los niños: otra para enfermería, en donde deberán colocarse las Amas enfermas, con atención á que muchas de estas mujeres solteras, que desean ocultar sus fragilidades, que no evitarían si fuesen a los hospitales, en cuyo caso resistirían entrar á lactar, de que resultaría perjuicio no pequeño á la crianza de expósitos: otro Quarto inmediato á el sitio en que esté el Torno para el recibimiento de niños, en que continuamente este una mujer destinada a él efecto" [sic]

También las dependencias destinadas a la administración y al personal exclusivo de la

Casa de Expósitos que tenía que vivir en ella debían estar separadas:
"una pieza de despacho para el oficial de Libros...: inmediato a ésta, y con la debida separación, habrá otro Quarto archivo en que se colocarán los papeles relativos á este Departamento. Habitaciones correspondientes para éste, y Mayordoma Rectora, en que precisamente han de vivir, .... Y finalmente todas las demás oficinas que se crean útiles y necesarias en ella, á fin de que todo se

\footnotetext{
${ }^{211}$ Ordenanzas para el gobierno y dirección de la Real Casa...., 1806.
} 
halle con el mejor orden y disposición para este cuidado y asistencia de dichos expósitos" [sic]

A partir de este momento su devenir histórico irá paralelo al de la Casa de Misericordia concluyendo en la unificación de 1847 en el Hospicio Provincial. A pesar de que sus rentas aumentaron, los problemas también lo hicieron por el aumento progresivo de las exposiciones en Valladolid, capital y provincia; dicen las Ordenanzas que "esta Cuna principal sea comprehensiva de todos los Pueblos de la Provincia". Si D. Juan Bautista habla de más de 100 expósitos en 1806, Elena Maza dice que en 1833 ingresaron 191 niños y pasaron a 357 en 1847; recoge también esta autora las estadísticas de Madoz para la década de los cuarenta que indican que un $16^{\prime} 66 \%$ de los niños nacidos en Valladolid fueron expuestos y otra estadística de 1844 que refiere una mortalidad en el centro del 432'02\%o, aunque Madoz la sitúa en el $957^{\prime} 6 \%^{212}$.

\subsubsection{LA CASA DE MATERNIDAD DE VALLADOLID}

La Junta Municipal de Beneficencia fundó en 1839 la Casa de Maternidad para refugio de mujeres embarazadas "ilegítimamente" que solicitaran su ingreso por carecer de medios de subsistencia o para "ocultar sus fragilidades". La mayoría de las mujeres refugiadas eran madres solteras sin recursos que luego entregaban a su hijo a la Casa de Expósitos y ellas mismas pasaban al departamento de lactancia para hacer de nodrizas a cambio de cama, comida y 40 reales mensuales. También se atendía a mujeres de pago pertenecientes a clases acomodadas que se refugiaban para ocultar el embarazo y entregar a su hijo en secreto. Se ubicó en el palacio de los Benavente junto con la Real Casa de Misericordia. Sus rentas eran muy limitadas, en el período que funcionó de forma independiente atendió entre 6 y 12 embarazadas según el momento, en el Anuario Estadístico de España de 1860 se contabilizan un total de 44 mujeres ingresadas en este año. La propia Junta justifica que su finalidad es "evitar multitud de crímenes, hijos de la desesperación del abandono y el que se reproduzcan con frecuencia los crueles atentados contra el producto de la concepción de que, por desgracia, aún tenemos noticias..." ${ }^{\prime 13}$. El problema de la ilegitimidad, más allá de las consideraciones

\footnotetext{
212 MAZA ZORRILLA E.: Valladolid: sus pobres ... 1985, p 267

213 Informe dado al Ilustre Ayuntamiento Constitucional de esta ciudad en 18 de marzo sobre el origen, servicios, recursos y reformas que necesitan los establecimientos de la misma. Junta Municipal de Beneficencia de Valladolid 1848). Citado por MAZA ZORRILLA E.: op. cit. También trata sobre la Casa de Maternidad CARASA P. en Historia de la Beneficencia en Castilla y León, 1991, pp 214 y ss
} 
morales, pero precisamente por ello y por la condición de estigmatización que implicaba, constituía, todavía en esta época, y más adelante hasta avanzado el siglo XX, un importante problema social por ser causa de infanticidios y abandonos, a pesar de una legislación cada vez más dura para estas situaciones. Se calcula que entre 1858 y 1861 el promedio anual de hijos ilegítimos en Valladolid fue del 16'66 \% del total de niños nacidos, un poco más elevado que el global de Castilla y León, $\left(16^{\prime} 20 \%\right)$ y algo inferior al de España $\left(18^{\prime} 18 \%\right)^{214}$

\subsubsection{FUNDACIÓN DEL HOSPICIO PROVINCIAL DE VALLADOLID}

Ya constituido el Hospicio Provincial de Valladolid por el Consejo Provincial desde 1847 e instalado en el palacio de los Benavente, con la ley de 1849 las Casas de Misericordia, de Expósitos y de Maternidad se catalogaron como establecimientos de carácter provincial y quedaron bajo la responsabilidad de la Diputación, unificadas así definitivamente bajo un gobierno único ${ }^{215}$. Entre octubre-noviembre de 1849 se aprobaron sus estatutos y estaba pendiente la contratación de las Hermanas de la Caridad.

Con la Diputación a cargo del Hospicio, no acabaron los aprietos económicos del establecimiento, más bien todo lo contrario y así se refleja en la Memoria económica que escribió en 1871 D. Ignacio María Bueno, Apoderado General del Hospicio Provincial ${ }^{216}$. En ella advierte que los problemas económicos que padece el Hospicio se vienen arrastrando desde antes del gobierno de la Diputación (a pesar de las agregaciones, de la Ley de Beneficencia de 1822, restablecida en 1836 , y de disposiciones posteriores ${ }^{217}$ que proporcionaron más rentas a

\footnotetext{
${ }^{214}$ Son datos del Anuario Estadístico de 1860 citados por CARASA P.: op. cit., 1991

215 Tanto PALOMARES J.M. (1975 pp 135-136) como la página web de la Diputación datan la fusión de los tres establecimientos en uno sólo, llamado desde entonces Hospicio Provincial, en 1847, por decisión tomada en la sesión provincial del 5 de enero. MAZA E. (1985, pp 302-303) dice que "su andadura oficial (del hospicio como entidad única) comienza el 1 de enero de 1950", después de que la Junta Provincial de Beneficencia de Valladolid, que se hizo cargo de la dirección del Hospicio, se constituyera por orden ministerial al amparo de la ley de 1849. Se trata de una "reforma, tendente sobe todo a la simplificación administrativa y al ahorro de personal, no significa variaciones en su sede ..., ni en su cometido asistencial"

${ }^{216}$ El título completo expresa detalladamente su contenido e intenciones: Memoria sobre la fundación del Hospicio Provincial de Valladolid, sus vicisitudes, estado actual, medios que podrían adoptarse para mejorar todas sus rentas, reivindicar todos sus derechos perdidos y aumentar los créditos con que hoy cuenta el mencionado establecimiento. Dedicada a la Excma Diputación Provincial por D. Ignacio María Bueno, su Apoderado General para la liquidación y gestiones necesarias hasta lograr el cobro de toda clase de créditos pertenecientes á los establecimientos de Beneficencia Provincial. Año de 1871.

217 En su Memoria, D. Ignacio María Bueno habla de la Ley de Beneficencia de 1822 y las leyes de 1841 y 1858 . En 1858 el Real Decreto del 2 de octubre restablece la ley de Desamortización del 1 de mayo de 1855, suspendida en setiembre de 1856. MAZA E. (1985 y 1987) hace una relación de la normativa legal que se produce a mediados del siglo XIX para regular el sector de la beneficencia y menciona, además de las anteriores, la ley de Beneficencia de 1849 (20 de junio), el Reglamento de 1852 (14 de mayo) que vendrían a regular y reestructurar el sector benéfico y
} 
la Casa) debido a la desidia de los responsables del Asilo en lo referente al cobro de las rentas concedidas $^{218}$.

En 1868, cuando se suprimieron las Juntas de Beneficencia y sus fondos y funciones se transfirieron a Ayuntamientos y Diputaciones, el Hospicio perdió definitivamente su autonomía económica y sus fondos pasaron a la Diputación Provincial de Valladolid, aunque para entonces ya no le quedaba prácticamente nada de su patrimonio a causa de la aplicación de la ley de Desamortización de Madoz de 1855. A cambio de la incautación de sus bienes el Hospicio percibió del Tesoro del Estado inscripciones nominativas intransferibles de deuda pública; se queja D. Ignacio María Bueno en su Memoria de la mala gestión que se hizo con ellas, "Ias láminas intransferibles que hoy posee el Asilo... de seguro no representan la décima parte del capital perdido" ${ }^{219}$. En definitiva, califica la coyuntura económica del Hospicio como "crítica y desesperada".

A pesar de las obras que se realizaron en el edificio de cara a su apertura, las condiciones del establecimiento y de sus instalaciones eran penosas, sobre todo desde el punto de vista higiénico-sanitario, así consta en la memoria de 1853 que se elaboró a raíz de la visita del Jefe Político y Presidente de la Junta Provincial; otro informe de 1859 recoge una situación similar lo que demuestra que las deficiencias no se subsanaron ${ }^{220}$. Estas condiciones son reflejo y consecuencia de la situación financiera del Hospicio y de la propia Diputación de Valladolid.

\footnotetext{
las R.O. de 1846 ( 25 de marzo, 3 de abril y 28 de setiembre), 1847 (26 de setiembre y 11 de diciembre), 1848 (23 de enero, 15 de mayo y 13 de agosto) y 1849 (15 de enero)

${ }^{218}$ La Memoria del Hospicio Provincial recoge su situación económica antes de pasar a manos de la Diputación. La tarea, advierte D. Ignacio María Bueno, no es fácil porque cuando la Real Casa de Misericordia pasó a llamarse Hospicio Provincial casi todos sus archivos y libros desaparecieron con ella. Recoge una breve historia económica de la Casa de Misericordia y realiza un análisis tan exhaustivo como se lo permite la documentación conservada y disponible, en el que queda patente la dejadez en el cobro y reclamación de las rentas que se adjudicaron en su momento al establecimientos por la agregación de las Obras Pías y que en muchos casos, dice, son ya imposibles de rescatar y reclamar: "Con tan decidida protección de los Reyes, y con tan positivos elementos, la Real Casa de Misericordia pudo, por espacio de muchos años, cubrir sus atenciones con tal desahogo, con tanta abundancia, que solo así puede explicarse el descuido que, desde los primeros tiempos, se observa en el esclarecimiento de bienes y rentas abandonadas por las Administraciones de las Cofradías y la pérdida y disminución de sus productos, hasta que la invasión francesa y los acontecimientos políticos que se sucedieron en los veinte primeros años de este siglo [s $\mathrm{XIX]}$, acabaron de arruinar casi por completo el edificio levantado sobre tan firmes cimientos. ... Pero si grandes y sensibles son las pérdidas sufridas durante los años citados, mayores y más sensibles todavía lo son las experimentadas desde aquella fecha hasta hoy, sin que escusa alguna pueda atenuar la inmensa responsabilidad de los que administraron tan benéfico Asilo".

219 D. Ignacio María Bueno hace responsables a los agentes encargados de su custodia, los primeros porque dice "sus cuentas pueden calificarse de monstruosas" y los que les relevaron "visto el ningún interés que los agentes se han tomado por el Asilo, dejando abandonados los derechos y rentas que todavía existen en la corte, y siendo su gestión ineficaz para lograr la liquidación de lo que vaya correspondiendo al mismo por las enagenaciones que diariamente se están verificando" [sic].

${ }^{220}$ MAZA ZORRILLA E.: op. cit., pp 301- 305
} 


\title{
2.2. EL HOSPICIO PROVINCIAL 1900- 1930
}

El Hospicio Provincial pasó a ser una institución de carácter exclusivamente infantil, incluyendo una sala de maternidad para dar refugio a mujeres que quisieran ocultar un embarazo ilegitimo o carecieran de recursos y que quisieran dejar al hijo en la Inclusa. El Reglamento del Hospicio de 1849 estableció el régimen interno del establecimiento y posteriormente se

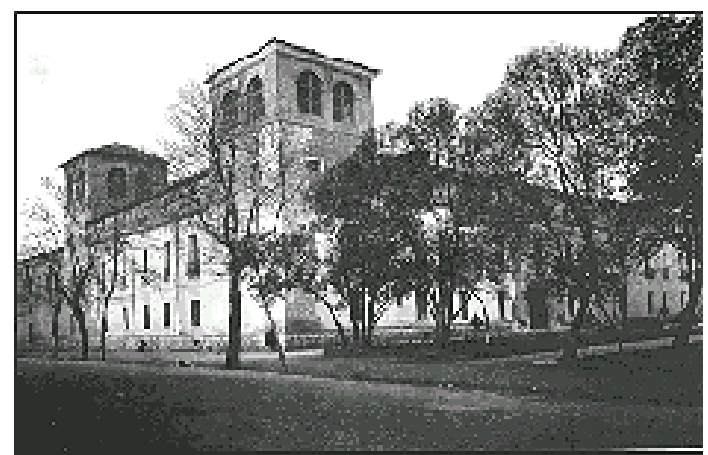

Imagen 2-3 El edificio del Hospicio Provincial en las primeras décadas del siglo XX. Fotografía de Carvajal. Imagen tomada de J. URREA: Arquitectura y nobleza: casas y palacios de Valladolid. 1996. realizaron algunas modificaciones en 1889 , 1910 y 1927, son los Reglamentos [a partir de ahora Regl.] que hemos analizado dado que son los que rigen en el periodo que interesa a este estudio; el de 1927 hace muy pocas modificaciones respecto al anterior, por lo que, si no se indica lo contrario, cuando hablemos del Regl. de 1910 nos referiremos a ambos. Empiezan todos estableciendo el objetivo de la institución en su primer artículo:

\begin{abstract}
"Reunidas en un solo Establecimiento denominado Hospicio provincial las antiguas Casas de Maternidad, Niños Expósitos y Misericordia, su objeto es dar albergue, sostenimiento, educación y enseñanza a los niños menesterosos, hijos o vecinos de la provincia, que por su edad o por imposibilidad física, no pueden atender a su subsistencia ni tienen en su familia personas que por su posición y con arreglo a la Ley están obligadas a cumplir con tal deber, y para albergar a las mujeres que habiendo concebido ilegítimamente reclamen la asistencia que requiere su estado."
\end{abstract}

En 1910 se añadió un artículo, el no 3, para dejar claro que no tiene fines correctivos: "El Hospicio, como establecimiento esencialmente benéfico, no tiene ni podrá tener el carácter de casa de corrección"

El centro quedó dividido en cuatro departamentos: "1o. De Maternidad, 2o. De Lactancia o Inclusa 3o. De conservación y crianza de niños menores de siete años. 4‥ De conservación, crianza y educación de niños mayores de siete años" (Art. no 2, Regl. 1889; Art. no 4 Regl. 1910). 
Institucional y económicamente, quedó "como Establecimiento provincial" dependiente de la Diputación Provincial de Valladolid (Art. no 2, Regl.1910).

\subsubsection{FINANCIACIÓN DEL HOSPICIO PROVINCIAL}

Las estrecheces económicas de nuestro Hospicio irían desde entonces parejas a las que padecían las Diputaciones, con un presupuesto muy limitado y estancado hasta que la Dictadura primoriverista aumentó sus fuentes de financiación ${ }^{221}$. Hasta el ejercicio de 1919 1920 los ingresos de la Diputación de Valladolid no llegan a los dos millones de pesetas, con una media de 1.660.144 pesetas (variando desde 1.492.651pts en 1903 hasta 1.861 .614 pts en 1918); en el siguiente quinquenio hasta 1925 la media de ingresos se sitúa en 2.233.267pts y a partir de entonces se duplican superando en 1929 los cinco millones de pesetas con una media de 5.019.641pts para este último quinquenio ${ }^{222}$

Hasta la reforma de la política provincial de la Dictadura las principales fuentes de ingreso de la Diputación de Valladolid eran las aportaciones de los municipios de la provincia y la recaudación de los establecimientos de Beneficencia, principalmente por el cobro de estancias. Las cantidades aportadas por el Hospicio eran insignificantes en comparación con el Manicomio, que era el que aportaba mayores ingresos, llegando a recaudar más de 900.000 pts por este concepto en el lustro 1925-30, debido a las estancias de enfermos de otras

\footnotetext{
${ }^{221}$ Las Diputaciones Provinciales tienen su origen en las Cortes de Cádiz; el artículo 325 de la Constitución de 1812 establece que "en cada provincia habrá una diputación llamada provincial, para promover la prosperidad presidida por el jefe superior" y determina que sus funciones fundamentales son el desarrollo y la prosperidad de los pueblos que conforman dicha provincia. El precepto constitucional se desarrolla con el Decreto de 23 de junio de 1813. Fernando VII las suprime 14 meses después de su constitución, se restablecen en 1820 y vuelve a suprimirlas a su regreso durante la llamada década ominosa (1823- 1833). El R. Decreto del 21 de septiembre de 1835 da forma a las Diputaciones que quedan como instituciones de carácter administrativo al servicio del poder central, constituidas por representantes de los municipios de la provincia y un Jefe Político en representación del Gobierno, llamado posteriormente Gobernador Provincial, como jefe superior de la provincia con atribuciones directivas y ejecutivas. La Comisión Provincial es el órgano ejecutivo de la Diputación, que se reunirá con frecuencia, dos o tres veces semanales, para resolver asuntos urgentes como las solicitudes de ingreso en el Hospicio y ejecutar los acuerdos de los plenos de la Diputación, que sólo se reúnen unos pocos días en dos sesiones anuales. Desde su creación sufrieron los vaivenes de la política nacional llegando incluso a ser suprimidas temporalmente en algunos momentos. Una característica común a todas las Diputaciones, a la que no sería ajena la de Valladolid, fue la falta de recursos y una dotación financiera insuficiente para atender todas las obligaciones que el Gobierno les iba cargando, hasta las reformas de la Dictadura de Primo de Rivera, que aumentaron de forma significativa sus ingresos. Véase sobre la Diputación Provincial de Valladolid: PASTRANA H.: La Diputación Provincial de Valladolid 1875- 1930. Política y Gestión. 1997; ANTA MUÑOZ A. DE: La Diputación Provincial de Valladolid en el siglo XIX (1813-1874), 2012; CANO R., REVUELTA C.: Educación y enseñanza en la Casa Hospicio de la Diputación Provincial de Valladolid (1723- 1900); 2007

222 Datos extraídos de los Presupuestos Generales de Ingresos y Gastos de la Diputación provincial de Valladolid. Se han consultado todos los presupuestos disponibles en el ADPVA para la época de estudio, faltan algunos como los correspondientes a los ejercicios 1900 y 1907
} 
provincias con las que la Diputación de Valladolid tenía conciertos, mientras que el Hospicio solamente recaudaba las estancias de las pensionistas de la Maternidad, que no pasaron de 6.000 pts, según se refleja en los presupuestos de estos 30 años $^{223}$.

La escasez de recursos financieros de la Diputación de Valladolid condicionó un déficit presupuestario $^{224}$ que afectó fundamentalmente al apartado de Beneficencia, el más importante del presupuesto. "Los establecimientos provinciales [Hospicio, Manicomio y Hospital Provincial]... consumen el mayor porcentaje de los recursos provinciales" 225 , en torno al 50\% con variaciones según años; al Hospicio provincial se destinaba aproximadamente un tercio de los fondos de este apartado.

El aumento considerable de ingresos en la Diputación de los últimos años no repercutió en la misma medida en la partida de fondos destinados a Beneficencia, aunque el Hospicio será el más beneficiado con un incremento importante en su presupuesto, como se puede ver en LA TABLA 2-1 226

\footnotetext{
${ }^{223}$ Tampoco el Hospital recaudaba cantidades importantes. Solamente el Manicomio generaba beneficios gracias a las estancias de dementes de otras provincias que carecían de este tipo de establecimiento y que pagaban por ello a la Diputación de Valladolid. Podemos leer en la carta de presentación del presupuesto de 1928: "La cantidad que se recauda de otras Diputaciones por el sostenimiento de sus dementes se aumenta en 10.000 pesetas, ya que están firmados los contratos con León y Soria para admitir alienados de aquellas provincias"

En el "Presupuesto general de ingresos y gastos: Año 1924/1925" de la Diputación de Valladolid aprobado el 11 de junio, de un total de $2.535 .585^{\prime} 58$ ptas de ingresos, la mitad, 1.257 .936 pts proceden del repartimiento entre los pueblos y 1.022.475'38 pts de los establecimientos de Beneficencia. El Hospicio aportó 22.776'54 pts en concepto de "Producto líquido de las inscripciones y resguardos de la Deuda perpetua al 4 por 100 interior, propiedad del Establecimiento" y 3.000 pts por estancias en la Maternidad. El Manicomio aportó a las arcas de la Diputación más de 925.000 pts sólo en concepto de estancias y el Hospital Provincial unas 20.000 pts.

En el "Presupuesto general de ingresos y gastos: Año 1928" se nota la mayor aportación estatal. No se hallan sumadas las aportaciones de los centros benéficos en un bloque único sino que están por partidas, así encontramos 38.653 pts que corresponden a los intereses de la deuda de los tres establecimientos, la mayoría correspondientes al Hospicio, 17.500 por venta de productos varios, y los ingresos "Por prestación de servicios" que fueron 6.000 pts de la Maternidad del Hospicio, 31.000 pts del Hospital y 850.500 del Manicomio; en total suman 943.653'68 pts, la aportación municipal ascendió a 1.058 .613 pts y los Ingresos llegaron en total a 4.860 .313 pts

${ }^{224}$ Dice PASTRANA (op. cit., pp. 158-160) que prueba del déficit presupuestario de la Diputación son precisamente "los trabajos preparatorios de los presupuestos anuales, verdadero catálogo de buenos deseos, que condicionan aspectos apremiantes e imprescindibles del futuro provincial. La realidad es que muy poco pude acometerse con las reducidas cantidades disponibles, y una y otra vez vemos asignadas partidas en presupuestos sucesivos para las mismas obras y atenciones, prueba evidente de que no pudieron realizarse en los anteriores".

${ }_{225}$ Presupuesto... de 1928. En la carta dirigida a la Diputación por la Comisión encargada de elaborarlo.

${ }^{226}$ Por abundar un poco en el tema con datos más concretos, podemos tomar el ejemplo que pone PASTRANA que toma el año 1909 como referencia de los primeros ejercicios en que el presupuesto para estos establecimientos se mantuvo prácticamente invariable, en el que de un total de 1.634 .055 pts presupuestadas se destinaron 268.743 pesetas para el Hospicio, 209.913 para el Hospital y 344.800 para el Manicomio. Ibídem pp 163 y 172.

Suman 823.456 pts, el $50 \%$ del presupuesto total. Podemos compararlo con otros posteriores

En el "Presupuesto general...: Año 1924/1925" los ingresos fueron de 2.535.585'58 ptas y el presupuesto de gastos para todos los establecimientos de Beneficencia ascendió a 1.544 .105 '33 pts, casi el $61 \%$ del total. El del Hospicio Provincial en particular fue de 390.830 '63 pts, el 25'3\% de lo asignado a Beneficencia. En el "Presupuesto general de ingresos y gastos: Año 1928" los ingresos de la Diputación casi doblaron a los de 1924 (4.860.327'59 pts), pero al capítulo de Beneficencia se destinó globalmente una cantidad menor (1.499.645 pts), el 30`85\% del total.
} 


\begin{tabular}{|c|l|c|c|c|c|}
\hline & & $1901-10$ & $1911-20$ & $1921-25$ & $1926-30$ \\
\hline DIPUTACIÓN & PRESUPUESTO & $\mathbf{1 . 5 8 2 . 9 8 5 p t s}$ & $\mathbf{1 . 7 8 8 . 7 7 7 p t s}$ & $\mathbf{2 . 2 3 3 . 2 6 7 p t s}$ & $\mathbf{5 . 0 1 9 . 6 4 1} \mathbf{p t s}$ \\
\hline \multirow{2}{*}{ BENEFICENCIA } & GASTOS & $\mathbf{7 2 6 . 7 8 9}$ pts & $\mathbf{9 6 1 . 6 8 0} \mathbf{p t s}$ & $\mathbf{1 . 3 4 8 . 5 3 3 p t s}$ & $\mathbf{1 . 6 0 1 . 4 7 6 p t s}$ \\
\cline { 2 - 6 } & $\%$ de Diputación & $48^{\prime} 62 \%$ & $54^{\prime} 00 \%$ & $60^{\prime} 38 \%$ & $31^{\prime} 90 \%$ \\
\hline \multirow{2}{*}{ HOSPICIO } & GASTOS & $\mathbf{2 4 5 . 4 7 1}$ pts & $\mathbf{2 8 3 . 5 8 5}$ pts & $\mathbf{3 5 6 . 5 0 2}$ pts & $\mathbf{5 5 8 . 5 5 4}$ pts \\
\cline { 2 - 6 } & \% de Beneficencia & $33^{\prime} 77 \%$ & $29^{\prime} 49 \%$ & $26^{\prime} 43 \%$ & $34^{\prime} 87 \%$ \\
\hline
\end{tabular}

TABLA 2-1: PRESUPUESTOS medios de la DIPUTACIÓN y promedio de los GASTOS de BENEFICENCIA y del HOSPICIO por décadas. Porcentaje que representan los gastos de Beneficencia sobre el total del presupuesto de la Diputación y de los gastos del Hospicio sobre el total destinado a Beneficencia. Los años 20 se dividen en dos quinquenios debido a la diferencia sustancial entre el primero y el segundo. El presupuesto anual de gastos de la Diputación se ajusta casi todos los años al céntimo a los ingresos que percibe. Elaboración propia a partir de los Presupuestos Generales de la Diputación Provincial de Valladolid desde 1901 hasta 1930

A la falta de recursos de la Diputación Provincial de Valladolid se sumaron la mala gestión y una serie de escándalos económicos dentro de la institución ${ }^{227}$ que agravaron el déficit y que fueron motivo de más de una denuncia pública.

"vivan tranquilos los concejales discutiendo al lado de la estufa el personal que ha de ocupar los empleos públicos... los Diputados que han cobrado las Comisiones Provinciales y cobrado cuatro duros por cada una de las 20 sesiones que al mes suelen celebrarse, aunque no haya habido dinero para alimentar á los asilados del Hospicio, Hospital y Manicomio"228

A ésto hay que añadir un contexto general de crisis sucesivas que tampoco ayudó: malas cosechas, epidemias, incluso situaciones como la I Guerra Mundial, que económicamente benefició al país por su neutralidad, pero que a nivel local provocó desabastecimiento de productos de primera necesidad debido a la especulación y al aumento de los precios ${ }^{229}$. Todo repercutía negativamente en los asilos provinciales, que en muchos casos no verían atendidas ni siquiera sus necesidades más básicas.

Una vez enajenado todo su patrimonio, el Hospicio Provincial de Valladolid se financiaría casi exclusivamente con el presupuesto concedido por la Diputación provincial, "Como Establecimiento provincial depende exclusivamente de la provincia y su sostenimiento

\footnotetext{
${ }^{227}$ PASTRANA H.: op.cit., pp 167-8. Como ejemplo de alguno de los escándalos que afectaron a la Diputación, en 1908 se detectan una serie de irregularidades en los documentos del Hospicio y se descubre que una partida de azulejos destinados a sus obras ha sido proporcionada por el Diputado Visitador del centro, algo prohibido terminantemente por la Ley Provincial, que además las vende por encima de su coste: "se han tomado azulejos, para una obra del edificio, del comercio del Sr Carnicer, visando la cuenta él mismo, como visitador interino, cargando a 17 pesetas el ciento, cuando él los ha tomado del comercio del señor Vaquero ... a 13'50 ptas., el ciento" [sic], pp $49-50$

${ }^{228}$ N.C. 14-11-1898 p 3. En efecto, en los Presupuestos constan las dietas de los Vocales de la Comisión permanente de la Diputación a razón de 20 pts por sesión, según lo decretado, lo que eleva el total en los primeros años a 14.000 pts., se disminuiría considerablemente esta partida a 9.500 pts en los años 20 y hasta 3.500 pts anuales a partir de 1928, a pagar solamente a los Diputados con residencia fuera de la capital.

${ }^{229}$ Ibídem: p 54 y 218. En Valladolid escasean y llegan a faltar patatas huevos, gas y carbón. La situación llega a ser tan crítica, que algunos artículos como el carbón faltan totalmente en los asilos provinciales en el mes de febrero de 1918, en el Hospicio tuvieron que quemar las puertas para la cocina. El Gobernador Civil tuvo que adoptar medidas extraordinarias y mandó expropiar seis vagones de carbón que se encontraban en la estación
} 
corre á cargo del presupuesto provincial en la parte á que no alcanzan sus recursos propios" (Art. no 2, Regl. 1910). Esto es lo mismo que decir que tenía una dependencia total porque los ingresos que generaba no revertían directamente en el establecimiento, sino que se incluían en el Presupuesto General de la Diputación. El ingreso más importante era el que correspondía a los intereses de las "láminas intransferibles" del Estado concedidas a cambio de los bienes desamortizados, que en los primeros años, junto con otros intereses y alguna renta que todavía poseía el establecimiento, suponían más de 29.000 pts y a partir de 1914 se quedó en una cantidad fija de 22.776 '54 pts anuales; el Hospicio Provincial, con sus tres casas, era el centro benéfico con más letras del Tesoro a su nombre pues era el que más patrimonio poseía $^{230}$

El Director debía "Ingresar en la Caja provincial las cantidades que recaude por estancias en la Maternidad, servicios de la Banda de música, limosnas al Establecimiento u otros conceptos" (Art. № 25, 10으, Regl. 1910 y las encontramos recogidas en los Presupuestos Generales de la Diputación de todos los años entre los Ingresos en la partida denominada "Eventuales", que incluye en "otros conceptos" los beneficios estimados obtenidos por la venta de artículos y productos del asilo. Son ingresos perdidos a favor de la Diputación que vienen a suponer entre 1.500 pts y 11.000 pts anuales para el periodo de 1900-1930. No son cantidades relevantes para el total de ingresos de la Diputación, pero, teniendo en cuenta la escasez de recursos de que adolecía el Hospicio, el haber contado con esos ingresos "Eventuales", aparte de la asignación de la Diputación, podría haber supuesto el alivio de alguna de las muchas necesidades que padecía. En 1901 se obtienen por este concepto 9.250 pts, por poner un ejemplo ilustrativo, y el gasto total en carne de ese año fue de 13.000 pts por la compra de 10.000 kilos de carne de vaca (con hueso), insuficientes para una población que el propio presupuesto estimó ese año en 450 asilados, aunque según nuestros cálculos la población a alimentar podría estar en torno a 500 personas ya que hay que incluir junto a los niños asilados con alimentación normal, las mujeres de la maternidad y el personal con derecho a ración, que incluye a las Hijas de la Caridad y las amas de cría. Si echamos mano de las medias estadísticas,

\footnotetext{
${ }^{230}$ En el Presupuesto General de la Diputación de 1928 en los ingresos por este concepto se anotan: [el subrayado es nuestro]

1 Producto líquido de las 108.110 pesetas nominales de la Deuda Perpetua al 4 por 100 interior, propiedad de la Diputación . 3.459'20 Pesetas

2 Producto líquido de las 562.155'71pesetas que posee el Hospital provincial en inscripciones de la Deuda perpetua al 4 por 10 interior ..................................................................... 11.588'84 Pesetas

3 Producto líquido de las 134.000'71pesetas que posee el Hospital de Dementes en inscripciones de la Deuda perpetua al 4 por 100 interior 4.288 Pesetas

4 Producto líquido de las inscripciones y resguardos de la Deuda Perpetua al 4 por 100 interior, propiedad de las casas Hospicio, Misericordia y Maternidad ................................ 22.776'54 Pesetas
}

Este es un apartado que no variaría porque no cambió el interés del $4 \%$, por lo que estas cantidades se van a mantener a lo largo de todo el período con la consiguiente pérdida de valor real. 
calculando sobre 500 nos salen $20 \mathrm{Kg}$ por persona y año, no llega a 55 gramos diarios de carne, hueso incluido ${ }^{231}$, que realmente, se ajusta a lo que establecen los reglamentos del Hospicio sobre alimentación.

Las estancias de la Maternidad junto con los intereses por el Papel del Estado y demás conceptos suponen anualmente una cantidad que oscila entre las $24.776^{\prime} 54$ pts de 1918 y las $38.486^{\prime} 02$ pts de 1901 , que representan entre el $9^{\prime} 6 \%$ y el $16^{\prime} 1 \%$ del gasto total del Hospicio ${ }^{232}$.

Las Hijas de la Caridad obtenían dineros adicionales de limosnas de particulares, labores de costura de las propias monjas y de las asiladas y excedentes de las cuadras. La Superiora debía entregar "al señor Administrador las limosnas que reciba para el Establecimiento, [pero] no así las que reciba para la comunidad o para algún fin determinado y especial, en cuyo caso las invertirá en conformidad con la voluntad del donante" e "invertirá en las mejoras más apremiantes del Establecimiento el producto de las labores de las acogidas" (Art. no 222 y 223, Regl. 1889). Según el reglamento, podía disponer del dinero conseguido y normalmente lo empleaba en gastos para el servicio religioso, como la compra de incienso o de un retablo para la capilla, y en arreglos del establecimiento. En 1903 la Superiora del Hospicio propuso "levantar un pabellón paralelo al dormitorio de niños cuya necesidad ha sido reconocida por [la] Diputación y Comisión Provincial..." y el Gobernador Civil advirtió a la Diputación que "...conviene aclarar suficientemente si los fondos con que se va a hacer la obra son donación de la Sra Superiora de las Hermanas de la Caridad ó anticipo a la Diputación provincial”233, a finales de año la Comisión Provincial acordó "dar gracias a la Superiora del Hospicio por invertir en mejoras para el establecimiento las cantidades que recibiera como

\footnotetext{
${ }^{231}$ Es una cantidad que se queda muy corta porque era casi la única fuente de proteínas de origen animal que recibían. Las recomendaciones actuales son de 3- 4 raciones semanales de 100-125 gr gramos de carne magra, pero dentro de una dieta equilibrada con una ingesta suficiente de proteínas; se aconsejan 2 raciones diarias del grupo alimentario de carnes, pescados y huevos, lo que a la vista del gasto en víveres no se alcanzaba ni de lejos en el Hospicio en la época. (Cfr.: Consejos para una Alimentación Saludable de la Sociedad Española de Nutrición Comunitaria (SENC) y la Sociedad Española de medicina de Familia (semFYCF). Madrid 2007; CARBAJAL AZCONA A.: Manual de Nutrición y Dietética. Universidad Complutense de Madrid. 2013; 2 a Guía de Alimentación y nutrición saludable. La Pirámide de Alimentación. Ayuntamiento de Valencia, Servicio de Sanidad. Valencia 2009; Guía de Alimentación para comedores escolares. Consejería de Sanidad de Castilla-La Mancha.

${ }^{232}$ Datos extraídos de los Presupuestos Generales de la Diputación para los años 1901 hasta 1930. Los ingresos "Por pensionistas de la sección de Maternidad, asistencia al parto y lavado de ropa" fueron de dos mil pesetas entre 1901-05, mil entre 1908-13, mil quinientas en 1914- 15 y luego varían entre las tres mil pesetas de 1922, 1924 y 1930, y las seis mil de 1927 y 1928. En el apartado de ingresos "Eventuales" de los Presupuestos se incluyen "Productos de talleres, Imprenta y banda de música" y "Venta de efectos que procedan del Establecimiento", que suponen 2.000 pts y 750 pts respectivamente en 1904 . Hasta 1913 aparece también una partida de "Donativos, legados y mandas" que contempla 500 pts anuales. Otro concepto son los ingresos "Por venta de efectos viejos, de ganado mular y caballar de desecho y otros análogos", en 1924 se consignan 1.500 pts y en 19285.000 pts "Por enajenación de efectos viejos, basuras, terneros, ganado de desecho, chatarra, trapos, huesos y otros".

${ }^{233}$ Carta del Gobierno Civil dirigida al Vicepresidente de la Comisión Provincial, Valladolid 15 de julio de 1903. Signatura: caja 2449, expediente 30481. ADPVA
} 
limosnas"234. Podían obtener cantidades no despreciables de las que debían dar cuenta anualmente a la Diputación, en 1905 declararon 12.234 pts y en 1908 fueron 16.692 pts. En la edición extraordinaria que la revista El Financiero Hispano-Americano dedicó a Valladolid en 1911 se refiere la donación de "25.000 pesetas que legó D. Juan Fernández Martín" para la construcción de la nueva escuela inaugurada el 30 de abril de ese año, dinero que no se refleja en los presupuestos generales de la Diputación ${ }^{235}$.

Surgieron repetidos debates dentro de la Diputación porque algunos diputados consideraban que estos ingresos eran de carácter provincial y como tal debían incluirse en el Presupuesto General junto con los demás que genera el asilo, a pesar de haberse obtenido con recursos propios y con actividades no financiadas por la Diputación ${ }^{236}$. En las Bases para la ejecución de los Presupuestos aprobadas por la Comisión de la Diputación en 1901 la primera advierte que "Continuarán prohibidos terminantemente los ingresos verbales en el Hospicio"; parece que esto contradice los artículos referidos anteriormente, que ya no aparecen en el Regl. de 1910, en el que se sustituyen por el que dice que el Director debe "ingresar en la Caja provincial las cantidades que recaude por ... limosnas al Establecimiento" (Art. № 25, 10ㅇ); ya no se dice nada de las limosnas entregadas expresamente a las Hijas de la Caridad. Hasta 1913 aparece consignada una cantidad fija de 500 pesetas en los Presupuestos Generales en una partida dentro de los ingresos "Eventuales" del Hospicio denominada "Donativos, legados y mandas", esta partida se reguló posteriormente con otras dos normas (En el presupuesto de 1928 se anexiona la normativa completa, no dice cuando se aprobó)

"Base 67. Todas las cantidades que procedan de donativos, legados y mandas a favor de los establecimientos benéficos se invertirán en deuda del Estado, si excediesen de 500 pesetas. Cuando de esta cantidad no excedan se aplicarán a la consignación que para este concepto existe en presupuesto.

Base 68. En todo caso se cumplirá inexcusablemente la voluntad de los donantes, cuando éstos expresen el destino que han de tener los legados, cualquiera que sea su cuantía.

Las 500 pts no vuelven a aparecer en los Presupuestos después de 1913, en su lugar encontramos algunos años, como en 1927, entre los ingresos "Eventuales" el concepto "Para aquellos ingresos que se produzcan y no tengan consignación en este presupuesto"

Desde su llegada, las monjas instalaron cuadras dentro de los establecimientos de beneficencia para criar vacas y cerdos para el consumo interno; es una actividad que provocó

\footnotetext{
${ }^{234}$ N.C. $18-12-1903$ p 1

${ }^{235}$ El Financiero Hispano-Americano. Extraordinario Valladolid julio de 1911, p 68; N.C. 29-04-1911, p 2

${ }^{236}$ PASTRANA H.: op. cit., p 205 y ss.
} 
polémicas por los riesgos sanitarios que lleva asociados, que terminaron en parte con la orden de cerrar las cochiqueras en 1903. El Hospicio mantuvo la vaquería, en ella trabajaban dos asilados y los animales eran propiedad de la comunidad de religiosas, hasta 1925-26 cuando cedieron las reses a la Diputación ${ }^{237}$. A partir de entonces, aparecen los ingresos de la vaquería del Hospicio en los presupuestos generales en el apartado de ingresos "Eventuales" pero no figura nunca la leche, que según el acuerdo de la Superiora con la Diputación, debía destinarse al consumo de las hermanas y de los acogidos, solamente se consignan los ingresos por la "Basura" generada ${ }^{238}$.

\begin{tabular}{|c|c|c|c|c|c|}
\hline \multicolumn{6}{|c|}{ PRESUPUESTOS DE GASTOS DEL HOSPICIO PROVINCIAL DE VALLADOLID 1901- 1930} \\
\hline 1901 & 239.078 pts & 1911 & 318.432 pts & $1920-21$ & $378.182 \mathrm{pts}$ \\
\hline 1902 & 229.563 pts & 1912 & 285.830 pts & $1921-22$ & 330.555 pts \\
\hline 1903 & 218. $937 \mathrm{pts}$ & 1913 & 308.143 pts & $1922-23$ & $326.41 \mathrm{pts}$ \\
\hline 1904 & $227.673 \mathrm{pts}$ & 1914 & $275.162 \mathrm{pts}$ & 1924-25 & 390.831 pts \\
\hline 1905 & 223.386 pts & 1915 & 263.849 pts & $1925-26$ & 282.200 pts \\
\hline 1906 & $241.621 \mathrm{pts}$ & 1916 & 260.766 pts & 1927 & 509.385 pts \\
\hline 1908 & $267.615 \mathrm{pts}$ & 1917 & 258.674 pts & 1928 & $552.198 \mathrm{pts}$ \\
\hline 1909 & $268.743 \mathrm{pts}$ & 1918 & 257.914 pts & 1929 & 592.437 pts \\
\hline 1910 & $292.619 \mathrm{pts}$ & $1919-20$ & $323.495 \mathrm{pts}$ & 1930 & 580.197 pts \\
\hline
\end{tabular}

\footnotetext{
${ }^{237}$ Las Hermanas controlaban la vaquería del Hospicio, las pocas hojas sueltas del registro diario del libro "Productos de Vaquería del Hospicio" de 1926 (Signatura: caja 2449, expediente 30487. ADPVA) están firmadas por la Superiora Sor Ignacia Domínguez y en ellas encontramos anotada la producción de leche en cada ordeño. En 1925 la Superiora comunicó a la Diputación la donación de las 10 vacas y el novillo de la vaquería del hospicio que eran propiedad de la comunidad a condición de que se respetara la cantidad que precisaban para consumo (N.C. 4-10-1925)

${ }^{238}$ En el Libro de la Vaquería de los años 1928 -1933 (Signatura: caja 441, expediente 4091. ADPVA) en una columna destinada a registrar PRODUCTOS vemos anotados los "Carros de Basura" obtenidos y se supone que vendidos; su producción era muy variable, desde 2 carros en noviembre de 1930, hasta 11 en enero de 1928 . No parece que, al menos en estos años el Hospicio llegara a contar con un vaquero. En el Reglamento de 1927 en el "Capítulo XXXIX. De la vaquería" se incluye entre el personal: "Art. 357. Al frente de la Vaquería habrá un Vaquero. Art. 359. A sus órdenes tendrá un asilado del Establecimiento a quien instruirá en la limpieza del establo, ganado y vasijas y en el ordeño de las vacas". Sabemos que trabajaban dos asilados porque así se recoge en la Memoria sobre los Estados del personal de 1908. En el libro de contabilidad de la vaquería de 1928-33, en cada hoja de registro mensual se pide la Firma del Vaquero, sin embargo ésta no aparece en ninguna de las páginas del libro y sólo encontramos la firma del Visto Bueno del director del Hospicio. No hay libro de cuentas del Hospicio de estos años para comprobar si entre los gastos de personal se incluye un vaquero, pero en los Presupuestos Generales de la Diputación no se contempla. A partir de 1925 encontramos en los presupuestos "Un Vaquero, sin ración, con jornal diario de 5 pesetas" y "un Ayudante de vaquero, con ración condimentada" en el apéndice referido al Hospital Provincial y el "Jornal de un Vaquero, con ración" en el del Hospital de Dementes (Presupuesto general de ingresos y gastos: Año 1928, pp 98,106 y 114). A partir de 1927 aparece entre los gastos del Hospicio un apartado para la Vaquería (véase puntos 414 y 415 del presupuesto de 1927, ó 435 y 436 en el de 1928) que incluyen la compra de ganado, pienso y utensilios, pero no se consigna ningún salario hasta 1930 en cuyo presupuesto encontramos en el punto 206 entre los gastos de personal del Hospicio una "Gratificación al ayudante de vaquería" de 500 pesetas anuales, véase Presupuesto general de ingresos y gastos... para el año natural de 1928, p 140. Por tanto podemos suponer que la vaquería siguió siendo atendida por los asilados bajo el control de las Hermanas.
} 
En 1899 el presupuesto para gastos del Hospicio Provincial fue de 242.919 pts ${ }^{239}$ y se modificó muy poco durante años, en 1918 fue de 257.913 '75 pts, con variaciones escasas en este intervalo de tiempo en torno a un promedio de 264.528 pts (ver TABLA 2-2). Desde 1919 irá en aumento, que será sobre todo importante a partir de 1927, llegando a doblarse respecto a presupuestos anteriores. Teniendo en cuenta que aún así siguió sufriendo carencias, podemos hacernos una idea de las penurias que tuvo que padecer el Hospicio.

Afirma Pastrana que "La falta de inversiones en Beneficencia se va a traducir en deficiencias imperdonables. ... La insuficiente dotación del Hospicio y la poca retribución de quienes trabajan en él, explican sus condiciones deplorables causantes de unos altísimos índices de mortalidad, cuya comparación con el resto de los asilos de la región escandalizan a sus propios responsables." ${ }^{240}$. A ésto hay que añadir un número de niños acogidos en aumento. De la falta de cuidados y de la mala calidad de los prestados por la institución a sus acogidos dan buena cuenta estos párrafos sacados de la Memoria que la Comisión Provincial dirigió a la Diputación en 1901:

\footnotetext{
"Una de las cosas más descuidadas en el Hospicio es la higiene individual... y sin higiene no hay bienestar ni salud posible en los asilados, aparte de que con ello resultan más costosas las estancias de los mismos.... es precisa la limpieza de la piel en general por medio de baños frecuentes y abluciones diarias y como hoy no hay en el establecimientos medios para subvenir esta necesidad... Es posible que la alimentación de los niños y niñas no sea todo lo reparadora necesaria para su crecimientos y desarrollo, al menos para aquellos de pobre complexión orgánica y anémicos que tanto abundan" ${ }^{241}$.
}

La Diputación de Valladolid por tanto era conocedora de las deficiencias del Hospicio Provincial, pero a pesar de ello se mantuvieron año tras año unos presupuestos raquíticos para atender la "abundancia de necesidades", que diría Elena Maza, que sufría. Parece que al final de la década de los veinte se intentan aliviar esas deficiencias; en la Memoria que acompaña al Presupuesto General de 1927, refiriéndose a los Establecimientos benéficos provinciales puede leerse que "El deseo de atender debidamente las deficiencias notadas en tan importantes servicios, es el propósito de todos los que componen la Corporación". Hay que reconocer en justicia que no toda la culpa fue de la Diputación de Valladolid, que en muchas ocasiones mostró muy buenas intenciones, aunque luego los hechos no acompañaran; detrás tenía un Gobierno que cada vez le asignaba más obligaciones sin proporcionarle medios suficientes y que se desentendió de la atención de centros como éste sin preocuparse de controlarlos ni de que recibieran fondos suficientes para prestar una atención digna a sus acogidos. Desde la

\footnotetext{
${ }^{239}$ N.C. 13-2-1899, pp 1-2

240 PASTRANA H.: op. cit., p 380

${ }^{241}$ Citado por MAZA E.: Pobreza, trabajo... p 885
} 
propia Diputación se reconocían los problemas presupuestarios y una parte fundamental era el tema de los ingresos y las dificultades recaudatorias, otra cuestión aparte era la distribución y uso de los fondos. En el Presupuesto provincial de 1914 La Comisión de Hacienda y Presupuestos incluía un informe en el que se quejaba de las dificultades para elaborarlo teniendo en cuenta que se partía de "un déficit inicial de 173.788 .33 pesetas". Para nivelar el presupuesto la comisión, aparte de reducir gastos, proponía normalizar los ingresos "pues desde el momento en que los ingresos se realicen sin retraso, habrá fondos para atender a los gastos que se produzcan, siempre que estos se ejecuten también dentro de la mayor normalidad... es necesario que la recaudación sea activa y segura y para ello es imprescindible la reglamentación de los apremios evitando el aplazamiento indefinido del cobro de cuotas en período ejecutivo". Respecto a los gastos proponían entre otras medidas "reducir los gastos en los Establecimientos disminuyendo la población de los mismos extremando la vigilancia en la admisión de enfermos, dementes y expósitos... y si es preciso acordando la salida de los acogidos que no deban estar en los Establecimientos ${ }^{\prime 242}$

\subsubsection{LA CASA DE LOS BENAVENTE, EL EDIFICIO Y SUS INSTALACIONES}

A pesar de los buenos propósitos muchas veces manifestados, la falta de recursos económicos y, por tanto, la falta de acondicionamiento, el mal estado de las instalaciones y las deficiencias asistenciales continuaron, incluso podemos decir que fueron en aumento a lo largo de las tres décadas del estudio debido a la racanería de la Administración, léase Diputación Provincial o Gobierno central, y también a la despreocupación de quienes tenían la capacidad política y económica de resolverlas. De otra manera no se entiende que todavía en 1924 encontremos en el Anuario de la vida local publicado por el Ministerio de la Gobernación estas manifestaciones sobre el Hospicio de Valladolid ${ }^{243}$ :

“Un viejo caserón sin condiciones para realizar los altos fines a que se dedica; si
a esto se añade la falta de consignaciones para realizar mejoras y la escasa
atención que se ha prestado a la educación e instrucción de los niños, a la
crianza de los pequeñuelos y a las estancias de las embarazadas, hay que
confesar paladinamente que el Hospicio de Valladolid precisa una radical
reforma en su edificio, en sus talleres, en sus escuelas, en su Cuna y en su
Departamento de Maternidad ... En definitiva, adolece....del atraso, de la rutina

\footnotetext{
242 Informe de la Comisión de Hacienda y Presupuestos al Proyecto de Presupuesto de 1914. ADPVA

243 Ibídem, p 866. dice además MAZA E. que "A pesar de los retoques aprobados..., la situación interna de estos centros (centros asistenciales públicos de Valladolid) deja mucho que desear, sobre todo en el caso de del Hospicio, que acentúa su contradicción entre las ideas y los recursos financieros"
} 
y de la limitación de medios económicos que de antiguo gravitan sobre la instauración y sostenimiento de los establecimientos de Beneficencia españoles"

No se ha conseguido localizar un plano completo detallado de aquel "sombrío caserón vetusto llamado Hospicio"244 ni planos parciales ni documentación que permita hacer una descripción precisa de la estructura y distribución del edificio, salvo un artículo de El Norte de Castilla de 1899 que hace una breve reseña al respecto; tanto en el Archivo Provincial como en el Municipal se han encontrado solamente unos pocos planos parciales que corresponden a distintos proyectos de ampliación y reforma. Sabemos que el palacio de los Benavente, ya convertido en Hospicio Provincial, conservó su estructura inicial alrededor de dos patios separados por la crujía, en la que se alojaba la escalera principal y la capilla, con dos plantas más las buhardillas y las torres rematando sus esquinas. El edificio se encontraba muy deteriorado por el abandono y los incendios sufridos y necesitó importantes arreglos que no concluyeron antes de su apertura; las obras continuarían durante todo el período de su uso como orfanato hasta finales de $1970^{245}$. El Hospicio se fue ampliando hasta llegar en su parte trasera al Paseo de las Moreras, ocupando terrenos cedidos por el Ayuntamiento, el antiguo convento de la Trinidad Descalza y una finca colindante que fue la Fundición Gabilondo, también conocida como "Fundición de la Trinidad"246.

Según la descripción del periódico local El Norte de Castilla, en 1899 las dependencias principales se situaban en torno a los dos patios principales, el primero con arcos de sillería que todavía hoy se conservan, y el segundo con las arcadas tapiadas en dos de sus fachadas para aprovechar las galerías. En la planta baja, alrededor del primer patio estaban

\footnotetext{
${ }^{244}$ N.C. 8-12-1903 p 1. Es habitual encontrar en los artículos de prensa de la época referidos al Hospicio términos como este para describir el edificio

${ }^{245}$ Cfr. URRERO (1996) y PALOMARES (1975). El arquitecto Pedro García González, responsable de la reforma inicial, en una nota escrita en el libro de cuentas el 28 de mayo de 1803 dice que los departamentos de Expósitos y del Hospicio están terminados a falta de algunas vidrieras y advierte que quedan otras zonas pendientes. El palacio conserva aún hoy su estructura. El primer patio columnado de estilo renacentista se mantiene abierto y el segundo se ha cubierto con una cúpula tras su rehabilitación para biblioteca pública. En la fachada principal conserva la primitiva portada, flanqueada por los escudos de la familia Benavente (Pimentel y Herrera)

246 Dice PASTRANA H. que la Diputación decidió la compra del local de la antigua fundición, aprobada por R.O. el 29 de diciembre de 1914, tras una carta del médico del Hospicio advirtiendo sobre los riesgos sanitarios por la falta de espacio en el establecimiento. La Diputación... p 208- 235.

En los presupuestos de 1914, 15 y 16 figuran los pagos aplazados por el "edificio anejo al Establecimiento llamado "Fundición de la Trinidad»"

Juan Agapito y Revilla dice en su Noménclator histórico de Valladolid que en la calle del Puente Mayor "estuvo el convento de religiosos trinitarios descalzos, con iglesia en la plazuela de la Trinidad,... En el convento hubo un taller de fundición que se llamó "de la Trinidad», que... desapareció hace ya muchos años". AGAPITO Y REVILLA J.: Las calles de Valladolid. Noménclator histórico. Valladolid. 1937, p 361.
} 
"situadas la Capilla, las escuelas, comedores, cocina, cuartos de aseo, dormitorios de hermanas y cuartos reservados y en el segundo patio los talleres de sastrería, zapatería, tejedores, retretes y otras dependencias. En la planta principal se [hallaban] instalados los dormitorios, salas de labores, salas de maternidad, el oratorio, el ropero, que es una magnífica estancia perfectamente decorada, amén de amplias galerías y en patios secundarios el establo para las vacas de leche, leñeras, lavaderos ${ }^{\prime 247}$.

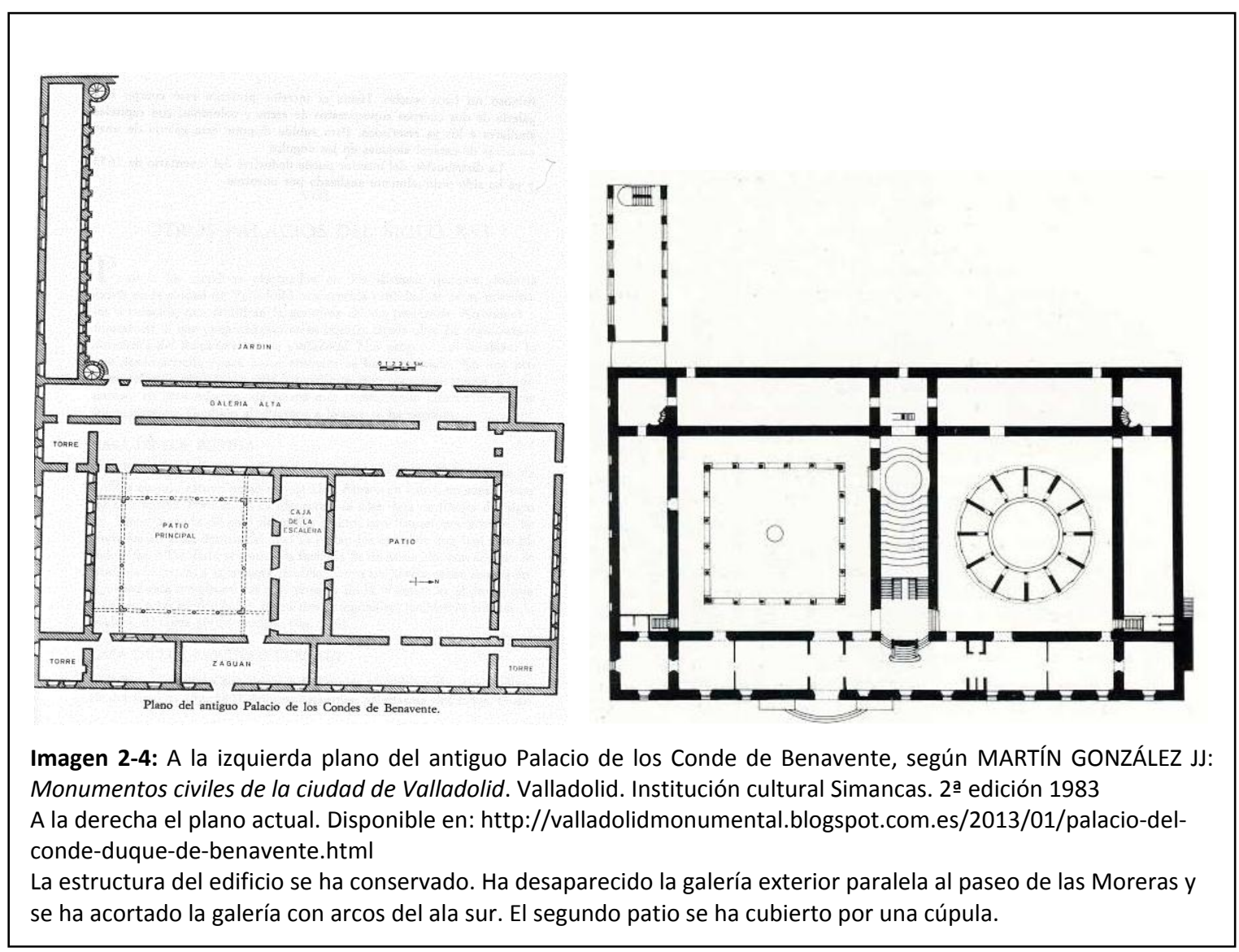

Aunque aquí no lo menciona, por la documentación encontrada en el ADPVA, podemos suponer que en la planta alta se encontraba la enfermería de los asilados. Fuera del edificio principal se fueron añadiendo construcciones como la panadería, construida en 1911

\footnotetext{
${ }^{247}$ N.C. 13-2-1899, pp 1 y 2 . Se publica un extenso artículo en dos páginas sobre el Hospicio Provincial. Hemos encontrado también la distribución del edificio en PASTRANA H: op.., pp 208 y ss., coincidente con la que aparece en el diario y en CANO GONZÁLEZ R., REVUELTA GUERRERO C.: Educación y enseñanza en la Casa Hospicio de la Diputación Provincial de Valladolid 2007, pp 74-74, que hace una descripción un tanto diferente, la falta de documentación sobre el tema solo permite hacernos una idea aproximada y propicia interpretaciones diferentes. Por ese motivo, ya que este artículo periodístico es de la época nos parece una buena fuente a falta de otras que corroboren lo que aquí se detalla.
} 
en la tapia que se levantó para cerrar los terrenos cedidos, casi forzosamente, por el Ayuntamiento y nuevos pabellones para dormitorios y escuelas ${ }^{248}$.

La falta de espacio del Hospicio y el hacinamiento consecuente fue un grave problema reconocido por todos, que se intentó paliar con nuevas construcciones, que requerían terreno. En 1909 la Superiora, Sor Francisca Orrio, planteó la construcción de un nuevo pabellón para escuela y dormitorio de niños y mantuvo largas negociaciones con el Ayuntamiento para conseguir los terrenos para su construcción en la zona lindante con el Paseo de las Moreras, lo que logró, finalmente, tras enfrentar al Ayuntamiento a una situación de hechos consumados. El 24 de mayo de 1909 se dirigió al Alcalde para solicitar el señalamiento de los límites y de paso conseguir una ampliación de terreno para el nuevo pabellón ${ }^{249}$ :

"La que suscribe, Superiora de la comunidad que regenta el Hospicio Provincial, á V.S. atentamente expone: Que entrando en su pensamiento hacer algunas obras de ampliación en los Pabellones de dicho Establecimiento con objeto de dar mayor capacidad á ciertas dependencias y desahogo a servicios de importancia que han de cooperar al mejor funcionamiento de edificio de tanta trascendencia, y como antes de hacer nada en concreto, desea la sean señalados las líneas á que por el paseo alto de las Moreras, haya de sujetarse la edificación,

A V.S. suplica que sea practicado el señalamiento de la línea debido, rogando á la vez que éstas guarden relación con las tapias del cuartel de Artillería por el mencionado paseo de las Moreras, en cuyo caso tendrá este Establecimiento más amplitud para desarrollar sús planes que no duda habrán de ser del agrado de V.S." [sic]

El Ayuntamiento aceptó la solicitud pero no fijó los límites que solicitaba la Superiora, quien, el 10 de abril de 1910, solicitó la licencia de obras declarando la urgencia de realizarlas y apelando al sentimiento de caridad:

"... que por acuerdo del Excmo Ayuntamiento se la concedieron el pasado mes de junio unos terrenos para edificar situados en el paseo de las Moreras ... y como quiera que está ya preparada la piedra y demás materiales para su edificación ... se sirva ordenar se me provea de la correspondiente licencia para edificar, pues tratándose de la construcción de un dormitorio para los niños de este hospicio y siendo de urgente precisión en bien de estos desgraciados pobres asilados, toda caridad es poca a remediar sus condiciones...." [sic]

\footnotetext{
${ }^{248}$ Se conservan tres planos en el ADPVA: "Tapia de cerramiento para agregar al Establecimiento el terreno que falta ocupar del que cedió el Excmo Ayuntamiento por la parte de las Moreras" (Signatura: caja 245, expediente 2766), Fachadas de los edificios y parte de la tapia que dan a las Moreras y laterales. ADPVA: caja 245, expedientes 2739 y "Croquis de la tapia y del edificio proyectado en el terreno cedido por el Excmo Ayuntamiento en las Moreras" de 1910 (caja 245, expediente 2767). Una copia de éste croquis se conserva también en el Archivo Municipal formando parte de un amplio expediente sobre ampliación y permiso de obras en el Hospicio.

${ }^{249}$ Expediente sobre ampliación y permiso de obras en el Hospicio. AMVA. Signatura: 598 -23
} 
Las obras se iniciaron y se tuvieron que paralizar por rebasar la línea fijada por el Ayuntamiento; con el edificio terminado el desacuerdo por los límites continuó. El expediente se cerró el 30 de septiembre de 1912 con un informe del Arquitecto municipal confirmando la alineación improcedente que se había hecho y los terrenos que añadía al Hospicio. La historia se repetía, no era la primera vez que se producían enfrentamientos entre el Ayuntamiento y el Hospicio por una cuestión territorial. En 1900 se solicitó la construcción de un pabellón de dos plantas hacia las Moreras y el Ayuntamiento lo autorizó con la condición de que debía

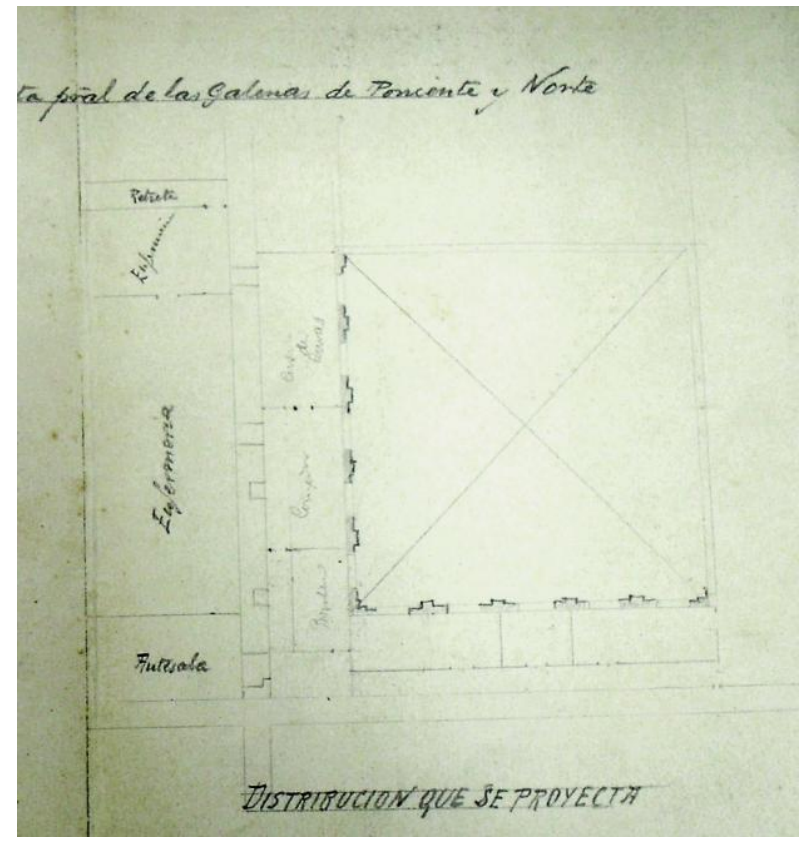

Imagen 2-5 Plano de la Distribución en planta principal de las Galerías de Poniente y Norte Reformas en las salas anejas a la Enfermería. ADPVA "construirse en el interior del edifico...

[sin] rebasar la línea legalmente

aprobada para el paseo de las

Moreras $^{\prime 250}$. El litigio de la tapia de

las Moreras venía de lejos ${ }^{251}$.

En 1911 se construyó un edificio con fachadas al patio y a las Moreras con aulas para la escuela en la planta baja y dormitorios en la superior" La "Escuela Modelo, capaz para 200 niños" se inauguró el 30 de abril La Superiora también participó en su financiación con una aportación de 16.344 pts, junto con otras donaciones como la ya

\footnotetext{
250 AMVA. Signatura:278-30

${ }^{251}$ AMVA. Signatura: CH C. 414- 61.: En 1887 el Ayuntamiento marcó unos límites "en beneficio de la vía pública" que suponían la expropiación al Hospicio de una superficie de $132,60 \mathrm{~m}^{2}$, a razón de 16 pesetas el $\mathrm{m}^{2,}$ en el ángulo de San Quirce y las Moreras. El Arquitecto Provincial Teodosio Torres y la Superiora reclamaron alegando que el nuevo lineamiento ensanchaba innecesariamente la vía pública y que el Hospicio perdía unos terrenos que entonces se dedicaban a corrales, lo que reduciría el espacio "redundando en perjuicio del necesario desahogo para el recreo de los niños asilados y de los intereses del Municipio que había de satisfacer por la superficie cedida desde luego la cantidad de 2000 pesetas". Se solicitó además que, siguiendo la línea recta, se cediera al Hospicio un triangulo de 30 metros en la esquina con la calle Emperador. La solicitud se desestimó y durante años se estuvieron cruzando reclamaciones y recusaciones; el argumento para el rechazo era estético: "bajo el punto de vista de la viabilidad no habría inconveniente en acceder a lo solicitado, pero no así bajo el punto de vista del ornato" "es mucho mayor la belleza de las vías cuando las fachadas que las delimitan se hallan paralelas a sus ejes, que en el caso contrario" (16 oct 1891). El Arquitecto insiste, solicita en abril de 1892 la construcción de un dormitorio de niños y la Comisión de Obras acuerda aprobarla "en cuanto que la obra que se solicita ejecutar tiene por objeto un servicio benéfico de gran importancia para el establecimiento de que se trata y que ha de contribuir poderosamente a la higiene y salubridad de los asilados"; siguiendo la línea que ya tenía marcada el hospicio. El 18 de mayo se expidió la licencia.

252 Hospicio Provincial. Proyecto de edificio para Escuela y Ampliación de dormitorios, Santiago Guadilla, Arquitecto Provincial 12 de febrero de 1911. Signatura: caja 245, expediente 2747. ADPVA
} 
mencionada de 25.000 pts, poniendo el resto la Diputación ${ }^{253}$.

Entre las muchas obras que se hicieron tenemos constancia, por los planos conservados en el A.D.P, de una reforma en la enfermería de los niños. Ocupaba el brazo Norte de la planta principal del segundo patio ${ }^{254}$. En el proyecto se ve que la enfermería constaba de una antesala, una sala grande, otra más pequeña y al fondo el "Retrete". En la reforma, en la galería que daba al patio se hicieron tres estancias, un "Cuarto de Curas", un "Comedor" y una sala en la que parece escrito "Ropero". Aunque está sin fechar, el plano debe ser de 1911 ya que en la parte inferior de la hoja está dibujado el proyecto de la tapia de las Moreras con la panadería, que se construyó en ese año (IMAGEN 2-5).

Este no era el emplazamiento original de la Enfermería, que debía encontrarse anteriormente en la planta alta del primer patio. En correspondencia del 7 y el 10 de febrero de 1902 el Director comunicaba al Vicepresidente de la Comisión Provincial el desplome del techo en la zona de la enfermería y avisaba del peligro de hundimiento del tejado

\begin{abstract}
"Tengo el honor de poner en conocimiento de V.S. que al caerse el cielo raso del cuarto destinado para los utensilios de los enfermos y donde el Profesor Médico hace las recetas se ha puesto de manifiesto la eminente ruina que amenaza toda la galería que da paso a la enfermería de los niños según ha resultado del reconocimiento hecho por el maestro albañil puesto que los pases que estan al descubierto están en tan malas condiciones que puede ocurrir de un momento a otro el desplome de todo el tejado y pueden ocurrir desgracias inevitables. [sic]
\end{abstract}

El mismo día 10 el Vicepresidente ordenaba al Ayudante de Obras Provinciales que se personara en el Hospicio y "tome las precauciones debidas á evitar desgracias presentando en la $1^{a}$ comisión que se celebre el dictamen proponiendo las obras necesarias". El Ayudante de Obras Provinciales escribió un informe al día siguiente, 11 de febrero, en el que exponía el "deplorable estado" de toda la cubierta de la galería incapaz de "sostener ni aun la pequeña carga del guarnecido y caña que componen el mencionado techo raso. En su consecuencia procede el desmonte y reconstrucción total de la espoleada galería y llevarse á cabo en idéntica forma que lo fueron las otras dos alas del patio" [sic]. Como se puede ver por la carta no es la primera vez que ocurría algo así, y, además, su autor era buen conocedor de las limitaciones

\footnotetext{
${ }^{253}$ El Financiero Hispano-Americano. Extraordinario Valladolid julio de 1911, p 68. Según cuenta El Norte de Castilla, que también recogió ampliamente la noticia, "el ilustre filántropo...don Juanito, como familiarmente le llamaban sus allegados" donó en su testamento 25.000 pesetas que se invirtieron "en construir un edificio de dos pisos, cuya planta baja se destinará a escuela de niños y á dormitorio de éstos la planta alta, se encargó el ilustre arquitecto provincial don Santiago Guadilla de la formación de los oportunos planos y presupuesto... hecha la subasta y adjudicada al importante industrial de esta plaza don Manuel Pradera, comenzaron las obras a fines de Febrero pasado para terminarse a 21 del corriente". N.C. 29-04-1911, p 2

${ }^{254}$ Plano sobre la "Distribución en planta principal de las Galerías de Poniente y Norte". Signatura: caja 245, expediente 2766 ADPVA.Esta obra se realizó junto con la tapia de cerramiento que lindaba con las Moreras y se encuentran los dos proyectos juntos aprovechando una misma hoja. No aparece autor ni fecha, es de suponer que se trate del mismo arquitecto provincial autor de los demás planos de la época
} 
presupuestarias de la Diputación y de las dificultades para costear este tipo de gastos extraordinarios porque, junto al presupuesto que asciende a "seis mil pesetas", él mismo propone que las obras "pueden ejecutarse por adición en presupuestos parciales de mil nuevecientas pesetas como se procedió en las dos citadas ultimamente" [sic]. La enfermería de niños se trasladó al "local de la Escuela antigua de las niñas", y en septiembre de 1904 se solicitaba la construcción en ella de un retrete.

Problemas cómo este no eran algo extraordinario en el Hospicio, las obras de reparación, acondicionamiento y ampliación fueron una constante. Además de los pocos planos conservados, hay algunos informes y $\operatorname{cartas}^{255}$ que demuestran la necesidad continua de dichas obras y ponen de manifiesto el mal estado del edificio, sus carencias y sus limitaciones de espacio. Los presupuestos para obras en el edificio se quedaban cortos y se hacía necesario ampliarlos, encontramos años en los que debe aprobarse un Presupuesto adicional $^{256}$, con la Dictadura de Primo de Rivera se alivió un poco la situación al aumentar los ingresos de la Diputación, los presupuestos para obras también lo hicieron de forma importante; aún así, las deficiencias eran muchas y muy graves.

Los presupuestos "Para toda clase de obras, previo acuerdo de la Diputación o Comisión provincial, para las de cristalería, hojalatería, carpintería y herrería, reparación y conservación del edificio y objetos de ferretería" fueron muy dispares a lo largo del período de estudio, oscilando en la primera década entre 4.350 pts en 1904 y 10.750 pts en 1908, aumentó en 1910-13 a 12.740 pts coincidiendo con obras como "las tapias y cerramiento hasta la entrada accesoria de la Fundición de la Trinidad" y a 15.000 pts los tres siguientes para incluir los plazos por la compra de la Fundición. En los presupuestos de 1924-25 se asignaron por este concepto 20.000 pts, pero luego encontramos a mayores como conceptos separados, 10.000 pts "Para obras de reforma en la Maternidad", 1.000 pts "Para obras en la Escuela" y 6.000 pts "Para construcción de una galería cubierta". En 1929 vuelve a aparecer consignada en el Presupuesto General una partida para obras en "la Maternidad y Expósitos del Hospicio" por un total de 28.000 pts. 1927 es un año también significativo en este sentido, a las 15.000 pts asignadas en el presupuesto ordinario "Para reparación y varias obras del edificio del Hospicio", se añaden otras cantidades importantes para distintas obras y se da explicación de la necesidad de llevarlas a cabo en el "Dictamen que la Comisión de Presupuestos presenta a la

\footnotetext{
${ }^{255}$ En la serie Correspondencia de acogida de menores hay una carpeta con cartas de febrero de 1902 a junio de 1905 sobre arreglos y obras en el Hospicio. Signatura: caja 2449, expediente 30481. ADPVA

${ }^{256}$ En el Libro de cuentas de 1902 -1903 (Signatura: caja 667, expediente 6717. ADPVA) vemos registrado un "Presupuesto para obras de reparación y conservación del edificio... 3.000 pts." y un "Presupuesto adicional... 5.000"; en 1904 fue de 7.000 pts ampliado con 1.000 pts más, cantidades que no coinciden con las que aparecen en los Presupuestos generales de la Diputación que asignaron para esta partida 4.350 pts en 1903 y 8.350 pts en 1904.
} 
Diputación con el proyecto de presupuesto extraordinario para el año 1927". Entre otros conceptos, se asignan 17.545 '20 pts "Para la habilitación de los locales donde estuvo instalada la antigua vaquería, destinándolos a escuela, comedor y planchador...", 4.794’98 pts "Para arreglo de un patio e instalación de retretes en la vaquería recién construida...", ya que, se explica en el Dictamen, "el patio donde estuvo instalado el lavadero viejo, que será en breve demolido, es necesario arreglarle porque a él confluyen las galerías de la Inclusa, y es de necesidad dotar de ventilación, luz y alegría a los que allí acoge la beneficencia provincial" [sic], 1978 pts por "la instalación de la calefacción en las dependencias de las Hermanas de la Caridad" y 33.695 '49 pts "Para habilitar los despachos de los señores Diputado Visitador y Director del Hospicio, la habitación de éste último y el capellán, además de la oficina de dicho establecimiento...". Como podemos ver, ni siquiera las dependencias de las Hermanas y de la dirección se libraban del mal estado del establecimiento. Dice el Dictamen que

\begin{abstract}
"Ni el Diputado-Visitador, ni el Director del Hospicio tienen despacho. Los asuntos que surgen en un establecimiento de la índole de éste, son resueltos en la oficina o en una habitación aislada sin decoro ni seguridad alguna. En el Hospicio, donde existe una Maternidad secreta, donde la lactancia de los depositados lleva muchos cuidados en los que la prudencia y la reserva son valiosos elementos... han hecho que la Diputación se decida a habilitar locales adecuados a los señores Diputado-Visitador y Director del Hospicio, por ser una necesidad imperiosa,; arreglar la oficina, y dotar de condiciones higiénicas las viviendas del Capellán y Director, hoy en vergonzoso estado". ${ }^{257}$ [sic]
\end{abstract}

Además, ese año se añaden 10.000 pts "Para reforzar el presupuesto ordinario ya que es insuficiente para las necesidades del año actual"

Entre los graves problemas que el edificio heredó del siglo anterior estaba la falta de servicios higiénicos y de acristalamiento de las ventanas. En el artículo de El Norte de Castilla (N.C.) de 1899 dice que "la nota dominante en el edificio es la falta de cristales ino en balde está ocupada por chicos! Pero eso sí, la diligente mano de las hermanas suple el vidrio roto con papeles cuidadosamente pegados que blanquean aquí y allám ${ }^{\prime 258}$. Seguramente más de un cristal se perdería por los juegos de los niños, pero no serían responsables de todos los que faltaban, en el libro de cuentas de 1901 hay anotados pagos por 244 cristales. Parece que la instalación de ventanas y cristales en el edificio se la tomaron con calma, en los libros de contabilidad ya se anotaron en 1864 gastos por "cinco ventanas nuevas con herraje para la enfermería, salas de destete y dormitorios de niñas" y "cristales nuevos para las ventanas nuevas" $^{\prime 259}$. En 1913, en el libro de cuentas del Hospicio se anotan en enero 108 cristales por un

\footnotetext{
${ }^{257}$ Presupuesto ordinario de Ingresos y Gastos de la Diputación Provincial de Valladolid para el Año Natural de 1927. pp 20-21. Signatura: caja 1242, expediente 7826. ADPVA

${ }^{258}$ N.C.13 de febrero de 1899 , pp 1

${ }^{259}$ Signatura: caja 962, expediente 7200. ADPVA
} 
valor de $156^{\prime} 10$ pts, en este caso, probablemente, una buena parte de éstos corresponderían a las obras en el "patio y escusados" que también se encuentra registradas en ese año ${ }^{260}$.

Es de suponer que un caserón vetusto y mal acristalado como éste, tenía que ser muy frío. Es éste un tema muy criticado, el frío de sus dependencias; la calefacción, o mejor dicho, la falta de ella pues la que había resultaba absolutamente insuficiente. En una nota al pie el artículo de El Norte de Castilla mencionado dice al respecto que "La calefacción se hace, en determinados sitios, con braseros, y en las salas de maternidad con estufas", podemos imaginarnos el resultado.

Se utilizaba preferentemente carbón y leña, con un gasto total de 5.362 pts en 1906 que aumentó a 12.000 pts en 1924 , y, poco a poco, se fueron introduciendo otros sistemas, parece que a cuentagotas; algo se aliviaría, aunque no llegaría nunca a ser suficiente. En 1903 se compró una estufa de petróleo por 31 pts, aunque este combustible no lo hemos encontrado en los presupuestos. En los libros aparecen compras aisladas de estufas, caloríferos y braseros, que no eran habituales. En el Presupuesto General... de 1910 se adjudican 2.500 pts para "calefacción por vapor de agua preferentemente para la Inclusa, Maternidad y dormitorios, mas en aquellos otros locales en que se considerara necesaria su instalación" y en febrero de 1911 la Comisión Provincial sacó a concurso la instalación de la calefacción en el Hospicio ${ }^{261}$, sin embargo no se refleja el gasto en los presupuestos ni de ese año ni de los sucesivos, únicamente se consignan anualmente 500 pts para gastos de "Mobiliario en las distintas dependencias del Establecimiento y objetos de calefacción" y en algunos presupuestos se rebaja esta asignación a 300 pts. En 1921 se realizaron obras para la "Colocación de estufas en distintos departamentos...", entre ellos la dirección y el aseo de niñas y en enero de 1925 se hizo la "Ampliación y reforma en la instalación de la calefacción de la Inclusa", que en 1926 necesitó "reparación". En el Presupuesto Ordinario ...para el Año económico de 1925-26 encontramos, solamente en la sección dedicada a Maternidad y Expósitos, un asiento de 3.000 pts para "instalación de gas y pago de consumo del mismo" y en los presupuestos luego consta ese consumo; mientras que en la sección dedicada Hospicio, lo que era el departamento de mayores, se mantiene la partida de 500 pts "para adquisición de

\footnotetext{
${ }^{260}$ Signatura: caja 1260, expediente 7864. ADPVA

${ }^{261}$ N.C. 2-02-1911 p1
} 
mobiliario y enseres de calefacción", que en el 2o semestre de 2006 se aumentó a 3.500 pts ${ }^{262}$. Ya vimos que en las dependencias de las Hermanas la calefacción se instaló en 1927.

El Hospicio ya contaba con agua corriente a principios de siglo, pero carecía de instalaciones higiénicas suficientes y adecuadas, las pocas que había eran penosas; contaban con dos lavatorios separados para niños y niñas en los que "los lavabos son de piedra, largos y estrechos...y pueden lavarse a un tiempo hasta sesenta niños", pero, "se nota la falta de una piscina donde se bañen a diario los infelices muchachos"263. En 1909 sorprende leer en la

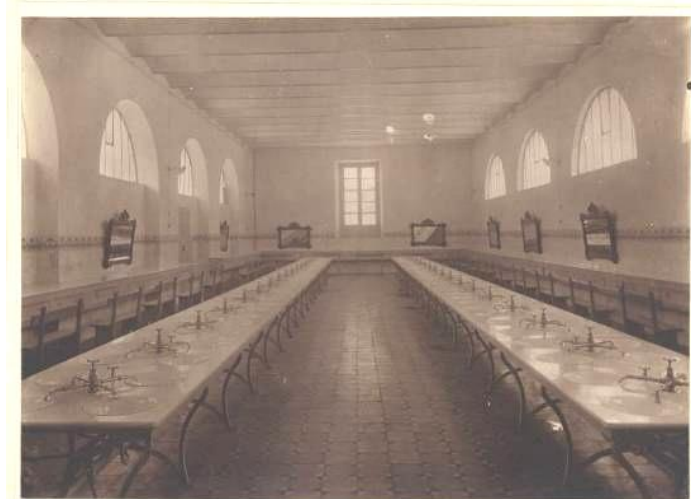

Imagen 2-6: Lavatorios del Hospicio. Son nuevos y han aumentado su capacidad, hay 120 lavabos. ADPVA, fecha probable 1911. prensa local que en la sesión provincial "al tratar de una cuenta por baños del Hospicio se lamenta muy oportunamente el señor Gavilán de tan excesivo e inútil gasto, siendo así que en el establecimiento existe un cuarto de baño", lo que muestra la sensibilidad que había respecto al tema; aunque también es cierto que finalmente con la intervención del "señor Bachiller, como visitador del Hospicio, [que] se lamenta de las deficiencias que se notan en dicho establecimiento" se aprobó la cuenta en cuestión ${ }^{264}$

La falta de higiene es otra de las cuestiones que se le reprocharían continuamente. Según El Norte de Castilla "todo lo que depende de la inmediata vigilancia de las Hermanas de la Caridad está aseado, limpio y curioso. No así los demás departamentos", tal parece que es el caso de "los patios de recreo [que] son sucios e impropios... En el segundo de dichos patios hállanse unos retretes que están pidiendo a gritos una inspección higiénica, con ellos basta y sobra para producir miasmas. No se conocen los inodoros ni el agua en esos sitios donde toda pulcritud es poca". Otro problema añadido, pero normal en las condiciones del Hospicio, eran "los ratones...terribles partícipes de la provisión de la despensa y... no hay medio de evitar las

\footnotetext{
262 Presupuesto ordinario de Ingresos y Gastos de la Diputación Provincial de Valladolid para el Año Natural de 1927. pp 84 y 100. Presupuesto general de Ingresos y Gastos de la Diputación Provincial de Valladolid para el ejercicio semestral de 1926; pp 19 y 30. Signatura: caja 1331, expediente 10645. ADPVA

${ }^{263}$ N.C. 5-8-1901, p 2

${ }^{264}$ N.C. 5-10- 1909, p 2
} 
consiguientes mordeduras"265. El Gobernador Civil tras una visita al establecimiento en 1901 denunció que en él "la higiene deja mucho que desear"266.

En 1877 se inició en la ciudad el suministro de agua, que avanzaba según se iban colocando las tuberías, y el Hospicio solicitó y consiguió del Ayuntamiento la concesión de un real fontanero "con el fin de llenar los múltiples servicios que de dicho líquido necesitan en el Hospicio". "El real fontanero... representa un suministro de 3.245 litros al día, equivalentes a poco más de 202 cántaros de á 32 cuartillos uno". El Ayuntamiento no tuvo inconveniente en concederlo, no obstante, su puesta en práctica planteó el problema técnico sobre la forma de controlar la cantidad de agua para no sobrepasar lo cedido. Para resolverlo se propuso al Hospicio la construcción de un depósito de la misma capacidad con un grifo en el exterior del edificio que sería "manejado por un dependiente del Excmo Ayuntamiento, el cual todos los días y a la misma hora abre la comunicación, llena el depósito y vuelve a cerrarla hasta el día siguiente". Es una cantidad de agua claramente insuficiente para todo el personal del Hospicio, incluso para aquella época" ${ }^{267}$. No sabemos durante cuánto tiempo recibió este "real fontanero", en los libros de cuentas desde 1900 aparecen pagos de 1.200 pts anuales por la "Dotación de Agua" más 100 pts por la "Reparación y conservación del filtro", parece una cuota fija y no consta el consumo. El "Suministro de agua, reparación y conservación de filtros" se presupuestó a partir de 1921 con 3.000 pts.

"El alumbrado se hace por medio de luz eléctrica"268. En estos años la instalación eléctrica, iniciada en $1898^{269}$, se fue ampliando; en los libros de control de gastos el apartado para "Alumbrado de todas clases, aparatos e instalaciones que fuesen necesarios", tenía un presupuesto de 3.390 pts en 1903 y de 2.526 pts en 1906; aquí se incluían en los primeros años tanto el alumbrado eléctrico (el gasto del mes de febrero de 1903 fue de 268,62 pts), como la compra de "bugías"270" [sic]. En 1913 este apartado registra la compra de "50

\footnotetext{
${ }^{265}$ Ibídem.

${ }^{266}$ N.C. publica una reseña de las visitas que realizó los días 5 de agosto de 1901, p 2, y 6 de agosto, p3.

${ }^{267}$ AMVA. Expediente de obras de elevación de aguas del rio Pisuerga. Signatura: C 313-29 CH

La OMS estima actualmente que el consumo de agua necesario para cubrir las necesidades de hidratación, higiene, limpieza y preparación de alimentos es de 100 litros por persona y día. Téngase además en cuenta que en la época estudiada el Hospicio contaba con animales y talleres que tenían un consumo adicional de agua.

${ }^{268}$ N.C. 13-2-1899, pp 1

${ }^{269}$ Libro de Actas de la Comisión Provincial, sesión del 30 de marzo de 1898. ADPVA

270 BUJíA: según el diccionario de la RAE de 1899, p 159- 2, es una "Vela de cera blanca, de esperma o esteárica". Escrito como "bugía" aparece en los diccionarios de la R.A.E. hasta la edición de 1832, en 1837 cambia la $G$ por $J$.

Todavía en la contabilidad de 1908 aparecen anotaciones por la compra de bujías: "25 Kg bujías esperma á 2"40 Kg" (Signatura: caja 928, expediente 7140). En 1901 se compraron 30 paquetes, a 1,10 pts cada uno. (Signatura: caja 476, expediente 4196. Libro de Recibos1901. ADPVA)
} 
lámparas", "400 Kilogramos de hilo de plomo", y "100m [de cable?] flexible", probablemente para alguno de los nuevos pabellones, puede ser el de maternidad recientemente renovado y que se estaba acondicionando por entonces, en ese año se presupuestaron "dos baños para el departamento de Maternidad en el nuevo local", sin embargo sólo se compró uno ${ }^{271}$. A partir de 1920, en los presupuestos la partida de alumbrado sólo aumentó a 5.000 pts, a pesar de las nuevas instalaciones, y desde 1924-25 entre los gastos de sirvientes se incluyeron 365 pts como "Retribución al asilado electricista".

El Hospicio también contaba desde principios de siglo con "Servicio Telefónico", desde 1901 aparecen pagos de una cuota anual de 145 pts, que se redujo a 85 pts en la última década para "satisfacer el abono del teléfono".

En el año 1904 se realizaron algunas obras para mejorar las escasas y deplorables instalaciones higiénicas, en 1901 se había denunciado la falta de baños. En marzo de 1904 "carecen de retrete las niñas" y el de los niños, construido en 1902, estaba todavía a falta de inodoros, puertas y ventanas y "precisa una gran reparación". La Comisión Provincial vista la "necesidad de recomponer la cocina de los asilados y colocar unas legiadoras ${ }^{272}$ y al mismo tiempo construir retretes para las niñas y recomponer el de los niños así como unas ventanas y puertas en el mismo edificio acordó previa declaración de urgencia del asunto" realizar las obras propuestas. En la sesión del 10 de junio la Comisión "a propuesta de los tres visitadores... aprobó hacer las siguientes reformas. 1ㅇa Arreglo de los retretes de los niños con instalación de inodoros; 2 Destinar para sala de aseo de aquellos el local que existe en el $2 \circ$ patio y que antes se destinaba á Carpinteria" [sic] y el día 21 se aprobó el presupuesto "para llevar a cabo las obras e instalar los aparatos para sala de aseo o lavatorios de niños"

\footnotetext{
${ }^{271}$ Mensual de cuentas. Año de 1913 Oficina. Signatura: caja 1260, expediente 7864. ADPVA

272 La legiadora era una especie de caldera de grandes dimensiones usada para hervir y desinfectar la ropa de la colada. No se encuentra este término en ninguno de los diccionarios históricos, a pesar ser de uso habitual en la época, que encontramos también en publicaciones científicas y periodísticas. En la revista médica de Teruel $L a$ Asociación, en el número 77 del 15 de junio de 1886 escribe el licenciado Miguel Franco Magallón a propósito de la última epidemia de cólera: "...referente á la higiene durante la epidemia ... una mujer destinada al efecto recogía las ropas de la cama y las ponía en ebullición por algunas horas en una legiadora Fenis..." y en La Farmacia Moderna, pag 234, a propósito de las desinfecciones que realizan los Laboratorios de Higiene en enfermedades contagiosas se incluye la "Ebullición en la legiadora de las ropas usadas por el enfermo". En La Vanguardia el 5 de septiembre de 1968 se anuncia una "LEGIADORA» completa, $3.500 \mathrm{~m} / \mathrm{m}$. diámetro cabida 22.500 litro". La palabra "legía", así escrita, sólo aparece en el Diccionario de Núñez de Taboada de 1825 que la define como "Agua en que ha hervido ceniza". La encontramos también así en diarios de principio de siglo XX como en un anuncio publicado en el diario El Autonomista (Figueras, 3-12-1905): "La Legía Progreso es higiénica y desinfectante. Destruye los gérmenes infecciosos, y para su uso no es necesario ni fuego, ni legiadora ni trabajo". Los diccionarios de Zerolo de 1895, p 1855, y de Toro y Gómez de 1901 definen la lejía como "Cocimiento de ceniza vegetal en agua que usan las lavanderas para la colada y sirve para blanquear y limpiar la ropa" y los diccionarios de la RAE dan definiciones similares, el de 1899 ( p 594, 3) dice: "Agua en la que se han disuelto una o varias sales alcalinas. La que se obtiene cociendo ceniza se utiliza para la colada". Se pueden consultar en la página web de la R.A.E. http://www.rae.es/.
} 
Todas estas obras tenían que ejecutarse "por adición", con presupuestos fraccionados, eso explica que el 10 de octubre de 1904 el Ayudante del Arquitecto Provincial todavía tenga que solicitar aprobación del presupuesto para colocar las cañerías de estas instalaciones

"Próximas á terminarse las obras que se ejecutan en el Hospicio provincial con destino a lavatorios, cuartos de baño y otras dependencias, tengo el honor de exponer a V.E. la aprobación de un presupuesto por cantidad de 1750 pesetas para colocación de cañerías de conducción de aguas como complemento de dichas obras" [sic]

La comisión aprobó el día 24 de octubre el presupuesto de obra tras un informe de los Diputados visitadores en el que manifiestan su necesidad:

\begin{abstract}
"Los visitadores en la propuesta que hace el Arquitecto para las obras necesarias de colocación de cañerías de conduccion de aguas tienen el honor de informar que las obras que se indican son de absoluta necesidad no solo por la debida conducción de las aguas procedentes del lavatorio de niños sino también las de la piscina, cuarto de baños especiales y retrete de la enfermería de niños, siendo de urgencia la ejecucion de las mismas por razon de higiene" [sic]
\end{abstract}

Todavía en mayo de 1905 quedaban cuestiones pendientes, "próximas a terminar las obras de la enfermería de los niños y sus retretes es de urgencia subir las aguas para el mismo" y se aprobó su presupuesto en la sesión de la Comisión del 15 de junio. En el plano de la enfermería de 1911 vemos que efectivamente el retrete se encuentra al fondo de la galería.

A pesar de estas obras, el escaso caudal de agua que llegaba al Hospicio no favorecía la adecuada higiene de los asilados. Dice Pastrana que "el poco caudal facilitado por la Compañía del Duero exige 24 horas para llenar las bañeras". Puede que esto tenga relación con la contratación de baños en el Pisuerga por indicación médica en verano, tanto para los asilados como para las hermanas, podemos ver los pagos por este concepto en los libros de cuentas del Hospicio y en los presupuestos generales de la Diputación, "Para baños en el río Pisuerga que prescriban para los asilados los señores Médicos". Ya figuran en el libro de gastos de 1863-64, incluso en este libro hay un asiento "por los gastos causados en los baños de Mar y minerales de las Hermanas y 14 acogidos en la temporada de verano" [sic]. A partir de 1909 aparece este concepto todos los años en los presupuestos generales y en 1912 se empezaron a mandar también niños al Balneario de las Salinas de Medina del Campo ${ }^{273}$, con una asignación para las dos actividades de 1.500-2.000 pts, excepto en el período 1916-20 en el que sólo se contemplan 500 pts para los baños del Pisuerga. En los presupuestos generales a partir de 1927 se incrementó notablemente esta partida con cantidades asignadas de hasta 16.000 pts

\footnotetext{
${ }^{273}$ N.C. 1-8-1915, p 5: en la sección dedicada a Medina del Campo hay una breve reseña: "Hoy ha llegado una colonia de niños del Hospicio, acompañados de dos hermanas de la Caridad, con objeto de tomar las aguas del balneario de las Salinas". El 18-8-1915, p 3 anuncian su regreso al Hospicio.
} 
"para los gastos que ocasionen las colonias de niños de este Establecimiento enviados para su salud a distintos puntos, baños en el río Pisuerga y Balneario de Medina del Campo". Es probable, como ocurre con otras partidas, que no siempre se gastara todo lo presupuestado; en el libro de "Registro de Certificaciones Año económico de 1919- 20"274 encontramos anotado un pago el día 31 de Agosto de 1919 de 253,26 pts a "Carlota Montes [por] 3.166 Baños en el río Pisuerga á 0,80 cents [céntimos], (2.052 niños y 1.114 niñas)", la partida contaba con 500 pts de presupuesto; ese verano los niños disfrutarían de 5 o 6 baños.

Siguiendo con cuestiones sanitarias de otro tipo, en 1911 para construir la panadería derribaron el local que se utilizaba para depósito de cadáveres, que vista la elevada mortalidad del asilo debía tener mucho uso, y el Director del Hospicio, Florentino Díez, lo tuvo que solicitar con urgencia el 5 de mayo de 1911 y de paso aprovechó para solicitar también un "Pabellón para instalar [una] estufa de desinfección" ${ }^{275}$ :

"Habiéndose tenido que hacer desaparecer el depósito de cadáveres de este establecimiento, no solo por encontrarse en muy mal estado, sino por ser preciso el terreno $p$ a la ampliacion de la Panadería que se está construyendo; $y$ siendo de imprescindible urgencia habilitar o edificar otro en sitio y forma conveniente; esta Dirección se cree obligada a solicitar de esa Corporación el correspondiente acuerdo y que por el Sr Arquitecto se proceda con toda urgencia a la formación de plano y presupuesto, habiendo cantidad bastante en la partida que para obras tiene esta casa; pudiendo ser el sitio mas a propósito la parte accesoria que linda con la carretera de la Moreras y con la puerta de entrada al corral de la fundición de la Trinidad". [sic].

La Comisión dio orden de elaborar los proyectos correspondientes y el arquitecto firmó el "Presupuesto para hacer en el que fue jardín, un cuartito para depósito de cadáveres de tres metros de anchura por cuatro metros de longitud" y el "Presupuesto de [un] pequeño pabellón para instalar [una] estufa de desinfección- junto al lavatorio de niñas- en el Patio de niñas". El 8 de junio se aprobaron los presupuestos. No sabemos si es que no se previó la necesidad de sustituirlo al tirarlo, o simplemente se siguió el procedimiento habitual para realizar obras en el Hospicio.

Añadido a los problemas presupuestarios, vemos que había un procedimiento burocrático que podía alargar las obras todo lo necesario, hasta que la Diputación tuviera

\footnotetext{
${ }^{274}$ Signatura: caja 1226, expediente 7763. ADPVA

275 Pabellón para instalar estufa de desinfección y depósito de cadáveres en el Hospicio Provincial proyecto del arquitecto provincial, Santiago Guadilla. Signatura: caja 245, expediente 2769. ADPVA
} 
presupuesto o interés en realizarlas ${ }^{276}$. También es cierto que procedían con más rapidez en situaciones que no permitían demora, si no eran muy costosas; en agosto de 1903 era necesario "asegurar" con urgencia una columna del patio, el Director lo solicitó el día 3, el 4 se aprobó el presupuesto y el 6 se comunicó al Gobernador. En el libro de cuentas del Hospicio está registrado el pago de 40 pts el 5 de agosto por el “arreglo de una columna del 1o patio"277.

No terminaban aquí los problemas del edificio, esto no es más que una muestra; todas sus dependencias van a exigir obras antes o después, incluso las del capellán y del director, que ya comentamos que en 1927 se encontraban "en vergonzoso estado" según dictaminó la Comisión de Presupuestos de la Diputación. Una carta de febrero de 1902, refiriéndose a dichas dependencias ya anunciaba que "...se hace necesario para que pueda habitarse algunas reparaciones como blanquear las alcobas, empapelar el comedor, pasillos... y para dar mas claridad y salubridad... abrir un hueco para ventana que de al patio" [sic]. El mismo director que firma esta carta, Justo Esteban, en enero de 1906 escribió un Informe sobre necesidades y mejoras del hospicio ${ }^{278}$ que es muy ilustrativo acerca de las muchas deficiencias del edificio y sus instalaciones. Resulta impactante en este informe que empiece mencionando en primer lugar la decoración de la dirección, que no dudamos que fuera necesaria, cuando a continuación presenta una larga relación de necesidades perentorias, que seguramente no incluía todas las que existían, y sabiendo lo limitado de los presupuestos:

\begin{abstract}
"Respecto a las obras y mejoras en el edificio, muchas son las necesarias, permitiéndome indicar a la Comisión que V.S. preside la decoración y renovación del mobiliario de esta oficina.

Otra mejora es hacer un local para lavatorio de las niñas, pues el que hoy tienen, aparte de estar ruinoso es oscuro, húmedo, frio e imposible que en dicho local puedan asearse, teniendo que hacerlo en un pasillo que da á la cocina y con facilidad el viento lleva a dicha dependencia, lo que todos repugnan... asi como teniendo en cuenta la ayuda que la Sra Superiora está dispuesta a hacer, terminar el pabellón para dormitorio de las niñas que lo tiene en la buhardilla, sin olvidar que urge un retejo general á todo el edificio puesto que hace veinte años que no se hace" [sic]
\end{abstract}

Las obras en el edificio continuaron, ninguna de ellas hizo una reforma total que finalmente permitiera acondicionarlo adecuadamente para su uso. En la Memoria estudio del

\footnotetext{
${ }^{276}$ El Director, normalmente, planteaba la necesidad y solicitaba la solución a la Comisión Provincial, que aprobaba las obras después del informe positivo de los Diputados Visitadores sobre la necesidad de realizarlas. Se solicitaba proyecto y presupuesto al Arquitecto Provincial quien elevaba su propuesta para aprobación de la Comisión y una vez aprobado desde la Diputación se comunicaba la resolución al Gobernador Civil.

${ }^{277}$ En la serie Correspondencia de acogida de menores, Signatura: caja 2449, expediente 30481 y Libro 1902-1903. Signatura: caja 667, expediente 6717. ADPVA

${ }^{278}$ Signatura: caja 4872, expediente 43333. ADPVA
} 
orfanato provincial. 1944- $1948^{279}$, aunque fuera de la época de estudio, hay algunos apuntes en el capítulo de obras que traemos aquí por su interés y porque demuestran ese estado permanentemente deficitario de las instalaciones. Empieza hablando de las malas condiciones que tenía el edifico, para luego alabar las mejoras hechas, no deja de ser un informe de carácter sobre todo político: "Cualquiera que vuelva la vista cinco años atrás, recordará los rincones, escaleras empinadas, falta de luz, de aire, dormitorios malolientes, pasillos obscuros, etc, etc, que había por toda la casa...". Nos Ilama la atención lo que se dice a continuación sobre la existencia en el Hospicio de celdas de castigo: "En nuestra labor demoledora... desaparecieron dos celdas de castigo obscuras y cerradas con grandes barrotes ... hicimos desaparecer las que había por toda la Casa, que era en casi todos los huecos de la misma y hasta en el patio principal del edificio hoy convertido en jardín." En la documentación consultada del ADPVA no se ha encontrado mención a estas celdas de castigo, pero se habla de "encierro en los cuartos de corrección" en el Reglamento de 1889, Art. 136, y "Reclusión de uno a quince días en los cuartos de aislamiento", en los Regl de 1910 y 1927, Art. 285, como castigo a los asilados por mala conducta. En la Memoria del director del Hospicio de 1906 podemos leer que "Necesario sería también tener un local destinado exclusivamente a los niños que no pudiéndoles corregir sus padres por sus malas inclinaciones, les recluyen para su corrección..."; lo que nos hace pensar que debía ser normal ingresar muchachos difíciles a solicitud de sus padres, utilizando en este caso el hospicio a modo de correccional. Los reglamentos advierten sobre este punto que el asilo no está para cumplir este tipo de función pero pueden admitir "en concepto de recluidos,... los niños jóvenes a quienes se hubiese impuesto en legal forma la detención autorizada en el artículo 156 del Código civil" y continúan diciendo que "Los así castigados cumplirán el correctivo en celdas o habitaciones destinadas a este objeto y no tendrán comunicación ni trato alguno con los asilados"280.

\subsubsection{PERSONAL Y GOBIERNO DEL HOSPICIO}

Conocemos el personal del establecimiento tanto por los libros propios de contabilidad como por los Presupuestos Generales donde se recogen sus jornales y los Reglamentos que nos ofrecen, además, una relación de las funciones, derechos y obligaciones de todos, incluidas las Hijas de la Caridad y las nodrizas.

\footnotetext{
${ }^{279}$ Signatura: caja 7593, expediente 10. ADPVA

${ }^{280}$ Reglamentos del Hospicio de 1910 y 1927 . Este punto no aparece en el de 1889
} 
El reglamento de 1889 en su Título décimo "De los empleados y dependientes del Establecimiento" en el artículo 173 presenta la relación de personal del Hospicio

"Para el gobierno y régimen interior del Establecimiento, además del número de Hijas de la Caridad necesarias según sea mayor o menor el número de acogidos y de los departamentos que se pongan a su cargo, habrá los empleados y dependientes siguientes: Un Director, un Secretario Contador, un administrador, un auxiliar para la oficina, un Capellán, dos profesores Médicos, un Profesor de Instrucción primaria, un maestro de música, un practicante, dos enfermeros [un enfermero y una enfermera, según el artículo 246], celadores uno por cada cincuenta acogidos, un portero y un aguador, un maestro sastre, un maestro zapatero, un maestro tejedor y un maestro carpintero"

Como puede verse en esta relación no entran las nodrizas pagadas por el Hospicio, aunque se incluyen en el apartado de empleados en los presupuestos. Con el tiempo no se ven mejorías, al menos los reglamentos no contemplan un aumento de personal, de hecho en la relación que aparece en el Regl de 1910 en su Art. 18 se reduce el personal administrativo y se produce la incorporación de una profesora en partos, interesante teniendo en cuenta la sección de Maternidad, pero a cambio de la enfermera.

\footnotetext{
"Los distintos servicios que se llenan en este Establecimiento están encomendados al personal compuesto de un Director, un Auxiliar Escribiente, un Capellán, Hermanas de la caridad, un Maestro de primera enseñanza, un Auxiliar del Maestro, Maestros de talleres, director de Música, un Médico, un Cirujano, un Practicante, una Enfermera comadrona, un Enfermero, cuatro Celadores, un Ordenanza y un Portero"
}

En el Regl. de 1927 (Art. 18 ) parece que ha aumentado ligeramente la sensibilidad respecto al tema de la salud de los acogidos, o mejor dicho, de la falta de ella dada la elevada mortalidad del centro, y aumenta el personal sanitario a "dos Médicos, [cambiando el cirujano por un médico general y] dos Practicantes, una Profesora en Partos, un Enfermero, una Enfermera" y se incorpora "un Profesor de Gimnasia" además de "un Vigilante nocturno y un Vaquero", a cambio se reducen a tres los celadores destinados al cuidado de los muchachos mayores.

Como dato curioso, desaparece la figura del aguador, lógicamente en cuanto llegó el suministro de agua potable al establecimiento, en 1900 que empieza este estudio ya no se precisaba. Más chocante aún para nuestra mentalidad actual es que el reglamento distinga entre los empleados que tienen o no el "beneficio" del agua, se entiende teniendo en cuenta la dificultad y el coste de conseguir cantidad suficiente para tanto personal incluido en el hospicio, podemos suponer los aspectos que tendrían menos prioridad a la hora del consumo:

"Este sirviente necesario hoy al Establecimiento, cuidará que no falte el agua, que tanto para los acogidos como para los empleados que gocen de ese beneficio, se precise.

Para la conducción del agua, habrá un carro con cuba tirado por una caballería mayor, la cual con todos los atalajes estará al cuidado de este sirviente, 
pudiendo ser auxiliado en el servicio de que se trata por un acogido que el director designará"

(Art. 282 y 283 del Regl de 1889)

La dirección del Hospicio cumplía únicamente funciones administrativas, la gestión económica corría a cargo de la Contaduría de la Diputación, que elaboraba los presupuestos y, una vez aprobados, sacaba a subasta los productos y servicios acordados y hacía los pagos, entre ellos los de las amas; el Director únicamente podía hacer por su cuenta compras que "no excedan de 50 pesetas" (Art. no 25 -13, Regl. 1910). La Diputación Provincial nombraba, por períodos de dos años, un "Diputado-Visitador" con labor de supervisión, al que debía rendir cuentas el Director y que en el Reglamento de 1927 se llama "Diputado- Delegado".

El Hospicio contaba con un Director "sin ración [y] con [un] sueldo anual de" 2.000 pts que se mantuvo fijo hasta 1914, aumentó hasta 3.900 pts en 1927 y en 1930 subió a 5.000 pts "con casa y luz"281. Sus funciones se definen en los Reglamentos, los de 1910 y 1927 las perfilan más detalladamente (Título XI- Regl. 1889; Capítulo IV- Regl.1910 y 1927). En ellos se advierte que todo el personal estará supeditado a él como Jefe del Establecimiento, aunque "no podrá reprender [a las Hijas de la Caridad] y únicamente lo hará presente a la Hermana Superiora, para que ésta adopte las medidas necesarias..." (Art. 178, Regl 1889 y 38 de 1910). El artículo 179 de 1889, que después se suprimió, le equiparaba en responsabilidad a la Señora Superiora en el cumplimiento de "las órdenes relativas al régimen económico del Establecimiento,... [debiendo ponerse] de acuerdo [con ella] para llevarlas a efecto". Entre las funciones que se mantienen está la de "Visitar con frecuencia todas las dependencias del Establecimiento para corregir las faltas que notare"; en 1899 se añadía que "no solo para asegurarse de si en ellos reina el orden debido, sino también el aseo y limpieza que son de desear y muy particularmente en estas Casas...". Debía además "proponer a la Diputación las mejoras y reformas que considere convenientes...", este punto también se modificó quitando la parte que le concedía permiso para disponer "la ejecución de aquellas obras cuyos gastos no pasen de 125 pesetas y se hallen comprendidos en el presupuesto...". Entre las nuevas funciones que se le adjudicaron en 1910 están las de "Expedir a las nodrizas externas las libretas correspondientes a los niños que han de criar, cuando reúnan las cualidades para aquellas requeridas. ..." y la de "Interesarse por el buen cuidado que las nodrizas deben prestar

\footnotetext{
${ }^{281}$ Todos los datos referentes a los jornales se han tomado de los libros de gastos del Hospicio de $1903-1906$ [Signatura: caja 1328, expediente 10615] y de 1909 [Signatura: caja 928, expediente 7140] y de los Presupuestos generales... de la Diputación de 1901 a 1930. ADPVA
} 
a los niños que se les hubiese confiado, adoptando las medidas que le sugiera su celo e inteligencia" (Art. 19- 21, Regl. 1910).

En 1906 se contrató para ayudar al Director en las tareas de oficina un "Auxiliarescribiente" que era responsable también de atender al público "para asuntos de carácter oficial, sobre los cuales dará a los interesados las noticias que soliciten de los acogidos, excepción hecha de los expósitos...", sobre los que estaba prohibido dar ningún tipo de información, y de formalizar las hojas de Registro de los acogidos con el "historial completo de su estancia desde el día de su ingreso hasta el de la baja definitiva" (Capítulo VI, Regl. 1910). Su salario anual fue inicialmente de 1.500 pts y en 1930 llegó a 3.000 pts.

Estos cargos eran nombrados en principio directamente por la Diputación y, aparte de los naturales conflictos de intereses en el seno del propio organismo provincial, parece que no siempre se escogió a las personas más idóneas. El director de la primera década del siglo, Justo Esteban, fue acusado en más de una ocasión por los Diputados- Visitadores por las deficiencias del centro; le debieron pedir explicaciones porque en enero de 1906 dirigió al Vicepresidente de la Comisión Provincial el informe, comentado anteriormente, sobre la situación de los asilados y del Hospicio con "las mejoras y necesidades que se hacen sentir". Al leerlo, en parte suena a justificación, sobre todo cuando intenta explicar cuestiones como la elevada mortalidad de la Inclusa, "difícil tarea, aparte de no ser de la competencia del que tiene el honor de dirigirse a usted". Debió resultar convincente, o se archivó el asunto como otras tantas veces, porque siguió en el cargo hasta que fue cesado por la Comisión Provincial en 1909, dice Pastrana que unos días después de ser detenido por escándalo público en las Moreras ${ }^{282}$; después fue nombrado director del Hospital Provincial ${ }^{283}$. Encontramos su firma como director en la correspondencia del Hospicio, pero no en los libros de registro de los asilados, que sí firmaron sus sucesores ${ }^{284}$. El cargo de Auxiliar tampoco se libró de polémicas; uno de los funcionarios que ocupó este puesto fue el protagonista en 1913-14 de lo que se dio en llamar el "escándalo Montiel" por falsear firmas y sellos, cobrar comisiones de las nodrizas y

\footnotetext{
${ }^{282}$ Cfr. PASTRANA H: La Diputación... p 209- 10. La elección de los directores de los establecimientos benéficos creó, además, más de un conflicto político en el seno de la Diputación.

${ }^{283}$ Encontramos la firma del mismo Justo Esteban como director del Hospital Provincial en una carta fechada el 11 de noviembre de 1912. Expediente con la estadística de la población existente en los servicios asistenciales en 1911. Signatura: caja 1619, expediente 12606. ADPVA

${ }^{284}$ Encontramos la firma de Justo Esteban en algunas cartas conservadas en el ADPVA en la sección Comunicaciones $e$ informes de acogida de menores fechadas entre 1901 y 1906. En el Libro de exposiciones de 1909, desde el 1 de enero, firma los registros como director Santiago del Diego hasta el nombramiento de Florentino Díez, cuya firma aparece en los registros del Hospicio a partir del 24 de julio de 1909; en ninguno de los libros anteriores aparece la firma del director del establecimiento
} 
emitir y cobrar cartillas falsas; después de un largo y polémico proceso la Diputación dio carpetazo al asunto sin exigir más responsabilidades ${ }^{285}$. Se decidió cubrir las plazas por oposición ${ }^{286}$, pero tampoco este sistema estaría exento de problemas y el primer nombramiento por esta nueva vía ya resultó controvertido ${ }^{287}$.

El Director no podía salir del establecimiento sin dejar alguien en su lugar y "en caso de ausencia o enfermedad" tenía que ser sustituido por el Capellán (Art. 31, Regl.1910), que aparte de cumplir con los servicios religiosos y llevar "escritas con orden y claridad las partidas sacramentales de Bautismo y las de defunción" en los libros correspondientes, debía "Instruir a los asilados de ambos sexos en los deberes de la Religión católica", "velar en todos los puntos del Establecimiento por la moralidad y corregir inmediatamente las faltas que contra ella se cometan" (Título XIV, Regl.1889; Capítulo VI, Regl.1910). Su salario se mantuvo fijo en 999 pts anuales hasta 1909 y fue en aumento hasta 3.000 pts en 1930

Las Hijas de la Caridad eran responsables del "gobierno interior del Establecimiento, sin perjuicio de las atribuciones del Director". En 1825 iniciaron su andanza en los establecimientos públicos de beneficencia de Valladolid haciéndose cargo del Hospital provincial de la Resurrección. Desde el inicio su gestión fue muy valorada, especialmente en los aspectos organizativo y económico, lo que animó a la Diputación a contratarlas para el Hospicio en 1855 y el Manicomio en 1876 y a ampliar sus funciones y responsabilidades, en detrimento de las que venían ejerciendo el personal administrativo; sobre todo en lo referente al abastecimiento de alimentos, ropa e incluso de la farmacia del Hospital, donde desplazaron al farmacéutico en su gestión. Esto, unido a la influencia incuestionable de la Iglesia en la mentalidad de la época, facilitó que las Hijas de la Caridad alcanzaran un status de poder en los establecimientos benéficos muy controvertido.

\footnotetext{
${ }^{285}$ N.C. 21-11-1913, p 2 y 5-11-1914, p 2 . Ingresaban niños que inmediatamente eran sacados para crianza por los padres, por cada niño Montiel cobraba quince duros. Se le exigió la dimisión y se decidió no denunciarlo.

${ }^{286}$ Esto no era nuevo, ya en 1901 la Comisión Provincial aprobó sacar las plazas del personal administrativo, médico y docente del Hospicio a oposición, "dadas las exigencias justas de la opinión pública..., para que no se atribuya de ningún modo á la Diputación la culpa de atender únicamente al favoritismo", pero "Como todas estas reformas no pueden llevarse a cabo por ahora dentro del presupuesto, se deja para el próximo y continuarán los mismos que ahora las desempeñan". N.C. 28-6-1901, p 2. La plaza de auxiliar administrativo se sacó a oposición después del escándalo Montiel en 1916. N.C. 8-01-1916, p 1.

${ }^{287}$ Cfr. PASTRANA H.: La Diputación... p 209- 10. La plaza de director salió en 1924. Este sistema siguió permitiendo la política de amiguismo que se venía practicando, el tribunal de la oposición debía seleccionar tres candidatos y la Diputación designaba al elegido entre ellos. El primer elegido por oposición fue el sacerdote D. Francisco Morillo, a pesar de que el primer propuesto por el tribunal era el que en esos momentos estaba ejerciendo funciones de director interino del Hospicio.
} 
Desde su llegada en 1855 al Hospicio, se hicieron cargo del gobierno interior del Hospicio y contaron con una dirección propia nombrada por la Congregación en la persona de la Hermana Superiora, que acabó convirtiéndose en "una dirección paralela", en muchas ocasiones con más interés por los asuntos del Hospicio e influencia que el Director, quien a menudo se limitaba a dar el visto bueno a sus actividades. En las primeras décadas del siglo XX se sucedieron como Superioras Sor Francisca Orrio, hasta 1915, sor Inés Rossel hasta 1918 y Sor Ignacia Domínguez ${ }^{288}$.

Su papel, tanto en el Hospicio como en los demás establecimientos benéficos fue a veces motivo de conflictos con el personal laico, levantó suspicacias y provocó fuertes polémicas entre los que apoyaban su labor religiosa y reconocían el beneficio económico que representaban para las instituciones y aquellos que creían que ejercían una influencia excesiva dentro de ellas ${ }^{289}$. No sólo no estaban supeditadas al director, sino que además, los estatutos les concedían "autoridad para reprender" y denunciar a todos los demás empleados del Hospicio "y reclamar del Director la corrección de los hechos". Por otra parte, el reglamento de 1889 en su artículo 219 les otorgaba total libertad para "observar las reglas comunes o particulares de su Instituto, sin que se las pueda obligar a cambiarlas o modificarlas...", aunque se delimitó en 1910: “Art. 42. Las prácticas religiosas a que vengan obligadas las Hermanas por las reglas de su Instituto serán cumplidas en forma que no retrasen ni dificulten el puntual desempeño de los servicios que las están asignadas.".

Las Hijas de la Caridad controlaban el departamento de mujeres, la Maternidad, la Inclusa, la enfermería, las escuelas de niñas y de párvulos, gestionaban el almacén general, la cocina y el ropero, se encargaban de la ropa desde su elaboración y reparación hasta el lavado y planchado y, por supuesto, se ocupaban de la Iglesia. La Superiora distribuía las tareas entre sus hermanas y para ayudarse "se valdrán de los acogidos" y de algunos sirvientes contratados (Título XV, Regl.1889; Capítulo VII, Regl.1910).

\footnotetext{
${ }^{288}$ Ibídem p 203. El N.C. publicó el funeral de sor Francisca el 15- 07- 1915 y el nombramiento de sor Inés el 22- 081915. Pastrana señala el gobierno de sor Inés hasta 1922, pero se encuentra publicado su fallecimiento en 1918, el N.C. publicaba la noticia de sus funerales el día 7 de Mayo de 1918. Su sucesora, sor Ignacia, estuvo en el cargo hasta 1929, cuando fue trasladada a Barcelona, el 3 de mayo publica el N.C. el acuerdo de le comisión de la Diputación de enviarle allí como recuerdo y agradecimiento un reloj despertador

${ }^{289}$ N.C. 6-7-1901, p2. En 1901, el Gobernador Civil, después de una visita al Hospicio y al Manicomio, en un comunicado sugiere a la Comisión provincial que tome medidas para resolver la posible "incompatibilidad entre el elemento laico y religioso encargados de la administración de dichos establecimientos" y se "propone que se nombre un inspector independiente del personal laico y religioso", no parece que la propuesta saliera adelante, al menos no hay constancia de que pasara de aquí, quizás porque se trataba de asunto harto complicado si se tiene en cuenta que quien no pertenece al grupo de religiosos es laico.
} 
A principios de siglo el centro contaba con 17 Hijas de la Caridad, su número se incrementó a lo largo del período de estudio a 18 en 1906, 21 en 1912, 23 en 1918 y 27 a partir de 1924, como podemos comprobar por los presupuestos. Tenían derecho a "ración y haber anual de 120 pesetas [cada] una", que se pagaba a la congregación. Este salario se mantuvo fijo durante años, hasta que en el presupuesto de 1924-25 se añadió una gratificación 1.620 pts "para mejora de haber de las Hijas de la Caridad", quedando desde entonces en 240 pts anuales, que se aumentarían finalmente a 300 pts en 1930. A mayores, todos los años se asignaba una partida para "Menudencias de despensa y postres para las Hijas de la Caridad", así lo encontramos consignado dentro del apartado de Gastos Generales tanto en los Presupuestos Generales como en los libros de contabilidad del Hospicio, donde también se anota como "postres y otras fruslerías"; en el libro de 1903 se anotan por este concepto 1.166 pts más un presupuesto adicional de 500 pts, en los presupuestos de 1925 y 1928 se fijan 1.750 pts. Incluso con estas concesiones, resultaban una mano de obra muy barata, cada hermana salía en 1928, por poner un año, a 244,81 pts anuales (sumando el salario y estas dos partidas de "mejora de haberes" y "postres"), sin contar cama y "ración". En conjunto, las 17 Hermanas en los primeros años cobraban 2040 pts, poco más que el Director, que por entonces tenía asignadas 2000 pts, y en 1930 suponen en total 8.100 pts, tanto como el Director y su Ayudante juntos. Aparte, la Diputación en el capítulo de Beneficencia, en el primer artículo de "Atenciones generales", incluía todos los años, según el compromiso adquirido en su día con la Congregación, una asignación "Para atender a los gastos de entierro de las Hijas de la Caridad, de los tres Establecimientos" (Hospicio, Hospital y Manicomio), que fue de 500 pts en 1903 y de 1.500 pts en 1925. Podemos comparar los emolumentos de las hijas de la Caridad con el resto del personal administrativo y de servicios en la TABLA 2-3 elaborada a tal fin.

La asignación de las Hijas de la Caridad era la misma en todos los establecimientos y se incluía en los presupuestos en la sección "PRACTICANTES, ENFERMEROS Y SIRVIENTES", junto con los celadores, el portero, las lavanderas, y las amas lactantes y las criadoras internas y externas.

Para la asistencia sanitaria el Hospicio debía contar, según los Reglamentos, con dos médicos y sus auxiliares, un practicante, una enfermera y un enfermero. En los libros, hasta 1906, sólo figura un médico, que no era titular de la plaza, por lo que cobraba la mitad de la asignación establecida para los titulares, 1250 pts anuales. En 1901 se anuncia la convocatoria de una oposición pero la plaza no se cubrió hasta 1905 con un salario anual de 2000 pts. En 1906 se contrató un segundo médico y en 1907 al tercero, quedando el Hospicio atendido por 
los tres hasta 1920, cuando el Presupuesto de ese año asignó al tercero "a prestar sus servicios en el Manicomio". Vuelven por tanto en esta última década a ser solamente dos médicos para el Hospicio, con una mejora sustancial en su salario, que subió a 3.245 pts en ese año, a 4.110 pts en 1927 y a 7.000 pts en 1930 para uno de ellos y 8.500 pts para el otro, con funciones de Director Médico.

Los médicos entre otras obligaciones tenían que "reconocer a su ingreso a todos los admitidos en el Establecimiento, disponiendo que no alternen con los demás si su contacto fuera peligroso", comunicar "cualquier caso de enfermedad epidémica o contagiosa que se presente", "visitar diariamente a los enfermos" y proponer "en los meses de Abril o Mayo los asilados que deban ser vacunados o revacunados". Debían además visitar "quincenalmente y en ocasiones que juzgue conveniente el Director... las habitaciones del Establecimiento, aconsejando y prescribiendo la adopción de las medidas higiénicas que les dicten su celo y conocimiento" y a "los acogidos en la hora de la comida adoptando las disposiciones que consideren oportunas para la salud de los mismos", lo que debían poner en conocimiento del Director, y anualmente redactar una Memoria anual dirigida a la Diputación "con todo cuanto la experiencia les sugiera para mejorar las condiciones sanitarias de la población asilada" (Título XVI, Regl.1889; Capítulo VIII, Regl.1910). Una vez más las intenciones sobre el papel son buenas, pero la realidad era muy diferente, los facultativos no podían dejar de ver las malas condiciones del establecimiento y de los niños y se conservan algunas Memorias, escritas por ellos o por los Visitadores, dirigidas a la Diputación con denuncias y sugerencias de mejora que en la mayoría de los casos terminaban archivadas.

Bajo sus órdenes tenían un practicante que el Regl de 1889 le exigía "permanecer de noche en el Establecimiento a fin de acudir a las necesidades del momento" (Art. 244), pero en los posteriores ya solo se dice que "permanecerá en el Establecimiento todo el mayor tiempo posible para atender de momento a los casos urgentes que ocurran" (Art. 49, 8ㅇ, Regl 1910; Art. 49, 8 o de 1927. Aparte de asistir a los médicos, preparar y acompañarles en la visita diaria de los enfermos y controlar que se cumpliera el tratamiento prescrito sobre medicación y alimentación de los enfermos, debía visitar la enfermería por la tarde para controlar el estado de los pacientes y avisar al médico si fuera preciso, vacunar y hacer sangrías, tenía la función de "cortar mensualmente el pelo a los acogidos y rasurar a los que lo necesiten una vez a la semana" y "enseñar el oficio de barbero a los acogidos que tengan aptitud y deseo de aprenderlo" (Art. 49 -5o y 9ㅇ, Regl.1910 Y 1927). Esta es una labor que no sabemos si en realidad la realizaba él, en los presupuestos se incluye una partida aparte "para gratificar a la persona que corte el pelo a los asilados" y en los libros del Hospicio aparece "gratificación a un 
barbero". En el Reglamento de 1889 esta labor se asignaba al enfermero, responsable también del aseo de los niños enfermos, mientras que el practicante debía controlar que realizara estas tareas correctamente y de forma adecuada. El practicante percibió un salario fijo de 995 pts anuales hasta 1920; en 1924 se contrató un segundo practicante, que no debía ser titular porque percibía un sueldo menor, y sus salarios mejoraron considerablemente hasta quedar en 3.500 y 3.000 pts respectivamente en 1930

Los enfermeros no cumplían las funciones que corresponden actualmente a esta profesión, sino las que tradicionalmente realizaban las personas que trabajaban en las enfermerías, lo que les dio nombre en la Edad Media, y que eran diferentes según el sexo. Las funciones que tenían asignadas en el Hospicio, según los reglamentos, eran las de "auxiliar a los Practicantes, hallarse siempre en las enfermerías para llenar los servicios que se les ordenare y cuidar de la limpieza y aseo de aquellos locales, así como de los enseres que tuvieren. El enfermero tendrá, además, a su cargo el cuidado y servicio de la estufa de desinfección, para la ropa y enseres de los enfermos infecciosos" (Art. 51 y 52, Regl.1910). También tenía adjudicado el cuidado, limpieza y desinfección del depósito de cadáveres, cuya Ilave estaba a cargo de una Hermana (Art. 222, Regl.1910). El reglamento de 1889 se extiende más en las obligaciones, características y salarios del enfermero y de la enfermera, los siguientes reglamentos son muy escuetos en estos puntos. El enfermero tenía un sueldo (en el año del Regl.1889) "de 15 pesetas mensuales, comida de los acogidos y un trage en cada estación, debiendo ser el nombrado mayor de treinta años, con condiciones de moralidad acreditada y que no exceda de cincuenta años" [sic].

En cuanto a la enfermera, aparte de atender las enfermerías, el Reglamento de 1889 dice que debía "prestar el servicio... [en] la clínica de Partos el cual, por su índole é incompatibilidad de las Hijas de la Caridad... necesita una atención preferente" [sic]. La incompatibilidad de las Hijas de la Caridad para prestar este tipo de asistencia se debía a su condición de religiosas, pues tradicionalmente el oficio de partera debían realizarlo mujeres que hubieran sido madres. Por la misma razón el Reglamento del Hospicio de 1889 exige que la enfermera sea mayor de veinticinco, preferiblemente viuda y discreta. En la sala de partos debía asistir al médico y atender a las puérperas, aunque todo esto ya no se recoge en los siguientes Reglamentos. En el de 1910 ya no le atribuyen estas funciones porque ya figura una matrona para atender la maternidad y los partos y ayudar al médico, sin embargo, en los presupuestos generales no se contempla la figura de "una profesora en partos" hasta 1925, con un salario anual inicial de 1.500 pts, que aumentó a 3.500 pts en 1929. La enfermera tenía asignada una "dotación...de 12 pesetas 50 céntimos mensuales y el alimento consiguiente, 
quedando siempre responsable del cumplimiento de sus deberes é inspeccionada su conducta por la Señora superiora" (Art. 246- 251, Regl.1889).

Es muy llamativa la diferencia salarial entre el enfermero y la enfermera, que con el tiempo se fue haciendo incluso mayor, aunque sus funciones eran diferentes, no parece que eso lo justifique. Si en 1901 cobraban 180 pts y 150 pts anuales respectivamente, en 1910 eran 365 y 175 pts, 550 y 225 pts en 1921 y desde 1926 los salarios quedan en 1500 pts "sin ración" el enfermero y 450 pts "con ración condimentada" la enfermera.

Las Hijas de la Caridad hacían funciones que podemos considerar de enfermería y de supervisión, suministraban las medicinas y los alimentos a los enfermos, cuidaban del aseo de sus ropas, acompañaban a los médicos en sus visitas controlaban al practicante y a los enfermeros, velaban a los moribundos y controlaban la farmacia, por llamar así a lo que era más bien el depósito de medicinas del Hospicio (Art. 52, 53, Regl.1910).

En el TABLA 2-3 se recogen los jornales de los empleados del Hospicio en los períodos 1903-06, en 1925 y 1928, a partir de los datos extraídos del libro de contabilidad de 1903$1906^{290}$, y de los presupuestos provinciales de los ejercicios correspondientes. Se escogen estos años como referencia para mostrar la evolución porque el libro de 1903-06 nos permite contrastar los datos reales con los que se consignan en los presupuestos, no se conserva un libro de contabilidad anterior y, además, este período es un reflejo fiel de toda la primera década en la que apenas se modificaron el número de personal y sus salarios. En cuanto a los años 1925-28 reflejan bien la situación de la última década, salvando 1930, año en que se produjo un aumento repentino muy significativo de los salarios, y por la existencia de una copia digital que facilita y permite profundizar la consulta. No se incluyen los maestros de la escuela y de los distintos talleres, que en los presupuestos también se consignan en un apartado diferente al de Personal. Es llamativo el incremento del salario de las Hijas de la Caridad que se duplicó entre 1925 y 1928, pasando de 120 a 240 ptas anuales, quedando aún así muy por debajo de lo que cobraban las mujeres contratadas para crianza y cuidado de los niños o la enfermera y la lavandera que cobraban 450 ptas en 1928.

\footnotetext{
${ }^{290}$ Hospicio provincial de Valladolid. Estadística general de gastos 1903, 1906. Signatura: caja 01328, expediente 010615. ADPVA
} 


\begin{tabular}{|c|c|c|c|c|}
\hline PERSONAL DEL HOSPICIO & \multicolumn{4}{|c|}{ SALARIO ANUAL EN PESETAS } \\
\hline \multicolumn{2}{|c|}{ EMPLEADOSADMINISTRATIVOSYFACULTATIVOS } & 1903-1906 & 1925 & 1928 \\
\hline Director & sin ración & 2.000 & 3.250 & $\begin{array}{l}3.900+ \\
\text { vivienda }\end{array}$ \\
\hline Auxiliar-escribiente" & sin ración & 1250 & 2.684 & 2.950 \\
\hline Médico & " & 2.000 & \multirow{2}{*}{$3.005+600^{\prime} 60$} & $3.600+$ \\
\hline $2^{\circ}$ Médico & “ & 1.250 & & $1.020^{\prime} 65$ \\
\hline Un Capellán & “ & 999 & $2.143+377^{\prime} 16$ & $2.530+667^{\prime} 88$ \\
\hline \multicolumn{5}{|l|}{ PRACTICANTES, ENFERMEROS Y SIRVIENTES } \\
\hline Un Practicante titular & " & 995 & 1.650 & $1.750+397^{\prime} 93$ \\
\hline $2^{\circ}$ Practicante titular & " & -- & 1.250 & 1.500 \\
\hline Profesora en partos* & & -- & -- & 1.500 \\
\hline Un Enfermero & + ración condimentada & 250 & 720 & 1.500 sin ración \\
\hline Una Enfermera & " & 175 & 365 & 450 \\
\hline Un Celador de $1^{a} *$ & " & 240 & ------ & \\
\hline Tres Celadores-inspectores** & " & 240 & 900 & 1.000 \\
\hline Un Vigilante nocturno, & " & --- & 600 & 1.250 \\
\hline Un Ordenanza & sin ración & ---- & 1.460 & 1.750 \\
\hline Lavanderas, & + ración condimentada & $180 \quad(\mathrm{x} 2)$ & $365(x 3)$ & 450 (x 3) \\
\hline Una Criada demandadera & “ & 60 & 90 & 90 \\
\hline Una Ayudante de cocina & " & ----- & 160 & 203 (x 3) \\
\hline $\begin{array}{l}\text { Para gratificar a la persona que corte } \\
\text { el pelo a los asilados }\end{array}$ & $-\cdots---$ & 300 & 750 & 750 \\
\hline Gratificación al Sepulturero**** & $-\cdots$ & 25 & 700 & 1000 \\
\hline Un Portero $* * * * *$ & sin ración & 750 & 1.150 & $1.500+150$ \\
\hline Un Hortelano & & --- & --- & 750 \\
\hline Hijas de la Caridad & + ración & 120 (x 18) & 180 (x 27) & 240 (x 27) \\
\hline Amas lactantes internas $* * * * * *$ & \multirow{2}{*}{$\begin{array}{l}+ \text { ración condimentada }+ \\
\text { cama }\end{array}$} & 20 pts/m (x20) & 35 pts /mes & 35- 45pts /mes \\
\hline Mujeres internas para cuidar niños & & ------- & 15 pts $/$ mes $(x 8)$ & 25 pts $/$ mes (x9) \\
\hline \multirow[t]{2}{*}{ Amas lactantes externas } & pueblo & $12^{\prime} 5 \mathrm{pt} / \mathrm{m}(\mathrm{x} 225)$ & $30 \mathrm{pts} / \mathrm{mes}$ & $45 \mathrm{pts} / \mathrm{mes}$ \\
\hline & capital & $10 \mathrm{pts} / \mathrm{m}(\mathrm{x} 20)$ & 25 pts /mes & $25 \mathrm{pts} / \mathrm{mes}$ \\
\hline \multirow[t]{2}{*}{ Criadoras externas de niños en destete } & pueblo & 8 pts/m (x300) & $15 \mathrm{pts} / \mathrm{mes}$ & $20 \mathrm{pts} / \mathrm{mes}$ \\
\hline & capital & 6'5 pts/m (x15) & $10 \mathrm{pts} / \mathrm{mes}$ & $15 \mathrm{pts} / \mathrm{mes}$ \\
\hline $\begin{array}{l}\text { Amas y criadoras internas y externas. } \\
\text { Total anual por este concepto }{ }^{* * * * * *}\end{array}$ & $\begin{array}{c}97.745(1901) \\
64.920(1905) \\
70.920(1906) \\
72.420(1910)\end{array}$ & $\begin{array}{l}72.420(1903) \\
73.170(1904) \\
67.920(1905) \\
70.920(1906)\end{array}$ & $\begin{array}{l}\mathbf{7 2 . 2 4 0} \\
\text { (Incluye leche, } \\
\text { harinas y } \\
\text { similares) }\end{array}$ & $\begin{array}{l}\mathbf{6 5 . 0 0 0} \\
\text { (Incluye leche, } \\
\text { harinas y } \\
\text { similares) }\end{array}$ \\
\hline
\end{tabular}

TABLA 2-3: Salarios percibidos por los empleados del Hospicio Provincial de Valladolid en el período 1903-1906, en 1925 y 1928. Elaboración propia

* La profesora en partos no aparece en los Reglamentos hasta 1927 ni hasta el presupuesto de 1926

** En los libros de presupuestos de 1925- 28 se consignan "Tres Celadores-inspectores" y "Un Vigilante nocturno", que no existía en 1901 -10, en los libros de contabilidad del Hospicio en estas fechas se registran los pagos a un "Celador 1 g" $^{\prime}$ "Tres celadores 2a á $240 \mathrm{pt}^{\mathrm{s}}$ uno".

***No aparece esta gratificación como tal en los presupuestos de 1925 y 1928. En ellos aparece el jornal para dos "encargados de conducir los cadáveres que resulten en los tres establecimientos, a razón de" 700 ptas cada uno en 1925 y 1.000 ptas en 1928

**** El Portero vivía con su familia en un local a la entrada del Hospicio y no tenía derecho a ración, lo que ocasionó problemas y quejas del Director a la Comisión Provincial por "los humos que salen de la cocina de [su] habitación [que] perjudican a la decoración del portal". El Portero se defendió diciendo que "no pueden evitarse al encender la lumbre... dadas las condiciones de la referida cocina". Se conservan estas cartas entre la Correspondencia del Hospicio, pero no hay contestación de la Diputación. Su sueldo mejora considerablemente a lo largo del tiempo. Sobre todo de 1925 a 1928

***** Se anota entre paréntesis el número de amas según figura en los presupuestos. Desde 1926 el salario de las amas de cría internas se fija en función de los niños que amamantan, si solo amamantan a su hijo no cobran nada, si amamantan un niño de la inclusa ganan 35 pts/ mes y si son dos 45 pts/mes.

En la última línea se anota el gasto total anual en Nodrizas, como figuran en el Libro de cuentas del Hospicio 1903-06, incluyendo las amas tanto internas como externas y las cuidadoras o criadoras, es decir a las mujeres que cuidan a los niños pero no los amamantan. En estos años se anotaron en un asiento aparte 1.000 pts en "Harinas lacteadas". En los presupuestos de 1925 y 1928 se desglosan los pagos de amas y criadoras internas y externas que se han sumado en esta tabla recogiendo el total; en el punto 432 del presupuesto se incluyen junto con los haberes de las amas internas la "compra de leche, harinas y similares que fuesen preciso para la crianza interna". 
Así mismo, podemos comprobar en la tabla la diferencia salarial por sexos, que se pone de manifiesto particularmente en el caso de los enfermeros; en 1928 el enfermero triplica el salario de la enfermera. También es destacable la disminución en el presupuesto para amas y criadoras en 1928, a pesar de que el incremento de sus salarios es importante.

Los jornales de los empleados del Hospicio eran iguales a los que percibían los del Hospital y el Manicomio, incluidas las Hijas de la Caridad, excepto para los médicos que en 1928 cobraban algo más los del Manicomio, según su categoría, y los Ayudantes de cocina que en el Hospital era un hombre y cobraba más del doble que las mujeres de los otros dos establecimientos. Resulta difícil compararlos con puestos equivalentes fuera de estos establecimientos, pero parece que los empleados no administrativos ni facultativos del Hospicio tenían un nivel salarial equiparable al de los trabajadores no cualificados del resto de la población, con un poder adquisitivo muy bajo, incluso en relación con el precio de los productos de primera necesidad $^{291}$.

\subsubsection{RÉGIMEN INTERNO DEL HOSPICIO.}

\subsubsection{Admisión}

El Hospicio admitía niños huérfanos, o cuyos padres se encontraran desaparecidos, ingresados en alguna institución o sin recursos para criarlos; hijos de mujeres solteras o viudas pobres "si carecen de condiciones para lactarles" (Art. no 5, Regl.1910) y "uno de los hijos legítimos dados a luz en parto doble por mujer pobre que no pueda lactar á los dos gemelos" (Art. no 6, Regl.1910). Salvo en el caso de los niños expósitos, el ingreso debía solicitarse a la Diputación por los parientes más próximos o en su defecto por las autoridades locales acreditando la condición de pobreza y la Comisión Provincial resolvía.

\footnotetext{
${ }^{291}$ Los ingresos de un albañil estaban en torno a 100- 110 ptas mensuales en el período de $1900-1925$ y de 170 ptas en 1930; el maestro albañil del Hospicio cobraba 148,95 ptas mensuales en 1925 y 166,66 ptas en 1928 . Un bracero venía a cobrar unas 50 ptas al mes en 1914 y 115 ptas en 1930, algo más que los celadores del Hospicio que en 1928 cobraban 83.33 ptas/mes. Una sirvienta en Segovia en 1930 cobraba unas 300 ptas anuales, (25/mes), lo mismo que las criadoras internas de la Inclusa provincial. El salario de un jornalero con trabajo estable podía oscilar entre 9001800 ptas (75- 150 ptas/ mes), similar al de los trabajadores no cualificados del Hospicio. Son salarios calculados a partir de los datos que ofrece MORENO LÁZARO J. en El nivel de vida en la España atrasada entre 1800 y 1936 . El caso de Palencia; p 27 y FUENTE NUÑEZ R. DE LA en: Evolución histórica de Segovia. 1900- 1936; p 123.
} 
"el dia 11 de Julio de 1906 ingreso en este Asilo por acuerdo de la Comisión provincial. Es hijo legítimo de Antonio y de Eusebia, vecinos de esta Ciudad. Es hermano de los que ocupan los tres folios siguientes" [sic] ${ }^{292}$

Existía una vía de urgencia para situaciones que no podían esperar, tales como el abandono del niño o la incapacidad para cuidarle por parte de su familia. El Presidente o el Vicepresidente de la Comisión podían ordenar la admisión provisional hasta la siguiente sesión (Art. no 9 -15, Regl.1910). También el Gobernador Civil podía dar orden de ingreso provisional, solía tratarse de niños encontrados en la vía pública, fugados de sus casas o que precisaban atención médica. En el folio no 102 del Libro de mayores de 1906 leemos

"El día 1 de julio ingreso en este asilo con carácter de enfermo por orden del Sr Gobernador Civil

Salió por orden del Sr Gobernador Civil el día 15 Julio de 1915" [sic]

En los reglamentos, a partir de 1910, se especifican con todo detalle las "condiciones de admisión" en el establecimiento (Capítulo II, Regl.1910), primando las condiciones de pobreza, abandono y la edad, marcando como límite para el ingreso 16 años en las niñas y 14 en los niños (Art. no 8, Regl.1910).

"Desde el día del ingreso se abrirá a cada asilado una hoja histórica en el libro correspondiente" con "sus circunstancias personales, motivo de la admisión y Autoridad que lo decretó", en la que se anotarán todas las "vicisitudes que experimente hasta su salida" (Art. 16, Regl.1910). Vimos en el capítulo dedicado a la documentación del ADPVA que, efectivamente, se llevaban los registros con todos estos datos y las características que tenían (ver los apartados sobre Libros de Exposiciones, de Salidas y de Mayores). Los niños se inscribían al ingreso en el libro correspondiente de Exposiciones o de Mayores, cada niño en un folio por orden consecutivo de ingreso. El año de la exposición y el número del folio en el libro de registro servía para la identificación del niño, a partir de 1908 se les empezó a asignar un número de filiación. Ya comentamos como los mismos datos se repiten en diferentes registros, cada departamento lleva un libro y los datos se transfieren entre éstos y los libros oficiales de la oficina, la comunicación se realizaba mediante papeletas oficiales diseñadas al efecto. Hemos encontrado entre los libros y entre los expedientes papeletas para notificar las exposiciones en el torno, para dar la orden de ingreso del niño a la Superiora, para registrar el nombre de la nodriza interna que se le asigna, para el reconocimiento médico, para la devolución de niños por las criadoras externas, papeletas de la Contaduría como resguardo de pago a las nodrizas externas. También se utilizaban notas oficiosas en trozos de papel,

\footnotetext{
${ }^{292}$ Folio no 103 del Libro de mayores acogidos 1906-1911. Signatura: caja 01869, expediente 016474. ADPVA
} 
descubrimos algunas entre los libros, con información de todo tipo desde el aviso de una bombilla fundida hasta la corrección de algún dato mal registrado o el fallecimiento de un niño.

Cuando los pequeños pasaban al departamento de mayores se les abría un folio nuevo en el libro correspondiente, llamado de "Libro de Mayores", en el que se anotaban las nuevas incidencias, aunque hemos comprobado que se seguían registrando también en los Libros de Exposiciones hasta la baja definitiva en el asilo, de hecho, en la mayoría de los casos los registros de estos últimos son más completos. Es un sistema que se presta a muchos errores por fallos de comunicación o en la transcripción de datos $y$, efectivamente, localizamos algunos, realmente pocos para la complejidad del sistema, sobre todo son cambios de nombres o de fechas o datos discordantes para un mismo niño en los distintos asientos. En algún caso podían suponer perder la pista de un asilado o dificultar su localización, como cuando se confunden los nombres de las amas que crían a los niños. En el folio no 40 de 1907 dice:

"El día 28 de Febrero 1907 le llevo Maria ¿? Sacristan, mujer de Martin Bermejo vecinos de Cuevas de Provancos.

No fue este numero el que llevo fue el 42" [sic]

No podemos saber cuántos errores de este tipo se pudieron cometer y pasaron desapercibidos, lo cierto es que se encuentran muchas correcciones dentro de los registros, pero también que la gran mayoría de los datos que hemos cotejado en los distintos libros son coincidentes.

"Todo acogido al ingresar será reconocido por el Facultativo, se le dará un baño general y se someterá a las demás disposiciones sanitarias establecidas" y no se mezclará con los demás hasta que "no ofrezca riesgo de contagio" (Art. no 17, Regl.1910). No hemos encontrado registros sanitarios entre la documentación del Hospicio, de hecho cuando empezamos a revisar los libros de asilados llegamos a sospechar que este punto del reglamento no se cumplía porque, salvo el diagnóstico en los caso de fallecimiento, no hay ningún dato médico en ellos. Nos llamó poderosamente la atención el hecho de que se recogiera todo tipo de datos al ingreso pero no se dijera nada del estado de salud del niño, cuando hay muchos casos en los que debía ser muy malo porque fallecía en unos días, incluso horas. Hasta que un día encontramos una papeleta suelta entre las hojas de un libro, una 
cuartilla impresa para certificar el reconocimiento médico, luego apareció alguna más en alguno de los expedientes personales revisados.

\subsubsection{Población acogida}

Con los registros se puede controlar bien el número de ingresados, desde la oficina tendrían que realizar estadísticas de control, más, sólo se conservan algunas. En la Memoria de $1908^{293}$ se recogen las estadísticas de población de ese año, en el que ingresaron en total 483 niños de todas las edades. Según el Informe de 1914- $1918^{294}$, el número total de ingresados en el Hospicio en estos años, sin contar las mujeres de la Maternidad, osciló entre 466 en 1915 y 583 en 1918, la mayoría eran niños lactantes. (TABLA 2-4)

\begin{tabular}{|c|c|c|c|c|c|c|c|}
\hline \multicolumn{8}{|c|}{ NIÑOS INGRESADOS ANUALMENTE EN EL HOSPICIO PROVINCIAL POR DEPARTAMENTOS } \\
\hline & 1905 & 1908 & 1914 & 1915 & 1916 & 1917 & 1918 \\
\hline LACTANCIA & 437 & 403 & 408 & 392 & 439 & 411 & 466 \\
\hline DESTETE & 19 & 17 & 20 & 22 & 40 & 33 & 42 \\
\hline MAYORES & 94 & 63 & 40 & 52 & 70 & 46 & 75 \\
\hline TOTAL & 550 & 483 & 468 & 466 & 549 & 490 & 583 \\
\hline
\end{tabular}

Resulta difícil saber cuántos asilados se podían encontrar internados en un momento concreto debido al movimiento que había de niños que salían y entraban repetidas veces del orfanato; parece que tampoco para los responsables era fácil el control, por eso periódicamente debían hacer un censo de la población interna; en los libros aparecen notas del tipo "1914-12-22: Registrado en población interna no ..."295; aunque a veces el niño no aparecía, como ocurre con el inscrito en el folio no 76 del libro de Exposiciones de 1909 que fue devuelto por la nodriza al acabar el período de destete en julio de 1914 y en "1915-07-26. Al confeccionar el Censo no aparece en el Asilo".

\footnotetext{
${ }^{293}$ Memoria. 1908. Signatura: caja 2449, expediente 30483. ADPVA

${ }^{294}$ Informe del número de acogidos entre 1914 y 1918. Signatura: caja 4051, expediente 38001. ADPVA

295 Esta fecha concretamente aparece en muchos registros del Libro de mayores acogidos 1906-1911, en los folios no 74 y 79 y el mismo mes en otros, por ejemplo el día 19 en el folio no 96 del mismo libro o el día 17 en el folio no 100 del Libro de Exposiciones de 1909, tomo 1‥ Parece que debieron hacer un censo de la población del Hospicio.
} 
El informe sobre movimiento de acogidos de 1906 y la Memoria de 1908 nos pueden servir de referencia para hacernos una idea de la población que vivía en el Hospicio ${ }^{296}$. El 1 de enero de 1906 había internados 27 lactantes menores de 15 meses, 1 niño de destete (entre 15 meses y 5 años) y 348 mayores de 5 años; suman 376 niños, más 17 mujeres en la sala de Maternidad. El 31 de diciembre de 1908 eran 457 niños internos: 32 lactantes, 14 de destete y 411 mayores de 5 años, más 16 mujeres en la Maternidad. En una crónica sobre el Hospicio publicada en El Norte de Castilla el 17 de julio de 1912 se dice que en él "se albergan 750 asilados de todas clases, edades y sexos", entendemos que incluye a todos los que vivían en el centro por esas fechas, posiblemente también a las mujeres de la maternidad.

En la Memoria que acompaña al Presupuesto General de la Diputación para el año económico 1922-23 se ofrece la "Estadística de asilados en el Hospicio provincial durante el año natural 1921 y defunciones ocurridas en igual período, en crianza interna y externa" pormenorizada por meses y un "Resumen comparativo en el último quinquenio" con los promedios mensuales, según éste el promedio de población interna para todo el quinquenio fue de 536 asilados y valores extremos de 608 internos en 1920 y 431 en 1921; no se dice en la estadística si se han contabilizado también las mujeres de la Maternidad. (TABLA 2-5)

Con estas cifras no es de extrañar que se acusara de falta de espacio, de hacinamiento, que se hicieran obras continuas de ampliación y nuevos pabellones y que los pobres presupuestos no permitieran mantener unos cuidados dignos, que exigirían una dotación de personal y de recursos de la que el Hospicio carecía; considerando el personal del asilo, que hemos visto anteriormente, es imposible tener un buen control de tantos niños y muchachos de todas las edades y, lo que es más importante, cuidarles medianamente bien.

Pero a efectos económicos no cuentan solamente los niños internos, hay que tener en cuenta también la población asistida que vivía fuera, particularmente los niños menores criados por nodrizas que cobraban un salario a cargo del presupuesto del Hospicio. En 1905, teniendo en cuenta la población que ya estaba y los nuevos ingresos e incluyendo las bajas, fueron asistidos $\mathbf{1 . 2 3 0}$ menores de $\mathbf{5}$ años y $\mathbf{4 7 7}$ mayores, en total $\mathbf{1 . 7 0 7}$ acogidos que durante más o menos tiempo estuvieron a cargo del Hospicio Provincial de Valladolid en ese año, a los que podemos sumar las $\mathbf{7 7}$ mujeres atendidas en la Maternidad. La Estadística... de $1911^{297}$ contabiliza la población asistida por el Hospicio durante ese año en 419 niños de la Inclusa y

\footnotetext{
${ }^{296}$ Los datos que presentamos a continuación se han extraído del "Estado demostrativo del movimiento de acogidos del Hospicio Provincial. 1906" [Signatura: caja 4872, expediente 43334], que recoge las estadísticas del año 1905 y la "Memoria. 1908" [Signatura: caja 2449, expediente 30483]. ADPVA

${ }^{297}$ Estadística de la población existente... 1911. Signatura: caja 1619, expediente 12606. ADPVA
} 
410 del Hospicio, más 74 mujeres en la Maternidad; son los datos que se enviaron al Instituto de Estadística sin ninguna explicación añadida, sin embargo no parece que se hayan sumado internos y externos de todas las edades, ya que el número que da para la Inclusa coincide con el de ingresos de ese año, según he podido constatar con los Libros de Exposiciones; faltarían por tanto las crianzas externas. Por otra parte, los 410 niños del Hospicio no serían los ingresos nuevos de ese año, sino los mayores de 5 años que se encontraban internos, como podemos deducir por los datos del cuadro que recoge los ingresos anuales y porque se corresponde mejor con los 429 que había en el asilo a finales de 1904 y 477 a finales de 1905 . Ocurre lo mismo con los datos que da El Norte de Castilla, el 12 de abril de 1902 el número de asilados era de 242 lactantes, 423 niños en destete y 432 mayores de cinco años, en total $1.097^{298}$.

Si volvemos al Resumen comparativo... de la Memoria de la Diputación de 1922- 23 podemos tener el promedio mensual del total de asistidos, internos y externos para el quinquenio previo, en el que podemos observar un descenso progresivo y significativo desde un promedio mensual de 1.088 asistidos en 1917 a 689 en 1.921 a expensas fundamentalmente de la población externa. (TABLA 2-5)

\begin{tabular}{|c|c|c|c|c|c|}
\hline \multicolumn{6}{|c|}{$\begin{array}{c}\text { PROMEDIO MENSUAL DE POBLACIÓN INTERNA Y EXTERNA EN EL HOSPICIO } \\
\text { PROVINCIAL DE VALLADOLID. QUINQUENIO 1917- } 24\end{array}$} \\
\hline & 1917 & 1918 & 1919 & 1920 & 1921 \\
\hline INTERNOS & 550 & 557 & 608 & 534 & 431 \\
\hline EXTERNOS & 538 & 427 & 270 & 247 & 258 \\
\hline TOTAL & 1.088 & 984 & 878 & 781 & 689 \\
\hline
\end{tabular}

Lo cierto es que las pocas estadísticas que hay son de difícil interpretación porque no detallan la población a la que se refiere, y nos ofrecen datos dispares. En todo caso, son cifras realmente abrumadoras, dadas las circunstancias.

\subsubsection{Vestuario}

Los asilados vestían uniforme confeccionado en el propio Hospicio "cuya tela se [fabricaba] en el taller de tejidos del Establecimiento", aunque la producción debía ser insuficiente porque en los libros de cuentas y en los presupuestos hay compras de todo tipo de telas. La ropa de las mujeres, de los niños pequeños y la de cama la confeccionaban las monjas

\footnotetext{
${ }^{298}$ N. C. $12-4-1902$, p 3
} 
con las asiladas (Art. no 157, Regl.1889; Art. no 278, Regl.1910), que también se encargaban de los arreglos y remiendos; la ropa de los niños se hacía en el taller de sastrería, en el que trabajaban 6 asilados mayores de 12 años bajo la dirección de un maestro sastre, según la Memoria de 1908, y el calzado se fabricaba en el taller de zapatería, donde trabajaban otros 6 muchachos. En los libros de gastos y en los presupuestos generales se encuentra la relación de materiales que se compraban para la confección de las prendas y los salarios de los maestros de estos talleres, aparecen también compras de alpargatas y alguna partida suelta de calzado $^{299}$. En 1919 se instala también una alpargatería en el Hospicio para consumo del establecimiento $^{300}$. Los asilados debían recibir, según los reglamentos, dos trajes en cada estación, de diario y de festivo; de algodón o lino en verano y de paño en invierno y dos pares de zapatos o borceguíes (Art.153-4, Regl.1889; Art. 275-7, Regl.1910). No se hacían distinciones por edad, salvo para los lactantes, para el resto figuran las mismas piezas de vestuario. Aunque no se contempla en los reglamentos, es de suponer que, por lo menos los pequeños, utilizarían los típicos blusones para cubrir la ropa, entre las compras figuran telas para fabricarlos y con ellos les vemos en un dibujo que aparece publicado en El Norte de Castilla en $1904^{301}$. Vestuario y calzado recibieron con frecuencia fuertes críticas por el "doloroso espectáculo de ver muchos niños y niñas, algunas veces en la época de frío, descalzos... casi desnudos y llenos de andrajos..." [1918 $]^{302}$.

Cada asilado disponía así mismo de dos juegos de cama, para mudarla "una vez al mes o cuando fuera preciso". Al menos eso dicen los reglamentos, que también establecían que cada cama debía disponer de "un jergón, colchón, dos sábanas, dos almohadas, una colcha y dos mantas", las de los más pequeños llevaban además un hule de protección. (Art. no 161, Regl.1889; Art. no 280- i2, Regl.1910). Los colchones también se hacían en el Hospicio, se compraba todo el material necesario, los había de lana y de "Paja larga ó de maíz". En los presupuestos generales de 1930 sigue apareciendo “Paja larga de maíz para jergones" ${ }^{303}$.

\footnotetext{
299 Ver "Registros de existencias de los centros de acogida de menores" el punto 10 del capítulo sobre Fondos del ADPVA, p 103

300 Presupuesto General de Ingresos y Gastos de la Diputación Provincial de Valladolid para el año económico de 1919- 1920. Autorizado por Real Orden de 7 de Marzo de 1919. Partida no 472, p 75

${ }^{301}$ N.C. 6-1-1904, p 1

302 Informe del diputado visitador Roldán Trápaga de 1918 sobre las malas condiciones del centro, citada por PASTRANA H: op.cit., p 221

${ }^{303}$ Presupuesto General de Ingresos y Gastos de la Excma. Diputación Provincial de Valladolid para el año natural de 1930. Aprobado en sesión de 13 de Diciembre de 1919. Partida no 411, p 142
} 
La alimentación es otro aspecto regulado en los reglamentos, con más detalle en los de 1910 (Capítulo XXVII) y 1927 (Capítulo XXVIII), el Regl.de 1889 sólo le dedica el Art. 152. Las compras registradas en los libros ${ }^{304}$ coinciden completamente con la relación que aparece cada año en los presupuestos generales de la Diputación y se ajustaba a lo reglamentado, al menos en cuanto a los productos consumidos. Los asilados mayores de tres años debían recibir diariamente "500 gramos de pan; 50 gramos de carne, ó 25 de bacalao, ó un huevo; 56 gramos de garbanzos, 28 gramos de tocino, dos centilitros de aceite", además de lo necesario para condimentarlos, y se distribuían en "sopa por la mañana, cocido á mediodía, y por la noche sopa, o bien arroz, patatas ó alubias ó bacalao". Una dieta que, sobre el papel, no parece diferir mucho de la que era habitual por entonces para la mayoría de la población, exceptuando, claro está, las clases con más recursos económicos. Los estudios nutricionales nos informan que la dieta de la población española en las tres primeras décadas del siglo XX era muy monótona y tenía el pan, las patatas y las legumbres como alimentos básicos que aportaban casi dos tercios del total del aporte calórico diario, calculándose un consumo medio de pan de 500 g por habitante y día. Tanto las cantidades de pan como las de legumbres incluidas en la dieta del Reglamento parece que concuerdan con los consumos medios para la población española de la época ${ }^{305}$. La alimentación de la clase obrera era muy deficiente y similar a la del Hospicio, a base de pan, en forma de sopas con aceite y agua en el desayuno, con garbanzos, patatas y un trozo de tocino salado al mediodía y patatas con bacalao o sopas de pan para la cena y sólo algunos se podían permitir vino y raramente carne ${ }^{306}$.

El menú del Hospicio queda muy lejos de las recomendaciones actuales para una alimentación saludable ${ }^{307}$, porque, además, no se incluían frutas ni verduras y tampoco los

\footnotetext{
${ }^{304}$ Ver Registros de existencias de los centros de acogida de menores, el punto 10 del capítulo sobre Fondos del ADPVA, $p 103$

${ }^{305}$ CUSSÓ SEGURA X, GARRABOU SEGURA R.: La transición nutricional en la España contemporánea:las variaciones en el consumo de pan, patatas y legumbres (1850-2000). Investigaciones de Historia Económica. 2007; (7) pp 69 100. Estos autores concluyen que durante las tres primeras décadas del siglo XX se produce una mejoría progresiva de la alimentación, aunque la ingesta calórica media de los españoles estaba por debajo de la de Europa occidental. Sobre el consumo de pan los datos varían en función de la clase social, con un consumo mucho más elevado en las clases economicamente más desfavorecidas en las que se refieren consumos de alrededor de $500-700 \mathrm{~g}$ diarios frente a $276 \mathrm{~g}$ en las clases más acomodadas. Respecto al consumo de legumbres aportan unos datos estimados muy variables con un consumo medio para la población española que oscila entre $26,5 \mathrm{~g}, 47 \mathrm{~g}$ y $100 \mathrm{~g}$ diarios según diferentes estudios. Se generalizó en esta época el consumo del pan blanco y aumentó de forma progresiva e importante el consumo de patatas y de forma moderada el de alimentos de origen animal

${ }^{306}$ FUENTE NUÑEZ R. DE LA: Evolución histórica de Segovia. 1900- 1936. Tesis doctoral, Departamento de Historia Contemporánea, Universidad Complutense de Madrid, 2007; pp 123-4, ando a PALOMARES IBAÑEZ, J. M.: La condición obrera y el asociacionismo en la ciudad de Segovia durante la Restauración en Academia de Historia y Arte de San Quirce, Segovia 1088-1988. Congreso de Historia de la Ciudad, Actas, Junta de Castilla y León, 1991, p. 741.

${ }^{307}$ Ya comentamos en la nota no 44 que las recomendaciones actuales son de 3- 4 raciones semanales de 100-125 gr gramos de carne magra, dentro de una dieta equilibrada con una ingesta suficiente de proteínas que debe incluir
} 
encontramos entre los artículos comprados ni en los presupuestos, únicamente hay patatas, pimiento, pero se refiere a "pimentón flor" como aparece en algunos registros (pimentón para condimentar), y judías pero por las cantidades que se compran, partidas de 300- 400 kilos debe tratarse de legumbres secas. No sabemos con seguridad si el Hospicio contaba con huerto propio al menos en los primeros años, parece ser que sí, pero no dentro de la finca del establecimiento. Ya hemos comentado que no aparecen sus gastos en los libros de contabilidad ni en los presupuestos, solamente el arriendo de una huerta en 1904, sin embargo, suponemos que puede tenerlo porque en los presupuestos generales de la Diputación desde el año 1905 entre los gastos de personal del Hospital de Dementes aparece una partida para "un hortelano, con la obligación de atender a la conservación y trabajos que se ocasionen en las otras huertas que llevan en arrendamiento el Hospital y el Hospicio"308. El Manicomio contaba con un huerta en San Pablo, según consta en el presupuesto de 1901 junto con el jornal del hortelano que la atiende, que aparece en los presupuestos de todos los años, además, solamente en ese año, uno de sus enfermeros figura "como hortelano" ${ }^{309}$. En la memoria sobre los Estados del Personal de 1908, en una relación de las "Ocupaciones de los asilados" figuran dos de ellos como hortelanos, puede ser que asistieran al hortelano del Manicomio pues los chicos del Hospicio trabajaban en distintos talleres y dependencias de la Diputación. A partir de 1928 en el presupuesto del Hospicio aparece en el apartado de subalternos un hortelano ${ }^{310}$, y desde 1927 encontramos en el apartado dedicado a la vaquería gastos para "herramientas y semillas para la huerta y jardines", hemos de suponer por tanto que la huerta existía, aunque no tenemos constancia de su producción; entre el personal del Manicomio sigue figurando su hortelano.

otras tantas raciones de 125- 150 gr de pescado y de huevos, de 2 a 4 raciones semanales de 60 - 80 gr de legumbres y un consumo diario de 2 a 4 raciones de lácteos equivalentes cada una a $200-250 \mathrm{ml}$ de leche. Se aconsejan 2 raciones diarias del grupo alimentario de carnes, pescados y huevos, lo que a la vista del gasto en víveres no se alcanzaba ni de lejos en el Hospicio en la época. (Cfr. Consejos para una Alimentación Saludable de la Sociedad Española de Nutrición Comunitaria (SENC) y la Sociedad Española de medicina de Familia (semFYCF). Madrid 2007. Disponible en: https://www.semfyc.es/pfw_files/cma/Informacion/modulo/documentos/guia_alimentacion.pdf; A. CARBAJAL AZCONA: Manual de Nutrición y Dietética. Universidad Complutense de Madrid. 2013. Disponible en: https://www.ucm.es/data/cont/docs/458-2013-07-24-cap-3-ingestas-recomendadas. pdf; 2ª Guía de Alimentación y nutrición saludable. La Pirámide de Alimentación. Ayuntamiento de Valencia, Servicio de Sanidad. Valencia 2009. Disponible en: http://www.valencia.es/ayuntamiento/alqueriasolache.nsf/0/4440AD9E67035D56C12579F9003A 2F83/\$FILE/2_Guia\% 20Nutricion. pdf; Guía de Alimentación para comedores escolares. Consejería de Sanidad de Castilla-La Mancha. Disponible en: http://www.castillalamancha.es/sites/default/files/documentos/20120511/ comedores escolares. pdf)

${ }^{308}$ Encontramos este asiento en todos los presupuestos, puede verse: Presupuesto Ordinario de Ingresos y Gastos de la Provincia de Valladolid para el año económico de 1905. Autorizado por Reales Órdenes de 11 de Diciembre de 1904 y 25 de Enero de 1905. Relación no 3 Practicantes, enfermeros y sirvientes del Hospital de Dementes, p 3; Presupuesto General de Ingresos y Gastos de la Diputación Provincial de Valladolid para el año económico de 192425. Autorizado por Real Orden de 11 de Junio de 1924. Partida no 324, p 44

${ }^{309}$ Presupuesto Ordinario de Ingresos y Gastos de la Provincia de Valladolid para el año económico de 1901. Relación no 3 Practicantes, enfermeros y sirvientes del Hospital de Dementes, p 39

${ }^{310}$ Presupuesto Ordinario de Ingresos y Gastos de la Diputación Provincial de Valladolid para el año natural de 1928. Aprobado en sesión de 16 de Diciembre de 1927. Partida no 195, p 106 
La fruta sólo se contemplaba para "los acogidos enfermizos o débiles" que debían recibir a mayores "un huevo para el almuerzo, 50 gramos más de carne y una merienda de fruta y queso"; los demás sólo la comían en ocasiones especiales. Vimos en los libros de cuentas cómo se incluían entre los gastos considerados extraordinarios y se compraban frutos secos, manzanas y castañas por Navidad y esporádicamente naranjas. En el libro de 1909 hay una única compra de 100 naranjas a 4 pesetas y en el libro "Mensual de cuentas...1913" sólo figuran dos compras de 600 naranjas en marzo y 500 en abril "para los músicos" de la banda del orfanato, que como premio cuando tocaban recibían también otros productos especiales como queso. Además del día de Navidad, tenían comida especial en la "festividad del titular del Establecimiento", San José, y el día "de reparto de premios" y dice el reglamento que "En los días de Nochebuena, Pascua y Año nuevo serán obsequiados con aguinaldos de turrón y castañas, nueces, higos u otros artículos equivalentes", en efecto estos productos aparecen en los libros de control de gastos por estas fechas con asientos del tipo de: "turrones y otras fruslerías". Por Navidad solían recibir más limosnas y donaciones que con frecuencia eran en forma de productos para ellos extraordinarios como galletas y naranjas.

\begin{tabular}{|c|c|c|c|c|c|}
\hline \multicolumn{6}{|c|}{ PRODUCCIÓN DIARIA DE LECHE EN LA VAQUERÍA DEL HOSPICIO PROVINCIAL DE VALLADOLID } \\
\hline \multirow[b]{2}{*}{1928} & \multicolumn{2}{|c|}{ Promedio mensual mínimo } & \multicolumn{2}{|c|}{ Promedio mensual máximo } & \multirow{2}{*}{$\begin{array}{c}\text { Promedio ANUAL } \\
97 \text { L./día }\end{array}$} \\
\hline & 58 L./día & febrero & 125 L./día & agosto & \\
\hline 1929 & 62 L./día & enero & 125 L./día & septiembre & 100 L./día \\
\hline 1930 & 53 L./día & noviembre & 129 L./día & mayo & 103 L./día \\
\hline 1931 & 61 L./día & octubre & 93 L./día & febrero & 79 L./día \\
\hline 1932 & 33 L./día & noviembre & 115 L./día & enero & 72 L./día \\
\hline 1933 & 42 L./día & junio & 76 L./día & abril & 53 L./día \\
\hline
\end{tabular}

Tampoco se compraba leche de forma habitual, salvo alguna partida destinada a la Inclusa ${ }^{311}$, y la producción de la vaquería era muy variable. En 1926 había diez vacas, descontando las recién paridas y las que estaban a punto de hacerlo, quedaban disponibles para ordeño de cuatro a seis que, según las anotaciones de las hojas conservadas del libro de la vaquería de ese año, dieron entre 59 litros diarios en octubre y 86 en julio. Tenemos constancia por las certificaciones de pagos de la compra de dos vacas el 30 de noviembre de 1926 y en el libro de la Vaquería de $1928-33^{312}$, que registra la cantidad diaria de leche obtenida, podemos comprobar que, con mucha variabilidad, la producción aumenta durante

\footnotetext{
${ }^{311}$ N.C. 1-11-1901, p 1. La Comisión Provincial aprueba el pago pendiente de leche suministrada al Hospicio y de 35 kilos de almidón por 1.400 pts.

312 Libro etiquetado como 1928. Signatura: caja 441, expediente 4091. ADPVA
} 
unos años, hasta que cae de forma importante a partir de octubre de 1932. En 1928 obtuvieron entre 58 litros [L] de media diaria en febrero y 125 L./día de media en agosto con un promedio anual de 97 L./día; en 1929 el promedio anual fue de 100 L./día. y de 103 L./día en 1930. Son cantidades claramente insuficiente para todo el personal del Hospicio (TABLA 2-6). Volviendo a la Estadística de 1908 comentada antes, a los 457 acogidos hay que sumar las 16 mujeres de la Maternidad, las 22 Nodrizas y el personal del Hospicio con derecho a "ración" que son otras 28 personas, incluidas las 18 monjas que había por entonces; lo que hace un total de "523 raciones", como se indica en la propia memoria. Los 125 litros de los mejores días darían para poco más de un vaso de leche (239 ml.) diario por persona.

De todos modos, en los reglamentos solo se contempla la administración de leche para los menores de tres años: "25 centilitros... [diarios que] se distribuirán por mitad entre el desayuno y la merienda".

En cambio, el vino, aunque no se incluye en la dieta reglamentada, aparece en todos los libros como un gasto corriente y en cantidades importantes, sirvan como muestra los 6.009 litros de 1902, con una media mensual de 575 litros que alcanzó los 812 en diciembre; los 6.590 litros de 1903 y los 7.200 de 1915, con un gasto anual que llega a superar las 3.000 pesetas y que solía requerir presupuestos adicionales. Parece mucho vino para un establecimiento de este tipo, más, teniendo en cuenta que el personal del Hospicio con derecho a ración era de 27 a 40 adultos, según los años, contando las hijas de la Caridad y sin contar nodrizas y mujeres de la maternidad. No obstante, ésta es una reflexión actual trasladada a aquella época, en la que era normal el consumo de vino en cualquier edad y condición, incluso se prescribía como fortificante para niños y amas; en el libro de contabilidad de 1863 en uno de los asientos dice "Vino para las Amas y acogidos en los días de Pascua" y en otros "cántaras de vino para las nodrizas". El consumo, y por tanto el gasto, de vino se moderó notablemente a partir de 1921, el presupuesto de ese año se rebajó de las 2.000 pts que se venían asignando en ejercicios anteriores a 360 pts. Con los libros de contabilidad del Hospicio hemos comprobado el gasto en vino de estos años. En el ejercicio 1919-20, hemos calculado a partir de los registros del libro que se compraron 6.387 litros con un gasto de $2.396^{\prime} 40$ pts, por encima del presupuesto asignado de 2.000 pts; quizás por eso se recortó al año siguiente porque en 1921 comprobamos que solamente se compraron 850 litros con un coste que calculamos en 319'50 pts, este año no llegaron a lo presupuestado. En el ejercicio económico de 1924-25 se asignaron 500 pesetas para esta partida y vemos por el libro de cuentas que 
tampoco se gastaron comprándose solamente 1.100 litros con un coste de $322^{\prime} 50$ pts $^{313}$; en 1929 se volvió aumentar hasta 800 pts, pero no hay libro de contabilidad de ese año para comprobar el gasto real. Los reglamentos de 1910 y 1927 en su artículo 273 dicen al respecto que "Sólo por prescripción facultativa se dará vino tanto a los acogidos como a las de la Maternidad e Inclusa" y en el libro de certificaciones de $1924-1925^{314}$ lo encontramos entre los gastos "Extraordinarios de enfermería" junto con pescados, limones, galletas o sesadas; los enfermos seguían la dieta prescrita por el médico.

Conocemos lo establecido en los Reglamentos, que ya marcaban una dieta en sí pobre e insuficiente, pero la realidad pudo ser bastante peor en cuanto a la cantidad y sobre todo la calidad de los alimentos servidos en el asilo, al menos en ciertos momentos. La comida pudo ser motivo de algún motín ${ }^{315}$ dentro del asilo y de algunas denuncias en la prensa e incluso dentro de la propia Diputación: "Tenemos un Hospicio... cuya alimentación ha sido mil veces incompleta" "16 "la talla de nuestros pobres hospicianos es bajísima, niños hay de doce y trece años que parece no han llegado a nueve"; tras la visita del Gobernador al Hospicio, "cada vez se confirma más la alimentación deficiente y mala que se da a los asilados", "el señor Gobernador presenció el repeso y examen de otros artículos de alimentación y... ha puesto una multa a algún abastecedor, por la calidad mala de lo que suministraba" ${ }^{317}$, en una sesión de la Comisión de octubre de 1901 se trató el tema de "la mala calidad de la comida del Hospicio" $^{318}$. El Director del Hospicio en 1906 pidió, en el informe ya mencionado que dirigió a la Diputación, que se "diera en el cocido carne diaria" a los muchachos que "asisten a los talleres" y "a algunas niñas para ayudar su desarrollo y evitar algún caso de tuberculosis". Debía ser algo público y notorio porque se hacían donativos en forma de comida tanto al Hospicio como a los demás establecimientos benéficos. Una de las razones para construir la panadería, después de valorar su rentabilidad, fue precisamente intentar mejorar este producto que resultaba caro y era de muy mala calidad, incluso el pan de primera que se compraba. Parece que el objetivo se cumplió, se surtía a los tres establecimientos provinciales de Beneficencia y después de un tiempo en marcha se pidieron informes y todos fueron muy

\footnotetext{
${ }^{313}$ Hospicio provincial. Registro de Certificaciones Año económico de 1919- 20. Signatura: caja 1226, expediente 7763; Hospicio provincial Registro... 1921- 22. Signatura: caja 920, expediente 7115; Hospicio provincial Registro... 1924 al 1925. Signatura: caja 1328 , expediente 10613

${ }^{314}$ Hospicio provincial Registro de Certificaciones Año económico de 1924 al 1925. Signatura: caja 1328, expediente 10613. ADPVA

${ }^{315}$ Cfr. PASTRANA H.: op.cit., pp 217-8

${ }^{316}$ N.C. 22-1-1901, p 1 . Artículo de crítica a la Diputación Provincial.

${ }^{317}$ N.C. 5 y 6-8-1901, p 2 y 3.

${ }^{318}$ N.C. $1-11-1901$, p 1
} 
favorables, en el sentido de que había mejorado considerablemente la calidad del pan consumido $^{319}$, incluso la prensa elogió el funcionamiento de la panadería ${ }^{320}$.

\subsubsection{LaVida en el Hospicio}

Niñas y niños del departamento de mayores estaban totalmente separados en el Hospicio; en el de menores, el dormitorio se dividía a partir de los tres años pero seguían juntos en la escuela de párvulos, de tres a siete años. Las hermanas se hacían cargo de los menores de siete años y del departamento llamado de mujeres, las mayores de siete años, y eran responsables de la tutela e instrucción de las niñas en las tareas "propias de su sexo" hasta su emancipación; mientras que los niños "se hallan bajo la tutela de varios celadores, mal pagados y con frecuencia carentes de las necesarias cualidades. A su falta de aptitud se achacan muchas de las deficiencias que se denuncian con frecuencia sobre el mal funcionamiento del Hospicio" ${ }^{\prime 321}$. En el reglamento de 1889 el departamento de hombres también se dejaba "al cuidado de las Hijas de Caridad,... auxiliadas por los celadores del

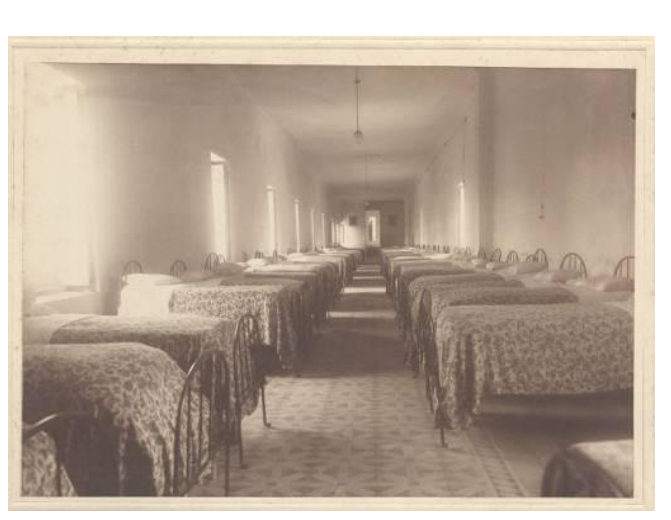

Imagen 2-7: Dormitorio de niños del Hospicio. ADPVA, sin datar, fecha probable 1911
Establecimiento", pero en el de 1910 sólo se les asignó el "aseo de los dormitorios" y los niños quedaron al cuidado de los "tres Celadores, mayores de 23 años y menores de 45, con alguna instrucción y de conducta intachable", al menos así está escrito, la realidad, por lo menos en ocasiones, era otra y hubo denuncias públicas y ceses por malos tratos y conductas inapropiadas ${ }^{322}$.

Entre las normas del Hospicio figuraban la prohibición a los asilados de fumar, beber, llevar armas, leer "libros, revistas y periódicos, sin previa autorización del Director" y utilizar "motes o apodos...que recuerden su condición de expósitos" (Art. 232, Regl.1910). "Las faltas de obediencia y aplicación, de buena conducta ó de otra clase..." recibirían "corrección" que

\footnotetext{
${ }^{319}$ Elaboración de pan. 1911. Signatura: caja 2450, expediente 30511. ADPVA

${ }^{320}$ N.C. $10-3-1917$

${ }^{321}$ PASTRANA H.: op.cit., p 207

${ }^{322}$ N.C. 4-3-1902 p 3. Una mujer que sacó a su hijo del Hospicio con 10 años puso una denuncia porque el niño tenía "tremendas contusiones por todo el cuerpo [que habían sido causadas por] un celador del Hospicio, dándole golpes con un garrote. El niño se encuentra grave...". El celador acabó siendo cesado.
} 
podía ir de una simple amonestación al aislamiento en celdas de castigo o a la expulsión del centro, aunque "en ningún caso se infligirá a los asilados castigo corporal, ni serán maltratados (Art. 136-7, Regl.1889; Art. 285-7, Regl.1910).

Los hospicianos podían recibir visitas los domingos, dos horas por la mañana y por la tarde (Art. 236, Regl.1910), sólo en “casos especialísimos y por motivos justificados" podían ser visitados fuera del horario establecido. También podían salir del Hospicio, sin pernoctar fuera, previa solicitud de sus parientes o personas responsables (Art. 247, Regl.1910); se quitó un artículo que aparece en el reglamento de 1889, el no 123, que establecía que los acogidos podían salir de paseo en los días fijados por el Facultativo y el Director acompañados por las Hijas de la Caridad las niñas y los niños por celadores. Aunque no sabemos con qué frecuencia, se hacían salidas y en ocasiones especiales las recogía la prensa (en Semana Santa procesionaban con el Santo Entierro, en las Ferias también acudían a celebraciones y recibían invitaciones para asistir a novilladas o al circo, pagado por donantes ${ }^{323}$ )

La escuela era obligatoria y funcionaba todo el año en dos sesiones de mañana y tarde, de manera "que los niños permanezcan en el local de la Escuela durante las horas más rigurosas del día", cinco o seis horas diarias, excepto en julio y agosto que eran sólo tres. Sólo tenían "vacación en las Escuelas los Domingos y días festivos, y media vacación en los días de Carnaval, Semana Santa y Pascuas de Navidad, limitando su duración todo lo posible" ${ }^{\prime 324}$.

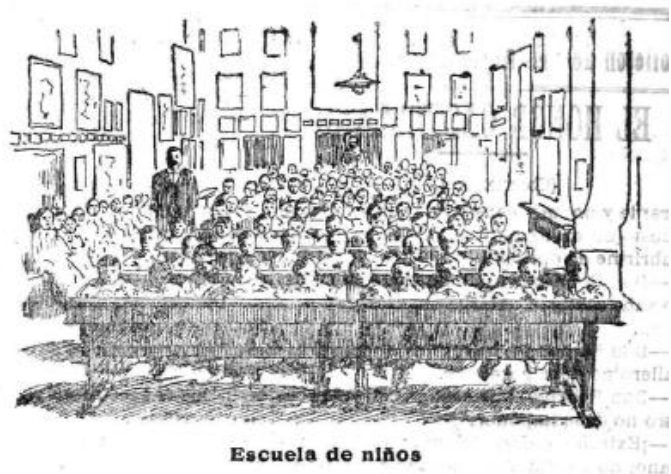

Imagen 2-8: Dibujo de la escuela del Hospicio. N.C. 6- 11904

La escuela de niños estaba a cargo de un maestro, que muchas veces faltaba, ayudado por un auxiliar y "dos pasantes de la clase de los acogidos... [que] se elegirán de entre los más adelantados de la Escuela... [y] les servirá de méritos para darles gratuitamente la carrera del Magisterio". Los maestros se sucedían, su inestabilidad constituía un serio problema y con frecuencia se denunciaba la escasa y mala formación que recibían los niños, además, la escuela tenía unas condiciones tan deplorables que El Norte de Castilla en 1901 la califica de "antro nauseabundo" y en 1899 denuncia que "la gran acumulación de niños, la mayoría de ellos de

\footnotetext{
${ }^{323}$ N.C. 25 y $26-9$-1902, p 2; 21-9-1904, p 1; 26-9-1905, p 1; 6-4-1912, p 1

${ }^{324}$ Todo lo referente a la instrucción de los asilados y las escuelas del Hospicio se recoge en el Título 17 del Regl.de 1889 y los Capítulos IX, X, XI y XII del Regl.1910 y 1927.
} 
corta edad, en un local reducidísimo, bajo de techo, falto de luz y ventilación, es causa necesaria de un positivo peligro para la salud de todos..." ${ }^{1325}$.

La escuela de niñas y de párvulos, la llevaban las monjas y el reglamento establece que "la Hermana que esté al frente... deberá hallarse en posesión del título de Maestra". El local también tenía muchas deficiencias aunque estaba en mejores condiciones, en 1906 se construyó una nueva escuela de niñas y en 1911 para los niños.

Para los asilados adscritos a los talleres funcionaba una escuela nocturna, a la que tenían que asistir desde el $1^{\circ}$ de Noviembre hasta el fin de Marzo, una hora y media o dos después de la cena. Los reglamentos dicen que estos talleres eran para niños mayores de 14 años, Art. 124 Regl.1910 y 122 Regl.1927, Capítulo XV De los Talleres:

\begin{abstract}
"Para el pase de los acogidos a taller será preciso que además de contar con la edad de 14 años cumplidos, o la que en su caso se halle determinada por disposiciones superiores, emitan informe favorable por escrito el Maestro de la Escuela y el Médico del Establecimiento. En el informe del Maestro se hará constar el grado de instrucción del asilado, y en el del Médico se hará mención de la complexión física y desarrollo corporal; expresando uno y otro los oficios a cuyo aprendizaje puede ser destinado el acogido, según sus condiciones."
\end{abstract}

Era una norma que el Hospicio se saltaba, incluso para los niños que salían del hospicio como aprendices o ayudantes; se podían amparar en la coletilla "o la que en su caso se halle determinada por disposiciones superiores". En la Memoria de 1908, referida anteriormente, se dedica una hoja para recoger "Ocupaciones y estado físico de los asilados mayores de 12 años" (la negrita es nuestra). Había 39 niños en los talleres del Hospicio, la imprenta era la que más ocupaba con 14 muchachos, el resto se repartía entre carpintería, albañilería, zapatería, sastrería y tejedores, en este año todavía no funcionaban la panadería ni la alpargatería. Hay que sumarles 2 vaqueros, 2 hortelanos, un carretero y un recadista; en total 45 muchachos. En la misma relación encontramos además 19 que tocaban en la banda, 33 que estudiaban música y 3 para Maestros. En la misma cuartilla hay una segunda columna en la que se recoge la lista de los que tenían defectos que les impedían trabajar: "Raquíticos y casi ciegos 3; Ataques periódicos nerviosos 1; Defectos que les impide trabajar (Hernias) 3" y en la última fila se anotan a los que tenían "Mal olor de aliento 2". Hay también un listado para "las niñas que están en el Asilo de más de 17 años de edad" que traemos completa porque resulta realmente curiosa, aparte de mostrar la diferencia a la hora de darles destino, no hay talleres para ellas, no cuentan como tal los de costura o la cocina y la lavandería donde ayudaban, lo que quiere

\footnotetext{
${ }^{325}$ N.C. 13 de febrero de 1899, p 1 y 22 de enero de 1901, p 1.
} 
decir que tampoco se les daba ninguna gratificación por ello y las destinadas para estudiar, sobre todo música, son bastante menos:

\begin{tabular}{|c|c|}
\hline \multicolumn{2}{|l|}{ De las 38 niñas que están en el Asilo de más de 17 años de edad } \\
\hline 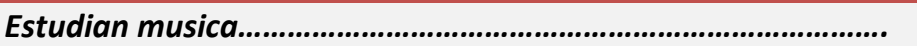 & 4 \\
\hline 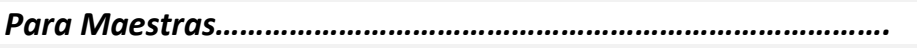 & 2 \\
\hline 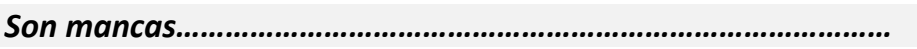 & 2 \\
\hline 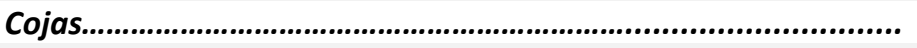 & 3 \\
\hline 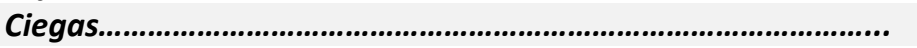 & 2 \\
\hline 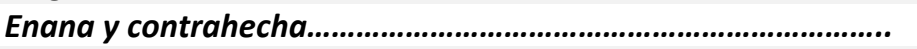 & 1 \\
\hline 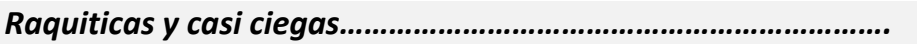 & 2 \\
\hline Maniaticas y alguna con amagos de locura............................... & 6 \\
\hline 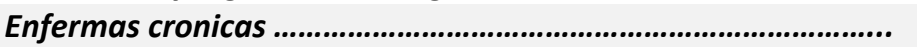 & 6 \\
\hline 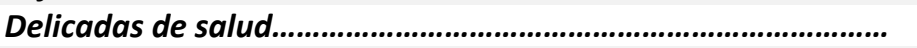 & 4 \\
\hline 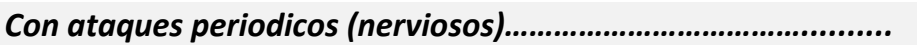 & 1 \\
\hline 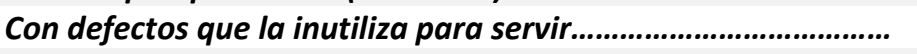 & 1 \\
\hline 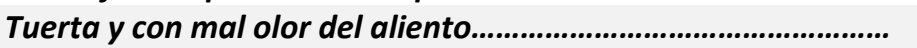 & 1 \\
\hline
\end{tabular}

TABLA 2-7: Reproducción literal del listado que se encuentra en la Memoria de 1908 sobre la ocupación de las niñas mayores de 17 años. ADPVA

Los horarios de los talleres eran similares a los que hacían fuera del Hospicio las industrias análogas y los chicos cobraban una gratificación dependiendo de su nivel: el primer año nada, el segundo "0'15 pesetas y el tercero 0'30 por día completo de trabajo", dinero que se les ingresaba en un cartilla de la Caja de Ahorros y del que les daban un 10\% en "Semana Santa y ferias de Septiembre".

Dicen los Reglamentos de 1910 y 1927 que después de la escuela o los talleres, el resto del tiempo debía dedicarse a "Ias prácticas religiosas, á las comidas y á un prudencial espacio para el recreo diario, se procurará que ningún asilado útil permanezca ocioso en el Establecimiento" (Art. 234-5,). También podemos leer en el Art. 224 que "Habrá en el Establecimiento "un local destinado a Gimnasio higiénico, donde acudirán diariamente todos los asilados que a juicio de los Facultativos necesiten ese medio de desarrollo físico". En los presupuestos

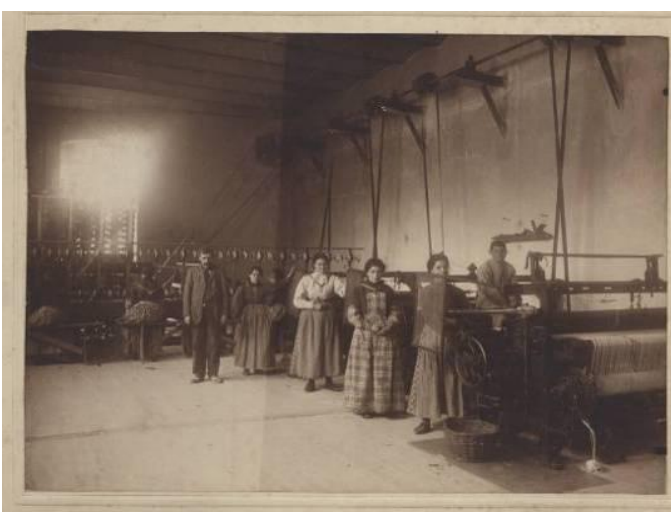

Imagen 2-9 Taller de tejidos del Hospicio. ADPVA, sin datar, fecha probable 1911 desde 1925 se contempla el jornal del Profesor de Gimnasia, con 1.250 pesetas anuales, pero no hemos encontrado consignados los 
pagos en los libros del Hospicio ni ningún documento que haga alusión a este asunto. Otra cuestión interesante sería saber qué niños podían ser candidatos a esta actividad.

\title{
2.2.4.6. Salida del Hospicio y Baja definitiva
}

El límite de edad para el acogimiento se estableció en 20 años, excepto para los que tenían la suerte de estudiar alguna carrera, pagada por la Diputación, en cuyo caso permanecían hasta terminarla, siempre que demostraran buen aprovechamiento: "En 31 de marzo de 1926 cumpliendo con lo preceptuado en el arto 239 del Reglamento de este Hospicio, causó baja definitiva por haber terminado la carrera de Sacerdote", (fo 442 del Libro de Mayores de 1906, el muchacho tenía 25 años). Entre los libros de gastos encontramos pagos por matriculas, derechos de examen y libros de asilados, de ambos sexos, que estudian, la mayoría la carrera del Magisterio. En los Libros de Exposiciones revisados encontramos muchos casos, sobre todo de mujeres, a las que se les daba de baja pasada esa edad, algunas se emancipaban a petición propia (fo 127 del libro de 1904 se emancipó con 26 años) y otras cuando contraían matrimonio (f o 168 del Libro de Exposiciones de 1906, baja a los 23 años), con el oportuno consentimiento de la Diputación Provincial que les concedía una dote de 200 pesetas $^{326}$.

Los expósitos y huérfanos podían solicitar la emancipación a partir de 17 años los chicos y 18 las chicas. Los padres podían solicitar la salida del hospiciano en cualquier momento, o, en su caso los familiares más cercanos siempre que tuviesen medios para criarlo; muy pocos niños mayores volvían con sus padres. En la Memoria del año 1905 se devolvieron 6 lactantes, 22 niños de destete y no consta ninguno mayor de 5 años, aunque en 1908 volvieron con sus familias 26 niños de este grupo de edad.

\begin{abstract}
"Inscrito en Pedrajas de San Esteban el 27 octubre de 1893
En 4 de Septiembre de 1910 cumpliendo acuerdo de la Comision Provincial fue emancipado por haber cumplido la edad reglamentaria, siendo entregado a su madre Julia Lopez que le ingreso en el patronato de Niños desamparados. En prueba de conformidad no firma ei recibo por no saber pero se extiende esta diligencia a su presencia y a su lectura se manifiesta conforme ${ }^{1327}$ [sic]
\end{abstract}

Este es un caso peculiar porque no suelen darse tantas explicaciones, además, se emancipó al chico con 17 años sin haberlo solicitado él, cuando había asilados con edades

\footnotetext{
${ }^{326}$ N.C. 2- 3- 1911 . Se atendían las peticiones en las sesiones de la Comisión Provincia, cuyos acuerdos se publicaban en los diarios.

${ }^{327}$ Sin no de filiación. Folio no 121 del Libro de mayores acogidos 1906 -1911. ADPVA
} 
superiores, y lo entregaron a su madre, que tampoco consta que lo hubiera solicitado, y que a su vez lo ingresó en el Patronato de Niños Desamparados ${ }^{328}$ que en esta época cumplía funciones de reforma ${ }^{329}$. Todo esto nos hace pensar que debía tratarse de un muchacho problemático, podían ser expulsados del Hospicio a cualquier edad por faltas graves. No hemos localizado registros donde se indiquen las faltas cometidas ni el paradero de estos muchachos:

"... inscripto en el R.C. de la Audiencia en 17 Noviembre 1898

1915-10-02 Cumpliendo acuerdo de la Comision Provincial fue espulsado del Establecimiento por faltas cometidas en el mismo" [sic $]^{330}$

A las "jóvenes en estado de servir" el Hospicio les procuraba colocación en el servicio doméstico, con un contrato en el que se estipulaba el salario a cobrar, los Reglamentos lo contemplan en los artículos 242-4. Los asilados podían solicitar la salida para trabajar o podían ser solicitados por el contratante, las niñas iban de sirvientas, los chicos para distintos oficios. No hemos encontrado una edad mínima para el trabajo de las niñas, para los chicos estaba dispuesto que fueran mayores de 16 años; sin embargo, igual que ocurría con los talleres, vemos en los libros que esta norma no siempre se respetaba. "En 22 de Junio de 1920, cumpliendo acuerdo de la Comisión provincial... fue entregado para enseñarle el oficio de hortelano..." ${ }^{331}$ un muchacho que contaba entonces con 13 años. "En 12 de Julio de 1911, cumpliendo acuerdo... fue entregada... para servicio doméstico... [una niña de 15 años] obligándose a satisfacerla un salario mensual de 6 pesetas mensuales por hora" [sic] ${ }^{332}$.

Aparte de los que "oficialmente" trabajaban, en los libros de registro encontramos con frecuencia niñas y niños que salían, desde que eran considerados ya mayores, "para compañía", normalmente de matrimonios que lo solicitaban.

\footnotetext{
${ }^{328}$ Los patronatos en la época eran "obras pías" creadas con fines benéficos y caritativos para atender a sectores marginados de la sociedad y funcionaban como una especie de sociedades tutelares. El Patronato de Niños Desamparados de Valladolid se fundó en 1904 por iniciativa de D. José María Cos y Macho, arzobispo de Valladolid, con la misión de "recoger, alimentar y educar, preservando, á los pobres muchachos, que con el dictado de Golfos, recorren las calles de la población, vagando y atemorizando muchas veces á la gente pacífica y perjudicando no pocas con sus raterías y malas mañas á honrados artesanos" [sic]. Empezó funcionando como una escuelacomedor con 110 muchachos a los que daban comida y merienda a la vez que les instruían "en la doctrina cristiana", les proporcionaban ropa y cama y les buscaban "ocupaciones" como aprendices o en labores temporales del campo. Se adquirió una finca de 130.000 pies cuadrados entre las calles Mirabel, Rondilla de Santa Teresa y la Plaza de San Nicolás y en 1906 se hicieron cargo las Hermanas de la Caridad constituyéndose como asilo, aunque siguió funcionando la escuela-comedor, los propios asilados participaron en las obras de reforma. "Los fondos... del Patronato son cuotas, limosnas y donativos destinados á [sic] los muchachos y empleados por orden del Sr. Arzobispo para la extinción de la Golfería y educación de esta clase desheredada de jóvenes del arroyo". (Patronato de Niños Desamparados de Valladolid-Memoria-Circular. Valladolid. 1907.

${ }^{329}$ Posteriormente pasaría a ser un asilo para jóvenes conflictivos y acabaría transformándose en Reformatorio en 1912 siendo trasladado finalmente al Pinar de Antequera en 1930. REVUELTA GUERRERO R.C.; GALENDE MATEOS A.: La Prehistoria para el Tribunal de Niños de Valladolid (1904-1948)

${ }^{330}$ No da más información. Folio no 83 del Libro 16 de mayores acogidos 1906 -1911. ADPVA

${ }^{331}$ Folio no 85 del Libro de Exposiciones de 1907, tomo 10. ADPVA

${ }^{332}$ Folio no 357 del Libro de mayores acogidos 1906-1911. ADPVA. Vimos otro ejemplo en el apartado dedicado a este libro en el que se entrega un niño de 15 años "para el oficio de herrero y carretero".
} 
"En 17 de Enero de 1914 cumpliendo acuerdo de la Comisión provincial fue entregada [una niña de 7 años] á Juan Sanchez Tejedor casado y vecino de Olmedo para compañía del matrimonio y no firma por no saber" [sic]. ${ }^{333}$

No todos los niños entregados eran tan pequeños, "En 27 de Mayo de 1915 y en virtud de orden del Sr Vicepresidente fue concedido... para compañía" un niño de trece años ${ }^{334}$. Salidas como ésta resultan un poco sospechosas cuando con esta edad ya se concedían niños para trabajar. En el libro de Exposiciones de 1907, folio no 403 consta la entrega de un niño de 12 años "para compañía y ayudarle en el oficio de cantero...", cuatro años después el niño se fugó y volvió al Hospicio, donde permaneció hasta que a los 21 años solicitó la emancipación.

Encontramos más de un caso como éste, niños que se entregan muy pequeños para "ayudar" y se escapan para volver al Hospicio.

"1916-01-28 [sic] Cumpliendo orden del Sr Vicepresidente... fue entregado para el oficio de herrero y carretero [con 15 años]...

28 Marzo= 1916 Se presento en esta dirección Julio $L$ á quien fue concedido declarando que se le había escapado...

29 Marzo 1916=Se presento el asilado en este asilo donde quedo.

En 20 de Agosto de 1918 fallecio en el rio Pisuerga a consecuencia de Asfixia por inmersion en el agua ${ }^{\prime 335}$ [sic]

Teniendo en cuenta las condiciones de vida del Hospicio, que no eran nada buenas, para que volvieran tras fugarse es de suponer que con los "cuidadores" que les asignaron debían encontrarse peor, pero en los libros no se da ninguna explicación.

También había fugas del Hospicio

"En 22 de noviembre de 1922 se fugó de este Asilo y se puso en conocimiento de la Comisión Provincial... En 8 de noviembre de 1923 fue dado de baja definitiva"336

y era habitual que se publicara en los diarios tanto las fugas como el reingreso en el Hospicio cuando los localizaban ${ }^{337}$. Los niños fugados que tenían más de 17 años, o de 15 si eran reincidentes, se daban de baja definitiva, las fugas de menores se ponían en conocimiento de las autoridades civiles, o de sus padres cuando los tenían. Una vez localizados, la Guardia Civil los devolvía al Hospicio, salvo que hubieran ido con su familia.

"En 29 de junio se escapó de este establecimiento y habiendo dado conocimiento al Sr Gobernador de tal fuga según comunicación fecha 16 de Julio comunican que según diligencias practicadas por Vigilantes de la inspección,

\footnotetext{
${ }^{333}$ Folio no 76 del Libro 16 de mayores acogidos 1906-1911. ADPVA

334 Folio no 79 del Libro 16 de mayores acogidos 1906-1911. ADPVA

${ }^{335}$ Folio no 74 del Libro 16 de mayores acogidos 1906-1911. ADPVA

${ }^{336}$ Folio no 71 del Libro de Exposiciones de 1907. ADPVA

337 N.C. 12-8-1902, p 3, se fugaron dos muchachos de 12 y 13 años, les detuvieron y devolvieron al asilo. El 2- 91902 se publica la fuga de una muchacha, no dice edad, que detuvieron en Torrelobatón.
} 
resulta que dicho asilado se halla en Ampudia en compañia de su familia por lo cual es dado de baja en este Asilo" [sic $]^{338}$

En los niños que salían del Hospicio para compañía o trabajo, las fugas y sobre todo las devoluciones al poco tiempo de su salida eran muy frecuentes, debemos de sospechar de situaciones de mala adaptación en el mejor de los casos, si no de malos tratos por parte de los cuidadores, no podemos asegurar nada con certeza porque ya hemos dicho que era normal no anotar en los libros de registro ningún comentario al respecto, aunque encontramos alguna excepción; casos de falta de cuidados y malos tratos por parte de los cuidadores, pocos para los que probablemente debía haber. Cuando el Hospicio tenía conocimiento del hecho y lo confirmaba, retiraba los niños que retornaban al asilo:

"En 9 Diciembre de 1910 fue devuelta por haberse denunciado en esta Direccion que los que la tenian vecinos de esta ciudad estaban muy pobres y la dedicaban a pedir limosna. Procede de la Exposición de 1905 folio 80"[sic $]^{339}$.

No se podían entregar niños para crianza a gente que no tuviera medios para mantenerlos, por lo que se ve, en este caso no se tomaron las debidas precauciones cuando se entregó la niña en 1905 a una nodriza externa, ni parece que la controlaran después. Lo más lamentable es que estas situaciones "casi" se justificaban. En el folio de inscripción de esta niña en el libro de Exposiciones de 1905 también se anota y se explica la vuelta al orfanato:

"En 9 Diciembre de 1910 reingreso en este asilo por haber sido recogida por la Direccion á virtud de denuncia de que los que la tenian son muy pobres y no podian mantenerla teniendo que dedicarla a pedir limosna. Todo lo que fue comprobado. Pasa al libro de 16 de mayores fo 400

En 2 Enero de 1911 la llevo Gregoria Cuesta..." [sic]

Más raro todavía es encontrar casos en los registros de denuncias de malos tratos hechas por los propios hospicianos como el de esta asilada de 17 años:

"Habiendose quejado esta asilada de los malos tratos que recibia en la casa que se encontraba la Comision Provincial en sesión de 24 de Febrero de 1911 acordó á instancia de Bernarda Ramos viuda vecina de Olmedo entregarla a la Marina San Jose (la asilada) para compañía en vistas de sus buenos antecedentes y quejas de la asilada referente á su anterior salida..." [sic] ${ }^{340}$

A Antonio le expusieron en el torno en 1912, hijo legítimo, su madre falleció. Le crió una nodriza externa decidió prohijarle al final del periodo de crianza remunerado, a los 6 años, pero tres meses después lo devolvió (30 de enero de 1918); salió de nuevo a los 11 años "para compañía de matrimonio" (7 de diciembre de 1923) y fue devuelto al Hospicio en 1928; el "4 de Marzo de 1930... fue entregado para dedicarle al oficio de panadero a Dn Marcelino...

\footnotetext{
${ }^{338}$ Folio no 115 del Libro 16 de mayores acogidos 1906-1911. ADPVA

${ }^{339}$ Folio no 400 del Libro 16 de mayores acogidos 1906 -1911. ADPVA

${ }^{340}$ Folio no 187 del Libro 16 de mayores acogidos 1906-1911. ADPVA
} 
comprometiéndose a entregar quince pesetas mensuales en esta dirección para la cartilla del acogido...", tenía en este momento 18 años, a los pocos días (el 30 de marzo) reingresó en el Hospicio y solicitó su emancipación concedida el 3 de junio ${ }^{341}$.

Historias como ésta, de entradas y salidas repetidas del Hospicio, encontramos muchas en los libros, podían reingresar si tenían menos de 20 años y casi nunca se registraba la causa del reingreso. Después de los miles de registros vistos, podríamos decir que éste fue un niño con suerte, primero por sobrevivir al orfanato y luego porque hasta los seis años, para bien o para mal, eso no podemos saberlo, tuvo estabilidad en cuanto a su "grupo familiar"; muchos niños ya durante el periodo de lactancia y destete pasaban por varias nodrizas y luego de mayores seguían cambiando de "cuidadores", aunque es éste un término que en muchas ocasiones no se podría aplicar a los que se hacían cargo de estos muchachos.

${ }^{341}$ Folio no 71 del Libro de Exposiciones de 1912, tomo 1‥ ADPVA 
Capítulo 3

\section{LA INCLUSA DEL HOSPICIO PROVINCIAL DE VALLADOLID}

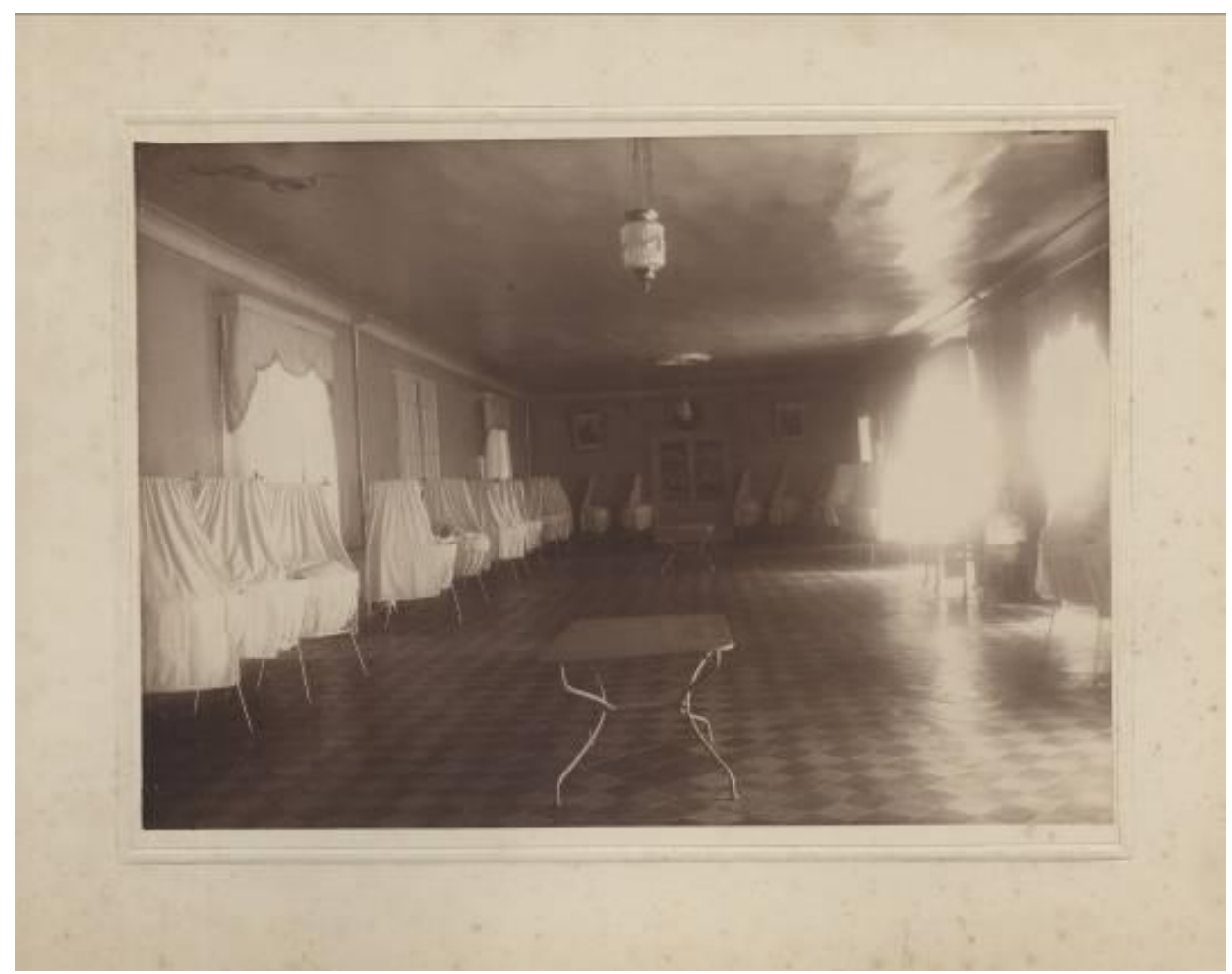

Imagen 3-1: Sala de Cunas del Hospicio Provincial. Archivo de la Diputación Provincial de Valladolid. Sin datar, fecha probable 1911 


\section{ÍNDICE DEL CAPÍTULO}

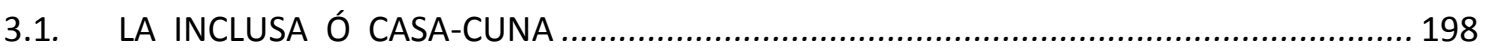

3.2. POBLACIÓN DE LA INCLUSA. MOVIMIENTO DE LACTANTES Y NIÑOS DE DESTETE. ...... 203

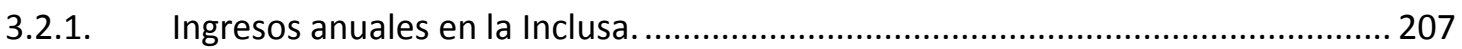

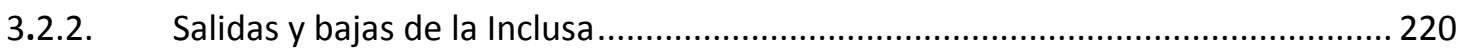

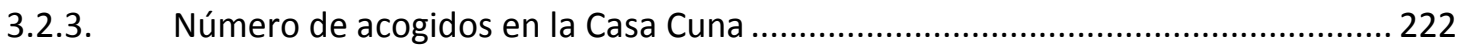

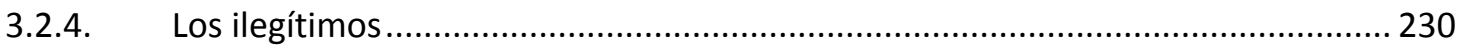

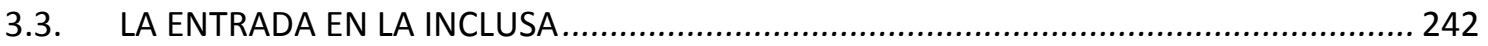

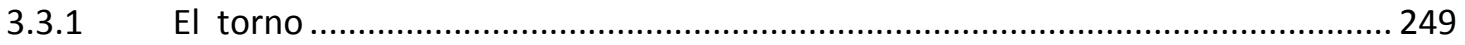

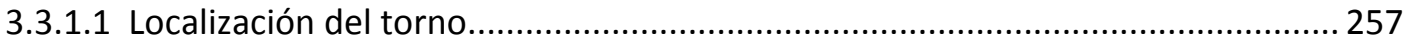

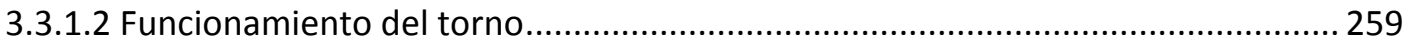

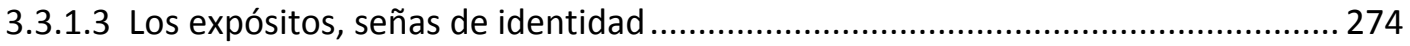

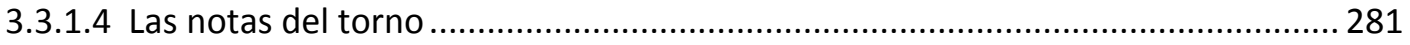

3.3.1.5 Marcas, recuerdos y señales de identificación ...................................................... 296

3.3.2 Vía oficial de ingreso en la Inclusa. Comisión Provincial de la Diputación y Gobernador civil ....................................................................................................309

3.3.3 Los expósitos de los pueblos de la provincia ........................................................... 321

3.3.3.1 Lugar de origen de los niños de la Inclusa de Valladolid..................................... 331

3.3.4 La Maternidad del Hospicio Provincial de Valladolid ............................................. 337

3.3.5 Los niños nacidos en el Hospital Provincial de la Resurrección ............................. 362

3.4 CONDICIONES DE VIDA Y CUIDADOS DE LOS NIÑOS DE LA INCLUSA ............................ 367

3.4.1 Identidad e identificación de los incluseros ............................................................ 374

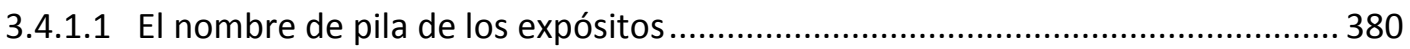

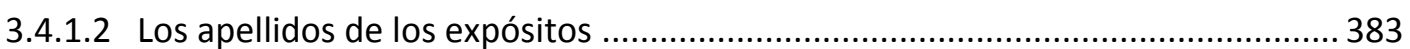

3.4.1.3 Identificación y registro para el control de los incluseros..................................... 392

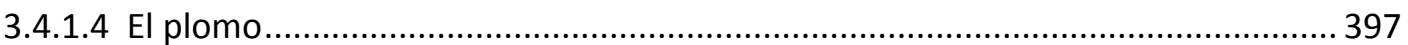

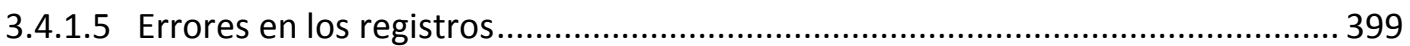

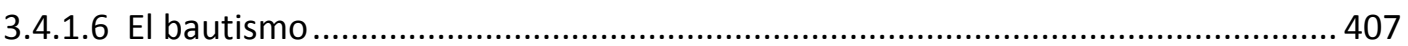

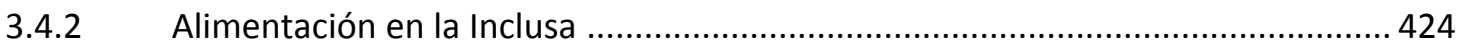

3.4.2.1 Lactancia materna y lactancia mercenaria........................................................ 425

3.4.2.2 Las nodrizas internas, un grave problema para la Inclusa .................................. 433

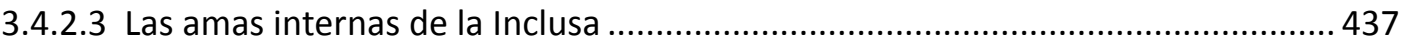

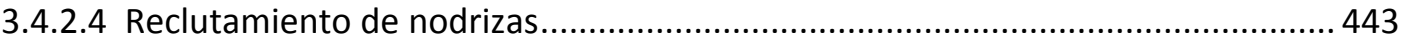

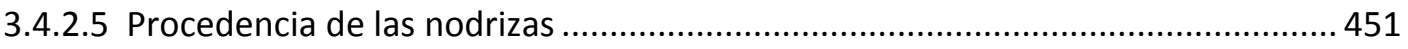

3.4.2.6 Patrón de comportamiento de las refugiadas..................................................... 454

3.4.2.7 Productividad de las nodrizas internas ............................................................... 456 


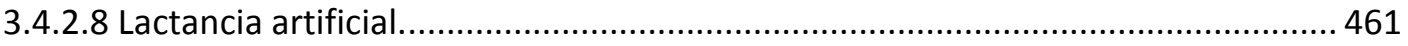

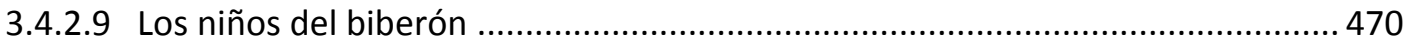

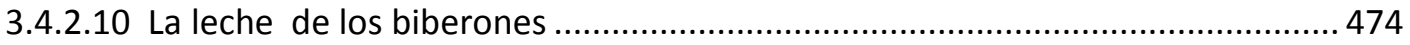

3.4.2.11 La alimentación complementaria y el destete .................................................... 477

3.4.2.12 Alimentación fuera de la Inclusa ......................................................................... 483

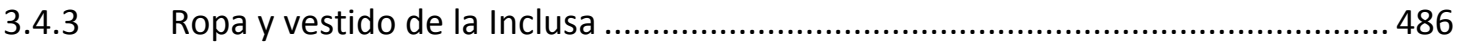

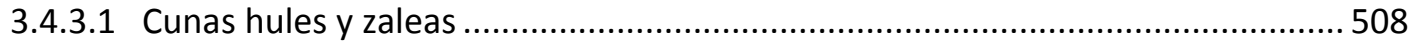

3.4.4 Higiene y salud de los niños de la Inclusa. ........................................................ 510

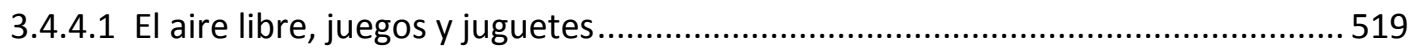

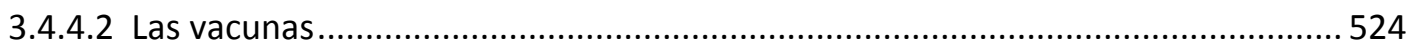

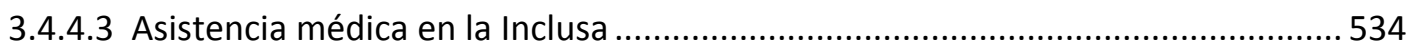

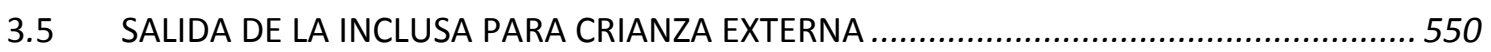

3.5.1 Los niños de la Inclusa reclamados por su familia .................................................. 555

3.5.2 El prohijamiento administrativo de los niños de la Inclusa....................................561

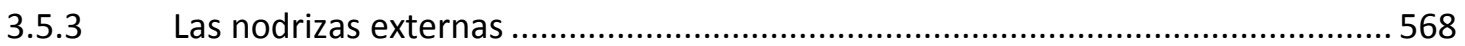

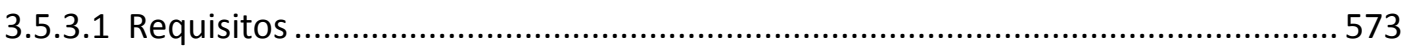

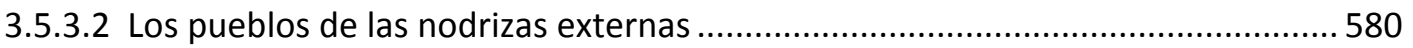

3.5.3.3 Devolución e intercambio de expósitos ............................................................. 583

3.5.3.4 Salarios, cartillas de cobranza y comisionados ..................................................... 590

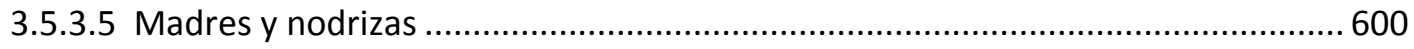

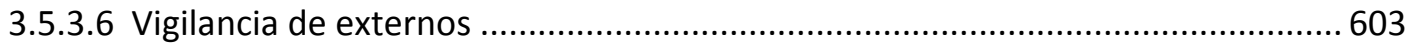

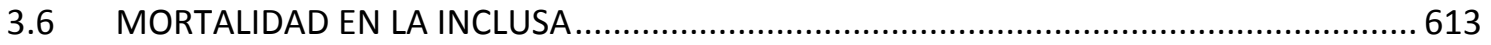

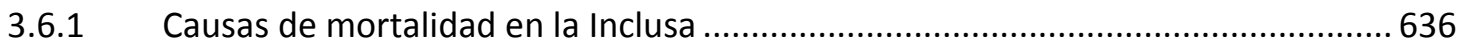

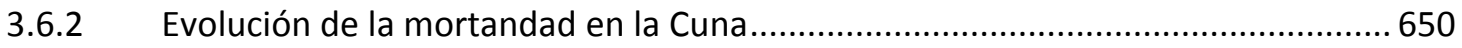




\subsection{La INCLUSA ó casa-CUNA}

Abandonado por mis padres, la caridad me recoge

Lema del torno de la Inclusa de Madrid

Las Inchusas son establecimientos llamados de beneficencia, verdaderos vertederos que recogen las inmundicias de la sociedad

Dr. Vidal Jordana. ${ }^{342}$

a Inclusa" era el nombre con el que también se conocía el "Departamento de Lactancia" y por extensión el departamento de Menores del Hospicio Provincial de Valladolid. Es el nombre que recibían en general las casas de acogida de expósitos, también llamadas casas Cuna.

En el Regl. de 1889 del Hospicio Provincial de Valladolid aparecen por separado los departamentos de" Lactancia" y de "Conservación y crianza de los niños menores de siete años"; posteriormente en los Reglamentos de 1910 y 1927 se habla del Departamento de la Casa-Cuna para referirse a los dos de forma conjunta, aunque en algunos documentos se llama también Inclusa, y en los Presupuestos Generales de la Diputación figura como departamento de Expósitos. En definitiva, se consideraban como una sección diferenciada del resto del hospicio, llámese Inclusa, Cuna o Casa de Expósitos.

Los Reglamentos de 1910 y 1927 siguen considerando dentro del Hospicio las mismas cuatro secciones determinadas en el de 1889 , con un ligero cambio en la forma de denominarlos

"Art. $4^{\circ}$ La Casa-Hospicio de Valladolid se divide en cuatro secciones o departamentos, a saber:

$1 .^{\circ}$ De niños menores de siete años.

${ }^{342}$ Conferencia del catedrático Vidal Jordana, Catedrático de Enfermedades de la Infancia de la Facultad de Medicina de Valladolid, en la Universidad de Valladolid sobre el tema "El problema de las Inclusas en España", artículo publicado en N.C. 3- 04-1927, p 3 
2. ${ }^{\circ}$ De niños mayores de siete años.

3. ${ }^{\circ}$ De lactancia o Inclusa.

4. 'De Maternidad"

Denominan Inclusa al Departamento de Lactancia, sin embargo no desarrollan un capítulo destinado específicamente a esta sección como hacía el Reglamento de 1889. En los nuevos reglamentos se dedica un título al Departamento de La Casa-Cuna, un término también muy utilizado en la época para referirse a este tipo de establecimientos, y que en la normativa del Hospicio designa de forma conjunta a las secciones de la Inclusa y de Menores. Existe cierta confusión con los términos porque, aunque generalmente por Inclusa se refieren al departamento de Lactancia y por Cuna a los dos en conjunto, en documentos tanto oficiales como oficiosos del Hospicio se utilizan de forma indistinta; por ejemplo en los Presupuestos generales de la Diputación de 1920-21 encontramos una partida para "harina lacteada, lactosa y similares para los niños de la Inclusa" y otra "para los gastos que origine la esterilización de la leche con destino a la Cuna", a pesar de que se refiere también a la Inclusa porque en el departamento de menores ya no había niños con lactancia. Realmente, la mayoría de las veces resulta irrelevante utilizar un nombre u otro ya que en definitiva se habla de infantes de muy corta edad y a la sección de menores pasaban niños con 15 meses, que desde el punto de vista pediátrico los consideramos todavía lactantes (hasta los 24 meses).

Tres eran los requisitos de admisión que establecían los reglamentos del Hospicio Provincial de Valladolid en su Departamento de la Casa-Cuna, la ilegitimidad y/o la pobreza y la edad menor de siete años. Los niños ilegítimos entraban directamente sin más requisitos, bastaba con exponerlos. Los hijos legítimos debían ser admitidos por la Comisión de La Diputación Provincial, previa solicitud

\footnotetext{
"Se recibirán en él [Departamento de la Casa-Cuna] todos los niños de ambos sexos habidos ilegítimamente y los de legítimo matrimonio que quedaren huérfanos antes de los siete años, en estado de pobreza. Estos no podrán ser admitidos sin previo acuerdo de la Diputación provincial.

Para recibir á los primeros deberán ser expuestos en el torno que con dicho fin se hallará colocado en el exterior del edificio"
}

Reglamento de 1910, Capítulo XXXII. Art. 307

La Inclusa y la Sala de Menores del Hospicio Provincial de Valladolid estaban "bajo la vigilancia, custodia y responsabilidad de las Hermanas de la Caridad" que se encargaban, además, de controlar a las nodrizas y las cuidadoras de los niños. 
La Inclusa, como otras zonas del Hospicio Provincial de Valladolid, también sufrió reformas, se conserva un plano del arquitecto provincial Santiago Guadilla fechado en $1910^{343}$ que debe ser el proyecto de la obra que se realizaría por entonces. En él podemos ver la

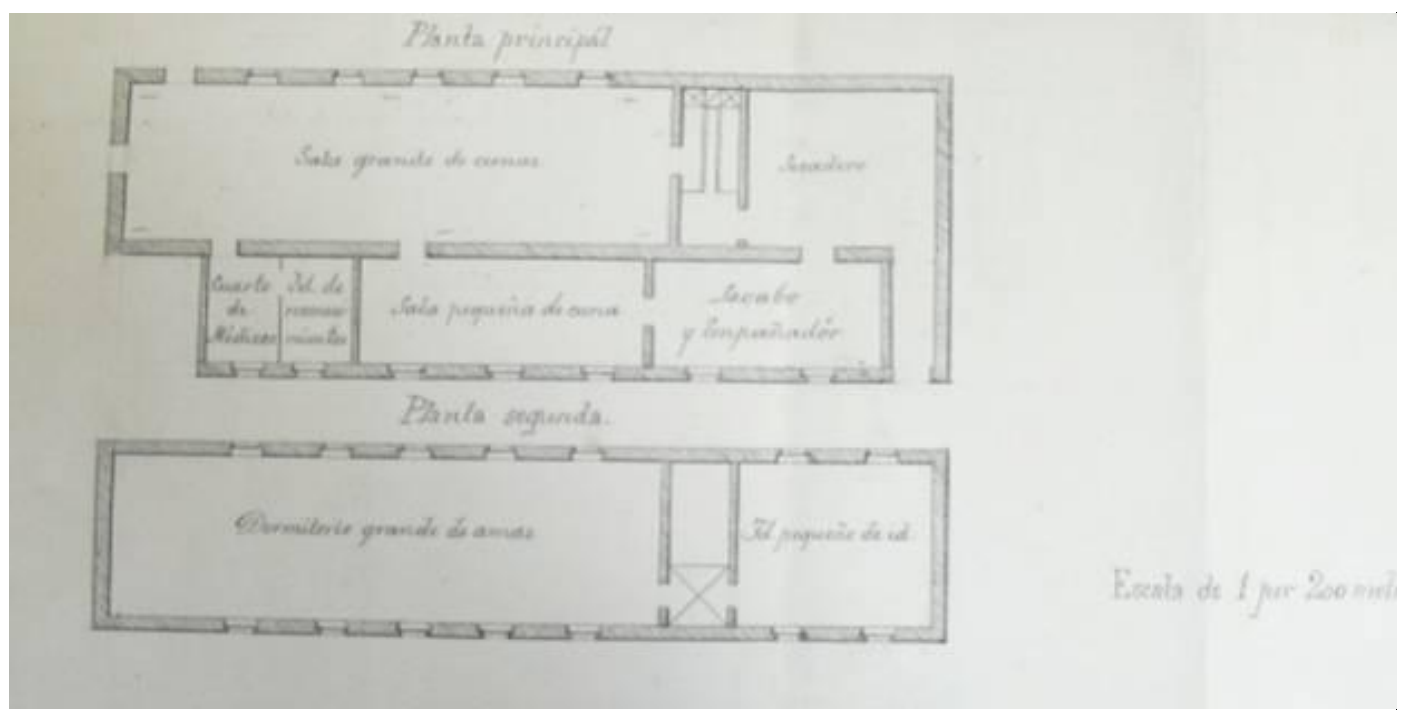

Imagen 3- 2: Plano de los dormitorios de niños y amas de la Inclusa. Santiago Guadilla, 1910. ADPVA

disposición de las salas de cunas y de nodrizas, una sobre otra, no se indica en qué parte del edificio se localizaban; sin embargo, comparándolo con el plano que nos ofrece Juan José Martín González ${ }^{344}$ podría corresponder al ala de poniente, la que da hacia el rio, en el primer patio y ocupando la primera y segunda planta (ver Imágen 3-4). La Galería Alta que se ve en el plano general podría corresponder al brazo que sobresale en la planta principal sobre la segunda planta en el plano de la Inclusa (IMAGEN 3-2). En este plano, en la planta principal se ven dos salas que comunican entre sí, denominadas en él "Sala grande de cunas" y, en lo que podía ser la galería cerrada, la "Sala pequeña de cuna". Junto a ellas, se encontraba el consultorio médico, dividido a su vez en un "Cuarto de médicos" y un "Id de reconocimientos". La Sala grande tiene cinco ventanas en una pared que debían dar al patio principal, y la Sala pequeña tres, que darían hacia el patio exterior que daba al paseo de las Moreras y al río, pero no debía gozar de mucha claridad ni de buena ventilación porque en el "Dictamen que la Comisión de Presupuestos presenta a la Diputación con el proyecto de presupuesto extraordinario para el año 1927" se justifica el arreglo de un "patio donde estuvo instalado el lavadero viejo ...porque a él confluyen las galerías de la Inclusa, y es de necesidad dotar[la] de ventilación, luz y alegría..." (p 21). Completando el ala, del otro lado de la escalera de acceso a

\footnotetext{
${ }^{343}$ Signatura: caja 245, expediente 2768. ADPVA

344 MARTÍN GONZÁLEZ J.J.: Monumentos civiles de la ciudad de Valladolid. Valladolid. Institución cultural Simancas. 2a edición 1983
} 
la planta, hay un cuarto para "Lavabo y Empañador ${ }^{345 "}$ y un "Secadero", que también comunican con las salas de cunas. Justo encima, en la segunda planta, se encuentran los dormitorios de las amas comunicando con las salas de cunas por una escalera de acceso. El "Dormitorio grande de amas" queda sobre la "Sala grande de cunas" y tiene diez ventanas entre las dos fachadas, la exterior y la que da al patio, el pequeño queda sobre el secadero y cuenta con cuatro ventanas, también a ambos lados. Tanto el dormitorio pequeño de amas como el secadero estarían ubicados en la torre de poniente, hoy desaparecida, en la esquina del edificio en la calle San Quirce (IMAGEN 3-2).

Llama la atención esta separación de amas y niños en plantas diferentes, aunque las salas queden una sobre otra. Probablemente éste sea un emplazamiento nuevo, pues ya hemos visto, que en las continuas obras del establecimiento para intentar acondicionarlo, se iba cambiando la ubicación de las salas. Según los reglamentos lactantes y nodrizas no podían dormir juntos pero las salas debían estar contiguas.

"Inmediata a la sala de lactar, habrá otra donde tendrán sus camas las nodrizas, pero nunca se les permitirá llevar á ellas los niños, á excepción de los casos en que el Facultativo lo ordene"

Art. 68 (Regl. 1889)

En el plano no se asigna ninguna zona como dormitorio para alguien que pueda cuidar a los niños más de cerca y en el ADPVA se conserva una fotografía de una Sala de Cunas en la que tampoco se aprecia en su interior ni espacio ni mobiliario de descanso destinado a adultos (en la portada del capítulo). Es una fotografía sin datar que aparece en la edición extraordinaria que publicó sobre Valladolid en julio de 1911 El Financiero Hispano-Americano, pero no cuadra la imagen que nos ofrece la foto con el plano de Guadilla de 1910 por la distribución de los ventanales, que en la fotografía aparecen a ambos lados y en el plano solamente figuran en una pared mientras que en la otra solo están los accesos a otros cuartos; por tanto la fotografía podría ser anterior a las obras de reforma. Resulta chocante, después de lo visto, que la revista El Financiero diga del Hospicio Provincial que "Está bien acondicionado", no obstante, también advierte que "Aún cuando en él se está haciendo mucho, aún queda mucho por hacer. Los servicios mejor montados son los de aseo y los de Casa-cuna" ${ }^{346}$. Esta buena impresión podría deberse a que estas zonas se hubieran arreglado recientemente en las obras proyectadas en 1910, pues unos años más tarde volvemos a encontrar afirmaciones bien contrarias. En 1918 el diputado visitador D. Luis Roldán Trápaga en una sesión de la Comisión

\footnotetext{
${ }^{345}$ EMPAÑADOR: Cuarto de empañar. EMPAÑAR: vendar. Envolver a las criaturas. Envolver con paños. Enciclopedia Universal Ilustrada Europeo-Americana. José Espasa e hijos Editores, tomo 19, p 1039

${ }^{346}$ El Financiero Hispano-Americano. Julio- 1911. Aporta las fotografías de los lavatorios y de la sala de cunas que hemos incluido en este trabajo y en efecto parecen locales nuevos y en buen estado.
} 
Provincial hizo un alegato, que fue muy aplaudido, en el que propuso reformas en el Hospicio incluyendo la Maternidad y la Inclusa; los diputados pidieron copia para estudiarlo detenidamente y se acordó nombrar una comisión y convocar una sesión extraordinaria para resolver el tema, pero nunca más se supo, en los meses sucesivos no se volvió a tratar el asunto en la Comisión Provincial. En la Memoria suscrita por los médicos del Hospicio... $1920^{347}$ se propone como una medida para reducir la alta mortalidad infantil "Higienizar los locales, hoy muy deficientes de la inclusa, construyendo algún pabellón para diluir la población infantil y poder aislar a los enfermos contagiosos" y el Anuario de la vida local de 1924 dice que "la Cuna", es uno de los departamentos que "precisa una radical reforma". Las obras por tanto, aunque eran continuas nunca eran suficientes; da la impresión a la vista de los documentos conservados de que se abordaban cuando no quedaba más remedio, ante situaciones de urgencia o extrema necesidad, pero luego no se realizaba un mantenimiento adecuado, por lo que con el paso del tiempo las nuevas instalaciones volvían a deteriorarse. Este parece un mal común a las inclusas de la época y sobre el que había quejas en todas, sobre la de Barcelona un informe médico de finales del XIX acusa que se fundó, como la de Valladolid, en "un edificio no construido ex profeso, ni propio para su destino [y] tiene hoy los mismos defectos de su origen, á pesar de las ampliaciones del local y de las obras constantemente realizadas en el decurso de los años... de modo que no reúne ninguna de las condiciones higiénicas estáticas que requiere un establecimiento de esta índole, y téngase en cuenta que por tratarse de una inclusa las necesita muy especiales" ${ }^{348}$

\footnotetext{
347 Año 1920. Memoria suscrita por los médicos del Hospicio Provincial relativa a la mortalidad de niños del establecimiento. Signatura: caja 4025, expediente 37809. ADPVA

${ }^{348}$ Casa Provincial de Maternidad y Expósitos de Barcelona. Inclusa. Estudio demográfico- médico del quinquenio 1883 á 1887 por los doctores D. Juan de Rull y D. José Cabot. Barcelona. 1889
} 


\title{
3.2. Población de la inclusa. Movimiento de LACTANTES Y NIÑOS DE DESTETE.
}

\author{
Los expósitos eran «hijos de la pobreza y de la vergüenza» \\ $y$ en no pocas ocasiones, de ambas situaciones a la vez
}

Vicente Pérez Moreda

La Inclusa, o Departamento de Lactancia, y el Departamento de Conservación y crianza de los niños menores de siete años, en la práctica funcionaban de forma independiente y en el edificio tenían estancias separadas, debido a las diferentes condiciones de crianza de los niños acogidos en cada uno de ellos en función de su edad. Sin embargo, a efectos administrativos se consideraban en conjunto como Departamento de la Casa-Cuna y así se encuentran tanto en los libros oficiales de registros de Entradas y Salidas de Menores, como en los Presupuestos Generales de la Diputación, donde aparece como Departamento de Expósitos, de ahí la dificultad para separar a los lactantes (en el sentido pediátrico, como grupo de edad menor de 2 años), que son el objetivo de este estudio del grupo de edad inmediatamente posterior. Los criterios de ingreso en este departamento quedan claramente recogidos en los reglamentos del Hospicio, niños ilegítimos y huérfanos pobres hasta 7 años.

La Inclusa, o Departamento de Lactancia, estaba destinada a niños hasta la edad de 18 meses, período considerado de lactancia por el Hospicio, que podía ser ampliado por prescripción del Facultativo para los lactantes de "difícil dentición ú otra enfermedad". A partir de este momento el niño entraba en el período llamado de "destete" o de "crianza" y pasaba al Departamento de Menores de siete años. Es la forma de alimentación la que por tanto restringía la pertenencia a uno u otro departamento, lo que en definitiva determinaba un gasto diferente para el Hospicio ya que condicionaba la necesidad de cuidadoras y los salarios que éstas percibían.

La normativa del Hospicio era clara en cuanto a la edad de los niños de cada departamento, hasta los 18 meses la lactancia y hasta los 7 años el destete. Estos límites debían ser muy comunes en los establecimientos de este tipo, como en los hospicios de Zamora, Pontevedra o Madrid ${ }^{349}$. Sin embargo ésta es una de las reglas sistemáticamente

\footnotetext{
349 Cfr. HERNANDO GARRIDO J.L.: op.cit; RODRÍGUEZ MARTín A.M.: El destino de los niños de la inclusa de Pontevedra 1872-190, 2008; REVUELTA EUGERCIOS B.A.: Los usos de la inclusa de Madrid, mortalidad y retorno a
} 
incumplida, seguramente por una cuestión económica ya que la crianza externa de los hospicianos solamente se pagaba hasta finalizar el destete y el salario de las amas lactantes era más alto que el de las criadoras Ilamadas "secas". En los propios Libros y documentos oficiales del Hospicio encontramos los límites recortados para ambos períodos y así aparecen registrados como "Lactancias de 1 dia á 15 meses" y “Destetes de 15 meses á 5 años”350.

Como ya hemos comentado, en los libros de Entradas de Menores se registraban las salidas de los niños con el nombre del ama que los iba a criar y sus retornos al hospicio, pero solamente en la primera salida se indicaba si era para lactancia o destete. En ningún caso hemos encontrado registrado el paso de una a otra forma de crianza, por lo que estos libros no nos permiten valorar con exactitud la duración de cada período. Muchas mujeres devolvían al hospiciano al terminar la lactancia, podemos suponerlo por las fechas de las devoluciones al hospicio y de los cambios de ama que encontramos en los registros, que con mucha frecuencia rondan el momento del cese de la lactancia y el paso al destete, aunque no siempre coinciden con exactitud. En este sentido, resultan más útiles los Libros de Salidas, ya que en ellos se registraban las amas externas de cada niño y los salarios que percibían; por los pagos anotados se puede conocer la duración de cada etapa. Solo se conservan Libros de Salidas de estas características hasta 1908, en los libros de 1909- 1910 y en el de 1913 únicamente se anotaron los nombres de las criadoras, sin más datos.

En la mayoría de los casos se puede constatar, cotejando los libros de Entradas y los pocos existentes de Salidas, que el periodo de lactancia solía finalizar en torno a los 15 meses, eran excepciones los que finalizaban antes de cumplir el año o después de los 18 meses; es posible que en estos casos se tratara de una decisión médica como dice el Reglamento, pero no hay constancia de ello en los libros. De hecho, parece que en general eran muy rigurosos con el final de la lactancia, pues en la mayoría de los registros he podido observar que se aplicaba el mismo día que el inclusero cumplía los 15 meses y en algunos casos en que se prolongó, se trataba de niños que ingresaron en la Inclusa con unos meses de vida y el tiempo para la lactancia se contó a partir de la fecha de ingreso y no de la de nacimiento. En el libro de Salidas de 1907 podemos ver que todos los niños que vivieron lo suficiente pasaron a destete a los 15 meses. En 1908 la mayoría se destetaron a los 15 meses, pero hubo de todo, algunos se adelantaron a los 14 meses (los no 41, 87, 130 ó 137) y solo ocasionalmente se encuentran más

principios del siglo XX (1890-1935). Madrid, 2011; ARANA AMURRIO J.I.: Historia de la Inclusa de Madrid. Cuadernos de Historia de la Pediatría Española. 2012. № 4

350 Así se recoge entre otros en los documentos del ADPVA: Niños ingresados ... para lactancia ... año 1905, Signatura: caja 4872, expediente 43325; Estado demostrativo del movimiento de acogidos.... 1906, Signatura: caja 4872, expediente 43334 y Memoria Estados de personal de 1908, Signatura: caja 2449, expediente 30483 
pequeños como el niño del folio no 71 que reingresó con 10 meses porque la nodriza no le podía criar, no consta el paso a destete pero tampoco se le asignó nueva nodriza, fallecería al mes siguiente en la Inclusa. También se encuentran niños con 18 meses ( $n$ ㅇs 21, 38, 265, 365 ó 380), pero son los menos.

De todos modos, los registros, en general para todos los libros consultados, no son uniformes en cuanto a su calidad y características, de manera que algunos parecen muy completos y en otros solamente se han hecho unas pocas anotaciones; en todo caso es muy raro que se explique la causa de la interrupción de la lactancia, solamente en algún registro consta que se debe a que ha finalizado el período correspondiente. Hay casos en los que no hay apuntes de pagos en el libro de Salidas pero según el libro de Entradas el niño debería estar con un ama externa, podría tratarse de situaciones de prohijamiento, pero no se puede asegurar porque no consta, es posible también que simplemente no se hayan anotado los pagos en el libro.

En cuanto al período de crianza o destete, solía finalizar a los 5-6 años, a pesar de que según los reglamentos debía durar hasta los 7 años; dependería de los presupuestos, del número de niños acogidos y es de suponer que en ocasiones también de las deficiencias en registros y controles. Al analizar los libros de Salidas se puede comprobar que el final de la crianza se aplicaba con bastante menos rigor que el de lactancia, encontrándose situaciones muy dispares incluso en un mismo ejercicio. 1907 fue un año irregular en este sentido porque el retorno de los niños al cumplir los 5 años, mes arriba o abajo, que en otros ejercicios era lo más frecuente, parece que en éste fue la excepción ${ }^{351}$ y la mayoría (los que vivieron lo suficiente) finalizaron el período de crianza exterior a los 6 años. Era habitual que el retorno al hospicio ocurriera unos meses después de finalizado el plazo, probablemente cuando las criadoras o sus representantes podían acudir al Hospicio para recibir los últimos pagos y entregar la cartilla de crianza, téngase en cuenta que la mayoría vivía fuera de la ciudad, incluso de la provincia; en estos casos los pagos por crianza no se prolongaban hasta la entrega del niño, terminaban en la fecha marcada. Así lo vemos como ejemplo en la inscripción no 119 de 1907 donde constan pagos hasta el mes de abril de 1913, cuando cumple el niño los 6 años, a pesar de que en el Libro de Entradas se registra "devuelto el 9 de octubre de 1913".

\footnotetext{
${ }^{351}$ En el folio no 302 de 1907 se dice de una niña que "En 18 de Enero de 1913 fue devuelta por los que la tenían por haber cumplido 5años" y en el libro de Salidas correspondiente al mismo ejercicio se comprueba que efectivamente los pagos por crianza se hicieron hasta septiembre de 1912, cuando cumplió los años; esta niña tuvo suerte y en marzo la volvieron a llevar los mismos que la criaron. Otro caso similar es el de la niña inscrita en el folio no 62 de 1907, en el que los pagos por destete también figuran hasta el día de su 5o cumpleaños, sin embargo no consta su reingreso en el hospicio, podemos suponer que se quedó con la familia que la estaba criando.
} 
En los demás años consultados, aunque lo habitual era una duración de 5 años, en todos hay irregularidades, sin que conste el motivo, como ejemplo podemos tomar el año 1908. Lo general en este libro es finalizar el destete a los 5 años con bastante rigor, como vemos en el folio no 99, en el que figuran pagos a la nodriza hasta el mismo día del cumpleaños del niño, sin embargo luego encontramos situaciones diversas. En el folio no 417 el niño fue devuelto por su criadora en 1914 y pasó al departamento de mayores casi con 6 años. Encontramos niños entregados a un ama a pesar de estar muy próximos al término del destete; como la niña del folio no 279 que estuvo con un ama hasta 1913 próxima a los 5 años y la volvieron a entregar en mayo de 1914, reingresando en el asilo en septiembre "por haber cumplido el período de destete", cumplía 6 años.

En general se calculaban y se cerraban los períodos de forma muy rigurosa al cumplir la edad, pero en ocasiones se cometían errores al confundir las fechas, la de nacimiento con la de ingreso o la de salida del niño del hospicio. El niño del folio no 53 de 1908 ingresó en el hospicio con más de 2 años, la primera criadora lo devolvió en 1911, con 6 años cumplidos, y volvió a salir hasta octubre de 1913, cuando hacía 8 años. Viendo cómo van los registros pudo tratarse de un error debido a que en el libro de salidas no se anotaba la fecha de nacimiento, solo la del ingreso en el Hospicio y se debió contar el tiempo a partir de entonces; llama la atención que reingresara con 6 años y no se dieran cuenta en ese momento de la edad del niño y lo volvieran a entregar; aparte de la cuestión registral, debía estar muy poco desarrollado para su edad. Otro error que ocurría en ocasiones era computar el tiempo desde la fecha de la primera salida del hospicio, así ocurre por ejemplo en el folio no 91 de 1907. Cuando la Contaduría se percataba del error, como ocurrió en este último caso, descontaban al ama el dinero entregado de más al calcular mal el tiempo de lactancia, aunque con el destete no parece que reclamaran la devolución, al menos en los libros del Hospicio no consta. Muchos de estos datos los he podido extraer únicamente de los libros de Entradas y no se han podido contrastar con los libros de Salidas porque éstos solo contienen registros hasta mediados de 1913 y no hay libros similares posteriores.

Aunque el médico de la Inclusa, según los reglamentos, podía alargar la lactancia, no he encontrado ningún registro en este sentido; por lo que podemos pensar que en casos en que se sobrepasaban las fechas establecidas, vale el comentado anteriormente del folio $n \circ 53$ de 1908, como no se dan razones al respecto, no podemos descartar que se tratara simplemente de "despistes", voluntarios o no, ya que el control de los niños criados fuera del asilo da la impresión de que en la práctica se escapaba al Hospicio y las irregularidades parece que no eran raras. En alguna ocasión incluso llegaron a publicarse en la prensa, como en julio 
de 1908 cuando en El Norte de Castilla se denunció el caso de un niño que estaba "en lactancia después de haber cumplido los cinco años"352; revisados los libros de Salidas, no encontramos constancia de este hecho, claro que parece improbable que algo así se registrara.

Muy pocas veces se encuentra anotado en los Libros de Exposiciones, que recogen el historial de los niños, cuándo se producía el cambio de lactancia a destete, a pesar de que para los internos suponía el paso de la Inclusa a la Sala de menores de 7 años. Para los niños de crianza externa con frecuencia coincidía con un cambio de nodriza, como habitualmente no se anotaba la causa de la devolución, podemos suponerlo por las fechas registradas. Tampoco se hacía ninguna anotación cuando el niño continuaba con la misma nodriza; se puede apreciar el cambio porque en los libros de Salidas, donde se anotaban las nodrizas y los pagos que recibían, se modificaba la remuneración del ama; es pues un control sobre todo económico.

Cabe pensar, por tanto, que la duración de cada período era una cuestión fundamentalmente logística y económica, que dependería principalmente de la disponibilidad de nodrizas y del presupuesto para su pago, ya que la política del Hospicio, según los reglamentos, era mantener internos a la menor cantidad de niños, especialmente lactantes, procurando la crianza externa a los más posibles, al menos así consta sobre el papel:

"Art. 79. Siendo indudablemente preferido al sistema de lactancia dentro del Establecimiento, el de entregar los niños á nodrizas externas, el Facultativo correspondiente de acuerdo con la Superiora, quedan encargados de facilitar la salida de los expósitos á la lactancia externa, procurando queden los menos posibles en la Casa". [sic] (Regl.1889)

\subsubsection{INGRESOS ANUALES EN LA INCLUSA.}

Ya se ha comentado que solamente se conservan en el ADPVA memorias de los años 1905 y $1908^{353}$ que ofrezcan datos anuales globales sobre el movimiento de asilados en el Hospicio Provincial de Valladolid; por lo que todos los datos referentes a ingresos y reingresos, salidas de la Inclusa para crianza, bajas definitivas y mortandad he tenido que calcularlos a

\footnotetext{
${ }^{352}$ N.C.: 19-7- 1908, p 1 . Se hace la denuncia en un artículo sobre Los escándalos de la Diputación. No sería la única vez que aparecen denuncias relacionadas con las nodrizas, en 1913-14 se denuncian irregularidades en los pagos en el que hemos llamado "caso Montiel" y en la página 2 del diario del día 9-8-1919 en un artículo sobre la sesión de la Comisión Provincial se recoge la denuncia del diputado Bocos sobre "los abusos de varias nodrizas del Hospicio".

${ }^{353}$ Niños ingresados... para lactancia... año 1905, Signatura: caja 4872, expediente 43325; Estado demostrativo del movimiento de acogidos... 1906, Signatura: caja 4872, expediente 43334 (este documento recoge los movimientos de personal durante el año 1905) y Estados del personal Año de 1908. Signatura: caja 2449, expediente 30483. ADPVA
} 
partir del análisis detallado de los Libros de Exposiciones del Hospicio, recogiéndolos hoja por hoja para poder obtener los datos anuales; 6.062 folios solamente de los libros de 1900 a 1913.

En primer lugar he extraído los datos de ingresos y salidas para cada uno de los años que se han podido consultar detalladamente. En el período 1900- 1913 ingresaron en la CasaCuna provincial de Valladolid 5.949 niños, sin considerar los 77 "nacidos muertos" en la maternidad. Resulta una media anual de $\mathbf{4 2 5}$ ingresos efectivos en la Cuna con valores extremos de 378 en 1901 y 477 en 1900 (ver GRÁFICA 3-1 y TABLA 3-2). Los niños "nacidos muertos" corresponden a las muertes perinatales de la Maternidad, es decir mortinatos y niños que fallecieron en las primeras 24 horas de vida; en los libros aparecen registrados en folio propio y en las memorias están contabilizados como ingresos; son niños que de no haber fallecido hubieran quedado en la Inclusa; considerándolos desde este punto de vista resulta un

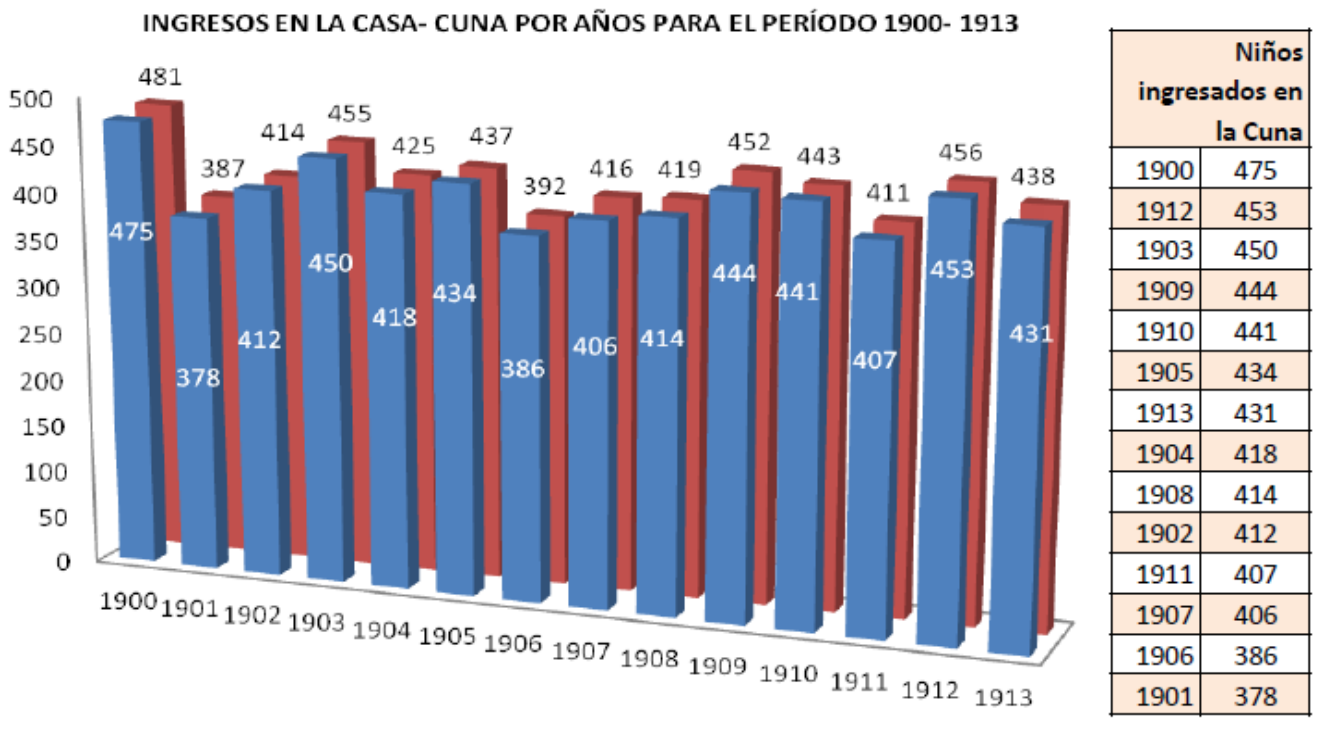

- INGRESOS VIVOS =INGRESOS TOTAL vivos + "nacidos muertos"

GRÁFICA 3-1: INGRESOS en la Casa-Cuna del Hospicio Provincial de Valladolid en el período 1900-13 de niños menores de 5 años. INGRESOS EFECTIVOS (solamente niños vivos) e INGRESOS TOTALES contando las muertes perinatales de la Maternidad. Tabla con los años ordenados según el número de ingresos efectivos. Elaboración propia.

total de $\mathbf{6 . 0 2 6}$ niños para todo el periodo y una media de $\mathbf{4 3 0}$ ingresos anuales. Dentro de la variabilidad que hay de unos años a otros no se puede establecer una tendencia determinada a lo largo de este periodo, como puede verse, en la tabla en la que hemos ordenado los años según el número de ingresos, de manera que los años con valores extremos son 1900 y 1912 con más ingresos y 1901 y 1906 los de menos, por este orden. 
Se conserva un Informe de acogidos en 1914- 1918 en el que se refiere de forma resumida el número anual de ingresos en cada departamento y en el que observamos que para la Cuna no solo no descendió sino que llegaron a superarse las cifras anteriores alcanzando en 1918 el número de 508 ingresos con un promedio para el quinquenio de 455 ingresos ${ }^{354}$.

Voy a considerar solamente los niños vivos, ya que son los que van a hacer uso y gasto en la Cuna y de cara a la comparativa estadística resulta más fiable el dato de los nacidos vivos. En su mayoría los niños llegaban a la Casa Cuna en el período neonatal, es decir, en el primer mes de vida según el concepto pediátrico 355 , y la mayor parte contaba con muy pocos días, incluso horas de vida al ingresar en el asilo. Elegimos para nuestra distribución por edades este concepto de neonato porque resulta difícil concretar más la edad de la mayoría de los niños que llegaron a la Inclusa en sus primeros días de vida, ya que no consta la fecha de nacimiento de muchos de ellos, tanto de los expósitos como de los niños ingresados con certificaciones. Es habitual encontrar en los libros únicamente las fechas del bautismo y/o la de inscripción en el Registro Civil y no la del nacimiento, sobre todo en los primeros libros, aún cuando se pudiera conocer porque se presentaban los correspondientes certificados o porque el niño hubiera nacido en el Hospital provincial. Al no estar registrada en los libros la fecha de nacimiento, tenemos de muchos incluseros una edad imprecisa, aunque seguramente sea muy aproximada por las otras dos.

"En 14 de Febrero de 1901 ingresa en este Asilo por acuerdo de la Comisión provincial con partida de bautismo donde dice ser hijo natural de Leoncia Gallego de estado viuda y vecina de esta ciudad. Bo [bautizado] en San Nicolás en 7 de junio de 1900... Falleció en dicho pueblo"356 [sic]

Tampoco se registraba la edad estimada ni referencia alguna, como podría ser la presencia de cordón umbilical, para poder hacernos una idea y clasificar a los niños en un grupo de edad; la ropa es lo único que a veces puede darnos una pista muy vaga y para una clasificación muy grosera y nada segura, simplemente para saber si se trataba o no de un bebé.

Para el período permitido de consulta 1900-13, con los datos extraídos y considerando que los niños expuestos sin bautizar, tanto en el torno de la Inclusa como en los pueblos, tendrían menos de un mes de vida y que las fechas de inscripción en el Registro civil y de

\footnotetext{
354 Ingresaron 428 niños en 1914, 414 en 1915, 479 en 1916, 444 en 1917 y 508 en 1918. Informe del número de acogidos entre 1914 y 1918. Signatura: caja 4051, expediente 38001. ADPVA

355 La Pediatría considera que el período neonatal abarca los primeros 28 días de vida, aunque por cuestiones prácticas se suele hacer extensivo al primer mes de vida. Hasta ese momento llama a los niños Neonatos o Recién Nacidos, por lo que a efectos de este trabajo nombraremos como RN a los menores de un mes de vida. A partir del mes de vida se les considera Lactantes

${ }^{356}$ Folio no 52 del 10 Libro de Exposiciones de 1901. ADPVA
} 
bautismo serían próximas a las de nacimiento con un margen de una a dos semanas, he calculado que:

El 87’05 \% de los niños ingresados en la Cuna tenían menos de un mes (RN)

el 8’53\% entre uno y doce meses ( $<1$ año)

el 4'42\% eran mayores de un año (>1 año)

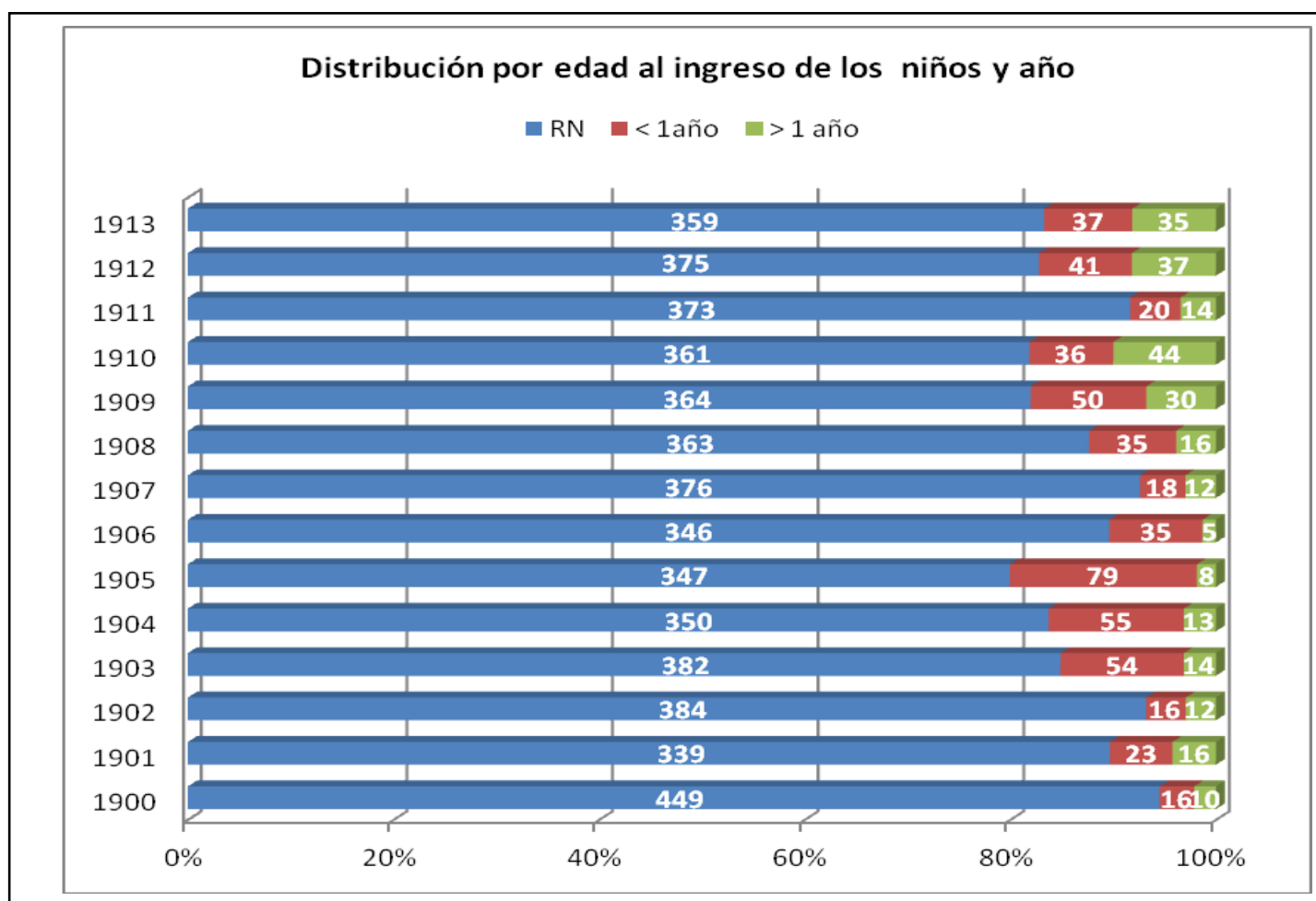

GRÁFICA 3-2: Comparativa porcentual de la edad al ingreso en cada año, en el interior de cada barra los valores absolutos. Grupos de edad: $\mathrm{RN}=$ neonatos= edad inferior a 1 mes; $<1$ año incluye los niños entre 1 y 12 meses y mayores de 1 año. Elaboración propia a partir de los datos extraídos de los Libros de Exposiciones 1900- 1913.

En la GRÁFICA 3-2 se recoge la distribución porcentual, junto con los datos en valores absolutos, por grupos de edad al ingreso en la Cuna de los niños durante los años de consulta permitida. La gran mayoría, más del $80 \%$, excepto 1905 , son neonatos (RN), es decir menores de 1 mes. En valores promedio para el período 1900- 1913 ingresaron en la Cuna anualmente 369 RN, 37 menores de 1 año y 19 mayores. 
Excepto en 1910, ingresaron más niños entre 1 y 12 meses que mayores de 1 año, con ligeras diferencias en general, de 2 a 7 niños más, aunque algunos años esa diferencia se disparó; es llamativa sobre todo en el período 1903-1906. Destacan, por el número inusual de lactantes de 1-12 meses, 1905 con 79 menores de un año, muy por encima de la media referida, y solamente 8 mayores y los años 1903 y 1904 con 54 y 55 menores y 14 y 13 mayores respectivamente. El hecho de que esta situación se repita durante unos años seguidos hace pensar que no fuera algo casual, sino que pueda existir algún factor condicionante, que no parece tener relación con el número total de ingresos. Ver GRÁFICA 3-3.

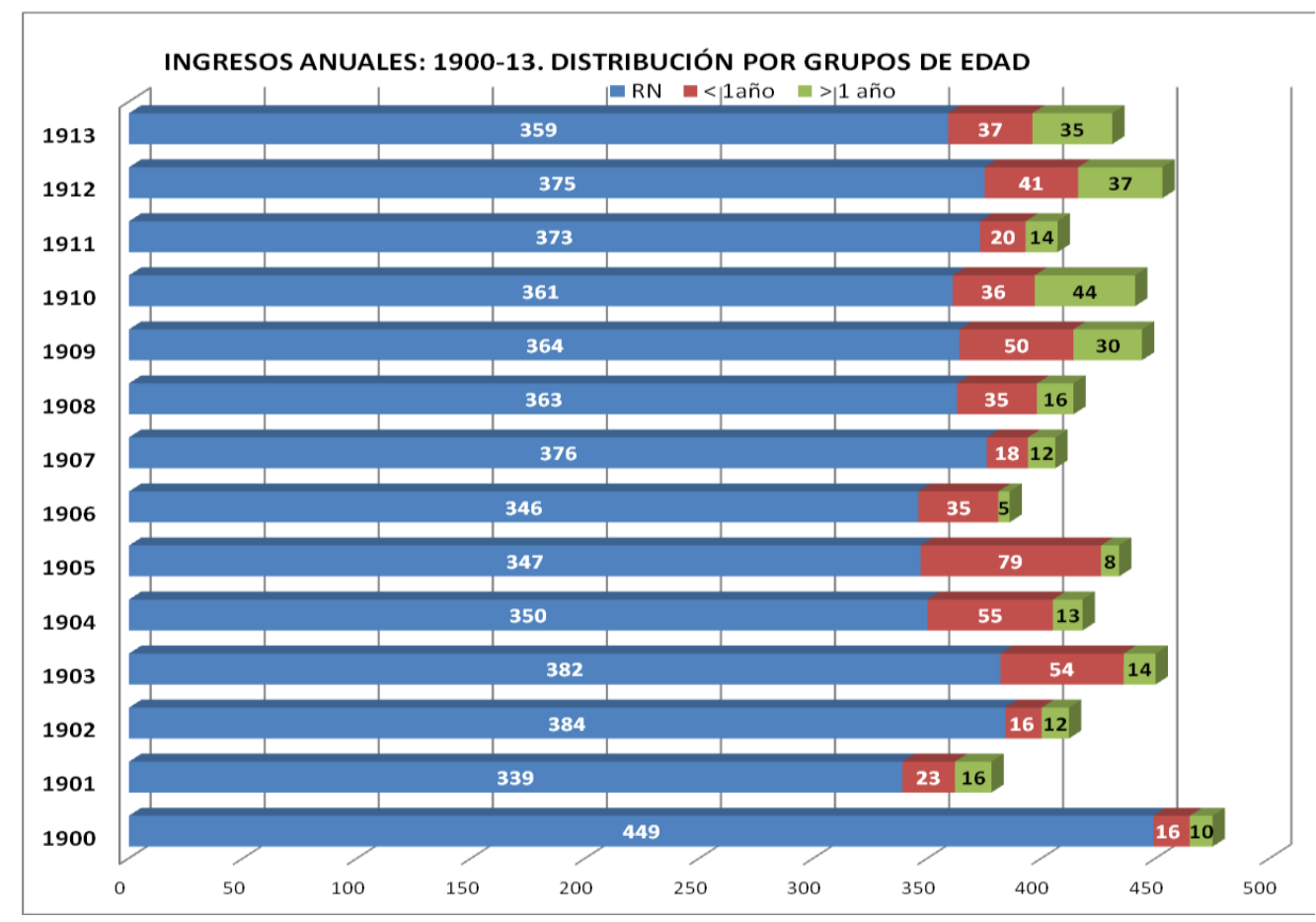

GRÁFICA 3-3: Ingresos anuales efectivos en la Cuna, distribución por grupos de edad. Elaboración propia a partir de los datos extraídos de los Libros de Exposiciones 1900- 1913.

Se hace un análisis más detallado de algunos años para desglosar dentro del primer mes los ingresados en su primer día de vida y en la primera semana y se recoge en la TABLA 3-1, teniendo en cuenta la dificultad que ya he comentado para concretar la edad de algunos expósitos de los que no consta la fecha exacta de nacimiento. Se han seleccionado 1906 y 1912 por tener valores extremos en cuanto al número de ingresos anuales, después de 1900 y 1901 que son los años con más y menos ingresos respectivamente pero que he descartado porque tienen un número muy elevado de niños sin fecha de nacimiento al no haberse registrado ni siquiera cuando se conocía y se han anotado solamente la de bautismo y de inscripción en el R.C. Entre los años en que se ha registrado el día del nacimiento en los casos que era conocido he seleccionado 1909 por estar temporalmente entre los anteriores y tener un número total 
de ingresos próximo a la media. No se ha seleccionado ningún año anterior a 1906 porque tienen en sus registros el mismo problema de imprecisión que 1900 y 1901. En la tabla no hemos considerado como ingresos los niños nacidos muertos en la maternidad porque a pesar de que se encuentran registrados en los libros de entradas no llegan a ingresar en la Inclusa ${ }^{357}$. Es difícil concretar el número de niños que ingresaron en sus primeros días de vida, ya se ha dicho que sobre todo muchos de los expósitos tenían una fecha incierta de nacimiento; no obstante, a los que llegaron sin bautizar y fueron bautizados e inscritos en el Registro civil en la Inclusa, les hemos considerado dentro del primer mes de vida; suponiendo que tendrían pocos días habida cuenta del significado y la importancia que tenía en la sociedad española y castellana de la época el bautismo, no era usual dejar a los niños sin bautizar ni retrasarlo demasiado por la elevada mortalidad que les afectaba ${ }^{358}$.

\begin{tabular}{|c|c|c|c|c|}
\hline \multicolumn{2}{|c|}{ EDAD de INGRESO } & 1906 & 1909 & 1912 \\
\hline \multirow{5}{*}{ 1 MES DE VIDA } & 1o día & 146 & 132 & 126 \\
\hline & 1a semana $(1 d-7 d)$ & 51 & 83 & 69 \\
\hline & $>7 d-1$ mes & 43 & 73 & 86 \\
\hline & EDAD INCIERTA & 106 & 72 & 94 \\
\hline & Total 10 MES & 346 & 360 & 375 \\
\hline \multicolumn{2}{|c|}{ Entre 1 MES y 1 AÑO } & 35 & 49 & 41 \\
\hline \multicolumn{2}{|c|}{ MAYORES de 1 AÑO } & 5 & 35 & 40 \\
\hline \multicolumn{2}{|c|}{ TOTAL INGRESADOS } & 386 & 444 & 456 \\
\hline \multicolumn{5}{|c|}{$\begin{array}{l}\text { TABLA 3-1: Edad de ingreso de los niños, años 1906, } 1909 \text { y } 1912 \text {. Se separan, dentro del } \\
\text { grupo que ingresó en su } 10 \text { mes de vida: a) los ingresados en el 10 día de vida, b) los que } \\
\text { ingresaron en la 1a semana y después del } 1 \text { o día, c) los que ingresaron en el primer mes y } \\
\text { después de la primera semana y d) con fecha incierta los que no tienen la fecha de } \\
\text { nacimiento pero por la del Bautismo y/o la del R.C. se han considerado dentro del primer mes } \\
\text { de vida. No se han incluido los niños nacidos muertos en la Maternidad. Elaboración propia. }\end{array}$} \\
\hline
\end{tabular}

Como puede observarse en la TABLA 3- 1 y en las GRÁFICAS 3-2 y 3-3, los neonatos (RN) no sólo constituían la mayor parte de los ingresos en la Inclusa, sino que además, eran mayoría los niños que entraban al poco de nacer, teniendo en cuenta que muchos de los que figuran en el grupo de edad incierta también podrían estar en su primeras horas de vida.

\footnotetext{
${ }^{357}$ Recordamos que en la época se consideraba como vivo a un recién nacido a partir de las 24 horas, si fallecía antes se consideraba a efectos legales un aborto. En el cuadro hemos descontado como ingresos los niños que en los libros se registran como "niño/a muerto/a", al tratarse de niños que murieron al nacer o en las primeras 24 horas de vida por lo que probablemente ni siquiera llegaron a pasar de la Maternidad a la Inclusa.

358 "La ceremonia del bautizo suele realizarse en los ocho días siguientes al nacimiento, entre las clases populares, después de la misa mayor del día festivo más próximo y entre las gentes más pudientes cuando mejor les parezca". MARTíN DE LA GUARDIA R., PÉREZ LÓPEZ P., PÉREZ SÁNCHEZ G.: La sociedad vallisoletana a comienzos del siglo XX: Comportamientos ante el nacimiento, matrimonio y muerte. Investigaciones históricas: Época moderna $\mathrm{Y}$ contemporánea, no 9, 1989, p 258
} 
Los datos de la TABLA 3-1 con la distribución porcentual de los niños ingresados en el primer mes de vida según los días que tenían al llegar a la Inclusa se han representado en la GRÁFICA 3-4 para hacer más visual la comparación entre ellos.

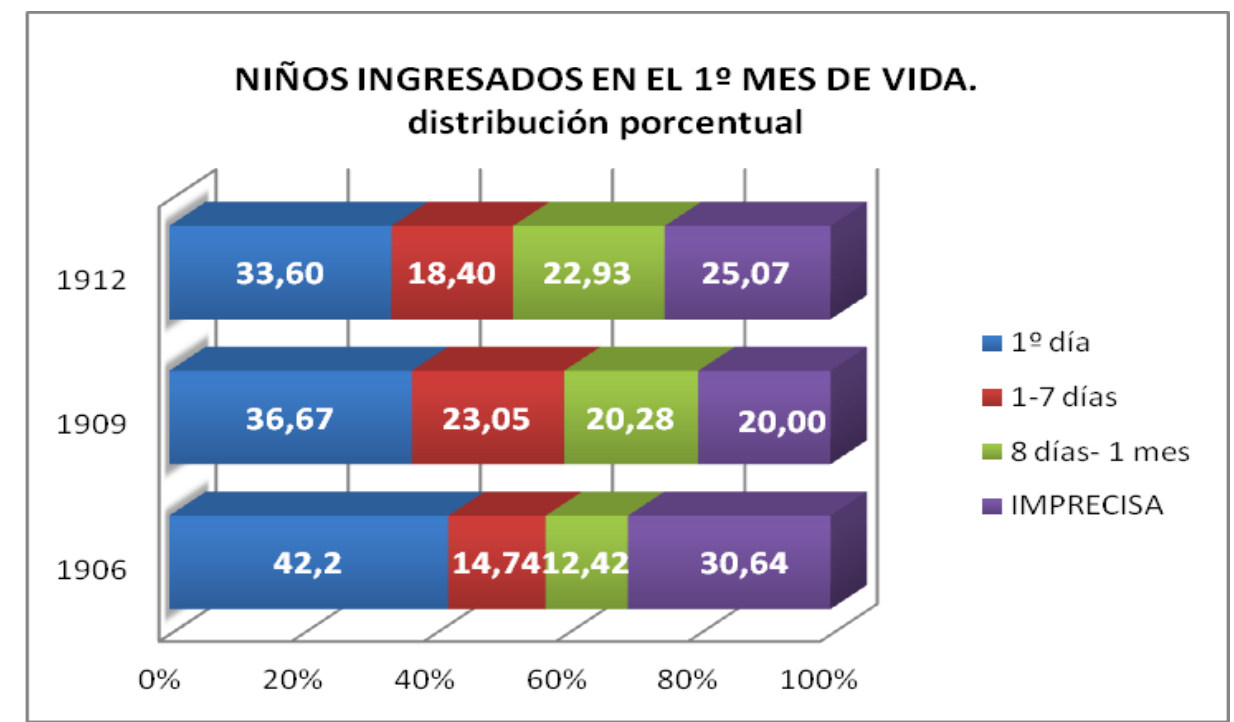

GRÁFICA 3-4: Niños que ingresaron en su primer mes de vida en la Cuna en los años 1906, 1909 y 1912. Distribución porcentual por grupos de edad. a) los ingresados en el 10 día de vida, b) los que ingresaron entre el 10 y 700 día, c) los que ingresaron después de la primera semana de vida y d) con fecha imprecisa los que no tienen la fecha de nacimiento pero por la del Bautismo y/o la del Registro Civil se han considerado dentro del primer mes de vida. No se han incluido los niños nacidos muertos en la maternidad. Elaboración propia a partir de los datos extraídos de los Libros de Exposiciones ADPVA.

Casi todos los niños de los 5.949 que ingresaron en la Cuna en los 14 años analizados se encontraban en el período de lactancia, solamente entraron 266 mayores de un año y, entre ellos, 245 niños lo hicieron directamente al grupo de Destete, lo que representa el 4'12\% de las entradas; hay años en que ni siquiera llegan a 10 los niños de destete, como 1906 con 4 niños y 1905 con 7.

Para hacernos una idea de la relevancia de todas estas cifras y situar los datos del Hospicio Provincial de Valladolid en el contexto de la población general, podemos echar mano 
de los censos y los datos demográficos de la época que nos ofrece el Fondo Documental del Instituto Nacional de Estadística (INE) para la ciudad y la provincia de Valladolid ${ }^{359}$.

\begin{tabular}{|c|c|c|c|c|c|c|c|c|}
\hline \multicolumn{9}{|c|}{$\begin{array}{l}\text { INGRESOS ANUALES POR GRUPOS DE EDAD EN LA CUNA PROVINCIAL Y PORCENTAJE SOBRE LOS } \\
\text { NACIMIENTOS DE LA PROVINCIA DE VALLADOLID }\end{array}$} \\
\hline & $\begin{array}{c}\text { NACIDOS } \\
\text { VIVOS EN } \\
\text { LA } \\
\text { PROVINCIA }\end{array}$ & RN & $\begin{array}{c}\% \text { DE } \\
\text { NACIDOS } \\
\text { VIVOS QUE } \\
\text { INGRESAN }\end{array}$ & $\begin{array}{c}<1 \\
\text { año }\end{array}$ & $\begin{array}{l}\text { MENORES DE } 1 \\
\text { AÑO QUE } \\
\text { INGRESAN /100 } \\
\text { NACIDOS VIVOS }\end{array}$ & $\begin{array}{c}>1 \\
\text { año }\end{array}$ & $\begin{array}{c}\text { TOTAL } \\
\text { INGRESOS } \\
\text { MENORES } \\
\text { DE } 5 \text { AÑOS }\end{array}$ & $\begin{array}{l}\text { MENORES DE } 5 \\
\text { AÑOS QUE } \\
\text { INGRESAN /100 } \\
\text { NACIDOS VIVOS }\end{array}$ \\
\hline 1900 & 10.379 & 449 & $4 ’ 33 \%$ & 465 & $448 \%$ & 10 & 475 & $4 ’ 58 \%$ \\
\hline 1901 & 10.767 & 339 & $3 \prime 15 \%$ & 362 & $3 ’ 36 \%$ & 16 & 378 & $3 ’ 51 \%$ \\
\hline 1902 & 11.043 & 384 & $3 \times 46 \%$ & 400 & $3 \prime 62 \%$ & 12 & 412 & 3'73 \% \\
\hline * 1903 & & 382 & & 436 & & 14 & 450 & \\
\hline 1904 & 10.679 & 350 & $3^{\prime} 28 \%$ & 405 & $3 ' 79 \%$ & 13 & 418 & 3’91 \% \\
\hline 1905 & 11.031 & 347 & $3^{\prime} 15 \%$ & 426 & $3 \times 86 \%$ & 8 & 434 & 3’93 \% \\
\hline 1906 & 11.205 & 346 & $3 \prime 09 \%$ & 381 & $3{ }^{\prime} 40 \%$ & 5 & 386 & $344 \%$ \\
\hline 1907 & 10.655 & 376 & $3 ’ 53 \%$ & 394 & $3^{\prime} 70 \%$ & 12 & 406 & $3 \times 81 \%$ \\
\hline 1908 & 10.298 & 363 & $3 ’ 52 \%$ & 398 & $3 \times 86 \%$ & 16 & 414 & $4 \prime 02 \%$ \\
\hline 1909 & 10.942 & 364 & $3.33 \%$ & 414 & $3 \prime 78 \%$ & 30 & 444 & $4^{\prime} 06 \%$ \\
\hline 1910 & 10.357 & 361 & $3 \times 49 \%$ & 397 & $3{ }^{\prime} 83 \%$ & 44 & 441 & $4 ' 26 \%$ \\
\hline 1911 & 10.431 & 373 & $3 \prime 58 \%$ & 393 & $3{ }^{\prime} 77 \%$ & 14 & 407 & $3.90 \%$ \\
\hline 1912 & 10.538 & 375 & $3 ’ 56 \%$ & 416 & $3 ’ 95 \%$ & 37 & 453 & $4^{\prime} 30 \%$ \\
\hline 1913 & 10.544 & 359 & $3 \times 40 \%$ & 396 & $3 ' 76 \%$ & 35 & 431 & $4^{\prime} 09 \%$ \\
\hline Promedio & 10.682 & $369^{\prime} 1$ & $3 \times 45 \%$ & $405^{\prime} 8$ & $3 ' 78 \%$ & 19 & $424^{\prime} 9$ & $4^{\prime} 00 \%$ \\
\hline
\end{tabular}

TABLA 3-2: Total de nacidos vivos en la provincia de Valladolid y de ingresos de menores de los distintos grupos de edad entre 1900 y 1913. Niños de cada grupo de edad que ingresaban cada año en la Cuna del Hospicio Provincial de Valladolid por cada 100 nacidos vivos en un año. En el grupo de menores de 1 año se han incluido también los neonatos ó recién nacidos (RN, en el sentido pediátrico de menores de un mes) Los datos sobre nacimientos se han extraído del Fondo Documental del INE (*No hay datos provinciales de 1903 en la página del Movimiento Natural de la Población, ver nota al pie ${ }^{361}$ ). Elaboración propia

Según los datos recogidos por el INE en los Movimientos Naturales de la Población, entre 1900 y 1913 el número de nacidos vivos en la provincia de Valladolid, osciló entre los 10.298 de 1908 y los 11.205 de 1906, como un año excepcional en este sentido, con un valor promedio de 10.682 nacidos vivos; en el período de 1920-30 descendió la media situándose en 9.348 nacidos vivos en la provincia. En todo caso, un dato altísimo comparado con el promedio actual que en la provincia de Valladolid para el período 2000- 2013 se ha situado en 4.541 nacidos, con valores extremos de 3.878 nacimientos en el año 2000 y 5.099 en el 2010

\footnotetext{
359 Se han consultado en el Fondo Documental del INE los Censos de 1900, 1910, 1920 y 1930 y El Movimiento natural de la población en cada uno de los años que abarca este estudio, de 1900 a 1930, aunque aquí nos vamos a limitar a los años que hemos podido consultar en el ADPVA, por tanto de 1900 a 1913 . En esta investigación he descubierto y a continuación notificado al INE un error en el archivo correspondiente al año 1903, en el que se encuentra cargado el Movimiento de la Población correspondiente a 1904, que se encuentra repetido. A fecha de hoy, abril de 2017, sigue sin corregirse. Documentación disponible en:

http://www.ine.es/inebaseweb/treeNavigation.do?tn=205628\&tns=205751\#205751
} 
(contando aquí a todos los nacidos, incluidos los fallecidos en las primeras $24 \mathrm{~h}$. que en las estadísticas de la época no se consideraban vivos y se registran aparte).

En las estadísticas de Nacimientos del Fondo Documental del INE se recoge el total de "Alumbramientos" y, por separado, los "Nacidos Vivos" y los "Nacidos Muertos, muertos al nacer ó antes de las primeras 24 horas de vida". Solamente tomamos para esta comparativa el dato de los recién nacidos vivos porque ofrece mayor fiabilidad, ya que el propio servicio de Estadística confiesa errores por omisión en los datos de nacimientos ${ }^{360}$ y hemos de suponer que el error es mayor en el caso de los nacidos muertos, que al considerarse como abortos no serían ni declarados ni inscritos con mucha más frecuencia. Esta es una circunstancia que plantea problemas a la hora de hacer estadísticas sanitarias fiables pues la mayor mortalidad infantil se produce precisamente en las primeras 24 horas de vida, etapa de mayor fragilidad y de mayor riesgo por los problemas relacionados con el parto y con el tipo y la calidad de la asistencia sanitaria.

A partir del análisis de los Libros de Exposiciones calculo que en el período de 1900 a 1913 ingresaron en la Inclusa provincial una media anual de 406 niños menores de un año, lo que supone que casi 4 menores de 12 meses ingresaban en la Inclusa anualmente por cada 100 nacidos vivos en el año en la provincia de Valladolid; de ellos, 369 eran neonatos, por tanto podemos decir que el $3^{\prime} 45 \%$ de los niños nacidos vivos en la provincia anualmente ingresaban en la Inclusa en su primer mes de vida. El promedio anual de mayores de un año que ingresaban en la Cuna del Hospicio era de 19 niños. (TABLA 3-2)

\footnotetext{
360 Movimiento Natural de la Población de España. Año De 1905. Introducción: "Los datos que informan nuestra estadística del Movimiento de población proceden de los Registros civiles. Ninguna fuente puede gozar de mayor autoridad en garantía de la exactitud de sus inscripciones, en cambio deja algo que desear en cuanto al número de los nacimientos inscriptos, pues según nuestras investigaciones no todos figuran en los Registros. No hemos evaluado la importancia de la omisión, porque para ello hubiera sido preciso comparar los datos de los Registros civiles con los procedentes de los libros parroquiales, confrontación que solo en parte se ha podido efectuar, por no haberse reunido en las Secciones de Estadistica los informes de todas las parroquias", (p XVIII]. Y más adelante, en la página XIX, se reconoce que 38.193, es la cifra que" expresa, probablemente con algún exceso, ...el promedio anual de nacimientos que se omiten en los Registros Civiles"
} 
Respecto a la distribución por sexos ingresaron en estos 14 años 2.844 niñas, que representan el $47^{\prime} 81 \%$ del total de ingresados y 3.105 niños, el $52^{\prime} 19 \%$. En general hay predominio de varones, con una diferencia media para el período de un 4’38\% sobre las niñas y con diferencias significativas en algunos años como en 1912 cuando ingresaron un 14'35\% más de niños que de niñas, en 1907 el número de varones fue un 13'79\% mayor, un 12'14\% más alto en 1902 y un 11'26\% en 1909. Solamente en 5 de los 14 años $(1903,1904,1905,1906$ y 1910) ingresaron más niñas y la diferencia máxima que se llega a alcanzar entre los dos grupos es de 5’70 \% en 1906 (ver GRÁFICA 3-5).

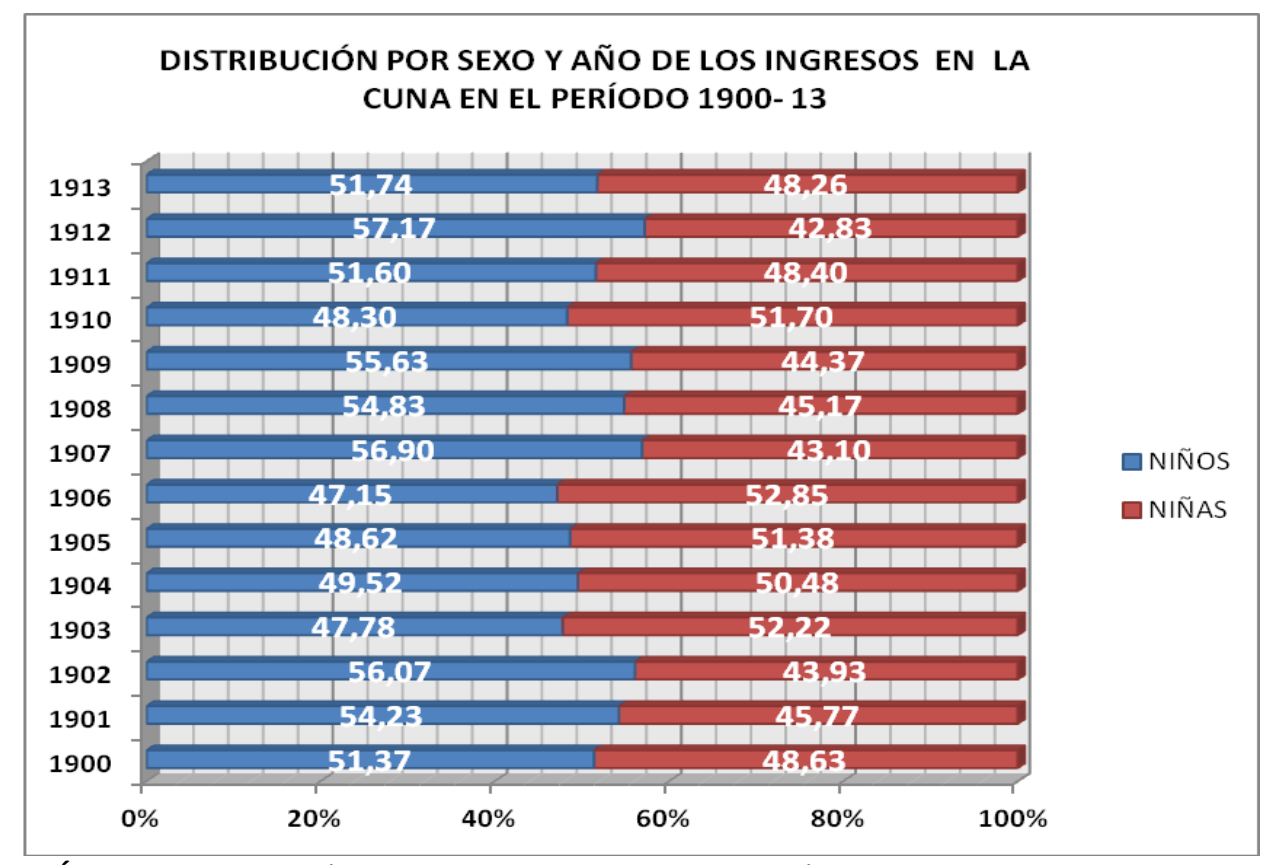

GRÁFICA 3-5: Elaboración propia a partir de los datos extraídos de los Libros de Exposiciones 1900- 1913. Al hablar de la Cuna se incluyen todos los ingresos registrados en los libros de Menores, por tanto los destinados tanto al Departamento de Lactancia ó Inclusa como al departamento llamado de Menores de siete años.

Es una diferencia que en principio llama la atención en una sociedad con preferencia por los varones y en la que podíamos esperar un abandono mayor de niñas, como señalan por otra parte algunos estudios sobre abandonos e infanticidios ${ }^{361}$, por lo que he realizado la comparación con los datos provinciales que nos proporciona el fondo Documental del INE sospechando que la causa esté en una proporción similar de nacimientos de uno y otro sexo; pero los datos obtenidos no confirman totalmente esta hipótesis, pues aunque hay un número mayor de nacimientos masculinos, no suceden exactamente en la misma proporción que los ingresos en la Cuna. Se recogen los ingresos de la Inclusa y los nacimientos provinciales por

\footnotetext{
${ }^{361}$ REVUELTA EUGERCIOS B A: op. cit. En su tesis cita los trabajos de HARRIS M.: “Why men dominate women?” en New York Times Magazine № 13 de noviembre, 1977; LANGER W. L: “Checks on population growth, 1750-1850" en Scientific American no 226, 1972.
} 
sexo en la GRÁFICA 3-6 y se comparan la proporción de niños y niñas de cada grupo, no tenemos datos provinciales de los nacidos vivos desglosados por sexo para los años $1901 \mathrm{y}$ $1903^{362}$. Podemos comprobar que todos los años han nacido un mayor número de varones, pero la diferencia respecto a las niñas no alcanza nunca el 4’5\%, ni siquiera en 1912 cuando hemos visto que en la Casa Cuna del Hospicio sobrepasa el $14 \%$.

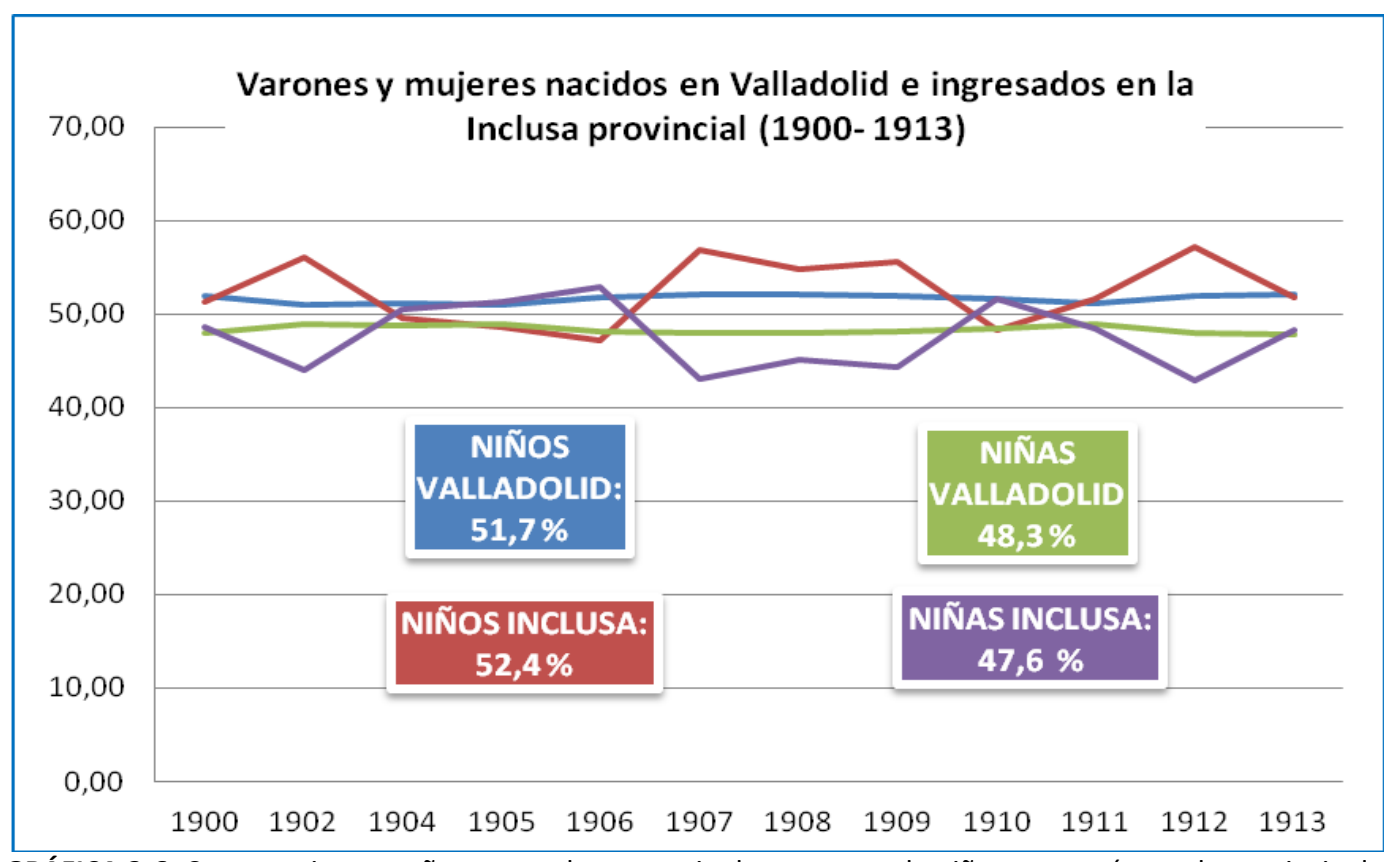

GRÁFICA 3-6: Comparativa por años entre el porcentaje de varones y de niñas que nacían en la provincia de Valladolid y los que ingresaban en la Inclusa. En los recuadros el promedio para los años 1900-1913, excluidos 1901 y 1903 al no contar con datos provinciales. Elaboración propia a partir de los datos extraídos de los Libros de Exposiciones 1900- 1913 y de las estadísticas del Movimiento Natural de la Población del Fondo Documental del INE.

Se suele utilizar la razón entre los sexos, el cociente en este caso entre el número de ingresos masculinos y femeninos, como un indicador de la existencia/ausencia de preferencia por un sexo u otro. En el caso de la Casa Cuna del Hospicio de Valladolid para el período 19001913, descontando los dos años que no hay datos del INE para hacer la comparativa, esta razón fue de 110 varones por cada 100 niñas (exactamente 110’23/100), en valores absolutos 2.684 niños y 2.435 niñas. Para el mismo período la razón entre los sexos para los nacimientos en la provincia de Valladolid fue de 107 niños por cada 100 niñas (exactamente 106'86/100). Podemos suponer que al tratarse en la mayoría de hijos ilegítimos, las mujeres que tenían que enfrentarse solas a la crianza de sus hijos eran las que generalmente debían tomar la decisión

\footnotetext{
${ }^{362}$ En las estadísticas del Movimiento Natural de la Población del Fondo Documental del INE no están desglosados por provincias y sexo los nacidos vivos de 1901. En cuanto al año 1903 a fecha de marzo de2017 siguen apareciendo los datos sobre nacimientos del año 1904. (comuniqué la incidencia por e-mail al INE a través de su página web el 8 de Julio de 2015 y recibí contestación inmediata en el sentido de que se revisaría y subsanaría)
} 
de abandonarles, aunque en muchos casos se vieran presionadas por la familia o el entorno, y parece que tenían una disposición ligeramente mayor a quedarse y cuidar a las niñas, en todo caso la diferencia es pequeña, del 3\%, o al menos no lo suficientemente amplia como para afirmar tajantemente que el sexo femenino daba ventaja en este sentido. Es muy probable que en el caso de los niños expuestos la decisión de abandonar la hubiera tomado la mujer antes del parto, por tanto antes de conocer el sexo de su hijo. Para comprobar si el sexo podía influir en la decisión de abandonar al hijo he tomado los niños que ingresaron después del primer mes y resultan 382 varones y 355 niñas, sale de una ratio de 107'60 varones /100 niñas, muy similar a la ratio por sexo provincial de nacimientos. No parece por tanto que el sexo del hijo haya sido un factor muy relevante en la decisión de abandonarlo en el caso de los incluseros del Hospicio Provincial de Valladolid, incluso es probable que se dieran casos en que la madre no llegara a ver ni a saber nada del hijo que iba a abandonar. En el Libro de 1902 en el folio no 378 se registra la siguiente nota que se dejó junto a un niño en el torno:

"Suplicando la bondad de conservar en esta criatura esta cadena y cruz para que algun dia pueda reclamarlo en nombre si es niño Lucio y si es niña Magdalena" [sic]

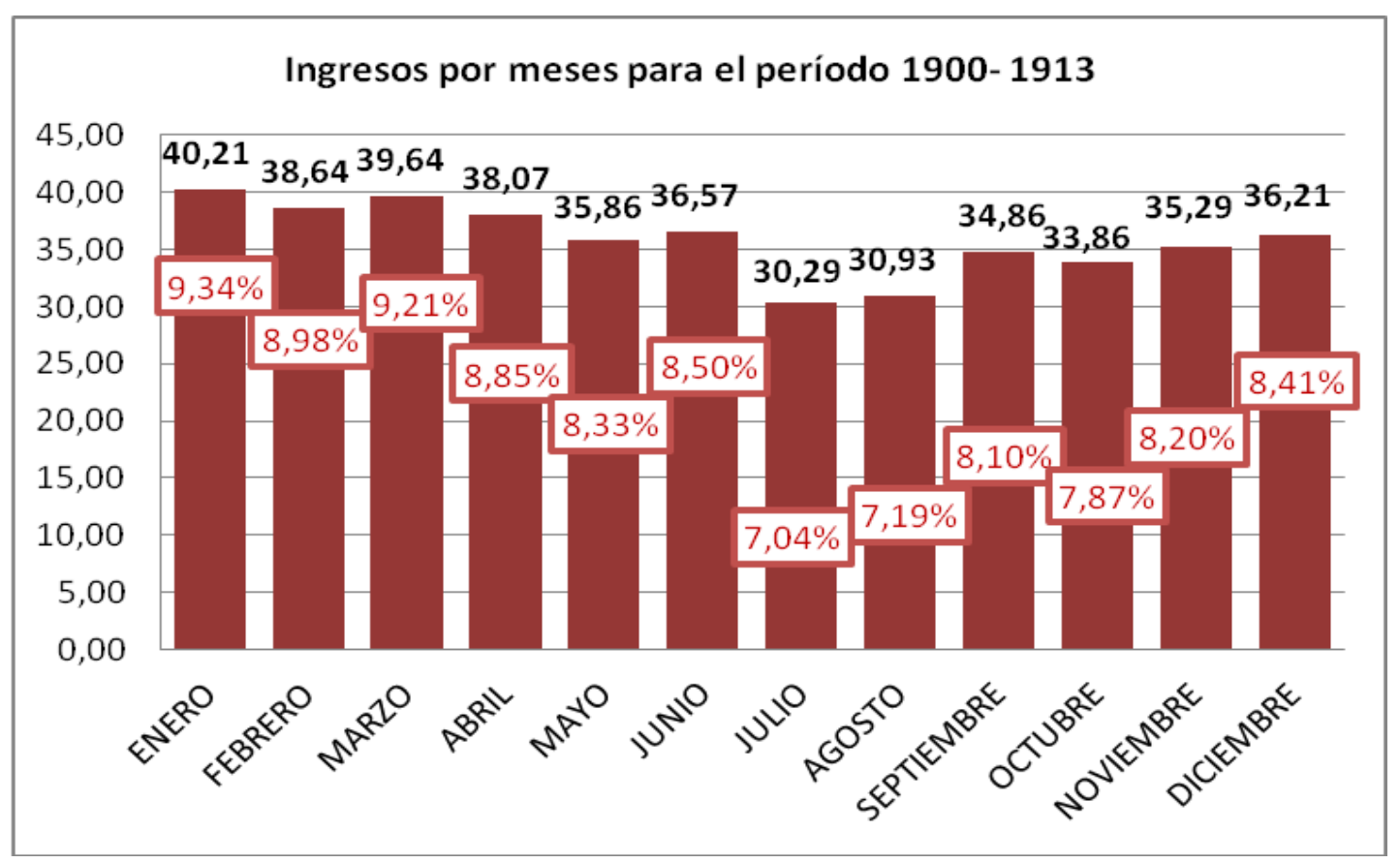

GRÁFICA 3-7: Niños ingresados por meses en la Cuna, valor promedio y porcentaje sobre el total anual. Elaboración propia a partir de los datos extraídos de los Libros de Exposiciones 1900- 1913.

Otro dato a valorar es la estacionalidad de los ingresos, en nuestra serie, los meses de más entradas han sido los invernales, enero con más del 9\% y un promedio para los 14 años de estudio de más de 40 niños nuevos, seguido de marzo con un promedio similar y febrero, (teniendo en cuenta que solo tiene 28 días y que si hacemos el cálculo para 31 días como 
tienen los otros dos meses saldría un promedio de $42^{\prime} 78$ ingresos/mes (ing/m)). En la GRÁFICA 3-7: se recoge el número medio de ingresos por mes y su distribución porcentual respecto al total anual. El promedio global es de $35^{\prime} 87 \mathrm{ing} / \mathrm{m}$ y en el invierno aumenta a $39^{\prime} 50 \mathrm{ing} / \mathrm{m}$; sigue por orden de frecuencia de ingresos la primavera (abril-mayo-junio) con $36^{\prime} 83 \mathrm{ing} / \mathrm{m}$ y el otoño con un promedio de 35'12 ing/m. La época con menos entradas en la Inclusa es el verano con $32^{\prime} 02 \mathrm{ing} / \mathrm{m}$ gracias a julio y agosto con un promedio de $30-31 \mathrm{ing} / \mathrm{m}$, septiembre se comporta como los meses otoñales. Este descenso en el verano nos hace pensar en la actividad laboral estacional puesto que tras la mayoría de los ingresos subyace la pobreza como problemática de fondo, puede estar por tanto relacionado con la estacionalidad de la actividad agrícola para una sociedad en la que predominaba este sector; julio y agosto son los meses de más actividad y por tanto de más trabajo temporal con las labores de siega y trilla, en septiembre finaliza la cosecha y la vendimia y en octubre es tiempo de siembra, mientras que el invierno es el tiempo de menos actividad y por tanto ofrece menos posibilidad de trabajar. Aparte de la actividad laboral un factor influyente en la variación temporal de los ingresos es la distribución de nacimientos a lo largo del año, sobre todo en relación con los nacimientos de la Maternidad y las exposiciones en el torno que solían ser de niños de muy corta edad. Las estadísticas que ofrece el Fondo Documental del INE nos muestran que los meses de menos nacimientos para el período 1900- 1913 fueron en primer lugar julio, seguido de noviembre, agosto y junio, mientras que marzo, enero, febrero fueron los de mayor natalidad por este orden, seguidos de abril, mayo, diciembre, septiembre y octubre ${ }^{363}$. Coinciden los meses de más nacimientos con los de más ingresos, en cuanto a los de menor número de nacidos solo en parte, para julio y agosto, noviembre ocupa el octavo lugar en cuanto al número de ingresados con un promedio muy próximo al general, pero junio es el quinto con $36^{\prime} 57 \mathrm{ing} / \mathrm{m}$ por encima de la media. He revisado los meses de junio pensando en la probabilidad de que ingresaran más niños nacidos en meses anteriores situándole en los primeros puestos a pesar de ser uno de los de menos nacimientos, pero no hay diferencias significativas con otros meses en ese sentido y la mayoría de sus ingresos son niños menores de un mes de vida. En 1912 por ejemplo, que es el año con más ingresos en el mes de junio, 46 en total, 7 niños tenían más de un mes, pero en ese mismo año en mayo ingresaron 40 niños y

\footnotetext{
${ }^{363}$ El Fondo Documental del INE en sus Memorias con el Movimiento Natural de la población ofrece cada año el Resumen de los nacimientos por meses, son datos nacionales que no están desglosados por provincias y se recogen en valores absolutos. Se han consultados los correspondientes al período 1900-1913. La Memoria de 1905 ofrece datos para el sexenio 1900- 1905 con datos en valores absolutos y promedios y el Anuario de1912 recoge el período 1900- 1907 en valores absolutos. Disponible en: http://www.ine.es/inebaseweb/libros.do?tntp=205002 He tomado los datos referentes solamente a nacidos vivos y como no hay una estadística global para establecer el orden según el número de nacimientos por mes he tenido que ir sumando los datos de cada año. Julio y noviembre se disputan los últimos puestos con poca diferencia entre ellos, de hecho en el sexenio 1900- 1905 noviembre tuvo menos natalidad, lo mismo ocurre con junio y agosto con una diferencia todavía más ajustada.
} 
8 eran mayores y en julio de 34 ingresos 7 también pasaban del mes, por tanto podemos considerarlo un mes en que los problemas de tipo socioeconómico influirían más en los ingresos de la Inclusa. Podemos decir que el número de ingresos en la Inclusa guarda relación con el de nacimientos, pero sin restar valor a los factores socioambientales que en definitiva eran los causantes de que se dejaran los niños en la Inclusa, en este sentido, también influiría el hecho de que justamente estos dos meses son los de mayor mortalida infantil.

\subsubsection{SALIDAS Y BAJAS DE LA INCLUSA}

A diferencia de los niños del Departamento de Mayores, que en su mayoría vivían en el asilo, la mayor parte de los menores que ingresaban en el Hospicio Provincial de Valladolid se criaban externos al establecimiento; unos permanecían fuera durante todo el período de crianza, otros sólo en parte y algunos entraban y salían del asilo repetidas veces. Hemos encontrado muy pocos niños que permanecieran siempre ingresados en la Cuna, o que no tengan registrada ninguna salida de ella antes de pasar al Departamento de Mayores; en total 17 en los 14 años analizados, algunos dudosos, y salvo en un registro erróneo y poco fiable, todos son niños que ingresaron con más de 4 años $^{364}$ (ver GRÁFICA 3-8 y TABLA 3-3, se recogen en el campo SOBREVIVEN, son niños que no llegaron a salir nunca para crianza).

Los menores que se encontraban internados en el asilo en su mayoría habían ingresado o habían sido devueltos recientemente y estaban a la espera de conseguir un ama externa, los de estancias prolongadas eran niños que por algún motivo no se entregaban a las nodrizas externas, podrían ser enfermos. Así se puede suponer a la vista del movimiento de niños que muestran los Libros de Exposiciones y teniendo en cuenta que la política del Hospicio daba prioridad a la crianza externa, "Siendo indudablemente preferido al sistema de crianza dentro del Establecimiento el de entregar a los niños a nodrizas externas..." (Art. 79, Regl.1889)

\footnotetext{
${ }^{364}$ En la TABLA 4-3 pueden verse los niños que no llegaron a salir de la Cuna para crianza y, entre los que se quedaron en ella, los que siguieron vivos hasta ser dados de baja por el Hospicio. Uno de ellos ingresó con casi 7 años, por lo que pasaría seguramente enseguida al libro de mayores y hay dos casos que se han contabilizado a pesar de que el registro es contradictorio tomando como válida la última anotación hecha: el primero es una niña que tiene anotado su fallecimiento en el libro al mes de vida y posteriormente se corrigió cuando a los 12 años se la entregó para "compañía de matrimonio" (1906 folio 228). En el otro caso no aparecen anotaciones después del ingreso hasta su emancipación a los 18 años, pero se ha dejado en medio un espacio en blanco muy amplio como si hubiera que escribir algo (1907 folio 125).
} 


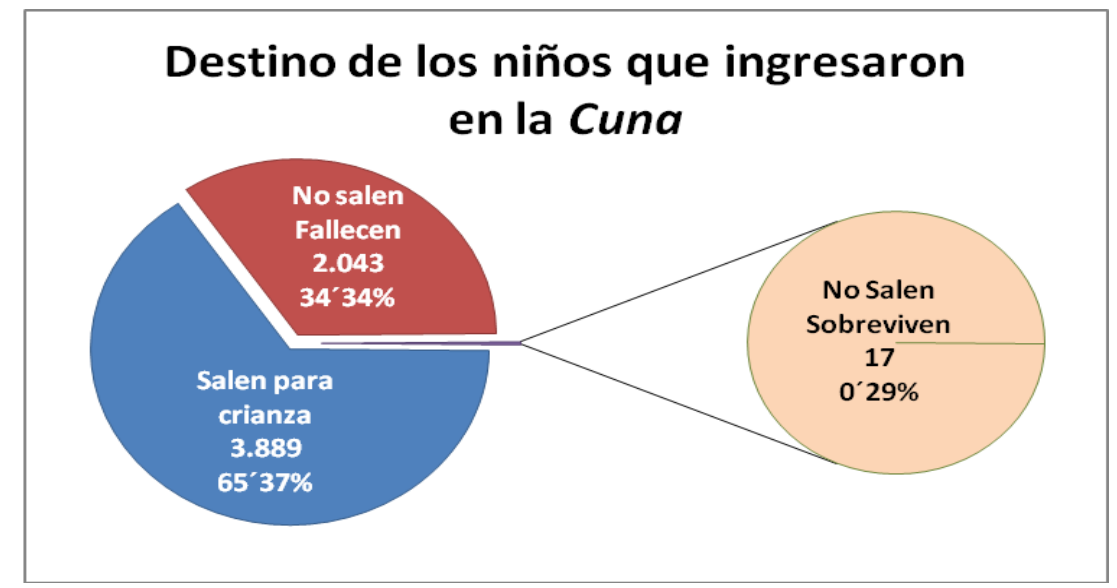

GRÁFICA 3-8: Destino de los niños ingresados, distribución en valores absolutos y en porcentaje para el período 1900- 1913. Elaboración propia a partir de los datos extraídos de los Libros de Exposiciones 1900- 1913

Sin duda ésta era la mejor opción, teniendo en cuenta el número de niños a los que la institución ofrecía asistencia y la altísima mortandad dentro de la Inclusa. Al analizar en los libros los movimientos de los menores de 5 años nos hemos encontrado que aquellos que no salían a criarse fuera del Hospicio, que eran muchos, morían prácticamente todos dentro de él. Podemos plantear dos tipos de hipótesis respecto a este hecho. La primera diría que "Los menores que no salían a criarse con amas externas estaban condenados a morir en el asilo". La segunda, igualmente penosa y en definitiva con el mismo resultado final, diría que "los niños no salían a criarse porque fallecían antes en la Inclusa". En todo caso, la realidad de las cifras de la TABLA 3-3 es durísima; en la línea NO SALEN, se recoge el número de niños que nunca salieron durante el período de crianza, o que no hay constancia al respecto, y dentro de este grupo se diferencian los que FALLECEN en el asilo y los que SOBREVIVEN, que pasaron al departamento de mayores y fueron dados de baja finalmente del Hospicio por volver con su familia o por emanciparse. Vemos que hay años en los que ningún niño interno durante todo el periodo de crianza sobrevivió al asilo, según consta en los Libros de Exposiciones del Hospicio; en el mejor de los casos, en 1907 y 1913 pudieron sobrevivir 4 niños de los 155 y 124 respectivamente que no llegaron a salir con nodrizas externas. Por tanto, en el año con datos más optimistas solamente sobrevivieron un 3’33\% de los niños que parece que no salieron nunca de la Cuna durante el período de crianza.

A pesar de que se ha comentado que la mayoría de los niños ingresados salían a criarse fuera, mirando la TABLA 3-3 podemos comprobar que algunos años era una mayoría escasa, poco más de la mitad; en 1909 solamente salieron para crianza el 534\% de los niños (237 en total); en 1902, 1903, 1908 y 1910 no alcanzaron el 60\%. En el otro extremo está 1912 con el 
85,43\% de los ingresados en ese año (387 niños); es el único año que se supera el $80 \%$. Lo terrible de estos datos es que el resto de los niños no salieron porque fallecieron antes.

\begin{tabular}{|c|c|c|c|c|c|c|c|c|c|c|c|c|c|c|c|}
\hline & & 1900 & 1901 & 1902 & 1903 & 1904 & 1905 & 1906 & 1907 & 1908 & 1909 & 1910 & 1911 & 1912 & 1913 \\
\hline \multicolumn{2}{|c|}{$\begin{array}{l}\text { INGRESADOS EN EL } \\
\text { AÑo }\end{array}$} & 475 & 378 & 412 & 450 & 418 & 434 & 386 & 406 & 414 & 444 & 441 & 407 & 453 & 431 \\
\hline \multicolumn{2}{|c|}{ SALEN PARA CRianza } & 377 & 234 & 224 & 251 & 305 & 293 & 240 & 251 & 242 & 237 & 237 & 304 & 387 & 307 \\
\hline \multicolumn{2}{|c|}{$\begin{array}{c}\text { \% DE LOS NIÑOS QUE } \\
\text { SALEN }\end{array}$} & $80^{\prime} 0$ & $61^{\circ} 9$ & $54^{\prime} 4$ & $55^{\prime} 8$ & $73^{\prime} 2$ & $67^{\prime} 5$ & $62^{\prime} 2$ & $61^{\prime} 8$ & $58^{\prime} 5$ & $53^{\prime} 4$ & $53^{\prime} 7$ & $74^{\prime} 7$ & $85^{\prime} 4$ & $71^{\prime} 2$ \\
\hline \multirow{3}{*}{$\begin{array}{c}\text { No } \\
\text { SALEN } \\
\text { DE LA } \\
\text { CUNA }\end{array}$} & No SAlen & 98 & 144 & 188 & 199 & 113 & 141 & 146 & 155 & 172 & 207 & 204 & 103 & 66 & 124 \\
\hline & FALLECEN & 98 & 142 & 188 & 198 & 112 & 141 & 144 & 151 & 172 & 207 & 203 & 101 & 66 & 120 \\
\hline & SOBREVIVEN & 0 & 2 & 0 & 1 & 1 & 0 & 2 & 4 & 0 & 0 & 1 & 2 & 0 & 4 \\
\hline
\end{tabular}

TABLA3-3: Porcentaje de niños que salen para crianza externa y mortalidad entre los niños que no salen de la Inclusa. En No SALEN se anotan todos los niños de los que no hay constancia en los libros de que llegaran a salir del asilo, los campos FALLECEN y SOBREVIVEN se refieren solamente a niños de este grupo. Elaboración propia.

\subsubsection{NÚMERO DE ACOGIDOS EN LA CUNA}

Al no contar con las memorias anuales del Hospicio sobre el personal asistido, resulta más complicado conocer para un momento concreto el número total de acogidos, internos y externos, que dependían del departamento llamado de la Cuna o de Expósitos. Solamente disponemos de los datos globales de 1905 y 1908, los otros documentos que nos sirvieron para hacer cálculos sobre la población total del Hospicio no desglosan sus datos por edad y no nos proporcionan información específica para los menores de 5 años; tomaremos por tanto estos dos años como referencia para el período de estudio. Son años que, por otra parte, no se encuentran muy alejados de la media de ingresos anuales; aquí vamos a considerar también a los nacidos muertos porque están incluidos en las memorias como ingresos, contando con ellos la media anual calculada de entradas para todo el período 1900- 13 es de 430 niños; en estos dos años ingresaron 442 niños en 1905 y 420 en 1908.

Según la memoria sobre los Estados del personal de 1905 el número total de menores de 5 años asistidos por el Hospicio al finalizar el año, sumando internos y externos, fue de $\mathbf{7 8 7}$ (290 lactantes y 497 niños de destete) y de $\mathbf{5 0 3}$ niños al final de 1908 (210 lactantes, 271 de destete y 12 sin clasificar). La diferencia entre los dos ejercicios se debe a que el número de acogidos a primeros de enero fue muy distinto en cada uno de ellos (793 en 1905 y 342 en 1908), mientras que el número de ingresos fue similar. También hay una diferencia 
significativa en el número de fallecidos, el mayor número de asistidos en 1905 condicionó un mayor número de defunciones, 434 frente a los 253 de 1908, en todo caso una mortalidad tremenda. Solo 28 niños fueron entregados a sus padres en 1905 y 6 niños en 1908. Los datos globales de los dos años se recogen en la TABLA 3-4.

TOTAL DE NIÑOS MENORES DE 5 años A CARGO DE LA INCLUSA: INTERNOS + EXTERNOS

\begin{tabular}{|c|c|c|c|c|c|c|c|c|c|c|}
\hline & \multirow{2}{*}{$\begin{array}{c}\text { AcOGIDOS } \\
\text { A } 10^{5} \text { DE } \\
\text { AÑo }\end{array}$} & \multicolumn{3}{|c|}{ INGRESOS } & \multirow[b]{2}{*}{ FALLECIDOS } & \multirow{2}{*}{\begin{tabular}{|c} 
DeVueltos \\
A SUS \\
PADRES
\end{tabular}} & \multicolumn{4}{|c|}{ ACOGIDOS A FINALES DE AÑO } \\
\hline & & LACTANTES & Destete & TOTAL & & & LACTANTES & Destete & $\begin{array}{c}\text { sin } \\
\text { clasificar }\end{array}$ & TOTAL \\
\hline 1905 & 793 & \multicolumn{2}{|c|}{437} & 437 & 434 & 28 & 290 & 497 & & $\begin{array}{c}787 \\
\left(768^{*}\right) \\
\end{array}$ \\
\hline 1908 & 342 & 403 & 17 & 420 & 253 & 6 & 210 & 271 & 12 & 503 \\
\hline
\end{tabular}

TABLA 3-4 de elaboración propia a partir de los datos extraídos del Estado demostrativo del movimiento de acogidos del Hospicio Provincial. 1906 y de la Memoria Estados de personal de 1908. ADPVA. En negrita y cursiva los datos presentes en los documentos, el resto son datos calculados (* entre paréntesis la cifra calculada para este dato a partir de los que proporciona el propio documento)

Al revisar los datos del informe de 1905 encontramos desajustes en el cálculo de los niños asistidos. En el documento se recogen al finalizar el año un total de $\mathbf{7 8 7}$ asistidos, según mis cálculos a partir de los datos que ofrecen los propios informes del Hospicio serían $768^{365}$. El error parece estar en el recuento de los niños de Destete, la forma en que se han recogido los datos en la memoria se presta a confusión al contabilizar algunos niños dos veces; 14 niños se han contado al ingresar en el Hospicio en el grupo de Lactancia y se vuelven a contar dentro del grupo de Destete en el apartado de los niños devueltos por las nodrizas; ocurre lo mismo con los 5 niños que figuran como "entregados por sus padres". Por tanto, los 497 niños de Destete contabilizados a final de año en la Memoria no sería un dato correcto, con los cálculos corregidos salen $478^{366}$.

\footnotetext{
365 La Memoria de 1905 muestra que los "Existentes en 31 de diciembre de 1905" son 290 niños de Lactancia y 497 de Destete, lo que suma los 787 que recogemos en la tabla. Cuando hacemos los cálculos en base a los demás datos que aparecen en ella, sumando el total de niños existentes el 31 de diciembre de 1904 (793) con los de nuevo ingreso durante el transcurso de 1905 (437) y descontando las bajas por fallecimiento y por entrega a sus padres (462), salen realmente 768 niños; hay un desfase de 9 niños.

En cuanto a los datos de 1908 recogidos en la tabla todos han tenido que calcularse a partir de la información de la memoria Estados de personal. Año de 1908

${ }^{366}$ En el Libro de Exposiciones de 1905 que se hacen registros hasta el folio 439, dos folios están anulados, por tanto hay en total 437 ingresos en la Cuna durante el año, contando a todos los menores de 5 años que ingresaron por primera vez en el establecimiento y a 3 "niños muertos" en la Maternidad del Hospicio. En el Estado demostrativo del movimiento de acogidos los 437 ingresos se encuentra registrado íntegramente en el apartado de Lactancia.

Cotejando con el Libro de Exposiciones de 1905, se puede comprobar que se han incluido en el total de ingresos de Lactancia a los 7 niños mayores de 15 meses que ingresaron en ese año, que por edad deberían ir en el apartado de Destete. Uno de ellos fue expuesto en el torno con su hermana más pequeña y una nota comunicando que se les dejaba por falta de recursos para criarlos, otro ingresó también con un hermano por orden del Presidente de la Diputación sin indicar el motivo y los 5 restantes entraron a través de la Comisión y son los que se cuentan como "entregados por sus padres" en el apartado del Destete, por tanto se han contado dos veces.
} 
En todo caso parece que hay un error contable a la hora de hacer la estadística, que no tendría mayor relevancia si no fuera porque nos hace pensar, junto con otros indicios que se irán comentando, en deficiencias en el control de los niños asistidos, en particular de los externos.

\begin{tabular}{|c|c|c|c|c|c|}
\hline \multicolumn{6}{|c|}{$\begin{array}{c}\text { MOVIMIENTO DE NIÑOS MENORES DE } 5 \text { AÑOS DEL } 1 \text { DE ENERO AL } 31 \text { DE DICIEMBRE } \\
\text { DE } 1905 \text { EN EL HOSPICIO PROVINCIAL DE VALLADOLID }\end{array}$} \\
\hline & & $\begin{array}{l}\text { LACTANTES } \\
<15 \text { meses }\end{array}$ & $\begin{array}{l}\text { DESTETE } \\
15 m-<5 \text { añ }\end{array}$ & & TOTAL $<5$ años \\
\hline Existentes a 31 dic & iembre 1904 & 333 & 460 & & 793* \\
\hline \multirow{4}{*}{$\begin{array}{r}\text { INGRESOS AÑO } \\
1905\end{array}$} & \multirow[t]{4}{*}{ TOTAL } & \multicolumn{3}{|c|}{437} & 437 \\
\hline & & \multicolumn{2}{|c|}{ por edad pasan a destete } & 76 & \\
\hline & & \multicolumn{2}{|c|}{ entregados por sus padres } & 5 & \\
\hline & & \multicolumn{2}{|c|}{ devueltos por amas externas } & 14 & \\
\hline \multicolumn{2}{|c|}{ TOTAL ASISTIDOS 1905} & \multicolumn{3}{|c|}{$333+437+460$} & $1.230 *$ \\
\hline \multirow{3}{*}{$\begin{array}{r}\text { FALLECIDOS } \\
\text { AÑO } 1905\end{array}$} & en la Inclusa & 278 & \multicolumn{2}{|l|}{10} & $288^{*}$ \\
\hline & con las amas & 120 & \multicolumn{2}{|l|}{26} & $146^{*}$ \\
\hline & TOTAL & $398 *$ & \multicolumn{2}{|l|}{36} & $434^{*}$ \\
\hline \multicolumn{2}{|c|}{ Devueltos a sus padres } & 6 & \multicolumn{2}{|l|}{22} & $28 *$ \\
\hline \multirow{3}{*}{$\begin{array}{l}\text { EXISTENTES A } 31 \\
\text { DICIEMBRE } 1905\end{array}$} & Internos & 27 & \multicolumn{2}{|l|}{$1^{*}$} & $28 *$ \\
\hline & Con amas & $\begin{array}{c}263 \\
\text { (223 de los ingresos } \\
\text { de ese año) }\end{array}$ & \multicolumn{2}{|c|}{$\begin{array}{c}(496) \\
\text { corregido } 477^{*}\end{array}$} & $740^{*}$ \\
\hline & TOTAL & 290 & \multicolumn{2}{|c|}{$\begin{array}{c}\text { (497) } \\
\text { corregido } 478^{*}\end{array}$} & $\begin{array}{c}(787) \\
\text { corregido } 768^{*}\end{array}$ \\
\hline \multicolumn{6}{|c|}{$\begin{array}{l}\text { TABLA 3-5: de elaboración propia a partir de los datos sobre el Estado demostrativo de } \\
\text { movimiento de acogidos del Hospicio Provincial. 1906. ADPVA. (Los datos en cursiva son los que } \\
\text { aparecen en el documento, el resto, con asterisco* han sido calculados,). }\end{array}$} \\
\hline
\end{tabular}

Se ha elaborado la TABLA 3-5 a partir de los informes de 1905 (IMAGEN 3-3) y el correspondiente Libro de Exposiciones, con los datos que aportan los documentos originales y los que a partir de ellos he calculado. Podemos estimar que el número total de menores de $\mathbf{5}$ años asistidos por el Hospicio de Valladolid a lo largo de 1905 fue de 1.230 niños (770 lactantes y 460 niños de destete, de los que fallecieron respectivamente 398 y 36 en cada grupo de edad y 28 volvieron con sus padres) ${ }^{367}$. Recordamos que para ese año se ha calculado un total de 1.707 niños de todas las edades asistidos por el Hospicio Provincial de Valladolid. [2.4.2. Población acogida] Con fecha 1 de enero de 1906 eran 27 los lactantes "existentes en el Establecimiento", y 263 los externos, "para su lactancia fuera...", de ellos 223 ingresaron en el

En el apartado correspondiente al Destete, se han registrado como ingresos a los 14 niños que fueron devueltos por las nodrizas, cuando realmente no son nuevos en el establecimiento y debemos considerarlos como ya incluidos entre los ingresados o entre las "existencias a 31 de diciembre".

${ }^{367}$ Se ha recalculado los datos de los niños de Destete asistidos a partir de los que el propio informe nos ofrece, descontando de los 555 que aparecen en el Total en la memoria los que están duplicados, es decir, los $76^{*}$ que pasaron desde el departamento de Lactancia por cumplir la edad, los $14^{*}$ devueltos por las criadoras y los $5^{*}$ entregados por sus padres. (* datos recogidos en la TABLA 3-5 dentro del campo ingresos año 1905) 


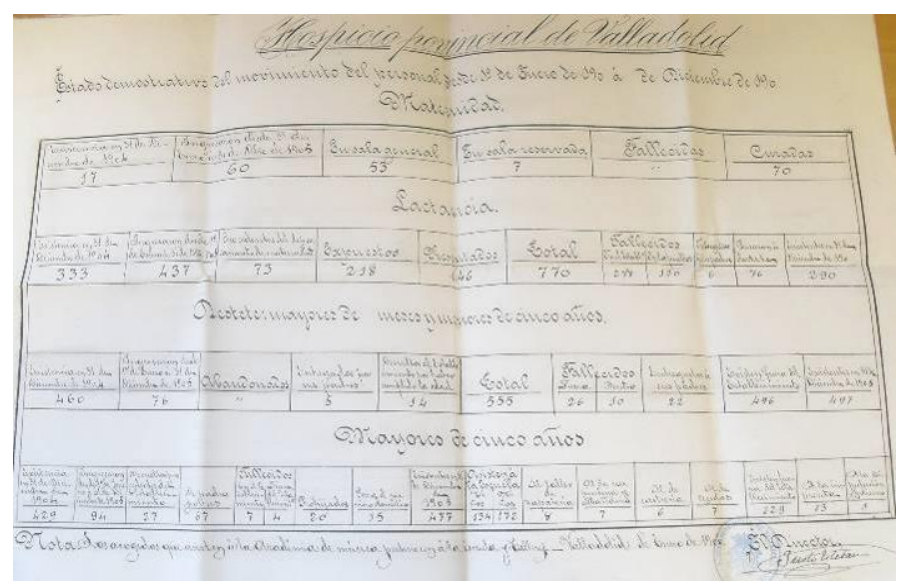

Imagen 3-3 Estado demostrativo del movimiento de acogidos del Hospicio Provincial. 1906. Recoge el movimiento durante el año 1905.

curso del año, y, en cuanto a los niños de Destete (entre 15 meses y 5 años), solamente uno se encontraba ingresado en esta fecha y 496 estaban criándose con amas externas.

La Memoria de 1908 nos ofrece datos globales con el estado del personal acogido a fecha de 31 de diciembre y las entradas y salidas durante todo el año. Sabemos que el 31 de diciembre se encontraban internos 32 lactantes y 14 niños menores de 5 años. La Memoria no recoge expresamente el número de niños que se estaban criando fuera, en su lugar contabiliza las cartillas que se presentaron a cobro, cada cartilla correspondía a un niño, por lo que sobre este dato se puede calcular que había 457 niños (se presentaron 188 cartillas de lactancia, 257 de destete y 12 no se presentaron o lo hicieron tarde y no se indica de qué tipo son, por lo que las he considerado sin clasificar). Por tanto, a finales de año eran en total $\mathbf{5 0 3}$ menores de 5 años dependientes del Hospicio. Ingresaron a lo largo del año 403 niños de lactancia y 17 de destete. De los 216 que salieron para crianza externa, 27 fueron devueltos y 39 fallecieron con las criadoras. Fallecieron en el Hospicio 214 niños, 17 de ellos habían sido devueltos por las amas externas, (de los 63 niños mayores de 5 años que ingresaron en ese año solamente uno falleció). Únicamente 6 niños volvieron con sus padres. No se registra en la memoria el número de acogidos al comenzar el año. (TABLA 3-6)

\begin{tabular}{|c|c|c|c|c|c|c|c|c|c|c|c|c|}
\hline \multicolumn{13}{|c|}{$\begin{array}{c}\text { MOVIMIENTO DE NIÑOS MENORES DE } 5 \text { AÑOS DEL } 1 \text { DE ENERO } 1908 \text { AL } 31 \text { DE DICIEMBRE DE } \\
1908 \text { EN EL HOSPICIO PROVINCIAL DE VALLADOLID }\end{array}$} \\
\hline \multicolumn{4}{|c|}{ Ingresos año 1908} & \multicolumn{4}{|c|}{ Salieron para crianza } & \multicolumn{2}{|c|}{$\begin{array}{l}\text { Fallecidos en } \\
\text { Hospicio }\end{array}$} & \multirow{2}{*}{\multicolumn{2}{|c|}{$\begin{array}{c}\text { Total } \\
\text { Fallecidos }\end{array}$}} & \multirow{2}{*}{$\begin{array}{l}\text { Devueltos a } \\
\text { sus padres }\end{array}$} \\
\hline Lactantes & \multicolumn{2}{|c|}{ Destete } & Total & Total & Devueltos & \multicolumn{2}{|c|}{ Fallecidos } & Total & Devueltos & & & \\
\hline 403 & 1 & 7 & 420 & 216 & 27 & & & 214 & 17 & \multicolumn{2}{|c|}{253} & 6 \\
\hline \multicolumn{13}{|c|}{ ACOGIDOS MENORES DE 5 AÑOS DEPENDIENTES DEL HOSPICIO A 31 DICIEMBRE 1908} \\
\hline \multicolumn{5}{|c|}{ INTERNOS } & \multicolumn{7}{|c|}{ Criándose fuera de la Cuna: CARTILLAS } & \multirow{2}{*}{ TOTAL } \\
\hline \multirow{2}{*}{\multicolumn{2}{|c|}{$\frac{\text { Lactantes }<15 \mathrm{~m}}{32}$}} & \multicolumn{2}{|c|}{ Destete $15 \mathrm{~m}-5 \mathrm{a}$} & Total & \multicolumn{2}{|c|}{ De lactancia } & \multicolumn{2}{|c|}{ De destete } & \multicolumn{2}{|c|}{ Sin tipificar } & Total & \\
\hline & & & 14 & 46 & \multicolumn{2}{|c|}{188} & \multicolumn{2}{|r|}{257} & \multicolumn{2}{|c|}{12} & 457 & 503 \\
\hline
\end{tabular}


En El Norte de Castilla encontramos en abril de 1902 una pequeña reseña en la que recogen el número de asistidos en las instituciones provinciales de Valladolid a fecha de 3 de abril de 1902. En el Hospicio provincial había "432 asilados mayores de cinco años; 423 en destete y 242 en lactancia; total 1.097 asilados $^{\prime 368}$, por las cifras que da se refiere a la suma de internos y externos y sale un total de 665 menores de 5 años asistidos en esa fecha.

Las cifras que tenemos sobre el número de menores de 5 años acogidos en estos años sobre los que tenemos datos son dispares, si tomamos el valor promedio como referencia para la época, a falta de otros datos más concluyentes, resulta una media de 682 niños dependientes del Hospicio, tanto en régimen interno como externo. Con los datos de los Censos de 1900 y 1910 he calculado un promedio de 34.660 niños menores de 5 años en la provincia de Valladolid para este período (7.011 en la capital), por lo que resulta que el $\mathbf{1 , 9 7 \%}$ de los menores de 5 años de la provincia estaban asistidos por el Hospicio Provincial.

\begin{tabular}{|c|c|c|c|c|c|}
\hline \multicolumn{6}{|c|}{ NIÑOS MENORES DE 5 AÑOS ASISTIDOS POR EL HOSPICIO PROVINCIAL DE VALLADOLID } \\
\hline № DE ACOGIDOS & 03-04-1902 & 31-12-1904 & 31-12-1905 & \multicolumn{2}{|c|}{$31-12-1908$} \\
\hline LACTANCIA & 242 & 333 & 290 & 220 & \multirow{2}{*}{+12} \\
\hline DESTETE & 423 & 460 & 478 & 271 & \\
\hline TOTAL & 665 & 793 & 768 & \multicolumn{2}{|c|}{503} \\
\hline PROMEDIO & \multicolumn{5}{|c|}{$682^{\prime} 25$} \\
\hline \multicolumn{6}{|c|}{$\begin{array}{l}\text { TABLA 3-7 de elaboración propia a partir de los datos extraídos del Estado demostrativo del } \\
\text { movimiento de acogidos del Hospicio Provincial. 1906, la Memoria Estados de personal de } 1908 . \\
\text { ADPVA y los datos del N.C. de 4- 04- 1902. }\end{array}$} \\
\hline
\end{tabular}

En los Anuarios Estadísticos de España que se encuentran en el Fondo Documental del INE encontramos datos sobre el Movimiento de expósitos en las Casas provinciales de las capitales a partir del año 1915. He extraído los datos de Valladolid y sumado los de cada campo, que se encuentran desagregados en el documento original por sexos, y se presentan en la TABLA 3-8

\footnotetext{
${ }^{368}$ N.C., 4 de abril de 1902, p 3. La noticia, muy breve dice:

"He aqui unas cuantas cifras harto elocuentes para necesitar comentarios.

En el Manicomio provincial había ayer 708 alienados, de los cuales 196 son de la provincia de Valladolid. En el Hospital provincial 274 enfermos, de los cuales son hombres 111 y 168 mujeres.

En el Hospicio provincial 432 asilados mayores de cinco años; 423 en destete y 242 en lactancia; total 1.097 asilados"
} 


\begin{tabular}{|c|c|c|c|c|c|c|}
\hline \multicolumn{7}{|c|}{ Movimiento de expósitos en la Cuna de Valladolid entre 1915 y 1930} \\
\hline \multirow{2}{*}{$\begin{array}{l}\text { VALLADOLID } \\
\text { ANUARIOS }\end{array}$} & \multirow{2}{*}{$\begin{array}{c}\text { ACOGIDOS EN } \\
\text { PRIMERO DE } \\
\text { AÑo } \\
\end{array}$} & \multirow{2}{*}{$\begin{array}{c}\text { ENTRADAS } \\
\text { DURANTE EL } \\
\text { AÑo } \\
\end{array}$} & \multirow[b]{2}{*}{ SUMA } & \multicolumn{2}{|c|}{ SALIDAS Y BAJAS } & \multirow{2}{*}{$\begin{array}{l}\text { MORTALIDAD } \\
\text { POR } 1.000 \\
\text { EXPÓSITOS }\end{array}$} \\
\hline & & & & POR DEFUNCIÓN & OTRAS CAUSAS & \\
\hline 1915 & 440 & 393 & 833 & 108 & 232 & $1299^{\prime} 65$ \\
\hline 1916 & 151 & 479 & 630 & 269 & 223 & $426^{\prime} 90$ \\
\hline 1917 & 138 & 522 & 660 & 290 & 340 & $448^{\prime} 50$ \\
\hline 1918 & 429 & 527 & 956 & 509 & 43 & $523^{\prime} 43$ \\
\hline 1919 & 41 & 391 & 432 & 293 & 87 & $678^{\prime} 24$ \\
\hline 1920 & 52 & 395 & 447 & 239 & 170 & $534^{\prime} 68$ \\
\hline 1921 & 38 & 431 & 469 & 268 & 161 & $583^{\prime} 88$ \\
\hline 1922 & 148 & 371 & 519 & 259 & 136 & $499^{\prime} 03$ \\
\hline 1923 & 149 & 395 & 544 & 271 & 172 & $498^{\prime} 16$ \\
\hline 1924 & 177 & 379 & 556 & 237 & 202 & $426^{\prime} 25$ \\
\hline 1925 & 186 & 368 & 554 & 270 & 127 & $487^{\prime} 36$ \\
\hline 1926 & 64 & 333 & 397 & 238 & 94 & $599^{\prime} 50$ \\
\hline 1927 & 65 & 365 & 430 & 151 & 233 & $351^{\prime} 16$ \\
\hline 1928 & 46 & 391 & 437 & 138 & 262 & $315^{\prime} 79$ \\
\hline 1929 & 27 & 463 & 500 & 156 & 259 & $312^{\prime} 00$ \\
\hline 1930 & 85 & 419 & 504 & 155 & 263 & $307^{\prime} 54$ \\
\hline
\end{tabular}

A la vista de las cifras que aparecen en la TABLA 3-8 y teniendo en cuenta las que se han obtenido a partir de los documentos del ADPVA, hemos de suponer, ya que no se da ninguna explicación al respecto, que los datos que se recogen en los informes sobre el movimiento de expósitos solamente se refieren a la Cuna, con sus dos secciones de acogida de los menores (lactancia y destete), que se consideraba y llamaba también Casa de Expósitos, y que se ha excluido el departamento de Mayores de 5 años del Hospicio. Sin embargo, las cifras que aparecen en el campo "ENTRADAS DURANTE EL AÑO" aunque cuadran con el número de ingresos que vimos para el período 1900- 1913 (ver TABLA 3-3), para el que se ha calculado una media anual de 425 niños, no concuerdan con los datos que ofrece el Informe de acogidos en 1914- $1918^{369}$ para estos años (ver TABLA 2-4 capítulo del Hospicio). Si comparamos los datos de la tabla, extraídos de los anuarios del INE (INE) calculando el total porque están separados por sexos, con los del Informe del Hospicio (HOSP), vemos que no encajan, no podemos concluir con seguridad a qué tipo de población del Hospicio se refieren los datos que nos están ofreciendo los Anuarios, ni a los grupos de edad ni al tipo de acogimiento, solo residentes en el Hospicio o también asistidos con residencia fuera de él. Según el Informe HOSP las entradas que da el INE para 1915 serían solamente de niños de Lactancia (392 en HOSP), para 1916 el

\footnotetext{
${ }^{369}$ Informe del número de acogidos entre 1914 y 1918. Signatura: caja 4051, expediente 38001. ADPVA
} 
dato del INE es justamente la suma de ingresos para lactancia (439) y destete (40) pero para el resto de los años no concuerdan las cifras. En 1917 el INE da 522 ingresos y el HOSP un total de 490 en los tres departamentos, incluyendo los mayores, la diferencia podrían ser las mujeres de la Maternidad que también se hubieran contabilizado en el informe del INE. 1918 Nos lo pone más difícil todavía, 527 entradas según el INE frente a 466 niños de lactancia, 42 de destete y 75 mayores (suman 583, 508 sin los mayores); no salen las cuentas, la única posibilidad que queda, considerando que los datos del INE deberían tener una base real, es que se hayan sumado los expósitos de la Cuna con las mujeres de la Maternidad. En todo caso, estos datos resultan muy poco fiables pero nos pueden dar una idea aproximada, tomándolos con la debida precaución. Según estas estadísticas de los Anuarios, en este período 19151930, ingresarían en la Cuna de Valladolid 6.622 niños, resultando una media anual de 414 niños (413'87), con incrementos llamativos durante los años 1917 y 18, en plena Primera Guerra Mundial, en los que se superaron los 500 ingresos (según el Informe del Hospicio 1918 también tuvo un total de ingresos muy por encima de los años previos).

Si la columna ENTRADAS nos ha ofrecido dificultades, aún es más complicado interpretar la de "ACOGIDOS EN PRIMERO DE AÑO"; no está claro si se refiere solamente a los menores que se encontraban internados en la Cuna al comienzo del año, si incluye internos y externos o si está computando a todos los internados mayores y menores dependientes del Hospicio, pues puede verse en la tabla que los datos son demasiado dispares de unos años a otros. Si tomamos como referencia las Memorias de 1905 y 1908, los datos de la mayoría de los años de la TABLA 3-8 parece que, aunque estén muy por encima de los que conocemos (28 en 1905 y 46 en 1908), pueden informar del número de niños internos en la Cuna, excepto para 1915 (440 niños) y 1918 (429 niños) que podrían ser el total de menores acogidos, incluyendo los externos (en 1908 fueron 503), o el total de asilados internos sumando mayores y menores (457 en 1908). Caben dudas para los años 1916- 17 y desde 1922 a 1925 en los que se registran entre 138 y 186 niños, muchos para ser solo los menores de la Cuna comparado con los datos que tenemos de 1905 y 1908, pero aún así, considero que es lo más probable porque parecen demasiado pocos para ser el total de asilados internos de todas las edades, recordemos que EI Norte de Castilla publicaba que el 17 de julio de 1912 en el Hospicio "se albergan 750 asilados de todas clases, edades y sexos", lo que incluiría posiblemente también a las mujeres de la maternidad. Podemos comparar también estos datos con los de la TABLA 2-5 del capítulo del Hospicio en la que se recogen los promedios de población interna y externa del quinquenio 1917-21 recogidos en la Memoria del año 1921 de la Diputación que aparecen en el Presupuesto provincial de $1922-23$ en la que se muestra un descenso significativo de la 
población externa y teniendo en cuenta que la mayoría de los externos eran menores, podemos suponer que aumentaría en proporción similar el número de internos en la Cuna. Estas cifras de internos tan elevadas tendrían relación con los problemas que tuvo el Hospicio en muchos momentos debido a la escasez de nodrizas externas, mal remuneradas y con un salario que prácticamente se mantuvo fijo en el período de estudio hasta la última década, cuando precisamente en el presupuesto de 1921 se dobló, pasando las amas lactantes de los pueblos de cobrar 15 pts a 30 pts mensuales y en 1926 se volvió a aumentar otro cincuenta por ciento hasta $45 \mathrm{pts} / \mathrm{mes}$. También justificarían que aparecieran en la prensa anuncios solicitando "amas secas para cuidar los niños del hospicio"370.

No he encontrado ningún documento que refiera la capacidad de la Cuna en el período de estudio, pero para hacernos una idea nos pueden servir los datos que daba el doctor Juan Bosch en su discurso de entrada en la real Academia de Medicina referentes a 1944 en el que decía que la Inclusa provincial de Valladolid estaba dotada con 66 cunas para lactantes y 56 para destetes ${ }^{371}$, en total 122 cunas, téngase en cuenta la tendencia a aumentar el número de internos frente a los externos.

Son realmente impresionantes las cifras de mortalidad que nos ofrecen los Anuarios, que recogemos en esta tabla porque así aparecen en los informes sobre expósitos, cifras que debemos decir que son muy diferentes de las que la propia Diputación ofrece para el quinquenio 1917-21 en la Memoria de 1921 que acompaña al Presupuesto provincial de 192223, que no llegan al 7\%. Trataremos más adelante el tema de la mortalidad de la Cuna. Ya se comentó al hablar de la población en el capítulo del Hospicio que las estadísticas que nos han llegado por diferentes vías son un tanto confusas y discordantes, no aclaran a que población específica se refieren por lo que nos encontramos con datos diferentes y en ocasiones difíciles de conciliar e incluso de comparar entre sí.

\footnotetext{
${ }^{370}$ N.C. 8- 10- 1919, p 2

371 BOSCH MARÍN J.: El niño español en el siglo XX. Madrid. Publicaciones "Al servicio de España y del niño español"; no. 109-112. 1947, p 159
} 


\subsubsection{LOS ILEGÍTIMOS}

Su madre no es muy buena y su padre peor, porque ofendieron al Redentor

Cuando mis padres se casen vendrán a por mí Notas transcritas a las cédulas de entrada de la Casa de Misericordia de León en el siglo XVIII que acompañaban a los niños abandonados en su torno $^{372}$

Los niños ilegítimos no necesitaban ningún trámite para ingresar en la Inclusa provincial, bastaba con dejarles en el torno o exponerlos en un lugar público, mientras que los hijos legítimos, según los Reglamentos, necesitaban la aprobación de la Comisión Provincial, previa demostración de la situación de pobreza.

"Se recibirán en él [departamento de la Casa-Cuna] todos los niños de ambos sexos habidos ilegítimamente... [que] deberán ser expuestos en el torno."

La ilegitimidad constituía en sí misma justificación para el ingreso en las inclusas, que se crearon para recoger a estos "desechados", "«hijos de la escoria y hez de la república»... pues eran los que en principio corrían mayor riesgo de rechazo y eliminación violenta" ${ }^{373}$. Carlos IV legitimó en la Novísima Recopilación publicada en 1805 el estado de los bastardos de padres desconocidos, pero solamente con efectos civiles; la posterior ley de Registro Civil de 1870 exigía la inscripción del carácter legítimo o ilegítimo del niño.

La ilegitimidad era todavía en las primeras décadas del siglo XX una condición social relevante y diferenciada; lo demuestra el hecho de que la encontramos recogida en los registros del Hospicio de Valladolid de la misma manera que se hacía en el Registro Civil y en las estadísticas demográficas nacionales. En base a los datos de los registros civiles, en las estadísticas del INE sobre nacimientos se diferenciaban Legítimos, llegítimos y Expósitos, tanto para los nacidos vivos como para los "nacidos muertos, fallecidos antes de cumplir 24 horas". La prensa local de Valladolid publicaba mensualmente los datos demográficos de la provincia y en los nacimientos también diferenciaba los ilegítimos, ya que publicaban "según datos de la Dirección general del Instituto Geográfico y Estadístico, procedentes del Registro Civil’”374.

En los libros de entrada de la Inclusa, al registrar a los niños se anotaban los nombres de sus padres cuando se conocían en el momento del ingreso, de lo contrario se escribía "de padres desconocidos" y se añadía, si se sabía, la condición de legítimo, ilegítimo o natural.

\footnotetext{
372 HERNANDO GARRIDO J.L. :op. cit., p 9

373 PÉREZ MOREDA. V.: op.cit., separata Mensajeros de la Paz no 14, p 5

${ }^{374}$ N.C. sección Movimiento Demográfico, diariamente publicaba el movimiento de la ciudad y mensualmente los datos provinciales
} 
"En 13 de Febrero de 1910 fue entregada en este Asilo por Francisca Val, vecina de Villalon con oficio del Alcalde, partida de bautismo y certificacion del Registro civil donde constan que fue expuesta á la puerta de una casa de la arriba citada Villa el día 10 del corriente y que es hija de padres desconocidos" [sic]

Folio no 53 del Libro 10 de 1910. Falleció en el asilo antes de un mes

Se utilizaba más el término "hijo natural", en pocos registros de los libros revisados, tanto de menores como de mayores, se encuentra el término ilegítimo, quizá porque se consideraba ofensivo, como lo calificó y por ello lo penalizó la legislación de Carlos IV. No podemos saber si estos términos se utilizaban en sentido estricto o se denominaba hijos naturales a los ilegítimos para evitar usar éste término por el castigo que imponía la Novísima Recopilación; aunque actualmente esto no tiene relevancia social, son términos con matices diferentes en su significado. Se define el hijo ilegítimo como "el que no procede de legítimo matrimonio", sin más, mientras que el hijo natural tiene una definición más concreta como el "habido de madre soltera y padre libre, que podían casarse al tiempo de tenerle". Tiene nuestra lengua otros términos para los ilegítimos; cuando los "padres no podían contraer matrimonio al tiempo de la concepción ni al de nacimiento", al hijo se le dice bastardo, borde, espurio, mancillado, o "habido en buena guerra". Los legítimos son "hijos de bendición" 375.

Al registrar a los hijos legítimos se anotaban los nombres de los dos progenitores

"En 17 de Agosto de 1909 ingreso en este Asilo por acuerdo de la Comisión provincial con certificacion del Registro Civil del distrito de la Audiencia donde constan que nacio el 13 de Febrero de 1908 y que és hija legítima de Vicente (difunto) y de Estefania" [sic]

Folio no 291 del Libro 2o de 1909. Falleció en el asilo.

En los ilegítimos solían escribir junto al nombre de la madre su edad y su estado social, soltera, casada o viuda, excepto en el caso de las mujeres "refugiadas en el asilo".
"María del Carmen Alfageme Rodriguez
En 18 de julio de 1910 ingreso por acuerdo de la Comision provincial con certificación del Registro civil donde consta que nació el 16 de Julio corriente y que es hija ilegitima de Quirina Alfageme Rodriguez, de estado viuda de 40 años de edad, natural de Verdemarban provincia de Zamora, vecina de Matilla de los Caños" [sic]

\footnotetext{
${ }^{375}$ En diccionarios y enciclopedias de la época se recogen otras variantes que no he visto utilizar en los libros revisados y que persisten en el diccionario de la RAE actual: ADULTERINO: "el nacido de un casado y una soltera, o de un casado y una casada que no son cónyuges", DE GANANCIA: "hijo natural", DE LA TIERRA: "el que no tiene padres ni parientes conocidos". En la entrada hijo se define también: DE LA CUNA: "el de la inclusa", DE LA PIEDRA: "expósito que se cría de limosna sin saberse sus padres", DE LECHE: "el niño con relación al ama que lo crió". Enciclopedia universal ilustrada europeo-americana, tomo 27, Hijos de J. Espasa Editores Barcelona 1925, pp 15911595; Diccionario de la lengua española por la Real Academia de la Lengua 1914, p545; ZEROLO E.: Diccionario enciclopédico de la lengua castellana. París Garnier hermanos, 1895, p1214; ALEMANY Y BOLUFER Barcelona, Ramón Sopena, 1917, p 897)

Disponibles en página web de la RAE: http://ntlle.rae.es/ntlle/SrvltGUIMenuNtlle?cmd=Lema\&sec=1.0.0.0.0.
} 
Folio no 256 del 2o libro de 1910. Falleció un mes después.

En ocasiones, cuando eran hijos naturales se anotaba también el nombre del padre, sin embargo he encontrado muy pocos casos y suelen ser niños expuestos en el torno con una nota en la que aparece escrito el nombre. Así lo vemos, en el folio no 439 de 1909, en la nota también dice que los padres son solteros y que el padre ha reconocido al niño

\section{"Eusebio Casares Vegas}

En 20 de diciembre de 1909 a las 16 horas fue espuesto en el torno de este Asilo con un papel que decía «El dia 16 diciembre nació este niño en Valladolid calle de San Juan numero 3 piso bajo. El fue inscrito en el Registro civil del Juzgado de la Audiencia con el nombre de Eusebio = esta bautizado en la parroquia de San Juan de Valladolid con el mismo nombre que en el Registro es hijo de Antonia Vegas soltera natural de Sieteiglesias y de Antonio Casares soltero natural de Viana de Cega que le tiene reconocido»..." [sic]

En una anotación posterior en el folio se advierte que

"(nota) "Este niño consta en el Registro Civil como de padre desconocido y con los apellidos sólo de la madre Vegas Valencia".

A pesar de esta nota añadida, no se hicieron cambios en el registro del libro. Tampoco en este caso es algo relevante porque el niño falleció unos días después.

En las memorias del Hospicio de 1905 y 1908 se recoge la condición legítima de los niños, pero, mientras que la de 1905 ofrece solamente la clasificación de los lactantes que ingresaron en ese año, la de 1908 clasifica a los residentes en el Hospicio al final del ejercicio y parece que se refiere únicamente a los mayores de 5 años, pues hace el cálculo para 411 niños que son los mismos que en el propio informe encontramos de esa edad, sin incluir los 46 menores internos en ese momento. Con estos datos y los extraídos de los libros de entradas de menores se puede comparar el aspecto de la legitimad entre los dos grupos de edad; los datos de los menores de 1908 he tenido que obtenerlos íntegramente de los Libros de Exposiciones. No tenemos datos para los mayores de 5 años de 1905 porque no aparecen en su memoria y no hay libro de Mayores para este año. La comparación, que puede verse en la TABLA 3-9, resulta muy ilustrativa porque evidencia una diferencia significativa con un porcentaje mucho mayor de hijos naturales y de padres desconocidos entre los niños menores de 5 años del Hospicio de Valladolid ( $77^{\prime} 8 \%$ en 1905 y $85^{\prime} 44 \%$ en 1908), mientras que entre los mayores vemos un predominio de los "Hijos de legítimo matrimonio" (66'8\% en 1908). La explicación puede estar en la procedencia de uno y otro grupo. Los hijos naturales y de padres desconocidos de la Inclusa son mayoritariamente niños nacidos en la Maternidad y niños expuestos en el torno del Hospicio o en los pueblos de la provincia y constituyen la mayoría de los ingresos. Teniendo en cuenta que la mortalidad de los incluseros era muy alta, pocos 
llegaban a pasar al departamento de mayores, en el que, aparte de estos pocos que conseguían sobrevivir, la mayoría de los ingresos se producía a solicitud de la propia familia, casi siempre por falta de recursos o por fallecimiento de alguno de los progenitores (TABLA 3-9)

\begin{tabular}{|c|c|c|c|c|c|c|}
\hline & & $\begin{array}{c}\text { Hijos } \\
\text { Legítimos }\end{array}$ & $\begin{array}{c}\text { Hijos } \\
\text { Naturales }\end{array}$ & $\begin{array}{c}\text { Padres } \\
\text { Desconocidos }\end{array}$ & $\begin{array}{c}\text { Sin - } \\
\text { Antece- } \\
\text { dentes }\end{array}$ & TOTAL \\
\hline \multirow{4}{*}{$\begin{array}{c}1905 \\
\text { MENORES } \\
\text { DE } 5 \text { AÑOS } \\
\text { INGRESOS }\end{array}$} & \multirow{2}{*}{$\begin{array}{c}\text { Datos } \\
\text { MEMORIA }\end{array}$} & \multirow{2}{*}{$\begin{array}{c}97 \\
\left(22^{\prime} 20 \%\right)\end{array}$} & $\begin{array}{c}85 \\
\left(19^{\prime} 45 \%\right)\end{array}$ & $\begin{array}{c}255 \\
\left(58^{\prime} 35 \%\right)\end{array}$ & & \multirow{4}{*}{437} \\
\hline & & & 340 & $\left(77^{\prime} 80 \%\right)$ & & \\
\hline & \multirow{2}{*}{ Datos propios } & \multirow{2}{*}{$\begin{array}{c}104 \\
\left(23^{\prime} 80 \%\right)\end{array}$} & $\begin{array}{c}169 \\
\left(38^{\prime} 67 \%\right) \\
\end{array}$ & $\begin{array}{c}164 \\
\left(37^{\prime} 053 \%\right) \\
\end{array}$ & & \\
\hline & & & 333 & $\left(76^{\prime} 20 \%\right)$ & & \\
\hline \multirow{4}{*}{1908} & \multirow{2}{*}{$\begin{array}{c}\text { MAYORES DE } 5 \\
\text { AÑOS } \\
\text { (MEMORIA) }\end{array}$} & \multirow{2}{*}{$\begin{array}{c}272 \\
\left(66^{\prime} 18 \%\right)\end{array}$} & $\begin{array}{c}34 \\
\left(8^{\prime} 27 \%\right)\end{array}$ & $\begin{array}{c}87 \\
\left(21^{\prime} 17 \%\right)\end{array}$ & \multirow{2}{*}{$\begin{array}{c}18 \\
\left(4^{\prime} 38 \%\right)\end{array}$} & \multirow[t]{2}{*}{411} \\
\hline & & & \multicolumn{2}{|c|}{121 (29'44\%) } & & \\
\hline & \multirow{2}{*}{$\begin{array}{c}\text { MENORES DE } 5 \\
\text { AÑOS } \\
\text { INGRESOS } \\
\text { Datos propios }\end{array}$} & \multirow[t]{2}{*}{$\begin{array}{c}61 \\
\left(14^{\prime} 56 \%\right)\end{array}$} & $\begin{array}{c}199 \\
\left(47^{\prime} 49 \%\right)\end{array}$ & $\begin{array}{c}159 \\
\left(37^{\prime} 95 \%\right)\end{array}$ & & \multirow[t]{2}{*}{419} \\
\hline & & & \multicolumn{2}{|c|}{$358\left(85^{\prime} 44 \%\right)$} & & \\
\hline \multirow[t]{2}{*}{1912} & \multirow{2}{*}{$\begin{array}{c}\text { MENORES DE } 5 \\
\text { AÑOS } \\
\text { INGRESOS } \\
\text { Datos propios }\end{array}$} & \multirow[t]{2}{*}{$\begin{array}{c}78 \\
\left(17^{\prime} 10 \%\right)\end{array}$} & $\begin{array}{c}196 \\
\left(42^{\prime} 99 \%\right)\end{array}$ & $\begin{array}{c}182 \\
\left(39^{\prime} 91 \%\right)\end{array}$ & & \multirow[t]{2}{*}{456} \\
\hline & & & 378 & $\left(82^{\prime} 9 \%\right)$ & & \\
\hline
\end{tabular}

Tabla de elaboración propia con los datos de las memorias del Hospicio sobre los Estados del personal de 1905 y 1908 (en negrita y cursiva) y los datos obtenidos del análisis de los Libros de Exposiciones de 1905, 1908 y 1912. Porcentaje que representa cada grupo respecto al total (Los niños sin antecedentes de 1908 son "niños ingresados por Orden superior a reserva de presentar documentos que no acompañaron", como explica la propia memoria). Se suman hijos naturales y de padres desconocidos, son niños expuestos y seguramente ilegítimos

Al cotejar los datos de la memoria de 1905 con los Libros de Exposiciones del mismo año encuentro un desacuerdo respecto a la legitimidad de los hospicianos; puede que en el informe anual se hayan tenido en cuenta datos conocidos después del ingreso que no se registraron en los libros, ya que no se solían hacer correcciones en los datos de identificación y filiación de la inscripción inicial (como vimos en el ejemplo del folio 439 de 1909). Para nuestro recuento hemos considerado como hijos naturales, además de los que constan como tal en los registros, 55 casos en los que se especifica que la madre es soltera o viuda y los 74 niños nacidos en la maternidad, de los que no se dice nada al respecto pero que llevan todos los dos apellidos maternos. En cuanto a los niños del torno, aunque muchos ingresaron con nombre e incluso con uno o dos apellidos escritos en la nota acompañante, los he considerado de padres desconocidos, excepto cuando la nota advierte sobre la naturaleza del niño o lleva el nombre 
de la madre o de ambos padres. Hay en este año de 1905 dos notas con el nombre completo de los dos progenitores y advirtiendo además que ambos son solteros, podemos considerarlos por tanto hijos naturales. En 1905 la Inclusa ingresó a 437 niños y en la revisión que hecha folio a folio, he contado en los dos libros del año 104 legítimos, 169 hijos naturales y 164 de padres desconocidos, o de los que no hay ninguna constancia en los registros.

He recogido estos datos en la misma TABLA 3-9 para poder comparar en igualdad de condiciones los dos años, ya que los datos de menores de 1908 se han tenido que obtener íntegramente del análisis de los Libros de Exposiciones. En 1908 hay un descenso significativo de hijos legítimos. De todos modos, casualmente, porque he tomado estos años por ser los que tienen informes anuales, son dos años peculiares ya que, como veremos, son los puntos extremos en cuanto a la mortalidad de la Inclusa, mientras que 1908 con 7 ingresos por debajo de la media tiene la mortalidad total más alta superando en más de 6 puntos el valor promedio, 1905 con 11 ingresos por encima de la media es de los años con menor mortalidad de los 14 revisados. Se ha tomado otro año para contrastar datos, se escoge 1912, por encima del promedio de ingresos y con la mortalidad más baja; su porcentaje de ilegitimidad se encuentra entre los de estos dos años. Debemos tener en cuenta que hablamos de porcentajes muy altos para los dos factores, ilegitimidad y mortalidad. También en la TABLA 3-9.

En las estadísticas oficiales que nos ofrece el Fondo Documental del INE sobre Nacimientos para la época de este estudio se recoge el número total de "Alumbramientos" y se dan por separado los "Nacidos Vivos" y los "Nacidos Muertos, muertos al nacer ó antes de las primeras 24 horas de vida", diferenciando además en cada uno de estos dos grupos los legítimos, ilegítimos y expósitos. He calculado los porcentajes que representan cada uno de ellos en la provincia de Valladolid para los dos años de las memorias. TABLA 3-10.

Como era de esperar, el porcentaje de ilegítimos es llamativamente más alto en el Hospicio (TABLA 3-9), no en vano una de sus funciones era precisamente recoger a estos niños que suponían una lacra social para sus familias, especialmente para la madre, y para sí mismos y una carga para muchas mujeres que era prácticamente imposible de sobrellevar en la época. Mientras que en la población general para la provincia de Valladolid la ilegitimidad está en torno al $5 \%$, en el Hospicio ronda el $80 \%$, lo que quiere decir que alrededor del $20 \%$ de los niños ingresados eran hijos legítimos $y$, debemos suponer, de familias sin recursos para su crianza. La ilegitimidad en Valladolid era más elevada que en otras provincias ${ }^{376}$, podemos

\footnotetext{
${ }^{376}$ Se dice en la Encuesta del Ateneo de 1901- 1902 en Nacimiento ficha 111 que la ilegitimidad era algo excepcional, pero diferencia a los hijos naturales: "En los pueblos de esta comarca hay pocos hijos ilegítimos. En
} 
comparar estas cifras con las que conocemos de la Inclusa de Pamplona con porcentajes bastante más bajos, 64'7\% en el primer quinquenio del siglo y 73'6\% en el período 1910 - 14 (en 1905 Navarra, con 1'1\% fue la segunda provincia con menor proporción de ilegítimos); en Madrid, la provincia con el mayor porcentaje, en la Inclusa representaban alrededor del $70 \%$ y en Barcelona en 1903 eran más del 60\% ${ }^{377}$ (ver TABLAS 3-13 y 3-14)

\begin{tabular}{|c|c|c|c|c|c|}
\hline \multicolumn{6}{|c|}{ TABLA 3-10: NACIMIENTOS EN LA PROVINCIA DE VALLADOLID EN 1905 Y 1908} \\
\hline & & TOTAL & LEGÍTIMOS & ILEGÍTIMOS & EXPÓSITOS \\
\hline \multirow{6}{*}{1905} & \multirow[t]{2}{*}{ NACIDOS VIVOS } & \multirow[t]{2}{*}{11.031} & \multirow{2}{*}{$\begin{array}{c}10.530 \\
\left(95^{\prime} 46 \%\right)\end{array}$} & $\begin{array}{c}345 \\
\left(3^{\prime} 13 \%\right)\end{array}$ & $\begin{array}{c}156 \\
(1,41 \%)\end{array}$ \\
\hline & & & & \multicolumn{2}{|c|}{501 (4’54\%) } \\
\hline & \multirow{2}{*}{$\begin{array}{l}\text { NACIDOS } \\
\text { MUERTOS }\end{array}$} & \multirow{2}{*}{$\begin{array}{c}294 \\
\text { (179 varones } \\
115 \text { mujeres) } \\
\end{array}$} & \multirow{2}{*}{$\begin{array}{c}275 \\
\left(93^{\prime} 54 \%\right)\end{array}$} & 19 & 0 \\
\hline & & & & \multicolumn{2}{|c|}{$\left(6^{\prime} 46 \%\right)$} \\
\hline & \multirow{2}{*}{$\begin{array}{l}\text { SUTa VIVOS y } \\
\text { MUERTOS }\end{array}$} & \multirow[t]{2}{*}{11.325} & \multirow{2}{*}{$\begin{array}{c}10.805 \\
\text { (95'41\%) }\end{array}$} & $\begin{array}{c}364 \\
\left(3^{\prime} 21 \%\right) \\
\end{array}$ & $\begin{array}{c}156 \\
\left(1^{\prime} 38 \%\right) \\
\end{array}$ \\
\hline & & & & \multicolumn{2}{|c|}{$520\left(4^{\prime} 59 \%\right)$} \\
\hline \multirow{6}{*}{1908} & \multirow{2}{*}{ NACIDOS VIVOS } & \multirow{2}{*}{10.298} & \multirow{2}{*}{$\begin{array}{c}9.732 \\
(94,50 \%)\end{array}$} & $\begin{array}{c}420 \\
(4,08 \%)\end{array}$ & $\begin{array}{c}146 \\
(1,42 \%)\end{array}$ \\
\hline & & & & \multicolumn{2}{|c|}{$566\left(5^{\prime} 505\right)$} \\
\hline & \multirow{2}{*}{$\begin{array}{l}\text { NACIDOS } \\
\text { MUERTOS }\end{array}$} & \multirow{2}{*}{$\begin{array}{c}291 \\
\text { (173 varones } \\
118 \text { mujeres ) }\end{array}$} & \multirow{2}{*}{$\begin{array}{c}258 \\
\left(88^{\prime} 67 \%\right)\end{array}$} & $\begin{array}{c}31 \\
\left(10^{\prime} 65 \%\right) \\
\end{array}$ & $\begin{array}{c}2 \\
\left(0^{\prime} 68 \%\right) \\
\end{array}$ \\
\hline & & & & \multicolumn{2}{|c|}{$33\left(11^{\prime} 33 \%\right)$} \\
\hline & \multirow{2}{*}{$\begin{array}{l}\text { Suma VIVOS y } \\
\text { MUERTOS }\end{array}$} & \multirow[t]{2}{*}{10.589} & \multirow{2}{*}{$\begin{array}{c}9.990 \\
\left(94^{\prime} 34 \%\right)\end{array}$} & $\begin{array}{c}451 \\
\left(4^{\prime} 26 \%\right)\end{array}$ & $\begin{array}{c}148 \\
\left(1^{\prime} 40 \%\right)\end{array}$ \\
\hline & & & & \multicolumn{2}{|c|}{599 (5’66 \%) } \\
\hline
\end{tabular}

Existe cierta discrepancia entre los datos que ofrecen las Estadísticas oficiales de la provincia de Valladolid y los calculados a partir de los registros de los Libros de Exposiciones del Hospicio. Los datos para el Movimiento Natural de la Población de España se obtienen a partir de los Registros civiles, como se advierte en las propias Estadísticas. El Hospicio daba parte al Registro civil de sus expósitos y de los nacidos en la Maternidad, mientras que los niños expuestos en los pueblos se inscribían y se bautizaban en la propia localidad antes de ser enviados al Hospicio provincial y aquí puede estar la fuente del error, aunque se supone que todos los expósitos de la provincia terminaban en la Inclusa provincial. La Estadística de

Rioseco es donde hay más, y apenas nacidos suelen ser llevados al hospicio de Valladolid. En los pueblos nacen bastantes hijos naturales muy especialmente en las clases bajas, y casi todos son legitimados por subsiguientes matrimonio. MARTÍN JIMÉNEZ I.: La sociedad vallisoletana en los albores del siglo XX... 2004, p 36

377 VALVERDE L.: Legitimidad e llegitimidad. : Recoge la autora en un cuadro en la p 1186 los porcentajes de ilegitimidad conocida en la Inclusa de Pamplona en algunos quinquenios hasta 1934. En el período $1920-24$ fue del $67^{\prime} 3 \%$ y en $1930-34$ del 72 '5\% 
Nacimientos para Valladolid cuenta 156 expósitos en 1905, mientras que los libros del Hospicio del mismo año registran 125 niños expuestos en el propio torno y 52 enviados desde los pueblos, que suman 177. Es probable que no todos los que procedían de los pueblos fueran considerados como expósitos, en el sentido estricto de la palabra en aquel momento, es decir que no fueran abandonados o expuestos, también podía haber entre ellos niños entregados por la familia particularmente en las dos Medinas, pues mientras que cuando los niños venían de otros pueblos de la provincia se solía registrar en donde fueron hallados, cuando venían de estas dos poblaciones simplemente se recogía que procedían de ellas.

En cuanto a las cifras de ilegítimos, en la Estadística provincial de la TABLA 3-10 aparecen por separado ilegítimos y expósitos, tal y como lo encontramos en el informe anual sobre el Movimiento Natural de la Población de España. Es razonable pensar que no todos los hijos ilegítimos acabarían en la Inclusa y que la mayoría de los expósitos serían ilegítimos, pero también sabemos que se exponían en el torno hijos legítimos por falta de recursos para su crianza; quizás por esa imposibilidad de conocer la filiación legítima o no de la mayoría de los expósitos, se reflejaban separadamente en las estadísticas. De todos modos, aunque en todos los informes anuales aparecen datos diferenciados, en algunos apartados de la estadística se dan también cifras globales como ilegítimas sin diferenciar los expósitos.

En todo caso, hemos de pensar que estos datos plantearían los mismos problemas en todo el territorio nacional. Vamos pues a comparar la provincia de Valladolid con otras y con la media nacional a partir de los datos que nos ofrece la Memoria sobre el Movimiento Natural de la Población de España.

En la Introducción de la Memoria de 1905 se ofrecen cálculos estadísticos globales del sexenio 1900-05, fijando la proporción nacional para este período de hijos ilegítimos, sin diferenciar a los expósitos que están incluidos, en el $46 \%$ ol dotal de nacidos vivos y muertos (4.051.307de nacimientos y 187.266 ilegítimos, que representan exactamente el 4'622\%) (TABLA 3-11). También comenta al respecto que "Nuestra cifra de ilegitimidad no es exagerada... es inferior á las de Escocia, Dinamarca, Hungría, Alemania, Bélgica, Francia é Italia, y mayor que las de Inglaterra, Irlanda, Países Bajos y Servia"378 [sic].

\footnotetext{
${ }^{378}$ Cfr. Movimiento Natural de la Población de España. Año de 1905. Introducción: Totales de la Nación: Conceptos Especiales (Nacimientos, Matrimonios, Defunciones); LII
} 


\begin{tabular}{|c|c|c|c|c|}
\hline \multicolumn{5}{|c|}{ Clasificación de los nacidos vivos y muertos según su legitimidad } \\
\hline \multicolumn{5}{|c|}{ NÚMEROS RELATIVOS } \\
\hline \multirow{4}{*}{ Nacidos vivos.............. } & \multirow{4}{*}{ 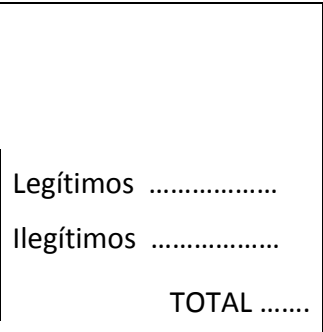 } & $\begin{array}{l}\text { Promedios del } \\
\text { sexenio }\end{array}$ & $\begin{array}{l}\text { Proporción } \\
\text { por } 10.000 \\
\text { habitantes }\end{array}$ & $\begin{array}{l}\text { Proporción } \\
\text { por } 1.000 \\
\text { habitantes }\end{array}$ \\
\hline & & 628.975 & $335^{\prime} 02$ & 932 \\
\hline & & 29.521 & $15^{\prime} 73$ & 43 \\
\hline & & 658.496 & $350 ’ 75$ & 975 \\
\hline \multirow{3}{*}{ Nacidos muertos....... } & \multirow{3}{*}{ 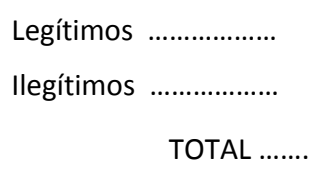 } & 15.032 & 8 & 22 \\
\hline & & 1.690 & $0 ’ 9$ & 3 \\
\hline & & 16.722 & 8 '9 & 25 \\
\hline \multirow{3}{*}{$\begin{array}{l}\text { Nacidos vivos y } \\
\text { muertos }\end{array}$} & \multirow{3}{*}{ 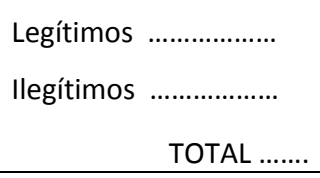 } & 644.007 & $343^{\prime} 02$ & 954 \\
\hline & & 31.211 & $16^{\prime} 63$ & 46 \\
\hline & & 675.218 & $359^{\prime} 65$ & 1.000 \\
\hline \multicolumn{5}{|c|}{$\begin{array}{l}\text { Nuestra cifra de ilegitimidad no es exagerada. Ya en la primera parte de estos comentarios } \\
\text { hemos tenido ocasión de observar que es inferior a las de Escocia, Dinamarca, Hungria, } \\
\text { Alemania, Bélgica, Francia e Italia y mayor que las de Inglaterra, Irlanda, Países Bajos y Servia }\end{array}$} \\
\hline \multicolumn{5}{|c|}{$\begin{array}{l}\text { TABLA 3-11: Movimiento Natural de la Población de España. Año de 1905, Introducción, } \\
\text { Totales de la Nación, Conceptos Especiales (Nacimientos, Matrimonios, Defunciones), p LII } \\
\text { (transcripción literal) }\end{array}$} \\
\hline
\end{tabular}

Más adelante ofrece la "relación entre el promedio de los nacidos en el sexenio de 1900 á 1905 y los totales de mujeres á fines de 1902" y presenta una tabla que recoge en una columna el "NÚMERO de nacidos ilegítimos por 1000 mujeres solteras y viudas", (la negrita es añadida). Tal parece que los hombres y las mujeres casadas no tenían hijos ilegítimos, o al menos da la impresión de que no eran de interés para la estadística nacional. (TABLA 3-12)

\begin{tabular}{|c|c|c|}
\hline $\begin{array}{c}E D A D \\
D E L A S M U J E R E S\end{array}$ & $\begin{array}{c}\text { NÚMERO de } \\
\text { nacidos legítimos por } 1000 \\
\text { mujeres casadas }\end{array}$ & $\begin{array}{c}\text { NÚMERO de } \\
\text { nacidos ilegítimos por } 1000 \\
\text { mujeres solteras y viudas }\end{array}$ \\
\hline 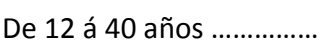 & 326 & 13 \\
\hline 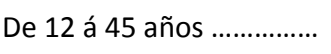 & 272 & 12 \\
\hline De 12 á 50 años .............. & 231 & 11 \\
\hline De 16 á 40 años ................ & 326 & 18 \\
\hline De 16 á 45 años ............... & 272 & 17 \\
\hline De 16 á 50 años ............... & 231 & 16 \\
\hline De todas las edades ........ & 181 & 5 \\
\hline
\end{tabular}

La nimia proporción de legítimos nacidos de viudas no alterará seguramente las cifras de la segunda columna

TABLA 3-12: Movimiento Natural de la Población de España. Año de 1905, Introducción, Totales de la Nación, Conceptos Especiales (Nacimientos, Matrimonios, Defunciones) p LIX (transcripción literal) 
Con los datos nacionales sobre Nacimientos del año 1905 he calculado el porcentaje de hijos ilegítimos sobre el total de nacidos vivos y muertos en 4 ‘ 46\%, por debajo del estimado para Valladolid que fue del 4'59\%.

\begin{tabular}{|c|c|c|c|}
\hline $\begin{array}{c}1905 \\
\text { PROVINCIAS }\end{array}$ & $\begin{array}{c}\text { TOTAL } \\
\text { NACIDOS }\end{array}$ & ILEGÍTIMOS Y EXPÓSITOS & $\begin{array}{c}\text { \% SOBRE EL TOTAL DE } \\
\text { NACIDOS }\end{array}$ \\
\hline Valladolid & 11.325 & 520 & 4’59 \\
\hline Burgos & 14.481 & 197 & $1^{\prime} 36$ \\
\hline León & 14.719 & 606 & $4^{\prime} 12$ \\
\hline Palencia & 7.991 & 175 & 2'19 \\
\hline Salamanca & 12.864 & 533 & $4^{\prime} 14$ \\
\hline Álava & 3.679 & 79 & $2 ' 15$ \\
\hline Alicante & 16.615 & 223 & $1^{\prime} 34$ \\
\hline Barcelona & 29.295 & 1.090 & $3 ’ 72$ \\
\hline Cáceres & 16.340 & 544 & $3^{\prime} 33$ \\
\hline Cádiz & 18.093 & 1.837 & $10^{\prime} 15$ \\
\hline Cuenca & 9.999 & 240 & $2^{\prime} 40$ \\
\hline La Coruña & 23.377 & 1.992 & $8 \prime 52$ \\
\hline Madrid & 26.542 & 3.924 & $14^{\prime} 78$ \\
\hline Lérida & 7.875 & 43 & $0 ’ 55$ \\
\hline Navarra & 9.779 & 109 & $1^{\prime} 11$ \\
\hline Pontevedra & 16.244 & 1.561 & $9^{\prime} 61$ \\
\hline Sevilla & 21.953 & 1.666 & 7’59 \\
\hline Valencia & 29.720 & 618 & $2^{\prime} 08$ \\
\hline Vizcaya & 11.968 & 554 & $4^{\prime} 63$ \\
\hline Zaragoza & 15.709 & 468 & 2'98 \\
\hline $\begin{array}{r}\text { ESPAÑA: total } \\
\text { nacional } \\
\end{array}$ & 688.058 & 30.698 & $4 \% 46 \%$ \\
\hline
\end{tabular}

Para comparar he seleccionado algunas provincias españolas y se recogen los datos en la TABLA 3-13 En primer lugar algunas del entorno (Burgos, León, Palencia y Salamanca) y a nivel nacional Cáceres y Barcelona, que tuvieron el mayor y menor coeficiente de natalidad; Lérida y Navarra, las que he calculado con menor porcentaje de ilegítimos; con el porcentaje más alto Madrid, la capital más poblada, y Cádiz; Álava fue la provincia menos poblada; Valencia la segunda con más población después de Barcelona; en total 20 provincias de la península. En el documento original del Fondo Documental del INE aparecen por separado nacidos vivos y muertos y dentro de cada uno de ellos legítimos, ilegítimos y expósitos para cada provincia. Para hacer la tabla he tenido que sumar los diferentes grupos y calcular los 
porcentajes. Tanto en el grupo de TOTAL NACIDOS como en el de ILEGITIMOS he sumado los nacidos vivos y muertos. Al calcular el porcentaje de nacimientos ilegítimos llama la atención las grandes diferencias que existen entre las provincias seleccionadas. Salvo Valladolid, León, Salamanca y Vizcaya el resto se alejan mucho de la media nacional calculada para este año de 1905 en $4^{\prime} 46 \%$.

En la relación de la TABLA 3-13 podemos comprobar que destaca muy por encima Madrid con un $14^{\prime} 78 \%$ de nacimientos ilegítimos, siendo en ese año la tercera provincia en población y la octava de menor natalidad, pero con una elevada emigración en su capital, que constituía uno de los destinos preferidos particularmente por las muchachas que iban a trabajar en el servicio doméstico, incluidas las nodrizas ${ }^{379}$. Muy por debajo encontramos Lérida y Navarra con unos porcentajes tan bajos y con tanta diferencia que nos hacen sospechar que probablemente muchos nacimientos ilegítimos no se declararon, al menos en el Registro Civil, de donde se toman los datos para la estadística nacional; en la Memoria que la acompaña se reconoce que no se han cogido datos de las parroquias por la imposibilidad material de hacerlo. También puede ocurrir algo que puede constatarse en los libros de nuestro Hospicio, que muchas mujeres solteras emigraban en busca de anonimato y de trabajo hacia las capitales, sobre todo a las que tenían más población y las de otras provincias. Muchas de las mujeres que dieron a luz en la Maternidad del Hospicio de Valladolid eran naturales de pueblos de provincias del entorno. En el caso de Lérida podemos pensar que por proximidad emigrarían a Barcelona, aunque esta capital, a diferencia de Madrid, no tuvo un porcentaje elevado de ilegítimos (un 3’72\%) a pesar de ser la provincia más poblada pero con la natalidad más baja del país en ese año. Lérida y Navarra, tuvieron un coeficiente bajo de natalidad respecto a la media nacional; por el contrario Burgos, también con una proporción muy baja de ilegítimos, 1'36\%, tuvo una natalidad elevada. No parece que se pueda explicar la diferencia en el porcentaje de ilegítimos solamente en función del tamaño de la población de las provincias ni de su natalidad; recogemos estos datos en la TABLA 3-14 para las mismas provincias ordenándolas por el porcentaje de ilegitimidad.

La tabla viene a corroborar la falta de correlación entre los tres campos recogidos. Las provincias con mayor ilegitimidad están entre las más pobladas, a excepción de Barcelona, Valencia o Alicante (1aㅡ 2 2a y 6a con mayor población de la lista) que están muy por debajo de la media nacional de ilegítimos. Después de Madrid (3a en población de la lista y con una

\footnotetext{
${ }^{379}$ Más del 90 \% de las sirvientas de Madrid capital a principios de siglo eran inmigrantes, en su mayoría jóvenes solteras procedentes del mundo rural DIAZ SIMÓN L.: El casco Antiguo de Madrid a principios del siglo XX. Máster en Historia Contemporánea, dirigido por OTERO CARVAJAL L.E. Universidad Complutense de Madrid
} 
natalidad muy por debajo de la media nacional), Cádiz y Pontevedra (la 8a y 7ạ) son las provincias con mayor proporción de ilegítimos, mientras que su natalidad está en torno al valor promedio y su población es muy similar y está por encima de la media (promedio nacional 388.304 habitantes/provincia). Valladolid es una de las provincias menos poblada de la lista (la 5으), pero está entre las de mayor natalidad (también la 5으) y con un porcentaje de ilegítimos por encima de la media. Son por tanto otras características de tipo socio-económico y cultural las que pueden determinar estas diferencias ${ }^{380}$

\begin{tabular}{|c|c|c|c|}
\hline PROVINCIA & Población Estimada & Natalidad Estimada \% & \% llegítimos \\
\hline Lérida & 270.536 & $299^{\prime} 05$ & $0 \prime 55$ \\
\hline Navarra & 309.044 & $30 \prime 91$ & $1^{\prime} 11$ \\
\hline Alicante & 485.250 & $33^{\prime} 59$ & $1^{\prime} 34$ \\
\hline Burgos & 336.935 & $39 \prime 37$ & $1^{\prime} 36$ \\
\hline Valencia & 836.344 & $35^{\prime} 07$ & $2 \prime 08$ \\
\hline Álava & 97.754 & $35^{\prime} 19$ & $2^{\prime} 15$ \\
\hline Palencia & 193.891 & $39^{\prime} 44$ & 2'19 \\
\hline Cuenca & 252.535 & $39^{\prime} 27$ & $2^{\prime} 40$ \\
\hline Zaragoza & 424.460 & $35^{\prime} 41$ & $2^{\prime} 98$ \\
\hline Cáceres & 371.155 & $42^{\prime} 00$ & $33^{\prime} 33$ \\
\hline Barcelona & 1.119 .392 & $26 ' 26$ & $3^{\prime} 72$ \\
\hline León & 388.198 & $37^{\prime} 38$ & $4^{\prime} 12$ \\
\hline Salamanca & 323.219 & $38^{\prime} 17$ & $4^{\prime} 14$ \\
\hline Valladolid & 283.079 & $38^{\prime} 67$ & 4'59 \\
\hline Vizcaya & 346.573 & $35^{\prime} 23$ & $4^{\prime} 63$ \\
\hline Sevilla & 559.324 & $37^{\prime} 20$ & 7'59 \\
\hline La Coruña & 669.490 & $34^{\prime} 83$ & $8 ’ 52$ \\
\hline Pontevedra & 462.714 & $33^{\prime} 48$ & $9^{\prime} 61$ \\
\hline Cádiz & 461.717 & $36^{\prime} 89$ & $10^{\prime} 15$ \\
\hline Madrid & 813.810 & $31^{\prime} 96$ & $14^{\prime} 78$ \\
\hline $\begin{array}{l}\text { ESPAÑA: total } \\
\text { nacional }\end{array}$ & 19.026 .921 & $35 ' 52 \%$ & $4^{\prime} 46 \%$ \\
\hline
\end{tabular}

Ya que estamos trabajando con las memorias del hospicio de 1905 y 1908, que ofrecen porcentajes distintos de ilegítimos, se recogen en la TABLA 3-15 los datos nacionales y de las provincias antes referidas para 1908, ordenándolas según la proporción de ilegítimos.

\footnotetext{
${ }^{380}$ Datos extraídos de la Memoria sobre el Movimiento de la Población de España del Año 1905 del Fondo Documental del INE. Los coeficientes de natalidad que se ofrecen, dice la misma Memoria, que son datos estimados considerando que existe un error en los registros por omisión, calculando en 38.193 "el promedio anual de los nacimientos que se omiten en los Registros civiles de toda España", p XIX
} 
En Valladolid el porcentaje de llegítimos y expósitos respecto al total de nacidos, vivos y muertos, en 1908 fue del 5'66 (ver TABLAS 3-10 y 3-15). Aumentó respecto a 1905 a pesar de que el número de nacimientos descendió, pero podemos comprobar en la tabla que también aumentó la media nacional y la de la mayoría de las provincias, manteniéndose por tanto la provincia de Valladolid en una situación relativa similar a la de 1905, en un punto intermedio respecto al porcentaje de niños ilegítimos y expósitos, pero por encima de la media nacional, más en 1908. También aumentó en este año y de forma importante la ilegitimidad entre los niños que ingresaron en el Hospicio, pasando de un 76'20\% del total de ingresos en 1905 a representar el $85^{\prime} 44 \%$ de los ingresos.

\begin{tabular}{|c|c|c|c|}
\hline $\begin{array}{c}1908 \\
\text { PROVINCIAS } \\
\end{array}$ & $\begin{array}{c}\text { TOTAL } \\
\text { NACIDOS } \\
\end{array}$ & $\begin{array}{l}\text { ILEGítIMOS Y } \\
\text { EXPÓSITOS }\end{array}$ & $\begin{array}{c}\text { \% SOBRE EL TOTAL DE } \\
\text { NACIDOS }\end{array}$ \\
\hline Lérida & 7.911 & 41 & 0,52 \\
\hline Alicante & 15.317 & 210 & $1^{\prime} 37$ \\
\hline Burgos & 13.220 & 208 & $1^{\prime} 57$ \\
\hline Navarra & 9.678 & 192 & $1^{\prime} 98$ \\
\hline Valencia & 28.670 & 675 & $2 ’ 35$ \\
\hline Palencia & 7.089 & 189 & $2^{\prime} 67$ \\
\hline Álava & 3.469 & 96 & $2 ’ 77$ \\
\hline Cuenca & 9.717 & 283 & 2'91 \\
\hline Zaragoza & 15.534 & 486 & 3'13 \\
\hline Cáceres & 16.230 & 508 & 3'13 \\
\hline León & 13.938 & 509 & $3 \prime 65$ \\
\hline Salamanca & 12.335 & 519 & 4.21 \\
\hline Barcelona & 30.379 & 1.375 & $4 \prime 53$ \\
\hline Vizcaya & 12.210 & 626 & $5^{\prime} 13$ \\
\hline Valladolid & 10.589 & 599 & $5^{\prime} 66$ \\
\hline Sevilla & 20.682 & 1.667 & $8^{\prime} 07$ \\
\hline La Coruña & 22.469 & 1.873 & $8 \prime 34$ \\
\hline Pontevedra & 16.233 & 1.477 & $9 \prime 10$ \\
\hline Cádiz & 17.270 & 1.780 & $10^{\prime} 31$ \\
\hline Madrid & 26.373 & 4.102 & $15^{\prime} 55$ \\
\hline ESPAÑA: total nacional & 674.435 & 32.030 & $4^{\prime} 75$ \\
\hline \multicolumn{4}{|c|}{$\begin{array}{l}\text { Tabla de elaboración propia con datos calculados a partir de los que se ofrecen en el } \\
\text { Resumen de los Nacimientos por provincias. Movimiento...........1908. pp } 4-5 \text {. En el } \\
\text { documento original aparecen por separado nacidos vivos y muertos y dentro de ellos } \\
\text { legítimos, ilegítimos y expósitos para cada provincia. }\end{array}$} \\
\hline
\end{tabular}




\title{
3.3. La entrada EN la inclusa
}

\author{
La miseria es quien me trai \\ porque con elta nací y con ella me engendré \\ [sic] Nota que acompañaba al pequeño Nicolás \\ Diciembre de 1712, torno de la Inclusa de Salamanca ${ }^{381}$
}

Los Reglamentos del Hospicio Provincial de Valladolid establecían de forma detallada quiénes y cómo podían ingresar en él. El Capítulo II, Sección Primera de los Reglamentos de 1910 y 1927 recoge las Condiciones de Admisión en el establecimiento:

Art.5. Sólo serán admitidos en el Hospicio los pobres que careciendo de personas a quienes correspondería ampararles, o que aún teniéndolas no pueden cumplir esa obligación, y se hallen comprendidos en algunos de los casos siguientes:

1. ${ }^{\circ}$ Huérfanos de padre y madre menores de edad.

2. ${ }^{\circ}$ Menores de edad e hijos de viudo o viuda, si éstos se encuentran impedidos para trabajar. lactarles.

3. ${ }^{\circ}$ Hijos de viuda o soltera, pobres, si carecen de condiciones para

$4 .^{\circ}$ Menores de edad y huérfanos de padre o de madre, si carecen de recursos para alimentarles. La menor edad a que se refiere este artículo, se entiende para los varones hasta los 14 años y las hembras hasta los 16.

Art. 6. Será también admitido en el Hospicio uno de los hijos legítimos dados a luz en parto doble por mujer pobre que no pueda lactar a los dos gemelos, cualquiera que sea su estado y el número de hijos que tenga

Los padres de estos niños habrán de ser necesariamente vecinos de esta provincia y su permanencia en el Hospicio será como máximo hasta que los niños cumplan $\mathbf{5 0}$ meses de edad, si no procede que continúen por otro concepto.

Art. $7 .^{\circ}$ Para los efectos del artículo $5 .^{\circ}$ se reputará que los interesados no tienen padre o madre si se hallan éstos en alguna de las situaciones siguientes: 1. Enfermo en un Hospital o Manicomio por el tiempo que dure su estancia en el Establecimiento. 2. Privados de libertad hasta que la recobren. 3. Ausentes en ignorado paradero. 4. Impedidos para el trabajo; y 5. Acogidos en una Casa de Beneficencia.

Todos los Reglamentos dedican una sección a cada departamento del Hospicio y, entre otras cosas, fijan los criterios de admisión y las vías de ingreso. En los de 1910 y 1927 la Sección III, Capítulos XXXII al XXXVI, se dedican al Departamento de la Casa-Cuna, de forma conjunta. El Reglamento de 1889 trata cada sección por separado, dedica el Título Il, capítulos 39-95, particularmente y de forma extensa a la Inclusa y un Título aparte al Departamento de conservación y crianza de los niños menores de 7 años.

\footnotetext{
${ }^{381}$ FERNÁNDEZ UGARTE M.: Expósitos en Salamanca a comienzos del s. XVIII, Salamanca. 1988, pp 95-96. Citado en PÉREZ MOREDA V.: op. cit., p 61
} 
Los requisitos de admisión en el Departamento de la Casa-Cuna, aparte de la edad, eran la ilegitimidad y/o la pobreza, no en vano Vicente Pérez Moreda dice que "Los expósitos eran "hijos de la pobreza y de la vergüenza», y en no pocas ocasiones, de ambas situaciones a la vez" ${ }^{382}$.
"Se recibirán en él todos los niños de ambos sexos habidos ilegítimamente y los de legítimo matrimonio que quedaren huérfanos antes de los siete años, en estado de pobreza. Estos no podrán ser admitidos sin previo acuerdo de la Diputación provincial.
Para recibir á los primeros deberán ser expuestos en el torno que con dicho fin se hallará colocado en el exterior del edificio". Regl 1910, Capítulo XXXII. Art.307

A pesar de que cuando el reglamento se refiere a los legítimos habla expresamente de los huérfanos, se admitían también, según acabamos de ver en la normativa sobre la admisión en el Hospicio, todos aquellos que no podían ser criados por sus progenitores por falta de recursos. El artículo 39 del Reglamento de 1889 establece claramente la función de la Inclusa provincial y describe los diferentes mecanismos de ingreso en ella:

\begin{abstract}
"Este departamento tiene por objeto proporcionar la lactancia á los niños expósitos de ambos sexos que nacieran en el de Maternidad, si sus madres determinan dejarles á cargo del Hospicio; a los habidos ilegítimamente y expuestos ó abandonados en cualquiera pueblo de la Provincia, así como los presentados en el torno del establecimiento ó entregados en la Dirección del mismo" [sic, la negrita es añadida]
\end{abstract}

En el siguiente artículo desarrolla lo que el Reglamento entiende por expósito a efectos del ingreso en la Inclusa, ampliando el concepto a todos los niños privados de lactancia materna cuya familia careciera de recursos para proporcionarles lactancia mercenaria:
"Para los efectos del artículo anterior, se considerarán así bien los expósitos: 1․ Los huérfanos de padre y madre que se hallen expuestos á ser abandonados por

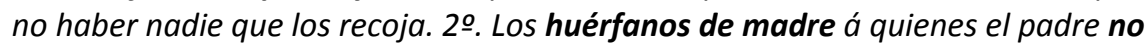 pueda proporcionar nodriza por falta de recursos. 3‥ Los que no puedan ser lactados por la madre, tengan ó no padre á causa de falta de salud y robustez en aquella, ni cuente con medios de costear su lactancia" [sic, negrita añadida]

El Hospicio Provincial de Valladolid no era pues muy restrictivo en los criterios de admisión en su Inclusa, aceptando a todos aquellos lactantes privados de lactancia materna y sin recursos para conseguir lactancia mercenaria. Los criterios de admisión no eran los mismos en todas las inclusas de la época, algunas como la de Sevilla solamente admitían, al menos en su normativa, niños ilegítimos y abandonados y excluían a los legítimos; la de Albacete admitía además huérfanos hijos de viudas sin recursos o de padres fallecidos; la de Oviedo según su reglamento excluía la pobreza como razón suficiente para el ingreso, salvo situaciones

${ }^{382}$ PÉREZ MOREDA V.: op. cit.,separata del discurso, Mensajeros de la Paz no 14, Madrid 2005, p 6 
excepcionales, y admitía solamente niños "verdaderamente expósitos", huérfanos completos e ilegítimos con condiciones, cuando eran el primer hijo de una mujer soltera, arrepentida, que tuviera "oculto su defecto" y necesitara proteger su honra. Había también inclusas más progresistas como las de Pamplona y Pontevedra que establecieron un sistema de ayudas económicas a madres lactantes pobres para que criaran ellas mismas a sus hijos pagándoles incluso una nodriza, llegado el caso, para evitar el ingreso de los niños; parece que esta política supuso una disminución muy significativa del número de legítimos abandonados en estas inclusas que la practicaron ${ }^{383}$. Es una política que no pudo extenderse seguramente por la falta de recursos de estas instituciones, que a duras penas cubrían muchas veces los gastos de atención a los niños acogidos, lo intentaron Casas como la de Oviedo, que pronto se vio desbordada por el número de solicitudes y no pudo hacer frente a los pagos comprometidos.

En la Inclusa de Valladolid, según ordenaban los reglamentos, los niños ilegítimos no precisaban de ningún trámite para su ingreso, mientras que los legítimos necesitaban el "previo acuerdo de la Comisión provincial". La sala de Maternidad de la Inclusa y la exposición en el torno o en lugares públicos se constituyen en las vías de entrada directa, sin más condiciones. En el caso de los expósitos, si los padres no querían revelar su identidad tenían totalmente garantizado el anonimato, es por ello que se exponían niños legítimos en el torno y probablemente en otros lugares para eludir o para acelerar los trámites de ingreso; en muchos casos se aportaban datos suficientes para la identificación y localización del niño, incluso certificados y documentos necesarios para su admisión en el Hospicio.

"Julio Lopez Alvarez.

El 21 de Julio de 1908 á las 20 horas fue expuesto en el torno de este Establecimiento con un oficio del Sr Alcalde de Castroñuno y un expediente incompleto de los exijidos para el ingreso en este Asilo y certificación del Sr Juez Municipal de Castroñuno donde dice que Julia Alvarez madre de este niño falleció en dicho pueblo en 17 de Julio del corriente año. De la información testifical se acredita que dicho Julio nació el 14 de Julio corriente y es hijo legítimo de Eugenio y Julia (esta hoy difunta)" [sic] $]^{384}$

\footnotetext{
${ }^{383}$ VALVERDE LAMSFUS L.: op. cit. 1990; RODRÍGUEZ MARTÍN A.M.: Una estrategia de supervivencia femenina: Las nodrizas sin retribución de la inclusa de Pontevedra, 1872-1903. 2007; MARTíNEZ GÓMEZ-SIMÓN L.M.: Las instituciones de atención social al menor en la ciudad de Albacete. Albacete. Instituto de Estudios Albacetenses "Don Juan Manuel" de la Excma. Diputación de Albacete, 2002; SÁNCHEZ FERNÁNDEZ L.V., COBO BARQUÍN J.C., RADHAMÉS HERNÁNDEZ M.: Marginación y pobreza desde la cuna: el niño expósito en el Concejo de Siero, Asturias (1800-1936). Revista de Demografía Histórica, XXXI, II, 2013, pp. 131-165

${ }^{384}$ Folio no 231. Libro de Exposiciones 1908, 1ㅇtomo. ADPVA
} 
La exposición en el torno de niños legítimos era un hecho sabido, reconocido y admitido siempre y cuando se pudiera demostrar una situación de pobreza de los padres que les imposibilitara criar al niño, de lo contrario, si se demostraba la condición de legítimo, dice el Reglamento de 1889 - que es mucho más explícito que los posteriores y da más detalles sobre el funcionamiento de la Inclusa en particular- que debía ser devuelto a sus padres, salvo que la Diputación ordenara lo contrario, y si tenían recursos se les cobraban los gastos ocasionados.

"ARTÍCULO 44. El que fuere expuesto en calidad de expósito y se inquiriese luego ser de legítimo matrimonio, será devuelto a sus padres, exigiendo a éstos los gastos que hubiere ocasionado al establecimiento, cuando contasen con recursos, pero si justificaren que carecían de ellos, se les entregará el hijo gratuitamente, á no ser que por circunstancias especiales la Excma Diputación ordenase su permanencia en el establecimiento..." [sic]

Este artículo ya no se encuentra recogido en los sucesivos reglamentos, pero hemos de suponer que se seguía aplicando, al menos en espíritu, puesto que todos son tajantes en cuanto a la aprobación por parte de la Diputación de la admisión de niños legítimos. Otra cuestión es que pudiera demostrarse la condición de legítimo del niño cuando era expuesto, podía resultar imposible si los padres no dejaban una nota con algún dato que lo facilitara. Algunas notas lo ponían fácil, daban tantos detalles que está claro que no se pretendía abandonar al niño sin más. En 1905 por ejemplo ingresa por el torno una niña con un certificado médico, en él se dice que la madre está enferma y el padre ingresado en el hospital, da los nombres de padres y abuelos y dice que la dejan por falta de recursos y que tienen intención de recogerla, la niña moriría de sífilis congénita en la Inclusa con mes y medio (Folio no 101, Libro 1905). La niña del folio 203 fue expuesta con 12 días de vida y una nota que daba todos sus datos personales y decía que la dejaban porque falleció la madre. Hay otros ocho niños del torno en ese mismo año que aportan notas en las que figuran datos suficientes para localizar a los padres, como la fecha de bautismo, de nacimiento, la localidad, incluso en siete de ellas aparecen sus nombres. En estos casos parece evidente que no hay pretensión de acogerse al anonimato del torno, sino que han optado por la vía más rápida; es la necesidad la que lleva a dejar al niño y además subyace la intención de recogerlo algún día al dar tantos datos identificativos; en algunas notas así se expresa:

\footnotetext{
"Nombre del niño Amadeo González Trigueros, tiene 3 años: es de Carrió (provincia de Oviedo: bautizado = la niña Pilar González Trigueros; tiene 10 meses es de Cistierna (provincia de León): está bautizada- Son hermanos, su madre = Valeriana Trigueros Nieto = Tomo esta decisión por falta de recursos ${ }^{\prime 385}$ [sic]
}

\footnotetext{
${ }^{385}$ Folio no 312. Libro de Exposiciones 1905, 20 tomo. ADPVA
} 
"Es hija de una mujer que no la puede criar ni darla a criar quiere por nombre se la ponga Florencia cuando pueda la reclamara" ${ }^{1386}$ [sic]

Se hacían indagaciones en los registros civiles, ayuntamientos y en las parroquias para averiguar si el expósito estaba bautizado e inscrito en el Registro Civil y, en su caso, bautizarle e inscribirle. En el libro de 1913, pegado al folio no 14 hay un trozo de papel que dice 6)

"Francisco Cardeñosa Tomillo...

De un mes próximamente de edad expuesto en este torno se precisa saber día de su nacimiento y parroquia del domicilio de su nacimiento" [sic] (IMAGEN 3-4)

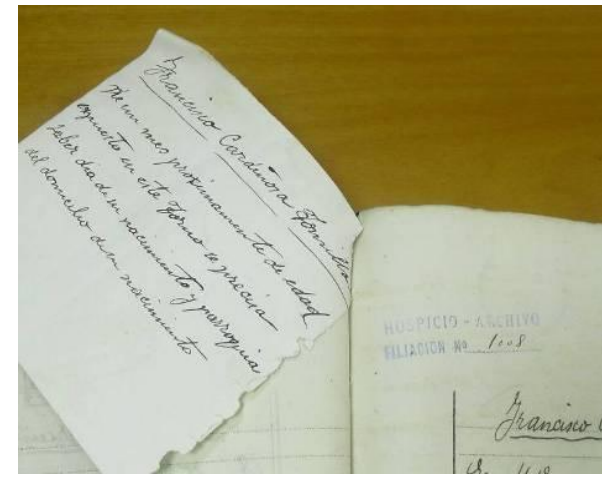

Imagen 3-4: Nota pegada al folio no 14 del Libro de Exposiciones de 1913. ADPVA
Este niño fue expuesto en el torno el 16 de enero de 1913, en el libro no se hace ninguna referencia a la posible edad del niño, como era por otra parte habitual, a pesar de que aparece en la nota, probablemente para facilitar la búsqueda. Parece que no se consiguió la información, al menos de forma más o menos inmediata, porque no se encuentra registrada.

"en 16 de Enero de 1913 á las 18 horas fue expuesto en el torno de este Hospicio con un papel que dice "este niño está bautizado e inscripto en el Registro Civil, se llama Francisco Cardeñosa Tomillo, no tiene Madre; suplica se le preste buena asistencia "...

Bautizado en Inscripto en el Registro Civil de ... 1904... Baja definitiva por hallarse con su padre." [sic]

También cabe la posibilidad de que simplemente se olvidara su registro ya que al año siguiente el niño se encontraba con su padre, puede que para entonces ya careciera de interés anotarlo pues era baja en el asilo.

En ocasiones conseguían localizar la fecha de inscripción en el registro civil y/o la fecha y parroquia del bautismo de los niños del torno y aparecen registradas posteriormente en los libros. Normalmente se trataba de casos en los que la nota que se dejó con el expósito brindaba datos suficientes, a veces, pocas, lo ponía fácil:

\footnotetext{
${ }^{386}$ Folio no 376. Libro de Exposiciones 1905, 20 tomo. ADPVA
} 
"En 18 de Febrero de 1908 á las 5 horas y 15 minutos fue expuesto en el torno de este Establecimiento con el adjunto papel que decía "Naturaleza del niño que se inclusa Padres naturales Agustin Mozo Martin de San Romas de la Ornija la defunta Madre Celestina Blanco Esteban natural de Fuensaldaña y el niño se Ilama Fidel Mozo Blanco Martin Esteban natural de Fuensaldaña á 18 de Febrero de 1908». Por ropas traía unos trapos.

Este niño entró sin documento alguno que expresase la edad que tiene, pero al parecer debe tener dos años cumplidos. Remitidos antecedentes por el Sr Juez y Párroco a petición de esta Dirección. Inscripto en Fuensaldaña 20 Octubre 1905 $B$ o [bautizado] en Fuensaldaña en 1 noviembre $1905^{\prime 387}$ [sic]

La nota da tantos detalles que parece de esas situaciones de abandono forzoso con clara intención de recuperar algún día al niño, en este caso el motivo parece ser el fallecimiento de la madre. Este es un asiento poco habitual porque se apunta la edad calculada del niño, algo que solo he encontrado en unos pocos registros, la edad se confirma con los certificados; pero sobre todo porque es de las pocas historias personales que he encontrado con un buen final, siempre supuesto, ya que Fidel volvió con su padre en 1910.

La mayoría de las veces la información no era tan explícita, en la nota simplemente se decía que el niño estaba bautizado y se daba su nombre y solo con eso, sin fechas ni localidad de nacimiento, en ocasiones conseguían los datos del registro y del bautismo. Expuesta en el torno el 13 de agosto de 1904, la nota decía "Aurea Fernández hija de Angela", consiguieron localizarla y aparece la fecha y parroquia del bautizo: “ $B$ a en $S$ Pedro el 18 de Julio 1904" ${ }^{388}$.

No obstante, no sabemos si se investigaba sistemáticamente la procedencia de los niños, eran muchos los que llegaban de forma totalmente anónima y sin ningún dato que sirviera de referencia y no sería fácil conseguir más información, pero da la impresión de que al menos se intentaba cuando tenían algún dato de dónde tirar y se hacía sin demora.

Hay que contar también con la ausencia de datos en los libros por omisión en el registro. La niña Atanasia, inscrita en el folio no 51 de 1906, fue expuesta con una nota que decía que estaba bautizada, pero no se registró la fecha de bautizo ni la inscripción en el R.C.. No consta su edad, ni una aproximación, como era habitual, puede ser que no se consiguiera información sobre ella, pero parece más un error por omisión porque ni siquiera se indica si la bautizaron en el asilo. Por otra parte, siete meses después volvió con la madre y pudo

\footnotetext{
${ }^{387}$ Folio no 53. Libro de Exposiciones 1908, 1ำ tomo. ADPVA

${ }^{388}$ Folio no 261. Libro de Exposiciones 1904, 20 tomo. ADPVA
} 
completarse entonces el registro; podía ser una niña legítima porque su segundo apellido coincide con el de la madre.

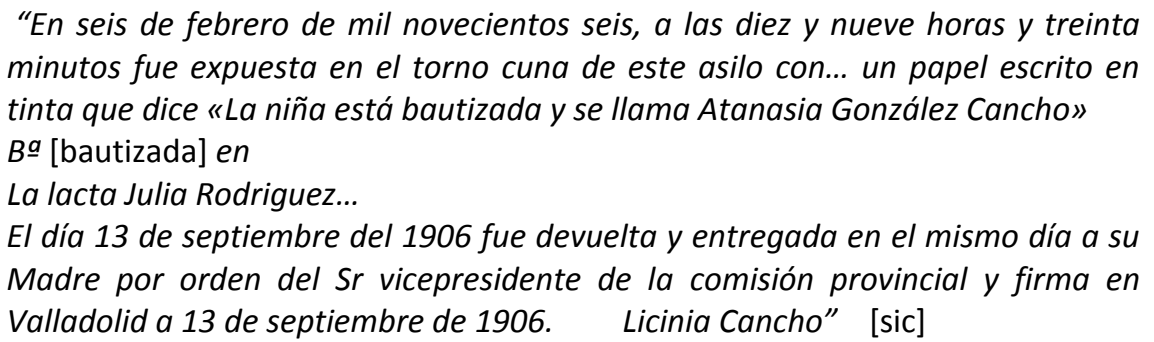

Según los registros de los Libros de Exposiciones consultados, la exposición en el torno fue la forma más frecuentes de ingreso y en segundo lugar la vía que podemos llamar oficial a través de la Diputación, por su cauce normal que era el acuerdo de la Comisión Provincial, o por la vía rápida que consistía en la orden directa del Presidente de la Diputación o el Vicepresidente de la Comisión. Siguen, por orden de frecuencia, los niños nacidos en la Maternidad del propio asilo y los expuestos en los pueblos de la provincia que eran trasladados a la Casa Cuna Provincial, los nacidos en el Hospital Provincial de la Resurrección y, finalmente, algunos casos contados de niños ingresados por orden del Gobernador Civil por vía de urgencia, y los nacidos en el Manicomio Provincial (ver GRÁfICA 3-9). Los niños del torno y de la maternidad del Hospicio pasaban directamente a la Inclusa. El resto, incluidos los que se trasladaban desde el Hospital provincial y los expósitos de los pueblos de la provincia entraban a través de la dirección, la oficina, como se dice en los libros de registro de la Inclusa.

"Enero $4 \quad$ año 1902

Folio 4 entro por la oficina una niña bautizada se llama Manuela Galan hingreso de Rioseco ropas trapos..." [sic]

"Mayo 1은 1902

Folio 75 entro por la oficina un niño sin bautizar hingreso del Hospital se le bautizo en este establecimiento..." [sic] 


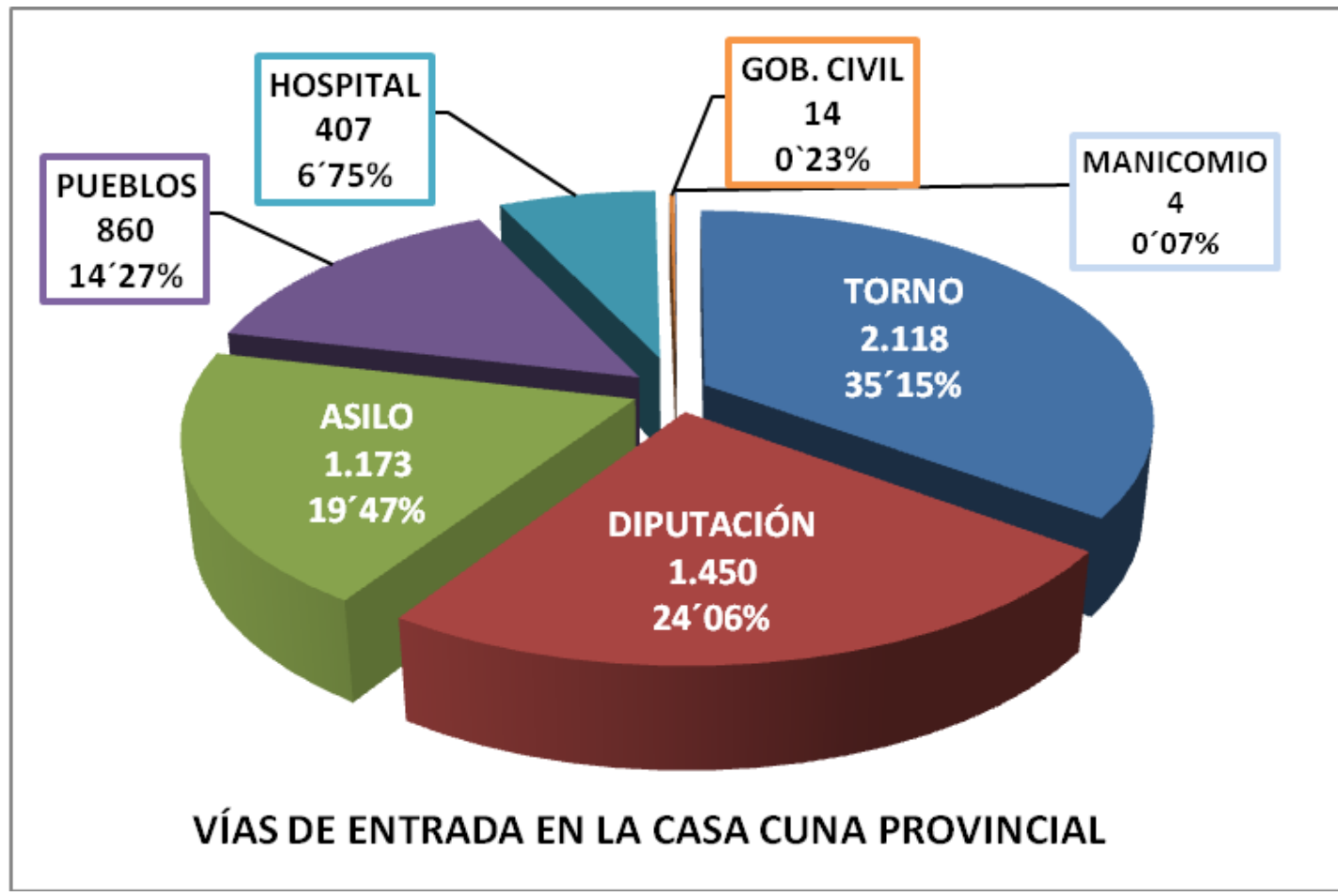

GRÁFICA 3-9: Distribución porcentual y en valores absolutos de los niños ingresados en la Casa Cuna según la vía de entrada en ella. Elaboración propia a partir de los Libros de Exposiciones del ADPVA. Se han contabilizado en este caso también los niños "nacidos muertos" considerando que eran candidatos a ingresar.

\title{
3.3.1. EL TORNO
}

\author{
Pues si el torno de la Inclusa \\ es un buzón verdadero, \\ ¿adónde llevan los ángetes \\ las cartas para el infierno?
}

Abrojos - XXXVI. Rubén Darío

El torno fue un elemento emblemático y controvertido de las inclusas durante el siglo XIX y las primeras décadas del siglo XX. Aunque los primeros tornos se remontan al siglo XII, su uso se generalizó en nuestro país a finales del siglo XVIII y principios del XIX; hasta entonces era utilizado casi exclusivamente en los conventos de clausura. Si buscamos en los diccionarios históricos de la RAE, aparece por primera vez con el significado que estamos utilizando aquí en 1611 en el diccionario de Sebastián de Covarrubias, pero para referirse únicamente al torno de los conventos o de lugares de encierro ${ }^{389}$.

\footnotetext{
389 En el diccionario de Nebrija todavía no aparece esta acepción, solamente recoge los significados: Torno para tornear. tornus. f. Torno para prensar. torcular, prenum. f. Diccionario de Antonio de Nebrija. Salamanca. Impresor de la gramática castellana. 1495?, p 190,2.
} 
"Torno, una cierta caxa, embeuida en una ventana, por donde se da recado a las Monjas y a otras personas recogidas y encerradas" [sic]

Esta misma acepción se recoge en el Diccionario de Autoridades de la Real Academia de la Lengua de 1739, p 304,2 y la primera vez que se mencionan las casas de Expósitos es en la 9ạedición de 1843, p 708,1

\begin{abstract}
"Máquina de base circular a modo de cajón dividido en varios senos, la cual gira sobre un eje, y colocada en el hueco abierto en una pared medianera, sirve para introducir y sacar lo que se ofrece sin necesidad de que se toquen ni vean las personas. Se usan en los conventos de monjas, casas de expósitos y otras partes. Rota loculata" [sic]
\end{abstract}

No es casualidad esta incorporación en la definición del torno en estas fechas, con cierto retraso como es habitual, puesto que para entonces ya era un elemento normal en las inclusas de nuestro país. En la última edición del diccionario de la RAE de 2014 ya ha desaparecido la alusión a las casas de expósitos, que todavía figuraba en la anterior de $2001^{390}$.

El miedo a la deshonra y a sus consecuencias sociales y familiares era el motivo principal del abandono de los hijos ilegítimos. Deshacerse del bastardo era la solución para "ocultar la vergüenza" y evitar el rechazo tanto social como familiar; los tornos de las inclusas vinieron a ofrecer anonimato a la "madre pecadora" sin necesidad de echar al hijo en lugares inhóspitos o cometer un infanticidio, preservando así su honra y la de su familia. Su uso se extendió sobre todo por el Sur de Europa cuando se despenalizó el abandono de los niños en ellos. El decreto napoleónico que generalizó su implantación en Francia ocasionó un aumento tan alarmante de los abandonos que a partir de 1826 empezaron a cerrarse y acabaron desapareciendo en 1860. La clandestinidad que brindaba el torno se convirtió en un elemento facilitador y favorecedor del abandono, de manera que provocó un aumento muy importante de las exposiciones de hijos legítimos, por lo que en la segunda mitad del siglo XIX siguiendo el ejemplo francés se fueron cerrando los tornos para evitar ese uso considerado abusivo y se restringieron los criterios de admisión en las inclusas para impedir el ingreso de los legítimos. Con la supresión del torno desaparecía el anonimato, los niños se recogían en una oficina dispuesta al uso y las madres tenían que aportar datos al entregarles. En España el proceso siguió un ritmo diferente, aunque también se experimentó un aumento de legítimos se culpó a

Fray Pedro de Alcalá añade la acepción de Torno para hilar. Diccionario de Fray Pedro de Alcalá. 1505, Granada, Juan Varela. p 496. Covarrubias incorpora la acepción de torno como ventana giratoria de los conventos. Diccionario de Sebastián de Covarrubias. 1611. Tesoro de la Lengua castellana o española. Madrid; p 1299, 2

${ }^{390}$ El diccionario de 2001 define el torno como "Armazón giratoria ... la cual se ajusta al hueco de una pared y sirve para pasar objetos de una parte a otra, sin que se vean las personas que los dan o reciben, como en las clausuras, en las casas de expósitos y en los comedores". La edición 23ㅇ de 2014 dice ya simplemente "Armazón giratoria, empleada para pasar objetos de una parte a otra, como en los conventos de clausura". 
la situación económica y frente a los que rechazaban el torno por el abuso que se hacía de él primó la idea de evitar infanticidios, mediante el anonimato que garantizaba. Su supresión se retrasó hasta el primer tercio del siglo XX; en 1910 se suprimieron dos de los cinco tornos con que contaba la provincia de Guipúzcoa, en 1927 el de Madrid, en 1931 el de Barcelona; en 1933 el de Pamplona y Pontevedra ${ }^{391}$.

En España se despenalizó el abandono de niños en el torno en 1796, Prácticamente todas las inclusas disponían de uno y además se colocaron tornos para evitar largos desplazamientos que podían hacer desistir a las mujeres de llevar a los niños a los establecimientos de acogida o causar el fallecimiento de éstos durante el traslado; según el RD de Carlos IV de 1796 estos tornos no debían distar más de doce o catorce leguas de la casacuna central; en la provincia de Valladolid se encontraban en Medina del Campo y Medina de Rioseco $^{392}$. Este decretó no despenaliba la exposición fuera el torno, el abandono de niños en otros lugares siguió considerándose delito

"El día 20 de octubre último dio a luz una niña, la joven vecina de esta localidad Teodosia Pérez Domínguez, de 18 años y soltera. El padre de ésta con objeto de ocultar su deshonra, el día 31 del mismo mes cogió a la niña y envolviéndola en unos pañales, la metió en una cesta y se la llevó diciendo á la joven madre que iba á depositarla en un establecimiento benéfico establecido en Toro.

En dirección á esa ciudad marchó el desnaturalizado abuelo, pero al llegar á Pinilla de Toro ató a la cuerda de una persiana que colgaba de un balcón, y allí... dejó abandonada á la criatura, á merced de la casualidad...

El cruel y despiadado abandono se ha descubierto hace poco... El juez ha ordenado la detención del padre de la joven parturienta, Ilamado Críspulo Pérez, orden que ha cumplido la guardia civil del pueblo de Tiedra"1393

\footnotetext{
391 VALVERDE LAMSFUS L.: op. cit., p 1.188; RODRÍGUEZ MARTín A.M.: La Casa de Maternidad y Expósitos de Barcelona, 1872-1903, p 141; REVUELTA EUGERCIOS B A: op. cit., p 132 y 216- 17 132. Refiere B. Revuelta que el torno de Madrid se suprimió definitivamente tras la polémica que se levantó cuando un bebé falleció en él degollado, p 217

${ }^{392}$ El Consejo de Castilla solicitó en 1790 a las autoridades eclesiásticas que informaran de la situación de las casas de expósitos de sus diócesis. La respuesta fue tan desoladora que el gobierno de Godoy decidió tomar medidas, al menos sobre el papel, a favor de los expósitos. El 5 de enero de 1794 se publicó el R.D. que los legitima: "Ordeno y mando... que todos los expósitos de ambos sexos, existentes y futuros,... sean tenidos por legitimados... y por legítimos para todos los efectos...". El R.D. de 11 de diciembre de 1796 se preocupa por defender "los intereses de la conservación de sus vidas y sus legítimos derechos...", en él se ordena que en cada diócesis se construyan tantas casas de expósitos como sea necesario para que la distancia a la casa central localizada en la capital no sea superior a doce o catorce leguas y que no se traslade a los expósitos fuera de la de la diócesis. La realidad es que el respaldo gubernamental casi se quedó sólo en esto, se construyeron nuevos asilos y se consiguieron donaciones caritativas para su sustento, pero poco más, la situación de los niños no cambió demasiado. FUENTE GALÁN: La situación de las inclusas en el siglo XVIII. La encuesta de 1790. Chronica Nova. 1997, no 24: pp 61-78. EGIDO T.: La Cofradía de San José y los niños expósitos de Valladolid (1540-1757). Revista de Estudios Josefinos. 1973, 53-54, pp 232-259. ARANA AMURRIO J.I.: Historia de la Inclusa de Madrid. Cuadernos de Historia de la Pediatría Española. 2012. № 4, pp 20-31. ${ }^{393}$ N.C. 27- 01- 1911, p 2
} 
Aún así, a pesar de la ley y de la existencia del torno, seguían abandonándose niños en otras partes, en ocasiones en lugares particulares y con intención de que se les encontrara pronto; quienes los encontraban, los trasladaban a la Inclusa Provincial. En el folio de inscripción se solían registrar estas circunstancias y el nombre de quien entregaba personalmente al expósito, según indicaban los reglamentos

"Según manifestación espontanea que hizo en esta Dirección donde se presento antes de depositarlo en el torno la mujer que lo traia, Ilamada Vidal Diez Escudero, este niño se encontró á la puerta de su domicilio San Isidro no11 patio á las cuatro horas del día de hoy y á su ruego se hace constar asi" [sic] (fo 167 LE 1909-1).

Llama la atención que según el registro antes de depositarlo en el torno a las 10 horas de la mañana la mujer pasó por la dirección del centro, en lugar de tramitar desde allí el ingreso parece que quisiera respetarse el procedimiento que le correspondía como expósito.

Otras veces los niños eran abandonados en lugares públicos y a su suerte

"En cinco de Agosto de mil novecientos ocho á las 17 horas y 30 minutos fué entregada en este Establecimiento por $D^{n}$ Ignacio de Inchaurbe (Presbitero) $D^{\underline{a}}$ Bernarda Martín, $D^{n}$ Candido Martin, $D^{n}$ Inocencio Velasco y Dn Juan Palacios, los cuales manifestaron habérsela encontrado en las Moreras un momento antes, que parecía recién nacida y precisaba inmediato bautismo y demás socorros. Inmediatamente se puso en conocimiento del Sr Juez de Instrucción del Distrito de la Audiencia a los efectos que procediesen y del Sr Presidente de la Excma Diputacion por lo referente á su ingreso y permanencia en este Asilo" [sic] (fo244. LE 1908-1)

La bautizaron María Nieves, como corresponde en el santoral al 5 de agosto, celebración de la Virgen de las Nieves, pero la pobre criatura fallecería "á las 8 horas del 8 de Agosto de 1908 á consecuencia de "congestión cerebral» según manifestación del Director facultativo al Juzgado de Instrucción". El caso tuvo amplio tratamiento en la prensa local, donde fue noticia en días sucesivos, ese mismo día del fallecimiento, ignorantes todavía del desenlace El Norte de Castilla publicaba

\section{"Criatura abandonada. \\ Padres desalmados}

Próximamente á las seis de la tarde, Cándido Martín e Inocencio Velasco, el conocido buñolero de la calle de doña Maria de Molina, encontraban, cerca de la antigua iglesia de San Agustín, y al pie de un árbol, un bulto misterioso, del que salían débiles quejidos.

Atraídos por la curiosidad, desenvolvieron los blancos paños que cubrían el bulto, y al hacerlo, vieron con sorpresa é indignación, una niña recién nacida, envuelta en blanquísimos pañales, que había sido abandonada, sin duda, por unos padres sin entrañas.

... se convino en trasladar á la infeliz criatura al cercano Hospicio provincial, donde fue depositada.

Un sacerdote forastero, don Ignacio Inchausti, que se había unido al grupo de curiosos, administró a la niña el sacramento del bautismo, bajo la forma de agua de socorro. 
... El angelito, á no haber sido por los piadosos sentimientos de quienes le recogieron, hubiera perecido..." ${ }^{394}$

Al día siguiente, con el mismo titular publicaban el fallecimiento de la niña.

"El triste desenlace que se temía para el lamentable suceso en que nos ocupamos, llegó ayer á primera hora de la mañana.

La infeliz criatura, que ha tenido por cuna el duro suelo hasta que la caridad la recogiera, falleció ayer á las ocho de la mañana en el Hospicio provincial..."

Aunque es imposible excusar algo así, a pesar del titular, probablemente la madre, o quien la abandonó, actuó más con ignorancia y terrible torpeza que con maldad pues el Hospicio quedaba muy cerca y el paseo de las Moreras, donde la dejaron, era un lugar próximo al río y transitado a esas horas del mes de agosto como se entrevé en la noticia, por tanto, pudo ser dejada allí bajo un árbol donde resultaría visible y estaría resguardada a la sombra para que la encontraran y la trasladaran fácilmente. Lamentablemente, parece que estos jardines eran un sitio propicio para este tipo de actuaciones donde se abandonaban niños con cierta asiduidad $^{395}$.

Igual que sigue sucediendo hoy día, aunque con más frecuencia por las circunstancias sociales, ocurrían hechos desconcertantes y la prensa se hacía eco de ellos. En 1900 El Norte de Castilla publicaba:

"Don Diego Feijoo, habitante en la calle de Colón núm 8, puso en conocimiento del alcalde de barrio de la Magdalena, á las seis de la mañana de ayer, que su criada, soltera, de 32 años, había dado á luz una niña con vida, sin que hubieran sospechado el estado en que se encontraba.

Personados el alcalde del barrio y el guardia municipal Juan Alvarez en el lugar del suceso reconocieron la habitación de la criada, encontrando entre los colchones de la cama una niña recién nacida con síntomas de asfixia.

La individua en cuestión fue conducida al Hospital provincial y la criatura al Hospicio" $^{\prime 396}$

El diario no comenta más; la noticia en sí lo dice todo, revela una situación tristemente frecuente en la época, que llevaba a algunas mujeres a conducirse así por la enorme dificultad que podía suponer sacar adelante en solitario a una criatura, aunque existía la opción, como estamos viendo mucho más utilizada, de dejarla en el torno de la Inclusa. Actualmente también nos sorprenden de vez en cuando noticias de niños abandonados incluso entre la basura, cuando hoy basta con avisar en el mismo hospital donde se atiende el parto que se quiere dejar al niño para adopción y los servicios sociales se hacen cargo de él. En el Libro de Exposiciones no hay constancia del ingreso de esta niña, ni por la oficina ni por el torno del

\footnotetext{
${ }^{394}$ N.C. 8 de agosto de 1908, p 2

395 En junio de 1920 aparecieron en una semana dos cadáveres de niños abandonados en las Moreras. N.C. 4 de junio de 1920, p 6

${ }^{396}$ N.C. 31- 08- 1900, p 2
} 
Hospicio, al menos no hay ningún registro donde se haga constar este hecho y ninguno de los ingresos alrededor de esa fecha se ajustan a las características de esta niña. Cabe la posibilidad de que falleciera o fuera trasladada con la madre al Hospital.

Noticias de este tipo, tanto locales como nacionales aparecían periódicamente, sobre todo cuando intervenían las autoridades públicas; a veces solo se publicaba una pequeña reseña de apenas unos renglones, como si fuera algo habitual.

"En el portal de la casa 11 de la calle Gabilondo fue hallada por dos jóvenes llamados Aniceto Narros y Nicolás Sancho una criatura de 20 a 30 días, que había sido abandonada por su desnaturalizada madre.

El subjefe de guardias municipales Sr Devesa dio las órdenes oportunas para que el niño fuera trasladado al Hospicio, donde ingresó con el número $77^{\prime \prime 39}$

En el libro de 1902 no se encuentra registrada esta circunstancia, con el no 77 figura Emeterio San José, pero sobre su ingreso solo se dice que fue expuesto en el torno cuna con unos trapos; antes del día 6 en que se publicó la noticia no se registra ningún otro niño que pudiera ser. Es llamativo como algunos registros de los Libros de Entradas son muy meticulosos con ciertos detalles y otros omiten a veces circunstancias como éstas.

En otras ocasiones los diarios las publicaban ampliamente, encontramos en la prensa crónicas que referían todo tipo de detalles escabrosos en una práctica de "amarillismo" periodístico que, aún siendo muy discutible, serviría para sensibilizar a la población frente al problema del abandono y el infanticidio. El 31 de enero de 1911 en El Norte de Castilla aparecían en un mismo artículo titulado "¿INFANTICIDIOS?" tres lamentables casos

"El feto aparecido en el retrete fue reconocido por el médico forense, quien afirma que era el de una niña, de tiempo y bastante robusta, tenía como dijimos ayer el cráneo fracturado y algunas erosiones. Estas fueron producidas sin duda por el número considerable de ratas que invaden aquellos lugares y que habían roído también parte de la cabeza del feto....

La policía encontró ayer por la mañana vestigios de un alumbramiento, abandonados en los paseos de las Moreras, pero parece que se ha comprobado que este hallazgo no puede guardar relación alguna con el otro suceso....

Anoche se descubrió otro suceso, que pudiera ser, y de aclararlo trata el Juzgado, otro infanticidio.... En la inspección de Vigilancia recibieron ayer confidencias relacionadas... con la comisión de un infanticidio en la Posada del Salamanquino, establecida en la calle de Miguel Iscar. La policía logró averiguar que una criatura nacida en dicha posada hacía aproximadamente un mes, había sido enterrada en una cuadra de la misma. ...hace un par de meses llegó a dicha posada, hospedándose en ella, una señora de Palencia a quien llamaban doña Mercedes..."

${ }^{397}$ N. C. 6-3-1902, p 3 
El trato de la prensa era más benévolo cuando se trataba de cuestiones de honra sin cometer infanticidio, aunque también se intervenía judicialmente

\section{"El suceso de ayer \\ UN FETO AL RIO}

En las primeras horas de la mañana de ayer circuló por nuestra capital la noticia de que se había cometido un infanticidio.... adivinaba la imaginación popular el desastroso final de una historia de amores y deshonra.

No eran exactas las noticias circuladas. No se trata de un infanticidio; se trata solamente de que una pobre joven ha procurado ocultar el aún inanimado fruto de su deshonra. Suceso vulgar por lo frecuente, en todos tiempos.

A las seis y media de la mañana de ayer, una joven regularmente agraciada de rostro y modestamente vestida, entró en el Vivero de San Lorenzo, se dirigió presurosa a la orilla del río, y observando si acaso la veía alguien, arrojó á las aguas un pequeño envoltorio que llevaba en los brazos.

El envoltorio cayó junto á la orilla y la joven marchó con prisa por donde había llegado.

Un pescador llamado Luis..., apercibieron el hecho y remando con fuerza atracaron la barca en la orilla, saltaron á tierra y avisaron al guarda del Vivero, Ramigio...

Este detuvo a la joven que huía y avisaron los otros á los agentes de la autoridad.

A los pocos instantes se presentó el cabo Tapia. Entonces se comprobó que el pequeño fardo arrojado al río, era un feto femenino envuelto en unos paños.

Así lo confesó la joven, añadiendo que en la madrugada anterior había abortado, y para ocultar su deshonra arrojó el feto al río.

...la muchacha manifestó... 19 años, soltera, natural de Almansa (León) y sirvienta en el piso... L La familia a la que sirve está ausente...

... el médico forense señor Velicia... reconoció el feto, que como arriba decimos es fenómeno y contaba pocos meses de vida intrauterina.

... advirtiose que sufría copiosa metrorragia, que soportaba con entereza notable. En vista de ello llevósela á la Casa de Socorro... prestaron á la joven los auxilios oportunos para contener la fuerte metrorragia, consecutiva al aborto, al parecer de 5 ó 6 meses.

Después la joven pasó al Hospital, donde quedó ocupando cama en la sala de detenidas... ${ }^{\prime 398}$.

Las noticias de este tipo eran frecuentes lo que servía de justificación a la existencia y mantenimiento del torno de las inclusas. Aunque no sea la mejor opción parece que, al menos en este aspecto de evitar que el niño fuera abandonado en cualquier lugar con riesgo para su vida, el torno cumplía la función para la que estaba pensado pues es probable que muchos de los expuestos en él hubieran corrido la misma suerte que los que recogen las noticias; tampoco podemos descartar que otros muchos no hubieran sido entregados a la Inclusa; difícil saberlo. En El Norte de Castilla en la sección dedicada a la actividad judicial de la ciudad se publicaban

\footnotetext{
${ }^{398}$ N. C. 28 de agosto de 1902, p 2
} 
los casos juzgados de infanticidio y las sentencias, la pena que se imponía era de 3 años, 6 meses y 21 días de prisión correccional ${ }^{399}$.

La casa de expósitos de la cofradía de San José de Valladolid ya contaba con un torno en su fachada ${ }^{400}$. La Real Casa de Misericordia, antes Hospicio de Pobres, sita en la casa de Híjar no tenía, al menos no se refiere en sus estatutos de $1785^{401}$ y no parece necesario por el tipo y la edad de sus acogidos, tampoco tenemos constancia de que existiera en el hospital de San Blas, donde se trasladó la casa de expósitos en 1776. En el nuevo edificio del palacio de los Benavente se colocó un torno, como lo aseguran las primeras ordenanzas de la Casa de Expósitos de 1806, donde al hacer la relación de las estancias que debe tener ésta y su distribución lo menciona expresamente, "Otro Quarto inmediatamente á el sitio en que esté el Torno para el recibimiento de niños, en que continuamente habrá de estar una mujer destinada á el efecto" ${ }^{402}$.

En marzo de 1920 la Comisión Provincial acordó quitar el torno de la Inclusa Provincial de Valladolid, con la oposición del diputado visitador del Hospicio D. Luis Roldán Trápaga ${ }^{403}$. Parece que el señor Trápaga finalmente se salió con la suya, o simplemente no se aprobó un presupuesto para acometer las obras necesarias porque a pesar del acuerdo de la comisión el torno no se retiró y siguió funcionando. En los reglamentos de 1927 sigue apareciendo en el Capítulo XXXIV dedicado al Departamento de la Casa-Cuna en su artículo 310, en el que podemos todavía leer que "Para recibir a los primeros (los ilegítimos) deberán ser expuestos en el torno que con dicho fin se hallará colocado en el exterior del edificio". No tenemos más noticias al respecto hasta 1936, en una reseña de las que publicaba El Norte de Castilla sobre las sesiones de la Comisión provincial de la Diputación. La sesión del 14 de mayo aprueba la puesta en marcha de las obras para quitar el torno y habilitar una oficina de recepción en su sustitución. En las fotografías que se conservan de la fachada de lo que a partir de 1940 se llamaría residencia Provincial, no se aprecia el torno (IMAGEN 3-5)

\footnotetext{
${ }^{399}$ Puede verse en N.C. 01- 09 - 1925, p 5; 24- 10- 1928, p 6

${ }^{400}$ Así lo recoge Teófanes Egido en La cofradía de San José y los niños expósitos de Valladolid (1540-1757), p 259

${ }^{401}$ Estatutos que se han formado por la Real Junta de Hospicio para el Régimen, y Gobierno de la Casa de Misericordia. 1785 Estatuto XIII, p 20. En ellos se habla de un torno en la cocina para pasar la comida a las mujeres, pero no para exposiciones

${ }^{402}$ Ordenanzas de la Real Casa de Misericordia de Valladolid. 1806, p 91, en el capítulo de dedicado a las Ordenanzas Generales para la casa de Expósitos.

${ }^{403}$ Publicado en El Norte de Castilla el 23- 3- 1920, p 3
} 


\section{"Sustitución del torno en la Inclusa}

Se facultó al señor Polanco para llevar a cabo esta sustitución, ya que aportó antecedentes y forma en que lo han realizado otras Corporaciones provinciales, quedando facultado para realizar las obras y señalar el local donde se establezca la nueva oficina de admisión de ingresos.

El señor Cuevas felicitó al señor Polanco por haber tan rápidamente llevado a cabo la propuesta formulada por él a la Comisión gestora" ${ }^{404}$

\subsubsection{Localización del torno}

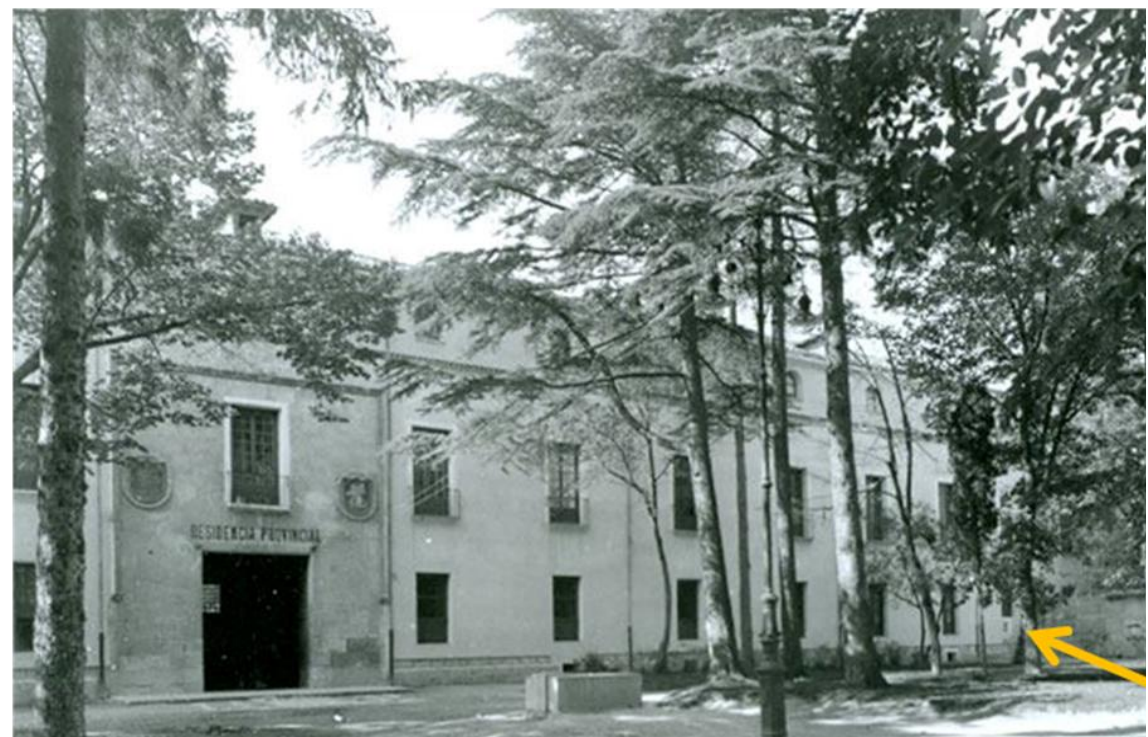

Imagen 3-5: Palacio de los Condes de Benavente. Fuente: Fundación Joaquín Díaz. Sin datar. (La flecha señala la ventana donde pudo estar el torno).

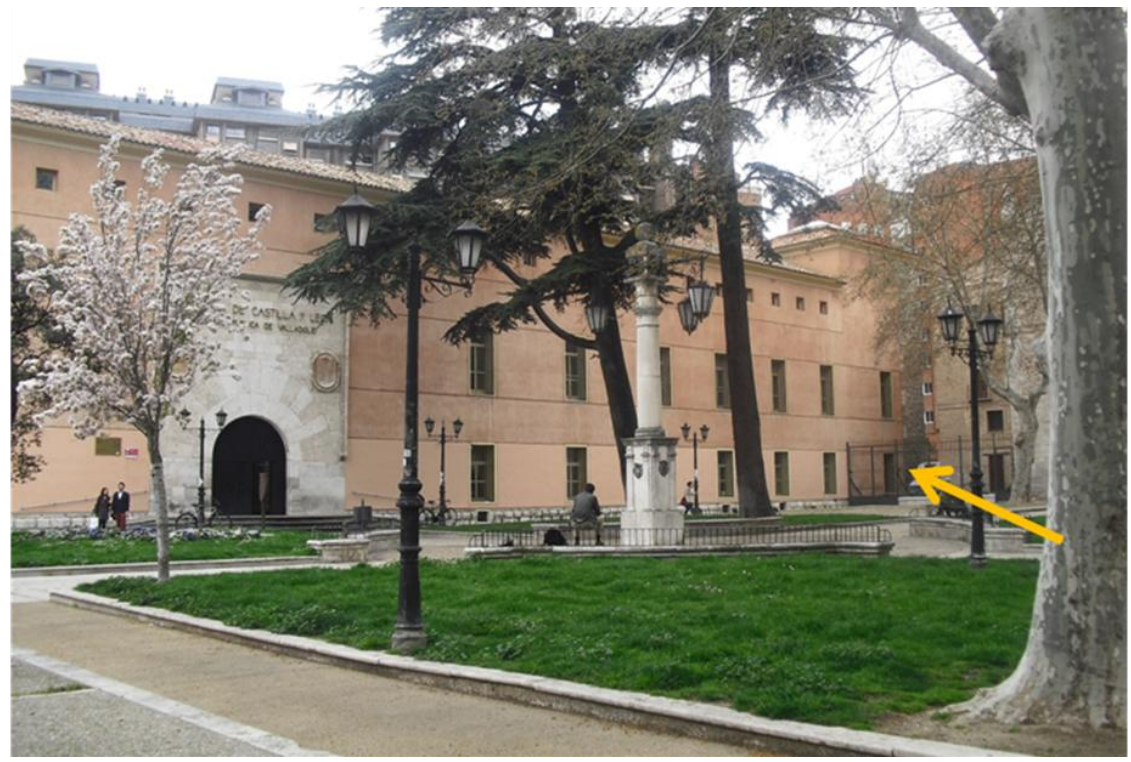

Imagen 3-6: Palacio de los Condes de Benavente. Fotografía actual de la autora

${ }^{404}$ N. C. 15 de mayo de 1936, p 3 
No tenemos constancia gráfica ni documental de la localización precisa del torno, pero analizando las pocas fotografías existentes del Hospicio pienso que podría localizarse en la fachada principal hacia la plaza de la Trinidad en la última ventana de la esquina que está junto a la iglesia de San Nicolás. Actualmente no queda rastro del torno en la fachada, pero ya en las fotografías anteriores a la última remodelación del edificio tampoco se aprecia, parece que cuando finalmente se decidió clausurar su uso se eliminó de la fachada y se cerró el hueco que ocupaba. Todos los ventanales de la planta baja hoy son iguales en forma y tamaño (IMAGEN 3-6), sin embargo, en una postal de la colección de la Fundación Joaquín Díaz ${ }^{405}$ se puede observar, aunque con cierta dificultad por la calidad de la imagen, que el último ventanal (el séptimo) es más corto y su base se encuentra a más altura que el resto, se ha recortado la mitad y en el espacio que queda debajo se aprecia un recuadro que podría haber correspondido a la ventana del torno (IMAGEN 3-5). La postal está sin datar pero por el cartel sobre la puerta que nombra al edificio como Residencia Provincial es posterior a la época de este estudio, por lo que para entonces el torno estaría ya cerrado. En la actualidad todos los ventanales son iguales, pero he podido comprobar que por las medidas, tanto del ventanal como del espacio que en la postal se ve cerrado, cabe perfectamente un torno de más de 80 $\mathrm{cm}$ de altura. De ser así la sala del torno estaría en la esquina norte de la fachada, en la zona menos visible de toda sus fachadas y más resguardada de miradas curiosas. Un extenso artículo dedicado al Hospicio provincial y publicado en El Norte de Castilla en 1899 confirma mis conjeturas y ubica el torno en esa esquina confirma mis conjeturas y ubica el torno en esa esquina

"El torno

El alma se apena, el corazón se estremece y el pensamiento se abisma al contemplar en la fachada del Hospicio, junto a la parroquia de San Nicolás, el torno, aquel negro agujero, puerta del anónimo, donde han sido depositados tantos miles y miles de inocentes criaturas, la mayoría de los cuales ha venido en mal hora al mundo, puesto que no han de saber lo que es un padre ni una madre, ni han de disfrutar nunca de las delicias del hogar. ¿Cabe vida más desventurada?

Ante aquel hueco insaciable acuden a nuestra memoria aquellos sentidos versos que Blasco compusiera, ante el torno de la Inclusa

El león con ser león adora su propia sangre;

y el chacal con ser chacal no vive sin sus chacales. Defiende el tigre a sus hijos, la pantera es tierna madre,

\footnotetext{
${ }^{405}$ Palacio de los Condes de Benavente. Postal de la Colección de fotografías de Castilla y León. Valladolid. (va 0977) Fundación Joaquín Díaz.
} 
los buitres de las montañas amorosos nidos hacen; y los hombres con ser hombres han hecho una casa grande, para almacenar los niños arrojados a la calle!"

\subsubsection{Funcionamiento del Torno}

Sigue diciendo el anterior artículo

"El torno del hospicio está dispuesto de tal manera, que el peso del niño depositado en él hace sonar un fuerte timbre colocado en la habitación interior, en la cual duermen Hermanas de la Caridad, que a su sonido acuden presurosas a recoger las infelices criaturas que el oleaje de las pasiones y de los vicios, de las hipocresías y los impudores abandona desamparados en aquel agujero... Son piltrafas de carne que se tiran al montón de lo inservible"

Los reglamentos nos describen el funcionamiento del torno de Valladolid, especialmente el Reglamento de 1889 que se extiende con más detalle al respecto; probablemente en los reglamentos posteriores se quitaron cuestiones que estaban ya establecidas y que se daban por hecho, pues hay directrices que aparecen en el primero y que se siguen cumpliendo, al menos a lo largo del tiempo de este estudio, aunque ya no aparezcan escritas en la normativa.

En la sala del torno debía estar siempre una Hija de la Caridad como responsable de recoger a los niños allí expuestos y tenía que haber tres o cuatro cunas y ropa suficiente para preparar el "atillo" [sic] o "envoltura completa", que era el ajuar completo con la ropa del hospicio que se asignaba a cada niño.

La tornera recibía a los niños, los desnudaba y exploraba en busca de señales características de identificación, los aseaba y los vestía con las ropas del hospicio. Debía observar también cuidadosamente tanto las ropas como cualquier objeto o nota escrita que les acompañara para registrarlo con todo detalle.

La Hermana tornera debía poner el ingreso en conocimiento de la Superiora y según los reglamentos debían "anotar enseguida con la mayor exactitud en el libro de registro, el día y hora en que se recibe, sexo á que pertenece, las ropas, alhajas y apuntaciones que se

\footnotetext{
${ }^{406}$ N.C. 13- 2- 1889, p 1
} 
entregasen, y todas cuantas circunstancias hubieran ocurrido á su presentación examinando desde luego su cuerpo, las ropas de envoltura y demás para ver si contienen alguna señal especial a fin de anotarla en el registro de identidad" (Regl. 1889. Art. 45)"consignando estos detalles con la mayor escrupulosidad. También anotará el nombre de los conductores si han manifestado deseos de que se haga" (Regl. 1889. Art. 45), se pretendía por tanto recoger todos los datos de interés para una posible futura identificación del niño. Cuando los niños llevaban alguna nota también la transcribían completa y literalmente. Todo se registraba en el libro de la Inclusa del año en curso, donde a cada niño se le asignaba un número siguiendo el orden de ingreso; los libros que se llevaban en la Inclusa para registro de los niños que ingresaban son los denominados Libros de Entradas que no tienen aspecto de ser oficiales, no llevan ni timbres ni sellos ni la firma del director; todos los que se conservan del periodo estudiado están escritos por la misma persona, podría ser la Superiora que en los primeros años y hasta 1915 era Sor Francisca Orrio, ya que el reglamento de 1898 encargaba a la Superiora el registro en el libro, aunque en los posteriores de 1910 y 1927 la tarea de registro en los libros de Entrada se adjudicó a la Hermana responsable del torno.

La Superiora daba aviso del ingreso al médico "para que este disponga lo que crea conveniente para su lactancia" (Regl de 1889, Art. 46) y al capellán "si no constase haber recibido el Santo Bautismo" (Regl de 1889, Art. 47). "Si la criatura expuesta reclamare con urgencia el auxilio del Facultativo y Capellán, la Superiora les pasará inmediatamente aviso, para que cada uno cumpla con su ministerio" (Regl de 1889, Art. 46). En caso de que el niño fuera encontrado sin vida debía ser examinado inmediatamente y el médico tenía que dar parte a la autoridad judicial si observaba signos de muerte violenta, "en otro caso al dar parte al Registro Civil para la inscripción del fallecimiento, se hará constar la circunstancia de haberse presentado ya sin vida en el torno de la Inclusa" (Regl 1910, Art. 317 y Regl 1927, Art. 320), En el período estudiado 1900-13 solamente tres niñas aparecieron muertas en el torno, se encuentran registradas en los libros como "Niña muerta", en una de ellas se anotó que estaba ya en estado de descomposición, pero en ninguno de los casos se dice si presentaban signos de violencia.

\section{"Niña muerta}

En 4 de Sbre de 1900 y hora de las tres y media de la mañana fue expuesta en el torno de este establecimiento un niño muerto en estado de descomposición"

\footnotetext{
${ }^{407}$ Folio no 334, Libro de Exposiciones de 1900. ADPVA. En el libro aparece el registro tal cual se transcribe aquí, en el encabezado que corresponde al nombre dice "Niña muerta" y en el texto "niño muerto". Los otros dos registros dicen:

"Niña muerta En 1o de Febrero de 1901 y hora de las veintitrés y cuarenta y cinco minutos fue expuesta en el torno de este asilo una niña muerta" (fo 40, LE 1901-1. ADPVA)
} 
Por supuesto, el ingreso debía notificarse también a la dirección del centro que además de registrarlo en sus libros de Entradas, también llamados de Exposiciones aunque incluían todos los registros de los menores tanto las exposiciones del torno como los niños entregados en la oficina, era responsable de inscribir en el Registro civil a los niños que no estuvieran inscritos todavía. En el folio correspondiente a cada niño en el libro de Entradas del año, asignado por orden de ingreso, se registraban todos los detalles anotados en el libro de la Inclusa que la Superiora pasaba en una papeleta preparada a tal efecto

"Pasará así mismo una papeleta conforme en un todo al asiento hecho en su libro de registro al Secretario Interventor, a fin de que éste en el suyo haga las anotaciones correspondientes sin omitir la más pequeña circunstancia que pueda conducir al reconocimiento del expósito algún día" (Regl 1889, Art. 46)

Los niños, antes de pasar a la sección de la Inclusa, se presentaban en la dirección del centro para asignarles e identificarles con el número de filiación que correspondería a su expediente y "En el caso de que la presentación se verificase á altas horas de la noche, la tornera penderá del cuello de los expósitos una tarjeta con el número que les correspondiere, según el orden correlativo de su presentación y hará las oportunas anotaciones en el libro. Tanto las criaturas como el atillo serán presentados a la Superiora y Director en las primeras horas del día inmediato, a no ser que causas graves exigiesen hacerlo antes" [sic] (Regl de 1889, Art. 49). La presentación del expósito en la dirección debía hacerse de una forma bastante inmediata porque en el libro de 1910 en el folio 146 se acusa de cierta negligencia en este aspecto: "En 15 de Abril de 1910 (aunque á esta Dirección no bajo hasta el 16 á última hora) á las 20 horas fue expuesto en el torno..."

Los registros de los Libros de Exposiciones, los libros oficiales que se manejaban en la oficina del centro, sobre la exposición en el torno respecto a fecha, hora, ropas y otros efectos así como las notas que llevaban los expósitos coinciden casi literalmente con las anotaciones de los libros de la Inclusa.

Entre los diferentes modelos de papeletas del Hospicio que se conservan en el ADPVA está la que se utilizaba para comunicar a la dirección las exposiciones en el torno, en la que se rellenaba la fecha y hora exacta de la exposición, si se trataba de un niño o una niña, el número de orden y la sala en la que colocaban al expósito:

"Niña muerta. En 23 de febrero de 1901 y hora de las diez y nueve fue expuesta en el torno de este asilo con chambra en buen uso un pañuelo id. de color y un trapo" [sic] (fo 64, LE 1901-1. ADPVA) 


\section{"fo $363 \quad$ Exposición de 1912 \\ En el día de hoy a las... 15 y 15... de la ............. ha sido expuesto en el torno un... niño... con las ropas que al dorso se expresan, cuya criatura se ha colocado en la Sala de los ... bautizados .... con el número \\ Valladolid 14 de octubre de1912, \\ La Superiora de las Hijas de la Caridad"}

Papeleta encontrada en el expediente del asilado Froilán Asensio Tábares, exposición de 1912 , folio $n=363^{408}$, en negrita el texto que en ella figura escrito a mano, el resto está impreso. (IMAGEN 3-7).

El nombre del niño aparece escrito a mano en una esquina, porque no forma parte de los datos que se piden a rellenar; esto parece normal teniendo en cuenta que muchos expósitos llegaban al torno sin nombre. También se ha anotado a mano y en lugar bien visible el número del folio que le correspondía siguiendo el orden de ingreso, (fo 363) y en un sello del

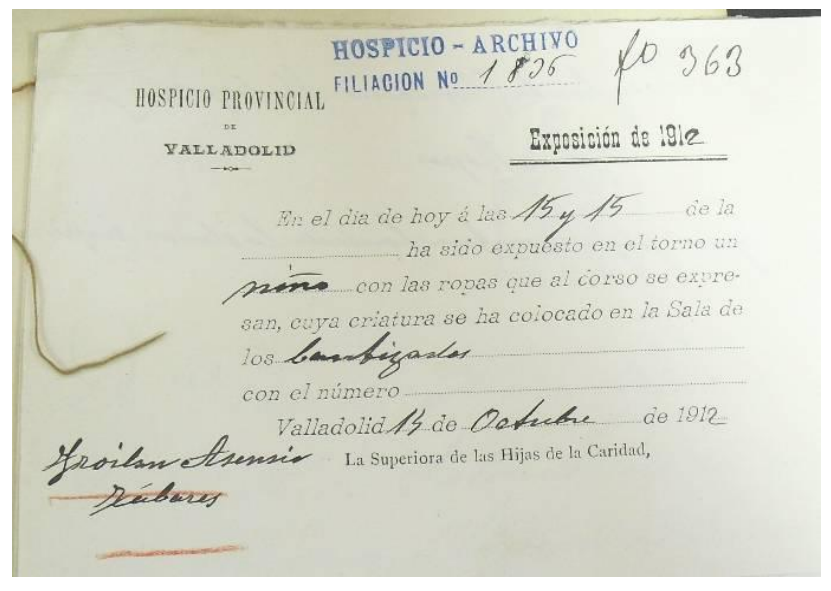

Imagen 3-7: Papeleta de exposición del folio no 363, año 1912. Niño "colocado en la Sala de los bautizados" ADPVA

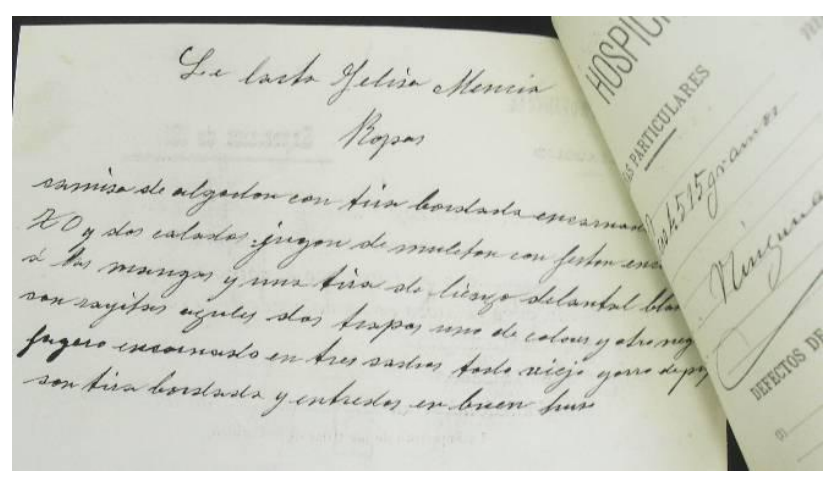

Imagen 3-8: Reverso de la papeleta de exposición encontrada en el expediente del folio no 269, año 1911.

Archivo del Hospicio, que ya se pondría en la dirección, el no de filiación asignado, también según orden de ingreso (1836). El número del folio sería el que la tornera tendría que colocar al niño en una tarjeta para identificarlo.

En el dorso de estas papeletas se recogía con detalle las ropas que presentaba al ingresar y el nombre de la nodriza asignada; esto mismo se encuentra registrado en el Libro de entradas o de Exposiciones. (IMAGEN 3-8).

Este niño en cuestión fue expuesto en el torno con una partida de bautismo, por eso en la papeleta ya se ha puesto su nombre y se destinó a la "Sala de los bautizados"; también se dejó un certificado del Registro

\footnotetext{
${ }^{408}$ Signatura: caja 1279, expediente 8310 . ADPVA
} 
civil donde dice que es hijo adulterino de una mujer casada cuyo marido no lo ha reconocido "por hijo suyo por haber nacido antes de los 180 días de su matrimonio", posibilidad contemplada en el Código Civil de 1889 en su artículo 117, vigente todavía hoy en día ${ }^{409}$; independientemente de cuestiones de tipo moral y legal, un niño de 180 días de gestación no sería viable en aquella época ${ }^{410}$.

Hay otra papeleta con las mismas características entre los expedientes en el № 269 de 1911 de un niño que fue encontrado a la puerta del Hospicio y recogido por la Hermana de servicio con un papel que tenía escrito el nombre y decía que estaba bautizado, no era un recién nacido, el facultativo le calculó una edad de mes y medio, por eso en la papeleta de ingreso se escribió el nombre y se le colocó en la "Sala de los bautizados".

Si en el momento del ingreso no tenían constancia de que el niño estuviera bautizado era "depositada la criatura arreglada y envuelta ya en ropas del Hospicio en la sala destinada a los no bautizados" a la espera de que "el Señor Capellán" le bautizara en la capilla del Establecimiento. Allí se ocupaba del niño la nodriza "que se halle en turno" y le alimentaba "con algún jarabe provisionalmente" o le lactaba hasta que el médico determinaba su régimen de alimentación (Regl 1889, Art. 47). "Después de bautizados, o si ya lo estuvieran a su presentación y antes de ser trasladados los

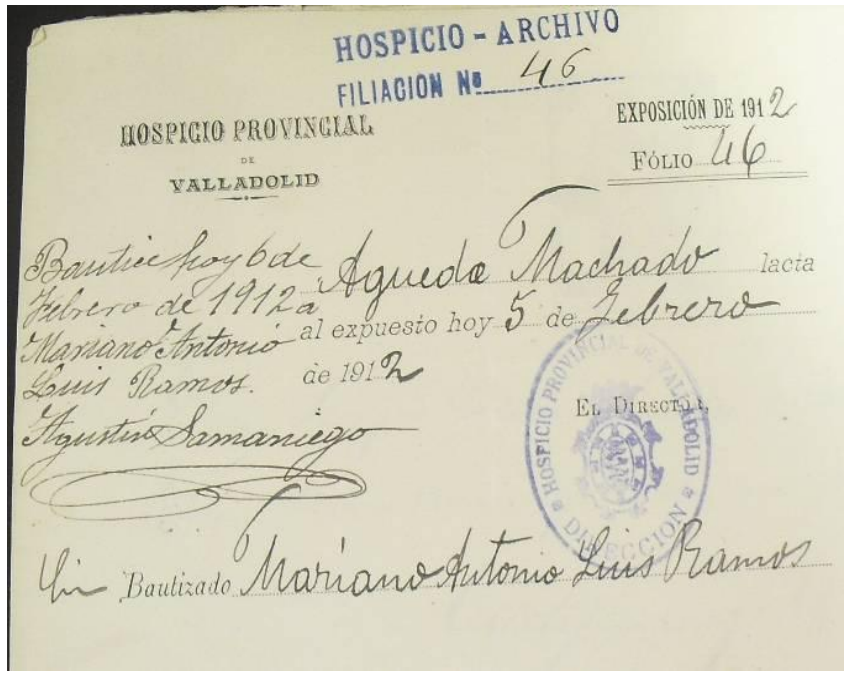

Imagen 3-9: Papeleta para comunicar la nodriza y el bautismo. Escrita a mano en un lateral la nota de bautismo del capellán. El niño llegó sin bautizar, se ha puesto "Sin" delante de "Bautizado...". Expediente Personal. Exposición 1912. Folio 46. ADPVA

\footnotetext{
${ }^{409}$ CÓDIGO CIVIL. Libro I de las personas. Título V De la paternidad y filiación. Capítulo II, Artículo 117: "Nacido el hijo dentro de los ciento ochenta días siguientes a la celebración del matrimonio, podrá el marido destruir la presunción [de paternidad] mediante declaración auténtica en contrario formalizada dentro de los seis meses siguientes al conocimiento del parto. Se exceptúan los casos en que hubiere reconocido la paternidad expresa o tácitamente o hubiese conocido el embarazo de la mujer con anterioridad a la celebración del matrimonio, salvo que, en este último supuesto, la declaración auténtica se hubiera formalizado con el consentimiento de ambos, antes del matrimonio o después del mismo, dentro de los seis meses siguientes al nacimiento del hijo".

${ }^{410}$ El Manual práctico de partos para uso de comadrones y parteras, escrito por el profesor Dr. D. RAPÍN de la Universidad de Lausana que se utilizaba en la época para la formación de las matronas dice que un parto prematuro "Tiene lugar entre la vigésima octava y la trigésima octava semana, cuando el feto es viable", p 332, lo que viene a ser entre 196 y 266 días; es decir, que con menos de 196 días el feto no era viable Actualmente sí sería viable. Hoy el límite de la viabilidad está en 23 semanas de gestación (160 días), teniendo en cuenta que con esta edad gestacional el niño necesitará asistencia intensiva y muy cualificada.
} 
expósitos a la sala de lactancia", se les colocará "pendiente del cuello, con la delicadeza y seguridad posibles un escudito con el número que ocupa en el folio de su partida en el libro correspondiente" (Regl de 1889, Art. 52, Regl 1910, Art. 316 y Regl 1927, Art. 319). Según los reglamentos los niños debían llegar a la sala de lactancia bautizados e identificados con su nombre y apellidos y con una nodriza asignada, lo que se comunicaba con una papeleta diseñada para tal fin. (IMAGEN 3-9)

Por papeletas como ésta, sabemos que separaban a los niños a su llegada a la Inclusa según que estuvieran bautizados o no. Esta separación se contempla en los reglamentos, los no bautizados iban a una sala o, al menos, a una zona aparte, "el sitio para los no bautizados" (Regl de 1910, Art. 310 y Regl. de 1927, Art. 313), hasta que recibían el bautismo o se confirmaba que habían sido bautizados. Esta actuación es una demostración de la mentalidad de la época y del peso que tenía la religión católica en la vida personal y social; el bautismo era algo esencial y esta separación parece un método para evitar posibles olvidos y asegurarse de que el niño era bautizado. Esta "sala de los no bautizados" podría ser la "Sala pequeña de cunas" que aparece en el plano de la Inclusa, aunque esto es pura suposición ya que no figura en ningún documento de los revisados.

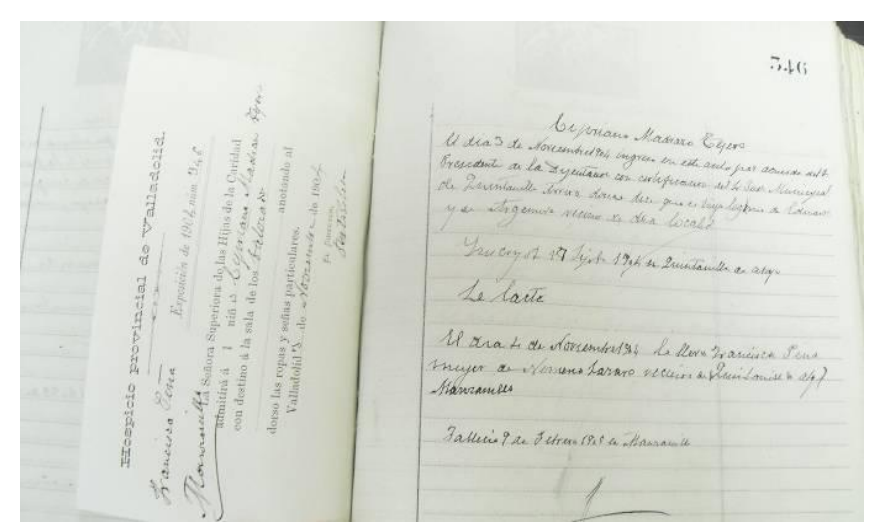

Imagen 3-10: Papeleta asignando a un niño a "la sala de los colocados". Folio no 346 del libro de 1904. ADPVA
Otro uso posible de dicha sala podría haber sido separar a los niños que tenían asignada nodriza externa ya que entre los libros se ha encontrado una papeleta con orden de ingreso en "la sala de los colocados". Esta papeleta está pegada al folio no 346 del libro de 1904 y todos los datos que en ella se recogen coinciden con lo

inscrito en dicho folio. Se trata del hijo legítimo de un matrimonio de Quintanilla de Arriba que ingresó el 3 de noviembre por acuerdo de la Comisión de la Diputación y que al día siguiente fue entregado a una nodriza y su marido "vecinos de Quintanilla de Abajo Manzanillo" [sic], según aparece escrito en el folio de registro. En la papeleta, firmada por el director y dirigida a la Superiora para que admita el ingreso del niño, aparecen escritos a mano en un lateral un nombre de mujer que coincide con el de la nodriza externa registrada en el libro y debajo el del pueblo Manzanillo, que está muy próximo a Quintanilla de Arriba y cerca de Quintanilla de 
Abajo, hoy Quintanilla de Onésimo, lo que puede explicar que en el libro se hayan escrito juntos los dos nombres ${ }^{411}$. No se han localizado más papeletas de éste tipo. (IMAGEN 3-10)

Un uso razonable de la "Sala pequeña de cunas" sería separar a los niños con problemas de salud, sobre todo con enfermedades infecciosas que precisaran aislamiento para evitar contagios, sin embargo según los reglamentos estos niños debían trasladarse a "la sala destinada a enfermería" (Regl. 1889, Art. 60), por lo que la "Sala pequeña de cunas" podría utilizarse para los otros dos usos mencionados anteriormente.

Los niños con una nodriza asignada, pasaban a la sala de lactancia, que podría corresponder con la que en el plano de la Inclusa llaman "Sala grande de cunas". En una papeleta oficial se comunicaba el nombre de la nodriza adjudicada y en esta ya se pedía registrar el nombre del niño una vez bautizado; se ha encontrado alguna de estas fichas entre los expedientes personales.

En las papeletas de este tipo que he encontrado, en los niños bautizados en el Hospicio aparece una nota manuscrita firmada por el capellán, Agustín Samaniego, con la fecha en que ofició el bautismo. Delante de la palabra Bautizado se ha escrito a mano la preposición "Sin".

"Agueda Machado... lacta al expuesto hoy... 5 ... de Febrero de 191... 2

Sin Bautizado .... Mariano Antonio Luis Ramos

(en el margen a mano) Bautice hoy 6 de febrero de 1912 a Mariano Antonio Luis Ramos [firmado] Agustín Samaniego "

Expediente Personal. Exposición 1912. Folio 46. Filiación no $1835^{412}$. En negrita el texto escrito a mano, el resto figura impreso (IMAGEN 3- 12)

El Reglamento de 1889 da a entender que en la sala de los no bautizados tenían por turnos una nodriza de guardia para ocuparse de los ingresos recientes ("Ia nodriza que se halle en turno") y, que una vez bautizado, al niño le asignaban su ama de cría y le pasaban a la sala de lactancia con los bautizados ["Después de bautizados, o si ya lo estuvieran a su presentación y antes de ser trasladados los expósitos a la sala de lactancia" (Regl de 1889, Art. 52). Esto

\footnotetext{
${ }^{411}$ Quintanilla de Abajo ha vuelto a recuperar su nombre recientemente, hasta hace unos meses era conocida como Quintanilla de Onésimo y está situado a 12,6 Km de Quintanilla de Arriba. Manzanillo es un pequeño pueblo que actualmente cuenta con poco más de 50 habitantes a 4,4 Km de Quintanilla de Arriba, y 16 Km de Quintanilla de Abajo

${ }^{412}$ Signatura: caja 1279, expediente 8311. ADPVA
} 
puede explicar las características de esta papeleta, donde solamente se recoge el nombre del ama lactante, la fecha de la exposición y el nombre del niño; parece hecha para comunicar el nombre de la nodriza y pensando en que los niños se bautizaban de forma muy inmediata al ingreso. Sin embargo, analizando los registros y comparando fechas da la impresión de que no se esperaba, ya que el bautizo se podía demorar unos días, y que la nodriza se asignaba al ingresar, al pasar al niño a la sección de la Inclusa aunque fuera a la "sala de los no bautizados". Además, como se ha visto anteriormente, en las papeletas de notificación de ingreso se escribía en el reverso, junto con las ropas, el nombre de la nodriza. Esto puede explicar por qué en algunos folios de los libros la fecha del bautismo aparece con una letra diferente, en una anotación posterior, mientras que el nombre del ama lactante se ha escrito con la misma letra que el resto de la inscripción de entrada. Podemos suponer por tanto que, a pesar de los reglamentos, la asignación de ama se hacía antes del bautizo al ingreso del niño.

El "Sin" escrito delante del renglón "Bautizado..." podría ser una forma de asegurarse de que, aunque el expósito tuviera nodriza, el bautismo estaba todavía pendiente y, una vez administrado, el capellán lo certificaba en la papeleta que se pasaba a la dirección para que apuntaran la fecha en el folio del niño. En el expediente de la Exposición 1912, Folio 46 se encuentran la papeleta con la orden de ingreso en la "sala de los sin bautizar" junto con la que asigna ama en la que se ha escrito "Sin Bautizado" y la nota de bautismo del capellán ${ }^{413}$, coinciden fechas y el nombre del ama con lo registrado en el folio del Libro de exposiciones.

En los libros se encuentran niños que apenas vivieron un día y que tenían ya una nodriza asignada, parece que antes de ser bautizados por las fechas de los registros

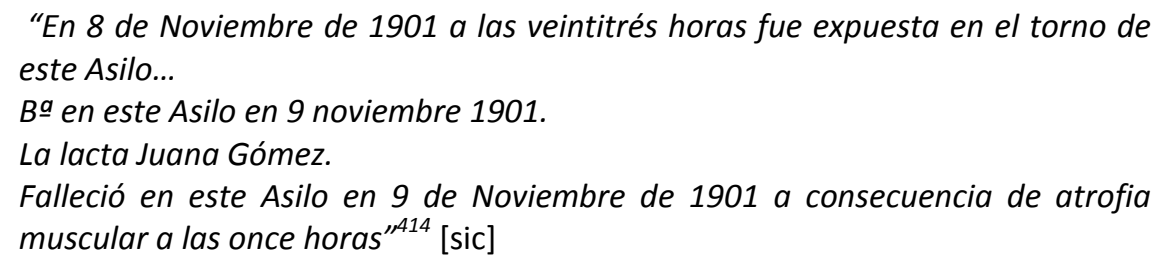

Es más prudente este proceder porque de esta manera el niño tenía una nodriza que se hacía cargo de él desde su entrada en la Inclusa sin tener que esperar al bautismo, que habitualmente no se producía de forma inmediata a su ingreso.

La clandestinidad era una de las razones de ser de los tornos, el anonimato estaba garantizado si quien hacía la entrega así lo pretendía y al suprimir el torno se quiso terminar con esta protección, en un intento sobre todo por reducir las entregas de hijos legítimos bajo

\footnotetext{
${ }^{413}$ Signatura: caja 1279, expediente 8311. ADPVA

${ }^{414}$ Fo 332 del Libro de Exposiciones de 1901- tomo 2. ADPVA
} 
ese uso clandestino. Sin embargo, al consultar los libros de la Inclusa da la impresión de que la exposición no era siempre un hecho tan secreto como pueda suponerse, al menos en este torno del Hospicio de Valladolid y en esta época que nos ocupa. Me baso en la cantidad de notas que se adjuntaban a los niños, aunque en algunas de ellas se aprecia al revés y se habla de "el niño adjunto" a la nota. En muchas de ellas se daban tantos datos de filiación del niño que la madre, o los padres, serían fácilmente localizables, en alguna aparecen hasta cuatro apellidos, nombre de padres y abuelos y la dirección completa; evidentemente en situaciones así no hay ánimo de ocultación. Otro aspecto de la clandestinidad es la nocturnidad, hay trabajos que advierten del uso preferente de las horas nocturnas para depositar al niño ${ }^{415}$, la noche con la oscuridad y la ausencia de gentes por las calles sin duda protegería la entrega anónima, esa protección se vería reforzada con la propia localización del torno, que, si se ubicaba donde hemos supuesto, se encontraría en un lugar resguardado, en la fachada principal en la esquina interior de la plaza protegido por la iglesia de San Nicolás y por el jardín que, por la foto que se conserva de principios de siglo, contaba con grandes árboles y matas que también ayudarían al ocultamiento de las personas que por ella circularan (ver fotografía de la portada del Hospicio en la IMAGEN 2-2). Parece el mejor sitio para localizarlo, al menos el más discreto, ya que la otra fachada daba a la calle San Quirce, una calle abierta y de paso.

He recogido todas las horas de las exposiciones, las que se encuentran registradas y son legibles, de los años consultados pensando en confirmar esta hipótesis de la nocturnidad como horario preferente de exposición, que parece a primera vista lo más lógico para la circunstancia que estamos tratando, y el resultado no ha podido ser más discrepante, al menos no demuestra una preferencia clara por las horas nocturnas para las exposiciones en el torno de Valladolid ya que más de la mitad de los niños fueron expuestos en horas diurnas. Si consideramos que la salida del sol tendría lugar como media entre las 6 y las 7 de la mañana y el ocaso entre las 6 y las 7 de la tarde ${ }^{416}$, en la franja intermedia de horas diurnas se

\footnotetext{
${ }^{415}$ Cfr RODRÍGUEZ MARTíN A.M.: op.cit. 2007 pp. 239-253; SÁNCHEZ FERNÁNDEZ L.V., COBO BARQUÍN J.C., HERNÁNDEZ MEJÍA R.: Marginación y pobreza desde la cuna: el niño expósito en el Concejo de Siero, Asturias (18001936), Revista de Demografía Histórica, XXXI, II, 2013, segunda época, pp. 131-165

RODRÍGUEZ MARTíN A.M. en sus estudios sobre la inclusa de Pontevedra ofrece una estadística según la cual casi la totalidad de los niños fueron expuesto en horas nocturnas (entre el $87^{\prime} 88 \%$ y el $100 \%$,) claro que habla de una inclusa con un número considerablemente inferior de exposiciones que ésta nuestra, entre 25 y 114. (p 241)

${ }^{416}$ Las horas medias oficiales de la salida y la puesta del sol en España sin considerar el horario de verano son las $7 \mathrm{~h}$ 09 min para el orto, o salida, y las $19 \mathrm{~h} 21 \mathrm{~min}$ para el ocaso. Teniendo en cuenta que en la actualidad en España tenemos una hora de adelanto sobre el horario que regía en las primeras décadas del siglo XX, para el período 19001913 las horas medias serían las 6’09 para la salida y las 18'21 h. En 1900 España adoptó los husos horarios y el tiempo solar medio en el meridiano de Greenwich para su hora oficial; en un RD de 26 de julio de 1900 firmado por la regente María Cristina se estableció que a partir del 1 de enero de 1901 todos los servicios, oficinas y transportes públicos se regirían por lo que se conocía como el "tiempo de la Europa Occidental", el referido al meridiano de Greenwich, y que las horas hay que contarlas en una serie continua a partir de la medianoche de 0 a 24 . El objetivo era unificar el tiempo horario en toda la península y Baleares eliminando las horas locales y armonizar con los horarios de otros países europeos, la mayoría del territorio, salvo una pequeña parte de Galicia y las islas Canarias,
} 
presentaron el 56'35\% del total de niños en el período de 1900-1913, sin contar con las horas crepusculares, es decir, los intervalos también variables antes de la salida y después de la puesta del sol en que el cielo está iluminado y que ampliarían por tanto las horas de claridad. Precisamente las horas más nocturnas, considerando como tales las que van de las 11 de la noche a las 6’59 de la mañana que son también las menos transitadas, fueron las menos frecuentadas en el torno de Valladolid; sobre todo el tramo entre las $24 \mathrm{~h}$ y las 5 de la mañana, en este espacio de 5 horas solamente se depositaron el 7’96\% del total de expósitos, y en particular entre las 4 y las 5h en 1902, 1903, 1907 y 1910 no se recibió ningún niño en los años analizados. A partir de las $7 \mathrm{~h}$ la afluencia al torno fue en aumento hasta alcanzar el pico máximo de la mañana alrededor de las $11 \mathrm{~h}$, de manera que en el intervalo horario de 9 a $13^{\prime} 59$, que es el de mayor actividad ciudadana de la mañana, se depositaron en el torno el $27^{\prime} 82 \%$ del total de niños en el período de 1900-1913. El uso del torno disminuyó considerablemente entre las 14 y las $15^{\prime} 59 \mathrm{~h}$, alrededor de la comida y la siesta, con niveles por debajo de los de la madrugada ( 6 y 7 de la mañana) para volver luego a incrementarse progresivamente. Fueron las últimas horas de la tarde y las primeras de la noche las de mayor número de exposiciones, entre las $19 \mathrm{~h}$ y las $22^{\prime} 59 \mathrm{~h}$ se recibieron el $30^{\prime} 19 \%$ de los expósitos, téngase en cuenta que es un intervalo de cuatro horas, mientras que en el siguiente tramo de ocho horas nocturnas entre las 23 y las 6'59 h llegaron el 16'13\%. En la GRÁFICA 3-10 puede verse la distribución a lo largo del día con el porcentaje de exposiciones para cada hora.

Este intervalo de 19 a 22'59 h recibió todos los años el mayor número de exposiciones, (ver GRÁFICA 3-10 y la tabla incorporada), son las primeras horas de la noche, justo después de la puesta del sol o del crepúsculo dependiendo de la estación del año ${ }^{417}$.

entran dentro del huso 0, el que está centrado en el meridiano de Greenwich. En marzo de 1940 se publicó en el BOE la Orden que dispuso que se adelantaba el huso horario en una hora para coincidir con el de la Europa Central. Por tanto actualmente en España tenemos una hora de adelanto sobre el horario que regía en las primeras décadas del siglo XX, sin contar con el adelanto adicional que se hace en los meses de verano y que ya empezó a hacerse de manera discontinua a partir de 1918, que por tanto no afecta a la época permitida de consulta para este trabajo. Cfr PLANESAS BIGAS P.: La hora oficial en España y sus cambios. Anuario del Observatorio Astronómico de Madrid para el año 2013 (IGN). Observatorio Astronómico Nacional. Instituto Geográfico Nacional - Ministerio de Fomento pp 373- 402.

${ }^{417}$ He recogido información sobre las horas de la salida y la puesta del sol para cada día del año de la página de Astronomía del Instituto Geográfico Nacional del Ministerio de Fomento y las he adaptado a la época de estudio descontando la hora que llevamos adelantada y la hora del horario de verano, teniendo en cuenta que hay ligeras variaciones, de unos minutos como mucho, de unos años a otros, para el período 1900- 1913 y las distintas estaciones del año la salida (ORTO) y la puesta del sol (OCASO) serían:
Invierno: enero- febrero y marzo:
ORTO: $77^{\prime} 46 \mathrm{~h}-6^{\prime} 53 \mathrm{~h}$
ORTO: $6,02 \mathrm{~h}-4^{\prime} 47 \mathrm{~h}$
ORTO: $4^{\prime} 48 \mathrm{~h}-5^{\prime} 45 \mathrm{~h}$
Primavera: abril- mayo y junio:
ORTO: 6'16h - 7'26h
OCASO: $17 \mathrm{~h}-18^{\prime} 10 \mathrm{~h}$
OCASO: $18,47 \mathrm{~h}-19^{\prime} 47 \mathrm{~h}$
OCASO: $19^{\prime} 57 \mathrm{~h}-18^{\prime} 52 \mathrm{~h}$
OCASO: $18 \mathrm{~h}-16^{\prime} 49 \mathrm{~h}$

(Como los cambios de estación se producen los días 21- 23 de marzo, junio, septiembre y diciembre he incluido el mes entero dentro de la estación que abarca más días) 


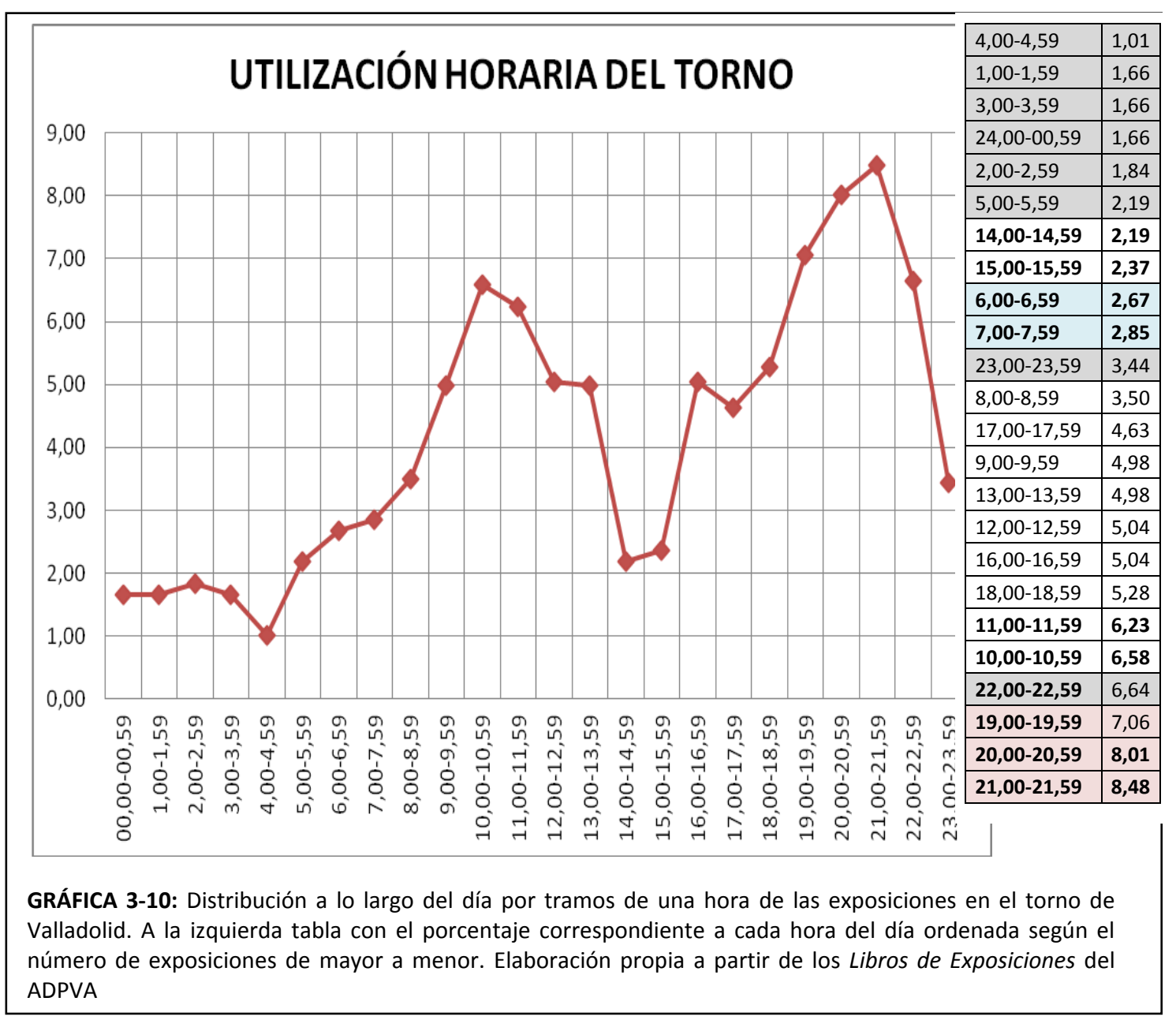

Teniendo en cuenta que la salida del sol y el ocaso tienen una variación estacional y que por consiguiente varía el número de horas diurnas y nocturnas, he analizado las exposiciones en cada estación. En los meses de otoño- invierno se adelantaron hasta en dos horas los tiempos de máxima exposición de manera que la franja horaria de 19 a 19’55 fue la más utilizada con el $10^{\prime} 2 \%$ del total de niños expuestos en otoño y el $10{ }^{\prime} 5 \%$ del total de niños expuestos en invierno, en estos meses el sol se pondría entre las $17 \mathrm{~h}$ y las $18 \mathrm{~h}$. En primavera y verano, cuando el ocaso sería entre las 19 y las 20h, el momento de máxima exposición se desplazó a las $21-21^{\prime} 55 \mathrm{~h}$ con el $13^{\prime} 7 \%$ y el $11^{\prime} 6 \%$ respectivamente del total de niños expuestos en los tres meses de cada estación ${ }^{418}$. En la GRÁFICA 3-11 puede verse la distribución porcentual para cada hora del día y por estaciones. Asimismo por la mañana cambian los tiempos de máxima exposición; en este caso coinciden también otoño e invierno con el intervalo de 10h$10^{\prime} 55 \mathrm{~h}$ ( $6^{\prime} 4 \%$ y $7^{\prime} 5 \%$ del total de las exposiciones de cada estación respectivamente) mientras

\footnotetext{
${ }^{418}$ He considerado los meses de inicio de cada una de las estaciones dentro de la anterior puesto que el cambio se produce al final, los días 21 a 23, es decir, como la primavera comienza el 21 de marzo he incluido este mes todavía en el invierno, ya que los datos horarios se recogieron por meses enteros.
} 
que en primavera se atrasó a las 11-11'55h y en verano se adelantó a las 9- 9'55h. En todas las estaciones la franja horaria de 14-15'55 horas tuvo la afluencia mínima de las horas diurnas, menor en primavera y especialmente en los meses de verano, cuando también se produce un bache en torno a las $18 \mathrm{~h}$, precisamente cuando en las estaciones frías empezaba la franja horaria de máxima exposición.

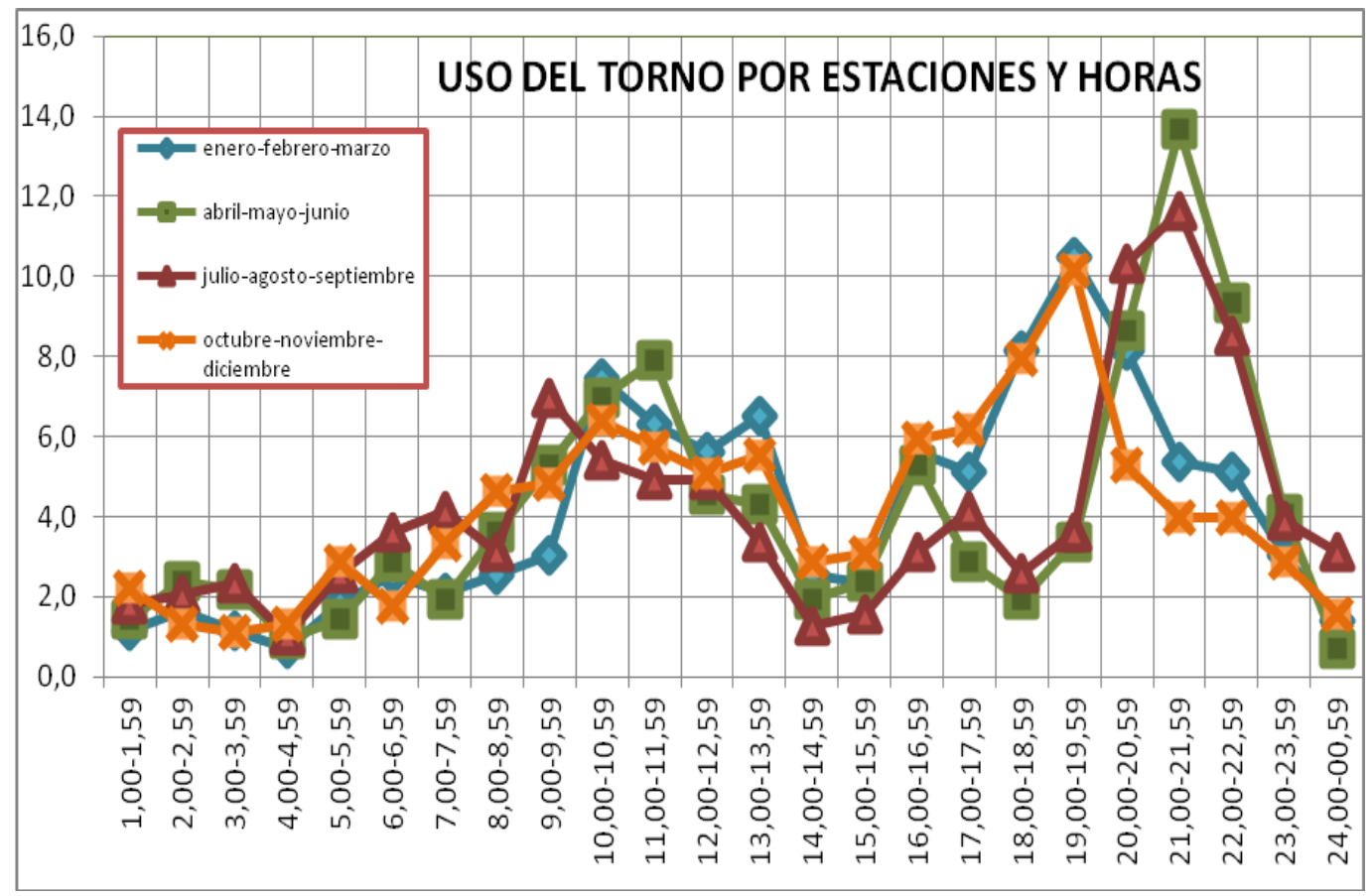

GRÁFICA 3-11: Distribución porcentual de las exposiciones en el torno de Valladolid a lo largo del día por tramos de una hora para cada estación. Elaboración propia a partir de los Libros de Exposiciones del ADPVA

El análisis considerando la estacionalidad y las variaciones en las horas de la salida y la puesta del sol ofrece una distribución similar al cálculo global con un porcentaje ligeramente más bajo para las horas diurnas que se queda en el $51^{\prime} 72 \%$ de las exposiciones, y por tanto un $48^{\prime} 28 \%$ para la noche (frente al $56^{\prime} 35 \%$ de día y $43^{\prime} 65 \%$ nocturno resultados del cálculo global, sin considerar la estacionalidad). Se ha representado en la TABLA 3-16 la distribución por meses con los intervalos nocturno y diurno, tomando como límites las horas justas, no están incluidos los tiempos que corresponden al alba y el crepúsculo vespertino, que aumentarían las horas de claridad, sobre todo en los meses de verano y primavera y por tanto elevarían el porcentaje de exposiciones diurnas. 


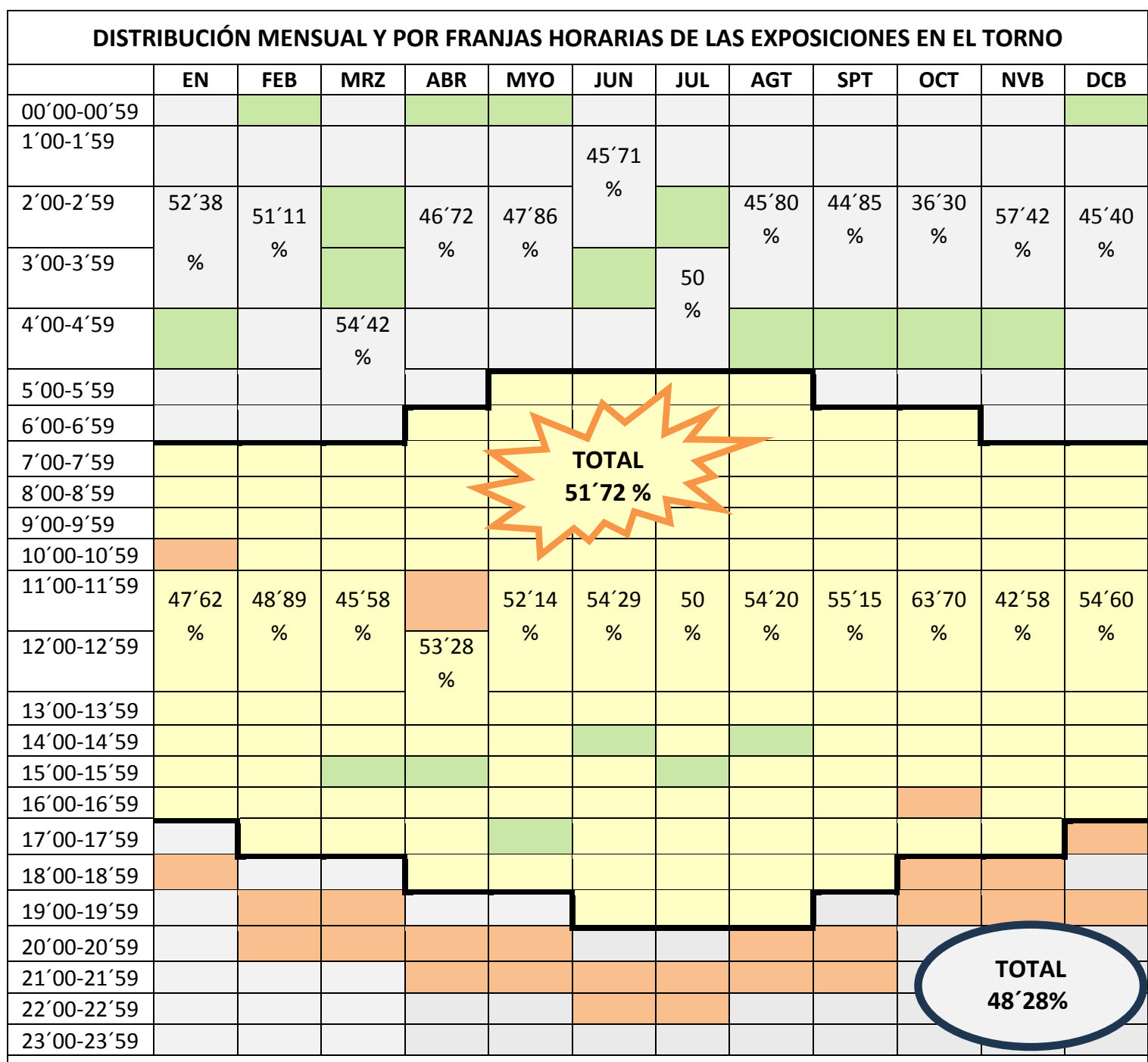

TABLA 3-16: Distribución mensual de las exposiciones en el torno de Valladolid en la franja horaria nocturna (gris) y diurna (amarillo) para el período 1900- 1913 con los porcentajes parciales por mes y los totales para cada franja. En naranja las horas con mayor número de exposiciones de cada mes y en verde las de menos (se han coloreado los dos valores más altos y más bajos, solamente uno de ellos cuando el segundo se repite en varias horas o se diferencia mucho del primero y está más próximo al tercero y siguientes y más de dos cuando coinciden los valores). Tabla de elaboración propia a partir de los datos extraídos de los Libros de Exposiciones del ADPVA y con los datos horarios calculados a partir de los que se ofrecen en la página de Astronomía del Instituto Geográfico Nacional del Ministerio de Fomento adaptándolos a la situación horaria del período 1900- 1913

A pesar de que en el cómputo global se presentaron en el torno más niños de día, en el análisis horario se observa que los tramos de mayor número de exposiciones comienzan una hora después de la puesta de sol, cuando ya habría finalizado también el crepúsculo vespertino y serían por tanto las primeras horas nocturnas las más frecuentadas; para todas las estaciones excepto para el otoño, y el mes de agosto, en que este momento de mayor actividad del torno comienza con el ocaso, por lo que todavía durante un tiempo variable según el mes habría cierta claridad crepuscular. Durante la mañana, entre las 9 y las 13 h hay también una actividad importante, sería el segundo tramo más frecuentado, con algunas horas que se sitúan entre las de más exposiciones. 
Considerando el total de exposiciones y su distribución horaria, no podemos afirmar que las exposiciones en el torno de Valladolid buscaran preferentemente la oscuridad, la relación global anual entre las exposiciones diurnas (D) y las nocturnas (N) da una ratio de 107 D/100 $\mathrm{N}$ aunque se observa cómo esta relación se modifica estacionalmente de manera que se invierte en los meses de invierno, justamente en los de más horas nocturnas. En enero, febrero y marzo, que pueden tener más de 13 horas nocturnas, hay más exposiciones en esta franja, la ratio para este trimestre es de $89 \mathrm{D} / 100 \mathrm{~N}$. Sin embargo diciembre, con las mismas horas nocturnas que enero tiene más exposiciones diurnas; es curioso el comportamiento en los tres meses del otoño porque noviembre es el mes del año con mayor proporción de exposiciones nocturnas $(74 \mathrm{D} / 100 \mathrm{~N})$ y precisamente octubre es el que tuvo más diurnas $(175 \mathrm{D} / 100 \mathrm{~N})$; para todo el trimestre invernal sale una ratio de 115D/100N. En primavera y verano predomina en todos los meses el uso diurno, salvo en el mes de julio en que se reparten las exposiciones de forma equitativa entre el día y la noche con la particularidad de que en las primeras horas de la tarde, las más calurosas, el número de exposiciones fue inferior incluso al de las horas nocturnas, lo mismo ocurre con agosto, de manera que en la franja horaria de las $14 \mathrm{~h}$ a las $19^{\prime} 55 \mathrm{~h}$ si comparamos estos dos meses con diciembre, que es en el que más niños llegaron al torno en este intervalo horario (74), en julio se presentaron un $74 \%$ menos (19) y en agosto un $66 \%$ menos (25). La ratio de la primavera (abril-mayo-junio) es de $114 \mathrm{D} / 100 \mathrm{~N}$ y del verano (julio-agosto-septiembre) de $113 \mathrm{D} / 100 \mathrm{~N}$. Podríamos por tanto decir que el volumen de exposiciones nocturnas tiene más que ver con la estacionalidad y el número de horas de claridad y oscuridad, siendo mayor en los meses invernales que tienen más horas de noche.

Habría que saber si la estacionalidad influye no solo en el horario de las exposiciones sino también en su proporción. Se ha analizado la distribución mensual de los ingresos del torno y se ha representado en la GRÁFICA 3-12 el promedio por cada mes del año para el periodo $1900-13$ y el porcentaje que representa respecto al total de exposiciones del torno. El promedio mensual de ingresos por el torno para el período de 1900-1913 es de $12^{\prime} 52$ exposiciones/mes (exp/m) y en la gráfica vemos como la distribución es similar a la del total de ingresos con poca diferencia de unos meses a otros, salvo para julio y agosto, con el mínimo de ingresos con promedios de 11 y $11^{\prime} 36 \mathrm{exp} / \mathrm{m}$ respectivamente. 


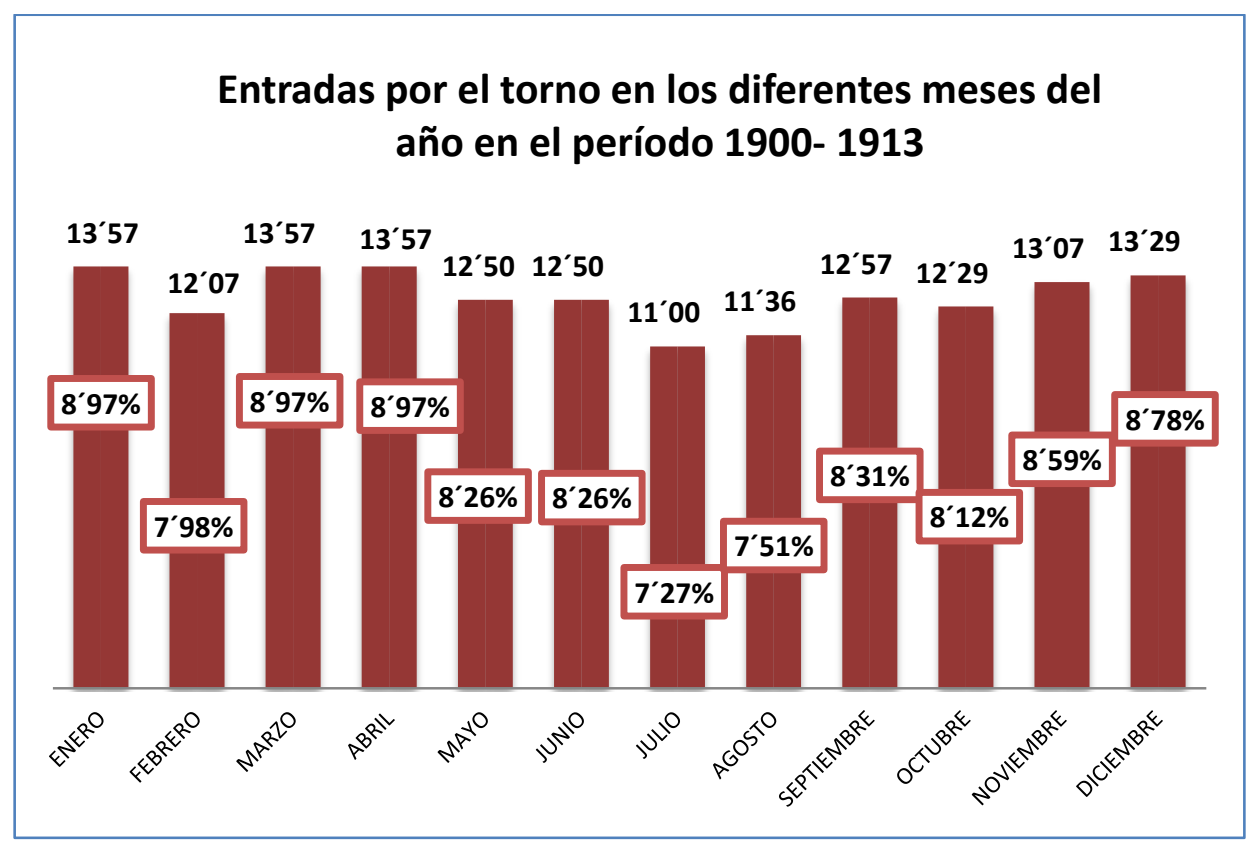

GRÁFICA 3-12: Promedio mensual de expósitos ingresados por el torno y porcentaje mensual respecto del total anual de entradas por esta vía. Elaboración propia a partir de los Libros de Exposiciones del ADPVA.

La época de más exposiciones fue el invierno, coincidiendo con la de más ingresos en general, con un promedio de $13^{\prime} 07 \mathrm{exp} / \mathrm{m}$. contando con el mes de febrero que, como es de esperar tiene un promedio menor que los meses vecinos al contar solo con 28 días (si hacemos el cálculo para 31 días como tienen enero y marzo el promedio de febrero sería similar con $\left.13^{\prime} 36 \mathrm{exp} / \mathrm{m}\right)$. Abril es un mes en el que vemos que se mantiene la tónica, con el mismo número de exposiciones a pesar de ser un mes de 30 días (si calculamos el promedio en función de los 31 días de enero y marzo se situaría en primer lugar con $14^{\prime} 02 \mathrm{exp} / \mathrm{m}$ ) y el número de exposiciones empieza a disminuir en mayo para empezar a aumentar nuevamente a partir de septiembre. En primavera y otoño el promedio de exposiciones es casi idéntico con $12^{\prime} 86 \mathrm{exp} / \mathrm{m}$ y $12^{\prime} 88 \mathrm{exp} / \mathrm{m}$ respectivamente, con el incremento comentado de abril y un ligero descenso en octubre. La época de menos ingresos tanto totales como del torno fue el verano con un promedio de $11^{\prime} 64 \mathrm{exp} / \mathrm{m}$, que está aumentado porque septiembre se aproxima a la media global (para un mes de 31 días como son los que le rodean, septiembre saldría con un promedio de 12'99 exp/m) (ver GRÁFICA 3-7 con la distribución por meses de todos los Ingresos en la Inclusa). Recordamos que julio y agosto son los dos meses de menos natalidad y marzo, enero y febrero los de más nacimientos ${ }^{419}$.

\footnotetext{
${ }^{419}$ Recordamos que según los cálculos basados en los datos que ofrece el Fondo documental del INE para el período 1900- 1913 el orden de mayor a menor natalidad sería: marzo, enero, febrero, abril, mayo, diciembre, octubre septiembre, agosto junio noviembre y julio. Julio y noviembre con poca diferencia entre ellos y lo mismo ocurre con junio y agosto.
} 


\subsubsection{Los expósitos, señas de identidad}

\begin{abstract}
Enel momento de presentarse en el torno del establecimiento una criatura, la H ÿa de la Caridad encargada de este servicio, dará aviso a la Señora Superiora, para anotar enseguida con la mayor exactitud en el libro de registro, el dia y hora en que se recibe, sexo á que pertenece, las ropas, alhajas y apuntaciones que se entregasen, y todas cuantas circunstancias hubieran ocurrido á su presentación, examinando desde luego su cuerpo, las ropas de envoltura y demás para ver si contienen alguna señal especial a fin de anotarla en el registro de identidad

Reglamento del Hospicio provincial de Valladolid de 1889. Art. 45
\end{abstract}

Aproximadamente el 35\% de los incluseros del Hospicio provincial de Valladolid entre 1900 y 1913 fueron expuestos en el torno del establecimiento, en total 2.118 niños, (ver GRÁFICA 3-9), con variaciones de unos años a otros, que van desde 126 (1905) hasta 183 (1900) exposiciones anuales y porcentualmente desde el $28^{\prime} 83 \%$ del total de ingresos de 1905 hasta el $41^{\prime} 85 \%$ de 1911 . Son cifras superiores a las de las inclusas de Madrid, en la que en el siglo XX los expósitos del torno no pasaron del 30\%, o de Pamplona y Barcelona que estuvieron entre el $10 \%$ y el $20 \%$; en la inclusa de Pontevedra se refieren cifras mucho más altas, del 92 '3\% en 1903, pero no tenía maternidad por lo que todos los niños se exponísn en el torno o se entregaban personalmente a la tornera ${ }^{420}$. La distribución por años, para los catorce revisados, se presenta en la GRÁFICA 3-13 se aprecia un incremento proporcional de los niños presentados en el torno de la Inclusa sobre el total de ingresos en los últimos años después de un período de cierta estabilidad durante toda la primera década y tras el descenso brusco de 1900 a 1901 (proporcional al número total de ingresos que también tuvo una caída significativa) sin que se hayan producido cambios en el funcionamiento de la Cuna, la normativa vigente era la misma, regía el Reglamento de 1889 , y por tanto se mantenían los criterios de admisión; la causa hemos de considerarla por tanto externa y de carácter socio-económico.

\footnotetext{
420 REVUELTA EUGERCIOS B A: op. cit., p 271; VALVERDE LAMSFUS L.: Legitimidad e ilegitimidad.., p 1.173; RODRÍGUEZ MARTín M.A.: La Casa de Maternidad y Expósitos de Barcelona, 1872-1903, p 141; RODRÍGUEZ MARTín M.A.: El destino de los niños de la Inclusa de Pontevedra, 1872-1903, p 357
} 


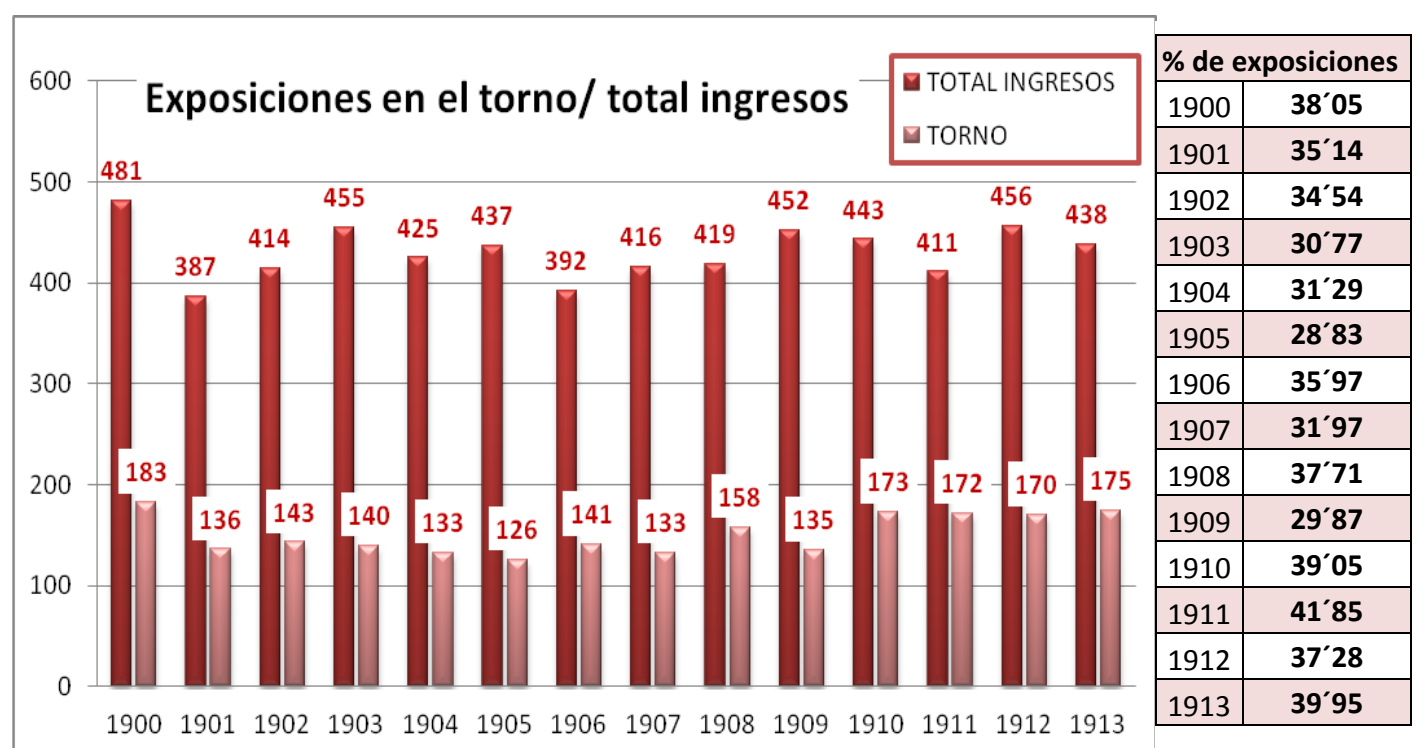

GRÁFICA 3-13: Distribución comparativa en valores absolutos y en tantos por ciento del total de ingresos en la Inclusa y los niños expuestos en el torno del Hospicio provincial de Valladolid en el período 1900- 1913. Elaboración propia a partir de los Libros de Exposiciones del ADPVA. En el total de ingresos se han contabilizado también los niños "nacidos muertos" de la Maternidad considerando que eran candidatos a ingresar. En el grupo del torno solamente se han contado las presentaciones en el torno del Hospicio, no se han incluido las exposiciones en los pueblos de la provincia.

En el capítulo Población de la Inclusa se hizo un estudio pormenorizado de las características de los niños que ingresaban en la Inclusa en cuanto a edad y sexo (apartado 2.1. Ingresos anuales en la Inclusa. Movimiento de lactantes y niños de destete) y a la condición de hijo legítimo o ilegítimo (apartado 2.4. Los llegítimos). Los resultados allí descritos podemos aplicarlos para los niños expuestos en el torno con ligeras variaciones (ver GRÁFICAS 3-2, 3-3 y 34 sobre la distribución por edad al ingreso y GRÁFICA 3-5 sobre la distribución por sexo).

Ya se comentó entonces que para muchos expósitos no se puede concretar con exactitud su edad porque no consta su fecha de nacimiento, en el caso de los niños del torno solamente tenemos la de aquellos que se presentaron con una nota que la refería. También se ha dicho como en algunos libros se han anotado las fechas de bautismo y/o de inscripción en el R.C. pero no la de nacimiento, aún cuando fuera conocida porque se presentaran certificados, y que habitualmente tampoco se escribía en el folio de registro una edad estimada ni referencia alguna que permita suponerla. Por eso, para estudiar la distribución por edad se han agrupado todos estos niños de edad imprecisa y los que llegaron sin bautizar se han incluido dentro del período neonatal, es decir en el primer mes de vida (RN), considerando que no era habitual retrasar más el bautizo y sospechando que muchos de ellos estarían incluso en las primeras horas o los primeros días de vida a tenor de los datos que nos ofrecen las exposiciones que permiten saber la edad de los niños. La misma consideración se ha tenido 
con los que, sin día preciso de nacimiento, fueron bautizados o inscritos en fechas que pueden estar dentro de ese margen de edad. Las GRÁFICAS 3-2 y 3-3, ofrecen la distribución por grupos de edad del total de niños ingresados, más del 85\% tenían menos de un mes. La TABLA 3-1 ofrece los datos desglosados para el primer mes de vida de algunos años diferenciando entre los niños que ingresaron en su primer día de vida, entre el segundo y el séptimo día y entre el 8o día y el primer mes con un grupo aparte para los niños de edad incierta. En ella vimos que los niños que ingresaban en su primer día de vida constituían el grupo más numeroso, engrosado en parte por los niños nacidos en la Maternidad. Haciendo el mismo tipo de análisis para los niños expuestos en el torno de la Inclusa Provincial vemos que se mantiene, incluso se supera, la elevada proporción de neonatos (RN) expuestos. Se ha representado la distribución porcentual según la edad de exposición para el período 1900- 1913 en la GRÁFICA 3-14.

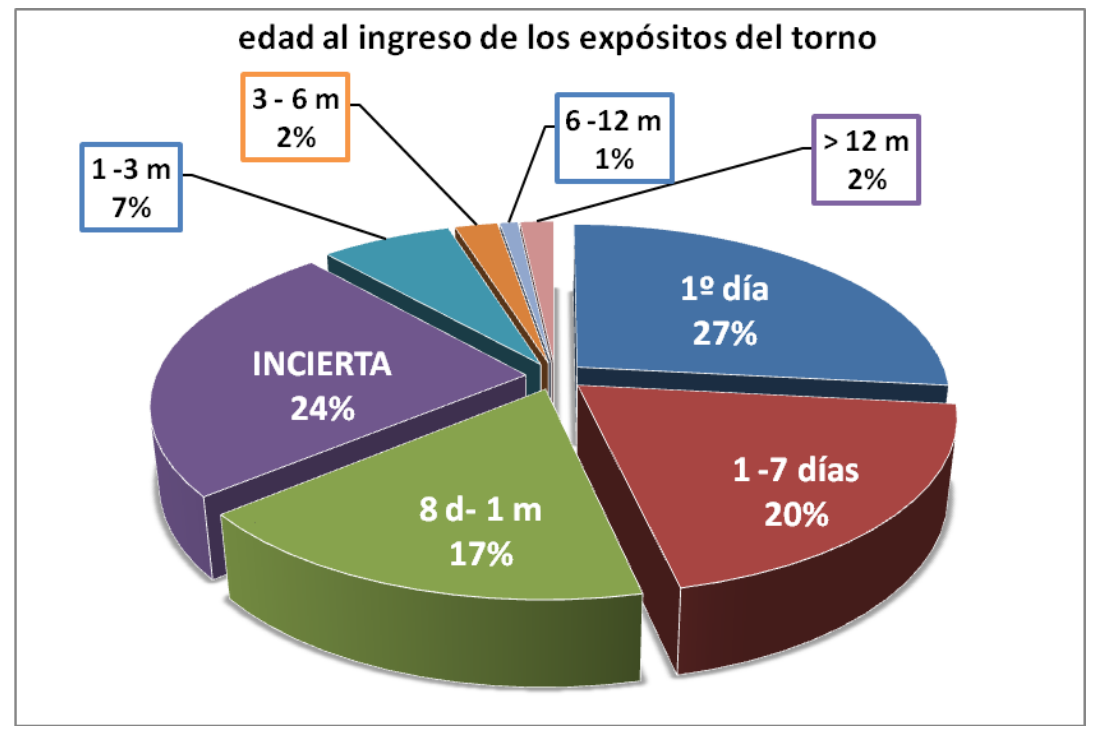

GRÁFICA 3-14: Distribución porcentual de la edad de ingreso de los niños expuestos en el torno del Hospicio Provincial de Valladolid entre 1900- 1913. Elaboración propia a partir de los Libros de Exposiciones del ADPVA. Solamente se han contado las presentaciones en el torno del Hospicio, no se han incluido las exposiciones en los pueblos de la provincia

La mayoría de expósitos han sido siempre bebés de muy corta edad, casi todos recién nacidos o menores de un mes, inclusas como Sevilla tenían más del 95\% y Madrid entre el 75\%- $80 \%{ }^{421}$; en esto coincide la Inclusa de Valladolid. Solamente el $12 \%$ de los expósitos del torno superaban el mes de vida, el $88 \%$ restante ingresaron dentro del período neonatal, considerando como ya he dicho los de edad incierta en este grupo, que suponen un nada despreciable $24 \%$.

\footnotetext{
${ }^{421}$ REVUELTA EUGERCIOS B A: op. cit., p 275; ÁLVAREZ SANTALÓ L.C.: Marginación social y mentalidad en Andalucía Occidental: Expósitos en Sevilla (1613-1910), p 2.
} 
El $27 \%$ del total fueron expuestos en su primer día de vida y otro $20 \%$ en los días siguientes, la mayoría entre el segundo y tercer día por lo que he podido comprobar en los libros. Casi la mitad, por tanto, se presentaron en su primera semana, serían seguramente bastantes más contando con muchos de los de edad desconocida.

En la GRÁFICA 3-15 se hace un análisis pormenorizado de algunos años ${ }^{422}$. Hay variaciones importantes en el grupo de los neonatos (RN) probablemente en función del grupo de edad incierta que, como puede verse, es también muy variable de unos años a otros. Lo que queda patente es la mayor proporción de niños de pocos días de vida y la escasa presencia de los mayores de un mes y particularmente de los mayores de un año.

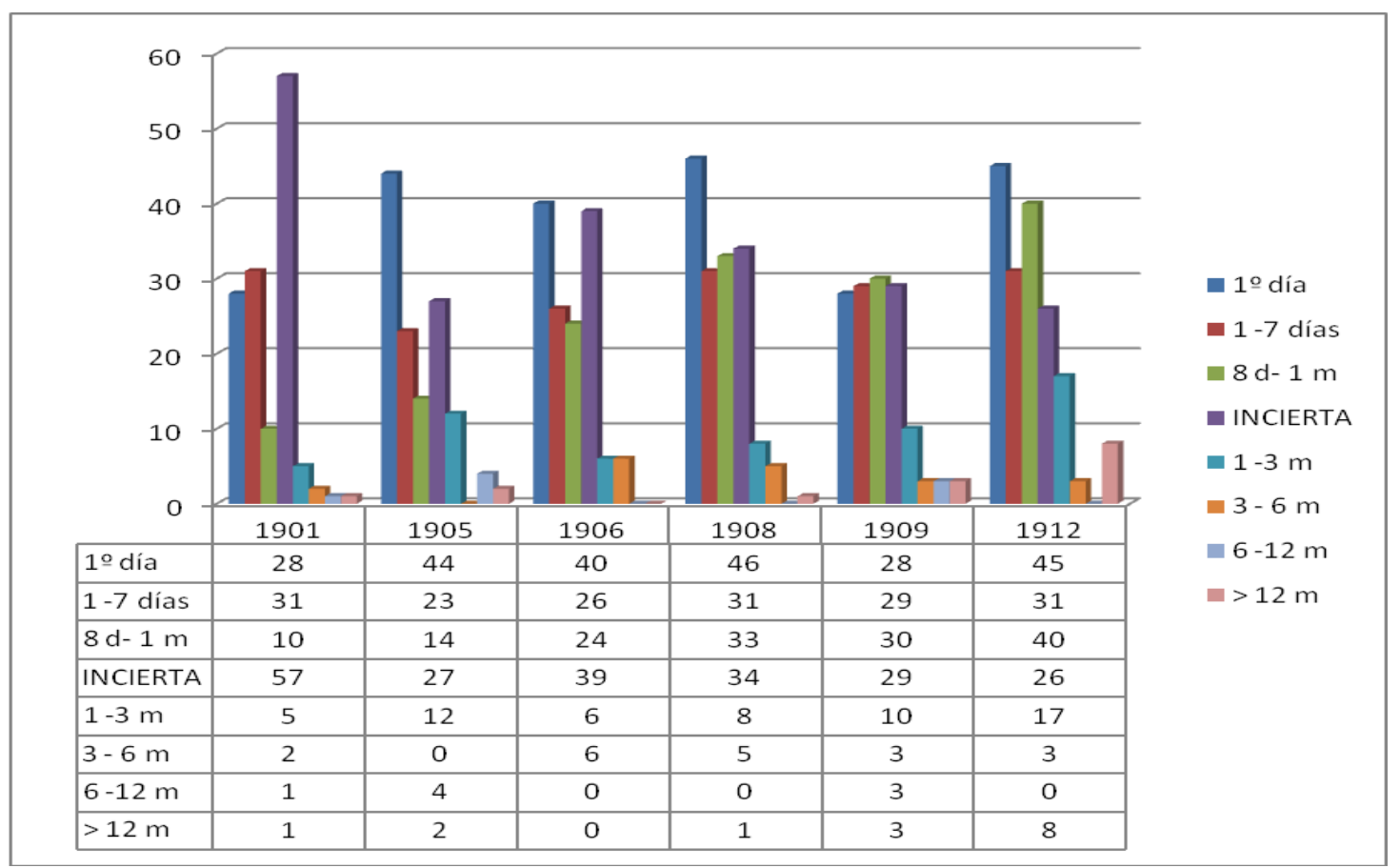

GRÁFICA 3-15: Edad de ingreso de los niños expuestos en el torno de la Inclusa Provincial, años 1901, 1905, 1906, 1908, 1909 y 1912. En el grupo de edad con fecha INCIERTA se han incluido los que no tienen fecha de nacimiento segura. Elaboración propia a partir de a partir de los Libros de Exposiciones del ADPVA. Solamente se han contado las presentaciones en el torno del Hospicio, no se han incluido las exposiciones en los pueblos de la provincia

Como era de esperar la mayoría de los niños expuestos eran hijos ilegítimos (el 92`43\% en nuestra serie), muchas de las notas que se dejaban en el torno lo dicen expresamente o lo dan a entender, pero ya sabemos que también se exponían hijos legítimos, seguramente optaban por esta vía por necesidad y urgencia. Solamente podemos contar como legítimos a los niños que aparecen así registrados en los libros, a sabiendas de que también podrían ser legítimos algunos de los que se presentaron sin ningún dato, para evitar la investigación y los

\footnotetext{
422 Se han tomado los mismos años que en la tabla 1 y se ha ampliado la tabla tomando 1901 para tener representación de los primeros años en que los registros parecen menos precisos, y algunos de los años centrales en torno a los que teníamos para ver si las variaciones de unos años a otros indican una tendencia o son independientes
} 
trámites exigidos a los legítimos, en todo caso, aunque puede haber más, la diferencia es notable . (GRÁFICA 3-16)

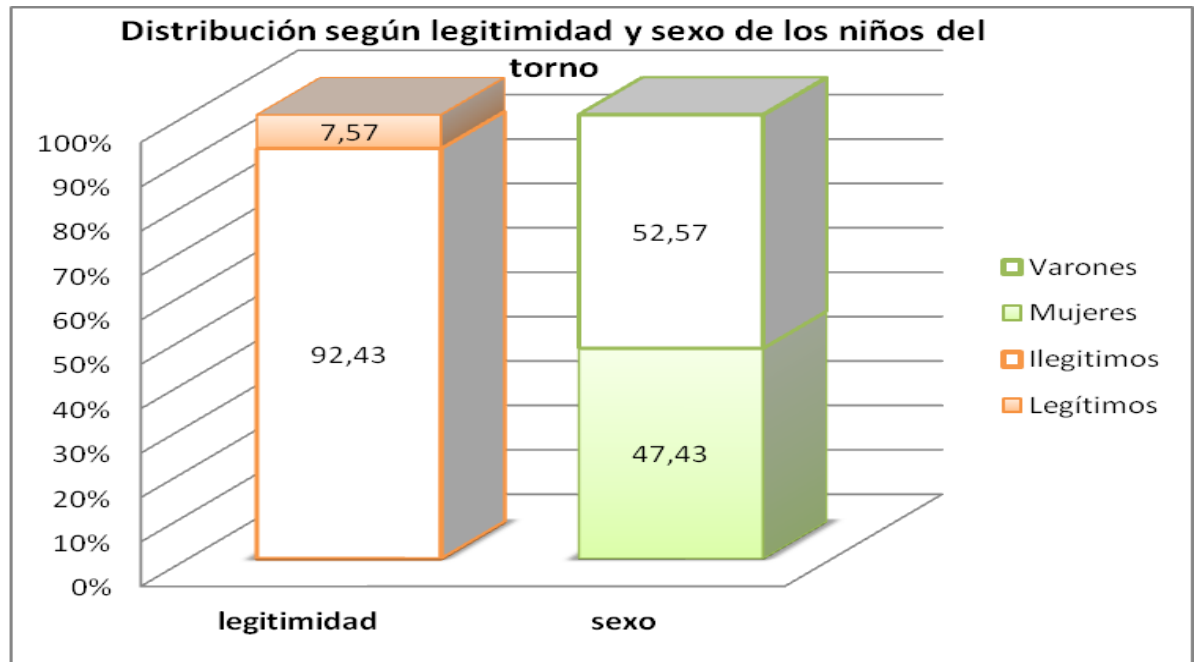

GRÁFICA 3-16: Proporción de hijos legítimos e ilegítimos y de varones y mujeres entre los niños expuestos en el torno de la Inclusa provincial en el período 1900-1913. Elaboración propia a partir de a partir de los Libros de Exposiciones del ADPVA. Solamente se han contado las presentaciones en el torno del Hospicio, no se han incluido las exposiciones en los pueblos de la provincia

Respecto al sexo, hay un 5'14 \% más de varones, es una diferencia que no parece suficientemente significativa como para afirmar que existía una preferencia clara por un sexo $u$ otro, supone una ratio de 112 varones/100 niñas, similar a la del total de ingresos (110 varones /100 niñas) y ligeramente más alta que la de la provincia de Valladolid (107varones /100 niñas). No podemos asegurar por tanto que el sexo fuera un factor determinante a la hora de decidir exponer al hijo. (GRÁFICA 3- 16)

En cuanto a la extracción social podemos imaginar el nivel socioeconómico totalmente desfavorable del entorno familiar de los niños expuestos por la circunstancia misma de abandonar al propio hijo, sobre todo cuando se trataba de legítimos, sin embargo sabemos que era una opción utilizada también para tapar deslices o guardar las apariencias por lo que cuando se trataba de hijos naturales la extracción social podía ser variable. Aún así podemos asegurar sin temor a equivocarnos que la gran mayoría de los niños procedían de entornos con recursos limitados, aún cuando no podemos hacer una evaluación totalmente precisa ya que solo contamos con algunas pistas que acompañaban a los propios niños, como las notas 
escritas o las ropas que llevaban. En los libros se describe minuciosamente la ropa de los niños expuestos, el tipo de prendas que llevaban, sus características y su estado, indicando si son nuevas o usadas o son trapos, incluso al hacer el relato de las prendas indicaban el estado de conservación de cada una de ellas. La mayoría se presentaban vestidos con "trapos", en 1906 así aparece registrado en 61 de los 136 expósitos del torno, la ausencia de una ropa apropiada hace pensar en situaciones de penuria económica, o al menos lo aparenta. En cuanto a las notas se repiten frases como "por falta de recursos es entregada..." (fo 15 de 1906) "por hallarse sin recursos para su sostenimiento" (fo 240 de 1909) "no tiene recursos para alimentarla" (fo 2 de 1909), "es por falta de alimentos" (fo 166 de 1901). Algunas declaran abiertamente la situación de pobreza extrema, "por estar viuda y pobre de solemnidad necesita encomendarle á la caridad..." (fo 309 de 1901), incluso la demuestran mediante certificados, "Certifico que la exponente es pobre y no tiene recursos... [firma] Alcalde de Barrio de Sn Ildefonso" (fo 292 de 1902). La mayoría de los niños eran hijos naturales o ilegítimos, lo que supone que las madres podían encontrarse solas frente a su crianza, además de marginadas socialmente precisamente por su condición de madres solteras. Esta condición de madre soltera o de viuda se expresa en muchas de las notas "es hijo de moza soltera" (fo 55 de 1901), "hijo natural de Lucia... de estado viuda..." (fo 16 de 1910) y en alguna se especifica que la madre trabajaba como sirvienta, de los pocos trabajos a los que podía optar una mujer y que, por otra parte, no le permitía criar con ella a su hijo "es hijo de Brígida ... de 25 años de edad y estado soltera y profesión sirvienta" (fo 252 de 1902). El fallecimiento, la enfermedad o el ingreso hospitalario de uno de los progenitores es otra de las circunstancias que encontramos en las notas de los niños expuestos, cuando faltaba el padre la familia quedaba sin ingresos y en situación de indigencia, "expediente de pobreza donde dice ser hija de Luisa Hernández de estado viuda" (fo 109 de 1904). Sin embargo, con la misma frecuencia encontramos la situación contraria, la falta de la madre, sobre todo cuando el niño era un recién nacido o un lactante suponía para un padre sin suficientes ingresos y sin apoyo familiar la imposibilidad de criarle si no podía costear una nodriza, notas que dicen que se deja al niño "por defunción de su Madre" (fo 114 de 1901), "y estando su Madre enferma y no teniendo recursos la metemos hasta que su Madre se ponga bien si Dios quiere" (fo no 218, 1912). Hay alguna nota aislada que deja entrever que el problema no es económico sino social "es de una familia acomodada" dice la nota del folio 52 de 1912, son hijos naturales que había que ocultar para que la madre y la honra de la familia no quedaran marcadas. En general las notas vienen a confirmar el uso de la Inclusa para el objetivo que señalan sus reglamentos, recoger y criar a los niños ilegítimos y a los pobres sin recursos y en la mayoría de los casos parece que se combinaban las dos situaciones. 
La mayoría de los expósitos echados al torno dela Inclusa, se presentaron con una nota manuscrita, que se transcribía literalmente a los Libros de Exposiciones, o con algún tipo de certificado oficial; hablamos de más del $80 \%$ de las exposiciones, con variaciones importantes de unos años a otros; en 1912 solamente 17 expósitos de los 170 del torno de la Inclusa se presentaron sin ninguna nota, en 1906 fueron 25 de 141. Es un porcentaje altísimo considerando los que tenía la inclusa de Madrid, entre un $40 \%$ y un $60 \%$, y un $15-20 \%$ las de Barcelona y Pamplona ${ }^{423}$. Además, algunos niños se exponían con objetos, señas o marcas de algún tipo que podían facilitar en el futuro su identificación; no se han encontrado muchos en esta revisión, aunque también este dato es muy variable, por seguir con los dos años referidos anteriormente, en 1912 solamente 18 niños se presentaron con algún tipo de señal, 4 de ellos no llevaban nota y en 1906 solo fueron 10 y 3 de ellos sin nota. Todo, junto con las características de la ropa, que podía ser otro dato más de reconocimiento del expósito, se anotaba meticulosamente en los libros; no he conseguido saber que se hacía exactamente con todo ello, es de suponer que los objetos personales se conservaran para el niño como señas de identificación y también probablemente como testimonio de su origen, pero no hay constancia, al menos documental. Es más dudoso el destino final de la ropa, ya que la Inclusa proporcionaba a cada niño su ajuar y muchos llegaban con ropas que se describen en los propios libros como trapos, es probable que el Hospicio las vendiera como tal. En los presupuestos generales de la Diputación en el apartado de ingresos eventuales del Hospicio figuran ingresos "Por enajenación de efectos viejos, basuras, terneros, ganado de desecho, chatarra, trapos, huesos y otros" ${ }^{\prime 424}$ y en el diario El Norte de Castilla encontramos publicada alguna subasta pública para venta de trapos del Hospicio ${ }^{425}$; aunque más asombroso me ha resultado encontrar subastas de "la comida sobrante del Hospicio", ya que con las carencias que tenía el establecimiento y las quejas que había sobre la mala alimentación de los hospicianos sorprende que pudiera sobrar comida como para subastarla ${ }^{426}$, si no podía ser aprovechada por ninguna de los establecimientos benéficos de la Diputación es de suponer que no sería apta para uso humano y no se vendería con este destino.

\footnotetext{
${ }^{423}$ REVUELTA EUGERCIOS B A. op.cit. pp 281- 282; VALVERDE LAMSFUS L.: Entre el deshonor y la miseria... pp 85- 86; RODRÍGUEZ MARTín M.A.: La Casa de Maternidad y Expósitos de Barcelona, 1872-1903, p.156. Bárbara Revuelta ha realizado el cálculo sobre una muestra del $20 \%$ de 4 años y el año 1915 completo y los datos de las otras autoras no coinciden temporalmente con el nuestro, pero aún así la diferencia es muy significativa. ,

${ }^{424}$ Citado del Presupuesto General de la Diputación de 1928, página 23

${ }^{425}$ N.C. 30 -10-1931, p 6; 11- 01- 1933, p 7; 27- 01- 1934 p 6

${ }^{426}$ N. C. 15 de febrero de 1929, p 2; 18- 02-1930 p 7. Unos días después de publicar la subasta de 1929, se publicó la adjudicación y en una pequeña reseña se dice que la Superiora había remitido una carta explicando la comida de los asilados, 28- 02- 1929 p 2.
} 


\subsubsection{Las notas del torno}

Los documentos del tipo de certificados se guardaban en el expediente del niño, así lo he comprobado en los que se conservan archivados, es de suponer que también allí se archivarían "los papeles" del torno, pero no he encontrado ninguno entre los expedientes que he podido revisar; si bien es cierto que solamente dos de ellos son de niños expuestos en el torno del Hospicio y uno se presentó con certificados que se conservan; el otro fue depositado en la puerta del Hospicio con "un papel" con su nombre completo y un relato minucioso de las ropas que llevaba puestas, como figura en su correspondiente folio (no 269 de 1911), pero el papel en cuestión no se encuentra ni en el libro ni en la carpeta de su expediente.

Entre toda la documentación revisada solamente he encontrado una nota escrita en un trozo de papel recortado a mano que podría ser del torno

"Mariano Rodriguez Nació hoy 3 de Julio a las 12 sin bautizar"

Se encuentra pillada en el Libro primero de 1902 delante del folio 227 en el que se registra una exposición del 3 de julio de ese año, pero no corresponde el nombre ni en el registro consta esta nota. Parece que se colocó ahí accidentalmente, no he conseguido localizar, para confirmar la fiabilidad del registro, entre ninguno de los años consultados a quién podría corresponder esta nota. Podemos dar por supuesta esa fiabilidad ya que parece que las transcripciones que se hacían a los Libros eran completas y fidedignas, salvo posibles errores, tanto que incluso se describían dibujos, rayas, sellos, o marcas de cualquier tipo que aparecieran en ellas, incluidas las características del papel donde iban o si estaban escritas a lápiz, tinta o a máquina. Probablemente, los reglamentos exigían una descripción tan minuciosa por seguridad, por la posibilidad de que la nota pudiera extraviarse y pudiera perderse un testimonio tan precioso en algunos casos para la comprobación de la filiación del niño. Aunque no he encontrado ninguno, es probable que los papeles del torno se archivaran con toda la documentación del niño; es probable que los papeles del torno se archivaran con toda la documentación del niño; entre los registros encontramos alguna pista que nos hace suponer así. En el folio 325 de 1908 se dice que el papel se une a su expediente

"En 14 de Octubre de 1908 á las 14 horas y 40 minutos fue expuesto en el torno de este Establecimiento con un papel por duplicado que se une a su expediente en el cual la madre declara que le dio a luz el 12 de Septiembre último en Castrillo de la Guareña provincia de Zamora donde fue bautizado e inscripto con el apellido de la madre por ser hijo de padre desconocido y que le pone en el torno por no tener leche para criarle" [sic] 
Este es uno de los casos en que la nota se presentaba por duplicado para que sirviera de resguardo para una futura recuperación del niño, en alguna se dice que alguien pasará a recoger la copia o que se quedan con una copia igual, o se solicitaba expresamente que el papel u otras señas que acompañaban al niño se conservaran a modo de comprobante.

Pero también es posible que no se conservaran todos de forma rutinaria, resultaría más práctico tenerlos registrados en los libros. En el folio no 246 de 1911 se registra un misterioso sobre con claves numéricas y lacrado que acompañaba al niño y se dice que se guardó en el expediente; no parece que se haga lo mismo con la nota que también llevaba, aunque en este caso el sobre en sí es la señal que se propone para el reconocimiento del niño

"En 11 de Julio de 1911 á las 24 horas fue expuesto en el torno de este asilo con un papel que dice "El niño nació a las 6 de la tarde= Miguel Mogon»...Entre las ropas tenía un sobre sellado con tres sellos de lacre encarnado y escrito por delante 9- $6-911=1752=1910=y$ en el reverso "este sobre no se abrira no presentándose otro igual» Este se archiva en el expediente" [sic]

En cuanto a las características de estas notas del torno, en los registros las encontramos de todo tipo, tanto en extensión como en la clase de información que brindaban, resulta complicado hacer un resumen y sobre todo hacer una selección, por la cantidad que por una u otra razón resultan interesantes. Hay notas muy escuetas, otras llenas de pormenores; algunas resultan curiosas por distintas causas, o demuestran cierta ingenuidad, otras son conmovedoras y trágicas; en el fondo todas encierran un auténtico drama personal y social.

Hay notas singulares como la que escribe este presbítero para unos gemelos expuestos en la que dice que los padres son desconocidos y a continuación da los nombres de los abuelos

"El infrascrito Presbitero encargado de la Iglesia filial de San Ginés de Villabragima. Certifico que Julian y Anatalia Garcia Villa natural y residente en esta villa y de padres desconocidos, nietos de Gabriel y Angela naturales y vecinos de la misma, nacieron el dia diez del presente mes á las dos de la tarde y fueron bautizados solemnemente ... Hay una rúbrica y un sello en tinta azul. Es hermano de la que ocupa el siguiente fo'" [sic] (fo 120, LE 1904- 1)

O ésta que advierte que la niña tiene madre conocida, una manera de advertir que no inscribieran a la niña como hija de padres desconocidos

"Esta niña no está bautizada y se la pondrá por nombre Ascensión Moral tiene madre conocida" [sic] ( fo 343, LE 1901-2) 
Resulta triste, denota cierta preocupación por parte de la madre, pero sobre todo porque la niña falleció a los 10 días "á consecuencia de sifiloma hepático”^27.

Pocos días viviría también el niño Clemente

"... expuesto en el torno de este Asilo con un papel que decía "Este niño nació el día 23 de Noviembre del año 1908 á las 8 de la mañana y esta bautizado con el nombre de Clemente y tiene Madre y Abuela" [sic] (fo 415, LE 1908- 2)

Una forma también de decir que era hijo natural, igual que su madre

Hay alguna nota que, por el contrario, dice que el niño no tiene madre

"Este niño esta bautizado é inscripto en el Registro Civil, se llama Francisco Cardeñosa Tomillo, no tiene Madre: suplica se le preste buena asistencia" [sic] (fo 14, LE 1913- 1)

En este caso debía referirse al fallecimiento de la madre, la última anotación del folio dice "Baja definitiva por hallarse con su padre". No se ha registrado ninguna fecha, ni de bautizo ni de inscripción, ni de baja, pero sabemos que sería un recién nacido o un lactante cuando ingresó porque se le asignó un ama para lactancia; sería uno de los casos en que los niños se ingresaban porque al fallecer la madre el padre no podía hacerse cargo de su crianza.

Muy sorprendente es la nota que presentó el niño del folio 378 de 1902 que decía

"Suplicando la bondad de V. conserve en esta criatura esta cadena y cruz para que algun dia pueda reclamarle, su nombre si es niño Lucio y si es niña Magdalena" [sic]

Era niño y le pusieron Lino, este nombre está sobrescrito en el encabezamiento del folio corrigiendo el de Lucio, es algo raro porque en general se respetaba el dictamen de las notas sobre el nombre del expósito, parece un problema de confusión en la transcripción.

En ésta otra se recalca el sexo del niño, por si acaso

"Varon-. Nació 17 de Julio á la hora doce y media del dia. Nombre Marcelino Gago. Sin bautizar con agua de Socorro del pueblo de Bamba" [sic] (fo 227, LE 1901- 1)

Hay varias notas de este tipo en las que se hace constar si es niño o niña, quizás es una forma más de asegurarse en una identificación futura, que por lo menos coincida el sexo.

Resulta conmovedora la ingenuidad de esta otra nota escrita en primera persona

"Me llamo Mariano Villarreal hijo de Jesusa Villarreal esta sin bautizado he nacido en Arroyo de Valladolid= He nacido dia 8 Septiembre del año 1911 y para que conste la firma mi madre en Arroyo 13 de Septiembre de 1911 = Felipa Villarreal = rubricado" [sic] (fo 311, LE 1911- 2)

\footnotetext{
${ }^{427}$ Lesión tumoral del hígado característico de la fase final de la sífilis.
} 
La mayoría de las notas son breves, pero hay también largas cartas, siempre copiadas literalmente, aunque ocuparan el folio entero, que suelen justificar al abandono, describir el dolor de la madre, solicitar una buena atención para el hijo abandonado y agradecerla y con frecuencia manifestar su futura recuperación

"El día veintitrés de Noviembre de 1905 á la una horas y cuarenta y cinco minutos fue expuesto en el torno cuna de este Asilo con ... un papel de carta de luto escrito en tinta morada que dice "Tordesillas, Noviembre 22/1905 = Sra Madre Superiora de la casa Ospicio de Beneficencia de la provincia de Valladolid= Un corazón afligido como es el de una madre que por circunstancias especiales tiene necesidad de separar del regazo de sus pechos a un hijo querido y le entrega en poder de otra segunda persona, cual no será lo que ella agradezca su buen trato su buen comportamiento sus caricias alagüeñas y considerando todo esto muchas veces inmerecido cree por ello nunca estar recompensado; mas como quiera que así lo considera reza por el bien de la casa, por el bien de los que se hallen en esa casa y por la Bondad de esas hermanas que a sus ordenes yacen como igualmente por la salud de la Sra Priora = Este niño que vá acompañado de esta esquela nació el 22 de los corrientes a la una de la madrugada, está por Bautizar sin recibir el agua de socorro. $=$ Deseamos con anhelo se le bautice con el nombre de Mauro Gonzalez: será bisitado a menudo y en su dia se le sacará cuando se realice la unión para la razón. = Pido a Dios se tenga presente mis peticiones y pongo por intercesor a su santo San Mauro = Damos las gracias a la Madre Priora y sus hermanas por no dudar de su buen comportamiento, pues en su día se recompensara a la Santa Casa = Tordesillas" [sic] (fo 405, LE 1905-2)

Y encontramos notas breves pero desgarradoras

"Este niño nació el dia 7 de Octubre, no está bautizado ni en el Registro nació en la capital = adiós cuidale bien adiós que su Madre es una desgraciada" [sic] (fo 395, LE 1912-2)

El niño falleció el 11 de febrero con la nodriza.

También me ha impresionado especialmente esta otra nota que recoge una situación que era normal en la época y como tal se vivía. Se deja en el torno al hijo de una nodriza mercenaria que está criando al hijo del autor de la nota, quien tiene a bien recomendar al niño. Era una realidad que hoy nos puede parecer tremenda, pero que entonces era una cuestión de trabajo y de supervivencia, una mujer que entrega a su propio hijo para poder criar al de otros; es incluso posible, porque era una práctica corriente entre las nodrizas mercenarias, que la nodriza se hubiera quedado embarazada para poder mantener la lactancia y el trabajo. El autor parece conocido en la Inclusa y se dirige a la superiora que por entonces era sor Francisca Orrio Después de dar todas las señas del niño y de la madre la nota en cuestión dice

\footnotetext{
"...Sor Francisca á usted recomiendo este angel de Dios, le entregue a la primera ama que se presente y le recomiende como Vd sabe hacerlo, es el hijo del ama que está criando á mi niño. La saluda y espera esta atención de Vd su affmo.s.s.q.b.s.m. Anto Masa Canales" [sic] (fo 273, LE 1901-2)
} 
Frente a estas mujeres que vivían amamantando niños ajenos, encontramos madres que tenían que dejar al hijo propio por no poder amamantarle, ni costear su lactancia. Muy lamentable por lo que encierra es la nota que aparece transcrita en el folio no 337 de 1901

\begin{abstract}
"Heste niño nació el dia 5 de Noviembre de este año hesta sin bautizar téngan la vondad de ponerle Leonardo del Olmo Garcia Hijo de Nica del Olmo Garcia, nació en la calle de la Penitencia no 4 á las 10 de la noche. = Hermanitas agan Vd. el favor de dar á este niño á un ama que tenga vastante pezón decirle de seguridaz que han esto porque le llevan por no tener su madre pezón suficiente y no a podido mamar favor que espero de VD. Dios se lo pagará" [sic]
\end{abstract}

El afán de la madre por asegurar una buena alimentación a su hijo no resultaría, le dejó en el torno el 12 de noviembre y falleció el 9 de diciembre en la Inclusa por desnutrición, puede que no llegara a salir con ninguna nodriza precisamente por su mal estado.

En ocasiones se referían ingresos temporales, aunque era infrecuente que el niño volviera con los padres; en el siguiente caso parece que así fue pues en una anotación final en el registro se lee "Entregado Marzo 1905". La nota del torno intenta mostrar que son gente conocida y de fiar, parece que busca "recomendaciones" para que se dé un buen trato al niño

\begin{abstract}
"Está bautizado en San Andrés este niño se llama Juan Gil dueñas. Nació el 24 de Septiembre de 9004. Su madre se halla en el Ospital pasaremos a recogerle en cuanto se ponga buena.- Valladolid 8 de Octubre del 9004. José Gil = rubricado = es sobrino de Dionisia la Viuda del Portero del Manicomio Probincial que también tiene ay tres niñas ". [sic] (fo 312, LE 1904- 2)
\end{abstract}

Incluso alguna nota se justifica por no escribir correctamente y eso que es bastante correcta pues ya vemos que incluso algunos encargados de hacer los registros de los libros también tenían sus fallos, todas las transcripciones recogidas en este trabajo están hechas copiando literalmente lo que figura en los libros

"Esteban Saez Gonzalez nació el dia 23 de Noviembre á las 10 de la mañana sin bautizar cuando le bautizen ustedes hacen el favor de ponerle Esteban ustedes dispensaran por las faltas Señores hacen el favor de ponerle= Esteban Saez Gonzalez=rubricado"

[sic] (fo 398, LE 1908- 2)

Las notas del torno, por clasificarlas de alguna manera, podríamos agruparlas en los siguientes tipos

a. Notas sin nombre que advierten que el expósito no está bautizado

\footnotetext{
“...expuesta en el torno cuna de este Asilo con... un papel escrito en lápiz que dice "No esta Bautizada»" [sic] (fo 7, LE 1905- 1)
} 
Tan escuetas como ésta son poco corrientes, normalmente se daba algún dato más, como la hora o el lugar de nacimiento, o la fecha de la exposición

"Esta criatura no está bautizada á nacido á las 6 de la mañana de hoy 23" [sic] (fo 442, LE 1909- 2)

"Esta niña ha nacido el dia 31 de Mayo á las 12 de la noche en Aldeuso [puede ser Aldeayuso] provincia de Valladolid y está sin bautizar" [sic] (fo 200, LE 1912- 1)

Este tipo de notas sin nombre alguno son las menos, en 1905 solo hay 5.

b. Notas con el nombre del niño, el que se le ha puesto o el que la madre o la familia quieren que se le ponga al bautizarle. En algunas simplemente figuraba un nombre

"... fue expuesto con un papel que dice "Se llama Catalina»" [sic] (fo 430, LE 1912- 2)

“...y un papelito que dice «Elvira Martin»" [sic] (fo 39, LE 1900- 1)

Solía indicarse o sugerir si estaba o no bautizado. El bautismo o su ausencia es un tema recurrente y presente en casi todas las notas

"... un papel en lápiz que dice "Que se llame Dolores, no esta acristianada»" [sic] (fo 105, LE 1902-1)

"Ha este niño se le pondrá el nombre que á continuación va escrito= Aquilino Pedro= rubricado" [sic] (fo 2, LE 1910-1)

A veces se pedía por nombre el santo del día, lo que era costumbre en la época, pero también servía de referencia para identificar al hijo

"Día 9 nacio á las tres de la tarde Santo del dia del dia $S^{n}$ Francisco, sin bautizar" [sic] (fo 98, LE 1910- 1)

"Gabriel Castillo Mangas... fue expuesto en el torno de este Asilo con un papel que dice "Este niño ha nacido en el dia de hoy á las 12 de la mañana, no ha recibido agua de socorro ni se ha bautizado se le pondrá el santo del día = 18 Marzo de 1913»" [sic] (fo 106, LE 1913-1)

Dar un nombre a la criatura permitía saber a quién se tenía que reclamar en caso de querer recuperarla

"Ba sin bautizar si pudiera ser se llamara Manuela Vallecillo para saber a la niña que había que reclamar por tener padre conocido. A nacido el dia 13 en Valladolid" [sic] (fo 60, LE 1907-1) 
Con mucha frecuencia se daba por lo menos uno de los apellidos suponemos que sería el de la madre, y datos como la fecha de nacimiento o la localidad de origen

"Este niño ha nacido hoy a la una de la mañana no ha recibido agua de socorro se desea le pongan de nombre Antolin Gonzalez =Valladolid 12 de Julio del año 1906" [sic] (fo 221, LE 1906-1)

"Nació el 22 de Junio de 1900 á las cuatro de la tarde. Está sin bautizar y deseo por lo tanto se llame Cesar Sierva que es el apellido de la madre pues dicho niño no esta reconocido por el padre. Valladolid 14 de Julio de 1900 por la madre Rosa Cierva" [sic] (fo 238, LE 1900-1)

"Esta niña ha nacido el dia 2 del mes de Abril de1911 a las 13 ha recibido agua de socorro por ser de siete meses se ruega le pongan por nombre Josefa de la Torre Gutierrez" [sic] (fo 108, LE 1911-1)

Josefa era una niña prematura, "de siete meses, o como también se decía, sietemesina, que no sobrevivió, falleció precisamente el "11 de Abril á consecuencia de falta de desarrollo".

Curiosa, por lo inusual es esta nota que solamente daba el nombre del padre, lo más corriente era dar el de la madre, es posible que hubiera fallecido

"Se llama la niña Maria Martin, nació el dia dos de Abril, padre Mariano esta bautizada el 3 Abril del 1912" [sic] (fo 177, LE 1912-1)

c. Notas con todos los datos de filiación, los nombres de padres, abuelos,

"En 21 de Mayo de 1912 á las 16 fue expuesto en el torno de este Asilo con un papel que dice "La niña Maria Juana Zarzuelo Horcajo nacio el 10 de Marzo á las 9 de la noche. Hija de Luis Zarzuelo Gonzalez y Maria Horcajo Velázquez, naturales de Nava del Rey y Urueña provincia de Segovia respectivamente, abuelos paternos Mariano y Cipriana y Maternos Pedro y Maria= Bautizada en la Parroquia de San Ildefonso en Valladolid el 17 de Marzo de este año"'" [sic] (fo 186, LE 1912- 1)

En el registro de este folio hay un error en las fechas, la última anotación dice que falleció "en 14 de Mayo de 1912", fecha anterior a la de la exposición

Incluso algunas daban también los nombres de los padrinos. Son notas escritas a modo de partida de bautismo

"En 7 de Abril de 1909 fue expuesto en el torno de este Establecimiento á las 10 horas del mismo con un papel que decía "Partida de un niño que nació en Cigales el dia 4 de Marzo de 1909 se llama Casimiro Sanz de Pedro hijo de Gregoria Sanz de Pedro natural de Megeces de Iscar abuelo Materno: Victor Sanz ya difunto abuela materna Celestina de Pedro, padrinos Juan Marcos = madrina Alejandra Mucientes" [sic] (fo 132, LE 1909- 1) 
d. Notas con otro tipo de señas para identificar al niño, como las ropas u objetos que presentaba al exponerlo en el torno

"En 19 de Mayo de 1908... fue expuesto... con un papel que copiado á la letra decía "el niño se llama Antonio Leza Alvarez. Este niño lleva una medalla con la estampa del Papa Leon 13 y las estampas de $S^{n}$ Pietro y $S^{n}$ Paolo»" [sic] (fo 160, LE 1908- 1)

"Valladolid 29 de Mayo de 1910 ingresa en el santo Hospicio una niña que se llama Irene Sanchez y lleva por señas un anillo de metal con las iniciales $U$ y $H$ para el día de mañana que sus padres puedan reclamarla" [sic] (fo 190, LE 1910- 1)

Los mismos objetos se describen junto con las ropas en sus folios de registro.

La propia nota en sí también podía servir cuando se escribía en algún tipo especial de papel

“... expuesta... con un papel (hoja de calendario) que decía "La niña Paulita Maderne, nació el dia 30 de junio de 1909»" [sic] (fo 230, LE 1909- 1)

“... expuesta... con una tarjeta postal representando á $S^{n}$ Antonio de Padua y al dorso decía "Esta niña esta sin bautizar mañana 17 pasaremos á por el recibo á esa nazida dia 16 á las 11 de la noche se llama Lucia Aguilar Hilario calle Marques del Duero no 37" [sic] (fo 158, LE 1908-1)

En el folio no consta que se presentara nadie "a por el recibo" del ingreso, la niña falleció unos días después "á consecuencia de Sífilis congénita"

e. Notas que declaran o dejan entrever la intención de recuperar al niño algún día, algunas estaban hechas a modo de resguardo para presentarlo en el momento de la reclamación

\begin{abstract}
"A nacido á las 10 de la noche del dia 5 de Julio de 1909 el niño que se llamará Miguel y que ingresa en este establecimiento benefico esto es para que la Madre le pueda reclamar ella se queda con otro igual á este= Valladolid 5 julio 1909= ingreso á las 12 y media del mismo día" [sic] (fo 235, LE 1909-1)
\end{abstract}

Miguel fallecería el 1 de agosto por una gastroenteritis

Realmente, todos los papeles que daban datos personales, de forma implícita estaban manifestando interés por el niño y por recuperarle algún día, todos esos datos podrían servir para que los padres reconocieran al hijo, pero también para que el hijo descubriera y reconociera a sus padres.

También había quien proponía una contraseña para el rescate del niño 
"Esta niña se halla inscripta y bautizada con nombre de Juana e ingresa en el torno el dia 14 de Junio, se suplica la contraseña de Juana" [sic] (fo 188, LE 1904- 1)

Algunas notas expresan el deseo de que se conserven para servir de recibo

"En 29 de Diciembre de1909 á las 19 horas fue expuesto en el torno de este hospicio con media tarjeta grande en la que se lee impreso a todo su largo y atravesado "David Martín" por cuyas letras está partida en esta mitad dice "Se ruega á esta Santa Casa de Misericordia acoja bajo su protección a este niño que nació en el dia veintinueve de Diciembre de mil novecientos nueve a las seis de la mañana. Se encuentra sin bautizar y por lo tanto se desea se le pongan los nombre de David Martín" al reverso "Se suplica la reserva de este comprobante». La media tarjeta tiene 4 dibujos en azul". [sic] (fo 448, LE 1909-2)

Entre las ropas este niño llevaba también "un escapulario azul de la Purísima"; falleció el 9 de febrero de 1910 en Villanueva de Duero según consta en su certificado de defunción, enviado por el Juez de dicho pueblo al asilo cinco años después, en abril de 1915.

Hay notas solicitando que el niño no saliera del asilo para poder recuperarle

"Se suplica al señor Director y Sra Superiora que a ser posible conserven esta niña en el establecimiento guardando esta y las ropitas que van marcadas con J.A. no esta bautizada y se suplica la pongan los nombres de Jesusa Francisca = Que la copia y no se entregara a quien no la presente 30 Octubre 1906" [sic] (fo 326, LE 1906- 2)

Jesusa no salió con una nodriza hasta el 15 de diciembre, no hay más anotaciones en el folio después de la salida.

Algunas notas incluso ponen fecha para recoger al niño

"Esta niña esta bautizada, se llama Maria C G. Padres ambulantes pero la recogerán el 15 de Junio de 1903 si dios los da salud. Conservese este papel. = metida en esta casa el 20 de Mayo de 1902" [sic] (fo 182, LE 1902-1)

María estuvo esperando en la Inclusa hasta el mes de septiembre y falleció al año siguiente en marzo.

La mayoría simplemente manifestaban el deseo de recuperar al niño algún día, lo que casi nunca ocurría, entre otras razones por la altísima mortalidad de estos niños, sin embargo, en algún caso, pocos, se cumplió

"Esta niña que se deposita en el Santo Hospicio nació el 28 de Julio de 1900 deseando que se la ponga por nombre Eladia Perez para poder reclamarla si la ley concede ese derecho. Valladolid 9 Agosto de 1900" [sic] (fo 308, LE 1900-2)

Se escribió en su folio que la reclamó "su Padre Zoilo Arribas" y más abajo se dice de él que firma como marido de la madre Sinforosa Pérez porque ésta no 
sabe; parece la típica situación en la que un hijo natural se escondía hasta que los padres legalizaban su situación, hay alguna nota que así lo dice expresamente

"... un papel en el que escrito á máquina se dice lo siguiente "Esta niña nació á las seis horas del dia siete de los corrientes en esta Ciudad y no está bautizada ni inscripta en el Registro Civil = Es hija de María Velasco Garcia, soltera huerfana y natural de Campaspero (Valladolid) = se desea que se la bautice e inscriba con los nombres de Maria Para que pueda verificarse el reconocimiento que la madre y el padre proyectan realizar cuando esten en condiciones, extienden por duplicado este documento, firmándoles la Madre y dos testigos. Se queda la Madre con un ejemplar como medio de identificación =Valladolid á trece de agosto de mil novecientos doce...." [sic] (fo 292, LE 1912- 2)

A continuación aparecen en la nota los nombres y firmas de la madre y los dos testigos. La niña estuvo un mes en la Inclusa y fallecería en el mes de octubre con la nodriza. En la nota "carta" que comentamos anteriormente del folio no 405 de 1905 también se manifiesta esta circunstancia "será bisitado a menudo y en su dia se le sacará cuando se realice la unión para la razón" [sic].

f. Notas que justifican el abandono por una cuestión de necesidad, por falta de recursos o imposibilidad de criar al niño. Hay muchas, de todas clases, pero todas se pueden resumir tristemente en la situación de miseria de sus protagonistas

"La presente niña Suplico á $V$ me la bauticen y sea conocida por el nombre de Maria Gonzalez y Perez. Dios guarde á Vs muchos años y no dudo an de mirar al Angel como esta desgraciada lo mira, la necesidad me obliga á desistir en la presente $=18$ de Enero de 1902" [sic] (fo 21, LE 1902-1)

La niña María falleció seis días después

"Este niño ingreso el dia 2 de Enero de 1910 se llama Angel Avedillo Cerrato =ingresa por estar su madre baldada ${ }^{428}$ de brazos y piernas y su padre no tener trabajo y tener 4 hijos más". [sic] (fo 1, LE 1910-1)

En una nota al margen se ha escrito "Este niño se llama en el Registro Marcelo Emilio Avedillo Cerrato bautizado en San Andrés nació el 9 de Abril de 1909“, no coincide el nombre, como vemos se buscaban los datos de los niños. Falleció en 1913 con la nodriza en Frumales (Segovia).

"En 25 de Junio de 1900 y hora de las diez de la noche fue expuesta en el torno de este Asilo con... un papelito que dice "La niña Adela Martin Sanchez nació el 3 de Junio de 1900 y por encontrarse sus padres sin recursos para ponerla un ama por estar su madres sin leche y enferma es por lo que se ben obligados a echarle a la Santa casa Valladolid 25 de Junio "..." [sic] (fo 254, LE 1900- 2)

\footnotetext{
428 BALDAR:"Impedir o privar alguna enfermedad ó accidente el uso de los miembros o de alguno de ellos"
} Diccionario de la lengua castellana por la Real Academia Española. Undécima edición. Madrid. 1869, p 94, 1 
Esta niña no llegó a salir de la Inclusa, falleció en abril de 1901, parece que dice que de "Ascitis"

"En 10 de Junio de 1912 á las 20 fue expuesta en el torno de este Asilo con un papel que dice "Esta niña se llama Sagrario San Jose Garcia, natural de Valladolid bautizada en la parroquia de San Miguel y estando su Madre enferma y no teniendo recursos. La metemos hasta que su Madre se ponga bien si Dios quiere se la reclamara»...

Nació el dia 13 de Marzo de 1910..." [sic] (fo 218, LE 1912-1)

La niña en cuestión tenía 2 años, se localizó fecha de bautismo y de nacimiento. No salió del asilo, falleció el 14 de noviembre de ese año " $a$ consecuencia de tuberculosis pulmonar"

g. Notas que advierten de la condición de legitimidad o ilegitimidad del hijo

"Nacida en el dia de hoy 22 de Mayo de 1910 á las cuatro de la tarde, no ha sido bautizada no ha recibido agua de socorro = Si fuera posible se le pondrá Paulina Juanes és hija natural" [sic] (fo 228, LE 1910- 1)

"Esta niña se llama Lupicinia Martin Torres, nació el dia 25 de Marzo de 1910, ha sido bautizada é inscripta en el Registro civil y és hija legitima y se reclamará en su dia" [sic] (fo 235, LE 1910-1)

Lupicinia falleció cinco meses después de la exposición en el pueblo de la nodriza que la criaba, seguramente la pusieron el nombre del santo del día

Algunas notas confunden el concepto de legitimidad, el significado legal de hijo legítimo con el de madre legítima referido a la madre verdadera

"Esta niña nació en Tudela de Duero el dia 31 de Diciembre de 1910 á las 8 de su mañana, se llama Luz Aurora de la Caridad, és hija natural de Vicente Salamanca... y legitima de Felisa Garcia.... Padres paternos...Padres maternos... Esta bautizada en Tudela de Duero" [sic] (fo 19, LE 1911- 1)

"Nació esta niña el dia 25 de Marzo del corriente año, es natural de Ciguñuela, hija legitima de Maria Fraile se encuentra bautizada con el nombre de Maria Concepción Fraile lo que pongo en conocimiento de el Sr Director del Sto Hospicio para que sea inscripta en los libros de su cargo" [sic] (fo 176, LE 1906- 1)

Incluso una madre se llama así misma putativa, ignorante la pobre del significado real del término, que no ha cambiado de entonces a ahora, y pensando seguramente en otro tipo de connotaciones culpables. Dice la RAE que putativa es reputada (o sea, reconocida) o tenida por madre sin serlo

"Memorial de nacimiento, el diez y ocho de Enero del año mil nuevecientos seis a las tres de su mañana nació en Valladolid una niña siendo su madre putativa Justa Perez quien desea se le ponga por nombre Petra por no haber recibido 
todavía el sacramento del bautismo por falta de recursos es entregada al Santo quien se encargará hasta que la Madre pueda recogerla = Valladolid 18 Enero 19060 la madre se llama Justa Perez" [sic] (fo 15, LE 1906- 1)

Tampoco esta pobre mujer tuvo ocasión de recuperar a su hija que falleció al mes siguiente en la Inclusa "á consecuencia de Bronquitis"

h. Notas preocupadas que apelan al buen corazón de los encargados del Hospicio, ruegan que se proporcionen al niño buenos cuidados, que no lo pierdan o que piden saber el paradero del niño

"Es niño se llamará Miguel Eusebio esta sin bautizar dia 9 de julio 1908 á las 9 de la noche se entrega se suplica á ustedes miren por el" [sic] (fo 219, LE 1908-1)

"Hoy dia lo ingreso en ese Establecimiento á las cinco de la tarde un niño que fue bautizado...se suplica al encargado del Establecimiento se interese por el niño para el dia que su afligida Madre pueda sacarle. Valladolid 10 de Junio de 1900" [sic] (fo 239, LE 1900-1)

"Valladolid 25 de febrero de 1902. Nació en esta capital en el mes de febrero dia 15 un niño que se llama Fernando Lopez Pinilla ijo de Segunda Lopez Pinilla. Pasado por el rregistro y Bautizado en la Parroquia de $S^{n}$ Juan Bautista. Ara el fabor de ese establecimiento de no perderle de bista. La madre" [sic] (fo 66, LE 1902-1)

María Justina fue expuesta el 31 de julio en el torno, tenía 8 meses de edad, la madre, preocupada, advierte que tiene la lengua enferma y suplica atención médica; hay enfermedades como la escarlatina, frecuente en la época que cursan con un aspecto característico de la lengua:

"Señora Superiora, tenga Vds compasion de esta pobresita niña, se llama Maria Justina Catedral esta bautizada en la parroquia de San Martin señora superiora ya que sé que tienen Vds un corazón tan beninno compadescase de esta niña que no tiene padre y preséntesela por caridad al medico que tiene la lengua enferma que dios se lo premiara a Vds dándole yo mil gracias. Maria Catedral" [sic] (fo 244, LE 1904- 1)

Se localizó y registró su bautismo: "B⿳a en San Martín en 20 Octubre de 1903"

Resulta tierna la preocupación de algunas notas y la dureza de la situación que se intuye de trasfondo

"Expuesta en el torno del Establecimiento por ropas unos trapos y un papel que decía haga el fabor le den leche en sopa cocida tiene Padres reconocidos..." [sic] (fo 20, LE 1907- 1)

Algunas ofrecen recompensas por los buenos cuidados 
"Esta niña nació el dia 17 de Marzo á las 3 de la tarde no esta bautizada y quiero que se la ponga Emilia Lopez Morejón = Cuidarlo bien pues será recompensado" [sic] (fo 104, LE 1912-1)

Aunque casi siempre se trataba de recompensas espirituales

"... fue expuesto en el torno... con un papelito que dice que Hoy á las once y media de la noche ha nacido este niño de padres desconocidos está sin bautizar y se desea se le ponga por nombre Isidoro que es el Santo del dia se ruega encarecidamente conserven este niño pues mañana si Dios quiere se pasara á preguntar por el la Virgen Santísima se lo pague a V. conservese este papel con el niño. Nota. Nació este niño á la hora citada el dia dos de Enero del año 1900 y se desea se le pongan los apellidos Barcenilla Gonzalez o sea Isidoro Barcenilla Gonzalez" [sic] (fo 2, LE 1900-1)

Hay papeles que solicitan que mantengan al expósito alojado en el Hospicio,

"como pensionista" o incluso ofreciendo recompensa

"El dia 17 de Enero del 1907 á las once y treinta fue expuesto... con... un papel que decía «Sr director del hospicio. Muy sr mio este niño que dejo a su cuidado deseo se le pongan los nombres de Manuel Mario Luis y quiero le conserven como pensionista el tiempo que sea en esa casa que ha nacido el 17 de Enero 1907 a las 10 de la mañana»" [sic] (fo 16, LE 1907-1)

La nota da a entender que se pagaría el alojamiento del niño, "como pensionista", pero en este caso no se ve la intención de recogerlo, las ropas que se describen en el folio eran nuevas y de calidad, propias de una familia pudiente. Manuel Mario Luis se mantuvo en la Inclusa hasta el mes de marzo, en el mes de enero siguiente falleció con la nodriza.

Alguna incluso concreta una generosa recompensa, aunque no demuestra mucha preocupación

"En veintinueve de Junio de mil novecientos cuatro... fue expuesta en el tornocuna de este Asilo con las ropas... y un papel escrito en tinta que dice "Esta niña se llamará Maria Maya Rubec de Fiord bautícesela será reclamada gratificándose a quienes la cuidaron con 1.000 pts. Guarden esta carta" [sic] (fo 219, LE 1904- 1)

La nota tiene un carácter impositivo, las ropas eran nuevas de algodón, piqué y lana y 1.000 pesetas eran muchas pesetas para entonces, que no tuvieron ocasión de gastarlas porque la niña falleció en el asilo el 6 de agosto "á consecuencia de una Infección purulenta". Parece otra de esas entregas para cubrir apariencias, es una circunstancia que no era muy habitual pero tampoco muy rara porque hay notas como la anterior y sobre todo ropas que denotan cierto poder adquisitivo; para estos niños la Inclusa no era una posibilidad de supervivencia sino una condena en muchos casos a muerte por los "pecados" de los que les engendraron y de una sociedad intolerante 
con ellos. El torno sería sin duda el recurso más fácil, pero seguro que no era la mejor opción y estos niños son algunos de los muchos ejemplos de ello.

También hay notas que piden que se coloque al niño con una buena cuidadora

"Este niño ha nacido el dia de hoy á las 7 y desean se le ponga Luis Lebrero Urrutia se recomienda á la Señora Superiora ponga en buena mano este niño que ya encontrara recompensa" [sic] (fo 42, LE 1912-1)

"Se suplica a Sor Angela le entregue á buen ama porque si Dios le conserva la vida será reclamado por su Madre" [sic] (fo 222, LE 1901-1)

Falleció una semana después en el asilo "á consecuencia de catarro intestinal"

O simplemente quieren saber el destino que se le dará al niño

"Este niño no está bautizado y se desea saber donde ba á criarse" [sic] (folio no 329, 1902)

O el número de su inscripción en el Hospicio, parece que conocían el funcionamiento

"...fue interna en el Hospicio Provincial el 4 de Abril y se desea hagan entrega á la persona que la entrega su numero del folio que le corresponde" [sic] (fo 137, LE 1900- 1)

i. Notas escritas por terceras personas, que pueden ser las que atendieron el parto, profesora o profesor de partos o el médico, sacerdotes, familiares, o las que presentaron al niño en la Inclusa

"El día 6 de diciembre de 1901 presenta Da Monica Gomez Profesora en partos una niña de pocas horas al parecer..." [sic] (fo 364, LE 1901- 2)

La nota no da ningún dato de filiación de la niña, los profesionales mantenían el anonimato de la madre si así lo deseaba y respetaban el secreto profesional. Hay una nota del doctor Macías Picavea, muy conocido y renombrado en la ciudad

"Nació el dia uno de Marzo de 1912 á las 7 de la tarde = es por consiguiente un Angel anónimo = lo entrega el Dr. Alberto Macias Picavea bajo secreto profesional” [sic] (fo 76, LE 1912-1)

Al niño le pusieron de nombre Ángel

También podían dar algunos detalles, es de suponer que con autorización de la madre

"El dia 1 de Marzo de 1904 fue expuesta en el torno cuna de este establecimiento a las tres y treinta de su dia envuelta en unos trapos y un papel que decía "D Santiago Ramos y Polo profesor en partos en ejercicio certifica que ha asistido al alumbramiento de la niña Angela Martin que ha nacido a las dos de la madrugada del día 1 de Marzo siendo hija ilegitima de Maria Martin soltera natural de Torquemada provincia de Palencia la criatura la dio el que 
suscribe el agua de socorro y para que conste doy presente en Valladolid a primero de Marzo de mil novecientos cuatro = Joaquin Ramos Polo=" [sic] (fo 78, LE 1904-1)

Como se ve hay un error al transcribir la nota, no coincide el nombre de pila del profesor en partos ${ }^{429}$ al principio y al final.

Encontramos entre las notas que se repetían algunas de estas personas, sobre todo profesionales como la "profesora en partos Doña Ciriaca Fernández", que aparece entre otros en 1901 (fo 10), en 1909 (folios 50, 95 y 214) o en 1912 ( fo 424), en las notas hacen constar su condición profesional, incluso algunos, curiosamente, con datos sobre su titulación, como una forma de dar más valor a lo que certifica en la nota. El mismo profesor de la nota anterior en otra escribía

"D Santiago Ramos y Polo profesor en partos con título gratuito concedido por $S$ $M$ el Rey d Alfonso XIII por méritos académicos: certifico que a la una de la fecha he asistido al nacimiento de la niña..." [sic] (fo 273, LE 1904- 2)

También se repiten mujeres como Paca Masedo, que no debían ser profesionales, o por lo menos no lo hacen constar, aunque probablemente eran conocidas y actuaba como parteras.

"Una niña que nació a las 13 horas del mes de Agosto de 1909 dia 16 se ha de Ilamar Maria López Rodriguez ingresó en el Hospicio de Valladolid a las 16 esta sin bautizar= la entrega Paca Masedo" [sic] (fo 288, LE 1909-2)

La misma Paca entrega al niño del folio no 92, 1910, aparece en varias exposiciones y en varios años.

j. Finalmente, ya hemos comentado que algunos niños se presentaban junto con certificados oficiales como el de inscripción en el RC o el de bautismo, incluso con otros documentos de los que formaban parte del expediente de solicitud de ingreso, como podían ser el certificado de pobreza o un certificado médico sobre la incapacidad para lactar de la madre. En estos casos no solía dejarse nota

"En 8 de Febrero de 1908 y hora de las trece y quince minutos fue expuesto en el torno de este Establecimiento con un expediente de pobreza incoado por el $\mathrm{Sr}$ Alcalde de Villavicencio al cual acompaña partida de bautismo, certificación del Sr Juez Municipal de Villavicencio donde dice que es hijo natural de María Pastor García y que nació el 14 de Enero de 1908, y con las ropas siguientes, trapos" [sic] (fo 41, LE 1908-1)

\footnotetext{
${ }^{429}$ El título oficial de lo que aquí denomina profesor en partos sería el de "Practicante autorizado para la asistencia á partos normales", que se reguló por RD firmado por la regente María Cristina el 31 de enero de 1902 y publicado en la Gaceta de Madrid no 32 el 1 de febrero con un programa de estudios común al de las Matronas o profesoras en partos. El 8 de octubre de 1921 se publicó el R.D., firmado el 7 de octubre por el rey Alfonso XIII, con los programas separados de los estudios de practicantes y matronas.
} 
En los libros se anotaban las circunstancias sociales más relevantes recogidas en los certificados, la coincidencia en el nombre del pueblo es totalmente casual

"En 12 de Abril de 1911 á las 11 fué expuesto en el torno de este Asilo con certificación del Juzgado Municipal de Villavicencio de los Caballeros en que consta nació el dia 2 del corriente y que és hija natural de Cesarea Martinez Fernandez, de 19 años de edad, casada hace cuatro meses y no habiéndola reconocido su marido por manifestar no ser hija suya, se declaró hija natural. Asi consta en el acta que se acompaña á la exposición" [sic] (f̊ 120, LE 19111)

Por supuesto, a la niña le pusieron los apellidos de la madre

\subsubsection{Marcas, recuerdos y señales de identificación}

Además de dejar un papel, o a veces en su lugar, en ocasiones con el niño se dejaban objetos personales, marcas o señales que podrían servir para su reconocimiento posterior.

Estas señas, vamos a considerarlas de identidad, podían ir en la misma nota, entre la ropa, o incluso en algún caso sobre el cuerpo del niño. Ya hemos visto como había notas que utilizaban papel o formatos peculiares como una hoja de calendario, estampas o postales de santos; he encontrado también notas escritas en "un prospecto de una función en la plaza de toros" (fo 400-1905), en un pliego oficial timbrado de 10 céntimos (han anotado incluso su número) (fo 25-1906), tarjetas con dibujos (fo 448-1909), escritas "en papel de luto" (papel que en señal de duelo lleva una orla negra) (fo 113-1910), en un cartón con un hilo negro (fo 86, 1912) o metida en "una bolsita atada con una cinta de seda encarnada" (fo 417- 1912). Estas peculiaridades quedaban registradas en los libros, incluso si la nota estaba escrita con tinta azul (fo 66, 1902), lápiz (fo 73- 1902), o “... en tinta encarnada” (fo 143- 1902)...

La ropa en sí misma también podía servir como recurso de identificación por eso se describían minuciosamente en los registros, relatando las piezas que se presentaron con el niño, su material, color, tipo de estampado, de adornos o bordados cuando los tenían; estado de conservación, si eran nuevas o viejas, si estaban usadas o en buen uso o eran trapos y si iban marcadas con letras se anotaban. Además, en algunas notas se advierte esta idea de usar 
la ropa como señal y se hacía el relato de toda la ropa, o de las prendas más significativas, que presentaba el niño al ser expuesto

"En el dia 4 de Mayo á las siete de la mañana fue entregado en el Hospicio de Valladolid que está bajo la bocación de Sn José, un niño con la mantilla encarnada estampada en negro, esto es para seña cuando pueda sacarle. Valladolid 4 de Mayo de $1901^{\text {,430 }}$ [sic]

El niño falleció en septiembre con su nodriza.

En algunas notas se pide incluso que se conserve la ropa para el niño

"Esta niña nació el dia 4 del mes de Marzo de 1901, esta sin bautizar y se suplica a la Sra Superiora que la ponga el nombre de Alfonsa Martin y le conserven para ella la envoltura que lleva 5 de Marzo de $1901^{, 431}$ [sic]

Alfonsa entre la ropa, "todo nuevo" llevaba "un pañal de algodón con las letras $R$ y $M$ " bordadas. La llevó una viuda a la semana y en 1919 reingresó por orden del Gobernador civil, no se dice la causa; al mes siguiente "fue entregada para el servicio de la casa de" un vecino de la capital hasta que se emancipó.

También se dejaban objetos en el torno a modo de resguardo, medias partes de algo que podían servir como comprobante futuro

"... y un papel en tinta que dice "nació este niño a las 21/2 de la mañana Abogado a $S^{\text {ta }}$ Isabel de Hungria y Santiago....., acompañaba entre las ropas media carta de baraja francesa, llamado siete de los negros ${ }^{\prime 432}$ [sic]

"Media medalla que parece de plata en un lado la mitad de un Sto que parece $S$ Jose y en el otro la letra L pendiente del cuello con su cordon blanco" ${ }^{\prime 433}$ [sic]

La mayoría son objetos que tienen un valor sentimental y que se podrían entregar a modo de recuerdo para el niño de su familia de origen y como testimonio de sentimientos de preocupación, protección y amor hacía él.

"En 10 de Junio de 1910 á las 20 horas y 40 minutos fue expuesto en el torno de este Asilo con un papel que dice: Alejandro Fombellida Sanz, fue bautizado el dia 5 en la parroquia de San Andres, hijo legitimo de Ramon y de Francisca (difunta) = en la bolsa que lleva el niño tiene metido un Sdo Corazon de Jesus, dos medallas; se ruega encarecidamente lo conserve el niño como igualmente el collar por ser un recuerdo de su madre ( $q$ e d) para que cuando sea mayor pueda conservarlo el ${ }^{\prime \prime 34} \quad$ [sic]

Los más habituales son del tipo de medallas, escapularios y evangelios, pequeños libritos que solían contener el prólogo del evangelio de San Juan y que se colgaban en el

\footnotetext{
${ }^{430}$ Folio no 146. Libro de Exposiciones de 1901- 1. ADPVA

${ }^{431}$ Folio no 76. Libro de Exposiciones de 1901- 1. ADPVA

432 Folio no 369. Libro de Exposiciones de 1901- 2. ADPVA

${ }^{433}$ Folio no 327. Libro de Exposiciones de 1902- 2. ADPVA

${ }^{434}$ Folio no 210. Libro de Exposiciones de 1910- 1. ADPVA
} 
"vestido de acristianar"; todos estos objetos cumplían una función protectora, eran usados tradicionalmente a modo de amuletos ${ }^{435}$ y por tanto constituían objetos de uso y recuerdo familiar. Me ha llamado la atención que entre las imágenes religiosas se repiten con mayor frecuencia la Virgen del Carmen y el Niño de Praga. La Virgen del Carmen era muy venerada en la ciudad de Valladolid ${ }^{436}$ y su escapulario o su medalla bendecidos liberan del Purgatorio ${ }^{437}$; en cuanto al Niño de Praga es una imagen en cera del niño Jesús que se encuentra en la Iglesia de Nuestra Señora de la Victoria de Praga también muy reverenciada en el mundo católico y a la que se atribuyen muchos milagros por lo que era uno de los amuletos de carácter religioso más característicos para la protección de las embarazadas y los niños. También encontramos a San José, la Milagrosa, la Purísima y otras Vírgenes, el Corazón de Jesús también conocido como el Detente porque en los escapularios solían llevar escrita esta palabra que expresa su poder para parar al demonio, san Ignacio de Loyola, protector del embarazo y también frente al demonio, un niño "en una bolsa lleva las reglas de san Benito" (fo 289-1913), un santo considerado gran protector y patrón de la buena muerte y por supuesto hay alguna cruz.

Aparte de las señas o recuerdos de tipo religioso se dejaban objetos de bisutería como collares, pulseras y sortijas, "gargantilla con abalorios" (fo 217-1901), "collar de abalorios color caramelo" (fo 258-1912), “pendientes de dublé438” (f-216- 1904), generalmente cosas de poco valor económico. Extraordinariamente aparece alguna joya, cadenas o medallas de oro o plata

\footnotetext{
435 El uso de amuletos así como numerosas tradiciones y supersticiones relacionadas con la maternidad y la infancia han persistido y algunas han llegado incluso hasta hoy, quizá por el sentimiento de vulnerabilidad e indefensión que sobre todo en épocas anteriores les rodeaba debido a la elevada mortalidad tanto de los niños como de las madres. La enfermedad estaba siempre presente y se luchaba contra ella según los recursos disponibles: religiosos, supersticiosos y/ o médicos. Era necesario amparar a los más débiles por lo que se utilizaban todo tipo de talismanes para proteger el embarazo, el parto, la lactancia y por supuesto a los niños. Por tierras de Castilla las embarazadas utilizaban etites o piedras de águila y las madres lactantes ágatas o piedras de leche que podían mantener o retirar la leche según se llevaran colgadas al pecho o a la espalda. A los recién nacidos, en especial antes del bautizo, para preservarles de todo mal se les colocaban colgados del cuello o entre la ropa escapularios, es típico el de la Virgen del Carmen con el Niño sacando almas del purgatorio o el corazón de Jesús con un detente, se llamaba detente porque tenía escrito alrededor del corazón: "Detente el Corazón de Jesús está conmigo" y la bolsita de los evangelios y prendido. Se seguía teniendo pánico al "mal de ojo" que podía causar daños incurables, por lo que se protegía al lactante con todo tipo de objetos "mágicos"; por Castilla se utilizaban higas, cuernos, colmillos de jabalí, ramos de coral y castañas de indias entre otras cosas y se creía que los niños hermosos y bien criados eran más vulnerables. Cfr. CARRIL A.: Etnomedicina Popular, p 106-108; BORRÁS LLOP J.: Historia de la Infancia en la España Contemporánea. 1834-1936, Ministerio de Trabajo y Asuntos sociales, Fundación Germán Sánchez Ruipérez. Madrid, 1996, p 34.

${ }^{436}$ La Virgen del Carmen tiene en Valladolid un santuario situado junto al cementerio municipal, que antaño fue la huerta del convento carmelita que se fundó junto a la antigua ermita, y una romería que se celebraba, y se celebra, el primer lunes de Pentecostés. También hay una imagen del Carmen en la iglesia de San Nicolás de Bari que ha tenido siempre muchos devotos

${ }^{437}$ Como amuleto protector es muy adecuada para los recién nacidos expuestos sin bautizar. En una estampa de Nuestra Señora del Carmen de las MM Carmelitas sin datar se recogen sus dos grandes promesas, las que hizo a San Simón, Superior de la orden carmelita en el siglo XIII, "El que muera con mi escapulario no padecerá el fuego eterno" y al Papa Juan XXII: "Yo, su madre de gracia, bajaré el sábado después de su muerte y a cuantos hallare en el Purgatorio los libraré y los llevaré al Monte Santo de la vida eterna".

${ }^{438}$ Debía ser un término de uso popular para referirse a imitaciones de oro, no se encuentra en los diccionarios de la RAE de la época. El diccionario de ZEROLO lo define como el "nombre que se da a los objetos de orfebrería falsos, cubiertos con una ligera capa de oro". E. ZEROLO. Diccionario enciclopédico de la Lengua castellana. 1895, p 898,1
} 
o niñas con "arillas de plata", (fo 436- 1900). Para no tener futuros problemas, cuando en el Hospicio no estaban seguros de que un objeto pudiera ser de materiales nobles, se limitaban a anotar su color: "una medalla amarilla en un lado tiene el Papa Leon 13 y en el otro Sn Pedro y Sn Pablo" (sic), (fo 160- 1908)

Muy pocos niños se presentaban con señales de este tipo en los libros, en un año como 1905 con 125 exposiciones en el torno solamente aparecen en ocho de ellas:

$\checkmark$ "una medalla blanca de la Virgen y San José pendiente de una cadena amarilla" (fo 33),

$\checkmark$ "una gargantilla de abalorios encarnados y una medalla con San José por un lado y por el otro el Ángel de la Guarda" (fo 149)

$\checkmark$ "unos evangelios viejos" (fo 218),

$\checkmark$ "un escapulario de la Milagrosa con la fecha escrita y una medalla blanca con la Purísima por un lado y San Luis por el otro" (fo 352)

$\checkmark$ "medalla de la Virgen del Carmen" (fo 353)

$\checkmark$ "escapulario de la Purísima y gargantilla de abalorios blancos" ( $f \circ$ 377)

$\checkmark$ "pendiente del cuello con un cordón de seda morada un corazón de Jesús y tres medallas blancas, una de San José y el Ángel de la Guarda otra la Milagrosa y otra del Niño de Praga." (fo 396)

$\checkmark$ "unos evangelios rotos" ( $f$ 416 )

$\checkmark$ "prendido con imperdible escapulario de la Virgen del Carmen" (fo 437).

Esta fue la tónica general para todo el período, no suelen llegar a diez los expósitos que presentan anualmente objetos "recuerdo", lo más habitual como recurso de reconocimiento del niño era la nota, si la llevaba, y la ropa de la presentación. Precisamente entre la ropa podía haber alguna prenda con características distintivas como "un pañuelo de flores" (fo 142 LE 1905-1), o una "corbata blanca de algodón usada por fajero" (fo 73 LE 19101). Lo más frecuente es que algunas piezas llevaran bordadas una o dos iniciales, aunque casi nunca coincidían con los nombres del niño, o los nombres familiares que aparecían en la nota, la misma niña anterior de la corbata llevaba una camisa "con puntilla encarnada y la letra L" y una nota donde decía que se tenía que llamar María Martínez. Es probable que en muchas ocasiones estas letras no tuvieran intencionalidad, aunque siempre serían un dato más de identificación, pero en otras eran una señal totalmente deliberada "traia puesto al vientre un trapo de algodón viejo con las letras J y $G$ y el número 106" (sic), la nota de esta niña decía que debía llamarse Agustina Ruiz y en el libro se dice que "entre las ropas traía un imperdible y una 
medalla blanca de la Virgen que se encontró después de hacer esta anotación" (fo 63 LE 19101). Los códigos numéricos son utilizados en ocasiones, a veces no parecen tener sentido, otras son fechas relacionadas con el niño o probablemente con eventos familiares o personales de los padres.

"Este niño se llama Enrique Corral es hijo de Dominica Corral = Nacio en Madrid el dia 11 de diciembre de 1907 ... pendiente al cuello una cadenita de oro con un corazón al parecer de lo mismo y una medalla de plata sobre dorada con el busto de Sn Jose y en dorso los números 11=12=8"139 [sic]

A veces un niño presentaba varios objetos de reconocimiento y entre ellos no solía faltar alguno de carácter protector religioso

"un anillo de metal amarillo lleva las iniciales $U \neq H$, un collar de abalorios negros con una cruz de nacar blanco, un $S^{\text {to }}$ Cristo de metal amarillo y una medalla amarilla en un lado San Ignacio y en el otro la Basilica de Loyola"440 [sic]

"Traia puestas las ropas siguientes ... pañuelo blanco con jareton y cuadritos, mantilla blanca de muletón con ondas adornadas con su cordoncito de seda azul, un fajero blanco labrado con una crucecita hecha de algodón encarnado todo en buen uso, una toquilla blanca vieja un detente y unos evangelios de raso azul bordado con sedas y abalorios con un corazón $n^{\prime 441}$ [sic]

Este niño es de los pocos que volvió con su madre, a los dos meses de su exposición, en la nota solamente se manifestaba su nombre y su fecha de nacimiento.

Algunas señales resultan curiosas como el niño que fue presentado "envuelto en un Norte de Castilla del 17 de Marzo", aparte, iba vestido con ropas que se describen como nuevas y además llevaba un ajuar muy completo, algo inusual, con varias piezas de distintas prendas, casi todo nuevo, en la nota da las datos del niño nacido el 18 de marzo y se pide "procuren no darle a nadie sin estas señas" (fo 93 LE 1906-1)

También llamó mi atención el registro de la niña María Luz Tránsito, folio 236 de 1911, que fue expuesta, entre otros objetos, con unos bizcochos y una nota con un punto de ingenuidad

"En 6 de julio de 1911... con un papel que dice "Esta niña se llama María Luz Tránsito Moizon y Alonso.......Al recoger la niña presentaré un papel igual a este si no se me pierde» Traía puestas las ropas... un collar de abalorios blancos y azulados, una cadenita con una medalla de la Purísima y en el adverso el nombre de Pilar y unos vizcochos envueltos en un papel" [sic]

Los bizcochos aparecen registrados como otra prenda más, podían ser como una pequeña gratificación para quien iba a cuidar a la hija abandonada, pero probablemente no

\footnotetext{
${ }^{439}$ Folio no 76. Libro de Exposiciones de 1909- 1. ADPVA

${ }^{440}$ Folio no 190. Libro de Exposiciones de 1910- 1. ADPVA

${ }^{441}$ Folio no 99. Libro de Exposiciones de 1911- 1. ADPVA
} 
pretendieran eso, ni ser una señal de identificación, sino que simplemente fueran para la niña que tenía casi dos años. No volvió con su madre, se crió con un ama que la prohijó hasta los diez años y reingresó en el asilo, no se dice como es habitual la causa del retorno, y falleció interna a los doce años "á consecuencia de tuberculosis peritoneal"

Inusual en estas circunstancias es un retrato que podría ser de la madre, se encuentra descrito en el libro junto con las ropas repitiendo exactamente lo que dice la nota que también acompañaba al niño

"este niño nació el dia 16 de Marzo de 1900 a las 4 1⁄... Ileba por señal un portaretratos con el retrato de una señora colgado de una cinta de seda azul" 442 [sic]

Es de suponer que estos objetos se conservarían para el niño, pero no he encontrado constancia documental al respecto en ningún registro, ni en los libros tanto de entradas como de salidas ni en los expedientes personales ni en cartas o documentos sueltos se hace mención a este asunto. Quizá por el temor de que desaparecieran, algunos padres utilizaban recursos más expeditivos y hacían marcas en el propio niño, que para ser realmente eficaces debían ser permanentes.

Las señas corporales permanentes son sin duda un buen elemento de identificación, por eso cuando el niño tenía marcas de nacimiento como lunares, manchas o una polidactilia se registraban en los folios de inscripción y solían mencionarse en las notas

"Policarpo Julio Madrazo Vega nació en Valladolid el dia 26 de Enero á las dos de la madrugada, en la calle.... Fue bautizado...siendo sus padrinos... es hijo de Carlota Madrazo Vega = El niño tiene una especie de lunar en el muslo izquierdo... ${ }^{A 43} \quad[\mathrm{sic}]$

“... expuesto en el torno de este establecimiento con un papel que dice "Valladolid dia 20 de Julio de 1910, el niño que entra en la casa de Maria tiene 6 dedos en la mano izquierda»= escrito á máquina se lee en el mismo papel "Lisboa fracape»..." ${ }^{\text {"44 }}$ [sic]

“... fue expuesto en la cuna del Establecimiento con las ropas... tiene la niña una mancha encarnada en el lado izquierdo" ${ }^{\prime 45}$ [sic]

La transcripción es fiel, hay un error en el registro pues era un niño y se llamaba Vicente y se presentó en el torno sin papel y como algo distintivo, aparte de la mancha, "una toquilla de pelo de cabra color de rosa".

\footnotetext{
${ }^{442}$ Folio no 108. Libro de Exposiciones de 1900- 1. ADPVA

${ }^{443}$ Folio no 51. Libro de Exposiciones de 1902- 1. ADPVA

${ }^{444}$ Folio no 261. Libro de Exposiciones de 1910- 2. ADPVA.

${ }^{445}$ Folio no 117. Libro de Exposiciones de 1904- 1. ADPVA
} 
El Hospicio registraba cualquier peculiaridad física en el folio de inscripción de los niños del torno, así como vimos que algunas niñas venían con pendientes, los dos o uno solo ("en la oreja derecha lleva una arilla al parecer de oro ${ }^{\prime 446}$ ), otras se presentaban con los agujeros abiertos y un hilo de seda en su lugar para que no se cerraran, quizás con vistas a colocárselos en el futuro

$$
\begin{aligned}
& \text { "Tiene las orejas abiertas y una seda blanca"447 } \\
& \text { "Tiene las orejas abiertas y lleva unas hebras de seda blanca" }{ }^{448}
\end{aligned}
$$

La nota de esta niña dice que nació seis horas antes de la exposición, podríamos decir que tuvo una historia inusual para una expósita, fue prohijada por la nodriza que la crió y la misma nodriza la entregó a su madre que la reclamó a los 8 años.

\begin{abstract}
"... expuesto en el torno cuna de este Hospicio con un papel que dice "Nacio la niña hija de Isidra Dominguez el dia 9 de Septiembre de 1910 á la hora de las tres de su mañana Recibió agua de socorro=Desea se ponga por nombre Maria» Traia puestas las ropas... todo usado, tiene el labio de arriba mellado" ${ }^{149}$ [sic]
\end{abstract}

Es raro que aparezcan cuestiones de tipo clínico en los libros, se registraban en la ficha médica archivada en el expediente personal pero pocas veces las vemos reflejadas en el folio de inscripción, en este caso se haría por ser una seña muy característica de identificación. De hecho en otro caso similar la anotación se ve que se hizo posteriormente, probablemente cuando se pasó a la dirección el reconocimiento médico, por los términos que emplea

\footnotetext{
" (Nota) Esta niña tiene el defecto de conformación de labio leporino con doble fisura palatina y conjuntivitis" ${ }^{450}$ [sic]
}

Esta niña se presentó en el torno sin nota y falleció tres días después "a consecuencia de Sífilis Congénita". La niña anterior se presentó con una nota pero en ella no se dice nada sobre el defecto congénito, las malformaciones todavía eran consideradas como un estigma social fruto del pecado, falleció en la Inclusa a los cinco días "á consecuencia de "Falta de desarrollo»". Lo mismo ocurriría en el caso del niño Manuel Chillón, expuesto en el torno con 4 días y una nota que decía que "se deja por no poderle atender no por abandono"; posteriormente se ha escrito

"este niño es manco de los antebrazos faltándole ambas manos y en la extremidad derecha tiene solo un dedo el pulgar y en la izquierda dos dedos el pulgar y el índice, siendo su estado general de atrofia muscular"${ }^{\prime 451}$ [sic]

\footnotetext{
${ }^{446}$ Folio no 284. Libro de Exposiciones de 1913- 2. ADPVA. Esta niña tenía un año de edad

${ }^{447}$ Folio no 283. Libro de Exposiciones de 1910- 2. ADPVA

${ }^{448}$ Folio no 347. Libro de Exposiciones de 1911- 2. ADPVA

449 Folio no 305. Libro de Exposiciones de 1910- 2. ADPVA

${ }^{450}$ Folio no 98. Libro de Exposiciones de 1909- 1. ADPVA
} 
El niño falleció también "á consecuencia de Falta de desarrollo" catorce días después.

La siguiente nota dice que el niño tiene estrabismo, "el mirar atravesado", se ha registrado en el libro porque se transcribió el papel del torno, si no fuera por eso probablemente sólo aparecería en su ficha médica,

"Recójase este niño.- A este niño trátenle con mucha consideración que en su dia dado muy posible será que se pueda reclamar ó saber quien le ha llevado se llama Amador Diez tiene 30 meses de edad tiene el mirar atravesado esta bautizado 1ㅇ de Octubre de 1903 = En el reverso pone "Ojo con este niño»"452 [sic]

Existe algún registro aislado de este tipo en los expósitos procedentes de los pueblos que entraban por la oficina; si no se anotaban por sistema en los libros es porque las anomalías físicas ya se encontraban registradas, pues se hacían constar en el Registro civil como señas de identidad

"... ingreso en este Asilo... con certificación del Sr Juez de Medina del Campo, donde dice que es hijo de padres desconocido con la seña particular de tener seis dedos cada pie y otros seis en la mano derecha haciendo un total de veinte $y$ tres $^{\prime \prime 453} \quad$ [sic]

No obstante lo más llamativo y tremendo son las marcas en el cuerpo del niño, sobre todo hay quemaduras, que parecen hechas a propósito y con la intención supuesta de servir de señal de identificación; un recurso sin duda desproporcionado y desesperado para asegurarse de la identidad del hijo al recuperarle. Una acción que parece tan cruel en el fondo está expresando la intención de recuperar al niño en un futuro más o menos mediato, téngase en cuenta que el propio hijo podía ser desconocido sobre todo si se dejó de recién nacido, lo más lamentable es que ese futuro casi nunca llegaba. Afortunadamente fue una táctica muy rara vez utilizada, recojo las que he encontrado, 8 en total en los 14 años en los Libros de Exposiciones:

“...en la pierna izquierda tiene una marca al parecer echa a fuego" ${ }^{454}$ [sic] (fo 67, LE 1906- 1)

En la nota se dice que era hija natural y que la ingresan porque falleció la madre. La niña tenía 10 días cuando la expusieron y murió cinco meses después con la nodriza.

"tiene una quemadura en el brazo derecho y un papel que decía "Reconózcase con el nombre de Benigna, sin bautizar»" [sic] (fo 148, LE 1905- 1)

\footnotetext{
${ }^{451}$ Folio no 419. Libro de Exposiciones de 1910- 2. ADPVA

452 Folio no 333. Libro de Exposiciones de 1903- 2. ADPVA

${ }^{453}$ Folio no 41. Libro de Exposiciones de 1903- 1. ADPVA

${ }^{454}$ Folio no 67. Libro de Exposiciones de 1906-1. ADPVA
} 
Este niño no llegó a salir del Hospicio, falleció en el asilo cuatro meses después " $a$ consecuencia de atonía gastrointestinal".

"En la nalga izquierda tiene una quemadura y un lunar en la paletilla del mismo lado" [sic] (fo 53, LE 1909-1)

Siempre sobraban, pero este pobre infeliz ya tenía un lunar como señal. Tampoco le sirvió de nada pues murió en el asilo dos meses después "á consecuencia de Enterocolitis".

La intencionalidad de las quemaduras queda clara, algunas están hechas con objetos como monedas para darles una forma reconocible, incluso se refieren en las notas del torno

"... expuesta en el torno... la niña tiene una quemadura en el brazo izquierdo en forma de una horquilla y un papel que decía= "La niña Bernardina Gonzalez Martin hija de Julia Gonzalez Martin... Contiene señas en el brazo Izquierdo, una marca que indica una U. Julia Gonzalez Martin" [sic] (fo 344, LE 1905- 2)

Esta niña sobrevivió pero no volvió con su madre, en la última anotación la Comisión acordó entregarla "para compañía" en 1912.

"Traia por ropas unos trapos y tiene una quemadura en el brazo izquierdo en forma de cinco centimos" [sic] (fo 392, LE 1911- 2)

La madre dio todos sus datos en la nota que dejó en el torno. La niña falleció con la nodriza año y medio después.

“... fue expuesta en la cuna... tiene una quemadura de cinco centímetros en la espalda y papel escrito con tinta que dice Se desea pongan á la niña Victoria Cachan nació el 30 de Marzo Esta sin bautizar lleva una señal en la espalda de una Moneda de 5 centimetros" [sic] (fo 155, LE 1902-1)

La niña falleció en el asilo al mes siguiente "á consecuencia de enterocolitis"

"Traía puestas las ropas siguientes, pañal de algodón un trapo, camisa de id con entredos y tira bordada jubón de percal blanco con ramos negros y verdes, mantilla de muletón blanca, fajero una tira id labrada, gorro de brillantina con tira bordada, todo en buen uso, una medalla de la Purísima de plata; una quemadura al lado izquierdo de espalda en forma de óvalo" (fo 147 LE 1912-1)

Por falta de señas que no quede, parece el caso de esta niña que ingresó a las 3 horas de nacer, por lo que dice la nota que la acompañaba. Falleció con la nodriza al año siguiente.

Hay un par de registros en los que no se dice que se trate de una quemadura

“... al ser expuesta la acompañaba un papel que decía "Deseo á esta niña se ponga el nombre de Esperanza y cuidad del brazo Izquierdo» que en el brazo izquierdo tiene al parecer la marca de una llave pequeña" [sic] (fo 116, LE 1909- 1)

Por el tipo de marca podemos suponer que ésta sería hecha a fuego. La niña falleció con la nodriza cinco meses después. 
Este tipo de procedimientos podía estar arraigado en la mentalidad contemporánea en relación con los expósitos, pues recoge Vicente Pérez Moreda que algunos padres entregaban a los niños marcados y que era una práctica habitual en algunas inclusas en épocas anteriores señalizar a los expósitos, incluso a hierro como al ganado, para mostrar la inclusa de origen con una marca imborrable y evitar algunos de los muchos fraudes que se cometían con estos niños; esta barbaridad se cambió por una medalla identificativa ${ }^{455}$

"... fue expuesta en el torno de este Asilo con un papel que dice "Esta niña se llama Victoria Garcia ingresó el 29 de Diciembre á las 2 de la mañana». Traía puestas las ropas... todo nuevo, todas las prendas menos la toquilla y el gorro llevan las iniciales B C en la espalda de señal tiene una V" [sic] (fo 387 LE 1912-2)

Esta niña falleció con la nodriza en 1912. En este caso no podemos asegurar ni siquiera que la marca, la inicial del nombre, fuera una lesión podría estar escrita con tinta, como ocurrió con la siguiente niña en la que en el registro dicen que la marca parece escrita a lápiz, al menos es incruenta y más que suficiente visto el resultado final, además puede verse que en esta niña también se colocaron otras prendas como señal

"... fue expuesta en el torno de este asilo con un papel metido en un sobre que decía "La niña que lleva esto se llama Luciana Fernandez, esta bautizada tiene dos meses cumplidos y una pequeña señal en el brazo izquierdo»= en el sobre se lee "Para que conste en los libros del Hospicio» Por ropas traia unos trapos, también tenia puesto un collar de abalorios azules con tres medallas blancas, una del Niño de Praga de San José, otra de la Virgen del Rosario y otra Milagrosa. En el brazo izquierdo tiene una cruz que parece hecha con lapiz" ." [sic] (fo 319, LE 1908- 2)

Es un caso que da que pensar, además de entregar varias señales dice el registro que la madre se presentaría posteriormente en la dirección para completar los datos de la niña, las circunstancias de esta mujer debieron ser muy penosas para entregar a su hija porque evidentemente no se desinteresó de ella, sin embargo no la recuperó, la niña falleció con la nodriza en 1910.

De toda esta serie, solamente volvió con su madre la niña del folio 301 de 1908, María Dolores fue depositada en el torno el 19 de septiembre de 1908 con unos trapos y sin ningún papel ni señal más que una quemadura en la pierna izquierda y el 19 de octubre se entregó a su madre por acuerdo de la Comisión.

\footnotetext{
455 PÉREZ MOREDA V. op.cit, p 91: Refiere prácticas realmente crueles, en el Hospital Real de Santiago existía en el siglo XVII la figura del "marcador de expósitos" que luego sería sustuido por el cirujano, que marcaban a los niños con un sello de plata al rojo vivo, por lo menos hasta principios del siglo XIX. En otras inclusas como la de Pamplona les agujereaban las orejas y les colocaban un hilo y aparecieron niños marcados a fuego, igual que en Palencia y Salamanca, pero advierte que podrían ser marcas hechas por los progenitores y que todavía a principios del siglo XX algunos padres solicitaban a la inclusa que marcara al niño para poder identificarle con más seguridad en el futuro.
} 
Todos los anteriores son niños del torno, sin embargo, en los libros de Entradas de la Inclusa he encontrado alguna señal más registrada en niños que entraron por la oficina y no se anotaron en los libros oficiales, probablemente porque estos llegaban la mayoría ya identificados, aunque también ingresaban por la oficina los expósitos de los pueblos; un expósito que se trajo desde Medina del Campo presentaba "una quemadura en la nalga izquierda en forma de cinco céntimos" (fo 416 de 1907). En la niña del torno en su folio, 241 de 1909 se han registrado "unos evangelios de seda color rosa con puntillas y antijuelas" (sic) (debe referirse a lentejuelas), en el libro de la Inclusa además han escrito "sedas en las orejas". En estos libros de la Inclusa parece que registraban con más cuidado todo lo que pudiera servir para el reconocimiento del niño en el registro del folio 343 de 1907 dice que "Entró por la oficina un niño bautizado con el nombre de Serafín Alonso ropas trapos tiene el labio de arriba mellado", esta peculiaridad no consta en su folio oficial, pero ya hemos dicho que este tipo de datos no se registraban en los libros, a pesar de ser muy identificativos, se reservaban a la ficha clínica. Vemos que también anotaban en el libro de la Inclusa las ropas de todos los niños, también los de la oficina no sé si con intención de conservar para el niño las prendas o como rutina, de la misma manera que se anotaban las del torno

"Abril 14. Año 1902 folio 142 entro por la oficina una niña bautizada con el nombre de Lucia Carmen tiene26 meses destete vino de luto y de corto salió..."

Visto todo lo anterior es obligado decir que ese afán por registrar todo lo que pudiera servir para identificar al expósito no es una preocupación exclusiva de la Inclusa de Valladolid, es algo general y todas las inclusas tomaban medidas similares, entre otras cosas por una cuestión legal, la ley obligaba en este sentido. La ley de 17 de junio de 1870 del Registro Civil en su artículo 49, dedicado a la inscripción del nacimiento de los expósitos, pide expresamente recoger todo lo que pueda servir para la identificación del niño ${ }^{456}$

Art. 49. Respecto á los recién nacidos abandonados ó expósitos en vez de las circunstancias números 3으 6ำ yo del artículo anterior se expresarán:

1 La hora, día, mes, año y lugar en que el niño hubiese hallado o expuesto

2 Su edad aparente.

3 Las señas particulares y defectos de conformación que le distingan

4o Los documentos ú objetos que sobre él ó á su inmediación se hubiesen encontrado; vestidos ó ropas en que estuviese envuelto y demás circunstancias cuya memoria sea útil conservar para la futura identificación de su persona.

\footnotetext{
456 (17 de Junio. Publicada en 20) Ley mandando establecer desde luego, con el carácter de provisional, el registro civil en la Península é islas adyacentes, conforme al adjunto proyecto de ley. 1870. Título II De los Nacimientos.
} 
Y va más lejos, porque el siguiente artículo exige conservar los documentos u objetos de fácil conservación que se presentaran con él y que sirvan para su reconocimiento

Art. 50. Los objetos encontrados en el niño expósito ó abandonado, si fueren documentos se encarpetarán y archivarán en la forma dicha en el art. 29, y si fueren objetos de otra clase, pero de fácil conservación, se custodiarán también en el mismo archivo que aquellos, marcándolos de la manera conveniente para que en todo momento puedan ser reconocidos.

En ocasiones, las menos, las señas cumplían con su función y servían para identificar al expósito, encontramos historias con final feliz; tan pocas que produce alegría sincera casos como el de María Dolores o el de Teófila:

"'En 31 de Enero de 1910 a las 12 horas fue expuesta en el torno de este Asilo con un papel que decía «Niña Teófila Ruiz Arranz hija legitima de Julian y Petra, nació el dia 13 de Octubre de 1909, á las ocho y media de la noche, esta bautizada e inscripta en el registro Civil, el padre se queda con nota igual para la confrontación en su dia" [sic]

Teófila salió para crianza el 7 de febrero y es probable que los padres la localizaran posteriormente, pues no consta en su folio que fuera reclamada ni devuelta por la nodriza, lo que habitualmente aparece registrado, y el último apunte dice "Baja definitiva por hallarse con los padres. Acuerdo Comisión 1914- 8- 24" (fo 34, LE 1910-1)

Valga el siguiente testimonio como resumen de este capítulo y reflejo de una situación que era habitual y socialmente aceptada, aunque no de forma manifiesta; lo único inusual de este registro del folio 118 de 1907 es el final, pero acabamos de ver que algunas veces estas historias acababan bien, o así nos parece teniendo en cuenta otros desenlaces posibles

"En tres de Abril de mil novecientos siete á las doce horas y treinta minutos fue expuesto en el torno cuna de este Asilo con las ropas siguientes... tiene colgado del cuello con un cordon negro media medalla blanca de la Virgen de la ropa toda usada y una carta que dice: en el sobre "A las Hermanas de San Vicente de Paul encargadas del torno y cunas del Hospicio de esta ciudad" y la carta que dice «Esta niña está bautizada. Se llama Juliana Vaquero. Nació el dia diez y siete de Marzo de este año 1907. Es hija de soltero y soltera pero que hoy no se pueden casar. Se ruega al Sr Director del hospicio D. Justo Esteban y a las hermanas encargadas del cuidado del expósito que procuren por esta niña, la cual se espera poder reclamarla pronto. Al desprenderse de ella su desgraciada madre pide por Dios que los encargados del establecimiento la sustituyan en los cuidados maternales. Valladolid 3 de Abril de 1907. La niña tiene una señal pero en las ropas que lleva, si se conserva esta carta con las señas de todo podrá ser reconocida. Se bautizó el dia 21 de Marzo. Su madre Lucia Vaquero Vazquez»...

En 17 de Febrero de 1913 fue entregada a su Madre cumpliendo acuerdo de la Comisión provincial y firma su recibo

[Firmado por] Lucia Vaquero" [sic] 
Viendo casos como este no podemos por menos de pensar los sufrimientos que se podrían haber ahorrado con políticas progresistas como la de la inclusa de Pamplona o la de Pontevedra que subvencionaban a las madres lactantes sin recursos para evitar la separación del hijo, aliviando al menos la situación de muchas familias y reduciendo el abandono de hijos legítimos. A este tipo de ayudas no optaban las madres solteras, parece que no se planteó como una posible solución la idea de pagar a las madres en vez de pagar la crianza a nodrizas mercenarias, quizás por miedo a la picaresca popular, lo que no es excusa porque existía de todas formas, o por una cuestión económica, aunque bastaría con pagar lo mismo a la madre que a la nodriza, si bien, es probable que saliera más caro porque quizás con este moderno método la mortalidad no habría sido tan alta, ya es imposible saberlo. De todos modos aún con ayudas económicas difícilmente una mujer soltera en la época podría hacer frente a la crianza de un hijo, los sueldos de las nodrizas eran miserables e insuficientes y los pocos trabajos a los que podía optar una mujer no permitían ni de lejos lo que hoy llamamos conciliación familiar.

\subsubsection{VÍA OFICIAL DE INGRESO EN LA INCLUSA. COMISIÓN PROVINCIAL DE LA DIPUTACIÓN Y GOBERNADOR CIVIL}

La vía reglamentaria de entrada en la Inclusa era a través de la Diputación. La Comisión provincial era la encargada de evaluar y resolver en sus sesiones las solicitudes de admisión en el Hospicio, en cualquiera de sus departamentos. La admisión del niño debía ser "solicitada necesariamente por sus padres, y en defecto de éstos por parientes próximos ó Autoridad local" "Las instancias [debían ser] dirigidas á la Diputación y presentadas en la Secretaría; y á la solicitud acompañarán documentos públicos expedidos por funcionarios ó autoridades competentes, que acrediten las condiciones exigidas para el ingreso en el Establecimiento" [sic] (Art. 9 y 10, Regl 1910 y 1927). Los tramites exigían acreditar que el niño y su familia cumplían los requisitos de admisión, que se especificaban en los Artículos 5 y 6 de los Reglamentos de 1910 y 1927; aparte de las circunstancias de orfandad o de ilegitimidad, en dichos artículos para las diferentes condiciones de ingreso se insiste en la situación de pobreza y la falta de recursos para criar y alimentar al niño (ver el apartado Entrada en la Inclusa).

Junto a los documentos de inscripción en el registro civil y de bautismo, debía por tanto acreditarse la imposibilidad de amamantar al niño mediante certificado médico y la 
condición de pobreza mediante la correspondiente certificación expedida por el ayuntamiento, condición que sería "apreciada por la Diputación teniendo en cuenta para cada caso el número de personas de que se componga la familia del causante, la naturaleza de los medios de fortuna con que cuenta y las demás circunstancias que puedan inducir al conocimiento de la verdadera posición de los solicitantes" (Art. 11). El reglamento de 1927 en su Art. 310 relata los documentos que deben presentarse para solicitar el ingreso, esta relación no aparece en la normativa anterior:
"Los que sean admitidos por la Diputación provincial para lactancia deberán presentar los siguientes documentos:
1 Instancia del padre, o de la madre a falta de éste, solicitando el ingreso
20 Certificación facultativa haciendo constar que la madre no puede lactar.
3o Certificación de pobreza, expedida por el secretario del Ayuntamiento con referencia a los amillaramientos, con el Vo $B$ o del Alcalde.
40 Certificación de ser vecino del pueblo con dos años de residencia.
5o Certificación de inscripción del niño o niña en el registro civil.
60 En caso de que hubiere muerto la madre, en lugar del documento número 2, se acompañará la certificación de defunción.
70 Si el niño o niña fuesen huérfanos y no tuvieren ninguna persona que le represente, el expediente se hará de oficio.
Para el ingreso de niños mayores de quince meses, el expediente constará de los mismos documentos, excepto el señalado con el número 2.
En todas las certificaciones que a estos fines se expidan se hará constar expresamente, que es con objeto de ingresar en el Establecimiento de beneficencia a que el expediente se contraiga."

Posteriormente, el ingreso debía ser aprobado en las sesiones de la "Comisión provincial, previo informe del oficial del Negociado de Beneficencia" (Art. 12). Entre la documentación revisada en el ADPVA solamente he encontrado una papeleta oficial con la resolución de la Comisión, pertenece a dos hermanos que ingresaron en el Hospicio en la sección de mayores (en negrita lo que aparece en la ficha rellenado a mano)

\footnotetext{
"Esta Corporación en sesión de... I día de hoy ha acordado el ingreso de los niños Bárbara y Jesús Villarroel de 9 y 8 años naturales de esta ciudad para ...cuidado... en ese Hospicio, de conformidad y á los efectos del Reglamento. Es adjunta la partida de...inscripción ó nacimiento de... precipitad...os niñ...os. Dios guarde á $V$. muchos años.

Valladolid... 7... de .. Febrero... de...1913

EL VICEPRESIDENTE (firma) $)^{, 457} \quad$ [sic]
}

Hoy nos resulta llamativo el adjetivo "precipitado" que se utiliza en esta papeleta oficial para referirse al niño admitido en el Hospicio, era una forma de llamar a los expósitos, niños abandonados, utilizando el término en el sentido de arrojado, lanzado o echado de $\mathbf{s i}^{458}$.

\footnotetext{
${ }^{457}$ Expediente personal L M (Libro de Mayores) 17, Folio 68. Signatura: caja 2224, expediente 24417. ADPVA
} 
En los casos urgentes que no podían esperar a la próxima reunión de la Comisión, el Presidente de la Diputación o el Vicepresidente de la Comisión provincial podían ordenar el ingreso provisional "siempre que el expediente presentado al efecto reúna los requisitos reglamentarios" (Art. 13), hasta que se presentaba toda la documentación en regla y lo aprobaba la Comisión. El 3 de abril de 1909 el Vicepresidente de la Comisión provincial envía al Director del Hospicio la orden de ingreso de la niña Dorotea, hija de madre soltera sin recursos para criarla, que ingresa ese mismo día en el Hospicio.

\begin{abstract}
"Vista una instancia de Robustiana Crespo vecina de Mayorga, he dispuesto ingrese para lactancia en ese Establecimiento su nieta Dorotea de 6 días de edad, hija de su hija Marcelina soltera por justificar que esta no puede lactarle ni cuenta con recursos para satisfacer los gastos que aquella ocasionaría. Se adjunta la certificación del R. C. inscripto. Dios guarde..." [sic]
\end{abstract}

La carta está escrita en un folio timbrado de la secretaría de la Comisión Provincial siguiendo el modelo oficial y firmada por el Vicepresidente, se conserva junto con el certificado del registro civil en el expediente de la niña, inscrita en el folio 127 del libro de 1909. Las pocas órdenes de ingreso que he encontrado en los expedientes personales tienen las mismas características, puede tratarse de hijos ilegítimos, como el caso anterior, o legítimos y recogen la circunstancia de que no se puede atender a su sostenimiento.

"Vista una instancia de Santos Garcia vecino de Mayorga y del expediente que acompaña he dispuesto el ingreso para lactancia en su Hospicio de su hija Eufemia Garcia de la Fuente por no podérsela dar la madre ni costeársela el recurrente... Valladolid 19 Sepbre 1912. El Viceprt." [sic]

En el margen lateral se lee: "1912 fo 331", que corresponde a su inscripción en el Libro de Exposiciones de 1912, folio no 331, donde encontramos el registro correspondiente:

"Eufemia Garcia de la Fuente.

En 19 de Septiembre de 1912 ingresó por Orden del Sr Vicepresidente con certificación del Registro civil donde consta que nació el dia 3 de Septiembre corriente y que es hija legitima de Santos y Margarita" [sic]

En las mujeres viudas la pobreza se debía presuponer, en la siguiente orden que se transcribe literalmente, con las tachaduras que en ella aparecen, se admite el ingreso de los hijos de una viuda, aunque parece que a última hora solo ingresó uno, es la única papeleta de las pocas localizadas, donde no se hace referencia a la falta de recursos.

\footnotetext{
${ }^{458}$ Entre las acepciones de la palabra PRECIPITAR, en los diccionarios, tanto de la época como el actual también está la que en sentido figurado significa "Exponer a uno a una ruina espiritual o temporal" RAE 1899 Diccionario de la lengua castellana por la Real Academia Española. Décimatercia edición. Madrid. pp 805, 1
} 
"Vista una instancia de Saurofila Vallecillo viuda, vecina de Urueña de 38 años de edad, he dispuesto el ingreso en ese Hospicio de sus hijos (Mauricio $\forall$ ) Modesto Abril Vallecillo de 5 - 3 años de edad

Son adjuntas las partidas de inscripción de los niños. Dios g... Valladolid 17 Febrero 1913. El Viceprt."

En el margen del folio: "Exp 913 fo 75"

En una esquina dice: "Solo ingreso el Modesto" [sic]

La propia Comisión podía acordar excepcionalmente el ingreso antes de completar todos los trámites, es de suponer que cuando se presentaban en fecha previa a la sesión

\section{"Agustín Alonso Martínez}

En 2 de Agosto de 1912 ingresó por acuerdo de la comisión provincial quedando en remitir la certificación del Registro civil tan luego se presentare. Por datos particulares suministrados se dijo que este niño es hijo de Elena Alonso Martínez, soltera natural de Serrada, de 24 años"459 [sic]

El niño falleció tres días después de su ingreso "a consecuencia de Enterocolitis"

Tanto si la admisión era aprobada por la Comisión provincial como si era por orden del presidente o vicepresidente de la Comisión, el ingreso en la Cuna se hacía a través de la oficina del Hospicio que pasaba la orden a la Superiora mediante una papeleta (en negrita lo que se ha rellenado a mano):

"Exposición de... 1913... núm 75...

La Señora Superiora de las Hijas de la Caridad admitirá a el niño... Modesto Abril Vallecillo... con destino á la sala de los ... Bautizados ... anotando al dorso las ropas y señas particulares Valladolid... 21... de...Febrero... de... 1913

El Director"

En la esquina superior se ha escrito: "Destete 3 años". Dos días después el niño, hijo de la viuda anterior de Urueña, salía para crianza con una viuda de la capital que probablemente lo prohijó, al menos no se hicieron más registros en su folio después de la salida y en el expediente solo hay dos justificantes de pago a la nodriza hasta agosto de 1913, con una nota en la que se advierte que en el próximo pago se presentará el "plomo".

La forma de ingreso, por acuerdo de la Comisión o por orden directa de su presidente o vicepresidente, se registraba en los libros de Entradas. El ingreso podía ser inmediato, el mismo día de la decisión, como si ya de antemano se diera por hecho. El 4 de febrero de 1908 la Comisión acordó admitir a cuatro niños, uno de ellos ingresó el mismo día, era un niño ilegítimo (fo 37):

\footnotetext{
${ }^{459}$ Folio no 280. Libro de Exposiciones de 1912- 2. ADPVA
} 
"Alejandro Vega

En 4 de Febrero de 1908 ingresó por acuerdo de la Comisión provincial de la misma fecha con certificación del Juez Municipal de Mayorga donde dice nació el 30 de Enero de 1908 y es hijo natural de Delfina Vega ${ }^{\text {"460 }}$

Los otros ingresaron los días 8 (fo 40) y el 9 (fo 45) de febrero, dos niños legítimos, el segundo huérfano de padre, y la última niña entró el 27 de febrero (fo 66) hija de madre soltera, que parece que se pensó mucho entregar a la niña. No es habitual encontrar en los libros registrada la fecha de la resolución.

La Comisión volvió a reunirse 13 días después, el día 17 de febrero, e ingresó ese mismo día el niño del folio no 52, hijo natural. Entre medias ingresó una niña el día 12 de febrero por orden del Vicepresidente, no se recogen las circunstancias que justifiquen la urgencia del ingreso para no poder esperar a la siguiente sesión, en el registro únicamente dice que "nació el 28 de Enero de 1908 y es hija legítima de Valentín y Encarnación". En los libros no se registraba habitualmente el motivo del ingreso cuando era por esta vía, solamente la condición legal, legítimo o natural o en todo caso huérfano de padre o madre; se entiende que si eran aceptados cumplían los requisitos de admisión y por tanto o eran hijos ilegítimos o de padres sin recursos. Excepcionalmente la orden podía llegar al Hospicio por vía telefónica, eran situaciones especiales y entonces si se justificaba el ingreso

"En 6 de febrero ingresó en este Asilo con carácter provisional de Orden del Sr Vicepresidente (telefónica) por encontrarse su Madre en el Hospital de Esgueva en periodo agónico y estar el niño abandonado sin perjuicio de que se remitirá la certificación de inscripción tan pronto como se tramite el expediente"

A pesar de la posibilidad de esta vía oficial rápida de ingreso por la orden directa del Presidente de la Diputación, que lo era también de la Comisión provincial, o del Vicepresidente de la Comisión, para eludir los trámites o reducir la espera hasta su resolución, o bien por evitarse dos viajes a la capital, se dejaban niños en el torno con la documentación exigida para el expediente de admisión. En 1908, por seguir con el mismo año de las citas anteriores, 17 de los 158 niños expuestos en el torno presentaron todos o parte de los certificados necesarios para la tramitación oficial

"En 17 de Diciembre de 1908 á las 17 horas fue expuesto en el torno de este Establecimiento con partida de bautismo certificación facultativa id de vecindad y pobreza, instancia dirigida al Sr Vicepresidente de la Comisión provincial y certificación del Juez municipal de la Villa de Iscar donde dice que nació esta

\footnotetext{
${ }^{460}$ Folio no 37. Libro de Exposiciones de 1908- 1. ADPVA
} 
niña el 20 de Septiembre de 1908 y que és hija natural de Pascuala Herrero Merino, soltera de 22 años natural y residente en Iscar" ${ }^{461} \quad$ [sic]

"expuesto en el torno con un expediente incompleto de los exijidos para ingresos..." ${ }^{462}[\mathrm{sic}]$

Otra posibilidad de ingreso por cauces oficiales era a requerimiento de una autoridad como el Gobernador Civil que podía ordenar la admisión inmediata en el asilo, sin solicitud previa por parte de la familia. Esta vía se utilizaba en ocasión de niños abandonados, perdidos, o que quedaban sin cuidadores de forma repentina. Según su situación podían ser acogidos en el Hospicio de forma permanente, en cuyo caso se tramitaba el ingreso y se aprobaba por la Comisión provincial, o de forma provisional hasta la solución del problema causante.

"En 1ㅇ de Marzo de 1901 ingresó por orden del Sr Gobernador Civil con el carácter interino con fecha 4 del mismo mes fue acordado su ingreso por la Comisión provincial con partida de bautismo donde dice fue hallada el día 26 de Febrero a las siete de la mañana fue expuesta á la puerta de la casa de Felipe Alvarez vecino de Palacios de Campos" $^{463}$ [sic]

"En diez y seis de Marzo de mil novecientos tres ingresó en este Asilo con carácter interino por orden del Sr Gobernador Civil por hallarse abandonados en la vía pública. Es hermano del que ocupa el folio 172 del Libro 14 de mayores de cinco años" ${ }^{464}$ [sic]

Este niño salió para crianza y en el mes de noviembre se entregó a su madre.

Estas órdenes escondían auténticos dramas familiares y sociales, realmente como todas las que rodeaban a estas criaturas que ingresaban en el orfanato. Encontramos niños que quedaban huérfanos e ingresaban todos los hermanos y que eran separados en el Hospicio por su edad

"En 19 de Enero de 1909 ingresó provisionalmente en este Asilo de Orden del Sr Gobernador Civil de esta provincia en cuya comunicación se dice que este niño nació en esta Ciudad, que tiene 3 años de edad y que és huérfano de padre y madre. Es hermano de los que ocupan los folios 267, 268 y 269 del libro 16 de mayores" $^{465} \quad$ [sic]

...niños abandonados porque los padres no los podían criar; en los folio 61,62 , y 63 de 1912 se registran 3 hermanos, el primero de 16 meses fue expuesto en el torno el 17 de febrero de 1912 y los otros dos, de 5 y 6 años ingresaron al día siguiente "con carácter provisional según oficio del Sr Gobernador Civil como Presidente de la Junta de protección a la

\footnotetext{
${ }^{461}$ Folio no 399. Libro de Exposiciones de 1908- 2. ADPVA

${ }^{462}$ Folio no 55. Libro de Exposiciones de 1909- 1. ADPVA

${ }^{463}$ Folio no 71. Libro de Exposiciones de 1901- 1. ADPVA

464 Folio no 104. Libro de Exposiciones de 1903-1. ADPVA

465 Fo 30. Libro de Exposiciones de 1909- 1. ADPVA
} 
Infancia"; cinco años después falleció uno de ellos en el Hospicio y la madre sacó a los otros dos ese mismo mes; da la impresión de que llevaba un seguimiento de sus hijos.

...niños que ingresaban porque los padres enfermaban o eran internados en el hospital o en alguna otra institución y no tenían quien les cuidara

"En 6 de Junio de 1909 á las 12 horas fue entregado en este Establecimiento de Orden y á presencia del Sr Gobernador de esta provincia ... que tiene este niño 8 meses de edad y que quedó abandonado por haber sido su madre trasladada en este mismo día al Pabellon de infecciosos del Hospital provincial..."

El 26 de julio este niño volvería con su padre, podían ser ingresos provisionales

"En 29 de Julio de 1911 ingresó provisionalmente de Orden del Sr Gobernador Civil con comunicación donde dice que esta niña tiene 3 años que se encuentra abandonada por hallarse su madre en el Hospital Provincial con síntomas de próximo alumbramiento y no tener familia que la recoja" ${ }^{467}$.

Dos días después volvió con su madre, pero el 4 de diciembre fue expuesta en el torno con todos sus datos; solo estuvo asilada dos días, "En 6 de Diciembre de 1911 fue entregada á su madre..."; no se dice en el registro si la madre se arrepintió o si la devolvieron por no considerar procedente el ingreso.

O niños que simplemente eran abandonados a su suerte y los padres desaparecían

"En 29 de Julio de 1911 ingresó por Orden del Sr Gobernador Civil de esta provincia con oficio en que se dice que esta niña tiene 6 años de edad que es hija de Miguel y María ambos de ignorado paradero ... Es hermana del que ocupa el folio 425 del libro 16 de mayores ${ }^{\prime 468}$

Esta niña sería entregada a su madre tres años después.

La dirección del Hospicio recibía la orden del Gobernador y debía comunicar el ingreso a la Comisión de la Diputación y se tramitaba el expediente para formalizar la admisión.

"En 25 de Marzo de 1911 ingresó provisionalmente de Orden del Sr Gobernador civil con un volante en el cual se ruega el ingreso por ser hijo de un vigilante que falleció el mismo día encontrándose la madre muy enferma y ser preciso su paso al Hospital, prometiendo dicha Autoridad remitir el expediente con los correspondientes documentos tan pronto como se termine. Este niño es hijo de Antonio y Ciriaca y nació en este mismo mes de Marzo sin que se precise día. Se dio cuenta a la Exma Comisión provincial. ..."

El propio Gobernador podía ordenar la salida del niño cuando se resolvía el problema

\footnotetext{
${ }^{466}$ Fo 202. Libro de Exposiciones de 1909- 1. ADPVA

${ }^{467}$ Fo 265. Libro de Exposiciones de 1911- 2. ADPVA

${ }^{468}$ Fo 263. Libro de Exposiciones de 1911- 2. ADPVA
} 
"ingresó en este Establecimiento con carácter provisional por orden del Sr Gobernador de la provincia... en 12 de Julio de 1901... El 14 de Julio de 1901 por orden del Sr Gobernador se le entrego a su padre y firma"

También ingresaban por esta vía niños con problemas judiciales en el departamento de Mayores y permanecían hasta la resolución del proceso, aunque los Reglamentos de 1910 y 1927 en su Artículo 3 dejan bien claro que el Hospicio no es un reformatorio

"El Hospicio, como Establecimiento esencialmente benéfico, no tiene ni podrá tener el carácter de casa de corrección. Serán admitidos tan sólo en concepto de recluidos por virtud de lo dispuesto en la Real Orden de 12 de marzo de 1891... Los así castigados cumplirán el correctivo en celdas ó habitaciones destinadas a este objeto, y no tendrán comunicación ni trato alguno con los asilados" [sic]

En la GRÁFICA 3-9 se puede ver la distribución de los niños ingresados en la Casa Cuna según la vía de entrada en ella para el período 1900- 1913.

Ingresaron 1450 niños a través de la Diputación provincial, la mayoría (dos tercios aproximadamente del total) lo hicieron por la vía reglamentaria cumpliendo con todos los trámites previos exigidos para la aprobación de su admisión en sesión ordinaria de la Comisión provincial y el resto mediante orden del Presidente o el Vicepresidente de la Comisión, de forma urgente y provisional hasta que se presentaba toda la documentación en regla y se aprobaba. Otros 14 niños entraron por orden del Gobierno Civil, como vía extraordinaria de urgencia. La GRÁFICA 3-17 recoge los ingresos por la vía oficial, incluyendo estos 14, ya que también se tramitaba su admisión y se aprobaba en la Comisión provincial.

\footnotetext{
${ }^{469}$ Fo 221. Libro de Exposiciones de 1901- 1. ADPVA
} 


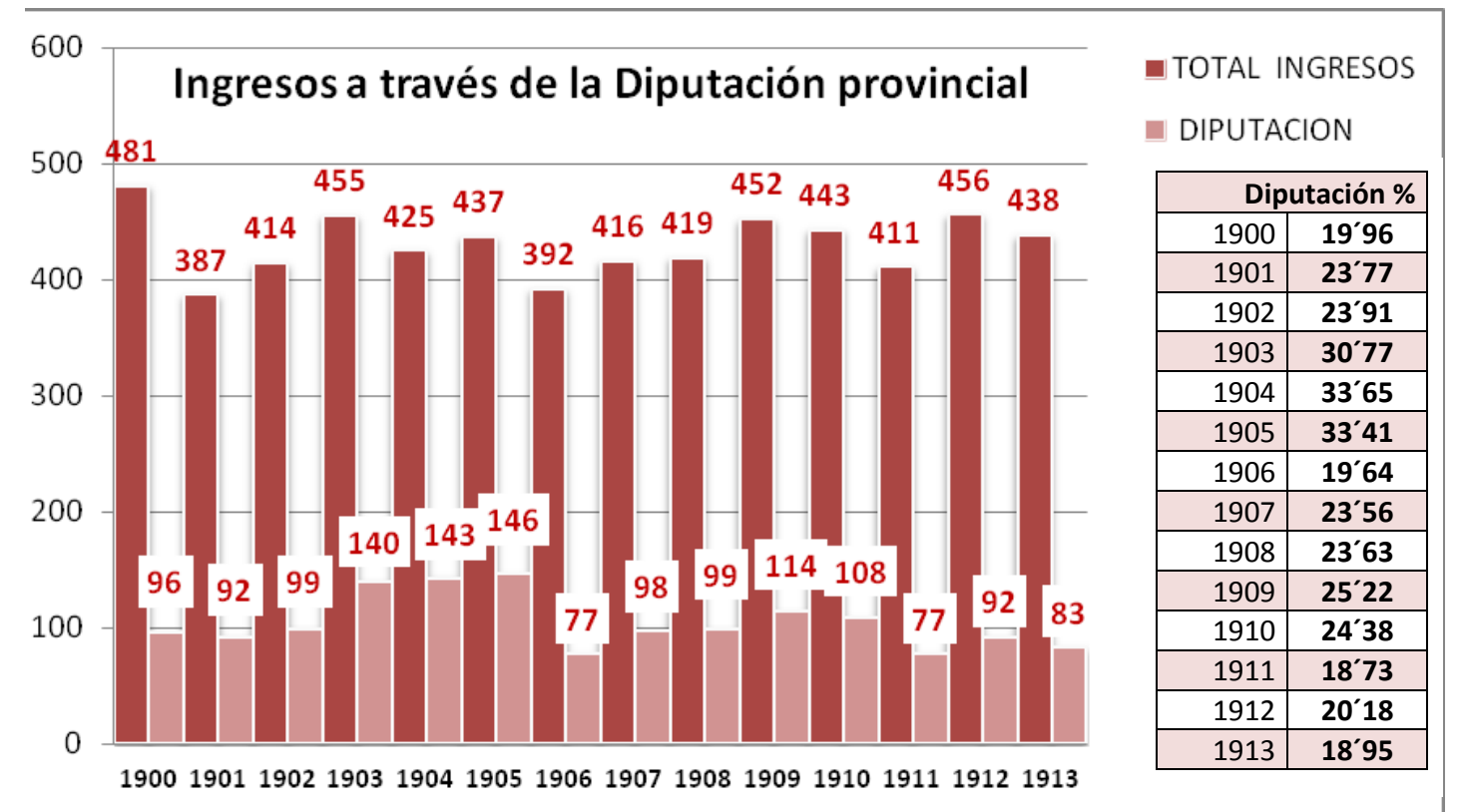

GRÁFICA 3-17: Distribución en valores absolutos y en tantos por ciento de los niños ingresados a través de la Diputación Provincial de Valladolid, por aprobación de la Comisión, por orden del presidente o vicepresidente o del Gobierno Civil en el período 1900-13. Elaboración propia a partir de los Libros de Exposiciones. ADPVA. En el total de ingresos se han contabilizado también los niños "nacidos muertos" considerando que eran candidatos a ingresar.

Puede apreciarse que el número de niños que entraron por esta vía que hemos considerado oficial fue muy variable de unos años a otros, con el mínimo en 1906 y 1911 con 77 ingresos (incluyendo 4 niños por orden del gobernador civil en este último año), que suponen menos del 20\% del total de entradas en esos dos años, y el máximo en 1905 y 1904 con 146 y 143 niños respectivamente, que representan más del 33\% del total anual en ambos ejercicios. Precisamente estos dos últimos años tuvieron el mínimo de ingresos por el torno de la Inclusa, mientras que 1911 fue uno de los ejercicios con más expósitos en valores absolutos y con mayor proporción porcentual (41'85\%). En la GRÁFICA 3-18 vemos la comparativa entre ingresos por el torno y por la Diputación; en general ingresaban más niños por el torno, hay años que llegan a duplicar sobradamente a los oficiales, con la mayor diferencia al final del periodo analizado y en 1900; en la primera década no hay tanta disparidad y en 1904 y 1905 los ingresos a través de la Diputación superaron a los expósitos del torno. Los niños que se depositaron en los otros dos tornos o se abandonaron en los pueblos de la provincia ingresaban "a través de la oficina" porque los ayuntamientos correspondientes tenían la obligación de presentar en ella al niño con los documentos de identificación solicitados, pero debemos considerarlos como lo que son, expósitos en el sentido literal del término, o lo que es lo mismo, niños expuestos o abandonados como lo eran los del torno de la Inclusa Provincial y que al igual que éstos ingresaban directamente sin solicitud previa ni intervención expresa de la Diputación. 

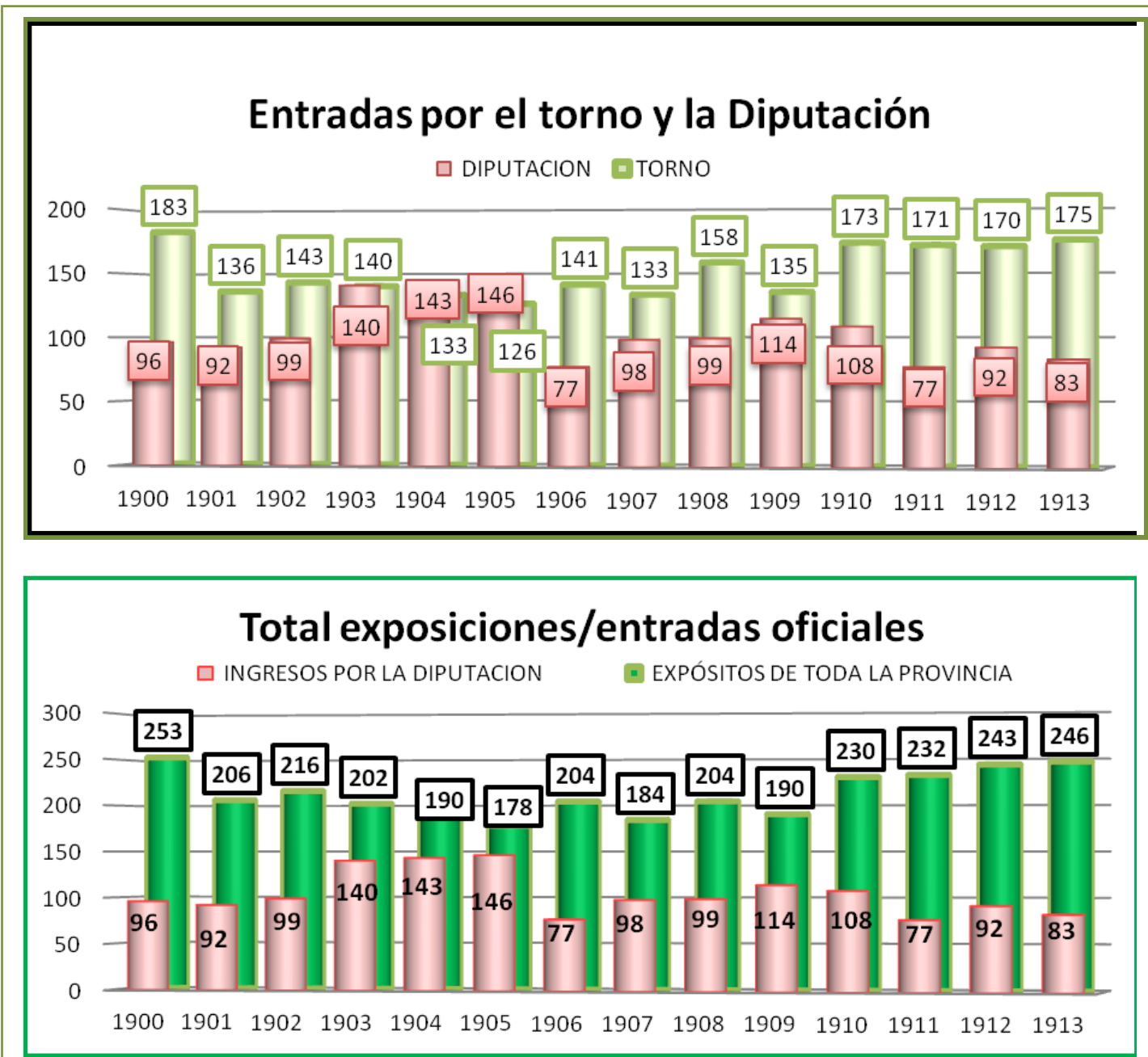

GRÁFICAS 3-18: Comparativa entre el número de niños ingresados a través de la Diputación Provincial de Valladolid en el período 1900-1913 y los niños expósitos que entraron por vía directa. En el recuadro superior se comparan las entradas por la Diputación con las entradas por el torno de la Inclusa Provincial y en la inferior con todos los expósitos de la provincia sumando los del torno de la capital con los presentados en los otros dos tornos y los abandonados en los pueblos de la provincia. Elaboración propia a partir de los Libros de Exposiciones del ADPVA.

Si comparamos el total de ingresos de expósitos, niños expuestos en el torno de la capital y en la provincia, e ingresos oficiales la diferencia lógicamente se incrementa incluso en 1904-05 a favor de los expósitos, llegando a triplicarse en 1911 y 1913. También en la GRÁFICA 3-18 se puede ver la comparativa entre los niños de ingreso directo sin trámites, los expósitos de los tornos y de los pueblos, y los niños ingresados mediante la vía oficial, solicitud y tramitación a través de la Diputación, considerando para los efectos como vía de entrada la que figura en los folios de registro.

No obstante en algunas ocasiones de forma excepcional estas vías de ingreso se entrecruzan; del mismo modo que hay niños de los pueblos que en lugar de entrar por la oficina se exponían en el torno de la capital con toda la documentación y eran trasladados a 
cargo del ayuntamiento correspondiente, también hay niños abandonados que en lugar de ser entregados al Hospicio directamente, que sería el mecanismo usual, ingresaron a través de la Diputación, por tanto mediante solicitud

"Justa San Jose

En 8 de Agosto de 1910 ingresó por acuerdo de la Comisión provincial con certificación del Registro civil de Rueda donde consta fue expuesta á la puerta de francisco Lopez el dia 7 del corriente y que és hija de padres desconocidos y parece tener unas diez horas de tiempo."${ }^{\prime \prime 70}$ [sic]

Resulta admirable, incluso diría que sospechosa, la estimación tan precisa de las horas de vida de esta niña.

Si analizamos las características de los niños en cuanto a edad, sexo y legitimidad encontramos que esta vía es peculiar y diferente de las demás.

Teniendo en cuenta que el ingreso debía solicitarse, siguen siendo mayoría los niños internados en su primer mes de vida, representan el $62 \%$ del total. Es difícil hacer una estadística fiable por días de vida como hicimos en los niños del torno porque en muchos libros se han anotado solamente las fechas de bautismo y del registro civil, son varios años enteros sin fechas seguras de nacimiento, por eso he tomado como más fiable el dato más global del período neonatal, el primer mes de vida. Entre los que tienen fecha de nacimiento no he encontrado ninguno que ingresara el mismo día, en cambio, hay unos pocos niños que ingresaron el mismo día que se inscribieron o se bautizaron (p.ej. 2 en 1908, 4 en 1906), pero no se puede suponer que fuera también la fecha de su nacimiento; hay algunos que ingresaron al día siguiente de nacer, son situaciones especiales como 2 gemelas en 1910 por orden del Vicepresidente, pero en casi todos se da la misma circunstancia anterior. Algunas de las órdenes de la presidencia o de la Comisión eran para ingresar a niños expuestos en algún pueblo de la provincia y que en lugar de presentarlos directamente en el Hospicio, que era lo habitual, se presentaron en la Diputación, en estos casos aunque la fecha de exposición y de presentación coincidan, tampoco podemos suponer que sea la del nacimiento porque no hay constancia en los libros; ya sabemos que era excepcional anotar una edad estimada, pero hay algún registro aislado:

"En 8 de Agosto de 1910 ingresó por acuerdo de la Comisión provincial con certificación del Registro civil de Rueda donde consta fue expuesto á la puerta de la casa de Francisco López el día 7 del corriente y que és hija de padres desconocidos y parece tener unas diez horas de tiempo, ${ }^{\prime 471}$

\footnotetext{
${ }^{470}$ Folio no 271. Libro de Exposiciones de 1910- 2. ADPVA

${ }^{471}$ Folio no 279. Libro de Exposiciones de 1910- 2. ADPVA
} 


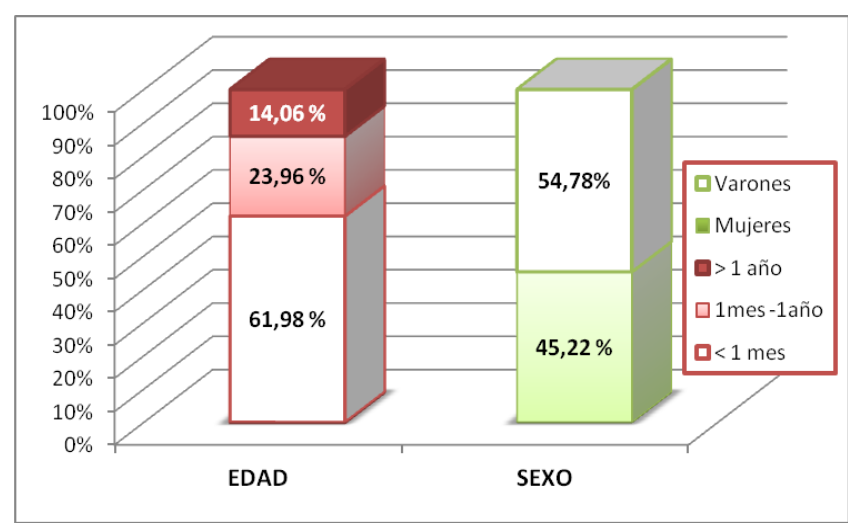

GRÁFICA 3-19: Distribución por edad y por sexo de los ingresados a través de la Diputación. Elaboración propia a partir de los Libros de Exposiciones del ADPVA.
Los lactantes que ingresaron por esta vía entre el mes y el primer año de vida representan casi el $24 \%$, más del doble que los del torno (11\%) y también son muchos más proporcionalmente los mayores de 1 año, un $14 \%$ frente al 2\% del torno. (GRÁFICA 3-19)

También la diferencia por sexos es más acentuada a favor de los varones, (GRÁFICA 3- 19). Con 802 varones y 662 niñas en total, la ratio por sexo para las entradas por la vía que hemos llamado oficial, Diputación y órdenes del gobernador, es de 121'15 varones/100 mujeres; recordemos que la del total de ingresos de la Cuna es de 110'23 varones/100 niñas, la del torno $111^{\prime} 76$ varones/100 niñas y la de la provincia de Valladolid para el mismo período de 106'86/100. A pesar de la diferencia no podríamos asegurar que existiera una clara preferencia por un sexo u otro a la hora de dejar niños en el Hospicio, téngase en cuenta que en ocasiones ingresaban todos los hijos, o varios, de una unidad familiar; es la situación familiar, social y económica la principal causante del ingreso, independientemente de que en algún caso aislado alguna familia pudiera decidir dejar o quedarse con un hijo de un sexo u otro, algo que no podemos saber porque no se encuentra registrado entre los documentos del Hospicio que se han podido consultar por entrar en fecha permitida. Habría que revisar todas las actas de la Comisión provincial y las solicitudes de admisión, si se conservan, para saber la situación familiar de cada internado; si hay información que permita conocer si se ingresaron todos o solo parte de los hijos y sus características, podríamos valorar si fue el sexo o la edad, o ambos factores, los que pudieron intervenir en la decisión de dejarles en el Hospicio.

Aparte de ingresar una proporción superior de niños mayores de un mes de edad y sobre todo de 1 año y de varones, ésta es la única vía por la que ingresaron también más hijos legítimos (el 57'13\%) que ilegítimos. (GRÁFICA 3-20) 


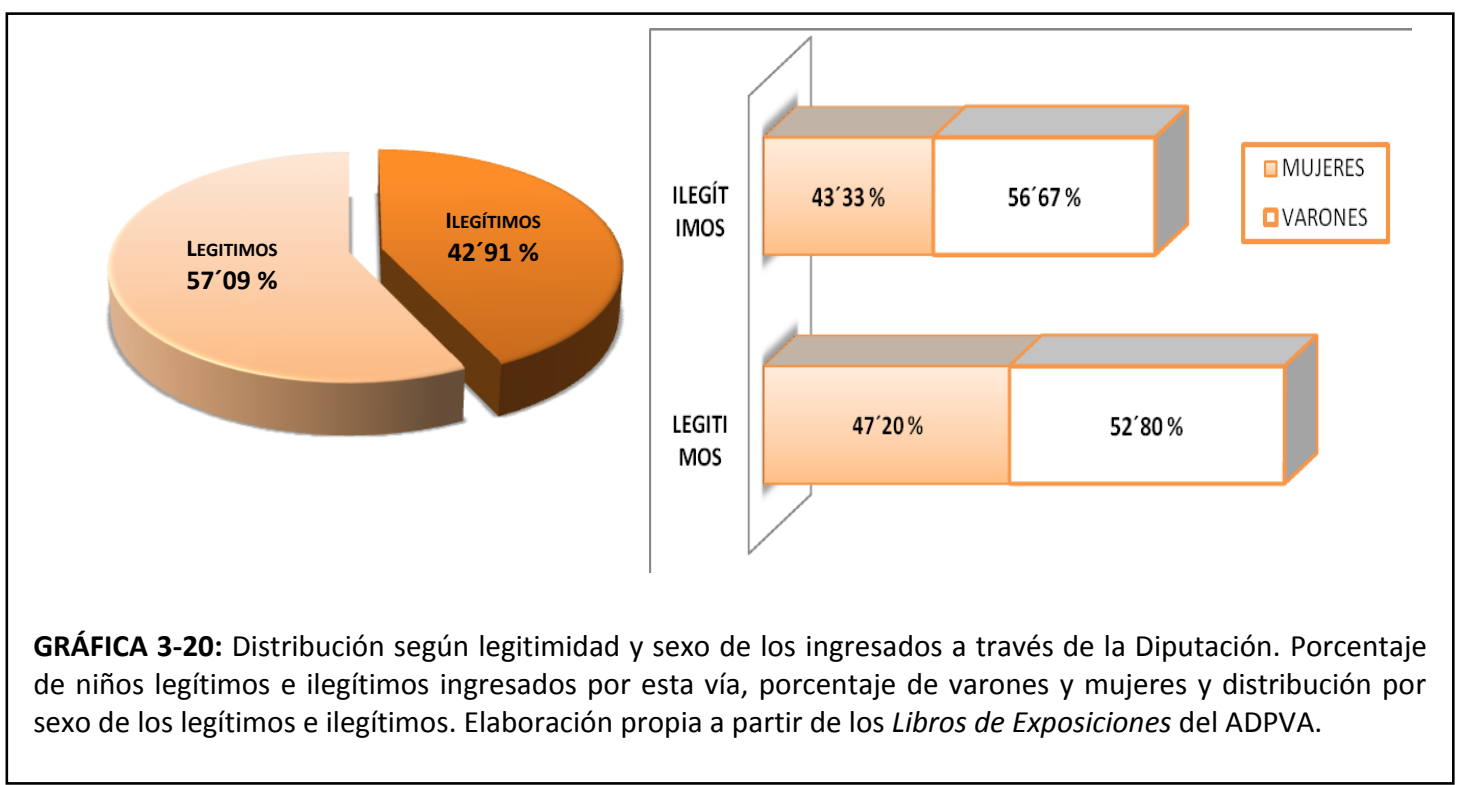

Si disgregamos estos dos grupos por sexo, encontramos una diferencia más significativa en la categoría de los ilegítimos con una ratio de 130'88 varones/100 mujeres, mientras que para los legítimos es de $111^{\prime} 86 / 100$, lo que viene a reforzar lo que acabamos de comentar, cuando las circunstancias conducen a la determinación de institucionalizar a los niños no influye el sexo en las familias con hijos legítimos, mientras que para los ilegítimos o naturales, que podrían ser en muchos casos el primer e único hijo, las madres podrían tener más apego por las niñas.

En cuanto al origen de estos niños desde el punto de vista territorial la mayoría (el 83\%) provenían de los pueblos de Valladolid y sólo un 14\% de la capital (204) (GRÁFICA 3-21). Para hacer este cálculo he considerado como lugar de origen de los niños, cuando no figura otro, el del bautismo, que es el único que aparece anotado normalmente, $y$ he descontado los 46 registros, que en la GRÁFICA 3-21 figuran como OTROs y representan el 3\% del total, en que no consta ninguna localidad o parroquia, son ile0gibles o irreconocibles y los de niños nacidos o bautizados fuera de la provincia, considerando que la familia tenía que ser residente en alguna localidad provincial pues era un requisito para el ingreso.

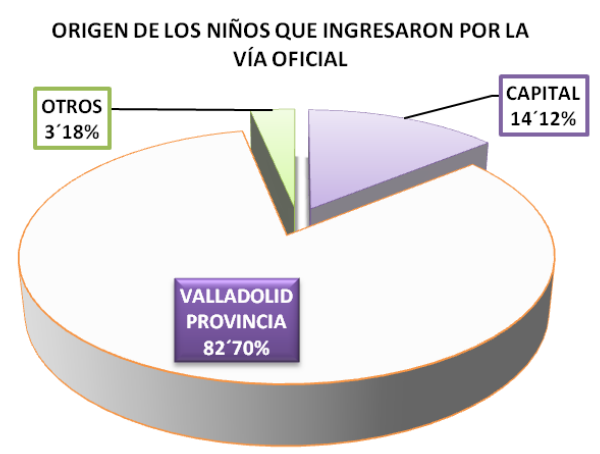

GRÁFICA 3-21: Distribución según lugar de origen de los ingresados a través de la Diputación. Elaboración propia a partir de los Libros de Exposiciones del ADPVA. 


\subsubsection{LOS EXPÓSITOS DE LOS PUEBLOS DE LA PROVINCIA}

El Hospicio de Valladolid era "un Establecimiento provincial" y como tal su Inclusa acogía a los expósitos de toda la provincia. Sabemos que algunos eran depositados directamente en el torno de la Inclusa, pero éstos ya se han considerado dentro del capítulo del torno y aquí nos vamos a ocupar de los que eran expuestos, o arrojados, como también les decían, en los pueblos y que después eran trasladados a la inclusa de la capital.

El R.D. de 11 de diciembre de 1796 de Carlos IV quería evitar los penosos viajes de los expósitos hacia las inclusas, que históricamente habían sido ocasión de una alta mortandad y, para defender "los intereses de la conservación de sus vidas y sus legítimos derechos...", ordenó construir tornos o casas filiales de expósitos, llamadas también "hijuelas", a una distancia no mayor de "doce o catorce leguas" (58- $68 \mathrm{Km})^{472}$ de la casa central localizada en la capital, de manera que los expósitos no debían trasladarse

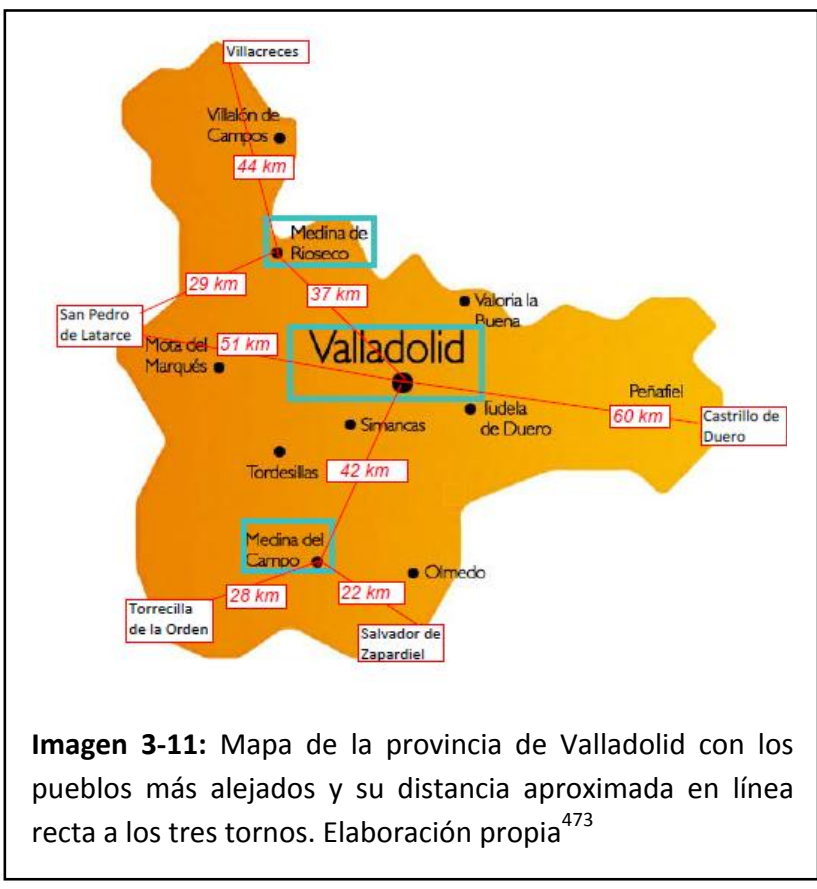
fuera de la diócesis. En Valladolid el Hospicio provincial era la casa central y se situaron tornos en las dos poblaciones más importantes después de la capital, que además están situadas estratégicamente de manera que quedaba cubierta toda la provincia con un torno a una distancia inferior a la establecida por el R.D. En la IMAGEN 3-11 $1^{473}$ se recogen las distancias en línea recta entre los tres tornos y los pueblos más alejados de la provincia, la distancia por carretera es mayor y puede variar mucho en función de su recorrido. El primer torno se situó al norte en la comarca de Tierra de Campos en la ciudad de Medina de Rioseco, a $40 \mathrm{~km}$ aproximadamente por la carretera actual de la capital y más o menos a medio camino de los pueblos más alejados del norte y del noroeste de la provincia (hacia el norte Villacreces y hacia el oeste San Pedro de Latarce). El otro en la villa de Medina del Campo, a unos $55 \mathrm{Km}$ por

\footnotetext{
4721 legua $=4^{\prime} 8280 \mathrm{~km}$

${ }^{473}$ Distancias en http://www.distanciasentreciudades.com/ y mapa en http://www.rutasdelsabor.es/
} 
carretera hacia el sur cubriendo este área de la provincia de manera que los municipios más alejados quedan a una distancia inferior a $40 \mathrm{~km}$ por carretera del torno (Torrecilla de la Orden y Salvador de Zapardiel). Quedaba libre el brazo que se extiende hacia el este, el municipio más alejado en esta dirección es Castrillo de Duero a $66 \mathrm{~km}$ de la capital por carretera, por tanto dentro de los límites que marcaba el R.D.

Los niños expuestos en los pueblos de la provincia o en los dos tornos debían trasladarse a la Inclusa provincial y se presentaban en la dirección del centro con la documentación solicitada para realizar el trámite del ingreso, por eso se decía en los libros de la Inclusa que entraban por la oficina. Los reglamentos recogían las condiciones del traslado, el Ayuntamiento del lugar de exposición debía correr con los gastos y el Alcalde respectivo era responsable de disponerlo. El Reglamento 1889 lo recoge en su artículo 53

"Cuando los expósitos fueren conducidos de los pueblos de la provincia, por disposición de los Alcaldes, se anotará el nombre y vecindad de la persona que los entrega y la partida de Bautismo que necesariamente han de acompañar, siendo condición precisa el que sean remitidos por nodriza que los lacte y cuide en el tránsito, en la inteligencia que una nodriza, solo podrá encargarse de conducir á la casa central ó hijuela, cuando más tres niños" [sic].

En los siguientes reglamentos se modificó este artículro solicitando que se presentara también la partida de inscripión en el RC. Dicen los artículos 309 del Reglamento de 1910 y 312 de 1927 que

"Cuando algún niño hubiera sido expuesto en alguno de los pueblos de la provincia, el Alcalde respectivo le conducirá a este Establecimiento por medio de un ama de cría que le alimente en el camino, acompañando certificación de su inscripción en el Registro civil y de haber sido bautizado, o negativa en su caso, y una envoltura completa, abonando a la mujer los gastos del viaje"

Otra de las cuestiones que se añadió en este artículo es que el niño se debía presentar en la Inclusa vestido correctamente, con "una envoltura completa". En los Libros de Exposiciones no se anotaba habitualmente la ropa de los niños que entraban por la oficina; en cambio, en los de Entradas de la Inclusa si se registraba, en los libros de 1902 y 1907-08 que tiene registros extensos, muy similares a los de los libros oficiales, se encuentran anotadas las las prendas con las que entraba el niño en la Inclusa y su estado y comprobamos que la mayoría de los niños expuestos en los pueblos llegaban vestidos con trapos

"Mayo 1ㅇ Año 1902

Folio 74 entro por la oficina un niño bautizado con el nombre de Macario Ruiz de Barrientos hingreso de Medina del Campo ropas trapos." 
En los últimos libros conservados de Entradas de la Inclusa con registros desde 1909 hasta $1913^{474}$ los asientos son más escuetos y esquemáticos, del tipo "hingresa de Medina del Campo trapos" (sic) (fo 151, 1910), "hingreso de Villalon ropas en buen huso" (sic) (fos 53 y 65. LE 1910), pero suficientes para comprobar que se hacía caso omiso del artículo reformado y en 1913 los niños seguían llegando en las mismas condiciones, es decir, que les enviaban tal cual eran encontrados

"entro por la direccion ropas trapos hingreso de Medina del Campo" [sic](fo60 LE 1912)

"hingreso de Rioseco ropas trapos" [sic] (fo 87 LE 1913)

"hingreso de Medina del Campo ropas en buen huso" [sic] (fo 202 LE 1913)

"hingreso de Medina del Campo ropas trapos" [sic] (fo 262 LE 1913)

También advierte el reglamento que el ama debía alimentar a los expósitos en el camino, "que los lacte" dice el Reglamento de 1889, y que tenía que cobrar los gastos del viaje. No puedo asegurar que se cumpliera ni una cosa ni la otra. En las dos Medinas, las mujeres encargadas del traslado parecen empleadas de los tornos. En el caso de Medina de Rioseco durante los 14 años revisados la encargada del traslado fue "Emilia Matobella", que aparece también en los libros como Matovella, Matovilla, Montobello o Montevello, y de ella se dice en los registros que era "vecina de Rioseco"; no parece probable que fuera una mujer lactante siempre, aunque no podríamos descartarlo con total seguridad dada la fecundidad de la época, es más factible que fuera una persona contratada para el torno ya que estaba institucionalizado.

\section{"Saturnino Lopez Esposito}

En 8 de Enero de 1900 le entregó en este Asilo Emilia Matobella vecina de Medina de Rioseco con partida de bautismo é inscripción del Registro Civil donde dice ser hijo de padres desconocidos" [sic] (fo 12, LE 1900-1)

En la Encuesta del Ateneo de 1901- 1902 se dice que era una empleada de la Diputación:

"A las 24 o 48 horas son llevados los recién nacidos a la cabeza de Partido (Rioseco) para que desde alli les lleve una mujer, que la Diputación tienen empleada para que les conduzca ala Casa-cuna o al Hospicio"${ }^{\prime 475}$

\footnotetext{
${ }^{474}$ Libro de Entradas y salidas de los niños de la Inclusa. Años de 19091910 1911. Signatura: Caja 409, Expediente 3979 y el libro Inclusa niños Dbre 1911 Año 1912 Año 1913 Fin. Signatura: caja 441, expediente 4092

${ }^{475}$ Encuesta del Ateneo de 1901- 1902. nacimiento, ficha 116. MARTíN JIMÉNEZ I.: La sociedad vallisoletana en los albores del siglo XX... 2004, p 37
} 
En Medina del Campo los registros nos muestran que fueron cambiando las mujeres que trasladaban a los expósitos; hasta septiembre de 1902 los traslados los hizo Joaquina Vaquero, cuya última entrega fue el día 30 de dicho mes (folio 311)

"Micaela Barrientos de Ruiz

El dia 30 de Septiembre 1902 fue entregada por Joaquina Vaquero vecina de Medina del Campo con comunicación del Sr Alcalde y partida de bautismo certificación del Sr Juez Municipal de dicha villa de Medina donde dice ser hija de padres desconocidos" [sic] (fo 311, LE 1902-2)

le sucedió Isidora Jimenez, o Gimenez, aparece escrito de las dos formas en los libros, por más señas viuda, portera del Hospital de Medina del Campo y mayor de 50 años de edad, que hizo entregas hasta finales de 1910, la última el 20 de diciembre (folio 427)

"Luisa Barrientos de Ruiz En 20 de Diciembre 1910 fue entregada por Isidora Jimenez mujer viuda vecina de Medina del Campo... fue expuesta esta niña en el torno de dicha Villa el 20 del corriente y que és hija de padres desconocidos" [sic] (fo 14, LE 1910-1)

y desde 1911 la responsable de los traslados fue Vicenta Tremiño.

Estas mujeres podemos afirmar que eran empleadas del torno de Medina del Campo, en algún folio así nos lo dicen, las encontramos como encargada del torno

\section{"Antonio Ruiz Botrán}

En 14 de Junio de 1912 fue entregado por Vicenta Tremiño mujer encargada del torno de Medina del Campo con oficio del Sr Alcalde, partida de bautismo y certificación del Registro Civil donde consta que fue expuesto en aquel torno en el dia anterior y que és hijo de padres desconocidos" [sic] (fo 223, LE 1912-1)

Y en otros como portera o como enfermera del Hospital de Medina del Campo

"Domiciana Ruiz de Barrientos

El dia 28 de Septiembre del 903 fue entregada en este asilo por Isidora Gimenez portera del Hospital de Medina del Campo..." [sic] (fo 325, LE 1903- 2)

"Julián Barrientos de Ruiz

En 29 de Enero de 1911 fue entregado por una enfermera del Hospital de Medina del Campo Ilamada Vicenta Tremiño... fue expuesto en el torno de aquella Villa el dia 28 del corriente..."

En las partidas de nacimiento que se encuentran en los Expedientes Personales de tres niños de Medina del Campo, figura Isidora Jiménez como la persona que los presenta para su inscripción en el Registro civil y de ella se dice que su profesión es recoger expósitos

"En la villa de Medina del Campo... compareció doña Isidora Jiménez natural de esta villa de cincuenta y tres años de edad de estado viuda su ejercicio recoger expósitos..." (Expediente Personal. Exposición 1908. Folio 128)

El torno de Medina del Campo se encontraba en el Hospital de la Concepción; en su capilla "Dn Antonio Rodriguez Sanz Pbro [presbítero] Capellán Administrador del Hospital 
General de esta villa de Medina del Campo" bautizaba a los niños antes de ser enviados a la capital, como podemos ver en los certificados de bautismo que desde allí se envíaron y que se conservan en alguno de los expedientes.

No se ha localizado en el Archivo, ni entre los expedientes ni en los libros ningún documento o anotación que indique la localización del torno de Medina de Rioseco, pero después de muchas indagaciones considero pudo ubicarse en el Convento de San Francisco donde se encontraban el Hospital de Santa Ana y la Casa Asilo de Beneficencia ${ }^{476}$, que sería la Casa-Torno como aparece en los registros de los Libros de Exposiciones del Hospicio; los niños se bautizaban en la iglesia próxima de la Santa Cruz, como también consta en algún folio de registro.

"En 29 de Abril de 1913 fue entregado por Emilia Matovilla vecina de Rioseco con oficio... fue expuesto en aquella Casa-Torno..." [sic] (fo 169, LE 1913-1)

"En 13 de Septiembre del 1900 le entregó Emilia Matobella, vecina de Medina de Rioseco... Bautizado en la parroquia de Santa Cruz de dicha villa en doce de Septiembre de mil novecientos" [sic] (fo 350, LE 1900- 2)

En Tordesillas todos los traslados los hizo durante los 14 años revisados Wenceslada Frutos, alguno de los niños que trasladó fue expuesto en la puerta de su casa

"En 4 de Septiembre de 1913 fue entregado por Wenceslada Frutos vecina de Tordesillas con oficio del Alcalde... donde consta que fue encontrada á la puerta de su casa que nació según noticias sobre el primero del corriente y que es hija de padres desconocidos" [sic] (fo 309, LE 1913- 2)

En Villalón se encargaron también las mismas mujeres, primero Mercedes García y después Francisca del Val

"Eusebia de San Miguel Torrequemada

En 19 de Diciembre de 1909 fue entregada por francisca del val, vecina de Villalon... que nació o fue encontrada en la reja de una casa de referida localidad" [sic] (fo 436, LE 1909- 2)

\footnotetext{
476 Dice Juan Ortega y Rubio que en 1985 en el Convento de San Francisco de Medina de Rioseco se encontraban el Hospital de Santa Ana, la Beneficencia y la Cárcel. El Convento de San Francisco, hoy museo, se desamortizó en 1836 y tras una petición del Ayuntamiento de Medina de Rioseco en 1850 la Dirección General de Fincas del Estado se lo cedió para "colocar en él el Hospital" de Santa Ana, dependiente de la Junta Municipal de Beneficencia y en 1881 las Hermanas de la Caridad se hicieron cargo de las funciones asistenciales. También se emplazó allí la Casa Asilo de la Beneficencia Pública fundada en 1821 por el Ayuntamiento para recoger desvalidos pobres. Las pesquisas realizadas entre gente de la población, incluso del Ayuntamiento sobre la ubicación del torno resultaron infructuosas. Cfr. ORTEGA Y RUBIO J.: Los pueblos de la provincia de Valladolid. ; GANDÍA MARTíNEZ M.C.: Archivo Municipal de Medina de Rioseco- Fondos del Hospital de Sancti Spiritus y Santa Ana. Boletín de la ANABAD, tomo 34, no 2-4, 1984; pp 263- 268, en pp 264, 265. ORTEGA Y RUBIO J.: Los pueblos de la provincia de Valladolid. Valladolid. 1895. Tomo II, pg 62
} 
Como en el caso de Tordesillas, a esta mujer, Francisca del Val, la encontramos trasladando a todos los expósitos de Villalón durante años y entre ellos algunos fueron abandonados en su propia casa, según consta en los registros de los libros

\begin{abstract}
"Francisco de San Miguel Torrequemada
En 3 de Abril de 1909 ingreso en este Asilo siendo entregada por Francisca Val Garcia vecina de Villalon con oficio de la Alcaldía, partida de bautismo y certificación del Sr Juez Municipal de referida Villa donde dice que este niño fue hallado en el portal de la casa de la misma que le entrega, á las 8 de la noche del 1 de los corrientes y que es hijo de padres desconocidos" [sic] (fo 128, LE 1909-1)

"fue expuesto á la puerta de la que la conduce" (fo 69, LE 1912)

"fue expuesto á la puerta de la calle en la casa que habita la misma que la entrega" (fo 361, LE 1912),
\end{abstract}

Da la impresión de que se supiera que estas mujeres se encargaban de los expósitos en su localidad. En otros lugares como Nava del Rey, La Seca o Rueda ocurre algo similar, aparecen mujeres diferentes haciendo los traslados pero hay nombres que se repiten y en ocasiones, no siempre, son niños expuestos en sus casas.

En los demás pueblos de la provincia no hay coincidencia de nombres, veremos que tampoco era frecuente encontrar expósitos; cada vez aparece una mujer diferente y muchas veces dicen los registros que era precisamente la que lo encontró abandonado en la puerta o en la ventana de su casa

"En 12 Junio de 1912 fue entregada en este Asilo por Gertrudis López vecina de Nava del Rey con oficio del Alcalde, partida de bautismo y certificación del Registro civil donde consta que (nacio) fue expuesto á la puerta de la casa de la que la entrega el día 7 de Junio corriente y es hija de padres desconocidos" [sic] (fo 219, LE 1912-1)

\title{
"Eutiquia Diez Garcia
}

En 18 de Febrero de 1913 ingresó siendo entregada por Eugenia Lorenzo vecina de Pozaldez con certificacion del Registro civil donde consta que nacio esta niña en dicha Villa siendo expuesta en la ventana de la casa de la misma que la entrega el seis de los corrientes y que es hija de padres desconocidos" [sic] (fo 65, LE 1913-1)

Como puede apreciarse en estas citas transcurrieron unos días desde la exposición hasta el traslado al Hospicio, lo que era bastante frecuente en los pueblos quizás porque había que organizar el traslado, en cambio en los tornos de las dos Medinas, que tenían una mujer encargada de los expósitos y de su traslado, solían mandar a los niños más pronto, en uno o dos días, incluso el mismo día de la exposición. 
En algunos casos los niños en lugar de entrar por la dirección fueron depositados en el torno, pero se hizo la entrega en las mismas condiciones, como si la oficina estuviera cerrada

"En 1o de Diciembre de 1912 á las 13 horas fue expuesto en el torno de este Asilo con oficio del Alcalde de Rueda, partida de bautismo y certificación del Registro civil en que consta que fue expuesto á la puerta de la casa de Gertrudis Alonso vecina de dicha Villa y es hijo de padres desconocidos" [sic] (fo 415, LE 1912- 2)

"En 12 de Febrero de 1901 fue expuesto en el torno de este asilo por Joaquina Vaquero vecina de Medina del Campo con expediente y partida de bautismo donde dice ser hijo de Agustin y Guadalupe vecinos de Medina del Campo" [sic] (fo 50, LE 1901-1)

Presentó el niño la mujer responsable del torno de Medina del Campo y es de los pocos casos de expósitos de los pueblos en que figuran los nombres de los padres.

En cuanto a las características de los niños abandonados en los pueblos o depositados en los tornos de las dos Medinas, el $51^{\prime} 84 \%$ fueron varones y el $48^{\prime} 16 \%$ mujeres y casi en su totalidad eran hijos de padres desconocidos, así figura en los Libros de Exposiciones donde se anota la filiación tal como figura en su partida de nacimiento; hay muy pocos registrados como hijos naturales, 31 niños en los que también se anotó el nombre de la madre, y solamente 6 figuran como hijos legítimos. No se anotaban normalmente más detalles en los libros de entradas, los datos sobre su exposición, la ropa o si se presentaron con una nota, no solía registrarse, aunque son circunstancias que debían conocerse porque según la ley del Registro civil debía hacerse constar en su partida de nacimiento. Únicamente se encuentra algún folio aislado que recoge este tipo de datos

"En 8 de Julio de 1900 le entrega en este asilo Polonia Martin vecina de Tudela con camisa de algodón jubón de percal gorro de pique pañal de algodón mantilla un trapo fajero blanco de algodón y un papelito que dice que se llama Mariano Castro y esta sin bautizar" [sic] (fo 273. LE 1900-2)

"En 19 de Noviembre de 1913 fue entregada por Vicenta Tremiño vecina de Medina del Campo con oficio de la Alcaldía, partida de bautismo y certificacion del Registro civil donde consta que fue expuesto en el torno de aquel Hospital el dia 18 de Noviembre de 1913 á las veinte horas con unos trapos viejos y que es hijo de padres desconocidos" [sic] (fo 398. LE 1913-2) 
Queda conocer el lugar de procedencia de los niños. El $14^{\prime} 27 \%$ de los niños que ingresaron entre 1900 y 1913 en el Hospicio de Valladolid (860) fueron expuestos en los pueblos de la provincia (GRÁFICA 3-9), la mayoría en los otros dos tornos, más de la mitad en Medina del Campo (451) y 188 en Medina de Rioseco. Siguen, según el número de expósitos presentados en la Inclusa de Valladolid en los 14 años revisados, Nava del Rey (con 48 niños), Villalón (40), La Seca (28), Pozaldez (16), Tordesillas (15), Rueda (13) y Tiedra (12); en los demás pueblos que hicieron

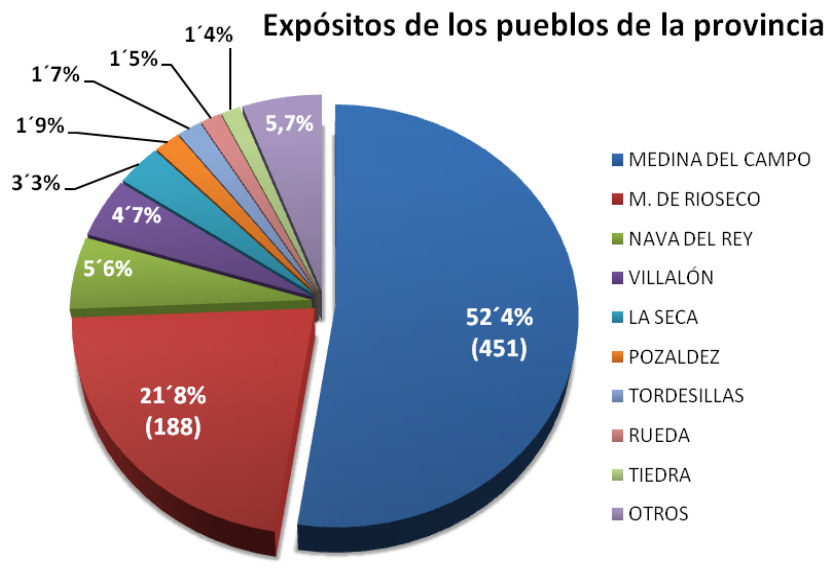

GRÁFICA 3-22: Distribución de los niños expuestos en los tornos y en los pueblos de la provincia de Valladolid en el período 1900- 1913. En OTROS se incluyen localidades donde solamente fueron abandonados 1-3 niños durante este período. Elaboración propia a partir de los datos extraídos de los Libros de Exposiciones. ADPVA.

entregas se abandonaron 3 niños en Matapozuelos y uno o dos en el resto (ver GRÁFICA 3-22). No es de extrañar que en la encuesta que se ha realizado a personas que vivieron aquella época digan que no era frecuente que se abandonaran niños y que casi nadie conoce directamente ningún caso de exposición.

En la IMAGEN $3-12^{477}$ se puede ver la localización de estos pueblos que llevaron expósitos a la Inclusa de Valladolid, en esta relación y en el mapa faltan algunos por la imprecisión de ciertos registros que no permiten una ubicación segura ${ }^{478}$.

\footnotetext{
${ }^{477}$ Mapa disponible en: http://www.zonu.com/Europa/Espana/Castilla-y-Leon/Valladolid/index.html

${ }^{478}$ En algunos registros de los libros se recogen pueblos que no son fácilmente identificables o que su localización es dudosa, por ejemplo se habla de Villanueva y de Villanueva de las Torres y ésta no es una población de la provincia de Valladolid, sino de Granada. En Valladolid se encuentran Villanueva de Duero, Villanueva de la Condesa, Villanueva de los Caballeros, Villanueva de los Infantes y Villanueva de San Mancio y se localizan en diferentes comarcas y alejados entre sí por lo que no he optado por ninguno de ellos. Sucede lo mismo con Villalba que existen tres pueblos posibles: Villalba de Adaja, Villalba de los Alcores y Villalba de la Loma. En otros casos de nombres dudosos he optado por la opción más probable, por ejemplo se registra Villaborde de Medina y debe ser Villaverde. Para la elaboración del mapa y la localización de las poblaciones he consultado el listado de pueblos de la provincia que aparecen en los Presupuestos Provinciales de la época y he utilizado el mapa provincial actual de la Diputación provincial de Valladolid disponible en:

http://www.diputaciondevalladolid.es/extras/MAPA_PROVINCIA_DE_VALLADOLID_carreteras_con_indice_de_pue blos.pdf
} 


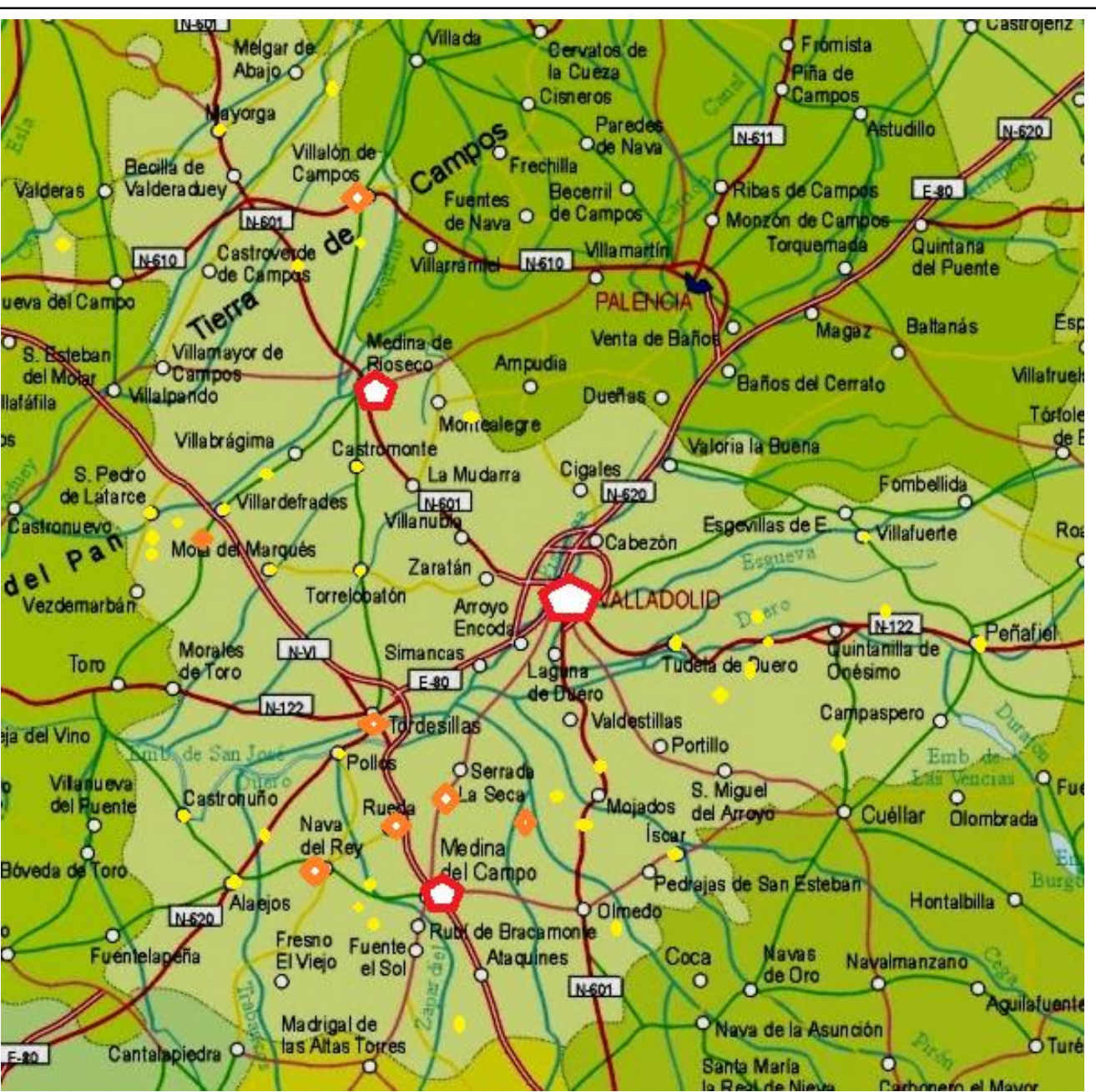

Imagen 3-12: Localidades desde donde se trasladaron expósitos a la Inclusa de Valladolid entre 1900- 13. Elaboración propia a partir de los datos de los Libros de Exposiciones ADPVA.

Poblaciones con torno

Poblaciones que enviaron más de 10 expósitos. Poblaciones que enviaron de 1 a 3 expósitos.

En el sur- suroeste de la provincia, aparte de los expuestos en el torno de Medina del Campo, en la que podía ser por proximidad su área de influencia se abandonaron niños en Bobadilla del Campo, Brahojos de Medina, Muriel de Zapardiel, Pozaldez, Villaverde de Medina, Alaejos, Castronuño, Nava del Rey, Matapozuelos, Pollos, Rueda, La Seca, Siete Iglesias, Ventosa de la Cuesta, y Tordesillas (zona sur de la provincia coloreada en rojo en el mapa de la IMAGEN 3-13). En el norte, en la Tierra de Campos, en la zona próxima a Medina de Rioseco, se expusieron niños en Ceínos de Campos, Cuenca de Campos, Mayorga, Roales, Villagarcía de Campos, Villardefrades, San Pedro de Latarce y Zorita de la Loma (zona coloreada en amarillo en la IMAGEN 3-13 ${ }^{479}$ ). En la parte más occidental de la zona centro (en color azul) en Benafarces, Castromonte, Mota del Marqués, Pobladura de Sotiedra, y

\footnotetext{
${ }^{479}$ Mapa interactivo de la Diputación provincial de Valladolid disponible en: http://www.diputaciondevalladolid.es/directorio_instalaciones/mapa.shtml
} 
Torrelobatón y hacia el este y sudeste en Bahabón, Peñafiel, Santibáñez de Valcorva, Sardón, Traspinedo, Iscar, Fuente Olmedo y La Pedraja, en la zona coloreada en verde en el mapa de la 4-13 y Olivares de Duero, Tudela de Duero, Villafuerte y Villavaquerín, localizados en el mapa justo por encima de esta zona, dentro de la franja central coloreada en azul.

En el mapa de la IMAGEN 3-12 puede apreciarse que casi todos los pueblos sin torno que presentaron más expósitos están muy próximos a Medina del Campo; Nava del Rey a $16 \mathrm{Km}$ aproximadamente, La Seca y Rueda a unos $14 \mathrm{Km}$ y Pozaldez a $11 \mathrm{Km}$, así como muchos de los que tuvieron uno o dos niños abandonados. Villalón, también entre los que recogieron más niños, queda a $35 \mathrm{Km}$ de Medina de Rioseco.

Si distribuimos a los expósitos por su comarca de origen, la mayoría, con un $68^{\prime} 5 \%$ del total, procedían del sur- suroeste de la provincia, de las comarcas Tierra de Medina y Tierra del Vino ${ }^{480}$; de la Tierra de Campos al norte

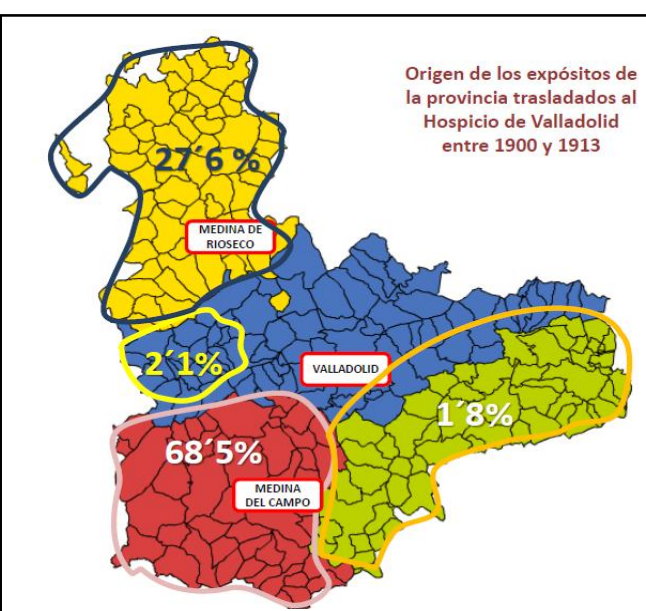

Imagen 3-13: Distribución territorial de los lugares de origen de los expósitos. Elaboración propia, datos de los Libros de Exposiciones ADPVA. y mapa tomado de la web de la Diputación provincial de Valladolid, que divide la provincia en cuatro comarcas. Tierra de Campos, zona Centro, zona Sur y zona Sureste. Se hace una distribución en función de los lugares donde se depositaron expósitos, con los porcentajes referidos a las áreas delimitadas.

provenían el $27^{\prime} 6 \%$ de los expósitos; de la parte más occidental de la franja central, en la comarca de los Montes Torozos, el $2^{\prime} 1 \%$ y el resto, un $1^{\prime} 8 \%$, de los territorios del este y el sudeste que corresponden a de las riberas del Duero y el Esgueva y la Tierra de Pinares. Se ha representado esta distribución en la IMAGEN 3-13 sobre un mapa interactivo que ofrece la Diputación de Valladolid que divide la provincia en cuatro zonas, la norte, coloreada en amarillo corresponde a la Tierra de Campos, la zona sur en rojo a las comarcas de Tierra de Medina y Tierra del Vino y la zona sureste en verde comprende la comarca de Tierra de Pinares y los pueblos de la ribera sur del Duero. En la zona centro, coloreada en azul, en el mapa se han incluido todos los pueblos de la franja central de la provincia desde la comarca de los montes Torozos al oeste hasta los pueblos más orientales del valle del río Esgueva y de la ribera norte del Duero, incluyendo Tudela de Duero, atravesado por el río.

Dentro de esta zona central llama la atención que solamente se expusieron niños en nuestro período de estudio en la parte más occidental y en algunos pueblos sueltos de la zona

\footnotetext{
${ }^{480}$ De la provincia de Valladolid, ya que esta comarca se extiende también por la provincia de Zamora
} 
oriental que hemos agrupado en el mapa de la IMAGEN 3-13 en ese $1^{\prime} 8 \%$ del sur-sureste. En los pueblos del entorno de Valladolid capital no consta que se abandonaran niños en ellos.

\subsubsection{Lugar de origen de los niños de la Inchusa de Valladotid}

Viendo los mapas anteriores la primera impresión es que los expósitos de Valladolid, sin contar con la capital, procedían de la zona norte y sobre todo de la zona sur de la provincia. Sin embargo, debemos recordar que estábamos hablando solamente de los niños que fueron abandonados en algún pueblo, casi siempre en la puerta o en la ventana de alguna casa, o depositados en los tornos de las dos Medinas y eran trasladados al Hospicio provincial de forma oficial, "con oficio del alcalde" ya bautizados e inscritos en el Registro civil y a cargo del ayuntamiento. Si volvemos a fijarnos en los expósitos que se depositaron en el torno de la Inclusa provincial podemos comprobar que allí se dejaron muchos niños de la provincia, incluso de las dos Medinas y de pueblos próximos a ellas a pesar de la existencia de los tornos. Por tanto en estas zonas que parecen estar libres de expósitos no se los encontraban en su territorio porque las madres o alguien de su entorno los llevaban y los exponían directamente en el torno de la capital.

Sabemos de la procedencia de los niños del torno porque nos lo cuentan algunas de las notas que se dejaban con ellos, si bien, es imposible conocer con exactitud cuántos podían ser y su lugar de origen porque en la mayoría de los casos no se dice nada al respecto.

Entre todos los niños depositados en el torno de Valladolid en el período 1900-1913, conocemos el lugar de nacimiento de 914 (el 43’38\%) por las notas que les acompañaban, 443 eran de la capital (el 48'47\%), 428 de la provincia (el 46'83\%) y 43 llegaron de fuera, incluyendo en este grupo algunos lugares de nombre dudoso que no he conseguido localizar dentro de la provincia de Valladolid, entre ellos nos encontramos niños nacidos en otras capitales como Palencia, Madrid, Pamplona y Pontevedra o en lugares tan alejados como El Piornal en Cáceres o Carrio en la provincia de Asturias; es muy probable que las madres se encontraran viviendo en Valladolid y no fueran allí expresamente a depositar a los niños, pero no podemos saberlo con certeza porque no se dice nada al respecto en las papeletas del torno. 
En cuanto a la localización de los pueblos de origen de los niños del torno de la Inclusa provincial, los que conocemos por las notas, aunque se repartían por toda la provincia, puede verse en los mapas de la IMAGEN 3-14 ${ }^{481}$ como la mayoría se encuentran en la franja central, hay dos concentraciones en la parte más nórdica de la Tierra de Campos y al sureste en Tierra de Pinares y la zona sur del entorno de Medina del Campo es en este caso la de menor porcentaje. He utilizado, además del mapa provincial por zonas, otro de los mapas interactivos que ofrece la Diputación provincial de Valladolid, que señaliza los lugares solicitados con su nombre, para que podamos valorar como se distribuyen territorialmente, cada localidad se ha marcado solamente una vez. En total se han contabilizado para los 14 años del estudio 126

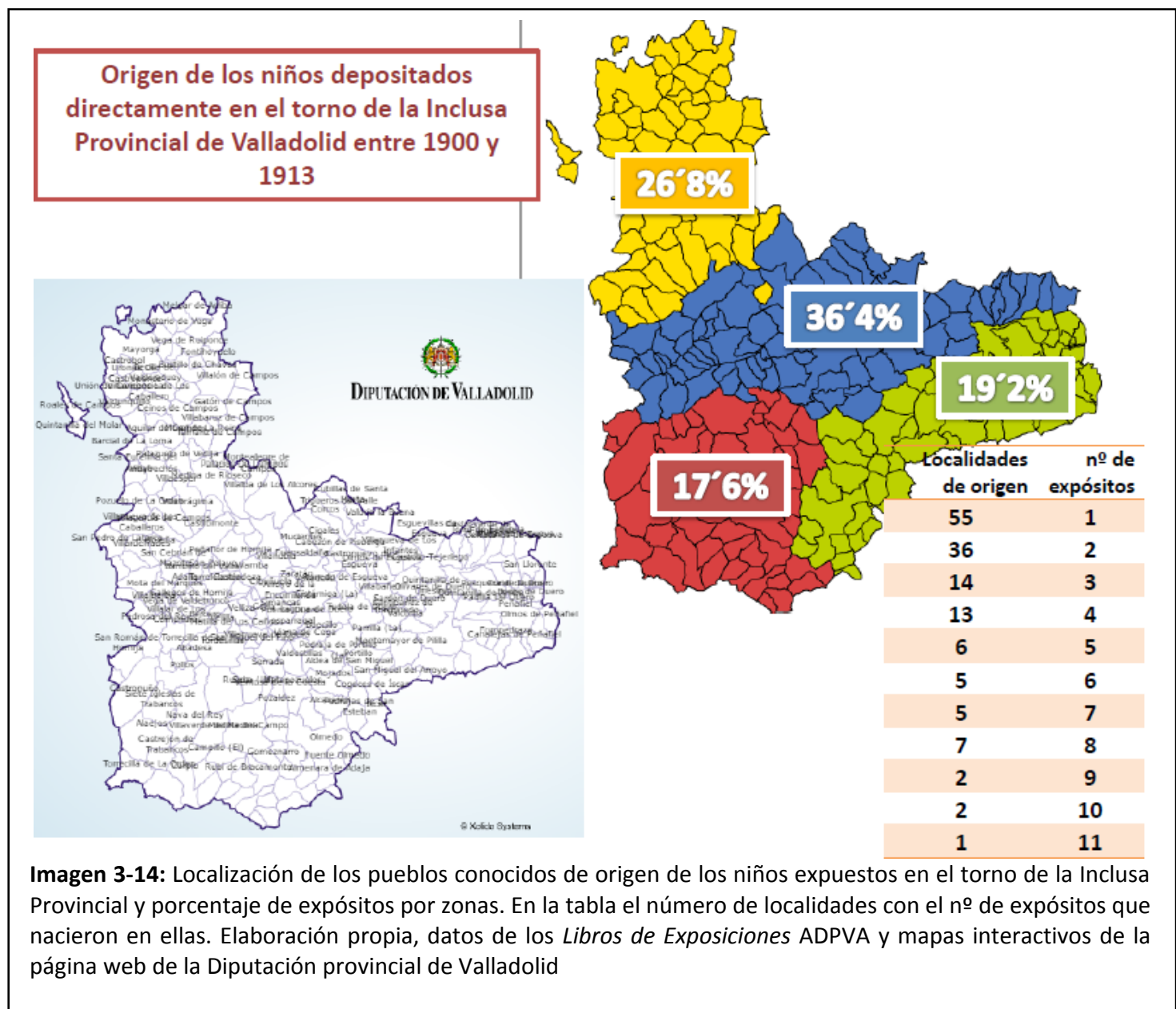

localidades de la provincia ${ }^{482}$, en la mayoría solamente nacieron uno (en 55 pueblos) o dos expósitos (en 36); los pueblos de nacimiento de más niños fueron Pozáldez (11 niños), Peñaflor y Ceínos de Campos (10 en cada uno) y Laguna de Duero y Peñafiel (9 en cada uno).

\footnotetext{
${ }^{481}$ Mapas interactivos de la página web de la Diputación provincial de Valladolid, disponibles en: http://www.diputaciondevalladolid.es/directorio_instalaciones/mapa.shtml http://www.diputaciondevalladolid.es/ayuntamientos/aytos-nuestros_pueblos/mapa/

${ }^{482}$ Actualmente la Diputación provincial contabiliza 225 municipios y 9 entidades locales menores.
} 
No se han observado diferencias significativas en la distribución territorial de los lugares de nacimiento de los expósitos de la Inclusa provincial en función del tiempo, salvo que hasta 1905 y en 1907 predominan los niños nacidos en la capital y después son más los de la provincia; hay diferencias en el número de expósitos del torno que procedían de los pueblos que aumentó de forma significativa en la segunda década (ver TABLA 3-17). Siempre según las notas o los documentos que se dejaban en el torno con ellos y que nos lo indican, que recordemos que no son todos; por tanto estos datos podrían modificarse si tuviéramos conocimiento del origen de todos los expósitos, algunos de los que tenían nota con el momento del nacimiento podrían haber nacido en la capital por el tiempo transcurrido hasta la exposición, pero no los he considerado así al no haber certeza ya que también podrían ser de lugares muy próximos. El número de niños procedentes de la capital (C) supera en conjunto durante el período 1900 -1913 al total de los que llegaron desde el resto de la provincia (P), (443C/428P, que supone una ratio de $\left.103^{\prime} 5 \mathrm{C} / 100 \mathrm{P}\right)$, sin contar con los que en la tabla aparecen como externos, que serían niños nacidos fuera de la provincia cuyas familias podrían estar viviendo en ella, probablemente muchos de ellos en la capital aunque no podemos asegurarlo al no tener constancia de ello.

\begin{tabular}{|c|c|c|c|c|c|c|c|c|c|c|c|c|c|c|c|}
\hline & 1900 & 1901 & 1902 & 1903 & 1904 & 1905 & 1906 & 1907 & 1908 & 1909 & 1910 & 1911 & 1912 & 1913 & TOTAL \\
\hline $\begin{array}{r}\text { VALLADOLID } \\
\text { capital }\end{array}$ & 43 & 34 & 31 & 28 & 29 & 20 & 16 & 30 & 20 & 17 & 35 & 42 & 45 & 53 & 443 \\
\hline PROVINCIA & 22 & 15 & 11 & 15 & 17 & 16 & 22 & 26 & 38 & 31 & 54 & 56 & 50 & 55 & 428 \\
\hline EXTERNOS & 3 & 2 & 1 & 1 & 5 & 5 & 2 & 0 & 2 & 0 & 3 & 4 & 9 & 6 & 43 \\
\hline
\end{tabular}

En un año como 1905 de los 125 niños expuestos en el torno sólo en 33 notas se comunicaba su localidad de origen, 20 eran de la capital y 16 de la provincia, 2 de Nava del Rey y los demás cada uno de una población diferente, desde la más próxima a la capital como Geria a $17 \mathrm{Km}$ a la más alejada Ceinos de Campos a 61km; entre las 5 localidades externas hay dos tan lejanas como la "villa de Padrón" (fo 310) y "Carrio de la provincia de Oviedo"; y (fo $312)^{483}$. Tomando otro año de la segunda década como puede ser 1912 , se revela el nombre de la localidad en 104 notas, 45 niños nacieron en la capital y 50 en lugares diferentes repartidos por toda la provincia sin seguir un patrón regular; llegaron niños desde las localidades más

\footnotetext{
${ }^{483}$ El resto de poblaciones de origen de los expósitos de 1905 fueron Pedraja (debe ser La Pedraja de Portillo a 24 $\mathrm{km}$ de Valladolid capital), Tordesillas (a $32 \mathrm{Km}$ ), Montemayor (de Pillilla a $37 \mathrm{Km}$ ), Rueda (a $42 \mathrm{Km}$ ), Pozaldez (44 $\mathrm{Km}$ ), Pedrosa del Rey (a $49 \mathrm{Km}$ ), Iscar (a $50 \mathrm{Km}$ ), Fompedraza (a $64 \mathrm{Km}$ ), Ceinos de Campos (a $61 \mathrm{Km})$. De otras provincias además de las dos mencionadas llegaron niños de Hoyales de Roa de Burgos a $84 \mathrm{Km}$ de Valladolid capital, Cistierna de León a $170 \mathrm{Km}$ y Cepeda de Salamanca a $200 \mathrm{Km}$. La niña nacida en Cistierna (fo 213) y el niño nacido en Carrio eran hermanos, el niño tenía 3 años y la niña 10 meses y los dos volvieron con sus padres 4 meses después. Podríamos suponer que vivían en Valladolid, pero es eso, pura suposición porque en ninguno de los dos folios se dice nada al respecto.
} 
próximas a la capital como Santovenia, Zaratán, Laguna de Duero o Wamba, hasta las más periféricas como Vega de Ruiponce y Monasterio de la Vega, a más de $80 \mathrm{Km}$; incluso de Medina de Rioseco, a pesar de tener torno, y de lugares próximos a ella como Villagarcía de

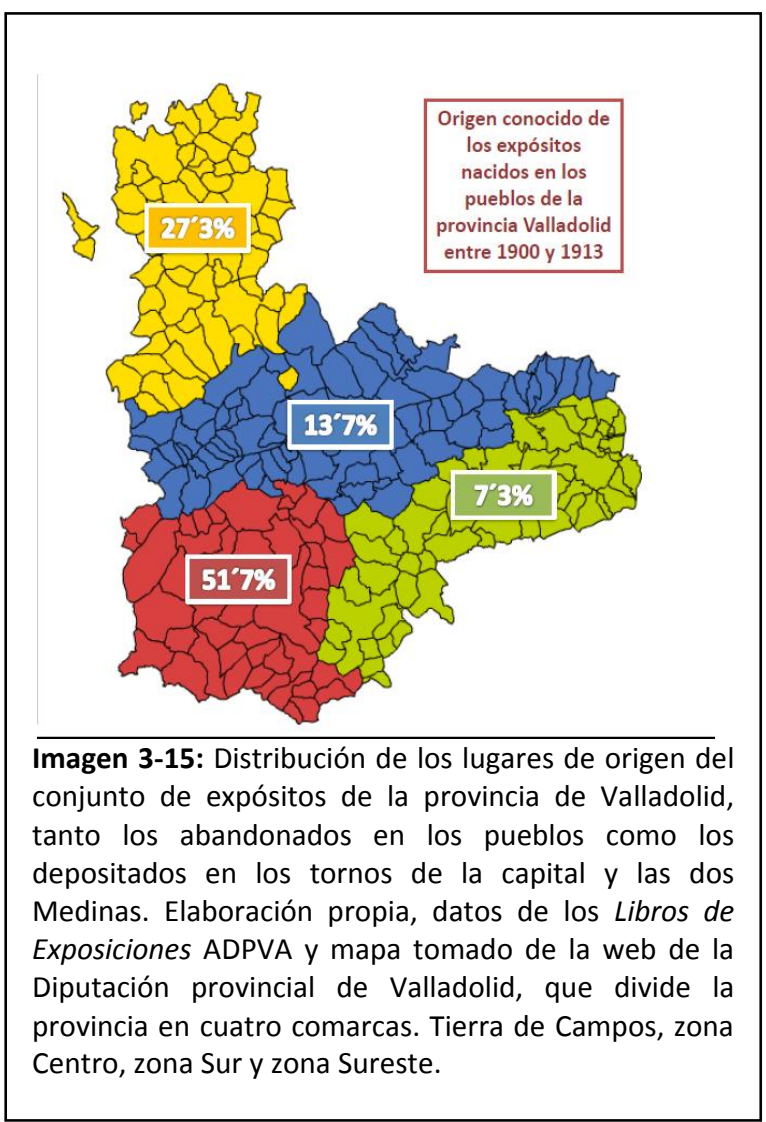

Campos o Villabrágima y a Medina del Campo como Pozaldez o Salvador de Zapardiel. También hay niños de pueblos de provincias limítrofes, de Segovia, que veremos que tiene una relación muy estrecha con nuestro Hospicio provincial, Burgos y Palencia y de lugares tan alejados como Pamplona, Pontevedra y El Piornal (Cáceres) $^{484}$.

Si consideramos todos los expósitos de Valladolid provincia, contando todos los niños abandonados en los pueblos y los que nacieron en ellos y se depositaron en los tres tornos, el provincial y los de la dos Medinas y excluyendo los nacidos en la capital, la distribución por comarcas se modifica según se aprecia en la IMAGEN 3-18. La zona sureste sigue siendo la que mandó menos expósitos a la Inclusa provincial, seguida de la zona centro, en la que hemos excluido como hemos dicho la capital; la zona sur del entorno de Medina del Campo envió más de la mitad de los niños de la provincia ingresados.

\footnotetext{
${ }^{484} 1912$ es uno de los años que llegaron al torno más niños con notas que revelaban su localidad de origen; de los 170 niños expuestos en el torno se conoce por la nota acompañante la localidad de origen en 104, de ellos 45 eran de la capital. Salvo Valoria La Buena (a $27 \mathrm{Km}$ de Valladolid capital), de donde llegaron 4 niños, Castronuevo de Esgueva $(a 17 \mathrm{Km})$, de donde llegaron 3 niños y Tordesillas $(32 \mathrm{Km})$, Mota del Marques $(39 \mathrm{Km})$ y Villardefrades (64 $\mathrm{Km}$ ) de donde se presentaron 2 expósitos, del resto de las localidades solo llegó un niño de cada una de ellas. Aparte de los comentados de Pamplona, Pontevedra y El Piornal (Cáceres), de fuera de la provincia llegaron de Palencia, Valdenebro (Soria, a $160 \mathrm{Km}$ de Valladolid capital), El Espinar (Segovia, a más de $100 \mathrm{Km}$ ), Aldeanueva (puede ser del Codonal, Segovia, a $78 \mathrm{Km}$ ), Valdezate (Burgos, a $74 \mathrm{Km}$ ), Guzmán (Burgos, $62 \mathrm{Km}$ ) y Ciruelos de Coca (Segovia, a $59 \mathrm{Km}$ ). De la provincia de Valladolid en este año se dejaron en el torno, que sepamos por las notas, niños de Santovenia, Zaratán, Laguna de Duero, Boecillo, Wamba, Puente Duero y Zamadueñas, todas ellas en un radio de $20 \mathrm{Km}$, Villanueva de Duero $(26 \mathrm{Km})$, San Martin de Valvení $(26 \mathrm{Km})$, Portillo $(30 \mathrm{Km})$, Montemayor (de Pililla, $37 \mathrm{Km}$ ), Matapozuelos (39 Km), Rueda (42 Km), Pedrajas de San Esteban, (45 Km), Palacios de Campos (46 $\mathrm{Km})$, Gallegos de Hornija $(47 \mathrm{Km})$, Vega de Valdetronco $(45 \mathrm{Km})$, Iscar $(50 \mathrm{Km})$, Palazuelo de Vedija $(52 \mathrm{Km})$, "Canillas" (debe ser de Esgueva, a $56 \mathrm{Km}$ ), Castronuño $(56 \mathrm{Km})$, Salvador de Zapardiel $(58 \mathrm{Km})$, Villagarcía de Campos $(58 \mathrm{Km})$, "Curiel" (de Duero, $60 \mathrm{Km})$, "Gatón" (de Campos, a $63 \mathrm{Km}$ ), Urueña $(66 \mathrm{Km})$, "Vecilla" (debe ser Becilla) de Valderaduey $(71 \mathrm{Km})$, Torrecilla de La Orden $(75 \mathrm{Km})$, Mayorga $(78 \mathrm{Km})$, La Unión de Campos $(80 \mathrm{Km})$, Santervás de Campos $(87 \mathrm{Km})$, Vega de Ruiponce $(83 \mathrm{Km}$ ) y Monasterio de la Vega $(87 \mathrm{Km})$.
} 
Para completar el panorama de la provincia, es necesario también tener en cuenta los niños que ingresaron por la vía que hemos llamado oficial, a través de la Diputación, es decir ingresos solicitados, por la familia o las autoridades, u ordenados por la autoridad. Casi todos los pueblos de la provincia ingresaron algún niño por esta vía en el período 1900-13, de los 237 pueblos que se recogen en los presupuestos provinciales, se han contabilizado 193 localidades de origen. De

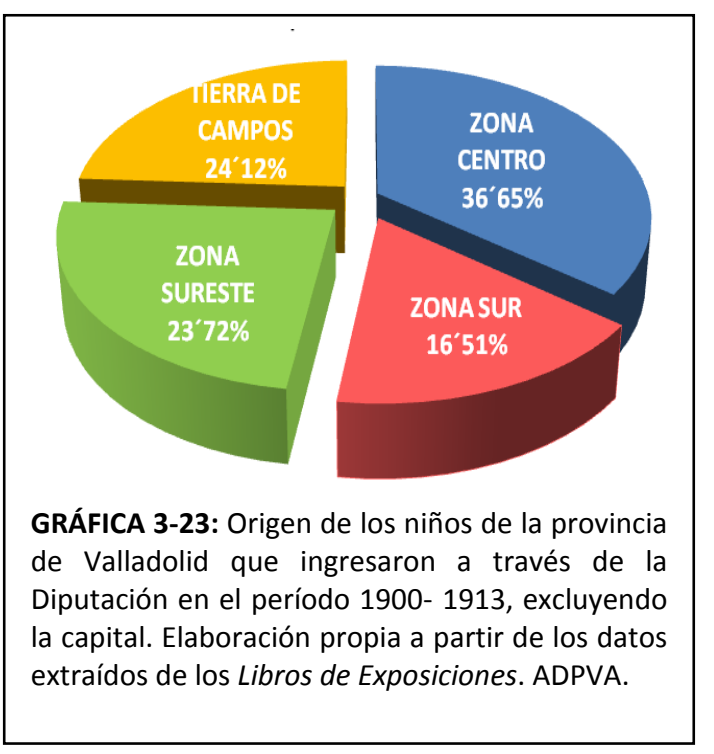
los 763 niños procedentes de los pueblos de la provincia que ingresaron a través de la Diputación, frente a 130 de la capital, el 36\% eran de la zona centro, apenas hay diferencias entre la zona norte, la Tierra de Campos, y el Sureste con el $24 \%$ y la zona sur del entorno de Medina del Campo no llega al 17\% (GRÁFICA 3-23).

Finalmente, para hacer una valoración global de los niños que procedían de los pueblos de la provincia de Valladolid, he considerado tanto los ingresos a través de la vía oficial como los expósitos de los pueblos y del torno de origen conocido; no he incluido los niños nacidos en la maternidad y el hospital porque son nacidos evidentemente en la capital por la circunstancia de encontrarse la madre institucionalizada en centros provinciales localizados en la ciudad, sin la posibilidad de tener el mismo servicio en otra localidad. En la GRÁFICA 3-24 puede verse la distribución según su origen, en los casos que es conocido, de los niños que ingresaron en la Inclusa provincial en el periodo 1900-13, casi el $70 \%$ procedían de los pueblos de la provincia (P), el $27 \%$ de la capital (C) y el 4\% (89) eran de fuera de la provincia, de algún lugar que no es legible o reconocible tal como figura en los folios o que no consta. Si calculamos la proporción entre los niños nacidos en los pueblos de la provincia $\mathrm{P}$ y en la capital $C$ sale una ratio muy elevada a favor de

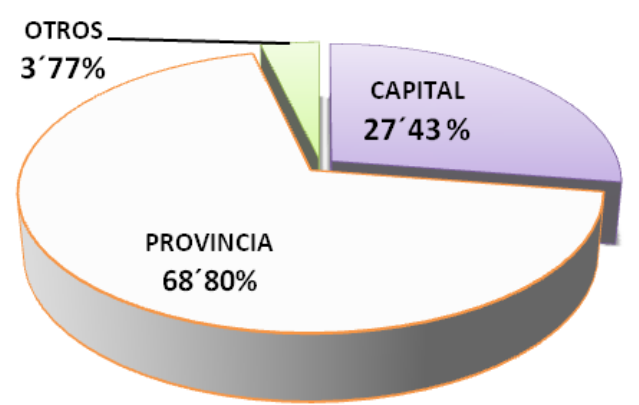

GRÁFICA 3-24: Origen conocido de los niños que ingresaron en la Inclusa Provincial en el período 1900-1913, excluyendo los nacidos en la Maternidad $y$ en el Hospital Provincial. Elaboración propia a partir de los datos extraídos de los Libros de Exposiciones. ADPVA.

la provincia con 250'85P/ 100C. Según los censos publicados en este mismo período 19001913, el promedio de población de la capital fue de 70.759 personas y el de la provincia, 
restando la población de la ciudad, fue de 212.910 con una ratio de 300`89P/100C, por tanto, aunque pueda parecer muy elevada la diferencia entre niños de los pueblos y de la capital, proporcionalmente ingresaron más niños de la capital; para una población equivalente saldría una ratio $83^{\prime} 36 \mathrm{P} / 100 \mathrm{C}$.

Si distribuimos los niños de la provincia en las cuatro zonas con las que estamos trabajando en base al mapa de la Diputación Provincial de Valladolid se mantienen la zona sur como la que más niños ingresó en la Inclusa (35\%), más del doble que la zona sureste que es la que envió menos (15\%) y las otras dos, centro y norte, con proporciones intermedias y muy similares entre sí (26 y 24\% respectivamente). Se puede ver la distribución territorial en la IMAGEN 3-16 sobre el mapa interactivo de la Diputación provincial de Valladolid que divide la provincia en cuatro

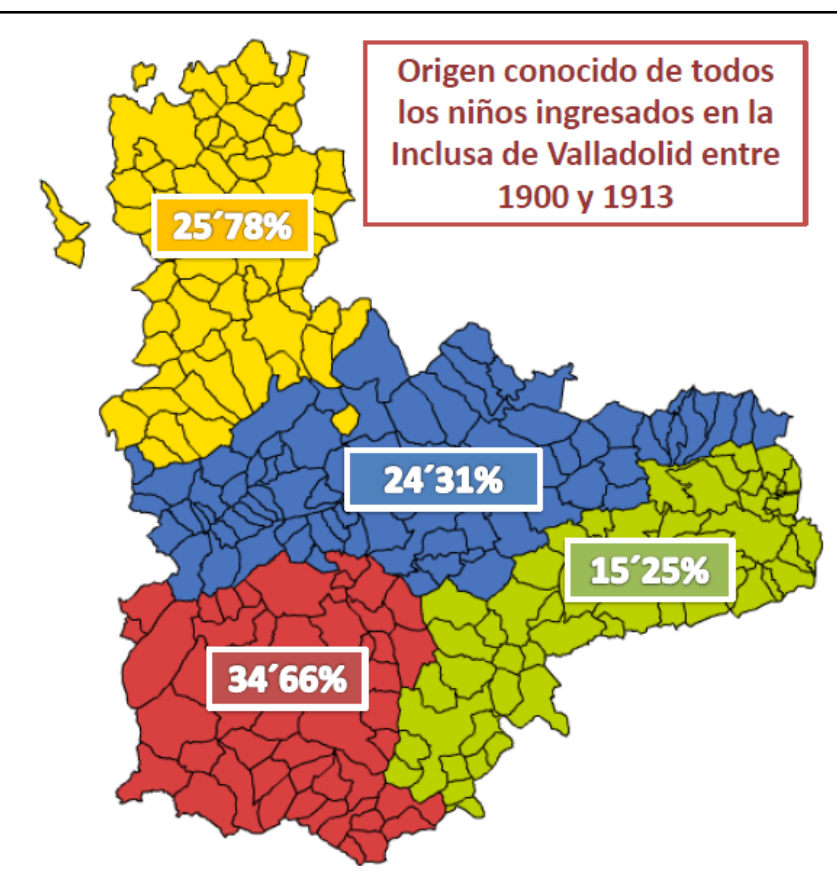

Imagen 3-16: Distribución de los lugares de origen de todos los niños de la provincia de Valladolid, cuyo origen se conoce, ingresados en la Inclusa Provincial por las distintas vías posibles entre 1900-13. Elaboración propia, datos de los Libros de Exposiciones ADPVA, mapa de la web de la Diputación provincial de Valladolid.

zonas, al norte en amarillo la Tierra de Campos, la zona centro en azul desde los Montes Torozos hasta los pueblos más orientales del valle del río Esgueva y de la ribera norte del Duero incluyendo Tudela de Duero, la zona sur en rojo corresponde a las Tierras de Medina y Tierra del Vino y la zona sureste en verde comprende la Tierra de Pinares y la Ribera sur del Duero. 


\subsubsection{LA MATERNIDAD DEL HOSPICIO PROVINCIAL DE VALLADOLID}

“CASA DE MATERNIDAD

Designanse con este nombre aquellos establecimientos públicos destinados al refugio y subsistencia de las mujeres que han concebido ilegitimamente y tratan de ocultar el embarazo y el parto" Lorenzo Arrazola. Enciclopedia española de derecho... ${ }^{485}$

El Departamento de Maternidad del Hospicio provincial de Valladolid se creó con los mismos fines que las llamadas Casas de Maternidad que proliferaron junto con las inclusas en todo el territorio nacional al amparo de la Ley de Beneficencia de 1822, que ordenaba en sus artículos 41 y 42 que cada provincia tuviera una Casa para "evitar los infanticidios y salvar el honor de las madres". El Reglamento de 1852 para la ejecución de la Ley de Beneficencia de 1849 mantiene la conveniencia de que en cada capital de provincia hubiera por lo menos una casa de maternidad y otra de expósitos. La Ley impulsó la creación de estas casas no sin polémica pues, como dice Lorenzo Arrazola en su Enciclopedia española de derecho... había quienes las consideraban "inmorales y funestos lugares de refugio; porque si la sociedad, dicen no encubriera la deshonra, habría mucha más cautela para no dar lugar a ella, al paso que protegiendo las concepciones ilegítimas y preservando sus frutos, parece que estimula á la deshonestidad, ó por lo menos la tolera y garantiza sus resultados". Él mismo hace la defensa con los argumentos que justificaron su creación "resguardar de la deshonra pública á quien, por el mero deseo de huir de ella, reconoce su falta anterior y demuestra no haberse extinguido en su corazón el sentimiento del deber; procurar disminuir el número de los mayores crímenes, del parricidio; arrancar á la muerte víctimas, tanto más dignas de protección, cuanto más desvalidas, serán siempre actos eminentemente caritativos y benéficos, que lejos de menguar la moralidad, la fortifican y de ella dan evidente testimonio. No conocen la naturaleza humana y sus debilidades los que creen sinceramente que por no existir casas de maternidad no existirían los deslices que las hacen necesarias" ${ }^{\prime 486}$

\footnotetext{
${ }^{485}$ ARRAZOLA L.: Enciclopedia española de derecho y administración, o Nuevo teatro universal de la legislación de España e Indias. Madrid. Tipografía General de Antonio Rius y Rossell. 1848-1870. pp 767- 769

${ }^{486}$ Ibídem, p 767
} 
El Reglamento del Hospicio de 1889 copiando casi literalmente el Art. 42 de la Ley de Beneficencia dice en su Art. 4ㅇ que su Departamento de Maternidad está destinado a "salvar el honor de las mujeres que han concebido ilegítimamente y evitar los infanticidios que la vergüenza provoca, serán admitidas en el mismo todas aquellas que demanden este socorro".

Este artículo se suaviza en los reglamentos posteriores que ya simplemente expresan en su Art. 293 que "Serán admitidas en este departamento las mujeres que habiendo concebido ilegítimamente reclamen la asistencia que necesiten por razón de su estado". El Reglamento de 1927 añadió “...y serán asistidas por una sola vez, exceptuando las pensionistas”, es decir las que pagaran pensión.

\begin{tabular}{|c|c|c|c|}
\hline MARÍA CALVO & 1905, julio, fo 264 & 1906, abril, fo 129; & 1908, dicbre, fo 385 \\
\hline MARÍA GONZÁLEZ & 1907, agosto, fo 268 & 1908, julio, fo 228 & 1909, octubre, fo 340 \\
\hline ANDREA HERNANDEZ & 1905, enero, & & 1906, julio, fo 225 \\
\hline JUANA SAN JOSÉ & 1905, abril, fo & & 1906, abril, fo 132 \\
\hline FELISA PEREZ & 1905, octubre & 351 & 1908, septiembre, fo 284 \\
\hline JULIA RODRÍGUEZ & 1905, diciemb & fo 411 & 1908, febrero, fo 44 \\
\hline ANGELA BLANCO & 1905, diciemb & fo 391 & 1909, marzo, fo 113 \\
\hline FRANCISCA PAREDES & 1905 , noviem & , fo 388 & 1910, febrero, fo 58 \\
\hline JULIA ALONSO R. & 1906, octubre & 320 & 1908, marzo, fo 98 \\
\hline EMILIA ROJO & 1906, octubre & 325 & 1908, agosto, fo 260 \\
\hline FLORENCIA POCERO & 1906, octubre & 302 & 1909, marzo, fo 106 \\
\hline PAZ MARTIN & 1906, agosto, & 262 & 1908, enero, fo 30 \\
\hline SABINA SANCHEZ & 1906, diciemb & fo 368 & 1908, marzo, fo 101 \\
\hline CONCEPCIÓN LOPEZ & 1906, abril, fo & & 1908, enero, fo 27 \\
\hline ANTONIA ANDRES & 1906, junio, f & & 1907, diciembre, fo 391 \\
\hline JUANA GONZALEZ & 1906, mayo, $f$ & & 1907, julio, fo 224 \\
\hline ESCOLASTICA OSMA & 1907 , febrero & 51 & 1908, octubre, fo 345 \\
\hline LEONCIA BUSNADIEGO & 1907, marzo, & 101 & 1909, septiembre, fo 307 \\
\hline CRESCENCIA RUIPEREZ & 1907, enero, & & 1910, abril, fo 130 \\
\hline CATALINA MONGE & 1907, marzo, & 102 & 1910, octubre, fo 341 \\
\hline ESPERANZA MOREJON & 1907, diciemb & fo 405 & 1910, febrero, fo 80 \\
\hline FELISA ELIPE & 1907, octubre & 331 & 1910, septiembre, fo 325 \\
\hline JUSTINA MARTINEZ & 1907, abril, fo & & 1908, marzo, fo 90 \\
\hline LEOCADIA CUESTA & 1907, noviem & , fo 352 & 1910, febrero, fo 56 \\
\hline MARIA FLANDES G. & 1908, marzo, & 103 & 1909, mayo, fo 190 \\
\hline JUANA MARBAN & 1908, marzo, & & 1909, noviembre, fo 388 \\
\hline FORTUNATA CUADRADO & 1908 , octubre & 320 & 1910 , agosto, fo 286 \\
\hline AGRIPINA ALONSO & 1908, noviem & , fo 348 & 1910 , septiembre, fo 335 \\
\hline PAULA FERNANDEZ & 1909, mayo; $f$ & & 1910, julio; fo 238 \\
\hline FRANCISCA RODRIGUEZ & 1909, abril; fo & & 1910, mayo; fo 169 \\
\hline \multicolumn{4}{|c|}{$\begin{array}{l}\text { TABLA 3-18: Relación de las mujeres que podrían haber reingresado en la Maternidad con las fecha } \\
\text { de nacimiento de los niños registrados en los Libros de Exposiciones y su no de folio. Elaboraciól } \\
\text { propia a partir de los datos extraídos de los Libros de Exposiciones. ADPVA. }\end{array}$} \\
\hline
\end{tabular}

Esta nueva condición no se encontraba en los reglamentos anteriores y al añadirse nos hace pensar que con cierta frecuencia habría mujeres que repetían estancia en la maternidad. Para comprobarlo reviso los datos sobre los niños de la Maternidad de los Libros de Exposiciones del período 1905-1910, son 519 incluyendo ambos años y los mortinatos, descartando las madres de gemelos que no aparecen más veces ( 3 en este período) y los 
nombres repetidos que por fechas no podrían ser de la misma mujer porque no daría tiempo a una gestación viable, he encontrado 30 nombres que se repiten, incluso dos aparecen en tres años diferentes. Esto hay que tomarlo con mucha reserva porque el único dato sobre la madre que figura en los Libros de Exposiciones es su nombre y casi siempre con un solo apellido, por lo que su repetición no nos asegura que se trate de la misma mujer. Los nombres que se repiten en tres ocasiones son María Calvo y María González, muy normales entre la población, de hecho en 1905 hay dos María Calvo y en 1908 tres María González, que por fechas de parto tendrían que ser mujeres diferentes. Lista de mujeres repetidas de la Maternidad: TABLA 3-18

Hay algunos nombres poco habituales, con los dos apellidos de la mujer, aquí solamente he puesto la inicial del segundo, que tienen bastantes probabilidades de referirse a la misma mujer, otros son más corrientes y caben más dudas al respecto, aunque vemos que coinciden los apellidos de los hijos. Si las 30 mujeres de la lista hubieran dado a luz en dos ocasiones en la Maternidad, representarían el 6'17\% del total de las 486 refugiadas que tuvieron hijos entre 1905-10.

\author{
"Maria F. Rodriguez Miralles \\ En 4 de Abril la dio á luz á las 10 horas la refugiada en este Asilo Francisca \\ Rodriguez" [sic] (fo 129. LE 1909-1) \\ "Gregoria Rodriguez Miralles \\ En 9 de Mayo de 1910 á las 8 horas y 30 minutos la dio la refugiada en este \\ Asilo Francisca Rodriguez" [sic] (fo 169. LE 1910-1)
}

Los reglamentos, aplicando la normativa legal vigente, establecían que las mujeres podían solicitar su ingreso en la Casa a partir del séptimo mes de gestación, antes de ese momento solamente podían ser admitidas por "motivos muy justificados" o las pensionistas que pagaban su estancia (Art. 50, Regl de 1889 y Art. 294, Regl de 1910 y 1927); la Ley de Beneficencia añade también al respecto en su Art. 43 que "cuando ganen el sustento con su propio trabajo", circunstancia ésta que no se ha recogido en ninguno de las reglamentos del Hospicio de Valladolid como condición que permita adelantar la entrada a la Maternidad. Justifica Lorenzo Arrazola que ésta es una medida para que "la beneficencia no degenere en inmerecida protección á quienes verdaderamente no tengan títulos suficientes á disfrutarlas... y por esto ha tomado como punto de partida el sétimo mes del embarazo. Entonces es cuando empieza á ser inminente el público deshonor y entonces cuando hay certeza de que las mugeres necesitan el benéfico refugio del establecimiento, como que ya no pueden disimular ante la sociedad su situación" [sic] ${ }^{487}$. El Reglamento de 1889 explica además que esas "causas justas

\footnotetext{
${ }^{487}$ Ibídem, p 768
} 
y graves a juicio del Director del Establecimiento o del Facultativo", que eran quienes debían aprobar el ingreso anticipado, eran "los malos tratamientos de que pueda ser objeto la joven por parte de sus padres o tutores y el abandono por completo de la misma por aquellos" (Regl 1889, Art. 6ㅇ).

Determina la Ley en su Art. 44 "la conveniente separación entre las mujeres acogidas según sus circunstancias y la conducta pública que hubiesen observado" y el departamento de Maternidad del Hospicio Provincial de Valladolid, para su cumplimiento, disponía de dos salas separadas; el criterio de separación era de carácter económico y clasista: "Habrá dos departamentos de Maternidad, uno general y otro particular ó de pensionistas distinguidas" (Art. 9o, Regl. 1889), departamentos que se corresponden con lo que en el Hospicio llamaban Sala General y Sala Reservada y que en los libros aparecen registradas normalmente con abreviaturas del tipo $S G$ y $R^{d o}$. Este artículo 9o no aparece como tal en reglamentos posteriores aunque en ellos distinguen entre las mujeres que ingresaban gratuitamente y las pensionistas, que diferencian a su vez en "dos clases, [de] 1ㅁ y $2^{\underline{q}}{ }^{\prime \prime}$, de manera que "el trato y habitación de las pensionistas guardará relación con la pensión que paguen y estarán independientes de las gratuitas" (Art. 299, Regl. 1910 y 19127). La sala General por tanto estaría destinada a las mujeres sin recursos y las pensionistas de 2 a y las "pensionistas distinguidas" se alojaban en la sala Reservada.

Como ocurre con otros departamentos del Hospicio, el Reglamento de 1889 se extiende más y nos hace un relato mucho más detallado del funcionamiento de la Maternidad, estableciendo una normativa que se seguiría aplicando en su mayor parte, aunque no se recoja después de forma explícita, por ello y porque estuvo vigente hasta 1910 voy a tomarlo como referencia principal recogiendo los cambios que se hicieron en los reglamentos posteriores. Dedica el Título Primero completo con sus 34 artículos al Departamento de Maternidad, a él irán referidos todos los artículos que en adelante se recojan con la numeración entre el 4 y el 38; los reglamentos posteriores dedican a la Maternidad la Sección II, a partir del Art. 293 (Reg) de 1910: capítulo XXXI con 13 artículos y RegI de 1927: 16 artículos en dos capítulos XXXII y XXXIII, dedicado este último a la profesora de partos.

El Departamento de Maternidad estaba a cargo de las Hermanas de la Caridad para todos los efectos tanto organizativos como disciplinarios, que estaban a su vez bajo las órdenes del director para las cuestiones administrativas y del facultativo para las de tipo médico. Una particularidad que debemos entender con la mentalidad de la época es que las monjas controlaban el departamento pero no podían asistir a las asiladas por una cuestión de 
tradición moral, para la atención directa de las mujeres en el parto estaba la enfermera, que por el mismo motivo debía reunir unos requisitos determinados según el Reglamento de 1889

Art 247. La enfermera estará obligada á prestar el servicio de su índole que la encargarán los Profesores, de acuerdo con la Superiora y principalmente el de la clínica de Partos, el cual por su índole és incompatibilidad de las Hijas de la Caridad, en estos casos necesita una atención preferente

Art 248. Esta enfermera será mayor de 25 años y no podrá exceder de cuarenta, en preferencia viuda sin hijos ó que haya sido ya madre, que acredite su prudencia y circunspección á juicio de la Superiora y Profesor encargado de este departamento.

Este artículo requiere de la enfermera de la Maternidad condiciones que tradicionalmente se exigían a las mujeres que quisieran practicar el oficio de parteras. Esta enfermera sería sustituida por una matrona a partir de 1925 según figura en los presupuestos, aunque en los reglamentos de 1910 ya se habla de una profesora en partos para atender la Maternidad y los partos normales y solo se mencionan sus funciones y no sus características porque como profesional titulada ya estaban reguladas legalmente. Las regulaciones sucesivas que se decretaron a partir de la ley Moyano (1857) respecto a la titulación oficial de Matrona recogen las cualidades que tradicionalmente se exigían a las Parteras ó Matronas, así, en el Reglamento aprobado por el Real Consejo el 16 de noviembre de 1861 sobre las Enseñanzas de Practicantes y Parteras, se establece en su Art. 20, y se mantiene en reglamentos posteriores, que "Para ser admitido á la matricula de parteras ó matronas es necesario: 1․ Haber cumplido veinte años de edad. 2 o Ser casada ó viuda. Las casadas presentarán licencia de sus maridos autorizándolas para seguir estos estudios y, unas y otras justificarán buena vida y costumbres por certificación de sus respectivos Párrocos" y demostrar conocimientos de primera enseñanza elemental. En el RD de 1904 que regula la carrera de Matrona, Art. 12, ya solamente se pide la mayoría de edad, por entonces en 23 años, la autorización del marido para las casadas y certificado de enseñanza primaria superior ${ }^{488}$.

\footnotetext{
${ }^{488}$ Reglamento para enseñanza de Practicantes y Matronas publicado en la Gaceta de Madrid el 28 de noviembre de 1861. Título III de los Alumnos, Capítulo I de las cualidades necesarias para ser admitido a matricula. Artículo 20. En este Reglamento se fija la edad para acceder a los estudios de matrona en 20 años cumplidos, 16 para los practicantes, aunque la mayoría de edad estaba por entonces en 25 años, y no se admiten mujeres solteras como parte de una tradición heredada que suponía que para ser partera la mujer debía ser casada y haber parido para entender como nacían los niños, una de las razones por la que las monjas no podían hacer estas funciones, la otra era la mala consideración social que tenían muchas de las mujeres que practicaban la partería.. El oficio de partear estuvo reservado a las mujeres durante siglos, "Ias matronas, que vulgarmente se llaman comadres en el oficio de partear", como dice Antonio Medina médico de los Reales Hospitales y examinador del Real Protomedicato en la Cartilla en el arte de partear que redactó en 1705 para su instrucción. A las parteras en muchas ocasiones se las acusó de brujería y malas artes debido a los conocimientos de hierbas y otros remedios que poseían y que utilizaban para atender partos, tratar los males propios de las mujeres y la esterilidad, evitar embarazos y provocar abortos. La Novísima Recopilación de 1805 de Carlos IV en el Libro VIII la Ley XI sobre los Exámenes de reválida en Cirugía para los Cirujanos, sangradores y parteras en el punto 9 recoge los mismos requisitos para las matronas en
} 
Tanto el médico, como la comadrona estaban obligados a atender inmediatamente a las acogidas en caso de "necesidad urgente". El médico encargado tenía que visitar la Maternidad "diariamente y siempre que fuere preciso a las albergadas en el mismo". El Reglamento de 1910 exigía a la matrona residir de forma "constante en el Establecimiento para intervenir en los alumbramientos normales, [y] cuando el parto presente algún síntoma de complicación llamará inmediatamente al Médico" (Art. 304). Posteriormente ya no debía residir pues el Reglamento de 1927 dice que "además de la visita de la mañana y de la tarde, la Profesora acudirá siempre que sea llamada y se constituirá de guardia permanente cuando alguna asilada presente síntomas de parto, aunque esté poco avanzado. Cuando para el desempeño de su cometido haya de permanecer de guardia en el Departamento, utilizará para su descanso la habitación particular dispuesta a este fin y disfrutará de la alimentación que se da a las pensionistas de primera clase" (Art. 306 y 307). Además de la obligación de guardar el secreto profesional, los reglamentos prohibían a la matrona intimar con las acogidas o hacer encargos para ellas "sin previa autorización de la Hermana del departamento" (Art. 304). En el Capítulo XXIII del Reglamento de 1927, se definen sus funciones y se describen las situaciones que debe considerar como graves y que requieren la intervención del Facultativo.

La Hermana encargada del departamento tenía que pasar "un estado diario de altas y bajas a la Dirección, sin designar nombres ni circunstancias que revelen los de las interesadas" y llevar las cuentas entregando "mensualmente en la Dirección las cantidades que reciba por pensiones de las acogidas, sin expresar las personas de quienes proceden, haciendo constar en el recibo los datos necesarios para llevar el libro de contabilidad de Maternidad" (Art. 297). El Director debía visitar periódicamente las salas, "cuando lo crea oportuno la Sala general... para examinar su estado y limpieza, oyendo privadamente las quejas o faltas que se denunciaren... Por lo que hace a la sala particular se colocará en el pasillo anunciándose de una manera convenida y si alguna acogida quisiera manifestar algo al Director lo hará sin darse a conocer"

cuanto a su estado civil y cualidades morales que el Reglamento de 1861 además de exigirlas demostrar limpieza de sangre. El estereotipo de la comadrona como una mujer con cierto carácter de marginalidad persistió hasta el siglo $\mathrm{XIX}$, sobre todo desde que los médicos empezaron a atender los partos de las mujeres más pudientes en el siglo XVII, por lo que la R.O. de 21 de noviembre de 1861 pretendió apartar de esa imagen a las matronas tituladas, entre otras cosas porque una de las funciones que se les atribuía era la de administrar el agua de socorro, de manera que en el Reglamento para las carreras de practicantes y matronas aprobado por RD del 16 de noviembre de 1888 se estableció entre los conocimientos que debían adquirir las Matronas el "Modo y forma de administrar el bautismo de necesidad a los párvulos, cuando peligra su vida"

Cfr: RAPIN D.: Manual práctico de partos para uso de comadrones y parteras, traducido por COROMINAS Y PEDEMONTE F., Barcelona. José Espasa Editor; "contiene todas las materias exigidas para el examen de Matronas por Real decreto del 10 de Agosto de 1904". VALLE RACERO J.I.: El saber y la práctica de las matronas: desde los primeros manuales hasta 1957. Matronas Profesión. 2002, no 9, pp 28- 35

En cuanto a la mayoría de edad, la Constitución Española en la Sinopsis del Artículo 12 que trata sobre este asunto relata la evolución histórica de esta fecha fijada actualmente en 18 años, que se ha ido rebajando desde las Partidas que la fijó en 25 años, en el Código Civil original de 1889 se bajó a 23 y a 21 en la reforma de 1972. 
(Art. 25). La dirección delegaba por tanto en la Superiora el control de las internas, del departamento y de los libros de la maternidad, salvo para decisiones finales importantes como el ingreso urgente o el castigo o expulsión de una asilada, que tenía que consultarlo o ponerlo en conocimiento de la dirección o del facultativo, y era la responsable de garantizar la confidencialidad de toda la información referente a estas mujeres, a las que en los libros de registro se las dice "refugiadas".

Mientras que los últimos reglamentos sobre la admisión de las refugiadas se limitaban a decir que "Ia hará la Hermana de la Caridad encargada del departamento, previo dictamen facultativo" (Art. 295), en el de 1889 se hace un relato más extenso e interesante en su Art. 7으, (la negrita es nuestra)

\begin{abstract}
"La admisión se hará por el Facultativo correspondiente, extendiendo este una papeleta que entregará a la persona interesada, con la cual se presentará á la Señora Superiora y esta le designará el día y hora en que haya de ingresar en el Establecimiento, advirtiéndola al propio tiempo las precauciones que debe tomar, á fin de evitar se sepa por nadie su ingreso. ....

Mas si alguna persona, por razones especiales como frecuentemente sucede, no quisiera entenderse con el Facultativo para ser admitida en el departamento de Maternidad, como pensionista, podrá hacerlo con la Sra Superiora solamente, la cual cuidará de exigir las estancias y demás gastos que la acogida ocasione"
\end{abstract}

Es de destacar ese interés insistente por proteger el secreto de la entrada en el asilo, habitual en este tipo de instituciones por mandato legal, y para proteger muy especialmente a las mujeres de la sala reservada que podían incluso saltarse el paso previo exigido a las demás de la aprobación del facultativo. El secretismo y la confidencialidad de toda la información sobre la mujer ingresada eran aspectos protegidos por la Ley de Beneficencia (LB): "Se observará el secreto más inviolable en este departamento, no debiendo hacerse pregunta ni información alguna sobre la conducta privada de las mujeres refugiadas, y será expelido inmediatamente el empleado ó dependiente que faltase de cualquier modo á tan importante obligación" (Art. 45 LB); "El descubrimiento de alguna mujer en estas casas no podrá servir de prueba legal contra ella" (Art. 46 LB ). Siguiendo esta normativa legal vigente, los reglamentos del Hospicio establecen que solamente se anotará el nombre de la refugiada si esta consiente de manera que "Se llevará con todo secreto y exactitud un registro de entradas y salidas en el que se anotará, el alta y baja de las asiladas con un número de orden, al lado del cual se consignará la fecha del ingreso y el nombre de cada una si voluntariamente lo quieren expresar", si la mujer no quería que se registrara su nombre en los libros tenía entonces que anotarlo junto con su "estado, naturaleza, edad y vecindad [en un] documento que sin leer será cerrado á su presencia en un sobre que se lacrará" y que se marcaba con el número asignado a la mujer en su registro. La Hermana encargada del departamento de Maternidad era la 
responsable de custodiar estos documentos que se devolvían a la mujer sin abrir cuando salía del centro y únicamente se podían abrir "por mandato expreso de la interesada ó si esta falleciere" (Art. 295, Regl 1910 y 1927). Hasta aquí lo que dicen los reglamentos, en la realidad no es posible saber si las mujeres en su momento consintieron, lo cierto es que en los libros de entradas de la maternidad aparecen registradas todas las mujeres con su nombre y localidad de origen (véase Registros de maternidad de los centros de acogida de menores en el capítulo dedicado a los Fondos del ADPVA, pag. 88), en muchas se ha anotado también el número de su cédula y algunos registros van más allá y aportan más datos: en el folio 75 del libro Entradas Maternidad 1906, 907 y $1908{ }^{489}$ en el margen superior se ha escrito "Certificación del Alcalde de Alcazarén de donde es natural y vecina, viuda de 34 años", en el 145 dice "de 18 soltera sirvienta" o en el folio 153 se lee "en concepto de presa PO del Sr Gobernador". Todas las mujeres registradas en este libro, 176 en total desde el 4 de octubre de 1906 hasta el 5 de septiembre de 1909, estuvieron ingresadas en la Sala General $\left(S G^{a l}\right)$, en él no se encuentra inscrita ninguna de la sala Reservada $\left(R^{d a}\right)$, por lo que cabe especular que para esta Sala Secreta, como también se la llamaba en los libros anteriores de la Maternidad, se llevara un libro aparte. En los libros de Entradas y salidas de los Niños de la Inclusa se anotaba, junto con el nombre de la madre, si se trataba de una refugiada de la Maternidad, la sala donde se encontraba; si consultamos los libros de los años 1906 hasta $1911^{490}$ encontramos en ellos niños que nacieron en esta sala $R^{d a}$ cuyas madres no aparecen registradas en el libro de la Maternidad, por ejemplo los niños de los folio 72 y 135 de febrero y abril de 1909, mientras que en las mismas fechas están inscritas todas las que en el libro de la Inclusa figuran en la $S G^{a l}$ (sala general). La normativa de confidencialidad, y por tanto el secreto, se respetaba más cuando se pagaba por ello, al menos en lo que a los registros se refiere. También para la Maternidad el Reglamento de 1889 refiere que el director debía llevar un libro "reservado donde anote las revelaciones que se le hagan por las acogidas para tener el historial de las mismas en caso de necesidad" (Art. 24), ya hemos dicho que no hay constancia en el archivo de estos libros reservados, si se llevaban libros paralelos en la dirección no se conserva ninguno. En los Libros de Exposiciones en el registro de los niños nacidos en la Maternidad el único dato que se anotaba de la madre era su nombre y normalmente solo con un apellido; el niño del folio 135 de 1909, comentado anteriormente, sabemos que nació en la $R^{d a}$ por el libro de Entradas de la Inclusa, en el de Exposiciones solamente dice lo mismo que en la mayoría de los registros similares

\footnotetext{
${ }^{489}$ Signatura: caja 929, expediente 7142. ADPVA

490 Libro Años 1906 Y 1907, 1908; Signatura: caja 1213, expediente 7736. Libro Entradas y Salidas de los niños de la Inclusa Años de 19091910 1911; Signatura: caja 409, expediente 3979. ADPVA
} 
"En 9 de Abril de 1909 á las 14 horas y 30 minutos le dio á luz la refugiada Basilisa Hernández que se encontraba en la Maternidad de este Hospicio".

12 años después esta "refugiada" recuperó a su hijo, final poco habitual para estos niños, y entonces si se anotó en el libro que era una mujer soltera de 39 años y que vivía en una calle céntrica y principal de la ciudad. Esta mujer no figura en el libro de la Maternidad.

Es muy raro que se den más detalles de la madre en los folios de inscripción de los libros oficiales o de Exposiciones en el caso de los niños de la Maternidad, como mucho en unos pocos se han anotado los dos apellidos o que la madre estaba en la sala general, no he visto ningún folio en estos libros en que se diga que era de la sala Reservada.

"En 4 de Septiembre de 1907 y hora de las dos y treinta minutos le dio á luz la refugiada de la sala general de Maternidad Julia Villagra San José" [sic] (fo 296, LE 1907- 2)

Más raro aún es que se aporten otros datos sobre la madre, solamente los encontramos en casos de hijos legítimos, de alguna mujer casada pero con circunstancias especiales como la de estar internada en el manicomio

"El dia 21 de Junio 1907 á las siete dio á luz en esta Asilo la refugiada procedente del manicomio provincial casada con Felipe Nistas procedente de Laguna de Duero" [sic] (f203, LE 1907-1)

O de alguna mujer viuda

"En 15 de Diciembre de 1907 y hora de las dos le dio á luz la refugiada en la sala General de Maternidad Mercedes Herrero de 36 años de edad viuda de Juan Martin que falleció el 22 de abril de 1907 habiéndose inscrito en el R. C. como hijo legítimo" [sic] (fo 399, LE 1907- 2)

Se ha registrado la fecha del fallecimiento del marido para justificar la consideración de legítimo del niño porque hasta su nacimiento han pasado más de los 180 días que marcaba el Código Civil para el reconocimiento de la paternidad ${ }^{491}$. Este tipo de registros en los Libros de Exposiciones son excepcionales.

Por todo ello resulta sorprendente un registro que encontré en relación con este tema en el libro de Exposiciones de 1904. En él, cuando una antigua refugiada reclamó a su hijo, se descubre que el nombre de la madre que se anotó en el folio del niño al hacer la inscripción era falso, de manera que antes de entregarle el niño se hicieron las comprobaciones pertinentes para comprobar que era su hijo. No indica como se demostró tal particularidad, pudo ser mediante ese posible libro paralelo de la dirección o por los datos particulares que aportara la mujer y permitieran la identificación. En todo caso este hallazgo supone que se respetaba el deseo de las mujeres de mantener el anonimato, aunque no se indica en qué sala

${ }^{491}$ CÓDIGO CIVIL. Libro I de las personas. Título V De la paternidad y filiación. Capítulo II, Artículo 117. Ver nota 411 
estuvo ingresada la mujer, y no se conserva el libro del departamento de Maternidad ni el de Entradas de la Inclusa de este año para poder comprobarlo, creo que pudo estar en la sala reservada porque el hijo salió pronto para crianza, a los 13 días de vida y la madre no se quedó a lactar como nodriza, revisando los folios de los meses siguientes no se encuentra como ama lactante con ninguno de los nombres, ni el real ni el ficticio.

\section{"Felix Gaspar San José Prado}

En seis de Enero de mil novecientos cuatro á las seis horas le dio á luz la refugiada en este Asilo Maria Torca...

Le lacta Maria Torca.

El 19 de Enero de 1904 le llevo Luisa Peña...

En 3 de Mayo cumpliendo acuerdo de la Comision provincial fue entregado a su madre Felisa Gonzalez Grijalvo vecina de Villaverde Mongina (apeadero de los Balbanes Burgos) que al dar á luz en este Asilo figuro con el nombre primeramente puesto en este asiento y que la Comisión prov ${ }^{a l}$ y esta Dirección han comprovado ser la misma que dio á luz este niño. No sabiendo firmar lo hace á su ruego su marido hoy" [sic] (fo 4, LE 1904-1)

Todos los reglamentos insisten en la privacidad y la inviolabilidad por ley de este departamento, de manera que se limita estrictamente la entrada de personas ajenas a él a las necesarias para atender a las mujeres, de ahí el llamarlas refugiadas, que también estaban obligadas a su vez a respetar el secreto.

"Art. 300. Declarada por la Ley la inviolabilidad de este departamento no se permitirá la entrada en él sino a las personas estrictamente necesarias para el servicio y para la asistencia religiosa y facultativa, quedando obligados todos los funcionarios o sirvientes que intervengan en el servicio del departamento a guardar secreto absoluto respecto a cuanto se relaciona con las acogidas en el mismo. Igual sigilo se recomendará que observe cada una de las acogidas por lo que a sus compañeras se refiere y a este fin se adoptarán en cada caso las medidas de precaución que el Director, el Médico o la Hermana estimen procedentes" [Regl 1910 y 1927] (la negrita es añadida)

Son varios los artículos que redundan en este aspecto, sobre todo en el Reglamento de 1889 que, además de recoger el artículo anterior (Art. 28), añade que incluso cuando se tratara de diligencias judiciales debían dar su aprobación el médico y el Gobernador. Vulnerar por parte de los empleados la obligación de mantener la más absoluta reserva, suponía el despido inmediato (Art. 35). Estaban prohibidas todas las visitas, incluidos padres y tutores, solo podían realizarse a petición de las propias asiladas o con su consentimiento y con la aprobación del médico de la maternidad (Art. 26). Cuando iba a tener lugar la visita del Gobernador o de miembros de la Diputación, dice el reglamento que "se anunciará también de una manera convenida, todas [las refugiadas] se cubrirán el rostro con un velo tupido, mas se procurará en tales casos oír el parecer del Facultativo correspondiente, para evitar los peligros que de tales 
visitas, pudieran resultar en determinados casos" (Art. 27). Estos artículos sobre las visitas a la Maternidad no aparecen en los reglamentos posteriores de 1910 y 1927.

El Art. 29 encarga a las Hijas de la Caridad, como responsables de la Maternidad, de mantener en ella la más absoluta reserva: "Encargadas de este departamento las Hijas de la Caridad, cuidará la Superiora que fuera de las personas destinadas al servicio del mismo no puedan en él las acogidas ser vistas por nadie ni aún por otras que se encuentren en su mismo caso, ni en su cuarto ni en las salidas que de aquél tuvieran que hacer". Esta normativa tan estricta parece aplicable solamente a las pensionistas de la sala particular, reservada o secreta, ya que en la sala general sería imposible teniendo en cuenta que era compartida por todas las mujeres, salvo las convalecientes, "en la citada sala general habrá el suficiente número de camas, teniendo preparados dos o tres cuartos o celdas para los partos y convalecencia de las paridas" (Art. 12).

En lo que respecta al comportamiento de las acogidas, solo se trata en el Reglamento de 1889 que hace a la Superiora responsable de promover actividades religiosas entre las acogidas y de velar para que guardaran el orden y limpieza del departamento y la compostura adecuada, evitando que "se hable licenciosamente [y que] se hagan revelaciones de ninguna clase, imponiendo á la que así faltare el correspondiente castigo". Si una vez reconvenida la mujer, no corregía su comportamiento, el castigo consistía, "de acuerdo con el Facultativo, [en] privarla de media ración por un día, ó dos ó más si reincidiese, teniendo en cuenta su estado y si estas correcciones no bastaren, se dará parte á la Excma Diputación para que resuelva lo conveniente" (Art. 32, 33 y 34). El castigo más severo era la expulsión del centro, "En 14 de Junio fue expulsada por insubordinación" la refugiada Gabriela Olea, todavía embarazada, ingresada en la sala General desde el 16 de abril de 1908 e inscrita en el folio 124 del libro de Maternidad. Según los reglamentos este castigo lo imponía "la Diputación, a propuesta razonada y fundamentada del Director" (Art. 285).

El mecanismo de entrada era diferente en el caso de hacerlo en una sala u otra. Para la sala general la mujer debía estar por lo menos en el séptimo mes de gestación y presentar "la cédula personal ó una papeleta del Alcalde, en la que conste su nombre, edad, estado y naturaleza; y si la conviniera puede hacerlo en pliego cerrado que se devolverá en igual estado á la salida" (Art. 10), aunque en este artículo el Reglamento de 1910 vuelve a insistir en la posibilidad de mantener ocultos los datos de identificación personal, parece que es un derecho que no se aplicaba o que las mujeres desconocían porque no he encontrado ningún registro sin nombre en los libros consultados, salvo el hecho que considero improbable de que los 
registros sin datos personales se inscribieran en otro libro. El médico reconocía previamente a la mujer y aprobaba su ingreso, en caso de enfermedad contagiosa podía negárselo y de tratarse de una situación urgente se le daba desde "la Dirección un pase para el Hospital provincial, mas en caso de urgencia y de no encontrarse en el Establecimiento dicho Facultativo, podrá ser admitida por la Superiora, sin perjuicio de ponerlo después en su conocimiento", por si no estuviera claro, termina este Art. 11 advirtiendo: "entendiéndose estas prevenciones para las que ingresen en la sala general". Ya vimos que las pensionistas si no querían ni siquiera tenían que pasar el reconocimiento médico, tampoco tenían que dar su nombre ni esperar al séptimo mes de gestación, bastaba con solicitar su ingreso y, eso sí, garantizar "suficientemente a juicio del Director el pago de sus estancias y gastos que ocasionen" y "se las designará para todos los efectos únicamente por el número que las corresponda, sin que por ningún concepto se revele su nombre, dado caso que lo manifestara" (Art. 13) y, llegado el momento o en caso de enfermedad, podían ser atendidas si así lo deseaban por un médico privado a cuenta suya y ajeno al Hospicio (Art. 19). En casos excepcionales, "atendida la educación y la conducta pública de alguna de las interesadas pobres", el médico o la Superiora podían determinar su ingreso en la sala reservada (Art. 15), hemos de suponer que para aislarla del resto.

No se permitía la salida del establecimiento a ninguna acogida hasta "estar completamente restablecida a juicio del Facultativo, cuidando de que su salida tenga lugar de modo que no sea notada, devolviéndose la ropa y papeles que hubiera entregado a su entrada" (Art. 22) y si alguna mujer quería salir antes de parir tenía que aprobarlo el facultativo y según la circunstancias se daba "aviso a la inspección de vigilancia" si era de la sala general o a la "persona que hubiera garantizado el pago de las estancias" si era pensionista, para hacer la liquidación correspondiente (Art. 23).

Solamente el Reglamento de 1889 contempla la actuación ante la enfermedad o el fallecimiento de las acogidas. En caso de enfermedad grave las refugiadas podían dar aviso a la familia, siempre con la aprobación del facultativo, si así lo solicitaban y si querían hacer testamento la dirección tomaba "las medidas convenientes para que se efectúe con la reserva posible" (Art. 18). Asombra como se mantiene el secretismo hasta el último momento, incluso en caso de fallecimiento, al menos para las pensionistas distinguidas. Dice el reglamento que cuando ocurriera a "alguna de las acogidas en el departamento reservado, el Director después de disponer se la dé sepultura con el mayor sigilo posible, lo pondrá en conocimiento de su familia, caso de ser conocida, o de la persona que hubiese respondido del pago de las estancias. El parte de defunción se pasará al juzgado municipal y el que se dé al cura párroco 
llevará la nota de "reservado", para que éste al consignar la partida adopte las precauciones que su prudencia le aconseje" (Art. 20). No se contempla en este artículo el mismo trato para las demás mujeres de la sala, aunque parece que intentaban localizar y avisar a la familia después del fallecimiento pues entre el libro de la Maternidad de 1863-1869 492 encontré una cuartilla suelta que recoge los datos de una mujer fallecida y de sus padres y dice

" $n$ o 41

Maria Martinez, soltera de 22 años de edad, natural de...

En la calle Real de Burgos no 2 habita una tia carnal de la Maria llamada también Maria Martinez

[en una nota al margen] Noticias suministradas por el celador D. Victor". [sic]

La hoja se encuentra en el folio 11 del libro que corresponde a esta mujer ingresada en la sala general y registrada con el no 41 y en el que no hay más datos que su nombre, las fechas de entrada y del parto y a continuación la liquidación de la cuenta por ella generada por "setenta y dos estancias que causó desde 7 de Juno a 17 Agto que falleció en el departamento de maternidad [tres días después del parto]... $288 r^{5}$ [reales] que pierde el Estab ${ }^{\text {to }}$ por la razón anterior según certificación del Profesor de Ciruga del mismo".

Evidentemente el alojamiento era muy distinto, la Sala General era una estancia común, mientras que la Reservada estaba "distribuida en celdas o cuartos numerados, de una capacidad bastante a contener una cama y todos aquellos muebles más indispensables para el uso común" (Art. 14). Todas "las camas de este departamento serán de hierro y contendrán, la sala general un jergón-colchón, dos sábanas de lienzo fuerte, almohada, dos mantas y una colcha. Y las de la particular, colchón además siendo las sábanas de lienzo más fino" (Art. 37).

Por lo que dice el Art. 305 de 1910, las acogidas debían vestir ropa del Hospicio, "Ias Hermanas... cuidarán de recoger las ropas de las asiladas para entregarlas a su salida", claro que, aunque no dice nada más, es de suponer que esto no se aplicaría a la sala reservada. El Art. 21 de 1889 dice que esa ropa podía servir para saldar en parte la cuenta de las refugiadas de la sala general cuando fallecían: "La Señora Superiora de las Hijas de la Caridad formará el inventario de las ropas y efectos que hubiera llevado para con su importe si procede de la sala general atender al pago de los gastos causados y lo restante se entregará a sus herederos ó personas que legítimamente lo reclamasen".

La alimentación de las refugiadas también se detalla en el Reglamento de 1889, en él se indica que "No se permitirá que las acogidas tomen otros alimentos que los que se

\footnotetext{
492 Maternidad Año 1863. Signatura: caja 1228, expediente 7771. ADPVA
} 
condimenten en la cocina del establecimiento y en cuanto a bebidas solo podrá hacer uso de vino o cerveza en cantidad proporcionada a las comidas según determine el facultativo" y después establece la dieta, diferente para unas y otras: "Por cada una de las acogidas en la Sala general se facilitará diariamente para su manutención 230 gramos de carne, 862 de pan, 43 de garbanzos, 29 de tocino y otros 29 de aceite, con la sal, pimiento y demás indispensable para su condimentación, comiendo todas reunidas. Estos artículos se distribuirán en sopa por la mañana, cocido al mediodía y sopa o patatas por la noche. Para reintegrar el establecimiento estos gastos se fija el tipo de una peseta por cada estancia" (Art. 30 y 36). "A las acogidas en la Sala particular se las dará chocolate por la mañana, cocido a mediodía, chocolate por la tarde y sopa, guisado de carne y ensalada por la noche, debiendo satisfacer por cada estancia que causen dos pesetas que pagarán por mensualidades adelantada." (Art. 37). En 1910 se mantiene igual la ración diaria de las pensionistas de la sala particular, aunque en la cena dice "sopa o ensalada" y sube el precio de la estancia a 2'25 pts (Art. 269), en cambio disminuye la de las refugiadas en la sala general quedando con "750 gramos de pan, 195 gramos de carne, 50 gramos de garbanzos, 56 gramos de arroz ó 70 de patatas, 28 gramos de tocino y tres centilitros de aceite...", el resto del artículo es igual salvo que al distribuir estos productos incluye carne por la noche y fija el coste de la ración diaria en 1'25 pesetas (Art. 268, C). El Reglamento de 1927 mantiene exactamente igual la ración de las refugiadas de la sala general, "y a las acogidas en la sala particular del departamento de Maternidad se las dará chocolate con leche o café con leche por la mañana, cocido y principio a mediodía... y postre en ambas comidas" (Art. 269), llaman principio al plato que se servía entre el cocido y los postres ${ }^{493}$. Se podía incluir vino en la dieta de las refugiadas "solo por prescripción facultativa" (Art. 273).

Los precios de la pensión completa podemos conocerlos por los reglamentos y comprobarlos con los libros de Entradas de la Maternidad y los Presupuestos de la Diputación. Los precios que acabamos de ver son los que se fijaron en el Reglamento de 1889, 1 pta para la estancia diaria en la sala general y 2 pts en la reservada, aparte se cobraban 5 pesetas por el servicio de lavado de la ropa (Art. 36 y 37). Por los libros de la Maternidad sabemos que anteriormente el coste diario era de 4 reales en la sala general y 6 en la "secreta" en 1863 y que subió a finales de 1869 a 5 y 8 reales respectivamente y se pagaban 8 reales por el lavado de ropa ${ }^{494}$. Los precios que estableció el Reglamento de 1889 se mantuvieron hasta que en el

\footnotetext{
${ }^{493}$ PRINCIPIO: (5a acepción) "Cualquiera de los platos de vianda u otros manjares que se sirve en la comida entre la olla o el cocido y los postres" RAE. Diccionario de la lengua castellana por la Real Academia Española. 1899 y 1914.

${ }^{494}$ En algunas anotaciones de 1863 hablan de 8 escudos, pero parece un precio desproporcionado, probablemente se trata de un error propiciado por los frecuentes cambios de moneda y de sus equivalencias en el siglo XIX, además, en el libro encontramos como se alternan los precios en milésimas (de escudo) y en reales y que en
} 
de 1910 el coste subió a 4 pts para las pensionistas de primera y 2 para las de segunda, en los libros de la Maternidad podemos comprobar que efectivamente los precios se mantuvieron estables durante todo este período, en 1909 seguían cobrando los mismos precios por las estancias y las 5 pts por el lavado de ropa, que ya no se indicará en los reglamentos posteriores. En el de 1927 se establecieron nuevos precios, que se confirmaron y publicaron en el Presupuesto de 1928 en las "Ordenanzas para exacciones provinciales", en el Anexo correspondiente a la "Maternidad secreta del Hospicio Provincial", en el que se ordenó la entrada en vigor el 1 de enero de 1928. El Art. 299 del reglamento dice que "Las que ingresaren como pensionistas se dividirán en dos clases de $1 \underline{a}$ y de $2^{2}$. Las de $1^{\underline{a}}$ abonarán 6 pesetas diarias por estancia más 50 pesetas por la asistencia que se prestare al parto. Las de $2 \underline{a}$ abonarán 3 pesetas diarias por cada estancia, anticipando las de ambas clases una quincena por lo menos. A su salida del establecimiento se liquidará la pensión devolviéndose el sobrante si le hubiere". Parece que la asistencia al parto solo se cobraba a las pensionistas de 1áa, que "estarán independientes de las gratuitas" y además podían recibir trato especial en "relación con la pensión que paguen" pudiendo "disfrutar de mejor habitación y comida diferente de la que la casa suministra, [pagando] una cantidad alzada en relación con el trato que quisiera recibir" (Art. 37). Las pensionistas de 1a eran las del departamento particular o reservado y las pensionistas de 2 a las que pagaban su estancia en la sala general.

Respecto a las mujeres que ingresaban "gratuitamente", realmente su estancia no resultaba tan regalada pues el Reglamento de 1889 decía que estas acogidas debían tener una "ocupación compatible con su estado en utilidad del establecimiento, ya que no cuentan con recursos para el pago de las estancias que causen, sin perjuicio de que luego puedan lactar á los expósitos el tiempo que estén obligadas a hacerlo" (Art. 31). Este artículo que las obligaba a trabajar para el centro no aparece en los reglamentos sucesivos, pero en ellos se mantiene la obligación de "lactar en el Establecimiento sin retribución durante un mes, o por tanto tiempo

muchas ocasiones no se escribe el tipo de moneda, así vemos que valoran la estancia en 400 milésimas en unas anotaciones y en 4 reales en otras.

José Bonaparte hizo un cambio en el sistema monetario español que hasta ese momento utilizaba como unidades de cuenta el escudo para el oro, el real para la plata y el real de vellón o el maravedí para el cobre imponiendo "la costumbre francesa de una única unidad de cuenta para las piezas de oro y plata, facilitando así su manejo y el establecimiento de equivalencias". Se adopta como unidad de cuenta en 1809 el real de vellón, que apareció oficialmente en época de Carlos II, y se establecieron nuevas equivalencias: 40 reales= 1 escudo, 20 reales= 1 duro, 4 reales= 1 peseta. Fernando VII en 1814 vuelve al sistema tradicional y durante el Trienio liberal se reimplanta el sistema de José I hasta el retorno del gobierno absolutista de Fernando VII en 1923, quien finalmente en su último año de reinado restableció el real de vellón como unidad de cuenta, en 1833. Isabel II mantiene este sistema hasta la reforma de 1848, que estableció un sistema decimal con el real de plata como unidad monetaria; 20 reales son un duro, 10 reales un escudo y 4 reales una peseta. Se abandona el sistema de los maravedíes, pero siguen en circulación las monedas antiguas, por lo que se tienen que establecer nuevas equivalencias y se siguen haciendo reajustes marcados por las crisis económicas y políticas. Precisamente en 1864, uno de los que se registran en el libro de la maternidad que estamos revisando, se establece como unidad del sistema monetario el escudo de plata, equivalente a 10 reales y a 40 pesetas. De Santiago Fernández Javier, Antecedentes del sistema monetario de la peseta. 2013. 
como el transcurrido desde el día de su ingreso hasta el que dieron a luz, si excediese de aquel" y "si por sus condiciones no pudiera lactar prestarán servicio en la Inclusa durante el tiempo antes indicado" o, como dice el Reglamento de 1910, "hasta indemnizar a la casa". Se añade en 1927 que si querían salir antes del tiempo fijado, tenían que abonar "Ias estancias causadas a razón de tres pesetas diarias" (Art. 298, Regl 1927), que era el precio diario en la sala general.

En los libros de la Maternidad, como ya hemos comentado, se anotaba sistemáticamente el nombre y naturaleza (localidad) de la mujer, fecha y sala de ingreso, fecha del parto y de su salida de la maternidad y, en su caso, de su paso a la Inclusa para lactar y a continuación encontramos en cada folio la liquidación oportuna, con los gastos generados por su estancia y los ingresos correspondientes por lactancia

"Pagó por 115 dias de estancias a razón de 1 peseta cada día mas 5 pesetas de lavado de ropas 120 [pesetas]" (fo 165, 1908 L. Maternidad)

Esta mujer estuvo ingresada 5 meses hasta que pasó a la Inclusa, donde solo se quedó a lactar 3 semanas, tiempo que descontaron al hacer la liquidación de su estancia en la sala general. En estos libros de la Maternidad no se consignaba nada sobre los hijos de las refugiadas. Tenemos que ir a los libros de registro de los niños, en el de Exposiciones de 1909 se encuentra en el fo 93 el hijo de esta refugiada, que lleva sus apellidos y al que estuvo lactando hasta que salió con una nodriza que luego lo prohijó. La mujer se quedó lactando a otro niño que falleció tres días después de que ella abandonara la Inclusa (fo 110, LE 1909-1)

"Pago por 23 estancias en Sala general mas 5 pesetas de lavado de ropa (precio de estancia 1 pta) 28 pesetas" (fo 173, 1909 L. Maternidad)

Esta refugiada estuvo lactando en la Inclusa durante dos meses, que se descontaron de su estancia en la Maternidad y al la liquidar resultó que tenía que pagar los 23 días que estuvo ingresada a mayores, más el lavado de ropa, 28 pts. Su hija está inscrita en el fo 62 del LE de 1909, la amamantó 5 semanas, hasta que salió con una nodriza. Con la tabla de Excel que he elaborado de este año puedo comprobar que la mujer lactó a dos niños más, uno a la vez que su hija durante unos días (fo 80 LE 1909-1) y el otro (fo 151 LE 1909-1) justo los 28 días que le habían resultado a pagar ( 23 días más el lavado equivalente a 5 estancias), empezando precisamente a partir de la fecha que le hicieron la liquidación; no obstante, esta parte de la estancia no está registrada en el libro de la Maternidad, probablemente se la inscribió como nodriza interna; suponemos que la cuenta quedaría saldada, era habitual que las nodrizas se quedaran hasta saldar su cuenta.

Solamente se remuneraba la lactancia de hijos ajenos, pero, como podemos comprobar con los ejemplos anteriores, no se cobraba la estancia a las mujeres que lactaban a 
sus propios hijos en la Inclusa, era norma, aunque no se recogió como tal hasta el Reglamento de 1910; si una refugiada quería "criar por sí misma [exclusivamente] a su hijo en la Inclusa, pasará a este departamento en calidad de nodriza, sujetándose a las condiciones generales de las demás amas, pero sin otra retribución que las estancias" (Art. 302), en el Reglamento de 1927 se añadió en este artículo "hasta que satisfaga las estancias causadas antes del parto", es decir que lactar al propio hijo en la Inclusa se consideraba como un servicio remunerado, que podía servir para saldar la cuenta con el Hospicio. Si nos fijamos en el folio no 152 del libro de Maternidad encontramos la inscripción de Asunción Escudero, ingresada el día 10 de septiembre de 1908 en la sala general, dio a luz el 16 de diciembre; su hija María Escudero está inscrita en el folio 396 del correspondiente libro de Exposiciones

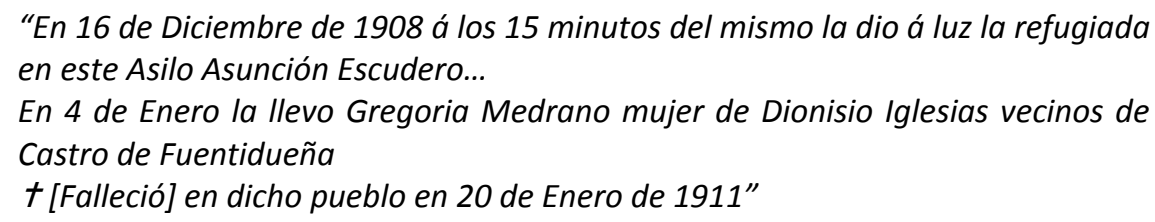

La madre pasó a lactar a la Inclusa el 23 de diciembre y se quedó según el libro de Maternidad hasta el 14 de noviembre de 1910; en su folio se han registrado todos los pagos por lactancia desde el 8 de abril hasta esa fecha. Empezó por tanto a cobrar cuando saldó su cuenta con la Maternidad, estuvo 103 días en la sala general y empezó a

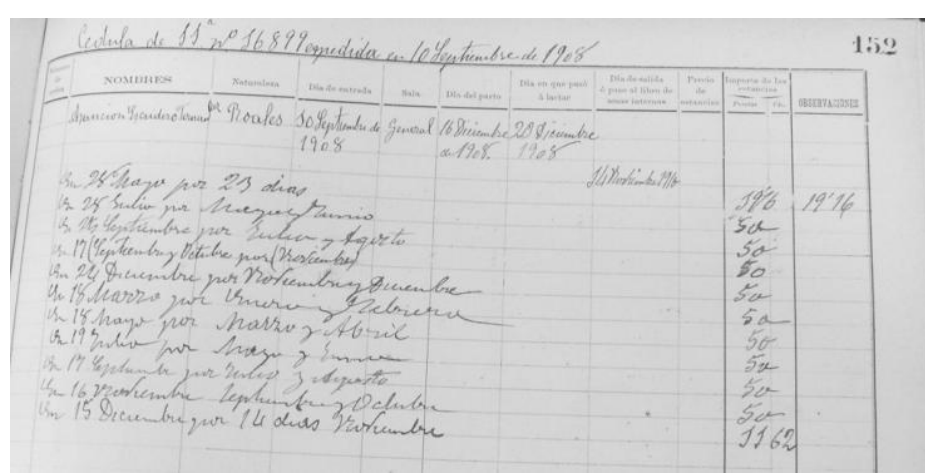

Imagen 3-17: inscripción del folio 152 del libro Entradas Maternidad 1906907 y 1908. ADPVA.

cobrar 103 días después de pasar a lactar (IMAGEN 3-17).

Las cuentas están claras, en definitiva, la mujer que no pagaba su estancia tenía que lactar en la Inclusa tantos días como había estado en la sala de la Maternidad. Por el libro de la Maternidad de 1863-69 que es más completo en cuanto a detalles sabemos que se libraban de pagar también las mujeres de la sala general que se remitían al hospital o que salían del asilo por enfermedad y las que perdían la lactancia, siempre certificado por el médico del establecimiento, y por supuesto las que fallecían. En los registros hay anotaciones del tipo de

$$
\begin{aligned}
& \text { "que pierde la casa por carecer de leche" [sic] } \\
& \text { "que no pago por pasar al Hospital" [sic] }
\end{aligned}
$$


"que pierde la casa por haber salido por enferma según la indicación del Profesor de Medicina de la misma" [sic]

"que pierde el Estabto (establecimiento)...[porque] fallecio en el departmto de maternidad" [sic]

No sabemos con seguridad si las refugiadas que lactaban permanecían en la Maternidad o si después del parto se quedaban unos días y luego pasaban a la sala de nodrizas de la Inclusa y el hijo a la de cunas, ni en qué momento cambiaban de sala. Se anotaban en dos campos diferentes las fechas del "Día en que pasó a lactar" y la del "Día de salida ó paso al libro de amas internas"; así se encuentra impreso en el libro y al leerlo y ver las anotaciones hechas no se distingue muy bien la diferencia, entendemos que el día que la mujer pasaba a lactar se incorporaba como nodriza interna de la Inclusa y cंentonces, el paso al libro de amas internas se consideraba a partir del momento que empezaba a criar a otros niños que no fueran su hijo?. No está claro; de todos modos, las salidas anotadas, en los casos en que se ha podido comprobar, corresponden con la salida de la Inclusa, no de la Maternidad.

En cuanto a la cuestión del tiempo de permanencia en la Maternidad después del parto, los libros no resuelven mucho. En el libro de Entradas Maternidad 1906, 907 Y $1908^{495}$, en la página no 2 está registrada Crescencia Rúa Pérez, que ingresó el 4 de octubre de 1906 en la sala general, dio a luz el 24 de enero de 1907, pasó a lactar el 1 de marzo y salió, del asilo, el 8 de agosto de 1907. Se anota debajo: "En 26 Sptbr cobro por cinco dias Julio y ocho Agosto 10 '82 [ptas]" (sic). Entendemos que estuvo 34 días lactando en exclusiva a su hijo (del 24 de enero al 1 de marzo), pero ¿en la Maternidad?; es posible porque desde el ingreso hasta el 1 de marzo hacen 144 días y como nodriza para la Inclusa estuvo 157 días, cobró los 13 días de diferencia.

Dos páginas después se encuentra Sofía Guerrero López, que ingresó el 14 de noviembre de 1906 en la sala general, dio a luz el 28 de febrero, pasó a lactar pasó a lactar 8 días después del parto, el 8 de marzo y salió del asilo el 10 de julio de 1907, aunque luego dice que cobró "En 25 Sptbr por 6 días Agosto 4 [ptas]" (sic). Calculando, son 143 estancias desde su ingreso hasta que pasó a lactar y 143 desde que pasó a lactar hasta el 6 de agosto, como en el caso anterior le cobraron hasta el momento que se puso a disposición de la Inclusa.

No conocemos la capacidad de la Maternidad y es difícil saber las mujeres ingresadas en un momento concreto; las refugiadas no se quedaban todas a lactar en la Maternidad, los

\footnotetext{
${ }^{495}$ Signatura: caja 929, expediente 7142. ADPVA
} 
reglamentos hablan de pasar a la Inclusa, donde, tengamos en cuenta, se encontraban los niños. A la vista de los ejemplos anteriores y con los cálculos hechos a partir del libro Entradas Maternidad 1906, 907 Y 1908, salvo algún caso que no cuadran fechas y cifras, podemos decir que las refugiadas podían quedarse en la Maternidad lactando a su hijo, pero ese tiempo tenían que pagarlo y empezaban a ser retribuidas a partir del momento en que pasaban a lactar, es decir cuando se ponían a disposición de la Inclusa, y entonces pasarían a la sala de nodrizas. Otra cuestión que se plantea es el de las mujeres de la Sala Reservada, comprobamos que todas lactaron a sus hijos hasta que salieron de la Inclusa y que ninguna lactó a otro niño, es evidente que no tenían necesidad de ello desde el momento que se encontraban como pensionistas; teniendo en cuenta la reserva que había con estas mujeres no parece probable que pasaran a la sala de nodrizas de la Inclusa, por lo que podemos suponer que permanecerían en la misma sala secreta amamantando a su hijo hasta su salida.

Por las Memorias anuales del Hospicio conservadas sabemos que el 1 de enero de 1906 había 17 mujeres internadas y el 31 de Diciembre 16; mujeres de estancias en general largas, en algunos casos de más de tres meses contando hasta la fecha del parto, tiempo de lactancia aparte. Las Memorias nos ofrecen el total anual de refugiadas atendidas en la Maternidad, fueron 77 en 1905 y 74 en 1911, presumimos que el total de las dos salas; la Memoria de 1908 diferencia los dos grupos y dice que durante el año ingresaron 83 mujeres en total, 72 en la Sala General y 11 en la Particular (ver capítulo de Población acogida del Hospicio). Son datos que no coinciden exactamente con los que podemos extraer de los Libros de Exposiciones, que nos permiten conocer el número de mujeres por el de niños nacidos e inscritos en los libros, en 1908 por ejemplo nacieron 90 niños en la Maternidad y no hubo gemelos, la diferencia se debe a que las memorias contabilizan a todas las mujeres ingresadas durante el ejercicio pero algunas daban a luz al año siguiente. Solamente en los libros de la Inclusa se anotaba la sala donde estaba internada la madre refugiada, con las siglas $S G$ o $R^{d,}$ por ellos podemos saber cuántos niños nacían en cada sala, aunque solamente disponemos de algunos años que se recogen en la siguiente tabla (TABLA 3-19).

\begin{tabular}{|c|c|c|c|c|c|c|c|}
\hline \multicolumn{8}{|c|}{$\begin{array}{l}\text { TABLA 3-19: MUJERES INGRESADAS EN LA MATERNIDAD DEL HOSPICIO PROVINCIAL } \\
1907-1913\end{array}$} \\
\hline AÑo & 1907 & 1908 & 1909 & 1910 & 1911 & 1912 & 1913 \\
\hline SALA RESERVADA & 12 & 11 & 17 & 6 & 8 & 5 & 9 \\
\hline SALA GENERAL & 82 & 79 & 94 & 65 & 62 & 76 & 64 \\
\hline TOTAL MATERNIDAD & 94 & 90 & 111 & 71 & 70 & 81 & 73 \\
\hline
\end{tabular}


Los niños de la Maternidad pasaban a la Inclusa, el Reglamento de 1889 dice que "Las criaturas que nazcan en este departamento se trasladarán a la sala de los no bautizados, y una vez alli" se seguían las mismas pautas que para los "niños expuestos o abandonados", es por eso que en los siguientes reglamentos se habla de ellos, por extensión, como expósitos (Art. 16). También pasaban, o al menos se anotaban en sus libros de Entradas, los hijos de las pensionistas de la sala reservada. No consta el dato de la sala en sus folios de registro, en los que si se anotaba siempre el nombre de la madre, a diferencia de los libros de la Maternidad que no recogían datos sobre ellos. La Memoria de 1905 dice que a primeros de enero se encontraban 17 mujeres en la Maternidad, ingresaron 60 a lo largo del año, 53 en la Sala general y 7 en la reservada, y que fueron 70 "curadas", lo entendemos como dadas de alta de la Maternidad. En ese año en los Libros de Exposiciones encontramos registrados 74 niños de la Maternidad, dos de ellos gemelos y tres mortinatos, por tanto 73 refugiadas parieron, entre las que tienen que estar las de la sala reservada. Lo que ya no podemos determinar, porque su inscripción en el libro de Exposiciones podía ser solamente un trámite obligado al estar el niño a cargo del Hospicio y porque no hay datos indicativos al respecto, es si los niños permanecían en la sala reservada con su madre o pasaban a una cuna de la Inclusa y solamente iban a la Maternidad a mamar. Resulta más razonable la permanencia con la madre, que permitiría ahorrarse una nodriza, pero en el caso de estas refugiadas no tendrían en principio ninguna obligación ni de lactar ni de cuidar al niño desde el momento que pagaban sus estancias, por tanto si lo hacían podría ser de forma voluntaria.

Todos los niños nacidos en la Maternidad se ingresaban, o al menos se inscribían en los libros de entradas, aunque según los reglamentos: "Podrán las albergadas disponer de los hijos que den a luz del modo que tengan por conveniente, bien sea dejándolos en la Inclusa o bien llevándoselos consigo a su salida del Asilo" (Art. 302); éste es un artículo modificado, en el Reglamento de 1889 la salida del niño con la madre tenía que ser autorizada y bajo condiciones: "Si la madre quisiera encargarse de criar a su hijo, podrá acceder a ello la Superiora, siempre que sea reconocido desde luego por ella y se obligue a criarle y educarle como tal" (Art. 17). A pesar de la posibilidad contemplada en los reglamentos de llevarse al hijo, la realidad es que en la mayoría de los casos los niños se quedaban en el Hospicio, solamente he contado 10 niños que se fueron con su madre cuando ésta salió del centro y dos de ellos fueron expuestos posteriormente en el torno.

"En 12 de Junio de 1901 y hora de las cuatro la dio á luz la refugiada en este asilo Antolina Prieto

La lacta la misma

En 18 de Junio de 1901 fue entregada á su Madre y para que así conste lo firma. 
En 27 de Agosto y hora de las veintidós volvió a ingresar por el torno de este Asilo con las ropas.... todo en buen uso y un papel que decía: "Hermana Sor Agueda. Esta niña se llama Carmen y nació en ese Hospicio el dia 12 de Junio... la suplico encarecidamente se tome todo el interés posible por ella...

Falleció en este Asilo en 12 de Septiembre de 1901 á las veinticuatro horas á consecuencia de catarro intestinal" [sic] (fo 179. LE 1901-1)

La salida de estos niños se ajustaba al Reglamento de 1889 , todavía vigente

"En 22 de Julio de 1909 á las 24 horas le dio á luz la refugiada en este asilo Maria Lasalle

En 21 de agosto de 1909 fue entregado á su Madre Maria Lasalle con arreglo 'á lo dispuesto en el arto 17 del Reglamento de este asilo interpretado en esta forma por el Sr Director y Sra Superiora, obligándose la Madre á lo mismo ordenado; no firma por no saber.

En 24 de agosto de 1909 á las 21 horas fue expuesto en el torno de este Asilo... Por ropas traia puestos unos trapos...

Falleció en este Asilo á las 2 horas" [sic] (fo 268, LE 1909-2)

Los dos niños fallecieron poco después, sobre todo este último debió llegar en muy malas condiciones pues vemos que fallecía a las dos horas de la exposición y que iba vestido con trapos, lo que nos hace sospechar las condiciones de precariedad en que viviría la madre.

Se aprecia en estos dos artículos, 17 y 302 de los Reglamentos de 1889 y 1910 respectivamente, un cambio de actitud por parte del Hospicio y de la Diputación como organismo responsable respecto a las refugiadas y sus hijos. Los dos mencionan que la mujer podía quedarse en la Inclusa a lactar; el de 1889 añadía: "pero si en lugar de esto [llevarse al niño] pidiese pasar de nodriza al departamento de lactancia, procurará [la Superiora] que su dicho hijo sea uno de los primeros que se den a lactar fuera de esta capital" (Art. 17), por lo que los niños de la Maternidad serían de los primeros en salir para criarse fuera. Este punto se retiró en 1910 y se cambió por la posibilidad de criar al propio hijo dentro de la Inclusa sin remuneración, algo que hemos visto que ya se venía haciendo aunque no estuviera reglamentado: "La que desee criar por sí misma a su hijo en la Inclusa, pasará a ese departamento... sin otra retribución que la comida reglamentaria" (Art. 302). Sorprendentemente al analizar las fechas de la salida de los niños de la Maternidad nos encontramos que precisamente después de 1910 salieron más pronto (ver GRÁFICA 3-26).

En el período estudiado de $1900-13$ el 19'47\% de los niños que ingresaron en la Inclusa nacieron en la Maternidad, en total 1.173 contando los nacidos muertos con un promedio anual de 84 niños (83'8); en dicho período hubo 10 partos gemelares, por lo que podríamos situar la media anual de mujeres atendidas en la Maternidad del Hospicio en 83 (83'1). Si contamos los niños que ingresaron efectivamente, descontando los mortinatos, fueron 1.099, con una media de $78^{\prime} 5$ al año. Los nacidos que ingresaron en la Inclusa fueron 570 niñas y 529 


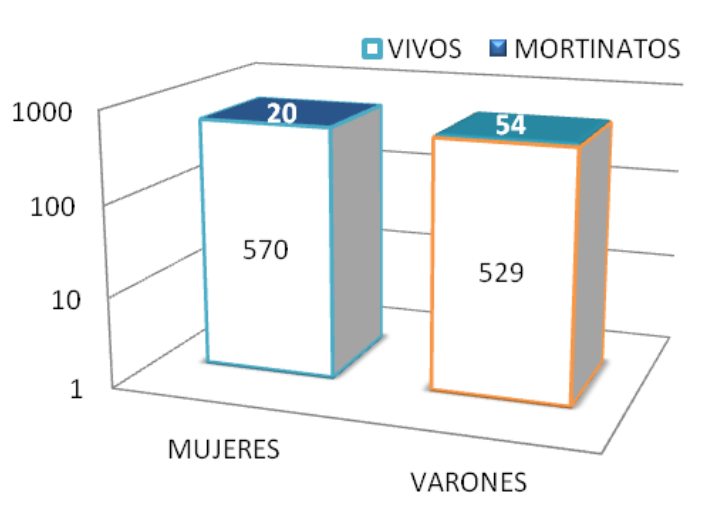

GRÁFICA 3-25: Sexo de los niños nacidos en la Maternidad, vivos y muertos en el período 1900-1913. Elaboración propia a partir de los datos extraídos de los Libros de Exposiciones. ADPVA. niños, $\quad 51^{\prime} 87 \% \quad$ y $\quad 48^{\prime} 13 \%$

respectivamente. Entre los mortinatos, el recuento es menos fiable porque en los folios solamente se pone donde debería ir el nombre niña o niño muerto y en 3 años en todos se ha escrito, niño, o así lo parece porque en algunos registros no se distingue bien; si todos éstos, que son 14 en total para esos 3 años, fueron realmente varones habrían sido 20 niñas y 54 niños, lo que sitúa el total de los nacidos en la Maternidad en 590 niñas y 583 varones, con una mortalidad periparto del 3’51\% para las niñas y del 10’21\% para los niños. (GRÁFICA 3-25)

En cuanto al carácter de legitimidad, hemos de presumir que la gran mayoría eran hijos ilegítimos, recordemos que el principal objetivo de la maternidad era precisamente ocultar estas situaciones; en los folios de registro no se hace referencia a ésta condición, pero descubrimos algunos casos de hijos legítimos, o al menos reconocidos por el padre, porque se ha especificado así, aparece el nombre del padre o podemos sospecharlo porque se utiliza el apellido maternos en segundo lugar; incluyendo estas tres situaciones, solamente contamos 12 niños que pudieron ser legítimos desde 1907 hasta 1913, antes no hay ninguno, pero no podemos tomar los apellidos como referencia porque se usaban los mismos para todos los niños (ver sección "Los apellidos de los expósitos")

Todos los niños de la Maternidad fueron lactados por su madre mientras permanecieron en la Inclusa, presumiblemente entre los que salían primero, en la segunda semana de vida, podrían estar los de la sala reservada. En 1905, cuando sabemos por la Memoria que en la sala reservada estuvieron 7 mujeres, hay 10 niños con estancias inferiores a dos semanas y ninguna de sus madres se quedó en la Inclusa a lactar, entre ellas podrían estar las pensionistas, que si podían pagar su estancia no necesitarían quedarse como nodrizas.

Mientras que hasta 1910 encontramos niños de la Maternidad que estuvieron más de un año ingresados en la Cuna, incluso en 1905 hay dos que permanecieron más de dos años, a partir de 1910 y a pesar de que el nuevo reglamento no indicaba ya nada al respecto, todos 
salieron en los dos primeros meses de vida, con la excepción de un niño que salió en 1911 con 48 días (fo 34. LE 1911-1) y otro en 1913 con 75 días (fo 40. LE 1913-1).

En estos 3 años posteriores al cambio de reglamento (1911-12-13) el 84\% de los 175 niños de la Maternidad que salieron para crianza lo hicieron en el primer mes de vida, el $15 \%$ en el segundo mes y sólo un 1\% entre el 3ㅇ y 40 mes. Evidentemente no se han contado aquí los que fallecieron en el asilo, todos lo hicieron dentro de ese intervalo de tiempo menos el niño del fo 53 de 1911 que falleció casi con 6 meses.

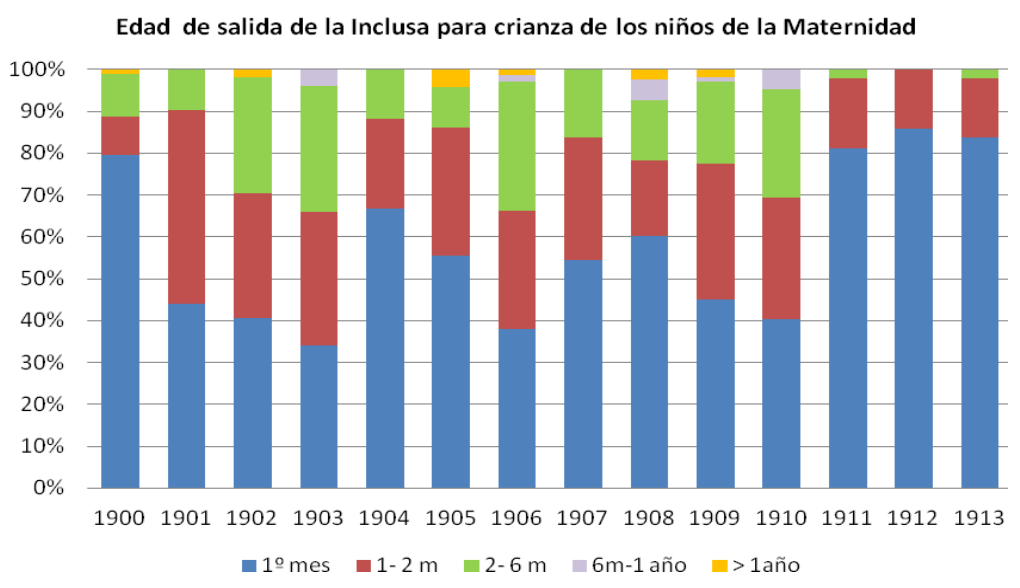

GRÁFICA 3-26: Edad a la que salieron los niños nacidos en la Maternidad para lactancia con nodrizas externas en el período 1900- 1913, porcentaje anual por grupos de edad. Elaboración propia a partir de los datos extraídos de los Libros de Exposiciones. ADPVA.

Hasta 1910, aunque con variaciones importantes de un año a otro, la mayoría también salió en los 2 primeros meses de vida, sólo en 1900 el porcentaje de salidas en el primer mes de vida se acercó al 80\%, sin embargo en todos los años encontramos niños que permanecieron hasta 6 meses y en casi todos estancias prolongadas en la Inclusa de más de un año (GRÁFICA 3-26). Si consideramos de forma global el período 1900-10, antes del cambio de reglamento, el 52\% de los niños de la Maternidad salieron a criarse en el primer mes de vida, el $26^{\prime} 7 \%$ en el $2^{\circ}$ mes, el $18^{\prime} 5 \%$ entre los 2 y 6 meses, el $1^{\prime} 5 \%$ entre 6 meses y 1 año y el $1^{\prime} 3 \%$ con más de 1 año de edad. En la GRÁFICA 3-27 se pueden comparar los dos períodos, antes y después de la publicación del nuevo reglamento de 1910. 


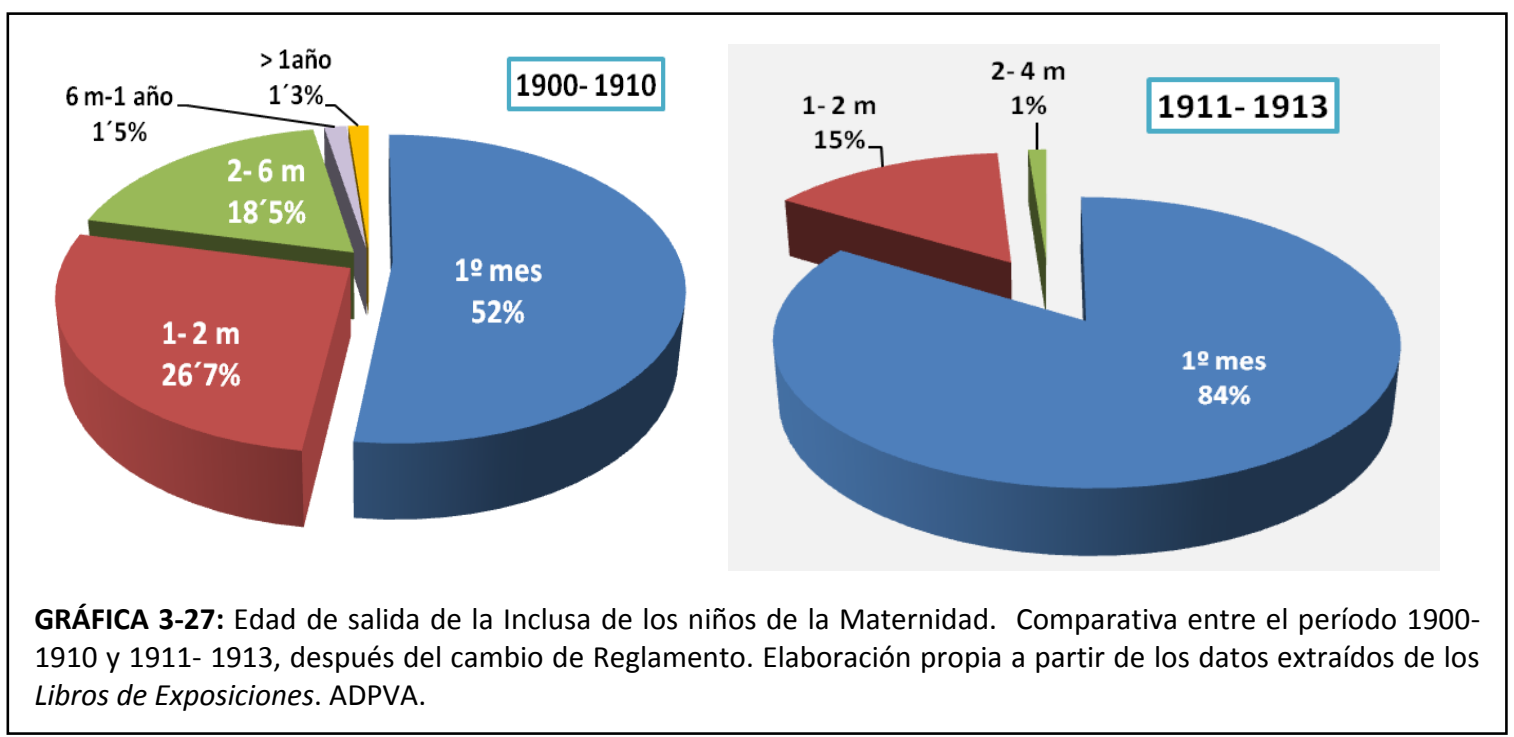

Los hijos de las refugiadas se bautizaban en la Iglesia del Hospicio, si estaban en peligro debían recibir "el agua de socorro por la Hermana de la Caridad ó la Comadrona". El Reglamento de 1889 no da instrucciones acerca del nombre que se adjudicaba a los niños al inscribirlos en el Registro civil, los primeros años, siguiendo con la idea de proteger la identidad de la madre, en vez de los apellidos maternos se ponía a todos San José, igual que a los expósitos del torno, no sabemos si a la madre se la permitía elegir el nombre de pila

"María de las Candelas San José

En 2 de Febrero de 1901 y hora de las nueve le dio á luz la refugiada en este asilo Brígida García" [sic] (fo 41, LE 1901-1)

En el nuevo Reglamento de 1910 y después en el de 1927 se dice que se inscribirá al niño con "el nombre y apellidos que la madre designe y en su defecto con los que el Director disponga" (Art. 301). Ya antes, empezaron a poner los apellidos maternos, o de los dos progenitores cuando eran hijos legítimos o cuando el padre reconocía al niño, algo muy poco habitual; solamente encontramos un registro en los años revisados de un hijo natural nacido en la Maternidad reconocido y que salió con su madre

"M C Rodriguez de la Viesca

La dio á luz la refugiada en este Establecimiento el dia 8 de diciembre á las 20 la refugiada en este Establecimiento Purificacion de la Viesca manifestando es hijo natural suyo y de Silverio Rodriguez... En 5 de Enero 1914 fue entregada á su madre" [sic] (fo 417, LE 1913-2)

Eran cautos a la hora de poner los apellidos paternos cuando podía haber sospechas sobre la legitimidad de los niños

"Luis Rivero Franco

En 20 de Junio de 1910 á las7 horas y 30 minutos le dio á luz la refugiada en este Establecimiento Virgilia Franco. ... 
Este niño fue reconocido por su padre e inscripto en el Registro civil como hijo legítimo de Luis Rivero y Virgilia.

Falleció en este Asilo á las 20 horas del 11 de Agosto de 1910 á consecuencia de Infeccion Gastrointestinal" [sic] (fo 225, LE 1910-1)

No sabemos si la elección de apellidos era siempre decisión materna, el Art. 301 así lo sugiere y es probable que así fuera, parece de todos modos que poner los apellidos maternos se convirtió en norma porque son muy pocos los niños que recibieron apellidos diferentes. Desde que empezaron a utilizarse a finales de 1906 solamente 32 niños de un total de 563 se inscribieron con apellidos que no eran los maternos (el 5’68\%); 1 sólo niño en 1908 y 1911, 2 en 1910, 3 niños en 1909, 4 en 1912, 8 en 1907 y 13 en 1913. Muchos eran niños de la sala reservada, aunque no todos, así lo he podido comprobar en los libros de la Inclusa disponibles, donde se anotaba la sala de la madre: 7 de los 8 niños de 1907 y los 2 de 1910; en cambio los 3 niños de 1909 nacieron en la general

\section{"Manuel Rodriguez Garcia}

En 10 de septiembre de 1912 á las 14 y 30 minutos le dio á luz la refugiada en este asilo Emiliana Temprano" [sic] (fo 319, LE 1912- 2)

En los Libros de Exposiciones comprobamos que el ama lactante en todos los niños nacidos en la Maternidad fue la madre, en los libros de los primeros años aparece escrito su nombre o dice que es la misma

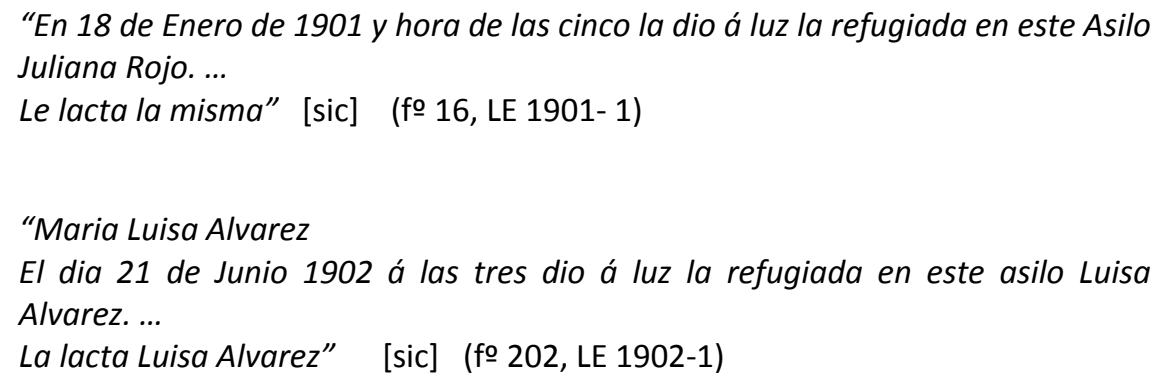

Casi al mismo tiempo que empezaron a poner a los niños los apellidos de la madre, dejaron de escribir el nombre de ésta en el lugar del folio destinado a anotar el nombre del ama que lactaba al niño en la Inclusa. A partir de los libros de 1908 ya no aparece escrito, pero eso indica que era ella misma, porque de lo contrario se hubiera anotado el nombre del ama correspondiente. 


\subsubsection{LOS NIÑOS NACIDOS EN EL HOSPITAL PROVINCIAL DE LA RESURRECCIÓN}

Los niños nacidos en el Hospital provincial que pasaban a la Inclusa eran considerados igual que los nacidos en la Maternidad del propio Hospicio, no precisaban trámites para su admisión, llegaban con un oficio del director del Hospital y la inscripción en el Registro civil. El traslado lo hacía una enfermera del Hospital, o en los primeros años la portera del mismo, según consta en los registros de los libros de entradas

"Francisco Rodriguez Mate

El dia 6 de Junio de 1904 fue entregado por la portera del Hospital provincial con papeleta del Sr Director del Hospital Provincial de la Resurreccion donde dice que esta inscripto en el registro civil donde dice que es hijo de Nicolasa viuda de Francisco Flores natural de Arrivas provincia de Palencia" [sic] (fo 176, LE 1904- 1)

Eran inscritos en el Registro civil por la dirección del Hospital pero se bautizaban en el Hospicio y, a diferencia de lo que ocurría con los niños de la Maternidad, siempre les ponían los apellidos maternos cuando era hijo natural o de ambos progenitores si eran hijos legítimos, en la cita anterior vemos que ponen al niño los apellidos maternos. Otra diferencia significativa es que se recogían en los folios de inscripción la condición de legitimidad o no y datos sobre la madre como edad, estado civil, origen o lugar de residencia o circunstancias consideradas relevantes, algo que hemos visto que no se hacía con las madres de la Maternidad; a estas mujeres que parían en el Hospital no les cubría el mandato legal de confidencialidad, que protegía la identidad de las refugiadas en las casas de Maternidad.

"Leonor Aparicio Matesanz

En 3 de Julio de 1909 fue entregada en este asilo por una enfermera del Hospital provincial con oficio del Sr Director de aquel asilo en donde consta que nació el día 1o de Julio de 1909 y que és hija de Cristina Aparicio Matesanz, natural y vecina de Serrada (Valladolid) de 19 años de edad, soltera" [sic] (f 233, LE 1909- 1)

Como curiosidad, un posible sobrino de esta mujer nació e ingresó en febrero, Blas Aparicio Matisanz, el segundo apellido no es exactamente igual pero bien podría ser el mismo mal escrito, la madre también es soltera y de Serrada y, rizando el rizo, la nodriza que le sacó se llamaba Cristina Aparicio, pero ésta estaba casada y era de Geria (fo 65, LE 1909-1).

\section{"Francisco Blazquez}

En 12 de Febrero de 1908 ingresó en este asilo procedente del Hospital provincial con oficio del Sr Director del mismo donde dice es hijo ilegítimo de Ines Blazquez soltera matriculada en la sección de Higiene Especial. Nacio el dia 11 á las 13 horas.

Fallecio en este asilo en 18 de febrero de 1908 á las 11 horas á consecuencia de Falta de desarrollo" [sic] (fo 48, LE 1908-1) 
Nos están diciendo que esta mujer era prostituta, algo que no encontramos en registros de la maternidad, ni de los niños ingresados a través de la Diputación. Recordamos que la sección de Higiene Especial era un servicio de inspección dependiente inicialmente del gobierno civil de cada provincia y a partir de 1889 de los ayuntamientos respectivos que tenía la función de vigilar y reprimir la prostitución y que obligaba a las meretrices a matricularse y pasar revisiones médicas periódicas a cambio de una serie de cuotas que estaban obligadas a satisfacer ${ }^{496}$. Parece que esta mujer estaba bien controlada desde el punto de vista higiénicosanitario, obsérvese que el fallecimiento del niño es por Falta de desarrollo, es decir por prematuridad y/o bajo peso, no dice que sea por sífilis congénita, un mal frecuente en la época, aunque la falta de desarrollo podría ser síntoma de este padecimiento. Esta mujer tuvo otro hijo que también dejó en la Inclusa en 1909 y está inscrito en el folio 360.

Encontramos algunos folios donde se registra también la profesión de la madre, en la mayoría no se dice nada, en los pocos que la indican la más frecuente es la de sirvienta, hay alguna otra matriculada, como la de la cita anterior, modistas y alguna "sin ocupación especial" (fo 319. LE 1909-2)

\begin{abstract}
"Teodora Ruiz Martin
En 9 de Diciembre de 1910 fue entregado por una enfermera del Hospital provincial con papeleta del Director donde dice que nació en aquel Establecimiento el dia 7 del corriente y que es hija de Antonia Ruiz Martin, soltera de 25 años de edad, natural de Valladolid, calle de 20 de Febrero, sirvienta" [sic] (fo 415, LE 1910- 2)

"Angel Soto Fernández

En 30 de Diciembre de 1908 le entregó en este Asilo una enfermera del Hospital general con oficio del Sr Director del mismo donde dice que nació el 28 del corriente y que és hijo de Silvina Soto Fernandez de 23 años, soltera, natural de Itero de la Vega (Palencia) y de profesión matriculada" [sic] (fo 417, LE 1908- 2)
\end{abstract}

\title{
"Joaquin Santa Maria Palacio
}

\footnotetext{
${ }^{496}$ ALCAIDE R.: El higienismo y la prostitución en la ciudad de Barcelona a finales del siglo XIX. En FRAILE P.: Modelar para gobernar: el control de la población y el territorio en Europa y Canadá, una perspectiva histórica. Barcelona. Publicaciones de la Universidad de Barcelona.2001; pp 275- 290

El reglamento de la Coruña de 1882 dice que "Corresponde al Médico higienista: 1o practicar por lo menos cada semana dos reconocimientos individuales en las mujeres públicas, con el interés y detención debidos" (Art. 21) y entre las cuotas que debían satisfacer las prostitutas o las amas de las "casas de recibir" dice que "Las pupilas satisfarán por todos los reconocimientos facultativos de que sean objeto á tenor de lo dispuesto en este reglamento, seis pesetas al mes las de 1ㅁ, cuatro las de $2 \underline{a}$ y tres las de3" ${ }^{\prime \prime}$. (Art 25). Reglamento de higiene especial de la provincia de La Coruña: comprende las secciones de La Coruña, Santiago y Ferrol La Coruña, Tip de la Casa de Misericordia, 1882, copia digital en :

http://www.galiciana.bibliotecadegalicia.xunta.es/es/consulta/registro.cmd?id=8843

Se puede consultar también. GUEREÑA J.L.: La prostitución en la España contemporánea. Marcial Pons, Ediciones de Historia. 2003. MONJE Y CUADRADO A.: Proyecto de reglamento de higiene y policía de la prostitución. Madrid : Imprenta de Emilio Vaquero, 1900
} 
En 26 de Diciembre a sido entregado por una enfermera....hijo de Pilar Santa Maria Palacio, soltera de 23 natural de Torre la Vega de oficio modista" [sic] (fo 436, LE 1910-2)

Lo que se dice pocas veces es la razón por la que se enviaba al niño desde el Hospital, salvo cuando la madre ingresaba o fallecía allí, aunque, por el perfil de las mujeres, parecen las mismas que provocaban el ingreso del resto de los niños en la Inclusa, la ilegitimidad y la falta de recursos

"En 2 de Junio de 1913 fue entregado por una enfermera del Hospital provincial con oficio del Director donde dice que nació el 30 de Enero de este año en Villalba del Alcor, hijo de Mariano y Maria, vecinos del mismo pueblo, encontrándose la madre en el Hospital provincial gravemente enferma y careciendo de leche. ...

Falleció en este Asilo á las 10 del 20 de Julio de 1913 á consecuencia de Atrepsia por dispepsia" [sic] (fo 209, LE 1913-1)

"En 27 de mayo de 1913 fué entregado por una enfermera del Hospital... és hijo de Salustiano y Angela encontrándose esta enferma en la sala de Sn Juan... y no poderle amamantar ni tiene leche ni medios ni aparatos para poder sustentar.... En 30 de mayo de 1913 fallecio en este asilo á consecuencia de congestion cerebral" [sic] (fo 200, LE 1913-1)

"En 14 de Septiembre de 1910 fue entregado por una enfermera del Hospital provincial con una papeleta del Director en que dice que este niño nació el dia 11 del corriente y que és hijo de Juan y Eleuteria de 35 y 24 años respectivamente natural el padre de Madrid y la madre de Pozal de Gallinas, la madre vive en calle Cerrada no 6 y el padre se ignora" [sic] (fo 313, LE 1910-2)

Hay incluso una madre que era asilada del Hospicio, resulta extraño que no fuera atendida en la propia Maternidad, pero no se da ninguna explicación al respecto

"En 13 de Junio de 1911 fue entregada por una enfermera del Hospital provincial... és hija de Ruperta Lopez soltera de 19 años residente en Valladolid. La Madre es procedente de este Hospicio" [sic] (fo 202, LE 1911-1)

Desde el Hospital provincial de la Resurrección llegaron a la Inclusa de Valladolid 407 niños, que representan el 6'75\% del total de ingresos en el período 1900- 13 (GRÁFICA 3-9). EI promedio anual fue de 29 niños, con diferencias significativas entre los primeros cinco años estudiados (1900-04) con una media anual de 19 y el resto del período en que sale un promedio de 35 niños (GRÁFICA 3-28). Fueron 212 varones y 195 niñas, la gran mayoría hijos naturales, solamente en 30 folios se dice que son legítimos. Conocemos algunos datos de las madres porque ya hemos dicho que en muchos folios se recogen; en los que dice el estado civil encontramos 290 solteras, 20 viudas y 35 casadas y tienen una edad media de 25 años para el período de estudio, con edades extremas de 16 años, hay dos muchachas de esta edad y otras 3 de 17 años entre los folios que tienen registrado este dato, y por arriba de 41 años (6 


\section{NIÑOS NACIDOS EN EL HOSPITAL PROVINCIAL}

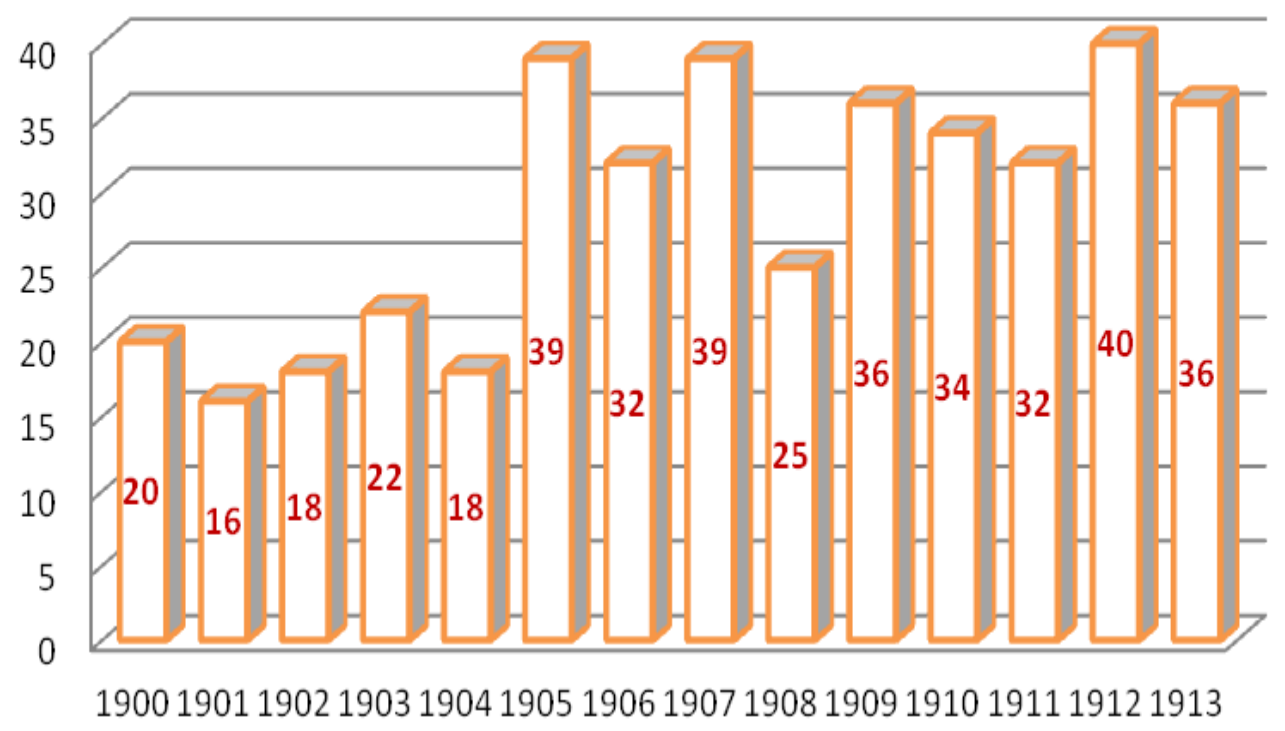

GRÁFICA 3-28: Niños ingresados en la Inclusa provincial de Valladolid nacidos en el Hospital Provincial. Distribución anual en valores absolutos para el periodo 1900-13. Elaboración propia a partir de los datos extraídos de los Libros de Exposiciones. ADPVA.

mujeres). En el caso de las viudas se aseguraban de la legitimidad del niño antes de poner los apellidos, en la mayoría de los casos no se dice nada y se ponen los apellidos de la madre, dándose por tanto por hecho que es un hijo ilegítimo, pero en ocasiones encontramos fechas en los registros para justificar si el niño era legítimo o no

"Domingo Fernandez Centeno

El dia 20 de Noviembre de 1907 fue entregado por la enfermera del Hospital provincial Micaela Diaz con oficio del Sr Director del mismo donde dice que es hijo legitimo de Tomasa Centeno Santos viuda hace ocho meses de Pascual Fernandez y que nació el dia 15 del corriente" [sic] (fo 374, LE 1907-2)

Las madres del Hospital tenían la posibilidad de entrar a la Inclusa a lactar, pero, a diferencia de las refugiadas de la Maternidad, para ellas no era una obligación

"Teodora Ruiz Villarejo

En 1 de Mayo de 1909 fue entregada en este Asilo por una enfermera del Hospital provincial con oficio del Director de este Establecimiento donde dice que nació el pasado mes de Abril y que és hija de Teodora Ruiz Villarejo natural de Tudela de Duero de 41 años de edad, de estado viuda hace 3 años según ha manifestado la interesada, residente en esta Ciudad calle de la Cruz Verde no 32 y natural de Tudela de Duero.

La lacta Florencia Pocero

En 13 de Mayo de 1910 cumpliendo acuerdo de la Comision Provincial de 23 de Abril último, fue entregada á su Madre vecina de esta Capital. No firma por no saber" [sic] (fo 164, LE 1909-1) 
Estaba claro que la niña no era del difunto esposo y se ponen los apellidos maternos. Esta mujer no lactó a su hija, pero luego la encontramos lactando a cinco niños de la Inclusa, la primera una niña del torno que también se apellidaba Ruiz

"Fernanda Ruiz Gutierrez

En 8 de Mayo á las 8 horas y 30 minutos fué expuesta en el torno de este Asilo con un papel que dice. Nació á las 10 y se llamara Fernanda Ruiz.... La lacta Teodora Ruiz" [sic] (fo 170, LE 1909-1)

Sabemos con seguridad que era la misma mujer porque aparece en el libro de la Maternidad en la parte dedicada a las Nodrizas internas de 1909 en el primer folio, allí dice que era natural de Tudela de Duero y que dio a luz en el hospital el 29 de abril, ingresó como nodriza el 5 de mayo, unos días después de su hija y estuvo lactando hasta el 17 de septiembre, unos días antes de que saliera su hija para crianza, el día 21; probablemente se haría cargo de ella aunque en el folio de la niña figura otra nodriza, la que podría haberla lactado hasta la llegada de la madre al asilo; esto no deja de ser más que una mera suposición pues en los libros no hay constancia de ello, pero la razón y el corazón y la coincidencia de fechas así lo sugieren. Según el libro de exposiciones cuando se fue se encontraba lactando desde el día 5 al niño Isaac Alonso del fo 308, que salió de la Inclusa el 5 de noviembre y tampoco se ha anotado la nodriza interna que la sustituyó.

En cuanto a los niños que nacieron en el Manicomio provincial fueron solamente cuatro los que entraron directamente, más un niño que también nació en el Manicomio en 1906 pero su ingreso se tramitó a través de la Comisión provincial (fo 297. LE 1906-2). El procedimiento y el registro es similar al de los niños del Hospital

"En 22 de Junio de 1909 fue entregado en este Hospicio por una enfermera del Manicomio provincial con oficio el Director de aquel Establecimiento donde dice que nació á las 13 horas del 21 del corriente y que és hijo de Isabel hoy enferma recluida en este Manicomio natural de San Juan de la Cistierna (Santander)" [sic] (fo 217, LE 1909-1) 


\title{
3.4. Condiciones de Vida Y CUIDADOS DE LOS NIÑOS DE LA INCLUSA
}

\begin{abstract}
"Una vez lavado, reconocido y filiado el futuro incluseroy después de bautizado con un nombre de los menos eufónicos, se entregaba á una nodriza interna, que dado el escaso número que pretendía el cargo, debido á su escasa remuneración y lo molesto del oficio, veianse obligadas á amamantar á varios niños á la vez, resultando ante el hambre horriblemente iguales"
\end{abstract}

M. Andreu. N.C. 9 enero 1913

"El niño, por su falta de madurez fisica y mental, necesita protección y cuidado especiales, incluso la debida protección legal, tanto antes como después del nacimiento"

Declaración de los Derechos del Niño. ONU 1959

Sabemos que en su ubicación dentro del edificio estaban separados el Departamento de Lactancia, también conocido como Inclusa, y el de Destete, que aunque aparece en los reglamentos como Departamento de Menores de 7 años, en otros documentos del Hospicio como las Memorias anuales se le denomina Departamento de Menores de 5 años porque en la práctica no solían pasar de esta edad los niños acogidos en él. A pesar de ser considerados como departamentos diferentes y de que las condiciones de vida en ellos efectivamente lo eran, los reglamentos de 1910 y 1927 hablan de Casa- Cuna para referirse a los dos de forma conjunta, aunque la mayoría de los artículos incluidos en su capítulo se refieren de forma exclusiva al de Lactancia. Puesto que este estudio se refiere especialmente a los niños lactantes en el sentido pediátrico del término, relacionado con la edad y por tanto con las características tanto fisiológicas como psicosociales del niño y no solamente con el aspecto alimentario, aunque nos centremos en la Inclusa por ser la sección de Lactancia, debo tratar la Cuna en general porque a ella pasaban los niños todavía dentro de la etapa que consideramos de lactante, además, en la práctica no había una edad fija para el cambio de un departamento a otro; por otra parte en los libros y documentos del Hospicio se utilizan indistintamente los términos Cuna, Inclusa y, aunque menos, también Casa de Expósitos para referirse a las dos secciones en conjunto, por lo que resulta difícil en ocasiones separarlas. Por tanto trataremos especialmente a los lactantes, pero recogeré aquellos aspectos de interés de los niños de la Cuna, los menores de 5 años. 
Los límites de edad establecidos en los Reglamentos, recordamos, eran los 18 meses para lactancia y 7 años para el destete, sin embargo en la práctica los cambios se hacían habitualmente a partir de los 15 meses y los 5 años respectivamente. Dice el Reglamento de 1889 que hasta los 5 años los niños no podían comer en el refectorio general, "mas si atendido su desarrollo físico conviniera el que pasaren al cuarto departamento [el de los mayores] se acordará así por el facultativo y la Superiora" (Art. 108); este artículo viene a justificar por qué a pesar de considerarse la edad de 7 años para el cambio de departamento la mayoría pasaban a los 5. En cambio, con los niños de lactancia no sólo no se justifica finalizarla antes, sino que se recomienda prolongarla si fuera necesario: "No obstante el tiempo prefijado en el artículo anterior [18 meses] podrán continuar en dicho departamento [de lactancia] aquellos expósitos que después de los diez y ocho meses de la lactancia se creyese ésta necesaria por el Facultativo, atendida su difícil dentición u otra enfermedad" (Art. 42); recomendación ésta que se cumplía en contadas ocasiones por lo que hemos podido ver.

Cuando los niños ingresaban en la sección de la Inclusa, tanto si procedían del torno como si entraban por la oficina o la maternidad, llegaban ya identificados con su número de filiación, una nodriza asignada y con su "atillo", el equipamiento de ropa que adjudicaban a cada uno (Regl de 1889, Art. 49) y ya llegaban vestidos con ropa del hospicio.

Sabemos que hasta que les bautizaban se separaba a los niños no bautizados. Al llegar a la Inclusa se colocaban en cunas numeradas; en "la sala o departamento de lactancia habrá preparadas las camas que se considere necesarias. Las cuales estarán numeradas y por el orden de entrada serán colocados en ellas los expósitos" y la Hermana de la Caridad responsable del departamento registraba en su libro junto con el nombre y el número del niño "el número de la cuna en que le deposite, encargando a las nodrizas que les coloquen siempre en la que les corresponda, vigilando muy especialmente este servicio". No sabemos la capacidad ni la ocupación habitual de la Inclusa, pero el número de cunas debía quedarse en ocasiones corto y lo solucionaban colocando dos bebés juntos "Si hubiera necesidad de colocar dos en una cama, se procurará que sean niño y niña para que ni por un momento pueda ofrecer duda alguna su identidad" (Regl de 1889, Art. 55, 56 y 59).

La Sala destinada a Destete estaba separada de la Inclusa y dividida "con el fin de que los expósitos estén separados por sexo á partir de los tres años", es decir que debían tener tres dormitorios, uno común para los menores de esa edad y otros dos para niños y niñas, hasta los tres años dormían en cunas y a partir de esa edad en camas, "unas y otras de hierro" (Art. 158). Las camas de esta sección también estaban numeradas y se exigía el mismo cuidado a la 
hora de registrar a los niños en el libro del departamento y de asignar y respetar para cada interno la cuna asignada, igual que en la Inclusa (Art. 105 y 106. Regl de 1889). Tampoco sabemos ni la ubicación ni la capacidad ni la ocupación media que podían tener las salas de destete.

Si nos basamos en la política del centro, que priorizaba la crianza externa y en las Memorias conservadas de 1905 y 1908 diríamos que la sección de Destete debía ser un departamento con baja ocupación, mientras que en la Inclusa habría más niños porque en ella se encontraban los lactantes ingresados hasta su salida con las nodrizas externas, que no solía ser inmediata. Según estas memorias, el 1 de enero de 1906 solamente se encontraba un niño de destete ingresado en la Cuna y 27 de lactancia, mientras que el 31 de diciembre de 1908 eran 14 niños de destete y 32 de lactancia (ver TABLAS $3-5$ y 3-6). Por otra parte, si nos fiamos de los datos de la TABLA 3-8 en la que se recogen los expósitos internos a partir de 1915 según datos de los Anuarios Estadísticos del INE, para el período 1915- 1930 el número de internos menores de 5 años entre las dos secciones de la Cuna, lactancia y destete, sería muy superior a la de esos dos años con una media de 98 niños (esto descontando los años 1915 y 1918 en los que se refiere un número por encima de 400 niños, que ya dijimos que probablemente recoja el total de acogidos, tanto externos como internos). Una media así supone que la Inclusa tendría un número muy elevado de lactantes, que bien podría estar muy por encima de 70 , tomando como referencia la media de los datos de las dos Memorias de 1905 y 1908. Son cifras que justifican las denuncias sobre las malas condiciones higiénicas y el hacinamiento del departamento que se harían por entonces, incluso por el equipo médico del Hospicio, como la que realizaron en la Memoria de $1920^{497}$ en la que manifiestan la necesidad de "Higienizar los locales, hoy muy deficientes de la inclusa, construyendo algún pabellón para diluir la población infantil y poder aislar a los enfermos contagiosos".

Ambas secciones estaban a cargo de las Hermanas de la Caridad, aunque el cuidado directo de los niños internos de la Inclusa lo realizaban las nodrizas o amas de cría, que residían en la misma Inclusa y estaban "subordinadas a la Superiora e Hija de la Caridad encargada inmediatamente del departamento" (Art. 63 Regl 1889 ). Se alojaban en dormitorios que según los reglamentos debían estar junto a la sala de los niños y en el plano conservado se encuentran inmediatamente encima de la sala grande de cunas y del secadero. No podían dormir con los niños ni llevar las cunas al dormitorio, sólo podían tenerlos con ellas por indicación médica. La Superiora, como responsable, debía "vigilar para que haya en todo el

\footnotetext{
${ }^{497}$ Memoria suscrita por los médicos del Hospicio Provincial relativa a la mortalidad de niños del establecimiento. 1920; Signatura: caja 4025, expediente 37809. ADPVA
} 
departamento el mayor orden, aseo y limpieza; que las cunas de los niños de lactancia y de destete, así como las de las nodrizas estén limpias y bien arregladas", además de controlar el ropero y enseres correspondientes. Por la noche una Hermana hacía guardia para "vigilar a las nodrizas y cuidar de que lacten á los niños que les estén destinados" (Art. 322-324 Regl 191027)

Hay poca información en los reglamentos sobre la sección de Destete en particular, solamente el Reglamento de 1889 dedica un capítulo separado para el Departamento de conservación y crianza de los niños Menores de 7 años, podemos suponer que para las cuestiones que no se tratan en él se aplicaría la normativa de las otras secciones. En él se manifiesta la separación por edad y sexo que hemos comentado antes, pero no habla de las encargadas de cuidar a los niños de esta sección, podrían ser las cuidadoras que llamaban "amas secas", nodrizas que ya no tenían leche para amamantar. Si ya eran de por sí pocas las amas de cría, debían ser muchas menos las que se quedaban después de lactar, hasta 1914 no se incluye en los presupuestos una partida para estas amas secas, "mujeres internas para cuidar niños que no salgan a crianza externa", 8 cuidadoras con un salario (ración y 12'50 pesetas) que era la mitad del que cobraban las 25 amas de cría internas y que podemos suponer que se harían cargo de los destetes. En 1919 encontramos anuncios en la prensa local solicitando "amas secas para cuidar los niños del Hospicio" ${ }^{498}$, en los presupuestos siguen apareciendo 8 cuidadoras y 25 amas internas hasta 1925, cuando aumentan a 16 con un salario de 15 pesetas, y a partir de entonces se muestra variable; se presupuesta una partida para 12 amas secas a 20 pesetas en 1926, se vuelve a 8 amas y 15 pesetas en 1928 y en 1929 y 1930 para 9 mujeres a 25 pesetas.

Los reglamentos recogen la preocupación por la educación de los asilados ya desde este departamento de Menores. De cara a la Dirección la responsable de esta sección, como de la Inclusa, era la Superiora y como tal estaba "autorizada para imponer a los párvulos las correcciones que su buen criterio le sugiera, atendida siempre la corta edad de aquellos" (Art. 114, Regl 1889). Hasta 1910 la separación por sexos a partir de los 3 años era total, no solo en los dormitorios, también en la escuela: "Habrá una escuela de párvulos para solo los varones, dirigida por una Hija de la Caridad, á la cual asistirán hasta la edad de diez años" y una "escuela de niñas menores de siete años [en la que les enseñaban] las labores compatibles con su edad, dándolas además la instrucción posible" (Art. 100 y 101, Regl 1889). A partir de 1910 se establece que "asistirán a esta Escuela [de párvulos] todos los acogidos de ambos sexos,

\footnotetext{
${ }^{498}$ N.C. 9- 08- 1919, p 2
} 
mayores de tres y menores de siete años" y que se dejaba "a cargo de una Hermana de la Caridad que tenga título profesional ó haya desempeñado esta enseñanza en el mismo u otro Asilo" (Art. 88 al 90, Regl de 1910- 27).

Para el desarrollo del niño son esenciales los componentes afectivo-emocional y moral desde edades tempranas. Erik Erikson ${ }^{499}$ en su Teoría del desarrollo psicosocial establece que hasta los 12- 18 meses el niño, dependiendo del vínculo que establezca con la madre y de que sus necesidades básicas estén cubiertas, adquiere sentimientos de satisfacción, seguridad, confianza y autoestima o, por el contrario, de abandono, aislamiento, desconfianza, vulnerabilidad y frustración, que van a determinar la calidad de sus relaciones humanas. El trato cercano y cariñoso es importante muy especialmente en la primera infancia; la actitud amorosa y de refuerzo y estimulación positivos por parte de padres y cuidadores son esenciales para el desarrollo sano de la personalidad. Por su parte, Albert Bandura ${ }^{500}$ en su Teoría de la personalidad plantea que el aprendizaje conductual es social, a través de las conductas que el niño observa en su entorno. Me gustaría poder desarrollar ampliamente los cuidados en esta área pero desgraciadamente no contamos con información; los reglamentos se limitan a decir que las nodrizas internas "prestarán con interés y cariño a los niños que están lactando los socorros y entretenimientos necesarios" (Art. 325 Regl 1910 y 328 Regl 1927); para las externas piden un trato similar al de un hijo, incluida la educación en los mayores de 5 años prohijados, y el Hospicio debía velar por ello

Art. 337. La nodriza al encargarse del expósito contrae como obligación natural la de alimentarle, cuidarle y vigilarle con la diligencia y cariño de hijo propio...

Art. 343. En el caso de continuar, será educado el expósito a expensas de sus encargados, según la clase a que éstos pertenezcan...

Art. 345. ...el Director se dirigirá semestralmente a los Alcaldes en cuyos pueblos residan expósitos menores de 17 años, pidiéndoles antecedentes, con carácter reservado, acerca de su estado, asistencia, trato, educación y demás que sea conducente para formar juicio exacto de si están atendidos con el esmero correspondiente. (Regl 1910)

La carencia afectiva en los niños no solo provoca trastornos psicosociales, sino que afecta también al crecimiento, incluso se ha descrito como causa asociada de mortandad. Aunque no podemos descartar posible excepciones, la situación de los niños internos sería la

\footnotetext{
499 ERIKSON E.H.: Infancia y sociedad. Buenos Aires, Horme-Paidós. 1983; El ciclo vital completado. Barcelona, Ediciones Paidós Ibérica. 1985; Juego y desarrollo. Barcelona, Crítica, 1982

500 BANDURA A.: Aprendizaje social y desarrollo de la personalidad. Madrid, Alianza, 1977; Teoría del aprendizaje social. Madrid, Espasa-Calpe, 1987
} 
que se describe hoy como hospitalismo $0^{501}$ debida a la institucionalización y a unos cuidados impersonales, teniendo presente que las nodrizas debían hacerse cargo de varios niños, aparte de las tareas que a mayores se les podía asignar, que además en muchos casos sus hijos habían sido entregados o habían fallecido y que su estancia en el Asilo era "obligada". La situación de los niños externos, que vivían con la nodriza, a pesar de encontrarse en un ambiente "familiar", no siempre era positiva afectivamente, la devolución de los niños después de años de crianza son suficiente demostración, incluso en los casos de prohijamiento, en los que podemos suponer interés y cariño hacia el niño que se ha cuidado, podía haber otro tipo de intereses como su explotación laboral, encontramos en los libros niños que eran devueltos después de criarlos y prohijarlos o los recogía la Diputación, no se explican los motivos

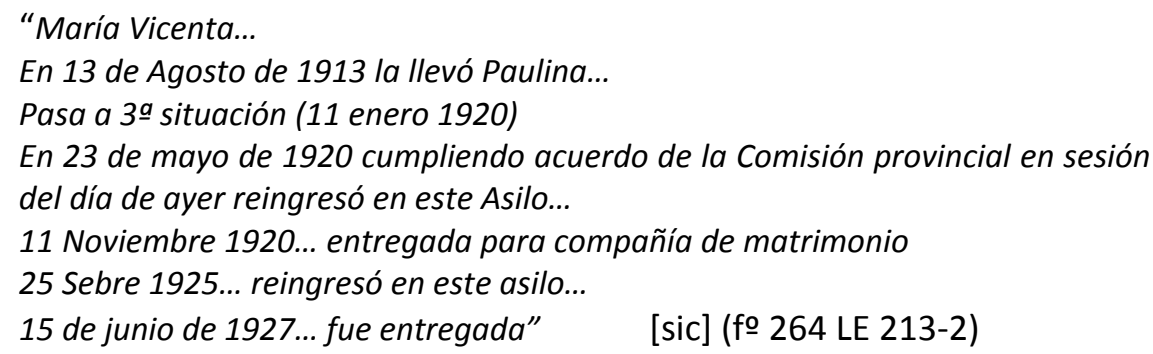

Esta niña tuvo suerte y volvió con el matrimonio que la sacó "para compañía" que finalmente la adoptó legalmente en 1952. Pocas veces ocurría esto. Muchos niños entraban y salían varias veces del Hospicio a lo largo de su acogimiento, en la Cuna o después en el Hospicio, casi un $2 \%$ de los que salieron para crianza externa tuvieron más de dos nodrizas. En relación con todas las vicisitudes que pasaban los niños dentro y fuera de la Inclusa se publicaba en El Norte de Castilla en 1913 esta tremenda opinión:

\begin{abstract}
"Hemos tenido ocasión de contemplar muy de cerca ese trasiego y conceptuábamos dichosos á los que morían en la casa a los pocos días de nacer. Probablemente de ahí debió partir el origen de la frase más estúpida que pudo inventar el egoísmo humano: "angelitos al cielo», velando con esa frase mistica
\end{abstract}

\footnotetext{
${ }^{501}$ Se habla del síndrome de carencia afectiva que en los niños institucionalizados se conoce como hospitalismo y que cursa con una clínica muy variada en función de la edad y las características del niño pero entre sus manifestaciones se describen alteraciones nutricionales como la anorexia y del sueño, mayor susceptibilidad a las infecciones y retrasos del desarrollo psicomotor y físico. Es bien conocido el trabajo de René Spitz en 1945 sobre el hospitalismo en orfanatos; estudió 91 casos de niños institucionalizados, el 37'5\% falleció antes de los 2 años y el resto a los 4 años padecía un retraso psicomotor. (SPITZ R.A.: Hospitalism; an inquiry into the genesis of psychiatric conditions in early childhood. Psychoanal Study Child. 1945, 1, pp 53-74) Se ha podido estudiar más recientemente el hospitalismo en los orfanatos rumanos que proliferaron cuando el gobierno prohibió la contracepción y dio a cambio la posibilidad de institucionalizar a los hijos (SPIRA A., SCIPPA L. y col.: Hospitalism in the year 2000: The psychological development of children in a Romanian orphanage. La Psychiatrie de l'Enfant. 2000, 43, pp 587-646). Se denomina retraso de crecimientos psicosocial la talla baja o el retraso en la pubertad asociados ala carencia afectiva o el abuso psicosocial. FERNÁNDEZ GARCÍA J.M.: Hipocrecimiento de origen psicológico. Sociedad española de Endocrinología Pediátrica. 1999, pp 113-123.
} 
un abandono y falta de caridad que indirectamente tiende a hacer buenas las teorías malthusianas ${ }^{\prime 502}$

Es ilustrativo el informe que el director Justo Esteban envió a la Comisión provincial en febrero de $1906^{503}$, en él da cuenta de la apatía y falta de afectividad de los niños criados con nodrizas externas, a las que, dice, solo les movía el dinero. Apunta además la importancia de separar a los más pequeños del resto para no recibir mal ejemplo, debido a que el Hospicio funcionaba como reformatorio recogiendo a los hijos "difíciles" de familias que no podían controlarles ${ }^{504}$; la escuela de párvulos estaba destinada inicialmente a niños de 3 a 10 años, se cambiaría y en el reglamento de 1910 ya figura solo hasta los 7 años. El cambio debió hacerse antes de este informe porque en él habla de las ventajas de la separación, que dice permitía, además, que la Hermana de la Caridad responsable de la escuela de párvulos prodigara a los niños las caricias y el afecto del que estaban tan faltos (transcripción completa en ANEXO 2)

\begin{abstract}
"Así, debido indudablemente a la separación de la enseñanza de los párvulos de la de los adultos, se nota un adelanto; al ser entregados para su lactancia y destete a nodrizas que no tienen por lo general otro interés que percibir la cantidad con que son retribuidas, si bien no es edad para poder apreciar lo que significa la caricia maternal, al ser devueltos al Establecimiento por haber cumplido los cinco años se podía apreciar sin grandes esfuerzos, seres insensibles a todo sentimiento, que se aumentaba desde esta edad en adelante al notar la falta de las caricias de aquellos que estando en el indiscutible deber de prodigárselas, la necesidad, el vicio, la fatalidad u otras causas que no es pertinente entrar en su averiguación, hace que les abandonen.

A remediar en lo posible esta falta, con muy buen acuerdo encomendó esa Comisión la enseñanza de los párvulos a la Hermana de la Caridad, que aparte de sus reconocidas virtudes, por el sólo hecho de ser mujer, sabe dispensarles toda clase de caricias, despertarles su amor al prójimo, los beneficios que de él reciben, en una palabra, hacerles aparecer a la vida como satisfechos de su existencia y que no odien por acto instintivo a la sociedad en que viven, precisamente porque en sus primeros años les faltó lo que á los demás hijos, el ósculo maternal"
\end{abstract}

\footnotetext{
${ }^{502}$ ANDREU M.: Vulgarización científica. N.C., 13- 01- 1913, portada

503 Informe sobre mejoras y necesidades del Hospicio provincial 1906. Signatura: caja 4872, expediente 43333. ADPVA

${ }^{504}$ Todavía en 1928 el Hospicio se seguía urilizando como reformatorio y la Comisión provincial reclamaba la construcción de uno "Se aprobó el ingreso en el Hospicio del menor Eleuterio Sáez González, hecho por el señor gobernador para su corrección, acordando rogar a dicha autoridad que careciéndose en aquel establecimiento de medios para la corrección de jóvenes cuya estancia además pudiera resultar perjudicial para los asilados, interese del Estado la construcción de un edificio que pueda cumplr con aquel fin". N.C. 6-09-1928
} 


\subsubsection{Identidad e identificación de los incluseros}

El niño tiene derecho desde su nacimiento a un nombre

Principio III de la Declaración de los Derechos del Niño. ONU 1959

"La presente niña suplico á V.me la bauticen y sea conocida por el nombre de María Gonzalez y Perez. Dios guarde a Vs. muchos años y no dudo an de mirar al Angel como esta desgraciada lo mira la necesidad me obliga á desistir en la presente. 18 Enero de 1902" [sic]

Nota presentada en el torno de Valladolid. Folio 21, Libro de 1902.

La mayoría de los expósitos y todos los niños nacidos en la Maternidad, que se consideraban también expósitos, se bautizaban en la capilla del Hospicio, cuya dirección tenía también la obligación por ley de inscribirles en el Registro civil (RC); había que imponerles un nombre y ésta era una de las cuestiones reglamentadas. También se bautizaban allí los niños nacidos en el Hospital provincial, pero éstos llegaban ya inscritos en el RC, por tanto con el nombre ya adjudicado.

En junio de 1870 se publicó la Ley, con carácter provisional del Registro civil ${ }^{505}$ que obligaba a hacer la inscripción de los expósitos en un plazo de tres días al cabeza de familia o responsable de la casa donde se hubiera hecho la exposición, en este caso al director

Art. 45. Dentro del término de tres días, á contar desde aquel en que hubiese tenido lugar el nacimiento, deberá hacerse presentación del recién nacido al funcionario encargado del Registro...

Art. 47. Están obligados a hacer la presentación...

5o El jefe del establecimiento público ó el cabeza de la casa en que el nacimiento haya ocurrido...

70 Respecto á los expósitos, el cabeza de familia de la casa ó el jefe del establecimiento dentro de cuyo recinto haya tenido lugar la exposición.

El director del Hospicio tenía pues la responsabilidad legal de formalizar la inscripción en el RC de todos los expósitos que no estuvieran registrados, de ahí que se anotara sistemáticamente en los Libros de Exposiciones la fecha en que se realizaba, para las inscripciones el Hospicio pertenecía al Juzgado del Distrito de la Audiencia de Valladolid.

Esta ley no estableció una normativa en cuanto a la imposición del nombre dando por supuesto que se seguiría realizando como venía siendo costumbre, únicamente dice al

\footnotetext{
505 (17 de Junio. Publicada en 20) Ley mandando establecer desde luego, con el carácter de provisional, el registro civil en la Península é islas adyacentes, conforme al adjunto proyecto de ley. 1870. Título II De los Nacimientos.
} 
respecto en su Art. 48. 50 que se pondrá "El nombre que se le haya puesto ó se le haya de poner", que es de aplicación también a los expósitos, según el Art. $49^{506}$.

El 13 de diciembre del mismo año se aprobó el Reglamento para la ejecución de las leyes de matrimonio y Registro civil que desarrolló la Ley en este aspecto marcando la pauta para las instituciones de acogida de expósitos en su artículo 34.3

"Cuando el recién nacido no tuviere ya nombre puesto, el declarante que hiciera su presentación manifestará cual se le ha de poner; pero el encargado del Registro no consentirá que se pongan nombres extravagantes ni impropios de personas, ni que se conviertan en nombres los apellidos.

Cuando el niño no tenga padres conocidos, el encargado del Registro le pondrá un nombre y un apellido usuales que no indiquen aquella circunstancia.

Si el niño fuere expósito, y entre los objetos hallados con él hubiera algún escrito que indique su nombre y apellido, o el deseo de que lleve algunos determinados, se respetará la indicación si no fuese inconveniente"

La ley advierte que no se deben imponer nombres que delaten la falta de filiación de los expósitos y que se respeten las indicaciones que se den al respecto en su exposición. Veremos que en la Inclusa de Valladolid, como en muchas otras, se cumplió sólo en parte.

En la Inclusa provincial de Valladolid cuando los niños ingresaban bautizados o inscritos se mantenía y se registraba el nombre de los certificados, igualmente se respetaban los nombres que aparecían en las notas del torno, tanto si el niño estaba bautizado como si no

${ }^{506}$ Art. 48. La inscripción del nacimiento en el Registro civil expresará las circunstancias...

1 으 El acto de la presentación del niño

2 - El nombre, apellido, edad, naturaleza, domicilio y profesión ú oficio de la persona que lo presenta y relación de parentesco ú otro motivo por el cual esté obligada según el art. 47 de esta ley, á presentarlo

3o La hora, día, mes y año y lugar del nacimiento.

4 - El sexo del recién nacido.

5o El nombre que se le haya puesto ó se le haya de poner.

6- Los nombres, apellidos, naturaleza, domicilio y profesión ú oficio de los padres y de los abuelos paternos y maternos si pudiesen legalmente ser designados, y su nacionalidad si fuesen extranjeros.

70 La legitimidad ó ilegitimidad del recién nacido, si fuera conocida; pero sin expresar la clase de esta, á no ser la de los hijos legalmente denominados naturales.

Art. 49. Respecto á los recién nacidos abandonados ó expósitos en vez de las circunstancias números 3ํ, 60 y 70 del artículo anterior se expresarán:

1․ La hora, día, mes, año y lugar en que el niño hubiese hallado o expuesto

20 Su edad aparente.

3 - Las señas particulares y defectos de conformación que le distingan

4 - Los documentos ú objetos que sobre él ó á su inmediación se hubiesen encontrado; vestidos ó ropas en que estuviese envuelto y demás circunstancias cuya memoria sea útil conservar para la futura identificación de su persona.

Art. 51. Respecto á los recién nacidos de origen ilegítimo, no se expresará en el registro quiénes sean el padre ni los abuelos paternos, á no ser que el mismo padre, por sí ó por medio de apoderado con poder especial y auténtico, haga la presentación del niño y la declaración de su paternidad.

Lo mismo se observará en cuanto á la expresión del nombre de la madre y de los abuelos maternos." 
"Si estuviera bautizado se pondrá con su nombre y con referencia á la partida de bautismo é inscripción en el Registro civil. Si no lo estuviere y el exponente dejara indicado el nombre se le pondrá éste" (Art. 314 Regl 1910 y 317 de 1927)

Bastaba con dar un nombre en la nota que se adjuntaba al niño

"Juanito Perez Fornies

...fue expuesto en el torno... con un papel que decía " Juanito Perez Fornies, hay una rubrica»" [sic] (fo 251, LE 1901-2)

Se puede comprobar en los registros que, salvo alguna excepción aislada, siempre se ponía el nombre que en las papeletas del torno se proponía, o que en algunas se imponía como si se supiera que el Hospicio cumplía con ese mandato.

Cuando la papeleta daba los apellidos maternos, se adjudicaban al expósito

"Marcela Frutos Suarez

En 18 de Enero de 1913 á las 11 horas y 30 minutos fué expuesta en el torno de este asilo con un papel que dice "Valladolid 16 de Enero de 1913 á las 4 de la tarde. Nació una niña el 16 de Enero á las 4 de la tarde de Librada Frutos Suarez la niña se ha de llamar Marcela Frutos sin bautizar»...

Bautizada en este Hospicio en 18 de Enero de 1913" [sic] (fo 18, LE 1900-1)

"Julio Alonso

En 20 de Enero de 1900 y hora de las siete de la tarde fue expuesto en el torno de este asilo con... un papelito que dice: "Hijo de Julia Alonso soltera este niño será mañana u otro dia sacado y se le pondrá por nombre Julio no esta bautizado» Bo en este asilo en" [sic] (fo 33, LE 1900-1)

En el folio de este niño no se ha anotado la fecha del bautismo. No fue recuperado por su madre, falleció en el asilo a los 6 meses de edad, unos días después de ser devuelto por la nodriza "á consecuencia de atrepsia"

Cuando faltaban los apellidos se añadían uno o dos según el caso

"Obdulia Rodriguez LLorente

En 18 Septiembre 1907 y hora de las diez y seis y 30 minutos fue expuesta en el torno del Establecimiento con un papel que decía "La niña Obdulia Rodriguez nació en Valladolid el dia 10 de Septiembre de 1907 sin recibir el santo sacramento del bautismo el siguiente dia de entregada se pasara recoger el folio para reclamarla en caso de necesidad"...

B⿳a en este asilo 21 Sepbre 1907" [sic] (fo 300, LE 1907- 2)

Según la fecha de nacimiento de la nota esta niña fue bautizada a los 11 días de vida. Tampoco fue reclamada por su madre y falleció en el asilo en 1914 "á consecuencia de infección gástrica"

No hay regularidad en los registros de la Inclusa en cuanto a los apellidos; en los libros de los primeros años la mayoría de las inscripciones se hacían con un solo apellido, después lo normal es que se registren los dos pero unas veces se añadía un segundo apellido al expósito 
que le faltaba como en la cita anterior, otras solamente se escribía el primer apellido aún siendo hijo legítimo y conociéndose los dos, podría deberse a la costumbre de adjudicar un solo apellido a los expósitos, sin descartar errores por omisión. Por el tipo de letra da la impresión de que las características del registro podían depender de quién lo hacía pues en el mismo año se pueden encontrar distintas formas en folios escritos por diferentes personas

"Esteban Labajo

En 7 de Agosto de 1900 y hora de las tres de la tarde fue expuesto en el torno de este asilo con... un papelito que dice: Lucia Labajo nació dia 5 de mañana Esteban Labajo se llama el niño

$B^{\underline{a}}$ [bautizada] en este asilo en 9 agosto 1900" [sic] (fo 306, LE 1900- 2)

\section{"Julian Sanchez}

En 28 de febrero de 1908 ingresó por acuerdo del Vicepresidente de la Comisión provincial con certificación del Juez Municipal de Palacios de Campos donde dice que es hijo natural de Petra Sanchez Sanchez y nacio en 17 de Febrero de 1908" [sic] (fo 67, LE 1908- 1)

Hasta tal punto se quería respetar el deseo expresado en las notas del torno, que se da el caso de presentar solamente unas iniciales y adjudicar al niño nombre y apellidos acorde con ellas.

"El día 28 de Enero de 1912= Se entregó en el Hospicio provincial de Valladolid un niño á las 9 y 1/2 noche= está sin bautizar B. A." (fo 37, LE 1912-1)

Solo con esas siglas le pusieron por nombre Benito Álvarez.

"Maria Rosa Benito Fernandez

En 7 de abril de 1911 á las 19 y 30 minutos fue expuesta en el torno de este asilo con un papel que dice "Nacio esta niña el 24 de Marzo a las cuatro de la tarde no está bautizada á petición de su Madre se la pondrá Maria Rosa B.F."Pegado a este papel traía una hoja de calendario pequeño correspondiente á este mismo dia del ingreso. ...

Bautizada en este Asilo en 8 Abril 1911

Se dio parte al Registro civil en 9 Abril de 1911" [sic] (fo 113, LE 1911- 1)

Las letras también podían ir entre la ropa como en la siguiente cita, aunque habitualmente éstas no se tenían en cuenta para los apellidos porque casi nunca las siglas bordadas coincidían con las del niño ni de la madre cuando en la nota se daban nombres

"Julia Maestro Prieto

En el dia 24 de Octubre de1907 á las 16 horas y treinta minutos fue expuesta en el torno de este Establecimientos una niña con un papel que dice "Valladolid á 24 Octubre 1907 la niña Julia es echada por el torno á 5 de la tarde y la entrega Estefania Tejedor Pintado becina de Valladolid, no esta bautizada deseo la pongan Julia" y por ropas las siguientes: pañal de algodón, camisa id, pañuelo id con ondas festoneadas y las letras M.P. jugon de pique, gorro id con tira bordada, mantilla de muletón blanca, fagero id, otro pañuelo de color canela, todo usado; un imperdible.

Ba en este asilo en 29 de Octubre 1907" [sic] (fo 342, LE 1907- 2) 
Esta niña es de las pocas que se presentó en el torno bien vestida, quizá por eso se respetaron las siglas pensando que estaban bordadas expresamente para ella; en la mayoría de los casos aparecen en ropa usada, incluso muy vieja.

Encontramos registros curiosos como el del folio 1 de 1901 de una niña que figura nombrada obedientemente como "Manuela C M San José", en la nota decía "Esta sin bautizar pónganse las iniciales C M. en Enero de 1901 á nacido á las doce de la mañana". Obsérvese que el 1 de enero en el santoral católico es el día de Manuel.

Comentamos en el capítulo dedicado a las notas del torno como muchas de ellas ofrecían datos de filiación que en ocasiones llegan a resultar contradictorios, debemos entenderlas teniendo en cuenta la inmediata inscripción del niño por el Hospicio en el Registro civil y la Ley que la regula, y en particular el punto 70 del Art. 48 y el Art. 51, aparte del mencionado Art. 34.3 del reglamento de 1870

Art. 48. La inscripción del nacimiento en el Registro civil expresará 7o La legitimidad ó ilegitimidad del recién nacido, si fuera conocida; pero sin expresar la clase de esta, á no ser la de los hijos legalmente denominados naturales.

Art. 49. Respecto á los recién nacidos abandonados ó expósitos en vez de las circunstancias números 3, 60 y 70 del artículo anterior se expresarán:

Art. 51. Respecto á los recién nacidos de origen ilegítimo, no se expresará en el registro quiénes sean el padre ni los abuelos paternos, á no ser que el mismo padre, por sí ó por medio de apoderado con poder especial y auténtico, haga la presentación del niño y la declaración de su paternidad. Lo mismo se observará en cuanto á la expresión del nombre de la madre y de los abuelos maternos.

Art, 34. 3o Si el niño fuere expósito, y entre los objetos hallados con él hubiera algún escrito que indique su nombre y apellido, o el deseo de que lleve algunos determinados, se respetará la indicación si no fuese inconveniente".

Así nos encontramos papeletas que ofrecían todos los datos incluso el nombre de los abuelos y parecen una copia de la inscripción en el RC, la mayoría eran hijos legítimos y en este caso así se podían adjudicar al niño los apellidos familiares y por su partida de nacimiento podría conocer sus orígenes. Las que insistían en que un niño tenía madre, o decían que el padre y los abuelos paternos eran desconocidos, venían a decir que el hijo era natural y se le podría poner el apellido materno si se había dado a conocer

"Valladolid 15 de Marzo de 1901. El día 15 de Marzo nació un niño á las 8 y media de la mañana el padres desconocido la madre se llama Simona Lorenzo los abuelos paternos desconocidos y los maternos conocidos Dionisio Lorenzo la abuela Tomasa y el niño se ha de llamar Raimundo Lorenzo" [sic] (fo 89, LE 1901-1) 
Las hay paradójicas que decían que un niño tenía madre o padres y al mismo tiempo que era de padres desconocidos, esto sería una forma de decir que se registrara al niño como "de padres desconocidos", de esa manera no se ponía expresamente en la partida de nacimiento que era ilegítimo

\section{"Ciriaco Barrientos Ruiz}

Este niño nació el dia 8 de Agosto de 1903 en Medina del Campo ponerlo por nombre Ciriaco y su Madre se llama ER, tiene padres y se suplica conserven esta papeleta Que es hijo de padres desconocidos" [sic] (fo 287, LE 1903-2)

La ley además no permitía registrar el nombre del padre o de la madre sin su consentimiento, por lo que aunque dieran sus datos con una advertencia así no podrían registrarlos ni utilizar los apellidos. En uno de los folios se puede leer que en la papeleta del torno se da el nombre del padre "... es hijo de Antonia Vegas soltera... y de Claudio Casares soltero natural de Viana de Cega que le tiene reconocido", aunque en el encabezamiento del folio sea registrado al niño con los apellidos Casares Vegas, en una anotación al margen del folio se ha escrito "Este niño consta en el Registro Civil como hijo de padre desconocido y con los apellidos solo de la madre, Vegas Valencia" (fo 439, LE 1909-2)

También resultan anecdóticos unos registros en que se advierte que los niños, procedentes de algún pueblo, se presentaron en el Hospicio con nombre diferente en la partida de bautismo y en la del RC.

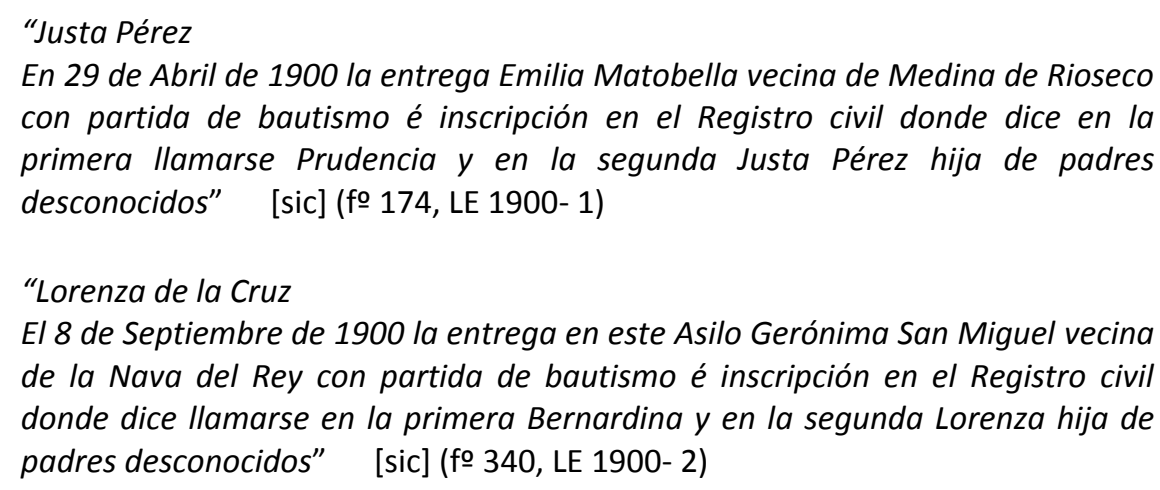
con partida de bautismo é inscripción en el Registro civil donde dice en la primera llamarse Prudencia y en la segunda Justa Pérez hija de padres desconocidos" [sic] (fo 174, LE 1900-1)

"Lorenza de la Cruz

El 8 de Septiembre de 1900 la entrega en este Asilo Gerónima San Miguel vecina de la Nava del Rey con partida de bautismo é inscripción en el Registro civil donde dice llamarse en la primera Bernardina y en la segunda Lorenza hija de padres desconocidos" [sic] (fo 340, LE 1900-2)

Como puede verse el nombre que se ha puesto en el folio es el del RC. La ley no obligaba expresamente a que coincidieran pero lo da por hecho ("el nombre que se le haya puesto o se le vaya a poner") y parece conveniente que así sea. Esta situación debía ser más habitual de lo que nos puede parecer porque la nueva Ley de 8 de junio de 1957 en su artículo 54 dice que "en la inscripción se expresará el nombre que se dé al nacido, que debe ser, en su caso, el que se imponga en el bautismo".

Incluso hay algún problemilla con las variantes ortográficas de los nombres. En el fo 185 de 1910 se ha escrito en una anotación al margen: "Según el Registro se llama "Geralda» y 
la partida Bautismo "Jerarda»", en el folio también se ha registrado como en el R.C. Geralda $^{507}$.

\subsubsection{El nombre de pila de los expósitos}

Cuando los niños llegaban sin bautizar y sin una propuesta de nombre, elegirlo podía representar un problema que el reglamento resuelve ordenando poner el santo del día, así se cumplen los deseos de la iglesia que pide poner un nombre del santoral católico y queda asignado un santo que actuará como protector ${ }^{508}$

"El nombre que haya de darse al expósito será el del Santo del día en que se reciba, á no ser que las madres o conductoras hayan designado á este fin un Santo determinados y en este caso se le pondrá además un segundo ó tercero que le distinga" [sic] (Art. 50 Regl. 1889)

De esta manera también se sigue una costumbre muy extendida en la época, ya hemos visto como incluso en algunas notas se pide expresamente que se ponga el nombre del santo del día, entre otras cosas, esto sería un mecanismo más para el reconocimiento futuro del niño pues así quedaba constancia de la fecha de nacimiento.

"Clara San Jose

En 12 de Agosto 1900 y hora de las diez de la noche fue expuesta en el torno... con un papelito que dice La niña que se presenta en la Santa Casa ha nacido el dia doce á las tres de la madrugada en el dia de Santa Clara por lo que se ruega que se la ponga este nombre al bautizarla su padre es desconocido y su madre Adela Calle que ha sido asistida por Médico aspira con la ayuda de Dios á recobrar á su hija algún dia.

$B$ a en este asilo en 13 de agosto $1900 . .$.

Falleció en este Asilo en 3 de Sbre de 1900 á consecuencia de atrepsia" [sic] (fo 314, LE 1900- 2)

\section{"Epifania Alonso Centeno}

En 8 de Abril á las 17 horas fue expuesta en el torno de este Hospicio con un papel que dice "Bauticen esa niña de Adela Alonso Centeno soltera, con el nombre del dia Santa Epifania = nacio ayer dia 7 de abril de 1910 en Valladolid»" "[sic] (fo 135, LE 1910-1)

Bastaba sugerirlo

\footnotetext{
${ }^{507}$ Ninguno de los dos aparece en el Santoral de Luis Carandell, podrían ser variantes de Gerardo/a; aunque en la web aparece san Geraldo en la página http://www.santoral.com.es/ el 12 de marzo y en http://www.santopedia.com/ san Geraldo o San Guerao obispo de Braga el 5 de diciembre

${ }_{508}$ La tradición de poner nombres del santoral llegó a ser ley, la Orden de 18 de mayo de 1938 prohibía la imposición de nombres "que no sean los contenidos en el Santoral Romano para los católicos" y en la nueva ley del RC de 1957se dice que "en la inscripción se expresará el nombre que se dé al nacido que debe ser, en su caso, el que se imponga en el bautismo. En FERNÁNDEZ PÉREZ E.A.: El nombre y los apellidos. Su regulación en derecho español y comparado. Tesis doctoral, Derecho Civil. Universidad de Sevilla, 2015.
} 
"En 10 de Marzo á las 12 horas fue expuesto en el torno de este Establecimiento con un papel que dice "Dia 9 nacio á las tres de la tarde santo del dia $S^{n}$ Francisco, sin bautizar»" [sic] (fo 98, LE 1910- 1)

El Reglamento de la Inclusa dice que se asigne el santo del día de la entrega porque la fecha de nacimiento podía ser desconocida. Revisando en algunos años los nombres que se pusieron a los niños que llegaron al torno de Valladolid sin bautizar y sin una propuesta para nombrarles he podido comprobar que la norma no siempre se cumplía. Hay fechas y nombres que son más emblemáticos y coinciden más, por ejemplo los niños expuestos en el torno en 1 de enero fueron bautizados con el santo del día, Manuel o Manuela ${ }^{509}$, los nacidos o ingresados en 17 de enero, festividad de San Antonio Abad, Antonio o Antonia y José o Josefa los del 19 de marzo y así ocurre con nombres como Natividad, Isidro o Isidra, Pedro o Petra, que aunque se ponían durante todo el año sobre todo los encontramos en torno a la fecha de su santo. En 1901, de 25 niños que se presentaron sin nombre en el torno, 14 se llamaron como el santo del día de la presentación y otros 7 como santos cuya celebración era unos días antes o después, en alguna ocasión coincide con el del día del bautizo (fo 153, Ascensión), pero son casos aislados y debe ser algo casual porque el nombre se adjudicaba al ingresar, antes de conocer la fecha del bautismo. Para los años que he revisado este asunto $(1901,1905,1908$ y 1912) he encontrado los siguientes resultados sobre el nombre adjudicado a los niños que llegaron sin él

$\begin{array}{lcccc} & 1901 & 1905 & 1908 & 1912 \\ \text { Niños expuestos en el torno sin nombre } & 25 & 26 & 32 & 25 \\ \text { Llamados como el Santo del día } & 14 & 13 & 13 & 7 \\ \text { Llamados como un Santo próximo } & 7 & 6 & 7 & 8\end{array}$

Parece que la norma se respetaba más en los primeros años, luego se va relajando y se usa menos. En ocasiones se ponía un nombre parecido al del santo del día, por ejemplo Marcelino por Marcelo, pero ya se sabe la complejidad del santoral en el que hay muchos "santos" cada día y muchos con el mismo nombre que se celebran en días distintos ${ }^{510}$. No he encontrado otro criterio para seleccionar el nombre de los niños del torno cuando no se seguía

\footnotetext{
${ }^{509}$ En 1901 en 1 de enero pusieron Manuel ( $₫ 1$ y 2), en 5 de enero Telesforo (fo 3) y Emiliana (fo 4), Fulgencio ( $₫$ o 14) el 16 de enero, Librada ( $f$ 16) el 18 de enero, Sebastián el 20 de enero (fo 19), Vicente (fo 22) el 22 de enero, Pablo (fo 29) el 25 de enero, festividad de la conversión de San Pablo; José María (fo 100) el 24 de marzo, festividad de san José Oriol presbítero; María Encarnación (fo 101) el 25 de marzo; Juan (fo 105) el 28 de marzo, san Juan Climaco; Victoriano (fo 106) 29 de marzo y Celestino y Marcelino (fo 115 y 116) el 6 abril. Todos ellos, entre otros, corresponden con el santo del día.

${ }^{510}$ Para la comprobación correspondiente he utilizado fundamentalmente El Santoral de Luis Carandell, publicado en 1996, CARANDELL L.: El Santoral de Luis Carandell, Maeva ediciones. 1996. Hay páginas web que coinciden mayoritariamente entre ellas y con el libro como con el libro y parecen muy fiables en este tema: http://www.santoral.com.es/y http://www.santopedia.com/
} 
el santoral, podría aplicarse lo que dicen los Reglamentos de 1910 y 1927 para los niños de la maternidad en su Art. 301 que otorga al director esa decisión, o que simplemente lo decidieran las hermanas de la Caridad porque en la papeleta que se pasaba a la dirección para comunicar la exposición se escribe el nombre al margen y es la misma letra que rellena la ficha y que firma, cuando lo hace, la Superiora (ver IMAGEN 3-9).

Los niños nacidos en la Maternidad eran todos bautizados en el asilo; la madre podía decidir y se respetaba su elección como se hacía con los expósitos del torno. Entre ellos hay niños llamados como el santo del día de nacimiento, podría ser por decisión materna, por costumbre, como lo solicitan muchas notas del torno, y algunos con el nombre de la madre, en su caso en su versión masculina ${ }^{511}$.

En cuanto a los nombres elegidos, la Iglesia recomienda que formen parte de su santoral ${ }^{512}$; algunos hoy nos resultan extraños, pero éste es un tema sujeto a modas, sobre todo a partir de 1977 que se liberalizó la imposición de nombre. Han cambiado mucho los gustos al respecto, de manera que en los libros de la Inclusa encontramos muchos nombres que hoy consideramos corrientes y tradicionales y que siguen en uso, pero también los hay que podemos calificar de raros o cuando menos curiosos. Nombres que en la época tampoco debían ser muy normales porque encontramos muy pocos en los libros como Baudilia, Decapolita, Potamiena, Sinesio, Mapálica, Nicéfora, Gliceria, Lupicinia, Mamerta o Trifón; no fueron todos elegidos por coincidir el día del santo con el nacimiento, la exposición o el bautizo de los niños, pero podían suponer una seña de identidad diferenciadora dentro de un colectivo uniforme.

\footnotetext{
511 En 1905, de 72 niños nacidos en la Maternidad 28 fueron bautizados con el nombre del santo del día de nacimiento y solamente 5 como la madre, en 1912 fueron 26 y 9 respectivamente de un total de 79 nacidos en la Maternidad

512 "El nombre es importante porque Dios conoce a cada uno por su nombre, es decir, en su unicidad. Con el bautismo, el cristiano recibe en la Iglesia el nombre de un santo, de modo que este ofrezca al bautizado un modelo de santidad y le asegure su intercesión ante Dios". Catecismo de la Iglesia católica. Compendio. 264.

"En el bautismo, el nombre del Señor santifica al hombre, y el cristiano recibe su nombre en la lglesia. Puede ser el nombre de un santo, es decir, de un discípulo que vivió una vida de fidelidad ejemplar a su Señor. Al ser puesto bajo el patrocinio de un santo, se ofrece al cristiano un modelo de caridad y se le asegura su intercesión. El "nombre de Bautismo" puede expresar también un misterio cristiano o una virtud cristiana. "Procuren los padres, los padrinos y el párroco que no se imponga un nombre ajeno al sentir cristiano" (CIC can. 855)". (CIC = Código de Derecho Canónico, canon. 855). Catecismo de la Iglesia católica. Artículo 2. III El nombre cristiano. 2156. Disponible en: http://www.vatican.va/archive/catechism_sp/p3s2c1a2_sp.html\#III El nombre cristiano
} 


\subsubsection{Los apeltidos de los expósitos}

Otra cuestión es la asignación de apellidos a los expósitos sin nombre ni datos de filiación. Todos los niños, por ley, debían ser inscritos en el Registro civil con nombre y apellidos. Tradicionalmente a los expósitos se les venían adjudicando apellidos que hacían referencia a su falta de filiación y les identificaban como tal, el más usado y conocido era precisamente el de Expósito, también eran frecuentes los de carácter religioso como "de Cruz", "de Dios" o "Santa María"; los que se referían al lugar de la exposición como "de la Iglesia", "del Río", "de la Fuente", "de la Villa" o de la localidad de origen como "Azpeitia", "de San Sebastián", "de Torrequemada" y los nombres de los patrones del lugar o de la inclusa. Otra característica diferenciadora tradicional era ponerles solamente un apellido ${ }^{513}$.

El Reglamento del Hospicio de Valladolid de 1889, solo daba instrucciones para el nombre, que debía ser el santo del día, no decía nada respecto a los apellidos; en el siguiente Reglamento de 1910 ya se contempla este tema y advierte que se utilicen apellidos corrientes que no señalen al expósito como tal

"En todo caso habrá de ser inscripto con nombre y dos apellidos que no den á conocer su procedencia ó cualidad de expósito". Art. 314 Regl 1910

Este texto recoge por fin, lo que marcaba la Ley del RC de 1870 y que desarrolla lo que en espíritu ya decía la Novísima Recopilación de 1805 de Carlos IV en cuanto a la legitimación y la igualdad de derechos civiles de los ilegítimos con los legítimos, sin duda un primer paso para evitar la discriminación era no utilizar marcar al expósito con un apellido identificativo.

A pesar de esta ley de 1870 el Hospicio de Valladolid siguió con lo que era costumbre en estos centros, adjudicando a los expósitos un apellido particular y distintivo, su patronímico fue San José, desde la primera casa su patrón protector. En los libros de los primeros años los niños están registrados con un solo apellido, salvo los que ingresaron a través de la oficina con

\footnotetext{
${ }^{513}$ También eran frecuentes apellidos vinculados a la religión católica como Patrocinio, Salvador, de las Ánimas, de los Santos, de Ramos, del Sagrado Corazón y los de carácter local como los Antolín en Palencia, patrón de la ciudad; Gracia o de Gracia en Zaragoza, por el Hospital de Nuestra Señora de Gracia; de la Encarnación en Albacete, por el monasterio del mismo nombre; de la Piedra en Toledo o los Goñi en Navarra, por el valle de Goñi. Cfr PÉREZ MOREDA V.: op cit, 2005; JIMÉNEZ LÓPEZ A. R.: Vida y muerte en la Inclusa de Madrid en el primer año de posguerra. UNED. Espacio, Tiempo y Forma Serie V, Historia Contemporánea, no 25, 2013, pp 369- 386; NEILA MUÑOZ C.M.: Etnohistoria del abandono. Los expósitos en los registros civiles (1871-1949). El caso de Trujillo (Cáceres). Asociación Cultural Coloquios Históricos de Extremadura. Trujillo. Sept 2011, p 15; MARTíNEZ GÓMEZSIMÓN L.M.: Las instituciones de atención social al menor en la ciudad de Albacete. Albacete. Instituto de Estudios Albacetenses "Don Juan Manuel", 2002; HERNANDO GARRIDO J.L.: op. cit., pp 4 -16; VALVERDE LAMSFUS L.: op. cit., p. 231-262; REVUELTA EUGERCIOS B A: op.cit.
} 
sus correspondientes certificados, y San José es el apellido adjudicado tanto a los expósitos que llegaban al torno sin nombre como a todos los nacidos en la maternidad del centro, que eran considerados como tal

"Apolonia San Jose

En nueve de Febrero de mil novecientos tres, á las diez y siete horas y treinta minutos, le dio á luz la refugiada en este Asilo Concepción Boto" [sic] (fo 56, LE 1903- 1)

Como además los nombres más corrientes se repetían, muchos de los niños se llamaban de forma similar, esos nombres raros que comentábamos antes podían ser por tanto un rasgo de identidad distintivo. A finales de diciembre de 1900 entre el 24 y el 26 nacieron dos niñas en el asilo y otra fue expuesta en el torno, se llamaron María Natividad Amalia San José (fo 481), Natividad San José (fo 482), y María Natividad San José (fo 483); en 1902 encontramos a Saturnino San José nacido el 10 de febrero (fo 45) y al día siguiente ingresó por el torno Saturnina Desideria San José (fo 46); jugaban con los nombres añadiendo uno o dos para diferenciarlos. No es de extrañar que Ana M Rodríguez ${ }^{514}$ hable de una identidad difusa y de problemas de identidad entre los expósitos, sin raíces familiares, sin un nombre propio y con un nombre que ya apuntaba marginalidad.

En 1903 se añade un segundo apellido a los incluseros de Valladolid, no es casualidad. La normativa legal sobre los apellidos de los expósitos publicada en 1870 propició seguir utilizando, como se venía haciendo, un solo apellido por una redacción confusa ya que hablaba de "la imposición de un nombre y un apellido usuales"; es por ello que el 11 de julio de 1903 se publica una Real Orden que aclara que se deben imponer "dos apellidos usuales" parte la ley se seguía incumpliendo por estas fechas en lo referente al tipo de apellidos y en las Inclusas se seguía utilizando el Expósito y similares, aunque la responsabilidad sería del encargado del Registro Civil (RC). Según se la atribuye la propia ley "Cuando el niño no tenga padres conocidos, el encargado del Registro le pondrá un nombre y un apellido usuales que no indiquen aquella circunstancia" (Regl del RC, Art. 34.3).

El apellido elegido en la Inclusa de Valladolid sería "Prado", en alusión a la Virgen del mismo nombre que se encuentra en el retablo mayor de la iglesia de San Nicolás de Bari ${ }^{516}$,

\footnotetext{
${ }^{514}$ RODRÍGUEZ MARTÍN A.M.: op.cit. 2008, pp. 353-388.

515 Cfr. FERNÁNDEZ PÉREZ E.A.: El nombre y los apellidos. Su regulación en derecho español y comparado. Tesis doctoral, Derecho Civil. Universidad de Sevilla, 2015, pp 207- 208

${ }^{516}$ La imagen de Nuestra Señora del Prado es una talla del siglo XII que procede del monasterio de los jerónimos del mismo nombre de Valladolid, que fue desamortizado en 1821 y pasó a utilizarse como cárcel y manicomio. La imagen llegó a la iglesia de San Nicolás en 1852 y se colocó en el retablo mayor en 1895 al terminar la reconstrucción que se hizo tras el incendio de 1893. GONZALEZ GARCíA C.: Valladolid sus recuerdos y grandezas..., Imprenta de Juan Rodríguez Hernando. Tomo I, 1900. pp 170- 172.
} 
parroquia del Hospicio, el mismo para todos. Se usó por primera vez en el niño bautizado como Alejandro San José Prado hijo de "la refugiada Estefanía Fernández" que nació en la Maternidad el 24 de abril de 1903 (fo 53); a partir de entonces los expósitos sin nombre en su presentación en la Inclusa y los nacidos en la Maternidad, que ya hemos dicho que tenían la misma consideración, Ilevarían todos los apellidos San José Prado hasta 1907, cuando dejaron de utilizarse. Al ser igual para todos, este apellido no disminuyó los problemas de identidad; son casi inevitables las repeticiones, aunque intentaban evitarlo porque hay menos de las que pudiéramos esperar; ésta podía ser otra importante razón para recomendar en el primer reglamento poner el nombre del santo del día, porque aunque hay nombres que se repiten muchos días, como cada día tiene varios santos había variedad para elegir. En 1905 encontramos 105 niños que recibieron los apellidos San José Prado, 4 se llamaron Juan, nacidos en marzo, junio y diciembre, 3 Manuel y 2 Manuela; en 1906 hay 90 San José Prado y no encontramos ni Juan ni Manuela y sólo 1 Manuel. En los Libros de Exposiciones en las primeras hojas del primer tomo se incorporaba un índice de los niños ingresados durante el año ordenado por la inicial del nombre, no del apellido, lo que permitiría, sobre todo los primeros años con apellidos iguales, controlar la repetición.

Los niños que se presentaron en el torno con un solo apellido recibieron por segundo el de Prado, aunque hay años como el de 1904 en el que seguimos encontrando muchos niños registrados con un solo apellido, incluso siendo legítimos y con certificados

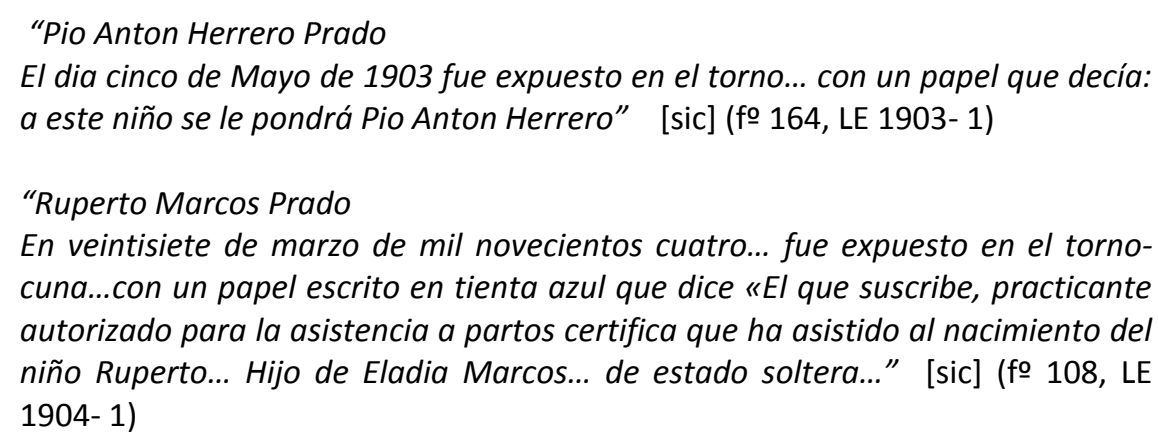
cuna...con un papel escrito en tienta azul que dice "El que suscribe, practicante autorizado para la asistencia a partos certifica que ha asistido al nacimiento del niño Ruperto... Hijo de Eladia Marcos... de estado soltera..." [sic] (fo 108, LE 1904- 1)

Cuando el nuevo reglamento de 1910 exigió poner apellidos corrientes que no delataran al inclusero, ya se estaba haciendo de hecho en la Inclusa de Valladolid desde 1907, la norma se mantuvo en el Reglamento de 1927 en el mencionado Art. 314, pero en ninguno de los dos se marca un criterio para su elección.

\footnotetext{
La parroquia de San Nicolás de Bari se encontraba anteriormente en la calle del Puente Mayor y se situó en su emplazamiento actual en el año 1837, en lo que fue el convento de los padres Trinitarios Descalzos también desamortizado, a petición del Ayuntamiento de la ciudad, "siendo alcalde primero don Mariano Campesino y segundo don Claudio Moyano". ORTEGA Y RUBIO J.: Historia de Valladolid (1881). Valladolid. Grupo Pinciano. Edición facsímil. 1991 pp 205 y 263
} 
Hasta finales de 1906 todos los incluseros de Valladolid llevaban pues los mismos apellidos y eran fácilmente identificables, con el problema de identidad añadido por la repetición de nombres. El último niño que los recibió fue Fermín San José Prado, hijo de "la refugiada Inés Bueno" y nacido el 19 de Octubre de 1906 (fo 315 del año), a partir de ahí no se vuelven a poner, salvo cuando son los de la madre, precisamente el primer expósito del torno después de este niño se llamó Ramón San José, tal como decía la nota que le acompañaba (fo 322 de 1906); San José es un apellido muy extendido en la provincia y a partir de este momento los niños de la Inclusa apellidados así lo recibirían de sus padres. La siguiente niña nacida en la Maternidad recibió los apellidos de su madre, $M N$. Alonso Rejero (fo 320) y el primer expósito que ingresó sin nombre después del mencionado anteriormente recibió el de Quintín Salustiano Alonso Peláez (fo 327).

Los nuevos Reglamentos de 1910 y 1927 establecen que las madres de la Maternidad podían decidir el nombre y apellidos del hijo, hasta 1907 los apellidos eran los mismos que para los expósitos del torno San José y luego también Prado

"Nacido que sea un expósito será bautizado en la Iglesia del Hospicio, é inscripto en el Registro civil con el nombre y los apellidos que la madre designe, y en su defecto con los que el Director disponga" Art. 301. Regl 1910 y 1927

y en la mayoría de los casos comprobamos que se cumple y se ponen los apellidos maternos, al menos el primero, ya que en el folio del niño solían escribir el nombre de la madre con un apellido solamente

"Maria Consolacion Herrero Moran

En 29 de Enero de 1912 á las 5 la dio á luz la refugiada Maura Herrero" [sic] (fo 38, LE 1910- 1)

Aunque algunas mujeres, que como vimos en el capítulo de la Maternidad eran las menos (el 5’86\%), preferían no adjudicar sus apellidos al niño; según el reglamento, en este caso elegirlos era función del director

"Maria del Carmen Fernandez Benito

En 26 de Febrero de 1910 á las 13 horas la dio á luz la refugiada en este Establecimiento Perpetua Robles" [sic] (fo 77, LE 1910-1)

"Francisco Lucas Pérez

En 3 de Diciembre de 1912 le dio á luz la refugiada en este Asilo Irene Lorenzo á las 13 horas y 30 minutos" [sic] (fo 12, LE 1912-1) 
En cuanto a los niños expuestos en los pueblos de la provincia, se enviaban ya bautizados e inscritos en el Registro civil, por tanto con nombre impuesto en la localidad de la exposición.

Los niños del torno de Medina del Campo son fácilmente reconocibles porque durante años recibieron los apellidos Barrientos de Ruiz o Ruiz de Barrientos

"Ceferina Ruiz de Barrientos

En veintisiete de agosto de mil novecientos tres fue entregado en este Asilo por Isidora Gimenez vecina de Medina del Campo con comunicación del Sr Alcalde de dicha localidad, partida de Bautismo é inscripción del Registro Civil donde dice ser hija de padres desconocidos" [sic] (fo 288, LE 1903- 2)

"Mauro Barrientos de Ruiz

En 22 de Enero de 1912 fue entregado por Vicenta Tremiño vecina de Medina del Campo... que fue expuesto en el torno de aquel Hospital el dia 21 del corriente y que es hijo de padres desconocidos" [sic] (fo 27, LE 1912-1)

Eran excepción los que no los llevaban y se trataba de niños que se presentaban en su torno con nombre o certificados de bautismo o de inscripción

\section{"Francisco de Castro Felipe}

En 12 de Febrero de 1901 fue expuesto en el torno de este Asilo por Joaquina Vaquero vecina de Medina del Campo con un expediente partida de bautismo donde dice ser hijo de Agustin y Guadalupe vecinos de Medina del Campo" [sic] (fo 50, LE 1901- 1)

\section{"Ildefonso Martin}

En primeros de Febrero de mil novecientos cuatro fue entregado en este Asilo por Isidora Gimenez, vecina de Medina del Campo con comunicación del Sr Alcalde de dicha localidad, partida de bautismo é inscripción del Registro Civil, donde dice ser hijo de Dionisia Martin, según papel con que fue expuesto" [sic] (fo 33, LE 1904- 1)

En 1912 todavía los utilizaban y en 1913 ya solamente imponían Ruiz, que de los dos parece menos reconocible, y no a todos sus expósitos

"Felisa Ruiz Sanchez

En 15 de Enero de 1913 fue entregado por Vicenta Tremiño vecina de Medina del Campo... que fué expuesto en el torno de aquella localidad el dia 14 de los corrientes y que és hija de padres desconocidos" [sic] (fo 12, LE 1913-1)

Tantos años utilizando los mismos apellidos supone que, de no llevar un registro escrupuloso, que no lo parece, se repetirían nombres, los encontramos incluso en el mismo año y mes. En febrero de 1905 se enviaron dos niños los días 20 y 22 con el nombre de Gabino Barrientos de Ruiz, folios 82 y 86, el último fallecería cinco días después "á consecuencia de falta de desarrollo", el primero en el mes de agosto con la nodriza. El mismo año encontramos 
dos Máxima Ruiz Barrientos (folios 80 y 289, ingresos de febrero y agosto, sólo sobrevivió la primera al hospicio). En 1906 hay dos Jacinto Ruiz de Barrientos (folios 58 y 68, ingresos de marzo y abril, los dos sobrevivieron al hospicio) y dos Joaquina Ruiz de Barrientos (folios 251 y 288, ingresos de agosto y septiembre, sobrevivió solo el segundo). En estos dos años se enviaron al Hospicio provincial en total 62 niños desde el torno de Medina del Campo, aparte de las coincidencias mencionadas, encontramos también una Carmen y $M \underline{a}$ del Carmen con los mismos apellidos y nombres en su versión femenina y masculina: Francisca, Francisco y Cayetana, Cayetano. Me ha llamado la atención que los nombres que podríamos Ilamar más peculiares, o menos usuales, se asignaban mucho más en Medina del Campo; utilizaban nombres como Acisclo o Mamerta quizás para evitar esas repeticiones, aunque encontramos repetidos otros como Telesfora Ruiz de Barrientos (en fo 5 de 1906 y fo 8 de 1909).

Estos apellidos, Barrientos y Ruiz, hacen referencia a dos benefactores de la villa de Medina del Campo, fundadores de dos de sus hospitales; D. Simón Ruiz Envito (1525-1597), célebre comerciante y banquero que fundó el Hospital Mayor ó General también llamado de la Purísima Concepción y San Diego de Alcalá ó de Simón Ruiz y D. Lope de Barrientos (13281464) natural de la villa, obispo de Segovia, Ávila y Cuenca, confesor de D. Juan II y preceptor del Príncipe D. Enrique y Canciller mayor de Castilla, que fundó en 1454 el desaparecido Hospital del Obispo o de la Piedad ${ }^{517}$, incendiado en 1810 sus bienes pasaron en 1865 al Hospital de Simón Ruiz.

Medina de Rioseco tenía el tercer torno de la provincia, el único de los tres que, al menos en el tiempo de este estudio, no utilizó apellidos discriminatorios para sus expósitos, ni siquiera en la época que lo hacía la Inclusa Provincial. En 1905 impusieron apellidos como Gallego Sánchez (fo 58), López Pérez (fo 259), Hernández Rodríguez (fo 328) o Martínez Castaño (fo 366) y en 1910 Catón Muñoz (fo 115), Gómez Pérez (fo 168), García Guerra (fo 198) ó Sanz Aguado (fo 203). En todos los libros consultados se mantiene esta tónica, además repiten poco, siendo los más frecuentes Pérez, García, Sánchez o López, hay también algún De la Iglesia o de Dios y Campos o de Campos, Rioseco se considera capital de la comarca de Tierra de Campos, pero aparecen de manera aislada.

\footnotetext{
${ }^{517}$ Historia de la Muy Noble, Muy Leal y Coronada Villa de Medina del Campo conforme a varios documentos y notas a ella pertinentes por D. ILDEFONSO RODRÍGUEZ Y FERNÁNDEZ Doctor en las Facultades de Sagrada Teología, Filosofía y Letras y Medicina, Catedrático de esta Facultad en la Universidad Central (antes en la de la Habana), Caballero de la Orden de Carlos III, etc, Madrid. Imprenta de San Francisco de Sales. 1903- 1904 Disponible en Biblioteca Digital de Castilla y León: https://bibliotecadigital.jcyl.es/es/catalogo_imagenes/grupo.cmd?path=10066355 Capítulo XIII Hijos distinguidos de Medina (Tomo II del Sr. Ayllón) pp 823- 827 y CAPÍTULO XXIII Que trata de algunos personajes principales ricos que ha habido en esta villa y de cosas notables que han hecho pp 1006- 1008
} 
En cuanto a los niños que venían de otros pueblos hay de todo, pero son frecuentes los apellidos delatores. Nava del Rey los primeros años adjudicó a sus expósitos el apellido San Juan, el más frecuente y al principio único, a partir de 1906 utiliza también San Miguel, de la Cruz o de la Iglesia y desde 1908 sigue el criterio de Medina de Rioseco y pone apellidos corrientes, se repiten los García, Gómez, González, Pérez, Rodríguez y Sánchez (I. Rodríguez Gómez, fo 250 de 1912). Pozáldez asignaba sobre todo el apellido San José, Villalón y Villalba de los Alcores pusieron hasta 1912 los apellidos San Miguel Torrequemada, Rueda sobre todo San Sebastián, Tordesillas ocasionalmente San José y La Seca apellidos normales y ocasionalmente Expósito, que lo encontramos también en algunos expósitos de diferentes localidades que mandaban niños al orfanato puntualmente, pero, a diferencia de otras provincias, en Valladolid era muy poco utilizado ${ }^{518}$. Otros pueblos usaban el toponímico de Alaejos, Tiedra

"Camila Gatón de Campos

En 20 de Julio de 1912 fue expuesta en el trono de este Asilo con certificación del Registro civil donde consta que nació en Gaton de Campos en 13 de Julio de 1912 y que és hijo de padres desconocidos.

Bautizada e inscripta en Gaton de Campos en 15 de Julio de 1912" [sic] (fo 268, LE 1912- 2)

"Maria Rosario de Castro Tiedra

En treinta de Marzo de mil novecientos siete fue entregada en este Asilo por Jimena Garcia, vecina de Tiedra con comunicación del Sr Alcalde de la localidad, partida de Bautismo e inscripción en el Registro Civil de dicha localidad donde dice ser hijos de padres desconocidos

Bo en Tiedra en 27 de Marzo de 1907" [sic] (fo 113, LE 1907-1)

Por si poner la localidad no era suficiente encontramos nombres con un peculiar sentido del humor

"Matías Aparecido de Tiedra

En 20 de Junio de 1901 le entrega en este asilo Petra Cuadrado vecina de Tiedra con partida de bautismo e inscripción en el Registro Civil donde dice ser hijo de padres desconocidos" [sic] (fo 189, LE 1901- 1)

\footnotetext{
${ }^{518}$ Como curiosidad, el INE tiene una página que permite conocer cuántas personas se llaman de una determinada manera. El apellido más frecuente es GARCíA, actualmente lo llevan 1.458.265 españoles como primero (el $34^{\prime} 808$ $\%$ ), 1.476 .816 como segundo y 80.199 en los dos apellidos.

EXPÓSITO lo tienen en total 73.628 españoles, (el 0’834 \%o de primer apellido y 429 en los dos apellidos). Jaén con 10.318 personas y Santa Cruz de Tenerife con 9.235 son las dos provincias que tienen un mayor número de nativos con el apellido EXPÓSITO, Barcelona tiene 6.917 y Madrid 5.915; las provincias de Castilla y León son las que tienen menos, Segovia sólo tiene 8, Soria 22, Zamora 34, Salamanca 36, Burgos 54 y Valladolid 86. Para comparar con algunas provincias con Inclusas que se mencionan en este trabajo Pontevedra tiene 801, Albacete 342 y Navarra 226 EXPÓSITO

SAN JOSÉ lo tienen en total 19.740 españoles (el 0’237\%o de primer apellido y 25 en los dos apellidos). Valladolid es la provincia española con más naturales apellidados SAN JOSÉ 6.621 en total, 20 personas tienen los dos, sigue Madrid con 4.181 y Barcelona con 830. Después de Cantabria, y Vizcaya siguen provincias castellanas próximas a Valladolid, Segovia tiene 499 personas con este apellido, Palencia 42, Zamora 365 y Burgos 331. En Albacete hay 41 nativos con este apellido, en Pontevedra 48 y en Navarra 205

Disponible en: http://www.ine.es/apellidos/formGeneral.do?vista=3
} 
Otro aspecto de interés relacionado con la falta de identidad de los expósitos, considerando como tales los que contemplaba el Hospicio, tanto los del torno como los de la Maternidad, es la confidencialidad de toda la información de la que disponía el Hospicio sobre sus orígenes, las confesiones que se pudieran hacer respecto a este tema tenían carácter secreto hasta el punto que según el Reglamento de 1889, debían hacerse personalmente " $a$ l Director, quien llevará un libro reservado, para anotar las revelaciones que se le hagan. Tampoco podrá darse por los empleados ó dependientes del Establecimiento, noticia alguna referente a dichos expósitos, y únicamente lo hará el Director, previa orden de la Excma Diputación" (Art. 54 y 55). No he encontrado entre la documentación tal libro, que sin duda sería muy interesante para valorar las circunstancias personales y sociales de las madres y familias, llamémoslas donantes, y este artículo no aparece en reglamentos posteriores, ni el libro aparece en la relación de los libros a cargo del director (Capítulo IV. Art. 26 "Los libros que el Director ha de llevar...". Reglamento de 1910 y 1927) por lo que no puedo asegurar que se realizara este tipo de registro. En los reglamentos posteriores no se recogen estos artículos, sin embargo se mantiene la confidencialidad en distintos puntos, lo que supone que los hospicianos, salvo que ingresaran con cierta edad, ignoraban todo sobre sus orígenes familiares

\begin{abstract}
"Al entregarle al expósito se guardará con la nodriza la más absoluta reserva respecto de su procedencia, señales con que entró y persona o personas que le condujeron" Art. 335, Regl 1910; Art. 339, Regl 1927.

[El Auxiliar- Escribiente] "Dará a los interesados las noticias que soliciten de los acogidos, excepción hecha de los expósitos, respecto de los cuales únicamente podrá manifestar si viven ó no" Art. 32, punto 4ํ, Regl 1910 y 1927.
\end{abstract}

Por no conocer, ni siquiera sabían su fecha de nacimiento con certeza. Los reglamentos indican la obligación de registrar "la partida de bautismo é inscripción en el Registro civil" pero no advierten nada sobre la fecha de nacimiento y por eso, sobre todo en los expósitos, pero también en niños que se presentaban en la oficina con certificaciones, no la encontramos anotada en los libros.

"En 27 de Febrero de 1901 y hora de las siete fue expuesto en el torno de este Asilo con certificación del Registro Civil de Alaejos donde dice ser hijo de padres desconocidos.

Inscripto en el Registro Civil de Alaejos en 21 de Febrero de 1901... Falleció en Velliza el 3 de Octubre de 1901" [sic] (fo 69 L. E. 1901- 1)

\footnotetext{
519 Art 314 del Regl de 1910 y 317 del Regl de 1927
} 
Tampoco se escribía habitualmente en el folio de registro la edad estimada al ingreso de los niños que no tenían datos, aunque en la inscripción en el Registro civil se tenía que poner, en los libros solamente la encontramos ocasionalmente en folios contados

"En 11 de Abril de 1909 á las once horas fue expuesto en el torno de este Asilo envuelto en unos trapos y sin papel ni documento alguno teniendo según dictamen facultativo al parecer treinta días de edad.

Se dio parte al Registro Civil en 13 de Marzo de 1909. Bautizado en este Asilo en 12 de Abril de 1909“[sic] (fo 137, LE 1909-1)

En niños que como este se apreciaba que podía tener ya muchos días de vida, anotarla podría ser a modo de referencia para intentar localizarle en los registros civiles y parroquias, o en niños más mayores por una cuestión organizativa para destinarles a la Inclusa o al Destete

"En 18 de Febrero de 1908 á las 5 horas y 15 minutos fue expuesto en el torno... Este niño entró sin documento alguno que expresase la edad que tiene pero al parecer debe tener dos años cumplidos." [sic] (fo 53, LE 1908-1)

Este niño en cuestión pasó a destete. Se confirmó una edad de 29 meses.

Parece que no se le daba demasiada importancia a la fecha del nacimiento frente a las otras dos que marcan la entrada del niño en la comunidad religiosa de fieles católicos y en la comunidad civil como ciudadano; tanto es así que había hospicianos que ignoraban incluso su edad, o como mucho tenían una idea imprecisa de ella. Entre los libros he encontrado la carta de un antiguo acogido solicitando información de cara a cumplir el servicio militar obligatorio

"Febrero 24 de 1925

Sr Director de los Establecimientos de Beneficencia de Valladolid

Muy señor mío y de toda mi consideración y respeto: Hijo de padres desconocidos y procedente de la casa cuna de ese Hospital e ignorando la edad que pueda tener y si me corresponde ya cumplir mis deberes militares para con la Patria suplico a V.S. se digne ordenar me sea remitida la partida de mi nacimiento, cuyos gastos remitiría en la forma que usted ordene.

Solo sé que salí de esa casa en el mes de abril de 1918 y me sacó para el pueblo de Villalón una señora cuyo nombre era Engracia Ramos esposa de Eugenio Curieses.

Mil gracias... [firmado] Germán San José Expósito"

La carta en cuestión se encuentra suelta en el libro de 1903 precisamente delante del folio que corresponde a su autor, el fo 324 con el no de filiación 89. Este muchacho nació en la Maternidad y por tanto se conocía su nacimiento; dice su folio: "El día veinte y seis de septiembre de 1903 le dio a luz á las catorce la refugiada en este asilo Germana Fernández". La identidad de la madre y el origen de los incluseros se guardaban celosamente, hasta el punto que este muchacho incluso desconoce que nació en el propio orfanato. Aunque hoy parezca chocante que a esas alturas de su vida ignorara su origen y su edad y que nadie, ni las nodrizas 
que le criaron ni él mismo hasta que fue necesario, se preocuparan por saberlo, ésta era una situación normal propiciada como hemos visto por los propios reglamentos del Hospicio

Esta situación debía ser común en las inclusas, en la de Pontevedra los asilados no solo desconocían su edad sino incluso algunos su nombe original y se colocaban el apellido Expósito aún teniendo uno propio. Recoge Ana María Rodríguez Martín, estudiosa de esta inclusa de Pontevedra, una cita muy gráfica al respecto, es una carta escrita en contestación a una antigua asilada "Tiene usted 57 años y no 50 como dice y no se llama Engracia Expósita sino J.G. P. del P.B." ${ }^{520}$

\subsubsection{Identificación y Registro para el control de los incluseros}

Al ingresar en la Cuna, cada niño era inscrito en el libro correspondiente de entradas de la dirección; etiquetados como Libros de Exposiciones, aunque en ellos se registraban todos los ingresos de menores por cualquier vía que se produjeran, había dos tomos por año y en ellos para referirse al departamento de Lactancia y de Menores hablan de forma conjunta de la Inclusa o de la Cuna. Los niños que ingresaban en el departamento de mayores del Hospicio se registraban en los Libros de Mayores. A cada niño se le asignaba en el libro correspondiente al año del ingreso un folio completo numerado según orden de entrada en la Cuna, "con objeto de anotar todas sus vicisitudes" y "reflejar el historial completo de su estancia en el Establecimiento desde el día del ingreso hasta el de baja definitiva"; el "auxiliar escribiente" de la dirección era el responsable de esta actividad de registro y de abrirle un expediente "en el que figurarán todos los documentos que se relacionen con el mismo"521. Parece que no era un personal muy estable porque en los libros se observan muchos cambios de letra, y de calidad de los registros, tanto en cuanto al contenido como a la forma de expresión y la ortografía, que en ocasiones no parecen de una persona demasiado instruida, como se supone que debería ser alguien con este cargo.

Al abrir el folio en la primera inscripción se registraban, después del nombre, los datos del ingreso: la vía, fecha, y también hora en el caso de los expósitos del torno y los nacidos en la Maternidad, persona que entregaba al niño en la oficina, nombre de la madre o de los padres, o en su caso si eran desconocidos, y los documentos que se presentaban con el niño.

\footnotetext{
${ }^{520}$ RODRÍGUEZ MARTíN A.M.: op. cit. 2008, pp. 353-388.

${ }^{521}$ Art. 32, punto 3으, Regl 1910 y 1927
} 
En los expósitos, además, ya sabemos que sistemáticamente y por exigencia legal entre otras cosas, se anotaba todo lo que pudiera servir como elemento de identificación: documentos entregados, transcripción de las notas que se presentaban con los niños y descripción detallada de las ropas, objetos y cualquier marca o señal que presentaban. A continuación se anotaba la fecha y lugar del bautismo y de la inscripción en el Registro civil y la nodriza interna asignada.

Ya se ha dicho que los reglamentos en lo relacionado con la inscripción en los libros del Hospicio no indicaban la obligación de anotar la fecha de nacimiento y exigen solamente recoger todos los datos precisos para realizar la inscripción en el Registro civil según la Ley 1870, Art. 49, en definitiva todos los que podían servir para el reconocimiento del expósito. Como la fecha de nacimiento podía desconocerse, se pide en su lugar registrar "1으 La hora, día, mes, año y lugar en que el niño hubiese sido hallado o expuesto." y "2o Su edad aparente.", dato éste que en los folios no se registraba habitualmente, pero que podría estar en la ficha médica del niño

A partir de los libros de 1908 este primer bloque de la primera inscripción se certificaba con la firma del director y el sello del Hospicio. A continuación se iban anotando las salidas del centro y los retornos, hasta que los niños por edad pasaban al Libro de Mayores, en cuyo caso se anotaba el libro y folio nuevos, o hasta que eran baja definitiva en el Hospicio. En muchos folios el registro no está cerrado y parecen incompletos, se deja de registrar en ellos. Tras la salida con una nodriza externa o la vuelta a la Inclusa a veces no hay más anotaciones, en algunos casos he podido comprobar que se han hecho en el Libro de Mayores, solamente he podido consultar el de 1906- 1911 y también en él ocurre lo mismo y hay registros sin un apunte final que sirva de cierre a la vinculación con el Hospicio. Es el problema de duplicar registros, porque en ocasiones está la misma información en los dos libros, en otras está repartida y la encontramos o en el de Exposiciones o en el de Mayores y podemos pensar que se corre el riesgo de que no esté en ninguno de los dos; este procedimiento dificultaría sin duda el control de los niños. Cuando salían para crianza se registraba el día de la salida, localidad y nombre de la nodriza y de su esposo y la fecha de la devolución al centro. En caso de fallecimiento, el lugar, la fecha, hora y causa si se producía en el asilo y solamente la fecha y lugar si ocurría con la nodriza y debajo se dibujaba una cruz bien visible, por lo que se identifican bien los folios de los niños fallecidos.

La Inclusa tenía su propio libro para control de entradas y salidas, donde también registraban todos los niños que entraban en su sección. Solamente se conservan los libros de 
entradas de la Inclusa de 1902 y de 1907- 1908 ${ }^{522}$, con registros similares al de los Libros de Exposiciones, incluso en algunos aspectos más detallados, y el de Entradas y salidas de 19091910 y $1911^{523}$ con información muy esquemática que sólo recoge el nombre del niño, de la nodriza interna, fecha y causa de la salida, aquí se anota simplemente si salió o falleció, y "Documentos, ropas y efectos presentados".

El número del folio y el año del ingreso servían para la identificación y control de los niños en el Hospicio, como cada año empezaba la numeración por el número 1 es necesario utilizar los dos datos juntos, número de folio y año cuando se utiliza esta referencia. A partir de los libros de 1908 cada niño tiene asignado además un número de filiación, que era un número personal e individual que correspondía a una serie indefinida, independiente y diferente del folio de registro, es una serie continua que sobrepasa los años. Sin embargo, el anterior sistema estaba muy arraigado y permitía tener localizado el año de ingreso y acceder fácilmente al historial del niño, por lo que se siguió utilizando y tanto en los folios de registro como en los expedientes personales aparecen los dos formatos de identificación; es más frecuente encontrar el formato folio y libro en la documentación, oficial y oficiosa, incluso llega a confundirse y aparece como número de filiación (ver IMAGEN 3-9. Exposición 1912, Folio 46. no de Filiación 1835). Por otra parte existían dos series diferentes de números de filiación, anotados en sellos de formato distinto.

El número de filiación va escrito en un sello que aparee estampado en la parte superior de los folios y en los expedientes personales. Hay dos tipos de sellos, uno tiene dos líneas que dicen "HOSPICIO ARCHIVO - FILIACIÓN №..." y el otro es un sello circular que dentro de un círculo dice únicamente "FILIACIÓN Núm...", se encuentran sellos de los dos formatos en todos los libros.

A partir de 1908 el sello con el no de filiación aparece en todos los folios de los Libros de Exposiciones, en los libros anteriores solamente lo llevan algunos folios aislados de manera que hay más sellos a medida que avanzan los años. Sin embargo el número no se asignó en 1908, fue posteriormente ya que los números de este año son más altos que los de 1909 y estos que los de 1910 y así sucesivamente, como si se hubiera ido retrocediendo, aunque en cada libro la secuencia empieza desde el primer folio y va ascendiendo; el primer número

\footnotetext{
522 Niños entradas en el año 1902. Signatura: Caja 1938. Expediente 16992. Niños entradas 1907- 1908. Signatura: caja 1938, expediente 16993. ADPVA

${ }^{523}$ Entradas y Salidas de Niños de la Inclusa. Años 1909-1910-1911. Signatura: Caja 409. Expediente 3979. ADPVA
} 
asignado en 1910 es el 768 y el último el 1130, 1909 empieza con el 1131. En todos los libros se alternan sin orden aparente los dos tipos de sellos, cuya numeración sigue una secuencia diferente e independiente.

Analizando los libros anteriores a 1908 se encuentran también los dos tipos de sellos, los números aparecen salteados, desordenados y los encontramos solamente en niños que "sobrevivieron" al hospicio, salvo en dos muchachos que fallecieron en 1917 y 1921 respectivamente, por lo que debió ser asignado con anterioridad a estas fechas. Probablemente se decidió utilizar el no de filiación como sistema de identificación y control de los niños o para organizar los expedientes y al hacer algún censo de población del Hospicio se fue asignando a los asilados que todavía no lo tenían, podría ser el censo de 1914-1915. Se han analizado inscripciones con y $\sin \mathrm{n}$ ㅇ de filiación y con los dos sellos, todos los niños ingresados antes de 1908 que tienen no de filiación seguían dependiendo del asilo, como internos o externos, al hacer este censo.

Los niños que se hallaban internos al hacer el censo tienen una anotación en el libro que así lo indica y el sello en su folio, tanto en los libros anteriores como posteriores a 1908

"En 30 de marzo de 1915 al verificar la formación del censo, aparece hallarse en el asilo practicando el oficio de panadero el referido Jose Maria" (sic)

En sello lineal el no de filiación 75. Fo 249, LE 1901-1

La fecha en la mayoría de los registros no se distingue bien porque se ha escrito en el margen y está pillada al encuadernar, a veces emplean el formato año- mes - día.

“..-12-15 Registrado en población interna número 158 de entrada" (sic)

En sello lineal el no de filiación 158. Fo 119, LE 1907- 1

"17 -12- 1914 - Registrado en población interna no 314 de entrada" (sic)

En sello lineal el no de filiación 314. Fo 329, LE 1911- 1

Entre los niños que no tienen número de filiación en los primeros libros están los fallecidos, los que se dieron de baja por volver con su familia y los que figuran como prohijados y los que no tienen ninguna anotación después de salir con una nodriza, es de suponer siendo optimistas que pasaron al libro de Mayores o se quedaron con ella.

Por otra parte, como cada sello tiene su propia serie de números, coinciden dos niños con el mismo número de filiación estampado en sello diferente. En el libro de 1911 todas las inscripciones tienen sello, la mayoría son circulares y la numeración es correlativa, pero se intercalan algunos del otro tipo con su propio orden de manera que encontramos en los folios 
no 23 y 24 los nos de filiación 497 y 498 respectivamente en sello lineal y en los folios no 25 y 26 los nos de filiación 0497 y 0498 en sello circular; la principal diferencia entre estos niños es la edad que tenían al ingreso y por tanto la que tendrían al asignarles el número ${ }^{524}$. Aún así no puedo asegurar que la edad determinara la asignación de una u otra serie de filiación porque en los primeros libros también encontramos los dos tipos de sellos, en 1900 por ejemplo hay 3 sellos de cada tipo ${ }^{525}$. En el sello circular todos los números llevan un 0 delante, es lo que marca la diferencia entre las dos series, en 1909 en el folio 7 encontramos el no de filiación 01137 en el sello circular y en el folio 11 el 1137 en el sello lineal.

Da la impresión de que cuando se empezó a funcionar con el no de filiación, que pudo ser en 1914, se asignaron con carácter retroactivo a todos los niños hasta los libros de 1908 y en los libros anteriores solamente a los que permanecían vivos y seguían acogidos, internos o externos. No he encontrado razón aparente para emplear uno u otro sello, salvo que se utilizaran en momentos distintos y se asignaran solamente a los niños que en ese instante estaban internos, o que precisamente se utilizara uno u otro sello según que los niños estuvieran internos o externos; en todo caso esto es pura especulación en un intento de encontrar explicación al sistema de filiación, es decir de identificación, que utilizaba el Hospicio. No he encontrado un registro con la relación de los números de filiación y los niños a los que corresponden. Es un sistema de filiación que parece complejo y confuso, que propicia coincidencias y que podría ser motivo de confusiones y errores, no es de extrañar que se siguiera utilizando preferentemente el folio y año, salvo posibles errores al transcribirlo, parece un sistema más seguro y sencillo.

\subsubsection{ElPlomo}

Todos los niños del Hospicio debían estar identificados con el número asignado, para ello al ingreso se les colgaba del cuello una medalla que llevaba su número troquelado. Dicen los reglamentos

"Bautizado el expósito é inscripto en el Registro civil, se le pondrá pendiente del cuello, con la delicadeza y seguridad posibles, un escudito con el número que

\footnotetext{
${ }^{524}$ Los del primer sello ingresaron con 5 y 2 años respectivamente, los del sello circular en el primer mes de vida, por lo demás, 3 ingresaron a través de la Diputación y uno del torno, 3 fueron devueltos a la familia y uno falleció 525 Los folios no 84, 106 y 241 llevan un sello de dos líneas con los nos de filiación 61,62 y 64 respectivamente y los folios no 167, 201 y 234 un sello circular con el número de filiación 63, 3037 y 2806. Todos ellos nacieron en 1900
} 
ocupa en el folio de su partida en el libro correspondiente" [sic] (Art. 315 Regl 1910 y 319 del Regl 1927)

Este escudito que dicen los reglamentos, se conocía en la Inclusa como "el plomo". Al revisar los libros llamó mi atención alguna anotación aislada del tipo "no trae plomo". Encontré también un trozo de papel pillado junto al folio 412 de 1907 que habla de lo mismo

"Pueden admitir en el Hospicio según me indica el Sr Contador, aunque no presentan el plomo a Fortunato Gonzalez $\operatorname{Exp}^{\text {on }} 1907$ fo 412 “ [sic]

Aunque en las primeras notas que vi de este tipo no se daban más pistas, me recordó a las placas de identificación de los soldados y pregunté al personal del Archivo ADPVA por si se conservaba alguno. La persona responsable de gestionar las búsquedas de información sobre niños del Hospicio me comentó que no sabían qué era exactamente, pero que en ocasiones les habían pedido la medallita que llevaban los hospicianos, que no la conocían porque no se conservaba ninguna en el archivo. Quiso la casualidad que unos días después estando en el archivo se presentaran dos mujeres buscando información sobre los orígenes de su madre que fue expósita de la Inclusa de Valladolid a finales de los años veinte y traían con ellas la medallita en cuestión, que amablemente me permitieron fotografiar (IMAGEN 3-18). Se trataba en efecto de una medalla de plomo, ya un poco desgastada, que en una cara tenía a San José, el patrón del Hospicio, representado con su imagen tradicional con el Niño en brazos en su papel protector y una vara florida simbolizando su oficio de carpintero, y en su perímetro el nombre del Hospicio de Valladolid; en la otra cara el número de filiación.

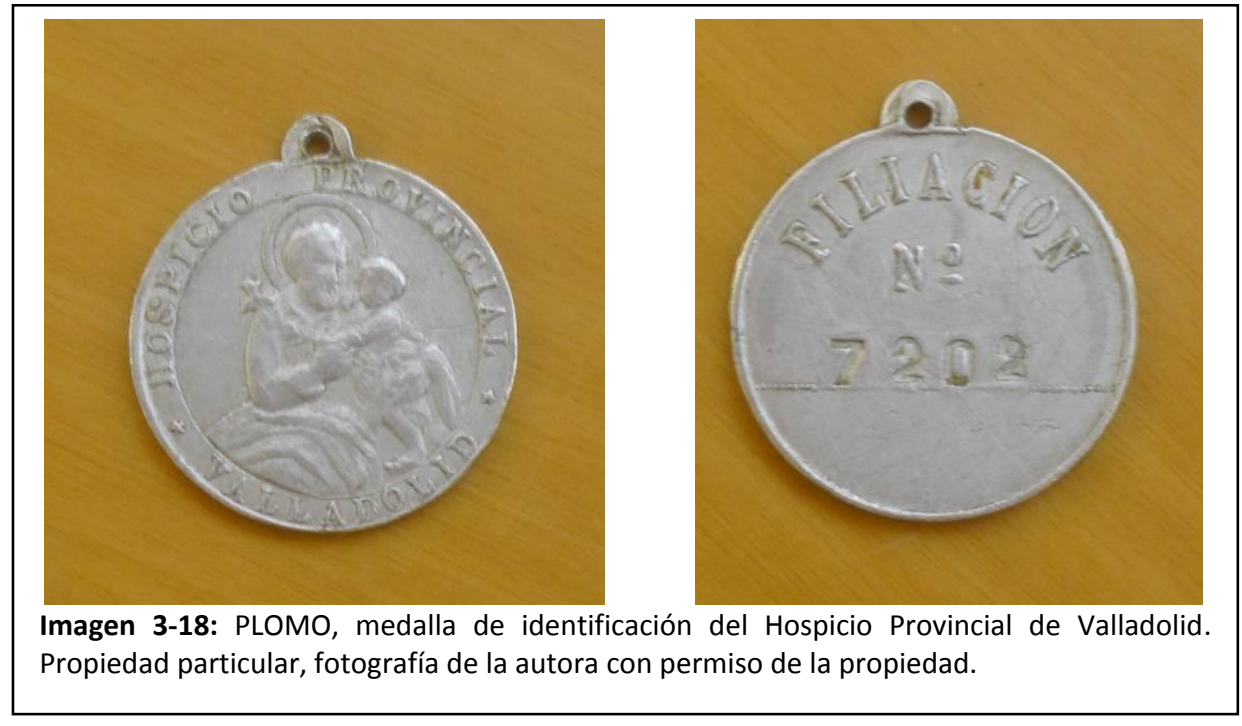

Más tarde encontré una anotación que también hacía referencia al plomo y a su valor identificativo 
"Según oficio del Sr Alcalde de Peñafiel de fecha 22 de Junio de 1908 resulta que el niño devuelto por Martina Arenas no fue este que se había llevado sino el que ocupa el folio siguiente llamado Felix Pinilla con el número 89 en el plomo que trajo puesto..." [sic] (fo 88, LE 1908- 1)

En efecto, en el folio 89 está inscrito el susodicho Félix Pinilla, en el folio de este niño ya figura un sello redondo con el número de filiación 01544, pero no lo tendría todavía adjudicado a su ingreso, por eso en el plomo se ha troquelado el número de su folio y, aunque aquí no lo dice tendría también el año. El número de filiación sustituiría a este otro sistema de identificación en el plomo.

El plomo es por tanto la medallita que llamaban los expósitos o el escudito que mencionan los reglamentos para la identificación de los hospicianos, que debían llevar siempre colgado al cuello desde el momento de su ingreso y mientras estuvieran bajo la tutela del Hospicio. El Reglamento de 1889 lo comenta con más detalle y dice que el escudo es un plomo

\begin{abstract}
"Después de bautizados, ó si ya lo estuvieran á su presentación y antes de ser trasladados los expósitos á la sala de lactancia, se les colocará un escudo en el cuello pendiente de un cordón consistente, cuyas dos puntas introducidas por el hueco de un plomo redondo, quedarán con la presión del sello en términos que no pueda salirse ni sacarse por la cabeza. Dicho escudo será del menor peso y grandor posible, para que no lastime ni incomode á los niños y contendrá por un lado la inscripción del Establecimiento, y por el otro el día, mes y año de entrada y el número que ocupe en el folio de su partida" (Art. 52. Regl 1889)
\end{abstract}

Esta es una forma de identificación común a los hospicios de la época que colgaban una medalla, plomo o escudo del cuello de sus hospicianos ${ }^{526}$ con su número de identificación en el centro y normalmente la imagen del santo o la virgen protectores a modo de "carné de identidad" como dice José Luis Hernando Garrido quien también cuenta como algunas inclusas como la de Santiago de Compostela utilizaban métodos más expeditivos y "un cirujano realizaba una tarja o incisión sangrante en un brazo de los niños expósitos recién ingresados" $^{\prime 27}$.

El plomo era pues la placa que permitía identificar a cada inclusero y como tal se cuidaba para evitar el cambio de identidad de los niños. El Reglamento de 1889 muestra

\footnotetext{
${ }^{526}$ HERNANDO GARRIDO J.L.: Los niños expósitos en tierras de Zamora durante el Antiguo Régimen. Revista de Folklore. Fundación Joaquín Díaz; edición digital no 364; pp 4 -16; MARTíNEZ GÓMEZ-SIMÓN L.M.: Las instituciones de atención social al menor en la ciudad de Albacete. Albacete. Instituto de Estudios Albacetenses "Don Juan Manuel", 2002; MONTIEL PASTOR J.: Anar per tornar. La Casa Provincial de Maternitat i Expòsits de Barcelona com a centre d'una xarxa de re-distribució de la població infantil (1853-1936). XI Congrés d'Història de Barcelona - La ciutat en xarxa. Archivo Histórico de la Ciudad de Barcelona, Ayuntamiento de Barcelona. Dic 2009. VALVERDE LAMSFUS L.: op.cit., p. 231-262; REVUELTA EUGERCIOS B.A.: op.cit., 187- 188.

${ }^{527}$ HERNANDO GARRIDO J.L.: op.cit., p 9.
} 
preocupación por evitar cambios de identidad de los niños, se dice que "cada dos o tres días, la hija de la Caridad encargada de este departamento [de lactancia], comprobará la identidad de los expósitos con el número que tengan, cuidando que no se cambie el escudo y las ropas correspondientes á cada uno de ellos" (Art. 58) y que debía controlar y advertir a las nodrizas para que no cambiaran a los niños de cuna (Art. 59).

\subsubsection{Erroresen los registros}

El proceso de registro de los niños exigía que la información se fuera repitiendo en sucesivas inscripciones y se transmitía desde la dirección, o la oficina, a la inclusa y viceversa a través de fichas impresas, o papeletas de carácter oficial, y de notas informales en trozos de papel. He ido hallando algunas de estas notas y papeletas sueltas entre los libros y en los expedientes personales; entre ellas, cédulas para transmitir la exposición en el torno, la asignación de nodriza, la orden de ingreso para los niños que entraban a través de la oficina, para el reconocimiento médico, para la entrega a un ama externa, para su devolución.... Cualquier procedimiento tenía su propia papeleta y a ellas habría que añadir las cartas, certificados y notas de todo tipo en papel no reglado. Al final la información se encontraba repetida en sitios y libros diferentes, el de la Inclusa, el de Entradas, el de Salidas, además de en los documentos, oficiales o no, correspondientes. Toda la documentación se debía guardar en el expediente que se abría al ingreso.

Tener libros distintos permite clasificar la información, pero cuando ésta puede incluirse en diferentes apartados se plantea el problema de organizarla y distribuirla de forma adecuada. Es lo que pasaba en la oficina del Hospicio a la hora de registrar la información de los niños, los que tenían la suerte de sobrevivir si seguían siendo acogidos del Hospicio pasaban a la sección de Mayores que tenía su propio libro. En los primeros años revisados, en los Libros de Exposiciones se anotaba, llegado el momento, el paso al correspondiente Libro de Mayores y no se hacían más registros en el primero

"Devuelta en 21 de Octubre 1912 pasa al folio 312 del libro 16 de mayores" [sic] (fo 360, LE 1902-2)

Probablemente porque esto suponía desperdigar la información de los niños de la Inclusa, sobre todo a partir de 1904 se van a continuar haciendo anotaciones en el folio del 
Libro de Exposiciones, recogiendo todas las entradas y salidas del niño hasta su baja definitiva en el Hospicio. Ya he comentado el problema de duplicar la información en estos dos libros, por una parte hay registros que dan la impresión de estar inconclusos, sin que pueda saberse en qué momento el asilado se desvinculó del Hospicio y es necesario ir de un libro a otro, hay información que se repite en los dos, incluso se da el caso de repetir folio para el mismo niño. La niña Saturnina Gutiérrez está inscrita en el folio no 198 del Libro de Exposiciones de 1902 y en él se dice que fue expuesta en el torno el 4 de junio de ese año y que "el dia 15 de septiembre la llevó Estefanía Sanz mujer de Pelayo Benito vecinos de Torreadrada (Segovia)". En el Libro de Mayores está registrada en su folio 305, en el que se lee que

\section{"Saturnina Gutierrrez}

En 21 de Septiembre de 1909 fue devuelta procede de la Exp ${ }^{\text {on }}$ de 1902 folio 198 la tenía Estefania Sanz vecina de Torreadrada

Bautizada en este Asilo en 6 de Junio de 1902 (sello del Hospicio y firma del director)" [sic]

En el Libro de Exposiciones en una anotación que se aprecia que es posterior y con diferente letra se ha recogido este apunte y se lee "Devuelta el 21 de Septiembre 1909" y debajo se añade que "Pasa al folio 401 del libro 16 mayores". En efecto, en el mismo libro de Mayores se vuelve a inscribir la misma niña en un folio diferente

\section{"Saturnina Gutierrrez \\ Pasa a este libro por haber cumplido la edad procede de la Expn 902 fo 198 \\ En 12 de Diciembre de1910 cumpliendo acuerdo de la Comisión provincial la llevaron... para compañía de matrimonio"}

En el libro de mayores no consta la fecha en la que se abre el folio y se hace la inscripción pero parece que una sería al devolver a la niña y la otra al cederla al matrimonio para compañía. El problema de este tipo de registros es que dificulta el control de los niños.

No es de extrañar que, con el trasiego de papeletas y de información, se cometieran errores y se perdiera o se cambiara información, teniendo además en cuenta el número de asilados y los diferentes tipos de comunicaciones que se hacían por este medio. Algunos son errores de transcripción, sobre todo hay fallos en las fechas, al menos estos son los que se pueden detectar a simple vista, como registros con fecha de defunción anterior a la del ingreso: la niña María Juana "En 21 de Mayo de 1912 fue expuesta en el torno...En 24 de mayo de 1912 la llevó Dorotea Santos... [y] falleció en dicho pueblo en 14 de Mayo de 1912"528; o inscripciones con fecha de nacimiento posterior al ingreso: "El día seis de febrero de 1907 á las

\footnotetext{
${ }^{528}$ Folio no 186. Libro de Exposiciones de 1912. ADPVA
} 
dos y treinta fue expuesto en el torno.... Este niño ha nacido el día siete de Febrero de 1907"1529. Algunos en principio parece que no tienen demasiada trascendencia, pero otros son más graves ya que repercutirían en el cuidado y control de los asilados, entre ellos los errores relacionados con las nodrizas, que se han podido detectar porque en los propios registros aparecen las rectificaciones:

"Isidora Quinzaños Rodríguez...

En 23 de Noviembre de 1912 la llevó Benita Paul mujer de Nicolás Fernández vecinos de Sacramenia

17 enero 1917- Pasa a 3a situación

Nota: Esta niña fue entregada a Luisa Orden de Navares de las Cuevas si bien la libreta o cartilla se dio equivocadamente a Benita Paul que llevó a Agapito Arnaiz Ninfa ( $F^{o n}$ [no de filiación] 761, 1911- fo [folio] 325. C a [no de cartilla] 308), y la Isidora, o sea esta acogida falleció en poder de Luisa en 23 de mayo de 1914" [sic] (fo 396, LE 1912- 2)

En el folio 325 de 1911 está inscrito el otro niño

"Agapito Arnaiz Ninfa...

En 25 de Noviembre de 1912 le llevó Luisa Orden mujer de Juan Iglesias vecinos de Navares de las Cuevas

Falleció en dicho pueblo el 23 de Mayo de 1914

Nota: Este niño no falleció en Navares de las Cuevas sino que la criadora había recibido por confusión la cartilla del mismo y al morir la niña que tenía en su poder a Isidora Quinzaños Rodríguez (Fon 969 - 1912- $f$ o 396) la enterraron como Agapito.

Este acogido fue devuelto en 9 de Enero de 1917 y falleció en este Asilo el 22 de abril de 1917" [sic] (fo 325, LE 1911-2)

Este error refleja falta de control sobre estos niños, durante cinco años estuvieron cambiados y nadie se percató, incluso dicen que entierran a la niña con el nombre del chico. Explican el error porque las cartillas de crianza, que se entregaban a las nodrizas y llevaban el nombre del inclusero, se cambiaron; las nodrizas probablemente serían analfabetas y no detectarían el cambio de nombre, pero esto debería haber afectado a los pagos porque la niña falleció 3 años antes y no se detectó el error hasta que uno de ellos volvió a la Inclusa. A la vista de todo esto, no podemos decir que estos niños estuvieran bien tutelados ni sus nodrizas controladas por el Hospicio. En el Libro de la Inclusa de 1911, el libro oficioso que se llevaba en el departamento, no se ha escrito nada sobre este asunto, no se conserva el libro de 1912.

Como he dicho algunos de estos errores solo los detectamos porque el mismo hospicio hacía la oportuna corrección en el libro, la cuestión que se nos plantea es cuántos más puede haber realmente y hasta dónde esos errores eran involuntarios, porque algunos suscitan dudas sobre su intencionalidad. En la prensa de la época aparecían noticias, como alguna que ya

\footnotetext{
${ }^{529}$ Folio no 48. Libro de Exposiciones de 1907. ADPVA
} 
hemos visto que cuestionan la buena fe o el buen hacer de algunos de los que debían velar por los niños acogidos y en último término la bonanza y la eficacia del sistema en sí. En 1908 en la sección dedicada a la Diputación informa que en el pleno del día 1 de agosto se ha propuesto reformar el sistema de pagos de las nodrizas externas porque un niño reclamado por su padre no aparece ${ }^{530}$. En 1928 se plantea también en el pleno elevar al fiscal una denuncia por el cambio de nombre de una asilada después de haberlo investigado desde la propia Diputación

"Visto el informe del diputado instructor del expediente incoado con motivo del cambio de nombre de una asilada del Hospicio, se acordó pasarle al señor fiscal de la Audiencia, por si hubiera lugar á exigir alguna sanción" ${ }^{531}$

En el folio 339 de 1911 pillada al encuadernar hay una nota en un trozo de papel

"Juana Bartolomé Rodriguez que en el libro falleció no és así, pues vive según las adjuntas certificaciones, sin que ni en la cartilla antigua ni en la moderna se diga falleció pues la nota del libro está equivocada"

En efecto, en el libro de Exposiciones consta que "Falleció en el Condado de Castilnovo en 6 de Marzo de 1912" y posteriormente, sin fecha, se ha corregido "Nota: el fallecimiento de esta niña que consta en el libro debe ser por herror pues según certificaciones de los Sres Juez y Cura de Sepúlveda dicha niña vive" (sic). En 1919 reingresó, probablemente enferma porque quince días después falleció "a consecuencia de faringitis pseudomembranosa", la pobre parecía predestinada.

Aunque, en general la información que ofrecen los libros de registro de la oficina y de la Inclusa es coincidente, hay algunas discrepancias, que yo haya podido detectar; el hecho de repetir la información podía dar lugar a errores en la transcripción:

En el folio 40 de 1911 del libro oficial se anota la salida con una nodriza externa que corresponde a otro niño, en este caso se dieron cuenta a tiempo, cuando le tocó salir al niño inscrito en el folio

El día28 de febrero 1907 le llevo María [parece que pone] Cop Sacristan mujer de Martín Bermejo vecinos de Cuevas de Provanco No fue este número el que llevo fue el 42

El dia 24 de Marzo le llevo Maria Garcia mujer de Gregorio Benito vecinos de Fompedraza" [sic] (fo 40, LE 1907-1)

En el folio del otro niño, no 42 la anotación se hizo bien

"El día 28 de febrero 1907 le llevo María Concepcion Sacristan mujer de Martín Bermejo vecinos de Cuevas de Provanco"

\footnotetext{
${ }^{530}$ N.C. $2-08-1908, \mathrm{p} 2$

${ }^{531}$ N.C. $16-02-1928, \mathrm{p} 3$
} 
Pero si vamos al libro de entradas de la Inclusa, allí encontramos otro error diferente, la salida está bien registrada en cuanto a fecha y localidad pero han cambiado el nombre de la nodriza y han puesto el del marido en femenino. El registro del fo 42 coincide

"Enero 28 Folio 40 entro por la oficina... salió el 24 de Marzo 1907 en Fompedraza P $P^{\text {cia }}$ Valladolid la mujer se llama Gregoria Benito"

Este sería un fallo propio de la transcripción de las notas informativas, pero otras diferencias entre los libros podrían ser significativas, incluso algunas resultan "sospechosas". Cuando los niños ingresaban "por la oficina", desde ésta se pasaban los datos a la Inclusa y se registraban en el libro propio. En 1907 encontramos registros con fechas discrepantes y con una nodriza externa de por medio.

En el libro de la Inclusa el 10 Abril de 1907 se registra la salida de la niña Domitila con una nodriza, que la devuelve a la Inclusa y la vuelve a sacar en el mismo día (IMAGEN 3-19)

"folio 126 entro por la oficina una niña bautizada con el nombre de Domitila Busnadiego Esgueva. Destete 24 meses vino de luto son hermanos). La llevó su padre el 20 de Abril 1907 la volvió en Febrero y volvió a salir el 24 de Mayo 1908 en Fuentesoto $P^{\text {cia }}$ Segovia la mujer se llama Juana Rojo devuelto el 4 de junio 1910 salio el mismo dia y la llevo la misma nodriza" [sic]

En cambio, en el libro de la oficina no se ha registrado lo mismo, aquí se dice que Domitila reingresó y no volvió a salir hasta 24 días después

"el dia 20 de Abril de 1907 fue entregada a Iginio por acuerdo de la comisión
provincial y firma por no saber.
En 7 de Marzo reingreso por acuerdo de la Comision provincial por no poderla
atender su tio Higinio que la había sacado.
En 24 de Marzo de 1908 la llevó para destete Juana Rojo mujer de Ciriaco Barrio
vecinos de Fuentesoto
Devuelta el 11 Mayo 1910
En 4 Junio la llevó destete Juana Rojo mujer de Ciriaco Barrio vecinos de Tejares
Segovia
Devuelta el 12 de Marzo de 1912" [sic] (fo 126, LE 1907-1)

Por edad debería reingresar en la Inclusa, pero en su libro no consta; aumenta la sospecha el hecho de que en la segunda salida la lleva la misma mujer y cambia el nombre del pueblo, podría ser que la nodriza se hubiera arrepentido de devolverla y se hubiera mudado, pero parece más una treta para despistar porque de ser así, salvo error por omisión, se habría anotado el cambio en el libro de la Inclusa. Al comprobar el libro de registros de pagos de las amas de $1907^{532}$ encontramos que en el período que Domitila estuvo supuestamente en el Hospicio no se pagó al ama, pero luego se prolongó el destete durante cuatro años en total,

\footnotetext{
5321907 Libro de los niños que salen para lactancia. Signatura: caja 849, expediente 7029. ADPVA
} 
hasta marzo de 1912 (IMAGENES 3-19 y 20); coinciden las fechas del libro de Exposiciones y el de salidas, no se ha anotado el retorno en el de la Inclusa porque para entonces esta niña contaría con 7 años, que tampoco era muy habitual entonces que el destete llegara hasta esta edad, por lo que pasaría al Hospicio y se registraría en el Libro de Mayores. Hay también otra diferencia entre los dos libros, en el de la Inclusa dice que le "la llevó su padre" y en el de Exposiciones que "reingresó...por no poderla atender su tía Higinia (o tio Higinio porque no se distinguen bien) que la había sacado", pueden ser fallos normales para el sistema de comunicación que se empleaba.

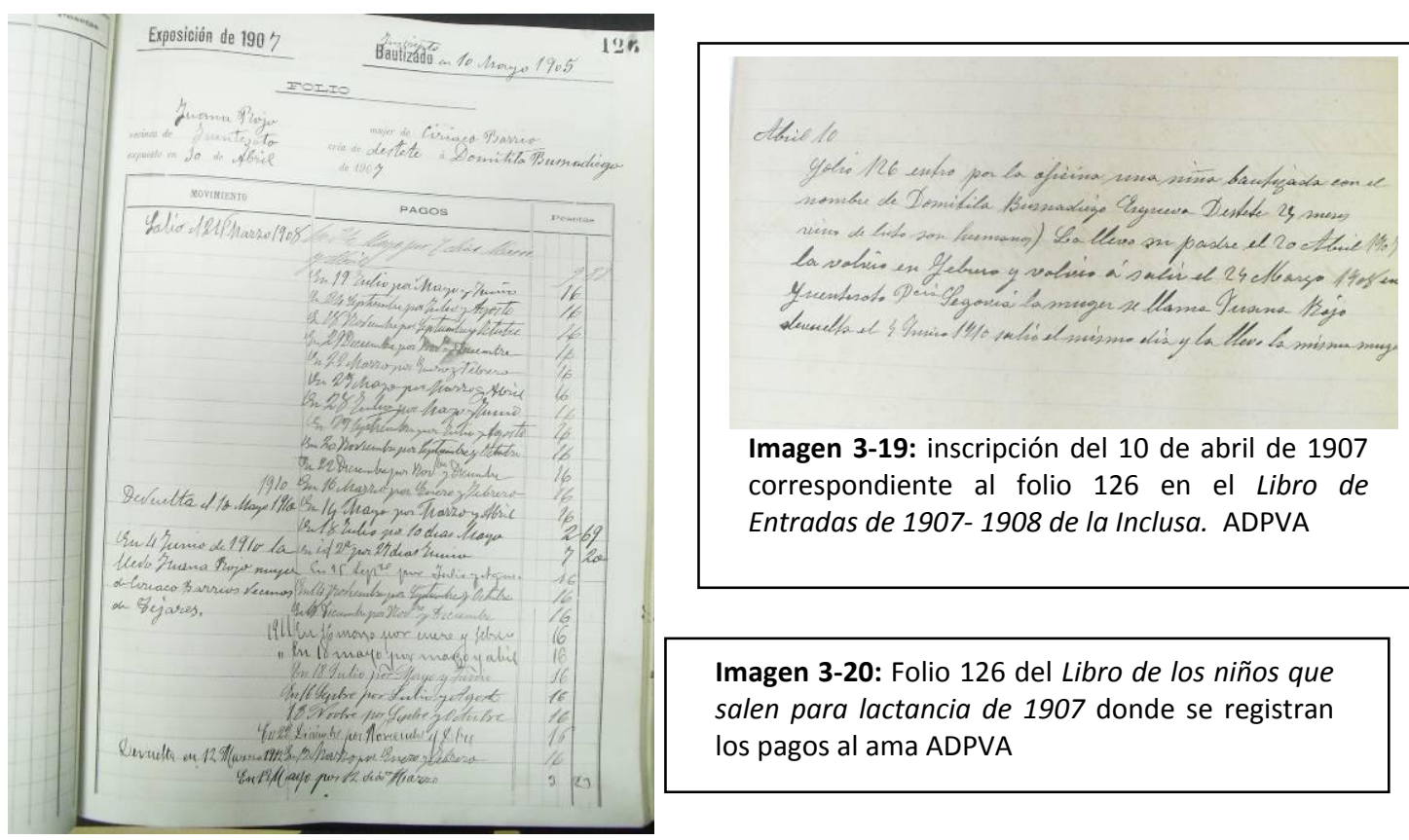

También en 1907 encontramos una situación bastante sospechosa y que vemos que se repite en 1902. En el libro de la Inclusa en el 2 de Marzo de 1907 se lee

"Folio 84 entro por la oficina una niña bautizada con el nombre de Felipa Herguedas y salió en el acto sin subir" [sic]

mientras que en el libro 1ㅇ de 1907 en el mencionado folio 84 podemos leer

"Felipa Hergueda Velasco

El dia 2 de Marzo ingreso en este asilo por orden del sr vicepresidente de la comisión provincial con certificado del Sr Juez Municipal de Cogeces del Monte que dice que es hija legitima de Pio y de Sergia vecinos de dicha villa Inscripto en Cogeces del Monte el dia 11 de Abril 1906 La lacta

El dia 8 de Marzo de 1907 la llevo Casimira Velasco mujer de Angel de la Fuente vecinos de Langayo" [sic] 
Después de este apunte no se ha escrito nada más. La primera cuestión que se nos plantea es dónde podría encontrarse esta niña de 1 año si no subió a la Inclusa y según dice el libro de la oficina ingresó el día 2 y salió el 8 y en segundo lugar parece mucha casualidad la coincidencia de apellidos, el segundo de la niña con el de la nodriza, sobre todo porque Cogeces del Monte, el pueblo de la niña y Langayo, el de la nodriza, distan unos $12 \mathrm{Km}$. Esta situación recuerda al comentado y polémico "escándalo Montiel" que saltó a la prensa local en $1913-14^{533}$, en el que estaba implicado este hombre que era el auxiliar de la dirección del Hospicio al que se le acusó entre otras cosas de que ingresaba niños que inmediatamente eran sacados por sus padres de manera que ellos cobraban por la crianza de su propio hijo, como si fuera un inclusero, y Montiel recibía una comisión de quince duros por cada niño. En el libro de salidas constan pagos a la nodriza por valor de 172'08 pts hasta el 24 de mayo de 1908, curiosamente en este folio se ha anotado a lápiz el total de lo pagado, que no figura en otros registros.

Comparando el Libro de la Inclusa de 1902 con los de Exposiciones del mismo año se encuentran casos similares de niños legítimos que ingresan por orden del presidente o el vicepresidente de la Diputación y que no llegan a subir a la Inclusa, que según la hemos situado estaría en la primera planta del edificio, la oficina por tanto se encontraría en la planta baja.

En la inscripción que corresponde al folio 170 dice el libro de la Inclusa que "entró por la oficina una niña bautizada de 3 años está en la Escuela", sin más, ni siquiera da el nombre; mientras que en el libro de Exposiciones se dan todos los datos, ingresó por orden del Presidente de la Diputación el 5 de mayo de 1902 y no salió hasta el 1 de septiembre que fue entregada al padre.

También se puede leer en el Libro de la Inclusa: "Fo 303 Benito se subió la papeleta de la oficina de dicho folio y se volvió á bajar por no haber traído arriba el niño que ocupa el folio 333 de dicha papeleta", mientras que en el libro oficial consta que era un hijo legítimo que ingresó por orden del Vicepresidente de la Comisión provincial, que era de Castrillo de Duero y que ingresó el día 22 de septiembre y salió el 5 de octubre con una nodriza de Sacramenia. Se repite la misma situación que ya hemos visto y que dado el caso ofrece dudas, estos dos pueblos distan unos $12 \mathrm{Km}$. Y volvemos a encontrarla en el folio 348, dice el Libro de la Inclusa: "Gerardo Ramos Álvarez se ha subido de la oficina la papeleta de dicho folio pero no han traído arriba el niño que ocupa el folio 348 de dicha papeleta", según la oficina el niño

\footnotetext{
${ }^{533}$ N.C. 21-11-1913, p 2 y 5-11-1914, p 2.
} 
estuvo ingresado una semana y en este caso los pueblos son Fuensaldaña y Corcos que están a una distancia también menor a $13 \mathrm{Km}$ (16 Km por la carretera actual)

Son situaciones cuando menos dudosas. Si se tratara de niños que se entregaban a sus propios padres y les pagaban la crianza no sería una mala actuación en caso de necesidad, siempre sería mejor mantener al niño con su familia; el problema de una operación de este tipo es fundamentalmente ético y legal, por una parte la falta de equidad al privar al resto de niños y familias necesitadas de este beneficio y por otra la falta de honestidad al saltarse las normas establecidas en los reglamentos por los mismos que las dictaban y que debían velar por su cumplimiento, esto sin pensar, porque no podemos demostrarlo y habría que mirarlo más detenidamente, que hubiera por detrás algún tipo de negocio.

Podemos suponer que si no se daban ayudas familiares para la crianza de niños necesitados sería por una cuestión económica y sobre todo por el temor a verse desbordados por la demanda como sucedió en la inclusa de Oviedo.

\subsubsection{Elbautismo}

Mipadrey mi madre me abandonaron pero el señor me acogió

Salmo 26, vers. 16. Lema utilizado por muchas inclusas

En una sociedad eminentemente católica y con una Iglesia muy influyente como era la de la época y lugar del estudio, el Bautismo tenía gran relevancia por sus connotaciones tanto religiosas como sociales, indispensable como rito de entrada a la comunidad cristiana y al "Reino de Dios". El Catecismo de la Iglesia Católica lo considera "el fundamento de toda la vida cristiana", "necesario para su salvación", imprescindible para limpiar a los seres humanos del "pecado original" con el que nacen y librarlos "del poder de las tinieblas y ser trasladados al dominio de la libertad de los hijos de Dios" ${ }^{534}$. A partir del siglo XIII se plantea en la Iglesia la

\footnotetext{
${ }^{534}$ Catecismo de la Iglesia Católica. Segunda parte. Segunda sección. Capítulo primero. Artículo 1. El sacramento del Bautismo: punto 1213 "El santo Bautismo es el fundamento de toda la vida cristiana, el pórtico de la vida en el espíritu ... Por el Bautismo somos liberados del pecado y regenerados como hijos de Dios, llegamos a ser miembros de Cristo y somos incorporados a la Iglesia ... (cf Concilio de Florencia: DS 1314...)".
} 
idea del Purgatorio, recogida posteriormente en los concilios de Florencia (1304) y de Trento (1580); se considera un lugar de expiación o de purificación, intermedio entre el paraíso y el infierno, destinado a "los que mueren en la gracia y en la amistad de Dios, pero imperfectamente purificados... a fin de obtener la santidad necesaria para entrar en la alegría del cielo", destino por tanto de las almas de los niños no bautizado ${ }^{535}$. El catecismo actual dice que "Ia tradición de la Iglesia habla... de un fuego purificador...antes del juicio final" y de la 'posibilidad de liberar a los difuntos del pecado mediante "Ias limosnas, las indulgencias y las obras de penitencia" en su favor. El destino eterno final de los no bautizados es incierto, en y después de este Limbo de los Justos, y morir sin el bautismo suponía problemas para el enterramiento hasta no hace mucho al no pertenecer todavía a la comunidad católica ${ }^{536}$, por eso, aunque inicialmente no había una edad establecida, desde el concilio de Salamanca (1335) el bautismo se acabó imponiendo en la infancia, adelantándose a los primeros días de vida debido a la alta mortalidad que en ellos se producía ${ }^{537}$. Según recoge la encuesta del Ateneo de 1901-1902, en Valladolid, como en general en el resto de España, lo habitual era celebrar el bautismo dentro de los ocho primeros días de vida, "generalmente tras la misa mayor del día festivo más próximo" ${ }^{538}$.

Como no todos los recién nacidos tienen la posibilidad de recibir el bautismo oficial de manos de un sacerdote, la iglesia concede la posibilidad de administrar el bautismo de urgencia, también llamado popularmente "agua de socorro" que puede administrar en caso de

\footnotetext{
"1215 Este sacramento es llamado también "baño de regeneración y de renovación del Espíritu Santo" (Tt 3,5),... sin el cual "nadie puede entrar en el Reino de Dios".

"1250 Puesto que nacen con una naturaleza humana caída y manchada por el pecado original, los niños necesitan también el nuevo nacimiento en el Bautismo (cf DS 1514) para ser librados del poder de las tinieblas y ser trasladados al dominio de la libertad de los hijos de Dios (cf Col 1,12-14), a la que todos los hombres están llamados. La pura gratuidad de la gracia de la salvación se manifiesta particularmente en el bautismo de niños. Por tanto, la Iglesia y los padres privarían al niño de la gracia inestimable de ser hijo de Dios si no le administraran el Bautismo poco después de su nacimiento (cf CIC can. 867; CCEO, can. 681; 686,1)".

"1257 El Señor mismo afirma que el Bautismo es necesario para la salvación (cf Jn 3,5). .... La Iglesia no conoce otro medio que el Bautismo para asegurar la entrada en la bienaventuranza eterna; por eso está obligada a no descuidar la misión que ha recibido del Señor ..."

Disponible en la página Web de La Santa Sede: http://www.vatican.va/archive/catechism_sp/p2s2c1a1_sp.html

${ }^{535}$ Catecismo de la Iglesia Católica. Primera Parte. Artículo 12, III La Purificación final o Purgatorio. Disponible en: http://www.vatican.va/archive/catechism_sp/p123a12_sp.html

Respecto al destino de los niños sin bautizar el catecismo actual no menciona expresamente el Purgatorio, pero lo sugiere. En el artículo sobre El sacramento del Bautismo dice en el punto 1261: "En cuanto a los niños muertos sin Bautismo, la Iglesia sólo puede confiarlos a la misericordia divina, como hace en el rito de las exequias por ellos. En efecto, la gran misericordia de Dios, que quiere que todos los hombres se salven (cf $1 \mathrm{Tm} 2,4)$ y la ternura de Jesús con los niños, que le hizo decir: "Dejad que los niños se acerquen a mí, no se lo impidáis" (Mc 10,14), nos permiten confiar en que haya un camino de salvación para los niños que mueren sin Bautismo. Por esto es más apremiante aún la llamada de la Iglesia a no impedir que los niños pequeños vengan a Cristo por el don del santo Bautismo".

${ }^{536}$ No fue hasta 1879 que el Ayuntamiento de Valladolid "en la sesión del 5 de Enero acordó destinar un local para el enterramiento de los no católicos, próximo al cementerio", en ORTEGA Y RUBIO J.: Historia de Valladolid (1881). Grupo Pinciano. Edición facsímil. 1991, pp 242

${ }^{537}$ Cfr. FERNÁNDEZ CONDE F.J.: La Religiosidad Medieval en España. Plena Edad Media (siglos XI-XIII).

${ }^{538}$ MARTÍN JIMÉNEZ I.: La sociedad vallisoletana en los albores del siglo XX...., p 29
} 
peligro inminente de muerte cualquier persona, incluso no bautizada "siempre que tenga intención de hacer lo que hace la Iglesia". Para ello basta derramar agua natural, en este bautismo no se precisa que esté bendecida, sobre la cabeza del niño mientras se dice la fórmula "Yo te bautizo en el nombre del Padre y del Hijo y del Espíritu Santo" y se le impone un nombre, que la iglesia quiere que sea el de un santo católico que será su protector e intercesor en el cielo. Existe incluso la posibilidad de "bautizar condicionalmente" cuando al nacer un niño, o dice también el catecismo que un feto, existen dudas sobre si está vivo o no, utilizando la fórmula "Si vives, yo te bautizo en el nombre del Padre y del Hijo y del Espíritu Santo". La Iglesia habilitó a las comadronas para dar este agua de emergencia, ya el Sínodo de Constantinopla de 1277 acordó que los párrocos instruyeran a mujeres laicas para que administraran correctamente este bautismo de urgencia $^{539}$, que se puede administrar también durante el parto antes de la salida total del cuerpo del niño, derramando el agua sobre la parte que asome cuando no es la cabeza, incluso al feto antes de nacer. En el siglo XVIII se ideó una jeringa especial para inyectar agua bendita en el útero sobre la cabeza del feto en caso de que

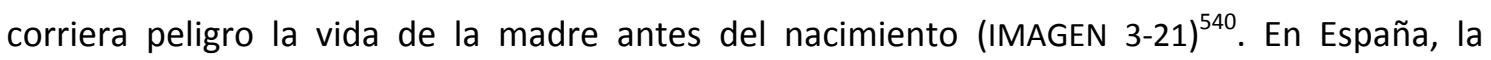
correcta administración del bautismo formaba parte del programa de formación y de las competencias profesionales de las matronas, el Reglamento de 1888 que regulaba la carrera de matrona en su artículo 12, que trata de los conocimientos a adquirir, en el punto 50 dice: "Modo y forma de administrar el bautismo de necesidad á los párvulos cuando peligre su vida" $[\text { sic }]^{541}$.

Estos bautismos tienen validez total y no deben repetirse, los bautizados así quedan ya libres del pecado original; posteriormente, si el niño sobrevive, el sacerdote oficiará el resto de la ceremonia del bautismo, obviando la parte del agua que se ha hecho en el de urgencia hasta

\footnotetext{
539 TOWLER B.: Comadronas en la historia y en la sociedad. Barcelona. Masson, 1997, citado en CARMONAGONZÁLEZ I., SAIZ-PUENTE M.S.: El bautismo de urgencia, función tradicional de las matronas. Matronas Prof. 2009; no 10, 4; pp 14-19; GANSO PÉREZ A I: Las parteras, un arte de mujeres para Mujeres. Una investigación sobre el Pasado. VALLADOLID 2016, pp 198- 203

${ }^{540}$ Imagen. Fuente: BABIES H.A, History, Art and Folklore. Nueva York: Fontanel, 1997. tomada de CARMONAGONZÁLEZ I, SAIZ-PUENTE M S: El bautismo de urgencia, función tradicional de las matronas. Matronas Prof. 2009; no 10, 4. "En los casos en que el parto se ha de terminar volviendo la criatura para sacarla por los pies, o empleando el fórceps, se debe prevenir el agua, y tenerla pronta para echarla sobre la parte de la criatura que primero se descubra". NAVAS J.: Elementos del arte de partear. Madrid. Imprenta Real, 1795.

"En tal aprieto el niño puede dentro del útero ser baptizado. El modo de que llegue el agua inmediatamente a la criatura no ay autor moderno que no lo diga; y es con una jeringuilla guiada de la mano hasta el mismo cuerpecito del feto, y rompiendo con la uña la telilla o secundinas, si acaso no están aun rotas, tocará primero al feto con el dedo y descargando sobre su mismo dedo la geringuilla, es preciso que el agua moje al niño; y como el dedo inmediatamente le toca se infiere, que le toca assi también el agua, entonces se dice la forma: "yo te baptizo en el nombre del Padre, y del Hijo, y del espíritu Santo, Amén; y de este modo queda baptizado" [sic]. B. DE GÁRATE Nuevo y natural modo de auxiliar a las mujeres en los lances peligrosos de los partos, sin operación de manos ni instrumentos. Pamplona. Oficina de Pasqual Ibáñez, 1756 (Citados en CARMONA-GONZÁLEZ I., SAIZ-PUENTE M S. op. cit.)

${ }^{541}$ R. D. de 16 de Noviembre de 1888
} 
completar el ritual. Se puede administrar el "bautizo sub conditione" o bajo condición siempre que no exista certeza de que se haya recibido el bautismo anteriormente, esto incluye aquellas situaciones en que existen dudas de que se haya realizado correctamente según el rito descrito por la Iglesia católica, por ejemplo si el agua se ha derramado en otro sitio que no sea la cabeza, lugar indicado por la Iglesia por ser el miembro principal

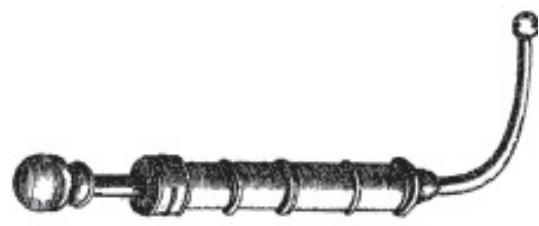

Imagen 3-21: Jeringa para el bautismo uterino. Fuente: BABIES H.A, History, Art and Folklore. Nueva York. 1997. del cuerpo, "Yo el infraescripto cura bauticé sub conditione y puse los santos óleos a una niña que nació el día catorce de febrero la que bautizó su abuelo materno Joseph Ballano antes de su abstracción tocándole el agua en una pierna (según su declaración) por parecerle amenazaba peligro" ${ }^{\prime 542}$. Para este bautismo bajo condición se utiliza la fórmula "Si no estás bautizado, yo te bautizo..."

Teniendo en cuenta la doctrina católica sobre el bautismo, el Hospicio cuidaba muy especialmente su observancia, no en vano estaba al cuidado de una comunidad de religiosas que velaban junto con el capellán, que era la segunda autoridad después del director dentro del establecimiento, por el cumplimiento de las normas morales y de la iglesia católica por parte de los acogidos y del personal subalterno y nodrizas ${ }^{543}$. Tanto en los ingresos a través de la Comisión de la Diputación como de los expósitos de los pueblos de la provincia, que habitualmente llegaban bautizados, se pedía entre los documentos que conformaban el expediente de admisión el certificado de bautismo. Los niños que llegaban a la Inclusa sin bautizar se separaban en "la sala destinado a los no bautizados".

La preocupación era también social, en la mayoría de las notas que se dejaban en el torno se hacía referencia al bautismo, directa o indirectamente con frases como "se ruega le pongan por nombre...". Algunas notas simplemente decían "está bautizado" o "no está bautizado", otras daban además el nombre que se quería para el niño:

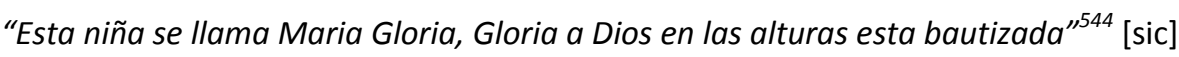

"La niña está acristianada y por nombre se llama Maria Angeles" "545 [sic]

\footnotetext{
542 En CARMONA-GONZÁLEZ I, SAIZ-PUENTE M S: op. cit.; pp 14-19.

${ }^{543}$ Entre las obligaciones del capellán desarrolladas en el Capítulo V, Art. 29 de los Regl de 1910 y 1927 y en el Título catorce del Regl de 1889 está la de "Velar en todos los puntos del Establecimiento por la moralidad y corregir inmediatamente las faltas que contra ella se cometan, dando cuenta al Director"

${ }^{544}$ Folio no 216. Libro de Exposiciones de 1904- 1. ADPVA
} 
"Esta niña que se entrega en este benefico establecimiento se ruega hagan favor de ponerla en el bautismo los nombres y apellidos siguientes Paca Codina Quirce = Valladolid 30 Enero $1908^{\prime 1546}$ [sic]

"Este niño se llama Julian Nuñez Casanova, nació el día 27 de enero a las cuatro de la tarde está bautizado en la parroquia de San Lorenzo. Valladolid 14 de febrero del $902^{\prime \prime 547}$ [sic]

Hay notas que advertían que el niño había recibido el agua de socorro:

"Nació el 25 de junio de 1909 en Palazuelo de Vedijas tiene agua de socorro nada mas y se inscribió en el Registro con el nombre de Josefa Trinia Cabrera, hija de Dorotea y padre desconocido" ${ }^{548}$ [sic]

"Nació este niño hoy día 6 de Agosto a las 16 y 40 recibiendo agua de socorro y yo como madre deseo se Ilame Leoncio Gimenez Garcia" ${ }^{1549}$ [sic]

"Se llama este niño Leonardo Gomez nacido en Montemayor (Valladolid) á las diez de la mañana del 18 de Agosto de 1909 en cuya única parroquia ha recibido las aguas bautismales $=$ no esta bautizado ha recibido agua de socorro" ${ }^{\prime 150}$ [sic]

En algunos casos se aportaba la partida de bautismo, o se daban toda clase de pormenores, hasta el nombre de los padrinos, incluso hay alguna nota escrita por el sacerdote o sellada en la parroquia:

\begin{abstract}
"Policarpo Julio Madrazo Vega nació en Valladolid el día 25 de Enero á las dos de la madrugada, en la calle Angel Garcia no 19. Fue bautizado el dia 2 de Febrero en la Iglesia de San Juan, siendo sus padrinos José Martinez y Martinez y Encarnacion Velez = año 1902 = hay dos rayas = es hijo de Carlota Madrazo Vega = El niño tiene una especie de lunar en el muslo izquierdo= hay una raya= el niño citado está bautizado en esta Parroquia en el día 2 de los corrientes. Valladolid 14 de febrero 1902= P.O. Luis Fuente [? ilegible] = hay una rubrica = hay un sello que dice "Parroquia de San Juan Bautista. Valladolid» "551 [sic]
\end{abstract}

"El día primero de febrero se bautizó en esta parroquia con los nombres de Carmen Maria Encarnacion una niña que dijeron ser hija de Asterio Pardo y Francisca Franco. Padrón. Febrero 14 de $1905=$ Arturo Montes = rubricado= hay un sello que dice "Parroquia de Santiago Apostol de la Villa de Padron»" ${ }^{552}$ [sic]

"En la Iglesia parroquial de mi cargo fue bautizado el seis de los corrientes un niño Ilamado Isidoro = Aguilar de Campos Abril 7/910= El Parroco $=$ Ceferino

\footnotetext{
545 Folio no 210. Libro de Exposiciones de 1904- 1. ADPVA

${ }^{546}$ Folio no 35. Libro de Exposiciones de 1908- 1. ADPVA

${ }^{547}$ Folio no 49. Libro de Exposiciones de 1902- 1. ADPVA

${ }^{548}$ Folio no 239. Libro de Exposiciones de 1909- 1. ADPVA

549 Folio no 286. Libro de Exposiciones de 1912- 2. ADPVA

${ }^{550}$ Folio no 293. Libro de Exposiciones de 1909- 2. ADPVA

${ }^{551}$ Folio no 51. Libro de Exposiciones de 1902- 1. ADPVA

${ }^{552}$ Folio no 310. Libro de Exposiciones de 1905- 2. ADPVA
} 
Zamora= rubricado. Hay un sello que dice "parroquia de Santa Maria de Aguilar de Campos»" ${ }^{\prime \prime 53}[\mathrm{sic}]$

Como se puede ver en las anteriores citas, la transcripción de las notas del torno era tan literal que recogían todos los detalles, hasta las rayas dibujadas entre el texto o la leyenda de los sellos.

Los reglamentos prohibían hacer "preguntas que tiendan a indagar la procedencia de los niños expuestos" (Regl de 1889, Art. 54), pero en cambio ordenaban que "al recibir un expósito la Hermana de la Caridad preguntará al que lo conduzca si está ó no bautizado. En el primer caso exigirá la partida de bautismo; en el segundo lo colocará en el sitio destinado para los no bautizados" (Regl de 1910, Art. 310 y Regl. de 1927, Art. 313) asegurándose así, al tenerlos aparte, de que todos los niños recién llegados eran acristianados. Es de suponer que en el torno no había normalmente oportunidad de semejante encuesta, en los Libros de Exposiciones, que recogen todos los datos del ingreso, raramente encontramos comentarios de la persona que depositaba al niño, no se puede saber si se anotaban en un "libro reservado" a cargo del director como dice el Reglamento de 1889 , no se ha localizado tal libro. Entre las escasas anotaciones de este tipo está la del folio no 323 de 1910 de un niño expuesto en el torno “

"En 19 septiembre de 1910 á las 15 horas y 30 minutos fue expuesto en el torno de este Asilo con un papel que dice "Este niño se Ilama Lucio Garcia nacio el dia 9 de septiembre á las 8 de la mañana y está pasado por el Registro». ...

Inscripto en el Registro Civil en 10 Septiembre de 1910

Bautizado en este Asilo en 22 Septiembre 1910...

Segun manifestación de Balbina Prieto, tia de este niño se llama Prieto de segundo apellido y nació en Castrejon y allí esta inscripto y bautizado, su madre es soltera y se llama Fortunata Garcia Prieto" [sic]

Se confirmó que el niño estaba inscrito en el R.C. pero no debía estar bautizado porque se hizo en el Hospicio tres días después de su ingreso.

En el folio no 363 del libro de 1909 de un niño que fue expuesto en el torno el 29 de octubre a las 11 horas y 45 minutos con "un papel" donde figuraban los nombres de los padres. En un margen del folio se ha escrito:

"Nota: según manifestación de la persona que le trajo al torno, es hijo natural por no estar casados los padres" [sic]

\footnotetext{
${ }^{553}$ Folio no 313. Libro de Exposiciones de 1910- 2. ADPVA
} 


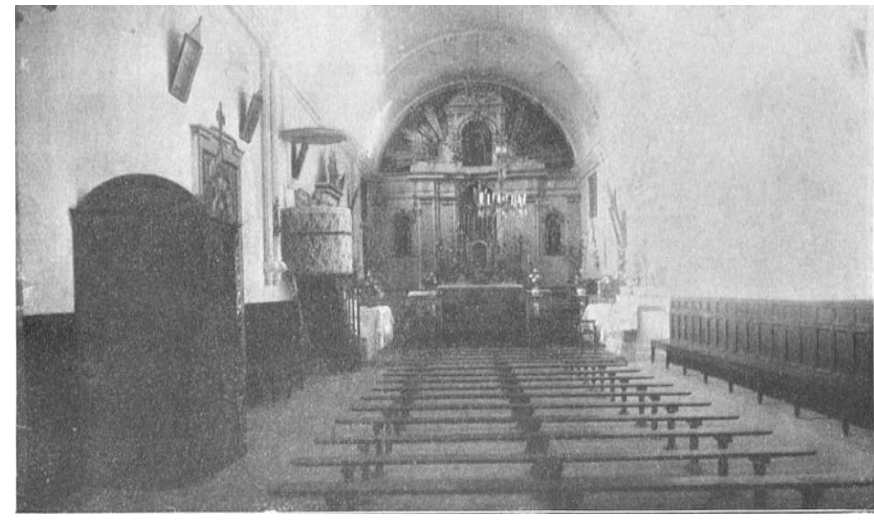

Imagen 3-22: Capilla del Hospicio Provincial. El Financiero Hispano Americano. Extraordinario Valladolid 1911, p 72
Aparte del registro propio del capellán en el libro de bautismos $^{554}$, se notificaba a la dirección el nombre de la nodriza y la fecha del bautizo en una papeleta (IMAGEN 3-9) que se guardaba en el expediente del niño y se registraban los datos en el folio correspondiente del Libro de Exposiciones. De esta manera también la dirección del centro controlaba los bautismos, "El Señor Capellán del Establecimiento, estenderá acto continuo del Bautismo la partida correspondiente en el libro de su razón, consignando en la papeleta de aviso que con aquel objeto se le hubiera pasado, el día en que haya tenido lugar y el nombre dado el expósito, cuya papeleta presentará a la Intervención para que practique las anotaciones oportunas" [sic] (Regl. 1889, Art. 51). Como cada proceso tenía su papeleta correspondiente, la anotación en los Libros de Exposiciones no se podía hacer hasta que la oficina recibía la nota correspondiente desde la Inclusa; en muchos folios la fecha y lugar del bautismo, y a veces también el nombre del ama, están escritos con distinta letra que el resto del registro de entrada, lo que hace pensar que estos datos se apuntaron más tarde; (p.ej. folios no 10 de 1900 o no 324 de 1909 de niños nacidos en la Maternidad y bautizados el mismo día; no 319 de 1909 de una niña nacida en el Hospital Provincial y bautizada en el Hospicio el mismo día del ingreso, o el no 31 de 1912 de un niño bautizado al día siguiente de su exposición en el torno). En algunos folios, no son demasiados considerando el volumen total consultado, no se han recogido estos datos y en renglones seguidos aparece escrito "Bautizado en..." y "Le lacta..." sinrellenar, ya que los dos datos iban juntos, o se perdió la papeleta o se olvidaron de registrarlos (p.ej. no 216 de 1904 o el no 14 de 1906). Da la impresión de que escribir los dos textos, a modo de plantilla, al ingreso y se rellenaban cuando llegaba la papeleta.

Es más frecuente que falte por consignar solamente la fecha de bautismo, lo que no supone que no se bautizaran los niños, es más que improbable que ocurriera algo así, dado el cuidado que ponían en ello; cabe más pensar en la pérdida de la papeleta de notificación, ya que el nombre del ama podía llegar antes a la dirección porque también se escribía en la

\footnotetext{
${ }^{554}$ Entre las obligaciones del capellán según los reglamentos estaba la de "Llevar escritas con orden y claridad las partidas sacramentales de Bautismo y las de defunción en libros formados anualmente con papel sellado de pobres, foliándolos y rubricándolos". Regl de 1910 y 1927. Capítulo V del Capellán. Art. 29, punto 4ㅇ․
} 
tarjeta de ingreso, o sencillamente en un descuido a la hora de hacer el apunte. Encontramos sin consignar el bautismo a niños nacidos en la propia Maternidad en cuyo folio se ha escrito el "Bo [bautizado] en este Asilo en..." sin la fecha (folios no 100 de 1901 o no 173 de 1904), niños fallecidos que recibirían por lo menos el agua de socorro ( $n$ o 35 de 1900) o niños expuestos en el torno sin bautizar (no 160 de 1908). La mayoría de los registros sin fecha de bautismo corresponden a niños ingresados desde la propia oficina por orden de la Comisión de la Diputación, en estos casos se daba por hecho que estaban bautizados, ya que el expediente de ingreso incluía la partida de nacimiento y bautismo, solo se anotaba en los niños que llegaban sin bautizar y se hizo en el Hospicio.

La importancia que se daba a esta cuestión se pone de manifiesto por el interés que se tomaban en comprobar si los niños expuestos habían sido bautizados.

"Si al ser expuesto en la inclusa un niño, trajese consigo alguna nota en que se hiciese constar haber sido bautizado en determinada parroquia, se reclamará de oficio la correspondiente certificación, procediéndose de nuevo á su bautismo en caso de no resultar comprobada dicha circunstancia, y consignándolo así en su respectivo expediente de ingreso" [sic] (Regl de 1910, Art. 313 y Regl. de 1927, Art. 316)

En este punto los reglamentos no hacen sino aplicar el Código de Derecho Canónico que en su canon 870 dice: "El niño expósito o que se halló abandonado, debe ser bautizado, a no ser que conste su bautismo después de una investigación diligente".

Cuando el expósito tenía una nota que indicaba que estaba bautizado o con datos que pudieran facilitar la búsqueda se hacían las diligencias oportunas. También se hacían cuando eran niños que por edad podían estar bautizados. Al menos se intentaba, como vimos en el apartado La entrada en la Inclusa (ver IMAGEN 3-7).

En el folio no 133 de 1910 se anotó la solicitud de información acerca de un expósito al párroco que escribió la nota dejada en el torno:

"Nota: Habiendose oficiado al Sr Cura párroco de Aguilar de Campos para que suministre mas antecedentes de este muchacho, en 12 de los corrientes contesto que este niño Isidoro tiene solo madre conocida de quien es hijo natural y se llama Placida Tomas de San Jose ... Bautizado e inscripto en Aguilar de Campos en 4 de Abril de 1910"1555 [sic]

En algunas notas se daban datos suficientes que podían facilitar las pesquisas. Silvino tenía 7 meses cuando fue expuesto el 24 de abril de 1910, su nota decía:

${ }^{555}$ Folio no 133. Libro de Exposiciones de 1910- 1. ADPVA 
"El niño Silvino Sendino Lopez nació el dia 12 de Septiembre y esta acristianado en la Iglesia de San Miguel y San Julian, nació el 12 de septiembre de 1909...

Bautizado e inscripto en Valladolid 14 Septiembre $1909^{\prime 1556}$ [sic]

En este caso la localización era cosa fácil y se registró

Cuando ya se conocía la parroquia correspondiente, se reclamaba de oficio el certificado de bautismo. "Remitidos antecedentes por el Sr Juez y Párroco á petición de esta Dirección ${ }^{\prime 257}$. No es habitual encontrar explicaciones en los registros de los Libros de Exposiciones, pero en ocasiones se encuentran algunas que resultan esclarecedoras, como las anotaciones del fo 216 del Libro de Exposiciones de 1909:

"En 22 de Junio de1909 á las 6 horas fue expuesto en el torno de este asilo con un papel que decía "El adjunto niño nació el dia Veintiuno de Mayo de 1909, fue bautizado y se le puso Jesus» Por ropas traía unos trapos.

De las diligencias practicadas por esta Dirección y según los libros de los dos Registros Civiles de esta capital resultó no estar inscripto ni se sabe donde fue bautizado, por cuyo motivo se dio parte al Registro Civil de la Audiencia en 23 de Junio de 1909 y se bautizó bajo condición en este Asilo en 23 de Junio 1909” [sic]

En primer lugar se comprobaba en los dos registros civiles de la capital, de los distritos de la Audiencia y de la Plaza; si el expósito estaba inscrito, por la dirección del domicilio se localizaba la parroquia. Entre los folios del libro de 1908 en el no 319 hay un trozo de papel roto que se refiere a una niña expuesta el 9 de octubre con una nota que dice tener dos meses y estar bautizada, en el papel leemos

"La niña Luciana P [incompleto, parte rota] Ver si está inscripta á principios de Agosto ultimo ó fin de Julio Si está, que dia nació y sus padres si son conocidos

En los dos Juzgados no está" [sic]

En una anotación en el folio de inscripción de la niña se dice que se presentó la madre, no consta si a requerimiento del hospicio ni en qué fecha pero parece, según está escrito, que pudo ser voluntariamente, y dio los datos de la niña

"Presentada la Madre en esta Dirección manifesto y pidio que se hiciera constar que esta niña nacio en la Maternidad de Zamora calle S. Torcuato 19 el 13 d Junio de 1918 y fue bautizada en dicho Asilo e inscripta en el Registro Civil en 14 de Junio de 1908"

En niños no inscritos en el R.C. tendrían que pedir información a las distintas parroquias de la ciudad, la mayoría de los expósitos eran nacidos en la capital, fuera de ella, en la provincia, la búsqueda resultaría mucho más difícil por la falta de medios apropiados. No

\footnotetext{
${ }^{556}$ Folio no 160. Libro de Exposiciones de 1910- 1. ADPVA

${ }^{557}$ Folio no 53. Libro de Exposiciones de 1908- 1. ADPVA
} 
parece que se buscara siempre información en los pueblos de la provincia ya que en la época este sería un trámite arduo y que se alargaría en el tiempo y encontramos niños bautizados uno o dos días después de su ingreso, tiempo que parece insuficiente para una consulta de este tipo en aquella época:

"En 11 de Abril de 1909 á las once horas fue expuesto en el torno de este Asilo envuelto en unos trapos y sin papel ni documento alguno teniendo según dictamen facultativo al parecer treinta días de edad.

Se dio parte al Registro Civil en 13 de Marzo de 1909. Bautizado en este Asilo en 12 de Abril de $1909^{\prime 558}$ [sic]

En el folio figura, tal cual se ha transcrito, que la inscripción en el registro se hizo en Marzo, es evidentemente un error puesto que se hizo desde el Hospicio y el niño ingresó el 11 de abril. Este niño sería bautizado el día 12, seguramente fue un bautizo bajo condición, aunque esto no se ha especificado en el libro.

Aún así encontramos algún caso aislado como el de Julián, nacido en La Seca

"En 9 de Marzo de 1908 á las 19 horas fue expuesto en el torno de este Establecimiento con un papel que decía «este niño se llama Julián Alvarez Mier y está bautizado"...

Se dio parte al RC en La Seca en 31 Enero 1908

Bo [bautizado] en La Seca en 31 Enero $1908^{\prime \prime 559}$ [sic]

Lograron localizar al niño fuera de la capital sólo con el nombre, probablemente manejaron datos que no constan en el Libro.

Cuando un niño podía estar bautizado pero no se conseguía demostrar, se le bautizaba "bajo condición" en el Hospicio y se registraba, aunque no solía indicarse el carácter condicional del bautismo. Expuesta en el torno a las 23 horas 30 minutos del 27 de junio con una nota que decía: "La niña está acristianada y por nombre se llama María Angeles", fue "Ba [bautizada] en este Asilo sub conditione en 28 de junio de 1904"560. El niño Gonzalo Mena, encontrado en la puerta del Hospicio con una nota que decía que estaba bautizado y una edad estimada de mes y medio, fue bautizado condicionalmente 8 días después de su ingreso, por el tiempo transcurrido puede que se hicieran las correspondientes indagaciones sin éxito. El bautismo "bajo condición" está registrado en su folio ( $n$ ㅇ 269 de 1911) y la nota del capellán en su expediente personal, "Bauticé hoy 12 de Agosto de 1911 condicionalmente a Gonzalo Mena

\footnotetext{
${ }^{558}$ Folio no 137. Libro de Exposiciones de 1909. ADPVA

559 Folio 76. Libro de Exposiciones de 1908, 10 tomo. ADPVA

${ }^{560}$ Folio no 210. Libro de Exposiciones de 1904. ADPVA
} 
[firmado] Agustín Samaniego [el capellán]. También se encuentra registrado en el Libro IX de los bautizados en el Hospicio de esta capital.

Se bautizaban también condicionalmente niños que según las notas del torno habían recibido el bautismo de socorro. Es normal este proceder, se hace por si acaso no se hubiera administrado el bautismo de urgencia correctamente, simplemente con no decir la fórmula completa y exacta el sacramento ya no es válido.

"El 23 de febrero de 1909 á las 15 horas fue expuesto en el torno de este Asilo con un papel que decía: "Nació este niño el dia 30 de Enero de 1909. Se le bautizo secretamente el dia 3 de febrero de 1909 se llama Jose Martin Cerrera de La Fuente; cuídesele que la casa no lo perderá si es posible que no salga fuera»...

Bautizado en este Asilo bajo condición en 23 de Febrero 1909" ${ }^{\prime 561}$ [sic]

Muchos de los niños que según la nota del torno estaban bautizados recibían el bautismo en el Asilo, no podemos saber si en todos los casos se hacían las indagaciones oportunas o simplemente en el libro no se registraba que se hacía bajo condición. La niña del folio no 132 del Libro de 1901 ingresó con 5 meses y la nota dice que estaba bautizada, pero se la bautiza en el asilo, se supone que bajo condición por la edad, aunque no figura.

"En 20 de abril de 1901 y hora de las 21 y treinta minutos fue expuesta en el torno de este Asilo con... un papelito que dice Juana Gregoria Fernandez nacio el 24 de Noviembre de 1900 esta bautizada Ba en este Asilo en 25 de Abril de 1901" [sic]

Prácticamente casi todos los niños que entraban por la oficina, a través de la Diputación o enviados desde algún pueblo, llegaban bautizados. En la capilla del Hospicio se bautizaba a todos los niños nacidos en la Maternidad del Hospicio y a los que enviaban desde el Hospital Provincial o el Manicomio, que alguno hay, y a los expuestos en el torno propio, que en su mayoría llegaban sin bautizar. La mitad de los niños ingresados se bautizaron en el Hospicio en los años consultados (el 50’01\%), de ellos casi la mitad eran expósitos (el 47’32\%), el resto, salvo casos contados, de la Maternidad y el Hospital. La mayoría de los niños del torno (el 70’31\%) recibieron el bautismo, en su fórmula solemne o bajo condición, en el asilo. Algunos niños eran bautizados el mismo día de su ingreso, pero son los menos pues normalmente no ocurría así. Comprobando en los libros las fechas de ingreso y de bautismo puede verse que éste podía retrasarse varios días, incluso en casos en que se sabía con toda seguridad que el niño no estaba bautizado; lo que resulta un tanto chocante habida cuenta de

${ }^{561}$ Folio no 80. Libro de Exposiciones de 1909. ADPVA 
la gran importancia que daban al bautismo, de que es una ceremonia breve y de que los reglamentos sugerían hacerlo pronto. Además, el capellán habitaba en el Hospicio, en los reglamentos de 1889 a 1927 no se dice nada al respecto, pero en las primeras ordenanzas de la Real Casa de Misericordia de 1806 se dice que "ha de vivir dentro de la Casa" (Art. 42). El capellán tenía aposentos propios en el Hospicio; en unas cartas encontradas en la carpeta Correspondencia de acogida de menores $^{562}$, el Director Justo Esteban se dirige al Vicepresidente de la Comisión de la Diputación provincial el 19 de febrero y el 30 de octubre de 1902 a propósito de arreglos en las habitaciones del capellán y de la dirección del Hospicio:

"Tengo el honor de poner en conocimiento de V. S. que al hacerme cargo de la habitación que ocupaba el que fue capellán de este establecimiento $D^{n}$ Narciso Bueno..." [sic]

"Tengo el honor de manifestar a V. S. que habiéndose blanqueado la habitación que ocupa el Sr. Capellán de este Establecimiento..." [sic]

Y en 1929 vuelven a realizarse obras en las habitaciones del capellán aprobadas en sesión de la Comisión provincial ${ }^{563}$

En general los niños no eran bautizados de forma inmediata, a veces el bautismo se retrasaba hasta 8- 11 días desde su ingreso, incluso en niños nacidos en la maternidad del Hospicio, y era frecuente bautizar varios niños a la vez, aunque no parece que el motivo del retraso fuera juntarlos porque también se bautizaban niños en solitario y en días casi seguidos. Tampoco se esperaba al domingo, día preferido por la Iglesia para celebrar los bautizos, se hacían con más frecuencia en días de diario ${ }^{564}$. Analizando la secuencia de fechas que aparecen en los registros no se observa una pauta establecida para bautizar, ni en cuanto al número de niños, ni a los días de la semana. Más bien da la impresión de que se celebraban los bautizos uno, dos o tres días a la semana, según la actividad del capellán o de la Inclusa, podía ser cualquier día y se bautizaban los niños que lo precisaran hasta ese momento (ver TABLA 3$16)^{565}$. Hay niños bautizados el mismo día de su ingreso, los menos, como ocurre en los de los

\footnotetext{
562 Signatura: caja 2449, expediente 30481. ADPVA

${ }^{563}$ N C. 27 junio 1929, p 3

564 Código de Derecho Canónico. Título I del Bautismo, canon 856: "Aunque el bautismo puede celebrarse cualquier día, es sin embargo aconsejable que, de ordinario, se administre el domingo o, si es posible, en la vigilia Pascual".

565 TABLA 4- 18: Tomando un año como puede ser 1904 encontramos algunos días en que se bautizó casi a diario y un solo niño (27, 28 y 31 de enero y 1 de febrero), pero en general se juntaban varios niños, sin que se vea una norma concreta en cuanto a fechas ni al número de niños (el 8 de febrero 5 niños, el 10 de febrero 4 niños, el 19 de febrero 4 niños, el 23 de febrero 3 niños, el 26 de febrero 4 niños, el 29 de febrero 2 niños). En la tabla se recogen el número de niños bautizados $\left(B^{\mathrm{s}}\right.$ ) en dos meses de diferentes años $(1904,1909$ y 1913). He recogido también el día de la semana para comprobar si existían días concretos para los bautizos, pero puede verse que tampoco esto es relevante ya que se bautizaba cualquier día incluso en domingo
} 
folios 285 y 287 de 1909 que nacieron en la maternidad el 14 de agosto a las 10'30 h. y las 17 horas respectivamente y fueron bautizados solamente ellos dos ese mismo día ${ }^{566}$; otros podían tener varios días de vida, para recibir el bautismo no parece que se tuviera en cuenta la edad sino que dependía de la fecha de ingreso y del día establecido para bautizar, normalmente no pasaban más de ocho días desde la entrada en la Inclusa. La niña Obdulia ingresó con diez días de vida y la bautizaron tres días después. Amelia nació en el Hospital Provincial, ingresó con tres días de vida y fue bautizada cuando contaba con once días; Leonor también nació en el Hospital Provincial e ingresó con tres días y fue bautizada con ocho días. No parece por tanto que para bautizar la edad fuera un criterio, sino que iba por orden de ingreso ${ }^{567}$.

\begin{tabular}{|c|c|c|c|c|c|c|c|c|c|c|c|c|c|c|c|c|c|}
\hline \multicolumn{6}{|c|}{1904} & \multicolumn{6}{|c|}{1909} & \multicolumn{6}{|c|}{1913} \\
\hline \multicolumn{3}{|c|}{ FEBRERO } & \multicolumn{3}{|c|}{ MARZO } & \multicolumn{3}{|c|}{ AGOSTO } & \multicolumn{3}{|c|}{ SEPTIEMBRE } & \multicolumn{3}{|c|}{ ENERO } & \multicolumn{3}{|c|}{ FEBRERO } \\
\hline \multicolumn{2}{|c|}{ DÍA } & \multirow{2}{*}{$\begin{array}{c}\mathbf{B}^{\mathbf{o}^{5}} \\
1\end{array}$} & \multicolumn{2}{|c|}{ DÍA } & \multirow{2}{*}{$\frac{\mathbf{B}^{\mathrm{S}}}{1}$} & \multicolumn{2}{|c|}{ DíA } & \multirow{2}{*}{$\frac{\mathbf{B}^{\mathbf{S}^{\mathrm{S}}}}{5}$} & \multicolumn{2}{|c|}{ DÍA } & \multirow{2}{*}{$\begin{array}{c}\mathrm{B}^{\mathbf{o}^{5}} \\
1\end{array}$} & \multicolumn{2}{|l|}{ DíA } & \multirow{2}{*}{$\frac{B^{0^{S}}}{2}$} & \multicolumn{2}{|l|}{ DÍA } & \multirow{2}{*}{$\begin{array}{c}\mathbf{B} \underline{5}^{\mathrm{S}} \\
3\end{array}$} \\
\hline 1 & LN & & 1 & MT & & 11 & $\mathrm{MC}$ & & 3 & VN & & 11 & SB & & 3 & LN & \\
\hline 3 & $\mathrm{MC}$ & 2 & 3 & $\mathrm{JV}$ & 1 & 14 & SB & 2 & 7 & MT & 4 & 18 & SB & 2 & 5 & $\mathrm{MC}$ & 2 \\
\hline 8 & LN & 5 & 10 & $\mathrm{JV}$ & 2 & 17 & MT & 1 & 9 & $J V$ & 1 & 24 & VN & 1 & 8 & SB & 3 \\
\hline 10 & $M C$ & 4 & 12 & SB & 1 & 20 & VN & 1 & 11 & $S B$ & 1 & 25 & SB & 2 & 12 & $M C$ & 1 \\
\hline 19 & VN & 4 & 14 & $\mathrm{LN}$ & 2 & 25 & $\mathrm{MC}$ & 3 & 15 & MC & 3 & 27 & $\mathrm{LN}$ & 2 & 14 & VN & 3 \\
\hline 23 & MT & 3 & 18 & $\mathrm{VN}$ & 1 & 26 & $\mathrm{JV}$ & 1 & 18 & SB & 4 & 30 & $\mathrm{JV}$ & 2 & 17 & LN & 1 \\
\hline 26 & VN & 4 & 22 & MT & 4 & 29 & DG & 2 & 26 & DG & 3 & & & & 19 & $\mathrm{MC}$ & 4 \\
\hline 29 & LN & 2 & 26 & SB & 1 & & & & 29 & MC & 3 & & & & 21 & $\mathrm{VN}$ & 1 \\
\hline & & & 28 & LN & 1 & & & & & & & & & & & & \\
\hline
\end{tabular}

TABLA 3- 20: № de niños bautizados ( $\left(\mathrm{B}^{\mathrm{s}}\right)$ cada día en los meses seleccionados. En DíA: fecha y día de la semana (LN lunes, MT martes, MC miércoles, JV jueves, VN viernes, SB sábado y DG domingo). Elaboración propia

Los niños que ingresaban en mal estado eran bautizados de forma más inmediata, en el mismo día o al día siguiente, dice el reglamento que se debía avisar de urgencia al capellán si al ingreso lo precisaran (Art. 48, Regl de 1889)

"En 23 de Diciembre de 1901 a las diez y nueve horas y treinta minutos de él, la dio a luz la refugiada en este Asilo... Ba en este Asilo en el 24 Diciembre 1901. Falleció en este Asilo el 24 Diciembre 1901 a consecuencia de desarrollo orgánico" [sic]

\section{"Inocencio San José}

En 28 de Diciembre del 1901 a las cinco dio a luz la refugiada en este Asilo...

$B \underline{a}$ en este Asilo en el 28 Diciembre de 1901.

Se dio parte al R. C. en 29 de Diciembre de 1901.

Falleció en este Asilo el 28 Diciembre 1901 á las veintitrés horas a consecuencia de Espasmo generalizado" [sic]

Son dos niños que apenas vivieron unas horas, fueron bautizados en solitario, están registrados en los Folios 385 y 387del Libro de 1901.

\footnotetext{
${ }^{566}$ Libro de Exposiciones de 1909- 2. ADPVA

567 Libro de Exposiciones de 1909- 2. Expediente Personal. Exposición 1911. Folio 229. ADPVA
} 
Si no se encontraba el capellán, el niño recibía el agua de socorro. "En 22 de Julio de 1904 a las veintidós horas a y treinta minutos, fue expuesto en el torno cuna" un niño que según la nota acompañante nació a las 7 de la tarde y que fallecería unas horas después "a las veinticuatro horas a consecuencia de una congestión cerebral"; fue " $B$ o [bautizado] en [el] Asilo recibiendo agua de socorro" (Libro 1904, fo 238).

En cuanto a los registrados como "niños muertos", fallecidos en la maternidad, solamente en el fo 148 del libro de Exposiciones de 1904 consta que se diera "agua de socorro", por lo que podemos sospechar que nacería con vida y pudo fallecer inmediatamente, aunque el registro es contradictorio

\section{"Niño muerto}

En el dia diez de mayo de 1904 y hora la una y media de la madrugada le dio a luz Maria Tejedor refugiada en este Maternidad, recibió agua de socorro y falleció

Falleció en este Asilo a la una y 30 minutos por nacer sin vida según el parte facultativo" [sic]

En ninguno de los demás registros de los Libros de Exposiciones pone nada del bautismo, podríamos suponer que nacieron muertos, sin embargo en el Libro de la Inclusa de 1902 en el registro del 17 de Abril se lee "Folio 137 nació en el SG (Sala General de la Maternidad) un niño que recibió agua de socorro y murió enseguida", en el libro oficial en su folio no dice nada, no olvidemos que la Inclusa la llevaban las Hermanas de la Caridad, que serían mucho más cuidadosas con ese asunto que el auxiliar de la oficina encargado de hacer los asientos en los libros.

Me ha llamado la atención que en los libros de los primeros años no se llevaban con tanto rigor las anotaciones sobre el bautismo, en muchos folios no se completó bien el registro y, o no se escribió nada, o aparece el "Bautizado en este Asilo en..." y falta la fecha, como si esta línea se escribiera sistemáticamente a modo de plantilla al registrar el ingreso y se rellenara después cuando llegara a la dirección la papeleta correspondiente con la fecha. Vuelvo a recordar que la calidad de las anotaciones es muy variable en cuanto al detalle y a la exactitud de los datos registrados, según quien hiciera el registro. En todos los libros se encuentran errores y registros incompletos, pero hay años como 1904 que destaca en este sentido.

De todos modos, para esta circunstancia, siempre se podía echar mano de los libros de Bautismo del capellán. Estos libros se encuentran hoy en la que era la parroquia del Hospicio, 
la iglesia de San Nicolás de Bari, situada haciendo esquina con el asilo en la misma plaza de la Trinidad, allí pasaron, según me han comentado en la propia iglesia, al desaparecer el Hospicio. Estos libros son muy escuetos en la información que recogen, nada que ver con las partidas bautismales normales en las que se recogen todo tipo de detalles. En los folios de los libros está impresa una plantilla para rellenar, hay 3 inscripciones en cada página, en ella se recoge simplemente la fecha del bautismo, el nombre del niño y de su madrina y el folio que ocupa en el Libro de Exposiciones. En el reverso del folio número 157 del "Libro IX de los bautizados en el Hospicio de esta capital", que recoge los bautizos desde el 24 de diciembre de 1985 hasta mayo de 1912 en 598 folios, está el primer bautizado de los ingresados en 1900, (en negrita la parte manuscrita), en este libro ni siquiera se reflejaba el tipo de bautismo

"En el Hospicio Provincial perteneciente á la Parroquia de S. Nicolás de esta Ciudad de Valladolid á... tres de Enero de mil nuevecientos... bauticé á... Manuel Aniceto San José ... que es de las criaturas de Niños Expósitos de dicha Ciudad y Provincia.

Está escrito en el libro de entradas del Hospicio Provincial al folio... 1 ... Fue su madrina ... Petra Maderal ... y lo firmo.

(firma) Narciso Bueno"

Don Narciso Bueno fue el capellán del hospicio hasta febrero de 1902, le sucedió Braulio de Matas y a partir de enero de 1904 Agustín Samaniego Pérez, que continuaba en el puesto en 1936. Aparece su firma en las papeletas de bautismo encontradas en los expedientes desde 1905 hasta 1912 (no hay anteriores) y le descubrimos también firmando como director accidental en 1905 (IMAGEN 3-23) encontraba ausente el director, como lo indicaban los reglamentos (Art. no 3, Regl. 1910 y 1927).Cuando faltaba el capellán le sustituía el párroco de San Nicolás, Teodoro Lefler González, que parece más meticuloso en el registro, haciendo constar el tipo de bautismo oficiado, que no diferenciaban los capellanes del Hospicio.

"En el Hospicio Provincial perteneciente á la Parroquia de S. Nicolás de esta Ciudad de Valladolid á .. veinticinco de Octubre de mil novecientos tres suplí las ceremonias .. bauticé á .. del bautismo solemne á Manuel San José Prado .. que es de las criaturas de Niños Expósitos de dicha Ciudad y Provincia y al que se le había administrado agua de socorro.

Está escrito en el libro de entradas del Hospicio Provincial al folio .. 363 .. Fue su madrina .. Petra Maderal .. y lo firmo, como Párroco de referida Iglesia- Lo tachado no vale- (firma) Dr. Teodoro Lefler González"

\footnotetext{
${ }^{568}$ Expediente Personal. Exposición 1905. Folio 158. Signatura: caja 2199, expediente 21740. ADPVA
} 


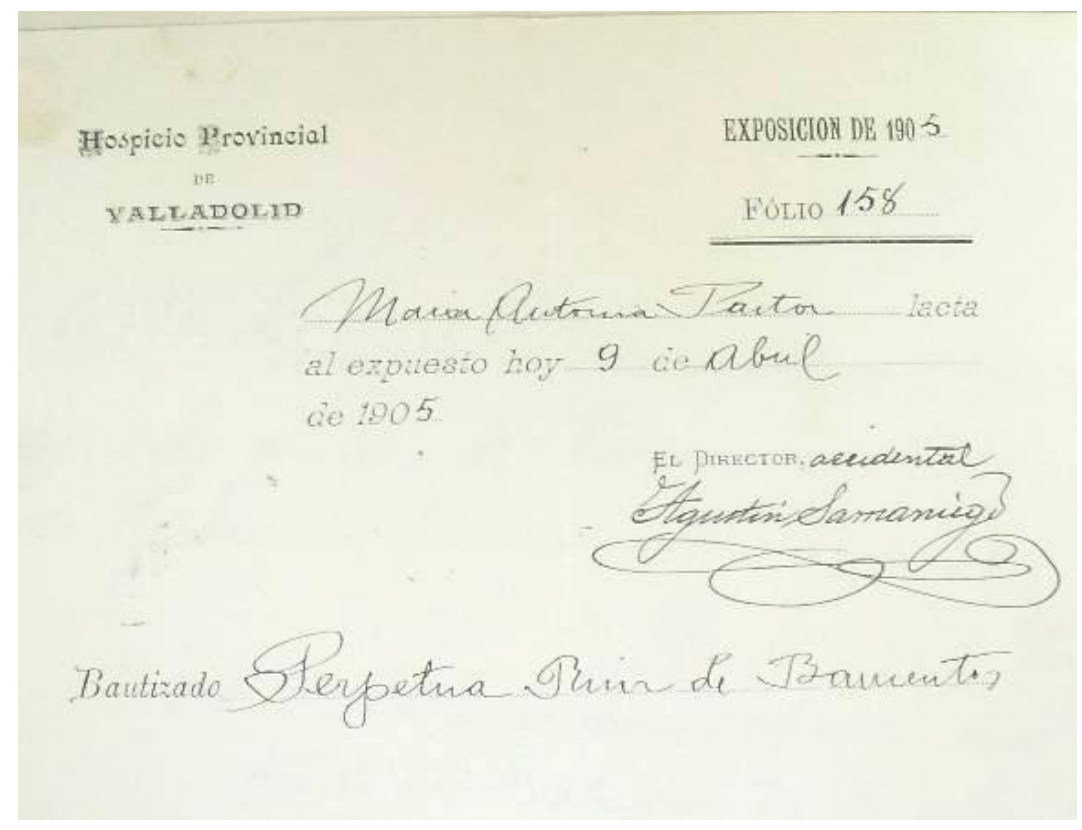

Imagen 3-23: Papeleta con la firma del capellán como director en funciones. Expediente Personal. Exposición 1905. Folio 158. ADPVA

En el folio de inscripción del niño tampoco se recoge que recibiera el agua de socorro, nació el mismo día 25 en la maternidad del asilo y falleció el día 27 por una gastrorragia, hemorragia digestiva.

No he encontrado ningún documento que haga referencia a la celebración del bautismo en el Hospicio, podemos suponer que sería una ceremonia rutinaria, tan diferente de las celebraciones populares como lo eran los registros. Antes de consultar los libros de bautismos me cuestionaba quiénes podrían ser los padrinos, teniendo en cuenta el significado que tienen para la Iglesia, pues no aparecen registrados en los Libros de Exposiciones, llegué a pensar que no tuvieran pues según el Derecho Canónico no son imprescindibles, aunque si convenientes ${ }^{569}$. En la cita anterior vemos que tenían asignada una madrina, siempre mujer, en la plantilla de la inscripción así lo contempla, y comprobamos en los libros bautismales que durante años fue la misma, probablemente se tratara de una Hija de la Caridad, que bien podía ser la responsable de la capilla. Petra Mayoral figura como madrina de todos los niños bautizados en el orfanato del libro noveno, que empieza en 1895, y sigue en el décimo hasta enero de 1915, la sustituyó María Sánchez que sigue figurando en el "Libro undécimo ..." hasta

\footnotetext{
569 Derecho Canónico. El sacramento del bautismo. Canon 872: "En la medida de lo posible, a quien va a recibir el bautismo se le ha de dar un padrino, cuya función es ... juntamente con los padres, presentar al niño que va a recibir el bautismo y procurar que después lleve una vida cristiana congruente con el bautismo y cumpla fielmente las obligaciones inherentes al mismo". Canon 873: "Téngase un solo padrino o una sola madrina, o uno y una ... elegido por quien va a bautizarse o por sus padres o por quienes ocupan su lugar o, faltando éstos, por el párroco o ministro; y que tenga capacidad para esta misión e intención de desempeñarla"
} 
mayo de 1920. En éste libro cambia el formato de la plantilla de registro y se amplía con más datos, entre otros el tipo de bautismo celebrado, nombres de los padres y de dos testigos, que también serían las mismas mujeres durante unos meses

\begin{abstract}
."En el Hospicio Provincial de esta Ciudad de Valladolid, Arzobispado de la misma, que pertenece á la Parroquia de S. Nicolás de Bari, á ... uno de Marzo .. de mil novecientos .. veinte ... bauticé ... solemnemente .. un ... niño ...á quien puse el nombre de.. Román Deusto Isbert... hijo de... padres desconocidos.

Está inscripto en el libro de entradas del referido establecimiento al folio .. setenta y siete .. donde se detallan las circunstancias que acompañaron á la presentación ... del niño ...expresado

Fué su madrina .. María Sánchez.. a quién advertí el parentesco espiritual y obligaciones contraídas; habiendo sido testigos ... Natividad Hernández y Manuela Alvarez .. Y a los efectos que procedan autorizo la presente partida, como ... Capellán del mismo
\end{abstract}

Fecha et supra (firma) Agustín Samaniego Pérez ${ }^{\prime 2570}$

De forma esporádica el director del Hospicio y su esposa apadrinaban algún niño, en el folio 118 del libro de 1902 hay una anotación al margen que casi no se lee porque ha quedado medio oculta al encuadernar, se entiende que fueron padrinos de este niño el director del establecimiento Dn Justo Esteban Martín y la Sạ Dạ Conrada, "según rito"; en el libro de la Inclusa se puede leer "se le bautizo en este Establecimiento el 29 de Marzo 1902 con el nombre de Luciano Justo y Conrado Neches, Justo y Conrado se le han puesto los padrinos que son el $S^{r}$ Director y su Señora". También la niña María Manuela Alba, que nació en la Maternidad del asilo tuvo por "padrinos a Dn Justo Esteban el director del Hospicio y su esposa Da Conrada Cebrian", lo dice en el libro de la Inclusa, el libro oficial en su folio el 164 de 1907 no lo menciona. Los dos fallecieron, así que no pudieron beneficiarse de ser ahijados del director, si es que realmente podía suponer alguna ventaja.

Aparte del bautismo, se celebraba el sacramento de la Confirmación en la parroquia de San Nicolás de Bari; se confirmaba a todos los niños de cualquier edad que en ese momento se encontraran en el Hospicio. La Confirmación no se registraba en los Libros de Exposiciones, solamente lo vemos en los de la Inclusa, recordamos que estaban a cargo de las Hijas de la Caridad, también anotaban si el niño estaba confirmado al ingreso, como Adrián de 6 años (fo 35 de 1909). En ellos podemos comprobar cómo niños de muy pocos días, algunos recién bautizados se confirmaban, todos en la misma fecha, pues suelen ser ceremonias en grupo

\footnotetext{
${ }^{570}$ Folio no 31 del Libro undécimo de los bautizados del Hospicio de esta Capital. Parroquia de San Nicolás de Bari. Valladolid.
} 
oficiadas por el Obispo de la diócesis. La primera ceremonia que encontramos registrada se celebró el 20 de junio de 1907 entre los confirmados estaban los niños ingresados el día anterior como Martín Lorenzo que fue bautizado en la capilla del Hospicio el mismo día 20 y luego confirmado en San Nicolás de Bari (fo 201). El 17 de mayo de 1910 es la siguiente ceremonia registrada, se confirmaron 51 niños de la Inclusa, entre ellos había ingresados en 1909 y en 1910 hasta ese día, el más pequeño nació en la Maternidad el día 14 y estaba recién bautizado. Parece que llevaban a todos los internos a la parroquia de San Nicolás, incluso los enfermos, Juliana de 4 meses falleció el mismo día "á consecuencia de nefritis" 571 , y Bernardino, que tenía 3 meses falleció 3 días después, el diagnóstico es ilegible, puede poner de indigestión, y a los cinco días fallecían Josefa "á consecuencia de catarro intestinal" y Juan "de atrepsia", también de 3 meses los dos ${ }^{572}$. La Confirmación es para la iglesia la prolongación del Bautismo, junto a éste y la Eucaristía se considera un sacramento de iniciación que supone la integración plena en la comunidad católica; la iglesia oriental lo sigue celebrando como en los primeros siglos del cristianismo inmediatamente después del bautismo, pero la iglesia romana prefiere administrarlo cuando el confirmando tenga "uso de razón", no obstante, si existe peligro de muerte dice que se debe hacer en cualquier momento aunque no se haya alcanzado ${ }^{573}$.

Puede decirse que la atención espiritual formaba parte de los cuidados que la Inclusa brindaba a sus asilados, a cargo del Capellán y de las Hijas de la Caridad, y en particular el Bautismo era considerado un deber inexcusable y rutinario que se realizaba con un protocolo sencillo que guardaba las formas básicas del rito. Normalmente se respetaba el nombre propuesto en las notas del torno.

\footnotetext{
${ }^{571}$ Folio no 51 de 1910, nació el 21 de enero de 1910, ingresó el 12 de febrero y le confirmaron y falleció el 17 de mayo.

${ }^{572}$ Folios no 141, 107 y 109 de 1907 respectivamente.

${ }^{573}$ Sacramento de la Confirmación. Catecismo de la Iglesia Católica. Disponible en:

http://www.vatican.va/archive/catechism_sp/p2s2c1a2_sp.html
} 


\subsubsection{ALIMENTACIÓN EN LA INCLUSA:}

La Casa o Departamento de Expósitos del Hospicio Provincial de Valladolid, también Ilamado La Cuna o Inclusa comprendía a su vez dos departamentos, el de Lactancia o Inclusa, para los infantes hasta los 18 meses, y el de los Menores de 7 años o de Destete; por tanto, como ya se ha dicho, era la forma de alimentación la que condicionaba la pertenencia a uno u otro departamento.

Ya hemos comentado como la alimentación de los incluseros fue una de las cuestiones criticadas y denunciadas muchas veces "Según nuestros informes, aún cuando se ha tratado de guardar absoluta reserva, se ha tomado declaración a alguna respetable persona que ocupa cargo en el establecimiento. Cada vez se confirma más la alimentación deficiente y mala que se da a los asilados"574. El problema no solamente era la escasez de presupuesto, "El señor gobernador presenció el repeso y examen de la carne y otros artículos de alimentación y, según nuestras noticias, ha impuesto una multa a algún abastecedor, por la mala calidad de lo que suministraba" ${ }^{575}$, incluso algún diputado provincial tenía intereses como contratista y se vio involucrado "Los garbanzos del Hospicio "tienen gorgojos», suministrados por un diputado, el Sr Carnicer" ${ }^{576}$, que era el Visitador del Hospicio, y por tanto el que ejercía el control por parte de la Diputación, y que se vio envuelto en otro escándalo el mismo año por una venta fraudulenta de azulejos también al Hospicio en la que actuó como intermediario ${ }^{577}$. No obstante, al final del periodo estudiado parece que mejoró algo la alimentación, “El presidente da lectura a una nota enviada por la superiora del Hospicio, en la que se detalla la comida dada a los asilados, congratulándose la Diputación del excelente trato que reciben los niños" ${ }^{578}$, claro que esto hay que tomarlo con cierta reserva porque es la propia Diputación la que hace esta declaración, lo que sí es un hecho objetivo es que en el intervalo entre las dos declaraciones se redujo la mortalidad de los incluseros y la alimentación también contribuiría a ello. Un optimismo un tanto exagerado respecto a las condiciones de los hospicianos demuestra también un artículo que publica El Norte de Castilla sobre los hospicios: "en general, los niños asilados comen mejor, duermen con más comodidad y disfrutan de mayor higiene que la

\footnotetext{
${ }^{574}$ N.C. 6- 01- 1901

${ }^{575}$ N.C. 5- 08- 1901

${ }^{576}$ N.C. 1- 08- 1908, p 2. Se plantea la polémica sobre si los diputados podían ser contratistas ya que éste mismo diputado, que era el que tenía el cargo de Visitador del Hospicio y por tanto de llevar el control se vio envuelto en otro escándalo por una compra también fraudulenta de azulejos para un baño en la que fue vendedor y comprador. N.C. 19- 07- 1908

${ }^{577}$ PASTRANA H.: op. cit., pp 167-8

${ }^{578}$ N.C. 28- 02- 1929
} 
mayoría de los niños de familias menestrales" ${ }^{579}$, en muchos casos sería verdad, pero no todo por mérito de los establecimientos sino por las condiciones sociales externas

\title{
3.4.2.1. Lactancia maternay lactancia mercenaria
}

\author{
"El parúr embellece y el crúar \\ envejece" \\ Refrán popular
}

Estudiamos una época en la que se conocían suficientemente los riesgos que suponía alimentar a los recién nacidos y lactantes de más corta edad con leche de origen animal, y en la que ya se había empezado, desde la segunda mitad del siglo XIX, a modificar estas leches naturales y elaborar fórmulas más adecuadas para la alimentación en los primeros meses de vida. Sin embargo, este sistema de alimentación, que conocemos como lactancia artificial y que hubiera servido para evitar muchos de los problemas de las inclusas y a reducir su tremenda mortalidad, en las primeras décadas del siglo XX todavía carecía de suficientes garantías, tanto por los tipos de leche disponibles y su composición, como sobre todo por las condiciones higiénicas de todo el proceso, desde la elaboración de la leche hasta la administración a los bebés. Por ello, por una cuestión de supervivencia, la lactancia natural, la que se hace con leche de nuestra propia especie, siempre se ha considerado la forma más ventajosa y preferida para alimentar a los lactantes en todas las épocas y lugares, también en las inclusas, donde la dificultad para hacerla con niños que han sido abandonados es evidente.

La Inclusa Provincial de Valladolid, denominada Departamento de Expósitos en los primeros reglamentos del Hospicio de 1806 (Ordenanzas para el gobierno y dirección de la Real Casa de Misericordia y Expósitos de la Ciudad de Valladolid), pasó a llamarse Departamento de Lactancia en el Reglamento de 1889, en el que se establecía como su primer y principal objetivo "proporcionar la lactancia á los niños expósitos" (Art. 39) Después de su ingreso, se presentaba el expósito "al Facultativo correspondiente para que éste disponga lo que crea conveniente con relación á su lactancia" (Art. 46) y la nodriza que se encontrara "en turno"

\footnotetext{
${ }^{579}$ N.C. 21- 10- 1913
} 
debía encargarse de la criatura recién llegada "alimentándola con algún jarabe provisionalmente, ó lactándola según lo ordene el Facultativo" (Art. 39).

Conocidos y reconocidos los riesgos de la lactancia artificial, la Inclusa Provincial de Valladolid, como se hacía en las demás inclusas, daba prioridad a la lactancia natural y a la crianza de los expósitos fuera del establecimiento; aunque no lo dice expresamente se sobreentiende en sus reglamentos cuando dicen que "para atender a la lactancia de los niños en la Inclusa habrá el correspondiente número de nodrizas".

Sorprende, entre los artículos del Reglamento de 1889, uno relacionado con las costumbres de la época respecto a la lactancia materna y que nos da a entender que debía ser una práctica habitual en la Inclusa la de sacar a los expósitos a casas privadas y utilizarlos para vaciar los pechos de las mujeres recién paridas.

"Articulo 62. Siendo peligroso para la salud de los niños el descargar los pechos a las paridas, la Superiora no permitirá que se saque ninguno con dicho objeto"

Este artículo ya no se encuentra en los reglamentos posteriores, por lo que podemos pensar que esta actividad se erradicó o, como ocurre con otros artículos suprimidos, que la prohibición se daba por supuesta. Esta práctica tiene que ver con la creencia, entonces mantenida, de que el calostro, la leche de los primeros días de lactancia, era perjudicial para los niños; uno de tantos mitos que han rodeado y siguen rodeando el tema de la lactancia, incluso algunos médicos decían que no es una verdadera leche ${ }^{580}$. Se recomendaba no dar el pecho el primer día, se decía que el recién nacido no necesitaba comer y, que mientras tanto, la madre debía recuperarse descansando y tomando sus correspondientes caldos de gallina. Había que buscar remedios para el llanto de los pequeños hambrientos, los médicos aconsejaban pequeñas cantidades de agua hervida azucarada, o en su lugar de manzanilla o té, y debía ser usual que dieran de beber a los niños en exceso, o al menos de ello se quejaban en los manuales; a nivel popular se utilizaban según costumbres otros remedios como agua de anises, caldo o incluso agua con vino y chupetes hechos con una tela rellena de pan azucarado o de bizcocho. Para evitar al bebé el peligro de los calostros, se utilizaban estos remedios o se recurría a ponerle a mamar de otra mujer que llevara lactando más tiempo hasta que a su madre le subiera la leche de verdad, a esta nodriza temporal se la llamaba en algunas zonas de Castilla tetera ${ }^{581}$. El problema que plantea esta práctica es que si el niño no mama y no descarga los pechos de la madre, por una parte esta va a sufrir molestias importantes debido

\footnotetext{
${ }^{580}$ BOIX BARRIOS J.: op. cit., p 62

${ }^{581}$ CARRIL A.: Etnomedicina Popular., p 109. Son prácticas que el Profesor Rafael Ramos prohíbe en su manual, Ramos R., Puericultura: higiene, educación y alimentación en la segunda infancia (niños de tres a siete años). Tomo II". Salamanca 1938 , p 113
} 
al acúmulo y retención de leche, que puede incluso llegar a provocar mastitis y por otra puede causar la retirada de la leche, lo que explica esa necesidad de vaciar los pechos de la madre que no está lactando utilizando a los pobres expósitos como sacaleches. Esta práctica de utilizar a los bebés de la Inclusa sin duda es moralmente reprobable porque lo hacían a sabiendas, aunque fuera equivocadamente, de que podría perjudicarles; sin embargo, sin esta consideración ética, podría hasta haber resultado beneficiosa a algún niño ya que sería un suplemento alimenticio, siempre que luego en el Hospicio comiera lo que le correspondía pues el calostro se produce en cantidades que pueden ser muy limitadas los primeros días, y sobre todo por el alto valor inmunológico que tiene que hace que hoy no solo no se desprecie, sino que por estas características se le considere la mejor leche que puede recibir el recién nacido los primeros días de vida. Las entrevistas realizadas nos pueden ofrecer información complementaria sobre los cuidados de los niños fuera del establecimiento, necesaria porque sobre el Hospicio la que tenemos es muy limitada y válida porque, siendo las nodrizas y cuidadoras del Hospicio mujeres de extracción social baja, los cuidados serían muy similares, aún cuando suponemos que en ciertos aspectos corregidos por el control de monjas y médicos. Pues bien, en esas entrevistas hemos encontrado otras soluciones a este problema mucho más éticas, aunque sorprendentes

"Una cosa que contaba mi madre es que como no había mamantonas para sacar la leche a las mujeres que se les morían los niños, había un hombre que se lo sacaba. Mamaba suave y decía que, cuando la leche era salada es que era de fulana. E incluso, otras veces, se las ponía un perrillo para que se lo sacara"1582
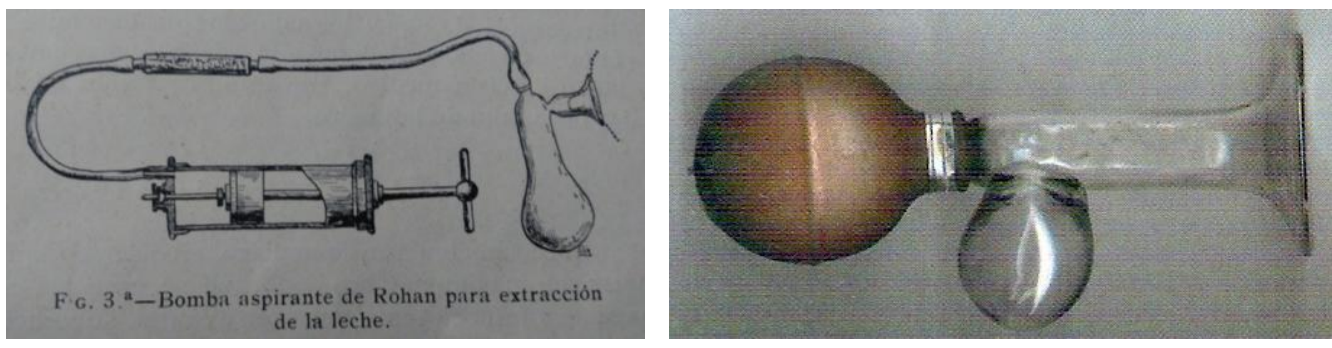

Imagen 3-24: A la izquierda sacaleches. Fuente: SUÑER E. Enfermedades de la Infancia, 1918, p 33. A la derecha sacaleches atmosférico de Hartmann, de tipo manual de pera.

A pesar de lo que dice este entrevistado, ya existían en el mercado bombas para la extracción de leche, aunque no se planteaba su uso para esta situación, aparte de que no estaban al acceso de todo el mundo. Inicialmente eran instrumentos de uso médico, hasta que empezaron a comercializarse en serie los sacaleches de pera (sacaleches atmosférico de

${ }^{582}$ Testimonio de Teo nacido en 1929 en San Miguel del Arroyo (Valladolid) 
Hartmann), que en formato y materiales más modernos todavía persisten (IMAGEN 3-24 ${ }^{583}$ ). Se destinaban fundamentalmente a casos en los que la lactancia no era posible por problemas como pezones invertidos o atróficos o dificultades en el niño del tipo del labio leporino con fisura palatina o la debilidad congénita que dificulta la succión y los propios médicos no los encontraban recomendables salvo en esas situaciones porque decían que a la larga perjudicaban a la mama. En todo caso, también es posible hacer la extracción manual de la leche.

El amamantamiento se ha reconocido desde siempre como la forma más idónea de alimentar a los niños en los primeros meses de vida y, durante siglos, ha sido su único medio de supervivencia a falta de una lactancia artificial adecuada. La muerte de la madre en el parto o la falta de producción láctea eran desgracias que obligaban a buscar otro medio de alimentar al recién nacido, el conocimiento empírico acumulado durante siglos aceptaba que la sustitución de la madre por otra mujer, una nodriza, era sin duda la mejor opción. A falta de nodriza, había que recurrir a la leche animal, cuando se podía disponer de ella, o a otro tipo de alimentos casi siempre inadecuados para los niños más pequeños; prácticas que suponían un riesgo muy importante para los infantes, sobre todo en los primeros meses de vida, tanto por la inmadurez funcional de sus órganos y sistemas orgánicos, que condiciona una tolerancia digestiva muy limitada en esta etapa de la vida, como por las malas condiciones higiénicas en la preparación y administración de estos alimentos alternativos que provocan infecciones gastrointestinales muchas veces mortales ${ }^{584}$.

La preferencia secular por la lactancia natural es por tanto una cuestión de necesidad y el recurso de las nodrizas a falta de la leche materna la mejor opción. Entre las clases populares estas nodrizas, o amas de cría, casi siempre eran mujeres del entorno social y familiar que se prestaban desinteresadamente a lactar al niño privado por distintas

\footnotetext{
${ }^{583}$ Sacaleches atmosférico de Hartmann. Fuente: http://www.historiadelamedicina.org/Instrumentos/instrumento_9.html

${ }^{584}$ A finales del siglo XIX ya se conocía la composición de la leche de mujer y de la de otros animales y se sabía que era diferente, será una de las razones científicas que se utilizarán para defender la lactancia natural y significará un paso importante en la alimentación del lactante porque va a permitir elaborar una leche artificial adecuada. Durante un tiempo algunos médicos reclamaron el análisis clínico de la leche materna para valorar la crianza, pero era tan complicado y había tantos criterios diferentes que finalmente en los años veinte se optó por tomar el estado nutritivo del lactante como el mejor indicador. Se reconocía que existen una serie de factores que pueden influir en la calidad y la cantidad de la leche, entre los que se mencionaban en la década de 1880 el temperamento y la edad de la mujer, la alimentación, la vivienda, el aire, la actividad física y la sexual, la menstruación y el embarazado, las emociones fuertes y las enfermedades.
} 
circunstancias de leche materna, en muchas ocasiones debido al fallecimiento de la madre debido a la altísima mortalidad asociada al parto. Entre las clases altas el recurso de las nodrizas se impuso como una moda que se convirtió durante siglos en un signo de estatus social, sólo las mujeres pobres, que por otra parte eran la gran mayoría, daban de mamar a sus hijos. Algunos autores han llamado revolución de la lactancia a la moda de "usar" nodriza, incluso la relacionan con el desarrollo demográfico de determinadas etapas pues reduciría el intervalo entre embarazos, ya que existía el convencimiento, y por ello la prohibición, de que la mujer lactante no podía tener relaciones sexuales hasta después del destete porque perjudicaban a la leche y a la criatura ${ }^{585}$.

Del otro lado estaban las nodrizas que lactaban hijos ajenos, la demanda por parte de las clases altas convirtió la lactancia en un mercado y un medio de ganarse la vida para muchas mujeres, con un contrato y un salario de por medio, es lo que llamamos lactancia mercenaria $^{586}$. Los que la justificaban en la Edad Media y Moderna echaban mano, entre otros

\footnotetext{
${ }^{585}$ Las mujeres que tenían ama podían tener una mayor fecundidad al seguir teniendo relaciones conyugales, sin embargo, resulta exagerado pensar que podía aumentar mucho la población teniendo en cuenta que esta situación habría que limitarla a los pocos que podían permitirse una nodriza, además, tampoco vamos a creer que todo el mundo respetaría la recomendación de abstinencia prolongada durante la lactancia.

A partir del siglo XI aumentó el número de hijos entre las clases nobles y algunos autores como MCLAUGHLIN lo relacionan con el hecho de que la mujer quedaba liberada de esta prohibición al no amamantar, de hecho, muchas veces el tomar amas de cría era una imposición del marido para tener a la mujer disponible, aumentar el número de embarazos o preservar su belleza. MCLAUGHLIN M.M.: Supervivientes y sustitutos. Hijos y padres del siglo IX al siglo XIII. En: DEMAUSE LI.: Historia de la infancia. Edit. Alianza Universidad. Madrid 1982, pp 121- 205.

En cuanto a la prohibición de tener relaciones sexuales durante la lactancia era una idea galénica que se afianzó en la mentalidad medieval y que motivó que la Iglesia las prohibiera. Se creía que después del parto la sangre menstrual se dirigía a las mamas y por eso no había menstruación. Del mismo modo que el feto se alimenta de la sangre materna, luego la naturaleza manda esa sangre a los pechos y se transforma en leche para seguir alimentando al niño. Según Bernardo Gordonio "La leche se multiplica por la muchedumbre de la sangre, y por la bondad y assi se mengua la leche por la poquedad de la sangre, e por su maldad". Su escasez podía tener muchas causas, todo aquello que lleve la sangre a otra parte o que la deseque, como el poco comer y beber y el mucho trabajo, o una abundancia de sangre de mala calidad, lo que ocurre cuando no se mantiene el equilibrio entre los humores y hay abundancia de cólera, de flema o de melancolía. A su vez, proponía solucionar la escasez según las normas galénicas aplicando lo contrario: comida, descanso o purgas y viandas frías o calientes dependiendo de la causa. Además Gordonio expone una relación de galactógenos, productos que aumentan la producción de leche: "Los goviernos, y los materiales de los quales se engendra la leche y se multiplica en los cuerpos limpios, es deccoción de trigo, y su harina, y almidon, y la confeccion que se llama alatria, y arroz, y cevada mondada, y la harina de los garvanços, y de las havas y ajonjali, y almendras dulces, y azeyte de ajonjoli, y higos passados, y gengibre blanco, y canela, y açucar pan: destas cosas se puede hazer govierno, o decoccion colada con vino o bebida o otra alguna confeccion..."

También daba remedios y recetas para el exceso de leche aplicando productos "fríos" como el vinagre, las lentejas o las habas y emplastos para cuando se cuaja la leche dentro del pecho, lo que se reconoce porque el pecho está frío y se congela la leche que aparece muy acuosa, o porque el pecho está muy caliente y se deseca la leche que entonces aparece amarilla. MARTíNEZ BLANCO C. M.: El niño en la literatura medieval, pp 204- 205

${ }^{586}$ El empleo de nodrizas profesionales se remonta a las civilizaciones más antiguas. En muchos casos se trataba de esclavas, en otros podemos considerarla como un oficio en el que existía un contrato entre una mujer y una familia y en el que se estipulaba un salario por un tiempo determinado, así ha persistido hasta avanzado el siglo XX en los países occidentales, hasta que se empezó a desarrollar la lactancia artificial industrial. Ya aparece en el código de Hammurabi, donde se regulan con normas muy precisas las relaciones entre los padres y las nodrizas, por ejemplo, se castigaba con cortarle los senos a la mujer que se le muriera un niño y que hiciera un contrato para otro infante
} 
argumentos, del tratado de Sorano ${ }^{587}$, muy influyente en la medicina de esas épocas, que aunque defendía la lactancia materna como la mejor opción, también escribió que

"si algo lo impide, se ha de elegir la mejor ama de cría, para que la madre no envejezca prematuramente desgastándose con la lactancia diaria. Para la madre es más conveniente con miras a su recuperación y a la gestación de otros hijos, evitar que se le dilaten los pechos..."

Al mismo tiempo que se impuso la lactancia mercenaria, surgieron moralistas detractores que no compartían estos argumentos ${ }^{588}$, entre otras razones por la convicción, que persistía desde los clásicos, de que a través de la leche el lactante mamaba las cualidades físicas y morales de la mujer que le amamantaba ${ }^{589}$. Por eso las nodrizas debían reunir una

sin que lo sepa el padre del fallecido. También por los papiros egipcios sabemos que el alquiler de nodrizas era una práctica común entre ellos, las que amamantaban a los hijos de los nobles podían alcanzar posiciones sociales elevadas, Amenofis III dio a su ama de cría el título de "Gran Amamantadora" y le hizo una estatua a tamaño natural. Con frecuencia aparecen en la Biblia y en la literatura griega y romana. En Roma las nodrizas se reunían en la columna lactaria, donde también se exponían los bebés abandonados, para ofrecer sus servicios.

Sobre la historia antigua del nodrizaje pueden consultarse MORALES J.L: El niño en la cultura española... tomo I, Madrid 1960; AGUILAR CORDERO M.: Lactancia materna, Madrid 2005; STERPELLONE L.: Historias curiosas de la Medicina, Barcelona 2009 o los distintos tratados publicados sobre Historia de la Pediatría como los de GRANJEL L. S.: Historia de la Pediatría, Madrid, 1965 e Historia de la pediatría española, Salamanca, 1980; MARTíNEZ VARGAS A.: Historia de la pediatría en España Madrid, 1946; OPITZ H., SCHMID F.: Historia de la pediatría, Madrid 1972; JUANEDA GABELAS M.: La lactancia en el Antiguo Egipto, Cuenca 2013; HUARD P., LAPLANE R.: Histoire illustrée de la pédiatrie, Paris 1981; ROSS B. J.: "El niño de clase media en la Italia urbana, del siglo XIV a principios del XV". En: DEMAUSE LI.: Historia de la infancia. Edit. Alianza Universidad. Madrid 1982, pp 206- 254.

${ }^{587}$ Sorano de Efeso es considerado como el padre de la Pediatría ya que escribió el primer tratado materno-infantil titulado "Sobre las enfermedades de las mujeres", que tuvo gran influencia en toda la medicina medieval y en el que se ocupa de la asistencia al parto, los cuidados del recién nacido, algunas enfermedades infantiles, los criterios para la elección de nodriza y el estilo de vida que ésta debe llevar.

${ }^{588}$ Ya en la época romana desde el siglo I-II nos encontramos con condenas de la lactancia mercenaria, salvo cuando la madre fallecía, estaba enferma o no tenía leche. Figuras como Plinio, Plutarco o Tácito la rechazan y advierten que puede dañar las relaciones materno-filiales. Desde Galeno, la mayoría de los médicos conocidos (como el aragonés Arnau de Vilanova, uno de los más importantes e influyentes de la Europa de los siglos XIII-XIV) y de los moralistas cristianos defendieron la lactancia materna frente a la mercenaria. San Bernardino de Siena, entre otros, fue muy crítico con ella, aceptaba como "razones legítimas" que la madre tuviera mala salud o leche insuficiente, pero condenaba como un motivo "ilegítimo" adoptarla para "procurarse más placeres". Se criticó sobre todo la costumbre que se extendió ya en la Edad Moderna de mandar a los niños fuera del hogar para ser amamantados. Las familias de clases pudientes ponían a sus hijos en manos de un ama de cría que habitualmente vivía en el hogar familiar, pero otras los mandaban a criar al campo a casa de la nodriza porque se pensaba que las mujeres rurales tenían más leche y que el aire era más saludable para el niño; el tiempo que permanecían los niños fuera era muy variable, en algunos casos sólo durante la lactancia, pero podía prolongarse hasta los 5 años o más.

${ }^{589}$ Sorano ya expresó la idea de que el lactante se asemeja a la nodriza, que sería repetida con insistencia por todos los autores medievales. San Bernardino de Siena en sus sermones denunciaba: "Aún siendo prudentes y de buenas costumbres y hábitos discretos... a veces ponéis a vuestros hijos en manos de una vulgar ramera y de ella por fuerza adquiere algunas de las costumbres de la que lo amamanta. Si la que cuida de él tiene malas costumbres o es de baja condición, el niño quedará marcado por esas costumbres por haber mamado su sangre contaminada". Las nodrizas eran mujeres que habían tenido un hijo que había muerto por distintas causas, se cree que en ocasiones se deshacían del hijo para poder trabajar e incluso que podían quedarse embarazadas para luego poder lactar, de ahí las acusaciones de rameras que hace San Bernardino; en otros casos trataban de ocultar al hijo propio cuando criaban al contratado en la vivienda de ellas. Normalmente eran mujeres consideradas de baja condición y no siempre lo hacían voluntariamente, algunos señores obligaban a las mujeres de su servidumbre a criar a sus hijos apartando a los propios. Podían tener otros hijos, siempre fuera del período de lactancia, que se consideraban hermanos de leche de los niños que amamantaban y que encontramos a menudo recibiendo privilegios cuando éstos eran reyes y nobles importantes. Por supuesto, no podían tener relaciones sexuales; si el niño moría y se demostraba que la nodriza había yacido con varón ambos eran castigados, así se recoge en algunos Fueros como el de Cuenca o Úbeda. 
serie de requisitos que llegaron a legislarse y se formalizaba un contrato entre el padre del lactante y el esposo de la nodriza en el que se acordaba entre otras cosas la duración de la lactancia ${ }^{590}$. Con la aparición de las inclusas aumentó la necesidad de nodrizas para criar a los expósitos y también la polémica. En las últimas décadas del siglo XIX, la preocupación por la infancia y por disminuir su mortalidad se convirtió en una cuestión de estado y se hizo a las mujeres principales protagonistas y responsables de tan difícil tarea. Se creó y se vendió el ideal de mujer y de madre, cuidadora del hogar y de los hijos; se exaltó la figura de la "buena madre", una mujer que criaba personalmente a sus retoños, y se pusieron en marcha de iniciativas para premiar a las que cumplían con los nuevos preceptos ${ }^{591}$. Todas las instancias públicas, incluidos los tratados de Puericultura y la misma Iglesia, recomendaban la lactancia materna $y$, en caso de precisar nodriza, que ésta viviera con la familia para que la madre cuidara a sus hijos, en lugar de mandarlos fuera con personas normalmente ignorantes

"La mujer madre, comprendiendo los grandes peligros a que su hijo está expuesto en su tierna edad, no lo confiará a manos mercenarias, querrá

\footnotetext{
Existía el firme convencimiento de que la leche transmite las cualidades físicas y morales de la madre aparte de la salud o la enfermedad. La calidad de la leche era un aspecto muy importante, tanto si era de madre como, sobre todo, si era de nodriza y se recomendaba "controlarla". La leche de mala calidad podía dar lugar a las peores enfermedades infantiles. Estas ideas venían de lejos, Según Avicena si la leche era demasiado densa o tenía un olor muy fuerte había que extraerla y dejarla al aire libre antes de dársela al bebé, para lo que habría que utilizar "biberones" como los que se han encontrado en lugares de Al-Andalus. Si al niño se le hinchaba el vientre se consideraba culpa de la "mala" leche. Para valorar la calidad de la leche se han hecho prácticas tan peculiares y que han persistido durante siglos como echar unas gotas en el ojo del lactante, si se le irritaba se desechaba la leche. En el Reggimento de Barberino dice que la leche de la nodriza debía ser "moderada en lo que respecta a cantidad, de color blanco y no amarillo (el calostro es de este color) ni verde y aún menos oscuro, de buen olor y sabor ni salado ni amargo, sino más bien dulce y siempre uniforme, pero no espumosa y abundante". ROSS B. J.: "El niño de clase media en la Italia urbana pp 209- 216

590 También se fijaba un sueldo que era variable de unas zonas a otras y que dependía de las cualidades de la nodriza y de que ejerciera en su casa o en la del niño. En la mayoría de los fueros de Castilla se fijaban doce mencales por los dos o tres primeros años. [MARTínEZ BLANCO C.M.: El niño en la literatura medieval (Para una historia social y de las mentalidades de la infancia).Universidad Complutense, Madrid 1991pp 234]

A la hora de la verdad muchos padres no eran demasiado exigentes, hay testimonios escritos que muestran que ni siquiera visitaban a sus hijos durante los meses o años que permanecían en la casa del ama de cría. También en ocasiones se producían tensiones con las madres que acusaban a la nodriza de alimentar al niño insuficientemente. ${ }^{591}$ En 1883 el doctor Tolosa Latour, médico del Hospital del Niño Jesús publicó "El decálogo de la madre" en la revista La madre y el niño que incluye algunos preceptos que iban contra la sabiduría popular: "1. Criarás a tus hijos con la leche de tus pechos, y a no ser posible, vigilarás su alimentación.2. No le destetarás hasta que tenga dientes... 4. Tendrás siempre limpio a tu hijo...no abrumándole con ropa ni desnudándole imprudentemente. 6. Le darás diariamente un baño de aire puro, y a ser posible de agua fresca. 8. Le vacunarás sin pretexto alguno. 10. Le acostumbrarás a sufrir las penalidades de la vida, a creer en algo y a practicar el lema de si quieres ser amado, ama" Citado en: BORRÁS LLOP J.M.: Historia de la Infancia en la España Contemporánea. 1834-1936, p 35. En la p 37 recoge también el Decálogo del Padre del mismo autor, por supuesto, nada que ver con las obligaciones de la madre, a modo de ejemplo cito el primer precepto. "Construirás una familia con amor, la sostendrás con tu trabajo y la regirás con bondad

En 1906 el doctor Martínez Vargas propuso la creación de una Póliza de Protección Infantil, una cartilla con la que se controlaba como cuidaban las madres a sus hijos y las premiaban con un premio en metálico cuando al cabo de un año habían actuado de forma adecuada y habían sabido eliminar comportamientos que perjudicaban al bebé. En la cartilla se decía: "Proteged a los niños sanos, son la alegría del hogar. El consuelo de la vejez, la perpetuidad de la raza, la savia de la nación; sin ellos el hogar es solitario, la vejez desvalida, la raza se extingue y las naciones desaparecen" En: MORALES J.L: El niño en la cultura española... tomo 1, p 666. Más que un valor por sí mismo, el niño era una garantía de futuro para los padres y para la nación.
} 
cuidarlos ella misma, y su educación moral y un noble corazón desecharán la vanidad y el vicio, amamantando a su hijo con cariño ${ }^{\prime 2592}$.

Los médicos empezaron a hablar de la mejor manera de hacer la lactancia y la conveniencia de establecer una técnica adecuada para que la madre pudiera lactar con éxito a sus hijos. Sigue diciendo Martina Castell

"La lactancia ha de subordinarse a ciertas reglas para no provocar desórdenes digestivos en el tierno niño y para alejar de la madre el riesgo de quebrantar su propia salud, viéndose obligada a recurrir a la lactancia mercenaria que sabido es la funesta influencia que ésta tiene sobre la vida del niño. En París, donde la lactancia mercenaria es la que más priva,.... de los 54.000 niños que aproximadamente nacen todos los años, más de la mitad mueren antes de cumplir los cuatro años, en Moscú.... la mortalidad de los niños pasa de un $80 \% "$."1593.

A pesar de la campaña de exaltación de la mujer-madre ideal y con ella de la promoción de la lactancia materna, la lactancia mercenaria persistió hasta avanzado el siglo XX. Se llegará a decir que "Las nodrizas son un mal necesario que evitan otro mayor", el de la alimentación artificial prematura ${ }^{594}$.

\footnotetext{
592 Martina Castell citada por FLECHA GARCÍA C.:"La educación de la mujer según las primeras doctoras en Medicina de la Universidad Española. Año 1882". en CABRÉ M., ORTIZ T.: Sanadoras, Matronas y Médicas en Europa. Siglos XII-XX, 2001, p 245

593 bídem, p 246.

Se empezaron a dar normas para la lactancia correcta: momento de iniciarla, regular las tomas y poner un horario, duración de las tetadas, intervalos, modo de colocarse el lactante y la madre, medidas higiénicas para ambos.

Para las mujeres trabajadoras la realidad era muy distinta, muchas no podían amamantar a los niños suficientemente por las jornadas excesivamente largas, sobre todo las trabajadoras urbanas y las rurales cuando había faena en el campo. Algunas mujeres no podían dar el pecho nada más que dos o tres veces al día y los lactantes permanecían semiabandonados la mayor parte del tiempo. Acababan destetándoles demasiado pronto para poder entregarlos al cuidado de alguna vecina o familiar que los alimentaba de forma artificial, ya que no solían disponer de nodriza, a pesar en su caso de la necesidad, salvo que una mujer del entorno tuviera la generosidad y la posibilidad de ofrecerse.

${ }^{594}$ BORRÁS LLOP J.M.: Historia de la Infancia en la España Contemporánea. 1834-1936, p 135 citando a Cabot, 1890
} 


\subsubsection{Las nodrizas internas, un grave problema para la Inclusa}

El nodrizaje se puede considerar cono una prestación sexwal especificamente femenina Era una inestimable ayuda a la escuálida economía familiar

Lola Valverde

Las nodrizas más sanas y acomodadas eran contratadas por particulares que pagaban más, por lo que has peores del mercado, las más pobres, débiles, e incluso enfermas, eran las que trabajaban para las inclusas españolas

Ana María Rodríguez

De la lactancia mercenaria se ha dicho que fue una estrategia de supervivencia de muchas mujeres "madres solitarias y de muchas familias pobres, suministrando una importante corriente monetaria a localidades y comarcas enteras ${ }^{\prime \prime 95}$. Las mujeres que necesitaban trabajar como nodrizas, antes de acudir a las inclusas preferían lactar en casas particulares, donde tenían mejor salario ${ }^{596}$ y mejores condiciones, aunque a cambio también a ellas se las exigía mucho más. Las clases más pudientes siguieron recurriendo a las amas de cría y, muy avanzado el siglo XX, todavía se mandaba a los niños a vivir con ellas al campo con la excusa de un ambiente más sano. En la prensa local encontramos diariamente anuncios de mujeres ofreciéndose de nodriza interna o externa como estos que recoge El Norte de Castilla en las tres primeras décadas

"Soltera, leche de un mes, desea para casa de los padres, dentro ó fuera de la población. Dirigirse a Pablo Coca. Villavendimio"

"Soltera de 21 años, leche de veinte días, desea para casa de los padres, dentro o fuera de la capital. Razón San Vicente de Palacio, Valeriana Benito"

"Casada, primeriza, de 24años, leche de dos meses, desea para su casa. Razón Piña de Esgueva, Eliseo Simón y en Valladolid, José María Lacort, 2, tienda"

\footnotetext{
595 PÉREZ MOREDA V.: La infancia abandonada.... 2005, p 128

${ }^{596}$ Según consta en el museo de las amas de cría de Selaya, las que lactaban a la casa real durante el reinado de Alfonso XIII, cobraban 3.000 pesetas al año la oficial y 1.500 la suplente, aparte de comida, alojamiento y vestido; frente a las 300 pts ( 25 pts al mes) que cobraban las amas internas de Valladolid y 540 pts las externas (45 pts al mes).
} 


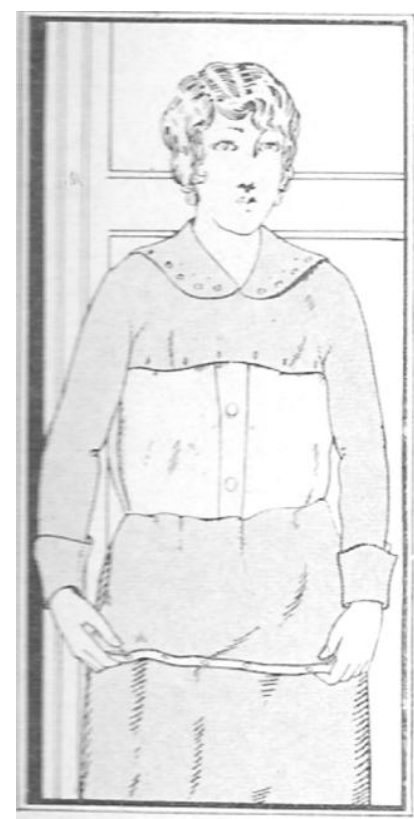

Fig. 11.-Disposición útil del restido de la nodriza para llenar el fin de dar el pecho.

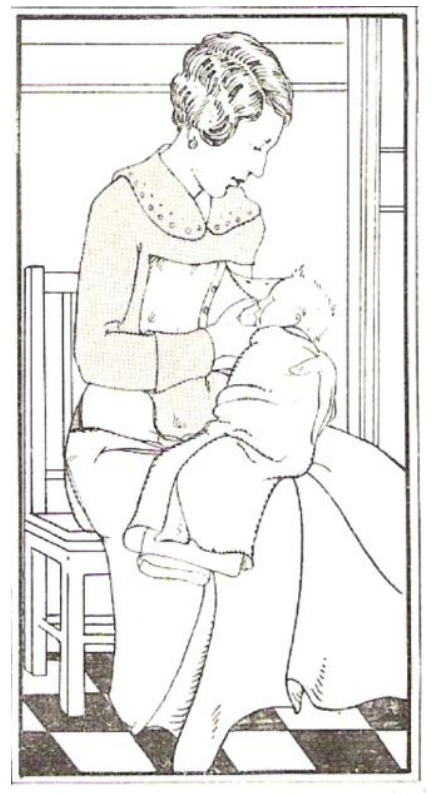

Fig. 12.-Manera de dar de mamar al niño. Disposición más cónoda de los vestidos para realizar este objeto.

Imagen 3-25: Traje de nodriza, modelo pensado para dar de mamar con recato; sería un diseño destinado a amas particulares. Entre la ropa que se describe en los reglamentos no entra la de las nodrizas que tendrían que usar la suya, solo tenían derecho a alojamiento y comida más el salario. Fuente: SUÑER E.: La salud del niño. 1920 , pp $17-18$

eran muy cotizadas, sobre todo las del valle del Pas desde que la casa real empezó a contratarlas. En las contrataciones entre particulares se preferían amas casadas porque se les suponía mayor moralidad que a las solteras, si bien éstas tenían la ventaja de no estar sujetas a un marido, y eran preferibles las mujeres de campo porque se suponían más sanas. Se les exigía un certificado de "buena conducta" que expedía el párroco y otro de buena salud que obtenían en consultorios como los de las Casas de Socorro ${ }^{598}$ donde se les hacían

\footnotetext{
597 "Respecto a la gestación, si bien en los primeros meses, al menos, no es un absoluto obstáculo para lactar al niño, hay que reconocer... que frecuentemente perturba la buena marcha de su nutrición. A este propósito ha dicho Cazeaux: "El embarazo que sobreviene durante la lactancia, es casi siempre una circunstancia fatal»....la existencia de la menstruación no es una condición recomendable... con frecuencia se observar... que durante los días de las reglas el niño sufre trastornos intestinales que solo excepcionalmente adquieren verdadera importancia". SUÑER E.: La salud del niño. 1918, p 83

${ }^{598}$ En las Casas de Socorro se realizaba el reconocimiento de las nodrizas para ratificar su salud frente a contrataciones de particulares. Se llegó a proponer incluso que se debería examinar al hijo de la nodriza para descartar que fuera sifilítico, hay denuncias como la de Suñer en el sentido de que no se examinaba al lactante a alimentar que también podía ser portador de una sífilis u otras enfermedades que podrían infectar a la nodriza.

Las Casas de Socorro, además de este servicio, disponían de consultorios de Puericultura, que en algunos sitios llamaban "Servicio de Pesa-niños gratuito" para conceder lactancias y suministrar vacunas. También se prestaba auxilio a las parturientas y se recogían niños perdidos o abandonados y huérfanos para ingresarlos en los establecimientos benéficos del Estado. En Valladolid se encontraba primero en la calle Muro y en 1929 se instaló en la calle López Gómez y en la prensa local se anunciaban a diario las consultas por especialidades, entre ellas las de enfermedades de los niños. algunos de los expósitos de la Inclusa nacieron en la Casa de Socorro (fo 380 y 405 LE 1912-2) y desde allí fueron enviados a la Inclusa. CARBALLO BARRAL B.: La Beneficencia Municipal de Madrid en el
} 
reconocimientos periódicos. Además debían cumplir una serie de exigencias como lavarse perfectamente, no beber bebidas alcohólicas, hacer ejercicio moderado al aire libre, ir bien abrigadas y sobre todo con brazos, cuello y pechos siempre tapados, incluso cuando amamantaban, para lo que se diseñaron vestidos especiales (ver IMAGEN 3-25) y dormir seis o siete horas sin interrupción, pero nunca con el niño; debían además tener el menor trato posible con los demás sirvientes, no podían tener correspondencia ni visitas y preferiblemente debían ser guapas ${ }^{599}$. Mención aparte merece el caso de las nodrizas contratadas por las Casas de Expósitos, que no siempre cumplían ni siquiera los requisitos mínimos debido a la escasez y la necesidad que había de ellas, todos los autores que han escrito sobre el tema coinciden en que eran mujeres que no serían aceptadas por particulares.

Tanto si era por necesidad como por elección, el uso de nodrizas era tan frecuente y provocaba tantos conflictos que se hizo necesario regular su actividad desde el punto de vista legal y sanitario; se publicaban consejos para elegir la más adecuada y en los consultorios públicos se hacían reconocimientos médicos a las candidatas; hasta los manuales de Pediatría y Puericultura trataban el tema de las condiciones que debían reunir y que se debían exigir para su elección. Todavía en una publicación pediátrica de 1944 se habla de nodrizas " $a$ distancia", que acogían a los lactantes en sus casas, y encontramos las siguientes consideraciones sobre La selección de nodrizas mercenarias

\begin{abstract}
"Hemos de considerar dos tipos de nodrizas: las nodrizas a distancia y las que viven en casa de los padres del niño que amamantan....

No todas las mujeres que son madres sirven para nodrizas, sino que hay que seleccionarlas exigiendo un mínimo de condiciones fisiológicas y morales. Asimismo, los niños sifilíticos o hijos de padres sifilíticos no deben entregarse a nodrizas sanas.

No acostumbran ser muy buenas nodrizas ni las muy jóvenes (menos de veintidós años) ni las talludas (más de treinta años), así como las que han llevado o llevan una vida de trabajos físicos agotadores. En general hay que preferir a las pueblerinas y descartar a las de las grandes ciudades. Las nodrizas solteras son de mal aconsejar y desde luego, deben rechazarse si son multíparas, por razones de índole moral. Deberá transcurrir un mínimo de dos meses después del parto para que se pongan a criar y conviene que su leche tenga, todo lo más seis meses más que el niño que han de amamantar. Su salud debe ser completa, exigiéndoles una serología negativa para la sífilis; su dentadura se hallará en buen estado y sus glándulas mamarias deberán presentar los caracteres anatomofisiológicos que corresponden a una buena
\end{abstract}

cambio de siglo: el funcionamiento de las Casas de Socorro (1896-1915), 2006; MORALES J.L.: El niño en la cultura española.... tomo 1. p 661. SUÑER E.: La salud del niño. Madrid 1920.

${ }^{599}$ Estas eran algunas de las reglas que se difundían sobre las cualidades de las nodrizas, es de notar que ha arraigado la prohibición, que empezó a instaurarse en la Edad Media, de no dormir en la misma cama con los niños por el miedo a asfixiarlos. El hecho de mantener a la nodriza incomunicada de su familia seguramente sería para evitar que abandonara la casa y retornara con los suyos y se la prefería guapa por la creencia en la transmisión de cualidades a través de la leche, aparte de que "Iucía" más. BORRÁS LLOP J.M.: Historia de la Infancia en la España Contemporánea. 1834-1936, pp 39 -41. 
secreción...A ser posible conviene examinar al hijo de la nodriza para saber si se está desarrollando normalmente ${ }^{\prime 600}$

El nodrizaje planteaba un problema ético importante, que se venía debatiendo desde el siglo anterior, el de los hijos de las nodrizas; estas mujeres eran madres casi siempre recientes, algunas habían perdido a su hijo, pero muchas para poder trabajar los dejaban con la familia, o los abandonaban, destetándolos muy precozmente y sometiéndoles al riesgo de una muerte temprana ${ }^{601}$. Existía respecto al tema una doble moral burguesa que criticaba duramente esta práctica de las nodrizas a la vez que se las obligaba a ello al no admitirlas en el trabajo con sus hijos, recordemos aquella nota del torno en la que un señor, sin duda "de bien" entrega el hijo de la nodriza que criaba al suyo (ver pág 285). Debido a ésta y otras cuestiones polémicas en relación con el nodrizaje, en el Congreso de Higiene y Demografía celebrado en Madrid en 1898 se puso de manifiesto la necesidad de adoptar medidas como la Ley Roussel que desde 1876 regulaba en Francia la lactancia mercenaria para impedir prácticas tan habituales dentro del mundo de las nodrizas como abandonar a sus hijos en las inclusas para trabajar lactando a otros niños, embarazarse continuamente para poder seguir trabajando o sacar niños de las inclusas para volverlos a depositar después en el torno y cobrar por su crianza. Se creó un movimiento promovido por el prestigioso pediatra Manuel Tolosa Latour que desembocó en la aprobación de la Ley de Protección a la Infancia en 1904, que realmente no se haría operativa hasta la publicación de su Reglamento en 1908, en el que se amplió el campo de acción de la ley a otros temas aparte del nodrizaje ${ }^{602}$.

Esta legislación se dirigía tanto a las nodrizas particulares como a las de las Inclusas, con las mismas exigencias; aunque a las inclusas solamente se ofrecían mujeres que por sus

\footnotetext{
${ }^{600}$ BUXÓ IZAGUIRRE P.: Enfermedades de los niños de pecho. Madrid 1944, p 153

${ }^{601}$ Estos niños tenían una mortalidad mucho mayor que los del entorno criados por sus madres. BORRÁS LLOP J.M.: Historia de la Infancia en la España Contemporánea. 1834-1936, p 135

Eran muy criticadas por el abandono de sus hijos, precisamente por los mismos que las contrataban y que de alguna manera lo exigían, porque normalmente no se consentía que el ama llevara con ella a su hijo, por miedo a que perjudicara la crianza del niño para el que se le contrataba. Cuando la crianza se hacía en casa de la nodriza solía ocurrir lo contrario, sobre todo en el caso de padres despreocupados que no le visitaban y de incluseros; entonces ella se dedicaba más al hijo propio y descuidaba al ajeno y, si no tenía leche suficiente para los dos o la perdía antes de finalizar el contrato, le alimentaba con leche animal y con papillas, incluso se ocultaban las dolencias del pequeño para retenerlo más tiempo.

Para reducir la mortalidad de los hijos de las nodrizas y los problemas asociados, se propuso que se escogieran entre madres que habían perdido al hijo o que éste tuviera más de doce meses y estuviera destetado y en caso contrario que se obligara a admitirlo en la casa con ella para criarlo junto con el contratado. E. Suñer: La salud del niño, p 13

${ }^{602}$ En el Reglamento, además de la reglamentación y vigilancia de la lactancia mercenaria, se contemplan: la protección y amparo a la mujer embarazada, la inspección de centros que alberguen niños, la persecución de delitos contra menores, el amparo de niños abandonados, la corrección de delincuentes y la educación de anormales.

Reglamento de la Ley de Protección a la Infancia aprobado el 24 de Enero de 1908 y publicado el 26. Disponible en: http://legishca.edu.umh.es/2016/08/03/1908-01-24-reglamento-de-la-ley-de-proteccion-a-la-infancia/
} 
condiciones no podían colocarse en casas particulares. En paralelo con el proceso hacia estos cambios legislativos se venía desarrollando la polémica contra la lactancia mercenaria; no obstante, las Inclusas dependían de ella para mantener con vida a sus asilados, precisamente las repetidas denuncias en la prensa local madrileña sobre la terrible mortalidad de los incluseros por falta de nodrizas desencadenó el proceso que desembocó en la Ley de Protección a la Infancia de 1904, que vendría también a regular a estas amas de cría que percibían salarios muy bajos comparados con los que cobraban las que trabajaban para particulares.

\subsubsection{Las amas internas de la Inclusa}

A falta de madres que pudieran lactar a los expósitos, la Inclusa de Valladolid, como las demás, procuraba contratar nodrizas, o amas de cría, en régimen de internado

"ARTí́CULO 63. Para que todos los niños sean lactados por de pronto y continúen lactándose á aquellos que no pudieren darse á criar fuera o que se devuelvan prematuramente, habrá un número de nodrizas internas suficientes á llenar tan importante servicio, las cuales estarán subordinadas á la Superiora e Hija de la Caridad encargada inmediatamente del departamento" [sic] (Regl 1889)

El oficio de nodriza requería, también para la Inclusa, de unas condiciones determinadas que se recogían en los reglamentos, en este sentido la Inclusa de Valladolid, como la de Pontevedra era bastante tolerante, comparada con otras como la de Toledo o Albacete que eran muy estrictas con estos requisitos, al menos en su normativa, porque a la hora de la verdad todas en algún momento se verían obligadas a dejar a un lado esos requerimientos por la necesidad acuciante de alistar amas lactantes a toda costa, así lo reconoce la casa de Barcelona, que en momentos de escasez de nodrizas éstas no tenían buenas condiciones. En Valladolid, las futuras nodrizas debían pasar una revisión médica al ingreso para demostrar que tenían condiciones para lactar, además, para su admisión necesitaban demostrar buena conducta moral y las casadas la autorización del marido

"Artículo 64. Serán admitidas por el Facultativo correspondiente siempre que resulte del reconocimiento hallarse en aptitud de poder criar y hagan constar su buena conducta moral, presentando además si son casadas el permiso del marido.

Artículo 65.Cada diez ó quince días, pero sin establecer período determinado, volverán á ser reconocidas por el Facultativo para cerciorarse si se encuentran en estado de poder seguir lactando" (Regl 1889) 
Se echa de menos en estos artículos una referencia al estado de salud de las amas, punto que se añadiría en el siguiente reglamento, quitándose además la alusión al estado civil de la nodriza y dejando en manos de la Superiora la selección; el artículo quedó redactado en los reglamentos sucesivos de la siguiente manera

"Art. 320. Será de la incumbencia de la Superiora la admisión y despedida de las nodrizas. A la admisión precederá un reconocimiento hecho por el Facultativo respecto a su sanidad y buenas condiciones para criar; en cuanto a sus cualidades morales deberá informarse a fin de que no sean admitidas de malos antecedentes"

Las circunstancias mandaban. Aunque primero la ética y el sentido común, y más tarde la normativa legal, aconsejaban seleccionar amas de cría de buena salud, los Hospicios generalmente no tenían mucho donde elegir. Las nodrizas que reunían las mejores condiciones se colocaban en casas particulares, si no era como amas de cría lo hacían para el servicio doméstico, las inclusas eran la última opción por sus salarios más reducidos y sobre todo por las condiciones de vida que les esperaban en ellas, donde tenían que atender varios niños, muchos con enfermedades infecciosas del tipo de la sífilis que les provocaban miedo y rechazo y se veían sometidas a un régimen de vida cerrado muy estricto y controlado por las Hijas de la Caridad. Lactar en una Inclusa se hacía por responsabilidad moral, mujeres que no tenían más remedio que dejar allí a sus hijos pero sentían la obligación de criarles al menos el tiempo que la institución les permitiera, o por mucha necesidad, cuando no tenían otra forma posible de ganarse la vida. La escasez de candidatas obligó a muchas inclusas a saltarse un aspecto tan importante como su estado de salud, algo que no importaba a quienes pensaban que a fin de cuentas la mayoría de los incluseros procedían de un entorno similar al de esas mujeres; se consideraba más importante que sirvieran para lo que se las contrataba, alimentar con su leche a los internos.

Entre las páginas del libro de la Maternidad se encuentran dos papeletas de 1913 con membrete y firma del médico que hizo el reconocimiento, el Dr. Gavilán, médico del Hospital de Esgueva; son las que presentaban al solicitar el ingreso. En ellas no dice nada del estado de salud de las dos mujeres, solamente hablan de sus condiciones para lactar, que en ambos casos eran "regulares", aún así las dos entraron como nodrizas internas, lo que viene a confirmar la poca exigencia que en la práctica se veían obligados a tener en la selección de estas mujeres. Únicamente se ha escrito en ambas:

\footnotetext{
"Reconocida Mónica Alonso= tiene regulares condiciones para lactar Firma del Dr. Gavilán Valladolid 20 de Marzo de 1913
}

Eulogia Iglesias Pérez soltera de 22 años reúne regulares condiciones para lactar 
Firma del Dr. Gavilán

Valladolid 3 de Abril de 1913

El mismo día del reconocimiento entraron como amas internas, sólo estuvieron 3 meses cada una de ellas, se conserva también la papeleta, firmada por la Superiora Sor Francisca Orrio para comunicar la baja a la dirección. Cobraron el salario que correspondía a las nodrizas internas a razón de 25 pts/mes. Una vez que las nodrizas estaban trabajando para la Inclusa debían pasar periódicamente, pero sin plazos fijos, un reconocimiento que hacían los médicos del centro para comprobar que seguían en condiciones de lactar, cuando ya no tenían leche se podían quedar al cuidado de los niños como amas secas.

En cuanto al estado civil, muchas inclusas exigían a la nodriza ser casada o viuda, dado que el hecho de ser madre soltera era moralmente reprobable, las solteras no podrían demostrar "buena conducta moral" y entrarían en el grupo que no podían ser admitidas por "malos antecedentes". Mientras que en las inclusas de Toledo o Albacete "estaba terminantemente prohibido que las solteras ejerciesen como Nodrizas internas" en la de Pontevedra se aceptaban solteras ${ }^{603}$. Como acabamos de ver la Inclusa de Valladolid no discriminaba en este sentido, en una de las citas anteriores una de las mujeres admitidas era soltera; otra vez es una cuestión de sentido práctico. El Reglamento de 1889 resulta diplomático en este asunto cuando pide el permiso del marido para las casadas, lo que como tantas otras cosas era obligado por ley y por costumbre, pero realmente no excluye al resto. Los reglamentos siguientes ya no dicen nada al respecto, la razón es la misma que en el caso anterior, aunque podían ofrecerse mujeres casadas, que ya sabemos que también entregaban sus hijos a las inclusas, la mayoría de las posibles candidatas eran madres solteras que no tenían recursos para criar a sus hijos por sí solas y, o no podían enfrentarse a la vergüenza y la marginación que suponía para ellas ser madres; la Inclusa se convertía en un refugio, de ahí lo apropiado del nombre de refugiadas que les daban en Valladolid, y en una salida temporal. No podemos saber el estado civil de las refugiadas que se quedaban a lactar en la Inclusa porque no figura en los libros, pero podemos suponer que la mayoría serían mujeres solteras. En el libro de la Maternidad en algunas nodrizas contratadas de fuera del asilo se ha anotado su condición de solteras (fo 29, LE 1910-1), aunque no siempre se hacía, en el caso de Eulogia, la mujer soltera del reconocimiento médico, no se ha hecho constar en su folio. Si se solía anotar la edad y estado civil de las madres que daban a luz en el Hospital, algunas de las que luego se

\footnotetext{
${ }^{603}$ RODRÍGUEZ MARTín A.M.: Algunos aspectos relativos a la Inclusa de Pontevedra, 1872-1903. Pontevedra, 2001, p 181; MARTÍNEZ-GÓMEZ SIMÓN L.M.: Las instituciones de atención social al menor en la ciudad de Albacete. Albacete. 2002, p 278; MARTín ESPINOSA N.M. y col.: Análisis de la mortalidad expósita de la Inclusa de Toledo y sus condicionantes (1900-1930). Asclepio 68 nำ1, 2016.
} 
quedaron lactando aparecen como solteras: El ama del folio 2 del libro de la Maternidad es madre del expósito del folio no 185 de 1909 es una mujer soltera de 19 años que dio a luz el 17 de mayo, el niño ingresó en el asilo el día 19 y la madre el 31 de mayo, cuando su hijo ya había fallecido el día 29. También la mujer del folio 3 "procede del Hospital" y permaneció en el asilo 13 días, por el libro de la Maternidad no sabemos nada más; por el folio de inscripción de su hijo (fo207, LE 1909), sabemos que tenía 20 años, era soltera y no le lactó porque el niño ingresó cuatro días antes que ella y le adjudicaron una nodriza.

Tampoco contemplan estos reglamentos la exigencia legal de que el hijo de la nodriza hubiera fallecido para asegurarse de que no era abandonado en la propia Inclusa o en otra. En esto también la Inclusa de Valladolid se mostró tolerante, interesadamente, teniendo en cuenta que la mayoría de las nodrizas eran madres solteras que podían no tener otra salida; se registra en los libros un caso en el que ingresan a la vez la madre a lactar y la hija por el torno, ambas fueron admitidas y se permitió a la madre cuidarla (fo 176, LE 1910-1), seguramente hubo más circunstancias similares aunque al ingreso no se reconocieran, ya que ésta era una práctica frecuente en todas las inclusas y por la que se impuso la norma a la que aludimos.

Los reglamentos regulaban la relación de las nodrizas con la Inclusa, como ocurre con otros aspectos el de 1889 se extiende más y con más detalle, algunos artículos se modificaron posteriormente y otros desaparecen, en muchos casos porque la norma se habría convertido ya en costumbre (Art. 63-78 Regl 1889, 318-329 Regl 1910 y 321-332 Regl 1927).

Dentro de la Inclusa las nodrizas estaban bajo la supervisión directa de las Hijas de la Caridad que controlaban su "admisión y despedida", el tiempo de estancia, "a los efectos de la contabilidad para acreditar haberes", la distribución equitativa de los niños y de las tareas que debían realizar, que cumplieran con su obligación de lactar "a los niños que las estén destinados", que mantuvieran "el mayor orden, aseo y limpieza" en sus personas, en las cunas y camas y en el departamento. Su "principal obligación [otras tareas aparte, era] la lactancia y cuidado de los niños"; en el Reglamento de 1910 se añade que son responsables de "su aseo y limpieza" y por fin se contemplan las necesidades psico-afectivas de los infantes cuando se agrega "Prestarán con interés y cariño á los niños que están lactando los socorros y entretenimientos necesarios, dando parte á la Hermana de la Caridad encargada de nodrizas de cualquier novedad que adviertan". Su dormitorio se encontraba junto a la sala de lactancia, para atender a los niños por la noche si era preciso, según el plano justo en la planta superior, pero tenían prohibido acostarles con ellas salvo "que el Facultativo lo ordene". También estaba 
prohibido lactar a los niños cuando se encontraban enfermas o indispuestas, si la enfermedad era leve se las atendía en el mismo Hospicio, pero si se alargaba se las trasladaba a su casa si vivían en la capital o al Hospital provincial, no refiere el Reglamento si cobraban durante la baja.Tenían terminantemente prohibido dar a los bebés nada por su cuenta, la alimentación estaba bajo prescripción médica.

Tenían que hacer vida común, comer juntas y cumplir con los deberes religiosos de oír misa y confesarse, más los que la Señora Superiora pudiera disponer. No se las permitía salir si no eran acompañadas por alguna Hermana y tenían que justificar sus "ocupaciones y conducta durante su ausencia"; era una norma preventiva común a estos centros, teniendo en cuenta que muchas de ellas eran mujeres solteras de honestidad dudosa; dice Ana M. Rodríguez que las Hermanas de la Inclusa de Pontevedra solicitaron una lavandera para evitar que las nodrizas tuvieran que salir por el peligro que suponía de tener encuentros con el otro sexo. Es una ordenanza que se endureció; en el Reglamento de 1889 se las permitía salir por turno de dos en dos con permiso del Facultativo y la Superiora. Tenían prohibido mostrar a los niños o revelar ningún dato sobre ellos, aquí el Reglamento añade, "ni manifestar sus nombres si lo supieran". En caso de faltas de comportamiento, si eran leves, entre el Facultativo y la Superiora decidían la penalización económica a imponer, en las faltas graves la Diputación tomaba la decisión, en el peor de los casos la expulsión del centro (Art. 321- 326 Regl 1910).

Todo esto a cambio de ración condimentada, cama y un salario que durante veinte años se mantuvo fijo, duplicándose después. Desde 1889 hasta 1902 cobraban 17'50 pts/mes; subió a 25 pesetas mensuales hasta 1925 cuando pasaron a cobrar 35 ptas y en 1928 se adaptó en función de los niños que atendía la nodriza cobrando 35 ptas/ mes si solo tenía uno además de su hijo y 45 si eran dos más. Cuando atendía únicamente a su hijo no tenía remuneración económica, sólo alojamiento y comida. Aunque estaban mal pagadas, lo que no voy a cuestionar dado su tipo de trabajo y responsabilidad, en las dos primeras décadas, tenían mejor sueldo que otras mujeres dentro de las trabajadoras con categoría de sirvientes del Hospicio, incluidas las hijas de la Caridad que cobraban menos de la mitad que ellas, 10 pts/mes inicialmente y 20 al final del período; en 1928 subieron todos los sueldos y algunos las sobrepasaron, la enfermera pasó de $14^{\prime} 5$ pts/mes a $37^{\prime} 5$ pts y las lavanderas de 15 pts/mes también a 37’5 también. Las que igualmente disfrutaron un incremento considerable de salario fueron las llamadas amas secas, las cuidadoras internas que no lactaban, que en los primeros años eran las peor pagadas con $12^{\prime} 5$ pts mensuales y pasaron a 30 pts en 1925 y 45 pts en 1928, este incremento tendría mucho que ver con la escasez de este tipo de cuidadoras (ver TABLA 2-3: en capítulo Hospicio). En todo caso las nodrizas internas de Valladolid cobraban 
bastante menos que las de Pontevedra que en 1902 ya cobraban $37^{\prime} 5 \mathrm{pts} / \mathrm{mes}^{604}$ o que las de Barcelona que a finales del siglo XIX y principios del XX cobraban 20 pts/ mes; 25 pts/ mes en Madrid, donde en 1918 ya cobraban 35 pts y en 192842 pts más una gratificación de 10 pts mensuales y un premio de fidelidad de 100 pts al cumplir un año de lactancia, y muy buena alimentación. Los sueldos de una nodriza particular en estas dos capitales en 1880 ya andaban por $40-50$ pts mensuales ${ }^{605}$.

El número de nodrizas internas y su salario los podemos conocer por los Presupuestos generales de la Diputación. El número varió entre 20, de 1905 a 1908 y 25, el resto de los años hasta 1914 , en los presupuestos siguientes no aparece este dato, hasta 1923 que refiere 30 nodrizas internas. En TABLA 3-19 se recogen la información que nos proporcionan los presupuestos y los reglamentos sobre estos dos asuntos; se puede ver que la evolución de los salarios de las nodrizas internas evolucionó a saltos, se mantenía fijo durante años (25 pesetas desde 1908 hasta 1923), y de repente se producían aumentos bruscos de 5 pesetas que representaban hasta el $20-25 \%$ de subida. Hasta 1914 no se contrataron cuidadoras para los niños que no lactaban, su salario era la mitad que el de las amas de cría; no sólo se pagaba el trabajo de estas mujeres, la leche era un valor importante para la Inclusa. (En TABLA 3-25 número de nodrizas y en la 3-27 los salarios, juntas en ANEXO 5).

TABLA 3-21 : SALARIO DE LAS NODRIZAS INTERNAS DE LA INCLUSA DE VALLADOLID (en pesetas/mes)

\begin{tabular}{|l|c|c|c|c|c|c|c|c|c|c|c|}
\hline & $\begin{array}{c}\text { REGL } \\
\mathbf{1 8 8 9}\end{array}$ & PR 1901 & PR 1904 & $\begin{array}{c}\text { PR } \\
1908 / 12\end{array}$ & PR 1911 & PR 1914 & PR 1920 & PR 1923 & PR 1925 & $\begin{array}{c}\text { REGL } \\
\mathbf{1 9 2 7}\end{array}$ & PR 1930 \\
\hline LACTANCIA & $17^{\prime} 50$ & $17^{\prime} 50$ & 20 & 25 & 25 & 25 & 25 & 30 & 35 & $35 / 45^{*}$ & $35 / 45^{*}$ \\
\hline DESTETE & & & & & & $12^{\prime} 50$ & $12^{\prime} 50$ & $12^{\prime} 50$ & & & \\
\hline
\end{tabular}

*35 si lacta solo 1 niño de la Inclusa ó $1+$ el suyo /45 si lacta 2 niños de la Inclusa

NÚMERO DE NODRIZAS INTERNAS CONTRATADAS ANUALMENTE POR LA INCLUSA DE VALLADOLID

\begin{tabular}{|l|c|c|c|c|c|c|}
\hline & 1901 & $1902 / 04$ & $1905 / 08$ & $1909 / 13$ & $1914 / 15$ & 1923 \\
\hline LACTANCIA & 24 & 25 & 20 & 25 & 25 & 30 \\
\hline DESTETE & & & & & 8 & 8 \\
\hline
\end{tabular}

Elaboración propia. Fuentes: Presupuestos generales de la Diputación de Valladolid (PR) y Reglamentos del Hospicio provincial (REGL)

La dieta de las nodrizas internas era similar en cuanto al tipo de alimentos a la de los asilados del Hospicio, incluidas las refugiadas de la Maternidad pero bastante más abundante y "reforzada" con un huevo frito y con $300 \mathrm{ml}$ de vino a mayores. En el Reglamento de 1889 se fijaba en:

\footnotetext{
${ }^{604}$ RODRÍGUEZ MARTÍN A.M.: op.cit. 2001, p 189

${ }^{605}$ ESPINA PÉREZ P.: Historia de la Inclusa de Madrid. Vista a través de los artículos y trabajos históricos Años 14002000, Madrid 2005 y REVUELTA EUGERCIOS B.A.: op. cit., p 314
} 
"400 gramos de carne, un kilo de pan de primera, 3 decilitros de vino, 58 gramos de garbanzos, 20 gramos de tocino y otros 29 de aceite y los demás artículos necesarios para condimentar la comida; cuya ración se distribuirá en sopa por la mañana, cocido al medio día y guisado por la noche, además almorzarán un huevo frito o cosa equivalente, debiendo comer todas reunidas" (Art. 76)

Debía parecer excesiva, porque en los siguientes reglamentos se redujeron las porciones y se retiró el vino quedando en: 830 gramos de pan, 330 gramos de carne, 58 gramos de garbanzos, 28 gramos de tocino, 4 centilitros de aceite, guisado de patatas con carne o hígado de ternera por la noche y el huevo frito en el almuerzo. En todo caso igual de monótona que la de los demás asilados y carente, al menos sobre el papel, de los mismos alimentos, leche, fruta, verduras y pescado (Art. 268) Sobre el tema de la alimentación de la mujer lactante han existido siempre muchas creencias y muy diversas con frecuencia fomentadas desde la actividad médica, empezando por decir que las mujeres debían comer mucho más para producir buena leche, lo que explica esta dieta más abundante que incluso la de las refugiadas, el vino estaba entre los llamados galactogogos, elementos capaces de aumentar la producción de leche, y "como eficaz coadyuvante a los distintos medios apuntados, deben mantenerse los pechos bien abrigados y calientes" ${ }^{\prime 606}$.

\title{
3.4.2.4. Reclutamiento de nodrizas
}

Un problema común a todas las inclusas era el déficit de nodrizas internas para lactar a los expósitos asilados. En 1901 se publicaba en El Norte de Castilla una noticia sobre la terrible mortalidad de la inclusa del torno de Zamora por falta de nodrizas

\begin{abstract}
"El gobernador civil de Zamora ha dicho a los alcaldes de los pueblos de aquella provincia una extensa circular, en la cual, entre otras cosas, les dice lo siguiente: "Apena el alma y tortura el corazón lo que está sucediendo en el Hospicio de esta capital. La mayor parte de los niños que entran por el torno se mueren, y se mueren de hambre». Termina la circular recomendando a dichas autoridades que, como carece el Hospicio de amas de cría, pongan en conocimiento de las mujeres que estén en condiciones de amamantar niños, ya sea en sus casas o bien en el establecimiento, que hagan el favor de prestar sus servicios, por lo cual recibirán treinta y cinco reales las que los lleven a su domicilio y ciento las que ingresen en el establecimiento, ${ }^{\prime 607}$
\end{abstract}

\footnotetext{
${ }^{606}$ Se aconsejaba eliminar de la dieta ajo, espárragos o coles porque dan olor y sabor a la leche y legumbres porque provocan gases y se consideraba que las sardinas, las avellanas y beber mucha leche aumentan la producción láctica, lo mismo que otros líquidos incluido el vino o la cerveza, en cambio, no se podía beber agua durante la tetada porque se aguaba la leche.

${ }^{607}$ N.C. 17- agosto- 1901, p 1
} 
Luis M. Martínez-Gómez dice que en la Inclusa de Albacete se daba la misma situación, habla de "una carencia endémica hasta bien entrado el siglo XX" en todas las inclusas españolas, provocada entre otras causas por la escasa retribución de las nodrizas, y acusa al sistema de inclusas de ser "una forma de infanticidio legal [en la que] Los niños y en especial los más pequeños, simplemente morían de hambre"; valgan como muestra dos citas que recoge en su libro, una denuncia en la prensa local de 1898 y otra de 1918

"En la casa Provincial de Maternidad hay dos nodrizas encargadas de la lactancia de diez niños. Podrán ser muy buenas las nodrizas; pero no es posible que cada una preste el necesario alimento a los cinco niños que les corresponden. ¿No podrá corregirse el mal? Si ha de hacerse que sea pronto, antes de que se mueran de hambre esos desgraciados ...

... en 1918 se detecta la insuficiencia que padecía la Casa de Maternidad en lo que se refería a las amas de leche para los lactantes. Era una carencia intrínseca de la Institución que, irremisiblemente, aparecía en cualquier momento con mayor virulencia. En virtud de una denuncia formulada ante el Consejo Superior de Protección a la Infancia se comprobó que esta Casa solamente disponía de cinco amas de leche para dieciséis niños y reconocidos éstos y pesados acusaban, casi todos ellos, un estado horrible de desnutrición" ${ }^{608}$

Los estudios sobre las inclusas de Madrid, Pontevedra, Toledo, Albacete, País Vasco o Pamplona revelan el mismo problema ${ }^{609}$, la de Barcelona reconocía que sus nodrizas tenían que lactar hasta dos y tres niños, pero que eran de buenas condiciones y bien escogidas ${ }^{610}$; la Inclusa de Valladolid tampoco iba a librarse. El número de amas internas era siempre insuficiente para amamantar a todos los lactantes asilados, para comprobarlo basta ver los libros de registro del Hospicio, tanto los de Maternidad, como los de Expósitos; muchas mujeres lactaban varios niños simultáneamente, los propios reglamentos contemplaban la posibilidad de que un ama pudiera lactar hasta tres bebés.

\begin{abstract}
"ARTí́CULO 53. Cuando los expósitos fuesen conducidos de los pueblos de la provincia, por disposición de los Alcaldes..., siendo condición precisa el que sean remitidos por nodriza que los cuide y lacte en el tránsito, en la inteligencia que una nodriza, solo podrá encargarse de conducir á la casa central ó hijuela, cuando más tres niños.
\end{abstract}

\footnotetext{
${ }^{608}$ MARTÍNEZ-GÓMEZ SIMÓN L.M.: Las instituciones de atención social al menor en la ciudad de Albacete. Albacete. 2002, pp 270- 28. Citas: El Defensor de Albacete, 8 de Agosto de 1898 y QUIJADA VALDIVIESO J: Albacete en el Siglo XX, Albacete.Imp. E. Ruiz. 1925.

${ }^{609}$ Cfr. ARANA AMURRIO J.I. DE: op.cit., pp 7-8; REVUELTA EUGERCIOS B.A: op. cit., pp 241, 318; VALVERDE LAMSFUS L.: op. cit., p 236- 237; JIMÉNEZ LÓPEZ. A. R.: Vida y muerte en la Inclusa de Madrid en el primer año de posguerra (2013), p 378; HERNANDO GARRIDO J.L.: op. cit., pp 6- 12; RODRÍGUEZ MARTín A.M.: op.cit. 2001 y 2008, p 364; PÉREZ MOREDA V: op.cit, 2005, p 9; MONTIEL PASTOR J.: Anar per tornar. La Casa Provincial de Maternitat $i$ Expòsits de Barcelona com a centre d'una xarxa de re-distribució de la població infantil (1853-1936), 2009; ALARCÓN MARQUEZ A.J.: Los expósitos de la Hijuela de Vera (1736- 1901), 2013; MARTín ESPINOSA N.M, COBO CUENCA A.I.: La mortalidad infantil y sus causas en la inclusa de Toledo entre 1900-1910, 2013, p 60; MARTíNEZ GÓMEZ-SIMÓN L.M.: Las instituciones de atención social al menor en la ciudad de Albacete, 2002, p 271

${ }^{610}$ Casa provincial de Maternidad y Expósitos de Barcelona. Estudio demográfico-médico del quinquenio 1883 á 1888 por los Doctores D. Juan de Rull y d. José Cabot. Barcelona. Tipografía de la Casa provincial de Caridad. 1889; pp 26- 28
} 
ARTÍCULO 66. Tendrán obligación las nodrizas de criar los niños que las distribuya la Hija de la Caridad encargada de esta sala, procurándose en esto la mayor igualdad y que cada una no tenga más de dos; pero no podrán exigir aumento en la retribución o salario si alguna vez ocurriera tener que lactar á tres" (Regl 1889)

"ARTÍCULO 551. Las nodrizas, además de una alimentación nutritiva, recibirán mensualmente el estipendio siguiente:

La que lacte su hijo solo, percibirá la alimentación.

La que lacte su hijo y otro de la Casa, 55 pesetas; la que lacte uno solo de la Inclusa, 55 pesetas; la que lacte dos de la Inclusa, 45 pesetas" (Regl 1927)

En 1901, el diputado visitador Eugenio María Vela confesaba en El Norte de Castilla "que había notado, haciendo un examen de los libros, la gran mortalidad que se registraba en la Inclusa, dependiendo este importante detalle de la falta de amas de cría y de la necesidad, como consecuencia de esta deficiencia, de amamantar tres o cuatro niños cada una" ${ }^{\prime \prime 11}$

Recordamos que los propios reglamentos marcaban el período de lactancia hasta los 18 meses, aunque podía ser modificado por prescripción médica y prolongarse en lactantes de "difícil dentición ú otra enfermedad"; a partir de ese momento el niño pasaba al período llamado de "destete" o de "crianza", que se reglamentaba hasta los 7 años. Sin embargo sabemos que habitualmente el inicio y el final del destete se adelantaban, seguramente más por problemas logísticos y económicos que por razones médicas, de hecho el mismo Hospicio en documentos tanto internos como oficiales habla de "Lactancias de 1 día á 15 meses" y "Destetes de 15 meses á 5 años" ${ }^{612}$. Una de las razones para adelantar el fin de la lactancia podía ser la escasez de nodrizas. En general las inclusas se movían en estos mismos márgenes de edad, entre los 15 a 18 meses la lactancia y los 5 a 7 años el destete ${ }^{613}$.

Ante la escasez de candidatas, incluso relajando las condiciones de ingreso, se optó por obligar a las mujeres que daban a luz en la Maternidad a amamantar a los expósitos y se las permitió lactar también a sus propios hijos. Este sistema que retenía por un tiempo a las refugiadas insolventes se convirtió en el método principal para conseguir nodrizas; las mujeres

\footnotetext{
${ }^{611}$ N.C. 5- 8- 1901, p 1

${ }^{612}$ Así se recoge entre otros en los documentos del ADPVA: Niños ingresados ... para lactancia ... año 1905, Signatura: caja 4872, expediente 43325; Estado demostrativo del movimiento de acogidos.... 1906, Signatura: caja 4872, expediente 43334 y Memoria Estados de personal de 1908, Signatura: caja 2449, expediente 30483

${ }^{613}$ Así era en las inclusas en general con alguna excepción como la de Burgos que prolongaba el destete hasta los 10 años. En la inclusa de Madrid, dice Bárbara A. Revuelta que la lactancia duraba 15 meses y pasaban después al período llamado de media lactancia que era de 7 años para los niños y 9 para las niñas y se reduciría a 5 y 7 , respectivamente, mientras que José-I de Arana dice que la lactancia duraba "por lo general 18 meses, y la llamada crianza que se extendía hasta los siete años" esta ligera discrepancia puede deberse a una diferencia temporal entre ambo; como ocurría en Valladolid, los reglamentos se iban modificando y su cumplimiento se ajustaría a las necesidades del momento. El período que indica Bárbara A. Revuelta corresponde al Regl de 1849.

Cfr. HERNANDO GARRIDO J.L.: op. cit; RODRÍGUEZ MARTíN A.M.: op. cit. 2008 y 2001; REVUELTA EUGERCIOS B.A: op. cit.; ARANA AMURRIO J.I. DE: op. cit
} 
que no podían pagar su estancia debían quedarse como amas tantos días como hubieran estado internas en la Sala General para "lactar en el Establecimiento sin retribución durante un mes, o por tanto tiempo como el transcurrido desde el día de su ingreso hasta el que dieron a luz, si excediese de aquel", se hacía por tanto la equivalencia un día de pensión en la Maternidad, = un día de lactancia en la Inclusa, de manera que la que se iba antes de saldar la deuda con su leche tenía que abonar las estancias pendientes "a razón de tres pesetas diarias". Como vimos en el capítulo de la Maternidad, solamente se remuneraba la lactancia de hijos ajenos, no obstante, lactar al propio hijo en exclusiva en la Inclusa servía para saldar la cuenta con el Hospicio; la madre que se quedaba en estas condiciones tenía la misma consideración de las demás nodrizas "pero sin otra retribución que las estancias", debiendo también permanecer "hasta que satisfaga las estancias causadas antes del parto"; esto no era totalmente cierto porque el tiempo que lactaba en la Maternidad no se descontaba. Normalmente, unos días después del parto, que eran muy variables en número, las refugiadas gratuitas pasaban a la sala de nodrizas de la Inclusa y el hijo a la de cunas; mientras permanecía lactando a su hijo en la Maternidad seguía corriendo la estancia y aumentaba la deuda, solamente empezaba a descontar a partir del paso a la Inclusa. En el capítulo de Maternidad se recogen algunos ejemplos demostrativos.

Este sistema de reclutamiento de nodrizas, que era común en las inclusas, se traducía en mejores perspectivas de supervivencia para los niños al dotarles de lactancia natural y de cuidadoras y aumentaba la posibilidad, aunque fuera muy remota por las circunstancias de estas mujeres, de que se llevaran con ellas al hijo. Sin embargo, iba contra la normativa del Hospicio de Valladolid ya que el reglamento no permitía inicialmente lactar al propio hijo; era una política común a muchas inclusas no permitir que los incluseros fueran lactados por su madre, aún cuando se encontrara interna como nodriza. Esta práctica que hoy parece inhumana y poco ética tenía su razón de ser en la miseria en que vivía parte de la población y en la picaresca que generaba. Un hecho constatado desde la existencia de estas Casas era que algunas mujeres depositaban a sus propios hijos para luego ofrecerse como nodrizas cobrando por lactarle. Esto que hoy forma parte de la asistencia social que se ofrece a madres sin recursos, en la época no se consideraba admisible por el efecto llamada que podía tener y por las consecuencias económicas para los centros, con recursos muy limitados la mayoría de ellos, al ser mucha la población necesitada. Las primeras Ordenanzas de la Real Casa de Misericordia y de Expósitos de Valladolid de 1806 desarrollan esto mismo en el capítulo "Los expósitos no se entreguen para su lactancia á sus propias madres dentro ó fuera de la Cuna principal":

"15. Dichos encargados cuidarán no se den á lactar las criaturas á sus madres, de que resultarían gastos insoportables á los fondos de la Casa, pues la 
experiencia tiene acreditado exponen muchas á sus propios hijos con el fin de sacarlos para dicha lactancia por percibir los intereses que reciben por este motivo: igualmente zelarán para que sean tratados en todo caso con el mayor zelo y caridad, á fin de que se les dé el alimento correspondiente..." (Ordenanzas Generales para el departamento de Expósitos 1806, p 101)

El Reglamento de 1889 siguiendo esta línea de pensamiento ya no prohibía expresamente la lactancia materna, pero estableció que los hijos de las nodrizas procedentes de la maternidad debían ser los primeros en salir del establecimiento

"Art 17. Si la madre... pidiese pasar de nodriza al dep.amento de lactancia, procurará [la Superiora] que su dicho hijo sea uno de los primeros que se den a lactar fuera de esta capital".

Norma que se retiró en el siguiente Reglamento de 1910

“Art. 302... La que desee criar por sí misma á su hijo en la Inclusa, pasará a este departamento en calidad de nodriza, sujetándose a las condiciones generales de las demás amas, pero sin otra retribución que la comida reglamentaria"

Realmente, como vimos en el capítulo dedicado a la Maternidad, la ordenanza de no dejar lactar al propio hijo no solo no se cumplió en el período de estudio, sino que, además, los niños nacidos en la Maternidad permanecían en la Inclusa con sus madres más tiempo antes de publicarse el Reglamento de 1910 que retiraba la norma que después; en la primera década el $52 \%$ de los nacidos en el establecimiento salió a criarse durante su primer mes de vida, mientras que después ese porcentaje subió al 84\% (GRÁFICAS 3-25 y 3- 27)

El cambió de actitud en los reglamentos y el incumplimiento de la norma escrita con anterioridad tuvo mucho que ver con la escasez de nodrizas; la posibilidad de cuidar al propio hijo y la obligación de permanecer en la Inclusa lactando a cambio de la estancia en la Maternidad resultaría un método de reclutamiento eficaz, aunque insuficiente dado el volumen de expósitos que ingresaban por las otras vías. También influiría la campaña que desde hacía años venían haciendo médicos e intelectuales a favor de la lactancia materna y contra la lactancia mercenaria, en una lucha precisamente por disminuir el número de expósitos y su tremenda mortalidad. Ya se ha comentado que esto no era nuevo, en la Edad Media las imágenes de las Vírgenes lactando querían enviar el mismo mensaje frente a la moda de usar nodrizas entre la nobleza y clases acomodadas, incluso podríamos remontarnos más en el tiempo y encontrar el mismo rechazo en pensadores como Plutarco ${ }^{614}$.

\footnotetext{
${ }^{614}$ La madre que amamantaba a sus hijos representaba en el Medievo el ideal de la maternidad, las imágenes de la Virgen amamantando a su hijo se prodigaron sobre todo en los siglos XII-XIV, María, Señora y Madre ideal, de naturaleza noble, amamanta a su Hijo ella misma en una muestra de amor maternal. La lactancia materna se "promocionó" así desde las obras iconográficas, literarias y didácticas, tanto las autoridades religiosas y morales como las médicas hablaban de sus beneficios y entre ellos destacaban el reforzamiento de la relación materno-filial,
} 
Las malas prácticas asociadas al oficio del nodrizaje y la preocupación por la mortalidad infantil dio lugar a un movimiento de opinión a partir del último tercio del siglo XIX a favor de la lactancia materna y contra el comercio de la lactancia mercenaria; las madres se consideraban moralmente responsables de la crianza directa y de la vida de sus hijos.

"La leche de la madre pertenece a su hijo y en ningún caso debe serle robada. La nodriza que deja a su propio hijo para ir a criar al ajeno, comete un crimen, autorizado es cierto por las leyes de protección a la infancia...porque la ley no se cumple ${ }^{\prime \prime 15}$

La lactancia materna prolongada se

defendió como la medida más importante para reducir los abandonos de niños y la mortalidad infantil y la regulación de la lactancia mercenaria junto con otras medidas de protección a la infancia se desarrollaron en la ley de 1904 y su Reglamento publicado en 1908 , entre ellas la protección a la mujer embarazada. Un aspecto a tener en cuenta que quedaba pendiente era el del trabajo, no todas las mujeres dejaban de amamantar a sus hijos por comodidad o por conveniencia, eran muchas las madres trabajadoras, sobre todo en las grandes ciudades, que abandonaban la lactancia forzadas

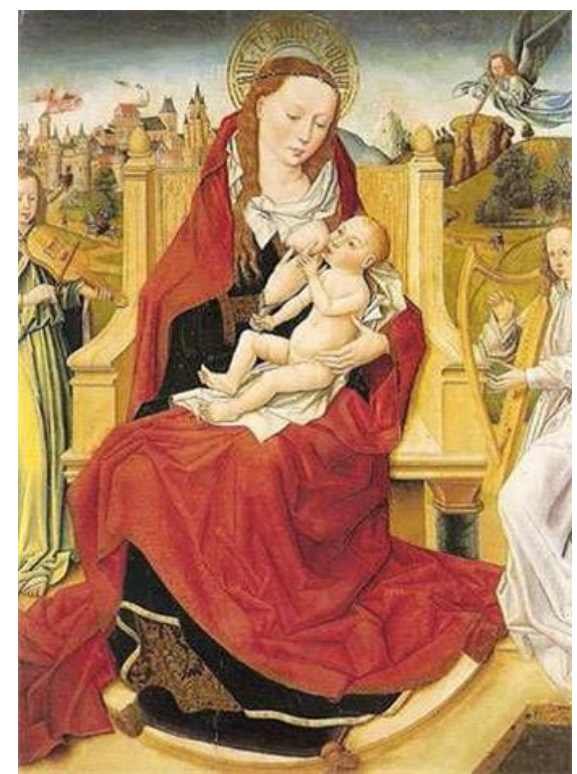

IMAGEN 3-26: Virgen de la leche. Pintura del siglo XV de influencia flamenca atribuida al taller de Diego de la Cruz. Museo de Burgos

por las circunstancias. Pediatras e higienistas argumentaron contra el trabajo de la mujer fuera de casa y promovieron el trabajo en el hogar por una cuestión social y de salud pública, la mujer como buena madre y reina del hogar sería la mejor medida para reducir la mortalidad, y defendían que las únicas excusas que se podían admitir para no lactar eran la falta de leche o la existencia de enfermedades maternas y problemas en los pechos. La Ley del 8 de enero de $1907^{616}$ estableció la obligatoriedad de reservar el puesto de trabajo a las trabajadoras hasta al

como una manera de evitar el abandono en los primeros años de vida y debido a la costumbre que se fue propagando de emplear amas de cría, que empezó primero entre las mujeres de clase noble y luego se fue haciendo extensivo a profesionales y artesanos acomodados, entre otras razones por la prohibición de tener relaciones conyugales durante la lactancia y por el miedo a perder la belleza.

${ }^{615}$ SUÑER E.: La salud del niño. Puericultura fundamental. Madrid 1920, p 11. Hace referencia a la Ley de 1904 y su reglamento de 1908 que, como muy bien dice en muchos casos se quedó en papel mojado porque se incumplían sistemáticamente, empezando por las instituciones públicas como las inclusas.

${ }^{616}$ Esta Ley de protección a la maternidad fue una de las más progresistas en cuestión social en su momento en el mundo. Se desarrolló a partir de una solicitud que presentaron Largo Caballero, Serrano y Mora al Instituto de Reformas sociales en 1906 justificada por "Ia propia condición de la mujer en el periodo anterior y posterior al alumbramiento, por las condiciones perniciosas del trabajo para los hijos". La ley prohibió el trabajo a las mujeres 
menos cuatro semanas después del parto, pero sin percibir salario alguno, con lo cual muy pocas mujeres pudieron acogerse a ella; en 1931 se institucionalizó el Seguro de Maternidad y se estableció una remuneración durante la baja maternal de 90 pesetas mensuales, estaba muy por debajo del salario ordinario pero representan ambas leyes un adelanto importante.

Se produjo por tanto un cambio de mentalidad en relación con las nodrizas de las inclusas que se refleja en ese cambio de actitud de la Cuna de Valladolid, una trasformación que no fue aislada, ocurrió también en las demás inclusas, realmente por imperativo legal, pues lo contrario sería ir contra la Ley de 1904, que por otra parte fue muy poco respetada tanto por instituciones públicas como por particulares. Mientras que en Pamplona separaban las madres de sus hijos mandándoles fuera, en Vizcaya las obligaban a lactar dos meses para la inclusa. En Madrid, los nuevos reglamentos también reflejaban el cambio, el de 1888 decía lo mismo que el de Valladolid en cuanto a que los hijos de las refugiadas serían los primeros en salir y en cambio el de 1915 diría que "las criaturas que nazcan en la Casa de Maternidad serán amamantadas por sus madres durante el tiempo de la estancia de éstas en la sala de puerperio, mientras el Profesor no encuentre motivo fundamental de contraindicación" ${ }^{617}$.

Esta transformación no dejaba de ser interesada, en el caso de las inclusas mantener la lactancia materna suponía garantizar al menos la lactación de los hijos de las refugiadas durante su permanencia en la Inclusa y enganchar nodrizas para los otros niños; resultaba una especie de trueque por un servicio prestado a mujeres que de otro modo no lo hubieran podido pagar. La mayoría de las refugiadas se quedaba sólo hasta saldar la cuenta que habían generado, pues después de una estancia más o menos prolongada vemos en el libro de la Maternidad que muchas ni pagaban ni percibían nada; las que no se quedaban a lactar tenían que abonar el importe íntegro de su estancia. La posibilidad de criar al propio hijo a cambio de alojamiento y comida explica estancias tan prolongadas en el Hospicio como la de Leopolda Calvo que permaneció en la Inclusa criando a su hijo (fo 214 LE 1905- 1) en exclusiva más de dos años (766 días), desde el 20 de mayo de 1905 hasta que falleció el niño el 6 de junio de 1907 por una estomatitis.

por un período no inferior a cuatro semanas después del parto que podía ampliarse hasta seis con justificación médica, durante el cual tenía derecho a que el patrono le reservara el puesto de trabajo en la fábrica. También podía aplicarse este derecho a partir del octavo mes de embarazo con certificación médica. El problema de esta ley es que no contemplaba un sistema que permitiera indemnizar económicamente a las mujeres durante su ausencia obligatoria del trabajo, lo que suponía para ellas verse privadas de un salario del que muchas no podían prescindir. GARCÍA GONZÁLEZ G.: La protección a la maternidad, cien años de la Ley de 8 de enero de 1907. Universitat Pompeu Fabra. IUS Labor 2, 2007. Disponible en: https://www.upf.edu/iuslabor/_pdf/2007-2/Historia2Guillermo.pdf ${ }^{617}$ REVUELTA EUGERCIOS B.A.: op. cit., p 209; VALVERDE L.: Los Niños expósitos y sus nodrizas en el País Vasco. San Sebastián, 1990 
Las mujeres de la Maternidad no eran suficientes para garantizar la lactancia de todos los pequeños asilados, por el libro sabemos que también se contrataban algunas mujeres externas al asilo. La preocupación por la altísima mortalidad de la Inclusa, que se consideraba consecuencia de la falta de nodrizas y del uso de la lactancia artificial, así como de las malas condiciones de muchos niños en crianza externa, llevó a la Comisión provincial en 1923 a tomar la decisión de equiparar a las mujeres que eran atendidas gratuitamente en la maternidad del Hospital provincial con las de la Inclusa, obligándolas a lactar para poder disponer de más amas de cría internas. En una carta la Diputación provincial comunica a los directores del Hospital Provincial y del Hospicio las decisiones aprobadas el 4 de septiembre para unificar los criterios en las dos maternidades, a pesar, dice, de la corriente creciente en contra de este tipo de procedimientos. Sin entrar en valoraciones éticas sobre la obligación de lactar impuesta a estas mujeres, no se trataba en la misma forma a unas y a otras, cuando sus requisitos y condiciones de ingreso eran similares y las estancias podían ser igual de dilatadas, solamente variaba el establecimiento donde se producían. La Diputación, en la misma carta hacía responsable al Estado de la falta de ayudas dirigidas a las mujeres embarazadas, que podrían evitar estos procedimientos que denomina "tributos de sangre"; a pesar de ello, considera abusivo y falto de equidad el régimen de las mujeres atendidas en el Hospital y calcula que si se hubieran quedado en la Inclusa a lactar habrían podido amamantar, y posiblemente salvar al librarles de la lactancia artificial, a ocho niños

\footnotetext{
"Actualmente las gestantes que ingresan en el Hospicio adquieren el compromiso de lactar a los niños del establecimiento durante un tiempo igual al que han estado asiladas; y las que permanecen en el Hospital se ven libres de este compromiso, dándose el caso anómalo de causar estancias durante cinco o seis meses sin contraer el menor compromiso de lactancia, beneficio del que disfrutan sean o no de la provincia.... Proponemos a esta Corporación que ...

Las embarazadas de la provincia de Valladolid o con dos años de residencia en la misma, tendrán derecho a permanecer en la maternidad durante un mes, y los días que pasen de este plazo tendrán la obligación de lactar en la Inclusa tantas fechas como estancias hubieran causado más de ese mes...

Palacio de la Diputación de Valladolid a 3 de agosto de 1923
}

Sabemos que esta decisión se implantó para las mujeres del Hospital porque en el ADPVA se conserva un libro, que no se ha podido consultar porque corresponde a 1923-1948, que se denomina "Amas internas procedentes del Hospital Provincial" ${ }^{618}$. Las mujeres casadas no tenían obligación de lactar en la Inclusa y las solteras de la provincia podían permanecer ingresadas hasta un mes exentas de ese deber, pagando con la lactancia las estancias

\footnotetext{
${ }^{618}$ Signatura: caja 1260, expediente 7861. ADPVA
} 
superiores. Sin embargo, no se aplicó en la misma medida para las refugiadas del Hospicio, al menos en el nuevo reglamento de 1927 no se recogieron estas modificaciones, realmente parece que se hizo una interpretación poco acertada de esta norma, pues se pasó a obligarlas a lactar un tiempo mínimo de un mes. Mientras que el reglamento de 1910 dice que "Las mujeres que ingresen gratuitamente en este departamento están obligadas á lactar en el Establecimiento sin retribución, tanto tiempo como el transcurrido desde el día de su ingreso hasta el que dieron á luz", en el de 1927 se añade que "...están obligadas... durante un mes, o por tanto tiempo como el transcurrido desde el día de su ingreso hasta el que dieron a luz, si excediese de aquél" (Art. 298) (texto íntegro de la carta que dirigió la Diputación a los ditrectores del Hospital y del Hospicio en ANEXO 8)

\subsubsection{Procedencia de las nodrizas}

La mayoría de las nodrizas internas procedían de la sala general de la Maternidad, la de no pensionistas o gratuitas; en 1912 cuento 112 amas internas, 89 eran refugiadas, son las únicas de las que sabemos con seguridad su origen porque se indica en los Libros de Exposiciones. Para saber la procedencia de las nodrizas podemos acudir al libro de Maternidad; en él se anotaba la sala de la residente y en todas aparece la sala general, no he encontrado, como por otra parte es lógico, ninguna mujer de la reservada. Como en los libros de la Inclusa conservados se anotaba la sala de las madres asiladas, he podido comprobar que ninguna de las pensionistas lactó expósitos. En la parte del libro dedicada al registro de nodrizas internas, y en las Entradas de la Inclusa, se indicaba también si procedían del Hospital, cuando no dicen nada damos por supuesto que serían contratadas del exterior. Entre ellas hay alguna antigua refugiada como Agustina Muñoz, soltera de 25 años, dice en su folio que salió en marzo de 1910 cuando su hijo falleció (fo 29, LE 1910- 1) y volvió como nodriza interna casi un año después, permaneciendo desde el 5 de febrero de 1911 hasta el 13 de marzo de 1912.

Las que daban a luz en el Hospital tenían la posibilidad, aunque no la obligación, de ir a la Inclusa a lactar. Muy pocas de estas mujeres pasaban a la Inclusa, por eso, en 1923 se propuso en la comisión provincial considerar a las que tenían asistencia gratuita igual que a las refugiadas del Hospicio y obligarlas a pagar la estancia como nodrizas internas. En 1909 ingresaron en la Inclusa 36 niños nacidos en el Hospital, pero solamente pasaron a lactar 19 de sus madres como nodrizas internas. A la vista de los datos registrados en los Libros de 
Exposiciones podemos decir que estas nodrizas no lactaban a sus propios hijos; se comentó en el apartado dedicado a la Maternidad el caso de Teodora Ruiz Villarejo que estuvo lactando a cinco niños mientras que su hija estaba a cargo de otra nodriza, Florencia Pocero (fo 164, LE 1909-1). La explicación está en el intervalo de tiempo desde que ingresó la niña el 1 de mayo hasta que llegó la madre el día 8, al ingreso a la niña se le asignó, como se hacía normalmente, una nodriza, aunque luego pudo cambiar. Compruebo que éste no es un caso aislado; también en 1909, Dorotea Monzón, soltera de 19 años procedente del Hospital lactó al hijo de Fausta López, casada, que estaba ejerciendo de nodriza interna y también dio a luz allí, mientras que a su hijo, Segundo Monzón (fo 185, LE1909-1) le lactó, siempre según el libro, otra nodriza, Vicenta Urueña, una refugiada que tuvo 27 lactantes en 14 meses. El niño Segundo falleció el 29 de mayo, unos días antes de que su madre Dorotea, que no sabemos qué día ingresó en la Inclusa, empezara a lactar a un expósito. Parece un despropósito tener madres e hijos en el mismo lugar y separados, salvo que fuera una opción elegida por la madre, una mujer que en muchas ocasiones intentaría no tener demasiado apego con un hijo del que sabía que se iba a separar; sin embargo, aunque no cuidara de él tendría que verlo estando dentro de la Inclusa. Es razonable pensar que muchas madres preferirían cuidar de su propio hijo teniéndole allí mismo, sin embargo, no podemos asegurar si se hacían cambios entre las nodrizas al no haber constancia escrita salvo del ama adjudicada inicialmente.

Hay otro grupo de nodrizas en las que se dice nada sobre su procedencia, serían mujeres que se ofrecían a la Inclusa y se las contrataba, sobre ellas no hay más datos que los que se anotaban en el libro de la Maternidad, que en la mayoría era solamente su naturaleza, o localidad de origen, ni siquiera tenemos edad o estado civil.

En los libros encontramos algunos registros sorprendentes que recogen la entrada de madre e hija, algo que en principio se quería evitar. Emérita Vélez entró el 17 de mayo de 1910 y en su folio se ha escrito que "su hija ingresó por el torno el mismo día fo 176 libro exp on". En el folio de la niña se ha escrito también una nota al margen "el mismo día ingresó como ama interna en esta Inclusa la madre de la niña Emérita" y aunque en el Libro de Exposiciones no se ha anotado quien "la lacta", en el de la Inclusa ("Entradas y salidas de los Niños de la Inclusa Años de 19091910 1911") figura su madre y además dice que era casada y la niña hija legítima, que nació en el Hospital provincial 22 días antes y "por ropas traía trapos". Esta mujer salió con su hija el 17 de junio de 1910 "por haber sido reclamada de Orden del Sr Juez del distrito de la Plaza de esta Ciudad para cumplir la pena impuesta á la Emerita, por hurto de un lingote en causa seguida al efecto. En 11 de Julio de 1910 reingreso esta niña después de cumplir la madre la pena impuesta" [sic] (fo 176, LE 1910-1) y falleció en el asilo el 16 de octubre "a 
consecuencia de Bronquitis capilar". La madre reingresó con ella y permaneció en la Inclusa hasta el 31 de octubre, después de su fallecimiento, en ese período la cuidó en exclusiva hasta el 18 de septiembre, cuando le asignaron dos niños más. En esto parece que también hubo un cambio de actitud porque en 1905 hubo una situación similar de una madre que ingresa en la Inclusa con su hijo, depositado en el torno, pero la debieron exigir lactar más niños y se fueron los dos porque en el folio de inscripción del niño se ha escrito que "no conveniendo a su madre criar más que a su hijo se marcha al día siguiente" (sic) (fo 263, LE 1905-2).

En 1911 en el libro de Exposiciones, fo 43 figura una niña expuesta en el torno el día 5 de febrero

"con un papel que dice "En la calle de Renedo número 9 nacio una niña el dia 12 de Enero de 1911 á la cual se la bautizó en la parroquia de la Magdalena y se la puso Sarita Blanco Muñoz hija de Cecilio blanco y Agustina Muñoz, abuelos...»... Por ropas traía puestos unos trapos" [sic]

En el margen del folio hay una nota: "El mismo día ingresa la madre de ama interna" y se registra como ama lactante a su madre: "La lacta Agustina Muñoz". La niña salió el 17 de marzo con una nodriza externa y el 19 de septiembre volvió con su madre, por poco tiempo, el 25 del mismo mes la volvió a depositar en el torno. Una historia que revela la desesperación de esta mujer que intenta a toda costa criar a su hija y el estado de pobreza en que debía vivir. No hay muchos registros de este tipo, pero éstos serían solamente los casos conocidos, es probable que alguna nodriza más se colara para estar con su hijo. En todo caso la Inclusa de Valladolid demuestra bastante tolerancia, teniendo en cuenta la normativa y el espíritu de las inclusas que rechazaban estas prácticas, y una actitud progresista actuando en cierta forma como lo hacen hoy los servicios de asistencia social al intentar evitar el abandono ayudando a la madre, aunque con limitaciones y sin resultado positivo en ninguno de los dos casos vistos.

\subsubsection{Patrón de comportamiento de las refugiadas}

No hay un patrón de comportamiento de las refugiadas respecto a la permanencia en la Inclusa lactando. La mayoría de las nodrizas internas procedían de la sala general de la Maternidad, la de no pensionistas o gratuitas. En los Libros de Exposiciones he comprobado que el ama lactante de todos los niños nacidos en la Maternidad siempre fue su propia madre, a partir de 1908 se dejó de anotar en los Libros de Exposiciones el nombre materno, pero tampoco se anotaba el de ninguna nodriza, por otra parte, en el libro de la Inclusa seguirían 
escribiendo el nombre y se comprueba que era la madre. El hecho constatado es que todas las refugiadas lactaban a sus hijos, por tanto también las pensionistas, aunque no podemos saber exactamente cuánto tiempo permanecían éstas en la Maternidad porque, como he dicho, no están registradas en el libro normal y además hay que tener en cuenta que, al pagar su estancia, en teoría no estarían obligadas contractualmente a quedarse lactando. Lo único que podemos valorar en el caso de aquellas pensionistas que sabemos con certeza que lo son, es la permanencia de los niños en la Inclusa gracias a los Libros de Exposiciones. Según éstos, hay estancias muy cortas; de 53 niños que sabemos con seguridad que nacieron en la sala reservada, sin contar cuatro fallecidos en las primeras horas, 25 salieron o fallecieron en los primeros 15 días de vida ( 8 en la primera semana); también hay estancias relativamente prolongadas: 17 niños salieron o fallecieron en la segunda quincena y 9 entre el primer y segundo mes de vida. Como no se anotaba nada más que el nombre de la nodriza inicial, ni tenemos registros sobre estas mujeres, no sabemos si durante toda la estancia de los niños permanecieron las madres en la Maternidad lactando; si les aplicaban el mismo criterio que a las mujeres de la sala general sería un tiempo que tendrían que abonar, pero no por ello vamos a descartarlo pues es de suponer que tenían posibilidades económicas o, si no ellas, alguien con medios se hacía cargo de su estancia. Los casos que nos plantean más dudas al respecto son dos niños que permanecieron en la Inclusa uno 113 días y otro 399, el primero murió por atrepsia en el asilo, el segundo salió para crianza externa.

Encontramos muy pocas mujeres como la mencionada anteriormente Leopolda Calvo que permanecieran como nodrizas durante toda la estancia del hijo lactándole en exclusiva; algunas, como ella, se quedaban hasta que el niño fallecía; son muy pocas, en 1908 solamente encontramos a Justa Aguado con una estancia superior a un año (436 días), no puso sus apellidos al niño pero permaneció interna hasta que falleció por una enteritis (fo 162, LE 19081). En otras ocasiones se quedaban hasta que el niño salía con una nodriza externa para crianza, es el caso de Andrea Hernández que estuvo más de 13 meses (410 días), (fo 2, LE 1905-1) o de Francisca Castañeda (399 días) (fo 312, LEE 1909-2). Estos son casos aislados, como mucho encontramos uno o dos anuales y en la mayoría de los años no detectamos estancias tan largas para cuidar al hijo en exclusiva; también podemos hacer la interpretación al revés y decir que el niño se mantenía interno mientras la madre permanecía en la Inclusa y se comprometía a cuidarle. Por lo que conocemos del funcionamiento del centro, estas mujeres tendrían asignada alguna tarea más que el cuidado de sus hijos.

En general las estancias prolongadas eran remuneradas e incluían lactar a varios incluseros. En 1905 la refugiada Encarnación Arapiles cuidó de su hijo los 18 meses del período 
de lactancia, exactamente 560 días, durante los cuales lactó, o cuidó, a 6 niños más, tres de ellos coincidiendo con su hijo y de éstos, dos fallecieron "a consecuencia de catarro intestinal"; cuando el hijo (fo 191, LE 1905-1) salió para crianza ella tomó un expósito y permaneció en la Inclusa otras dos semanas.

Las refugiadas gratuitas que no podían pagar su estancia se quedaban lactando aunque el hijo falleciera al nacimiento; en 1912 nacieron tres niños muertos y sus madres fueron nodrizas internas: Eufrasia Alonso parió el 23 de marzo y se quedó lactando a tres niños de forma sucesiva hasta el 17 de septiembre, María Trapero lactó a dos niños también sucesivamente durante 13 días y Consuelo Zarzuelo solamente a uno durante 11 días; estas mujeres permanecerían en la Inclusa hasta saldar la cuenta de su estancia en la Maternidad.

No podemos asegurar que durante su permanencia en la Inclusa los niños estuvieran siempre con la misma nodriza, no hay constancia en los libros, ni de esto ni de lo contrario; en los folios donde dice "Le lacta" solamente figura el nombre de la que se le asignaba al ingreso. En ninguno de los folios revisados aparece más de una nodriza, a pesar de que es probable que durante su ingreso algunos expósitos pasaran por más de una mano dado el movimiento de amas que había en la Inclusa, pero no se anotaba el cambio en el libro de Exposiciones. En los casos vistos la coincidencia temporal de la estancia de madre e hijo nos hace dar por buena la idea de que estarían juntos.

Contrastando el único libro de la Maternidad que se ha podido consultar (1906-1909) con los de Exposiciones, podemos comprobar que no todas las amas se quedaban hasta que los niños asignados salían de la Inclusa, o fallecían: Orosia Olmedo salió el 21 de enero y el niño que estaba criando el 31 del mismo mes (fo 392, LE 1908-1); Epifanía Cid terminó de lactar el 12 de julio de 1909 estando a cargo de la expósita Dorotea Álvarez (fo 179, LE 1909- 1) que falleció el 1 de agosto por una enterocolitis. Ni siquiera en estancias largas, en las que podíamos pensar que unos días más o menos darían lo mismo, María Galindo estuvo según el libro de la Maternidad 19 meses trabajando para la Inclusa y salió el 5 de enero de 1910 estando con la expósita Loreto Alfageme que falleció el 8 de febrero por una bronquitis capilar, le asignaron en total 19 niños más su hijo y 12 fallecieron; Teresa Romero estuvo como nodriza 16 meses y cuando salió estaba lactando un niño que falleció un mes después por gastroenteritis. Para muchas mujeres lactar solamente era un trabajo como otro cualquiera. Los niños que se quedaban sin nodriza deberían ser asignados a alguna otra, si no para lactancia por lo menos para hacerse cargo de sus cuidados, en ninguno de sus folios hay constancia del cambio. 
Tampoco se quedaban todas las nodrizas-madre hasta la salida, o el fallecimiento, de sus propios hijos: Francisca González salió de la Inclusa el 17 de agosto de 1908 y su hija falleció interna el día 29 por catarro intestinal; María Arribas salió de lactar el 27 de septiembre de 1908, su hijo falleció en la Inclusa el 8 de octubre por gastroenteritis.

En el libro de la Maternidad sólo encontramos un apunte que dice que la madre "se llevó a su hijo José". La refugiada dio a luz el 29 de mayo de 1908 y pasó a lactar a la Inclusa el 5 de junio, lactó a su hijo José, (fo 172, LE 1908-1) hasta el 8 de julio, fecha en que el niño salió con una nodriza externa. La madre continuó lactando en la Inclusa y allí seguía cuando el niño fue devuelto "sin justificar el motivo". José no volvió a salir y su madre permaneció lactando hasta el 5 de enero de 1910, es entonces, después de 20 meses, cuando se anota en su hoja que se llevó al hijo con ella. En el folio del niño dice

"En 7 de Enero le llevó su Madre autorizada para ello por la Comisión provincial y conforme á lo dispuesto en el Reglamento cuando la Madre se obliga a cuidarle y reconocerle como tal hijo. No firma su recibo por no saber".

En los catorce años revisados solamente otras tres refugiadas se llevaron a sus hijos al salir de la inclusa, 46 más los recuperarían al cabo de más o menos tiempo.

\subsubsection{Productividad de las nodrizas internas}

Por el libro de Maternidad ${ }^{619}$ podemos saber cuánto tiempo podía estar una nodriza lactando en la Inclusa, pero no se ofrecen datos referentes a los niños que criaba; tenemos que echar mano de los Libros de Exposiciones y de los de Entradas de la Inclusa para evaluar, examinando folio a folio, cuántos niños crió cada una, por cuánto tiempo y las coincidencias temporales que nos permitan detectar los que alimentaba simultáneamente. Podemos ver algunos de los casos más llamativos.

$\checkmark$ IRENE RAMOS: dio a luz el 22 de diciembre de 1911 en la sala general, lactó a su hijo en exclusiva hasta el 11 de enero (fo 410, LE 1911- 2) y, según el Libro de la Inclusa, a otros 26 niños después, hasta el 6 de septiembre de 1912, muchos de ellos de estancias cortas y tuvo un período de 14 días sin lactar. En alguno de los registros no coinciden los dos libros, el de Exposiciones y el de la Inclusa. (En los folios 105 y 273 del libro de Exposiciones no consta el nombre de la nodriza,

\footnotetext{
${ }^{619}$ Entradas Maternidad 1906, 907 Y 1908. Signatura: caja 929, expediente 7142. ADPVA
} 
mientras que en el de la Inclusa figura Irene Ramos y en el fo 261 LE aparece esta nodriza mientras que en el de la Inclusa está registrada María Marcos). Llegó a tener a su cargo a 6 niños simultáneamente; es imposible que pudiera lactar a todos a la vez, se podría hacer como mucho lactancia mixta, sin embargo no consta. El resultado es que salvo dos de ellos de estancias cortas ( 3 y 6 días) los demás fallecieron 5 en el mes de julio: uno por sífilis, otro por atrepsia por dispepsia (una forma de desnutrición por alteración digestiva crónica con diarreas de origen alimenticio) y 3 por infecciones gastrointestinales y el último en septiembre por un colapso. Los problemas digestivos de cuatro de ellos nos hacen sospechar en alimentación con biberón, sobre todo en el caso de la atrepsia que es de origen alimenticio; salvo uno de los niños que sobrevivió que tenía 3 meses, los demás los cogió en su primer mes de vida. Su hijo salió para crianza y fue devuelto el 28 de junio de 1913 falleciendo diez días después en la Cuna por enterocolitis.

MARÍA SAEZ: dio a luz en la Maternidad el 5 de julio de 1912, lactó a su hijo hasta el 12 de agosto, cuando salió para crianza externa (fo 247, LE 1912- 1). Según el libro de la Inclusa lactó a otros 33 niños hasta el 31 de marzo de 1913. Como en el caso anterior hay registros que no coinciden en los dos libros y aparecen nombres diferentes de nodrizas (en el fo 261, del LE de 1912 figura precisamente Irene Ramos y en el mismo año en el fo 442 María Sánchez y en el fo 443 María Reguero) o en el de Exposiciones no se ha anotado ningún nombre (fo 370, LE 1912- 2). Durante el tiempo que estuvo con su hijo se hizo cargo de otros 6 niños, a partir del 16 de julio, uno de casi 3 meses y los demás menores de 12 días. Coincidieron a la vez 4 niños con su hijo y, 5 de los 6 fallecieron entre el 29 de julio y el 7 de agosto, uno de sífilis congénita, uno por una atrepsia por dispepsia y los otros tres por infecciones gastrointestinales. Solamente sobrevivieron a la Inclusa su hijo, que salió para crianza externa el 12 de agosto, aunque luego fallecería en el pueblo de Torreadrada en octubre, y otro niño (fo 287, LE 1912- 2) que también salió al mes de su ingreso y murió con la nodriza en enero de 1913.

Carmen Calvo dio a luz el 24 de noviembre de 1913 y a partir del 7 de diciembre y hasta el 12 de octubre de 1914 lactó a 31 niños más. Evidentemente no todas las nodrizas eran así de productivas y no siguen un patrón fijo, muchas lactaban únicamente a sus hijos, otras se hacían cargo de algunos más después de salir su hijo de la Inclusa hasta saldar su cuenta y 
otras cogían niños coincidiendo o no con el propio y prolongaban su estancia cobrando ya por ello; era muy habitual que coincidieran, como hemos visto dos o más lactantes juntos.

\begin{tabular}{|c|c|}
\hline Albacete & $3{ }^{\prime} 00$ \\
\hline Almería & $1^{\prime} 60$ \\
\hline Badajoz & $2-10$ \\
\hline Burgos & $3 \prime 80$ \\
\hline Castellón & solo biberón \\
\hline Granada & $2 \prime 08$ \\
\hline Guadalajara & 4 \\
\hline Huesca & $1^{\prime} 22$ \\
\hline León & $2 ’ 55$ \\
\hline Logroño & $12^{\prime} 00$ \\
\hline Palencia & $1^{\prime} 95$ \\
\hline Santander & $2 \prime 92$ \\
\hline Soria & solo biberón \\
\hline Tarragona & $6^{\prime} 33$ \\
\hline Toledo & $1^{\prime} 75$ \\
\hline Zaragoza & 2 \\
\hline Valladolid (1900-1913) & $3 ’ 52$ \\
\hline
\end{tabular}

Bárbara A. Revuelta en su tesis sobre la inclusa de Madrid $^{620}$ nos ofrece una tabla sobre el número de niños por nodriza en distintas inclusas españolas a partir de los datos de las Inspecciones de las Inclusas realizadas por el Consejo Superior publicados en 1918 que reproduzco en la TABLA 3-22, en ella faltan datos sobre la provincia de Valladolid. No dispongo de los datos de 1918 porque se sale del período de consulta permitido, pero puedo proporcionar la media para el intervalo 1900- 1913 que es de 3’52 niños por nodriza, con mucha variabilidad, la mayoría (el $42^{\prime} 24 \%$ ) solamente tuvieron un niño, el $24 \% 2$ ó 3, pero hay un $8 \%$ a las que se han contabilizado más de 20 niños durante una estancia de meses en la Inclusa, aparte de las arriba mencionadas Vicenta Urueña está entre las mujeres que criaron más niños, 27 en total contando a su hijo, desde que dio a luz en la Maternidad el 17 de julio de 1908 hasta el 20 de septiembre de 1909. En la tabla, las inclusas de Castellón y Soria en la fecha no disponen de nodrizas internas y alimentan a sus asilados solo con biberón.

Sofía Guerrero López dio a luz el 28 de febrero, pasó a lactar el 8 de marzo y salió del asilo el 10 de julio de $1907^{621}$, consultando el libro de Exposiciones de 1907 y el Libro de la

\footnotetext{
${ }^{620}$ REVUELTA .B A.: op. cit., p 316

${ }^{621}$ Ibídem, p 4
} 
Inclusa Años 1906 y 1907, 1908 ${ }^{622}$ comprobamos que lactó a su hijo (fo 79) hasta que salió el 24 de abril y la encontramos como nodriza interna de otros cuatro niños más. Por las fechas de entrada de cada uno de ellos vemos que le asignaron el primero estando todavía con su hijo, los otros tres los cuidó simultáneamente, los tres fallecieron. No sabemos, porque no hay constancia escrita en los libros, si los alimentó solamente al pecho o se ayudó con biberón, ni siquiera en el último de ellos que falleció por sífilis. Las fechas de inicio y final de lactancia de cada uno se han recogido en la siguiente TABLA 3-23 para valorar las coincidencias temporales

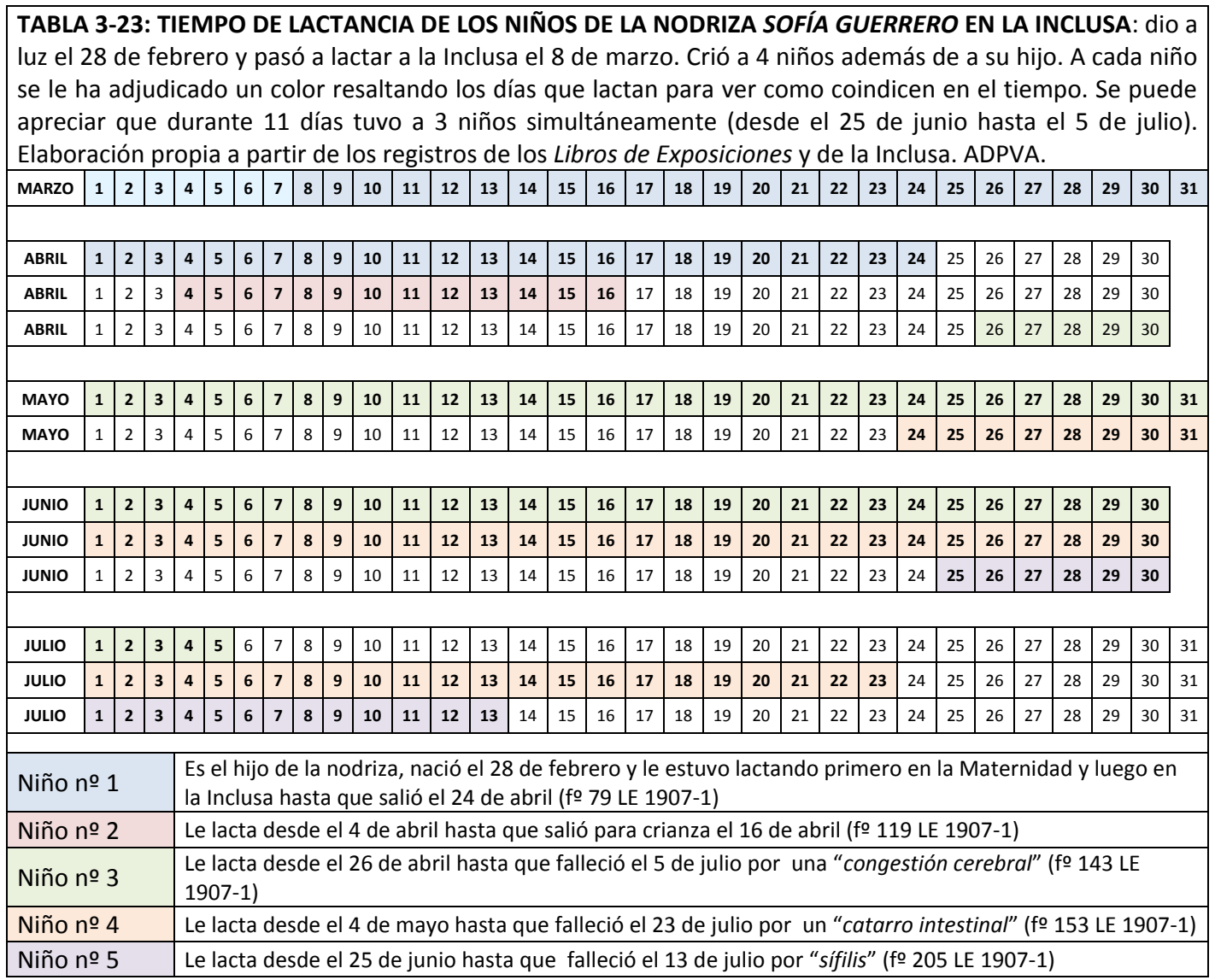

Otra cuestión que merece mención aparte es la de las nodrizas sifilíticas. Se supone que las nodrizas debían reunir buenas condiciones de salud y la sífilis debería excluirlas para la lactancia porque por entonces se consideraba que era una de las formas de transmisión de la enfermedad, aunque hoy sabemos que solo hay riesgo si existen lesiones en el pezón. Examinando los libros observo que una de las nodrizas que figuran en el libro de la Maternidad, Ezequiela Pastor, tenía que padecer sífilis porque su hijo falleció en el asilo a los 13 días de vida por este mal congénito (fo 389, LE 1909-2). Según dice su folio de registro la

\footnotetext{
622 Signatura: caja 1213, expediente 7736. ADPVA
} 
mujer llegó al centro conducida por agentes municipales que la encontraron enferma en las Moreras, pasó a lactar el 22 de diciembre y estuvo casi 7 meses lactando, hasta el 7 de julio de 1910, tiene pagos por lactancia desde el 18 de mayo. Al examinar el Libro de Exposiciones de 1910 no la encontramos registrada durante este tiempo en ningún folio como nodriza. En el período que se supone que estuvo lactando hay 19 folios en los que no figura el nombre de la mujer que lacta, 12 de esos niños fallecieron y en 3 expósitos la causa fue también una sífilis congénita. Podemos pensar que les lactó ella, lo que nos hace plantear una nueva hipótesis para estas situaciones en las que no se registra en el folio de inscripción a la nodriza, que se tratara de mujeres que, como ésta, fueran sifilíticas o por otros motivos, no reunieran condiciones. Otro asunto sería saber cuáles podían ser esas condiciones excluyentes porque encontramos por ejemplo a la refugiada Epifania Cid que según el libro ingresó "en concepto de presa por orden del Gobernador Civil" en septiembre de 1908 y permaneció lactando en la Inclusa casi nueve meses; le asignaron 6 lactantes, 4 fallecieron, dos de ellos también por sífilis congénita y su hijo falleció con 39 días de vida de tuberculosis generalizada.

Este hallazgo nos ratifica en la idea de que en la práctica no se daba importancia a las condiciones sanitarias de las nodrizas y podemos además plantear la hipótesis de que nodrizas como Ezequiela, sifilítica, se adjudicaran a niños con sospecha de padecer también el mal congénito, que podrían ser rechazados por mujeres limpias de esta enfermedad estigmatizante. En 1905 fallecieron por sífilis 21 niños en el asilo, 4 nacieron en la Maternidad y 3 de estas madres lactaron expósitos, es decir que estarían infectadas. Una de ellas tuvo a 13 niños, se murieron 5 y solamente uno por sífilis. Otra lactó a 4 niños y se murió uno por esta enfermedad, la tercera tuvo a 3 expósitos que sobrevivieron. Es decir, que 6 de los 24 niños fallecidos por este mal podemos asegurar que fueron lactados por mujeres enfermas, entre ellos sus hijos, el resto de niños fueron lactados por otras nodrizas internas y 8 de ellos salieron para crianza externa. De los 41 registros en que no consta el nombre de la nodriza, no aparece el diagnóstico de sífilis en ninguno de los que fallecieron en el asilo, en los 8 niños fallecidos en los pueblos de crianza no se anota la causa. Se revisa 1909 y 1912 y la situación es similar, todos los niños fallecidos por sífilis tienen un ama adjudicada en los libros, algunos llegaron a salir antes para crianza externa; muchas de las madres de estos niños, que serían enfermas, lactaron en la Inclusa y son contados los expósitos lactados por estas mujeres que también fallecieron por sífilis. En cuanto a los niños que no tienen adjudicada ama tampoco figura ninguno fallecido por esta enfermedad, en los que fallecen en pueblos se desconoce la causa. A la vista de estos resultados no parece que se tuviera en cuenta la condición de sifilítica de la nodriza a la hora de adjudicarle niños, por lo que podemos pensar que al revés 
tampoco se haría, salvo en niños con síntomas claros que pudieran ser rechazados por nodrizas limpias de este mal. Un aspecto a tener en cuenta en relación con esta enfermedad es que la sífilis congénita puede manifestarse de forma muy tardía, incluso después de varios años.

No puedo cerrar este capítulo sin resaltar una observación hecha a partir de los datos que hemos ido viendo y que enlaza con el capítulo siguiente, todos los niños que se quedaron sin nodriza fallecieron por infecciones gastrointestinales, menos uno por bronquitis. Es probable que estos niños, si no había nodrizas disponibles, pasaran a lactancia con biberón.

\subsubsection{Lactancia artificial.}

La falta de nodrizas obligaba a utilizar lactancia artificial, a pesar de sus reconocidos peligros; se trataba de elegir entre dos riesgos, o dos males, la muerte por hambre o por comer inadecuadamente. El doctor Vidal Jordana, catedrático de Enfermedades de la Infancia que se hizo cargo de la Inclusa Provincial, decía en una conferencia que pronunciaba el 2 de abril de 1927 en el salón de actos de la Universidad de Valladolid sobre El problema de las inclusas en España que "Los niños alimentados con biberón en las Inclusas se mueren todos" 623

La lactancia artificial (el uso de una leche diferente a la de nuestra propia especie), ha sido siempre el recurso utilizado cuando por algún motivo no era posible la lactancia natural, ya sea materna o mercenaria, aun cuando se conocían sus riesgos, porque se consideraba de más alimento que sopas, papillas y gachas, que eran ya la última opción a falta de cualquier tipo de leche. Se conservan "biberones" ${ }^{\prime 24}$ de toda clase (vasos de alimentación o en definitiva utensilios para este uso) datados con una antigüedad de más de 2.000 años para administrar a los bebés leche animal o de la propia madre extraída manualmente y existen reseñas sobre su uso en Egipto, Grecia y Roma ${ }^{625}$. Se empleaba la leche de origen animal ofreciéndosela a los

\footnotetext{
${ }^{623}$ N.C. 3- 4- 1927 , portada

${ }^{624}$ En los diccionarios de lengua castellana encontramos por primera vez el término BIBERÓN en el gran Diccionario de Adolfo de Castro y Rossi de 1852, p 379, 2: Aparato para dar de mamar a los niños que no se crían al pecho. E primer diccionario de la RAE que lo recoge es el de 1884, 12a edición, p 149, 2: (del fr. biberon; del lat bibere, beber. Instrumento para la lactancia artificial, que consiste en una botella pequeña de cristal o porcelana, con un pezón de goma elástica, de teta de vaca o de marfil reblandecido, para la succión de leche.

${ }^{625}$ Cfr: MIRALLES SANGRO M.T.: Pequeña historia del biberón. Madrid 2012; MCLAUGHLIN M.: Supervivientes y sustitutos. Hijos y padres del siglo IX al siglo XIII. En: DEMAUSE LI.: Historia de la infancia. Madrid 1982, pp 121- 205 En la Edad Media está documentado lo que se llamaba el cuerno de mamar, un cuerno pequeño y pulido agujereado en la punta donde se colocaban dos trocitos de pergamino para que el niño pudiera chupar. Se dice que
} 
infantes en biberón o de forma directa, poniéndoles a mamar del animal escogido (nos viene a la memoria la imagen de Luperca, la loba capitolina, amamantando a Rómulo y Remo y en la mitología griega la cabra Amalthea a Júpiter). Se recurría a la leche de animales domésticos, sobre todo de cabra y, en menor medida, de vaca, oveja y de burra; a pesar de que la leche animal no se consideraba adecuada para los niños; entre otras cosas, se llegó a pensar que los lactantes podían adquirir las cualidades del "animal nodriza".

"Aseguraos de que el ama de cría tiene leche suficiente, pues de no ser así puede dar al niño leche de cabra o de oveja o de burra o de otro animal, y el niño o la niña alimentados con leche de animales no tiene una inteligencia normal como el alimentado con leche de mujer, sino que siempre tiene cara de estúpido y vacuno y de no estar bien de la cabeza"1626,

Es una creencia que ha persistido durante siglos; todavía en 1913, en un artículo de Vulgarización cientifica, podemos leer lo siguiente sobre la lactancia con leche de cabra:

"El vulgo asigna a los niños criados por las cabras un carácter en extremo voluble y caprichoso. Hemos tenido ocasión de comprobar ese detalle en algunos niños criados en tales condiciones; entre ellos uno muy allegado a nosotros, a quien una cabra crió durante cinco meses y ni en la familia, ni en los negocios, fue modelo de constancia y formalidad. $Y$ no titubearíamos en aconsejar a la mujer lo pensara mucho antes de unirse a un hombre a quien una cabra se hubiera encargado de criarle ${ }^{\prime 627}$

El animal preferido para la lactancia era la cabra, por su disponibilidad y porque permitía que el niño mamara directamente de sus ubres, la leche de burra también fue apreciada y utilizada, sobre todo en hospitales y centros de acogida ${ }^{628}$; en los Presupuestos

Santa Isabel de Turingia tenía uno de plata, la plata al oxidarse, además de oscurecerse pasa a estado coloidal y tiene efecto germicida, los del pueblo llano eran de cuerno de animal. Algunos museos europeos los conservan, en el cuadro La cocina parva (1563), Brueghel El Viejo pinta una anciana alimentando a un niño con el cornete y de él se habla en La espantosa y admirable vida de Roberto el diablo. Anónimo del siglo XII

"Y cuando este diablo mama, muerde siempre a la nodriza, grita y ruge sin cesar, nunca está contento si no refunfuña. Las nodrizas tenían tanto miedo de alimentar a este demonio, que le confeccionaron un cuerno y nunca más le volvieron a amamantar"

También se utilizaba una especie de manga pastelera con un trozo de esponja natural que se impregnaba de leche en el cuello y se cubría de un lienzo fino y biberones en forma de botella de base ancha fabricados artesanalmente en terracota, madera, cuero, cerámica, estaño, plata o vidrio y la mayoría Encontramos biberones de madera en el cuadro de Brueghel El Viejo Señores de visita en una granja, o en el cuadro anónimo la Virgen María dando el biberón al niño Jesús. La mayoría eran de una sola pieza, por lo que resultaban muy difíciles de limpiar y las tetinas muy duras o incómodas y antihigiénicas. En el siglo XIX se empiezan a fabricar industrialmente, en vidrio y con diseños diferentes, según el fabricante, y las tetinas separadas y de goma.

${ }^{626}$ Cita extraída del Libro de buoni costumi de Paolo da Certaldo, del siglo XIV (citado por ROSS B.J. en "El niño de clase media en la Italia urbana del siglo XIV a principios del XV, p 211, En DEMAUSE LI. Historia de la infancia. Madrid 1982, pp 206- 254. Existía el miedo a que el niño alimentado con esta leche se pareciera al animal, este riesgo se manifiesta a menudo en textos italianos, ya que las balias (nodrizas) vivían en el campo y debía ser frecuente que utilizaran la leche de animales cuando les faltaba la suya o ya no era suficiente. En épocas de epidemias de peste por la dificultad de encontrar nodrizas sanas disponibles y por el miedo al posible contagio.

${ }^{627}$ N.C. 9- 01- 191, p1. Artículo escrito por ANDREU M. en la sección de Vulgarización científica

${ }^{628}$ STERPELLONE L.: Historias curiosas de la Medicina. Barcelona. 2009.

Se decía que las burras, aunque son poco dóciles y tienen ubres muy grandes, se prestaban voluntariamente al amamantamiento de los niños enfermos y eran muy resistentes a las enfermedades infecciosas y que una burra garantiza tres tomas diarias de un niño durante un año. En el siglo XIX la mayoría de los pediatras aconsejaban la 
generales de la Diputación de Valladolid entre la relación destinada a la "Botica" del Hospital Provincial hasta 1915 se encuentra una partida destinada a "leche de burra y sanguijuelas". Finalmente, para la alimentación con biberón acabó imponiéndose la leche de vaca, por cuestiones sobre todo económicas dada su mayor abundancia, aparte de ser la más parecida a la leche humana entre las de uso habitual en los países europeos y Norteamérica; en los primeros años del siglo XX ya se conocía la composición de estas leches

"Es un acuerdo hoy día general el de reconocer que la leche, por excelencia, apropiada para la artificial lactancia, es la de vaca. Especialmente... en niños sanos. La leche de burra puede considerarse todavía útil como producto dietético en niños delicados... La leche de cabra es un recurso de alimentación obligado en algunas regiones españolas en donde aún no existe, por lo menos en suficiente proporción el ganado vacuno.

\title{
LECHE DE BURRA
}

Su composición química la hace en ciertos aspectos, por ejemplo el del azúcar, más análoga a la leche de mujer; lo mismo puede decirse respecto a la caseína.es un alimento... ligero y fácil de digerir. ...Los inconvenientes que presenta son su carestía, las actuales dificultades de provisión... Como alimento en ciertos trastornos digestivos de los niños pequeños, puede alcanzar gran utilidad. ... Las condiciones biológicas de la leche de burra permiten considerarla, exclusión hecha de la leche de mujer, como el primero de los substitutivos para la alimentación del lactante en las ocho primeras semanas de su vida...

\begin{abstract}
LECHE DE CABRA
La leche de cabra ofrece más condiciones nutritivas que la anterior por su mayor riqueza en manteca, aunque es menos azucarada y tiene la ventaja que este animal da más cantidad de leche que la burra. Cuando se puede vigilar de cerca es de buenos resultados poseer una cabra que proporcione la leche necesaria, pura y exenta del peligro de intoxicaciones que siempre son de temer en las leches de procedencia desconocida. Sin embargo esta recomendación solo podemos pronunciarla con grandes reservas... [por] la frecuencia con que la cabra transmite la malaria. En nuestro país esta endemia se halla tan extendida por todas las regiones particularmente por la levantina que en la práctica, sólo por este peligro, puede considerarse rechazable dicho alimento...
\end{abstract}

leche de burra para los cinco o seis primeros meses, otros proponían después de ésta continuar con la de vaca y dejar la de cabra para el final de la lactancia, al final se acabó imponiendo la leche de vaca, salvo en pueblos y zonas donde las cabras eran muy abundantes como ocurría en el Levante español. Se podía ofrecer mediante un biberón o con cuchara, o bien el niño podía mamar directamente.

A principios del siglo XIX, un médico alemán publicó un libro titulado La cabra, la mejor y más delicada nodriza que provocó tal auge de la lactancia directa con cabras que persistió hasta el siglo XX, hay evidencias de que hasta la llegada de las leches artificiales industriales, se seguía utilizando sobre todo en el medio rural tanto en la península como en otros países europeos, es el caso de Francia o Italia. El método de la lactancia directa se empleaba sobre todo en los pueblos, y en algunas instituciones que no podían disponer de biberones o que lo preferían como una forma más higiénica de alimentar al lactante. Para el amamantamiento se ataba a la cabra. le sujetaban las patas para que no pudiera cocear y se colocaba al bebé debajo. Para evitar el peligro que podía suponer una leche tan densa como la de cabra, se recomendaba buscar animales jóvenes y recién paridas que se alimentaran sólo de hierba fresca y ofrecer al lactante después de mamar un poco de agua sola o azucarada ${ }^{628}$. Muchos médicos criticaron la lactancia animal directa por los riesgos de contagio de enfermedades como la tuberculosis con las vacas o las fiebres de malta con las cabras. La manipulación no mejoraba las cosas, ya sabían que la leche se contamina con microorganismos que la descomponen, en 1921 el doctor Suñer recomendaba no consumir la leche cruda. ${ }^{628}$

En el Jardín del Palacio de la Biblioteca Nacional de Madrid se encuentra la obra Hermanitos de Leche del escultor Aniceto Marinas (1866-1953) que representa a un niño y un chivito mamando juntos de una cabra junto a un hombre que le cuida, un viudo. 


\begin{abstract}
LECHE DE VACA
La vaca proporciona la leche en mayor abundancia, y por su composición, este producto se parece más a la leche de mujer que la de cabra, y aunque... [es] muy susceptible a la tuberculosis,... razones de carácter económico, principalmente, hacen que su uso se haya generalizado por todo el mundo.

Cualquiera que sea la procedencia de la leche de vaca, es condición indispensable que, desde la selección de los animales hasta el último detalle en la conservación de la leche, se esté de acuerdo con los preceptos más rigurosos de la higiene..."
\end{abstract}

La alimentación artificial suponía un grave peligro para el lactante porque las condiciones higiénicas eran muy malas en todo el proceso, desde la producción, el transporte y la distribución de la leche hasta la preparación y la administración al niño. La Comisión de la Asociación Médica para el estudio de la leche higiénica exigía 40 requisitos, que recoge

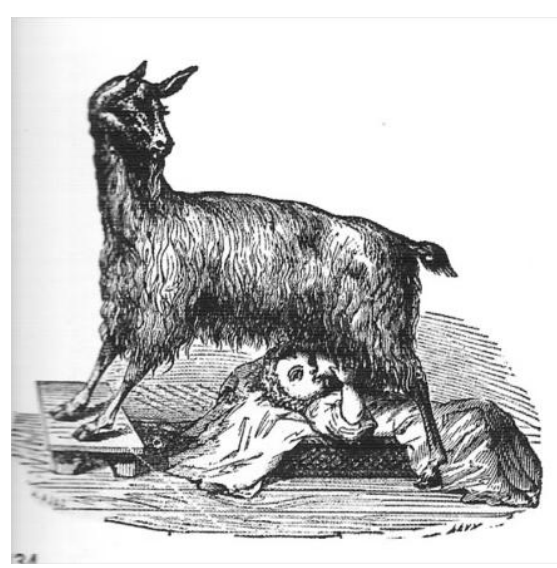

Imagen 3-27: La cabra nodriza. Revista higiene de la infancia 1891
Suñer ${ }^{630}$, para considerar una leche de vaca como "leche certificada" siguiendo los criterios norteamericanos, que regulaban desde el tipo de pasto, al estado de los establos, la higiene y tipo de vida de la vaca y del vaquero, el ordeño, almacenaje, esterilización, envasado y transporte de la leche. El profesor Marfan en 1925 advertía: "Si para su desgracia no puede recibir su alimento natural, si hay necesidad de alimentarle con la leche de los animales, para disminuir los perjuicios de la supresión del pecho, hay que preparar esta leche de una manera especial; es necesario que su madre, o cualquier otra persona se la haga tomar observando unas reglas rigurosas" ${ }^{\prime 631}$, que mayoritariamente no se cumplían. Resultaba difícil en las ciudades encontrar leche de calidad y era cara. Los establos de vacas no cumplían con la reglamentación establecida y con frecuencia era adulterada, sobre todo se aguaba, en proporciones que podían llegar hasta el $80 \%{ }^{632}$, siendo éste quizás el método menos perjudicial entre los que se empleaban. Más del $80 \%$ de las muestras analizadas en el laboratorio municipal de Madrid en 1901 y 1902 carecían de condiciones para el consumo. Denunciaba Suñer en los años veinte que "la industria lechera... se halla muy distante en el (país) nuestro de proporcionar un producto irreprochable para lactar a nuestros niños. Lo que en otros lados se llama "leche certificada», es para nosotros cosa desconocida en absoluto".

\footnotetext{
${ }^{629}$ SUÑER Y ORDÓÑEZ E.: Fisiología y clínica de la nutrición del lactante. Madrid: Ediciones Fax, 19??. s.a.

${ }^{630}$ Ibídem

${ }^{631}$ MARFAN Profesor y col. Pediatría. Tomo I. Barcelona 1925, p 6

${ }^{632}$ BORRÁS LLOP J.M.: Historia de la Infancia en la España Contemporánea. 1834-1936. Madrid, 1996, p 135
} 
Esta leche la consumían principalmente niños pobres e internos, se utilizaba en familias que no disponían de ama de cría sustituta de la madre y en las instituciones cuando tenían dificultades para conseguir nodrizas y para los niños enfermos que nadie quería lactar. A pesar de la lucha que se desarrolló contra la lactancia mercenaria, los mismos que la denostaban también tenían muy claro que era preferible a la lactancia artificial, al menos hasta que ésta alcanzó unas mínimas garantías, sobre todo en los centros cerrados

\begin{abstract}
"A pesar de los perfeccionamientos que ha tenido la lactancia artificial, es, sin embargo, un recurso que, examinado a la luz de suficientes estadísticas, se ve que da un resultado muy deficiente, pues aproximadamente puede calcularse que para un niño que muere por lactancia natural o mixta, mueren tres o cuatro de los sometidos al biberón. Este resultado se ve del modo más tristemente elocuente en nuestras inclusas. En el departamento de lactancia artificial exclusiva es raro el recién nacido que se salva, en tanto que son muchos los que logran vivir cuando reciben la leche de mujer, por eso se tiende a obligar a las madres que dan a luz en las maternidades anejas a la inclusa, a que permanezcan uno o dos meses, por lo menos, al lado de su hijo lactándole. ... con ello se disminuyen las probabilidades de que fallezca, pues la época peligrosa por que atraviesa el niño es la consecutiva al nacimiento y las cuatro a seis semanas que siguen"1633
\end{abstract}

Afirma Ana M. Rodríguez que "La lactancia artificial equivalía a una condena a muerte". Aun así, las Inclusas tuvieron que recurrir a ella desde su creación, siempre por la misma causa, la desproporción entre el número de expósitos y de nodrizas ${ }^{634}$; en la de Madrid disponían del Departamento del biberón; recoge la misma autora que "Todavía en 1917 los médicos de la Inclusa de Madrid calificaban la sala del biberón como "herodiada» y "antesala del Cielo»"635, aún en 1927 se publicaba en la prensa madrileña que "Respecto a la lactancia con biberón, es tan funesta que la mortalidad en la Inclusa llegó al 100 por 100, eso que se siguieron todos los métodos" ${ }^{\prime 636}$. Dice José Luis Hernando que (antes del siglo XX) “Los dos problemas más graves de los lactantes eran la alimentación artificial ante la falta de nodrizas y el sistema de conducción de niños hasta las inclusas", los problemas del traslado se redujeron notablemente desde la instalación de tornos e hijuelas próximas a las casas centrales, pero los problemas asociados a la lactancia artificial persistieron hasta que, bien avanzado el siglo XX, se desarrollaron métodos tanto en la preparación como en la elaboración de leches con garantías higiénicas y mínimas condiciones dietéticas.

\footnotetext{
${ }^{633}$ SUÑER E.: La salud del niño. Puericultura fundamental. Madrid 1920, pp 19- 27

634 "En Toro hasta disponían de cabras para alimentar a los niños cuando faltaban nodrizas (como en Madrid, Santiago de Compostela, Burgos, Ronda, Badajoz y Málaga), los críos mamaban directamente de la teta del animal mediante un cajón acondicionado con almohadas donde la cabra era inmovilizada de patas (en la inclusa de Burgos el invento fue mucho más sofisticado, pues la leche llegaba hasta el niño filtrada mediante esponjillas)". HERNANDO GARRIDO J.L.: op.cit. En la Casa de Expósitos de Almería también se utilizaba leche de cabras que se criaban en la huerta del centro. BUENDÍA MUÑOZ A. y GARCÍA MORALES I.: La Enfermería en la Almería de los Siglos XVIII y XIX. Almería. 2003, p 142

${ }^{635}$ RODRÍGUEZ MARTíN A.M.: op.cit. 2008, p. 365

${ }^{636}$ La Voz, 14 de febrero de 1927, p 8. Citado por REVUELTA EUGERCIOS B.A.: op.cit., p 307
} 
Refiere Bárbara A. Revuelta que según una serie informes que aparecieron en la revista Pro-Infantia entre 1918- 19 sobre las Inspecciones de las Inclusas realizadas por el Consejo Superior, solamente la de Toledo afirmaba no utilizar el biberón y la de Zaragoza decía usarlo sólo para los enfermos, mientras que en las otras 14 se utilizaba lactancia artificial o mixta. En cuanto a las condiciones higiénicas con que se hacía esta lactancia artificial los mismos informes recogían todo tipo de situaciones, desde la desinfección del biberón con hierros candentes en la de Tarragona, el uso de un único biberón con la tetina rota y atada con un hilo en Granada o de dos biberones para alimentar a todos los bebés pasándolos de un a otro según se iban cansando de tomar en Badajoz. ${ }^{637}$

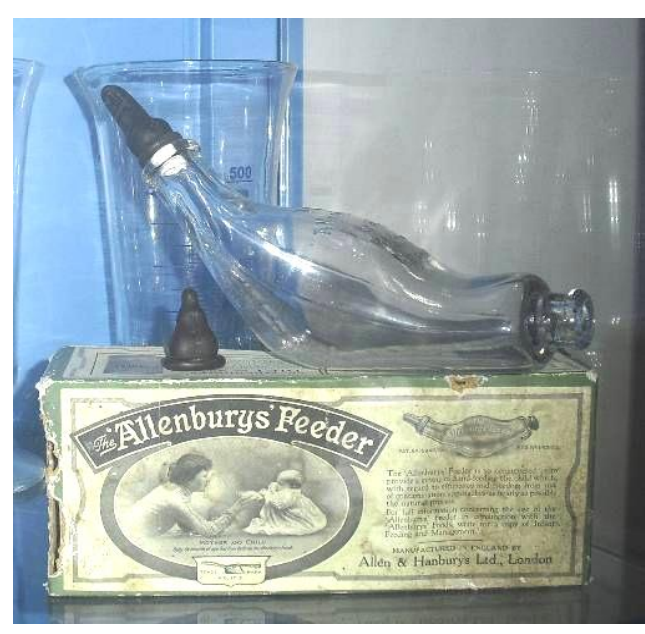

Imagen 3-28: Biberón fabricado por la casa inglesa Allen\&Hanburys a partir de 1894. Fotografía de la autora.
En la Inclusa de Valladolid se hacía también uso del biberón; tenían que recurrir a la lactancia artificial, como otras inclusas, por la falta de nodrizas. No se hace referencia a ella en las primeras ordenanzas ni en el Reglamento de 1889 pero tenemos constancia de su utilización por los presupuestos y por las compras de artículos de lactancia anotadas en los libros. La primera compra de "tetinas y biberones" aparece en el libro de 1906, en los libros de cuentas solamente encontramos

documentada esta compra y otra en 1909 de "300 frascos cristal y 100 tapones goma roja" para biberones y en 1924 recibos por 75 "botellas biberón" y "6 docenas de tetinas". Sin embargo en todos los presupuestos generales de la Diputación aparecen desde 1906, "[partida no] 131 - Idem [material] de enfermerías, tetinas, ligadores y otros análogos". No podemos descartar que no se hicieran compras con anterioridad porque este material iba incluido en los gastos de enfermería, pero sí podemos asegurar que la lactancia artificial se utilizó en la Inclusa Provincial de Valladolid por lo menos desde 1906 en adelante.

En los reglamentos de 1910 y 1927 ya se incluye un capítulo con cinco artículos dedicado en exclusiva a la lactancia artificial (el XXXV y XXXVII respectivamente) y nombra como la Gota de Leche, a la sección que se encargaba de prepararla y administrarla, el

\footnotetext{
${ }^{637}$ REVUELTA EUGERCIOS B.A.: op. cit., pp 310- 311
} 
equivalente al Departamento del Biberón. Establecen que se emplearía en caso de no tener nodrizas suficientes para lactancia y que estaría bajo la prescripción y control del médico de la Inclusa, que debía indicar la pauta que se tenía que seguir con cada niño.

Art. 346. El Director del Establecimiento procurará que todos los expósitos sean alimentados y criados por nodrizas; pero si el número de éstas fuera insuficiente, se empleará para los que las falten, la lactancia artificial, dirigida e inspeccionada diariamente por el Facultativo encargado de la Inclusa.

Art. 350. El Facultativo encargado de la Inclusa hará un cuadro en que se especifiquen las horas de dar la leche a estos niños, cantidad en cada vez y composición de la misma según las edades de aquéllos. Este cuadro se colocará en el punto más visible del departamento y la Hermana se encargará de que se haga rigurosamente con arreglo a él. Si algún niño por su estado de salud, o deficiente desarrollo, necesita variársele la cantidad, calidad y composición de la leche, se determinará por el Facultativo esta variación y se hará como éste disponga, previa orden escrita que trasmitirá al personal encargado de la Gota de Leche.

Según los reglamentos, las cuidadoras de esta sección eran las embarazadas de la sala general no pensionistas y las asiladas mayores que por sus defectos físicos no podían salir del Hospicio, naturalmente, supervisadas por una Hermana

Art. 350. Al cargo de esta lactancia artificial estará una de las Hermanas de la Caridad, auxiliada por las embarazadas no pensionistas que se hallen en condiciones de prestar este servicio, y por las acogidas mayores de 20 años que sin ocupación especial, o por sus defectos físicos, permanezcan en el Establecimiento.

No se indica que por ello recibieran ninguna compensación, a pesar de que, es de suponer, no solo darían los biberones a los niños, estas mujeres se encargarían de cuidarles en los demás aspectos. Parece que no se valoraba su tiempo ni su trabajo ya que esta dedicación en la sala del biberón no les servía para pagar sus estancias, en el único libro que he podido consultar de la Maternidad, que abarca desde el año 1906 al 1909 y por tanto un periodo en el que sabemos que se utilizaba el biberón con seguridad, no he encontrado ningún registro que testifique que una mujer ha colaborado en la Gota de Leche, por lo que podemos afirmar que era un trabajo no remunerado para las refugiadas internas en la Maternidad, porque de serlo se hubiera descontado de las estancias a pagar que se refieren en sus folios de registro.

También podrían estar en esta sección las refugiadas gratuitas que después del parto "por sus condiciones no pudieran lactar [que] prestarán servicio en la Inclusa durante el tiempo antes indicado" (Art. 298 Regl 1910 y 1927) hasta pagar su estancia en la Maternidad. Se 
quedarían en calidad de amas secas, que tampoco debían ser fáciles de conseguir fuera, pues su salario era la mitad que el de las nodrizas.

Revisando los tiempos de lactancia de las nodrizas internas encontramos que, del mismo modo que se podían juntar con cinco o seis niños a su cargo, tenían períodos de inactividad aparente, en lo que a la lactancia se refiere. Hay tanto mujeres de estancias largas como Justa Pérez, que después de lactar a tres niños a la vez estuvo sin criar desde el 21 de septiembre hasta el 8 de octubre; como nodrizas de estancia corta, es el caso de Rosario Hernández, que lactó a su hijo hasta el 17 de enero de 1912 y hasta el 4 de febrero no le asignaron otro niño o de Guadalupe Platero que está en la misma circunstancia y estuvo dos semanas sin lactar. Es imposible lactar 6 niños a la vez en condiciones, como los que llegó a tener a su cargo Irene Ramos, lo más razonable es pensar que haría como mucho lactancia mixta, combinando pecho y biberón, y que incluso alguno solo fuera alimentado con lactancia artificial como podría haber ocurrido en concreto con Aurelio de las Mulas que falleció por sífilis congénita (fo 191 LE 1912-1). En cuanto a esas pausas, son frecuentes y se encuentran en muchas nodrizas, la misma Irene Ramos tiene dos intervalos uno de 7 y otro de 14 días sin un lactante asignado. Podían estar motivadas por enfermedad, pues el reglamento les prohibía lactar mientras tanto, pero por las fechas y las características de algunas de ellas no parece probable, ni que el Hospicio pagara por nada a cambio. El otro posible destino de todas estas mujeres que no lactaban sería ocuparse de los niños de biberón en la Gota de leche, o en la sala de destete, donde también se precisaban cuidadoras, pues recordemos que en ella se asilaban niños desde 15 meses de vida.

Se preocupa además el reglamento de las condiciones higiénicas de este tipo de lactancia, que tantos riesgos entrañaban para los lactantes

Art. 351. No se dará a ningún expósito leche que no esté esterilizada; al efecto, se dota a la Inclusa de los aparatos de esterilización necesarios a cargo de personal competente y de una Hermana de la Caridad.

Art. 352. La Hermana de la Caridad encargada de la Inclusa cuidará muy especialmente de que todas las vasijas, frascos, tetinas y útiles empleados en la lactancia artificial, sean lavados y esterilizados antes de hacer uso de ellos en el departamento Gota de Leche.

En los libros de cuentas de 1921 y 1923-24 encontramos una partida para "Esterilización de la leche con destino a la Cuna"; consultando los presupuestos generales vemos que esta partida aparece a partir del ejercicio 1920- 21 con una asignación de 500 pesetas, "para los gastos que origine la esterilización de la leche con destino a la Cuna", 
algunos años, como 1929, aparece incluida junto con las harinas lacteadas en la partida destinada a las nodrizas consignada como "aparatos y material para la "Gota de Leche»"

El nombre de "Gota de Leche" hace referencia a una institución que suministraba de forma gratuita, o a precios muy bajos, leche esterilizada en biberones a lactantes que no podían ser alimentados por sus madres, o lo eran de forma insuficiente, y no disponían de nodriza. Además de dispensar leche, se ofrecía una consulta pediátrica para controlar a los infantes y educar a las madres. Desde principio de siglo fueron apareciendo dispensarios, de subvención municipal o dependientes de corporaciones benéficas, en las distintas ciudades españolas, en Valladolid se fundó en $1910^{638}$. Por extensión, el Hospicio llama Gota de Leche a la sección de lactancia artificial que preparaba, siempre según las indicaciones médicas, y esterilizaba los biberones de los lactantes.

\footnotetext{
${ }^{638}$ La "Gota de Leche" surgió en Francia a finales del siglo XIX para paliar la desnutrición y reducir la mortalidad de los lactantes de las clases más desfavorecidas. El primer consultorio de La Gota de Leche lo fundó Pierre Budin en el Hospital de la Caridad de París en 1892 y el primero en España lo abrió en Madrid el doctor Rafael Ulecia en 1904. Si bien, ya existía un precedente; en 1890 el doctor Vidal Solares fundó, y costeó a sus expensas, en Barcelona el primer Consultorio de Enfermedades de los Niños y dos años después el Hospital de los Niños Pobres donde estableció un consultorio que funcionaba como una Gota de Leche pues suministraba leche y harina a los lactantes, pero además atendía niños hasta los trece años, les suministraban caldo, verduras, carne y pan, aparte de medicinas y de subsidios en metálico. A este consultorio no se le considera una Gota de Leche como tal porque al principio no esterilizaba la leche. Desde que Ulecia trajo la idea a España, se fueron abriendo consultorios por todo el país desde 1902 hasta 1928 se fundaron más de cuarenta. Datos de las sucursales de la Gota de Leche de Madrid durante la República informan de más de medio millón de litros de leche al año repartida entre 12.000 lactantes.

En Valladolid, los solicitantes tenían que presentar un certificado de pobreza. Se utilizaba leche de vaca que servían las vaquerías de la ciudad con las que la institución tenía un acuerdo, la leche se esterilizaba y se servía en biberones. En la consulta se pesaba a los bebés semanalmente, se preguntaba y aconsejaba a las madres, se fijaba la cantidad de leche que había que suministrar diariamente y se registraban los datos.

Posteriormente muchos de estos centros se convirtieron en Instituciones de Puericultura al asociar al consultorio la Escuela de Maternología con la función de educar a las madres mediante la organización de charlas y cursos sobre higiene, alimentación y profilaxis. A estas Escuelas se añadieron iniciativas como la de premiar la asistencia con dinero en metálico, lo que daría lugar a partir de 1929 a las libretas de ahorro del Instituto Nacional de Previsión, a imitación de Póliza de Protección Infantil, que puso en marcha el doctor Martínez Vargas en 1906.

Cfr: BORRÁS LLOP J.M: Historia de la Infancia en la España Contemporánea 1834-1936, Madrid, 1996, pp 166- 168; MORALES J.L.: El niño en la cultura española... tomo 1, Madrid, 1960, p 292 y 666; GARCÍA, E.: La Gota de Leche: Casa Cuna de Gijón. Gijón, Ayuntamiento, 2003; SUREDA GARCÍA B.: Extensión universitaria y lucha contra la mortalidad infantil: la gota de leche de Mahón (1904-1913), en RUIZ BERRIO J. coord.: La educación en España a examen (1898-1998): Jornadas nacionales en conmemoración del centenario del noventayocho, 1999; MUÑOZ PRADAS F.: Las Gotas de Leche y el descenso de la mortalidad en España (1900-1936), en Revista de Demografía Histótica, vol. 30l no2, 2012, pp. 127-164. MUÑOZ PRADAS F.: La implantación de las Gotas de Leche en España (1902-1935): un estudio a partir de la prensa histórica", en Asclepio: Revista de la medicina y de la ciencia, vol. 68, fasc. 1, enero-junio 2016, pp 131- 165.
} 


\subsubsection{Los niños del biberón}

Lo que no dicen los reglamentos es qué niños eran alimentados con lactancia artificial, tampoco se indica nada en los folios de registro, únicamente en el Reglamento de 1889 dice que al ingresar, la nodriza que se encontrara "en turno" debía encargarse de la criatura "alimentándola con algún jarabe provisionalmente, ó lactándola según lo ordene el Facultativo" (Art. 39). Podían pues, ser alimentados con biberón hasta que se les asignara nodriza, siguiendo las indicaciones médicas; también considero probable que se alimentaran así los más mayorcitos y de estancias largas, sobre todo los que eran devueltos por las nodrizas externas, pues, aún estando todavía en período de lactancia, nunca encontramos anotado en su registro el nombre del ama que le seguirá lactando en la Inclusa. Otra opción que no podemos descartar, teniendo en cuenta que las amas lactaban en muchas ocasiones más de dos niños simultáneamente, es el empleo de la lactancia mixta, combinando la natural con el biberón o que simplemente la nodriza asignada en los libros era la responsable del niño y de alimentarle de una forma u otra. El niño Atanasio Rodríguez fue expuesto en el torno el 10 de junio de 1902 (fo 211) con una nota que decía:

"Este niño esta bautizado y se llama Atanasio Rodríguez nació el 7 de Marzo este niño no mama mas que la leche de baca por no tener su madre leche" [sic]

Al niño se le adjudicó una nodriza: "Le lacta Gregoria Pérez" y falleció cinco días después "a consecuencia de sífilis", pero por las circunstancias, crianza previa con leche de vaca y sífilis es fácil que se le alimentara con biberón.

Según los libros, a casi todos los niños se les asignaba una nodriza al ingreso y se registraba su nombre; en algunos folios no figura, puede tratarse de un error de omisión porque en muchos casos se ha escrito "Le lacta" pero falta el nombre; en otros folios vemos que el nombre del ama se ha escrito más tarde porque está con otra letra y además hay folios en los que se omite también la fecha del bautizo y esto, con seguridad, se trata de un descuido porque es totalmente improbable que quedara un niño sin bautizar. Por tanto, cuando no figura el nombre del ama anotada en el folio de registro tras el ingreso del expósito, puede ser que simplemente, como parece en muchos casos, se tratara más de un olvido, pero otra opción es que no la tuviera asignada y el niño se destinara a lactancia artificial, no lo considero tan probable porque incluso éstos niños necesitarían una cuidadora, salvo que en la Gota de Leche las cuidadoras se ocuparan de los niños de forma global sin una asignación personal.

Tomando al azar un año para analizar los casos en que no figura el nombre del ama, en 1905, encontré 30 lactantes sin ama asignada que fueron entregados a nodrizas externas en 
los 3 primeros días, 25 el mismo día de su ingreso. Todos estos niños entraron a través de la comisión provincial, por lo que podría estar prevista su salida, puede ser que por eso no se les llegara a asignar un ama lactante, pudieron ser alimentados con biberón, o al pecho, no podemos desechar ninguna de las dos opciones por el hecho de no constar el nombre del ama.. Algunos de estos niños, sospechosamente, fueron a las mismas localidades de origen, 0 a alguna próxima, algo que examinaremos en el apartado dedicado a las nodrizas externas y que nos hace dudar incluso de su ingreso recordando los casos vistos en el capítulo de Errores de Registro de niños inscritos en los Libros de Exposiciones cuyo ingreso no consta en los de la Inclusa y el también mencionado escándalo Montiel, que ingresaba niños para entregarlos luego a sus padres a cambio de una comisión. Descartando estos casos de lactantes de permanencias mínimas, en ese año hubo otros 9 niños de estancias entre 5 y 36 días sin constancia escrita de nodriza asignada y, menos uno que murió por falta de nutrición en la Inclusa a los 4 meses, el resto salió para crianza. No podemos excluir el uso del biberón para ellos ya que las amas podían estar en ocasiones muy sobrecargadas, además hay coincidencia temporal; como se puede ver en la TABLA 3-24 tres de ellos coincidieron en enero- febrero y otros tres en septiembre- octubre

\begin{tabular}{|c|c|c|c|c|c|c|c|c|c|}
\hline no de folio & 20 & 41 & 55 & 131 & 195 & 317 & 328 & 340 & 386 \\
\hline fecha de ingreso & $16-01$ & $28-01$ & $6-02$ & $27-03$ & $6-05$ & $1-09$ & 10- 09 & 22-09 & 6- 11 \\
\hline fecha de salida & 11- 02 & 18- 02 & 11- 02 & 2- 08 & 15- 05 & 29- 09 & $16-10$ & 28- 10 & 2- 12 \\
\hline
\end{tabular}

En 1912, tomando otro año por comparar, fueron 26 los lactantes sin asignación de ama. La estancia más larga fue de 118 días; tres de ellos fallecieron en la Inclusa por infección gastrointestinal y uno por atrepsia por dispepsia, es decir, por desnutrición; el resto salió para crianza; los niños pudieron ser alimentados con lactancia artificial, o no, como en el caso anterior no podemos asegurar nada al respecto, tampoco podemos descartar que se hiciera lactancia mixta y la nodriza se ayudara con biberones.

Si hacemos caso de un artículo de la prensa local que trataba sobre la Inclusa ideal, respecto a la alimentación de los expósitos decía que debía hacerse

"... hasta los cinco meses, exclusivamente con los pechos de sus madres o nodrizas [excepto para los infecciosos], instituyendo desde ese tiempo hasta cumplir el año la alimentación mixta y exclusivamente con biberón hasta los veinte meses ... pudiendo en los últimos seis meses asociarse el uso de papillas siempre que el médico lo creyera pertinente ${ }^{\prime 639}$.

\footnotetext{
${ }^{639}$ N.C. 9- 01- 1913., p 1; columna escrita por M. ANDREU titulada Vulgarización científica
} 
Estudios sobre otras inclusas, como Pontevedra y Madrid, afirman que los niños infecciosos, sobre todo los sifilíticos eran rechazados por las nodrizas y pasaban directamente a la sala del biberón, a fin de cuentas existían indicaciones médicas en ese sentido, pues las lesiones que pueden presentar son contagiosas

"Ios asilados... infectados por vicios especiales... sería su crianza encomendada exclusivamente al biberón"

Sorprendentemente, dado el miedo que existía al contagio de esta enfermedad, incurable hasta la aparición posterior de la penicilina, en nuestra Inclusa no parece, a la vista de los datos hoy disponibles en sus libros, que se siguiera esa práctica; entre los niños de 1905 y 1912 (años comentados anteriormente) que no tenían ama adjudicada en los libros, ninguno falleció por sífilis. En 1905 perecieron 29 niños por sífilis, 21 en la Inclusa y 8 fuera, y todos tuvieron nodriza interna, igual que en 1912 todos los fallecidos por sífilis (17) tuvieron ama y murieron 9 en el asilo

"En 2 de Junio de 1912 á las 22 horas y 30 minutos fue expuesto en el torno de este Establecimiento con un papel que dice Este niño nació el dia 30 de Mayo de 1912 á las 7 de la tarde se llama Fernando Barniedo Luna. Esta bautizado... Le lacta Agueda Machado'...

Falleció en este Asilo á las 7 del 7 de Julio de 1912 á consecuencia de Sífilis congénita" [sic] (199 LE 1912-1)

También se entregaban para crianza, 8 fallecieron en 1912 con las nodrizas externas

"En 13 de Noviembre de 1912 á los 45 minutos fue expuesta en el torno de este Hospicio envuelta en una toalla de buen uso...

La lacta Martina Santos.

En 22 de noviembre de 1911 [sic] la llevó Manuela Delgado... devuelto el 13 de Febrero de 1913

Falleció en este Asilo á las veintiuna del 22 de Abril de 1913 á consecuencia de Sifilis Congénita" [sic] (397 LE 1912-2)

En total fallecieron 376 niños por sífilis congénita en el período 1900-1913, solamente en 5 de ellos no aparece un nombre de nodriza en su folio: fo 163 de 1904, fo 229 de 1904, fo 165 de 1907, fo 321 de 1907 y fo 273 de 1913, algunos incluso salieron a criarse con nodrizas, pero fueron devueltos uno o dos mes después, probablemente cuando aparecieran síntomas evidentes $^{641}$.

\footnotetext{
640 Ibídem.

${ }^{641}$ En 1904, además de los dos reseñados en el texto, fallecieron por sífilis sin haber salido de la inclusa los niños de los folios no: $16,29,39,102,142,211,317,339,363,412$ y 428; a los que hay que añadir 3 más que salieron para crianza y fueron devueltos por las nodrizas externas: el 45,47 y 350, En el caso de 1912 fallecieron 19 niños por sífilis, 4 de ellos salieron para crianza externa y dos de éstos fallecieron con las nodrizas, uno a la edad de 4 años. Es también reseñable, como muestra de que la falta del nombre del ama que lacta puede ser un descuido, que los tres folios anteriores al reseñado en el texto tampoco tienen anotado el nombre de la nodriza y fallecieron uno por falta de desarrollo (270), otro por tuberculosis pulmonar (272) y el tercero en el pueblo con la nodriza, y no consta causa.
} 
En todos los folios que recogen el nombre de la nodriza, delante se ha escrito "Le lacta", si lo interpretamos literalmente podemos decir que le alimentaba al pecho. A los niños con sífilis de la maternidad, del mismo modo que a los no infectados, les lactaba su madre. En cuanto a los expósitos nacidos fuera de la inclusa a los que se asignaba nodriza, cabe la posibilidad de que se tratara de niños inicialmente asintomáticos, ya que la expresión clínica de la sífilis congénita puede ser muy tardía, pues era una enfermedad con la que se tenían muchas precauciones sobre todo en centros como hospitales e inclusas por el miedo al contagio. Otra explicación es que la nodriza también fuera sifilítica, pero ya hemos visto que esto no solía ocurrir, o al menos no era una práctica habitual en la Inclusa de Valladolid.

\begin{abstract}
"Se procurará por todos los medios posibles que ésta [su lactancia] sea natural y materna, pero en el caso de que la familia se incline por una lactancia mercenaria, el médico procurará oponerse a la misma siguiendo a los dictados de su conciencia, a fin de evitar el contagio de la nodriza sana. Solamente en el caso excepcional de encontrarse una nodriza sifilitica con buenas condiciones para lactar, puede permitirse sin escrúpulos la crianza del niño. Innumerables son los casos de nodrizas contagiadas por la sifilis de los niños que han tomado ${ }^{\prime \prime 462}$
\end{abstract}

Tenemos constancia escrita del uso del biberón debido a la carencia de nodrizas y para los infecciosos por una Memoria que se conserva escrita por los médicos del Hospicio en 1920; es probable que se siguieran los mismos criterios para estos 14 años que se han podido consultar detalladamente, pero al no haber constancia documental no me atrevo a afirmarlo absolutamente porque la situación de la Inclusa empeoró en este tiempo, debido, como cuenta la misma memoria, a un descenso muy significativo en el número de nodrizas externas que condicionó a su vez un incremento muy importante de internos en la Inclusa en detrimento por tanto de sus condiciones alimentarias y de vida

\begin{abstract}
"...entregado a los cuidados de una nodriza, cuyo pecho ha de compartir con otros tres o cuatro compañeros de desdicha: la insuficiente alimentación del pecho, es complementada con leche de vaca, constituyéndose una lactancia mixta, en teoría, pues bien se comprende que en la práctica es una lactancia artificial, con gotas, muy pocas, de leche de mujer, y esto en el mejor caso, porque muy frecuentemente, sea por la carencia de nodrizas o bien por el riesgo de contagio, ha de instituirse desde el primer momento la lactancia artificial... $^{1643}$
\end{abstract}

\footnotetext{
${ }^{642}$ SUÑER Y ORDÓÑEZ E.: Enfermedades de la infancia. Tomo II, Madrid. 1918. p 268

${ }^{643}$ Año 1920. Memoria suscrita por los médicos del Hospicio, relativa a la alta mortalidad de niños en el Establecimiento. Signatura: caja 4025, expediente 37809. ADPVA
} 


\subsubsection{Laleche delosbiberones}

Hemos de suponer que la lactancia artificial se haría con la leche de la vaquería del Hospicio, puesto que en el período estudiado la de vaca ya se consideraba desde el punto de vista médico la más recomendable y el Hospicio nunca compró leche animal; por otra parte, la leche no entraba en la dieta habitual de los niños mayores de 3 años según los reglamentos, por lo que cabe pensar que la producción sería para los más pequeños y puede que para el personal. Los médicos aconsejaban hervirla y rebajarla con agua, siempre que fuera de calidad y que no se hubiera adulterado previamente, como ocurría muchas veces con la que se compraba.

Suñer en su manual de Puericultura fundamental ${ }^{644}$ da instrucciones completas para hacer la lactancia artificial correctamente:

1․ Utilizar, siempre que se pueda, leche de vacas sanas, que tengan una composición normal...

Vamos a presumir que la vaquería y las vacas del Hospicio estarían en buenas condiciones, aunque dificilmente serían todas las que se exigían para alcanzar la categoría de leche certificada, y que su leche no se adulteraba

20 que esta leche haya sido sometida durante cierto tiempo a temperatura suficiente para destruir los gérmenes más importantes... La pasteurización de la leche, sometiendo la misma durante una hora a temperaturas que no pasen de 60 grados centígrados, es el método ideal...

Para este proceso, y para la higiene de los biberones y tetinas, se destinarían los gastos para esterilización de la leche de la Cuna que dicen los presupuestos. Ya entonces se recomendaba lavar bien biberones y tetinas y esterilizarlos o hervirlos antes de su uso.

Era bien sabido que los bebés de pocos meses no podían tolerar la leche de vaca, "administrada pura, antes de que el niño tenga seis o siete meses, suele ser mal tolerada" por eso se recomendaba su dilución, al principio al medio para luego ir echando menos agua hasta ofrecerla entera a partir de los seis meses; la pauta estaba en función de la edad del niño ${ }^{645}$ :

$$
\begin{array}{ll}
1^{\text {er }} \text { mes de la vida: } & 1 \text { parte de leche y } 1 \text { de agua } \\
\text { 2o y 3o mes: } & 2 \text { partes de leche y } 1 \text { de agua } \\
\text { 2o trimestre: } & 3 \text { partes de leche y } 1 \text { de agua }
\end{array}
$$

\footnotetext{
${ }^{644}$ SUÑER Y ORDÓÑEZ E.: La salud del niño. Puericultura fundamental. Madrid 1920, pp 20- 24

${ }^{645}$ SUÑER Y ORDÓÑEZ E.: op. cit., 1933 ? y 1920
} 
Leyendo los manuales de puericultura y pediatría se entiende la insistencia de los reglamentos en que la pauta de alimentación de los niños fuera prescrita exclusivamente por los médicos de la Inclusa, la alimentación se consideraba un factor determinante respecto a la alta mortalidad infantil, siguiendo con Suñer decía al respecto:

\begin{abstract}
"Interesa saber que la mayor o menor mortalidad infantil depende del género de lactancia que se utilice de un modo fundamental...

La dosificación del alimento que se da al niño al niño es una de las cosas más importantes y delicadas en toda lactancia, sea natural, mixta o artificial. Solo el médico es competente para juzgar y decidir en este sentido, adaptándose a las condiciones de cada individuo" ${ }^{\prime \prime 46}$
\end{abstract}

En la lactancia, la cantidad de leche, igual que se sigue haciendo actualmente, se calcula en función del peso del bebé, por entonces se estimaba para el primer semestre de vida $125 \mathrm{gr}$ de leche diarios por cada Kg del niño. Aunque existían distintas pautas, en general en el período de estudio se recomendaba no dar nada el primer día, tampoco con la lactancia materna, y luego espaciar los biberones 2 horas la primera quincena de vida, $2 \frac{1}{2}$ la segunda y a partir del segundo mes 4 horas, dejándole descansar "durante la noche, al menos en los tres primeros meses, el niño no debe tomar nada".

Los pediatras aconsejaban además añadir un cocimiento harinoso al agua "es preferible a la dilución con agua pura el empleo de un cocimiento hecho con una cucharadita de buena harina de avena por 160 gramos de agua" $^{647}$ y una cantidad determinada de azúcar. Con este procedimiento se conseguía mejorar la tolerancia de los bebés a la leche de vaca, pues al diluirla se disminuye su carga osmótica y proteica, excesiva para el sistema

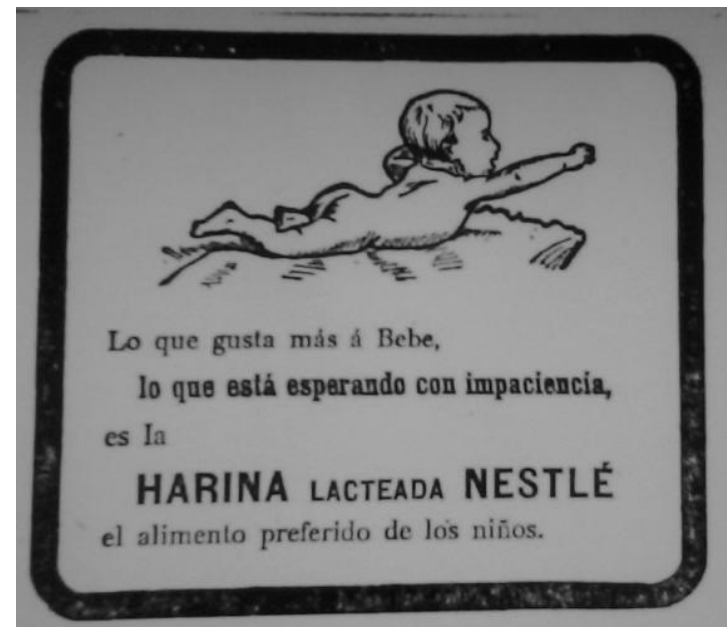

Imagen 3-29: Anuncio de Harina lacteada Nestlé. N.C. 10- 7- 1913, p 5 renal y metabólico de los lactantes más pequeños, y con la harina y el azúcar se aumentan los hidratos de carbono, mucho más abundantes en la leche humana. Ya se conocía la composición grosera de ambas y en la segunda mitad del siglo XIX se empezaron a hacer modificaciones en la leche de vaca para adaptarla a la alimentación de los infantes más pequeños. En 1867 se empezaron a comercializar en Europa las Harinas Lacteadas ${ }^{648}$, hechas a base de leche de vaca, harina de

\footnotetext{
${ }^{646}$ Ibídem

${ }^{647}$ SUÑER Y ORDÓÑEZ E.: op. cit., 1920, p 19- 23; BOIX BARRIOS J.: Manual de puericultura, p 69

${ }^{648}$ En 1866 el farmacéutico suizo de origen alemán Henry Nestlé, buscando una alternativa barata y saludable a la leche humana para alimentar a los bebés más pequeños cuando las madres no podían lactar, elaboró y después
} 
trigo y azúcar, en definitiva como el preparado que acabamos de comentar; en la década siguiente llegaron a España y empezaron a publicitarse como sustitutos de la leche materna avaladas por médicos como el doctor Benavente de la Inclusa de Madrid que decía "haber encontrado en la Harina Lacteada del Sr Nestlé un medio que evitará en lo sucesivo todo conflicto por falta de nodrizas" ${ }^{649}$. En esta época también empezó a utilizarse la leche condensada; se difundió su uso porque daba más garantías higiénicas, era cómoda y fácil de manejar, fue valorada como más nutritiva al ir enriquecida con azúcares y sobre todo por la influencia de la publicidad, que ya comenzaba a ser un arma muy poderosa; aunque había discrepancias entre los pediatras respecto a sus beneficios, algunos pensaban que era "mala como alimento de los niños [precisamente] por el exceso de azúcar que contiene y su pobreza en vitaminas" ${ }^{\prime 650}$.

Por los libros de cuentas de la Inclusa sabemos que se empiezan a comprar "Harinas lacteadas para los niños de la Inclusa" en 1903, 400 botes ese año; anteriormente se podían haber elaborado en la propia inclusa pues disponían de los ingredientes, la leche de la vaquería, harina y azúcar. Desde este año figura en todos los libros de cuentas y en los presupuestos generales junto con otros productos dietéticos infantiles en una partida "Para harina lacteada, lactosa, azúcar de leche para los niños de la Inclusa"; la lactosa es el azúcar que se recomendaba para adicionar a la leche de los lactantes "el azúcar de leche (lactosa) debe ser el utilizado, pues a él le corresponde la consideración de hidrato de carbono fisiológico" ${ }^{\prime 651}$. Aunque en realidad lactosa y azúcar de leche son la misma cosa, en los presupuestos y los libros de cuentas por "azúcar de leche" se refieren a la leche condensada, que en la época también se denominaba así. Aparece por primera vez con este nombre en 1924 , cuando se compraron" 48 botes".

comercializó una fórmula que llamó Harina Alimenticia y posteriormente Harina Lacteada, cuyo éxito hizo que su uso se propagara rápidamente.

${ }^{649}$ EI Siglo. 24- 12- 1885, p 5

${ }^{650}$ SUÑER Y ORDÓÑEZ E.: op. cit., 1920; BOIX BARRIOS J.: Manual de puericultura. Otros autores como BUXÓ opinaban que convenientemente diluida era apta y mejor tolerada que la de vaca en niños sanos, aunque la desaconsejaban en caso de diarrea. La leche condensada empezó a comercializarse en 1856 en Estados Unidos, era un concentrado de leche de vaca con azúcar que se podía conservar por más tiempo sin necesidad de refrigeración. También se fabricó en principio sin azúcar, como lo que hoy llamamos leche evaporada, pero era menos duradera y tuvo menos éxito. En Europa la comercializó, con el nombre que ha llegado hasta hoy de La Lechera, la empresa suiza Anglo Swiss Condensed Milk Company, que acabó fusionándose con Nestlé en 1905. En ese mismo año se abrió la primera factoría española de Nestlé y las casas comerciales que fueron surgiendo como Natel o El Niño en España, al igual que Nestlé ofertaban primero la leche condensada para la lactancia y luego las harina lacteada para el destete y ambos productos, que empezaron como alimentos exclusivamente infantiles, se acabaron promocionando también para adultos, deportistas y ancianos.

Puede verse un anuncio publicitario en prensa de la leche condensada $E L$ NIÑO en la hemeroteca del diario $A B C$ : http://hemeroteca.abc.es/nav/Navigate.exe/hemeroteca/madrid/abc/1927/05/07/018.html.

${ }^{651}$ SUÑER Y ORDÓÑEZ E.: op.cit 1933? 
Otras casas comercializaron las harinas lacteadas. Era habitual en la prensa de la época presentar los anuncios publicitarios como si fueran un artículo periodístico escrito por personajes relevantes, en el caso de las harinas lacteadas, como vimos anteriormente, entre los autores se encontraban directores de inclusas y afamados pediatras, también en la prensa local de Valladolid los encontramos

"Natel en la nutrición de los niños Continuamos la publicación de valiosas opiniones sobre la alimentación infantil. El doctor don Román Carazo, director de la Inclusa de Burgos dice:

"Los resultados obtenidos con Natel son tan excelentes y se manifiestan con tal rapidez que....me permiten afirmar se trata de un producto insustituible, que debe emplearse siempre que se imponga u régimen de lactancia artificial o mixta, pudiendo afirmar que muchos niños en esta Inclusa deben su vida al empleo de Natel...»

El profesor G. Vidal Jordana, de la Facultad de Medicina y la Inclusa de Valladolid comunica:

"Sigo obteniendo muy brillantes resultados con el empleo de Natel, siendo tan sorprendentes sus resultados, que tengo el decidido propósito de emplearlo sistemáticamente en la alimentación de los niños» LABORATORIOS LLOPIS- Paseo Rosales, 12 - MADRID”652

$\mathrm{Ni}$ en los libros de cuentas ni en los presupuestos se recoge la marca comercial de las harinas que se compraban para la Cuna. No eran el único producto infantil que se publicitaba utilizando las inclusas como reclamo.

\subsubsection{La Alímentación complementaria y el destete}

Se llamaba y se llama alimentación complementaria a la introducción en la dieta del lactante de otros alimentos diferentes de la leche y destete a la finalización completa de la lactancia natural. Son dos cuestiones que siempre han sido polémicas en relación con la dieta de los lactantes, muy influidas por los usos locales y con recomendaciones y pautas muy diversificadas incluso en la misma época.

En general los médicos coincidían en que la introducción precoz de otros alimentos diferentes de la leche es un peligro que puede ser mortal para el lactante, por lo que el destete y la alimentación complementaria, el momento y la forma de hacerlos, se consideraban otro de los caballos de batalla para reducir la mortalidad infantil. Coexistían distintos criterios y pautas médicas, que en lo único que coincidían es en que no debía darse nada más que leche

${ }^{652}$ N.C. 23- 12- 1912, p 2 
en los primeros meses y no había unanimidad a la hora de establecer por cuánto tiempo. Tradicionalmente la lactancia se prolongaba tanto como duraba la producción de leche en la mujer, salvo que quedara embarazada, y se ofrecían otros alimentos complementarios a base de pan o harinas a medida que la madre notaba que producía menos y que el niño se quedaba con hambre. Las prácticas populares no siempre coincidían con las recomendaciones médicas, pero a finales del siglo XIX y primeros años del XX algunos pediatras todavía respaldaban en parte esta práctica y recomendaban dar únicamente leche hasta el segundo año de vida, e incluso después, y en todo caso mantenerla como el alimento principal y predominante suplementando la lactancia con papillas o sopas de pan hervido; sin existir tampoco acuerdo a la hora de decidir a partir de qué momento. La propuesta médica que finalmente se impuso fue la de hacer lactancia exclusiva, preferentemente materna, hasta los seis meses y a partir de ese momento empezar introduciendo las papillas hechas de leche de vaca, azúcar y harinas de trigo, maíz, tapioca, o sémola, mejor malteadas, es decir torrefactadas, para hacerlas más digestivas al convertir el almidón en maltosa, y después, poco a poco y con criterios muy variables, los demás alimentos. Algunos proponían, siguiendo un modelo alemán, empezar ofreciendo zumo de frutas, de naranja o uva, desde el tercer mes a los niños con lactancia natural y antes del segundo a los alimentados con lactancia artificial exclusiva ${ }^{653}$.

A falta de otro tipo de documentos, la única información que tenemos sobre la dieta de los niños en el Hospicio es la que nos ofrecen los reglamentos. Para los menores de 18 meses que estaban en el Departamento de Lactancia se sobreentiende que ésta era la única modalidad de alimentación y advierten que no podían ser alimentados más que al pecho de las nodrizas, salvo indicación médica, prohibiéndolas ofrecer a los lactantes ningún otro alimento.

\footnotetext{
653 "En un niño bien lactado, sobre todo si toma leche de mujer, durante los tres primeros meses de su vida somos partidarios de no dar absolutamente nada. A partir de esta edad (en los lactados con biberón exclusivamente, de un mes a mes y medio antes) es conveniente darles zumo de frutas maduras, no ácidas, exentas de gérmenes, tres o cuatro veces al día, en los intervalos de sus tomas de alimento... zumo de naranjas dulces o de uva...

Hacia el sexto mes, el infante mejor atendido en su lactancia necesita otros alimentos distintos de la leche que exclusivamente venía tomando... debe principiar por la administración de papillas hechas con buena leche de vacas... son muy de aconsejarla tapioca, sémola, maicena, gofio de trigo y de maíz, harina de trigo, pan rallado tostado, aparte, naturalmente de estas mismas o de otras harinas malteadas, a las que siempre damos preferencia. La papilla debe prepararse con dosis de fécula, azúcar, leche y tiempo de ebullición diferente según la edad del niño". SUÑER Y ORDÓÑEZ E.: La salud del niño. ...p 19-31 y Fisiología y clínica de la nutrición del lactante. Puede consultarse también entre otros manuales y tratados de Pediatría: BOIX BARRIOS J.: Manual de puericultura; VELASCO Y LLAMAS S.: Puericultura, p 19; BOIX IZAGUIRRE P.: Enfermedades de los niños de pecho, p 138,

En la actualidad tampoco hay unanimidad en cuanto al modelo a seguir, pero existen una serie de normas de obligado cumplimiento. Se debe mantener la lactancia materna exclusiva, o en su defecto la artificial, hasta los seis meses y a partir de ahí introducir la alimentación complementaria, manteniendo la leche como alimento principal. Se puede adelantar la introducción si es necesario, pero nunca antes de los cuatro meses, y es importante hacerlo de forma lenta y progresiva comprobando la tolerancia del lactante a cada nuevo alimento. No se puede dar leche de vaca hasta después de los doce meses.
} 
En la Inclusa la dieta de los lactantes estaba por tanto bajo prescripción médica y supervisada por la Hermana responsable, que debía controlar todo lo que comían los bebés

"ARTÍCULO 67. A ninguna nodriza se le permitirá dar más alimento á los niños que la leche, á no ser que la Hija de la Caridad por disposición del Facultativo ordene se les dé otro alimento, en cuyo caso será suministrado á presencia de aquella"

Sabemos por los gastos que figuran en los libros de cuentas y los presupuestos que se hacían papillas pues constan las compras de diferentes harinas y de azúcar destinados expresamente a las papillas de los niños de la Inclusa; las harinas lacteadas inicialmente se emplearon como sustitutos de la leche materna y posteriormente, según fueron apareciendo otros preparados lácteos, leche condensada, evaporada, humanizada..., se relegaron a su uso en papillas.

Desde 1901 hay compras de azúcar, "100 Kilogramos de azúcar para la papilla de los ninos" [sic] y algunos años de harina de arroz. En los libros de 1922, 23 y 24 figura la compra de "botes de banarina"654, una harina de plátano y en 1925 y 26 de tapioca, sémola, maicena y miel. Que no aparezcan otros años no significa que no se compraran porque todos estos gastos se englobaban en una partida presupuestaria

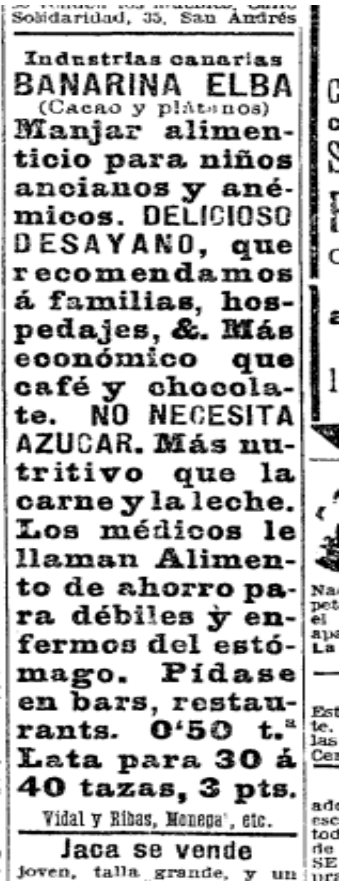

Imagen 3-30: Anuncio de BANARINA. La Vanguardia 27- 04 - 1921, p 21 denominada "Para Amas lactantes internas y para compra de leche, harinas y similares que fuesen preciso para la crianza interna". Estas harinas y el azúcar servirían para las papillas de los lactantes, aunque que no podemos decir exactamente a partir de qué edad se incluían todos estos productos en la dieta, en todo caso según las indicaciones médicas. En el artículo de la prensa local comentado anteriormente sobre las inclusas (N.C. 1913) se decía que las

\footnotetext{
654 En una breve reseña se presenta la banarina en el semanal "El nuevo Mundo" en su no 886 del jueves 29 de diciembre de 1910, p 11, como "una nueva harina de plátano... (de) composición análoga a los cereales, diferenciándose de ésta en fuerza porque es menos rica en materias azoadas. En cambio, el almidón que de ella se saca es muy superior al de la harina de los cereales. Según un fabricante de Jamaica, la mejor manera de preparar la harina de plátano es la siguiente: Se escogen frutos que estén próximos a la madurez y se les pela con cuchillo de plata, de marfil, de madera (el acero determina cierta coloración en el plátano); se les coloca en una vasija llena de agua de lluvia y luego se sacan para cortarlos en rebanadas que se ponen a secar, cando están secas se les pasa por un molino". Sorprendente.

Encontramos también anuncios de la misma época en la que se compra la banarina en el hospicio. En la Vanguardia, en su edición del 27 de abril de 1921 en la página 21 hay un anuncio que dice "Manjar alimenticio para niños, ancianos y anémicos. DELICIOSO DESAYUNO...Más económico que café y chocolate. NO NECESITA AZUCAR. Más nutritivo que la carne y la leche" [sic].
} 
papillas debían introducirse a partir de los 14 meses, es posible que al escribirlo se hubiera tomado como referencia la Inclusa Provincial. Lo que seguramente no les darían son los zumos, las frutas no entraban en ninguna de las dietas de los asilados, más que de forma extraordinaria.

Los reglamentos establecían la dieta de los asilados del Hospicio Provincial de Valladolid incluida la del Destete, fijando su comienzo a los 18 meses, aunque sabemos que en la práctica podía hacerse antes, a los 15 meses. La primera cuestión por determinar sería la relativa al momento idóneo de retirar definitivamente la lactancia natural. Éste es un tema controvertido, en el que han ido cambiando las pautas con el tiempo y en el que no encontramos criterios unánimes ni siquiera para un momento concreto ${ }^{655}$. En 1918 Enrique Suñer publicaba:

¿Cuánto tiempo debe durar la lactancia? He aquí una pregunta cuya contestación suscita opiniones contradictorias. En tanto que los pediatras alemanes e ingleses consideran suficiente el plazo de 9 a 10 meses en los casos normales, para la escuela francesa debe prolongarse más tiempo. Comby por ejemplo defiende el criterio de prolongar la lactancia hasta los 15 a 20 meses. Ambos extremos considero que son exagerados, y por lo que hace referencia a nuestra raza y a nuestros climas creo que no hay inconveniente en fijar en 12 a 14 meses el término del periodo de lactancia ${ }^{1656}$

En otra publicación dos años después ampliaba ligeramente el período, "como término medio entre los doce y quince meses" ${ }^{\prime 657}$. En todo caso estaban más o menos de acuerdo en hacerlo de forma individualizada, según las condiciones del niño, "siempre que [su] desarrollo y crecimiento lleven una marcha normal”658; algunos tomaban la dentición como

\footnotetext{
${ }^{655}$ Siempre se ha tenido claro que la mejor alimentación en los primeros meses de vida era la leche de mujer, lo que se ha discutido mucho y ha sido muy variable, de unas sociedades a otras y de unos tiempos a otros, es la duración de la lactancia. Sorano aconsejaba la lactancia hasta el año y medio al menos, pero también sugirió que podía prolongarse hasta completar la dentición y Avicena la recomendaba durante dos años. En la Edad Media sabemos que en general el período de lactancia era muy prolongado, en torno a los dos ó tres años, incluso podía alargarse más. Aldobrandino (siglo XII) fija la edad del destete en torno a los 2 años, Barberino (1314) también y Bartholomeus (1490) entre los 10 y los 24 meses. En las Partidas se dice que las madres deben alimentar y criar a sus hijos hasta los tres años. McLaughlin sospecha que la lactancia podía ser más corta en las niñas y en las clases campesinas, de hecho, Gordonio en su tratado aconseja dos años para las niñas y dos años y medio para los niños. Con frecuencia el destete se producía por un nuevo embarazo, cuando llegaba el momento, para facilitarlo se recomendaba a la mujer que se frotara el pecho con sustancias amargas para que la criatura lo rechazara y por hambre empezara a comer otras cosas. En la lactancia mercenaria la decisión del destete la tomaba el padre dependiendo de su disponibilidad económica. Aunque podía variar el momento del destete todos coincidían en que debía hacerse poco a poco. Cfr: MORALES J.L.: El niño en la cultura española... Madrid 1960; MCLAUGHLIN M.: Supervivientes y sustitutos. Hijos y padres del siglo IX al siglo XIII. En: DEMAUSE LI. edit.: Historia de la infancia. Madrid 1982, p 148. DEMAUSE LI.:"La evolución de la infancia" en DEMAUSE LI. edit: Historia de la infancia.; en la página 66 presenta un cuadro con la edad de destete en diferentes fechas y lugares. También en Lactancia materna de AGUILAR CORDERO M.J.en la pg 7 se ofrece un cuadro sobre la duración de la lactancia en distintas épocas.

${ }^{656}$ SUÑER Y ORDÓÑEZ E.: Enfermedades de la Infancia. Tomo I. 1918, pp 41-42

${ }^{657}$ SUÑER Y ORDÓÑEZ E.: La salud del niño. Madrid. 1920, p 30

658 Ibídem
} 
referencia y situaban el destete en "el lapso que media entre la salida de los primeros incisivos y la aparición de los cuatro caninos" ${ }^{\prime 659}$, es tanto como decir desde los 10 meses aproximadamente que se completa la salida de los cuatro incisivos centrales hasta los 24 meses que se puede completar la de los cuatro caninos. Sobre todo en los países del sur de Europa, se insistía mucho en no hacer el destete en verano, entre los meses de mayo a septiembre, siendo "preferible prolongar la lactancia a exponer al niño a los trastornos digestivos del verano".

En cuanto a la forma de hacer el destete tampoco había acuerdo, unos pediatras preconizaban hacerlo bruscamente, pero otros preferían un procedimiento lento, como una "ampliación del sistema de alimentación complementaria", es decir, ir sustituyendo de forma paulatina las tomas de pecho por alimentos nuevos, de esta manera el niño se va adaptando progresivamente a la nueva dieta y se mejora la tolerancia digestiva. La leche, ya de vaca y hervida, debería seguir siendo un alimento básico y a partir de los 2 años, o una vez completada la dentición del niño, que suele ocurrir en torno a los 30 meses, se aconsejaba irle introduciendo progresivamente en la dieta propia de la segunda infancia, que entonces se consideraba de los dos a los siete años, y no sentarle a comer con los adultos hasta los cuatro años más o menos. Una dieta adecuada hasta los siete años debía incluir leche de vaca hervida, frutas y verduras.

Teniendo en cuenta todo lo anterior, podemos dar por correcto el momento establecido para el destete en la Inclusa de Valladolid, incluso el adelanto a los 15 meses; también entra dentro de lo que se consideraba aceptable la norma recogida en el Reglamento de 1886 de no sentar a comer a los niños en el refectorio general hasta los cinco años (artículo 108). Tampoco podemos juzgar como errónea la forma de hacerlo, un cambio brusco y radical de dieta porque como se ha dicho anteriormente algunos pediatras lo consideraban apropiado. Después de la dieta a base de leche y papillas de harina de los menores, pasaban a comer prácticamente igual que los mayores, garbanzos, patatas, carne y tocino, variaban las cantidades; la leche solamente se daba hasta los tres años, el equivalente a media taza en el desayuno $(125 \mathrm{ml})$ y otro tanto en la merienda

"Art. 268. La ración diaria de los acogidos en el Hospicio será la siguiente:

A) Para los diez y ocho meses a tres años de edad: 25 centilitros de leche, 300 gramos de pan, 28 gramos de garbanzos, 50 gramos de patatas, 30 gramos de

${ }^{659}$ VELASCO S.: Puericultura. Buenos Aires. 1946, pp 41- 45 
carne, 15 gramos de tocino, 25 centilitros de aceite, e ingredientes para su condimento.

La leche se distribuirá por mitad entre el desayuno y merienda; el resto, entre el almuerzo, comida y cena.

A partir de los 3 años todos los niños asilados comían igual, como vemos incluso las cantidades eran fijas y ya no se incluía la leche.

B) Para los de tres años en adelante: 500 gramos de pan, 50 gramos de carne 0 25 de bacalao un huevo; 56 gramos de garbanzos, 28 gramos de tocino, 25 gramos de arroz y 2 centilitros de aceite, e ingredientes para su condimento. Estos se distribuirán en sopa por la mañana, cocido a mediodía y por la noche sopa, o bien arroz, patatas o alubias o bacalao"

En las festividades del día del patrón, Nochebuena, Pascua y Año nuevo, "se suministrará a los acogidos comida extraordinaria" y ocasionalmente "siempre que con este objeto fuese hecho algún donativo", cuando particulares o sociedades filantrópicas hacían donaciones en forma de determinados alimentos o de "banquetes". En las fiestas de Navidad eran "obsequiados con aguinaldos de turrón y castañas, nueces, higos u otros artículos equivalentes". También podía variar la comida cuando enfermaban y se mejoraba en los niños considerados enfermizos

"Art. 272. La comida de los enfermos se ajustará a la prescripción facultativa y la de los acogidos enfermizos o débiles se mejorará con u huevo para el almuerzo, 50 gramos más de carne y una merienda de queso o frutas"

Como se puede ver la leche solamente se contemplaba en la dieta de los asilados hasta los tres años, tampoco se administraba a las embarazadas ni a las nodrizas. Verduras y frutas tampoco se incluían a ninguna edad, ya se vio que se compraban ocasionalmente, como un extraordinario, y para las enfermerías. Si se cumplía la normativa, era una dieta fija para todos los días, salvo los extraordinarios comentados ${ }^{660}$.

Parece que la dieta real del Hospicio sería tal como dicen los reglamentos porque las compras del establecimiento, como se puede comprobar en sus libros de cuentas, se ajusta a

\footnotetext{
660 Podemos comparar la dieta del Hospicio con la que propone Suñer en sus tratados y manuales, teniendo en cuenta que eran libros dirigidos a pediatras o a madres de clases pudientes. Es una dieta variada en la que propone diferentes comidas para cada día de la semana y que incluye a diario leche, fruta y verdura y alterna carne pescado y huevo. Recojo una de las propuestas para cada edad

"Niños de dos a cuatro años. Desayuno: leche, 250 gramos, con cacao y avena o leche sola con u poco de café y cacao. Pan tostado con miel o mermelada o mantequilla muy fresca. Comida: caldo de verdura con sémola, tapioca o fideo fino. Un trozo de pescado blanco, cocido o al horno (merluza o lenguado). Una compota hecha puré. El caldo se puede hacer también con carne magra, de preferencia de ternera. Merienda: pan y fruta o pan y mermelada o pan y miel. Cena: un puré de patatas, solo o mezclado con un poco de puré de zanahorias o de espinacas. Compota y fruta. (El puré de patatas puede ser sustituido por otro de lentejas o judías Pan de preferencia tostado, agua potable."

"Grupo de 4 a 6 años. Miércoles. Desayuno: un vaso de leche con un tercio de chocolate.pan con mantequilla y miel. Almuerzo: puré de lentejas y repollo. Gallo con salsa de tomate. 1 naranja. 1/2 [pan de] viena. Merienda: 1 vaso de leche. 1 galleta María. Cena: huevo pasado por agua con bechamel. Crema de chocolate. 1/2 viena."
} 
los ingredientes indicados, son los mismos que aparecen también en los presupuestos generales de la Diputación. Ya decía en el capítulo de las Fuentes que me llamó la atención una "lista de compra", muy corta y poco variada en el que frutas como las naranjas o manzanas se incluían como gastos extraordinarios o como "menudencias de despensa", cosas prescindibles y de poca importancia. También en este apartado se incluía el pescado fresco, aparte del bacalao que formaba parte de las compras y la dieta rutinarias, en cambio vimos como el vino se compraba en cantidades importantes sobre todo en las primeras décadas. Puede consultarse el apartado de 2.2.4.4. Alimentación del capítulo del Hospicio, en el que se trató la dieta de los asilados, ya que a partir de los 3 años todos comían lo mismo.

La dieta del Hospicio, a partir del destete era por tanto monótona e incompleta y si hacemos caso de las críticas, en algunos momentos podría también haber sido insuficiente y de mala calidad. Aun así, según el artículo que publicaba El Norte de Castilla sobre los hospicios en 1913, podía ser mejor que la de muchos niños "de familias menestrales" ${ }^{661}$, vamos por tanto a ver cómo podía ser la alimentación de estos.

\subsubsection{Alimentación fuera de la Inclusa}

Existían costumbres muy arraigadas que incluían la introducción de alimentos inapropiados demasiado pronto, sobre todo cuando no se podía hacer lactancia materna y no se disponía de nodriza. Sabemos que desde muy temprano, a veces desde las primeras semanas, se utilizaban papillas o gachas de pan o harina mezclados con agua o leche y se usaban chupones hechos de trapo y rellenos de pan y azúcar. A los tres meses se daban ya alimentos como patatas cocidas, arroz o sopas de ajo; cuando salían los primeros dientes corteza de pan y era muy normal dar a los niños vino entero o rebajado con agua. Pronto se les daba de comer lo mismo que a los adultos y para ayudar al lactante la madre masticaba su comida antes de dársela ${ }^{662}$; la fruta y las verduras apenas se utilizaban en la alimentación infantil, al igual que en la del adulto. En la Cartilla Higiénica del Niño, expedida por el Instituto de Puericultura de Gijón en 1927 entre los Consejos a las madres decía: "Los mayores

\footnotetext{
${ }^{661}$ N.C. 21- 10- 1913

662 RAMOS R.: Puericultura, p 49 y BORRÁS LLOP J.M: Historia de la Infancia en la España..., p 155.

También DeMause recoge este dato en "La evolución de la infancia", DEMAUSE LI.: Historia de la infancia referida a la Inglaterra de 1485. Se trata de una costumbre ancestral muy extendida que ha persistido también en algunos pueblos y regiones de Castilla hasta bien entrado el siglo XX. Al darle al lactante el alimento masticado se le ofrecía "predigerido" gracias a las enzimas salivares y por tanto resultaba más fácil de tolerar.
} 
enemigos de los niños menores de cuatro años son el vino, el café, las frutas y la carne. Prívale de ellos y tendrás a tu hijo sano y alegre. No lo hagas, y cuenta por seguro que pagarás con lágrimas tu desobediencia a este leal consejo" ${ }^{\prime 663}$. Podemos contrastar estos datos con los de las entrevistas realizadas, aunque éste es un tema en el que he tenido que hacer una selección, porque hay bastante confusión en algunos entrevistados que nos relatan en ocasiones más lo que ellos hicieron con sus hijos que lo que corresponde a su infancia o lo mezclan. He descartado todos los relatos que mencionan productos o prácticas que con seguridad sabemos que corresponden a etapas posteriores a la guerra civil.

Coinciden todos los entrevistados en que el primer alimento era la leche materna, podía ser el único recurso, "No había vacas o comías la teta o sopas de ajo no había nada más"; cuando la madre no podía lactar, les daba el pecho otra mujer de la familia o una vecina y si no había nadie disponible les daban leche de vaca, de cabra ó "leche de oveja que había por alli", sopas o papillas. Alguno tuvo hermanos de leche y "para que el ama de cría tuviera suficiente leche le daban comida" y hay quien conoció a alguna nodriza del hospicio. Recuerdan que había niños que mamaban hasta los 3 años y más, "había niños muy retardados que incluso se andaban, salían a jugar y todavía mamaban de la madre"; dice alguno que hasta que la madre se quedaba embarazada 664 " "porque a la mujer se la va la leche" ó "porque la leche ya no alimentaba, y era mala", aunque no siempre se interrumpía la lactancia

\begin{abstract}
"Entre las vecinas y familia se ayudaban. Cuando los niños no agarraban bien el pecho de la madre, se los ponía otra mujer, se les daban de unas a otras hasta que el otro se acostumbraba a mamar o estaba fuerte, se ayudaban muchísimo. Recuerdo que a los 3 años todavía mamaba, buscaba a mi madre y cerraba la puerta para que no me vieran. Mi hermano mamó también hasta muy mayor, mi madre decía que tenía los morros de mamar. Una vecina que no tenía leche crió a su hija con leche de cabra. Es una zona en la que había muchas cabras. La niña era muy pequeña, podía tener 6 o 7 meses, la cabra se subía en un banco de enea y la madre colocaba a la niña bajo la cabra y mamaba. También se usaba leche condensada cuando la madre no tenía leche suficiente y los niños se quedaban con hambre. Se hacía con agua hervida". (Avelina A., 1919, Rodilana)

"Tanto yo como mis hermanas fuimos alimentados del pecho de mi madre, antes no había nada más. Por entonces, las mujeres, no "quedaban barbechas» ningún año y se quedaban embarazadas cuando estaban alimentando a otro hijo, parían cada muy poco tiempo... De oídas sé que una tía mía dio de mamar a una niña". (Teo 1929, San Miguel del Arroyo)
\end{abstract}

\footnotetext{
${ }^{663}$ La Gota de Leche. Casa Cuna de Gijón. Edita Ayuntamiento de Gijón. 2003

${ }^{664}$ Se seguía creyendo que la leche de la mujer embarazada era mala por lo que un nuevo embarazo implicaba el destete rápido del lactante, a pesar de que se intentó convencer a las madres de que no existe ningún riesgo poniendo el ejemplo de las hembras de los animales que lactan embarazadas. Lo mismo sucedía con la menstruación, incluso los médicos decían en los años veinte que alteraba al lactante y provocaba pérdida de peso, heces verdes y vómitos. Debía ser muy habitual suspender la lactancia por este motivo, porque también advertían con insistencia que no era perjudicial, que la familia no debía asustarse por esos síntomas y que se podía volver a lactar sin peligro para el niño.
} 
Sobre el momento de empezar a comer otras cosas aparte de la leche, no hay acuerdo y falla bastante la memoria, pero si recuerdan y coinciden en que les daban papillas o sopas a base de pan: "pan esmigado con agua y azúcar"; sopas de leche, que a pesar del nombre solían hacerse solo con agua; sopas de aceite, "hacían una papilla con aceite agua y pan, como las sopas de ajo sin ajo, untaban el pan y lo machacaban"; o la que llamaban "sopa boba, que llevaba aceite, agua y azúcar"; "pan hervido con aceite" o papillas hechas con harinas que "se tostaban en el horno o en una sartén" (así se malteaban)

\begin{abstract}
"Se daban también "papas» que se hacían con miga de pan agua y aceite y un poco de azúcar y papillas con maicena.

Todas estas cosas se daban a niños ya mayorcitos, a partir del año o así y cuando la madre ya tenía poca leche y el niño se quedaba con hambre. Y les daban trozos de pan para morder y les podían hacer las papillas con caldo de carne. Se hervía un trozo de carne muy magra en un cazo pequeño y se usaba el jugo para hacer la papilla de pan y aceite. No comían fruta, no se comía, nadie, solo uvas porque había viñas.

No recuerdo chupetes. Los niños se chupaban todos el dedo. Biberones tampoco he visto, enseguida les daban las papillas. Debian pasar del pecho a comer con cuchara" (Avelina A., 1919, Rodilana)

"Al principio les daban el pecho a los niños y cuando terminaban con el pecho les daban sopas cocidas con aceite que las madres se lo metían en la boca, lo machacaban bien y luego con la cucharilla otra vez se le daba al niño. También se les hacia papillas de harina metiéndola al horno para que se tostara... Más tarde ya se sentaban todos a la mesa, se ponía la cazuela en el centro y el más espabilado era el que más comía". (Teo 1929, San Miguel del Arroyo)
\end{abstract}

Algunos ni siquiera recuerdan que hubiera biberones, pasaban "del pecho a comer con cuchara", ni chupetes, "se chupaban todos el dedo" o dicen que "no eran como los de ahora", "mi hermana tenía un chupete de tela, era un saquito que tenía pan, leche y azúcar".

Cuando empezaba la dentición les daban "trozos de pan para morder" y cuando tenían dientes la comida de los adultos, si hacía falta se la masticaban antes, mencionan sopas de cocido, requesón, purés de garbanzos, patata cocidas, "mi madre cocía pucheros de lentejas, uno para comer y otro para cenar". La mayoría no recuerda tomar cosas como café o vino, pero alguno dice que le daban pan con vino, vino a cucharadas, vino con agua o vino quinado para fortalecerles, que comían igual que los adultos y "el vino no faltaba nunca", en una zona de viñas.

En definitiva la dieta de los niños de clases populares como eran los entrevistados, casi todos además de zonas rurales, se parecía más a la del hospicio que a la que aconsejaban los pediatras. En general no hablan de tomar leche después de la lactancia, ni frutas, solamente una mujer comenta que comía uvas de los viñedos, tampoco mencionan las verduras; patatas, 
legumbres y sopas es lo que más recuerdan. Aunque no llegan a decir que pasaron hambre, muchos nos dan e entender que sufrieron muchas estrecheces

"Aprendíamos a comer rápido, como no había comida... no era como ahora que hay de todas las cosas" (Flocela C. M., 1929, Castroverde de Campos)

\subsubsection{ROPA Y VESTIDO DE LA INCLUSA}

Al ingreso después de lavar y asear a los niños se les vestía con ropas del Hospicio, se les adjudicaba su ajuar, es decir un equipo completo de ropa que se marcaba con su número, y a cada niño se le abría una cuenta en la que se anotaba toda la ropa que se le asignaba (Regl 1910 y 1927, Art. 179). Lo encontramos también denominado como "atillo" [sic], así aparece escrito incluso en los reglamentos, se refiere sin duda al hatillo o hato, que los diccionarios de la época definen como la "ropa y pequeño ajuar que uno tiene para el uso preciso y ordinario" $^{665}$.

Como ya hemos comentado, en los folios de registro se anotaban las ropas con que llegaban los expósitos al torno, no se hacían descripciones de este tipo en los ingresos por otra vía, en el caso del torno estaban obligados por ley a registrar todo aquello que pudiera servir para reconocer al niño en el futuro. Se describían generalmente con bastante detalle las prendas y su material, color, tipo de estampado, adornos o bordados cuando los tenían y su estado de conservación, si eran nuevas, viejas, estaban usadas, en buen uso o eran trapos.

Muchos niños llegaban vestidos, o envueltos, en parte o totalmente con "trapos"

"En siete de Enero de mil novecientos tres á las diez y seis horas y treinta minutos fue expuesto en el torno cuna de este Asilo envuelto en unos trapos" [sic] (fo 6, LE 1903-1)

"En 10 de Noviembre de 1912 á las 7 y 30 minutos fue expuesto en el torno cuna de este Asilo con las ropas siguientes: unos trapos prendidos con un imperdible" [sic] (fo 393, LE 1912-2)

Les dejaban también envueltos en todo tipo de prendas caseras, casi siempre viejas como servilletas, toallas, sábanas, delantales, enaguas; como si se hubiera improvisado y envuelto al niño en lo primero que pillaron en ese momento; puede ser que la madre no dispusiera de nada mejor o más apropiado, que no hubiera preparado ropa para el hijo al

665 Diccionario de la Lengua Castellana por la Real Academia Española. 14a edición. Madrid. 1914, p 273, 2 
tener previsto entregarlo o no tuviera interés en hacerlo, o simplemente que el parto se hubiera presentado de forma imprevista o anticipada.

"En 11 de Mayo de 1912 á las 23 y 30 minutos fue expuesta...envuelta en dos servilletas prendidas con dos imperdibles, una servilleta en buen uso la otra vieja y zurcida con las letras RR bordadas, lleva una cinta blanca pendiente del cuello con una medalla cuadrada al parecer de plata con la Imagen de San José y en el anverso un ramo y la inscripción Recuerdo de San José de la morada prendido con otro imperdible" [sic] (fo 174, LE 1912-1)

"El dia 13 de Febrero de 1902 á las trece horas de su dia fue expuesto en la cuna del Establecimiento envuelto en un refajo de lana roto" [sic] (fo 47, LE 1902-1)

"En veintiocho de Mayo de mil novecientos dos á las once horas fue expuesto en el torno cuna de este Asilo, envuelto en un delantal viejo" [sic] (fo 418, LE 19021)

"En 22 de marzo de 1913 á las 20 y 40 minutos fue expuesto en el torno de este Asilo con un papel que dice "Estos dos niños han nacido á las 2 de la tarde y no están bautizados». Le expusieron envuelto en una enagua usada con volante y junto á su hermano gemelo que ocupa el folio siguiente" [sic] (fo 115, LE 19131)

La mayoría de los expósitos llegaban vestidos con ropas más o menos usadas, que podían mezclarse con prendas nuevas o muy viejas

"Florencia... fue expuesta con... camisa de algodón, jubón de piqué, gorro id con tira bordada, pañal un trapo, todo usado" [sic] (fo 117, LE 1911-1)

"Dorotea... Traia puestas las ropas siguientes: camisa de algodón con puntilla, gorro id, jugon de percal blanco y encarnado, crucero con pintas negras, todo en buen uso, pañal y mantilla dos trapos" [sic] (fo 187, LE 1908-1)

"Manuel ... Traia ...: pañal de algodón, pañuelo id, dos vendas de hilo, camisa id, gorro id, otro de bombasí, dos jubones de muletón labrado mantilla id, fajero blanco labrado todo nuevo, delantal de franela negro con motas blancas usado, nube ${ }^{666}$ de color rosa de lana usada" [sic] (fo 6, LE 1909-1)

Incluso, aunque son los menos, en algunos casos el niño se presentaba con toda la

ropa nueva. Teodoro fue expuesto con siete horas de vida

"Traia puestas las ropas siguientes: pañal de hilo con bainica, camisa de algodón con canesú bordado, jubón de piqué con tira bordada, jubón de piqué con tira, gorro id, mantilla de bayeta blanca, fajero blanco labrado con impermeable todo nuevo" [sic] (fo 201 LE 1913-1)

(se encuentra así escrito, literalmente, el jubón aparece dos veces, podían ser dos piezas, y sin duda se ha confundido impermeable con imperdible)

\footnotetext{
${ }^{666}$ NUBE: Prenda usada por las mujeres para abrigarse el cuello y la cabeza. (DE TORO Y GÓMEZ, MIGUEL: Nuevo Diccionario Enciclopédico llustrado de la lengua castellana. París-Madrid, Librería Armand Colin-Hernando. 1901) Especie de chal muy ligero, hecho de punto, con que las señoras se envolvían la cabeza al salir de noche de casa, del teatro y de otros lugares cerrados. (Real Academia Española. Diccionario de la lengua española. Décima sexta edición. Madrid. Espasa-Calpe. Año de la Victoria [1939).
} 
En ocasiones, las más raras, se advierte que la ropa estaba pensada para el expósito al estar marcada con las iniciales de su nombre

"El día 24 de mayo de 1904 á las veinte y dos fue expuesto con las ropas siguientes: pañal de algodón pañuelo camisa con canisu bordado y tira bordada color rosa jugon de franela blanco de algodón con tira bordada color rosa mantilla de bayeta blanca fajero blanco labrado gorro de pique todo nuevo todas las prendas tienen las letras F.O menos el gorro y un papel que decía este niño se desea se llame Fernando del Olmo Solano nació á las siete de la tarde del dia 24 se suplica el recibo es entregado el mismo dia por Alfonsa Lopez" [sic] (fo 169. LE 1904-1)

Un año como 1905, de 119 registros sobre la ropa, en 39 se refieren solo trapos, en otros 20 se mezclan trapos con otras prendas y solamente en 11 toda la ropa es nueva, en los demás se mezclan piezas usadas y en buen estado En 1909 de 133 registros 45 refieren solo trapos y otros 28 mezclan trapos con otras prendas de mejor uso, en 2 la ropa es muy vieja, y solo en 8 todo es nuevo, el resto mezcla también ropa usada y en buen estado.

La ropa del Hospicio estaba reglamentada y casi toda se fabricaba en sus propios talleres, tanto el vestido y calzado de los asilados como la ropa blanca del establecimiento; la confeccionaban los asilados mayores, los muchachos trabajaban en los talleres de sastrería y de zapatería dirigidos por los maestros sastre y zapatero y las muchachas en el taller de costura que gobernaban las monjas.

\begin{abstract}
"Art. 156. Para vestir y calzar á los acogidos, habrá un maestro sastre y otro zapatero, los que ayudados de los acogidos que sean necesarios, harán todas las prendas y calzado de que hayan menester los asilados de uno y otro sexo bajo la dependencia del Director y Superiora, á cuyas órdenes sujetarán las obras que confeccionan

Art. 157. Las Hijas de la Caridad se encargarán de hacer las prendas que necesiten las acogidas para su uso, así como las ropas de camas y demás que sean precisas, cuya tela se fabricarán en el taller de tejidos del Establecimiento..., se valdrán del auxilio de las acogidas" [sic]. Regl 1889
\end{abstract}

El Hospicio tenía telares y un maestro tejedor, pero no cubría las necesidades del establecimiento, se tejían telas de hilaza para prendas del tipo de pañales, sábanas y camisas. Los presupuestos, y de forma más detallada los libros de cuentas, recogen todo el material de confección que se compraba, indicando además en ocasiones el uso al que iba destinado; en el apartado "Camas, ropas vestuarios y útiles de cocina" podemos encontrar hilaza de hilo para pañales y almohadas (en 1909 se compraron 392 kilos a 5'10 pts/k), cretona para atillos, busqueta para atillos, madapolán para atillos (en 1908 se compraron 300 metros de cada una de estas telas a 0'60 y 0'80 pts/m), bayeta doble para atillos (200 metros en 1909 a 5'75 pts/m), muselina de lana para mantillas y gorras de niños (en 1909 se compraron 312 metros a 1 '50 pts/m), cordellate para mantillas, fortuna para gorros y camisas, navarra para blusas, 
francesilla para delantales de niños y niñas, algodón para medias y calcetines, muletón blanco para refajos de verano, lanilla y vicuña para abrigos de niñas, pana y paño para trajes de niños, lienzo para forros y para remendar y algodón para medias y calcetines, entre otros. También hay material para la fabricación de calzado: suela, vaqueta, calcuta, badanas y otros

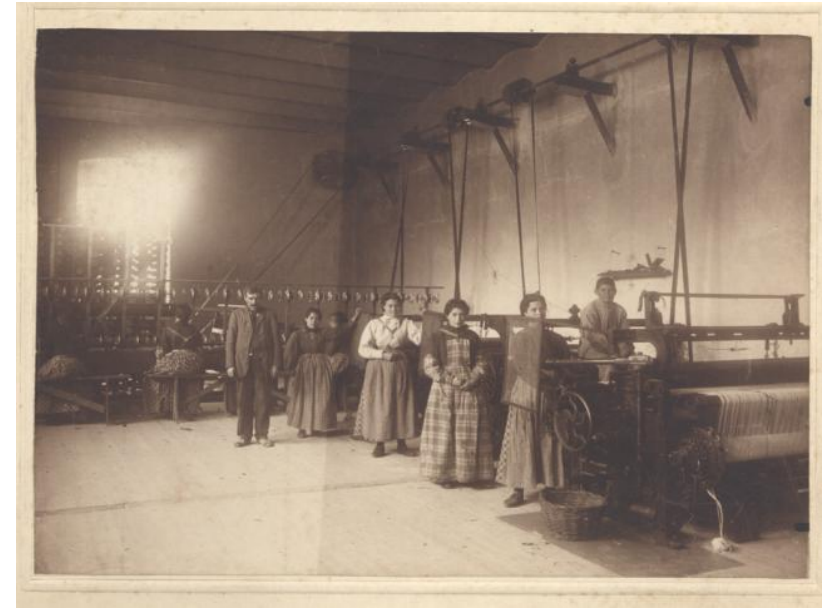

Imagen 3-31: Taller de tejidos del Hospicio Provincial de Valladolid. ADPVA. Sin datar, fecha probable 1911 para la confección de borceguíes de niños y botas de niñas.

Se compraban algunas piezas confeccionadas, pocas: Toquillas de lana para las asiladas, boinas para niños, pañuelos moqueros, pañuelos para la cabeza, y fajeros para niños de la inclusa (en 1909 se compraron 58 docenas y media a 5'10 pts/docena) y también calzado hecho, zapatos, botas y alpargatas (en 1909 se compraron 100 pares de botas y 48 pares de calzado a 5 pts/par y 122 docenas de alpargatas de varias medidas a 6'16 pts/docena).

"El cuidado y conservación de estas ropas estará a cargo de las Hijas de la Caridad exclusivamente" (Regl 1889, Art. 155). El hospicio disponía de un almacén con el ropero general, a cargo de las monjas, y dos roperos, "uno destinado para las prendas de uso diario de los varones, y el otro para el de las hembras", a cargo de un celador y una Hermana respectivamente, responsables de "conservar debidamente las ropas y hacer lo necesario para qué sean compuestas en el caso de algún deterioro" (Regl 1910 y 1927, Art. 199-206).

La Hermana encargada del almacén llevaba el control de la ropa que se adjudicaba a cada acogido y los reglamentos prohibían sacar "del almacén ninguna prenda de vestir sin que previamente se haya dado otra de baja mediante orden escrita del director", excepto la que formaba el equipo de cada niño a su ingreso (Art. 182 y 183). Cuando un asilado fallecía o salía definitivamente, la ropa se reparaba, se higienizaba y se devolvía al almacén, solamente en el caso de que estuviera inservible se daba de baja, previa orden de la dirección.

"Art. 207. Al fallecimiento de algún acogido, limpiarán y desinfectarán las ropas, procurando se hagan en ellas los reparos necesarios para conservarlas en buen uso y las pongan a disposición del Director para que dé la orden de ingreso en el 
Almacén. Lo mismo se hará en los casos en que por haber salido un acogido dejare parte de su equipo". (Regl 1910-1927)

A los asilados que abandonaban el Hospicio al cumplir la edad se les dejaba el traje de diario y en el Reglamento de 1927 se añadió que también el de los domingos "si no tuviese parientes que se hicieran cargo de él" (Art. 231).

Cuando fallecía un expósito en crianza externa, la nodriza debía devolver "el escudo y las ropas que hubiere recibido del Establecimiento, excepto la prenda que se emplee para la mortaja" y cuando las prendas no se devolvían, se descontaba su valor de los haberes del ama dependiendo del tiempo de estancia que llevara el niño con ella "por el valor íntegro de las mismas, si no hubieran transcurrido tres meses desde su entrega; de la mitad pasados seis meses y de la tercera parte si hubiere vivido nueve meses el expósito, cuyo descuento no tendrá lugar si hubiere vivido un año" (Regl 1889, Art. 93 y 94).

No hay ningún artículo que refiera lo que se hacía con las ropas que vestían los niños al ingresar, ya que según los reglamentos no se usaban dentro del Hospicio, "Los acogidos que no estén exceptuados expresamente usarán sólo las prendas de vestir que en el Asilo se les facilite" (Regl 1910, Art. 274), es de suponer que las que estuvieran en buen estado se conservarían y podrían formar parte del atillo que llevaba el inclusero al salir a criarse fuera.

En el torno tenían dispuesta la ropa para envolver a los expósitos, desde el almacén se entregaban paquetes de veinte envolturas completas. Se llamaba envoltura al "conjunto de pañales, mantillas y otros paños con que se envuelve a los niños" ${ }^{\prime 67}$. Dicen los reglamentos de 1910 y 1927 que "Cada envoltura constará de dos pañales de lienzo, dos mantillas de bayeta, dos jubones de percal, dos gorros, dos fajas, dos camisitas y dos pañuelos para el cuello" (Art. 312 del Regl 1910, y Art. 315 de 1927). El ajuar de los niños de la Inclusa no cambió con el tiempo, estas mismas ropas constituían el "atillo" que se entregaba a la nodriza externa cuando el niño salía para crianza, así lo dice expresamente el reglamento de 1889.

“Art. 82. Al entregarse un expósito se dará a las nodrizas las ropas siguientes por duplicado: camisa de algodón y pañal de lienzo, gorro y jubón de percal, pañuelo de tres puntas de algodón, fajero, mantilla de bayeta doble y otra sencilla".

El pañuelo de tres puntas de algodón, que aparece en este artículo se corresponde al pañuelo, que seguramente por error de interpretación en los reglamentos posteriores dice

\footnotetext{
${ }^{667}$ Diccionario de la Lengua Castellana por la Real Academia Española. 14a edición. Madrid. 1914, p 422, 3
} 
para el cuello y que debía de tratarse de la toquilla, prenda usada habitualmente para envolver y arropar a los lactantes.

Entre los libros revisados del Hospicio, apareció suelto medio folio arrancado de un cuaderno con una lista de prendas de vestir para entregar a una niña que se encontraba en crianza, dice la papeleta

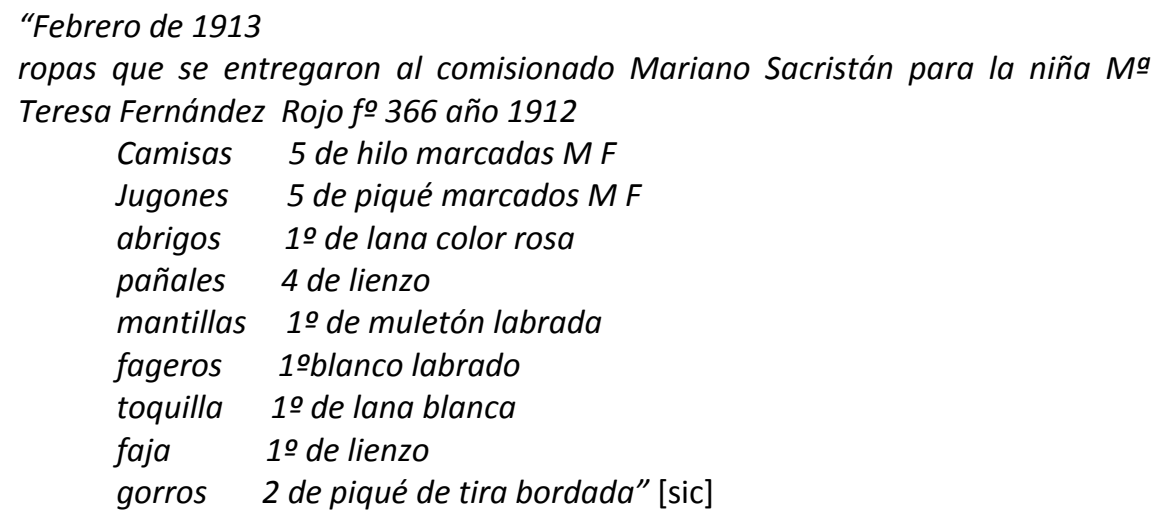

La niña María Teresa Fernández en cuestión se encuentra inscrita, como dice la nota, en el fo 366 del 2o libro de 1912, nació en la Maternidad el 16 de octubre de ese año y el día 28 la llevaron unos vecinos de Sebulcor (Segovia), donde falleció el día 21 de abril de 1913, dos meses después de entregada esta ropa. En el folio del libro de exposiciones no consta si la nodriza devolvió las ropas ni el plomo como ordenan los reglamentos. Esta lista no se corresponde exactamente con lo que reglamentado en cuanto al número de piezas, además es de suponer que no sería la primera entrega de ropa porque la niña salió con la criadora cuatro meses antes, pero tampoco hay otros indicios que nos hagan suponer que el Hospicio proporcionaba ropa a las nodrizas durante la crianza, aparte de la que se suministraba cuando se llevaba al niño, se suponía que el salario era para atender a las necesidades del niño, entre otras la de vestido. Las piezas con las iniciales de la canastilla mencionada podrían ser entregadas por la madre de la niña ya que las del Hospicio, según dicen los reglamentos se marcaban con el número del expósito, parece improbable que utilizaran las iniciales como distintivo porque habría muchas coincidencias.

La vestimenta que describen los reglamentos para los niños de la Inclusa es solamente la envoltura, usada en los primeros meses de vida, no refieren la que se utilizaba después, cuando el niño empezaba a andar, lo que llamaban vestido de corto, ni cuándo se hacía el cambio a la ropa de los mayores, que ya era similar a la de los adultos. Si refieren que el vestuario de los asilados debía ser "uniforme", además de que solamente podían vestir las ropas del Hospicio que estaban “determinadas por el Reglamento" (Regl 1910, Art. 274) 
"Art. 153. Vestirán los expósitos una misma clase de trajes, según sus edades y sexo, sin permitir que los padres $u$ otras personas les den cuando estén en el Establecimiento ropas de superior calidad á las que usen los demás.

Art. 154. Cada expósito tendrá un traje completo para diario y otro para los días de fiesta o asistencia de algún acto público, tres camisas de lienzo, dos pares de borceguíes y dos gorras. Y las mujeres dos refajos interiores, uno de bayeta regular y otro de la ordinaria, una enagua, tres vestidos, tres gabanes, una mantilla y dos pares de zapatos" [sic] (Regl 1889)

El Reglamento de 1910 establece que los asilados tendrán dos trajes para cada estación, el de diario y de trabajo y el de fiesta y detalla algo más las piezas que incluye cada uno.

\begin{abstract}
"El vestuario de los varones será uniforme y consistirá en chaqueta y pantalón de patén de algodón ó hilo para el verano y boina y en iguales prendas de paño con almilla de algodón y calcetines para el invierno y dos pares de borceguíes.
\end{abstract}

El traje de las asiladas, también uniforme, se compondrá de enaguas de cotón, vestido de indiana y pañuelo de hombros ó gabán para el verano y de refajo de muletón, vestido de franela de algodón o tartán, mantón de lana ó gabán para el invierno, usando además en todo tiempo medias de algodón y dos pares de botas o zapatos" [sic] Regl 1910 y 1927, Art. 275 y 276

Las niñas mayores los días de fiesta llevaban además "mantilla de muselina". No dice a partir de qué edad usaban los niños este uniforme, en el reglamento de 1889 se incluyen los artículos que hacen referencia al vestuario a continuación del que habla de la alimentación en los mayores de 18 meses, podría ser ésta la edad para empezar a vestir estas ropas, aunque parece muy pronto para las costumbres de la época. Los niños de la Cuna por edad podrían ir de corto, pero, como hemos dicho, no se recoge en la normativa del centro.

A falta de información más completa sobre los usos de la Cuna en cuanto al vestuario, hemos de buscarla fuera. Es de suponer que el vestuario de los incluseros se ajustaría a los usos de la época, pero, aunque se ha escrito mucho sobre la Historia del traje y la evolución del vestido a través de los siglos, hay muy pocas referencias bibliográficas a la vestimenta infantil, las reseñas son aún menores cuando se trata del vestuario de los recién nacidos ${ }^{668}$. Las revistas de moda, que aparecieron en París a mediados del siglo XVIII, no empezaron a tratar

\footnotetext{
${ }^{668}$ Cfr: PORRO FERNÁNDEZ C. A.: Notas sobre indumentaria infantil en Castilla y León. Revista de Folklore. №263. Año 2003; BOUCHER F.: Historia del traje en occidente. Barcelona. Montaner y Simón. 1963; BOEHN M., MORALES M.L.: La moda. Historia del traje en Europa, 9. Siglo XX: 1900- 1920. Barcelona. Salvat 1956; MERINO ARROYO C., HERRERO GÓMEZ G.: La vida cotidiana en Valladolid a principios del siglo XX (Encuesta del Ateneo 1901-1902). Valladolid. Castilla Ediciones, 1999; LIMÓN DELGADO A., CASTELLONE HERRERO E.: El ciclo vital en España (encuesta del Ateneo) I. 2. Nacimiento: (alumbramiento, bautizo, hijos ilegítimos). Madrid. Edición Crítica, 1990; LERA DE ISLA A.: Bautizos, bodas y entierros, Cuadernos Vallisoletanos. Ed. Caja de Ahorros 1986; CASADO LOBATO C.: La indumentaria tradicional en las comarcas leonesas. León Diputación de León. 1993; PROST A., VICENTE G.: Historia de la vida privada, 9, La vida privada en el siglo XX. Madrid. Taurus, 1991
} 
este tema hasta fines del siglo XIX, clara muestra de la escasa importancia que se daba al mundo infantil; también es cierto que esas revistas eran totalmente elitistas y que sus propuestas estaban muy alejadas de la mayoría de la población. Por otra parte, hasta el último tercio del siglo XIX el traje de los niños era casi una copia del de sus padres en tamaño pequeño, Marta Blanco señala que en España "aún a principios del siglo XX el traje del niño está impregnado de elementos que pertenecen al guardarropa de los adultos" ${ }^{\prime 669}$; en lo que se refiere a los recién nacidos lo primero que publicaron las revistas fue modelos de "vestidillos sobre todo para los bautizos con un gran delantal bordado"670. Los libros y artículos de puericultura que proliferaron en la época daban consejos sobre el vestido de los niños, de ellos podemos extraer información, teniendo en cuenta que proponen lo que los pediatras entendían que era lo ideal y que por tanto podía no coincidir con la situación real, sobre todo en los niños de clases más bajas ${ }^{671}$. Sirva como ejemplo el manual de Enrique Suñer ${ }^{672}$ en el que afirma que cualquiera que sea el traje utilizado debía reunir las siguientes condiciones:

"1‥ Que sea lo más simplificado posible.

2‥ Que deje sueltos aunque abrigados, los miembros inferiores, a fin de que éstos puedan disfrutar de movimientos.

3‥ Que procure la contención y abrigo del vientre."

La sujeción del vientre era una idea fija en el cuidado de los bebés por el temor a los enfriamientos y a las hernias, para evitarlos se utilizaba el fajero, prenda imprescindible en la canastilla. El fajero era una banda de tela larga y estrecha que se enrollaba al cuerpo del niño, "de unos $80 \mathrm{~cm}$ de largo por 6 de ancho. En uno de los extremos se cosía un hiladillo cuyo final, después de rodear al niño, se remetía entre la faja para que quedara bien fajado y no le molestaran los nudos" ${ }^{\prime 673}$; se decía a nivel popular y médico que servía para sujetar los órganos abdominales y protegerlos del enfriamiento. Debía ser costumbre apretarlo, como los pañales que envolvían al niño, porque todos los manuales advertían que debía evitarse, asimismo, recomendaban utilizar vendas anchas pues las estrechas al recogerse decían que actuaban

\footnotetext{
669 BLANCO CARPINTERO M.: Abrigo de niño, 1890. Conferencia en el Museo del traje. El modelo del mes, septiembre 2009. Marta Blanco es investigadora de moda en la Universidad Complutense de Madrid, doctora en Literatura por la Universidad Complutense su tesis doctoral trata sobre la moda en el siglo XIX.

${ }^{670}$ BOUCHER F.: Historia del traje en occidente: desde la antigüedad a nuestros días. Barcelona. Montaner y Simón. 1967. p. 286

${ }^{671}$ Puede consultarse entre otros: SUÑER Y ORDÓÑEZ E.: op.cit., 1920; VIDAL SOLARES F.: Puericultura e higiene de la primera infancia. Barcelona. Luis Gili, 1915; BOIX BARRIOS J.: Manual de puericultura. Valencia. Librarías de F. García Muñoz, imp. 1941; MARFAN Profesor y col.: Pediatría. Tomo I. Barcelona. Editorial Pubul. 1925; RAMOS R.: Puericultura: higiene, educación y alimentación en la primera infancia (del nacimiento a los tres años). Tomo I. Barcelona 1941 y Puericultura: higiene, educación y alimentación en la segunda infancia (niños de tres a siete años). Tomo II. Salamanca 1938; VELASCO Y LLAMAS S.: Puericultura. Buenos Aires. Editorial Caymi. 1897; ROBERTSON P.: El hogar como nido. La infancia de la clase media en la Europa del siglo XIX. En: Historia de la infancia. DEMAUSE LL. Madrid. Edit. Alianza Universidad. 1982

672 SUÑER Y ORDÓÑEZ E.: La salud del niño...1920, pp 43- 46;

${ }^{673}$ Eusebia Romero en la página etnográfica de Alcozar (Soria)
} 


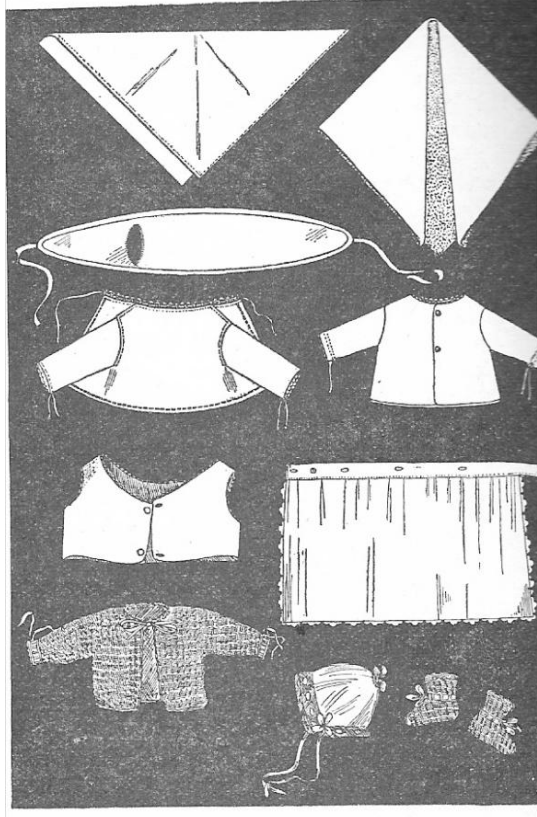

Fig. 28. -De izquierda a derecha y de arriba abajo. $=1$. $3.0^{\circ}$, faja. 4. $\circ^{\circ}$, camisa. 5.o, jubon. 6.०, cuerpo sin m

magen 3-32: Ropas de los bebés según Suñer. Fuente: SUÑER E.: "La salud del niño (Puericultura fundamental", 1920 como cuerdas y podían provocar una dispepsia que es causa de llantos y vómitos ${ }^{674}$. Los primeros días para proteger el cordón umbilical y evitar su herniación se utilizaba el ombliguero o venda ombliguera, aunque también lo encontramos nombrado como fajero, la diferencia entre uno y otro, independientemente del nombre utilizado, era que el ombliguero se colocaba directamente sobre el ombligo y la faja o fajero iba por encima de los pañales sujetándolos.

Sin embargo, a pesar de que se recomendaba abrigar bien el vientre, no se aconsejaba el exceso de abrigo corporal, por el contrario los pediatras denunciaban que se arropaba excesivamente a los bebés. El doctor Enrique Nogueras, catedrático de Enfermedades de la Infancia en una conferencia en la Universidad "censura duramente la alimentación inadecuada que se les da á los niños y alude después a la falta de limpieza con que se les cría y al abrigo excesivo que se les pone arbitrariamente distribuido y perjudicial, pues les produce sudores y molestias que les debilitan" ${ }^{675}$, los médicos pensaban que "por regla general se les pone demasiada ropa a los niños. Esta costumbre debería desaparecer" ${ }^{\prime 676}$.

Aconseja Suñer vestir a los bebés colocándoles primero un pañal doblado en forma de pico, sobre él el fajero atado con cintas, una camisita, un jubón ${ }^{677}$ (hasta aquí coincide con la ropa proporcionada por la Inclusa) y luego añade un cuerpo sin mangas, la enagua, gorro, botitas de punto y abriguito de lana. Lo que Suñer llama aquí enagua podría equivaler o sustituir a la mantilla que formaba parte de la envoltura del Hospicio, pero en una tela más fina. Se llamaban enaguas, o enagua, a la falda larga hasta los pies, interior o exterior ${ }^{678}$ y la mantilla, o mantillas, era la pieza que envolvía a los bebés por encima de los pañales desde la

\footnotetext{
${ }^{674}$ MARFAN y col. op. cit. p 120

${ }^{675}$ N.C. 21 de febrero de 1922, p 5

${ }^{676}$ VELASCO Y LLAMAS S.: op. cit. , p37

677 JUBÓN: Vestidura que cubre desde los hombres hasta la cintura, ceñida y ajustada al cuerpo. Diccionario de la Lengua Castellana por la Real Academia Española. 14a edición. Madrid. 1914. Imprenta de los sucesores de Hernando, $\mathrm{p} 483,1$. En muchos registros del Hospicio aparece escrito como JUGON

${ }^{678}$ ENAGUAS: Vestidura que usan las mujeres y cubre desde la cintura, donde se ata, hasta los pies. En la mayor parte de nuestras provincias sólo dan este nombre a las que se hacen de lienzo blanco y sirven interiormente debajo de los guardapiés; pero en otras llaman á éstas enaguas blancas y entienden por enaguas a toda especie de guardapiés, como no sea negro, que entonces se llama saya o basquiña. Úsase a veces en singular. Diccionario RAE. 14a edición. Madrid. 1914, p 402, 3.
} 
cintura hasta por debajo de los pies (IMAGEN 3-32). La primera impresión al leer los consejos que daba Suñer en su manual a "las [madres] principiantes" es que no había vestido a muchos bebés. Dice

\begin{abstract}
"La introducción del jubón y de la chaquetita es uno de los escollos más arduos con que se tropieza en las primeras pruebas, porque los bracitos del niño se adhieren al tejido haciéndose muy difíil su deslizamiento en el interior de las mangas. Se resuelve esta dificultad construyendo, con papel fuerte, unos cucuruchos que se introducen de dentro a fuera en cada manguita, dejando asi el camino abierto y expedito para la introducción del brazo del niño, que sigue en su movimiento progresivo, el del cucurucho previamente colocado y de un modo simultáneo á la extracción de este último"
\end{abstract}

No deja de ser una solución ingeniosa e ingenua.

Sobre la vestimenta posterior, propone Suñer vestir al niño de corto a los 6 meses, puede hacerse antes en los meses estivales, y ese vestido corto estaría constituido por un pañal triangular, una faja de franela para el vientre, una camisa de hilo o de algodón, un jubón de franela o de piqué, una braga, una enagua con cuerpo y sin mangas, un vestido, unos calcetines y unas sandalias. "En tiempo de verano la camisa, el jubón y el vestido sin mangas. En tiempo frío, estas prendas deben llevar mangas y además se les pondrá una camiseta y un abriguito de lana. Para salir una capa con capucha. Suprimidos los gorros". Este vestido corto vemos que no diferencia entre niños y niñas. Para los "niños mayorcitos", no indica edad, únicamente dice que en el exterior deben llevar "el gabán de suficiente abrigo" y en invierno proteger las piernas con medias y que en casa no deben abrigarse mucho evitando "ropas interiores fuertes", esto no sería aplicable evidentemente al Hospicio, donde el invierno debía ser muy frío, teniendo en cuenta las características del edificio.

Más fiable en cuanto a la vestimenta real de los niños de las clases más populares, y por tanto más próximo a lo que sería la vestimenta de la Cuna, es el trabajo de Carlos Antonio Porro Fernández "Notas sobre indumentaria infantil en Castilla y León" ${ }^{679}$ en el que diferencia tres etapas en la evolución de la vestimenta infantil desde el nacimiento hasta que el niño se viste como los adultos: el Fajado de cuerpo entero, el Fajado de mantillas y el Manteo. Dice que "durante los primeros días de vida, el niño permanecía aprisionado entre las envueltas anudado de pies y manos, inmovilizado completamente, estiradas las piernas y los brazos pegados al cuerpo cubierto por un pañal fajado". Esta costumbre de envolver o fajar al niño estaba muy extendida por todo el mundo desde la antigüedad, se creía que fortalecía los

\footnotetext{
679 PORRO FERNÁNDEZ C. A.: "Notas sobre indumentaria infantil en Castilla y León”. Revista de Folklore. № 263. Año 2003, pp 96-108
} 
huesos y los enderezaba ${ }^{680}$ y persistía a pesar de que se venía desaconsejando desde hacía tiempo; Martina Castells, la primera doctora en medicina española, en 1882 diría:"saber que la limpieza facilita la transpiración cutánea y aumenta la robustez y que al envolver a su hijo no debe hacerlo comprimiendo sus miembros porque se crean posturas viciosas y se limita el crecimiento $^{\prime \prime 681}$, incluso Rousseau ya recomendó quitar las mantillas ceñidas y dejar al lactante sólo con pañales y permitirle gatear libremente para que se fortaleciera ${ }^{682}$. Esta etapa del enfajado completo, según dice Carlos Porro, duraba entre un mes y 40 días, pasados los cuales se liberaba al niño parcialmente, momento que se conocía como el "sacamanos", que era motivo de celebración familiar pues suponía que el niño había sobrevivido los días más críticos y que en algunos lugares coincidía con el día en que la madre volvía a la iglesia; si el niño fallecía en los primeros meses se le solía amortajar fajado de cuerpo entero ${ }^{683}$. Hay muchas e importantes fuentes iconográficas que muestran el enfajamiento, véase el Niño

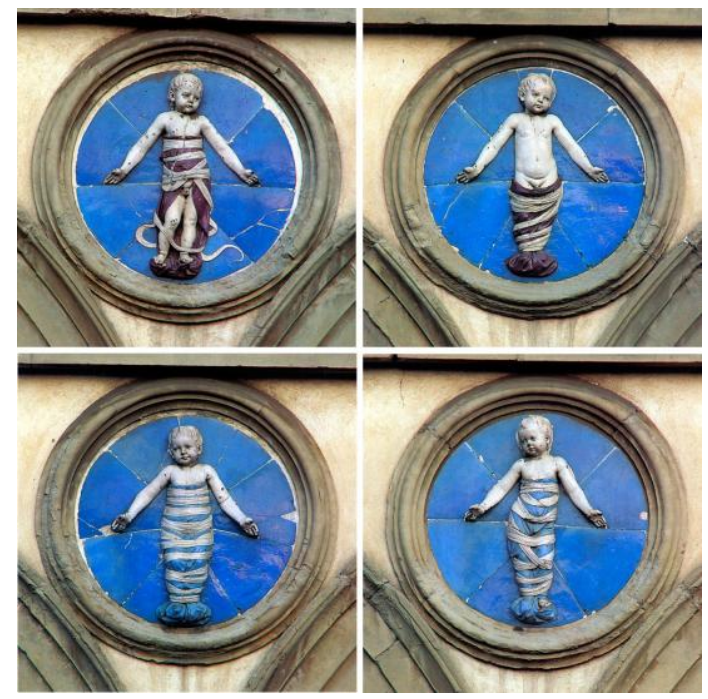

Imagen 3-33: Niños enfajados. Medallones del Ospedale Santa María degli Innocenti de Florencia

\footnotetext{
${ }^{680}$ La sujeción se consideraba desde antiguo uno de los cuidados básicos y más importantes de los primeros meses, necesaria para evitar que el lactante se autolesionase, por ejemplo para que no se arrancase los ojos o que no se rompiera las piernas por ponerse de pie demasiado pronto, aparte de prevenir deformidades y mantener el calor natural que favorece la digestión del alimento. En un tratado sobre partos escrito por Rösslin en el siglo XV, médico alemán que seguía las enseñanzas clásicas sobre todo de Sorano, se dice: "Así cuando se envuelve al niño con las bandas y se le acuesta en la cuna, la nodriza debe poner toda su diligencia y atención para que todos los miembros queden bien sujetos y en su sitio, y hacerlo con toda suavidad y dulzura, y no torciéndolos y atropelladamente, lo cual deberá hacerse también varias veces al día: pues en esto sucede como en los retoños... tal cual los dispongan cuando son jóvenes así crecerán y permanecerán siempre. Y así el niño, si se le envuelve con fajas y vendas, enderezando sus miembros, crecerá derecho y erguido, si le tuercen, crecerá igual, y a la negligencia de muchas nodrizas puede atribuirse la encorvadura y deformidad de muchos hombres y mujeres que de lo contrario podrían ser tan bien parecidos como los demás". TUCKER M.J.: El niño como principio y fin: La infancia en la Inglaterra de los siglos XV y XVI. En DEMAUSE LL: Historia de la infancia. Madrid. Edit. Alianza Universidad. 1982, pp 255- 285.

En realidad esas deformidades entre otras razones podían deberse a un raquitismo por la falta de vitamina $D$, una poliomielitis u otras enfermedades deformantes, incluso a las contracturas provocadas por el mismo fajamiento,.

${ }^{681}$ CASTELLS M. (1852- 1884), citada en: FLECHA GARCÍA C.:"La educación de la mujer según las primeras doctoras en Medicina de la Universidad Española. Año 1882". En CABRÉ I., PAIRET M.: "Sanadoras, Matronas y Médicas en Europa. Siglos XII-XX." Barcelona Icaria editorial. 2001; pp 245- 249

682 VIGARELLO G.: Lo Sano y lo malsano: historia de las prácticas de la salud desde la Edad Media hasta nuestros días. Madrid. Abada Editores. 2006, p 217

${ }^{683}$ PORRO FERNÁNDEZ C.: op.cit., p 2 y MERINO ARROYO C., HERRERO GÓMEZ G.: op. cit: "Transcurridos los 40 días la mujer salía para ir a misa. Avisaban al sacerdote e iban a celebrar la misa de purificación o de parida....Con una vela encendida y su hijo en los brazos acudía al pórtico del templo donde los esperaba el cura, el cual, después de los perceptivos rezos y la imposición de la estola al niño, permitía la entrada al interior a la madre y al hijo", p 35.

"También es costumbre extendida que la madeofrezca a la criaturaa la Virgen ese día". MARTíN DE LA GUARDIA R., PÉREZ LÓPEZ P., PÉREZ SÁNCHEZ G.: La sociedad vallisoletana a comienzos del siglo XX: Comportamientos ante el nacimiento, matrimonio y muerte. 1989, p 257
} 
Jesús fajado en La adoración de los Magos de Diego Velázquez o en las miniaturas de las Cantigas, por no hablar de los famosos medallones de Andrea dela Robbia que adornan la fachada del Ospedale Santa María degli Innocenti de Florencia que muestran las distintas fases de la fajadura en las que iban liberando al niño de las vendas, empezando por los brazos (IMAGEN 3-33) y, por poner algún ejemplo próximo a nuestro Hospicio, el Retablo de San Juan Bautista de la iglesia de San Salvador de Valladolid.

En general en el siglo $X X$ ya se utilizaba poco el vendaje completo en bandas; el enfajado completo, aparte de que a nivel médico ya entonces no era recomendable, resultaba muy engorroso de realizar, requería mucho tiempo y dificultaba precisamente por eso la higiene del niño ${ }^{684}$. Al igual que hacía Suñer, en las primeras décadas del siglo XX se aconsejaba permitir la movilidad de las piernas, no obstante, a nivel popular se seguía envolviendo a los niños con más o menos firmeza.

"Puede influir en el lloro alguna pulga 'doblez de las mantillas debido á la mala costumbre de fajarles. Y también porque se haya ensuciado y le moleste la humedad. Es en lo que principalmente deben fijarse los que estén al cuidado del niño, en que esté limpio y seco, colocando entre sus piernecitas una punta de pañal ${ }^{\prime \prime 685}$

Entre los médicos de la época se discrepa entre usar la envoltura o las nuevas ropas a la inglesa que se van abriendo camino poco a poco. En un tratado de 1925 todavía se dice que la envoltura no se debe usar "... tal como aún se aplica en ciertos sitios, estrechamente apretado, sujetado con vendas arrolladas alrededor del cuerpo.... Nuestro «maillot» [la envoltura] de hoy deja los brazos libres, no aprieta el tórax ni el abdomen y debe ser en su parte inferior bastante suelto para permitir los movimientos de los miembros inferiores... El vestido a la inglesa exige mayor vigilancia, deja mayor libertad de movimientos pero expone más fácilmente a los niños a acatarrarse ${ }^{\prime 686}$; el modelo inglés proponía el uso de calzones o

\footnotetext{
${ }^{684}$ La iconografía disponible muestra que la fajadura era muy similar en todas las épocas y lugares en que se utilizó. No debía resultar fácil de colocar y además debía llevar su tiempo por lo que no se cambiaba a menudo, menciona DEMAUSE un texto de Filadelfia de 1830 en el que se dice que la envoltura en fajas y pañales era tan complicada que se tardaba hasta dos horas en vestir al lactante. (DEMAUSE LL.: La evolución de la infancia. En DEMAUSE LL.: Historia de la infancia. Edit. Madrid Alianza Universidad. 1982; pp 15-92) Con esta fajadura se bañaba raras veces a los niños, si nos atenemos a recomendaciones como la de Arnau de Vilanova en su obra Speculum no se cambiarían más de una o dos veces al día. Las lesiones de la piel debían ser frecuentes, por una parte por la propia compresión que hacía el vendaje y por otra por la falta de higiene. En la biografía de San Pedro Damián escrita por Juan Lodi se cuenta que su madre "agotada por los partos", pues era una familia muy numerosa y empobrecida, rechazó y descuidó al niño y una mujer se lo recriminó y "liberó de las vendas los miembros entumecidos del niño, lo acercó al fuego desnudo para calentarlo y curó las ronchas o costras que lo cubrían frotándolo con abundante aceite" (MCLAUGHLIN, M.: Supervivientes y sustitutos. Hijos y padres del siglo IX al siglo XIII. P 126)

${ }^{685}$ ANDREU M.: Vulgarización científica. N.C. 19-12- 1912, portada

${ }^{686}$ MARFAN y col.: op. cit., pp 119-120. El profesor VELASCO en cambio defendía el estilo inglés que."...hay que procurar que las piernas queden en absoluta libertad de movimientos. El mejor sistema de vestir a los pequeñuelos es el llamado inglés, que resulta cómodo e higiénico", VELASCO Y LLAMAS S.: op cit, p 37. En los primeros años del siglo XX también se utilizó como sustituto de la envoltura una especie de saco acolchado que sujetaba con firmeza piernas y cuerpo y dejaba libres los brazos y en él se mantenía al lactante las primeras ocho semanas de vida.
} 
culottes, que lentamente acabarían imponiéndose ya avanzado el siglo XX. Todavía en 1941 el doctor Boix dice en su manual a propósito de la fajadura que "en España son numerosos los tipos usados, pero abundan particularmente aquellos que comprimen al niño" ${ }^{\prime 687}$. Algunas de las entrevistas realizadas confirman esa forma de vestir a los niños, si no enfajados totalmente, si envueltos y prietos

\footnotetext{
"Los primeros meses a los niños se les ponía un "jugón", camisilla y jersey de lana. Al niño se le envolvía con la toquilla, y a algunos se les fajaba". (Felisa D., 1919, Osma)
}

"Los niños iban tan apretados que solían quedarse sin fuerzas en las piernas, por lo que tenían problemas para aprender a andar". (Pedro R., 1931, Fuente Olmedo)

"Cuando nacías pañal, mantilla y en el orín crecía la gente $Y$ muy apretados con un fajero y una camisilla o jersey" (Joaquina M., 1921, Quintanilla de los Oteros)

Este modelo de envoltura de medio cuerpo se corresponde con la segunda fase que refiere Porro; una vez que se retiraba el fajado de cuerpo entero se dejaba al niño "en mantillas", con los brazos libres y de cintura para abajo envuelto con pañales y "culeros" cubiertos por las mantillas de empañar. Es el tipo de vestimenta que vienen a relatar en las entrevistas realizadas, los entrevistados coincidiendo también entre ellos y con lo que cuenta Porro al menos en lo que al vestido "en mantillas" se refiere; en ninguna se habla del enfajado completo, pero si insisten en la forma de envolver a los niños con los pañales y mantillas, que también llaman "ropones". Los pañales eran piezas rectangulares de unos $70 \mathrm{~cm}$ de ancho por $80 \mathrm{~cm}$ de largo hechos de telas del tipo de lino, algodón y muchas veces de sábanas o retales viejos y los culeros nos cuenta alguna entrevistada que eran como un pañal o empapador de lana, eran de materiales más gruesos y absorbentes ${ }^{688}$. Sobre los pañales se colocaban las

\footnotetext{
Las fechas en que se dejaron de usar las bandas arrolladas son muy variables de unos sitios a otros, en Inglaterra fueron los primeros a finales del XVIII o principios del XIX, pero en 1877 todavía se describía a los niños alemanes como momias maniatadas con metros de venda que se quitaban una o dos veces al día como mucho. los vendajes se mantenían hasta los seis meses más o menos, luego se les ponía en el suelo para que aprendieran a arrastrarse. El vestido inglés hacía más fácil acostumbrar al niño a sentarse en el orinal, las nodrizas inglesas le sentaban un rato todos los días desde muy temprana edad para adiestrarle pronto en el control de esfínteres, demasiado temprano visto desde nuestra perspectiva y conocimientos, y argumentaban que la fajadura, al mantenerle muy tieso, dificultaba esta práctica (ROBERTSON P.: op cit, 1982; p 449). Como sea que las nodrizas inglesas y su estilo pedagógico estricto se consideraban un modelo entre las clases que podían permitírselo, este adiestramiento se puso de moda y en un artículo del N.C. del doctor ANDREU contaba: "Al nacer el segundo de nuestros hijos, vino para apadrinarlo nuestra buena madre, pulcra y cuidadosa en extremo. Cogió al niño por su cuenta y desde lo diez días de nacido, con verdadera paciencia de abuela, le abría a ciertas horas los pañales y le incorporaba para orinar. Y continuó así un día y otro día, y de tal modo se acostumbró el pequeño a aquella operación, que en lo sucesivo ni una sola vez, por descuido siquiera, se orinó en la cuna. Al sentir necesidad, se revolvía y lloraba, hasta que se le incorporaba para orinar, como si se tratara de un niño ya crecido". N.C. 19-12-1912, portada

${ }^{687}$ BOIX BARRIOS J.: op.cit, p26- 27

688 CULERO: "El pañal que ponen a los niños para poderlos limpiar a menudo sin desenvolverlos". Diccionario de la lengua castellana por la Real Academia Española. Undécima edición. Madrid. Imprenta de Don Manuel Rivadeneyra. 1869, p 231, 2
} 
mantillas de empañar, también llamadas envueltas o hatos de envolver, que eran prendas de uso exterior de tela de muletón, felpa o piqué, blancas o en color, de medidas parecidas a las del pañal, solían llevar algún bordado y puntillas ${ }^{689}$. Se utilizaban las mantillas para sujetar y dar calor al niño y también para lucimiento en fiestas, en cuyo caso iban más adornadas y se utilizaban mejores telas, era especial la del bautizo, la "mantilla de acristianar", que en muchas familias era un tesoro que usaban todos los hijos, que se guardaba y se heredaba. Para el lucimiento de los bebés en las ocasiones especiales se ponían gorritos, se usaban dos si hacía frío, uno de lana de abrigo y encima otro más fino de adorno, y todas las ropas se cubrían con el

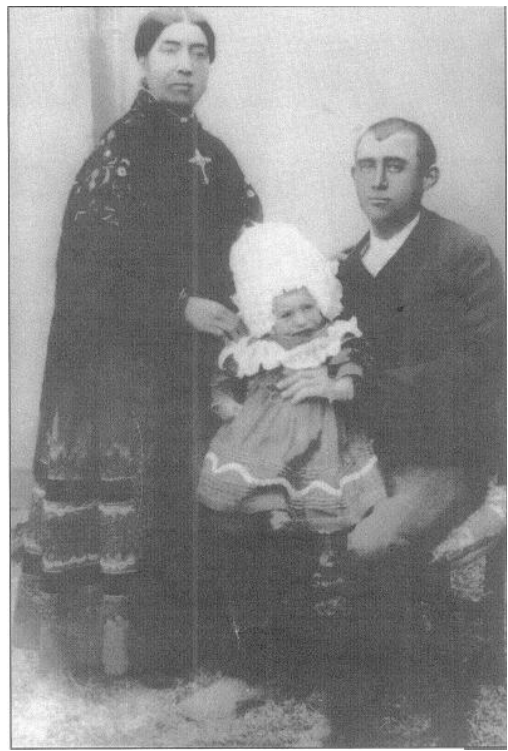

Imagen 3-34: Familia de Campaspero 1907, niño con gorrito y faldón. Fuente: Campaspero. Las imágenes de nuestra vida. $1900-1980$.

faldón, especie de vestido largo que se usaba sobre todo en celebraciones como el bautizo y que entonces se confeccionaba con telas más ricas (batista fina, organdí) y con profusión de adornos. "Era como un vestido de manga larga y con la falda que sobrepasara los pies. Iba abierto por la parte de atrás y se abrochaba con botones desde el cuello a la cintura. Este último faldón sólo se ponía para cristianar y luego se guardaba para los otros hijos y hasta podía pasar de una generación a otra ${ }^{690 "}$. Como es normal, estas ropas, consideradas un lujo, no se encontraban entre el atillo de la Inclusa, aunque algún expósito las llevaba puestas al ingreso; tampoco se mencionan los patucos o peúcos entre la ropa de la Inclusa, pocos entrevistados los mencionan, los pies quedarían por tanto cubiertos con los pañales y la mantilla, "Si el niño tiene cubiertos los pies con los pañales no necesita zapatitos o peúcos; en caso contrario se le pondrán de lana o algodón"691

\footnotetext{
"Especie de cucurucho de lienzo que se pone a los niños en la parte posterior para su limpieza" Diccionario de la lengua castellana por la Real Academia Española. Madrid. Imprenta de los Sres. Hernando y compañía Décimatercia edición, 1889, p 297, 2.

${ }^{689}$ Eusebia Romero en la página etnográfica de Alcozar (Soria) dice que alrededor se remataba "con una tela fina de cualquier color, siempre pensando en que las costuras quedaran planas para evitar los roces en el cuerpo del niño y resistieran los continuos lavados". Testimonio de Eusebia Romero Riaguas en El cuidado de los niños. AlcozarEtnografía. Página web elaborada por la Vocalía de Cultura de Alcozar. Disponible en: http://www.alcozar.net/etnografia/cuidado\%20ninos.htm 690 Ibídem

${ }^{691}$ BOIX BARRIOS J. op.cit, p 267
} 
La etapa que llama Porro "el Manteo ${ }^{692 " ~ d i c e ~ q u e ~ l l e g a b a ~ " T r a n s c u r r i d o ~ e l ~ m e d i o ~ a n ̃ o ~ o ~}$ varios meses más, cuando el niño ya se mantenía en pie, cuando estaba bien tieso, iniciaba sus andaduras o dejaba la lactancia", entonces se le "vestía de corto", se sustituían las envueltas por sayas, picos y braguitas tanto si era niño como si era niña para que pudieran tener las piernas sueltas y ensayar sus primeros pasos, aunque para dormir se siguieran utilizando las mantillas. El cambio de vestimenta, se hacía cuando el tiempo mejoraba y quedaban atrás los

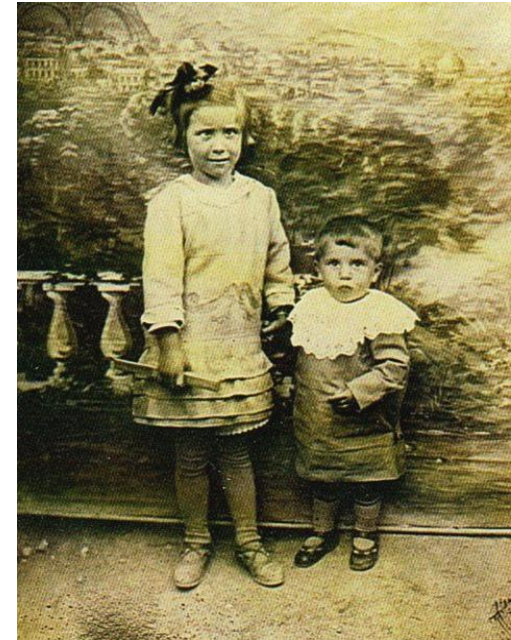

Imagen 3-35: Niño de $1 \frac{1}{2}$ año vestido de corto fotografía cedida por $\mathrm{M}^{\mathrm{a}}$ Victoria Rojo. Datación: 2 -7- 1926 fríos más recios, dice Porro que sobre el 1 de marzo, festividad del Santo Ángel y algunos entrevistados que por San José, así pues según cuando hubiera nacido el niño podía "estar en mantillas" seis o siete meses. Los infantes usaban el manteo, hasta los tres o cuatro años, cuando ya empezaban a diferenciar los sexos por la vestimenta. Dice Porro que según las costumbres podía alargarse más y que usaban en esta etapa "una prenda denominada según lugares, sayo, mandil o mandilete, de cuerpo entero (jubón y manteo), similar al baby actual, de diferentes tejidos y cerrado mediante botonadura en la delantera, en la espalda o con lazos en la cintura y que se usaba hasta la edad escolar". Fallan más los recuerdos de los entrevistados al hablar del "vestido de corto", quizá también porque parece que había más variedad y se mezclaban prendas infantiles y de adulto, hablan del uso de blusones y de peleles o pololos ${ }^{693}$, pantalones, bragas y vestidos. (IMAGEN 3-35)

"El día de San José, solían poner a todos los bebes de corto, les quitaban las mantillas y los ponían unas braguitas o un pantalón o un vestidito corto" (Avelina P., 1925, Alba de los Cardaños)

Unos dicen que llevaban debajo pañales y otros no recuerdan, "iban con el culo al aire, se agachaban y hacían sus cosas", y algunos que los peleles y pantalones estaban abiertos

"y el pantalón tenía una abertura y el niño se agachaba y hacía lo que necesitase, no llevaba pañal" (Joaquina M., 1921, Quintanilla de los Oteros)

\footnotetext{
692 MANTEO: ropa de bayeta o paño que traían las mujeres de la cintura abajo, ajustada y solapada por delante. Diccionario de la lengua castellana por la RAE. 14a edición. Madrid 1914, p 651,3

${ }^{693}$ En alguna entrevista (Avelina A., por ejemplo) definen los peleles como trajecitos de cuerpo entero hasta media pierna y de una sola pieza que se abrochaban atrás. En los diccionarios de la época no aparece el término como tal. Encontramos pelele desde la edición de 1817 como "figura humana de trapos y paja..." o en su segunda acepción como "persona simple o inútil" ( $\mathrm{p}$ 655-1) y no aparece hasta la edición de 1947 la tercera acepción como "traje de punto de una pieza que se pone a los niños para dormir" ( $\mathrm{p} 1334,3)$. El término pololo aparece por primera vez en la edición de 1895 del diccionario de Elías Zerolo en la acepción de "especie de moscardón" (p 1727, 1)
} 
"Como no había pañales a los niños se les ponían unas gasas y unos peleles con una abertura, eran unos pantalones con la parte del culo descosido" (Laura B., 1929, Palomares de Béjar)

En el mismo Hospicio tenemos una valiosa fuente de información en los registros de los Libros de Exposiciones, que también nos permiten hacernos una idea de cómo se vestían fuera los niños en la época, aunque es limitada porque la mayoría de los expósitos llegaban en los primeros meses de edad y solamente relatan las prendas, no su uso.

Las ropas de los recién nacidos y lactantes de pocos meses coinciden con la que se recoge en los reglamentos de la Cuna y con la que hemos ido viendo. Eladia Alejandra apenas tenía tres horas de vida, según se decía en la nota, cuando la expusieron

\begin{abstract}
"en el torno-cuna de este Asilo con las ropas siguientes: pañal de algodon, pañuelo id, camisa de hilo con tira bordada sin mangas, jubón de muletón, meadera de bayeta blanca, mantilla de muletón labrado con tira bordada, gorro id, fagero azul labrado, todo en buen uso" [sic] (fo 58, LE 1902-1)

"en 25 de Febrero de 1910 á las 13 horas fue expuesto en el torno de este Asilo con un papel que decía "Se la pondrá Maria Martinez á nacido á las 8 de la mañana de hoy y no esta bautizada». Traia puestas las ropas siguientes. Pañal de algodón, camisa id con puntilla encarnada y la letra L, jubón de muletón blanco con tira bordada á las mangas, mantilla de bayeta blanca grande, todo en buen uso, corbata blanca de algodón como fajero" [sic] (fo 73, LE 1910-1)

“... Traia puestas las ropas siguientes... pañuelo blanco con jareton y cuadritos, mantilla blanca de muletón con ondas adornadas con su cordoncito de seda azul, un fajero blanco labrado con una crucecita hecha de algodón encarnado todo en buen uso, una toquilla blanca vieja un detente y unos evangelios de raso azul bordado con sedas y abalorios con un corazón" [sic] (fo 99, LE 1911)
\end{abstract}

La edad de quitar "las mantillas" ya hemos visto que no era fija y aunque Suñer la sitúa en los 6 meses, dependía mucho de la estación, y en muchos sitios el "vestido de corto" estaba fijada por costumbre; Manuel de 7 meses todavía iba en mantillas cuando llegó a la Inclusa

"El dia 22 de Octubre de 1904 fue expuesto en el torno del Establecimiento a las 18 treinta con las ropas siguientes; pañal de algodón, camisa id con puntilla jugon de muleta labrado mantilla de bayeta amarilla fagero blanco de punto gorro de pique con tira bordada faldón de percal de color claro todo usado" [sic] (fo 330, LE 1904-2)

A continuación en la nota que acompañaba al niño se describían también las ropas que llevaba puestas, todo coincide, en vez del faldón dice "un delantar largo"

Los niños que llegaron con más de 7 meses al torno ya no vestían la envoltura, vestían de corto, las prendas les dejaban las piernas libres y llevaban zapatos. Ángel tenía 8 meses, le expusieron el 2 de enero de 1910, era el quinto hijo, el padre estaba sin trabajo y la "Madre baldada de brazos y piernas" 
"...traia puestas las ropas siguientes: braga de algodon, camisa id con puntillas, enaguas id, jubón de piqué, refajo ${ }^{694}$ de ganchillo de lana color rosa y canela, corse de color, calcetines rayados negros y encarnados, zapatos de color, vestido de percal color ceniza con rayas azules, toquilla de lana blanca, abrigo de paño color canela, todo usado" [sic] (fo 1, LE 1910-1)

María Francisca fue expuesta en el torno con poco más de un año vestía:

"camisa de algodón, dos bragas id, enagua id con puntilla, jubón de color, justillo ${ }^{695}$ id vestido de percal rayado encarnado y blanco, refajo de lana color rosa medias negras, botas de color, babero de pique con tira bordada, todo en buen uso" [sic] (fo 141, LE 1909-1)

Eugenio Sanz fue expuesto con 2 años

"Traía puestas las ropas siguientes. Camisa de algodón, jubón id enagua id vestido de percal blanco y encarnado, calcetines y zapatos todo usado" [sic] (fo 193, LE 1913-1)

Román fue expuesto con 4 años

"por hallarse su Madre enferma y no teniendo recursos en cuanto se ponga buena Dios mediante se la reclamará.... Traía puestas las ropas siguientes: enagua de algodón, camisa de color, falda id, vestido blanco con bordado, justillo, jubón, medias negras, botas id." [sic] (fo 240, LE 1912-1)

Algunas veces simplemente ponían que vestían de corto; Andrés tenía 15 meses,

"Viste de corto con ropas usadas" [sic] (fo 44, LE 1912-1)

Como podemos ver por las citas anteriores, en estas edades, como en los primeros meses, no había distinción por sexo ni en el vestido ni en los colores, niños y niñas vestían la misma ropa de corto, básicamente camisa y jubón, braga, enagua y vestido, medias y zapatos; aunque ya empezaba a diferenciarse y se empezaban a utilizar prendas de adultos, encontramos algún niño con pantaloncito

Pedro Sacristán fue expuesto con más de 3 años (39 meses) y vestía con

"camisa blanca y negra de algodón, calzoncillos de punto, pantalones color marino azul botas negras todo usado delantal blanco y negro" [sic] (fo 349, LE 1913-2)

También los colores, el azul y el rosa empiezan a utilizarse como distintivo de género. Amadeo, tenía 3 años y vestía delantal azul

\footnotetext{
${ }^{694}$ REFAJO: saya exterior de que usan las mujeres en algunas provincias de España, es ordinariamente corta y se cruza por detrás. Diccionario de la lengua castellana por la RAE. 14a edición. Madrid 1914, p 876, 2.

SAYA: ropa exterior que visten las mujeres más o menos plegada por arriba y que baja desde la cintura hasta los pies. Ib. p 926, 1

695 JUSTILLO: Vestido interior sin mangas, que ciñe el cuerpo y no baja de la cintura. Diccionario RAE. 14ạ edición. Madrid. 1914, p 497, 2.
} 
"camisa de algodón, enagua id, delantal azul y blanco, medias y botas, todo usado"

Su hermana Pilar tenía 10 meses y estaba ataviada con falda rosa

"justillo de color, jubón de piqué, camisa id con entredos, enagua de algodón, falda de percal color rosa vestido blanco, medias de color, zapatos id, todo usado"

[sic] (fos 312 y 313 1905)

En las entrevistas la mayoría dice que se vestían igual niños y niñas, pero algunas mencionan que ya se diferenciaba el uso del rosa y el azul. Al Hospicio llegaron niños muy pequeños enlutados, precisamente la muerte de la madre o el padre podía ser la causa de su ingreso

"Abril 10 Año 1907 folio 12 entro por la oficina una niña... Destete 24 meses, vino de luto son hermanos"

Su hermano de 4 años ingresó con ella, los dos iban de luto, en el Libro de Exposiciones no da más explicaciones. Cuando se guardaba luto familiar los niños también se enlutaban, a cualquier edad, en alguna entrevista así se testimonia

"desde los dos años siempre estaba de luto porque se murió madre de parto y quedé huérfana luego también de padre muy chica" (María P, 1931, Salamanca)

"Si moría alguien de la familia los niños también vestían de luto aunque fueran muy pequeños y lo llevaban durante unos años". " (Avelina A., 1919, Rodilana)

En el periodo de estudio, en el Hospicio, por las ropas que se refieren en los reglamentos, podemos asegurar que ya tampoco se utilizaba la fajadura completa y los niños se vestían desde el principio envueltos en mantillas; aunque en lo que denominaban la envoltura se incluían dos fajas se refiere seguramente a los fajeros, que era como se llamaban a las fajas que se

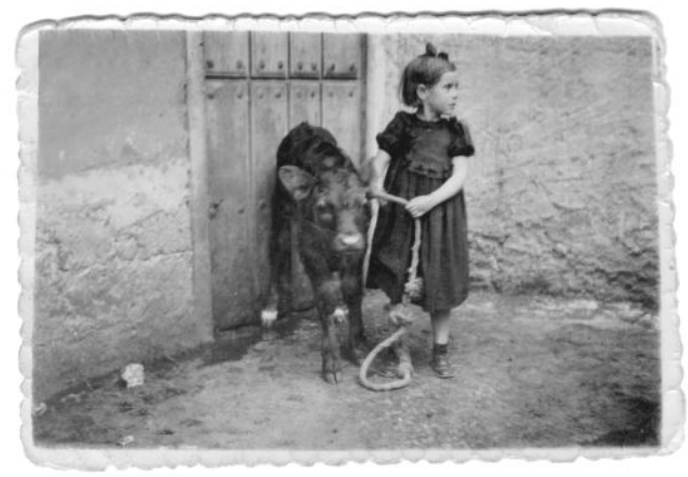

Imagen 3-36: Niña de de luto, edad 3- 4 años, calcetines y ropa interior de ganchillo también en negro (madre de la autora). Fecha probable 1933-4 utilizaban en los bebés, en los libros de cuentas de todo el período se pueden ver todos los años las compras de más de cincuenta docenas de fajeros. Podemos suponer que las condiciones del vestido de los asilados serían similares a lo que nos han contado en las entrevistas. Coinciden los entrevistados en que se abrigaba mucho a los niños, "se les abrigaba demasiado", "porque se mojaban mucho al hacerse pis y podían coger frio" y en que "Ilevaban la tripa muy abrigada". 
"se les abrigaba mucho con el faldón de extremeña que se llamaba así y era de lana gorda" (Flocela C., 1929, Castroverde de Campos)

"Se ponía mucha ropa a los bebés, se les abrigaba mucho, se cruzaba con toquilla de lana". (Ventura, 1922, Villada)

"Sí se les abrigaba mucho porque entonces no había calefacción ni nada, sobre todo a los niños que acababan de nacer porque perdían mucho frío y en esa época un niño podía morir muy fácil de un resfriado" (Laura B., 1929, Palomares de Béjar)

También hay bastante coincidencia en la escasez de limpieza de la ropa, en general dicen que se cambiaban y se lavaban poco los pañales y sobre todo las mantillas, que cuando solamente estaban mojadas se dejaban simplemente secar, debido a la falta de agua corriente.

"La ropa se cambiaba y lavaba muy poco. No había agua en casa y en el pueblo no hay río. Tenían que traer agua de los pozos y lavaban en unos lavajos [charcas de agua llovediza que rara vez se secan] que estaban alrededor del pueblo eran profundos y no se secaban nunca y en la cárcava. Se iba a los lavajos que había en el pueblo y cada 15 días se iba con el burro hasta el río y los que tenían más dinero iban cada semana a los lavaderos de Medina del Campo. Luego se dejaba la ropa al sol. No se usaba lejía, el sol quemaba más que la lejía. También se dejaba por la noche a los rayos de luna, que es mejor que el sol y dejaba la ropa blanca, blanca

Los pañales mojados no se lavaban, se ponían a secar" (Avelina A., 1919, Rodilana)

"Los pañales se lavaban metiéndolos en agua hirviendo para quitar las manchas, se cambiaban a menudo. Las mantillas no se lavaban tanto, por la noche se ponían a secar en el brasero. Tenían varias para recambio". (Angel y María, 1927, Salamanca)

"Les cambiaban poco de ropa, cuando estaban sucios" (Ventura, 1922, Villada)

"La mantilla se cambiaba cada día y el resto de ropa cada semana. Si estaba muy sucia la ropa, se la cambiaban". (Carmen A., 1924, Caleruega)

"No había pañales [como los de ahora]. Los niños se orinaban en la mantilla, que se cambiaba una vez al día". (Pedro R., 1931, Fuente Olmedo)

Para el aseo de los niños y empañarles o envolverles había en la Inclusa un cuarto para Lavabo y Empañador y un Secadero junto a las salas de cunas, según el plano de 1910 (plano en IMAGEN 3-1) y sabemos que el edificio ya contaba con agua corriente a principios de siglo, aunque también tenía problemas con el suministro de agua y las instalaciones higiénicas. El Hospicio contaba con lavanderas, además de las propias asiladas que tenían que colaborar en el lavado de la ropa, el jabón se compraba y se fabricaba en el propio establecimiento, se hacían compras de lejía y disponían de legiadoras que hervían y desinfectaban la ropa y que serían muy útiles sobre todo para prendas como pañales y mantillas.

No puedo por menos de recoger algunos testimonios como muestra y resumen de la vestimenta de los infantes de las clases populares de la época 
"Los lactantes se vestían con camisas de tela, camisetas y pañales también de tela o de trapos. No había pijamas. Las camisas se metían por dentro de los pañales que se sujetaban con cintas largas como una faja estrecha y fina y luego se envolvían en mantillas y manteos que se ataban con una faja más ancha y gruesa. Los vestían así hasta los 7- 8 meses. Cuando quitaban las mantillas ponían blusones para resguardar la ropa. Se ponían pantalones a los niños, había pantalones con dos braguetas, una por delante y otra por detrás. ". (Angel B y María P, 1927, Salamanca)

"Los lactantes pequeños usaban pañales de tela y encima un culero, [tela de un metro que le envolvía] y se colocaba a partir de la cintura y por arriba camiseta o jubones. Los pañales eran de tela. A los bebés les abrigaban con mucha ropa y toquillas, a veces demasiado. Al año se ponían peleles abiertos por debajo. Se les cambiaba poco de ropa. (Sagrario B, 1929, Pozuelo de la Orden)

Es muy interesantes sobre el tema del vestido el testimonio de Avelina A. (1919,

Rodilana) que empezó a trabajar en una casa a los 14 años y tuvo que cuidar un niño desde los 11 días de vida

"Les vestían muy feos, porque les tenían en mantillas casi hasta un año. Primero los pañales eran un cuadro y las mantillas más grandes y los ponían cruzados envolviéndoles las piernas. Por arriba los jubones y se sujetaban con un fajero que daba varias vueltas. Se usaban patucos para que no se enfriaran los piececitos. Los pañales se hacían con trapos viejos, sábanas muy gastadas, así estaban más finos y encima las mantillas que les abrigaban, para las ocasiones de fiesta se ponía encima los faldones que tenían la falda con vuelo, se hacían de piqué. Los fajeros se bordaban y los de fiesta también eran de piqué. Los fajeros eran muy bonitos. Luego el niño se envolvía entero con una toquilla, por encima de las mantillas. Estaban muy abrigados y casi no se podían mover. Las personas mayores se preocupaban mucho de que los bebés estuvieran bien envueltos para que no cogieran frío, sobre todo los piececitos y llevaban la tripa muy abrigada.

Todas esperaban al día de San José a ponerles en corto, era un detalle de todas, esperaban a quitarles las mantillas. Por San José los niños se ponían de corto se quitaban las mantillas y les ponían los peleles de punto inglés, que se abrochaban atrás. [No recuerda que se colocaran debajo pañales], algunos iban con el culo al aire, se agachaban y hacian sus cosas".

Y sobre todo, por la lucidez de sus recuerdos y su estilo de buen comunicador y de

hombre sencillo, sano y recio de campo y vida dura, el testimonio de Teo (1929, San Miguel del

Arroyo)

"Los niños al nacer les vestían con una meadera metida entre las piernas como un paquete. Por esto, por la forma de envolverles, algunos se quedaban con las piernas vueltas un poco hacia dentro y de mayores se les han quedado las piernas así. A este atuendo se le llamaba el ropón, las mujeres cosían un trapo encima de otro y encima de otro... asi hasta 4 y era como hacían el ropón.

Los niños estaban en mantillas hasta que tenían por lo menos 1 año. Cuando empezaban a andar se les ponía de corto. A los niños se les vestía con ropita de uno a otro, en mi época no existía el azul para los niños y el rosa para las niñas. Estaban los pantaloncillos con culera que eran abiertos atrás para cuando tenían que hacer caca, se agachaban y ya no había que bajarse los pantalones. Me acuerdo exactamente lo que comentaban los mayores de un niño que le dijo al maestro "señor maestro si no me pega usted le digo una cosa», y el maestro 
le dijo "a ver que es lo que tienes que decir», "pues que mi madre de unos pantalones viejos de mi padre me ha hecho unos nuevos para mí».

Verlo no, pero sí de oídas contaban en el pueblo de un maestro y una maestra a la que llamaban "la tía media liebre» que cuando en el pañal se hacían los niños la caca lo quitaba un poco y lo ponía al sol y cuando se secaba, lo restregaba y se lo volvía a poner. Pasaba la gente por delante y decían "ya está la tía media liebre aireando los pañales" porque los tenía colgados en las cuerdas.

A los niños antes se les abrigaba mucho. En las casas no había calefacción y como había poca ropa, se lavaba por la noche para que se secara para el otro día. También me acuerdo de que el colchón que yo tuve era de las mazorcas de maíz".

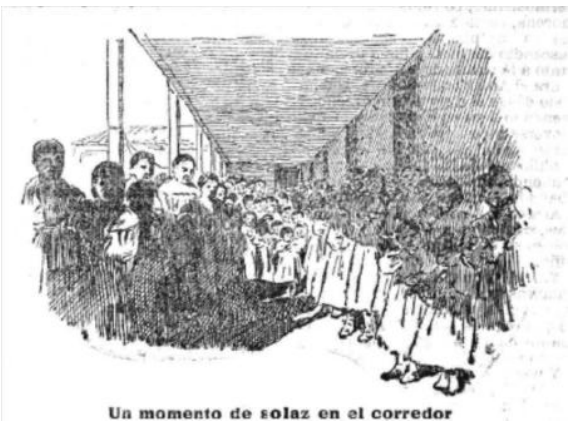

Imagen 3-37: En el Hospicio. N.C. 6-11904, portada
Teniendo en cuenta la ropa de la Inclusa, lo que cuentan Suñer, Porro, las entrevistas realizadas y sobre todo las prendas que se recogen en los Libros de Exposiciones, la envoltura "en mantillas" que vestirían los asilados de pocos meses podemos concluir que estaría constituida por los pañales, que se colocaban envolviendo las piernas del niño dando dos o tres vueltas desde la cintura y colocando una punta

entre las piernas para evitar escoceduras, sobre ellos se colocaba la mantilla también enrollada y se sujetaba todo con el fajero superpuesto, que daba varias vueltas al cuerpo del niño y se ataba con cinta o se sujetaba con un imperdible, Para la parte superior del cuerpo se les vestía con una camisa de tela fina que solían ser sin costuras y abiertas por detrás con un solo botón o atada con cintas y encima el jubón, especie de blusa o chaqueta ajustada de tela más fuerte como el muletón o la franela. "entre el pañal y la mantilla se pillaba la camisa y el "jugón" para que así quedaran bien sujetas todas las ropas, pues sobre la mantilla se le ataba la faja"696. EI gorro, que formaba parte del atillo, se usaba siempre en los niños pequeños, tanto fuera como en casa, y se recomendaba su uso sobre todo en las casas frías, como era el caso de la Inclusa. La vestimenta se completaba con la toquilla para abrigar al niño envolviéndole.

\footnotetext{
${ }^{696}$ Eusebia Romero en la página etnográfica de Alcozar (Soria)
} 
Ya hemos dicho que en los reglamentos no se refiere el traje de corto pero seguramente se utilizaría por comodidad y economía, no parece razonable vestir lactantes y niños de pocos años con los trajes de los mayores, similares a los de los adultos, bastaría adaptar las ropas de los primeros meses y cambiar las mantillas por bragas, que "se hacían con tela de rizo y era muy práctica. Consistía en una especie de triángulo doble; un triángulo se colocaba de atrás para delante y el otro de delante para atrás y se ataban los dos extremos con hiladillo" o por una pieza similar que popularmente llamaban ranitas "tenían forma de bragas abiertas por la parte de delante que se abrochaban en el centro de la barriga. Se hacía con tela de rizo y en la parte inferior, por dentro, se reforzaba con otra tela para que no se rompiera y aguantase bien los múltiples lavados. Esta pieza se podía cambiar si el resto de la ranita todavía estaba aprovechable ${ }^{\prime 697} \mathrm{y}$ por encima cubrirle con un vestido o blusón, lo que más tarde se llamaría baby. Refiere José Luis Hernando que en la casa de expósitos de Toro el hatillo de los "niños de pan", lo que sería el vestido de corto, estaba constituido por "dos camisas de lienzo, dos enaguas, jubón negro,

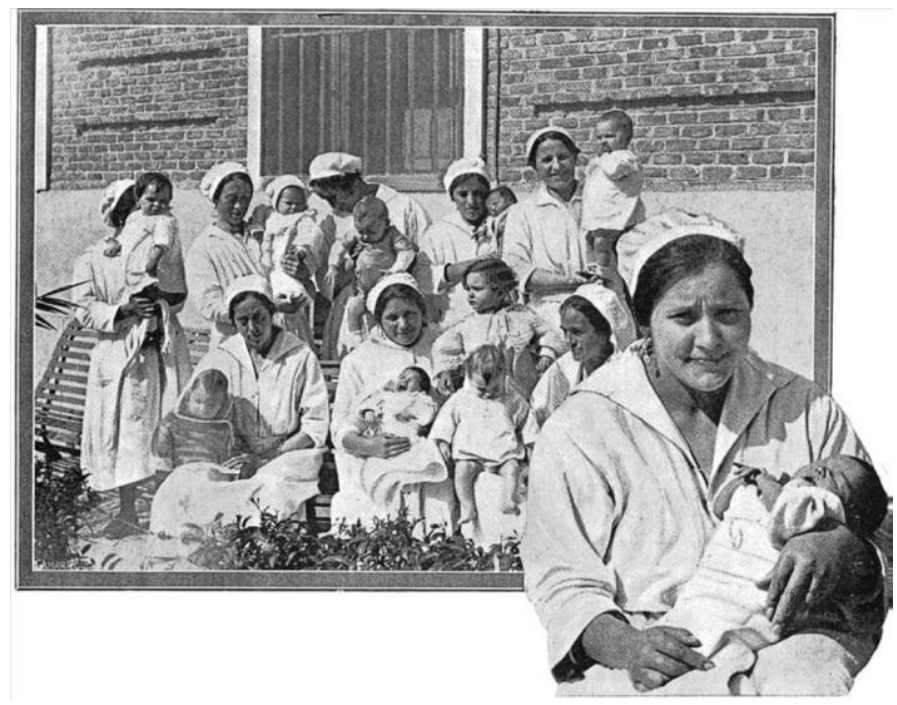

Imagen 3-38: Una visita a la Inclusa la tragedia del niño expósito. El Nuevo Mundo 15- 4- 1927, p 13 dos manteos, un par de talegas [culeros], de calcetas y de zapatos" ${ }^{\prime 698}$. No he conseguido localizar fotografías de niños pequeños de la Inclusa de Valladolid, ni en el archivo Provincial ni en la hemeroteca, únicamente un dibujo en 1904; el día de Reyes El Norte de Castilla dedicaba la edición a los niños y en la portada mostraba una serie de dibujos del Hospicio, en el que recogemos aquí (IMAGEN 3-37) los pequeños, al fondo, aparecen vestidos de corto. En la IMAGEN 3-38 vemos una fotografía de la Inclusa de Madrid publicada el 15 de abril de 1927 en El Nuevo Mundo en la que se ven un grupo de nodrizas con sus expósitos, unos vestidos en mantillas y otros de

\footnotetext{
${ }^{697}$ Ibídem

${ }^{698}$ HERNANDO GARRIDO J.L: op.cit; pp $4-16$.
} 
corto, el estilo de la vestimenta de Valladolid sería similar porque era la forma habitual de vestir a los niños ${ }^{699}$.

Otra cosa diferente sería la calidad de esas ropas, que no siempre fue la adecuada, como desvela aquella denuncia del diputado visitador Roldán Trápaga en 1918 "doloroso espectáculo de ver muchos niños y niñas, algunas veces en la época de frío, descalzos... casi desnudos y llenos de andrajos...", recordemos que los reglamentos decían que la ropa debía ser reparada y no se podía dar de baja si no lo ordenaba el director y por lo que dice la denuncia el aprovechamiento podía llegar a ser exhaustivo.

\subsubsection{Cunas, hules y zateas}

También se confeccionaba la ropa blanca del establecimiento, entre las compras hay estopa para rodillas (también llamadas rodeas o simplemente trapos de cocina), algodón para sábanas, hilaza de hilo para almohadas, carolina para bozos de cama, Cretona para colchas; incluso se fabricaban colchones de lana y jergones de paja, en los libros en la partida dedicada a Camas, ropas, vestuarios y útiles de cocina encontramos compras de cutí para colchones y terliz para jergones (telas fuertes que se utilizaban en sus fundas), lana blanca para colchones y paja larga ó de maíz para colchones y jergones, aunque en los presupuestos también hay una partida que incluye colchones de muelles. Únicamente se compraban confeccionadas las mantas de lana blancas o encarnadas (en 1909 se compraron 124 a 12'05 pts/una).

El reglamento establecía que hasta los 3 años los niños debían dormir en cuna y luego pasaban a camas, todos los años se incluía en los presupuestos una partida para adquisición y compostura de camas de hierro y algunos años incluían cunas

"Art. 158. Hasta la edad de tres años, dormirá cada expósito en su cuna y de aquella edad en adelante, en camas catres unas, y otras de hierro". Regl 1889

La ropa de cama y cuna también estaba reglamentada, se mudaban mensualmente, o cuando fuese preciso, y para proteger los colchones de las cunas se utilizaban hules que se compraban por metros todos los años, Hules impermeables para cunas que ocupan los niños de la Inclusa (en 1908 se compraron 21'5 metros a 11'50 pts/m)

"Art. 159. Las camas de la sala de lactancia, contendrán un jergón, colchón, un hule, dos sábanas, dos almohadas, una colcha y dos mantas.

\footnotetext{
${ }^{699}$ Artículo y fotografía disponibles en http://hemerotecadigital.bne.es/issue.vm?id=0002108665\&page=12\&search=EXP\%C3\%93SITO\&lang=es
} 
Art. 160. Todas las demás camas contendrán las mismas prendas, a excepción del hule

Art. 161. Para todas ellas y con el fin demudar las camas y cunas una vez al mes ó cuando fuese preciso, deberá haber la ropa blanca necesaria".

$\left(\operatorname{Reg} \mid\right.$ 1889) ${ }^{700}$

En los primeros años hay compras de zaleas, también se llamaban popularmente pellejos, son piezas de piel de carnero $u$ oveja que conservan su lana que se usaban para proteger el colchón de la humedad, se colocaban debajo de la sábana con la lana hacia arriba en invierno para dar calor e invertida en verano ${ }^{701}$. Se dejaron de comprar en 1905 , no

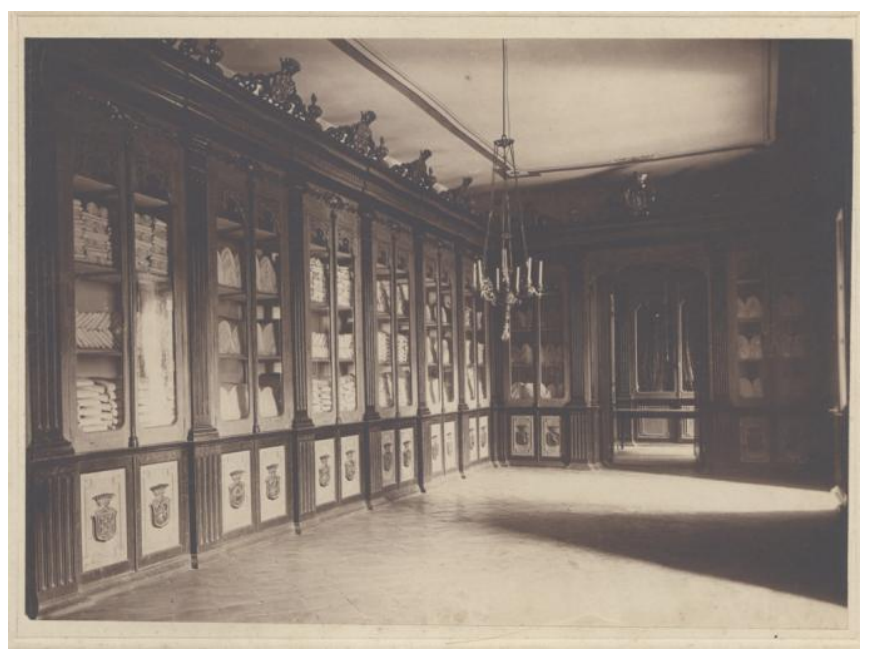

Imagen 3-39: Ropero del Hospicio Provincial de Valladolid con un precioso armario lencero. Archivo de la Diputación Provincial de Valladolid. Sin datar, fecha probable 1911 son artículos muy higiénicos para un sitio como La Cuna, teniendo en cuenta el tipo de pañales que se utilizaban se mojarían con frecuencia y, además de retener la humedad, si no se cambiaban a menudo ésta acabaría pasando a los colchones. En la página etnográfica de Alcózar se dice sobre ellas

"En la cama se ponía un pellejo. Cuando el niño era pequeño y se orinaba, pues ponías el pellejo a secar; pero, cuando eran más mayores, pues tenías que cambiarlos: poner uno y lavar el otro, y después los tendías en la bardera del corral a que se secaran al sol."

Las zaleas fueron sustituidas en la Inclusa por hules, igual de antihigiénicos, aunque al ser impermeables, resultarían más prácticos a la hora de preservar los colchones de la humedad. En uno de esos artículos de Vulgarización científica que publicaba con frecuencia El Norte de Castilla dedicado a los cuidados en la infancia sobre la cuna de los bebés descartaba el uso de unas y otros y aconsejaba los jergones de paja de maíz, más higiénicos porque la paja se podía renovar con frecuencia

"arreglada con preferencia con gergón de paja, sobre el cual se coloca vayeta limpia con su sábana correspondiente. Nada de hules ni pieles que tiendan á

\footnotetext{
${ }^{700}$ Estos cuatro artículos se mantienen exactamente igual en los reglamentos posteriores de 1910 y 1927 , artículos del 279 al 282

${ }^{701}$ ESPASA, tomo 70, 1930, pg 906

702 Testimonio de Eusebia Romero Riaguas en El cuidado de los niños. Alcozar - Etnografía. Página web elaborada por la Vocalía de Cultura de Alcozar. Disponible en:

http://www.alcozar.net/etnografia/cuidado\%20ninos.htm
} 
estancar la humedad y á ser posible de maíz por su mayor limpieza, prestándose perfectamente á ser renovados cuando su olor amoniacal se haga perceptible. $Y$ cubriéndolo con una manta de lana ligera y rodeados su cuerpecito con un par de botellas de agua caliente, perfectamente envueltas, á fin de sostener sin peligro, á su alrededor una temperatura agradable y uniforme, sobre todo en invierno"$^{\prime 703}$ [sic]

La paja de maíz que compraba el hospicio se usaría por tanto para los jergones de las cunas y camas de los más pequeños y es de suponer que se renovaría periódicamente porque hay compras anuales importantes, en el libro de cuentas de 1902 figuran tres compras en abril, agosto y noviembre por un total de 14'5 quintales y en 1903 una compra en el mes de septiembre de 50 quintales por un valor de 350 pesetas. Los colchones y jergones de paja eran de uso normal Teo de San Miguel del Arroyo (1929) dice que "también me acuerdo de que el colchón que yo tuve era de las mazorcas de maíz"

\subsubsection{HIGIENE Y SALUD DE LOS NIÑOS DE LA INCLUSA.}

No podemos dudar de que el sentimiento de preocupación por la salud de los acogidos, por mejorar sus condiciones de vida y las condiciones higiénicas del centro, fuera auténtico, porque hay documentos como algunas Memorias que lo manifiestan, pero la vida real muestra otra cara; las continuas quejas al respecto ponen de manifiesto la escasez de mejoras y de soluciones para estos problemas. Detrás de la falta de presupuestos podemos sospechar cierta desidia y falta de interés real por parte de los responsables últimos por resolverlos, sirva como ejemplo las negociaciones interminables entre la Diputación y la Facultad de Medicina en los años 20 para conseguir que los médicos de la facultad se hicieran cargo de los departamentos de Maternidad y de la Inclusa con objeto de intentar disminuir su terrible mortalidad. Las intenciones serían indudablemente buenas, pero, como tantas veces ocurre, la realidad era muy diferente, nadie podía dejar de ver las malas condiciones del establecimiento y de los niños y se conservan algunas cartas y Memorias que las recogen, dirigidas a la Diputación y escritas tanto por los facultativos como por el director y los diputados Visitadores, con denuncias y sugerencias de mejora que, en la mayoría de los casos, parece que terminaron archivadas.

Así como los reglamentos se ocupan de la alimentación y el vestido de los asilados, la higiene se menciona solamente de pasada, acaso se daba por hecho (?). El Reglamento de

${ }^{703}$ N.C. 19 diciembre de 1912, portada 
1889 únicamente dice de forma general en su Art. 61 que "en el servicio de este departamento [de lactancia] alternarán las Hijas de la Caridad, según lo disponga la Superiora, la cual celará para que se llene cumplidamente, así como de su aseo y limpieza" y atribuye a las nodrizas como principal responsabilidad "la lactancia y el cuidado de los niños" (Art. 69), sobreentendemos que la higiene formaba parte de esos cuidados. En cuanto a la sección de destete es algo más explícito, pero excesiva y sospechosamente breve, solamente dice que "hasta que se lleve a cabo la separación de sexos en este departamento, la Hija de la Caridad encargada del mismo, cuidará que tanto los niños como las niñas se las lave y peine todos los días" (Art. 111); este artículo se refiere a los menores de 3 años, que es la edad en la que se realizaba la separación por sexos según el reglamento (Art. 105). Se echan de menos indicaciones higiénicas un poco más explícitas, aunque habla del aseo diario, no dice cómo tiene que ser, sospechamos que no se refiere a un aseo general y no indica cuándo y cómo hacer éste último. Tampoco dice nada sobre el aseo de los niños a partir de los 3 años, es probable que una vez separados por sexos en algunos aspectos se les diera cierta independencia y en lo que se refiere a la higiene recibieran el mismo trato que los mayores, de ser así, tendrían que asearse ellos mismos bajo supervisión como se dice en el reglamento "se destinará una habitación para los niños y otra para las niñas mayores de siete años con objeto de que se laven y peinen por sí solos todos los días y a la hora que designe el Facultativo y la Superiora, presenciando este acto las personas designadas por aquella" (Art. 135).

Si tenemos en cuenta la escasez de baños en el establecimiento, seguramente no erramos mucho al pensar que el aseo general de los niños debía ser muy poco habitual, yo diría más bien que algo extraordinario. Se recogen en el capítulo sobre el Hospicio Provincial de Valladolid (ver punto 2.2 La Casa de los Benavente, el Edificio y sus Instalaciones) las muchas deficiencias higiénicas del centro, recordamos que en 1901 no disponía de baños, así lo denunciaba la propia Comisión Provincial que en su Memoria ya vimos que decía que "Una de las cosas más descuidadas en el Hospicio es la higiene individual... y sin higiene no hay bienestar ni salud posible en los asilados,.... es precisa la limpieza de la piel en general por medio de baños frecuentes y abluciones diarias y como hoy no hay en el establecimientos medios para subvenir esta necesidad...". El propio Gobernador Civil declaraba que en el Hospicio "la higiene deja mucho que desear". En 1904 "carecen de retrete las niñas" y el de los niños estaba falto de inodoros, puertas y ventanas. En 1909 el Hospicio disponía de un único cuarto de baño, que, sorprendentemente, al diputado señor Gavilán debía parecerle suficiente ya que ante una propuesta de obras para ampliarlo "se lamenta muy oportunamente de tan excesivo e inútil gasto, siendo así que en el establecimiento existe un cuarto de baño"; en 1913 
se presupuestaron "dos baños para el departamento de Maternidad", sin embargo sólo se compró uno. Un problema añadido y también denunciado era el escaso caudal de agua que llegaba al Hospicio, de manera que aunque hubiera bañeras, llevaba casi un día entero llenarlas. Por cuestiones higiénicas, pensando más en la salud que en el recreo de los niños, se contrataban en verano "baños en el río Pisuerga que prescriban para los asilados los señores Médicos" y en 1912 se empezaron a mandar también niños al Balneario de las Salinas de Medina del Campo.

Para los menores ingresados no había por tanto normas higiénicas específicas, para los externos el reglamento exigía entre las obligaciones de los cuidadores tenerlos "siempre aseados y limpios" (Art. 101). Esta exigencia la daremos por supuesta para los internos en el Hospicio, no obstante, teniendo en cuenta las condiciones higiénicas del edificio, la falta de bañeras y de un caudal de agua suficiente, el frío en los meses invernales y la escasez de personal no parece probable que este aspecto fuera convenientemente atendido, de ello da fe la tasa de infecciones, principal causa de la altísima mortalidad del centro.

Resulta penosa la situación real del Hospicio y la dejadez, al menos aparente y desde la perspectiva actual, de los responsables del centro en relación con este asunto. Sin que sea una justificación, además de la falta de fondos, y a veces de interés, de la Diputación para hacer frente a todas las cuestiones de carácter social dependientes de ella, sin duda también influyó una mentalidad en la que el aseo y la higiene personal era algo secundario, lo que explica actitudes como la del diputado Gavilán, todo ello a pesar de la preocupación y las recomendaciones que se hacían desde instancias sanitarias y políticas. El interés por la falta de higiene de la población general y en particular de la infantil, llevó incluso a proponer "El Baño en la Escuela", con los argumentos grandilocuentes de la Higiene Social

"El desprecio del cuerpo que durante siglos fue norma de la educación, dio por resultado la degeneración de las razas, sobre todo en las grandes poblaciones. Ganadas por las predicaciones de los pensadores y escarmentadas por descalabros en las contiendas guerreras, son muchas ya las naciones civilizadas que han inaugurado un movimiento a favor de la educación física. Las generaciones encerradas en tugurios, apenas gozaron de las gracias que con mano pródiga concede el Creador y ahora desean que sus hijos disfruten del aire, de luz, del agua, activando así las funciones vitales. ... Nuestras escuelas son auténticas mazmorras, que casi todas carecen de patios, pero en todas las localidades hay paseos, jardines, campo, donde los niños pueden respirar aire puro ... Menos fácil es conseguir que se bañen los niños... en todas las localidades de alguna importancia hay casas de baños á las que podían acudir los niños de las escuelas ... el baño de los niños pobres podría costearlo la misma escuela... podríamos probar a los extranjeros que nos visitan que los niños 
españoles también se bañan y haríamos un grandioso bien en la obra de la educación" ${ }^{\prime 704}$

En las primeras décadas del siglo XX son frecuentes las publicaciones sobre el tema de la higiene y los cuidados infantiles, aunque evidentemente éste no era el método más eficaz para llegar de forma masiva a la población porque precisamente los sectores más necesitados de esta información no tenían ni medios económicos ni recursos para llegar a ella teniendo en cuenta la pobreza y el analfabetismo dominante; no obstante, el Hospicio contaba con un equipo médico y por tanto hemos de suponer que con los conocimientos suficientes al respecto, otra cosa serían los medios. Los médicos junto con las Hermanas de la Caridad, responsables de los departamentos de menores y de la maternidad, deberían instruir a las cuidadoras y, como dice el reglamento, velar para que los asilados recibieran unos cuidados adecuados. A falta de normas higiénicas en los reglamentos, podemos echar mano de alguna de esas publicaciones para hacernos una idea de lo que podría hacerse en el Hospicio, o mejor dicho, de lo que debería hacerse. Podemos tomar como ejemplo el libro del doctor Enrique Suñer "La salud del niño", que fue responsable precisamente en la Universidad de Valladolid de la cátedra de Enfermedades de la Infancia desde 1906 hasta 1921

\begin{abstract}
"Deberá tomarse la costumbre, para toda la vida, de bañarse diariamente al niño... rebajando poco a poco la temperatura del agua, sin llegar nunca a dar el baño frío, sino solamente templado o muy moderadamente fresco (alrededor de $30^{\circ}$ C)... el enjabonamiento del niño no debe hacerse cada día; sólo cada tres o cuatro, pues el jabón llega a desgastar el epitelio, haciéndolo vulnerable a los agentes traumáticos. Es también muy conveniente... que el agua no entre en la boca ni en la nariz... pues no siendo el agua hervida, expondríamos al niño a infecciones intestinales, que debemos evitar a todo trance.

Después del baño, el niño debe envolverse en una toalla rusa, caliente... y a continuación será una gran práctica la de friccionarle por todo el cuerpo con un trozo de franela empapada en alcohol de romero o en una buena colonia.

El baño en el niño exige... que la temperatura de la habitación sea la debida (18 ó 20 o C). Cuando no se tiene el recurso de una buena calefacción en invierno, se recurrirá a quemar un poco de alcohol en una jofaina...o se le llevará a la cocina o a otra habitación en la que exista un poco de calor y buena temperatura.

Terminadas las manipulaciones del baño, más la fricción consecutiva, espolvoréese todo el cuerpo del infante y muy especialmente sobacos, ingles y genitales, con polvos de talco, finamente pulverizados, o de borato de sosa..." 705
\end{abstract}

\footnotetext{
704 CALDERÓN J.: El baño en la escuela. N.C. 30 enero 1913, p 2

705 SUÑER Y ORDÓÑEZ E.: La salud del niño (Puericultura fundamental, Madrid: Ediciones Fax; 1920, pp 36- 42. Enrique Suñer fue Catedrático de Patología General de la Facultad de Medicina de la Universidad de Sevilla desde1902, posteriormente ocupó la cátedra de Enfermedades de la Infancia de la Universidad de Valladolid y en 1921 la de Pediatría de la Universidad de Madrid. Fue Consejero de Instrucción Pública desde 1926 en los últimos años de la dictadura de Miguel Primo de Rivera, y cesado bajo el gabinete presidido por el general Berenguer en 1930. En 1923 fundó La Escuela Nacional de Puericultura y en 1930 fue nombrado Presidente de la Sociedad de Pediatría de Madrid. Durante la guerra civil y posteriormente ocupó diferentes cargos de índole sanitaria
} 
La prensa daba recomendaciones similares pero más sucintas, sirvan como ejemplo los artículos de Vulgarización Científica que periódicamente publicaba El Norte de Castilla ${ }^{706}$.

Todas las recomendaciones insistían en la importancia de la higiene de niños y especialmente de los lactantes y no solo del baño diario, sino en aspectos tan básicos como que "el niño esté siempre limpio y seco", "colocando entre sus piernecitas una punta del pañal". Suñer resaltaba que "tantas veces como el niño se ensucie, es menester lavar las partes manchadas con agua simplemente... Después de ser lavado se cambiarán los pañales que se hubieran ensuciado con la deposición o con la orina. El dejar que las deyecciones o la misma orina permanezcan en contacto con la piel del niño, es motivo de enfermedades cutáneas que enrojecen las partes internas de los muslos y los genitales, produciendo afecciones de tendencia a la cronicidad y muy rebeldes para ser curadas. Después de estos aseos parciales espolvoréese la piel con el talco o el borato de sosa"m07.

Esta insistencia de los expertos en algo que hoy nos parece tan elemental es el resultado de la falta de higiene que era habitual en el cuidado de los bebés, sobre todo en las clases más populares, debido a la falta de medios y de conocimientos y a la fuerza de la costumbre que hacía que se vieran adecuadas prácticas totalmente antihigiénicas e insanas. Ya vimos como en las entrevistas realizadas la mayoría coinciden que se cambiaban muy poco los pañales a los bebés, algunas incluso dicen que solamente una o dos veces al día; el baño diario por supuesto tampoco se practicaba, la falta de agua corriente y el frío eran parte de las razones para no hacerlo, la mayoría recuerdan que se bañaba poco a los niños, se les lavaba por partes en la cocina, el lugar más caliente de la casa

\begin{abstract}
"A los niños no se les bañaba, se calentaba agua en una palancana, se les limpiaba un poco y ya estaban listos. No teníamos ni cuarto de baño. Cuando se hacían caca sí se les limpiaba pero que yo recuerde no nos bañaban, y si se irritaban se les ponía polvos de talco. Nos cambiaban los pañales cada vez que estaban sucios y la ropa se lavaba por la noche y al día siguiente nos ponían la misma porque no teníamos casi ropa. Igual lo que se tenía puesto y dos o tres ropones más". (Teo 1929, San Miguel del Arroyo)

"No se bañaba a los niños, se les lavaba por partes con una tela. Les lavaban a diario la cara y el culo". (Sagrario B, 1929, Pozuelo de la Orden)
\end{abstract}

"Los niños se lavaban muy poco. No había agua en casa. Les limpiaban con una esponja. Nunca les bañaban. Se lavaban en una artesa. Cuando ya eran más

\footnotetext{
${ }^{706}$ ANDREU M., Vulgarización Científica, N.C. 19 diciembre 1912, portada: "Los niños deben lavarse desde el día que nacen, instituyendo el baño diario y que ya no debe dejarse en ningún tiempo ni estación. En los primeros días basta una palangana grande en donde quepa el cuerpo, con agua templada al principio, sobre todo en invierno; al temple de la habitación después, fría del todo más tarde. Y para la cabeza, cara y manos fría siempre, con agua y esponja distinta, secándolo rápidamente con una toalla fina y usada, espolvoreándole á continuación todas las juntas con polvos de licopodión ó cualquier fécula; constituyendo un buen procedimiento el tener á mano un braserillo de fuego bien pasado para echarle espliego y sahumar con él todas sus ropitas"

707 SUÑER Y ORDÓÑEZ E.: La salud del niño...., pp 36- 42; ANDREU M., N.C. 19 -12- 1912, portada.
} 
mayorcitos ponían la artesa en el patio y a eso de las cuatro cuando el agua ya estaba caliente les bañaban. Siempre se tenía agua calentita para lavarles el culito cuando se ensuciaban" (Avelina A., 1919, Rodilana)

"Las madres lavaban a los niños en una palancana, les enjabonaban con lo que podían, y luego les aclaraban con una regadera que tenía agua caliente. De pequeños les bañaban en la cocina porque hacía más calor. Se les bañaba cuando la madre podía, cada 2-3 días, y a veces cada semana... Los pañales cuando se manchaban, y estaba la madre, a veces hasta que no volvía del campo tenían que esperar". (Felisa D., 1919, Osma)

"En verano nos bañaban 7 días seguidos con agua calentada por el sol, en barreños que se llenaban de agua y se dejaban al sol para que se calentara. era muy bueno" (Angel B y María P, 1927, Salamanca)

Los expertos recomendaban para la higiene diaria el uso de polvos absorbentes y cicatrizantes para proteger la piel del bebé como el talco, el borato de sosa, féculas o el licopodión ${ }^{708}$. La escasa higiene debía producir irritaciones de la piel con mucha frecuencia, en las entrevistas realizadas nos cuentan del uso de los polvos de talco, que parece que era lo más habitual, junto con el aceite, en su lugar usaban sucedáneos caseros como el agua de lavar las patatas, que tiene féculas, o tan inapropiados como la cal de las paredes

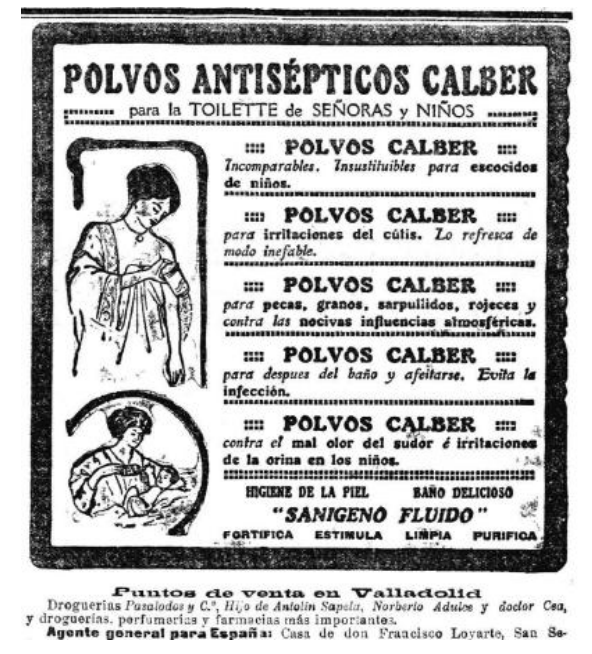

Imagen 3-40: Anuncio de Polvos Antisépticos Calber. N.C. $18-06-1914$, p 4

\begin{abstract}
"Usaban para lavar a los niños el agua de lavar las patatas. Después de peladas y cortadas se dejan en agua para lavar y queda un agua más densa y decían que iba muy bien para lavar a los niños.

Se escocían mucho, usaban polvos de talco y les daban aceite corriente" (Avelina A., 1919, Rodilana)
\end{abstract}

\footnotetext{
708 Licopodión es el polvo de las esporas del licopodio, un helecho llamado también pino de tierra o azufre vegetal. En los diccionarios de la época no encontramos el término licopodión, en su lugar, sobre el LICOPODIO el diccionario de Zerolo dice: "Nombre que se da en farmacia al polen del licópodo. Es de color de azufre, pulverulento y sutil, no se disuelve en el agua, muy adherente a la piel y susceptible de inflamarse cuando se pone en contacto con un cuerpo en ignición. No tiene olor ni sabor. La medicina le tiene como diurético y le aconseja para secar las excoriaciones que se producen en los muslos de las personas muy gruesas y de los niños". ZEROLO, E. Diccionario enciclopédico de la lengua castellana. París, Garnier hermanos, 1895, p 1374, 1.

El borato de sosa, conocido como bórax tiene una acción antiséptica y fungicida, previene irritaciones de la piel y antiguamente se usaba también en productos de higiene bucal antisépticos, en desuso por su toxicidad.

Los polvos de fécula también tienen efectos absorbentes y refrescantes e impiden la acción de irritantes locales Los polvos de talco se han utilizado ampliamente en la higiene del bebé, empezaron a comercializarse a finales del siglo XIX en una mezcla de talco y ácido bórico que tiene efecto antitranspirante, calmante y antiséptico. Los polvos de talco, junto con el jabón son de los primeros productos que se comercializaron para la higiene del bebé por empresas de perfumería como Calber, Font o Ausonia, dirigidos a un público que podía pagarlo. Bebés, usos y costumbres sobre el nacimiento. Ministerio de Educación, Cultura y Deportes. 2013.

Hoy se siguen comercializando todos ellos, aunque su uso en polvo para la higiene de los bebés no se aconseja porque son productos irritantes para las vías respiratorias que pueden provocar neumonitis.
} 
"Lavaban a los niños con agua, y si se irritaban les echaban aceite, o un poco de jalbiegue que lo sacaban rascando la pared, y hacía de polvos de talco" (Felisa D., 1919, Osma)

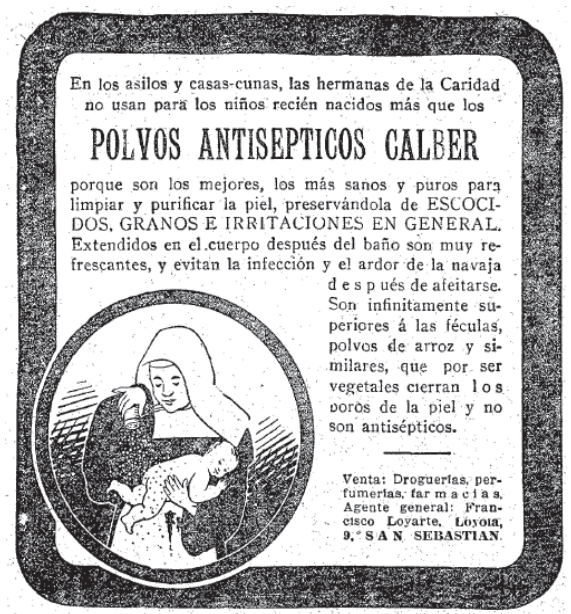

Imagen 3-41: Anuncio de Polvos Antisépticos Calber. ABC. 16-08-1916, p 2
El jabón se compraba y se fabricaba en el propio establecimiento, como consta en los libros de cuentas y los presupuestos, donde figura un apartado para Jabón o fabricación de este artículo, con una dotación de 1.500 pts en 1904, 3.570 en 1914 y 3.000 en 1924. El presupuesto para Suministro de agua, reparación y conservación de filtros pasó de 1300 a 1.250 y 3000 pts en los mismos intervalos de tiempo. A pesar de los gastos en carbón, estufas y calefacción, algunos destinados expresamente a la Inclusa, por sus

características el edifico era muy frío. No hay presupuestos ni constancia de la compra de polvos para la higiene de los bebés, salvo que estuvieran incluidos en los apartados genéricos de Material de enfermerías o Efectos de droguería, los anuncios en la prensa indican que no eran productos de uso popular por su coste $(2,70 \text { pesetas en } 1930)^{709}$, aún cuando en algún momento se utilizaron como reclamo publicitario las inclusas y las Hijas de la Caridad, por el reconocimiento social que inspiraban. (IMÁGENES 4-40 Y 4-41).

Un aspecto importante en la higiene de los bebés en los primeros días de vida era el cuidado del cordón umbilical, dada la alta frecuencia de infecciones (onfalitis) y sus riesgos, entre las causas de muerte de los asilados encontramos alguna gangrena umbilical; los manuales recomendaban que fuera cortado y ligado por "el médico o matrona experta" e indicaban la forma correcta de hacerlo y de cómo curarlo posteriormente

"La matrona hace alrededor del cordón umbilical, á cuatro traveses de dedo del cuerpo del feto un doble nudo con un cordón de buena calidad, preparado de antemano y que tenga á lo menos 30 centímetros de largo. Aprieta el nudo apoyando los puños uno contra otro por los dedos meñiques. Esta medida evita el arrancamiento del cordón del ombligo si se rompiera el lazo.... A cuatro traveses de dedo de esta ligadura se una segunda igual, y luego se corta el cordón entre las dos ligaduras..."

\footnotetext{
${ }^{709}$ Cartel publicitario de Polvos Da-Da Perfumería Font de Barcelona, datado en 1930. Museo del Traje. CIPE Disponible en: http://ceres.mcu.es/pages/Main

${ }^{710}$ RAPIN D.: Manual práctico de partos para uso de comadrones y parteras, por el Dr. D. Rapín de la Universidad de Lausana. Barcelona. s.a. José Espasa editor, pp 178- 212
} 
En los presupuestos hasta 1910 y en los libros de cuentas hay una partida denominada textualmente "para material de enfermerías, tetinas, biberones, ligadores y otros análogos", estos ligadores podrían ser los cordones empleados para la ligadura del cordón umbilical, una de nuestras entrevistadas cuenta que "el cordón se ataba con una cuerda untada en aceite que vendían tal cual en la farmacia" ${ }^{711}$, en los siguientes presupuestos ya no se especifica y se denomina de forma genérica "material de enfermerías y curas"

Hasta su desprendimiento, en los primeros días de vida para evitar las onfalitis se aconsejaba que el agua del baño fuera "hervida y las manos que bañan al niño se hallen muy lavadas y jabonadas, con las uñas cortadas al rape y cuidadosamente cepilladas. Una infección del cordón en estos primeros días puede producir una erisipela mortal, lo mismo que una erosión hecha al lavarle con las uñas o con otro objeto cualquiera no desinfectado" y después para la cura del cordón "Se prepara una compresa pequeña, cuadrada de unos 15 centímetros $\mathrm{cm}$, de lienzo fino, que se corta por uno de sus lados hasta la mitad, se coloca el cordón en este corte, se le envuelve, se dobla hacia arriba o hacia el lado izquierdo del vientre y se fija por medio de una venda no muy apretada que tenga de ancho unos tres traveses de dedo y sea lo bastante larga para dar tres veces la vuelta al cuerpo; esta venda [ombliguera] se fija por medio de unas cintas cosidas en uno de sus cabos y no con imperdibles. Esta cura se cambia cada día hasta que caiga el cordón. Debe procurarse no tirar del cordón y dejarlo caer por sí solo... tampoco debe untarse la compresa con grasa ó cerato... una vez ha caído el cordón se reemplaza la compresa por un cuadrado de lienzo doblado, colocado sobre el ombligo y fijado con una venda hasta que la cicatrización sea completa" ${ }^{\prime 112}$. Suñer prohíbe una práctica que era habitual, la de untar el cordón con aceites o grasas, las entrevistas realizadas nos lo confirman

"el médico les ataban un hilo y alrededor ponían un trozo de tela de lienzo moreno y luego les aplicaban aceite de oliva, para que se cayera antes, y así lo dejaban hasta que se cayera el cordón" (Avelina P., 1925, Alba de los Cardaños)

"El cordón umbilical se ataba con un cordón y se curaba con aceite de oliva"713

Una práctica también habitual, que los pediatras han combatido enérgicamente porque ha llegado casi hasta nuestros días, era la de exprimir las mamas de los recién nacidos que presentaban tumefacción mamaria los primeros días de vida, una de nuestras entrevistadas nos lo cuenta

\footnotetext{
${ }^{711}$ Testimonio de BELARMINA G.C. nacida en Candanedo de Fenar, León, en 1924, su "abuela era una de las dos parteras que había en el Valle del Fenar"

712 Ibídem, pp 210, 212; SUÑER Y ORDÓÑEZ E.: op. cit., pp 36- 38; Bebés, usos y costumbres sobre el nacimiento. Catálogo del Museo del traje. CIPE. Exposición temporal. Ministerio de Educación, Cultura y Deportes. 2013, p 10

${ }^{713}$ Entrevistas a Avelina, nacida en 1925 y criada en Alba de los Cardaños y a Sagrario nacida y criada en Pozuelo de la Orden, la segunda de ocho hermanos ayudó a criar a los pequeños, en otras entrevistas cuentan también que se aplicaba aceite, pero también en algunas se dice que no se hacía nada solo lavarlo y vendarlo.
} 
"Ios niños dormían mal muchas noches porque tenían un líquido con aspecto de leche en las mamas que les producía picor. Bastaba con ordeñársela para que durmieran bien, era bastante habitual" (Belarmina G., 1924 Candanedo de Fenar)

Esta práctica para extraer el líquido que contienen estas mamas tumefactas, que se conoce como leche de brujas ${ }^{714}$ por su aspecto blanco, es uno de los muchos mitos que existían en torno a la crianza de los bebés y era causa de mastitis a veces terribles que acababan en sepsis y en los casos más severos podían llegar a provocar la muerte del bebé; todavía recuerdo la insistencia de mis profesores de enfermería pediátrica en que no se debía hacer nada en esta situación, que forma parte de los procesos adaptativos considerados en principio fisiológicos que sufren los neonatos, que, La ciencia médica de la época tampoco recomendaba la expresión de las mamas, en el Tratado elemental de enfermedades del niño de D'huc actualizado y ampliado en 1870 sobre el tema podemos leer:

"Hinchazón de las mamas de los recién nacidos.

En algunos niños, las mamas están obstruidas y dilatadas por un humor serosolinfático; algunas veces ofrecen una dureza muy notable. Esta hinchazón que ataca indistintamente a ambos sexos, no exige otro tratamiento que una compresión moderada. Si la induración persiste, bastará cubrirla con cataplasma para hacerla desaparecer.

Como vemos recomendaban compresión y cataplasmas, que sería lo que se aplicaría en el caso de una mastitis. El único cuidado inicial considerado actualmente es la observación y vigilancia para detectar precozmente una infección.

\footnotetext{
${ }^{714}$ En torno a la crianza de los niños han existido siempre muchos mitos, algunos de los cuales han llegado hasta hoy, uno de ellos es el que tiene relación con esta "leche de brujas", científicamente galactorrea del recién nacido, las nuevas madres quizás ya no oigan hablar de ella, pero sus madres y seguro que sus abuelas sí la conocerán. Se llama así a la secreción de aspecto lácteo que puede aparecer en algunos neonatos, tanto niños como niñas, que presentan un aumento de la zona mamaria denominado ginecomastia fisiológica neonatal. Esta ingurgitación mamaria es una situación benigna causada por los altos niveles de estrógenos del final del embarazo y su paso transplacentario hacia el niño; se manifiesta a partir del tercer día de vida y se resuelve espontáneamente en 2- 4 semanas a medida que van descendiendo los niveles de hormonas maternas en la criatura.

Existía la creencia de que esta secreción mamaria era producida por espíritus malignos que robaban la leche de la madre a los niños, de ahí el nombre de leche de brujas, y dado que la tumefacción mamaria puede llegar a ser realmente llamativa se intentaba extraer la secreción exprimiendo las mamas para aliviar la tensión, lo que provocaba como hemos comentado frecuentes infecciones.

Era una práctica antigua y muy extendida, Francesco da Barberino en Del Reggimiento e de costumi delle donne ordenaba a las balias (nodrizas italianas) en el siglo XIII "apretar los pechos del niño con frecuencia para sacar la leche que haya en ellos" (citado en: DEMAUSE LL.: "La evolución de la infancia", en: DEMAUSE LL. edit, Historia de la infancia. p 39)
} 


\subsubsection{El aire libre, juegos y juguetes}

Una preocupación constante en la época, como una forma de reducir la mortalidad infantil, era conseguir "la robustez" del niño de forma temprana, hacerle fuerte frente a las enfermedades, para ello en ocasiones se proponían métodos que hoy nos pueden parecer erróneos o desproporcionados, como el uso de agua totalmente fría para el baño de los bebés, en este sentido Suñer en la cita que hemos visto anteriormente era prudente teniendo en cuenta que aconsejaba el agua, "moderadamente fresca", a 30ㅡ. Una condición considerada importante para adquirir esa robustez era el aire libre, ya que en la época no era habitual sacar de casa ni pasear a los bebés.

"El aire y el sol... son indispensables para la vida del niño.

A poco de nacer, previo el endurecimiento con los baños de aire en casa, el niño debe salir diariamente al exterior...

En general, nuestras clases acomodadas no entran ampliamente en la costumbre de tener con tiempo bueno o mediano al niño fuera de casa. $y$, sin embargo, esta costumbre tenazmente seguida es la que permite curtir al pequeño y entrenarlo para que no sea víctima constante de enfriamientos y de procesos respiratorios ${ }^{\prime 175}$

El Reglamento de 1889 en el Art. 111 antes mencionado, después de hablar de la necesidad de lavar y peinar a los niños pequeños dice que "la Hija de la Caridad encargada del [departamento de menores], cuidará... de que permanezcan encerrados lo menos posible, destinándose para recreo un local donde puedan distraerse y adquirir robustez conveniente", entendemos que se refiere a un local para juegos y ejercicio y se supone que al aire libre, podía ser alguno de los patios que tenía el Hospicio, aunque por lo que sabemos es probable que no hubiera demasiado espacio apropiado para el juego, por lo menos de los más pequeños, pues en ellos se encontraban la vaquería y los talleres.

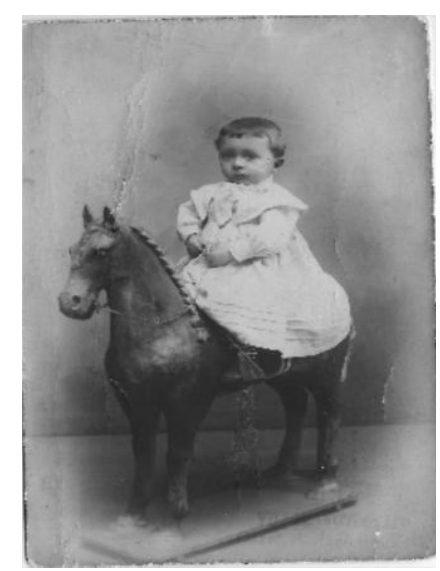

Imagen 3-42: Lactante vestido de corto montado en caballito de madera. 1927 Fotografía cedida por Marta Donis

El ejercicio y el juego son elementos esenciales para la maduración vital del niño, tanto para su desarrollo físico como psicomotor, cognitivo y psico-social; para él constituyen una necesidad, la OMS incluyó el juego entre los derechos del niño (Art. 31). Juego y juguetes son nociones que asociamos automáticamente a infancia, nada dicen los reglamentos del Hospicio al respecto más que el artículo que acabamos de mencionar. Sí reconoce la necesidad de

\footnotetext{
${ }^{715}$ SUÑER Y ORDÓÑEZ E.: La salud del niño., p 48
} 
ejercicio y lo incluye como parte de la actividad de la escuela, incluso de los pequeños de 3 a 7 años: "bajo la dirección de la Hermana encargada de ella, tendrán una hora de gimnasia entre mañana y tarde los párvulos, los cuales se dedicarán a ejercicios sencillos e inofensivos, con el único fin de adquirir mayor vigor y desarrollo corporal. Cuando algunos de los párvulos, por su escaso desarrollo o viciosa conformación no puedan hacer gimnasia ó necesiten hacerla especial, la Hermana seguirá las indicaciones del Profesor facultativo" (Art. 88 al 90, Regl de 1910 y 1927). Los niños necesariamente tendrían tiempo de ocio que dedicarían al juego, para los mayores dicen los reglamentos que los celadores tenían que "Hallarse constantemente entre los asilados cuando estuviesen entregados a sus juegos y diversiones y corregir en el acto las faltas que cometan" (Art. 161- 3o Regl de 1910 y 1927),aunque intentaban que no fuera demasiado:"contando con el tiempo destinado a las prácticas religiosas, a las comidas y a un prudencial espacio para el recreo diario, se procurará que ningún asilado útil permanezca ocioso en el Establecimiento" (Art. 254 Regl de 1910 y 1927) y las "faltas de obediencia y aplicación, de buena conducta o de otra clase... [se castigaban entre otros con la] Privación de recreo" (Art. 285, Regl de 1910 y 1927). Para los pequeños no dice expresamente nada, pero hemos de suponer que se aplicarían normas similares adaptadas a su edad.

En los presupuestos y entre los gastos del Hospicio no figura la compra de juguetes, solamente en 1924 en "Gastos imprevistos" aparece una partida presupuestada con 249'75 pesetas para "diferentes juguetes". Los niños del Hospicio jugarían a los juegos populares de la época, la mayoría sin juguetes o con juguetes muy elementales o de elaboración casera, los más mayorcitos jugarían a juegos como la pídola, el escondite, guardias y ladrones, rayuela, las tabas o las chapas ${ }^{716}$.

Por la prensa sabemos que por Reyes se hacían campañas en la ciudad para regalar juguetes a los "hospicianitos", además de "agasajarles" con comidas especiales y festejos; no serían los juguetes más deseados y carísimos como los caballitos de madera o las casitas de muñecas, pero los había más asequibles y siempre ilusionantes para los niños, desde sencillas peonzas a humildes muñecas. En 1915 en El Norte de Castilla se anunciaban "millares de juguetes para todos los gustos, desde 50 cts á 250 ptas la pieza en los Almacenes Guillén" ${ }^{717}$. En diciembre se iniciaba la campaña para recoger juguetes, ropa, comida y dinero para los

\footnotetext{
${ }^{716}$ Cfr: DIAZ GONZÁLEZ J.: Algunos juegos tradicionales. Revista de Folklore 1981, no 5; CONTRERAS SANZ F.: Juegos infantiles. Revista de Folklore 1983, no 30; MARTín NICOLÁS J.C.: Juegos tradicionales y deportes autóctonos de Castilla y León. León, 2002, Universidad de León

Alcozar-Etnografía. Página web elaborada por la Vocalía de Cultura de Alcozar. Disponible en: http://www.alcozar.net/etnografia/cuidado\%20ninos.htm

${ }^{717}$ N.C. $17-3-1915, \mathrm{p} 1$
} 
niños pobres y a los "del sombrío caserón vetusto que se llama Hospicio" (N.C. 8- 12-1903, p 1), y el 5 de enero se hacía el reparto de donativos

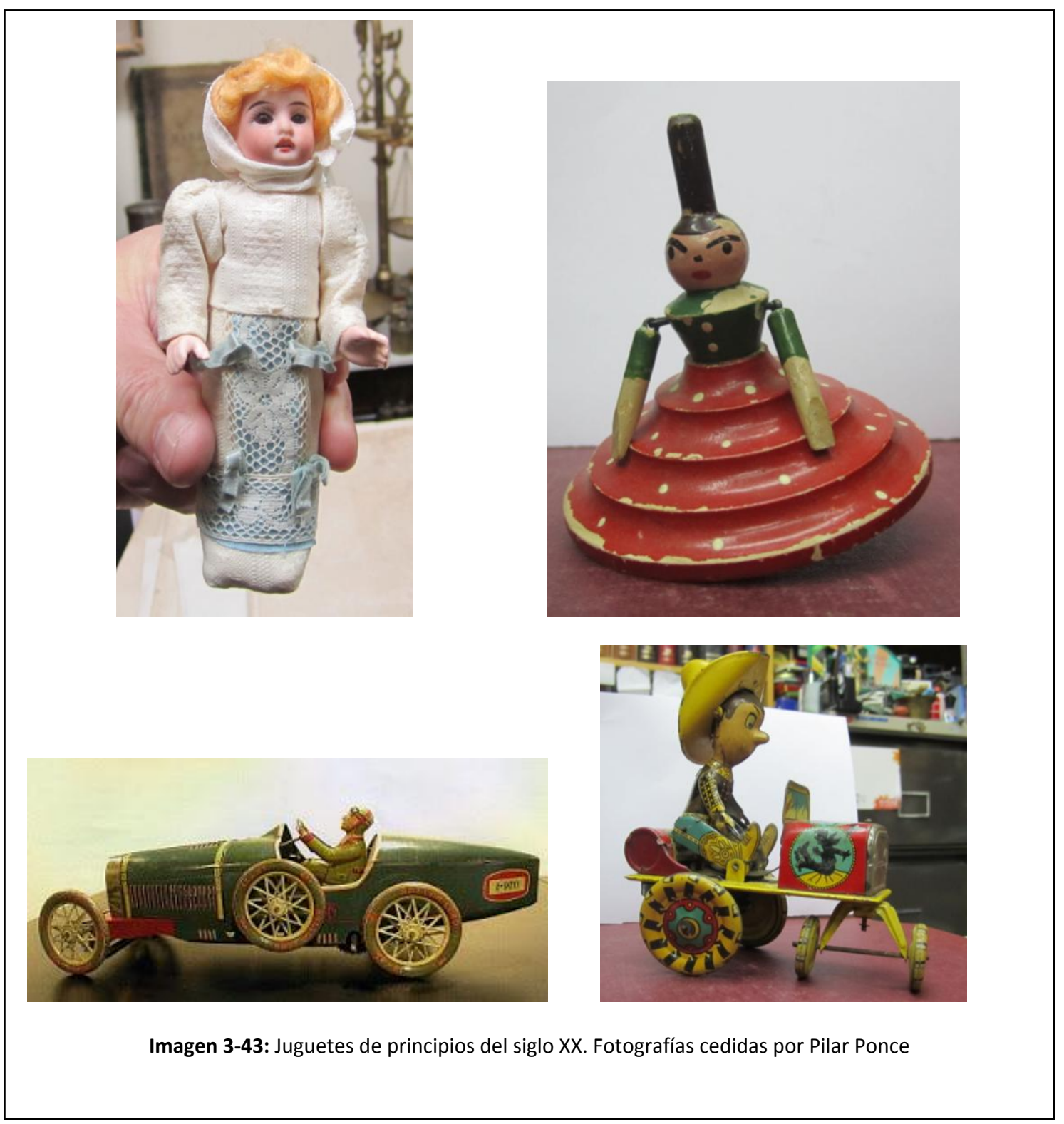

“Ayer celebró sesión la Diputación provincial...

A propuesta del señor Pinilla y en votación nominal, por once votos contra seis de los señores... se acordó conceder cincuenta pesetas a la Juventud Liberal con destino a la adquisición de juguetes que llevó anoche a los niños del Hospicio" (N.C. 6 -1- 1921, p 2)

"El domingo por la tarde se celebró en el hospicio provincial una animada velada organizada por la Congregación de María Inmaculada y San Estanislao .... Comenzó la velada con un afinado coro cantado por los niños... A continuación se pusieron en escena el juguete La bolsa o la vida, admirablemente interpretado por... y El Tío de Buenos Aires... También fue muy aplaudida la 
asilada Dominga San José que, en los intermedios interpretó algunas composiciones en el piano. A la simpática fiesta, que fue amenizada por la banda del Hospicio asistió numerosa concurrencia y todos los asilados del establecimiento con el señor Director, hermanas de la Caridad y demás personal de la casa. Los asilados fueron obsequiados con chocolate y churros, obsequio costeado por el director de la Congregación..." (N.C. 11 -1-1921, portada)

"Ayer a mediodía se efectuó en el Hospicio provincial la comida con que la Sociedad Peña Castellana agasajaba a los asilados con motivo de la fiesta de los Santos Reyes. Se sirvió a los asilados el siguiente menú: ordubres, paella, pescadilla, longaniza, postres y vino, encargándose de la distribución las señoritas Beatriz y Juli Stampa; Trinidad, Paquita, Emilia y Natividad Vicente; Sagrario, Margarita y Anita Pinedo; Pilar Pradera...

Merced a la suscripción abierta por la Diputación provincial, los asilados de sus establecimientos han tenido juguetes..." (N.C. 7 -1- 1923, p 2)
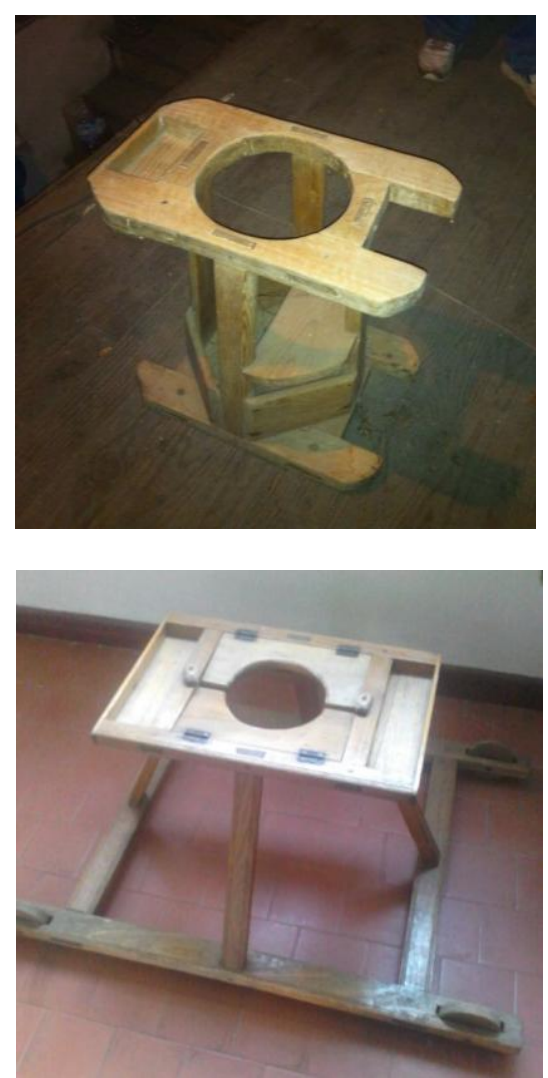

Imagen 3-44: Carretones utilizados por nuestros entrevistados. Fotografías cedidas por Noemí Marcos y Elsa Valdivieso
Estaba muy extendido el uso de artilugios para ayudar a los bebés a estar de pie y a andar porque se pensaba que "Ias piernecitas del niño todavía son muy débiles para sostener el peso del cuerpo". En realidad se empezaba demasiado pronto, con muy pocos meses, los médicos se quejaban en los años veintetreinta de que se tenía demasiada prisa por hacer andar al niño. A principios del siglo $\mathrm{XX}$, se utilizaban una especie de columpios que le colgaban por las axilas, que luego se desecharon, a nivel popular se usaban pañuelos que se sujetaban a la cintura y por debajo de los brazos, también andaderas de varas, polleras o corros de mimbre y andadores y carretones, que en principio eran de madera y que obligaban al lactante a estar de pie o ligeramente sentado pero en posición prácticamente eréctil con la cadera apenas apoyada, y como las caídas eran muy frecuentes, usaban chichoneras para proteger la cabeza ${ }^{718}$. Los manuales solían estar en contra de estos métodos si se utilizaban demasiado pronto, "cuando todavía las piernas del bebé no tienen demasiada fuerza", y decían que lo mejor era tirarle en el suelo "al llegar a los ocho meses" para que pudiera gatear rodeado de sillas que le permitieran sujetarse

\footnotetext{
${ }^{718}$ BORRÁS LLOP J.C.: op.cit, p 47
} 
o bien, en los "parques" que ya existían en los años veinte y siempre aconsejaban dejarle evolucionar a su ritmo. "Es una práctica absolutamente condenable la de aquellos padres que se obstinan en querer que el niño ande pronto" ${ }^{\prime 719}$.

No se han encontrado compras de accesorios infantiles como tronas para sentar a los más pequeños o andadores para ayudarles a mantenerse de pie y a andar, puede ser que se hicieran en la carpintería del establecimiento, pues los de las clases populares eran de fabricación casera (IMAGEN 3-44).

En las entrevistas, la mayoría de los entrevistados dicen que no se ponía a los niños a gatear, de la cuna pasaban a los andadores para que empezaran a andar pronto. En todas están de acuerdo en que no se usaban cochecitos de bebé de paseo, algunas incluso dicen que todavía no había, sin duda era un artículo de lujo.

"Para enseñarlos a andar utilizaban "polleras» o "carretones»" (Pedro R., 1931, Fuente Olmedo)

"Sacaban a los niños de la cuna no les ponían a gatear. Les ponían en un carrito con barras para salir a la calle con el pico, una Banda para colgarles porque no había cochecitos de paseo" (Vicenta I., 1920, Villabrágima)

"Después de los 6 meses los sacaban de la cuna y los colocaban en el suelo o en los corros de mimbre para que aprendieran a gatear y a andar. Dentro del corro había unas cintas para que el niño pudiera sentarse. Los corros se volcaban mucho sobre todo al chocar con las puertas. (Angel B. y María P., 1927, Salamanca)

"Cuando tenían unos meses se ponía una manta en el suelo y luego para que aprendieran a andar les ponían en el carretón o en la pollera y los hermanos mayores cuidaban de los pequeños.

No había cochecitos, los niños se sacaban a la puerta de casa o a la plaza" (Sagrario B, 1929, Pozuelo de la Orden)

"De pequeños estaban siempre en la cuna. No se ponía a andar a los niños no recuerdo que se les pusiera a gatear. Les ponían en una manta o en un ruedo de esparto. Les sentaban en sillitas que tenían un agujero en el centro para el orinalito, como tronas bajas con una tabla por delante, las usaban para niños mayorcitos, como un año. Usaban andadores, eran como un tacatá que tenían cuatro ruedas y les colocaban cosas para que jugaran, el niño tenía que estar de pie". (Avelina A., 1919, Rodilana)

"Se ponía a los niños en el suelo sobre una manta para que empezaran a gatear. Para enseñarles a andar les ataban un pañuelo entre las piernas y rodeando la tripa, y les cogían desde atrás. También usaban el carretón y las varillas, que era un cajón en el que se metía al niño y lo empujaba de un lado a otro" (Felisa D., 1919, Rodilana)

\footnotetext{
${ }^{719}$ VELASCO Y LLAMAS S.: op.cit, p 39
} 
"Se les ponía en el suelo a los bebes sobre mantas para que empezaran a gatear. Para enseñarles a andar se utilizaban el tacatá de madera o cuerdas alrededor de los brazos, si no se disponía de esto, aprendían solos agarrándose en los sitios que podían" (Margarita C., 1927, Esguevillas de Esgueva; Victorina G., 1928, Palazuelo de Vedija y Acacia S., 1929, Venialbo).

"Para enseñar a los niños a andar, cogíamos un pañuelo y se le poníamos sobre la cintura y por debajo de los brazos. Luego cogíamos las dos puntas del pañuelo y así les llevábamos a andar; les poníamos el pañuelo para que no se "caerían". También se usaban las varillas, el carretón y el andador. El andador era de madera, y tenía tres ruedas. El niño se

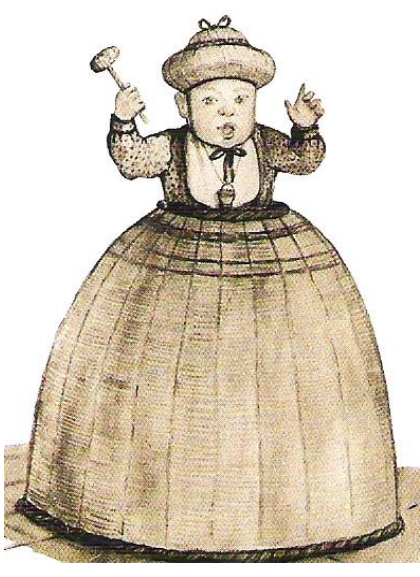

Imagen 3-45: Pollera. Museo de las Artes, Industrias y Tradiciones populares de Barcelona agarraba al palo de arriba y así iba andando.

El carretón era como un asiento, y allí se metía al niño para que no se "movería". Y las varillas eran dos varas en las que iba metido una cosa de madera parecido a un cajón. El cajón tenía un redondel por donde se metía al niño, y ese cajón corría por las varillas para que la criatura pudiera andar. El niño ponía los pies en el suelo y empujaba el cajón; de esa forma corría una vez para un lado y otras veces para el otro" ${ }^{\prime 720}$

\subsubsection{Lasvacunas}

La época de este estudio corresponde a la etapa higienista y economicista de la medicina, un período en el que la higiene adquiere interés especial, principalmente la Higiene Social, precisamente por la carencia de ella, por las consecuencias que esa carencia tenía sobre la salud particular y pública y sobre todo por la altísima mortalidad general y especialmente infantil y por el coste social que todo ello implicaba ${ }^{721}$. La salud de la población, y en especial de la infancia, se consideraba esencial para la supervivencia y el engrandecimiento de los

\footnotetext{
${ }^{720}$ Testimonio de Eusebia Romero Riaguas en El cuidado de los niños. Alcozar-Etnografía. Página web elaborada por la Vocalía de Cultura de Alcozar. Disponible en: http://www.alcozar.net/etnografia/cuidado\%20ninos.htm

${ }^{721}$ A finales del siglo XIX y comienzos del XX empieza a cambiar la concepción biológica de la salud, se admite que además del agente causal existen otros factores relacionados con la etiología de las enfermedades (se pasa de la teoría unicausal a la de la multicausalidad) y que el proceso biológico está ligado a las condiciones que rodean la vida humana. Aparece el concepto social según el cual no basta con tratar el agente, es necesario modificar el medio para erradicar las enfermedades. Además de los factores de carácter puramente sanitario se empezarán a tener en cuenta otros de tipo económico y social. Se empieza a calcular las pérdidas económicas producidas por las enfermedades y a hablar de rentabilidad social en relación con la salud individual y colectiva de la población. Se llega a definir la Higiene como "la ciencia de la economía de la salud". LÓPEZ PIÑERO J.: Historia de la Pediatría, Valencia 2009; BABINI J.: Historia de la Medicina. Gedisa. Barcelona, 1980
} 
pueblos, las "razas", y de las naciones. Es una idea defendida y repetida por los médicos y particularmente por los pediatras más relevantes de la época como los doctores Tolosa Latour, Martín Vargas o el mismo Suñer que la recoge en su manual de puericultura en el primer capítulo donde habla de "la enorme mortandad de niños que no sólo llenaba de luto los hogares, sino que privaba a España de brazos y cerebros para defenderla y engrandecerla..." y de los derechos del niño señalando como "el primero y más fundamental el de nacer sano"

"Como el cimiento de una vida feliz es la salud, por eso el niño, antes de engendrarse, tiene derecho a que sus padres no sean enfermos. Las personas tuberculosas, avariósicas, perturbadas mentalmente, no suelen engendrar hijos sanos, sino todo lo contrario. Su descendencia llena cárceles y hospitales, aumenta las estadísticas de mortalidad, e influye, en una proporción cada vez en aumento, en la degeneración de la raza y en la decadencia de la Nación.

Como españoles, debemos desear que nuestros compatriotas sean normales, fuertes, bien desarrollados. La fortaleza y el vigor animan al trabajo, fuente de riqueza. Una raza pujante crea una nación grande y España necesita ser grande en lo futuro para hacer honor a su glorioso pasado y realizar misiones trascendentales en el porvenir ${ }^{\prime \prime 22}$

En 1866 se creó el Instituto de Higiene de Munich, punto de partida de una nueva especialidad médica, la Higiene Pública, considerada como una ciencia social para la salud, que lograría convencer a los Estados con argumentos científicos de la necesidad de una legislación sanitaria eficaz y de la importancia de mejorar la salud pública mediante la puesta en marcha de medidas preventivas de carácter social, algunas tan novedosas como el empleo masivo de vacunas y suero para prevenir infecciones ${ }^{723}$. Desde su descubrimiento, las vacunas se fueron implantando de forma lenta y no exenta de polémica, la antivariólica sería la primera y durante mucho tiempo la única administrada masivamente. A pesar de reconocerse los beneficios de la vacunación, se generaron muchas controversias, no solo entre la clase política sino sobre todo entre la clase médica, como ocurrió con las vacunas anticolérica o la antituberculosa del doctor Ferrán ${ }^{724}$, de manera que en los manuales de pediatría de los años veinte todavía no se

\footnotetext{
${ }^{722}$ SUÑER Y ORDÓÑEZ E.: op. cit., 1920, p 7

${ }^{723}$ El conocimiento de los gérmenes causantes de las enfermedades infectocontagiosas y de su mecanismo de transmisión permitieron organizar sobre una base científica una importante serie de medidas preventivas, entre ellas el desarrollo de vacunas y sueros, además de otras que ya se venían realizando de forma empírica como el saneamiento y control de aguas. GARCÍA ESTEBAN A.: De los Centros de Acogida a las Instituciones Sanitarias; LÓPEZ PIÑERO J.: Historia de la Pediatría y artículos de distintos autores en Asclepio. Revista de $H^{a}$ de la Medicina y de la Ciencia, no 56, enero 2004

${ }^{724}$ En 1883 Koch descubrió el vibrión colérico y en 1885, coincidiendo con una grave epidemia en la península que asoló especialmente los barrios populares de las ciudades, en su mayoría carentes de alcantarillado y servicios higiénicos, el doctor Jaime Ferrán preparó la primera vacuna anticolérica eficaz. A pesar de la gran aceptación popular, su aplicación masiva causó tal rechazo entre la clase médica española que el Ministerio de la Gobernación la prohibió y sólo permitió su administración al propio doctor Ferrán y en presencia de un empleado gubernamental. Problemas similares tuvo con su vacuna antituberculosa, que se acabó desviando para el tratamiento y no la prevención. En 1882 Koch descubrió el bacilo responsable que lleva su nombre y en 1906 se descubrió la vacuna antituberculosa que se ha generalizado conocida como BCG (bacilo Calmette-Guerin, sus
} 
contemplaba como una medida preventiva eficaz, en el manual de puericultura de E. Suñer que estamos citando no se dice nada sobre este tema.

En los años de este estudio la única vacuna cuyo uso se había generalizado era la antivariólica, debemos reconocer la preocupación tanto de las autoridades sanitarias como políticas de la época por la vacunación de la población general y también de forma particular por la del Hospicio, el hecho de que siguieran apareciendo epidemias con una morbimortalidad muy elevada y el temor que provocaban era suficiente justificación. El interés político y sanitario se reflejó en la publicación en 1798 de una Real Orden que decretó la introducción de la vacunación obligatoria frente a la viruela ${ }^{725}$ en hospitales, casas de expósitos y de misericordia y el 21 de abril de 1805 se publicó el edicto de creación de salas de vacunación en los hospitales peninsulares y un decreto declarando la vacunación obligatoria; es de destacar que fue el primero de Europa de este tipo. Sin embargo y a pesar de esta normativa legal ya existente, en 1903 tuvo que aparecer otro decreto de vacunación obligatoria coincidiendo con una epidemia de viruela que se desarrolló en 1902- 1903, que alarmó a una población que había sufrido y todavía recordaba otras epidemias con altísima morbimortalidad ${ }^{726}$. En Valladolid la prensa local se hacía eco de la preocupación que

descubridores), que se empezó a aplicar en 1921 en niños. BABINI J.: Historia de la Medicina ; GONZÁLEZ NÚÑEZ J.; La Historia Oculta de la Humanidad, Barcelona 2006

La vacuna antivariólica se administraba mediante una incisión en el brazo o en el muslo en la que se inoculaba el virus, se protegía para evitar el rascado y se prohibía el baño durante unos días hasta que se caía la pústula, se indicaba en el segundo trimestre de vida si era posible.

${ }^{725}$ Dice Vicente Pereda en su discurso de ingreso en la Real Academia de Historia La infancia abandonada, hablando de la contribución de los expósitos a los avances de la Pediatría que en los hospicios la viruela fue "donde antes y de forma más completa quedó prácticamente erradicada pues en ellos se conservó y aplicó a los niños, antes que a los otros, la vacuna de Jenner, que España extendió muy pronto a sus territorios ultramarinos, en la ambiciosa expedición de Balmis y Salvany, una gesta que sería recordada. luego por el poeta Manuel José Quintana, y que ha sido reconocida como uno de los primeros ejemplos de campaña sanitaria de alcance internacional y "la mayor cruzada histórica de la medicina preventiva. Para ello, embarcaron en 1803 en el puerto de La Coruña a veintidós expósitos gallegos, a los que se fue vacunando sucesivamente, con el objeto de mantener activo el fluido vacuno durante la travesía"; la historia de esta expedición ha sido recogida recientemente en la película "22 ángeles"

${ }^{726}$ Durante los siglos XIX y XX Europa no se va a librar del azote de algunas epidemias mortíferas: el cólera, la fiebre amarilla y la gripe fueron las principales y antes del descubrimiento de la vacuna, la viruela, que a principios del siglo XIX era todavía la enfermedad más devastadora pudiendo afectar al $60 \%$ de la población. Su mortalidad estaba en torno al $30 \%$ de los afectados y el resto corría riesgo elevado de padecer ceguera, esterilidad o quedar con cicatrices y marcas profundas en la piel; se calculan 300 millones de víctimas durante el siglo XX en todo el mundo hasta su erradicación

El cólera, también conocido entonces como la peste azul, fue importado desde el valle del Ganges a partir de 1830 y provocó seis grandes pandemias hasta fines del siglo, que iban a "reproducir los miedos medievales", y algunas revueltas sociales; los Gobiernos llegaron a acusar a determinados "miserables" de contaminar fuentes y alimentos y la ira popular se volcó contra algunos colectivos como judíos, médicos o sacerdotes, dependiendo de los lugares. Laín Entralgo diría que "se trata de una enfermedad propia de una sociedad sanitariamente mal protegida... (en un planeta en plena) expansión comercial".

La fiebre amarilla, o vómito negro, apareció repetidamente a lo largo del siglo XIX, España sufrió tres grandes epidemias y en el siglo XX todavía era muy temida, a pesar de que fue erradicada de los principales centros americanos de origen. Era originaria de África y se asentó de forma endémica en América Central y el Caribe, desde donde llegó a los puertos europeos provocando brotes frecuentes, España fue un puerto de entrada fácil. A finales del siglo XIX se descubrió el mosquito responsable de la transmisión y a principios del XX una comisión enviada a 
producían estas epidemias con noticias casi diarias sobre su evolución y con anuncios insistiendo en la vacunación, reconocida ya entonces como la medida más eficaz de prevención, como el tiempo ha demostrado, aunque algunos sectores de la población parece que se resistían a vacunarse.

"La alarma respecto a la propagación de la peste varicolosa era fundada... son numerosos los casos de peste en Valladolid... A pesar de todo esto aún hay personas que no vacunan a sus hijos por temor a la peste. $O$, lo que es lo mismo, que la ignorancia de los padres se paga después con la muerte de los hijos" ${ }^{\prime 727}$

A pesar de sus consecuencias, parte de la población no acababa de convencerse de los beneficios de la vacuna, en parte por miedo a sus efectos, que en ocasiones fueron nefastos por usar sueros en mal estado, de manera que cuando surgió una nueva epidemia en 19101911 el médico de la Beneficencia doctor Alberto Macías Picavea en un artículo publicado en EI Norte de Castilla y titulado La Viruela ¿Problema sanitario? se lamentaba de esa resistencia a la vacunación, siendo una medida tan sencilla que bastaba para terminar con la enfermedad, acusaba a la población marginal invacunada de su origen y lo planteaba como un problema social, fruto de la miseria, la falta de higiene y la ignorancia

"En Valladolid hay 2.000 familias que, vencidos, o sustraídos voluntariamente a la lucha de la vida permanecen fuera de toda disciplina social tomados de un compuesto de miseria e ignorancia que los hace inabordables a toda redención próxima y directa. ... La vacuna en esta ocasión ha sido prodigada liberalmente, sin tasa, por nuestro Municipio. ... en cambio la grey de la bohemia y de la

Cuba por el gobierno estadounidense al finalizar la guerra hispano-norteamericana adoptó una serie de medidas higiénicas que consiguieron erradicar la enfermedad de las zonas de estos territorios y por ende de Europa.

Otra enfermedad epidémica temida en este período fue la gripe, se produjo una pandemia con varios brotes entre 1889-1892 de enorme difusión mundial afectando en algunos lugares a más de la mitad de la población y provocando una mortalidad importante fundamentalmente entre niños y ancianos de todas las clases sociales. A partir de este brote se mantuvo de forma endémica en gran parte del mundo constituyendo una de las principales causas de morbimortalidad hasta alcanzar el punto culminante en la gran pandemia de 1918-1919, de la que se ha llegado a decir que ha sido "la peor plaga de la humanidad". Mal llamada "gripe española", realmente se originó en 1918 en Kansas en el mes de marzo y se expandió rápidamente por el trasiego de tropas de la Primera Guerra Mundial. Cursó en oleadas y en unos meses mató más gente que la guerra, se cree que afectó casi a la mitad de la humanidad, se estiman entre 20 y 50 millones de muertos, por lo que se considera el acontecimiento histórico más mortal en un corto período de tiempo. A España llegó en el mes de mayo y algunos cálculos estiman hasta 250.000320.000 muertos de una población en torno a veinte millones. Provocó varios brotes y el más mortal fue el segundo que a España llegó en agosto, el ferrocarril fue un importante aliado trasladando a las gentes de las vendimias, a las de las fiestas de los pueblos y a los soldados reclutas. En la península afectó a los núcleos urbanos con mayor intensidad y virulencia que en Europa, causando una tasa de mortalidad en algunos lugares de hasta el $2 \%$ de la población. La impotencia y el pánico que provocó en la sociedad española y europea son comparables a la experimentada en la Edad Media ante las pestes, se plantearon incluso hipótesis medievales de tipo religioso y astrológico para explicarla y se llegó a pensar en la posibilidad de tratarla con sangrías. Como los tratamientos medicinales no siempre funcionaban, a nivel popular se recurría a remedios como el ajo, el café, los vinos espiritosos o el coñac. La cuarta y última oleada en el invierno de 1920 afectó sobre todo a niños pequeños.

No podemos dejar de mencionar la tuberculosis, que no cursa en brotes epidémicos como las anteriores pero era mortal, afectaba a todas las edades y clases y se mantuvo de forma endémica a lo largo de todo el siglo XIX y principios del XX. A partir de 1870 aumentó de forma considerable afectando preferentemente a las clases urbanas más desfavorecidas por lo que pasó de ser considerada "la enfermedad elegante de los románticos" a ser una enfermedad vergonzante, propia de clases bajas y símbolo del "mal vivir". GONZÁLEZ NúÑEZ J.; La Historia Oculta de la Humanidad, Barcelona 2006.

${ }^{727}$ N.C. 30 de octubre de $1903, \mathrm{p} 1$ 
ignorancia permanece limpia y virgen de vacuna como al principio de la epidemia, y como siempre; y esta es la traca que lentamente va prendiendo la mecha del contagio y claro es que la epidemia no termina hasta que no termine la carga de los invacunados, escondidos en sus mechinales. ... La memoria colectiva, que es la más floja de todas las memorias, debe recordar que a principios de 1903 tuvimos otra epidemia de viruela con los mismos orígenes: esto es, una masa grande de proletariado sin vacunación.

El problema no es sanitario, es sencillamente un aspecto del problema social: miseria e incultura, con la falta consiguiente de hábitos y costumbres en este caso sanitarios ${ }^{\prime 728}$

Desde la prensa local se seguía insistiendo en la importancia de la vacunación y de recibir las dosis de recuerdo para evitar el contagio; también se recogía la preocupación generada por la epidemia de cólera que se había iniciado en algunas capitales europeas como Trieste y en Túnez y Persia con noticias sobre su evolución y artículos sobre las medidas que debían adoptarse en previsión de su llegada a Valladolid

"El inspector provincial de Sanidad dio cuenta detallada de la epidemia variolosa, desde su comienzo el 6 de marzo del pasado año hasta la fecha y de todas las medidas sanitarias que habían adoptado para evitar su propagación. La Junta mostrose conforme y acordó insistir en la campaña de vacunación y revacunación que viene realizándose como medio más eficaz para que no se repitan las invasiones.

De los datos expuestos por el señor Durán resulta que el número total de invasiones habidas en esta capital desde que se declaró la epidemia ha sido el de 250, habiéndose curado 142 y fallecido 28. De estos casos han sido aislados en el pabellón de infecciosos 61. Actualmente hay en tratamiento 41 enfermos, ocho de los cuales se hallan aislados en aquel pabellón.

Se acordó también reproducir al Ayuntamiento de esta capital el informe aprobado por la Junta en 12 de Septiembre último en previsión de la epidemia colérica" $^{729}$

La alarma social que ya había provocado la epidemia de viruela se incrementó con la posibilidad de la llegada de la epidemia de cólera y

"La Junta de Sanidad comenzó a adoptar disposiciones encaminadas a evitar en lo posible el desarrollo de las enfermedades infecciosas....

Uno de los principales factores es la salubridad y la higiene públicas, convendría que la vigilancia de la policía urbana no se ejerciese con tanta pasividad ... para que desaparecieran los focos de infección que existen en la capital, muchos de ellos en calles céntricas, en algunas de las cuales, existen gallineros, palomares y establos cuya limpieza se hace por lustros, además de los montones de estiércol que se ven en el centro de los corrales"

Parece que en esta epidemia de viruela, que resultó más virulenta en Valladolid que la de 1903, se implicaron más los agentes sociales y se volvió a poner en marcha una campaña de

\footnotetext{
${ }^{728}$ N.C. 28 de marzo 1911, p 1

${ }^{729}$ N.C. 20 febrero de 1911, p 1

${ }^{730}$ N.C. 27 de enero de 1911, p 1
} 
vacunación antivariólica, la vacuna de la ternera como también era conocida, gratuita para la población pobre, como en la ocasión anterior

"Instituto de vacunación. Pasaje de Gutiérrez

Se vacunará directamente de la ternera hasta el día 20 inclusive del mes de octubre, á las 11. A las 14 gratis para los pobres.

Venta de tubos garantizados. ${ }^{1731}$

Se llevó a cabo la "vacunación pública gratuita en las escuelas municipales, por los médicos de la Beneficencia municipal" ${ }^{732}$, se repartió suero entre los pueblos de la provincia y se vacunaron algunos colectivos como los empleados de Renfe, soldados o los médicos y los estudiantes de medicina que colaboraban en las vacunaciones masivas; preocupaba especialmente su difusión al centro de la ciudad

"aumenta la epidemia... ayer se registraron seis nuevos casos de viruela... También se registró ayer una defunción. ... la epidemia que antes solo existía en los barrios extremos ha entrado ya en el centro de la capital. En la Facultad de Medicina se está efectuando la vacunación de alumnos de todos los cursos"1733

La Junta provincial de Sanidad acordó nombrar médicos vacunadores

"que se encarguen diariamente de realizar dicho servicio en los domicilios de todas las familias incluidas en el padrón de la Beneficencia municipal [y exigir a los presidentes de todas las sociedades benéficas] tener vacunados y revacunados a todos sus asociados" 134

En los tres primeros meses de 1911 la epidemia de viruela se recrudeció y en marzo se duplicó el número de víctimas, todas ellas personas sin vacunar de forma completa

"Nuevas invasiones. Desgraciadamente la epidemia variolosa desarrollada en nuestra capital desde hace más de un año no tiende a desaparecer. Como en el día anterior, durante la tarde de ayer se vacunó al público en los centros establecidos por el Ayuntamiento...

Hasta últimos de diciembre los fallecidos de viruela no pasaban de 13, pero durante los tres meses últimos, en que la epidemia ha aumentado con proporciones lamentables, las defunciones han sido mucho más numerosas. El número total de fallecidos desde el mes de marzo de 1910 hasta la fecha es 37.

De un año seis niños y una niña.

De uno á cuatro años diez niños y cinco niñas

De cinco á diecinueve años once varones y dos hembras

De 20 á 39 años un varón

De 40 á 59 años un varón.

Es de advertir que de los 37 fallecidos 25 no estaban vacunados y los 12 restantes no habían sido revacunados una vez pasado el plazo de inmunidad de la vacuna ${ }^{\prime 735}$

\footnotetext{
${ }^{731}$ N.C. 29 octubre 1903, p 1

732 N.C. 7 de marzo de 1911, p 1

${ }^{733}$ N.C. 19 de febrero de 1911, p 1

734 N.C. 24 de marzo de 1911, p 1

735 N.C. 11 de marzo 1911, p 2
} 
En 1911 el pabellón de infecciosos del Hospital provincial se había quedado pequeño y se propuso instalar "camas para variolosos en el edificio de Chancillería que ocupó el Colegio de Huérfanos", pero vecinos y autoridades sanitarias protestaron por el riesgo de "llevar al barrio de San Pedro el grmen de una enfermedad tan expuesta al contagio". El mismo día se publicaba la decisión de la Comisión provincial de "que se proceda a la vacunación de los empleados y asilados en los establecimientos de Beneficencia" ${ }^{136}$. Finalmente se decidió "instalar en el Pinar de Antequera varios barracones para infecciosos"

En la anterior estadística que nos ofrece El Norte de Castilla llama la atención la diferencia significativa entre sexos 29 varones y sólo 8 mujeres; sin embargo, respecto a la edad la enfermedad se comportó, como es normal, afectando más a los más jóvenes, 7 menores de 1 año, 15 de 1 a 5 años y 13 de 5 a 19 años. A pesar de estos datos, y del mayor riesgo de transmisión que existe en lugares como el Hospicio donde la población infantil se concentra y tiene un contacto mayor, no hay constancia de que falleciera ningún niño interno en la Cuna provincial por viruela en ninguna de las dos epidemias.

En los Libros de Exposiciones de los años revisados desde 1900 a 1913 no encontramos registrado ningún fallecimiento por esta causa; al menos entre los menores internos, no podemos saber si falleció alguno de los que estaban en crianza externa porque en la mayoría de los registros no figuran las causas de fallecimiento, sabemos que todos los asilados eran vacunados, no tenemos constancia de que los externos recibieran la vacuna o las dosis de recuerdo, al estar fuera del centro recibirían la vacuna en las mismas condiciones que la población donde se estuvieran criando. Debido a la preocupación por las enfermedades infectocontagiosas, responsables de la altísima mortalidad de la Inclusa, y en cumplimiento de la RO de 1798, en el reglamento de 1889 se recoge la vacunación de los acogidos "Los profesores cuidarán especialmente de llenar la indicación de la vacuna cuando lo consideren oportuno revacunando a los acogidos que a su juicio fuese necesario". En épocas de epidemia se vacunaban todos los asilados del Hospicio frente a la viruela, la prensa local lo testifica (IMAGEN 3-46)

"Cumpliendo el acuerdo adoptado días pasados por la Comisión provincial, han sido vacunados todos los asilados en el Hospicio provincial" 738

Pasada la epidemia se siguió vacunando de la viruela, de forma gratuita a "los pobres".

"Directamente de la ternera de once á una y á las dos, gratis á los pobres los dias 27 y 28. Venta de tubos a peseta cada uno"1739

\footnotetext{
${ }^{736}$ N.C. 11 de febrero de $1911, \mathrm{p} 1$

${ }^{737}$ N.C. 23 de marzo de 1911, 24 marzo 1911

${ }^{738}$ N.C. 24 de noviembre de1902, p 1
} 
En 1927 en el Presupuesto provincial en un anexo que fija los precios de determinados servicios puede leerse "Las vacunaciones antivariólica y antitifica para todos los vecinos de los pueblos de la provincia, gratuitas" (pg 71), suponemos que se incluirían los asilados del Hospicio, puesto que en 1921 se declaró obligatoria la vacunación frente a la viruela, que se proclamó erradicada el 9 de diciembre de 1979.

La vacunación frente al tifus se generalizó en España a partir de la recomendación de la Real

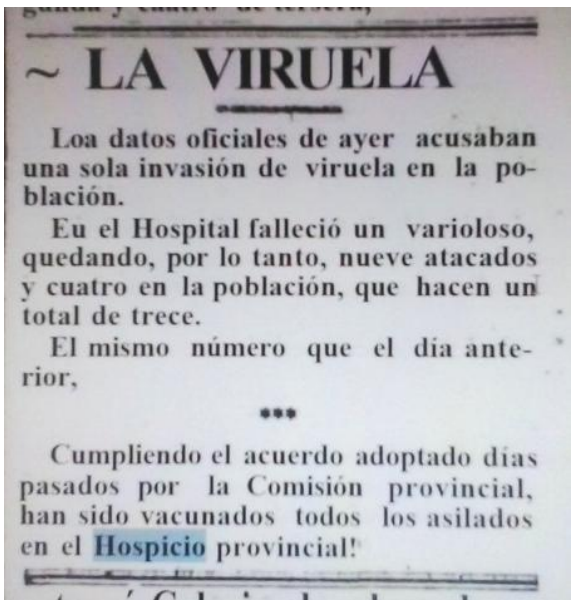

Imagen 3-46: La Viruela. N.C., 24-11-1902

Orden de 16 de julio de 1913 y la de 30 de noviembre de 1921 le dio carácter de obligatoriedad en caso de epidemia y especialmente en instituciones cerradas; el mismo Estado reconocía entonces que salía más barato vacunar que aplicar medidas de higiene pública para depurar el agua de consumo

\begin{abstract}
"Para contrarrestar tan terrible plaga, que después de la tuberculosis es seguramente la que ocasiona mayor número de víctimas en nuestra nación, no hay más que dos remedios higiénicos fundamentales de carácter público. Uno es el de la dotación de las aguas de bebida, microbiológicamente puras a todas las poblaciones, y el otro es el uso de las vacunaciones preventivas. El primero tropieza en España con inconvenientes casi insuperables, nacidos de la necesidad de un previo, formal y detenido estudio de los proyectos, del largo plazo que exige su ejecución, y sobre todo de la falta de recursos económicos de los pueblos y del Estado para llevarlos a cabo; en cambio el segundo medio, aunque considerado por lo pronto de más limitado radio de acción, es altamente económico y de muy fácil realización práctica" ${ }^{740}$
\end{abstract}

Otra cuestión diferente era la vacuna antituberculosa, a pesar de la altísima morbimortalidad de la tuberculosis que afectaba especialmente a la población infantil y por supuesto a nuestro Hospicio, siendo la enfermedad infecciosa de mayor mortandad fuera de las épocas epidémicas. Las denuncias por la falta de medidas oficiales de higiene social eran continuas en la prensa; en 1904, con ocasión de la Real Orden que decretó formar los comités antituberculosos provinciales y municipales se podía leer en El Norte de Castilla.

"Que la tuberculosis aumenta en España, que el número de muertos que ocasiona es cada vez más alarmante, que por todas partes se habla de sus terribles estragos y que son muy contadas las personas que procuran prevenirse, "higienizarse», para eludirles, es cosa por todos conocida.

\footnotetext{
${ }^{739}$ N.C. 28 marzo 1913, p 1

740 Preámbulo de la Real Orden Circular de 16 de julio de 1913.
} 
No nos damos cuenta de los mortíferos efectos de la terrible enfermedad hasta que las poblaciones se diezman, hasta que en las familias entra su germen de muerte para aniquilarlo todo... la tuberculosis arranca centenares de existencias... restando del gran libro de la vida cifras espantosamente crecidas que dentro del hogar suponen ríos de lágrimas y dentro de las leyes económicas inmensa pérdida de capitales. ...la patria toda ve mermada su población, gracias a la apatía dominante, cien veces más incurable que la tuberculosis". ${ }^{741}$

A pesar de la existencia de esos comités, también en Valladolid, donde se creó un pabellón de infecciosos en el Hospital provincial en 1905 y más tarde un pabellón de niños tuberculosos, la magnitud del problema seguía aumentando

\begin{abstract}
"La tuberculosis entendemos interesa muy de cerca a la ciudad de Valladolid... para que queden a cubierto y bien garantizados los altos y primordiales intereses de la salud pública... permitiéndonos indicar a las muy dignas autoridades ... que no olviden que la tuberculosis no es un proceso baladí, puramente personal y de quimérica trascendencia, no, sino que ... es de gran magnitud y de la mayor trascendencia por envolver dicha cuestión de higiene pública dos aspectos, uno de orden económico y otro social de penosa resolución... la pacientísima labor de recopilación realizada por los estadistas y demógrafos nos demuestra con la fría elocuencia de los números, 1 o que la tuberculosis es la enfermedad que más bajas ocasiona en las poblaciones entre todas las de carácter infectocontagioso, 20 que la tercera parte de las personas que mueren entre 15 y 60 años de edad es debido a la tuberculosis y 3o , que España pierde anualmente debido á esta causa morbosa unas 30.000 vidas aproximadamente ${ }^{742}$
\end{abstract}

En Europa se estaba utilizando desde 1921 la vacuna del bacilo de Calmette-Guérin (BCG) y en algunos países como Austria era obligatoria, mientras que en España, a pesar de la dimensión social y sanitaria de la enfermedad, en 1927 todavía continuaba la polémica relacionada con la vacuna antituberculosa y la pugna entre los partidarios de la vacuna BCG y la antialfa del doctor Ferrán; como resultado de esta controversia no se reglamentaba su administración, hasta que en 1931, una vez fallecido Ferrán, el gobierno recomendó la BCG, que se estaba mostrando más eficaz

\footnotetext{
"Ha llegado el momento de que el Gobierno, asesorado imparcialmente, decida pronto la obligatoriedad de vacunar contra la tuberculosis a todo recién nacido Piensen los españoles y el gobierno que con la vacuna de Jenner se ha borrado de los países civilizados el espectáculo repugnante de las caras acribilladas por las cicatrices de las viruelas y de las enormes cifras de ciegos y de defunciones debidos a tan cruel enfermedad

Es pues necesario vacunar contra la tuberculosis a todos los que vayan naciendo en nuestro país por amor a la Humanidad, por respeto a la ciencia y por el crédito sanitario de España... y que el Gobierno, mirando por el porvenir de nuestra raza les apoye... por concentrarse en dicha medida la aspiración obligada a procurar el aumento de la vitalidad y de la salud de nuestros
}

\footnotetext{
${ }^{741}$ N.C. 22 de junio de 1904, p 1

${ }^{742}$ N.C. 30 de diciembre de 1913 , p 2
} 
ciudadanos que es lo mismo que levantar el nivel de su poderío y de su riqueza"743

El doctor Ferrán estuvo en Valladolid en 1927 y vacunó a los niños del hospicio; en la sesión de la Comisión provincial del día 6 de julio se acordó

\begin{abstract}
"Hacer constar ${ }^{744}$ un expresivo voto de gracias para el doctor Ferrán, que en su reciente visita á esta ciudad impuso la vacuna antituberculosa de su invención á los niños del Hospicio

La Comisión con este motivo se congratuló de haberse anticipado a la Real orden que impone dicha vacuna como obligatoria, viendo con el mayor gusto las atenciones que la presidencia tuvo para el distinguido médico catalán"
\end{abstract}

A lo largo de los años treinta se irían introduciendo otras vacunas además de la tuberculosis y el tifus a medida que se fueron desarrollando, frente a la difteria, tosferina, tétanos, y su administración se convertiría en una de las actividades prioritarias de los consultorios y centros para la atención materno-infantil. Hasta los años sesenta no se implantó la vacunación obligatoria y sistemática.

La mayoría de nuestros entrevistados, nacidos todos antes de 1935, fueron vacunados de la viruela, 10 dicen que no, 15 no recuerdan y 2 comentan que no existían las vacunas, pero uno de ellos dice que "vacunas no había, solamente me acuerdo lo que ponían con una pluma, igual era la viruela", es probable que como la vacuna de la viruela no se inyectaba como se hace actualmente con la mayoría no la estén considerando como tal vacuna, además también

\footnotetext{
${ }^{743}$ Diario $A B C$, 6-enero -1927, pp 7 y 9. Se puede consultar en la hemeroteca digital del diario http://hemeroteca.abc.es/nav/Navigate.exe/hemeroteca/madrid/abc/1927/01/06/007.html El Diario $A B C$ publicaba este artículo titulado La vacunación contra la Tuberculosis, escrito por el doctor CODINA CASTELLVÍ, eminente médico y miembro de la Real Academia Nacional de Medicina, en relación con la polémica desatada por la vacuna antituberculosa que en otros países ya se había implantado como obligatoria, mientras que en España se disponía de una vacuna desarrollada por el doctor Ferrán que, sin embargo, no se estaba utilizando con fines preventivos, sino terapéuticos y que fue motivo de muchas controversias. Dice el artículo que en España "se sustentan tres opiniones fundamentales: una arremete (y censura agria y despiadadamente) contra todo lo que se ha hecho y se hace por quienes han dirigido y dirigen la lucha antituberculosa; otra se lamenta de que aún se hace poco en contra del terrible mal; y otra afirma que cuanto se hace es inútil, contraproducente y fomentador de vanidades, y reclama urgente y constantemente la vacunación...". Reconoce la eficacia, ya demostrada por entonces, de la vacuna de la viruela, "En el fondo de las tres opiniones, como en el ánimo de todo médico, se agita la idea de que el mejor recurso de lucha antituberculosa es una vacuna eficaz, como lo mejor para luchar contra la viruela no es edificar hospitales para variolosos, sino vacunar y revacunar..." y comenta que "Las autoridades sanitarias de Austria han dispuesto, de acuerdo con el Gobierno, que se establezca, con carácter obligatorio, la vacunación tuberculosa, según el procedimiento del ilustre médico francés doctor Calmette... ésta vacuna se administra durante la primera semana del nacimiento por la boca; se considera totalmente inocua y se facilita gratuitamente por el instituto Pasteur a quién la solicite, pero con la exclusiva finalidad de la vacunación, no como un tratamiento más de la enfermedad...". Por entonces en España el doctor Ferrán había desarrollado otra vacuna antituberculosa "Ilamada antialfa... [que] tiene, entre la clase médica, sus partidarios, sus indiferentes y sus enemigos, lo propio que en Francia los tiene la de Calmette, quien me decía que solo había 17.000 recién nacidos vacunados en dicha nación... En nuestro país, con ser muchos más los vacunados con la vacuna Ferrán, hay que convenir que ha sido desviado su empleo hacia el lado terapéutico y representan ínfima minoría los vacunados con fines profilácticos, es decir en los primeros días del nacimiento antes de tropezar el recién nacido con el terrible bacilo de Koch."

${ }^{744}$ N.C. 7- 7- 1927 , portada
} 
se referían a ella como suero ${ }^{745}$. 32 entrevistados afirman que recibieron la de la viruela y 13 recuerdan que le pusieron alguna pero no saben muy bien cual, aunque muchos se están refiriendo también a la viruela por las indicaciones que dan sobre su forma de administración, "Ias vacunas que nos ponían eran raspadas en la piel no como ahora. Se quedaba una cicatriz grande, pero a mí nunca se me llegó a quedar la cicatriz", "lo que hacían era rasparnos la piel y luego echarnos la vacuna". La vacuna antivariólica se administraba mediante una incisión en el brazo o en el muslo en la que se inoculaba el virus, se protegía para evitar el rascado y se prohibía el baño durante unos días hasta que se caía la pústula, se indicaba en el segundo trimestre de vida si era posible. Algunos entrevistados hablan de otras vacunas como el tétanos y tienen cierta confusión pues mencionan algunas que es improbable que recibieran como el paludismo, probablemente confundida con la del tifus, la polio o el sarampión, que son muy posteriores, la polio se desarrolló en los años 50 y el sarampión en los 60; en esta cuestión están mezclando recuerdos de su infancia con los que tienen sobre sus hijos. Ninguno menciona la vacuna contra la tuberculosis y solo uno frente a la difteria, que por edad pudieron haber recibido.

\subsubsection{Asistencía Médica en la Inclusa}

Al revisar los libros me llamó poderosamente la atención el hecho de no encontrar en los registros, salvo excepciones contadas, ningún detalle sobre el estado de salud de los niños en el momento del ingreso, sobre todo viendo la meticulosidad con que se registraban otros datos como las ropas que llevaban, sin duda pensando en una futura reclamación de los padres. Teniendo en cuenta que muchos morían en los primeros días de vida, podemos sospechar que no debían llegar en muy buenas condiciones. Según dicen los reglamentos todos los niños al ingresar debían ser vistos por el médico del Hospicio, inmediatamente si se presentaban en muy mal estado, aunque el reglamento es un tanto ambiguo ante esta situación: "Si la criatura expuesta reclamare con urgencia el auxilio del Facultativo y Capellán, la Superiora les pasará inmediatamente aviso, para que cada uno cumpla con su ministerio"

\footnotetext{
${ }^{745}$ En 1796 el médico rural Jenner inoculó pus variólico en un niño sano de 8 años, quería experimentar y comprobar si era cierta la creencia que se había extendido que las personas que habían contraído la "viruela boba" o "peste de las vacas" no se contagiaban de viruela. (Afectaba a las ubres y se contraía al ordeñarlas, pero la clínica en el ser humano era muy leve). A los dos meses le volvió a inocular pus, esta vez de una persona enferma, y el niño no enfermó. Este experimento, éticamente muy cuestionable, dio paso a la primera vacuna, nombre que se generalizó a partir del origen vacuno del suero empleado para la inmunizaciones; los anuncios en prensa hablaban del suero de la ternera. BABINI J.: Historia de la Medicina, Barcelona, Gedisa. 1980, p 121
} 
(Regl de 1889, Art. 48). Suponemos que si el niño llegaba muy mal a juicio de la Hermana encargada del torno, que era la que le recibía, ésta avisaría a la Superiora, la que a su vez debía avisar con urgencia al médico, que no estaba de guardia permanente en el centro. A pesar de que hay pocas evidencias y no hay constancia en los libros de registro del estado de salud de los niños, parece que se cumplía con la norma de realizar un reconocimiento médico al ingreso ya que en tres expedientes personales de los que se han podido revisar por entrar en el período de consulta permitido se conserva la papeleta correspondiente, con fecha del mismo día de entrada o del día siguiente. Se trata de una ficha impresa con membrete del Hospicio en la que se recogía la edad estimada del niño, los hallazgos de la exploración, la presencia de "señas particulares", entre las que se incluía el peso, y de "defectos de conformación". Curiosamente, en esta ficha no se recogía el nombre del niño, en su lugar se anotaba el no del folio donde estaba inscrito y el sello con el número de filiación, lo que pudo dar lugar a errores como el que veremos. La ficha se archivaba en el expediente del niño, pero los datos en ella recogidos no se pasaban a ninguno de los libros, ni siquiera la edad estimada. Solo muy ocasionalmente se encuentra en los libros algún registro que estime la edad en un niño del torno, como en el caso de Gonzalo Mena inscrito en el folio no 269 del Libro de Menores de 1911 donde se anotó, contra la costumbre, la edad supuesta: "Del reconocimiento facultativo resulta tener este niño la edad al parecer de mes y medio." Esta anotación probablemente se deba al hecho de que era un niño expuesto con una nota que decía que estaba bautizado y precisarían una edad aproximada para comprobarlo y localizar la parroquia, lo que no se debió conseguir porque una semana después se le bautizó en la Inclusa "bajo condición". El reconocimiento médico se realizó el mismo día del ingreso, el 4 de agosto de

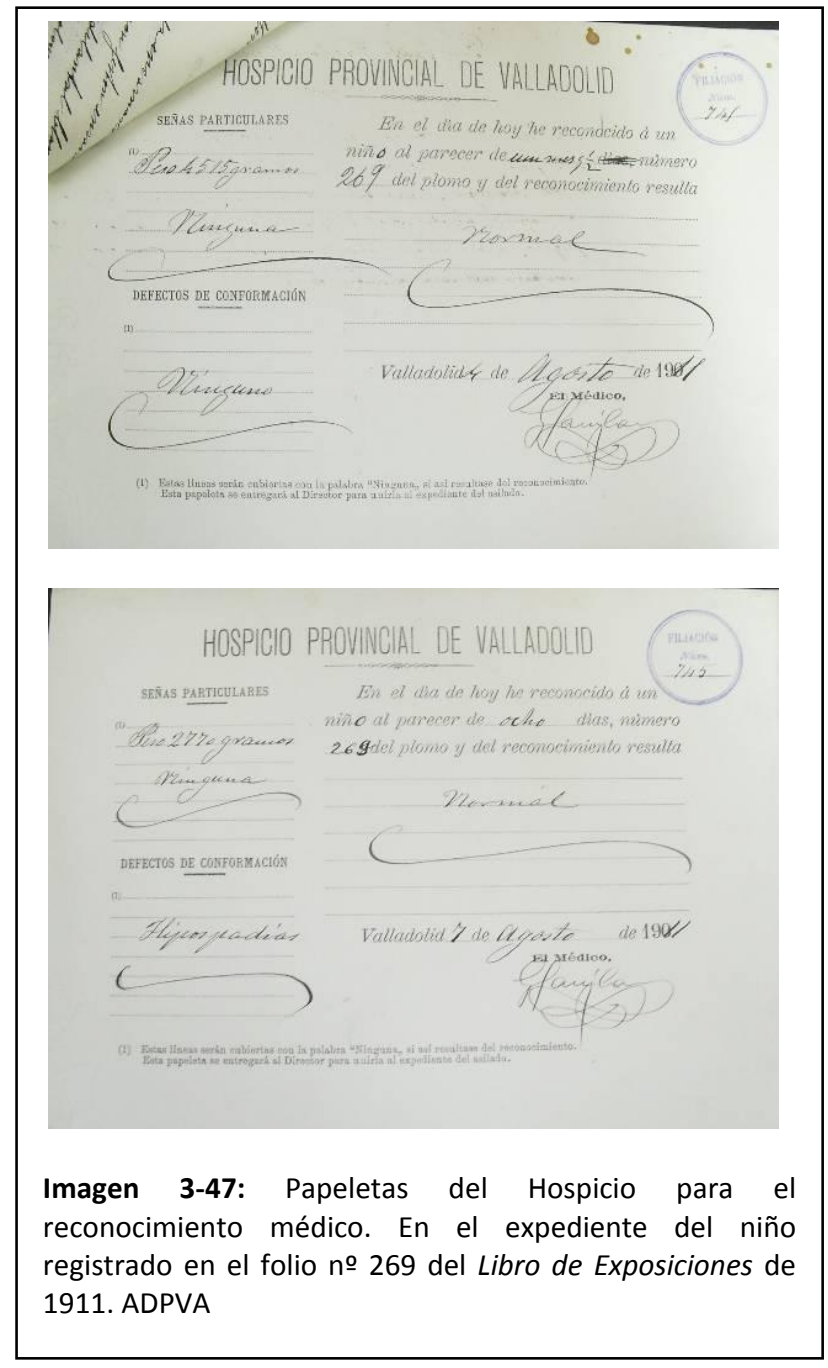
1911. 
Este es un caso curioso por varios motivos, el niño no fue expuesto en el torno, sino en la puerta del establecimiento donde le encontraron y le entregaron dos policías municipales a las 5 y media de la madrugada, así consta en la carta del Juzgado que se encuentra en el expediente en la que se solicita información sobre señas de identificación y estado de salud del niño. No está la respuesta en el expediente, sabemos que se contestó el día 10 de agosto de 1911, según consta en la misma carta del juzgado, pero no sabemos qué es lo que se comunicó sobre el estado de salud del niño porque en la misma carpeta se encuentran dos fichas de reconocimiento médico diferentes con el mismo número de folio y el mismo número de filiación, números que corresponden ambos al niño llamado Gonzalo Mena, según he podido comprobar en el Libro de Exposiciones de 1911, donde los datos anotados coinciden con los del expediente. Es imposible que las dos fichas, en las que no figura nombre, puedan corresponder al mismo niño; sorprende en este caso un error de este tipo, sobre todo teniendo en cuenta que había por medio un requerimiento judicial que debería suponer un mayor cuidado en los registros de este niño en cuestión (fichas en IMAGEN 3-47). En la primera papeleta, fechada el mismo día del ingreso, la edad estimada es de mes y medio, como figura también en el folio de inscripción, el peso anotado 4.415 gr. y la exploración es normal; la segunda está fechada tres días después, el 7 de agosto, el niño en cuestión tiene una edad estimada de ocho días, el peso es de 2.770 gr. y en los "defectos de conformación" figura un hipospadias. Esta segunda ficha por la edad estimada no corresponde al niño del folio no 269 llamado Gonzalo Mena al que se calculó mes y medio. Revisando el Libro de Exposiciones del año, el día 7 de agosto solamente ingresó una niña (folio no 271), por lo que esta ficha no puede pertenecer a ella ${ }^{746}$; podría corresponder al niño del folio no 270, ingresado inmediatamente después de Gonzalo el 6 de agosto y expuesto en el torno a la una de la noche "con oficio del Alcalde de la Mota del Marqués ... donde consta que nació el día primero del corriente y que es hijo natural de Alejandra Fernández soltera de 19 años", en su hoja de registro no cuenta nada más de interés salvo que falleció el día 21 y no se conserva su expediente.

Entre los expedientes personales solamente se encuentran otras dos papeletas de reconocimiento médico. La primera está fechada el 3 de abril de 1909 pertenece a una niña de 6 días de vida que ingresó por acuerdo de la comisión provincial ese mismo día, era hija natural y la entregó su abuelo materno porque la madre, soltera, no podía criarla; en la papeleta del reconocimiento, a pesar de conocerse la edad exacta, se le calculan quince días, todos los demás datos del expediente coinciden con los de su folio de registro (no 127. Libro 1909).

\footnotetext{
${ }^{746}$ En la papeleta pone que es un niño y el hipospadias es una anomalía congénita exclusivamente masculina que consiste en que la abertura de la uretra se ubica en la cara inferior del pene en lugar de estar en la punta de éste
} 
Extraña la falta de coincidencia respecto a la edad de la niña y que se haga una estimación de la edad cuando se conoce la real, da la impresión de que el médico no consultaba los registros de los niños; en cuanto al error en la edad estimada es normal pues no es fácil calcular la edad exacta, probablemente la niña ya no tendría cordón umbilical (que suele desprenderse en la segunda semana de vida), o lo tendría ya muy necrosado. La otra papeleta, fechada el 3 de julio de 1911, es de una niña de 3 días que ingresó en esa misma fecha procedente del Hospital Provincial de la Resurrección donde nació, está registrada en el libro de Exposiciones de 1911 en el folio no 229 y aparece como ingresada el día 4 de julio, pero todos los demás datos coinciden con el expediente. Aunque son pocas las papeletas conservadas, podemos presumir que se realizaba el reconocimiento médico al ingresar los niños y que se hacía el día del ingreso o al siguiente, incluso los niños que procedían del hospital donde supuestamente también habrían sido reconocidos.

No tenemos constancia de los controles sanitarios que se realizaban a los niños de la Inclusa durante su estancia, aparte del que se practicaba al Ingreso, no se conserva ningún libro de registro de la enfermería o del servicio médico ni se han encontrado entre los expedientes o entre los libros otros informes médicos de los niños. Entre los folios de registro encontramos niños que salieron para crianza y que poco después fueron devueltos por encontrarse enfermos o fallecieron

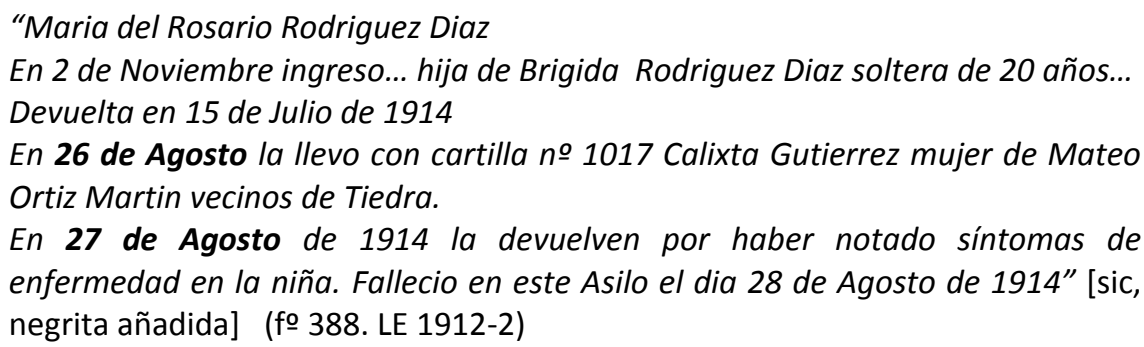

Esta niña nació en octubre de 1912, salió con una primera nodriza que la devolvió como vemos en Julio, ya no era un bebé, tenía casi 2 años y en la segunda salida debía estar realmente muy enferma cuando la devolvieron al día siguiente y falleció, no dice la causa.

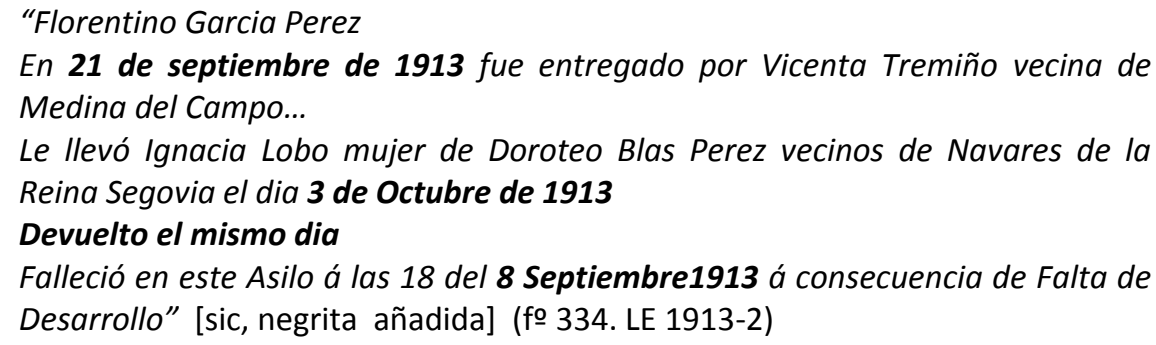

La fecha de defunción registrada es errónea, es anterior incluso al nacimiento, es bastante probable que fuera el 8 de octubre por el hecho de que se le devolvió el mismo día de 
la salida y por el diagnóstico "Falta de desarrollo" que se aplicaba a los recién nacidos prematuros y de bajo peso.

"En 5 de Septiembre á las 20 y 30 minutos fue expuesto en el torno... Bautizado e inscripto en Valladolid en 30 de Enero de 1913.

En 7 de Septiembre de 1913 le llevó Adriana...

El dia 9 de Septiembre de 1913 fallecio en Quintanilla de Abajo" [sic, negrita añadida] (fo 312, LE 1913-1)

"El dia 26 de Abril del 1906 fue entregado por una portera del Hospital provincial... hijo de Carmen soltera de 24 años natural de Palencia

El dia 16 de Agosto de 1906 le llevo Micaela San Jose mujer de Crispulo Hernandez vecinos de Peñaflor.

Falleció en dicho pueblo 19 Agosto 1906" [sic, negrita añadida] (fo 146, LE 1906-1)

Estos niños fallecieron a los dos- tres días de salir y no se dice la causa en sus registros; podríamos recoger testimonios parecidos. María de Felipe Pérez, hija legítima ingresada con mes y medio en abril de 1905 salió para lactancia el 22 de julio y falleció el 24 con la nodriza (fo 146). Modesto Astudillo Prado, expuesto en el torno en julio de 1905 con diez días, salió el 6 de noviembre y falleció el 8 con la nodriza (fo 264). Tampoco se dice la causa en sus registros. Todos los años encontramos casos similares de niños devueltos que fallecen en los primeros días de su salida del Hospicio, lo que nos hace pensar que ya no iban en buenas condiciones. La pregunta es si se conocía su estado de salud o no, es probable que en algunos casos se entregaran ciertos niños a las nodrizas para darles una oportunidad de sobrevivir, como Florentino, visto anteriormente, que falleció por "Falta de desarrollo", pero como en la mayoría no se ha registrado la causa del fallecimiento ésta idea no es más que un supuesto.

El Hospicio disponía de dependencias destinadas a la atención de los asilados enfermos, la enfermería de los niños en principio debió estar emplazada en la planta superior y luego se trasladó al ala de Norte de la planta principal del segundo patio. (ver La Casa de los Benavente, el Edificio y sus Instalaciones en el capítulo del Hospicio y la IMAGEN 2-6). Según los reglamentos, el Hospicio disponía de una enfermería, aunque hablan de 4 refiriéndose a las dependencias dispuestas para esta función; el Reglamento de 1910 dice que estaba dividida en dos secciones, de Medicina y de Cirugía y con "la debida separación de sexos y edades y de enfermedades infecciosas o contagiosas" (Art. 208). La separación por sexo y edad ya se contemplaba en el reglamento anterior, de 1889, pero no así la de enfermedades contagiosas, en él podemos leer que "Las enfermerías o clínicas serán cuatro: una destinada para las nodrizas y las embarazadas e independiente de la de los demás asilados, otra de niños de dos a siete años para ambos sexos, en las cuales se procurará el debido aislamiento para las 
enfermedades médicas y quirúrgicas, otra por el mismo orden e división que la anterior para varones adultos y otra en iguales condiciones para las mujeres"; llama la atención que habla de "varones adultos" para referirse a los muchachos mayores de 7 años y que no hay una sección para los menores de 2 años. Explica además que la sala de las puérperas era independiente y estaba aislada del resto de los enfermos para proporcionarles "Ia tranquilidad y absoluta independencia que necesitan" (Art. 170 y 171, Regl 1889), es de suponer que estaría junto a las salas de Maternidad. El Reglamento de 1910 dice que "todas las operaciones quirúrgicas estarán a cargo del Cirujano" (Art. 54), en el de 1927 no particulariza y dice "de los Médicos" (Art. 53), y parece que solamente se remitían al Hospital Provincial de la Resurrección, también dependiente de la Diputación, las "llamadas grandes operaciones", con el acuerdo de los facultativos del centro. En el proyecto que se conserva en el ADPVA de la reforma de la enfermería ${ }^{747}$ aparecen dibujadas una Sala de Curas que podría ser utilizada como quirófano, ya que no se ve ninguna otra dependencia destinada a esta posible función, una Antesala y dos salas de diferente tamaño denominadas cada una en el plano como Enfermería, no se refiere su uso; podría ser la enfermería de niños y la sala más pequeña para los infecciosos.

Como hemos visto, los niños de lactancia no tenían sitio en la enfermería, por tanto se atendían en su propia sala cuando enfermaban, solamente en el caso de que "en alguno de los niños se notase el padecimiento de una enfermedad contagiosa se le trasladará a la sala destinada a enfermería" (Art. 60).

Seguramente los más pequeños estarían mejor atendidos en su propia sección por las nodrizas porque las Enfermerías estaban muy mal dotadas de personal, para las cuatro dependencias descritas según edad y sexo se contaba con un médico, dos a partir de 1906, un practicante que no residía en el centro pero debía permanecer "en el Establecimiento todo el mayor tiempo posible para atender de momento a los casos urgentes que ocurran" (Art. 49- 8으, Regl 1910), un enfermero y una enfermera que debían "hallarse siempre en las enfermerías para llenar los servicios que se les ordenare" (Art. 50 Regl de 1910), más las Hijas de la Caridad en número no determinado, aunque no podían ser muchas teniendo en cuenta todas las tareas que tenían asignadas y que debían atender o controlar directamente, casi todos los servicios del Hospicio (el torno, los departamentos de menores, mujeres y niñas, la escuela de párvulos y la de niñas, almacén, ropero, cocina, refectorio, lavandería, Iglesia), y que tampoco eran demasiadas, menos de 20 hasta 1912. Los reglamentos establecían el personal de las

\footnotetext{
747 Plano sobre la "Distribución en planta principal de las Galerías de Poniente y Norte". Signatura: caja 245, expediente 2766. ADPVA. No tiene autor ni fecha.
} 
enfermerías y regulaban sus funciones (Título diez y seis del Regl de 1889 y Capítulo VIII de 1910 y 1927) (ver capítulo Personal y Gobierno del Hospicio pág 163).

Los médicos, aparte de tratar a los enfermos, debían velar por la salud de los asilados controlando que recibieran cuidados apropiados en relación con la alimentación, el vestido y la higiene; tenían que pautar la dieta de los lactantes y según el reglamento podían decidir prolongar la lactancia después de los 18 meses "atendida su difícil dentición u otra enfermedad" (Art. 42. 1889), vigilar y en su caso corregir la alimentación de los niños asilados haciendo visitas periódicas al refectorio en las horas de las comidas, también debían vigilar que el vestido de los asilados fuera apropiado, "cuidarán de que en las estaciones correspondientes se cambie el vestido y el calzado a los acogidos" y sobre todo las cuestiones de tipo higiénico y la vigilancia epidemiológica: "girarán por lo menos dos veces al mes detenidas y escrupulosas visitas de inspección higiénica al Establecimiento, llamando la atención de cuanto consideren oportuno a fin de evitar y precaver enfermedades contagiosas y desarrollo de las mismas" (Art. 240 Regl 1889). Debían pasar informes a la Dirección y una Memoria anual a la Diputación recogiendo las deficiencias observadas y las propuestas de mejora, si estos informes fueron veraces parece que quedaron en su mayoría en papel mojado a la vista de las condiciones denunciadas continuamente y sobre todo de la alta mortalidad del centro.

Aunque la población que debían atender eran niños y mujeres y ya existían las correspondientes especialidades médicas, no se pedía a los médicos del Hospicio ser especialistas $^{78}$, lo único que se pide en los reglamentos de 1889 y 1910 es que uno de ellos fuera cirujano, y así debía ser porque en los libros de registro de la Maternidad y en algunos documentos como informes sobre las nodrizas se habla del "Profesor en Cirugía". En 1901 el médico del Hospicio era Don Evaristo Millán ${ }^{749}$, el mismo que en 1903 se anunciaba en la

\footnotetext{
${ }^{748}$ La Pediatría y la Puericultura surgieron en la segunda mitad del siglo como especialidades médicas dedicadas a la población infantil enferma y sana respectivamente, la Pediatría se centra en el aspecto clínico y la Puericultura en el higiénico-social. En España la primera cátedra independiente de Enfermedades de la Infancia se creó en Madrid en 1886, hasta entonces el estudio y práctica de la medicina del niño iba unido a las de las mujeres, en el Plan de estudios de 1845 se denomina a esta rama médica conjunta "Clínica de partos y enfermedades de mujeres y niños". Como especialidad médica tardó en desarrollarse y en implantarse, en la relación de médicos existentes en el país que publicó el Anuario sanitario de España de 1909, una publicación que era de carácter comercial, solo 10 aparecen como pediatras y puericultores, aunque entre ellos ni siquiera se encuentran los catedráticos de pediatría de la época. RODRÍGUEZ OCAÑA E.: Rafael García-Duarte Salcedo y la consolidación de la Pediatría en la España del primer tercio del siglo XX, Cuadernos de Historia de la Pediatría española, no 3, junio 2012, pp 4- 17

${ }^{749}$ N.C. 28- 06- 1901, p 2. El artículo resume los acuerdos de la Comisión de la Diputación, entre ellos una convocatoria de oposiciones para los cargos de las instituciones provinciales y aparece la relación de los que estaban ocupando las plazas en ese momento
} 
prensa local como "Médico director del Hospicio provincial. Especialista en partos distócicos y enfermedades de los niños" ${ }^{\prime 750}$.

Los médicos, atendían a los niños de la Inclusa por indicación de la Hermana de la Caridad responsable del departamento, que entre otras funciones tenía que cuidar "de que en las indisposiciones de los niños, no se les de otros medicamentos que los que recete el Facultativo, ni se les aplique ningún remedio por común y sencillo que sea sin el consentimiento de aquel" (Art. 60 Regl 1889). El reglamento prohibía el uso de remedios caseros, algo que era normal en la época propiciado por la ignorancia y la falta de recursos, porque muchos de ellos podían ser terriblemente

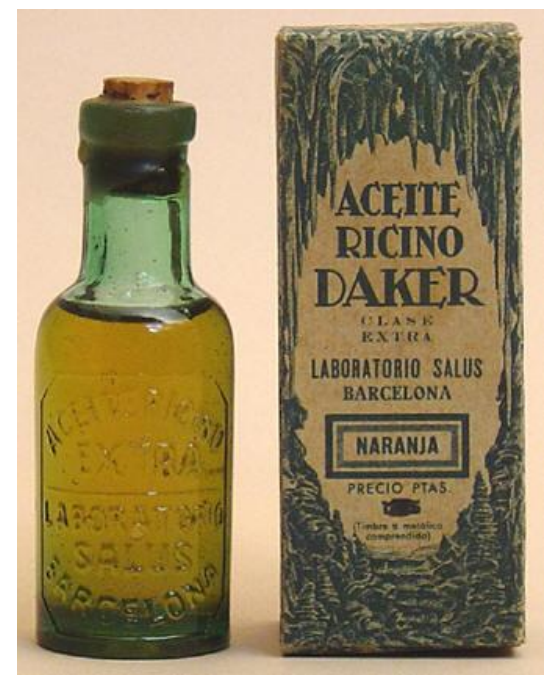

Imagen 3-48: Envase de aceite de ricino perjudiciales, especialmente para los niños y las gestantes, una población muy susceptible.

La lucha contra esta medicina tradicional, muchas veces de carácter más supersticioso que empírico, era uno de los caballos de batalla de la medicina de estas décadas. Sirva como ejemplo del uso y de la importancia social que tenían estas prácticas las entrevistas que hemos realizado, todos los entrevistados reconocen el uso de remedios caseros, muchos dicen que las medicinas eran muy caras, había muy pocas y las tenía que hacer el boticario. Tampoco tenían fácil acceso a la atención médica, en esto podríamos decir que los niños internados en el Hospicio eran casi unos privilegiados al disponer de facultativos, la mayoría afirma que solamente acudían al médico cuando fallaban esos remedios y algunos entrevistados cuentan que si la madre no sabía se consultaba a alguna vecina, que "siempre había quien sabía mucho de estas cosas", "mi madre era muy mañosa y la llamaban mucho las vecinas cuando necesitaban ayuda"; también para ciertos temas se acudía más a curanderos, "se usaban más las curanderas que los médicos y acertaban más", "Mi madre era curandera, curaba las hernias. Les hacia una venda con dos nudos huecos, un nudo lo ponía en la hernia y el otro le pasaba alrededor de sus partes y luego volvía otra vez para atrás y ya lo ataba. Había otra curandera en el pueblo que curaba cuando se les salía un hueso de los brazos o de las piernas y tiraban a ver si se curaba". En muchos pueblos no tenían médico, "estaba en siete pueblos e

\footnotetext{
${ }^{750}$ N.C. 28- 06- 1901, p 1, anuncia "Consulta de doce á dos. Cruz del Val 1, segundo"
} 
iba andado de un pueblo a otro", y algunos nos dicen que no todo el mundo podía pagarlo, aunque también reconocen que, en los pueblos sobre todo, muchas veces le pagaban en especie, "se pagaba lo que se podía", "se le solía pagar con fanegas o celemines de trigo", "Tenían una iguala y le pagaban lo de todo el año después del verano, recogida la cosecha o de la vendimia", "Las tierras se sembraban, se cultivaban, se segaban, se llevaban a la era, y cuando estaba hecho se vendía el trigo y entonces se llevaba al médico lo que habían pactado, un cuarto o dos cuartos al año, pues se le llevaba. Con el trigo le pagaban".

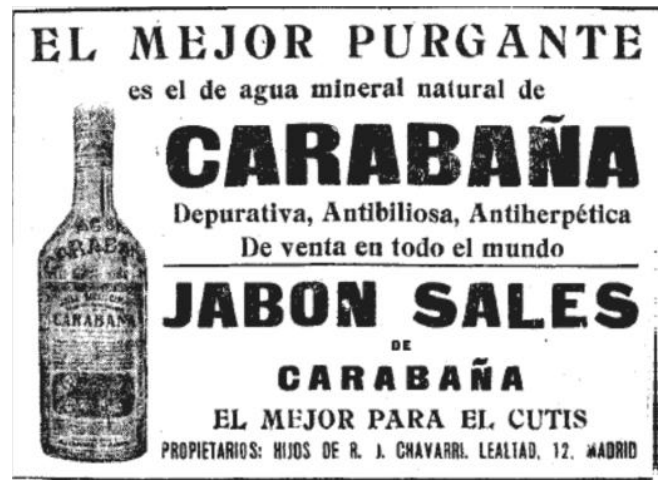

Imagen 3-49: Anuncio de Agua de Carabaña. El Sol, 2-05-1924, p 2
Un remedio que todos recuerdan haber probado en la infancia, "porque sabía fatal", es el aceite de ricino, "les tapaban la nariz y se lo daban por la boca" para purgarles, cuando tenían dolores de tripa y empachos, "eso daba mucha diarrea"; las purgas, como ocurriera con las sanguijuelas servían para todo, "cuando había fiebre se purgaba porque no se sabía de donde procedía", incluso alguno recuerda que se lo hacían tomar como castigo en el colegio.. Para el estreñimiento de los bebés recuerdan que se empleaban también hojas de geranio, una ramita de perejil, el rabo de la hoja de malvas o una cerilla de cera que algunos dicen se untaban en jabón o aceite y que se introducían por el recto, "nos ponían una cala ${ }^{751}$, metían una cerilla por el culete", y supositorios caseros con el jabón que se hacía en casa; también alguno refiere agua de carabaña ${ }^{752}$. Para los cólicos y los dolores de tripa lo más habitual era el anís estrellado en infusión y las friegas con aceite caliente en la tripa, también alguno refiere agua de orégano y cáscara de pepino cocida. Para vómitos y diarreas lo que más recuerdan es que les dejaban "sin comer y a esperar" y la manzanilla, "se daba manzanilla para todo, para la tripa, para los ojos..." y otras cosas que se han seguido empleando como el arroz blanco, el té y el agua con limón. Un problema frecuente en los niños, aunque no era vital, era el de las lombrices, para el que nos han dado remedios tan curiosos como "la Oración de San Agustín 9 días seguidos", también "se ponía en el ano del niño un trapo blanco mojado de aceite" y, menos inofensivo que los anteriores, "les ponían un collar de ajos, se los comían y bebían

\footnotetext{
751 CALA: "Pedacito de jabón, de raíz de perejil o de otra materia, que se introduce por el ano para facilitar la evacuación del vientre". (3a acepción). Diccionario RAE. 14a edición. Madrid. 1914, p 179, 2

${ }^{752}$ Es agua del manantial La Fuente de la Salina en el Cerro de Cabeza Gorda de Carabaña, a 50 Kms. de Madrid. Conocido desde época romana, se empezó a explotar comercialmente en 1883 y entre sus efectos la casa destacaba el de laxante y depurativo. Ramón y Cajal, entre otros, analizó estas aguas que todavía se comercializan. La empresa explotadora del manantial también fabricaba jabones con sus sales.
} 
orujo". Un remedio que también nombran muchos es el aceite de hígado de bacalao, para el apetito y la anemia y alguno se acuerda de los vinos quinados, el vino Sansón, "el farmacéutico le decía a mi madre que comprara vino en la cantina que era mejor que el de casa y así me preparaba lo que llamaban el quinado que era como un reconstituyente. Este farmacéutico, recuerdo, que en mi enfermedad me cuidó mucho. Él decía cuanto quinado podía beber". Para resfriados, tos, mocos y dolor de pecho lo más recordado son las cataplasmas a base de aguarrás caliente, harina de linaza o mostaza, "era mostaza que se ponía húmeda y se ponía con mucho calor en el pecho para los catarros"; otros remedios eran raíz de malvavisco, naranja asada, miel y miel con limón, infusiones de orégano, requemado de orégano y azúcar, flor de malva y hojas de eucalipto. Dos de los entrevistados nos hablan de las ventosas, "si tenías catarro te ponían una moneda en el pecho o en la espalda, una ventosa, y un algodón empapado en alcohol por encima y lo prendían. Inmediatamente ponían un vaso encima y se inflamaba. Cuando ya se desprendía el vaso te quedaba un círculo morado y se te curaba el resfriado", "con una moneda de bronce colocaban una cerilla la doblaban y ponían un vaso para ventilar los bronquios". Para la fiebre la mayoría no recuerda ningún remedio, "se tapaba mucho al niño para que la sudara" y como mucho se colocaban "paños de agua fría en la frente y se rezaba". La salida de los dientes se aliviaba dando a morder cosas al bebé como "la llave de un armario fría", "un chupete en azúcar o anís o algo asi", "un palito se envolvía con un trapo mojado y se les frotaban las encías, "con el dedo de la madre mojado en agua fría por las encías" o con "una pomada que hacía mi abuela con cardos de las tierras, valía para todo". El dolor de oídos es un dolor agudo y muy intenso y es muy frecuente en la infancia, para aliviarlo nos relatan dos remedios gotas de aceite caliente o leche de la madre o de alguna mujer que estuviera lactando, con la particularidad, dicen algunos, de que el hijo y el enfermo debían ser de sexo contrario, "cuando a un niño le dolía el oído le ponían debajo de la teta de una mujer que estuviera criando al pecho a una niña y se le echaba un chorro de leche. Si era una niña la del oído el chorro de leche tenía que ser de la madre de un varón", "si el niño estaba malo de los oídos se pedía a una mujer que estuviera amamantando a una niña que echara leche en un dedal...". A veces los bebés lloran de forma inconsolable y sin saber por qué, sobre todo por las noches es difícil de llevar, "pues que iban a hacer, ponerles a la teta y ya está", "si no dormían se les echaba un poco de azúcar cuando se tenía en el chupete", también les daban miel, manzanilla, hierbas cocidas en agua o "anises en granito y lo cocían y dejaban reposar y le untaban el chupón para dormir", "los anises los usábamos para todo", o fabricaban el chupete con "una bola de tela con agua y azúcar". "Cuando los niños no se lavaban la cabeza, les solía salir un tipo de costra que se llamaba "capacete" y para poder quitárselo utilizaban aceite", se refiere a la llamada costra láctea, que realmente no tiene que ver con la alimentación ni con la 
falta de higiene, es un tipo de dermatitis seborreica que aparece en los primeros años de vida y es de origen desconocido; "a los 2 años, al morir mi madre se me cubrió la cabeza con una costra que no podían quitar. Me llevaron a una curandera y al levantarla había una piojada; fue porque echaba de menos a mi madre"; el aceite, aceite inglés, también lo usaban para los piojos, con otros remedios como "un unto de color gris un poco espeso para los colegios, se llevaba la taza a la farmacia alli te lo hacían y cuando volvías lo pagabas". Golpes y heridas son parte de la infancia y recuerdan que se usaba "árnica casera para los golpes", una "llave fría para los chichones", para irritaciones y escoceduras a falta de polvos de talco "se raspaba la pared y los polvos que caían se les echaba por las zonas irritadas" y para las heridas la respuesta más frecuente es agua y jabón "que era lo que teníamos" y después "agua con sal" y alcohol, "te lo echaban en las heridas, se envolvían con un trapo, se ataban con un hilo y a jugar" y en su defecto aguardiente o vino, "las heridas que mis hermanas o yo nos hacíamos en el campo, mi padre nos las curaba con la bota de vino echando un chorro y nos ataba un cacho de camisa para que no sangrara". Es en este tema de las heridas en el que hay más variedad de respuestas, pan con aceite, aceite de oliva y raíces de argamula real, "azúcar o miel de abejas, la malva y en las heridas infectadas y los granos, la cebolla", agua oxigenada, que empezó a usarse en la década de los 20 por eso también algunos entrevistados dicen que entonces no existía, y cataplasmas de hojas de morera, hierbas del campo, harina de linaza o de "cebolla y hojas de las higueras" y un recurso que se está estudiando actualmente, dos entrevistados cuentan que "las heridas las curaban poniendo encima telas de araña", se utilizaban para cortar el sangrado, se ha comprobado científicamente su efecto anticoagulante y además son cicatrizantes y antisépticas.

No todos estos remedios que hoy llamamos tradicionales andaban muy descaminados, algunos han servido de base para desarrollar posteriormente tratamientos científicos, como es el caso mencionado de la aplicación de las telarañas, muchos de ellos son fruto del conocimiento empírico acumulado durante siglos y algunos llegaron a incorporarse a las indicaciones médicas, y otros partían de recomendaciones antiguas y se seguín practicando por la fuerza de la costumbre sin cuestionarlos. Como el conocimiento popular iba muy por detrás del científico he comparado estos remedios caseros con los tratamientos que aparecen en el Tratado elemental de enfermedades de la mujer y del niño de Fabre y D'Huc actualizado por Rogelio Casas en $1870^{753}$. Recojo alguno como muestra, veremos que los hay similares a

\footnotetext{
753 CASAS DE BATISTA R.: Fabre y D'Huc. Tratado elemental de enfermedades de la mujer y del niño. Nueva Edición notablemente reformada y adicionada con los adelantos más modernos e importantes de la especialidad... Madrid, Carlos Bailly- Bailliere, 1870
} 
los remedios populares, incluso en ocasiones éstos últimos son preferibles desde la perspectiva y el conocimiento actual

Irritaciones y escoceduras de los bebés ( $p$ 404)

"Conviene en primer lugar, para precaver estas escoriaciones una esmerada limpieza en los niños, y además tan luego como se adviertan, lavar la parte afecta con leche ó un cocimiento de raíz de malvavisco; si esto no bastase se emplearán algunos polvos absorbentes como los de carcoma, almidón, licopodio, etc"

\section{Costra láctea: ( $p$ 404-5)}

"Algunos niños al nacer presentan en la piel del cráneo una especie de casquete o costra dura y amarillenta, que se rompe y se desprende por escamas. Se cree por el vulgo que garantiza el cráneo de los accidentes a que está expuesto... No solo es inútil sino que conviene hacerla desaparecer, pues impide la conveniente transpiración de la cabeza: por lo común basta para desprenderla frotar la piel del cráneo con un cepillo, pero algunas veces esto no es suficiente y se necesita emplear cataplasmas emolientes sobre la cabeza a una temperatura poco elevada e igual si es posible a la de las partes donde se aplican, a fin de evitar una congestión cerebral: se tendrá después cuidado de lavar todas las mañanas la cabeza con un cocimiento emoliente y enjuagarla bien después"

\section{Cólicos del lactante (pp 421-422)}

"En los dos primeros meses después del nacimiento, los niños suelen padecer frecuentes cólicos, a lo que están más expuestos si tienen mucho apetito y la leche de las nodrizas no es de buena clase por el mal régimen...como igualmente el tener mucho tiempo los pies fríos....se le prescribirán baños tibios, lavativas y aplicaciones de servilletas calientes o fomentos emolientes sobre el vientre. Si estos medios no bastasen... se administrará una infusión de anís o hinojo con unas gotas de éter sulfúrico; por último si existe embarazo gastrointestinal se dispondrá el jarabe de achicoria compuesto o el de flores de melocotón [purgantes]... Si las deyecciones son verdosas y frecuentes y el niño exhala un olor agrio deberán prescribirse los absorbentes... en ayunas una cucharada de magnesia líquida..., conviene igualmente hacerla tomar a la nodriza"

La leche de las nodrizas, o los pies fríos, se consideraba responsable de muchos males de los bebés y "las castigaban" con los mismos tratamientos. Son preferibles los remedios populares que nos han contado que alguno de éstos.

Insomnio de los niños ( $p$ 407):

"Cuando la causa del insomnio es desconocida, la salud del niño no se halla amenazada directamente, pero con el tiempo puede alterarse; se procurará hacer cesar este mal con el uso de calmantes, teniendo mucho cuidado en no emplear los preparados del opio, pues en los niños son muy a menudo perjudiciales por el aflujo de sangre que determinan hacia la cabeza"

Una vez más, es más sabio el conocimiento popular, hoy utilizamos en los cuidados neonatales la succión del pecho o del chupete y una solución de sacarosa (agua azucarada) 
como métodos analgésicos de efecto científicamente comprobado, liberan endorfinas, opiáceos naturales que produce nuestro cuerpo, y calman al recién nacido. El chupón con azúcar o productos dulces y sobre todo el pecho son en primera instancia remedios mejores, si no subyace una situación que provoque incomodidad en el niño, como tener frío o estar sucio, ni una patológica, calma a los niños y les ayudaría a dormir.

\section{Dentición (p 433-437)}

"Si los accidentes son leves se abandonará el trabajo a la naturaleza, bastando humedecer a menudo las encías y la boca con un hisopillo mojado en el cocimiento de malvavisco con miel. Siempre que se pueda se pasará el dedo por la encía, en lo que encuentran alivio los niños, también es útil darles un pedazo de orozuz [regaliz] o de malvavisco para que se lo lleven a la boca"

El tratamiento de las molestias habituales es similar a los remedios populares. Cuando había complicaciones también se complicaban las medidas terapéuticas y hablan incluso de la aplicación de "una o dos sanguijuelas detrás de las orejas"

Diarrea: da una serie de tratamientos dependiendo de las circunstancias, algunos sorprendentes hoy como hacer sudar al niño o emplear laxantes, lo que aumentaría las pérdidas y los riesgos, o la aplicación de sanguijuelas en lactantes (pp 422- 424)

"Del segundo al tercer mes es ordinariamente la época en que los niños están más expuestos a padecer diarrea.... Las bebidas emolientes con una disolución de goma arábiga ó el agua de arroz ligeramente azucarada y un régimen análogo a la nodriza son los primeros medios que debemos emplear.

Cuando la diarrea se resiste a estos medios ...se recurrirá a los purgantes amargos, tales como el jarabe de achicoria compuesto o el de flores de melocotón....

Cuando la diarrea es producida por la dentición sería peligroso cohibirla ..., en este caso están indicados los baños, los semicupios [baños de la mitad inferior del cuerpo], las lavativas, las cataplasmas, los fomentos emolientes y por último algunas sanguijuelas al ano.

...la diarrea es producida muchas veces por la supresión de la transpiración... por esto, después de haber acostado al niño se procurará hacerle sudar con las infusiones de saúco o de borraja y por medio de vejigas llenas de agua caliente aplicadas a los pies y renovadas a menudo..."

\section{Estreñimiento ( $p$ 421):}

"para combatir la constipación, se administrará al recién nacido el agua de salvado o el cocimiento de ciruelas y algunas lavativas emolientes, así como los supositorios de jabón o de manteca de cacao. Si estos medios no bastasen, se recurrirá a los baños tibios, que son muy eficaces para favorecer las evacuaciones intestinales cuando la constipación es rebelde y por último a los purgantes ... cuando sean la causa de la constipación los malos alimentos que usa la nodriza, se la dispondrá un régimen conveniente. Si la leche es demasiado gruesa, se la mandará hacer uso de alimentos ligeros y de las tisanas de cebada ó avena" 
Para la otalgia, el dolor de oídos, dice: "se inyectará en el oído la leche templada, un cocimiento emoliente y al mismo tiempo las cataplasmas" ( $p$ 313) y da la receta de la cataplasma [que llama] anodina para utilizar "En las flegmasías [inflamaciones] acompañadas de dolores agudos", que por su composición sería un producto de botica

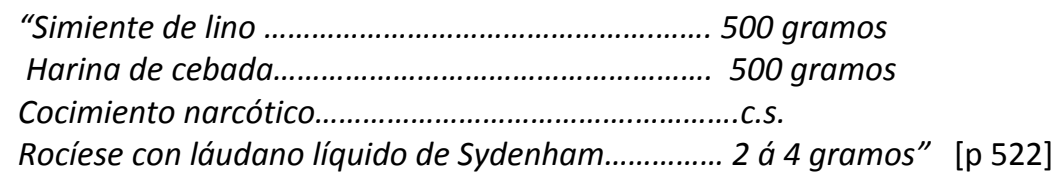

Para las lombrices describe diferentes métodos que en definitiva son purgantes, en algunos casos excesivos: "los amargos y purgantes son, en general, las sustancias que se emplean para expulsar las lombrices, entre los últimos nos merecen gran confianza el aceite de ricino , a la dosis de treinta a sesenta gramos..." (p 497)

Para los piojos, finalmente, en el tratado se propone "el aseo, las lociones emolientes y el cortar los cabellos... mas si esto no bastase, podrá recurrirse a la pomada mercurial" y Rogelio Casa recoge tres fórmulas, dos mezclan sulfuro mercúrico, una con alcanfor y otra con manteca, y la tercera nitrato mercurioso con pomada de pepino. Una de estas pomadas podría ser el "unto de color gris un poco espeso" que una de nuestras entrevistadas contaba que recogían con una taza en la botica del pueblo.

Volviendo a la Inclusa Provincial, probablemente algunos de estos remedios se seguirían empleando, aunque parece que el servicio médico estaba al día. La Inclusa disponía de incubadoras para el cuidado de los niños prematuros, lo que no deja de resultar asombroso teniendo en cuenta su reciente descubrimiento y que su uso y comercialización todavía era controvertido, además de costoso ${ }^{754}$. Las inclusas vieron en este artilugio la posibilidad de

\footnotetext{
${ }^{754}$ Se atribuye al doctor Tarnier, obstetra francés el diseño de la primera incubadora buscando el medio de evitar la hipotermia que asociaba a la alta mortalidad de los niños prematuros. Ya se conocía la importancia de mantener calientes a los recién nacidos, pero los medios convencionales como bolsas de agua caliente o envolturas de algodón podían resultar insuficientes para los niños prematuros. Tarnier, preocupado por el elevado número de prematuros de la maternidad de París y su alta mortalidad, e inspirado en las incubadoras de pollos, ideó una especie de caja con tapas de cristal y dos compartimentos, en el inferior se colocaban recipientes con agua caliente y en el superior se colocaba al niño. A pesar de las críticas de muchos colegas consiguió demostrar con un estudio la reducción significativa de la mortalidad de los niños prematuros de la maternidad, aunque haciendo honor a la verdad y visto desde el momento actual, no fue solamente el hecho de meter al niño en la incubadora, sino los cuidados añadidos y novedosos como alimentarles con sonda lo que aumentó su supervivencia. En 1880 se patentó la primera incubadora cerrada y su uso se popularizó en exposiciones internacionales como la de Berlín en 1896, Londres en 1897, París en 1900 o la Pan-Americana de Búfalo-New York en 1901. A pesar de que moralmente son totalmente reprobables esas exposiciones, en las que se mostraban como atracciones de una feria a prematuros criándose dentro de las incubadoras cuidados por médicos y enfermeras y apartados de sus madres, consiguieron demostrar que era posible mejorar la supervivencia de estos niños controlando la temperatura ambiental.
} 
aumentar la supervivencia de los expósitos y reducir sus escandalosas cifras de mortalidad; aunque la realidad es que una incubadora supone una ayuda importante, sobre todo para los recién nacidos prematuros o pequeños, pero sin unos cuidados y una alimentación adecuados no sirve de nada. Otros establecimientos como los de Madrid o Barcelona también las adquirieron (IMAGEN 3-50 $0^{755}$ ).

En el Presupuesto general de la Diputación de 1905 se adjudicaron 500 pts para "dos cunas incubadoras" (pg 43), y en el libro de cuentas del año consta la compra de una incubadora por ese precio en el mes de diciembre. También se

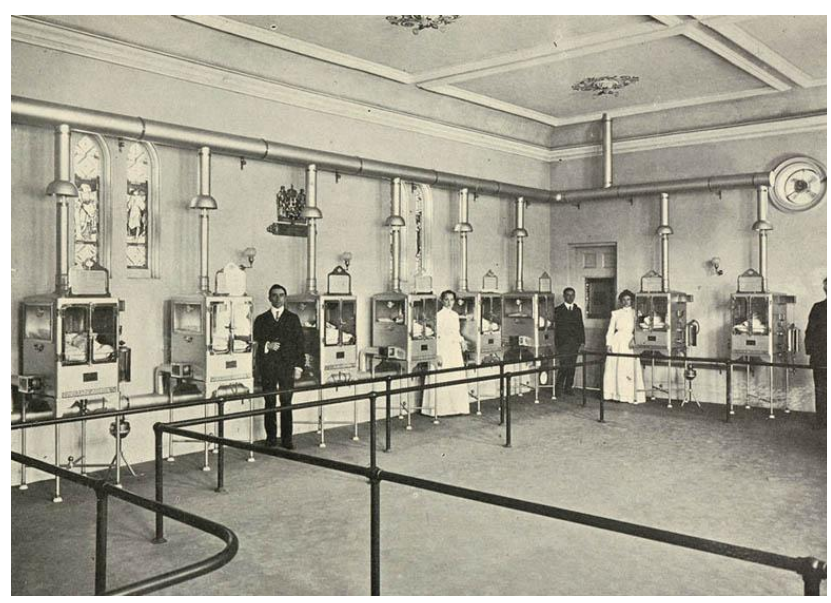

Imagen 3-50: Incubadoras en la Exposición Panamericana de Buffalo en 1901. Fuente: The Pan-American Exposition Illustrated presupuestaron 1.500 pts en 1909 "Para una incubadora para recién nacidos" (pg 50), y aparece un pago por ese valor el 30 de Septiembre en el libro de cuentas del Hospicio, certificación no 399 (fo 168). Es razonable pensar que entre los recién nacidos que ingresaban en la Inclusa habría un alto porcentaje de prematuros y niños de bajo peso, dadas las características de las madres y las circunstancias de la gestación, mujeres en la mayoría con pocos recursos y que además debían ocultar su estado; así encontramos que la "Falta de desarrollo", diagnóstico médico que se atribuía a estos niños, era una de las principales causa de mortalidad. Tenemos constancia de la existencia de incubadoras en la Inclusa y de su uso por un registro en el libro de Exposiciones de 1910

"En 27 de Diciembre de 1910 fue entregado por una enfermera del Hospital provincial con papeleta del Director donde dice que nació este mismo dia a las 15 horas que solo recibió agua de socorro... Por nota dice el mismo Sr Director que este niño no es del tiempo y que se le entrega enseguida en este Hospicio para ver si en la incubadora se consigue que siga viviendo. Le lacta Sabina Sanchez

Falleció en este asilo en 28 de Diciembre de 1910 á las 21 h á las 30 horas de edad á consecuencia de "Falta de desarrollo»" [sic] (fo 439. LE 1910-2)

BAKER J. P.: The Incubator and the Medical Discovery of the Premature Infant. Journal of Perinatology 2000; 5, pp 321-328. DEL MORAL T., BANCALARI E.: Evolución de la actitud frente al recién nacido prematuro. Bol Pediatr 2010; 50 (Supl. 1), pp 39-42

755 Incubadoras en la Exposición Panamericana de Buffalo en 1901. Fuente: The Pan-American Exposition Illustrated (Buffalo, N.Y.: C. D. Arnold, 1901), p. 101. Disponible en: http://library.buffalo.edu/pan$\mathrm{am} /$ exposition/health/medical/incubators.html 


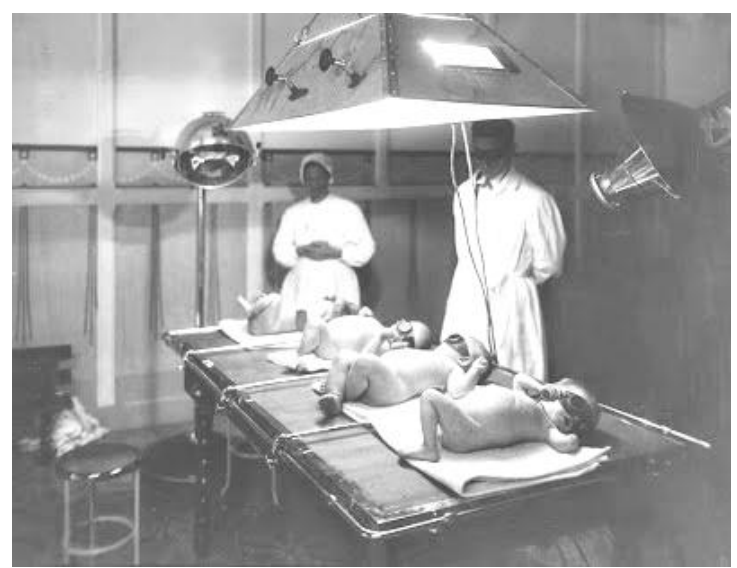

Imagen 3-51: Solárium artificial en el Pabellón Rosa de la Casa Provincial de Maternidad y Expósitos de Barcelona. Fotografía de Josep Brangulí.
Parece que los responsables del Hospicio y el equipo médico, con el beneplácito y por supuesto los fondos de la Diputación, estaban interesados en los avances tecnológicos que por estos años iban apareciendo tímidamente para mejorar la supervivencia de la población infantil. Así encontramos que las incubadoras no son el único material moderno que se adquiere

en la Inclusa, en 1909 se adquiere un pesa-niños (IMAGEN 3-52 $2^{756}$ ) por importe de 99 pesetas y más tarde, en 1927 en el Presupuesto general de la Diputación hay una partida de 1.500 pts "para material de helioterapia artificial" (pg 41) y en 1929 y 1930 se vuelven a presupuestar 2000 pts para "Material de higiene y desinfección para la inclusa y material de helioterapia artificial" (pg 57), compras más sorprendentes si cabe que las de las incubadoras porque, aunque ya se había difundido el uso de la helioterapia natural para el tratamiento de la tuberculosis, la helioterapia artificial se dio a conocer como tratamiento pediátrico en el Congreso Nacional de Pediatría de 1923, en este sentido la Inclusa de Valladolid sigue el ejemplo de la Casa de Expósitos de Barcelona,

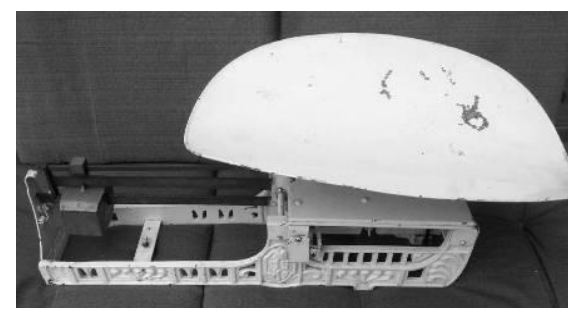

Imagen 3-52: Báscula pesabebés de la época. Fuente: Internet (nota a pie 763) considerada modélica, que ya disponía de una sala de incubadoras y un solárium artificial (IMAGEN 3$51^{757}$ ). En los niños se utilizaba preferentemente la helioterapia con rayos ultravioletas para tratar trastornos del crecimiento, raquitismo, espasmofilia (tetania), asma infantil, tuberculosis no exudativas y lesiones no febriles ${ }^{758}$.

\footnotetext{
756 IMAGEN 4-52: Báscula pesabebés de la época. Fuente: Internet http://www.ebay.es/itm/ANTIGUA-BASCULABALANZA-FARMACIA-PARA-BEBES-/222346207944?hash=item33c4dde2c8:g:BasAAOSwJb9Wq4VI

757 IMAGEN 4-51: Solarium artificial en el Pabellón Rosa de la Casa Provincial de Maternidad y Expósitos de Barcelona. Fotografía de Josep Brangulí. Exposición Josep Brangulí Barcelona 1909-1945. Archivo Nacional de Cataluña. Disponible en:

http://cultura.elpais.com/cultura/2010/11/11/album/1289430002_910215.html\#1289430002_910215_00000000

${ }^{758}$ La helioterapia consiste en el uso terapéutico de la luz solar. El Sol ha sido considerado por muchas civilizaciones primitivas como una divinidad, fuente de vida y energía y desde antiguo se han reconocido sus efectos beneficiosos para la salud; los egipcios ya lo utilizaron con fines terapéuticos y es conocido que muchas casas romanas tenían un solárium para tomar baños de sol curativos. En los siglos XVIII y XIX resurge el interés por los efectos de la luz solar y se empieza a promover su uso para tratar úlceras, raquitismo, astenias, trastornos del desarrollo y enfermedades óseas y articulares y se utilizó sobre todo como el tratamiento preferente y el más eficaz de la tuberculosis. Su
} 


\subsection{SALIDA de la inclusa para crianza EXTERNA}

La salida de la Inclusa podía ser temporal o definitiva. La salida temporal era la que tenía lugar para la crianza del niño con nodrizas externas, que podía producirse en cualquier momento a lo largo del período de lactancia y destete y que finalizaba como ya se ha dicho entre los 5 y los 7 años. La crianza de los incluseros durante este tiempo estaba remunerada; al finalizar esta etapa las nodrizas habitualmente devolvían a los niños al Hospicio, pero podían mantenerlos con ellas sin percibir retribución; entonces el niño pasaba a la situación de prohijado, que en los libros llaman también "3모 situación". Los que regresaban a la Inclusa, un vez finalizada la crianza pasaban al departamento de Mayores, de allí podían salir para trabajar o, sobre todo las niñas podían ser "entregadas para compañía" de familias que lo solicitaban; en ambos casos la comisión provincial debía dar su aprobación. La baja definitiva del Hospicio se producía cuando el niño era devuelto a sus padres, o, lo que tristemente ocurría con más frecuencia, cuando fallecía. Los que sobrevivían y llegaban a la mayoría de edad eran emancipados, circunstancia que puede corresponder a lo que en algún folio denominan "la cuarta situación".

"Art. 79. Siendo indudablemente preferido al sistema de lactancia dentro del Establecimiento, el de entregar los niños á nodrizas externas, el Facultativo correspondiente de acuerdo con la Superiora, quedan encargados de facilitar la salida de los expósitos á la lactancia externa, procurando queden los menos posibles en la Casa". [sic] (Regl.1889)

\footnotetext{
empleo se extendió con éxito durante el siglo XIX por Inglaterra, Suiza, Austria, Francia y países centroeuropeos y Norteamérica, donde surgieron sanatorios basados en esta terapia, primero con luz solar y más tarde acabaron descubriendo y utilizando la helioterapia artificial. En España, a pesar de tener mejores condiciones climatológicas no alcanzó los mismos resultados y no interesó hasta finales de siglo, pero en los primeros años del siglo XX aparecieron numerosos estudios y publicaciones sobre su uso y sus beneficios; la Sociedad de Pediatría premia y publica en 1914 un trabajo del doctor Enrique Ortega y Díez titulado "La Helioterapia en el tratamiento de las tuberculosis infantiles" en el que se referían curas con temperaturas de 30-40ㄷ en períodos de seis meses a dos años y en 1923 en el Congreso Nacional de Pediatría el doctor Arturo Perea y Prats presentó una comunicación sobre La Helioterapia natural y artificial. Aunque se reconoce que la helioterapia artificial es menos efectiva que la natural, permite realizar el tratamiento en los días nublados y hacer exposiciones locales y seleccionar el espectro de luz, ultravioleta o infrarroja. La aplicación debía ser directa y hacerse de forma progresiva y protegiendo la cabeza y los ojos y especialmente cuidadosa en los niños por tener una piel mucho más sensible. Se aconsejaba en los lactantes empezar con medio minuto diario en el pecho y en la espalda durante dos semanas y luego aumentar un minuto al día hasta llegar a 6 minutos diarios. En niños se usaba sobre todo la helioterapia de rayos ultravioletas, la de infrarrojos estaba indicada en trastornos circulatorios, tróficos (úlceras) y musculoesqueléticos dolorosos. Su uso se contraindicaba en procesos febriles, inflamaciones agudas, la sífilis, el paludismo, el embarazo y durante la menstruación. BIEDMA LÓPEZ E.: Aproximación al estudio de la helioterapia. Revisión histórica. Medicina Naturista, 2007, vol 1- no 2, pp 86- 100
} 
La Inclusa de Valladolid, como todas en general, daba prioridad a la crianza de los niños. Aparte de otras consideraciones sobre el bienestar de los expósitos y la tremenda mortalidad que afectaba a todos estos centros, por una cuestión logística, la falta de espacio y de recursos para criar de forma adecuada al enorme número de niños de los que llegaban a hacerse cargo. Puede que por eso, por que resultaba obvio y estaba asumido como el procedimiento a seguir, este artículo de 1889 ya no aparece en los siguientes reglamentos, pero el espíritu sin duda se mantuvo durante el período de este estudio y, salvo los niños que fallecieron en la Inclusa, practicamente todos salieron en algún momento para crianza externa, de manera que también podríamos dar la vuelta a esta afirmación y decir que los niños que no salían casi en su totalidad fallecían en el asilo. En el punto 2.2 Las salidas de la Inclusa vimos que en los 14 años revisados en los libros del Hospicio solamente 17 de los niños que no salieron nunca sobrevivieron a la Inclusa (GRÁFICA 3- 8 Y TABLA 3-3).

El tiempo de permanencia en la Inclusa desde el momento de su ingreso hasta que salían por primera vez para crianza externa, o algunos, muy pocos, de vuelta con su familia, era muy variable; había niños que salían el mismo día de su llegada, mientras que otros no conseguían salir nunca y pasaban directamente a la sección de Mayores, si sobrevivían. La mayoría de los niños tenían una primera estancia corta, inferior a un mes, el 74'67\% (2.904 de un total de los 3.889 que salieron de la Inclusa en algun momento) fueron realmente muy pocos, menos del $2 \%$, los que permanecieron más de 6 meses internados desde su llegada hasta su primera salida (solo 67 niños del total en los años de consulta) (ver GRÁFICA 3-29 y en ANEXO no 3: SALIDAS DE LA INCLUSA la distribución por años). Esta primera salida no siempre era la única, algunos regresaban y volvían a salir varias veces.

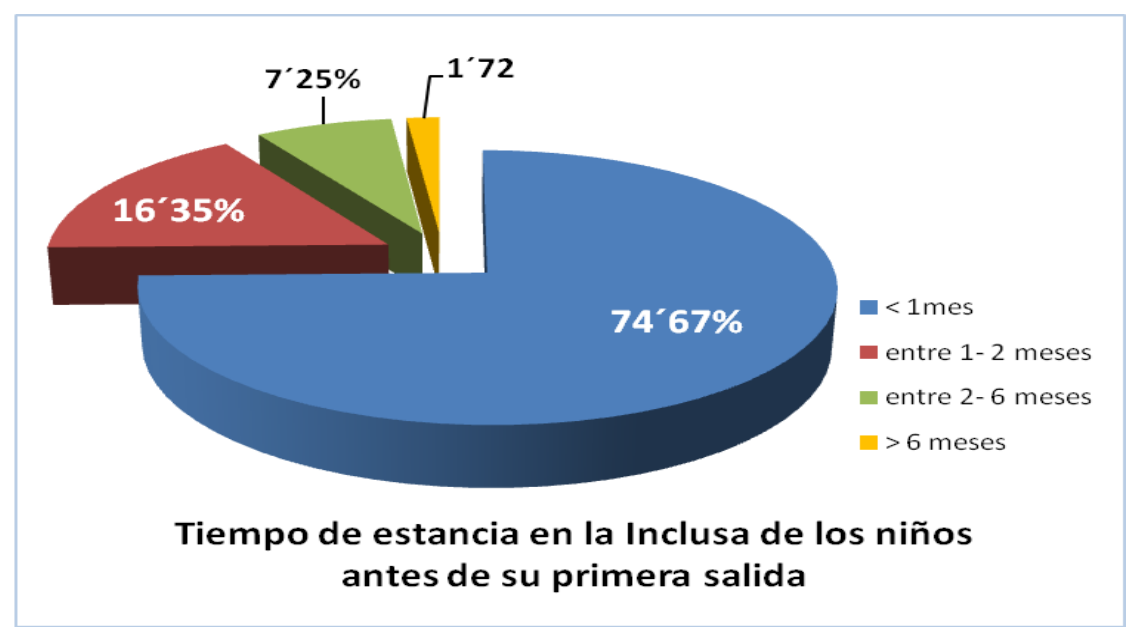

GRÁFICA 3-29: Tiempo de permanencia en la Inclusa de los niños que salieron en alguna ocasión para crianza externa o con los padres antes de su primera salida en el período 1900- 1913. Elaboración propia a partir de los datos extraídos de los Libros de Exposiciones. ADPVA. 
No podemos asegurar a qué se debían estas diferencias, sobre todo para ese casi $9 \%$ que permanecía más de 2 meses, los reglamentos no definen los criterios, el momento o el orden de salida de los incluseros para la crianza externa; salvo un artículo en el de 1889, el no 85 , que se retiró posteriormente porque en la práctica no se cumplía ya que daba prioridad para salir a los niños de la Maternidad y luego a los que pudieran resultar facilmente identificados porque tuvieran alguna marca o llegaran con el nombre puesto.

La principal razón que podía condicionar la salida de los niños sería la disponibilidad de nodrizas externas, pero esto no justifica las estancias más largas pues a todos les tendría que llegar su momento. Otra razón podía ser el estado de salud de los niños, es de suponer que los que se entregaban a las nodrizas estaban sanos o por lo menos en buenas condiciones y que de lo contrario serían retenidos hasta su mejoría. Esto no justifica tampoco estancias de años, salvo que se tratara de niños con defectos o enfermedades graves que fueran rechazados por las criadoras, lo que es posible pero no podemos confirmar porque este tipo de situaciones no se recogen en los folios de registro ni en ninguno de los expedientes personales que se han podido consultar. El tiempo de estancia también podría tener relación en algunos casos con la posibilidad de que los padres les reclamaran, aunque en este caso habría que saber en qué circunstancias el Hospicio decidía mantener a los niños internos porque el hecho de estar criándose fuera de la Inclusa no era óbice para regresar con la madre o la familia, de hecho la mayoría de los incluseros en ese momento se encontraban en poder de los criadores y la Comisión provincial, o el Hospicio en su nombre, simplemente se los reclamaba una vez aceptada la devolución solicitada por los padres. Además, encontramos en los libros muchos registros en los que los niños salen, y además en algunos casos muy pronto, a pesar de que por la situación familiar y que condiciona el ingreso se supone que éste podría ser en principio algo temporal, aunque luego podía alargarse mucho, por ejemplo niños que se entregaban a la Inclusa por enfermedad o por el internamiento de alguno de los padres en el hospital o expósitos del torno con notas como las que en su momento vimos que avisaban de la intención de recuperarle pronto o que directamente solicitaban que se le conservara interno

"Román San Jose Garcia

En 24 de Julio de 1912 á las 21 horas fue expuesto en el torno del Establecimiento con un papel que dice "Este niño... entra por hallarse su madre enferma y no teniendo recursos en cuanto se ponga buena Dios mediante se la reclamará]"

Román tenía casi 4 años cuando fue depositado en la Inclusa y permaneció interno durante 3 años hasta que el 
"18 Agosto 1915: Cumpliendo acuerdo de la Comision provincial fue entregado á su padre Gerardo San Jose y firmo á su ruego" [sic] (fo 240 LE 1912-1).

En cambio Guadalupe es una niña que ingresó con 3 años en el mes de marzo a requerimiento del Gobernador civil porque su madre que era viuda había sufrido un accidente y fue sido ingresada en el Hospital y en el Hospicio "se recibio Orden que se comunicó al Director del Hospital para que en cuento salga la Madre del Hospital recoja la chica y la lleve en su compañía". Aunque se podía prever una estancia no excesivamente larga la niña después de un mes se entregó a una nodriza y a los 4 meses la reclamó su madre

\footnotetext{
“En 14 de Marzo de 1913 ingresó por Orden del Sr Vicepresidente de la Comisión provincial á instancia del Gobernador civil...

En 19 Abril de 1913 la llevó Francisca... vecinos de Torreadrada (Segovia)

Devuelta en 6 de Agosto de 1913.

En cumplimiento de acuerdo de la comisión provincial fue entregado á su Madre María Fajardo vecina de Valladolid calle de Cruz Verde 24 y en prueba de conformidad firma su recibo" [sic] (fo 99 LE 1913-1)
}

Puesto que la mayoría de los niños no estuvieron ingresados más de un mes antes de salir de la Inclusa por primera vez y además descubro que algunos salían incluso el mismo día de su ingreso, decido hacer un estudio pormenorizado en algunos años de estas estancias cortas (permanencia $\leq 30$ días). Se seleccionan: 1913 por ser el año con más salidas en el primer mes de vida, el 90'23\% (277 de un total de 307); 1906 por ser el que tuvo menos con el $52^{\prime} 92 \%$ (127 de 240 ) y 1901 , con el 73’08\%, por ser el que está más próximo a la media (73’13\%). Después de este primer análisis y a la vista de los resultados decido incluir otros años para comparar y poder valorar mejor las situaciones más extremas. En 1913 aprecio un número de salidas en la primera semana muy por encima de los otros años, por lo que tomo 1912 por contigüidad y por ser el segundo en número de salidas (337 sobre 387 que hacen un $\left.87^{\prime} 08 \%\right)$ del total. También por proximidad y por estar entre los porcentajes mínimos, se escoge 1905 (con el 64'85\%) y, para valorar otros dos años consecutivos y con porcentajes equidistantes de los extremos, 1908 y 1909. Los resultados se recogen en la TABLA 3-25.

Dentro de estas estancias que he llamado cortas (de hasta 30 días) en estos años analizados se puede observar que más de un tercio de los niños salieron en la primera semana y que la mayoría no permaneció en el asilo más de dos 15 días (988 de un total de 1.450, lo que supone el $68^{\prime} 14 \%$ de las estancias cortas y el $51 \%$ del total de las 1.937 salidas que tuvieron lugar en estos años). En los últimos años las salidas son más precoces, en 1912 más 
de la mitad de los niños salieron del establecimiento en la primera semana, con la excepción de 1905, cuando 30 niños se entregan para crianza el mismo día de su llegada a la Inclusa.

\begin{tabular}{|c|c|c|c|c|c|c|c|c|c|c|c|c|c|}
\hline \multicolumn{14}{|c|}{$\begin{array}{l}\text { TABLA 3-25: ESTANCIAS CORTAS EN LA INCLUSA ( } \leq 1 \text { MES) ANTES DE LA PRIMERA SALIDA EN LOS AÑOS } \\
1901-05-06-08-09-12-13\end{array}$} \\
\hline & $\begin{array}{l}\text { TOTAL } \\
\text { SALI } \\
\text { DAS }\end{array}$ & $\begin{array}{l}0-7 \\
\text { días }\end{array}$ & $\begin{array}{c}7- \\
15 \\
\text { días }\end{array}$ & $\begin{array}{c}\text { 16- } 30 \\
\text { días }\end{array}$ & $\begin{array}{l}\text { Total 10 } \\
\text { mes }\end{array}$ & $0 \mathrm{~d}$ & $1 \mathrm{~d}$ & $2 \mathrm{~d}$ & $3 \mathrm{~d}$ & $4 \mathrm{~d}$ & $5 \mathrm{~d}$ & $6 \mathrm{~d}$. & $7 \mathrm{~d}$ \\
\hline 1901 & 227 & 48 & 63 & 60 & 171 & 1 & 2 & 1 & 3 & 7 & 15 & 9 & 10 \\
\hline 1905 & 293 & 58 & 47 & 87 & 192 & 30 & 6 & 4 & 1 & 3 & 10 & 2 & 2 \\
\hline 1906 & 236 & 11 & 38 & 81 & 130 & 1 & 0 & 2 & 0 & 4 & 2 & 2 & 0 \\
\hline 1908 & 231 & 48 & 78 & 56 & 182 & 3 & 4 & 3 & 5 & 9 & 4 & 13 & 7 \\
\hline 1909 & 222 & 53 & 49 & 62 & 164 & 1 & 5 & 3 & 4 & 8 & 9 & 11 & 12 \\
\hline 1912 & 372 & 190 & 90 & 54 & 334 & 7 & 29 & 26 & 28 & 31 & 23 & 22 & 24 \\
\hline 1913 & 307 & 144 & 71 & 62 & 277 & 13 & 26 & 27 & 16 & 14 & 21 & 8 & 19 \\
\hline $\begin{array}{r}\text { Tota- } \\
\text { les }\end{array}$ & 1937 & 552 & 436 & 462 & 1.450 & 56 & 72 & 66 & 57 & 76 & 84 & 67 & 74 \\
\hline \multicolumn{2}{|c|}{$\begin{array}{l}\text { Promedios } \\
\text { anuales }\end{array}$} & $78^{\prime} 9$ & $62 ' 3$ & $66^{\prime} 0$ & $207^{\prime} 1$ & $8^{\prime} 0$ & $10^{\prime} 3$ & $9^{\prime} 4$ & $8^{\prime} 1$ & $10^{\prime} 9$ & $12^{\prime} 0$ & $9^{\prime} 6$ & $10^{\prime} 6$ \\
\hline
\end{tabular}

Tiempo de permanencia en la Inclusa de los niños ingresados antes de su primera salida, se recogen las salidas según el momento en que ocurrieron. Se presenta el no total de salidas en cada año y el total de las que se produjeron en el primer mes desde que los niños llegaron a la Inclusa, contando las estancias de 0 a 30 días. Se detalla el $n$ o de niños que permanecieron ingresados hasta una semana, los que salieron dentro de la segunda semana de estancia y de la segunda quincena y en las columnas de la derecha pormenorizadas día a día las salidas que tenían lugar desde el mismo día del ingreso, estancia 0 , hasta el séptimo. Se han tenido en cuentan tanto los niños que en esta primera salida fueron con criadoras externas como los que retornaron con sus padres. Tabla de elaboración propia a partir de los Libros de Exposiciones. ADPVA

En los años analizados en la TABLA 3-25 salieron de la Inclusa 1.937 niños, 1450 lo hicieron en el primer mes desde su ingreso, con un promedio anual de 207 y un porcentaje del $744^{\prime} 85 \%$ que se ajusta al porcentaje global para los 14 años de consulta como puede verse en la GRÁFICA 3-29 (74'67\%), lo que nos permite globalizar también el resto de los resultados. Durante el segundo mes de estancia salieron 319 niños con un promedio anual de $48^{\prime} 6$ niños y un porcentaje sobre el total de salidas del 16'47\% (16'35\% en el global de la GRÁFICA 3-29); 132 salieron entre el 20 y el 60 mes, promedio anual de $45^{\prime} 5$ y $6^{\prime} 81 \%$ del total y 36 tuvieron estancias largas y salieron después de 6 meses con un promedio anual de 5'8 niños y un procentaje del 1'86\% que vemos que también se ajustan al global de los 14 años de consulta permitida. 


\subsubsection{LOS NIÑOS DE LA INCLUSA RECLAMADOS POR SU FAMILIA}

En los años analizados en la TABLA 3-25, 58 niños regresaron con sus padres, representan el 2’99\% del total de salidas de la Inclusa. Su distribución en cuanto al momento de salida resulta peculiar porque la mayoría tuvieron estancias cortas, 31 salieron en el primer mes, pero hay menos niños de estancias medias (4 salieron en el segundo mes y 6 entre el $2 \stackrel{0}{0}$ y el 6의 que de estancias largas; 17 permanecieron varios años ingresados en la Inclusa antes de volver con sus padres.

Estos 17 niños que fueron reclamados por la madre, el padre o algún familiar de forma tardía no salieron para crianza y casi todos pasaron al departamento de Mayores del Hospicio; realmente algunos por edad podrían haber entrado ya directamente en él pues cuatro de ellos ingresaron con 5 - 6 años; salvo dos lactantes de 6 y 20 meses respectivamente, los demás eran mayores de 3 años. Todos ellos permanecieron internos más de dos años antes de volver con la familia: 16 años la niña del fo 332 de 1913 hasta que la reclamó su madre, ingresó con 4 años; hay otra estancia de 12 años (fo 311 LE 1908-1); 3 niños permanecieron más de 7 años ( fo $^{\mathrm{s}} 356$ LE 1908; 163 LE 1909 y 421 LE 1912) y el resto entre 2 y 5 años. Salvo uno de ellos que se expuso en el torno, los demás entraron de forma reglamentaria a través de la Diputación, solamente 2 era hijos naturales y los otros 15 eran legítimos.

No podemos asegurar que estos muchachos fueran retenidos en el Hospicio esperando el momento de poder salir con sus padres, en sus folios de inscripción no se dice nada al respecto. Tampoco en los reglamentos se contempla esa posibilidad. En algún folio de los que recogen estancias muy largas se encuentran notas del tipo "No debe salir hasta que se haga entrega de la misma a sus padres", al final dicha entrega no se producía por motivos que no dicen y a continuación se escribía "puede entregarse" para autorizar la salida con una nodriza (fo 168 LE 1913-1). En otros folios encontramos anotaciones como "Avisar al Vicepresidente de la Comisión provincial cuando la devuelvan", pero en ellos no se registra después nada o se anota una nueva salida con otra nodriza (fo 84 LE 1913-1); probablemente se tratara también de reclamaciones fallidas, porque al final los padres no quisieran o no pudieran recuperar al niño o que no lo aprobara la comisión provincial, incluso no podemos descartar que no se localizara al expósito y no se pudiera devolver.

En el libro de Exposiciones de 1904 se encuentra una carta encuadernada junto al folio 62 de inscripción de Félix Gómez, no se lee la fecha completa, el año ha quedado pillado al encuadernar. Es de su madre solicitando información del niño y de lo que debe hacer para 
recuperarle, no coinciden los apellidos de ninguno de los dos en la carta y en el folio, pero sí el resto de la información y por fechas no puede tratarse de ningún otro expósito

"Muy sr mío de mi mayor respeto. El día 21 de Febrero de 1904 nació en el Hospital de esa capital un niño y fue llevado al Hospicio el día 23 de febrero de 3 a [no se lee] dela tarde y con un papel entre larropa con el nombre de felix galache y si $V$. se dignara contestarme si es vivo o muerto y lo que necesito para sacarle mucho se lo agradecería pues soy su Madre.

Con el Mayor respeto le b.s.m.

Quintina Galache"

No podemos saber con certeza si recuperó al niño porque la última anotación del folio es la que corresponde a la salida con una nodriza "El dia 4 de Marzo de 1904 le llevo Francisca Diez mujer de Ulpiano Rodriguez vecinos de Villanueva de los Caballeros".

Los reglamentos regulaban la devolución de los acogidos a su familia y establecían los requisitos necesarios, exigiéndoles en primer lugar la identificación del niño reclamado con datos que no dieran lugar a dudas al respecto, en segundo lugar una indemnización al establecimiento por los gastos generados por su crianza y a la nodriza por los gastos que ocasionara su traslado y finalmente demostrar buena conducta para educar al niño convenientemente. Coinciden los tres reglamentos, los de 1910 y 1927 dedican a este asunto un capítulo titulado "Devolución de expósitos" que recoge tres artículos, idénticos en ambos:

Art. 354. A quien solicite hacerse cargo de un expósito, declarando ser su padre o su madre, le será entregado si en la instancia que habrá de presentar consigna con precisión el día y la hora del nacimiento de aquél, en el departamento de Maternidad, o en el que fué expuesto en la Inclusa, o relata los detalles y circunstancias que concurrieron en uno u otro caso de modo tan preciso que no haya duda respecto a su identificación.

Art. 555. La devolución del expósito se concederá mediante el abono de los gastos ocasionados por su crianza, a no ser que se acredite la pobreza de quien lo reclama; pero en todo caso habrá de satisfacerse una cantidad prudencial para indemnizar a los encargados del expósito que se encuentren fuera de la población donde radique la Inclusa por el gasto de traslación a dicho punto y estancia fuera de casa.

Si los interesados desean ir por sí mismos a recoger el expósito en el pueblo donde se encuentre, lo harán por su cuenta, sin necesidad de otro desembolso por razón de viaje.

Art. 356. Se suspenderá la entrega de los niños reclamados cuando se tenga noticia de que los padres observan mala conducta, por todo el tiempo en que haya fundadas sospechas de que no les darán buena educación.

El reglamento de 1889 básicamente dice lo mismo, más un punto añadido que dice que la devolución se hará siempre que haya mejorado la situación de la familia 
"Art. 151. Los niños de padres pobres enfermos ó abandonados serán devueltos á los mismos ó á sus abuelos si mejorasen de fortuna ó de condición á juicio de la Excma Diputación"

Cumplidos los requisitos, la Comisión valoraba y acordaba la devolución. Respecto a los pagos reclamados, al menos en los Libros de Exposiciones, donde se anotaba la resolución y el acto de entrega del niño, no se hacía referencia a este aspecto; es probable que se pasara por alto o se excusara la deuda, ya que la mayoría de las familias de los expósitos no podrían permitírselo. Los mismos reglamentos decían que debían hacerse "en función de la posición de los padres y si estos no contasen con recurso alguno [se] podrá relevarles de dicho pago" (Art. 150 Regl 1889)", podían por tanto librarse si demostraban no tener medios económicos. Por otra parte, en los Presupuestos Generales de la Diputación en el apartado de ingresos del Hospicio no figuran partidas por este concepto, mientras que aparecen los ingresos por las pensionistas de la Maternidad. En el libro de 1904, junto al folio 26 se encuentra suelta una carta manuscrita en papel timbrado de la madre del niño que está inscrito en él reclamándole

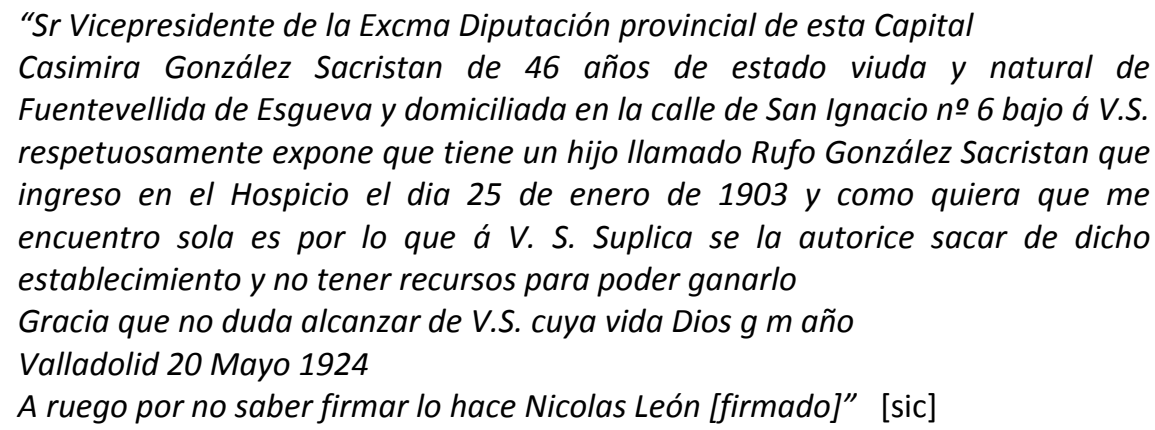

La carta da mal la fecha de ingreso del muchacho, que fue en 1904 y no en 1903 como se dice en ella, y la madre ya alega de antemano falta de recursos. En el folio de inscripción del muchacho no se ha escrito nada, la última anotación corresponde a la salida para crianza externa el 8 de febrero de 1904; por edad cuando se recibió la carta en 1924 el muchacho podría estar emancipado.

También contemplaban los reglamentos la posiblidad de evitarse el pago de los gastos del traslado del niño, cuando se encontraba con una nodriza fuera de la capital, yendo a recogerlo personalmente. Tampoco hay constancia de que se hiciera este pago a la criadora, ni por parte de los padres ni por parte del Hospicio, no figura este concepto en los libros de cuentas de las amas; además el niño podía ser devuelto por la nodriza o por el comisionado coincidiendo con el cobro por la crianza; en algunos folios de este libro se encuentra pegada 
una nota que avisa que el niño está "Reclamado", de esta forma se llamaría la atención para tenerlo en cuenta al hacer los abonos a las nodrizas (IMAGEN 3-53).

De un total de 3.889 niños que salieron de la Cuna en los 14 años consultados, 127 volvieron con su familia

Imagen 3-53: Folio del Libro de Amas de 1901 en el que se iban anotando los pagos que se hacían a las nodrizas directamente, sin pasar por una nodriza externas. La nota que dice "Reclamado" está pegada externa (el 3'27\% del total de salidas).

Aparte de estos niños, que algunos pudieron ser conservados a propósito en el centro, también podían regresar con sus padres si éstos los reclamaban, los que estaban en poder de las nodrizas externas. Cuando los padres, o en ocasiones otros miembros de la familia como abuelos o tíos, reclamaban a un niño, la Comisión provincial valoraba la solicitud y si la aprobaba requería la devolución del expósito a la nodriza; la devolución siempre se registraba en el folio del niño en el Libro de Exposiciones y se requería la firma de la persona a la que se hacía la entrega, o de alguien autorizado cuando ésta no sabía escribir

"Devuelta el 9 de Enero de 1911

En 10 de Enero de 1911 cumpliendo acuerdo de la Comision provincial fue entregada á su Madre María vecina de esta Ciudad que no firma por no saber". [sic] (fo 307- LE 1910-2)

"Debuelto el dia 17 de Agosto de 1914.

El mismo dia fue entregado á su padre Aquilino Esteban que le tenía reclamado y firma el recibo su hermana" [sic] (fo 23 LE 1913-1)

En todos los Libros de Exposiciones encontramos registrada la vuelta del niño al Hospicio antes de ser entregado a sus padres; solamente en unos pocos folios se dice que el expósito pasó directamente de la nodriza a la familia, puede ser que para evitar los gastos del traslado o para agilizar el procedimiento .

"12 Nbre 1916. Entregado á su madre directamente por la criadora según oficio del Sr Director" [sic] (fo 167 LE 1913 -1)

En los 14 años estudiados he contabilizado un total de 485 niños que volvieron con su familia, lo que representa el 8'15\% de un total de 5.949 ingresados (sin contar los registrados como "nacidos muertos"), algunos, como hemos visto, lo hicieron ya en la edad adulta después 
de pasar toda la infancia internos en el Hospicio o con nodrizas. El promedio resultante es de $34^{\prime} 6$ niños al año, pero con una distribución muy variable, desde 10 expósitos reclamados en 1902 hasta 59 en 1912 y 1913. La mayoría eran hijos legítimos, el 5546\%, frente a un $23 \%$ de ilegítimos, en el resto no se puede asegurar la pertenencia a un grupo u otro porque los registros no indican nada al respecto o plantean dudas y mayoritariamente ingresaron por la vía reglamentaria a través de la Diputación (5443\%), a continuación, muy por detrás, están los que entraron por el torno $\left(28^{\prime} 04 \%\right)$ y la Maternidad (10'10\%). Algunos de los que fueron reclamados por sus padres regresarían después otra vez al Hospicio, por el torno o por la vía oficial mediante nueva solicitud a la Diputación (fo 179 LE 1901-1; fo 333 LE-2), incluso hay algunos niños que salieron y reingresaron en dos ocasiones (fo 373 LE 1909; fํㅗ 31 , 2 y 176 de 1910) y se ha registrado un caso de una niña reclamada por su padre que finalmente no llegó a salir (fo 181 LE 1909), aunque, como he señalado, no puedo descartar que esto mismo ocurriera en esas otras situaciones en que se anotaba que no debía salir o que había que avisar a la comisión. En total se cuentan 18 niños en los 14 años del estudio que después de ir con sus padres regresaron al Hospicio (3'71\% del total de los que volvieron con su familia) (TABLA 3-26)

TABLA 3- 26: № de niños que volvieron con sus padres en cada año, $n$ o de hijos legítimos e ilegítimos y de los que se desconoce su condición o los registros plantean dudas. Distribución de estos niños según la vía por la que entraron en la Inclusa. En el campo RETORNAN se recogen los niños que fueron otra vez ingresados en el Hospicio. Tabla de elaboración propia

\begin{tabular}{|c|c|c|c|c|c|c|c|c|c|c|}
\hline & \multirow{2}{*}{ NiÑOS } & \multirow{2}{*}{ LeGítIMOS } & \multirow{2}{*}{ ILEG } & \multirow{2}{*}{ Dudosos } & \multicolumn{5}{|c|}{ VÍA DE ENTRADA } & \multirow{2}{*}{$\begin{array}{l}\text { RETORNAN } \\
\text { AL HOSPICIO }\end{array}$} \\
\hline & & & & & DiputACIÓN & TORNO & AsIto & Pueblos & HOSPITAL & \\
\hline 1900 & 32 & 15 & 3 & 14 & 18 & 9 & 5 & & & 2 \\
\hline 1901 & 24 & 7 & 5 & 12 & 10 & 10 & 2 & 2 & & 2 \\
\hline 1902 & 10 & 10 & 0 & 0 & 7 & 2 & 1 & 1 & & 1 \\
\hline 1903 & 31 & 16 & 10 & 5 & 19 & 6 & 3 & 1 & 2 & 1 \\
\hline 1904 & 24 & 11 & 2 & 11 & 13 & 7 & 4 & & & 2 \\
\hline 1905 & 39 & 23 & 2 & 14 & 20 & 12 & 1 & 2 & 4 & 0 \\
\hline 1906 & 18 & 6 & 2 & 10 & 4 & 9 & 5 & & & 1 \\
\hline 1907 & 22 & 6 & 5 & 11 & 12 & 7 & 1 & 1 & 1 & 0 \\
\hline 1908 & 37 & 20 & 14 & 3 & 16 & 14 & 5 & 1 & 2 & 1 \\
\hline 1909 & 49 & 25 & 19 & 5 & 24 & 8 & 12 & 2 & 3 & 3 \\
\hline 1910 & 50 & 34 & 16 & 0 & 31 & 10 & 2 & 7 & & 4 \\
\hline 1911 & 31 & 21 & 6 & 4 & 24 & 6 & & 1 & & 1 \\
\hline 1912 & 59 & 40 & 15 & 4 & 33 & 19 & 3 & 1 & 3 & 0 \\
\hline 1913 & 59 & 35 & 13 & 11 & 33 & 17 & 5 & 2 & 1 & 0 \\
\hline TOTAL & 485 & 269 & 112 & 104 & 264 & 136 & 49 & 21 & 16 & 18 \\
\hline
\end{tabular}

En algunos casos la vuelta con los padres debió hacerse sin conocimiento del Hospicio ni de la Comisión provincial. Sobre todo en los libros de 1913 encontramos varios folios en los 
que después de registrar la entrega a una criadora, y su marido, sin que figure la devolución que siempre se registraba, se da de baja a un niño por encontrarse con sus padres:

"Se dio de baja definitiva por encontrarse con sus padres" (fo 78 LE 1913-1)

"Baja definitiva por hallarse con sus padres" (fo 79 LE 1913-1)

Estas anotaciones no llevan fecha y significan que en algún momento el niño ha pasado a manos de los padres sin la mediación del Hospicio, que la vuelta podía ser incluso desde su salida, pero sobre todo, que estos niños y sus nodrizas han estado fuera del control institucional. Muchas de estas notas aparecen en los libros de 1913, pero no considero que fuera algo que sucediera especial y exclusivamente en este año, sino que por entonces se decidió tomar medidas para localizar a estos niños. Hago esta suposición porque precisamente en ese año se cambiaron las cartillas que se entregaban a las nodrizas para controlar mejor los pagos que recibían y de paso, presumimos, controlarlas mejor a ellas y a los niños; además, este intento de controlarlos podría estar relacionado el escándalo Montiel, relacionado con las amas externas, que ya hemos comentado que se desató por entonces.

Encuentro también un registro sobre un niño reclamado por sus padres al que el Hospicio no pudo localizar porque la criadora estaba en paradero desconocido

"En 11 de Octubre fue entregada por una enfermera del Hospital General... En 2 de Noviembre de 1907 la llevo Anacleta Lopez mujer de Tiburcio Requejo, vecinos de Castrillo de Duero (Valladolid) Reclamada

Habiendo sido reclamada á Castrillo Tejeriego para entregarla á su Madre, según acuerdo de la Comision provincial, el Alcalde de referido pueblo contesta que Tiburcio Requejo y su mujer Anacleta Lopez trasladaron su residencia á Bilbao sin que dé mas antecedentes por lo que se pone en conocimiento de la Comision provincial en 28 Marzo de 1911" [sic] (fo 328 LE 1907-2)

Después de esta anotación ya no se ha escrito nada en el folio de esta niña por lo que hemos de pensar que no se consiguió localizarla. No sería un caso único, aunque probablemente no siempre se registraría algo así. En 1908 en una sesión de la Comisión provincial recogida en la prensa algunos diputados denuncian "el desbarajuste administrativo que existe en aquel establecimiento [el Hospicio provincial]" y proponen

"que el secretario examine los libros de ingreso para indicar las modificaciones que deban hacerse, porque hasta pudiera anotarse la existencia de un niño sin que tuviera efecto

(El señor Alvarez: Ya ha ocurrido un caso parecido)

Habla de un niño ingresado en el Hospicio y que al venir a buscarle su padre, no apareció ni se ha logrado hallarle. Se instruyó expediente y hasta intervino el 
Juzgado de Segovia pero no sacándose nada en limpio-frases textuales- se abandonó toda acción.

(Estas declaraciones producen gran asombro en los señores diputados)" [sic] ${ }^{759}$

Aunque seguramente ésta no sería una situación frecuente, porque tampoco eran muchos los niños reclamados, este registro y la nota de prensa vienen a demostrar la falta de control del Hospicio, y de la Diputación como último responsable, sobre los niños externos y sus nodrizas. En todos los libros se encuentran muchos folios en los que después de registrar la salida con las criadoras no se vuelven a hacer más anotaciones, estos niños podrían estar con sus padres o seguir con ellas en una especie de adopción no legalizada.

\subsubsection{EL PROHIJAMIENTO ADMINISTRATIVO DE LOS NIÑOS DE LA INCLUSA}

Una vez terminado el período remunerado de crianza, lo más frecuente era que las nodrizas devolvieran los niños a la Inclusa, si no lo habían hecho antes; no obstante, si deseaban seguir cuidándoles podían solicitarlo y quedarse con ellos sin percibir remuneración, circunstancia que en los libros, sobre todo de los primeros años, se ha registrado como 3 a situación y que corresponde a la figura legal que se denominaba prohijamiento administrativo. Al revisar los libros, de vez en cuando encontraba un folio en el que, generalmente el último

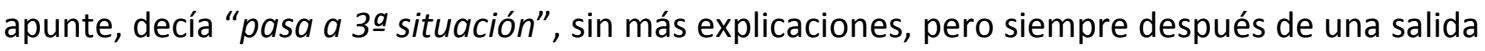
con criadores externos, y que en principio no pude descifrar porque esta expresión ni se recoge en los reglamentos del Hospicio ni en los diccionarios de la época.

"En 22 de Enero de 1912le llevó Luisa Garcia mujer de Rafael Hergueda vecinos de Peñafiel.

30 enero 1918

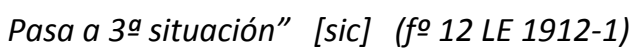

No podía tratarse ni del regreso del expósito a la Inclusa, ni de la vuelta con los padres, ni del paso a la sección de Mayores, ni de la emancipación o el fallecimiento porque normalmente se registraban estas circunstancias y en este último caso además se dibujaba una cruz. Casi la única opción disponible era la adopción, pero despistaba el hecho de que al mismo tiempo y en ocasiones en los mismos libros en otros folios se anotaba simplemente "Prohijado", que viene a ser lo mismo que adoptado. En una inscripción dice que la 3 ạ situación supone la baja en población externa (no retribuida), pero no que sea la baja definitiva

${ }^{759}$ N.C. 2- 08- 1908, p 2 
del establecimiento, por lo que no podría tratarse de una adopción legal ya que en ese caso el niño sería dado de baja exactamente igual que cuando volvía con los padres

"En 9 de Junio de 1914 le llevo Paula Prieto Nogeral mujer de Marceliano Ortega Sanchez vecinos de Geria, Valladolid.

En 7 de Octubre manifestó verbalmente el encargado del niño que ocupa esta inscripción que ha cambiado la residencia a Laguna de Duero.

Se le dio de baja en población externa y pasa á $3^{\underline{a}}$ situación (no retribuida)" [sic] (fo 343 LE 1912-2)

En el folio de este niño, que nació en la Maternidad y en la fecha de esta anotación contaba ya 6 años, no hay ninguna anotación después de ésta, por lo que es de suponer que el niño se quedó con la criadora.

La pista final que resolvió la incertidumbre sobre esta expresión la encontré en uno de los folios de inscripción:
"17 Octubre 1916 Se personó en esta dirección Sotero Martin Sanz manifestando, que á partir de esta fecha se queda con la asilada á que se refiere esta inscripción sin percibir retribución ninguna y con el carácter de prohijada y en virtud de esta diligencia pasa a 3ํㅗ situación" [sic] (fo 338 LE 1911-1)

Según esto podemos suponer que la 1a situación podía corresponder a la de los acogidos internos, la 2a a la de los externos en crianza retribuida y la 3 a a la de los externos $\sin$ retribución y en condición de prohijados.

En los diccionarios de la RAE prohijar se define como: "recibir como hijo, con los requisitos y solemnidad que establecen las leyes al que no lo es naturalmente". El Espasa añade que en Derecho es adoptar y al definir este otro término en una acepción que tampoco aparece en los diccionarios de la RAE dice: "por extensión cuidar, recoger, amparar una criatura, sin que preceda ni medie formalidad legal ${ }^{\prime 760}$. Este es sin duda el sentido en que se utiliza el término prohijar en el Hospicio porque según el Código Civil vigente en la época el prohijamiento de expósitos se regulaba exclusivamente "por leyes de carácter administrativo" sin los efectos legales de la adopción, de manera que para este tema remitía a lo que disponía el Reglamento de 1852 de la Ley de Beneficencia ${ }^{761}$.

\footnotetext{
${ }^{760}$ Enciclopedia Espasa, Enciclopedia Universal Ilustrada Europeo-Americana. José Espasa e hijos Editores; tomo 2, 1908, p 985 y tomo 47, p 850

${ }^{761}$ La adopción se regulaba por el Código Civil, 24 julio 1889 (Libro I, Título VII) Capítulo V De la adopción. (modificado posteriormente por la Ley de 17 de octubre de 1941) pero el prohijamiento de expósitos se siguió regulando por la Ley de Beneficencia, Reglamento 14 de Mayo de 1852, arts 22 al 25. En los comentarios a la ley de adopción dice Aranzadi en su Diccionario de Legislación " Hoy cabe destacar tres categorías o matices de la relación
} 
Los reglamentos del Hospicio van a regular el prohijamiento siguiendo la normativa legal vigente desarrollada en el Reglamento de 1852 y en el Código Civil de 1889, que, entre otras cosas, disponían que "cada establecimiento tiene todas las facultades de tutores". Aunque los dos primeros reglamentos hablan simplemente de prohijamiento o de adopción, en el de 1927 se sustituyen por "prohijamiento administrativo", por lo demás el capítulo que dedica a este asunto está calcado del reglamento de 1910. Con esta expresión se define con más exactitud la situación legal del expósito prohijado, de esta manera se evitarían posibles errores a que probablemente la anterior normativa pudo dar lugar.

En primer lugar determinan quienes pueden ser prohijados y sobre todo los requisitos que deben reunir los prohijantes. El Reglamento de 1889 es poco explícito, simplemente exige que los prohijantes sean honrados y tengan medios suficientes

"Art. 142. Los niños que no fuesen reclamados por sus padres, abuelos y parientes, podrán ser prohijados por personas honradas que tengan posibilidad de mantenerlos y educarlos; pero este prohijamiento no producirá más efectos que los que determinen las leyes"

Los reglamentos siguientes se extienden más, recogiendo la normativa legal sobre este punto, que imponía una serie de condiciones en cuanto a la edad y el estado civil de todos los implicados en el procedimiento. Donde el reglamento de 1910 dice simplemente prohijado el de 1927 especifica prohijados administrativamente (o sea para compañía), con lo que deja claro que no se trata de una adopción

Art. 255. Podrán ser prohijados administrativamente (o sea para compañía) los niños de ambos sexos expósitos o huérfanos de padre y madre, acogidos en el Hospicio provincial por las personas que se hallen en el pleno uso de los derechos civiles y reúnan las circunstancias y cumplan los requisitos que se establecen en los artículos siguientes

Art. 254. Entre el prohijante y el prohijado deberé mediar una diferencia de edad que será como mínimo:

De 15 años si el prohijante es casado.

De 20 años si el prohijante es soltero o viudo y el prohijado es varón.

De 25 años si el prohijante es soltero o viudo y la prohijada es niña.

\footnotetext{
familiar o cuasi-familiar que se constituye por el hecho de recibir como hijos, o cuando menos como convivientes y protegidos a quienes no lo son por naturaleza: la adopción, caracterizada por la forma civil y solemne del acto y por su permanencia y efectos garantizados por las leyes civiles; el prohijamiento, caracterizado por su forma administrativa y no solemne, pero sí constatada oficialmente y por la garantía indirecta que a la relación jurídica presta la intervención de un organismo público como la Comisión Provincial y, en fin, el acogimiento que se distingue por la forma meramente privada y por la ausencia de toda garantía que impida a quien acoge romper la relación en el momento en que lo tenga por conveniente". Se puede consultar sobre el tema MARTíNEZ ALCUBILLA M.: Diccionario de la Administración Española. Compilación de la Novísima Legislación de España peninsular y ultramarina... por don Marcelo Martínez Alcubilla. Madrid. Sexta edición. 1914- 1925: Abandono, Tomo I, pp 53- 54; Adopción, Tomo I, pp 323- 326; Prohijamiento, Tomo XII, p 596 (remite a Adopción); Expósitos, Tomo VII, pp 419420; Hijos, Tomo VIII, pp 546- 568; Protección a la Infancia, Tomo XII, pp 701- 720. DE ARANZADI E.: Diccionario de Legislación por Estanislao de Aranzadi. Pamplona. Editorial Aranzadi. 1951: Adopción, Tomo I, pp 858- 863; Abandono de familia y niños, Tomo I, pp 12- 14; Sanidad maternal e Infantil, Tomo XIV, pp 523- 534.
} 
En este caso no se otorgará el prohijamiento de niñas mayores de 10 años de edad.

Se muestran bastante más exigentes con los prohijantes que el reglamento de 1889 , también recogiendo la normativa legal vigente

Art. 255. Se prohíbe el prohijamiento administrativo:

A los que no sepan leer ni escribir.

A los eclesiásticos.

A los que tengan descendientes legítimos.

Al cónyuge sin consentimiento de su consorte.

A los que no satisfagan alguna contribución por inmuebles o por industrial, o no cuenten con ingresos propios de carácter permanente en cantidad suficiente para el sostenimiento de la familia.

Los prohijamientos sin duda suponían una ventaja tanto para los expósitos, si caían en buenas manos, como para el Hospicio que se liberaba de una carga económica, y estas exigencias parecen excesivas para la mayoría de los posibles prohijantes de los incluseros, que en principio serían las nodrizas externas y su familia. El requisito de saber leer y escribir ya de entrada podía limitar mucho los candidatos, dado el alto nivel de analfabetismo de la época, por lo que en el siguiente artículo se matiza y se relaja esta exigencia

\begin{abstract}
Art. 256. En casos especiales podrá la Diputación dispensar a los que intenten un prohijamiento administrativo, del requisito de saber leer y escribir, siempre que reúnan las demás condiciones exigidas y sean estas tan recomendables que aconsejen prescindir de aquella circunstancia.
\end{abstract}

Aunque el prohijamiento no determinaba una relación legal de filiación, se exigía que los prohijantes no tuvieran descendientes legítimos y así lo debían indicar expresamente al hacer la solicitud; en el reglamento de 1889 no se recoge esta exigencia y solamente se pide que presenten certificación "de la familia con que cuentan". La solicitud exigía además que se certificara buena conducta y recursos económicos y en base a los documentos presentados la Comisión provincial resolvía

Art. 257. El que pretenda prohijar un expósito o huérfano de los acogidos deberá solicitarlo mediante instancia firmada de su puño y letra, haciendo constar que carece de descendientes legítimos y expresando de qué edad próximamente ha de ser el niño o niña que desee prohijar.

Si el solicitante es casado, la petición será en nombre propio y en el de su consorte, suscribiéndola ambos cónyuges.

A la instancia deberán acompañarse los documentos siguientes:

A) Certificación de la partida de bautismo, o del acta de inscripción de su nacimiento.

B) Certificación del Alcalde y Cura párroco correspondiente acreditando la buena conducta del solicitante y que se encuentra en condiciones para mantener y educar convenientemente al expósito que intenta prohijar. 
C) Certificación del líquido imponible con que el prohijante figura en los repartimientos de contribución y cuota anual que satisface.

Si la posición social del adoptante se debe a otra clase de bienes, deberá acreditar cuales son éstos. En vista de estas justificaciones y de los informes que en su caso se considere necesario pedir, la Diputación concederá o negará el prohijamiento.

Entre la documentación del Hospicio no se conservan expedientes ni documentos de prohijamiento, salvo una carta de 1877 de un mesonero de San Miguel del Arroyo solicitando "una joven de catorce o diez y seis años del hospicio" "para los oficios propios de su sexo", como criada; propio de la mentalidad de la época. Si tenemos en cuenta que la crianza de los expósitos se pagaba y que, salvo alguna posible excepción, era esa la razón principal para comprometerse a ella, seguramente la gran mayoría de las nodrizas tampoco cumplirían con los requisitos económicos. Por eso me parece razonable pensar que en la práctica eran mucho más flexibles de lo que marcaba la normativa, de hecho hay alguna inscripción en los libros que hace pensar que el proceso era más sencillo y que la simple solicitud podría ser suficiente, ya que se sobreentiende que en su día para ser nodriza se le exigieron los correspondientes certificados, aunque luego se formalizara.

"En esta fecha se presentó la criadora y manifestó que habiendo terminado la edad de cobranza por lactancia y destete se quedaba con él con carácter de prohijado" [sic] (fo 93 LE 1909-1)

No hay anotaciones posteriores en el folio. Como se dice en la cita, prácticamente todos los prohijamientos que se encuentran en los libros registrados con fecha, se producen al finalizar el período retribuido de crianza

"En 13 de Abril de1909 le llevó Eumenia San Jose mujer de Niceto Acebes vecinos de Pesquera de Duero.

1905. 02. 24 Cumplió el periodo de destete y pasa a 3a situación" [sic] (fo 83 LE 1909-1)

El prohijamiento administrativo aplicable a los expósitos no era una adopción legal completa, el niño quedaba al cuidado del matrimonio que lo solicitaba, que se hacía cargo de mantenerle y educarle, pero sin derechos legales en cuanto a apellidos o herencias.

Art. 258. El prohijamiento administrativo obliga al prohijante a mantener al prohijado sano o enfermo, vestirle y calzarle, dedicarle a una carrera, profesión $u$ oficio y darle una educación conforme y correspondiente a la posición de aquél, sin que puedan volverlo al Asilo de su procedencia a no ser por motivos justificados que serán apreciados por la Diputación. 
El reglamento de 1889 además de estas obligaciones básicas habla de las cualidades morales exigibles a los prohijantes

Art. 144. Se cuidará que los expósitos encuentren en los padres adoptivos, no solo medios de subsistencia, sino una probidad experimentada, lecciones y ejemplos de moral y medios bastantes de instrucción.

El prohijamiento no suponía un compromiso legal permanente por lo que el prohijado podía ser devuelto, aunque los reglamentos ponían trabas y exigían justificación. No obstante, en este punto se van suavizando; el de 1889 dice que no se puede "devolver [al niño] al Hospicio, a no ser que por alguna causa grave lo consintiese la Excma. Diputación", el de 1910 dice que "por motivos muy justificados" y en el de 1927 podemos ver en la cita que ya solo se dice que "por motivos justificados". En los libros se recogen algunos casos de devoluciones después del prohijamiento, pero no se da la razón.

"En 2 de Marzo de 1912 le lleva Petra Hernando mujer de Francisco Val vecinos de Fuentesoto Segovia

30 enero 1918 Pasa a 3a situación

En 18 de abril de 1918 fue devuelto por la criadora" [sic] (fo 71 LE 1912-1)

La Diputación seguía siendo responsable último del prohijado de manera que podía recuperarle en cualquier momento, "podrá siempre anular el prohijamiento, si se justificase no ser beneficioso para el expósito" (Art. 145 Regl 1889) e incluso devolverlo a los padres

Art. 260. Aun cuando algún expósito estuviese ya prohijado será devuelto a sus padres que lo reclamaren, los cuales, con la intervención de la Diputación, se concertarán antes con el prohijante sobre el medio y forma de ser indemnizado de los gastos hechos en la crianza del prohijado. Regl 1910 y 1927

El prohijamiento era una condición considerada similar al nodrizaje externo, sin remuneración; en el reglamento de 1889 en un artículo adicional, en el que se habla de los premios que la Diputación concedía a las criadoras que presentaran a los niños mejor cuidados, incluye "a las que aun después de esta edad [siete años] los prohijaran como propios". El prohijado seguía dependiendo legalmente del Hospicio y la Diputación que mantenían la tutela sobre sus acogidos y por tanto el compromiso de seguirles controlando como a los asilados en crianza externa para asegurarse de que eran cuidados correctamente.

Art. 259. El Director del Hospicio pedirá una vez al año a las autoridades locales de la residencia del prohijado, un informe acerca de la situación en que el mismo se encuentre. La Diputación volverá a tomar bajo su amparo al que hubiese salido prohijado tan pronto como existan motivos fundados de que el prohijante le da malos tratamientos, es de mala conducta, le abandona o descuida su educación y no le proporciona la enseñanza de alguna profesión, arte u oficio. 
Por la misma razón, al llegar a la edad"762 (a partir de "17 años los varones y 18 las hembras"; Art. 240 Regl de 1910 y 1927,) el prohijado tenía que solicitar formalmente la emancipación, de manera que, al menos sobre el papel, debía volver al hospicio hasta que la Comisión provincial resolvía y le daba la baja definitiva, quedando así su situación legal normalizada
"Casilda Fernandez Serrano...
En 14 de Junio de 1911 fue entregada para destete á Felisa Rodriguez mujer de Manuel Andrade vecinos de esta Ciudad calle de las Lecheras no 14
1915. 04. 09. Cumplió periodo destete y pasa a 3a situación.
10 julio 1929. En esta fecha, cumpliendo acuerdo de la Excma Comisión Provincial del 19 del mes anterior fue emancipada a petición propia por haber cumplido la edad reglamentaria, quedando en compañía del matrimonio $D$. Manuel Andrade y $D^{\underline{a}}$ Felisa Rodriguez. En prueba de conformidad firma fecha ut supra [firma, los paréntesis aparecen escritos] Casilda (Andrade) Fernandez" [sic] (fo 134 LE 1909-1)

Esta muchacha, nacida y expuesta en el torno en 1909, desde los 2 años vivió con los que debía considerar sus padres adoptivos, aunque legalmente no lo fueran, se emancipó a los 20 años y al firmar dio testimonio de ello poniendo entre paréntesis, como si le hubiera traicionado el subconsciente, el apellido del que para ella era su padre.

Al no establecer lazos de filiación el prohijamiento permitía la devolución del expósito a su familia biológica, que tenía derecho a recuperarle en cualquier momento si lo reclamaba; a pesar de lo que dicen los reglamentos, no se recoge en los libros si los prohijantes recibían algún tipo de indemnización

\begin{abstract}
"En 6 de Septiembre de 1912 ingresó por Orden del Vicepresidente... Por noticias que da la Abuela de este niño que es quien le entrega dice ser hijo de Alejandro y Juana ya difuntos, que nació en Rioseco y que tiene 27 meses. La abuela se llama Petra Martin Santervas.

12 Octubre 1915: Se verificó cambio de criadoras y pasa a poder de Lucia Lobo ... (pasa á 3ㅁ situación el 26 octubre 916)

En 3 de abril de 1923, cumpliendo acuerdo de la Comisión provincial fecha 28 de noviembre último fué entregado á su Abuela Antonia Negro..." [sic] (fo 316 LE 1912-2)
\end{abstract}

Es difícil saber exactamente cuántos niños fueron prohijados, da la impresión de que no siempre se registraba, sobre todo en los libros de los primeros años. Hay muchos folios en los que los registros terminan cuando el expósito sale de la Inclusa con una nodriza externa, no se hacen más anotaciones y no se cierra el historial del niño como debía hacerse de forma reglamentaria, con la baja definitiva, por devolución a los padres o fallecimiento del expósito,

\footnotetext{
${ }^{762}$ El Reglamento de 1889 establecía que las mujeres "a los veintitrés años serán emancipadas si son huérfanas y si son expósitas a los veinticinco. Único medio de evitar su perdición según lo viene enseñando la experiencia. ... Los acogidos varones serán emancipados a los quince años si antes no han sido reclamados por sus padres ó parientes y los expósitos lo serán a los diez y siete, de edad bastante para proporcionarse por sí mismos lo suficiente para las necesidades de la vida" (Art. 128 y 129)
} 
o con la vuelta a la Inclusa, en cuyo caso podía pasar a la sección y a los libros de Mayores, aunque se solían seguir haciendo anotaciones hasta la emancipación o la muerte. Es difícil saber el destino final de estos niños cuyo historial no se ha completado, la primera impresión es que se quedaron con las nodrizas, pero podrían también haber vuelto con sus padres e incluso al Hospicio a la sección de adultos o haber fallecido. Si tenemos en cuenta que en los folios de inscripción de los Libros de Exposiciones debía recogerse todo lo referente al destino y la localización de los expósitos y que el reglamento obligaba a requerir periódicamente información de los acogidos, estos folios con el final en blanco sugieren que el Hospicio perdió su pista de los niños. En los libros de los 14 años consultados solamente en 238 folios se ha anotado Prohijado ó Pasa a 3a situación, con una distribución muy variable, hay años en los que no encontramos ninguna anotación de este tipo, como en 1900, en cuyos libros hay 58 folios en los que no se ha escrito nada después de la salida del expósito para crianza externa y 1901 con 35 folios sin final. En otros encontramos los dos tipos de registros: en 1903 hay 33 niños prohijados y en 10 folios se ha dejado en blanco el final, en 1904 son 33 prohijados y 47 folios sin final y en 191326 niños y 4 folios respectivamente.

\subsubsection{LAS NODRIZAS EXTERNAS}

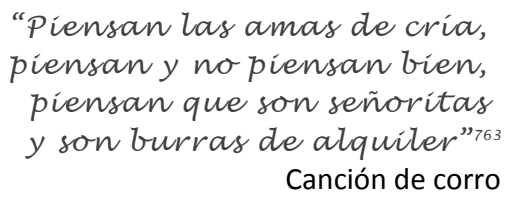

Con las nodrizas externas los reglamentos eran más exigentes que con las internas, al presentar la solicitud de un expósito para crianza debían acreditar buena conducta moral, buenas condiciones para lactar y medios económicos suficientes. No se excluía a viudas y solteras pero se preferían las mujeres casadas y siempre se registraba el nombre del marido de la nodriza; esta preferencia no está escrita en la normativa pero se aprecia solo con echar un vistazo a los libros, la gran mayoría son mujeres casadas solo hay algunas viudas y son

\footnotetext{
${ }^{763}$ FRAILE GIL J.M.: Amas de cría, campesinas en la urbe. Revista de Folklore no 221. Valladolid. 1999, pp 147- 159. La copla refleja el sentir popular sobre esas nodrizas que trabajaban en casas particulares que se lucían como muestra del estatus de la familia y se consideraban una élite entre los sirvientes. Cuenta José Manuel Fraile que es una copla satírica que alude a las burras de leche que pasaban diariamente a primera hora de la mañana ofreciendo su mercancía y que se ordeñaban en el momento. Su leche era apreciada sobre todo para enfermos y embarazadas y ha quedado el dicho "que ya han pasado las burras de leche" que equivale a decir que ya es muy tarde para permanecer en la cama.
} 
contadas las mujeres solteras; como ejemplo, entre más de 300 nodrizas externas cada año, en 1905 solo encontramos 6 viudas, en 1908 hay 12 viudas y una soltera y en 1912 hay 23 viudas y una soltera. La nodriza no podía escoger al expósito que se llevaba para criar y no podía ser de la localidad natal de éste ni de lugares próximos. Estos eran los requisitos exigidos, al menos sobre el papel, en la práctica veremos que su cumplimiento era limitado, aunque no toda la responsabilidad sería siempre del Hospicio o de la Diputación.

Podemos conocer el número de nodrizas contratadas anualmente hasta 1915 por los presupuestos generales, en años posteriores ya no se indica cuantas nodrizas se pueden contratar, solamente se recoge el total destinado al pago de su salario en una partida que incluye el gasto previsto de leche y otros alimentos infantiles. (TABLA 3-27).

TABLA 3-27: NODRIZAS INTERNAS Y EXTERNAS CONTRATADAS ANUALMENTE POR LA INCLUSA DE VALLADOLID

\begin{tabular}{|c|c|c|c|c|c|c|c|c|c|c|c|c|c|}
\hline & & 1901 & 1902 & $03 / 04$ & 1905 & $06 / 08$ & $09 / 10$ & $11 / 12$ & 1913 & $14 / 15$ & 1923 & $\begin{array}{c}1925 / \\
1926 \\
\end{array}$ & $\begin{array}{r}1928 / \\
1929 \\
\end{array}$ \\
\hline \multirow{2}{*}{ INTERNAS } & LACTANCIA & 24 & 25 & 25 & 20 & 20 & 25 & 25 & 25 & 25 & 30 & - & - \\
\hline & DESTETE & - & - & - & - & - & - & - & - & 8 & 8 & $16 / 12$ & $8 / 9$ \\
\hline \multirow{2}{*}{ LACTANCIA } & PUEBLO & 365 & 240 & 200 & 185 & 225 & 225 & 225 & 300 & 300 & - & - & - \\
\hline & CAPITAL & 48 & 20 & 20 & 20 & 20 & 20 & 20 & 20 & 20 & - & - & - \\
\hline \multirow{2}{*}{ DESTETE } & PUEBLO & 500 & 416 & 350 & 300 & 300 & 300 & 250 & 250 & 250 & - & - & - \\
\hline & CAPITAL & 48 & 20 & 15 & 15 & 15 & 15 & 15 & 15 & 15 & - & - & - \\
\hline
\end{tabular}

Número de nodrizas contratadas por la Inclusa de Valladolid, de lactancia y de destete, internas y externas, rurales y de la capital. Se recogen individualmente los años en que hay algún cambio y se mantienen agrupados los que tienen datos comunes. Tabla de elaboración propia a partir de los datos que ofrecen los Presupuestos generales de la Diputación. ADPVA. Hasta 1915 en los presupuestos se recogía el número de nodrizas, a partir de entonces solamente aparece el montante total destinado a esta partida sin dar el número de contrataciones previstas.

En la TABLA 3-27 podemos observar que hasta 1912 el número de nodrizas de destete fue superior al de lactancia, lo cual es razonable teniendo en cuenta que abarcaba un período de tiempo mucho mayor y por tanto a más niños; desde 1913 se invierte esta relación, lo que supone que un número mayor de externos eran devueltos al finalizar la lactancia y quedarían internados en la Cuna. La razón de este cambio puede estar en los salarios, por el destete cobraban la mitad que durante el período de lactancia, mientras que los gastos de crianza del niño tendrían que ser mayores, suponiendo que fuera criado al pecho. Por la Memoria de 1920 escrita por los médicos del Hospicio sabemos que a partir de 1915 se redujo casi a la mitad el número de nodrizas externas, debido, dicen, a lo reducido del salario y a la competencia de las inclusas de las provincias limítrofes que lo subieron, cuando precisamente veremos que una buena parte de las nodrizas eran de la provincia de Segovia

"...mientras en el año de 1915 las lactancias externas eran 729, disminuyen progresivamente en los años sucesivos, hasta llegar en el 1918 a 367, existiendo una 
diferencia de 362 que quedan internados, pasando de la lactancia mercenaria unipersonal a la mixta o artificial y cambiando el aire de la aldea por el de la Inclusa.

Las causas de la disminución de la lactancia externa en estos últimos años pueden reducirse a una, la carestía de los artículos de primera necesidad, la nodriza externa con 15 pesetas mensuales que la abonan apenas si puede comprar el jabón necesario para el lavado de ropas; por otra parte las Diputaciones de la provincias limítrofes han aumentado la retribución a 25 pesetas mensuales, así se explica la falta de solicitud de niños de pecho y como lógica consecuencia el aumento de mortalidad en el Hospicio"$^{\prime \prime 64}$.

Así como con las nodrizas internas valorábamos cuántos niños cuidaba cada una de ellas, en este punto tenemos que valorar cuántas nodrizas tenía cada niño. Algunos expósitos de la Cuna pasaban por las manos de varias nodrizas durante su crianza, 2 niñas del periodo de consulta permitido llegaron a tener 5: Luisa Sánchez (fo 377 LE 1903-1), que en dos ocasiones fue devuelta en el mismo día que se entregó a las nodrizas y que reingresó definitivamente a los 5 años, pasando al libro de Mayores, y por tanto a la correspondiente sección del Hospicio; y Angela Rubio (fo 80 LE 1907-1), que también fue devuelta en dos ocasiones el mismo día de su salida, pero que al final tuvo más suerte y en 1910 "fue entregada a su Madre". La mayor parte de los niños tuvieron solamente una nodriza, lo que no significa que todos estuvieran con ella durante el período de crianza completo, muchos fallecieron durante esta primera salida del hospicio (1.765). De un total de 3.889 niños que salieron de la Cuna, 127 volvieron con su familia directamente (el 3'27\% del total de salidas). De los 3.762 restantes que pasaron a crianza externa, 3.164 solo tuvieron una nodriza (84'10\%), 521 tuvieron dos (13'85\%), 65 tuvieron tres, 10 niños estuvieron con 4 nodrizas y 2 con 5 (incluyendo en estos datos a los fallecidos con ellas). En total durante la crianza externa fallecieron 1.990 expósitos, a los que hay que añadir otros 470 que murieron en el asilo después de ser devueltos. En la TABLA 3-28 recojo los niños que salieron, el número de nodrizas que tuvieron, los que fallecieron con ellas y los que sobrevivieron al período de crianza externa; incluso descontando los fallecidos, puede comprobarse que mayoritariamente pasaron solamente por una nodriza externa.

No se permitía a las nodrizas lactar a más de un expósito de forma simultánea, ni se les podía entregar uno si estaban criando a su hijo, para evitar la competencia entre ambos que podía resultar muy desfavorable para el inclusero. Esto en cuanto a la lactancia; en los reglamentos no se decía nada sobre los niños de destete, ni contra la posibilidad de criar niños diferentes en momentos distintos. En la práctica no se penalizaba la devolución ni el

\footnotetext{
764 Año 1920. Memoria suscrita por los médicos del Hospicio Provincial relativa a la mortalidad de niños del establecimiento. Signatura: caja 4025, expediente 37809. ADPVA
} 
fallecimiento de los expósitos, algunas amas externas después de perder o devolver un primer niño solicitaban otros.

TABLA 3-28: № de nodrizas externas que tuvieron los niños de la Inclusa de Valladolid en el período 1900- 1913 y $n$ o de niños que fallecieron con ellas según el $n$ o de orden de las criadoras

\begin{tabular}{|l|c|c|c|c|c|}
\hline \multicolumn{2}{|c|}{ Niños que salieron para crianza externa } & $\begin{array}{c}\text { No de niños que fallecieron } \\
\text { con las nodrizas }\end{array}$ & \multicolumn{2}{c|}{$\begin{array}{c}\text { Niños que sobrevivieron a } \\
\text { la crianza externa }\end{array}$} \\
\hline Con 1 nodriza & 3.164 & Con la 1a nodriza & 1.765 & A 1 nodriza & 1.399 \\
\hline Con 2 nodrizas & 521 & 2 a “ & 204 & A 2 “ & 317 \\
\hline Con 3 nodrizas & 65 & 3 a “ & 20 & A 3 “ & 45 \\
\hline Con 4 nodrizas & 10 & 4 a “ & 1 & A 4 “ & 9 \\
\hline Con 5 nodrizas & 2 & & & A 5 “ & 2 \\
\hline & 3.762 & 1.990 & & & 1.772 \\
\hline
\end{tabular}

Al revisar los libros, hay nombres de nodrizas que se repiten, incluso de unos años para otros, y las encontramos con varios niños sucesivamente; como siempre se anotaba el nombre del marido y la localidad de residencia, podemos diferenciar bien si en los casos de coincidencia se trata de la misma mujer o no. Los niños ingresados en 1905 salieron con 302 nodrizas, 21 aparecen repetidas en los libros de ese año y otras 15 más las encontramos en los libros de 1906; seis de ellas llegaron a sacar 3 niños de forma sucesiva y en intervalos variables. Algunas hicieron un cambio de expósitos de manera que el mismo día que devolvían uno, o al siguiente, le entregaban otro; solía ocurrir cuando la devolución era por reclamación de los padres. Bonifacia Castaño de Sequeros (Burgos) sacó a la primera niña para lactancia el 3 de junio de 1905 (fo 185) y la devolvió el 26 de agosto porque la reclamó su madre. Ese mismo día le entregaron a cambio otro expósito (fo 284) que falleció con ella el 3 de noviembre de 1905 y el 17 del mismo mes le concedieron una tercera niña (fo 378 ) que tuvo hasta el final del período de crianza, devolviéndola el 12 de octubre de 1909; volvería a por ella, el día 1 de noviembre de 1910: "la llevaron los mismos por desearlo asi y haberla cuidado bien". Esta mujer puede servir de ejemplo de nodriza empujada por algo más que el puro interés económico, que no me atrevo a llamar lucrativo porque el salario no daba para lucrarse. Como en el caso de esta mujer, aunque se muriera un expósito no se descartaba a la nodriza, incluso en ocasiones le entregaban otro a cambio el mismo día del fallecimiento o muy inmediatamente. Estefanía Melero de Aldeanueva de la Serrezuela (Segovia) también tuvo 3 niños, el primero (fo 23 de 1905) se le murió a los siete meses de tenerlo, el 18 de agosto de 1905, no se registró la causa en el libro de Exposiciones; al día siguiente le entregaron otro niño para lactancia (fo 283), que también falleció con ella el 9 de octubre de 1907; después de dos niños fallecidos, en 1908 le entregaron un tercero para destete (fo 350 de 1906). Ya hemos comentado que las devoluciones no se justificaban en los libros, encontramos casos que a la 
vista resultan chocantes: Ruperta Encinas de Tordesillas devolvió un expósito el 7 de diciembre de 1905 (fo 371), no se sabe la causa pero el niño no volvió con sus padres ni parece que estuviera enfermo ya que salió 4 días después con otra nodriza, sorprende que el mismo día 7 le entregaran otro a cambio ( $f \circ$ 406), los dos eran de lactancia. A Hermenegilda Martin también le concedieron un expósito (fo 196 de 1905) al día siguiente de devolver otro, el primero fallecería unos días después en el asilo, no se entiende bien la causa, parece que por disentería (fo 198 LE 1905-1), como en muchos otros casos podría haberle devuelto precisamente por estar enfermo.

A pesar de que los reglamentos decían que no se podía escoger niño, parece que tampoco penalizaban a la nodriza que rechazaba alguno. Fidela San José, de San Miguel de Bernuy, tuvo cuatro niños, primero una niña que tuvo que devolver porque fue reclamada (fo 75 de 1906), el mismo día le dieron otra niña (fo 144 de 1906), que a su vez devolvió cuando tenía un año en abril de 1907. El día 30 de abril de 1908 le concedieron un niño de destete que devolvió en el mismo día (fo 302 de 1908) y el 26 de mayo siguiente le entregaron una niña de destete (fo 102 de 1908), que ya crió hasta el final del periodo remunerado.

Es muy llamativo el caso de Leocadia Sánchez, "mujer de José Pulido, vecinos de Aldeanueva de la Serrezuela (Segovia)", que la encontramos seis veces en los libros, una en 1906 y el resto entre 1908 y 1909, se descarta otra porque no coinciden los demás datos. Tiene la particularidad de que llegó a tener a 2 niños de destete juntos: el primer expósito se le murió a los 14 días de sacarlo de la Inclusa (fo 276 LE 1908-1) y le entregaron a continuación dos niñas de forma sucesiva para lactancia, que tuvo que devolver porque las reclamaron sus padres (fo 290 y 370 de 1909); el mismo día que devolvió a una, el 6 de noviembre de 1909, le entregaron la otra y se repitió jugada cuando devolvió a ésta el 20 de diciembre y sacó al niño Víctor Estébanez (fo 249 de 1908). Este cuarto niño por edad (16 meses) sería ya de destete, lo tuvo con ella todo el período de crianza devolviéndolo el 15 de octubre de 1914 con 6 años cumplidos. Coincidiendo por tanto con él, sacó a Timoteo Diez el 12 septiembre 1910, por edad también para destete (fo 102 de 1909), que falleció el 14 de febrero de 1911; en octubre del mismo año, a pesar de tener todavía a Víctor Estébanez le entregaron a José Negrete (fo 233 LE 1906-1), un niño ingresado en julio de 1906 que tenía ya 5 años y que estuvo con ella hasta el 4 enero 1913 cuando finalizó el destete. Es muy raro que tuviera adjudicados dos niños de forma simultánea, aunque fueran de destete; situaciones como ésta que podamos confirmar solo se dan de forma muy aislada. "Máxima Carrascal, mujer de Francisco Herrero, vecinos de Fompedraza" sacó tres niños, a lldefonsa, la primera, el mismo día que ingresó en la Cuna el 15 de abril de 1905, tenía tres meses y era hija legítima de un matrimonio de Canalejas y 
acabaron prohijándola (fo 166 de 1905). En 1906, teniendo por tanto a su cargo a Ildefonsa, ya en destete, sacó otros dos niños para lactancia; uno el 15 de julio de 1906, Quirino, que falleció ocho días después, y el otro el 24 de febrero de 1907, que falleció el 24 de marzo siguiente.

También tuvo varios niños "Felisa San José, viuda, vecina de Aldeanueva de la Serrezuela (Segovia)", del mismo pueblo que Leocadia Sánchez; caben dudas sobre si coincidieron en el tiempo porque el primer niño (fo 360 de 1908), que se llevó para lactancia el 20 de noviembre de 1908, no tiene anotado en su folio nada después de salir con ella; pudo ser devuelto o fallecer porque en enero le entregaron una segunda niña para lactancia, que fallecería con ella en agosto del mismo año (fo 401 de 1908) y después, sucesivamente, dos niños de destete que devolvió por reclamación de los padres (fo 369 y 401 de 1909). Hay otra Felisa San José en el libro de 1905 (fo 415), que puede ser la misma porque coincide la localidad de residencia, aunque entonces no era viuda; sacó una niña en enero de 1906 que falleció con ella en agosto del mismo año.

Aunque solamente se autorizaba un niño a cada nodriza, resulta difícil saber con exactitud si podían tener en ocasiones, de forma no reglamentaria, más de uno, debido a esos registros incompletos. "Manuela González, mujer de lldefonso Sacristán, vecinos de Cuevas de Provanco (Segovia)", sacó a 4 niños; del último sabemos que lo devolvió (fo 57 LE 1908-1), pero de los otros 3 no conocemos su paradero porque no se ha escrito nada después de salir con ella, lo que ocurrió el 11 de diciembre de 1905 (fo 371 de 1905), el 14 de enero de 1906 (fo 416 de 1905) y el 15 de diciembre de 1906 (fo 326 de 1906). Parece muy improbable que le entregaran estos tres niños para criarse juntos porque todos eran de lactancia.

\subsubsection{Requisitos exigidos a las nodrizas externas}

El Reglamento de 1889 les exigía en primer lugar contar con medios económicos para mantener al niño, circunstancia ésta que, aunque muy razonable desde la perspectiva actual, chocaba de lleno con la realidad social del momento, ya que precisamente la mayoría de las veces eran los niños los que proporcionaban un medio de subsistencia, o al menos una ayuda importante, a las nodrizas.

“Art. 80. Las nodrizas externas al solicitar un expósito para criarle, justificarán previamente los medios de subsistencia con que cuentan, su buena conducta 
moral y la de su esposo si son casadas lo cual se consignará en una certificación que dará el Alcalde y Cura párroco del pueblo donde proceda...

Este artículo ya no se recoge así en los reglamentos sucesivos y solamente exigían contar con medios a las mujeres que sacaban niños de destete, cuya crianza resultaría más cara que la de los lactantes alimentados al pecho y, sin embargo, el salario que les pagaba el Hospicio era la mitad. En la práctica tampoco parece que se demandara siempre demostrar solvencia económica (Art. 344 Regl.1910 y 347 Regl.1927)

"Art. 344. La persona que desee obtener con remuneración un niño que haya pasado del período de lactancia, pero que no haya cumplido seis años, deberá hacer constar que es de buena conducta y que tiene bienes o medios suficientes para mantenerle." (Regl.1910)

Un requisito que era imprescindible invariablemente para conceder un expósito era demostrar buena conducta "moral política y social" certificada por el Alcalde y el Cura párroco de la localidad. Entre los expedientes personales consultados se encuentran los certificados de de las criadoras, casi todas para niños de lactancia, salvo dos viudas que solicitaban un niño de destete; sólo en uno de ellos se manifiesta que la mujer tiene medios económicos suficientes

"Certifico que Petra Cano de estado viuda domiciliada en la calle Fernando V no1 Obseva vuena conducta y tiene posibles para poder mantener la criatura que solicita...

Valladolid 21 de febrero de 1913. El Alcalde de Barrio [firma y sello]

Certifico yo el infrascrito Cura Ecónomo de la Antigua. Que $D \underline{a}$ Petra....ha observado buena conducta moral y religiosa y según informes de personas fidedignas tiene medios más que suficientes para atender al cuidado y sustento del niño que desea sacar del Hospicio provincial de esta ciudad.

$Y$ para que conste, pongo, firmo y sello la presente en Valladolid á veintiuno de Febrero de mil novecientos trece" [sic] (Expte personal fo 75 1913)

Por lo que podemos comprobar en los expedientes, las solicitudes se resolvían de forma rápida si había expósitos disponibles. El certificado que acabamos de ver corresponde a un niño que ingresó el 21 de febrero de 1913 y que el 23 fue entregado a esta mujer que pudo quedarse definitivamente con él ya que no se ha escrito nada más después de la salida.

No se exigía a las nodrizas ser casadas, en caso de serlo el reglamento de 1889 exigía hacer extensivo el certificado de buena conducta y moralidad a sus maridos (Art. 80). Pocos certificados se refieren a los dos, al marido sólo lo mencionan; en los reglamentos posteriores solo se pide "a las mujeres que acrediten...su buena conducta" (Regl 1910, Art. 330)

" $D$ " Gavino Bernal Alvaro Juez Municipal de este pueblo de Valleruela de Pedraza, partido judicial de Sepúlveda, provincia de Segovia 
Certifico: Que Jesusa Sanz Alvaro de esta vecindad de treinta y dos años de edad de estado casada, con Pedro Alvaro de la misma vecindad de oficio pastor, es persona que hasta la fecha á oserbado y oserba buena conducta.

Valleruela de Pedraza á catorce de Abril de mil novecientos cinco. El Juez $M$ [firma] Gabino Bernal" [sic] (Expte personal fo 158 1905)

Nótese que el Juez Municipal que extiende el certificado, y que será responsable de certificar las buenas condiciones del expósito en poder de esta nodriza, tiene el mismo apellido que el matrimonio, coincidencia que por otra parte es frecuente en localidades pequeñas.

En 1910 se retiró la referencia al estado civil y al marido, sin embargo en los libros se continuó registrando el nombre del esposo, o en su lugar se anotaba si era viuda o soltera.

"En 11 de Junio de 1912 le llevó Alfonsa Pecharromán mujer de Eusebio González vecinos de Torreadrada" [sic] (fo 216 LE 1912-1)

"En 19 de Agosto de 1912 le llevó Teresa Pascual viuda vecina de Torreadrada" [sic] (fo 244 LE 1912-1)

Aparte, se añadió la condición de "que no lacten a ningún otro, aunque sea su propio hijo", que no debía cumplirse, por lo que se exigió en el siguiente reglamento que el hijo tuviera una edad suficiente para estar destetado o que hubiera fallecido quedando finalmente redactado este artículo en 1927 de la siguiente manera:

"Art. 553. Se entregarán niños para lactar fuera del Establecimiento a las personas que acrediten con certificación del Alcalde y Cura Párroco su buena conducta y que no lacten a ningún otro, para lo cual presentarán en la Dirección certificación de nacimiento del hijo propio, que será mayor de 18 meses, o de defunción, en caso de haber fallecido"

Y una vez demostradas estas circunstancias tenían que pasar el reconocimiento médico para valorar fundamentalmente sus condiciones para lactar.

"Art. 332. Antes de la entrega del niño será reconocida la nodriza por el Facultativo de la Inclusa, quien manifestará si se halla sana y en aptitud de lactario bien, consignándolo así en el correspondiente documento" (Regl 1910)

En el Reglamento de 1889 se contempla la posibilidad de que el facultativo de la Inclusa acuda a hacer el reconocimiento a casa de la solicitante cuando se trate de "una recién parida en la capital [que] deseara criar un expósito y por su estado no pudiese salir de casa". Tendrían que ser mujeres cuyo hijo hubiera fallecido para poder entregarle un inclusero. Este artículo ya no se recoge en reglamentos posteriores

En el mismo certificado de buena conducta el médico de la Inclusa añadía una nota acreditando sus condiciones para la lactancia, en ninguno se hace referencia a su estado de salud. En el certificado citado anteriormente se añadió: 
"Buena condición para lactar Valladolid 17 de Abril de 1905

[firma] Evaristo Millán [médico de la Inclusa]" [sic] (Expte personal fo 158 1905)

Cuando la mujer solicitaba un niño de destete, como no tenía que lactar, no se hacía el reconocimiento médico. En el mismo expediente de la cita anterior, y por tanto para el mismo niño, hay otro certificado de buena conducta de una viuda que quiere solicitarle para destete

" $D^{n}$ Juan Sanz Galindo, Juez Municipal de este pueblo de Torreadrada:

Certifico: Que María García Sobrado de estado viuda y vecina de este pueblo es de buena conducta y antecedente y la considero merecedora y de confianza para que se le entregue un niño para criarle de destete, pues según me manifiesta se propone solicitarle al Hospicio Provincial de Valladolid...

...en Torreadrada á dieciocho de Julio de mil novecientos nueve [firmado]" [sic] (Expte personal fo 158 1905)

Este expediente corresponde a una niña expuesta en el torno de Medina del Campo el 9 de abril de 1905. En su carpeta solamente se conservan estos certificados junto con los del ingreso; por el libro de Exposiciones podemos saber algo más de ella, una de tantas historias amargas de la Inclusa. Su primera nodriza, Jesusa, la sacó el mismo día que pasó el reconocimiento médico, el 17 de abril, y la devolvió al cabo de cuatro años el 22 de septiembre de 1909. Al día siguiente "Ia llevó María García viuda vecina de Torreadrada", con la que estuvo hasta el 17 de Julio de 1912. Para entonces había cumplido los siete años por lo que finalizó su período de crianza; a pesar de la "suerte", supuesta, de esta primera etapa que transcurrió toda fuera del establecimiento, ya no volvería a salir, pasó toda su vida institucionalizada; en su folio no se da razón, simplemente, debajo de la última nota de devolución un apunte dice que en "1974 Fue trasladada a la Residencia de Ancianos Cardenal Marcelo González", perteneciente también a la Diputación de Valladolid. (fo 158 LE 1905-1).

Una vez que la nodriza se consideraba apta se le asignaba el expósito que debía criar, según los expedientes consultados la entrega se hacía en el mismo día de la revisión médica, de esta manera se ahorraba el viaje a las nodrizas de fuera de la capital. Para evitar fraudes, todos los reglamentos advierten que las criadoras no podían escoger niño, solamente se les permitía elegir su sexo.

"Art. 86. Debiendo observarse la mayor reserva acerca de la procedencia de los expósitos, se prohíbe la entrega á las personas que solicitan una criatura determinada". (Regl 1889)

"Art. 336. No se le permitirá á la nodriza escoger expósito para lactar, sino únicamente expresar el sexo, y una vez hecho tomará el que se la entregue por la Superiora de las Hijas de la Caridad". (Regl 1910) 
Sin embargo, encontramos nodrizas que devolvían al expósito al poco de entregárselo, incluso el mismo día, y luego le concedían otro; si no podían elegirlo directamente parece que si podían rechazarlo. En el Libro de Salidas de 1906 se encuentra una carta suelta en la que se solicita una "criatura determinada", como dice el reglamento. Está firmada por el Juez municipal de Torreadrada el 12 de mayo de 1908 y certifica que Gregoria "es de buena conducta y antecedentes, como igualmente su marido y la [considera] merecedora de que se la entregue una criatura de destete para criarla y cuidar de ella" y que "se propone solicitarla", la sorpresa viene a continuación cuando dice que "desea la niña Nicasia Pacheco" que, añade, "accidentalmente tiene en su poder". Esta solicitud se explica porque, en la fecha en que se escribió esta carta, la nodriza llevaba dos meses con la niña; decir que accidentalmente es una forma de eludir explicaciones ya que la expósita Nicasia salió el 31 de enero de 1907 con María Moreno de Navares de Enmedio y por lo que parece al acabar el tiempo de lactancia se la cedió a la tal Gregoria; lo que veremos que también estaba prohibido. En el libro de Salidas se ha anotado que fue devuelta el 15 de marzo y que "en el mismo día la llevó Gregoria mujer de Benito vecinos de Torreadrada", pero en su folio de inscripción (fo 376 de 1906) no figura esta segunda nodriza y simplemente se ha anotado debajo de la salida con la primera y cerrando la historia de la niña que "Falleció en otro pueblo en 1 de Octubre de 1907"; la distancia entre los dos pueblos viene a ser de $12 \mathrm{Km}$ en línea recta. Ésta era una manera de someter al Hospicio a una política de hechos consumados, haciendo el traspaso de los expósitos entre las nodrizas la primera se evitaba tener que dar explicaciones y la segunda se aseguraba la crianza de la niña, que a su vez podemos decir que se ahorraba tener que regresar al Hospicio para volver a salir. Como procedimiento no está mal, el problema es la ocultación del hecho

El Reglamento de 1889 se extiende más y señala el orden de salida de los expósitos

“Art. 85. Las nodrizas no tendrán derecho más que á elegir el sexo de la criatura y recibirán la que designe la Hija de la Caridad, prefiriendo siempre y en primer término las que hayan nacido en el departamentos de Maternidad, en segundo los que entraren señalados, en tercero los que hayan recibido nombre por encargo de los conductores y en cuarto todos los demás".

Precisamente ordenaban salir en primer lugar a todos los que tendrían más posibilidades, aunque realmente fueran remotas, de ser reclamados por sus madres; también serían los más fáciles de reconocer y por tanto más susceptibles a la hora de cometer fraudes. Este artículo se suprimió en los siguientes reglamentos y en un intento de controlar mejor la designación de nodrizas se puso directamente en manos de la Superiora. A pesar de todo, las ordenanzas no siempre se cumplían, ni antes ni después. 
Aunque en la normativa no se dice nada sobre las condiciones del expósito que salía para crianza, no todos debían considerarse aptos; a Dionisia García la entregaron "en el mismo día [de su ingreso con dos días de vida] por no haber otro niño con condiciones" (fo 334 LE 1911-2). Es razonable suponer que los niños se entregarían sanos y en buenas condiciones, si bien hay registros que nos hacen sospechar que no siempre era así. La niña Sebastiana Casado fue "Devuelta al día siguiente por enferma" (fo 21 LE 1913-1). A la niña Javiera Santos la devolvieron dos nodrizas consecutivas al día siguiente de sacarla; en su folio dice que al ingreso no tenía en su cuerpo "marca ni señal alguna que la distinga" y ya había estado con una nodriza anteriormente. En la última devolución se anota que la niña no reunía las condiciones para lactar; falleció once días después de su retorno a la Inclusa

"En 20 de Setiembre de 1914 la llevó Jenara Simones mujer de Eusebio González Izquierdo vecinos de Sacramenia (Segovia). Devuelta el 21 de Setiembre 1914. En 24 de Septiembre de 1914 la lleva para lactarla con libreta 1079 Severiana Tordesillas Peña mujer de Bonifacio Pérez vecinos de San Miguel de Vermuy. Al dia siguiente fue devuelta a esta casa por la Severiana por no reunir la niña las condiciones para lactar.

Falleció en este Asilo el dia 6 de Octubre de 1914 á consecuencia de Neumonia" [sic] (fo 414 LE 1913-2)

Aunque no pudieran elegir, o precisamente por eso, en ocasiones las nodrizas no estaban conformes con el expósito asignado, las razones no se explican en los registros pero bien podía ser un aspecto poco saludable; encontramos niños que fueron devueltos de forma casi inmediata a su salida, incluso en el mismo día, y alguno que ni siquiera llegó a salir porque la nodriza lo rechazó al recibirlo

"En 23 de Septiembre de 1907 la llevó juliana Poza Vaquerizo mujer de... Queda anulado este asiento por haberle devuelto en el mismo dia la Juliana Poza" [sic] (fo 105 LE 1913-1)

"Con esta fecha la llevó con cartilla de destete no 1099 Victoria... [tachado] Anulada esta salida porque no quiso llevarla después de entregada" [sic] ( $f 098$ LE 1913-1)

Muy elocuente en relación con todo este asunto es el caso de la niña Aurelia Recio (fo 117 LE 1908-1), en el libro de amas tiene una hoja abierta con los datos de la nodriza adjudicada, se anota la salida e inmediatamente se rectifica porque ese mismo día falleció

"Salio 21 Abril 1908

No salió esta niña después de hacer el asiento Falleció en este Asilo el 21 Abril 1908"

En su folio de inscripción no se refiere la salida frustrada, solo se recoge el fallecimiento en la misma fecha debido a una sífilis congénita, todavía no tenía un mes de vida, era hija de madre soltera de 27 años y había ingresado por la oficina. 
Se debía guardar la más absoluta reserva sobre el origen e identidad de los expósitos entregados, eliminando incluso las marcas de la ropa (Regl de 1889), según esto los expósitos no llevarían consigo al salir nada que pudiera identificarles, y si alguien hacía donaciones al niño o a la nodriza para su atención, tenían que pasar por el Hospicio

"Art. 87. Se cuidará por tanto que las nodrizas no lleguen a sospechar dicha procedencia, y si por alguna persona se entregase dinero con destino á la nodriza de un niño determinado o ropa para éste, se dispondrá su entrega en la forma que se creyere conveniente, á fin de alejar toda sospecha; pero nunca facilitaran las ropas que estuvieran marcadas, en cuyo caso harán que desaparezcan dichas marcas ó se reemplacen por otras del Establecimiento". (Regl 1889)

Recordamos que en un trozo de papel había una lista de ropa que se entregó "al comisionado Mariano Sacristán para la niña Mํㅗ Teresa Fernández Rojo" y que entre ella había algunas prendas con las iniciales; algo así no se consideraría romper el compromiso de confidencialidad pues a fin de cuentas son las iniciales de un nombre ya conocido en prendas que además tendrían un uso limitado. No sabemos qué se hacía con los demás objetos familiares que se depositaban en el torno como medallas o collares, no hay constancia de que se entregara a las nodrizas y tampoco es lógico que así se hiciera pues la estancia con ellas en principio era provisional; tampoco se anota nada al respecto en los libros en caso de prohijamiento, vuelta con los padres, emancipación o fallecimiento.

Un requisito añadido a partir de 1910 fue el referido a la localidad de las nodrizas, en el reglamento se agregó un artículo que prohibía mandar expósitos a poblaciones próximas a la suya de origen; esta sería una medida que pretendía evitar el abandono de hijos legítimos, niños que se dejaban en la Inclusa y luego se sacaban para cobrar su crianza.

"Art. 333. Ningún expósito o huérfano en el Establecimiento podrá encargarse a nodriza del pueblo de su nacimiento o exposición, ni de los limítrofes a éste".

La adición de este artículo nos hace pensar que ésta era una práctica frecuente (ver 4.1.2.2. Errores de Registro y 4.2.3.1. Los niños del biberón). En el capítulo Errores de registro vimos casos de niños inscritos en 1902 en los libros oficiales que según los de la Inclusa no llegaban a ingresar, "se ha subido de la oficina la papeleta de dicho folio pero no han traído arriba el niño que ocupa el folio 348 de dicha papeleta", y que sospechosamente se adjudicaban a nodrizas externas de localidades muy próximas a las suyas de origen. Al estudiar en 1905 el posible uso del biberón y analizar los folios sin asignación de ama interna encontré 35 lactantes, todos menores de un año, que fueron entregados a nodrizas externas el mismo día de su ingreso, o uno o dos días después, y me llamó la atención que todos entraron a 
través de la Comisión provincial entre enero y mayo, 3 de ellos fueron a parar a sus localidades de origen (folios no 145, 169 y 170) y muchos a alguna próxima: un niño de Tudela de Duero se entregó a una nodriza de Traspinedo, a 11'5 Km de distancia (fo 42); otro de La Cistérniga fue a Valladolid, a $7 \mathrm{Km}$ (fo 48), el tercero, de Sardón de Duero, primero fue a la capital para luego cambiar de nodriza y acabar en el mismo pueblo (fo 140); el cuarto, de Peñafiel, fue a parar a Olmos de Peñafiel a $9 \mathrm{~km}$ escasos (fo 213 ) y una niña procedente de Quintanilla de Abajo acabó en Olivares de Duero a menos de $2 \mathrm{Km}$ de distancia (fo 154); entre Peñafiel, Castrillo de Duero y Fompedraza, distanciados menos de $10 \mathrm{Km}$, se intercambiaron cinco niños. (ANEXO 4) Son situaciones que recuerdan las irregularidades que vimos respecto a la adjudicación de nodrizas externas en el fraudulento y polémico caso Montiel, un auxiliar de la dirección del Hospicio acusado de ingresar niños para entregárselos inmediatamente a sus padres en calidad de criadores con retribución, por una comisión de quince duros (75 pesetas) por niño y por supuesto sin que constara el parentesco en los registros.

Con la inclusión de este artículo 333 parece que esta práctica disminuyó. En 1912, de 26 lactantes sin asignación de ama interna, solamente he detectado irregularidades en las estancias más cortas en una niña ingresada por la comisión provincial, procedente de Villabrágima y que salió al tercer día a Tordehumos, a menos de $5 \mathrm{~km}$. No obstante el problema no desapareció porque el escándalo del señor Montiel se desarrolló en 1913-14.

Desde luego se necesitaba la complicidad de funcionarios del Hospicio pues la asignación de nodrizas se hacía en el establecimiento.

\subsubsection{Los pueblos de las nodrizas externas}

Los expósitos de la Inclusa de Valladolid que salieron para crianza con nodrizas externas fueron repartidos prácticamente por toda la geografía provincial, además muchos fueron a pueblos colindantes de las provincias de Segovia y Burgos y alguno aislado a localidades de Zamora, Palencia, Salamanca y Soria. Se analizan detalladamente la mitad de los años consultados de forma alterna y se cuentan más de 215 localidades distintas, (algunas no se han podido identificar con seguridad), con un promedio de 8'24 expósitos en cada una (en los censos de la época se refieren 237 poblaciones en la provincia de Valladolid). La distribución fue muy desigual, el 4'15\% de los lugares recibieron más de un tercio de los 
expósitos (el 3540\%). La mayoría de las poblaciones (el 47\%) no recibieron más de uno o dos expósitos mientras que 9 de ellas, incluyendo la capital acogieron a más de 60 (el 35\%). Salvo Tiedra (al oeste de la zona centro de la provincia de Valladolid), la capital (en el centro) y Peñafiel (al este de la provincia), los otros 6 pueblos que recibieron más expósitos están muy próximos y son uno de de Burgos, de la comarca de la Ribera (lindando con Valladolid y Segovia) y los otros 5 de Segovia, en concreto del norte de la comarca de Tierra de Sepúlveda, lindando con Valladolid y Burgos. Por orden de más a menos expósitos y por tanto nodrizas, se encuentran en primer lugar Torreadrada (Segovia), seguida de Tiedra (Valladolid), ambas con más de 100 expósitos en 7 años, y a continuación Sacramenia (Segovia), Castrojimeno (Segovia), Valdezate (Burgos), Aldeanueva de la Serrezuela (Segovia), Valladolid capital, Cuevas de Provanco (Segovia) y Peñafiel (Valladolid); casi la mitad de los niños fueron a parar a la provincia de Segovia (el 47\%). Se concentraron sobre todo en una zona localizada al sureste de la provincia que abarcaba las comarcas limítrofes de Segovia y Burgos, allí fueron en estos años más del 75\% de los expósitos para crianza externa repartidos entre la Tierra de Cuellar y Tierra de Sepúlveda de la provincia de Segovia (47\% del total), Sureste de Valladolid y localidades próximas (15\% del total) y la Ribera de Burgos (14\%). La zona centro acogió al 10\% de los expósitos, incluyendo la capital donde se quedaron un tercio de éstos (el 3’36\%), y excluyendo a Tiedra y localidades próximas donde fueron a parar el $9 \%$ del total, el sur de la provincia y la parte norte de la Tierra de Campos junto con algún pueblo de otras provincias y otros no identificados se llevaron el resto (menos del 4\%) (ver mapa en IMAGEN 3-54)

Si comparamos este mapa con el que utilizamos para representar las localidades de origen de todos los niños ingresados en la Inclusa (IMAGEN 3-16) vemos que las proporciones se han invertido en las comarcas de Tierra de Campos y del Sur de la provincia, que podemos definir como "dadoras" de expósitos, son las que más niños entregaron, pero sobre todo las que recibieron menos y por tanto las que tenían menos nodrizas, con mucha diferencia entre ambos datos y respecto al resto de la provincia. La zona Centro, que incluye la capital, también entregó más niños que recibió, salvo la zona en torno a Tiedra al oeste, que fue más "receptora". Aunque Tiedra pertenece al Centro, la he diferenciado porque en esta localidad y su entorno, incluyendo pueblos próximos que pertenecen a Tierra de Campos, se concentraron casi tantas nodrizas y expósitos como en el resto de toda la zona Centro, capital incluida. Lo más sorprendente es el equilibrio de la Zona Sureste de la provincia, si a ella pertenecían un $15^{\prime} 25 \%$ de todos los niños ingresados en la Inclusa, a ella fueron a parar el $15^{\prime} 04 \%$ de los expósitos que salieron para crianza externa. Hay que tener en cuenta que los porcentajes señalados en el mapa y que estamos comentando no son para el total de niños ingresados, 
sino que se refieren, como he señalado, a los niños que salieron con nodrizas, hablamos por tanto de un número considerablemente inferior porque hay que descontar los que fallecieron en el asilo antes de salir. Aún así resulta chocante; Mercedes Granjel, en un estudio comparativo entre las localidades de origen de los niños y las de las amas en Extremadura llegó a la conclusión de que "Ias localidades que registran un alto índice de abandonos no suelen coincidir con las de residencia de las amas...por el contrario, en las regiones y localidades donde el fenómeno de la exposición era menos intenso el número de nodrizas es muy superior" ${ }^{\prime 765}$.

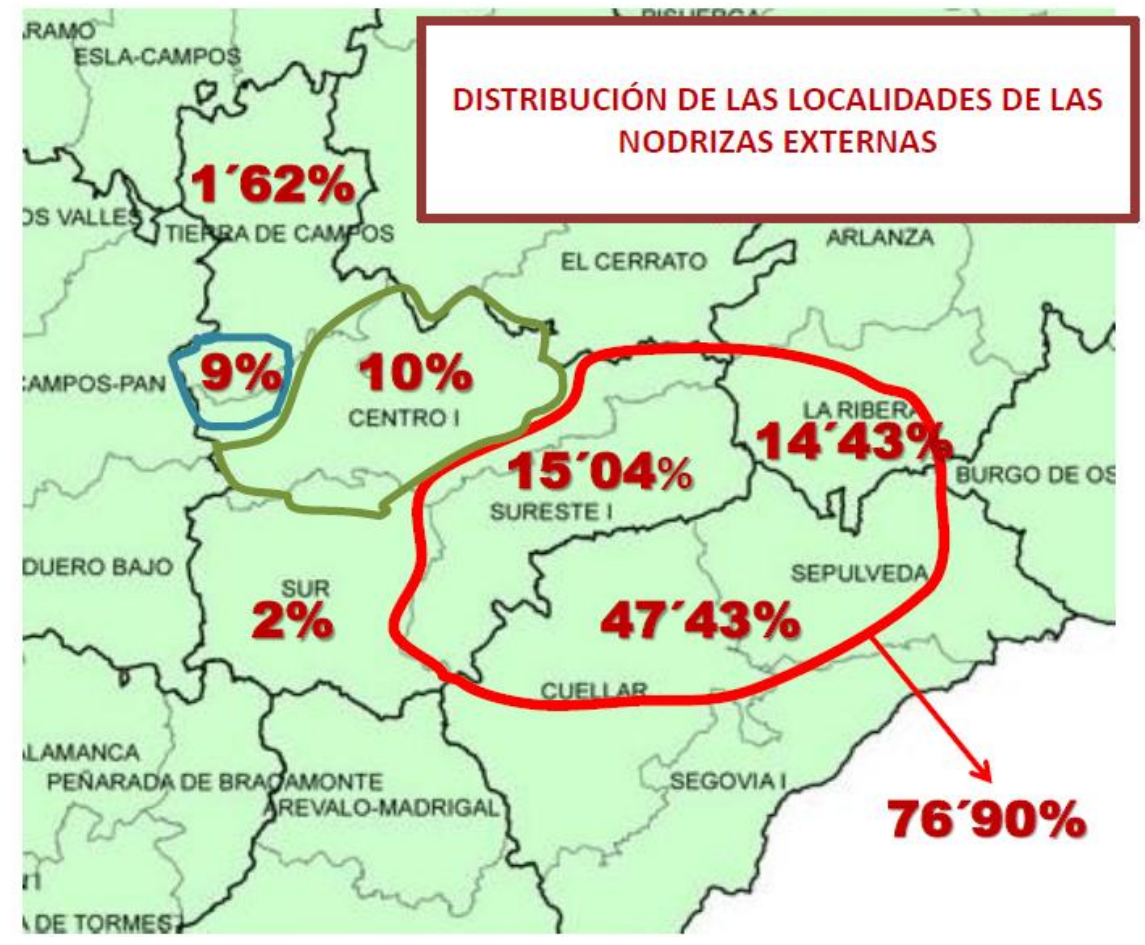

Imagen 3-54: Distribución de las localidades de las nodrizas externas de los niños de la Inclusa de Valladolid. Elaboración propia. (Mapa de regiones de la Junta de CyL)

Coincide con nuestros resultados para toda la provincia incluida la capital, pues a ella pertenecían el $27^{\prime} 43 \%$ de los niños que ingresaron en la Inclusa, descontando los de la Maternidad y el Hospital, (GRÁFICA 3-24) y solamente el 3'36\% de las nodrizas, excepto para la zona Sureste. También se cumple en la zona más al oeste de la provincia que he diferenciado en el mapa por presentar una densidad mucho más elevada que la de las comarcas que la rodean; en conjunto son seis localidades: la principal, Tiedra, pertenece a la zona Centro, al igual que Pobladura de Sotiedra y San Cebrián de Mazote, además de San Pedro de Latarce, Urueña y Villardefrades que son de Tierra de Campos, situados todas a una distancia de Tiedra entre 2 y $10 \mathrm{Km}$ en línea recta. El conjunto de estos 6 pueblos recibió al 9\% de los expósitos en

\footnotetext{
${ }^{765}$ GRANJEL M.: Mortalidad de expósitos y lactancia mercenaria en la alta Extremadura: 1915- 1925. Braga 1993
} 
crianza, mientras que envió al hospicio al 2’25\% del total de niños ingresados. Faltaría saber el comportamiento de las regiones de Segovia y Burgos que parecen receptoras, no podemos asegurarlo a falta de conocer cuántos expósitos originaron porque en su mayoría se entregarían a sus inclusas provinciales, aunque sobre todo parece claro para las comarcas segovianas de Tierra de Cuellar y Tierra de Sepúlveda, que recibieron casi la mitad de todos los que salieron de la Inclusa de Valladolid en el intervalo de tiempo que se ha podido estudiar.

Viendo el mapa y la distribución de las nodrizas externas y sus expósitos, no es de extrañar que en las localidades más alejadas que coinciden con las que recibían más expósitos (las situadas al sureste de la capital y Tiedra al oeste) existieran comisionados o intermediarios que operaban entre las nodrizas y el Hospicio, de los que hablaremos más adelante

\subsubsection{Devolucióne intercambio de expósitos}

Al hacerse cargo de un expósito, la nodriza contraía "como obligación natural la de alimentarlo, cuidarlo y vigilarlo con la diligencia y cariño de hijo propio" (Art. 337 Regl 1910) siendo "responsable de cualquier desgracia que pueda ocurrir al expósito si ésta tuviera lugar por abandono o negligencia en el cuidado del mismo, cuyo expediente de indagación se formará de oficio ante el Alcalde del pueblo" (Art. 84 Regl 1889).

La devolución se podía producir por finalización del contrato o por reclamación de los padres o del Hospicio. La nodriza por su parte podía devolver al expósito en cualquier momento, justificándolo convenientemente. Con mucha suerte el niño pasaba todo el tiempo de crianza con una nodriza

\footnotetext{
"Angela San Jose

En 28 de Enero de 1900 y hora de las ocho de la noche la dio a luz la refugiada en este asilo Dominica San José...

En 10 de Febrero de 1900 la lleva Margarita Rodriguez mujer de José Rivas vecinos de Olmos de Peñafiel.

Devuelta el 25 de Enero de 1905 pasa al libro [de Mayores] 15 fo 70" [sic] (fo 44 LE 1900-1)
}

Ángela fue devuelta al finalizar el período remunerado de crianza a los 5 años, ya vimos que no siempre tenía la misma duración, en el mismo libro, unos folios más adelante, en el no 50, otra niña estuvo con la nodriza hasta los 6 años cumplidos; las dos tuvieron el mismo final, fallecieron en el asilo, en la primera no se refiere fecha ni causa, de la segunda sabemos que fue al mes siguiente de reingresar por escarlatina. 
Era frecuente el cambio de criadora al pasar de un período al otro, muchas mujeres devolvían al niño al finalizar la lactancia, mucho mejor remunerada que el destete; los contratos por lactancia y destete eran independientes y la devolución por fin de contrato no tenía penalización.

Las nodrizas podían devolver a los niños antes de terminar los períodos contratados, de lactancia o crianza, siempre que justificaran la causa, que podía ser por enfermedad o por imposibilidad para criar, por falta de leche. Sin justificación, perdían el derecho al cobro "hasta indagar la causa que haya podido motivar la devolución, y en su vista se la abonará o perderá el débito que tenga a su favor" (Art. 91 Regl 1889). No podemos saber hasta qué punto se cumplía con esta norma por lo mismo que ya he comentado en otras ocasiones, en los Libros de Exposiciones no se registraban detalles; en las devoluciones generalmente se anotaba sólo la fecha sin dar más explicaciones. En algunos folios se registra la falta de justificación

"En 28 de febrero le llevo Teresa Rodriguez...

Devuelta el 6 de Julio de 1908. Sin certificado

Falleció en este Asilo en 13 de Julio de 1908 á las cuatro horas consecuencia de indigestión" [sic] (fo 65 LE 1908-1)

Obsérvese que el niño fallece una semana después de su reingreso por lo que la devolución pudo ser precisamente por estar enfermo, aunque este punto no se contemplaba en los reglamentos; se daban muchos casos similares.

En los libros de cuentas de las amas también se anotaban registros de este tipo; suelen ser notas escritas con lapicero, de esta manera se podía retirar si se resolvía el hecho que las producía, algunas son apenas legibles como si se hubieran intentado borrar. En el folio 403 de 1910 se lee "Devuelta el 2 de octubre de 1911" y con lapicero "Sin certificado del médico", mientras que en el folio correspondiente del libro de Exposiciones no se ha escrito nada. El error se debió subsanar porque se hicieron todos los pagos a la nodriza hasta la fecha de la devolución; hay papeletas y folios en los que se dejan pagos pendientes por este motivo. En el folio 368 de 1910 del libro de amas a la nodriza se le pagó solamente un mes, en vez de los dos que era lo normal porque, dice en lapicero "No justificó Abril", en el siguiente pago debió presentar el certificado porque se hizo el cobro. No podemos asegurar que la falta de observaciones de los registros significara siempre una actuación reglamentaria con la presentación de los justificantes exigidos, pero podría ser así en la mayoría de los casos; hemos de pensar que lo normal sería que se cumpliera la normativa por el riesgo de no cobrar el salario adeudado. Entre las hojas del libro de amas aparece un certificado médico justificando la devolución del niño inscrito en el folio 379 de 1908. 
"Don Julio Lorente Licenciado en Medicina titular de Castronuevo de Esgueva Certifico: Que Petra Repiso Gregorio, casada con el vecino de este pueblo Manuel Martín, se hallaba lactando al expósito del Hospicio Provincial de Valladolid Juan de la Cruz Lázaro, hallándose este niño en estado raquítico debido á la escasez y poco nutritiva leche de la nodriza, siendo poco probable el que pueda criar al referido expósito sin seguro peligro de su existencia.

$Y$ para que lo haga constar expido el presente con el visto bueno de Alcalde de Castronuevo de Esgueva á doce de Marzo de mil novecientos nueve"

Al hacer la devolución de los expósitos se rellenaba una ficha de "Baja en nómina por devolución del acogido" que firmaban la Superiora y el director, en la que aparte de los datos exigidos, se anotaba si la cartilla que se entregó a la nodriza junto con el niño había sido "recogida" y "Tomada razón" cuando se había presentado justificación.

La niña María Viñas salió con una nodriza al mes de vida el 5 de mayo de 1908 y regresó el 3 de julio de 1909 "sin justificar y sin cartilla"; falleció el 7 de julio "á consecuencia de Enterocolitis". La muerte fue tan inmediata a su regreso que cabe pensar que se encontraba enferma, más aún teniendo en cuenta que no presentó certificado médico ni la cartilla que era necesaria para el cobro. El reglamento de 1889 establecía que los niños que fueran devueltos antes de tiempo debían ser reconocidos por el médico del establecimiento y que en caso de encontrarse en mal estado se debía investigar el trato que habían recibido de las nodrizas y la Diputación podía tomar medidas sancionadoras si se demostraba que no era adecuado

Art. 92. Todo expósito devuelto antes de tiempo al Hospicio, será reconocido por el Facultativo del mismo, y si resultara encontrarse en mal estado, se oficiará al Alcalde, Cura párroco y Señoras de la Asociación, á fin de averiguar el comportamiento de la nodriza, si fue consultado el Facultativo del pueblo y este dispuso se le administrase algún medicamento. Si de los informes pedidos aparecieren confirmadas las sospechas de mal tratamiento, además de perder lo que se la adeude, se pasarán las diligencias con informe del Facultativo de la casa á la Excma. Diputación, para que esta obre como proceda.

En el libro de 1909 hay unas cartas referidas al niño del folio 412, en la primera el director del Hospicio pide informes al Juez municipal de Castrillo de Duero cuando reingresó "en virtud de las lesiones que tiene en la mano izquierda para proceder a su curación"

"Sírvase V. manifestar a esta Dirección a la brevedad posible, si el asilado Pedro González del Valle... ha sido la causa de las lesiones que tiene en la mano izquierda, la caída con un cántaro de agua que se le rompió y se le clavaron los pedazos, con el fin de justificar la causa citada, y al propio tiempo se servirá participarme si el Médico de dicha localidad se negó a prestarle la cura necesaria después de la 19 cura" 
El juez municipal contestó confirmando todos los términos, también "Que preguntado al Sr titular [el médico], manifiesta ser cierto todo lo dicho, por creer no tiene obligación de asistirle gratuitamente"; a pesar de ello el muchacho se quedó ingresado.

Son muchos los niños que podemos suponer que no regresaron en buenas condiciones porque fallecieron poco después de su retorno:

$\checkmark$ Fo 370 LE 1906-2: regresó el 11 de agosto de 1906 y falleció el mismo día “de diarrea", estuvo 10 meses con la nodriza.

$\checkmark$ Fo 212 LE 1909-1: devuelto el 28 de agosto de 1910 y falleció el mismo día “" $a$ cosecuencia de raquitismo", estuvo 14 meses con la nodriza.

$\checkmark$ Fo 324 LE 1909-2: regresó el 7 de abril de 1910 y falleció el mismo día por meningitis aguda, estuvo 6 meses con la nodriza.

$\checkmark \quad$ Fo 374 LE 1912-2: devuelto por la segunda nodriza el 1 de octubre de 1914 falleció el dia 2 "de colapso cardiaco", estuvo con ella 6 meses.

$\checkmark$ Fo 187 LE 1909-1: volvió el 29 de abril de 1910 y falleció el 1 de mayo " $a$ cosecuencia de raquitismo", permaneció 11 meses con la criadora.

$\checkmark$ Fo 409 LE 1906-2: regresó el 17 de septiembre de 1906 y falleció el 23 de septiembre "a consecuencia de catarro intestinal", estuvo 9 meses con la nodriza.

Estos son sólo unos pocos ejemplos, se puede hacer una lista muy larga, sin embargo, en la mayoría de los folios no se dice nada ni se da ninguna pista sobre el estado de los niños al regresar a la Inclusa. Es probable que muchos ya no salieran bien del establecimiento, podemos suponerlo cuando se devolvían casi inmediatamente y poco después fallecían

\footnotetext{
"En 28 de Febrero de 1908 le llevo Manuela Calvo... Devuelto el mismo dia Fallecio en este Asilo el 2 de Marzo de 1908 á consecuencia de Congestion cerebral" [sic] (fo 62 LE 1908-1)
}

En algunos folios, como ya se ha visto, así se indica: a María del Rosario Rodríguez "en 26 de Agosto de 1914 la llevó Calixta Gutiérrez ... En 27 de agosto de 1914 la devuelven por haber notado síntomas de enfermedad á la niña. Fallecio en este Asilo el dia 28 de Agosto de 1914"; no se recoge la causa (fo 388 LE 1912-2). Aunque no dice nada, la situación de Julio Bermejo sería similar ya que falleció "a consecuencia de atrepsia", que no se instaura en los tres días que estuvo con la nodriza, y falleció el segundo día de su retorno (fo 428 LE 1912-2), o niños como Casimiro Cuadrado (fo 121 LE 1909-1) que solo estuvo 14 días con la criadora y falleció a los dos días de reingresar "a consecuencia de sífilis congénita". 
Sería injusto decir que el regreso de todos estos niños era siempre para deshacerse de ellos, aunque muchas veces se plantea la duda. Isidoro Sáez (fo 178 LE 1912-1), falleció el mismo día que fue devuelto "a consecuencia de sífilis congénita", estuvo con la nodriza todo el tiempo de crianza, no podemos saber si lo devolvió porque finalizaba el período retribuido o porque estaba muy enfermo. En ocasiones, como la del niño que reingresó para curar las lesiones en la mano, la devolución sería para que recibieran atención médica en la enfermería del Hospicio o en el Hospital dado el caso

"En 31 de dcbre de 1907 le llevo Estefania Cantera...

En 7 de Agosto de 1910 fue llevado al Hospital provincial por Orden del sr Vicepresidente por padecer viruela hemorrágica, según certificacion del Medico de este Hospicio.

En 25 de Agosto fue dado de alta y devuelto a este Hospicio habiendo resultado que padecio Purpura hemorragica.

En 25 de agosto de 1910 fue entregada á los mismos que le tenian y que cuidaron siempre bien de él con mucho cariño" [sic] (fo 411 LE 1907-2)

Si la nodriza no podía atender al cuidado del niño debía devolverlo, teniendo terminantemente prohibido pasarlo a otra cuidadora sin conocimiento del Hospicio. El Reglamento de 1889 indicaba que cuando la nodriza se viera en la necesidad de dejar al niño por falta de leche, "indisposición u otra causa grave" bastaba que lo certificara el médico del pueblo y comunicarlo al alcalde que era el encargado de informar a su vez a la Diputación.

"En 22 de Diciembre de 1909 le llevó Agueda Iglesias viuda vecina de Castrojimeno.

1915 Según certificado del Secretario del Juzgado municipal de Castrojimeno esta niña fue traspasada a poder de la vecina de Castrojimeno Serapia San Frutos por Agueda Iglesias vecina del mismo pueblo a cuyo poder estaba" [sic] (fo 410 LE 1909-1)

Sin embargo este procedimiento, que parece simple pero que impone el control del expósito y de la criadora, no se debía cumplir normalmente; este registro que acabamos de ver es extraordinario, muchas veces el traspaso entre nodrizas no se comunicaba, en los libros apenas se encuentran anotaciones de este tipo, en cambio si encontramos las que dicen que "falleció en otro pueblo" para indicar que no era el de la criadora que le sacó. En los siguientes reglamentos se endureció esta norma, la nodriza debía justificar la causa del cese y el Hospicio tenía que autorizar el cambio, "previo dictamen facultativo". "La que lo hiciese sin estos requisitos perderá el derecho al abono de la lactancia y la será exigida la responsabilidad en que haya incurrido con arreglo a la Ley" (Art. 88 Regl 1889 y 337 y 334 Regl 1910 y 1927)

"En 14 de Enero de 1914 la llevo Laureana Parra...

En 17 de mayo cumpliendo el art 334 del Reglamento pasó á la criadora Ildefonsa Cuesta González vecina de Hinojosa" [sic] (fo 60 LE 1913-1) 
"En 18 de enero de 1918 autorizó la Dirección el cambio de criadoras pasando la acogida a poder de Fructuosa Iglesia Peña mujer de Mariano García Vallejo vecinos de Navares de las Cuevas (Segovia). En 18 de Abril de 1918 fue devuelto por la criadora" [fo 198 LE 1912-1]

Este niño cambió entre nodrizas del mismo pueblo, como el de dos citas más arriba.

Aunque a partir de 1910 se encuentran más registros con el cambio autorizado de nodriza y notas del tipo "Devuelto por la criadora", a pesar del endurecimiento de la normativa se siguieron haciendo traspasos a espaldas del Hospicio; el niño inscrito en el fo 7 de 1912 salió con "Maria Alvaro mujer de Serapio Peña vecinos de Castrojimeno" (sic) y en la siguiente anotación dice que "En 15 enero 1918 fue devuelto por Wenceslao Lobo marido de Sotera Pozo (difunta) vecino de Carrascal del Rio". En el mismo año al niño Alejandro "En 8 junio de 1912 le Ilevó Manuela Lobo mujer de Meliton Martin vecinos de Castrojimeno Segovia" (sic) y cuando fue reclamado por su padre se anotó "Le tiene hoy Micaela Martin Lobo de Castroserracin" (sic), que por los apellidos podría ser hija de los anteriores (fo 206 de 1912). También es cierto que los registros de este tipo son menos habituales a partir de entonces, sin embargo se siguen encontrando cambios de criadora anotados con fecha del mismo día o del siguiente y que podrían tapar situaciones de este tipo y ser el reconocimiento por parte del Hospicio de traspasos irregulares entre nodrizas.

En los Libros de Exposiciones se registraban los datos básicos sin dar normalmente explicaciones, lo que hace que se planteen dudas ante muchos registros incompletos, equívocos, poco claros o aparentemente erróneos, intencionalmente o no y en los folios de inscripción se detectan muchas irregularidades en relación con las nodrizas externas, situaciones dudosas e inexplicadas, sobre todo en lo que respecta al traspaso no autorizado de niños entre ellas, a pesar de la prohibición y del riesgo consiguiente de penalización. En definitiva, para el Hospicio resultaba más cómodo, tenía al expósito "colocado" sin necesidad de trámites ni de tener que reingresarlo y se evitaba una estancia más o menos larga hasta que pudiera salir con otra nodriza.

Eran prácticas en las que seguramente el Hospicio no estaba implicado, pero reconocerlas era tanto como confesar falta de rigor en la entrega y en el control de los niños externos y de las nodrizas, quizás por eso en muy pocos folios se refleja claramente que se ha cometido una irregularidad

"En 20 de Noviembre de 1908 le llevó Felipa Fra ${ }^{c o}$ Padilla mujer de Inocencio Pecharroman vecinos de Torreadrada provincia de Segovia 
[escrito en el margen del folio] Denunciado por traspaso á otra ama En 10 de Septiembre de 1909 fue devuelto por Isidra Parra que le estaba criando por cesion que del niño la hizo la Felipa Francisco su convecina. El niño viene muy enfermo" [sic] (fo 352 LE 1908-2)

Evidente resulta el registro del folio 349 del Libro de amas de 1910, solo figura una nodriza de Cobos de Fuentidueña y para ella son los pagos anotados, pero al margen en lapicero se ha escrito "Le tiene Mauricia vecina de Carrascal del Rio", entre las dos localidades hay $3 \mathrm{Km}$; en el libro de Exposiciones solo figura la primera.

Los cambios solían ocurrir entre nodrizas de la misma localidad o de lugares próximos. La niña Emilia Gómez Pérez fue entregada para crianza en mayo de 1913 a "Josefa de Frutos viuda vecina de Navares de las Cuevas Segovia" y fue devuelta en marzo de 1915 "por Catalina Pecharromán de Torreadrada" (fo 171 LE 1913-1), ambas localidades están a 8 Km de distancia en línea recta. He recogido intencionalmente este ejemplo porque estas localidades, junto otras de la provincia de Segovia, se repiten con frecuencia en este tipo de transacciones; la explicación puede estar en la distancia, son lugares alejados de Valladolid capital de 70 a 100 $\mathrm{Km}$ incluso más, y en los intermediarios o comisionados de los que hablaremos.

Hay otras situaciones que además de ser irregulares resultan muy sospechosas. También en 1913 y en dos folios consecutivos, no 230 y 231, nos encontramos un caso más particular aún, dos niños que fueron intercambiados entre las nodrizas, dándose además la circunstancia de que éstas eran su madre y su prima respectivamente: los dos fueron expuestos en el torno el mismo día, el 17 de junio de 1913, y salieron el 19; a Gregorio Iglesias (fo 230 LE 1913-1) le llevó "Eduvigis A[?] Hernando viuda vecina de Pradales" y a Trinidad Hernando (fo 231 LE 1913-1) "Gregoria Medrano mujer de Dionisio Iglesias vecinos de Fuentidueña", obsérvense los apellidos de todos ellos. También coincide, casualmente?, la fecha de devolución, el 12 de abril de 1915, con la sorpresa de que a Gregorio Iglesias lo devuelve "Gregoria Medrano mujer de Dionisio Iglesias" que resultó ser, según consta en una anotación añadida, su madre y a Trinidad Hernando la devuelve la que resultó ser su prima Eduvigis Abad Hernando; cada niño fue entregado a su familia en el mismo día por orden del Vicepresidente. Probablemente no llegaran ni siquiera a ingresar y simplemente se anotaron las fechas para dejar constancia del trámite. Todo este lío de niños y amas nos hace sospechar en un fraude en el que posiblemente estuvo implicado alguien del Hospicio, la explicación más sencilla es que se entregaron los niños en la forma descrita intencionalmente, para no levantar sospechas y a sabiendas de ambas partes para luego intercambiarlos, porque parece muy complicado llevar a cabo un engaño así sin la participación de alguien desde dentro del 
Hospicio; aparte del cruce de niños que ya en sí es muy sospechoso, se añade la coincidencia de todas las fechas de entrada, salida y devolución. Como en los folios no se ha explicado nada tenemos que suponer que al detectar el Hospicio la anomalía las avisaría para "arreglar el entuerto" devolviendo cada expósito con sus parientes y dándoles inmediatamente de baja. Por fechas esta historia encaja también con el escándalo Montiel que se desató en 1913- 14.

\subsubsection{Salarios, cartillas de cotranza y comisionados}

Los salarios de las nodrizas se fijaban en los reglamentos y en los presupuestos, variaban dependiendo de la edad del expósito, de la correspondiente modalidad de alimentación, lactancia o destete, y de la localidad de las criadoras, pueblo o capital. Se remuneraba mucho mejor la lactancia que el destete y vivir en un pueblo frente a la capital, con diferencias considerables.

Este sistema hoy nos puede resultar paradójico si aplicamos criterios economicistas, se entiende que la crianza de los niños de destete resulta más cara que la de los lactantes alimentados al pecho al tener que añadir el gasto de su alimentación y sin embargo el salario del destete era la mitad. Siendo la época más crítica para los bebés sus primeros meses de vida con una mortalidad altísima en aquellos años y siendo la falta de lactancia natural el riesgo más importante, a la criadora no solo se la pagaba por sus cuidados sino, sobre todo, por su leche. En cuanto a la localidad de la nodriza, también se supone que la vida es más cara en la ciudad y sin embargo se pagaba más a las nodrizas rurales porque se consideraba que ofrecían una vida más saludable al expósito.

Los límites de edad eran los mismos que venimos diciendo, hasta 15- 18 meses lactancia y hasta 5 -7 años el destete, o período de crianza.

En el Reglamento de 1889 se estableció una cantidad para la capital (11 pts/mes) y otra para las nodrizas de fuera (12'50 pts/mes), sin diferenciar la edad de los niños. En el Presupuesto general de la Diputación de 1901 ya aparecen los salarios para el destete externo y a la lactancia de la capital se le asignaron 10 pts/mes en lugar de las 11 que decía el reglamento. Podemos ver en la TABLA 3-29 que los salarios de las nodrizas externas se mantuvieron sin cambios hasta 1911. En el Reglamento de 1910 se aumentó el salario de lactancia y se disminuyó el de los destetes diferenciando por edad hasta los 48 meses y de 48 a 
72 meses; sin embargo, los Presupuestos de la Diputación de 1911 no aplicaron la rebaja y respetaron los salarios subiendo además la lactancia en pueblos. En 1920 se produjo una subida significativa en todas las partidas y en 1927 de la lactancia en pueblos. Se recogen en las tablas también los datos de las nodrizas internas para comparar, téngase en cuenta que, además del salario, que era mayor que el de las externas, tenían alojamiento y comida.

TABLA 3-29: SALARIO DE LAS NODRIZAS INTERNAS Y EXTERNAS DE LA INCLUSA DE VALLADOLID

\begin{tabular}{|c|c|c|c|c|c|c|c|c|c|c|c|c|c|}
\hline & & $\begin{array}{r}\text { REGL } \\
1889 \\
\end{array}$ & $\begin{array}{c}\text { PR } \\
1901\end{array}$ & $\begin{array}{c}\text { PR } \\
1904\end{array}$ & $\begin{array}{c}P R \\
08 / 12\end{array}$ & $\begin{array}{l}\text { REGL } \\
1910 \\
\end{array}$ & $\begin{array}{c}\text { PR } \\
1913\end{array}$ & $\begin{array}{c}\text { PR } \\
1914\end{array}$ & $\begin{array}{c}\text { PR } \\
1920\end{array}$ & $\begin{array}{c}\text { PR } \\
1923\end{array}$ & $\begin{array}{c}\text { PR } \\
1925 / \\
1926 \\
\end{array}$ & $\begin{array}{l}\text { REGL } \\
1927 \\
\end{array}$ & $\begin{array}{c}P R \\
1928 / \\
1930 \\
\end{array}$ \\
\hline \multirow{2}{*}{ INTERNAS } & LACTANC & $17^{\prime} 50$ & $17^{\prime} 50$ & 20 & 25 & - & 25 & 25 & 25 & 30 & 35 & $\begin{array}{c}35 / 45 \\
*\end{array}$ & $\begin{array}{c}35 / 45 \\
*\end{array}$ \\
\hline & DESTETE & - & - & - & - & - & - & $12^{\prime} 50$ & $12^{\prime} 50$ & $12^{\prime} 50$ & $15 / 20$ & 15 & $15 / 25$ \\
\hline \multirow{2}{*}{ LACTANCIA } & PUEBLO & $12^{\prime} 50$ & $12^{\prime} 50$ & - & - & \multirow{2}{*}{15} & 15 & 15 & 30 & - & 30 & 45 & 45 \\
\hline & CAPITAL & 11 & 10 & - & - & & 10 & 10 & 25 & - & 25 & 25 & 25 \\
\hline \multirow{2}{*}{ DESTETE } & PUEBLO & - & 8 & - & - & \multirow{2}{*}{$\begin{array}{l}7 \text { '50/ } \\
6 * *\end{array}$} & 8 & 8 & 15 & - & 15 & 20 & 20 \\
\hline & CAPITAL & - & $6^{\prime} 50$ & - & - & & $6{ }^{\prime} 50$ & $6^{\prime} 50$ & 10 & - & 10 & 15 & 15 \\
\hline
\end{tabular}

Salario de las nodrizas en pesetas/mes.

* Los dos datos de la fracción se corresponden con el número de niños que lacta la nodriza interna: en el numerador el salario cuando lacta 1 niño de la Inclusa (solo o + el suyo) / en el denominador cuando lacta 2 niños de la Inclusa (el suyo aparte en caso de que también lo esté criando).

** Los dos datos de la fracción se corresponden a distintos periodos de edad: desde $18 \mathrm{~m}$ a 48 meses /desde $48 \mathrm{~m}$ hasta 72 meses del niño.

Tabla de elaboración propia a partir de los datos de los reglamentos del Hospicio (REGL) y de los Presupuestos generales de la Diputación (PR). ADPVA

Al llevarse al expósito se entregaba a la nodriza "el atillo" (sic), la canastilla con el ajuar completo del expósito, y parece que podía llevarse la ropa que se expuso con el niño en el torno si no tenía marcas muy evidentes que apuntaran a la identidad de los padres o que no se pudieran retirar. El niño llevaba colgado del cuello el plomo identificativo con su número de filiación, que la nodriza no podía retirar bajo ningún concepto y que debía devolver a la Inclusa con el niño o en caso de su fallecimiento. En la Dirección le entregaban "una cartilla en que conste el nombre del expósito, núm del folio que tiene en el libro, el de la persona que le saca para lactar y derechos y obligaciones que adquiere" y que servía para control de los pagos.

Durante el período estudiado se utilizaron dos modelos de cartillas o libretas, que se imprimían en la imprenta del Hospicio, (IMÁGENES 2-29 Y 2-30); entre la documentación del Archivo se encuentran varios recibos como justificantes del cambio de la libreta de cobranza de la criadora por otra de nueva remodelación en 1913. Las cartillas se registraban en un libro aparte, el Registro especial de Cartillas de Lactancia y Destetes, en el que a cada una se le adjudicaba un número, diferente e independiente del número de filiación de los expósitos. Los 
pagos con la cantidad y la fecha se registraban también en los Libros de cuentas de las amas externas y en una ficha abierta para cada cartilla.

Entre la documentación del Hospicio, en el Archivo provincial se encuentra una "Cartilla para niños de lactancia en los pueblos pertenecientes al Hospicio provincial" de 1907, anterior al cambio; debía existir otra similar para el destete, pero no se encuentra ninguna. En el interior se anotaba en una plantilla impresa el número del niño, año de exposición y folio, las fechas del bautismo, de exposición y de salida, el nombre de la nodriza y de su marido y su localidad de residencia. Bajo estos datos se podía leer el artículo 91 del reglamento de 1889

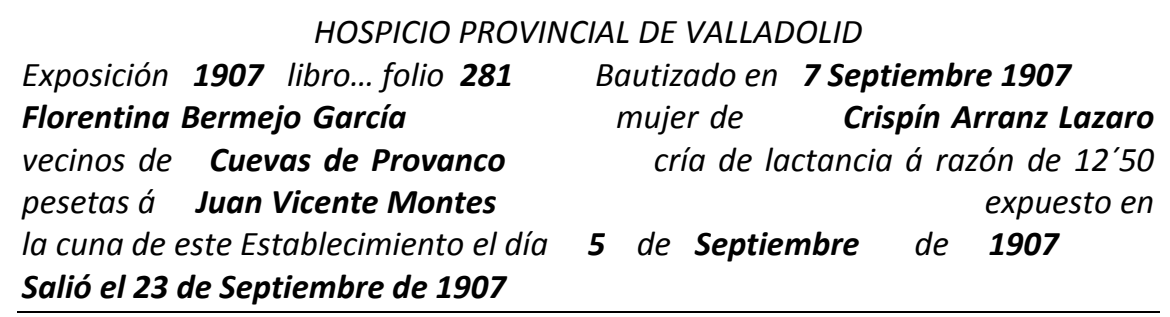

Art. 91. La nodriza que vuelva el expósito sin justificar que está enferma o imposibilitada para criar, se la suspenderá el pago de lo que se le adeude hasta indagar la causa que haya podido indagar la devolución, y en su vista se le abonará ó perderá el débito que tenga á su favor" [sic] (en negrita lo que está escrito a mano

A continuación, la cartilla tiene 15 vales con sus respectivos resguardos, correspondientes al pago de 15 mensualidades por lactancia. Los vales, que estaban numerados, se arrancaban de la cartilla y servían como justificante de pago para el Hospicio

Talón no 15 correspondiente á la exposición no ... del lib .... fol...

Vale por 12'50 pesetas que le serán entregadas á la interesada ó persona que presente este cupón, como importe del 15o mes de lactancia, el cual se acompañará como justificante á la nómina correspondiente.

Los resguardos, que quedaban en la cartilla eran un certificado de vida que debía presentarse para el cobro firmados por el cura Párroco y el Juez municipal del pueblo de la nodriza: "Certificamos que el expósito á que se refiere esta cartilla existe hoy día de la fecha...". Así se hacía en cumplimiento del artículo 89 del reglamento de 1889

\footnotetext{
“...recibirán una póliza arreglada al modelo usual para estos casos y que deberán presentar al cobro de cada mensualidad para anotar en ella los pagos certificándose en cada póliza por el Sr Cura del pueblo donde resida y por el Alcalde la existencia del expósito y el estado en que se encuentre, sin cuyo requisito no se pagará"
} 
Con este sistema se limitaba la lactancia a 15 meses, precisamente en él puede estar parte de la explicación de las diferencias que en cuanto a su duración se producían entre unos niños y otros; lo mismo ocurriría con el destete, aunque no haya cartilla de muestra podemos imaginar que sería similar a ésta. Al haber 15 cupones en la cartilla, si no se controlaba la edad de salida del niño, a la nodriza la pagarían hasta 15 mensualidades, por lo que los niños que salían con más edad podían ver prolongada la lactancia y por la misma razón el destete.

Esta cartilla a simple vista no parece mal sistema para controlar a los expósitos en lactancia externa; la firma de dos autoridades locales debía certificar su existencia, que se encontraban en poder de la criadora y que estaban en buenas condiciones. En la realidad algo no funcionaba bien, en una sesión de la Comisión provincial en agosto de 1908 en la que se debatió la pérdida de un expósito reclamado por su padre, el diputado Visitador propuso la reforma de las cartillas "el mismo señor Alvarez, secundando al señor Gavilán en la exposición de reformas necesarias, declara que está conforme con las modificaciones que se imponen en las cartillas"766, sin embargo el cambio no se hizo hasta 1913.

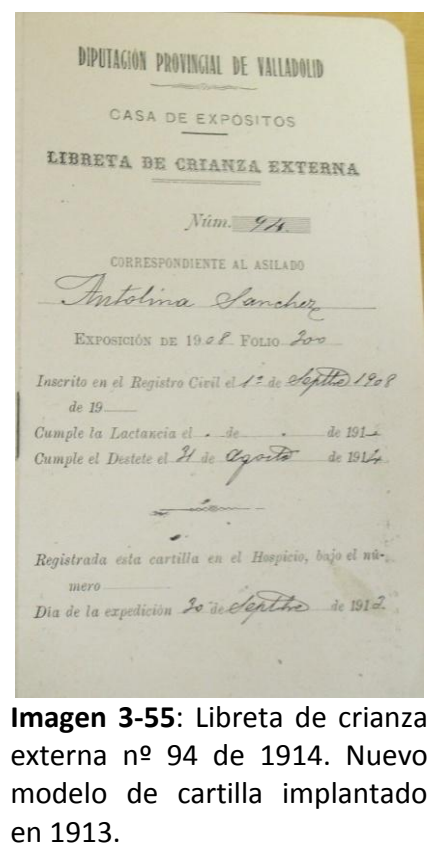
en 1913.

Las nuevas cartillas mostraban en la portada su número; el nombre, año de Exposición y Folio de inscripción del expósito; las fechas de inscripción en el Registro civil, de expedición de la cartilla y de finalización de los periodos de lactancia y destete del niño titular, además del sello del Hospicio con su número de filiación (IMAGEN 3-55). En el interior se recogían en primer lugar algunos artículos completos del reglamento de 1910: el 331, que define la duración de los dos períodos de crianza y la retribución que les correspondía, el 334 sobre la prohibición de pasar el niño a otra nodriza sin autorización, el 337 sobre las obligaciones que las nodrizas contraían con el expósito, el 339 sobre los pagos, el 341 sobre el fallecimiento del expósito y el 342 y 343 sobre la posibilidad de prohijamiento y el compromiso que conllevaba. A continuación se reseñaban tres Advertencias Importantes y después la Diligencia de Salida con la fecha de la primera vez que le sacaban "para su crianza externa" firmada por el director del Hospicio.

\footnotetext{
${ }^{766}$ N.C. 2- 02- 1908, p 2
} 


\section{ADVERTENCIAS IMPORTANTES}

19 No se pagará cuota alguna sin previa presentación de esta libreta y del certificado de existencia del niño ó del fallecimiento en su caso

2a Si la cobranza se verifica con autorización, ésta tendrá que presentarse suscrita por la criadora ó su marido, si es casada, ó por un testigo á ruego si no sabe firmar

3a Esta libreta acompañará al niño en todas sus situaciones de crianza, por lo que debe ser entregada en el Establecimiento al propio tiempo que aquel ó acompañada del certificado de su defunción, suspendiéndose, en otro caso el pago de las cuotas devengadas

En la página siguiente se registraban los datos de las nodrizas, nombre, localidad y fechas en que el niño era entregado y devuelto a la Inclusa. En cada cartilla se podían registrar hasta cinco nodrizas. En las hojas restantes se anotaban los pagos: fecha, concepto (lactancia o destete) y la cantidad.

Si no presentaban la cartilla no cobraban, como se dice en las advertencias, en algunos folios de los libros de cuentas de las amas y en papeletas de pago se han registrado anotaciones del tipo "Suspendida hasta que traiga la cartilla"

Los pagos se hacían cada dos meses, siempre a mes vencido y en las fechas que fijaba la Diputación y que se anunciaban en la prensa local

"La ordenación de pagos de esta Diputación provincial ha dispuesto que desde el día 23 al 30 del corriente, ambos inclusive, se abra el pago de los haberes devengados por las mujeres que lactan y cuiden niños del Hospicio provincial, correspondientes á los meses de Noviembre y Diciembre últimos"

A las nodrizas de la capital el nuevo reglamento de 1910 les exigía acudir con el niño para cobrar y si éste no tenía buen aspecto se lo retiraban hasta examinarlo el médico

Art. 339. ...Si las nodrizas son de la capital presentarán en el acto del cobro al expósito para cerciorarse del estado de su salud y asistencia, haciendo que sea reconocido por el Facultativo en el caso de observar en el expósito aspecto enfermizo. Cuando del reconocimiento resulte que el niño está en mal estado por descuido o abandono, no se abonará a la nodriza cantidad alguna y le será aquél retirado y vuelto a la Inclusa, y si consiste en que no se halla en condiciones de criar se la abonará lo que alcance, pero se la privará del expósito. Art 339 Regl 1910

Las mujeres de los pueblos no tenían que presentar al niño en todo el período de crianza; en su lugar, debían presentar certificado médico y de vida, como recordaba la cartilla

Art. 340. Si las nodrizas son de fuera de la Capital presentarán con la libreta que se las entregó certificación del Alcalde y Facultativo titular en que conste que el expósito vive y está bien cuidado.

\footnotetext{
${ }^{767}$ N.C. 21-01- 1900, p 1
} 
El reglamento de 1910 ordenaba que el certificado lo firmara el alcalde y, el médico del pueblo, en vez del cura como se pedía en 1889. El Hospicio disponía de unas papeletas oficiales en las que el Juez municipal de la localidad de la nodriza certificaba "que el niño... que está al cuidado de (la nodriza) de esta vecindad, se halla en la actualidad existente". En el reverso se encontraba la autorización que "la criadora que no pueda presentarse al cobro firmará por sí, o por testigo a ruego"

\section{"AUTORIZACIÓN PARA COBRAR}

La que suscribe autoriza a .... vecino de .... Para cobrar en la dependencia correspondiente de la Excma. Diputación provincial de Valladolid las cuotas pendientes de pago por la crianza de .. I niñ.. a que se refiere la certificación de la vuelta.

Fecha y firma de la interesada o testigo a ruego"

Se conservan en el Archivo provincial unas cuantas de estas papeletas de cobro, llevan la firma del alcalde o del juez municipal de la localidad de residencia de la nodriza certificando que el expósito al que se refieren "se halla en la actualidad existente", en ninguna de ellas aparece firma ni reseñas de un médico; pero sobre todo lo que más llamó mi atención es que en muchas de ellas aparecen repetidamente las mismas personas autorizadas: Celedonio Martín Moretón de Tiedra, Tomás Martín de Torreadrada, Fabián Calvo de Tejares y Mariano Sacristán de Fuenterrebollo. Estos hombres serían lo que en distintos documentos llaman comisionados, ordinarios, apoderados o intermediarios; recordemos la lista de ropa que se entregó "al comisionado Mariano Sacristán para la niña Ma Teresa Fernández Rojo"; en el libro de exposiciones de 1910 en el folio 210 se dice que la niña Obdulia Martínez "fue devuelta a este Establecimiento por el comisionado Juan Calvo con oficio del Alcalde de Aldeonsancho". Las localidades de todos ellos se sitúan en las zonas de mayor densidad de nodrizas, Tiedra al oeste y al sureste en la provincia de Segovia (ver mapa en IMAGEN 3-54)

Según el diccionario de la RAE de 1889 un comisionado es el "encargado por un cuerpo, comunidad ó sujeto particular para entender un negocio" y entre las acepciones de ordinario se encuentra la de "arriero ó carretero que habitualmente conduce personas, géneros u otras cosas de un pueblo a otro" ${ }^{\prime 768}$. Estos comisionados eran particulares que hacían de intermediarios entre las nodrizas de los pueblos más alejados y el Hospicio, cada dos meses se acercaban a Valladolid los días de cobro fijados por la Diputación con las cartillas, los

\footnotetext{
768 Diccionario de la lengua castellana por la Real Academia Española. Décimatercia edición. Madrid. Imprenta de los Sres. Hernando y compañía. 1899. Comisionado: p 245,2. Ordinario: p 717,2.

La Enciclopedia Espasa da otras acepciones: Dícese del correo que viene en períodos fios y determinados, a distinción del extraordianrio que se despacha cuando conviene. Recadero. E. Espasa, tomo 40, pp 220-221
} 
justificantes y las autorizaciones de las nodrizas para cobrar en su nombre. Salvo el residente en Tiedra, los demás eran de los pueblos de Segovia y cubrían las localidades más alejadas de la capital hacia el sureste.

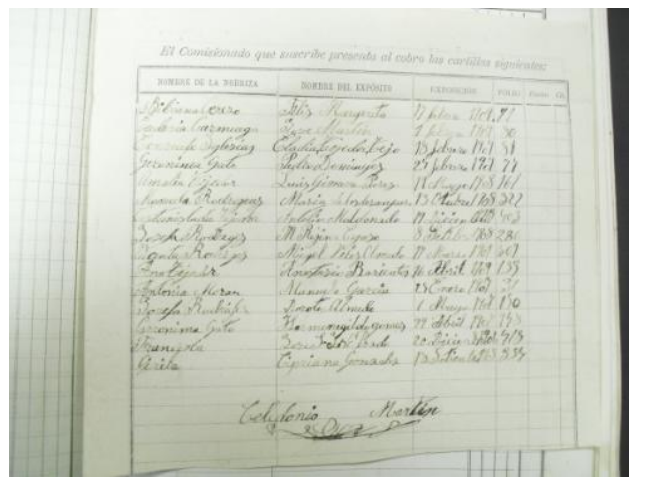

Imagen 3-56: Lista de cartillas que cobraba el comisionado Celedonio Martín. ADPVA
Se conserva una cuartilla manuscrita con la "lista de las cartillas que presenta al cobro Valentin Gallego por los meses de Setiembre y Obtubre" (sic). En ella aparecen los nombres de 22 mujeres y junto a ellas lo que compruebo que se trata del folio y año de exposición de los expósitos a su cargo, todos inscritos entre 1889 y 1903. Los nombres de las nodrizas de la lista coinciden con los que aparecen registrados en los folios referidos, salvo el que corresponde al no 261 de 1900, en él no figura la misma mujer que en la lista y el niño inscrito en ese folio falleció en 1900. Las nodrizas en su mayoría son de Castrillo de Duero, las demás de Valdezate, Torreadrada, Cuevas de Provanco, Sacramenia, Peñafiel y Olmos de Peñafiel, localidades próximas entre sí. La niña del folio 303 de 1902 era también natural de Castrillo de Duero, una hija legítima que entró por la Comisión, y la nodriza residente en Sacramenia; localidades separadas unos $10 \mathrm{Km}$ en línea recta; después de la salida no hay más anotacionsen su folio. Esta situación es similar a la de la niña del folio 211 de 1903, ingresó también por acuerdo de la Comisión, era hija legítima nacida en Valdearcos de la Vega y la nodriza de Castrillo de Duero, a $8 \mathrm{Km}$ en línea recta; y se repite en la niña del folio 41 de 1902, hija legítima de Olmos de Peñafiel y la nodriza residente en Valdezate, a una distancia de $10 \mathrm{Km}$; como en muchos de los folios de los expósitos de la lista, no se han hecho más anotaciones después de la salida con la nodriza. Son circunstancias cuando menos dudosas, por la proximidad entre las localidades de las nodrizas y de algunos niños. Más llamativo es el caso de la primera ama del listado, Saturia Nava de Castrillo de Duero que devolvió a la niña que figura en la lista (fo 130 de 1903) el 22 de julio, cuando se estaban reclamando los meses de septiembre y octubre; sin más datos no podemos afirmar nada porque podría tratarse de atrasos.

Hay otra lista similar en un folio impreso y partido que en la cabecera dice "El Comisionado que suscribe presenta al cobro las siguientes cartillas:" y debajo tiene una tabla donde se recogen los campos "Nombre de la nodriza; Nombre del Expósito, Exposición, Fólio, Pesetas, Cts." (IMAGEN 3-56). Esto viene a confirmar que el Hospicio aceptaba este sistema de comisionados. En este caso se trata de Celedonio Martín y presenta 15 cartillas de niños 
ingresados entre 1906 y 1909, no figura la fecha de la presentación, pero por indicios sería de mediados de 1909. Llama la atención que una de las nodrizas, "Gerónima Gato" (sic) tiene dos expósitos, uno de 1907 (fo 148) y otro de 1909 (fo 77); en la lista, que no sigue ningún orden concreto ni por iniciales ni por fechas, se han colocado separadas, en el cuarto lugar por arriba y en el tercero por abajo, como si se quisiera camuflar. Compruebo en los Libros de Exposiciones que en efecto esta nodriza sacó a los dos niños y los tuvo durante unos meses juntos, al segundo lo sacó para lactancia el 2 de marzo de 1909 y al primero, que ya estaba en destete, lo devolvió el 20 de septiembre de ese mismo año, mejor dicho, el niño pasó a manos de otra nodriza de la misma localidad, en el folio de inscripción dice "En el mismo día le llevó Antonia Tejedor viuda, vecina de Tiedra" (fo 148 de 1907); como es habitual no se dan explicaciones en los folios. Hay dos nodrizas en la lista que solo figuran con el nombre de pila, Francisca y Cirila y que no he conseguido localizar en los libros, ni sus nombres ni los de los expósitos aparecen en los folios indicados, es más, el libro de 1906 no tiene un folio con el número 418 que aparece en el listado asociado a Francisca porque solamente se hicieron inscripciones hasta el folio 394; tampoco aparece en ese folio en otros años. Hay otros 2 nombres de la lista que no se encuentran en los folios indicados; Miguel Vélez no ocupa el folio 309 de 1909 como dice el listado, lo encuentro en el libro de 1907, en este caso el error puede deberse a que la nodriza "Vicenta Rodríguez Martin viuda vecina de Tiedra" lo sacó el 17 de marzo de 1909, fecha que se ha anotado en la que corresponde a la de exposición. Al otro niño y a su nodriza no he conseguido encontrarlos en estos años. Este comisionado era de Tiedra y todas las nodrizas que he podido localizar son también de allí o de lugares próximos como Puebla de Sotiedra o San Pedro de Latarce. Se repiten situaciones similares a las de la otra lista, aunque en ésta no se encuentra coincidencia ni proximidad entre las localidades de los expósitos y de las nodrizas, a cambio, encontramos que cuando se se hizo un "traspaso" el expósito fue a parar a una nodriza de la misma zona.

Entre las hojas del libro de amas de 1910 hay una carta que transcribo íntegra por ser muy interesante no solo en relación con ese tema; una nodriza escribe al Hospicio para reclamar unas cuotas que no ha cobrado y que corresponden al tiempo transcurrido desde que la nodriza anterior le traspasó el expósito hasta que el Hospicio reconoció el cambio

"Cantalejo 29 de Marzo de 1911

Señor Director del Asilo de niños espositos

Muy señor mio. Al asilo que $V$. tan dignamente dirige pertenece la niña Francisca Melero Martin que en el mes de Enero de 1910 se la dieron para criarla a Demetria Blanco San Jose esposa de Pablo Sanchez residentes en la Puebla de Pedraza (Segovia) y a causa de esta no poderla criar se la cedió a la que suscribe Simona Merino esposa de Pedro San Inocencio domiciliados en esta villa de Cantalejo en Mayo del mismo año y como quiera que hasta el mes de 
septiembre de espresado año no me fue adjudicada esa niña por esa casa asilo, se me adeudan los cuatro meses que transcurrieron sin adjudicármela motivo a que en la cartilla consta que la criaba la Demetria, y con el fin de cobrarlos le fue dada la mencionada cartilla al ordinario Mariano vecino de Fuenterrebollo como encargado de cobrar para que lo efectuara, el cual me dice que hasta la fecha no se lo han abonado y que la cartilla la dejo en ese establecimiento; en vista de lo expuesto me dirijo á $\mathrm{V}$. por medio de la presente á fin de que si lo cree justo ordene me sean satisfechos el importe de los cuatro meses citados aun cuando sea a nombre de la Demetria que esta me lo entregara a mi, y en caso de que ya lo haya cobrado el ordinario ya espresado tenga la bondad de decírmelo para reclamarle a él dicha cantidad pues en atención a disponer de muy pocos recursos me es de necesidad cobrar lo antes posible.

Dándole las gracias anticipadas se ofrece á V...

á ruego por no saber firmar"

Leyendo entre líneas se entiende que el traspaso de la niña se hizo de forma particular y el Hospicio dio la conformidad más tarde, de esta manera las dos mujeres se evitaban los trámites y podían seguir cobrando, una u otra; la nodriza que reclama reconoce su situación de necesidad económica y parece que no se fía totalmente del ordinario, porque pregunta si las cuotas pendientes ya las había cobrado éste, aunque no dice el apellido es uno de los que hemos comentado anteriormente y que aparece en las papeletas de cobro, Mariano Sacristán de Fuenterrebollo. En el Libro de cuentas corrientes con las amas externas se hizo una anotación en 1911, cuando la niña estaba ya con una tercera criadora ${ }^{769}$

"En 15 de noviembre se satisfizo á Mariano Sacristan apoderado de Demetria Blanco los meses de Marzo, Abril, Mayo Junio Julio Agosto y 14 dias de septiembre que como 19 ama de esta niña se debían del año 1910"

El 1 de junio de 1911 la niña volvió a ser traspasada por el mismo sistema a una tercera nodriza también de Cantalejo, el mismo pueblo de su predecesora; en el folio de inscripción se han anotado la devolución y la salida con la misma fecha.

Los comisionados no figuraban en las nóminas de la Diputación, aunque se reconociera su labor de intermediarios; eran particulares y por tanto hay que suponer que recibirían alguna "gratificación" por parte de las nodrizas. Viendo tantas irregularidades como las que se han detectado en relación con las nodrizas externas, como cambios de ama no autorizados o fallecimientos no comunicados, y sobre todo en las localidades más distantes, que coinciden

\footnotetext{
769 La niña en cuestión se encuentra inscrita en el libro de Exposiciones de 1909, tomo 2, folio 411 y, como dice la carta, en él consta que salió con Demetria Blanco el 17 de enero de 1910, que la devolvió el 14 de septiembre y la sacó Simona Merino de Cantalejo, la autora de la misiva, el día 15. No se reconoce por tanto el cambio hasta esa fecha, de hecho los atrasos se le pagan a Demetria Blanco porque solamente había percibido dos meses. Estas fechas coinciden con las que se han registrado en el folio 411 del Libro de cuentas corrientes con las amas externas. Lactancias de 1909. Después de la tercera nodriza, la niña regresó al Hospicio con 5 años y ya no volvió a salir hasta los 13 años, en 1922, para compañía. Hasta que se emancipó a los 22 años fue entregada a dos familias más para el servicio de la casa.
} 
con las zonas que tenían comisionados conocidos, no resulta disparatado suponer que estos hombres podrían estar detrás de muchas de ellas. La exigencia de justificar la devolución del niño a riesgo de perder el salario ya ganado puede ser una de las razones de estos intercambios entre nodrizas a espaldas del Hospicio y los comisionados o intermediarios podrían haber mediado en el traspaso de más de uno; la vuelta al Hospicio del niño podía suponer para ellos perderlo, tanto si se quedaba interno como si era destinado a un pueblo que quedara fuera de su área de influencia. Los casos comentados de las nodrizas de la lista del comisionado Valentín Gallego recogen circunstancias más dudosas, demasiada cercanía entre las localidades de las nodrizas y las de origen de algunos niños y sobre todo que éstas últimas se encuentren dentro del área de influencia del comisionado. Que muchos de los folios de inscripción de este listado dejen el final del historial de los niños en blanco provoca también desconfianza, máxime cuando se trata de hijos legítimos de la zona y sabiendo que, como veremos, muchos niños acababan con sus padres de forma no reglamentaria.

Son situaciones que hacen pensar en la existencia de cierta "mafia" en torno a los expósitos y las nodrizas, una cuestión interesante para estudiar más a fondo. Lamentablemente este sistema de intermediarios y las irregularidades con las nodrizas debía ser común. Bárbara A. Revuelta en su tesis sobre la inclusa de Madrid habla también de agentes encargados del cobro de las crianzas, que en Madrid era trimestral, y recoge la denuncia que hacía Philip Hauser ${ }^{770}$ en 1902 de este sistema que explotaba a las nodrizas externas de manera que los intermediarios se encargaban de los cobros y adelantaban el dinero a las nodrizas con una importante comisión que rebajaba la retribuciones que recibían estas mujeres que ya eran bajas de por sí. En otras inclusas, como la de Barcelona hasta los primeros años del siglo $\mathrm{XX}$, no se exigía a las nodrizas recoger al niño personalmente, en su lugar tenían mujeres que llamaban conductoras que sacaban a los expósitos y los repartían entre las nodrizas a cambio de una comisión ${ }^{771}$. No he encontrado más indicios que los aquí mostrados, que son muy sugerentes pero no prueban de forma concluyente la existencia del sistema de explotación de las nodrizas que denuncia Bárbara Revuelta, ni cómo se ejercía; sin embargo, no andamos descaminados sospechando que la intervención de estos comisionados no era honesta, digamos que no en todos los casos, desde luego no era desinteresada, prueba de ello es la propuesta que hace un diputado en 1917 para terminar con este sistema

"El señor Rico propone que se nombre en cada cabeza de partido un individuo que se encargue de pagar a alas nodrizas que lactan niños del Hospicio,

\footnotetext{
${ }^{770}$ HAUSER P.: Madrid bajo el punto de vista médico social. Madrid 1902

771 REVUELTA EUGERCIOS B.A: op. cit., p 338 y RODRÍGUEZ MARTín A.M.: La Casa de Maternidad y Expósitos de Barcelona, 1872-1903, citado .por REVUELTA EUGERCIOS
} 
evitando que los intermediarios que ahora las representan para el cobro de sus haberes, las exploten. Además podrían servir para inspeccionar la crianza.

El señor Allué indica como más fácil que se las pague mediante el giro postal. El señor Moncada propone que se haga el pago utilizando los capataces de peones camineros ${ }^{\prime \prime 772}$

\subsubsection{Madres y nodrizas}

En los libros encontramos casos de niños que volvieron con sus padres sin que el Hospicio tuviera constancia de ello, fueron recuperados directamente de las nodrizas sin la mediación del Hospicio ni la aprobación de la Comisión provincial

"En 26 de Abril de 1912 á las 23 y 30 minutos fue expuesto en el torno de este Asilo con un papel que dice "Andrés Pernia Verdejo nació el 27 de Febrero de 1912= esta bautizado é inscripto en el Registro civil como hijo natural le reclamaran sus padres en su dia hoy no pueden». Por ropas traia unos trapos. ... En 27 de Abril de 1912 le llevó Evarista Prado mujer de Magin Gomez vecinos de Villanubla.

Baja definitiva por hallarse en poder de sus padres" [sic] (fo 152 LE 1912-1)

La vuelta con los padres de este niño no se hizo por la vía reglamentaria, pues siempre se hacía constar en el folio de inscripción la aprobación de la Comisión provincial y el día de la entrega, firmando los padres o alguien en su nombre. Debió pasar de la nodriza a los padres directamente; es de los pocos casos en que los padres pudieron cumplir con el deseo expresado en la nota de la exposición de recuperar a su hijo. El siguiente niño, Timoteo, murió en su pueblo natal y en su folio no dice que estuviera con la nodriza, lo que puede tener dos explicaciones: o bien los padres consiguieron localizarlo y recuperarlo o se hizo una salida fraudulenta de la Inclusa

\section{"Timoteo de la Torre Reyes}

En 20 de Julio de 1912 ingreso por acuerdo de la Comisión provincial con certificación del Registro civil de Olmos de Peñafiel donde dice que nació el día 25 de Marzo de 1912 y que es hijo de Adriano y Tomasa...

En 27 de Julio de 1912 le llevo Valentina Bermejo, mujer de Francisco Perez vecinos de Cuevas de Provancos (Segovia)

Falleció en Olmos de Peñafiel en 7 Agosto de 1917" ' [sic] (fo 265 LE 1912-2)

La distancia entre las dos localidades, Cuevas de Provancos, residencia de la nodriza, y Olmos de Peñafiel, naturaleza del niño, no llega a $10 \mathrm{Km}$. En todo caso el cambio de localidad del niño se hizo a espaldas del Hospicio ya que, la nodriza debía comunicarlo y si el traslado era fuera de la provincia lo tenía además que autorizar la Comisión provincial

\footnotetext{
${ }^{772}$ N.C. 5- 05- 1917, p 2
} 
"Por orden del Sr Presidente se autorizo al Tomás Herrero el traslado de la niña Herminia Alonso a Benasain" [sic] (fo 6 LE 1905-1)

Como vimos, los parientes del expósito podían recogerlo directamente para ahorrarse los costes del traslado, o para agilizar el trámite, pues de lo contrario una vez resuelta la reclamación tenían que esperar a que el Hospicio se lo notificara a la nodriza y que ésta devolviera al niño y algunas, por alargar la cobranza o por pena, debían hacerse las remolonas. En alguno de los justificantes de pago conservados se leen notas, generalmente escritas a mano, del tipo: "se suspende hasta que traiga el niño que está reclamado". Cuando la nodriza entregaba directamente el expósito a sus padres de forma reglamentaria se reflejaba en los libros junto con la autorización oficial: "Fue entregada por la nodriza a sus padres según oficio del Sr Vicepresidente de la Comisión Provincial" (fo 366 LE 1909-2), "Entregado a su madre por la criadora según oficio del Sr Director" (fo 167 LE 1913-1). Los padres se trasladaban hasta el lugar de residencia de la nodriza llevando la autorización correspondiente, que debían presentar a la autoridad local ${ }^{773}$

"3 nobre- 1928 esta fecha cumpliendo el acuerdo de la Comisión
provincial del día 4 de Abril último se entrega un oficio de esta Dirección para el
Sr Alcalde de Valtiendas (Segovia) a su madre Alejandra Olmos Aranda mayor
de edad casada vecina de Villaverde de Iscar (Segovia) con el fin de hacerse
cargo de su hijo, la cual firma esta diligencia en prueba de conformidad y de
hacerse cargo del mismo" [sic] (fo 8 LE 1913-1)

Por todo lo visto es razonable la sospecha de que había alguna irregularidad en esas situaciones que hemos comentado en que los niños aparecían o fallecían en su pueblo de origen sin que en los libros se haya recogido el cambio de localidad o cuando simplemente se anotaba que se les daba de "baja definitiva por hallarse en poder de sus padres"

Aunque en algunas ocasiones se admitieron a sabiendas como nodrizas internas a madres que habían depositado a su hijo en el torno, el Hospicio no era tan tolerante con las nodrizas externas. En el primer caso se veía beneficiado en el sentido de que conseguía junto al expósito un ama de cría para alimentarle, que, a mayores, podía lactar algún niño más; de no alimentarle la madre tendría que hacerlo otra ama. Si se admitía que un niño externo fuera criado por sus propios padres a cargo del Hospicio, se abría la veda a muchas familias necesitadas y a la picaresca; la lista de candidatos y los gastos generados podrían ser interminables. Sin embargo, no hay más que revisar los libros; es evidente que no había

773 Este niño fue expuesto en el torno el 6 de enero de 1913, nació en Pedrajas de San Esteban en noviembre de 1912 y su madre entonces era soltera. Salió con una nodriza el 14 de enero de 1913 y todavía estaba con ella en calidad de prohijado cuando le recogió su madre; estaba a punto de cumplir 16 años. 
suficiente control, una función que debía realizar la dirección desde dentro del Hospicio y el diputado Visitador desde fuera por parte de la Diputación, hasta el punto que hay folios en los que se ha registrado la suspensión de pagos a la nodriza por irregularidades de este tipo después de meses incluso de más de un año de su contratación. Son casos que forman parte de ese grupo de niños que salían el mismo día que entraban y que por las fechas podrían ser también parte de los chanchullos del auxiliar Montiel:

"Juana Martin

En 6 de Agosto de 1913 á las 21 fue expuesto en el torno de este Asilo con un papel que dice La niña se llama Juana Martin bautizada el dia 27 de mayo en San Llorente. Por ropas traia puestos unos trapos ...

En 6 de Agosto de 1913 la llevó Manuela Cuesta mujer de Alejandro Martin vecinos de Castro de Fuentidueña. Segovia.

1904- 08- 21. Por acuerdo de la Comisión Provincial se suspendió el pago por ser la hija de la criadora" [sic] (fo 279 LE 1913-2)

En la inscripción solo se anotó el primer apellido de la niña, aunque da a entender que disponían de las partidas de bautismo y del Registro civil, de esta manera no resultaba tan llamativo el fraude pues ya coincidía el apellido de la niña y el del marido de la criadora.

En otras ocasiones se pudieron falsear los datos en el folio de inscripción; la niña Elisa Martín Yagüe fue entregada el mismo día que salió a "Isabel Esteban, mujer de Santos Martín vecinos de Fuentenebro" (Burgos). Se le dio de baja definitiva porque "Ia criadora que figura en la nota anterior es madre de la asilada", no se ha apuntado fecha. Nótese que en el folio no coinciden los apellidos de madre e hija. (fo 343 LE 1913-2).

Y la mayoría de las veces no se dan razones, simplemente se da de baja al niño por encontrarse con sus padres, sin que conste en qué momento fue con ellos

"En 1o de Abril de 1911 la llevó Petra Gomez mujer de Máximo Martin vecinos de Rabano

Suspendido pago por acuerdo de la Comisión P por hallarse con sus padres" [sic] (fo 97 LE 1911-1)

"En 29 de Enero de 1913 la llevó María Castro Vicente mujer de Pedro Garcia vecinos de Pradales

Baja definitiva por estar con sus padres" [sic] (fo 36 LE 1913-1)

"En 25 de Febrero de 1913 la llevó Ignacia Velasco Pecharromán mujer de Raimundo Barbudo vecinos de Aldeasoña (Segovia)

Baja definitiva por hallarse con sus padres" [sic] (fo 79 LE 1913-1)

Las niñas de estas dos últimas citas nacieron en Rabano (Valladolid), la segunda (fo 79) ingresó por acuerdo de la Comisión y fue con la nodriza a Aldeasoña (Segovia), a menos de 7 $\mathrm{Km}$ de Rabano. Podríamos pensar, dada la proximidad de las dos poblaciones, que se entregó para crianza de forma fraudulenta a sus padres. En todo caso, el traspaso de la nodriza a los 
padres se hizo a espaldas del Hospicio, pues no se ha registrado ni el acuerdo de la Comisión, ni la fecha de entrega, ni aparece la firma los padres o de alguien en su nombre aceptando.

Este tipo de situaciones no eran exclusivas de nuestro Hospicio. En la inclusa de Pontevedra contaban con algunas "nodrizas sin retribución" que sacaban a los expósitos y que en muchos casos, según comenta Ana M Rodríguez, ${ }^{774}$ eran las propias madres de los niños y así lo acababan reconociendo algunas. Esto sería una forma de recuperar al hijo sin tener que reconocerlo, lo que podría ayudar a "tapar la falta" en caso de hijos naturales habidos antes del matrimonio; de todas formas no suponía un fraude como los que venimos comentando, sino que para el Hospicio sería una situación ventajosa al ahorrarse un salario por crianza.

\subsubsection{Vigitancia de externos}

Los reglamentos disponían que los expósitos de los pueblos debían ser controlados por las autoridades locales, alcalde y cura párroco. En 1889 se adjudicaba además a las "Señoras Socias bienhechoras nombradas en el pueblo a donde se lleve a criar el niño... que velen por el mismo con el celo que les está encomendado" (Art. 89 Regl 1889), parte ésta que se retiró en la normativa sucesiva ${ }^{775}$.

Además, para cobrar cada mensualidad, las nodrizas de fuera de la Capital debían presentar junto "con la libreta que se las entregó", en la que se registraban los pagos, "certificación del Alcalde y Facultativo titular en que conste que el expósito vive y está bien cuidado", "sin cuyo requisito no se pagará" (Art. 89 Regl 1889, Art. 340 Regl 1910 y 343 Regl 1927). Este artículo imponía un sistema de vigilancia de los expósitos y sus nodrizas que, por los indicios hallados, no podemos sino pensar que en la realidad fallaba con frecuencia. Da la impresión de que el Hospicio, que hemos visto que en ocasiones era estricto con la normativa,

\footnotetext{
${ }^{774}$ RODRIGUEZ MARTíN A.M.: op.cit., 2007, núm. 15

775 La ley de Beneficiencia de 1849 otorgaba a las Juntas de Damas la función de auxiliar a las Juntas Provinciales de Beneficencia en la inspección de los expósitos y de las maternidades, en su artículo 12 ordenaba establecer donde fuera posible "Juntas de señoras... que cuiden de las casas de expósitos... de las de maternidad, de las de párvulos o de cualquier otro establecimiento de beneficencia que se considere análogo". Desaparecían en 1868; el Real Decreto de 27-4-1875 creaba la Junta Central de Señoras y promovía la creación y organización de juntas locales de señoras auxiliares y el R.D. de 17-7-1884 las Juntas de Señoras para colaborar con diputaciones y ayuntamientos en la supervisión de los los expósitos y centros benéficos femeninos e infantiles. MAZA ZORRILLA E.: Pobreza y asistencia social en España, siglos XVI al XX. Valladolid. 1989; RODRÍGUEZ MARTíN A.M.: La participación femenina en la beneficencia española. La junta de damas de la casa de maternidad y expósitos de Barcelona, 1853-1903. 2014; PÉREZ MOREDA V.: La infancia abandonada en España: (siglos XVI-XX). Discurso de ingreso en la Real Academia de la Historia
} 
en otras se relajaba demasiado y no verificaba su cumplimiento. Entre los expedientes que se han podido consultar se encuentran las papeletas de pago mencionadas anteriormente con la firma del juez municipal; no consta en ellas informe ni firma de médico alguno y tampoco hay certificados médicos entre la documentación de dichos expedientes. Si el sistema funcionaba correctamente, y no podemos afirmar que nunca lo hiciera, esto no debía constituir un inconveniente, el Hospicio sobreentendía que las autoridades locales como responsables de custodiar a los expósitos no sólo certificaban que estaba vivo, como se afirma en la papeleta, sino también que estaba siendo cuidado adecuadamente. Así ocurrió en el caso de la niña Obdulia Martínez, que reingresó a instancias de las autoridades locales por estar mal cuidada

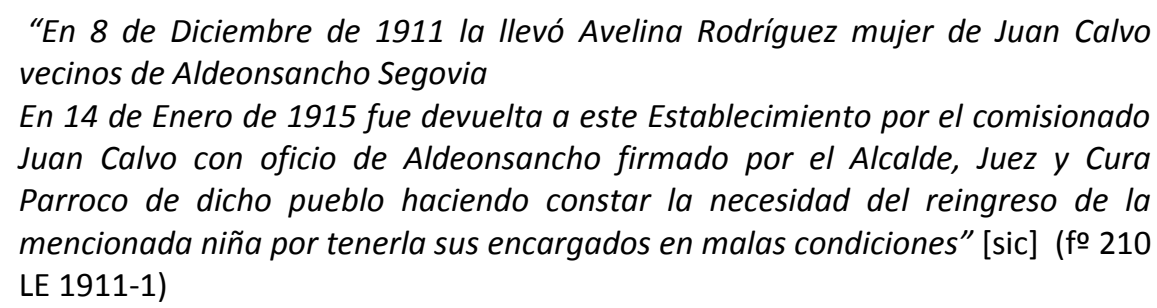

Aunque este ejemplo puede demostrar que el sistema funcionaba, al mismo tiempo lo pone en entredicho. Resulta llamativo que Obdulia, que por entonces contaba más de 6 años, llevaba 4 años con los cuidadores sin que al parecer nadie se apercibiera de su situación; obsérvese también que el comisionado que la devolvió se llama, "casualmente?", igual que el marido de la nodriza. Las autoridades tomaron medidas pero diríamos que un poco tarde.

El principal problema de este método era dar por hecho y cargar todo el control en ayuntamientos, médicos y párrocos locales, que podían verse comprometidos con estas funciones de inspección, sin mantener una vigilancia más cercana de los expósitos y de las nodrizas. Hay en los libros muchos ejemplos que ponen de manifiesto la falta de supervisión, directa e indirecta, por parte del Hospicio y que cuestionan este sistema en el que la Diputación parece que se limitaba muchas veces a pagar por tener a los niños "colocados" fuera del asilo sin valorar sus condiciones de vida. Al niño Luis López Roldán (fo 111 de 1913) en 1913 “le llevó para destete Vicenta Rodríguez Martín de estado viuda y vecina de Tiedra" y lo devolvió en enero de 1916; en su folio se ha anotado que "Esta criadora no debe llevar más niños por haber devuelto a éste lleno de miseria". Al menos en 1913 no le entregaron más expósitos, pero es lamentable que en más de dos años nadie advirtiera el estado de Luis hasta que regresó al Hospicio; el mecanismo establecido para el control de los expósitos en los pueblos, léase autoridades locales, no siempre funcionaba. 
En la documentación encontrada comprobamos que las autoridades locales cumplían a requerimiento del Hospicio o de las nodrizas, el alcalde de Tudela de Duero responde al director ante la demanda de información sobre los expósitos de su localidad

“... tengo el honor de contestar que el niño Jose Maria Vicente Rodriguez se
halla en poder de Genara Redondo mujer de Juan Vela los cuales residen en esta
población, debiendo significar á V.S. que segun antecedentes adquiridos dicho
niño se encuentra bastante delgadito tal vez por falta de la lactancia necesaria
efecto de la mediana ó mala alimentación que tiene la Genara por escasez de
recursos como pobres jornaleros del campo.
Al propio tiempo cumplo con el deber de decir á V.S. por lo que pueda interesar
á ese establecimiento benéfico, que según han oído en la vecindad á los
referidos Genara y Juan, se están preparando para marcharse inmediatamente
de esta villa, con dicho niño á la población de Zafra en Extremadura.
Dios g á V.S. ma
Tudela de Duero a 11 de Septiembre de 1906
[firmado por] El Alcalde accidental Tomás Presencio" [sic]

La carta se encuentra en el Libro de Salidas de 1905-09, en el folio que corresponde al no 374 del Libro de Exposiciones de 1905, tomo 2. En ninguno de los dos dice si se retiró el niño a estos criadores pero debió ser así porque en el primero solo se han anotado pagos hasta el 20 de septiembre de 1906 y en el segundo se ha registrado que volvió con su madre el 31 de diciembre de 1906. No deja de resultar sospechoso que la madre, soltera, era natural de Badajoz, se encuentra registrado porque dio a luz en el Hospital provincial, y que los criadores pensaran en trasladarse a esa provincia, no se puede establecer relación entre ellos a simple vista porque los apellidos, al menos los registrados, no coinciden.

El Hospicio podía retirar el niño a la nodriza si incumplía con su cuidado, se demostraba maltrato o negligencia

Art. 90. Así como las nodrizas podrán devolver prematuramente al Establecimiento la criatura que reciban, así éste está en el deber de reclamárselas si su conducta diere lugar á ello. Regl 1889

Aunque en los demás reglamentos no se recoge literalmente este artículo, se sobreentiende cuando exigen que las criadoras tengan a los niños bien cuidados. Cuando el Hospicio o la Diputación tenían conocimiento de situaciones de falta de cuidados o de malos tratos, casi siempre por denuncias que en los libros no se suele recoger de quién venían, se abría la investigación pertinente y si se demostraban ciertas se reingresaba al expósito. Son historias que se encuentran con más frecuencia en los libros de mayores, pero en los de Exposiciones encontramos también algunas, niños retirados a las nodrizas y reingresados al Hospicio porque se les tenía mendigando o en muy malas condiciones 
"El día 27 de Marzo de 1905 la llevo Brigida Gonzalez mujer de Severino Cerbeño vecinos de esta ciudad habitando en la calle Portillo de Balboa no 2 En 9 de diciembre de 1910 reingreso en este Asilo por haber sido recogida por la Direccion á virtud de denuncia de que los que la tenían son muy pobres y no podían mantenerla teniendo que dedicarla á pedir limosna. Todo lo que fue comprobado" [sic] (fo 80 LE 1905-1)

No siempre se puede hablar de maltrato intencionado, por acción u omisión, y éste puede ser un ejemplo de ello. En 1921, cuando la muchacha de esta historia tenía 16 años, fue entregada de nuevo, por acuerdo de la Comisión, a los mismos que la tuvieron, "a Severino Cerbeño empleado en el Exmo Ayuntamiento residente en la calle Democracia núm 3"; parece que su situación económica había mejorado, así se hace ver en el registro, y la reclamaron. Aunque en su día la niña no fuera más que una fuente de ingresos para este matrimonio, como en la mayoría de los casos de nodrizaje, un final así ayuda a conciliarnos con la triste historia de expósitos y nodrizas porque deja entrever que no siempre el único móvil era económico y que en esta relación también podía haber mucha humanidad.

La distancia sin duda era un condicionante importante a la hora de controlar a los hospicianos externos, era un problema común a todas las inclusas en relación con la crianza fuera del asilo. En la capital el control parecía más sencillo, según los reglamentos las nodrizas tenían que presentar al niño al ir a cobrar y en caso de no estar en buenas condiciones lo reconocía el médico y se lo podían retirar (Art. 339 Regl 1910 y Art. 342 Regl 1927). Sin embargo, a la vista de algunos registros encontrados tampoco en la capital la vigilancia de los niños se ejercía de forma efectiva; o no se cumplía con la normativa y se hacían los pagos sin presentar al niño o había criadores que conseguían burlar al Hospicio, se refieren prácticas en otras inclusas como presentarse con otros niños para la cobranza, es sabido que la miseria física y moral y la necesidad agudizan la picaresca

"El día 23 de Agosto del 902 la llevo Josefa Sanchez mujer de Francisco Ortega, vecinos de esta ciudad que habitan calle del Soto no 45 [añadido en lapicero] Carretera del Carmen letra F.

En 10 de Agosto de 1911 fue recogida por los Agentes de la Autoridad por encontrarla recojiendo basuras por las calles y reingresada en este Hospicio, la Comisión provincial acordó quedase en este Establecimiento y no se diese en manera alguna á los que la tenían. Pasa al libro 16 de Mayores" [sic] (fo 338 LE 1900-2).

La niña en cuestión nació en el asilo en 1900 y llevaba 9 años con la nodriza, por tanto, había sobrepasado el tiempo de crianza y estaría en calidad de prohijada, una situación que, según los reglamentos no eximía al Hospicio de su responsabilidad sobre los expósitos. Podemos concluir lo mismo que en el caso anterior, el Hospicio y la Diputación actuaban de 
forma correcta y no dudo que prontamente en cuanto tenían conocimientos de situaciones de este tipo, sin embargo fallaba el mecanismo para detectarlas a tiempo; no hay ningún registro entre el de salida y el de reingreso, no se supo nada de ella hasta que la recogieron los agentes municipales, ni siquiera se ha anotado la condición de prohijada, da la impresión de que simplemente no se siguió su pista.

Los Libros de Exposiciones no suelen dar explicaciones sobre la devolución de los niños a la Inclusa, por lo que es difícil valorar con sus registros si se cumplían las condiciones que la normativa marcaba y si expósitos y nodrizas estaban suficientemente supervisados; en ocasiones se encuentra información adicional en otros libros. En el folio 360 de 1910 está inscrito el niño Juan de Sebastián que tuvo dos nodrizas antes de fallecer en el asilo al año de vida, no se anotaron las causas de las devoluciones; en el Libro de cuentas de las amas de 1910 se escribió "devuelto el 5 de Junio de 1905 por denuncia se lo recojio" [sic]; no dice de quien partió la denuncia ni en qué consistió y a la nodriza, que vivía en la capital, le pagaron todo el tiempo de lactancia.

Muy demostrativos del escaso control real de los externos son los casos comentados de niños que volvían con sus padres sin el conocimiento o la obligada autorización del Hospicio, pero sobre todo los casos de niños que no habían sido dados de baja y de los que el Hospicio perdía la pista durante años sin hacer nada aparentemente por localizarlos. La dejadez por parte de los responsables de la institución llegó al punto de ignorar el fallecimiento de sus acogidos

"Enrique Garcia Grande...

En 6 de Junio de 1911 le llevó Alejandra Camarero mujer de Vicente Requejo vecinos de Valdezate

18 dicbre 1916._. En esta fecha nos fue remitida la partida de defunción de este asilado, donde consta que falleció en Valdezate al mes de edad" [sic] (fo 187 LE 1911-1)

Tardaron cinco años en conocer la defunción de esta criatura, cabe preguntarse qué pasó durante este tiempo. Para que el ama cobrara su salario tendría que haber presentado el correspondiente certificado de vida; parece complicado mantener un engaño así tanto tiempo porque tendría que entregar uno falso. Parece difícil que las autoridades responsables dieran conscientemente certificados de vida falsos, y sobre todo repetidamente durante años, pero es algo que no podemos descartar; podían hacerlo de forma automática aun desconociendo el paradero de los niños para evitar enfrentamientos con los cuidadores, que eran vecinos de la localidad, o ser parte interesada por tener relaciones familiares o de vecindad; incluso es otra 
opción que las nodrizas engañaran a las autoridades haciendo pasar a otro niño por el expósito $^{776}$. Aún cuando las autoridades locales podían estar implicadas en el engaño, o simplemente tuvieran una actitud de dejar hacer, también cumplían. Se conserva una carta del Juez municipal de Mambrilla de Castrejón reiterando la defunción de un expósito ya comunicada previamente al Hospicio ante la petición de la nodriza que le había estado criando del necesario certificado para cobrar

"Tengo el honor de comunicar a $V$ que con fecha 26 de Enero del corriente año se remitió certificación del fallecimiento de Benito Toquero bermejo de dos años de edad, procedente de ese Hospicio provincial de su digno cargo, cuyo fallecimiento tuvo lugar el dia 22 del mismo mes y habiéndose presentado en este Juzgado municipal en estos últimos días Bonifacia Granado Miguel quien estaba encargada de la lactancia de dicho niño con la cartilla para que se la firmara y visto que tiene cobrado parte del mes de Marzo último, fecha posterior á la de su fallecimiento, me apresuro á comunicarlo á V. por si se hubiera estrabiado la certificación.

Dios gue á V. m.a.

Mambrilla de Castrejón á 14 de Junio de 1907.

[firmado] El Juez municipal Victoriano Palomino" [sic]

En el mes de junio, cuando se escribió esta misiva la nodriza tendría que cobrar abril y mayo y por lo que se dice en ella ya había cobrado el pago anterior de febrero- marzo a pesar de que el niño falleció en enero, cabe preguntarse quién firmó entonces el certificado de ese recibo si el niño ya estaba muerto.

Volviendo a la anterior cita sobre el niño Enrique García Grande, la otra opción que queda para explicar la tardanza en conocer su fallecimiento no es mejor porque, si la nodriza no reclamó el pago durante cinco años, nadie en el Hospicio se preocupó por saber qué era de éste niño; insisto en que aun cuando estuviera en la condición de prohijado el Hospicio tenía la responsabilidad de comprobar si vivía o no y en qué estado se encontraba. Los reglamentos disponían que las nodrizas tenían la obligación de notificar el fallecimiento de los niños a su cargo mediante la correspondiente "certificación literal de la defunción, librada por el juez municipal" (Art. 341, Regl 1910 y 344, Regl 1927). El reglamento de 1889 era más exigente y requería que el fallecimiento "se justificara por una certificación que dará el facultativo, expresando la enfermedad que hubiera ocasionado la muerte, otra del Señor Cura párroco, referente al día que hubiera recibido sepultura y la partida del sepelio del Registro civil", además de que la nodriza devolviera "el escudo y las ropas que hubiere recibido del Establecimiento, excepto la que se emplee de mortaja" (Art. 93, Regl 1889). En los folios de

\footnotetext{
${ }^{776}$ URIBE-ECHEVARRIA FLORES A. cuenta como los párrocos, responsables de dar informes sobre los expósitos y las nodrizas, intentaban evitar enfrentamientos cuando los informes eran desfavorables enviándolos de forma reservada y entregando a los interesados el visto bueno para presentarlo ante la Diputación. Marginalidad "protegida": mujeres y niños..., pp 149-150
} 
inscripción habitualmente solo se registraba la fecha y localidad de la defunción, raramente se anotaba la causa de fallecimiento de estos niños que estaban en poder de las nodrizas

El caso de Enrique García no era un hecho aislado, podían pasar años sin conocer el paradero real de algunos expósitos

\begin{abstract}
"En 5 de septiembre de 1909 la llevó Francisca Martín mujer de Luciano Blanco vecinos de Torreadrada (Segovia)

En Abril de 1916 se pidieron antecedentes del paradero de la niña que ocupa este folio y el dia 19 de Mayo remitió el Sr Juez de Torreadrada certificación de defunción, en la que consta que falleció en dicho pueblo en 13 de Octubre de 1910" [sic] (fo 280 LE 1909-2)
\end{abstract}

En este año de 1909 se encuentran en los libros otros cuatro niños en la misma situación (folios 24, 42, 49 y 253), todos ellos fallecieron entre 1909 y 1910 pero el Hospicio no se enteró hasta que en 1915-1916 solicitó "antecedentes de la situación" en que se encontraban. En estos dos años la dirección del Hospicio mandó circulares a todos los ayuntamientos donde debían residir expósitos en crianza para informarse de su paradero y estado y recibió de vuelta informes como éstos de niños que llevaban hasta más de cinco años fallecidos. Teniendo en cuenta la alta mortalidad de la época, debemos pensar en este posible final para parte de esos folios inacabados. Realmente en estas historias sin terminar caben todas las posibilidades, si triste es que el Hospicio no tuviera conocimiento del fallecimiento de los expósitos, el colmo es que tampoco lo tuviera de niños que estaban ingresados, en el folio 387 de 1912 hay constancia de esta dejadez
"En 4 de noviembre de 1912 le llevo Fructuosa Iglesias mujer de Mariano Garcia vecinos de Navares de las Cuevas
En 25 de noviembre de 1914 cumpliendo acuerdo de la Comisión provincial fue entregado a su padre debiendo hacer constar que el niño al hacer la entrega se encontraba en este Establecimiento no obstante lo que dice la nota precedente"

Todos estos hechos vienen a demostrar el incumplimiento sistemático de la normativa en lo referente a la vigilancia de los acogidos externos por parte tanto del Hospicio como de la Comisión provincial y de la Diputación como responsables últimos. No disponían de un sistema directo de control de los niños de crianza externa y de sus nodrizas; otras inclusas como la de Albacete contaban con la figura del Visitador de nodrizas, dependiente de la Diputación, que hacía visitas de inspección a lo largo de toda la provincia acompañándose del médico de la localidad y de dos testigos ${ }^{777}$. En Valladolid la vigilancia se hacía a distancia; el director del Hospicio tenía la obligación de solicitar periódicamente información de los expósitos a los alcaldes de las localidades donde residían (Art. 345 Regl 1910 y Art. 348 1927)

\footnotetext{
777 MARTÍNEZ-GÓMEZ SIMÓN L. M.: op.cit, p 287
} 
"Art. 345. Para cumplir mejor con la alta inspección y vigilancia que la Diputación se propone tener sobre los acogidos, el Director se dirigirá semestralmente a los Alcaldes en cuyos pueblos residan expósitos menores de 17 años, pidiéndoles antecedentes, con carácter reservado, acerca de su estado, asistencia, trato, educación y demás que sea conducente para formar juicio exacto de si están atendidos con el esmero correspondiente." (Regl 1910).

Los reglamentos establecían un control semestral que por lo que hemos visto no se hacía con regularidad, desde luego no con esa frecuencia. El diputado Visitador, representante de la Diputación, como responsable de controlar el funcionamiento del centro, parece que también pasaba por alto este asunto y lo mismo debemos decir de la Comisión provincial que no pedía cuentas; solo cuando saltaban las alarmas.

Aparte del control que hemos comentado anteriormente, realizado en 1915-16, solamente hay constancia documental de otros dos, uno en 1906 y otro posible en 1903. Se conservan dos cartas idénticas enviadas el 16 de enero de 1906 a los curas párrocos de Corrales de Duero y Cantalejo solicitando informes de los expósitos que debían vivir en sus localidades

\begin{abstract}
"Siendo de imprescindible necesidad para esta Dirección conocer el estado y situación en que se hallan los asilados de este Establecimiento que por cualquier causa se autorizara su salida, he de merecer de V., en bien del servicio benéfico, se sirva manifestarme el que tengan los niños que en su localidad residan; esperando de su celo me informe á la mayor brevedad de cualquiera incidente que ocurra, lo cual recibiré con la mayor reserva, agradeciéndole en nombre de la Excelentísima Diputación cuántos datos me facilite.

Dios guarde á V. muchos años.

Valladolid á 16 de Enero de 1906

El Director [firmado] Justo Esteban

Sr Cura párroco de Cantalejo" [sic) (en negrita lo escrito a mano)
\end{abstract}

Junto a ellas se encuentran las correspondientes respuestas en una plantilla impresa donde se debía anotar el nombre de las nodrizas y de los niños que tenía cada una y si estos vivían o habían fallecido y en ese caso en qué fecha. En la respuesta de Cantalejo, el 25 de enero, figuran 6 expósitos, en 5 se ha escrito "vive", hay una niña de la que se dice "se ignora por no tener noticia de ella". En la de Corrales del Duero, fechada el 6 de febrero, solamente figuran dos niñas, de la primera se dice que "falleció el día 18 de febrero de 1901" y de la segunda

"En los libros de este archivo parroquial no figura como fallecida, antes por el contrario según datos de personas, parece ser vive en Peñafiel en compañía de los padres la mencionada Basilia Gonzalez".

Se repiten historias ya vistas, niños fallecidos o de vuelta con sus padres sin conocimiento del Hospicio. También se conservan las contestaciones en enero de 1906, en la 
misma plantilla, de los alcaldes de Carrascal del Río y Castrojimeno. En la de Carrascal del Río se dan referencias de 17 expósitos y sus nodrizas, dos niños habían fallecido en marzo de 1904 y octubre de 1905 y el resto estaban vivos, de una niña dice que "se encuentra enferma" y del resto "en buen estado" o "en estado inmejorable" y en un caso que "no existe tal nodriza". En la de Castrojimeno hay un listado de 18 niños, solamente se ha anotado el fallecimiento de tres de ellos en marzo y noviembre de 1905 y en enero de 1906, del resto no se dice nada.

De 1903 solamente se conserva una carta del párroco de Fuentespina escrita en una plantilla igual a las utilizadas en los casos anteriores en la que solamente refiere una nodriza y una expósita, la niña Ángela San José que dice "vive y es tratada como á hija por su nodriza Juana Albarez vecina de esta Villa" (sic)

Todo este tipo de prácticas irregulares que hemos visto a lo largo de este apartado venían siendo habituales en las Inclusas desde tiempo atrás, fraudes y picaresca han rodeado a sus nodrizas podríamos decir que en todos estos establecimientos desde su existencia a la vista de los trabajos publicados sobre ello, desde la falta de cuidados y el maltrato de los expósitos, hasta situaciones vistas de nodrizas que querían seguir cobrando aunque ya no tenían al expósito o madres que entregaban al hijo para luego sacarlo y cobrar por criarlo ${ }^{778}$.

\begin{abstract}
"Los administradores de la inclusa tuvieron que habilitar un cuerpo de inspectores que recorriesen aquellos pueblos para poner coto a la serie de irregularidades que se venían cometiendo. Algunas nodrizas daban a beber a los niños jugo de adormidera para que no las molestasen, o restregaban sus mejillas con polvos rubificantes para hacerles parecer sonrosados y sanos ante la visita de un inspector o frente a la curiosidad de los vecinos. Otras veces vendían la carne que les había suministrado la inclusa para la dieta de los niños. Por último, en un elevado número de casos, si el niño fallecía, se ocultaba su muerte para seguir cobrando el estipendio; y asi durante años si había suerte de que no llegase por allí la inspección o se podía burlar ésta alquilando para la ocasión el niño de otra familia" ${ }^{\prime 779}$.
\end{abstract}

No vamos a cargar todas las tintas sobre las nodrizas porque, como se ha visto, algunos de los fraudes que se cometían no hubieran sido posibles sin la participación de alguien desde dentro y porque en definitiva los responsables de los niños eran los establecimientos y las Diputaciones. Endurecer la normativa pudo mejorar el control pero no fue suficiente, en

\footnotetext{
778 DEMERSON P.: La Inclusa de Madrid, Madrid 1983; REVUELTA EUGERCIOS B.A.: op. cit.; VALVERDE LAMSFUS L.: Entre el deshonor y la miseria. Infancia abandonada en Guipúzcoa y Navarra. Siglos XVIII y XIX, Bilbao 1994;. VALLECILLO CAPILLA M; Política demográfica y realidad social en la España de la Ilustración. La situación del niño expósito en Granada (1753- 1814), Granada 1990; GÓMEZ RUIZ T.: El Hospital Real de Santa María Magdalena y la Casa de Expósitos de Almería, Almería 1997; TARIFA FERNÁNDEZ A.: Pobreza y asistencia social en la España Moderna. La cofradía de San José y niños expósitos de Úbeda (siglos XVII y XVIII), Jaén 1994

${ }^{779}$ DE ARANA AMURRIO J.L.: op. cit., pp 20- 31
} 
Valladolid como en otras Inclusas faltó un sistema efectivo de vigilancia cercana de expósitos y nodrizas, lo que se pone de manifiesto entre otras cosas por la ausencia de información y documentación sobre ellos. La carencia de registros en los libros después de la salida de los niños con las nodrizas y de informes en los expedientes personales es común también en las inclusas, es el caso de la de Madrid ${ }^{780}$ o de las de Pamplona, Barcelona, Sevilla, Guipúzcoa o Pontevedra y, como considera Ana M Rodríguez Martín, creo que con razón, esta ausencia de información se debe sobre todo "a la falta de actuaciones"

En descarga del Hospicio, sin que sirva de justificación, debemos reconocer que el número de niños que tenía fuera del establecimiento era considerable y difícil de calcular ni siquiera aproximadamente, porque a los expósitos en crianza externa, que serían los más fáciles de controlar por los pagos que se realizaban a las nodrizas, había que sumar los que estaban prohijados y los que se cedían, ya de la sección de Mayores, para compañía y para trabajar. Todos ellos seguían siendo dependientes del establecimiento y en último término de la Diputación provincial hasta que se daban de baja definitiva. Los sistemas de registro y archivo disponibles y la dispersión de los hospicianos tampoco ayudaban, ni seguramente unos presupuestos limitados para tanta demanda asistencial. No podemos saber si todos estos inconvenientes se hubieran podido superar con algo más de intención por parte de quienes tenían la responsabilidad y los medios para hacerlo.

\footnotetext{
780 REVUELTA EUGERCIOS B.A.: op.cit.; refiere el mismo problema que he encontrado yo con los Libros de Exposiciones, una información muy escueta y que se limita a registrar entradas y salidas, expedientes incompletos y el resto de la información desperdigada.

${ }^{781}$ RODRÍGUEZ MARTÍN A.M.: op.cit. 2001.
} 


\subsection{Mortalidaden la inclusa}

Raro era el dia que no habia enterrillo $\sigma^{282}$

Angetitos al cieto

Dicho popular

Al hablar de forma general de mortalidad infantil, podemos entender la que afecta a toda la infancia, no obstante a la hora de hacer y valorar las estadísticas sanitarias hay que ser precisos y fijar los límites porque cada año de vida disminuye la susceptibilidad del niño y con ella la mortandad, de forma que las tasas presentan diferencias muy significativas según la edad; conviene por ello aclarar el concepto desde el punto de vista pediátrico y demográfico. La mortalidad infantil, propiamente dicha, se refiere al número anual de lactantes menores de un año fallecidos por cada mil recién nacidos vivos; se considera uno de los indicadores más importantes del estado de salud de una población y de su nivel de desarrollo social y sanitario, además de ser, como dice Antonio Arbelo ${ }^{783}$, uno de los mejores y más sensibles indicadores demográficos socio- económicos. Actualmente se prefiere utilizar como indicador socio-sanitario más

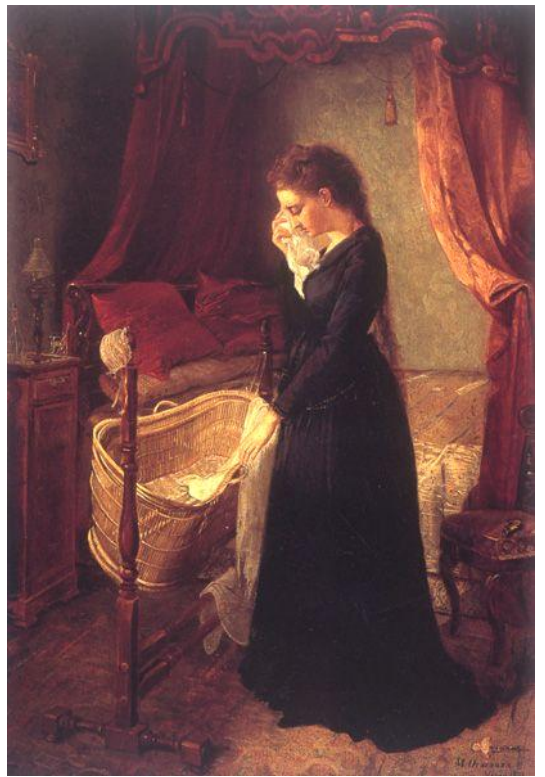

Imagen 3-57: La cuna vacía. Manuel Ocaranza, 1871 sensible la mortalidad en los primeros cinco años de vida; para que no haya confusión con la infantil, se denomina mortalidad de menores de 5 $a_{\tilde{n} o s}{ }^{784}$. También se hace necesario recordar que las estadísticas oficiales españolas de

\footnotetext{
782 Dicho por Isabelino Molpeceres de Cogeces del Monte

${ }^{783}$ ARBELO CURBELO A.: La mortalidad de la infancia en España (1901-1950). Dirección General de Sanidad. Madrid, 1962, p 266

${ }^{784}$ A pesar de que el primer año de vida es el de máximo riesgo y por ello el de mayor mortalidad, la edad preescolar se mantiene como un período de la vida de gran vulnerabilidad, sobre todo durante el segundo y tercer años de vida, por lo que se habla de mortalidad preescolar para referirse a las defunciones que suceden después de un año y hasta los cinco sin cumplir por cada mil nacidos vivos. La mortalidad de menores de 5 años suma la mortalidad infantil y la preescolar, "es un indicador relevante del nivel de desarrollo social de un país. Refleja la disponibilidad, la utilización y el acceso a los sistemas de salud" (Naciones Unidas, 2010). "Los cálculos de las
} 
mortalidad infantil anteriores a 1975 no incluían a los niños fallecidos en las primeras 24 horas de vida porque legalmente no se consideraban nacidos vivos sino abortos ${ }^{785}$.

Refiere Antonio Arbelo las dificultades para realizar un estudio adecuado de la mortalidad en la infancia en España en las cuatro primeras décadas del siglo $\mathrm{XX}^{786}$; el Instituto Nacional de Estadística, entonces Dirección General del Instituto Geográfico y Estadístico, en esta época no solía dar los datos de mortalidad infantil según el indicador actual en función de los nacidos vivos, sino referidos al número total de fallecimientos o de habitantes y no aplicaba todos los años criterios idénticos. En su trabajo sobre la mortalidad infantil de la primera mitad del siglo XX en España Arbelo muestra unas tasas iniciales elevadisimas y en descenso progresivo con altibajos: desde el 185,91 por mil nacidos vivos en 1901, la tasa llegó en 1910 al 149\% y se mantuvo alrededor de este valor en la segunda década con picos como el de 1918 que subió hasta $183 \%$ o coincidiendo con la pandemia de gripe española; en los años veinte estuvo en torno a $130 \%$ y disminuyó hasta $117 \%{ }^{787}$ en 1930 y a $109 \%$ en 1935 . En cuanto a la mortalidad de los menores de 5 años según los criterios actuales tenemos que calcularla y no aparecen datos suficientes todos los años ${ }^{788}$. Si tomamos como referencia el año 1910 , con los cálculos realizados a partir de los valores absolutos que nos dan las estadísticas oficiales, la mortalidad de los menores de 5 años se sitúa en el $280^{\prime} 44 \%$ (por mil nacidos vivos) ${ }^{789}$. Más de

muertes de menores de cinco años por su causa especifica son importantes a fin de diseñar las intervenciones necesarias para reducir la mortalidad infantil". (Mortalidad de lactantes y menores de cinco años UNICEF, 2001).

${ }^{785}$ Las estadísticas sobre mortalidad infantil para ser fiables y poder compararlas deben rectificarse sumando el dato de las defunciones de las primeras 24 horas, sin embargo no es posible corregir los años anteriores a 1919 porque no constan registros de lo que llamaban "abortos". Además, hay que tomar con cautela algunas cifras porque se producían muchos fallos registrales que podían ser incluso intencionados, como ejemplo se podían registrar niños de unos días como nacidos muertos para que figuraran como abortos y así aliviar los trámites y gastos del entierro. BORRÁS LLOP J.M.: Historia de la Infancia en la España Contemporánea. 1834-1936, Madrid, 1996, p 111- 117.

La estadística sanitaria nació en la Edad Moderna con los registros de defunciones que se implantaron a raíz de las grandes epidemias y se institucionalizó a mediados del siglo XIX con el desarrollo de la Higiene pública. El primer registro civil se fundó en Inglaterra en 1838 y serviría de modelo para el resto de Europa. La obligación de realizar registros parroquiales se implantó en Castilla en el siglo XIV, en el XVI ya tenían la estructura actual de los Quinque libri: bautismos, comuniones, entierros, confirmaciones y matrimonios. Constituyen una fuente importante de información, pero muy incompleta desde el punto de vista sanitario. El primer censo español de población por inscripción nominal y directa se realizó en 1857 y en 1863 se empezó a registra información en el llamado Movimiento Natural de la Población, que recogía datos de los archivos parroquiales. Los registros civiles se implantaron en España definitivamente a partir de 1870 y recogían datos sobre edad, sexo, lugar de nacimiento, domicilio y fecha, lugar y causa del fallecimiento LÓPEZ PIÑERO J.M.: Historia de la Pediatría, Valencia 2009, p 551. ${ }^{786}$ ARBELO CURBELO A.: La mortalidad de la infancia en España (1901-1950), Introducción, p XVIII

${ }^{787}$ ARBELO CURBELO A.: op.cit. En la tablJ.M.a que ofrece Arbelo en la página 263 aparece una tasa de mortalidad infantil para 1930 de 177, se trata sin duda de una errata, al recalcularla con los datos que da la misma tabla sobre nacimientos y defunciones sale 117, la tasa de 1929 de la tabla es de 123 y la 1931 de 116 . Las tasas en los años de la Guerra Civil fueron de 109 en 1936 y 130,120 y 135 en los años sucesivos; la de 1925 fue de 136.

${ }^{788}$ Ibídem. Arbelo la recoge dividida en mortalidad del segundo año de la vida y mortalidad preescolar (de 2 a 5 años) con datos referidos al total de la población en tantos por mil habitantes y no a los nacidos vivos como se calcula la mortalidad infantil; esta es la forma en que aparece también en los informes del Instituto Nacional de Estadística, lo que no nos facilita compararla con la mortalidad infantil ni sumarla con ella.

${ }^{789}$ Sumando los fallecimientos de niños en el segundo año (41.006) con los preescolares de 2 a 5 años (44.679), resulta un total de 85.685 muertes que para una natalidad de 649.975 niños en ese año representa una tasa de 
la cuarta parte de los niños nacidos en un año morirían en los primeros cinco años de vida. El resumen del Instituto Nacional de Estadística de 1902 reconoce en su Introducción "la gran mortalidad de la infancia", la mortalidad infantil representaba "casi la cuarta parte del total" de defunciones nacionales de todas las edades y la mortalidad de los menores de cinco año "más de dos quintas partes"790 En el resumen de 1923 sigue afirmando que "Las cifras ponen de manifiesto la enorme mortalidad de los menores de un año... sin embargo, en las otras edades va disminuyendo el número de fallecidos de un año a otro, lo que prueba evidentemente que las condiciones sanitarias de la nación van mejorando"791. Para hacernos una idea de la evolución de la mortalidad de 1 a 5 años podemos volver a los datos que nos ofrece Arbelo; el primer dato sobre la mortalidad para este intervalo completo de edad corresponde a 1908 con una tasa de 4'75 por mil habitantes, que empezó a descender notablemente en los años veinte hasta llegar en 1930 a 2'28 y en 1935 a 1'68 por mil habitantes ${ }^{792}$.

Por sexos, la mortalidad infantil fue mayor en los varones, con una ratio en torno a 110 varones/ 100 mujeres, diferencia que va descendiendo en los grupos de más edad y que no es un dato representativo de la época ya que se debe a las características fisiológicas de ambos sexos que hacen al niño más frágil. En cuanto al estatus social, estimaciones de finales del XIX hablan de la muerte de un hijo de familia acomodada por cada dos pobres y cuatro naturales ${ }^{793}$.

Valladolid se encontraba entre las provincias con mortalidad infantil más elevada del país, con tasas del 254\%\% en 1901, 184 en 1910, 220 en 1920, 170 en 1930 y 160\%o en $1935^{794}$.

$131^{\prime} 83$ muertes de 1 a 5 años por mil nacidos vivos; si sumamos la mortalidad infantil (96.594 menores de un año con una tasa de $148^{\prime} 61$ ) resultan 182.279 defunciones en total, que representa una mortalidad de los menores de 5 años (de 0- 5 años) de 280'44 por mil nacidos vivos en 1910.

790 "... gran mortalidad de la infancia, de cada 1.000 defunciones $246^{\prime} 48$, casi la cuarta parte del total, fueron niños menores de 1 año y 441'42, ó sea, más de dos quintas partes, de menores de cinco". En cuanto a las cifras para Valladolid provincia que ofrece el resumen de 1902, por cada 1000 defunciones, 286'14 fueron menores de 1 año (2.294 niños) y $212^{\prime} 14$ de 1 a 5 años ( 1.701 en cifras absolutas) y para Valladolid capital de cada 1.000 defunciones $282^{\prime} 31$ fueron menores de 1 año y 176'84 de 1 a 5 (con cifras absolutas de 629 menores de 1 año y 394 de 1 a 5). Resumen de los hechos registrados en 1902. Defunciones. Movimiento Natural de la Población. Fondo documental. INEbase Historia. Disponible en: http://www.ine.es/inebaseweb/pdfDispacher.do?td=205766\&ext=.pdf

791 Movimiento Natural de la Población. Fondo documental. INEbase Historia. Disponible en: http://www.ine.es/inebaseweb/pdfDispacher.do?td=206437\&ext=.pdf

792 Ibídem. Las tasas recogidas resultan de sumar las que ofrece Arbelo para la mortalidad de un año de edad (de 12 a 24 meses) en página 365 y la mortalidad preescolar en página 411.

793 BORRÁS LLOP J.M.; Historia de la Infancia en la España Contemporánea. 1834-1936, p 137.

794 Junto con Valladolid, en las primeras décadas del s. XX se encuentran otras provincias de la región entre las de mortalidad infantil más alta del país, Burgos tuvo el 243\% y Palencia el 199\%o en 1901; la tasa más alta en este años fue la de Cáceres con el 277'19\% y la más baja la de Baleares con el 10141\%.. ARBELO A: op.cit., pp 315- 319 
Las principales causas de mortalidad infantil durante las tres primeras décadas fueron las diarreas, con una diferencia considerable respecto a las demás, seguidas de las bronquitis agudas e infeccciones respiratorias y "la debilidad congénita y los vicios de conformación", también muy separadas del resto ${ }^{795}$. El hecho de que las diarreas sean la causa principal de muerte significa que están interviniendo factores de tipo ambiental y social varios, fundamentalmente de tipo alimenticio e higiénico, desde las condiciones del abastecimiento de agua y los saneamientos a las condiciones higiénicas del entorno familiar.

La medicina higienista de principios del siglo XX señalaba como responsables de la alta mortandad infantil la miseria, la ignorancia de las madres y dentro del discurso moralista y maternalista dominante, la falta de moral que asociaban por una parte a las malas costumbres de las clases populares y por otra a la "alimentación viciosa", como llamaban algunos a la lactancia mercenaria, y a la negación de las mujeres a lactar a sus hijos. El doctor Tolosa Latour principal promotor de la Ley de Protección a la Infancia de 1904 diría que "Instruir a la mujer es la suprema aspiración de la higiene contemporánea"796

La mortalidad de los expósitos era muy superior a la del resto de la población infantil, es especialmente trágico el siglo XIX cuando se llegaron a alcanzar en algunas inclusas tasas próximas al $100 \%$ de los acogidos, lo que ha llevado a Álvarez Santaló a referirse a ellas como "un sistema organizado de infanticidio"797,

"Aún así, el hecho de llegar a la Inclusa vivos ya suponía una mínima esperanza de supervivencia que no tenían aquellos que eran abandonados sin idea de que fueran recogidos ${ }^{\prime 798}$

El interés por los expósitos y su tremenda mortandad, cuestiones morales aparte, se convirtió en un tema de preocupación política y económica, había que cuidarles para que "se hagan fructuosos, y útiles a la Patria" ${ }^{1799}$; un ejemplo es la Novísima Recopilación de las Leyes de España... mandada formar por el Señor Don Carlos IV en 1805 que se ocupa De los expósitos; y de las casas para su crianza, educación y destino con criterios utilitaristas y

\footnotetext{
795 Para hacernos una idea, un año como 1910, de un total de 96.594 niños menores de 12 meses fallecidos, sin contar los de las primeras 24 horas de vida, más de un tercio (28.153) lo fueron por diarreas, 16.017 por debilidad congénita y vicios de conformación y 15.889 por bronquitis aguda y neumonías. A mucha distancia siguen, meningitis y otras infecciones como coqueluche (tosferina) y sarampión. ARBELO CURBELO A: op.cit., p 335 Se llamaban vicios de conformación a las malformaciones y deformidades congénitas y se entendía por debilidad congénita cuando el neonato "tiene sus órganos y aparatos incompletamente desarrollados... un niño no acabado, de escaso peso y de funciones incompletas (inmaduro)". BOIX BARRIOS J.: Manual de puericultura, 1941, p 251 -252 ${ }^{796}$ Discurso inaugural del primer Congreso de Higiene Escolar de 1912. RUIZ RODRIGO C., PALACIO LIS I.: Higienismo, Educación ambiental y previsión escolar (Antecedentes y prácticas de Prevención social en España (1900-1936). Valencia 1999, p 109

797 ÁLVAREZ SANTALÓ L.C.: op.cit, pp 160- 166.

798 VIDAL GALACHE F., VIDAL GALACHE B.: op.cit, p 103.

${ }^{799}$ Cita recogida por PÉREZ MOREDA V. en La infancia abandonada en España (siglos XVI-XX) p 24 que corresponde a las Ordenanzas del Real Hospital de Oviedo, 1752, pp 2-4
} 
poblacionistas. Sin embargo, "los objetivos filantrópico de la salud y la supervivencia del niño" irán prevaleciendo cada vez más claramente ${ }^{800}$ dando como resultado actuaciones legislativas como la ley de Protección a la Infancia de 1904, e iniciativas prácticas en las que junto a la clase política se implicaron médicos, intelectuales y filántropos que con más o menos éxito intentarían en el siglo XX mejorar las condiciones de vida de los expósitos y combatir su elevadísima mortalidad intentando implantar un nuevo modelo de Inclusa.

Si la mortalidad infantil se considera un indicador muy fiable de la situación sociosanitaria de una población, a falta muchas veces de información directa suficiente, podemos contemplar la de los expósitos como un reflejo fiel y objetivo de sus condiciones de vida, que informa de la calidad de los cuidados que recibían, o de su falta, sobre todo de las condiciones higiénico- sanitarias y nutritivas. En repetidas ocasiones hemos hablado de la alta mortalidad de la Inclusa de Valladolid, ahora toca analizarla.

Era un tema que preocupaba, de ello dan testimonio muchos artículos publicados en la prensa local, unas veces solo manifestándola en tono conmovedor y lírico, otras de denuncia, a veces solicitando soluciones, otras con propuestas para una Inclusa modelo

"A medida que el verano con sus calores agobiantes avanza, en los Hospicios aumentan pavorosamente las defunciones de niños pequeñitos.

Te prometí- ioh, lector que pese á mi advertencia continuaste leyendo!- una noticia amarga y dolorosa, y ahí la tienes: muchos niños sin madre agonizan á diario sobre las frías cunas del Hospicio; muchos niños sin madre, hijos de la miseria ó del pecado, suben al cielo cada día desde el vetusto caserón sombrío, muchos niños que al llegar al cielo se verán sorprendidos por la dulcedumbre de la eternal ventura, porque no gustaron, para imaginársela, la tibia leche amorosa de los pechos de su madre.

Yo he sentido, al deducir de una leve operación mental la aterradora cifra, un estremecimiento de dolor en las entrañas y una oleada de piedad que empujaba las lágrimas a mis ojos. $Y$ he tomado mi pluma pecadora y he empezado a emborronar estas albas cuartillas, sin acordarme del arte admirable de componer bellas páginas, pensando solo en que era un deber mío poner ante los ojos del lector descuidado esa noticia trágica, para que también se estremezcan sus entrañas dolorosamente y se desborde la piedad en su corazón.

Yo no sé si puede remediarse esa cruel mortandad de niños sin madre, con un más grande tutelar cuidado de las Diputaciones, con un noble rasgo filantrópico de los poderosos, con una generosa acción colectiva de los menos ricos". ${ }^{801}$

Las cifras de mortalidad en las inclusas eran bien conocidas, la denuncia también era social, ante la falta de interés y la hipocresía de la población general hacia "los hijos de todos",

\footnotetext{
800 PÉREZ MOREDA V.: op.cit. separata del discurso, p 4; en discurso completo p 30, 34, 42,45.

${ }^{801}$ N.C. 14- 07- 1901, p 1
} 
artículos que intentaban impactar utilizando para los Hospicios calificativos como "almacenes de carne putrefacta"

"Cuando formados de dos en dos salen a paseo los hospicianitos... todas las personas les contemplan compasivas. iQué majos!- iPobrecitos!- iMírales qué limpios van!... tras de estas ó parecidas exclamaciones, el silencio hace presumir un cúmulo de consideraciones, que no por calladas son menos expresivas.iPasan los hijos de todos!... De los hospicianitos, que muere el 75 por 100, nadie se acuerda. Llevan en sí la mayor parte el virus ponzoñoso de la sifilis, el raquitismo, la degeneración, y cúmplese con recogerles en el almacén oficial y con que vayan viviendo o muriendo, según su constitución....

¡No seamos frívolos ni egoístas ino hagamos almacenes de carne putrefacta!!

Para eso valiera más poner en vigor las leyes de Esparta. Matarles, pero no hacerles sufrir. Es más caritativo... y más económico ${ }^{\prime 802}$

Estas dos citas son ejemplos del inicio y final del período que he podido documentar con los libros y expedientes de la Inclusa, parece que la situación no cambió con los años, los datos y las cifras nos dirán si efectivamente fue así, aunque ya un simple vistazo a los libros nos confirma las peores sospechas. En los folios de los niños fallecidos al final, cerrando su historial se dibujaba una cruz, el primer libro que me entregaron en el Archivo para consulta fue el segundo tomo de 1905 que se inicia en junio, había tantas cruces y tan seguidas, que me alegraba sinceramente cuando un folio no la tenía.

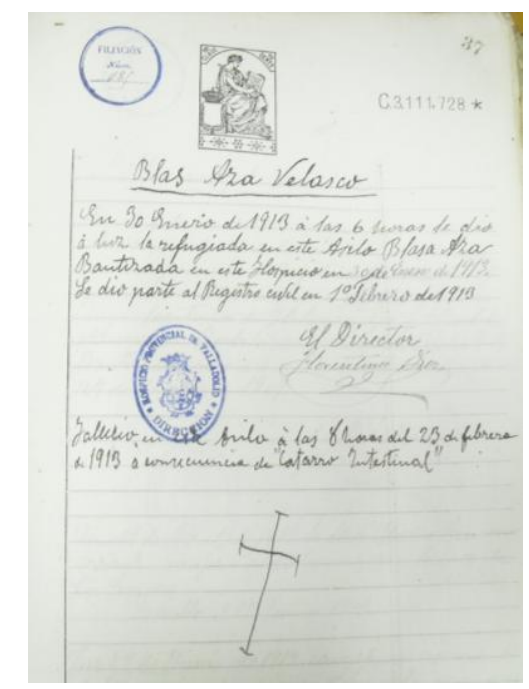

Imagen 3-58: Folio de un niño de dos meses fallecido en la Inclusa (fo 37 LE 1913)

pertinentes.
El primero de los cálculos que debemos realizar es el de la tasa global, el total de acogidos de la Cuna que fallecieron en el intervalo de consulta 1900-1913, sin contar los 77 registrados como nacidos muertos. Generalmente los estudios sobre la mortalidad expósita se centran en los niños internos, pero, dado que, aunque estuvieran con nodrizas en crianza externa los niños eran responsabilidad de la Inclusa y que sus condiciones de partida y su historia de vida era diferente de la del resto de la población infantil me parece interesante estudiar la mortalidad global de los expósitos de Valladolid, internos y externos, aunque luego se hagan los análisis

${ }^{802}$ N.C. $25-10-1913$, p 2 
Considerando solamente los ingresados vivos, 5.949 niños (3.105 varones y 2.844 mujeres), fallecieron en el departamento de la Cuna, dentro o fuera de ella con las nodrizas, 4.406 menores de 5 años (2.308 varones y 2.098 mujeres) (vamos a considerar esta edad como el límite de la Cuna $)^{803}$; otros 164 expósitos fallecieron con edades comprendidas entre los 5 y los 21 años, dependientes ya del departamento de Mayores (84 varones y 80 mujeres). En total suman 4.570 los niños fallecidos de todas las edades, (2.392 varones y 2.178 mujeres). Estos datos suponen que el $74^{\prime} 06 \%$ de los niños que ingresaron en la Cuna fallecieron, dentro o fuera de ella con las nodrizas, antes de cumplir 5 años de edad, más otro 2'76\% lo haría pasada esa edad en el departamento de Mayores.; sin duda una cifra terrible, ni siquiera la cuarta parte de los expósitos sobrevivieron a la Cuna. (GRÁFICA 3-30). Teniendo en cuenta que hay un $77^{\prime} 45 \%$ de registros con el final en blanco, que no han cerrado el historial, ( 443 folios en

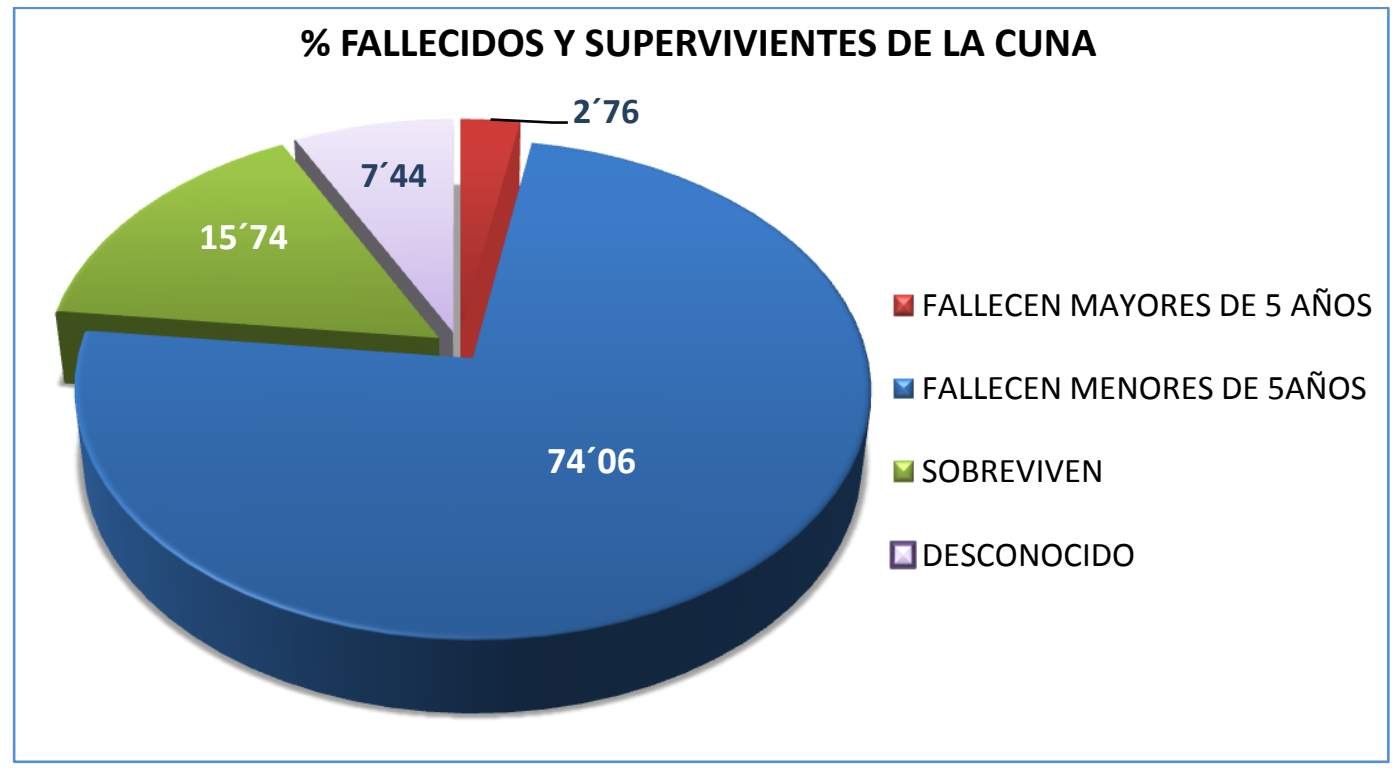

GRÁFICA 3-30: Niños fallecidos, internos y externos de todas las edades y los supervivientes; porcentaje sobre el total de los que ingresaron en la Cuna provincial entre 1900 y 1913. En el grupo DESCONOCIDO se encuentran los niños que no tienen cerrado el historial y de los que se ignora el destino. Elaboración propia

\footnotetext{
${ }^{803}$ Bárbara Revuelta expresa en su trabajo sobre la Inclusa de Madrid y su mortalidad la dificultad para comparar la mortalidad expósita entre diferentes instituciones debido a "la generalizada precariedad de la documentación conservada", que en nuestro caso también es aplicable y a la falta de indicadores similares a los empleados para la población general. REVUELTA EUGERCIOS B A.: op.cit., p 389.

En nuestro caso, como en el de la mayoría de los estudios sobre el tema hemos recurrido al cálculo de la mortalidad de la Inclusa en porcentajes sobre el total de los ingresos anuales, aunque no sea un indicador como el que se utiliza en las estadísticas poblacionales oficiales creo que sirve para hacernos una idea bastante precisa de la situación en el establecimiento. Por otra parte, hay que tener en cuenta que la mayoría de los niños ingresaban y fallecían, como veremos, en su primer año de vida y que la mortalidad infantil es precisamente hasta un año. Un problema que también se plantea para la comparación es la edad de permanencia de los expósitos que podía variar de unos centros a otros, aunque generalmente estaba entre 5 y 7 años. Aunque en la Inclusa de Valladolid podía variar también entre estas dos edades, dado que los niños que permanecían en ella después de los 5 años eran casos aislados, pues a esa edad se pasaban al departamento de Mayores, por lo que vamos a considerar a los niños de la Inclusa, o Cuna, como menores de 5 años.
} 
los 28 Libros de Exposiciones), éstos y todos los datos que demos sobre mortalidad pudieron ser más elevados puesto que no podemos descartar ningún destino final posible para estos niños, desde el fallecimiento hasta su paso al Hospicio al departamento de Mayores, el prohijamiento o la vuelta con la familia.

El sexo no fue un factor relevante, la relación varones/mujeres respecto a la mortalidad fue equivalente a la del ingreso, en los tres datos (ingresados, fallecidos totales y fallecidos menores de 5 años) se conserva la ratio en torno a 110 varones/100 mujeres. Para la provincia de Valladolid la ratio para los menores de 5 años $^{804}$ fue de 113 varones/100 mujeres, ligeramente más elevada que la de nacimientos (GRÁFICA 3-31).

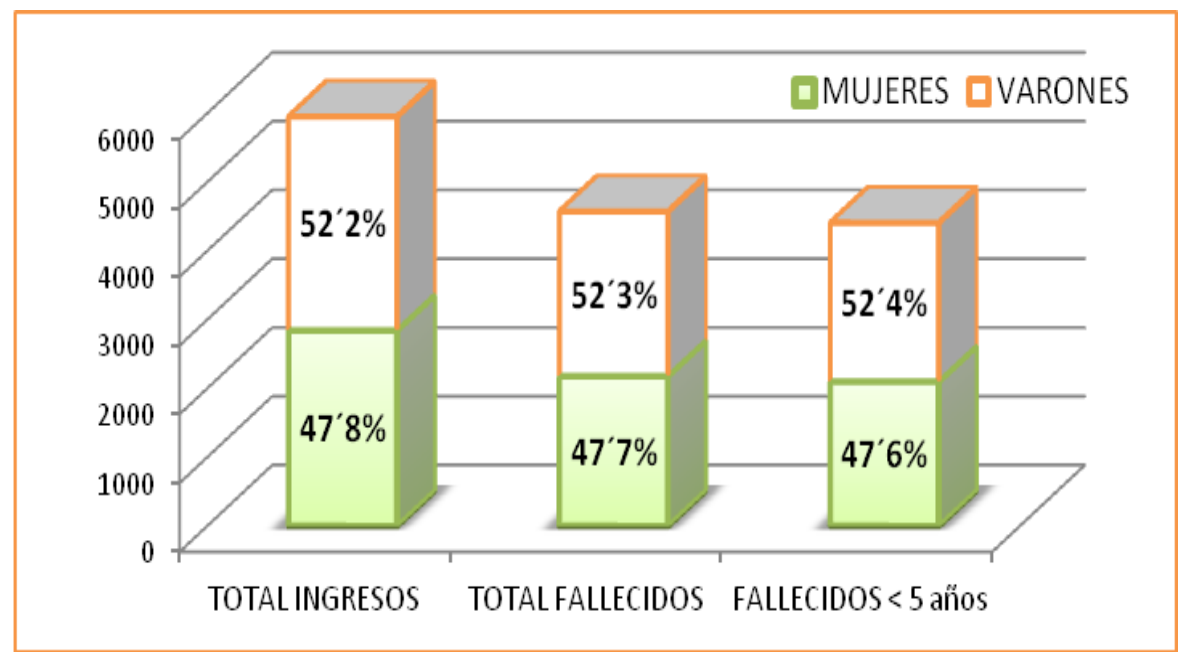

GRÁFICA 3-31: Comparación y distribución por sexos de los niños ingresados en la Cuna y los fallecidos, el total y los que fallecieron en la Cuna menores de 5 años entre 1900 y 1913. Elaboración propia

Por grupos de edad calcularemos la mortalidad neonatal (menores de 1mes), la infantil (menores de 1 año) y de menores de 5 años. Fallecieron 589 niños con una edad comprendida entre 1 y 5 años y 3.710 niños menores de 1 año, de ellos 1.004 en el primer mes de vida y 2.706 entre el mes y el año. Hay un grupo de 107 niños con edad imprecisa, que se han considerado dentro del cálculo global como menores de 5 años al fallecer en el departamento de la Cuna aunque no se puede precisar con seguridad la edad de su defunción. La mayoría murió en el primer año de vida; en la GRÁFICA 3-32 se representa la distribución porcentual por grupos de edad de todos los fallecimientos contando los de edad imprecisa en una categoría

\footnotetext{
${ }^{804}$ Movimiento Natural de la Población de España. INEbase Historia. Fondo documental. Se ha calculado con datos de 1900 y 1901, en los demás años hasta 1913 no se presentan los datos de las defunciones de los menores de 5 años por sexo y provincia; se presentan por sexo y estado civil (solteros, casados y viudos).
} 
aparte, son un porcentaje pequeño que no modificaría sustancialmente el que corresponde a las otras categorías (Si solamente consideramos las fechas de defunción conocida el porcentaje de muertes neonatales pasaría al 23'35\%, teniendo en cuenta que en ningún caso estamos contando los nacidos muertos que podrían haber fallecido en las primeras 24 horas y que entre los folios con final en blanco podría haber defunciones).

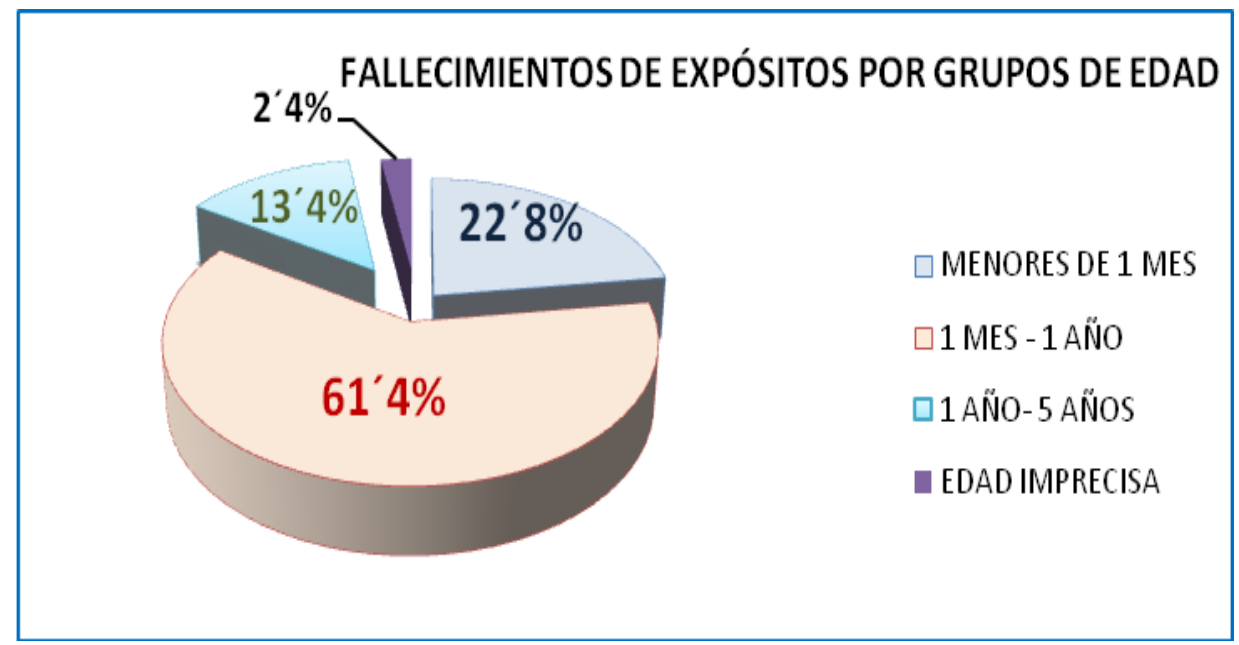

GRÁFICA 3-32: Distribución porcentual de los fallecidos de la Inclusa (menores de 5 años) por grupos de edad, internos y externos, entre 1900 y 1913. Elaboración propia

Calculando los datos sobre el total de ingresos, para el período 1900-1913 resulta, como hemos visto, una mortalidad en los menores de 5 años dependientes de la Inclusa de Valladolid, internos y externos, del $74^{\prime} 06 \%$, la mortalidad infantil se sitúa en el $62^{\prime} 36 \%$ (incluida en la de menores de 5 años) y la neonatal en el 16'88\% (incluida en la infantil). Son datos sin duda tremendos que no podemos comparar por no disponer de información equivalente para otros establecimientos. En la TABLA 3-30 se recogen los datos anuales de los fallecimientos en la Cuna en valores absolutos, el total y por grupos de edad, junto con el de ingresados vivos y la mortalidad calculada en porcentaje sobre el total de éstos; los de edad imprecisa no se han asignado a ningún grupo específico pero se han incluido en el global de menores de 5 años. El año de máxima mortalidad infantil de la Inclusa de Valladolid fue 1901 con el 71'4\%, y el de mínima en 1912 con el 46'6\%; para el grupo de edad de 0- 5 la máxima se dio en 1908 con casi el 80\% y la mínima en 1912 con el 67’33\%. El director del Hospicio provincial, Justo Esteban, reconocía en 1906 una mortalidad próxima al 75\% en la Inclusa de 
Valladolid, muy por encima de las de provincias vecinas ${ }^{805}$, véase en la TABLA 3-30 que la que hemos calculado en 1906 para el total de expósitos es del 73’06\%.

\begin{tabular}{|c|c|c|c|c|c|c|c|c|c|}
\hline \multicolumn{10}{|c|}{$\begin{array}{l}\text { TABLA 3-30: DEFUNCIONES POR GRUPOS DE EDAD Y AÑO DE } \\
\text { INCLUSA PROVINCIAL DE VALLADOLID }\end{array}$} \\
\hline \multirow[b]{3}{*}{1900} & \multirow[b]{2}{*}{$\begin{array}{l}\text { TOTAL } \\
\text { INGRESOS } \\
\text { VIVOS }\end{array}$} & \multicolumn{8}{|c|}{ FALLECIMIENTOS } \\
\hline & & \multirow{2}{*}{\begin{tabular}{|c|} 
TOTALES \\
361
\end{tabular}} & \multirow{2}{*}{$\begin{array}{l}\text { MENOS } \\
\text { DE } 1 \\
\text { MES } \\
73\end{array}$} & \multirow{2}{*}{\begin{tabular}{c|}
$\begin{array}{c}\text { DE } 1 \\
\text { MES A } 1 \\
\text { AÑO }\end{array}$ \\
255
\end{tabular}} & \multirow{2}{*}{\begin{tabular}{|c|}
$\begin{array}{c}\text { DE } 1 \\
\text { AÑO A } 5 \\
\text { AÑ̃S }\end{array}$ \\
16 \\
\end{tabular}} & \multicolumn{2}{|c|}{$\begin{array}{r}\text { TOTAL MENORES DE } \\
1 \text { ANNO }\end{array}$} & \multicolumn{2}{|c|}{$\begin{array}{r}\text { TOTAL MENORES DE } \\
5 \text { años }\end{array}$} \\
\hline & 475 & & & & & 328 & $69^{\prime} 05 \%$ & 355 & $74^{\prime} 74 \%$ \\
\hline 1901 & 378 & 301 & 86 & 184 & 16 & 270 & $71^{\prime} 43 \%$ & 292 & $77^{\prime} 25 \%$ \\
\hline 1902 & 412 & 329 & 114 & 154 & 27 & 268 & $65^{\prime} 05 \%$ & 311 & $75^{\prime} 49 \%$ \\
\hline 1903 & 450 & 356 & 95 & 207 & 34 & 302 & $67^{\prime} 11 \%$ & 350 & $77^{\prime} 78 \%$ \\
\hline 1904 & 418 & 293 & 59 & 174 & 37 & 233 & $55^{\prime} 74 \%$ & 285 & $68^{\prime} 18 \%$ \\
\hline 1905 & 434 & 305 & 58 & 163 & 59 & 221 & $50^{\prime} 92 \%$ & 300 & $69^{\prime} 12 \%$ \\
\hline 1906 & 386 & 289 & 61 & 158 & 54 & 219 & $56^{\prime} 74 \%$ & 282 & $73^{\prime} 06 \%$ \\
\hline 1907 & 406 & 317 & 82 & 198 & 22 & 280 & $68^{\prime} 97 \%$ & 306 & $75^{\prime} 37 \%$ \\
\hline 1908 & 414 & 341 & 68 & 193 & 70 & 261 & $63^{\prime} 04 \%$ & 331 & $79^{\prime} 95 \%$ \\
\hline 1909 & 444 & 341 & 79 & 191 & 65 & 270 & $60^{\prime} 81 \%$ & 335 & $75^{\prime} 45 \%$ \\
\hline 1910 & 441 & 345 & 72 & 227 & 35 & 299 & $67^{\prime} 80 \%$ & 334 & $75^{\prime} 74 \%$ \\
\hline 1911 & 407 & 327 & 63 & 215 & 26 & 278 & $68^{\prime} 30 \%$ & 306 & $75^{\prime} 18 \%$ \\
\hline 1912 & 453 & 330 & 31 & 180 & 86 & 211 & $46^{\prime} 58 \%$ & 305 & $67^{\prime} 33 \%$ \\
\hline 1913 & 431 & 335 & 63 & 207 & 42 & 270 & $62^{\prime} 65 \%$ & 314 & $72^{\prime} 85 \%$ \\
\hline TOTALES & 5949 & 4570 & 1004 & 2706 & 589 & & & & \\
\hline promedios & $424^{\prime} 93$ & $326^{\prime} 43$ & $71^{\prime} 71$ & $193^{\prime} 29$ & $42^{\prime} 07$ & & 55 & & \\
\hline \multicolumn{6}{|l|}{ Edad imprecisa } & \multicolumn{4}{|c|}{107 (promedio 7'64) } \\
\hline \multicolumn{10}{|c|}{$\begin{array}{l}\text { Ingresos y fallecimientos en valores absolutos y porcentaje de las defunciones de los niños internos y } \\
\text { externos menores de } 1 \text { año y menores de } 5 \text { (los de } 1 \text { año incluidos) respecto al número total de ingresos } \\
\text { vivos. Los niños de edad imprecisa se han contado en el total de menores de } 5 \text { años Elaboración propia a } \\
\text { partir de los datos de los Libros de Exposiciones. }\end{array}$} \\
\hline
\end{tabular}

Para una media anual de 425 ingresos en la Cuna, el promedio de defunciones totales (internos más externos) fue de 315 menores de 5 años (incluyendo los de edad imprecisa): 72 neonatos, 193 lactantes de 1 a 12 meses (suman 265 menores de 1 año) y 42 niños entre 1 y 5 años (el promedio de los 107 de edad imprecisa es de 7'64, que son los que faltan para sumar los 315 de media).

El cálculo de la mortalidad infantil (menores de 1 año) de los expósitos de la Inclusa es importante porque podemos compararlo con la de la población general, aunque en el primer caso se toma como referencia el total de ingresados y en la estadística oficial el de nacimientos. No se puede establecer la misma comparación con los niños de 1 a 5 años porque los datos que nos ofrecen las estadísticas oficiales y que recoge Arbelo se han calculado sobre

\footnotetext{
805 “...comparando el número de ingresos de niños de lactancia en esta Asilo con los de León, Zamora, Astorga, Salamanca, Palencia y Burgos, viene a ser proporcionalmente el mismo, no sucediendo esto por desgracia con relación al número de fallecimientos, pues si en las poblaciones citadas oscila entre el 45 al 49 por ciento, en este llega al 75..." Informe sobre mejoras y necesidades del Hospicio provincial. (1906). Signatura: caja 4872, expediente 43333. ADPVA
} 
el total de la población general y no sobre los nacidos vivos. En los expósitos de Valladolid se observa con dificultad el descenso progresivo de la mortalidad infantil que se estaba produciendo en la población general debido a que la evolución es en altibajos con variaciones anuales significativas; hay picos en 1907 y 1911 que coinciden con incrementos de la mortalidad infantil local y provincial, aunque si se observa bien, comparando la evolución de la mortalidad de los expósitos con la de la capital donde se situaba la Inclusa y la provincia, donde se localizaban las nodrizas, podemos decir no seguía las mismas pautas que la de la población general. Puesto que muchas de las nodrizas de los expósitos de Valladolid eran de la provincia de Segovia, reviso sus tasas de mortalidad infantil, que oscilaron entre el $205^{\prime} 02 \%$ o de 1902 y el $151 \%$ o de 1909 con un promedio de $177^{\prime} 8$, mucho más bajas que la de la provincia de Valladolid.

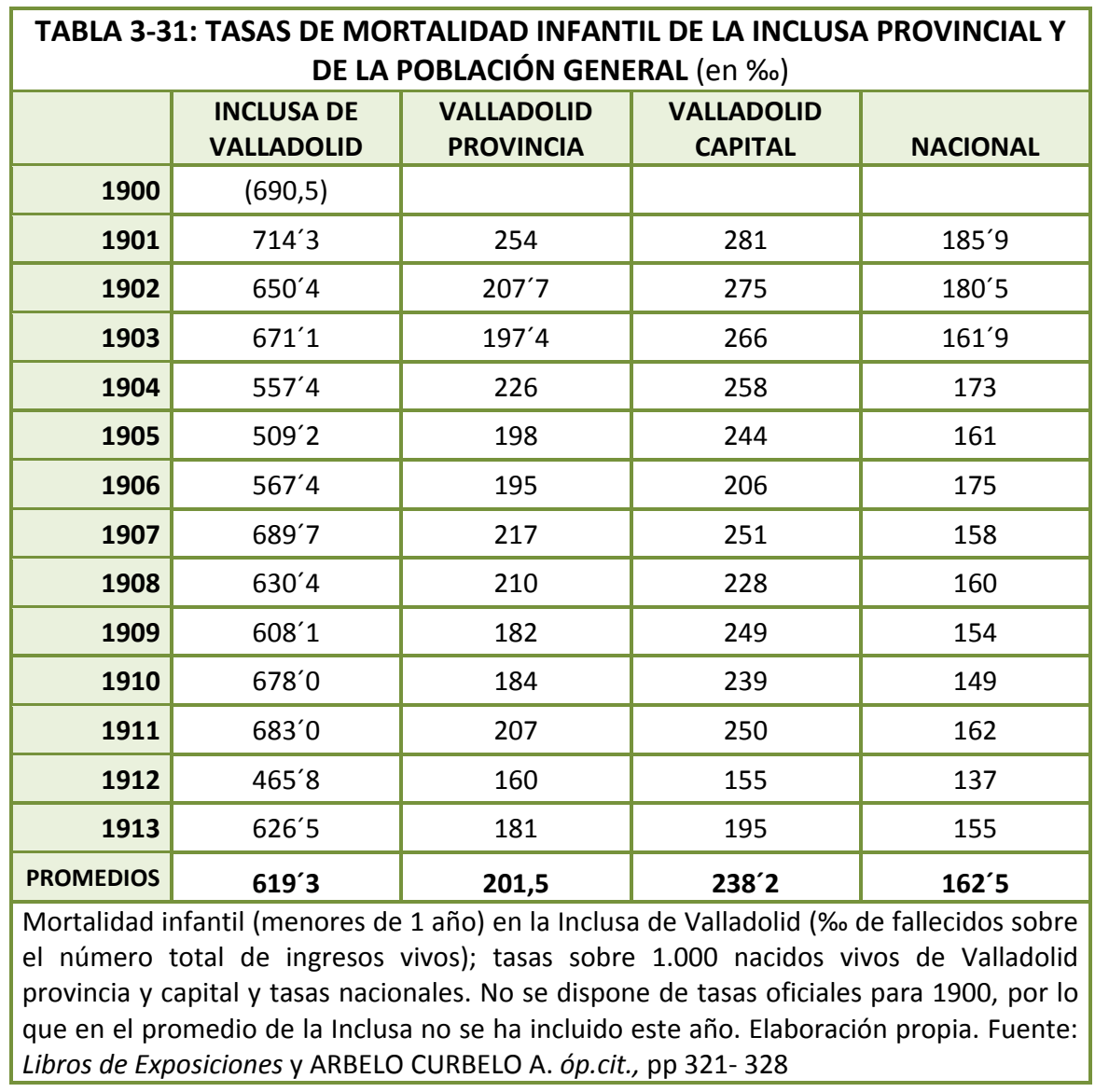

Si comparamos los valores promedio, los de la Inclusa triplican a los de la provincia; podríamos decir que las probabilidades de sobrevivir más de 1 año para un niño nacido en la provincia de Valladolid en el intervalo 1901- 1913 eran del 80\%, para uno de la capital del 76\% y para un niño que ingresaba en la Inclusa Provincial se reducían al $38 \%$ 
Podemos apreciar mejor la evolución si consideramos todo el período globalmente. En la TABLA 3-31 se recoge la mortalidad infantil de los expósitos de la Inclusa en el periodo estudiado y los datos de la capital y la provincia de Valladolid (en tantos por mil, como se presentan normalmente los índices de mortalidad). Entre 1901 y 1913 la mortalidad infantil de la Inclusa pasó del $71^{\prime} 43 \%$ del total de ingresos vivos al $62^{\prime} 65 \%$, que representa una rebaja del 12'3\% (tomamos 1901 como punto de partida porque no tenemos datos de la mortalidad infantil general de 1900), mientras que la nacional se redujo en un $16^{\prime} 3 \%$; mucho más importante fue el descenso que se produjo en Valladolid provincia y capital, del $28^{\prime} 7 \%$ y el 30 6\% respectivamente, aún así, como puede verse en la TABLA 3-31 se mantuvieron en todo el período muy por encima de la media nacional, sobre todo la ciudad, como corresponde a una población con unas condiciones higiénicas más que deficientes ${ }^{806}$. El descenso en la población de expósitos de menos de un año fue discreto; pero si nos fijamos en la mortalidad global de la Inclusa de la TABLA 3-30, considerándola hasta los 5 años, no se aprecian cambios, empieza con un $74^{\prime} 74 \%$ en 1900 y termina con un 72'85\% en 1913.

Para analizar la mortalidad de los expósitos de la Cuna, en sus dos departamentos de Lactancia y Destete, no basta con saber cuántos de los niños que ingresaron fallecieron, tenemos además que valorar otros aspectos. En primer lugar determinar los que fallecieron dentro de la Inclusa y los que lo hicieron fuera con las nodrizas y luego, dentro de los que murieron internos, separar los que no llegaron a salir nunca de la Inclusa de los que salieron para crianza y fueron devueltos por las nodrizas.

Del total de 4.406 menores de 5 años acogidos del departamento de la Cuna que fallecieron, 2.407 lo hicieron dentro del establecimiento (54'63\%) y 1.999 con las nodrizas externas (45'37\%), la diferencia no llega a 10 puntos (GRÁFICA 3-33), lo que significa que la mortalidad externa también fue muy alta.

Si valoramos la mortalidad dentro de la Inclusa contando los fallecimientos de los niños internos sobre el total de ingresos vivos nos sale una media para el periodo 1900-1913 de $40^{\prime} 46 \%$. Es una cifra que podemos comparar con las que tenemos de otras inclusas para

\footnotetext{
${ }^{806}$ Valladolid se encontraba entre las provincias con mortalidad infantil más elevada del país, con tasas del 254'\%o en 1901, 184 en 1910, 220 en 1920, 170 en 1930 y 160\%o en 1935 Junto con Valladolid, otras provincias de la región están entre las de mortalidad más alta en las primeras décadas del s. XX, Burgos con el 243\% y Palencia con el 199\% 1901 y el 160 y 185\%o respectivamente, las más altas de España, en 1935.En 1901 la tasa de mortalidad infantil más elevada la tuvo Cáceres: 277,19\% y la más baja Baleares: 101,41\%o. En 1935 la más alta como hemos indicado fue la de Palencia y la más baja la de Gerona con un 51,94\%, una diferencia considerable. ARBELO CURBELO A.: op.cit., pp 315- 319
} 
este período de principios del siglo XX, para el que no contamos con demasiados datos, hay más estudios y datos sobre los siglos previos. La Inclusa de Valladolid se sitúa entre las de mortalidad más baja. Ana $M$ Rodríguez $^{807}$ nos ofrece datos hasta 1903 de algunas inclusas, para el intervalo 1900- 1903 la media de la mortalidad expósita calculada en tantos por cien de fallecidos sobre el total de ingresos fue en Valladolid del $42,13 \%$ frente al: $41^{\prime} 88 \%$ en Pontevedra, $48^{\prime} 48 \%$ en Barcelona y en Oviedo del $42^{\prime} 7 \%$ solamente para el primer

FALLECIDOS DENTRO DE LA CUNA Y CON LAS NODRIZAS EXTERNAS

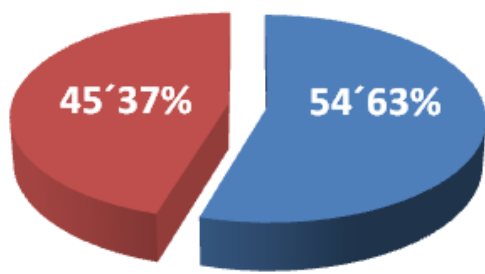

- FALLECIDOSEN LA CUNA

- FALLECIDOS CON NODRIZAS

GRÁFICA 3-33: Distribución de los fallecidos según el lugar de defunción, dentro del establecimiento o fuera con las nodrizas externas. Elaboración propia

año de ingreso y del 56'3\% para los 5 años ${ }^{808}$. Pedro Espina ${ }^{809}$ ofrece una estadística sobre la Real Inclusa de Madrid para el periodo 1903- 1920, en ella se registran, literalmente, los "Fallecidos por 100 ingresados"; para el periodo 1903-1913 resulta una media del 62'91\%, no se indica si se refiere solamente a los que fallecieron dentro de la inclusa o si se han incluido también las muertes de los externos en crianza, aunque parece que es solo de los internos porque todos los trabajos sobre esta Inclusa resaltan su elevada mortalidad sobre todo hasta $1920^{810}$

Podemos comparar de forma más completa la mortalidad de nuestra Inclusa con la de Pamplona para el mismo período gracias a los datos anuales que ofrece Arantzazu UribeEtxebarria por grupos de edad para los grupos de menores de 1 año y menores de 7. Para el periodo 1900- 1913 la mortalidad infantil en la Inclusa de Valladolid tiene un promedio del $39^{\prime} 04 \%$ y la de Pamplona del $42^{\prime} 34 \%$, en cuanto al siguiente grupo de edad, aunque para nuestra Inclusa el estudio se ha hecho para menores de 5 años, para poder hacer la comparación he realizado los cálculos para el mismo grupo de edad 0-7, resultando porcentajes son del $42^{\prime} 07 \%$ y el $51^{\prime} 52 \%$ respectivamente. En la TABLA 3-32 se recogen los datos de las dos inclusas con los de la mortalidad en las respectivas capitales (en tantos por mil).

\footnotetext{
${ }^{807}$ RODRÍGUEZ MARTín A.M.: El destino de los niños de la Inclusa de Pontevedra, 1872-1903. Cuadernos de Estudios Gallegos, 2008, no 121, enero-diciembre, pp. 361.

808 SÁNCHEZ FERNÁNDEZ L.V., COBO BARQUÍN J.C., RADHAMÉS HERNÁNDEZ M.: Marginación y pobreza desde la cuna: el niño expósito en el Concejo de Siero Asturias (1800-1936). 2013; p 161. (Cita a JUNCEDA AVELLO, 1984)

809 ESPINA PÉREZ P.: Historia de la Inclusa de Madrid. Vista a través de los artículos y trabajos históricos Años 14002000. Edita oficina del Defensor del Menor en la Comunidad de Madrid, Madrid 2005; p 344

${ }^{810}$ Bárbara Revuelta la sitúa con la mortalidad más alta hasta 1920, desde cuando bajó de forma significativa hasta niveles por debajo del 40\%. REVUELTA EUGERCIOS B.A.: Los usos de la inclusa de Madrid, mortalidad y retorno a principios del siglo XX (1890-1935). Madrid, 2011; pp 392
} 
Salvo en el intervalo 1909-1910, las tasas fueron más bajas en la Inclusa de Valladolid en los dos grupos de edad. Si consideramos la mortalidad local, vemos que no se correlaciona con la de las inclusas, ya que, como puede apreciarse, la de la ciudad de Pamplona fue notablemente más baja que la de Valladolid durante todo el periodo y por eso mismo la diferencia con la de su inclusa mucho mayor. La mortalidad de los expósitos internos, aunque lógicamente influida por las condiciones locales, sobre todo relacionadas con la salubridad e higiene pública, parece que era una cuestión condicionada fundamentalmente por el funcionamiento de los asilos respectivos.

\begin{tabular}{|c|c|c|c|c|c|c|}
\hline \multicolumn{7}{|c|}{$\begin{array}{l}\text { TABLA 3-32: MORTALIDAD INFANTIL DE LAS INCLUSAS PROVINCIALES DE VALLADOLID Y NAVARRA } \\
\text { Y DE SUS CAPITALES (en \%o) Y TASAS EN EL GRUPO DE EDAD de } 0 \text {-7 años }\end{array}$} \\
\hline & $\begin{array}{c}0-1 \text { año } \\
\text { INCLUSA } \\
\text { VALLADOLID }\end{array}$ & $\begin{array}{l}\text { VALLADOLID } \\
\text { CAPITAL }\end{array}$ & $\begin{array}{c}\text { 0-1 año } \\
\text { INCLUSA } \\
\text { NAVARRA }\end{array}$ & PAMPLONA & $\begin{array}{c}\text { 0-7 años } \\
\text { INCLUSA } \\
\text { VALLADOLID }\end{array}$ & $\begin{array}{c}\text { 0- } 7 \text { años } \\
\text { INCLUSA } \\
\text { PAMPLONA }\end{array}$ \\
\hline 1900 & $286^{\prime} 3$ & & 470 & & $305^{\prime} 3$ & 583 \\
\hline 1901 & $460^{\prime} 3$ & 281 & 406 & \multirow{4}{*}{197} & $481^{\prime} 5$ & 489 \\
\hline 1902 & $504 ’ 9$ & 275 & 573 & & $536^{\prime} 4$ & 622 \\
\hline 1903 & 480 & 266 & 592 & & $493^{\prime} 3$ & 639 \\
\hline 1904 & $294^{\prime} 3$ & 258 & 487 & & $308^{\prime} 6$ & 552 \\
\hline 1905 & $373^{\prime} 3$ & 244 & 500 & \multirow{5}{*}{167} & $410^{\prime} 1$ & 589 \\
\hline 1906 & $409^{\prime} 3$ & 206 & 446 & & $440^{\prime} 4$ & 577 \\
\hline 1907 & $416^{\prime} 3$ & 251 & 488 & & $42,6^{\prime} 1$ & 581 \\
\hline 1908 & 471 & 228 & 433 & & $536^{\prime} 2$ & 549 \\
\hline 1909 & $495^{\prime} 5$ & 249 & 288 & & $533^{\prime} 8$ & 456 \\
\hline 1910 & $473^{\prime} 9$ & 239 & 337 & \multirow{4}{*}{139} & $485^{\prime} 3$ & 485 \\
\hline 1911 & $297^{\prime} 3$ & 250 & 301 & & $314^{\prime} 5$ & 391 \\
\hline 1912 & $185^{\prime} 4$ & 155 & 296 & & $251^{\prime} 7$ & 430 \\
\hline 1913 & $317^{\prime} 9$ & 195 & 311 & & $366^{\prime} 6$ & 418 \\
\hline PROMEDIOS & $390^{\prime} 4$ & $238^{\prime} 2$ & $423^{\prime} 4$ & $167^{\prime} 7$ & $420^{\prime} 7$ & $515^{\prime} 2$ \\
\hline
\end{tabular}

En el punto 3.2.2. Salidas y bajas de la Inclusa (pág 220) se analizaron los niños que salieron para crianza y la mortalidad de los que no llegaron a salir nunca, prácticamente del $100 \%$, solamente 17 de los niños ingresados en los 14 años analizados podemos decir que sobrevivieron a la Inclusa sin haber salido nunca de ella y pasaron directamente desde este departamento al de Mayores, son niños que habían ingresado con 4 años o más. No sabemos si los demás niños no salieron porque murieron antes, el hecho es que prácticamente todos los que quedaron en la Inclusa fallecieron; lo que justifica la prioridad que se daba a la crianza externa. 
El 34'34\% de los niños que ingresaron en la Cuna fallecieron en ella sin haber salido nunca desde su ingreso (ver GRÁFICA 3-37), la distribución por años fue muy irregular con porcentajes muy variables que van desde el 14'6\% de 1912 hasta el 46'6\% de 1909, la explicación puede tener relación con el tiempo de permanencia en la Inclusa.

\begin{tabular}{|c|c|c|c|c|c|c|c|c|c|c|c|c|c|c|}
\hline & 1900 & 1901 & 1902 & 1903 & 1904 & 1905 & 1906 & 1907 & 1908 & 1909 & 1910 & 1911 & 1912 & 1913 \\
\hline $\begin{array}{l}\text { INGRESADOS EN } \\
\text { EL AÑO }\end{array}$ & 475 & 378 & 412 & 450 & 418 & 434 & 386 & 406 & 414 & 444 & 441 & 407 & 453 & 431 \\
\hline $\begin{array}{c}\text { \% SALIDAS EN EL } \\
10 \text { MES }\end{array}$ & $66^{\prime} 9$ & $45^{\prime} 2$ & $36^{\prime} 9$ & $31^{\prime} 8$ & $55^{\prime} 3$ & $44^{\prime} 2$ & $33^{\prime} 7$ & $43^{\prime} 1$ & 44 & $36^{\prime} 9$ & 39 & $62^{\prime} 2$ & $73^{\prime} 7$ & $64^{\prime} 3$ \\
\hline $\begin{array}{c}\text { \% FALLECEN SIN } \\
\text { SALIR DE LA CUNA }\end{array}$ & $20^{\prime} 0$ & $37^{\prime} 6$ & $45^{\prime} 6$ & 44 & $26^{\prime} 8$ & $32 ' 5$ & $37^{\prime} 3$ & $37^{\prime} 2$ & $41^{\prime} 5$ & $46^{\prime} 6$ & 46 & $24^{\prime} 8$ & $14^{\prime} 6$ & $27^{\prime} 8$ \\
\hline $\begin{array}{c}\% \text { MORTALIDAD } \\
\text { INTERNA 0-1 AÑ̃O }\end{array}$ & $28^{\prime} 6$ & $46^{\prime} 0$ & $50 ` 5$ & $48^{\prime} 0$ & $29^{\prime} 4$ & $37^{\prime} 3$ & $40^{\prime} 9$ & $41^{\prime} 6$ & $47^{\prime} 1$ & $49^{\prime} 6$ & $47^{\prime} 4$ & $29^{\prime} 7$ & $18^{\prime} 5$ & $31^{\prime} 8$ \\
\hline $\begin{array}{l}\text { \% MORTALIDAD } \\
\text { TOTAL 0- } 1 \text { AÑO }\end{array}$ & $69^{\prime} 1$ & $71^{\prime} 4$ & 65 & $67^{\prime} 1$ & $55^{\prime} 7$ & $50^{\prime} 9$ & $56^{\prime} 7$ & 69 & 63 & $60^{\prime} 1$ & $67^{\prime} 8$ & $68^{\prime} 3$ & $46^{\prime} 6$ & $62 ' 7$ \\
\hline \multicolumn{15}{|c|}{$\begin{array}{l}\text { TABLA 3-33: Fallecidos sin salir de la Cuna. Total de niños ingresados, porcentaje de niños que salieron en el primer } \\
\text { mes de su ingreso y que fallecieron en la Cuna sin llegar a salir comparado con la mortalidad infantil interna y la } \\
\text { total (sumando internos y externos menores de un año), calculados sobre el total de ingresos vivos. Elaboración } \\
\text { propia (resaltados en rojo los datos más negativos y en verde los más positivos) }\end{array}$} \\
\hline
\end{tabular}

En la TABLA 3-33 se ha recogido el porcentaje de niños que fallecieron en la Cuna sin llegar a salir nunca y de los que salieron en el primer mes de su ingreso (vamos a llamarlas salidas tempranas= un tiempo máximo de permanencia de 30 días), en ella podemos comprobar que existe relación entre ambos factores. 1912 fue el año en que salieron más niños de forma temprana, en este año más de la mitad de los que partieron para crianza lo hicieron en la primera semana desde su ingreso (el 51'08\%); el siguiente año con menor mortalidad fue 1900 y se cumple la misma premisa, es el segundo año en porcentaje de salidas tempranas, siguen, cumpliendo esta relación 1913, 1911 y 1904. En el otro extremo, 1909 y los años con mayor mortalidad (1902, 1903 y 1910), son los que tuvieron menos porcentaje de salidas tempranas; en 1909 solamente el 23'88\% de los niños que salieron de la Inclusa lo hicieron en la primera semana. Podemos afirmar que cuanto más tiempo permanecían los niños internos en la Cuna mayor era su riesgo de fallecer, aunque veremos que no por ello se libraban, la mortalidad fuera también era muy elevada.

En este sentido, Lola Valverde en su trabajo sobre los expósitos de Navarra y Guipúzcoa, aunque referido a una etapa anterior a este estudio, confirma una mayor mortalidad de los expósitos que se internaban en la Inclusa de Pamplona que de los que desde sus parroquias en Guipúzcoa se enviaban directamente a lactar con nodrizas externas sin ser 
institucionalizados ${ }^{811}$ y para los que ingresaban en la Inclusa de Pamplona Arantzazu UribeEtxebarria confirma una relación inversa entre las salidas tempranas y la mortalidad en el primer año, de manera que cuantas más salidas tempranas se producían, menor era la mortalidad ${ }^{812}$. Este resultado se comprueba también en el caso de la Inclusa de Valladolid para la mortalidad infantil interna (\% del total de fallecidos dentro de la Inclusa menores de un año sobre el total de ingresos vivos), como puede observarse en la misma TABLA 3-3. Los años con más altas tempranas tienen menor mortandad interna, 1912 en concreto es el que tuvo el índice más bajo con el $18^{\prime} 5 \%$ y le sigue también 1900 con el $28^{\prime} 6 \%$. No se da la misma relación si consideramos el total de la mortalidad infantil de los expósitos dependientes de la Inclusa (internos y externos), para esta categoría 1912 sigue siendo el de mortandad más baja (466\%), pero 1900 ocupa el segundo lugar de las más altas y entre los siguientes años con más del 60\% de salidas tempranas, 1901 y 1911 tuvieron una mortalidad también entre las más elevadas, en torno al $70 \%$, solo tres años cumplen con esta relación inversa ocupando puestos similares en ambas categorías, por tanto no podemos establecer ninguna correlación entre ambas.

En definitiva, esto supone que la mortalidad fuera de la Inclusa también era muy elevada y si analizamos por años la distribución de las defunciones dentro y fuera del establecimiento, comprobamos que en algunos, los de menor mortalidad interna, fallecieron más niños externos. En la GRÁFICA 3-34 se comparan los dos grupos con el de defunciones totales y el de ingresados. Aunque en la mayoría del periodo la mortalidad interna superó a la externa, incluso hubo años como 1909 (242 internos -99 externos), 1902 o 1908 en los que la diferencia fue de más del doble; en otros como 1911, 1913 y sobre todo 1900 y 1912 en los que las proporciones se invirtieron con mayor mortalidad externa (216 externos frente a 145 internos en 1900 y 200-130 en 1912); son precisamente los cuatro años con la mayor proporción de salidas tempranas, con más del $60 \%$.

Disponemos entre la documentación del ADPVA de un cuadernillo hecho a mano que ofrece de los "Estados de personal. Año $1908^{\prime 1313}$ con un análisis bastante completo e interesante. En el informe, en forma de cuadros resumen del año 1908, se recoge que de los 420 menores de 5 años que ingresaron ese año, fallecieron 259 (el 60'23\%), 215 internos y 39 en el exterior contando entre ellos los 5 nacidos muertos; dentro de la "Casa" 214 niños (211 menores de 15 meses). El número total de defunciones entre los 457 niños de todas las edades que en ese año se encontraban en crianza externa o ingresos han contado el total de los 420

\footnotetext{
${ }^{811}$ VALVERDE LAMSFUS L.: Entre el deshonor y la miseria. Infancia abandonada en Guipúzcoa y Navarra. Siglos XVIII y XIX, Bilbao 1994

812 URIBE-ECHEVARRIA FLORES A: op.cit., pp 194- 197

${ }^{813}$ Estados de personal. Año 1908. Signatura: caja 2449, expediente 30.483. ADPVA
} 
folios de registro ocupados en los dos Libros de Exposiciones de ese año, pero de ahí tenemos que descontar cinco inscripciones dascendió a 129 (28’22\%). Las diferencias con los datos que hemos ido calculando se deben a que come "niños muertos" y un folio en blanco (fo 416), por lo que los ingresos efectivos fueron 414. Las cifras de mortalidad tampoco coinciden debido por una parte a que la memoria está hecha a año vencido y recoge los fallecidos solamente durante 1908, mientras que en nuestros datos hemos recogido todos los fallecidos que ingresaron y están inscritos en los Libros de Exposiciones de este año, y por otra parte a que en el caso de los externos podían tardar incluso años en enterarse del fallecimiento y registrarlo. Aún así los datos de la memoria y los nuestros son próximos, dada la elevada mortalidad en los primeros meses de ingreso, para nuestros cálculos la mortalidad de 1908 fue del 63'04\%. En cuanto a la mortalidad exterior está muy infravalorada, en la memoria se recogen solamente 39 defunciones de niños ingresados en 1908 y en los libros he contado 113 inscripciones, (46 fallecieron en 1908, 45 en 1909, 13 en 1910, 5 hasta 1913 y otros 3 mayores de 5 años); si sumamos esta diferencia al total de los 129 fallecidos externos de todas las edades que cuenta la memoria suman 203 y el porcentaje de la mortalidad exterior ya se situaría en el $44^{\prime} 42 \%$, sin contar con las defunciones no conocidas por el Hospicio, que está próxima a la que hemos calculado ene este año del $46^{\prime} 70 \%$. Significa esto que hay que ser cautos con los datos que proporciona el propio Hospicio, incluso la Diputación como veremos, sobre mortalidad y analizarlos porque según se presentan, intencionalmente o no, dan una imagen mucho más benévola.

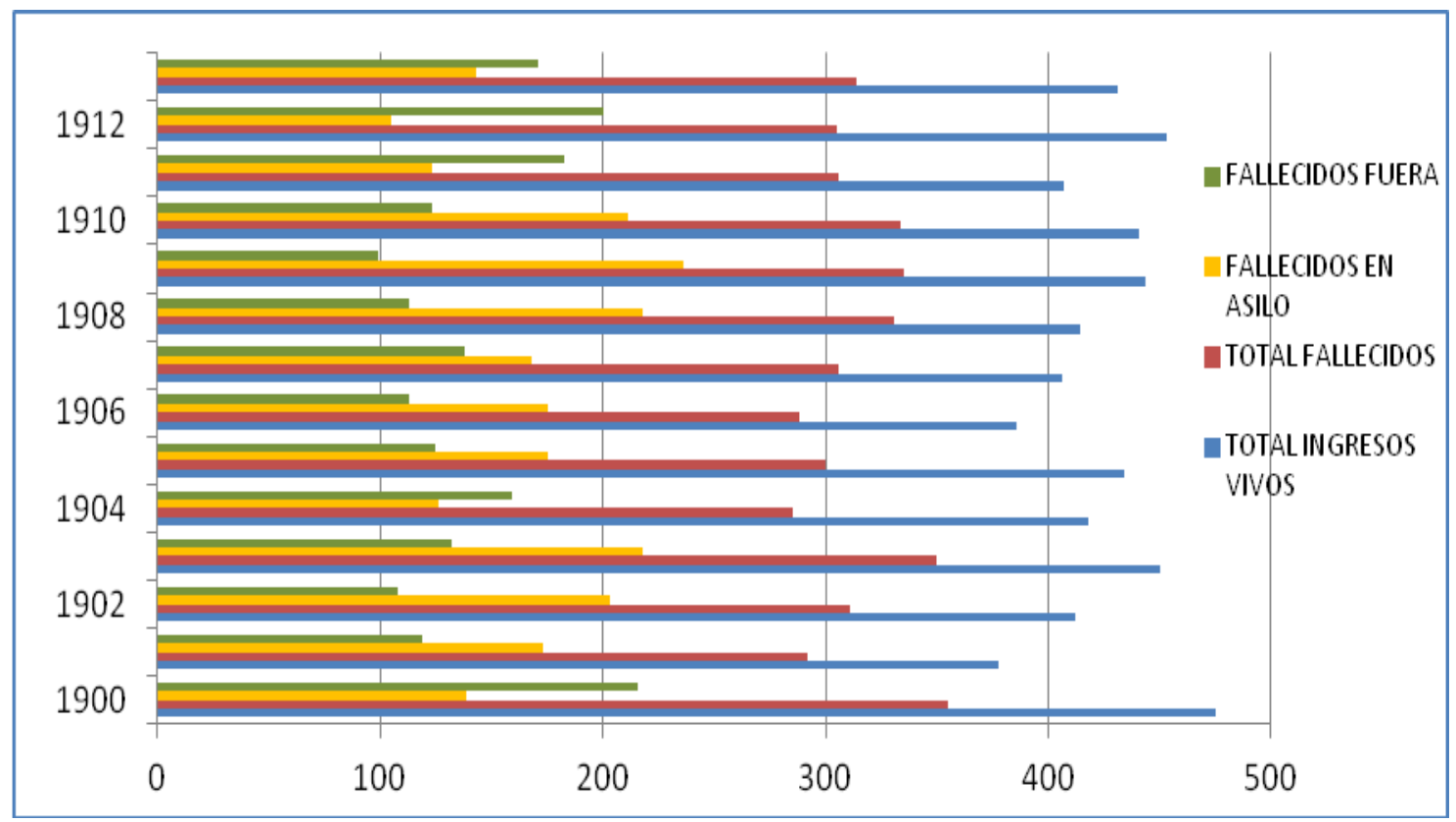

GRÁFICA 3-34: Comparativa entre los fallecidos dentro y fuera del establecimiento, el número total de defunciones y el total de ingresos anuales. Elaboración propia 
La mortalidad con las amas fue por tanto también muy alta, representa un porcentaje medio del $33^{\prime} 35 \%$ sobre el total de ingresos anuales. Si lo calculamos solamente sobre los que salieron a crianza externa sube de forma considerable, hasta el 53'14\%. En las salidas se han contado solamente los que fueron con nodrizas, descontándose los 127 que salieron de la Inclusa para ir directamente con sus padres, aunque si se han contado los que regresaron con la familia después de pasar por las manos de una o más amas. Suponen 3.762 expósitos de los que fallecieron 1.999, es decir que más de la mitad de los niños en crianza externa fallecieron con las nodrizas.

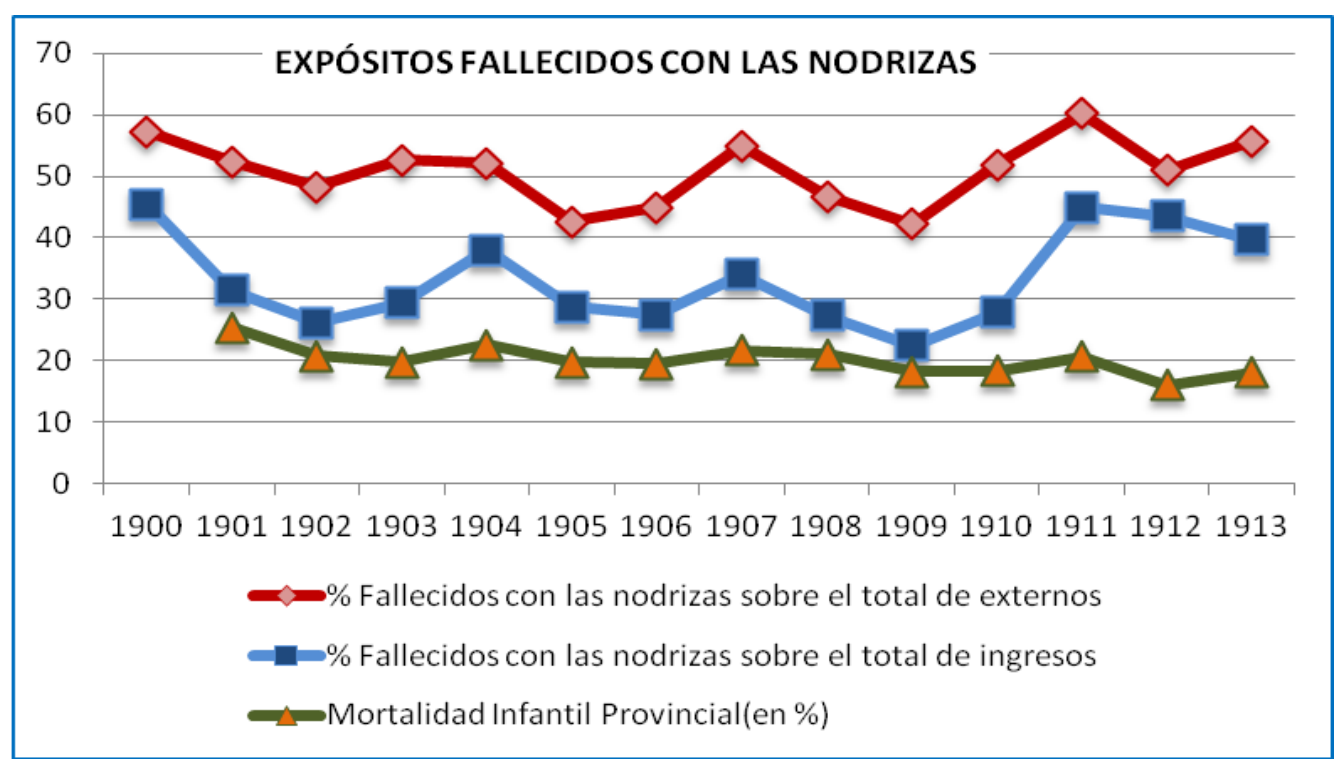

GRÁFICA 3-35: Porcentaje de expósitos fallecidos con las nodrizas, calculado sobre el total de ingresos y sobre el total de salidas para crianza externa anuales, y mortalidad infantil provincial (en \%). Elaboración propia

En la GRÁFICA 3-35 se representa la distribución anual de los dos valores (fallecidos con las nodrizas sobre el total de ingresos y sobre el total de niños externos). El pico máximo aconteció en 1911 con porcentajes que representan el 60'2 \% de los niños externos y el 45\% sobre el total de ingresados; en 1900 se alcanzaron el 57'3\% y $45^{\prime} 5 \%$ respectivamente. En el límite inferior está 1909 con porcentajes del $422^{\prime} 2 \%$ de externos y $22^{\prime} 5 \%$ del total de ingresos, coincide que éste es el año con más muertes de internos que no llegaron a salir. En 1912, el año con más salidas precoces, fallecieron con las nodrizas el 50’9\% de los niños en crianza externa, un dato que es el valor promedio de la serie y que sin embargo respecto al total de ingresados representa el $43^{\prime} 5 \%$, el tercer valor más alto. Esta mortalidad tan alta de los externos está en relación con la alta mortalidad infantil provincial, de manera que, aunque no coinciden los años de máxima incidencia en las dos categorías, si hay cierto grado de 
coincidencia en la evolución de ambas, como puede apreciarse en la GRÁFICA 3-35, de modo que los picos de mortalidad expósita acompañan a incrementos de la mortalidad provincial.

Quedan por analizar las defunciones que corresponden a los niños que salieron para crianza externa y fallecieron en la Inclusa después de que las nodrizas les devolvieran, que se han incluido dentro de la mortalidad interna, pero merece la pena valorar por separado. Representan el 6'37\% del total de niños que ingresaron en la Cuna, la mitad fallecieron en el primer mes de su retorno (50'04\%) y un $31 \%$ entre el primer y el sexto mes. Hay que tener en cuenta que muchas veces volvían precisamente a la Inclusa por enfermedad para recibir atención médica, el escaso salario que cobraban las nodrizas no daba para gastos médicos; por eso esta práctica era habitual en todas las inclusas españolas ${ }^{814}$. Estos niños representan el $10^{\prime} 05 \%$ del total de los que salieron con nodrizas externas, con este dato resulta que el $63^{\prime} 14 \%$ de los niños que salieron para crianza externa fallecieron o con las nodrizas o posteriormente al regresar a la Inclusa.

Recapitulando y desagregando los datos de la GRÁFICA 3-30 en lo que se refiere a las defunciones de los menores de 5 años según que tuviera lugar dentro o fuera de la Cuna y que hubieran estado o no en crianza externa, la distribución de los niños ingresados en la Cuna entre 1900 y 1913 queda como se representa en la GRÁFICA 3-36 un tercio falleció antes de salir para crianza y otro tercio con las nodrizas, si contamos otra décima parte que fallecería al regresar o al cabo de unos años, quedan como ya habíamos visto menos de una cuarta parte de supervivientes, siendo optimistas y contando en ellos a los niños sin el historial cerrado. Lo sorprendente de esta distribución es la igualdad que existe entre la mortalidad interna de los niños que no llegaron a salir con las nodrizas y la externa y que lo que marca la diferencia entre la mortandad de los niños internados y de los externos recae precisamente en los retornados, teniendo en cuenta que muchos de ellos volvieron enfermos.

\footnotetext{
${ }^{814}$ RODRÍGUEZ MARTín A. M: El destino de los niños de la Inclusa de Pontevedra, 1872-1903 (2008), p 361. Cita esta autora a: AGUIRRE BARRIO J.: Mortalidad en la primera infancia, sus causas y medios de atenuarlas, Madrid 1885, $\mathrm{p}$ 132. VALVERDE LAMSFUS L.: op.cit p 226 y ÁLVAREZ SANTALÓ L. C.: op.cit., p 180.
} 


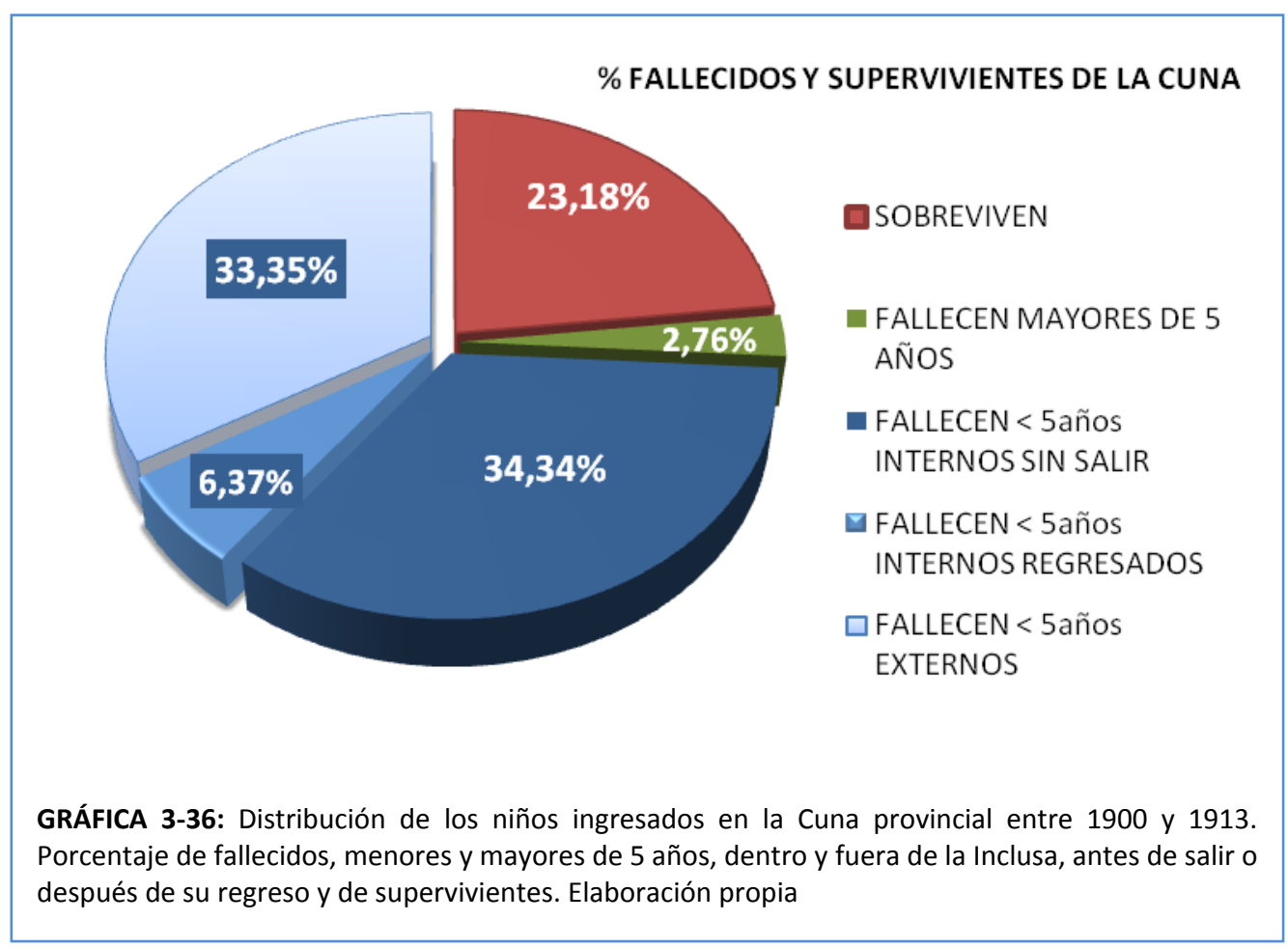

Ante estos datos cabe plantearse si le merecía la pena a la Inclusa mandar a los niños con las nodrizas y la respuesta es doblemente afirmativa, por un lado aunque vistas así en conjunto las proporciones son similares, no hay que perder de vista que todos, o casi todos los que se quedaban internos estaban condenados a morir, con las nodrizas tenían casi un $50 \%$ de más posibilidades, en realidad, $46^{\prime} 86 \%$ para los externos y bajaba a $38^{\prime} 81 \%$ para los que retornaban. Por otro lado por una cuestión logística y económica, la Inclusa no tenía capacidad para criar tantos niños internos ni para conseguir tantas amas para ellos. Es por ello que León C. Álvarez Santaló ante la tremenda mortalidad expósita mantenida a lo largo del tiempo habla del "costo de la muerte" planteando que para las inclusas no resultaba rentable reducirla ${ }^{815}$

La estacionalidad era un factor muy influyente en la mortalidad de la infancia y en sus causas, al analizar la repercusión en la de la Cuna, encontramos que coincide con la de los niños de la población general con un incremento significativo en los meses veraniegos, julio y agosto especialmente. En GRÁFICA 3-37 se muestra la evolución de la mortalidad de los expósitos de la Cuna provincial a lo largo del año con la distribución mensual en valores absolutos, no se han contabilizado los fallecimientos registrados en los libros sin fecha o con fecha dudosa.

\footnotetext{
${ }^{815}$ ÁLVAREZ SANTALÓ L. C.: op.cit., p 121.
} 


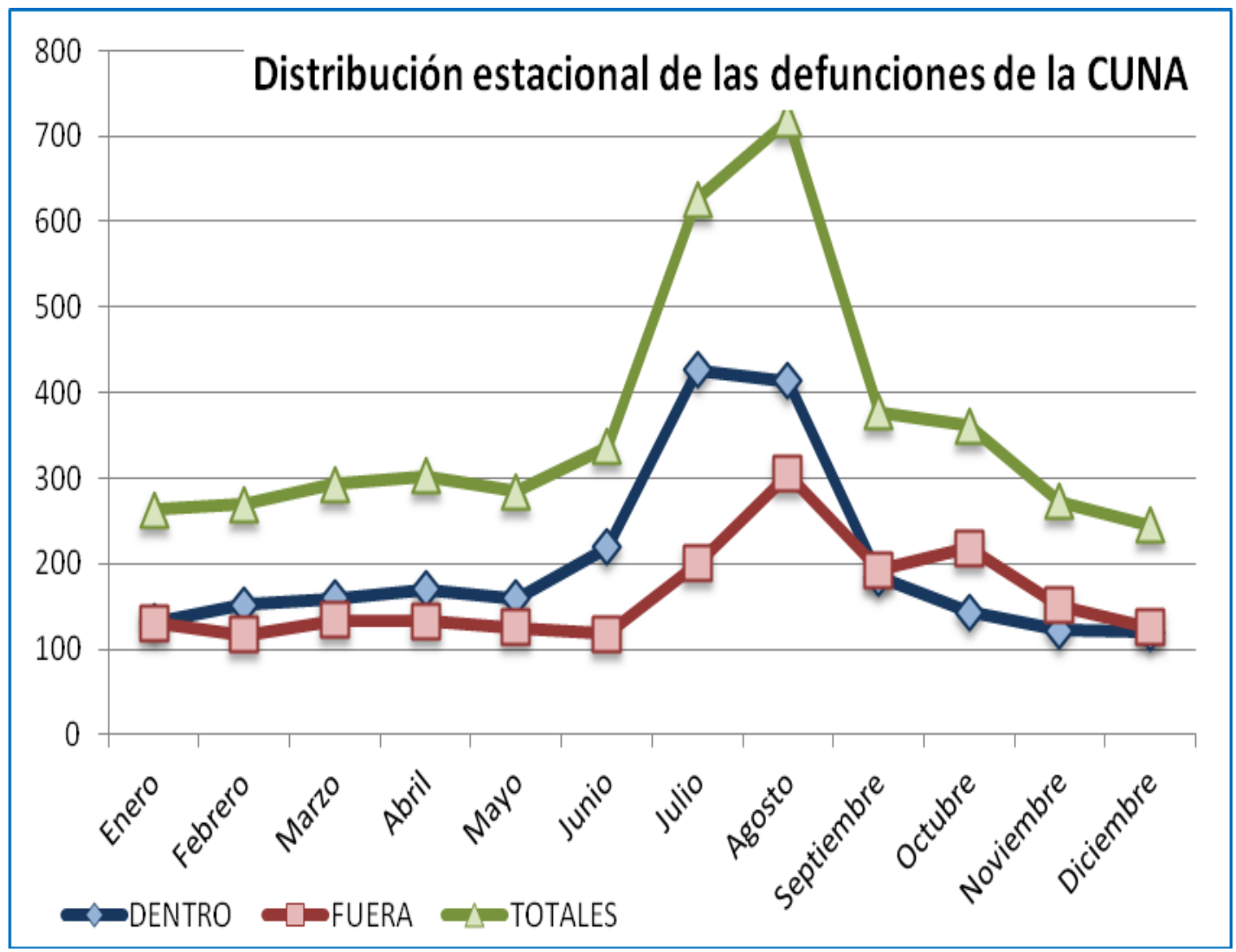

GRÁFICA 3-37: Distribución por meses de las defunciones de los niños de la Cuna provincial, del total y de los fallecimientos dentro y fuera del establecimiento entre 1900 y 1913, en valores absolutos. Elaboración propia

Aunque hay bastante coincidencia en la tendencia general entre los datos de mortalidad dentro y fuera del establecimiento, hay algunas diferencias entre ambas. En conjunto, considerando el total de internos y externos, los meses más fríos, de noviembre a febrero fueron los más benévolos, mientras que en los meses cálidos, de junio a octubre, acumularon más de la mitad de la mortalidad total (el 55'63\%) que se concentró especialmente en julio y agosto (entre los dos coparon el 30’92\% del total). En la GRÁFICA 3-38 se puede comparar la distribución mensual de los fallecimientos dentro y fuera de la Cuna, en relación al total y los valores promedios para cada grupo y mes, aunque en estos meses el comportamiento de cada grupo fue diferente, por lo que es necesario analizarlos por separado. 


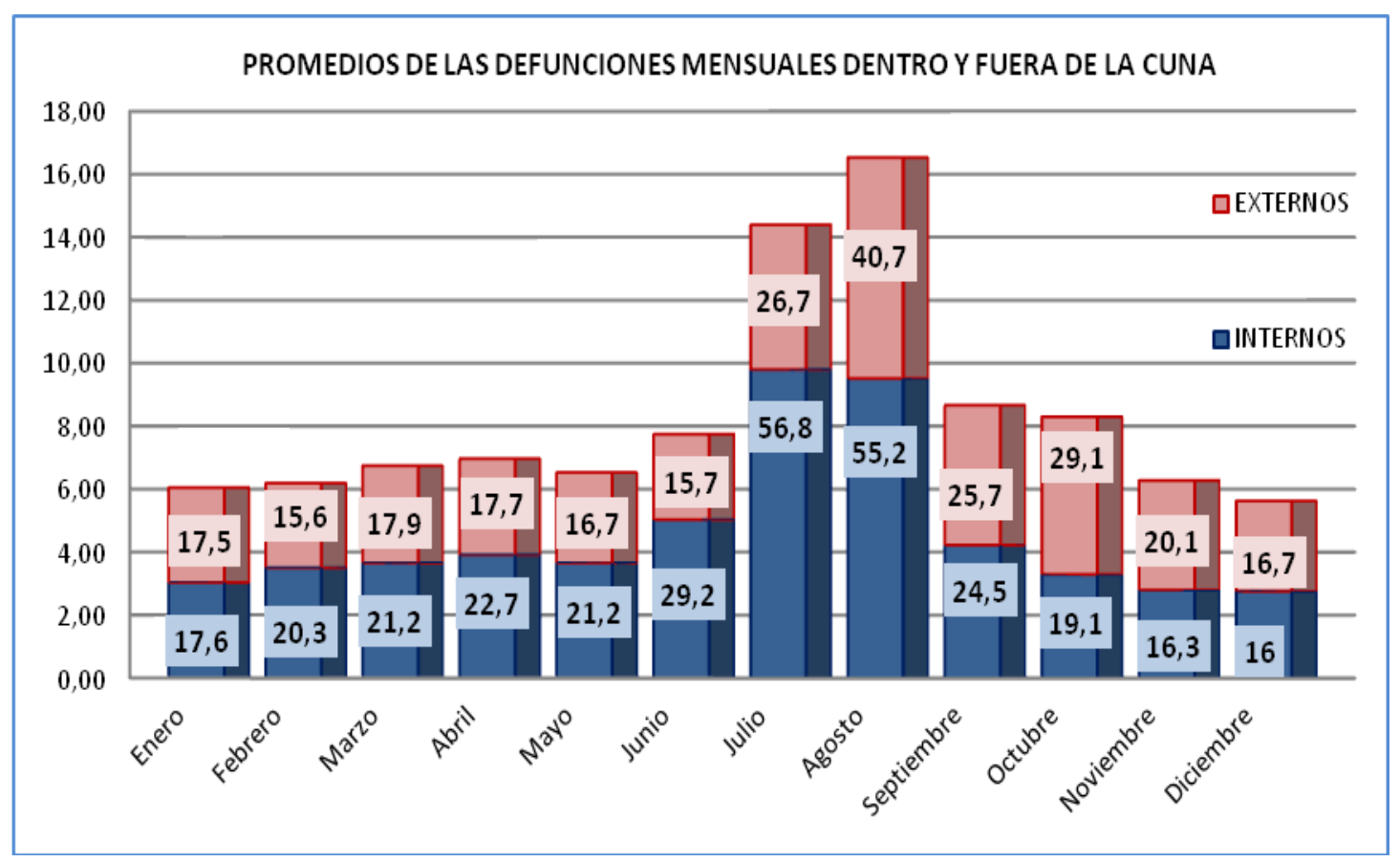

GRÁFICA 3-38: Distribución por meses de las defunciones de los niños de la Cuna provincial dentro y fuera del establecimiento entre 1900 y 1913. La gráfica recoge el porcentaje respecto al total de fallecimientos (internos más externos) y en los recuadros el promedio mensual de cada grupo. Elaboración propia

Julio y agosto, por este orden son los meses con el máximo número de muertes entre los internos y con bastante diferencia respecto al resto del año (426 y 414 respectivamente en valores absolutos), les siguen los meses adyacentes, junio y septiembre por este orden. Entre los externos el peor mes y muy destacado es agosto (305 fallecimientos), seguido de octubre y julio en segundo y tercer lugar (218 y 200 respectivamente).

De febrero a agosto, ambos inclusive, fallecieron más internos, pero a partir de septiembre se invierte la mortalidad y fallecieron más niños con las nodrizas. La diferencia más significativa entre los dos grupos es la del mes de julio con más del doble de fallecidos dentro de la Inclusa; en junio, con valores absolutos mucho más bajos, también los fallecimientos internos casi doblaron a los externos. Recordemos que el promedio de ingresos mensuales en la Cuna para este período de 1900-1913 fue de 35'87 niños, muy ampliamente superado por las muertes de internos en los meses de julio y agosto. Hay también que tener en cuenta que entre los fallecimientos habría niños ingresados en meses y años previos, sobre todo entre los externos. En GRÁFICA 3-39 se muestra el porcentaje mensual respecto a los totales anuales de cada grupo, internos y externos, por separado. 


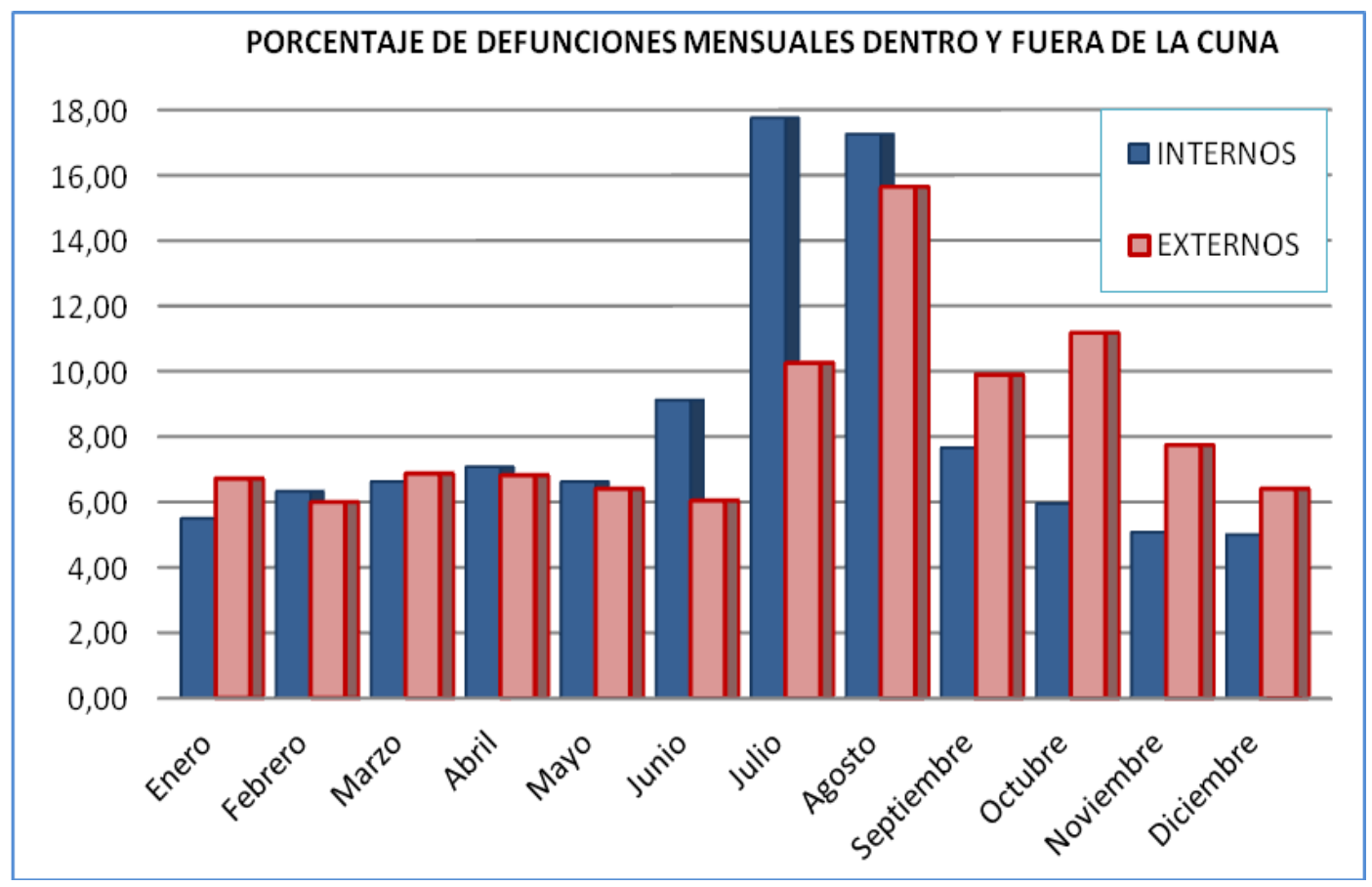

GRÁFICA 3-39: Distribución por meses de las defunciones de los niños de la Cuna provincial dentro y fuera del establecimiento entre 1900 y 1913, en porcentajes respecto al total de fallecimientos de cada grupo. Elaboración propia

Es llamativa la mortalidad externa en los meses de octubre y noviembre, que superaron incluso a la de junio, mientras que en la Inclusa la mayor mortalidad se concentró en los meses más calurosos y octubre no destaca, con una mortalidad menor que la de los meses primaverales. La distribución mensual de la mortalidad externa coincide con la que recoge Arbelo para la población infantil general de las primeras décadas del siglo XX, con mayor incidencia en el segundo semestre del año, de julio a noviembre. Arbelo justifica esta distribución en función de la climatología y particularmente de la temperatura máxima diaria; afirma que el pico máximo de mortalidad corresponde a los meses estivales de temperaturas máximas, pero que la mortalidad se mantiene elevada durante unas semanas después de ceder el calor ambiental ${ }^{816}$. Esta explicación parece cuestionable para la provincia de Valladolid en la que los meses de octubre y noviembre no son normalmente calurosos, sus temperaturas máximas se sitúan por debajo de las del mes de mayo con un promedio en octubre inferior a

\footnotetext{
${ }^{816}$ ARBELO CURBELO A.: op.cit, pp 293- 298. Dice además ARBELO que” de la temperatura máxima, mínima y media, es la máxima la que más estrecha relación guarda con la mortalidad infantil" y establece que hay mayor riesgo a partir de $25^{\prime} 5^{\circ} \mathrm{C}$ y de $20^{\circ} \mathrm{C}$ para los niños criados con lactancia artificial. (p 294)

Siendo Valladolid una provincia situada en la Meseta Central con un clima continental de extremos, consulto los promedios mensuales de las temperaturas máximas diarias. La AEMet (Agencia Estatal de Meteorología) recoge para la provincia de Valladolid en el período 1981- 2010 las siguientes (en ํ) : mayo: 21으, Junio 27, julio: 30’7, agosto: $30^{\prime} 1$, septiembre: $25^{\prime} 6$, octubre: $18^{\prime} 9$ y noviembre $12^{\prime} 4$. Disponible en: http://www.aemet.es/es/serviciosclimaticos/datosclimatologicos/valoresclimatologicos?l=2422\&k=cle
} 
$19{ }^{\circ} \mathrm{C}$, pero el hecho es que este mes se situó en el segundo lugar en el período estudiado con una mortalidad incluso superior a la de julio. Como sea que en los niños que fallecían fuera de la Inclusa no se anotaba la causa de la defunción en los libros, no podemos saber con exactitud a qué tipo de procesos se debía la mortalidad de estos dos meses, entre los internos por orden de frecuencia fueron las infecciones gastrointestinales (siguiendo en frecuencia a los cuatro meses previos) y los problemas nutricionales y digestivos (por detrás solamente de julio y agosto), seguidos de cerca por sífilis e infecciones respiratorias (por detrás sólo de marzo).

El hecho de que dentro de la Inclusa no se cumpla con este criterio de estacionalidad y después de julio y agosto se produzca una caída muy brusca en septiembre puede deberse precisamente a la altísima mortalidad de esos dos meses, que por otra parte son los dos que tuvieron ingresos mínimos (GRÁFICA 3-7), por lo que, teniendo además en cuenta que más del 90\% de los niños salían en los dos primeros meses desde su entrada (GRÁFICA 3-29), en los meses siguientes el número de internos sería más bajo.

\subsubsection{CAUSAS DE MORTALIDAD EN LA INCLUSA}

Falta analizar las causas de la mortandad de los expósitos de la Cuna provincial de Valladolid. Solamente las conocemos en los niños que fallecieron dentro del establecimiento, en su folio de inscripción se anotaba fecha, hora y motivo de la defunción. En los fallecidos con las nodrizas, salvo alguna excepción, no se ha apuntado la causa, simplemente la fecha y el lugar, a pesar de que debería conocerse pues la normativa obligaba a enviar al Hospicio el certificado de defunción, es probable que se archivara sin más en el expediente, hay alguno suelto. Una cruz en el folio indicaba la baja por defunción.

"Falleció en este Asilo en 22 de julio de 1904 á las veinticuatro horas á consecuencia de una congestion cerebral" [sic] (fo 238 LE 1904-1)

“El dia 9 de septiembre falleció en Quintanilla de Abajo· [sic] (fo 312 LE 1913-2)

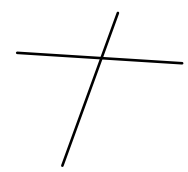


Las principales causas de mortalidad infantil en España durante las tres primeras décadas según la nomenclatura que utilizaba para la época el Instituto Nacional de Estadística fueron las "diarreas y enteritis", seguidas de lejos por el conjunto de "bronquitis agudas" y "neumonías", que se recogen por separado, y por la "debilidad congénita y vicios de conformación", también muy alejadas del resto ${ }^{817}$. En el grupo de edad de 1 a 5 años se mantienen las infecciones como la causa principal de mortalidad ocupando las meningitis el tercer lugar desplazando a los problemas congénitos ${ }^{818}$. Las causas de mortalidad para todos los niños de 0 a 5 años para las tres décadas y más concretamente para el período 1900-1913 se mantienen en el mismo orden referido para los menores de un año (mortalidad infantil), las meningitis ocupan el cuarto lugar. Si agrupamos todas las enfermedades consideradas clasicamente infantiles, por ser en esta edad cuando suelen aparecer, recogidas en las estadísticas oficiales por separado con las nomenclaturas "Sarampión”, "Difteria y Crup", "Coqueluche" (tosferina) y "Escarlatina", en conjunto se situarían en los menores de 5 años en tercer lugar por delante de los problemas congénitos, a expensas principalmente de una incidencia especialmente alta en el grupo de 1 a 5 años:

\begin{tabular}{|c|c|c|}
\hline 0-1 años & 1-4 años & 0-5 años \\
\hline diarreas y enteritis & diarreas y enteritis & diarreas y enteritis \\
\hline $\begin{array}{c}\text { bronquitis agudas y neumonías } \\
\text { debilidad congénita y vicios de } \\
\text { conformación }\end{array}$ & bronquitis agudas y neumonías & bronquitis agudas y neumonías \\
\hline meningitis & meningitis & infantiles \\
\hline & $\begin{array}{c}\text { debilidad congénita y vicios de } \\
\text { conformación }\end{array}$ & $\begin{array}{c}\text { debilidad congénita y vicios de } \\
\text { conformación }\end{array}$ \\
\hline & & meningitis \\
\hline
\end{tabular}

TABLA 3-34: Principales causas de mortalidad por orden de incidencia y por grupos de edad, según la nomenclatura utilizada para la época por la Dirección General del Instituto Geográfico y Estadístico

En definitiva se confirman los procesos infecciosos como responsables de la mayor parte de la mortandad en la infancia con una tasa que supera el $75 \%$ sobre el total ${ }^{819}$.

\footnotetext{
${ }^{817}$ Para hacernos una idea, un año como 1910, de un total de 96.594 niños menores de 12 meses fallecidos, sin contar los de las primeras 24 horas de vida, más de un tercio (28.153) lo fueron por diarreas y enteritis; 19.868 por bronquitis agudas, neumonías y otras enfermedades respiratorias (excepto la tisis); 16.917 por debilidad congénita y vicios de conformación. A mucha distancia siguen, meningitis (6.630 casos) y otras infecciones como coqueluche (tosferina) y sarampión. ARBELO CURBELO A.: op.cit., p 335; Movimiento Nacional de la Población 1910. Defunciones por causa y edad

Se llamaban vicios de conformación a las malformaciones y deformidades congénitas y se entendía por debilidad congénita cuando el neonato "tiene sus órganos y aparatos incompletamente desarrollados... un niño no acabado, de escaso peso y de funciones incompletas (inmaduro)". BOIX BARRIOS J.: Manual de puericultura, 1941, p 251 -252

${ }^{818}$ Arbelo para el grupo de edad de mayores de 1 año y menores de 5 recoge solamente las estadísticas a partir de 1941; los datos referidos se han tomado directamente del Fondo Documental del INE.

${ }^{819}$ Calculada sobre la estadística de 1905 y 1910. Fondo Documental del INE. Movimiento Nacional de la Población 1905. Defunciones por causa y edad. Idem 1910.
} 
Para la Inclusa se van a hacer los cálculos sobre el total de causas de mortalidad legibles registradas en los Libros de Exposiciones, pues algunas son indescifrables según están escritas e incluso en ocasiones, aunque es poco habitual, faltan en niños internos, el número de diagnósticos en externos no es representativo. Algunas de estas causas registradas en los Libros de Exposiciones son diagnósticos que actualmente están en desuso o son conceptualmente diferentes, por lo que para entenderlos en el sentido con que en su momento se utilizaron se han empleado libros y tratados de Pediatría de la época, incluso en ocasiones ha sido necesario echar mano del Espasa para algunos términos ${ }^{820}$. Dada la variedad de diagnósticos que aparecen en los libros como causas de los fallecimientos de los niños internos, algunos similares o próximos, se han agrupado en categorías clínicas; en la Cuna para el período 1900- 1913 también las infecciones gastrointestinales constituyeron la primera causa de mortalidad seguidas por orden de incidencia de enfermedades nutricionales y digestivas, sífilis, infecciones respiratorias y de otro tipo y la debilidad congénita (GRÁFICA 3-40)

Las INFECCIONES GASTROINTESTINALES causaron en la Cuna el $28^{\prime} 62 \%$ de los fallecimientos registrados en los Libros de Exposiciones, en las estadísticas nacionales se recogen con la nomenclatura "diarreas y enteritis" y representaron el $21^{\prime} 76 \%$ del total de muertes en menores de 5 años en $1905^{821}$. En esta categoría se han incluido los procesos infecciosos que afecten a los tramos inferiores del aparato digestivo y que aparecen en los Libros de Exposiciones como catarro ${ }^{822}$ intestinal, colitis, colitis crónica, diarreas, disentería crónica, enteritis, enteritis aguda, enteritis crónica, enterocolitis, gastroenteritis, infección gastrointestinal o irritación intestinal.

\footnotetext{
${ }^{820}$ Se han consultado: SUÑER Y ORDÓÑEZ E.: Enfermedades de la infancia (doctrina y clínica). Tomos I, II y III, 1918 y 1921; MARFAN Profesor y col. Pediatría, 1925; BOIX BARRIOS J.: op.cit, 1941; VELASCO Y LLAMAS S.: op.cit, 1897; BUXÓ IZAGUIRRE P.: Enfermedades de los niños de pecho, 1945; RAPIN D.: Manual práctico de partos para uso de comadrones y parteras, por el Dr. D. Rapín de la Universidad de Lausana, s.a.; CASAS DE BATISTA R.: Fabre y D'Huc. Tratado elemental de enfermedades de la mujer y del niño... RECHE ANDRÉS J.: La Pediatría española a través de la revista "La Medicina de los niños, 1900-1936", 1981; BOSCH MARín J.: El niño español en el siglo XX. Discurso de recepción en la R.A.N. de Medicina, 1947; Enciclopedia Universal Ilustrada Europeo-Americana, 1908- 1925

${ }^{821}$ Se ha tomado el año 1905 como referencia para comparar los datos nacionales con los de la Inclusa. Para obtener los datos nacionales para el grupo de menores de 5 años es necesario sumar los parciales que ofrecen las estadísticas oficiales que presentan los datos desglosados por sexos y para los grupos de edad "De menos de 1 año" y "De 1 a 4 años"; el siguiente grupo es de mayores "De 5 a 9 años". En ese año el total de defunciones a nivel nacional de menores de 5 años fue de 207.880, en la categoría "diarreas y enteritis" se registraron 45.232 casos. Fondo Documental del INE. Movimiento Nacional de la Población 1905. Defunciones por causa y edad.

${ }^{822}$ Aunque actualmente entendemos por CATARRO la afectación respiratoria, especialmente de la garganta y de la nariz que produce un aumento de la secreción nasal, el significado en la época era más amplio y se extendía a cualquier mucosa, por lo que lo encontramos en procesos localizados en otros aparatos diferentes del respiratorio con diagnósticos como catarro de las vías biliares. El diccionario de la RAE lo define hasta 1989 como: "Flujo o destilación procedente de las membranas mucosas. Inflamación aguda o crónica de estas membranas con aumento de la secreción habitual de moco", RAE, 1889, p 209, 3
} 


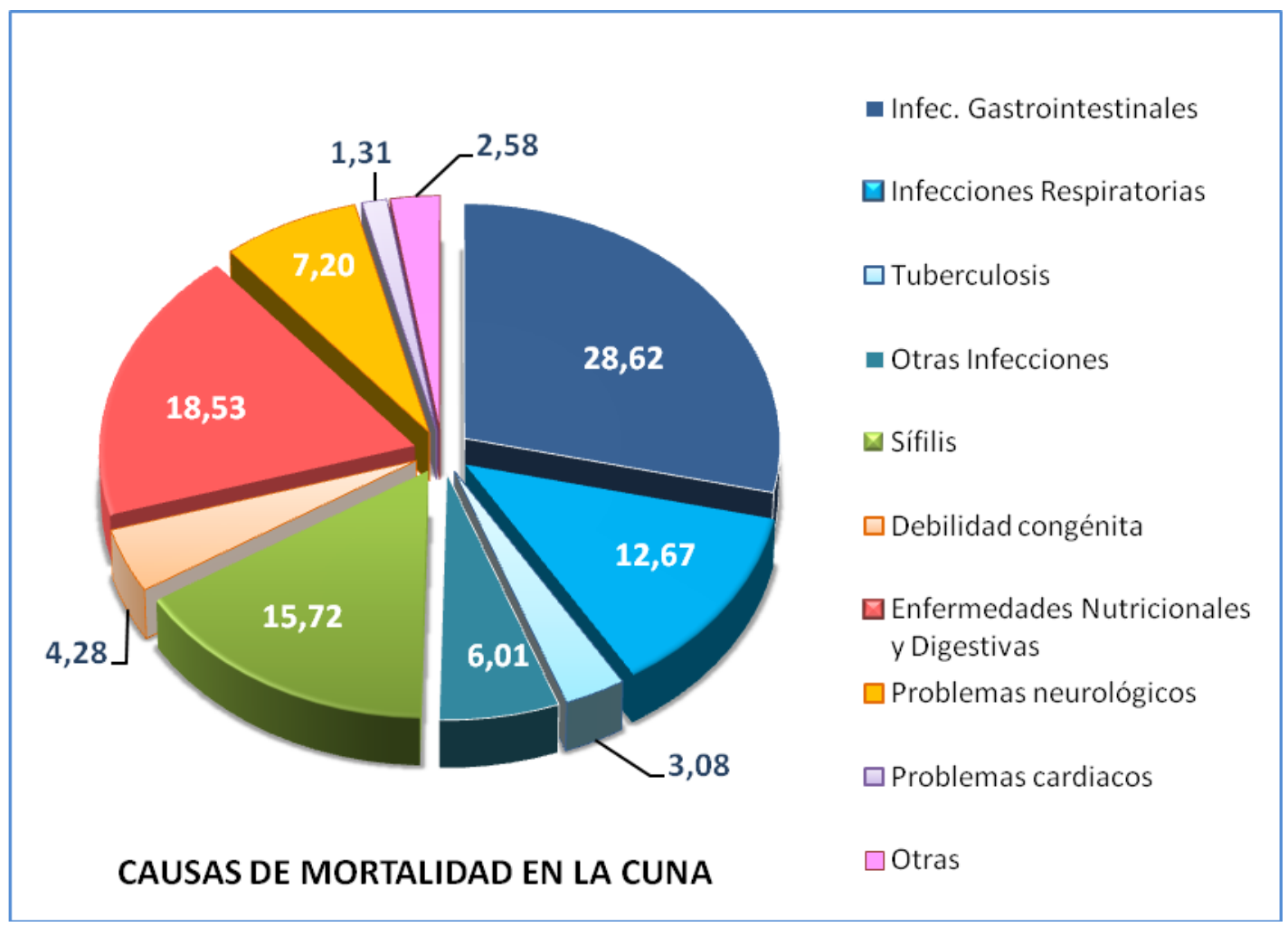

GRÁFICA 3-40: Distribución porcentual de las causas de defunción de los niños internos en la Cuna provincial entre 1900 y 1913. Elaboración propia

Las enfermedades NUTRICIONALES Y DIGESTIVAS, de carácter no infeccioso, constituyeron la segunda causa de defunción en la Cuna con el $18^{\prime} 53 \%$ sobre el total, en ellas se han incluido los diagnósticos: anemia general, atonía gástrica, atonía gastrointestinal ${ }^{823}$, atrepsia, atrepsia por dispepsia, dispepsia, atrofia ${ }^{824}$, consunción ${ }^{825}$, empacho gástrico,

\footnotetext{
${ }^{823}$ ATONÍA: falta de tono y vigor, o debilidad de los tejidos orgánicos, particularmente de los contráctiles. ATONÍA GÁSTRICA ó GASTROINTESTINAL: decaimiento, escasez de fuerzas en las funciones, falta de movilidad gastrointestinal. Enciclopedia Espasa, tomo 6, p 944; RAE 1899, p 107, 3

${ }^{824}$ ATREPSIA: trastorno nutritivo muy grave propio de los primeros meses de la vida en niños lactados artificialmente que provocaba una malnutrición caracterizada por un descenso progresivo del peso hasta causar la muerte, se denominaba también ATROFIA INFANTIL. No se conocía su patogenia, pero se consideraba consecuencia de repetidos errores alimenticios en las primeras semanas de vida, entre las teorías más aceptadas estaba la que atribuía su origen a la leche como responsable; se podía asociar a infecciones crónicas como la sífilis o la tuberculosis. Los síntomas que se describían corresponden a los de una malnutrición severa: descenso constante y progresivo de peso, ausencia de panículo adiposo, atrofia muscular, vientre distendido, delgadez de miembros y tórax, edemas locales, alteraciones del tránsito intestinal. Los casos más graves de atrepsia no respondían al tratamiento que era básicamente dietético.

ATREPSIA POR DISPEPSIA: forma de desnutrición por alteración digestiva crónica con diarreas de origen alimenticio DISPEPSIA: trastorno digestivo y nutritivo de origen generalmente alimentario, por exceso o por la mala calidad de la dieta que cursa con diarrea por malabsorción. Se le atribuía también como causa una posible infección o "los calores del verano". Pronóstico benigno con un buen tratamiento dietético. Se podía complicar sobre todo en verano y desembocar en una atrepsia.

Para el tratamiento de las atrepsias en los menores de tres meses se proponía leche de mujer o en su falta de burra, con una correcta dosificación de la leche; Suñer recomendaba entre las leches modificadas que fueron desarrollándose (hechas a partir de la leche de vaca para alimentar a los lactantes) la desengrasada y la albuminosa. Entre las propuestas terapéuticas una indicaba utilizar un preparado a base de arsénico, "una gota de licor de Fowler por día", otros más conservadores aconsejaban sobre todo cuidados higiénicos y dietéticos más que
} 
gastritis $^{826}$, indigestión ${ }^{827}$ y raquitismo ${ }^{828}$. El escrofulismo a pesar de que en estos años se seguía considerando una enfermedad de tipo nutritivo realmente era una variante de tuberculosis, por lo que se ha incluido en esa categoría ${ }^{829}$. Los problemas digestivos se recogen en las estadísticas oficiales nacionales como "Afecciones del estómago (excepto el cáncer)" y representaron el $0^{\prime} 86 \%$ del total para el grupo de edad de menores de 5 años $^{830}$. Las

farmacológicos, como administrar al niño "jugo fresco de carne mezclado con unas gotas de limón", baños salinos y el uso de incubadora. SUÑER Y ORDÓÑEZ E.: Enfermedades de la infancia, tomo 1, pp 285- 293; BUXÓ IZAGUIRRE P.: op.cit, 1945, pp 74- 81, 217- 221, RECHE ANDRÉS J.: op.cit, pp 46- 47.

825 CONSUNCIÓN: "disminución lenta y progresiva de fuerzas y reducción del volumen de los órganos. Es un problema común a todas las enfermedades de lesiones profundas y también a los vicios de nutrición general. Sinónimo de enflaquecimiento y maciación". Enciclopedia Espasa, tomo 15, p 104

${ }^{826}$ La GASTRITIS AGUDA se consideraba un estado congestivo de la mucosa gástrica de origen infeccioso que cursa con fiebre que puede ser muy elevada, vómitos y normalmente estreñimiento y que se puede presentar de forma aislada o subordinado a otras enfermedades infecciosas. Se consideraba que en los adolescentes podía aparecer por una astenia nerviosa provocada por los esfuerzos intelectuales excesivos o por cualquier causa agotante del sistema nervioso. Se le daba también el nombre de EMPACHO GÁSTRICO, Gastritis Catarral o catarro agudo del estómago. La GASTRITIS CRÓNICA se denominaba también DISPEPSIA CRÓNICA y habitualmente se acompañaba de diarrea moderada por malabsorción. SUÑER E.: Enfermedades de la infancia, 1, pp 397- 400; CASAS DE BATISTA R.: op.cit, pp 499- 500. En los libros de Exposiciones se encuentran registradas simplemente como gastritis, puesto que la aguda es un proceso leve, para ocasionar la muerte deberían ser cuadros graves y las hemos considerado por eso como procesos crónicos y por tanto dispépticos, por otro lado solo se registran cuatro casos que apenas modifican los porcentajes de las categorías infecciones gastrointestinales o enfermedades digestivas en la que se han incluido 827 La INDIGESTIÓN "es muy frecuente en los niños y depende de la avidez irreflexiva con que acumulan frecuentemente en su estómago una cantidad considerable de alimentos" (CASAS DE BATISTA R.: op.cit, pp 499). Como parece poco probable que en la Cuna fallecieran niños por exceso de alimentos, nos quedamos mejor con la otra causa posible que indica Suñer, las malas condiciones de los alimentos, por su mala calidad o su mala preparación. Esto, sobre todo si se dan condiciones distróficas de debilidad digestiva en el niño, puede ocasionar la indigestión o DISPEPSIA AGUDA y se pueden producir "estados comatosos alarmantes que dan origen al síndrome del coma dispéptico". SUÑER Y ORDÓÑEZ E.: Enfermedades de la infancia, tomo 1, pp 391- 394.

${ }^{828}$ EI RAQUITISMO es una avitaminosis D, es decir, una alteración nutricional por déficit de vitamina $\mathrm{D}$ que en la época aparecía en los primeros meses sobre todo en niños alimentados con lactancia artificial y que tenían falta de exposición a la luz solar porque se les sacaba poco a la calle. Además de este origen, se le atribuía asimismo carácter hereditario por lo frecuente que era que también los padres lo hubieran padecido. Las infecciones y los trastornos digestivos lo favorecen apareciendo de forma más precoz y más grave. "Para el tratamiento tres cucharaditas de aceite de hígado de bacalao diarias", también se proponía la helioterapia con radiaciones ultravioletas y la hidroterapia con baños de mar o agua salada templada. BUXÓ IZAGUIRRE P.: op.cit., pp 205- 210; SUÑER Y ORDÓÑEZ E.: Enfermedades de la infancia tomo 2, pp 263- 298.

${ }^{829}$ EI ESCROFULISMO: "vicio de nutrición que se declara en la infancia y que se caracteriza por lesiones cutáneas y mucosas de tipo generalmente tórpido. Ataca a los niños mal cuidados y amamantados. La falta de luz, de ventilación, de una alimentación a propósito influyen en gran manera en su etiología". Provocaba infartos ganglionares del cuello y lesiones en el cuero cabelludo y ya se consideraba como posible precursor de una tuberculosis. "El tratamiento ha de ser preventivo, dirigiendo bien la lactancia y no dejando que tome carne hasta los dos años. Se escogerá un régimen donde figuren los huevos, el pescado, el queso, las patatas, choricería y dulces". (Enciclopedia Espasa, tomo 20, p 982). Se consideraba además que afectaba al sistema linfático "el temperamento linfático predispone a padecerlas, se observan generalmente en los sujetos mal alimentados que habitan sitios bajos y húmedos y que se hallan en una profunda melancolía. ... se mira como hereditaria. Los padres la transmiten a sus hijos más que las madres y no es contagiosa... sin embargo el coito en ciertas circunstancias parece haberla comunicado" (CASAS DE BATISTA R.: op.cit, pp 448- 449). Suñer en su tratado de 1921 afirma que en las lesiones escrofulosas se descubrió el bacilo de Koch causante de la tuberculosis, por lo que debía considerarse una variante de esta enfermedad, dice además que se le había denominado también DIÁTESIS ESCROFULOSA, inflamatoria o exudativa por las reacciones de este tipo de carácter crónico habituales en estos niños, de manera que esta variante era más benigna precisamente por estas lesiones exudativas que podían ser la mejor defensa del organismo frente a la tuberculosis. SUÑER Y ORDÓÑEZ E.: Enfermedades de la infancia, tomo 3, pp 309- 312

${ }^{830}$ Para un total de 207.880 defunciones en 1905 a nivel nacional de menores de 5 años en este grupo clínico se registraron 1.782 casos. Fondo Documental del INE. Movimiento Nacional de la Población 1905. Defunciones por causa y edad. 
enfermedades nutricionales no tienen nomenclatura propia, por lo que se supone que estarán dentro del apartado "Otras enfermedades".

La SíFILIS, que en la inclusa es la tercera causa de mortalidad con el $15^{\prime} 72 \%$, en el conjunto nacional tiene muy poca representatividad, en 1905 un 0'25\% (525 casos para un total de 207.880 defunciones de menores de 5 años); de hecho las estadísticas nacionales a partir de 1910 ya no la recogen por separado. En esta categoría se han incluido los diagnósticos que aparecen en los Libros de Exposiciones como sífilis, sífilis congénita, estomatitis sifilítica y gomas sifilíticos ${ }^{831}$.

Las INFECCIONES RESPIRATORIAS se situaron

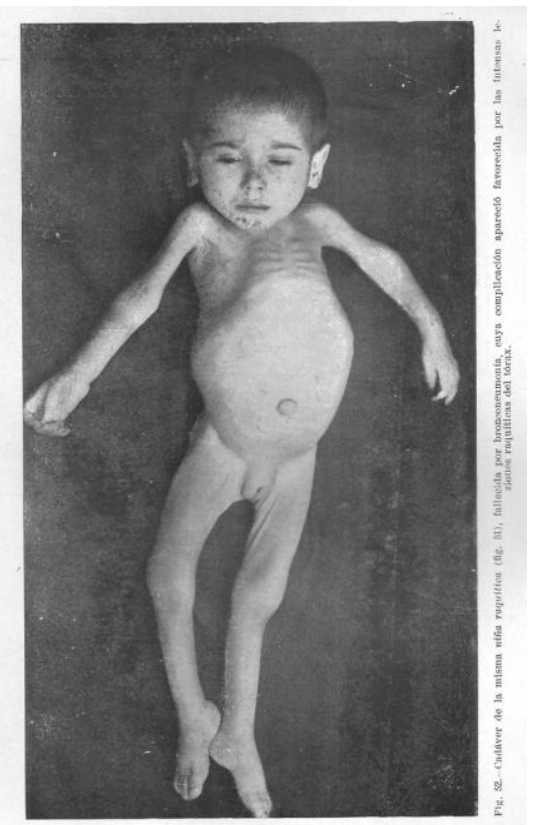

Imagen 3-59: Niña raquítica fallecida. Fuente: BUXÓ P.: Enfermedades de los niños de pecho. Lámina XVI. Aparte de las deformidades óseas, propias del raquitismo, muchos de los fallecidos por desnutrición en la Inclusa tendrían un aspecto similar

en la Inclusa en cuarto lugar con el 12'67\%; en esta

categoría se han incluido las que afectan a todo el tracto respiratorio tanto alto como bajo: angina infecciosa, anginas, bronconeumonía, bronquitis, bronquitis agudas, bronquitis capilar $^{832}$, bronquitis crónica, catarro bronquial, catarro capilar, catarro crónico, catarro espasmódico, catarro generalizado, catarro gripal, catarro pulmonar, coriza aguda, coriza grave $^{833}$, faringitis ulcerosa, catarro laríngeo, catarro laríngeo bronquial, laringitis, falso

\footnotetext{
${ }^{831}$ SÍFILIS: "causa importante de mortalidad y morbilidad, denominada más disimuladamente avariosis". "Afecta a los niños con más frecuencia entre 1- 15 años...". Se sospechaba que procedía "del padre en la mayoría de los casos, pero puede ocurrir que los primeros hijos sean sanos y los siguientes enfermos... Se ha descrito la transmisión a la nodriza por el pezón y al revés", presentando el niño lesiones en la boca. Las Casas- Cuna se consideraban un lugar de riesgo para la transmisión de la sífilis adquirida a través de nodrizas sifilíticas y por la falta de medidas de higiene. Su agente causal se identificó en 1905. Los síntomas pueden presentarse ya en los primeros días de vida en forma de lesiones cutáneas y coriza (rinitis) con secreciones contagiosas, además de lesiones orgánicas; también pueden tardar meses e incluso años en aparecer. Uno de los síntomas característicos, aunque dice Suñer que poco habitual, en los recién nacidos era el llamado "grito de los heredosifilíticos". Entre las manifestaciones tardías pueden presentarse el llamado GOMA SIFILÍTICO, "proliferación de un tejido conjuntivo infiltrado por un líquido mucoso" que se acaba necrosando y formando úlceras. Se proponía como tratamiento preventivo la abolición o la reglamentación de la prostitución y "el desarrollo de una exquisita higiene pública y de una cultura moral". El tratamiento curativo se hacía con derivados mercuriales y con un producto que tenía arsénico en su composición llamado Salvarsán, "arsénico que salva", descubierto en 1909 por Paul Ehrlich, que luego fue mejorado y se denominó Neosalvarsán y se administraba en inyección intravenosa, y con la aplicación de bismuto en las lesiones. SUÑER Y ORDÓÑEZ E.:Enfermedades de la infancia, tomo 2, pp 263- 298; RECHE ANDRÉS J.: op.cit, pp 399 - 446

832 BRONQUITIS CAPILAR: "Inflamación de la mucosa bronquial capilar, cuando afecta a los pequeños bronquios. También Ilamada BRONQUITIS DIFUSA". Enciclopedia Espasa, Tomo 9, p 970.

833 CORIZA: "Inflamación catarral de la membrana de las fosas nasales. Puede ser agudo o crónico". Enciclopedia Espasa, Tomo 15, p 690.
} 
crup $^{834}$, laringitis membranosa, laringitis pseudomembranosa y neumonía. En la estadística nacional esta categoría se recoge con las nomenclaturas "Bronquitis aguda", "Bronquitis crónica", "Neumonías" y "Otras enfermedades del aparato respiratorio [excepto la tisis]" y suponen el $19^{\prime} 11 \%$ del total de causas de mortandad en menores de 5 años ${ }^{835}$.

La tisis o tuberculosis pulmonar se ha dispuesto también para la Inclusa en una categoría propia en la que se han incluido además todas las formas de TUBERCULOSIS: escrofulismo, diátesis escrofulosa, meningitis tuberculosa, peritonitis tuberculosa, tuberculosis intestinal, tuberculosis peritoneal, tabes mesentérica ${ }^{836}$ y tuberculosis generalizada; este grupo clínico representó el 3’08\% sobre el total de causas de mortandad ocupando el séptimo lugar. En el conjunto nacional se recogen en las nomenclaturas "Tuberculosis pulmonar", "Tuberculosis de las meninges" y "Otras Tuberculosis" y representaron el 2'67\% del total de causas de muerte en los menores de 5 años ${ }^{837}$.

En las estadísticas nacionales el grupo "DEBILIDAD CONGÉNITA Y VICIOS DE CONFORMACIÓN" constituye la tercera causa de mortalidad infantil y la cuarta para el total de los menores de 5 años (considerando todas las infecciones que hemos llamado infantiles en un grupo común). En la Inclusa no encontramos registros que contemplen vicios de conformación, es decir malformaciones y defectos congénitos, como causa del fallecimiento, debido a que en los libros se ha anotado el hecho final que provoca la defunción; sin embargo, problemas de este tipo podían subyacer en muchas de las muertes registradas. Hay una inscripción que dice "meningitis meníngea por ulceración de espina bífida" en 1909; otras meningitis podrían tener su origen en la misma malformación; lo mismo se puede decir por ejemplo de los problemas cardíacos que podrían ser de origen malformativo. Solamente podemos recoger por tanto para la Inclusa la debilidad congénita ${ }^{838}$, diagnóstico referido a niños prematuros y de bajo peso,

\footnotetext{
${ }^{834}$ FALSO CRUP también conocido como LARINGITIS ESTRIDULOSA o LARINGITIS CATARRAL ESPASMÓDICA es una inflamación de la laringe que afecta a niños menores de 5-6 años, que provoca espasmos transitorios y que en los casos más severos podría llegar a causar la obstrucción completa y permanente de la vía aérea con la consiguiente asfixia. Cursa con un ruido inspiratorio característico y suele presentarse por la noche. es diferente de las laringitis membranosas y del crup diftérico. SUÑER Y ORDÓÑEZ E.: Enfermedades de la infancia, tomo 2, pp 29- 34.

${ }^{835}$ Se calculan en 1905 en total 39.720 casos entre las cuatro nomenclaturas para los dos grupos de edad y sexos. Movimiento Nacional de la Población 1905. Defunciones por causa y edad.

${ }^{836}$ TABES MESENTÉRICA: tuberculosis de los ganglios mesentéricos. Enciclopedia Espasa, Tomo 58, p 2775. Son ganglios peritoneales, por tanto se localizan a nivel abdominal

${ }^{837}$ Sumando los datos nacionales para las tres nomenclaturas para varones y mujeres en los dos grupos de edad de menores de 5 años salen 5.550 casos.

838 DEBILIDAD CONGÉNITA: se refiere al neonato que "tiene sus órganos y aparatos incompletamente desarrollados... un niño no acabado, de escaso peso y de funciones incompletas (inmaduro)". Lo más característico es que son niños con poco peso, menos de $2.500 \mathrm{~g}$, pueden ser prematuros o no. No tienen fuerza para mamar $y$ están adormilados y muy poco activos. Con tendencia a la hipotermia y el esclerema y a las infecciones. Las causas apuntan casi todas a la madre entre ellas la miseria o infecciones como la sífilis. El pronóstico depende de la gravedad y el tratamiento incluye calorificación, cuidados higiénicos para evitar infecciones y alimentarles adecuadamente, preferiblemente con lactancia materna directa o con cuchara o cuentagotas y si es insuficiente
} 
que aparece en los libros como: deficiencia de desarrollo, falta de desarrollo, falta de nutrición, falta de reacción, mal desarrollo y causas asociadas a ella como algidez, enfriamiento ${ }^{839}$ y esclerema ${ }^{840}$. Mientras que en la estadística nacional para el grupo de menores de 5 años la categoría "Debilidad congénita y vicios de conformación" representa el 8’37\% ${ }^{841}$, en la Inclusa sólo supone el $4,28 \%$ del total de fallecimientos. No obstante, como ya he comentado, considero que los datos de la Inclusa para esta categoría están infravalorados, los vicios de conformación y la debilidad congénita podrían ser en muchos casos el problema subyacente; como solamente podemos contar con los casos registrados lo demás sería especular.

A continuación se encuentran los problemas de tipo NEUROLÓGICO, sin contar los procesos infecciosos incluidos en el grupo de infecciones. En esta categoría, que representa el $77^{\prime} 20 \%$ del total (el 9’01\% si contáramos las meningitis y encefalitis) se han incluido las siguientes causas: ataque epiléptico, coma, congestión, congestión cerebral, congestión meníngea, congestión por empacho ${ }^{842}$, derrame seroso cerebral, espasmo generalizado, eclampsia, eclampsia de los $R N^{843}$, hemorragia cerebral, hidrocefalia y parálisis grave. Este grupo clínico se contempla en la estadística nacional como "Congestión, hemorragia y reblandecimiento cerebrales" y constituyen el 1'08\% del total. La "meningitis simple" está separada en una categoría propia y se presentó en un 7’57\% de las causas de muerte en

lactancia mixta, en último término la lactancia artificial, pero "ensombrece aún más el pronóstico". Rechaza Suñer en su tratado, con muy buen criterio, la práctica recomendada por un pediatra francés cuando estos niños no engordaban consistente en provocar pequeñas escarificaciones en su piel que permitieran extraer de 18 a 20 cc de sangre, lo que, aparte del riesgo infeccioso, supondría anemizar aún más a niños que no suelen ir sobrados de sangre, de manera que muchos no soportarían una pérdida de este tipo. BUXÓ IZAGUIRRE P.: op.cit., pp 39- 48; SUÑER E.: op.cit, tomo 1, pp 18- 29.

${ }^{839}$ ALGIDEZ: "Descenso anormal de la temperatura del cuerpo, que reconoce por causa una lesión o desorden interno. La algidez no se relaciona sino con el hecho del frío y nada tiene que ver con la sensación del mismo. A veces se hace progresiva y parece constituir en sí misma la enfermedad". Enciclopedia Espasa, tomo 4, p 642.

EI EDEMA ÁLGIDO es propio de prematuros que primero presentan una piel roja y turgente y luego tinte ictérico con hipotermia y edema localizado que se va extendiendo hasta generalizarse pudiendo tener un desenlace fatal rápido. Son propios de niños que por sus condiciones tienen problemas para mantener la temperatura corporal, prematuros o débiles congénitos, que pueden llegar a alcanzar temperaturas rectales de 30-32ㅇ y precisan medidas de apoyo térmico como meterles en una incubadora o envolverles en capas de algodón. BUXÓ IZAGUIRRE P.: op.cit., pp 51-52; SUÑER E., Enfermedades de la infancia, tomo 1, pp 18- 29.

${ }^{840}$ ESCLEREMA: Endurecimiento de la piel y del tejido celular subcutáneo de consistencia cérea y aspecto cianótico con hipotermia que se presenta en los débiles congénitos de tercer grado en los primeros días de vida y anuncia su muerte próxima casi segura. El frío la favorece, se dice que tiene aspecto de cadáver congelado y requiere calorificación urgente. BUXÓ IZAGUIRRE P.: op.cit., pp 51-52; SUÑER E.: Enfermedades..., tomo 1, pp 44-47.

${ }^{841}$ En 1905 se recogen 17.398 casos en la categoría "Debilidad congénita y vicios de conformación" en los dos grupos de edad que conforman el de menores de 5 años para ambos sexos, a expensas fundamentalmente de los menores de un año. Fondo Documental del INE. Movimiento Nacional de la Población 1905. Defunciones por causa y edad.

${ }^{842}$ La CONGESTIÓN POR EMPACHO se consideraba consecuencia de una INDIGESTIÓN por su "influencia sobre el cerebro, pues las principales afecciones de este órgano traen su origen de lesiones del tubo digestivo". Para su tratamiento se debían utilizar sanguijuelas en el cuello y enemas purgantes CASAS DE BATISTA R: op.cit, p 499

${ }^{843}$ LOS ESPASMOS son convulsiones clónicas generalizadas o no y la ECLAMPSIA el síndrome caracterizado por convulsiones clónicas generalizadas que se presentan en ataques de repetición. Aunque es raro es posible que durante un ataque sobrevenga la muerte. SUÑER E.: Enfermedades de la infancia, tomo 3, p 28- 30. Viene a ser una forma de epilepsia, aunque se consideraba diferente, habiéndose reservado hoy el término eclampsia para un cuadro convulsivo que aparece en la mujer durante la gestación o el puerperio. 
menores de $5 \operatorname{años}^{844}$, mientras que en la Cuna las meningitis representaron un 1'81\% del total de fallecimientos; esta menor incidencia probablemente se deba a la mayor presencia de otros cuadros infecciosos que se recogen como causa en los libros; no obstante, sobre todo en los niños más pequeños, cualquier infección especialmente si es grave puede complicarse fácilmente con una meningitis.

Los problemas CARDIOLÓGICOS constituyeron el 1'31\% de las causas de muerte en la Cuna y entre ellos se encuentran: ataque de asistolia, colapso cardiaco, endocarditis, insuficiencia mitral, insuficiencia valvular, obliteración del agujero de Botal, lesión cardiaca y paresia cardiaca ${ }^{845}$. A nivel nacional como "Enfermedades orgánicas del corazón" solo se registraron en el total de menores de 5 años un $0^{\prime} 45 \%{ }^{846}$.

En el grupo OTRAS de la GRÁFICA 3-40 se han incluido el resto de causas no recogidas en las demás categorías y que se encuentran de forma aislada en los registros de los Libros de Exposiciones, muchas solamente en una o dos inscripciones, como: cirrosis hipertrófica “dentición laboriosa" ${ }^{847}$, eccemas (lácteo ${ }^{848}$, generalizado, de escroto), hemorragias (internas, generales, gástricas y umbilicales, las cerebrales se han incluido en los problemas neurológicos), hemólisis, "hidrohemia" y "anasarca" ${ }^{849}$, ictericia, "imbecilidad"850, obstrucción intestinal, "problemas de la dentura", quemaduras, úlceras por decúbito o uremia.

\footnotetext{
${ }^{844}$ En 1905 se registraron 2.247 casos de problemas neurológicos y 15.745 de meningitis simples, excluyendo en este grupo las de origen tuberculoso. Movimiento Nacional de la Población 1905. Defunciones por causa y edad.

${ }^{845}$ La asistolia es la ausencia de latido cardiaco; una paresia es un término que hace referencia a la parálisis o el debilitamiento en la contracción de las fibras musculares por tanto, el ATAQUE DE ASISTOLIA y la PARESIA CARDIACA son equivalentes al paro cardiaco el colapso cardiaco es una insuficiencia cardiaca que en su forma más grave puede provocar el paro. En cuanto al agujero de Botal, también llamado agujero o foramen oval es una comunicación que existe en el corazón fetal entre las dos aurículas que permite el paso de sangre desde la aurícula derecha a la izquierda; se cierra funcionalmente en las primeras horas de vida de manera que cesa el paso de sangre a su través, pero el cierre anatómico se produce tardíamente y el orificio puede persistir durante años. En algunas cardiopatías congénitas se mantiene funcionante.

${ }^{846}$ En 1905 se registraron solamente 944 casos de problemas cardiacos a nivel nacional. Movimiento Nacional de la Población 1905. Defunciones por causa y edad

${ }^{847}$ Por DENTICIÓN DIFICIL se entendía la "coincidencia de varios dientes en la erupción, lentitud en la misma, fenómenos inflamatorios de las encías..." Denuncia Suñer en su tratado de Enfermedades de la Infancia "el abuso que en otras épocas se ha hecho por médicos y profanos de la erupción dentaria como agente etiológico de enfermedades que hoy día se ve que tienen como causa otros agentes". SUÑER Y ORDÓÑEZ E.: op.cit, tomo 1, p 325 ${ }^{848}$ COSTRA LÁCTEA, CHURRE O SEBORREA DEL RECIÉN NACIDO: variedad de eczema típico de los lactantes que padecen trastornos de alimentación y que consiste en una corteza grasienta que cubre la cabeza formada por escamas gruesas y opacas, que a veces huele a queso rancio y que puede llegar hasta la frente. Se trata con cuidados higiénicos, si con el lavado no se desprende se aplica vaselina salicílica para ablandarla durante la noche BUXÓ IZAGUIRRE P.: op.cit., pp 267- 268; SUÑER Y ORDÓÑEZ E.: Enfermedades de la infancia, tomo 3, p 859.

Don Rogelio Casas de Batista en su manual de Enfermedades de la mujer y del niño a propósito de esta costra que él llama "costra seca de la piel del cráneo" cuenta que "Se cree por el vulgo que garantiza el cráneo de los accidentes a que está expuesto, ya por su poco espesor ya por no estar osificadas las fontanelas; pero este es un error. No solo es inútil, sino que conviene hacerla desaparecer, pues impide la conveniente transpiración de la cabeza... se necesita emplear cataplasmas emolientes sobre la cabeza a una temperatura poco elevada e igual si es posible a las partes donde se aplica, a fin de evitar una congestión cerebral..."(pp 404- 405)

${ }^{849}$ HIDROHEMIA: Abundancia excesiva de serosidad en la sangre. Enciclopedia Espasa, tomo 55, p 548.
} 


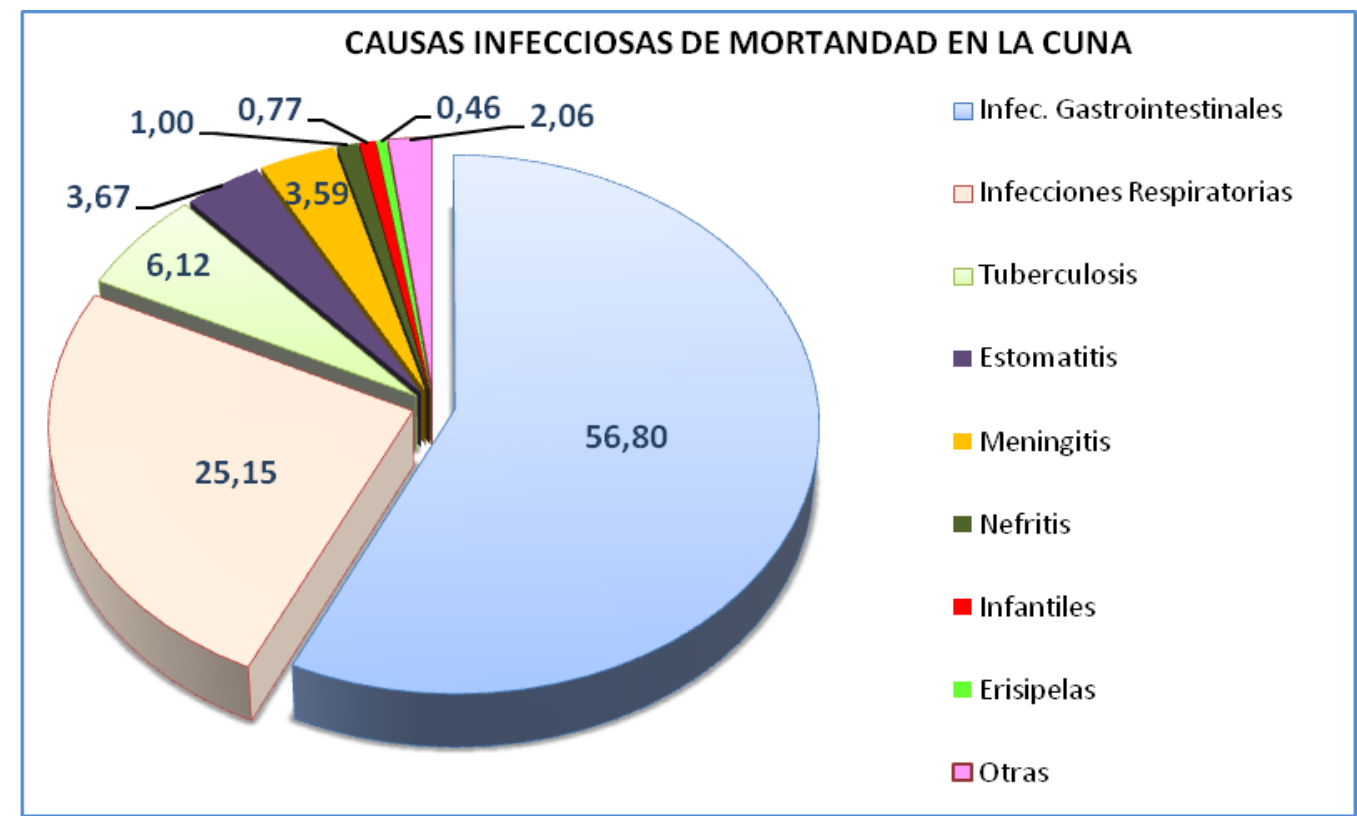

GRÁFICA 3-41: Distribución porcentual de las infecciones adquiridas responsables de la mortalidad en la Cuna provincial, excluida la SÍFILIS, entre 1900 y 1913 Elaboración propia

En conjunto, la causa principal y mayoritaria de las muertes en la Inclusa Provincial para el período 1900-1913 fueron las infecciones; sin contar con la sífilis, causaron el 50’38\% de la mortalidad total de los internos. Se ha excluido la sífilis, que sumaría un $15^{\prime} 72 \%$ más, porque en los niños, aunque puede darse el caso de sífilis adquirida, mayoritariamente se trata de una infección congénita que depende por tanto de las condiciones maternas, mientras que las demás son infecciones adquiridas relacionadas con las condiciones de vida y del medio. En los Libros de Exposiciones la encontramos registrada en muchos casos simplemente como sífilis y no podemos asegurar que cuando no lleva apellido sea adquirida. Entre las infecciones adquiridas, como se deduce a la vista de los porcentajes globales, el grupo mayoritario con más de la mitad de este tipo de procesos es el de las infecciones gastrointestinales (56'80\%), seguidas de las respiratorias (25'15\%), tuberculosis en todas sus variantes $\left(6^{\prime} 12 \%\right)$, estomatitis $^{851}$, meningitis (en esta categoría se han incluido también las encefalitis) (ver

Es un término en desuso, que hacía referencia a un exceso de líquidos que cursa con edemas. El término ANASARCA se sigue utilizando en el mismo sentido, hace referencia a un edema generalizado

${ }^{850}$ La IMBECILIDAD se llamaba también DEBILIDAD MENTAL CONGÉNITA y se consideraba un defecto intelectual hereditario de intensidad muy variable, la forma más grave se denominaba IDIOCIA. "La supervivencia en gran parte depende de los cuidados que con él se tienen. El idiota completo suele vivir poco" por enfermedades asociadas, con frecuencia la tuberculosis SUÑER Y ORDÓÑEZ E.: Enfermedades de la infancia, tomo 3, pp 149- 166.

${ }^{851}$ Las ESTOMATITIS son procesos inflamatorios de la boca que pueden cursar con aftas o pequeñas úlceras de la mucosa y que pueden ser o no de origen infeccioso; las infecciosas podían extenderse a todo el tubo digestivo y causar diarrea. Podemos entender que las que encontramos registradas serían procesos graves para causar la muerte. Aparecen en los libros como estomatitis, estomatitis aftosa o estomatitis ulcerosa, no se han incluido aquí las estomatitis sifilíticas, que se han contado en la categoría de la sífilis. La ESTOMATITIS AFTOSA se consideraba transmitida por la leche de vaca, con origen en la fiebre aftosa que padece este animal. La ESTOMATITIS ULCEROSA se consideraba una infección bucal grave que se relacionaba sobre todo con la segunda dentición, la caries y "con las malas condiciones generales de los sujetos que la padecen" y "las malas condiciones de asepsia de la boca". 
GRÁFICA 3-41). He tenido que agrupar las enfermedades consideradas clásicamente infantiles para que tengan representatividad porque su incidencia en la Inclusa fue muy baja, en esta categoría he incluido sarampión, coqueluche (o tosferina) y escarlatina, no se dio ningún caso de varicela, las tres juntas suman 10 casos, la mitad de sarampión, y en conjunto no llegan al $1 \%$ del total de procesos infecciosos. Tampoco se registró ningún caso de viruela dentro de la Inclusa en el período analizado (1900-1913), mientras que a nivel nacional causó más del triple de muertes (1.685) en menores de 5 años que la sífilis. La razón de esta ausencia de viruela en la Inclusa está en la vacunación, mientras que toda la población interna se vacunaba, por ley como hemos visto, para la población general en este período era voluntaria y el acceso era muy limitado, en parte por el miedo que ocasionaba; cuando la vacunación se hizo masiva la incidencia de la viruela disminuyó de forma radical ${ }^{852}$. En la gráfica se ha representado también el porcentaje de nefritis y erisipelas ${ }^{853}$ y en la categoría Otras se han incluído el resto de procesos infecciosos que aparecen de forma aislada como: absceso flemoso, fiebre catarral, fiebre dental, fiebre generalizada, flemón difuso, forunculismo, hepatitis aguda, gangrena umbilical, infección purulenta, muguet, otitis supurada o septicemia general.

Se ha recogido en gráfica aparte la distribución de las enfermedades infecciosas incluyendo la sífilis (GRÁFICA 3-42), como puede observarse, ella sola fue responsable de casi la cuarta parte de las defunciones de origen infeccioso de la Cuna.

\footnotetext{
Causaba complicaciones digestivas, respiratorias y maxilares y en los casos más graves una gangrena de la boca conocida como NOMA de mortalidad casi segura. SUÑER Y ORDÓÑEZ E.: op.cit. 1921, tomo I, pp 336-337.

Suñer ya sospechaba otro origen para la ESTOMATITIS AFTOSA porque se presentaba también precediendo cuadros infecciosos como el tifus y en otras intoxicaciones alimentarias distintas de las ocasionadas por la leche. Una variedad más intensa es la estomatitis herpética, que presentaban niños constitucionalmente predispuestos.

852 Las estadísticas del Fondo Documental del INE revelan un descenso brusco de las muertes por viruela en los menores de 5 años durante los años veinte gracias a la vacunación; el número de defunciones por esta causa pasó de 2.036 en 1920 a 1.305 en 1921, 810 en 1922 y 310 en 1923. Fondo Documental del INE. Movimiento Nacional de la Población.

${ }^{853}$ La ERISIPELA es una infección frecuente en los niños producida por un estreptococo y relacionada con traumatismos espontáneos o quirúrgicos por contagio a través de objetos contaminados; aparece con frecuencia en niños con pequeñas erosiones de la piel que pueden pasan desapercibidas SUÑER E.: op.cit., tomo 3, pp 804- 806 La ERISIPELA DEL RECIÉN NACIDO es rara y de carácter maligno; se acompaña de toxemia, fiebre alta y hemorragias. Es una infección bacteriana que dice Suñer aparecía coincidiendo con epidemias de infecciones puerperales en las maternidades y esporádicamente "por las manos mal desinfectadas de las personas que atienden al niño o por el material insuficientemente esterilizado que se utiliza en la ligadura y en el apósito del cordón". Incurable con los tratamientos de la época como compresas de alcohol, colodión o rayos ultravioleta, se empezó a curar cuando empezaron a utilizarse las sulfamidas a partir de 1935.BUXÓ IZAGUIRRE P.: op.cit., p 69, SUÑER Y ORDÓÑEZ E.: op.cit., tomo 1, pp 98- 99.

COLODIÓN: Disolución en éter del residuo del algodón [celulosa] descompuesto por el ácido nítrico. se emplea como aglutinante en cirugía y para la preparación de planchas fotográficas. RAE 1889, p 241, 1
} 


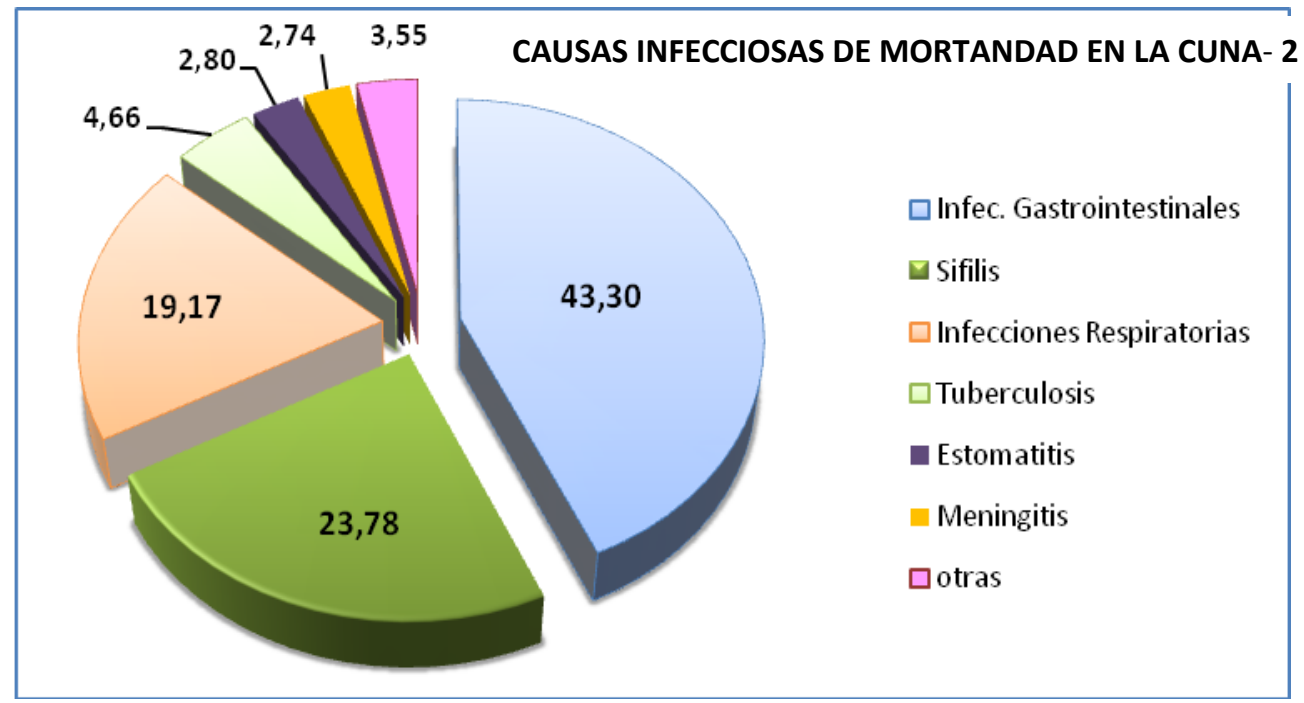

GRÁFICA 3-42: Distribución porcentual de las infecciones adquiridas responsables de la mortalidad en la Cuna provincial, incluyendo la SÍFILIS CONGÉNITA, entre 1900 y 1913 Elaboración propia

Se han ido mostrando datos nacionales para el grupo de edad de menores de 5 años para compararlos con los de la Inclusa Provincial, en la GRÁFICA 3-43 se recogen ambos para las categorías más significativas. Llama la atención la enorme diferencia que hay en algunos de los grupos establecidos, sobre todo es muy llamativa en el caso de la sífilis y de las alteraciones de tipo nutricional y digestivo con poca representatividad a nivel nacional y una incidencia muy elevada en la Inclusa, mientras que ocurre al revés en el caso de las infecciones que hemos llamado infantiles. La razón está en relación con las condiciones de ingreso y de vida en la Inclusa y su patrón de mortalidad, en el que hay un predominio claro de la mortalidad infantil sobre la de 1 a 5 años (más del 84\% de los niños fallecieron antes de cumplir un año de vida), mientras que a nivel nacional no existe tanta diferencia entre los dos grupos de edad. En el año 1905, que se ha tomado como referencia, la mortalidad infantil representó solamente el 52 '05\% del total nacional de menores de 5 años (fallecieron 108.199 menores de 1 año y 99.681 niños mayores de 1 y menores de 5 años). Predominan en la Cuna enfermedades que afectan más a los lactantes, infecciosas y alimentarias. La elevada incidencia de trastornos nutricionales y digestivos refleja el problema que planteaba la escasez de nodrizas; que una mujer tuviera que criar a varios niños suponía una insuficiente lactancia natural y por tanto obligaría al uso de la artificial con todos los riesgos reconocidos, incluido precisamente el de su alta mortalidad. En cuanto a las infecciones, son reflejo de las malas condiciones sanitarias del centro, del propio internamiento con la obligada convivencia de una población muy susceptible a las infecciones por su edad con enfermos y de la falta de cuidados médicos e higiénicos, con pocos profesionales sanitarios y las nodrizas, mujeres que muchas veces 
tampoco eran saludables, al cargo de los niños. Las infeccciones gastrointestinales se relacionan también con el tipo de lactancia y con las condiciones higiénicas de la alimentación; como en la población general se producían epidemias dentro de la Inclusa sobre todo en los meses de verano (de los niños ingresados en 1913, en el mes de agosto fallecieron 39 y 20 de ellos fue por esta causa, para 1910 la relación en el mes de agosto fue de 34 gastroenteritis de 62 defunciones).

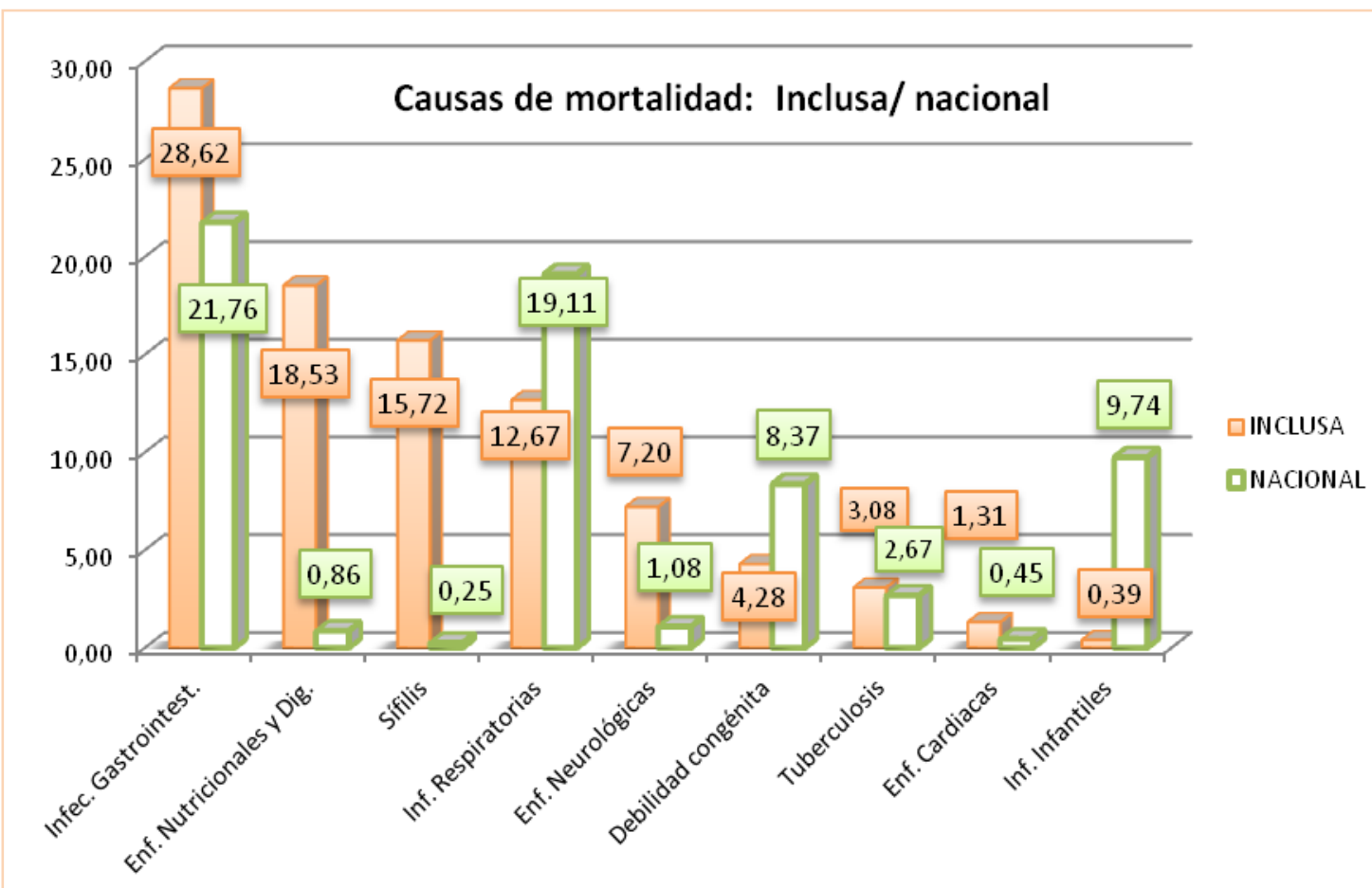

GRÁFICA 3-43: Principales causas de defunción de los niños internos en la Cuna provincial con el porcentaje sobre el total de defunciones en el período 1900 y 1913, comparada con los porcentajes nacionales para el grupo de edad de menores de 5 años. Elaboración propia

La baja incidencia de enfermedades como el sarampión y la escarlatina también puede relacionarse con la edad, ya que se presentan con más frecuencia después del año (en las estadísticas nacionales la incidencia en el grupo de 1 a 4 años multiplica hasta por 4-5 a la de los menores de 12 meses; aún así parece muy escasa para una población interna y por tanto con mucho contacto y un elevado riesgo de contagio, sobre todo en el caso de la tosferina que afectaba más a los lactantes más pequeños. En este sentido cabe pensar que estas infecciones estaban infradiagnosticadas o simplemente desplazadas por otras causas. Son también anormalmente bajos los datos de la llamada debilidad congénita y sobre todo de las malformaciones y defectos congénitos, sobre los que ya he dicho que considero que están enmascarados por otras patologías sobreañadidas. La enorme diferencia en el caso de la sífilis a favor de la Inclusa tiene relación con el alto porcentaje de hijos ilegítimos que ingresaban en 
ella (alrededor del $80 \%$ del total ingresos) en comparación con la ilegitimidad reconocida a nivel nacional (en torno al 5\%).

Dado que la principal causa de mortandad dentro de la Inclusa eran las infecciones, la distribución de sus causas sigue un patrón epidémico, de manera que hay mucha variación de unos años a otros en su distribución mensual. Casi la única constante es el predominio claro de procesos infecciosos en los meses de julio y agosto con la mayor tasa de gastroenteritis, más del $53 \%$ del total anual se dieron entre estos dos meses. Las infecciones respiratorias, que tuvieron su mayor frecuencia en marzo y octubre (10’1\% cada uno), a continuación con muy poca diferencia nos las encontramos en julio y agosto (9'97\% cada mes). También los problemas alimentarios y digestivos fueron más frecuentes en verano, no es de extrañar por su relación directa con las infecciones gastrointestinales que pueden alterar los procesos digestivos y particularmente el de absorción intestinal y con el tipo de alimentación, siendo la lactancia artificial especialmente peligrosa en estos meses; incluso la sífilis congénita, que no tiene relación estacional, se registra más seguramente por la repercusión negativa de otros procesos infecciosos o alimentarios agravándola.

Podríamos decir que el verano era mortal para los expósitos internos y en particular estos meses de julio y agosto que acumulaban el $35 \%$ de la mortalidad interna anual. La mortalidad de los externos en estos meses era solo era un poco más benévola, suma el $25^{\prime} 9 \%$ del total anual, pero a cambio los siguientes meses de septiembre y sobre todo de octubre tenían tasas más altas como podemos observar en las GRÁFICAS 3-37, 3-38, 3-39. Para el intervalo de junio a octubre (los de tasas más altas) la mortalidad expósita, calculada de forma independiente para cada grupo, fue del $57^{\prime} 75 \%$ del total anual para los internos y el $53^{\prime} 03 \%$ para los externos. No tenemos datos oficiales sobre la distribución mensual de la mortalidad infantil y de menores de cinco años para los años de este estudio, los que ofrece el INE son para la población general desagregados por sexo, estado civil y en establecimientos benéficos; para este grupo y el de los solteros julio y agosto muestran también una incidencia claramente mayor. La frase recogida al comienzo de este capítulo es de Isabelino de Cogeces, cuenta que sobre todo en los meses de verano "raro era el día que no había enterrillo", así llamaban en el pueblo al entierro de los niños "chicos", las campanas tañían a muerto de una forma diferente, también dependiendo de que el difunto fuera hombre o mujer, y él con otros niños del pueblo llevaban el féretro agarrado por una anillas primero a la iglesia y luego al cementerio. 


\subsubsection{EVOLUCIÓN DE LA MORTALIDAD EN LA INCLUSA}

Para los años posteriores a 1913 contamos con algunos datos resumidos proporcionados por el propio Hospicio, la Diputación y los Anuarios Estadísticos de España del Fondo Documental del INE. Son discordantes y de difícil interpretación porque no definen la población que contemplan.

En el Hospicio encontramos un Informe de acogidos en 1914- $1918^{854}$, que recoge en un cuadro-resumen la relación de acogidos ingresados y fallecidos, disgregados por sexos y departamentos. En él se observa un alto número de ingresos en la Cuna, en particular en 1918 cuando se sobrepasaron los 500, pero sobre todo un progresivo incremento de la mortalidad con saltos importantes primero en 1917 y aún mayor en 1918. Entendemos que al menos los datos de estos dos años deben referirse al total de acogidos, internos y externos. TABLA 3-35

\begin{tabular}{|r|c|c|c|c|c|}
\hline \multicolumn{7}{|l}{$\begin{array}{l}\text { TABLA 3-35: Ingresos y defunciones en la Cuna en el quinquenio 1914- 1918. Elaboración } \\
\text { propia. Fuente: Informe de acogidos en 1914- 1918, ADPVA }\end{array}$} \\
\hline & 1914 & 1915 & 1916 & 1917 & 1918 \\
\hline TOTAL INGRESOS & 428 & 414 & 479 & 444 & 508 \\
\hline TOTAL FALLECIDOS & 99 & 107 & 239 & 305 & 410 \\
\hline$\%$ FALLECIDOS & $23^{\prime} 13$ & $25^{\prime} 85$ & $49^{\prime} 90$ & $68^{\prime} 69$ & $80^{\prime} 71$ \\
\hline
\end{tabular}

La propia Diputación, por otra parte, ofrece un resumen del movimiento de asilados para el quinquenio 1917-21 en la memoria que acompaña al presupuesto provincial de 192223 separando internos y externos, que se reproduce en la TABLA 3-36. No se indica sobre qué valor se ha calculado el tanto por ciento de fallecidos y los datos resultan inverosímiles para la Cuna, no tienen nada que ver con los del informe anterior ni con los que ofrecen los Anuarios Estadísticos de España para las mismas fechas ${ }^{855}$, si comparamos los datos de 1917 y 1918 podemos comprobar que no hay ninguna coherencia entre ambos informes. La falta de coincidencia en el número de asilados puede deberse a que el informe del Hospicio se refiere a los ingresos anuales y el de la Diputación podría referirse a la población total de todos los

\footnotetext{
854 Informe del número de acogidos entre 1914 y 1918. Signatura: caja 4051, expediente 38001. ADPVA

${ }^{855}$ Más difícil aún de interpretar es otro cuadro que recoge el movimiento de asilados de 1921 con el número de asilados y de fallecidos mes a mes, separando también internos y externos. El porcentaje mensual de fallecidos no llega al $7 \%$ de los asilados, por la cifra entendemos que se refiere al total de todo el Hospicio, pero al final suma los datos de todos los meses y da un increíble valor de 5.182 internos, que no tendrían cabida en el Hospicio, 321 fallecidos y un porcentaje del 73,59\%, para la población externa refiere 3.094 asilados y 51 fallecidos. Presupuesto General de Ingresos y Gastos de la Diputación Provincial de Valladolid para el año económico de 1922- 23. Memoria
} 
departamentos del establecimiento; en cuanto a los porcentajes de mortandad da la impresión de que se han dividido por diez pues no llegan a un inverosímil 7\%.

\begin{tabular}{|c|c|c|c|c|}
\hline \multirow{3}{*}{ AÑOS } & \multicolumn{4}{|c|}{ POBLACIÓN } \\
\hline & \multicolumn{2}{|c|}{ INTERNA } & \multicolumn{2}{|c|}{ EXTERNA } \\
\hline & Asilados & $\begin{array}{l}\text { Fallecidos } \\
\text { Tanto p. } 100\end{array}$ & Asilados & $\begin{array}{l}\text { Fallecidos } \\
\text { Tanto p. } 100\end{array}$ \\
\hline 1917 & 550 & $4^{\prime} 87$ & 538 & $1^{\prime} 47$ \\
\hline 1918 & 557 & $6^{\prime} 38$ & 427 & $2^{\prime} 10$ \\
\hline 1919 & 608 & $4^{\prime} 60$ & 270 & $0 ’ 67$ \\
\hline 1920 & 534 & $4^{\prime} 47$ & 247 & 2'02 \\
\hline 1921 & 431 & $6^{\prime} 13$ & 258 & $1^{\prime} 64$ \\
\hline \multicolumn{5}{|c|}{$\begin{array}{l}\text { TABLA 3-36: "Resumen comparativo en el último quinquenio. Promedio Mensual". } \\
\text { Fuente: Presupuesto General de Ingresos y Gastos de la Diputación Provincial de } \\
\text { Valladolid para el año económico de 1922- 23. Memoria. ADPVA }\end{array}$} \\
\hline
\end{tabular}

Interpretaciones aparte, en la tabla se advierte a simple vista un descenso importante del número de externos desde 1919 y una diferencia considerable entre la mortalidad exterior e interior, con el pico de 1918 en relación con la epidemia de gripe española, en lo que coincide con el informe anterior, se observa también un repunte interno importante en 1921.

En la TABLA 3-8 se presentaron datos sobre el Movimiento de expósitos en las Casas provinciales de las capitales de los Anuarios Estadísticos de España referidos a la Cuna de Valladolid, extraigo aquí los datos referidos a la mortalidad para tenerlos presentes (TABLA 3-8)

\begin{tabular}{|l|c|c|c|c|c|c|c|c|}
\hline & 1915 & 1916 & 1917 & 1918 & 1919 & 1920 & 1921 & 1922 \\
\hline $\begin{array}{c}\text { Mortalidad } \\
\text { por 1.000 } \\
\text { expósitos }\end{array}$ & $129^{\prime} 65$ & $426^{\prime} 90$ & $448^{\prime} 50$ & $523^{\prime} 43$ & $678^{\prime} 24$ & $534^{\prime} 68$ & $583^{\prime} 88$ & $499^{\prime} 03$ \\
\hline & 1923 & 1924 & 1925 & 1926 & 1927 & 1928 & 1929 & 1930 \\
\hline $\begin{array}{c}\text { Mortalidad } \\
\text { por 1.000 } \\
\text { expósitos }\end{array}$ & $498^{\prime} 16$ & $426^{\prime} 25$ & $487^{\prime} 36$ & $599^{\prime} 50$ & $351^{\prime} 16$ & $315^{\prime} 79$ & $312^{\prime} 00$ & $307^{\prime} 54$ \\
\hline
\end{tabular}

Ya comenté en su momento que estos datos son de interpretación incierta porque no se encuentran bien definidos, de forma que no podemos afirmar con seguridad a qué tipo de población acogida se refieren, tampoco concuerdan con los que acabamos de ver de 19141918 del Hospicio, ni con los de la Diputación para el quinquenio 1917-21. En este caso podría tratarse solo de la mortalidad interna porque para la total sería un descenso muy considerable y poco verosímil respecto a los años previos que hemos analizado (recordemos que el 
promedio para 1900-13 y el total de expósitos es del 740`6\%o). Por eso debemos tomarnos con cautela las cifras de mortalidad que nos ofrecen, sobre todo la de $1915, \tan$ baja respecto a las previas y a las que se recogen en los años posteriores que no es creíble para la Cuna, podría referirse a todos los departamentos del Hospicio; los picos de 1918 y 1921 de los otros dos informes se amplían aquí a todo el intervalo entre los dos años.

En todo caso se produjo un aumento de la mortandad interna que tendría mucho que ver con la reducción del número de niños en crianza externa por falta de nodrizas, como refleja el resumen de la Diputación y denunciaron los médicos del Hospicio en $1920^{856}$.

El de la mortalidad expósita fue un problema no resuelto en la Inclusa de Valladolid en las primeras décadas del siglo XX, que se mantuvo en tasas muy altas y superiores a la de los niños de la población general. La Diputación era conocedora de la situación a través de informes del personal del Hospicio y de los propios diputados y en muchas de sus sesiones se planteó el problema, aunque no fue capaz de poner remedio en estos años.

No podemos decir que no existiera preocupación por esta cuestión, se tomaron medidas, o se intentaron; la vacunación frente a la viruela fue un buen ejemplo, aunque el mérito no fue solo de la Diputación y de la Inclusa Provincial ya que existía un mandato legal (RO de 1798) que obligaba a la vacunación de los expósitos. Hemos podido comprobar que se vacunó a los hospicianos internos con muy buen resultado porque no se registró en nuestro periodo de estudio ningún caso mortal de viruela.

Pero la preocupación más parece algo puntual ya que no se tomaron medidas globales para enfrentar el problema de forma efectiva. La solución requería intención, buena organización y planificación y una importante cantidad de recursos no siempre disponibles; en su lugar, se fueron poniendo parches, a medida que los problemas se iban haciendo más acuciantes, con eficacia muy limitada. La alimentación era sin duda un factor determinante respecto a la alta mortalidad infantil, "Ia mayor o menor mortalidad infantil depende del género de lactancia que se utilice de un modo fundamental..." ${ }^{157}$; se reconoció siempre que el problema se asociaba a la falta de nodrizas; sin embargo no se supo o no se pudo resolver, ya que la solución pasaba por una lactancia artificial que por entonces suponía un riesgo mortal

\footnotetext{
856 Año 1920 Memoria suscrita por los médicos del Hospicio, relativa a la alta mortalidad de niños en el Establecimiento. Signatura: caja 4025, expediente 37809. ADPVA

${ }^{857}$ SUÑER E.: La salud del niño. ... 1920 y Fisiología y clínica de la nutrición del lactante. 1933?
} 
"que había notado, haciendo un examen de los libros, la gran mortalidad que se registraba en la Inclusa, dependiendo este importante detalle de la falta de amas de cría y de la necesidad, como consecuencia de esta deficiencia, de amamantar tres o cuatro niños cada una"858 (1901)

"La espantosa mortalidad de la lactancia artificial, la explotación ejercida con muchos niños sometidos a la lactancia externa nos obligan a procurar los medios para que la Inclusa disponga del mayor número posible de amas de cría Comisión Provincial Sesión 4 sepbre 1923"

También se sabía que no era el único problema de la Inclusa Provincial; las condiciones higiénicas del edificio, la falta de bañeras y de un caudal de agua suficiente, el frío en los meses invernales y la escasez de personal al cuidado de los niños y en particular de profesionales sanitarios para tanta población a su cargo sumaban riesgos importantes. El informe del director Justo Esteban en 1906 ponía de manifiesto algunas de estas cuestiones junto a la escasez de nodrizas, que decía que era más severa en la Inclusa de Valladolid que en las de poblaciones cercanas, como los factores contra los que había que actuar y añadía otras causas "inevitables" a la que él mismo consideraba enorme mortalidad de la Inclusa, las malas condiciones en que llegaban los expósitos y las infecciones congénitas que portaban

“... por un lado las malas condiciones que anteceden a su exposición, pues generalmente ocurre que á las pocas horas de nacer es muy posible que sin recibir el primer calor de la madre, son expuestos y como derivación lógica fallezcan á consecuencia de falta de reacción; por otro lado, si se tiene en cuenta las enfermedades que adquieren por dentro del claustro materno ( $y$ que con facilidad propagan), queda reducida la mortalidad a un 50 por ciento y á remediar este mal deben dirigirse todos los esfuerzos, ya que en el veinticinco restante sus causas son inevitables"

Después de catorce años la situación no cambió, las tasas seguían siendo similares. Los médicos del Hospicio dirigieron a la Comisión provincial el 12 de febrero de 1920 una Memoria ${ }^{859}$ que analizaba el problema de la elevadísima mortalidad de la Inclusa (transcripción completa en ANEXO 6). En ella confesaban una tasa del $58 \%$ en 1917, que consideraban que era "relativamente consoladora" comparada con la de otras como la de Barcelona, a la que adjudicaban "la aterradora cifra de más de un 90\%", y que "Ia casi totalidad de las defunciones ocurre en niños de 0 a 3 años". Los motivos los atribuían al "débil organismo infantil... mucho más expuesto a ser vencido por agentes morbosos" y a

“...los propios y característicos de la internación en los Hospicios; en estos Establecimientos arrojan la miseria y el vicio un verdadero detritus, piltrafas

\footnotetext{
${ }^{858}$ N.C. 5- 8- 1901, p 1

859 Año 1920 Memoria suscrita por los médicos del Hospicio, relativa a la alta mortalidad de niños en el Establecimiento. Signatura: caja 4025, expediente 37809. ADPVA
} 
humanas con todo género de taras patológicas, muy especialmente tuberculosas y sifilíticas" (negrita añadida)

Además apuntaban al establecimiento obligado y prematuro de la lactancia artificial, "o bien por el riesgo de contagio" o "por la carencia de nodrizas", de manera que cada recién nacido tenía que compartir pecho "con otros tres o cuatro compañeros de desdicha" y a "la convivencia con una gran cantidad de niños en locales de medianas o francamente malas condiciones higiénicas". Pero sobre todo atribuían el "aumento progresivo de mortalidad desde el año de 1915" en la Inclusa a una disminución progresiva de "las lactancias externas" hasta la mitad "existiendo una diferencia de 362 [niños] que quedan internados, pasando de la lactancia mercenaria unipersonal a la mixta o artificial y cambiando el aire de la aldea por el de la Inclusa". Señalaban como causa de esta disminución "la carestía de los artículos de primera necesidad" y el escaso sueldo de las nodrizas externas que se mantenía fijo desde 1913 (TABLA 3-29 y/O ANEXO 5) ("con 15 pesetas mensuales... apenas puede comprar el jabón necesario para el lavado de ropas"), junto a la competencia de las Inclusas de las provincias limítrofes, cuyas Diputaciones "han aumentado la retribución a 25 pesetas mensuales".

En la misma Memoria proponen posibles soluciones “... para salvar las vidas de algunos niños y que en su día puedan ser ciudadanos útiles"

10. Favorecer por cuantos medios estén a su alcance la lactancia materna... debe estimularse a las madres lactantes con subsidios metálicos, alimentos, premios, \&, haciéndoles entender honrada y sinceramente el inminente peligro de muerte que sus hijos arrastran internándoles en la inclusa.

2‥ Estimular asimismo a las nodrizas internas y externas para aumentar en lo posible su número.

3o. Higienizar los locales, hoy muy deficientes de la Inclusa, construyendo algún pabellón para diluir la población infantil y poder aislar a los enfermos contagiosos.

4…. incrementar el [número] de matronas o amas secas

5․ Aumento de un practicante...

Parece que la Memoria no cayó en saco roto, al menos en lo que al sueldo de las nodrizas se refería; la sesión provincial "del 13 de Febrero acordó... se fije en 30 pesetas la retribución a las nodrizas externas y 25 a las de la Capital...". Esta subida se recogió ya en los presupuestos de 1920 para las lactancias y se subió además el salario del destete a 15 pesetas en pueblos y 10 en la capital. Los demás puntos quedaron pendientes, no parece que se incrementara el número de nodrizas, más bien lo contrario, los presupuestos informan de una subida de 25 a 30 internas en 1923 y en cuanto a las externas a partir de 1920 ya no concretan el número sino el dinero que se adjudicaba para su contratación, que bajó de forma drástica 
de 90.570 pesetas en el presupuesto general de 1920-21 a 60.000 en el siguiente con los mismos salarios y a 56.000 pesetas para el total de nodrizas internas y externas y gastos de lactancia en general en el de 1927 (ver TABLAS 3-27 y 3-29 en ANEXO 5). En 1930 se aumentó de repente a 110.000 pesetas todo este bloque referido a la crianza de los expósitos de la Cuna.

Esta denuncia también desembocaría en la decisión por parte de la Diputación de llegar a un acuerdo con la Facultad de Medicina para que sus profesores se hicieran cargo de la atención médica de la Cuna como parte de la estrategia para reducir su mortalidad. Se conservan las cartas que son testigo de las negociaciones, no exentas de problemas, que mantuvo el organismo provincial con los catedráticos de la Facultad entre 1922 y 1924 . Se buscaba un acuerdo similar al que tenían en el Hospital provincial, en el que los catedráticos de la Facultad se harían cargo de la asistencia médica de la sala de Maternidad y de la Inclusa y la Diputación controlaría la parte económico- administrativa. Lo interesante de esta correspondencia es que reconoce la "aterradora", en palabras suyas, mortalidad infantil de la Inclusa y sus deficiencias y plantea la necesidad de reorganizar los dos departamentos, Maternidad e Inclusa "en los servicios, en el material y en los locales" para disminuirla. Así dice la Comisión provincial en la primera carta fechada el 29 de julio de 1922 y dirigida a la Diputación (transcripción completa en ANEXO 7) y propone ceder el control médico a los profesores de la Facultad, no porque se considerase incompetentes a los facultativos del establecimiento, sino por la falta de medios materiales científicos en el Hospicio de los que, dice, la Facultad tiene sobradamente ya que "el Estado no regatea cuanto necesita en bien de la enseñanza y del progreso de la ciencia".

\footnotetext{
"Los departamentos de Maternidad e Inclusa que hoy existen en el Hospicio son pequeños y con defectos higiénicos.
}

En casi todas las Memorias que la Comisión provincial eleva a la Diputación en pleno se han dedicado algunas consideraciones sobre estos dos servicios encareciendo la urgencia de poner remedio a las deficiencias notadas ya en los locales, ya en el tratamiento de las acogidas y niños de la Inclusa.

La mortalidad de éstos es aterradora en algunas épocas...

En diferentes sesiones se ha tratado de este asunto importantísimo conviniendo todos en que tanto la Maternidad como la Inclusa necesitan una reorganización.

Los profesores pasarían a hacerse cargo de la asistencia médica de los dos departamentos el 1 de octubre de ese mismo año, de forma gratuita, manteniendo la Diputación el control económico-administrativo y se quedó pendiente de formar una "comisión mixta de Sres Diputados y Catedráticos para que proceda inmediatamente a redactar las bases de un contrato en el que se deslinden atribuciones, se declaren derechos y 
obligaciones de cada parte y aprobado éste por ambas entidades, se eleve al Excmo Sr Ministro de Instrucción pública para su Superior y definitiva aprobación". La propuesta se aprobó en todos sus términos en la sesión del 2 de agosto de 1922 y el 14 del mismo mes se comunicó al Gobernador civil el acuerdo entre la Diputación y la Facultad de Medicina para que lo transmitiera al ministro de Instrucción Pública para su aprobación. El 29 de septiembre cuatro diputados junto con los catedráticos de la Facultad de Medicina hacen una visita al Hospicio, se presentan al personal y a las Hermanas de la Caridad, solicitan autorización para que los alumnos puedan acceder a la sala de Maternidad y toman el relevo a los médicos del establecimiento que quedan para la atención de los mayores (ANEXO 7)

“... como Profesores encargados de la asistencia de la Maternidad e Inclusa conforme y en cumplimiento del acuerdo adoptado... [en el transcurso de esta visita] se indicó la conveniencia de que su visita [se refiere aquí al reconocimiento médico de las salas de Maternidad] fuera acompañada de los alumnos de la asignatura para que estudiasen los casos clínicos que en dicho departamento puedan presentarse. ... [y se] acordó que desde luego se autorizara... también se acuerda dirigir oficio a los referidos Sres Médicos para que desde primero de curso se encarguen de la asistencia de dichos departamentos...

Así mismo se acuerda oficiar a los Médicos provinciales del Hospicio para que cesen en la visita a dichos departamentos quedando a su cargo la de la asistencia a los niños y niñas que no pertenezcan a ninguno de los citados departamentos"

La Diputación hizo sus deberes y nombró a los diputados que debían constituir la comisión mixta "que establezca y concreten las bases el alcance y condiciones" del contrato de colaboración. No así la Facultad de manera que no se formó la comisión mixta ni por tanto se reguló el convenio, lo que dio lugar a problemas. Los profesores se hicieron cargo de los departamentos pero el acuerdo parece que no funcionaba bien, en la sesión provincial del 30 de agosto de 1923 se volvió a recoger la preocupación por la alta mortalidad de la Inclusa, se denunció que los facultativos la tenían desatendida y se reiteró la necesidad de formar la comisión mixta o cerrar el convenio

"... se manifestó que tiene noticias que en la Inclusa hay una mortalidad alarmante y desea que se tomen las medidas necesarias para evitarlo; que tiene también noticia que los Médicos de la Facultad que se hicieron cargo de este departamento han estado fuera de Valladolid y es preciso que se les haga entender que tan importante servicio no puede quedar abandonado... entendiendo la Comisión que no puede consentirse que ni un solo día pase sin hacerse la visita a dicho departamento ... se acuerda recordar al Sr Decano de la Facultad de Medicina la conveniencia de designar los señores Profesores ... advirtiéndole que de no hacerlo en un plazo prudencial se entiende que desisten de prestar los servicios médicos que se les tenía encomendados" 
El catedrático de Obstetricia, y en aquel momento decano, Isidro de la Villa contestó que había estado ocupándose de asuntos de la Maternidad y comprando material

“...elegir locales para mejorar el servicio actual, que no reúne ninguna de las condiciones necesarias. Además en reciente viaje por el extranjero ha adquirido material, sobre todo de esterilización, que falta en absoluto para la maternidad. Atendiendo sin embargo su deseo... inmediatamente nos pondremos de acuerdo con la comisión nombrada por V. S. para remediar la mortalidad infantil"

En marzo de 1924 la sesión provincial todavía requería al decano de la Facultad que designara a los responsables de negociar las bases del acuerdo. La Diputación no cumplió su amenaza a pesar de que no se formó la comisión mixta y las relaciones continuaron, desde entonces la Facultad se encargó de la asistencia médica de la Maternidad y la Inclusa. Esta colaboración, junto con otras medidas higiénicas y generales, finalmente dio sus frutos y consiguió rebajar la mortalidad de la Inclusa a partir de 1927 como puede verse en la TABLA 3-37. Entre otras medidas, en septiembre de 1923 se unificaron los reglamentos de las maternidades del Hospicio y del Hospital Provincial con el objeto de reclutar más nodrizas, estableciendo la misma obligación de lactar, de la que libraban a las mujeres casadas, a las acogidas en los dos establecimientos. La sesión provincial de la Diputación reconocía la altísima mortalidad infantil ocasionada por la lactancia artificial y la explotación que en muchos casos sufrían los niños criados con nodrizas externas y así justificaba su decisión de obligar a las mujeres del Hospital a hacer de nodrizas; hasta entonces se habían librado aunque hubieran permanecido ingresadas varios meses. Admitían que era un tributo de sangre trasnochado que no existiría si se ayudara económicamente a las mujeres, pero calculaban que con las estancias impagadas del Hospital se habrían podido criar al pecho ocho niños más: (ANEXO 8)

"...las que permanecen en el Hospital se ven libres de este compromiso, dándose el caso anómalo de causar estancias durante cinco o seis meses sin contraer el menor compromiso de lactancia...

... ha dado lugar este régimen abusivo y falto de equidad, a dos mil quinientos treinta y cinco estancias indebidas, que... hubiera permitido criar ocho niños más que se hubieran sustraído a la lactancia artificial de tan enorme mortalidad.

Es indudable que las modernas y humanitarias corrientes de protección a la mujer embarazada suprimen estos tributos de sangre prestando a la mujer ayuda económica durante los últimos meses de su embarazo; pero esto no puede ser misión exclusiva de la Diputación y sí del Estado...

La espantosa mortalidad de la lactancia artificial, la explotación ejercida con muchos niños sometidos a lactancia externa nos obligan a procurar los medios para que la Inclusa disponga del mayor número posible de amas de cría... 
... Las embarazadas casadas podrán permanecer en la maternidad desde el séptimo mes de su embarazo, sin obligación de criar a ningún niño".

El doctor Vidal Jordana, catedrático de Enfermedades de la Infancia de la facultad de Medicina de Valladolid dio una conferencia en 1927 sobre el tema "El problema de las Inclusas en España". Demuestra conocerlo bien, como encargado médico de la provincia que era; el resumen que publicó la prensa local es muy interesante porque recoge los problemas presentes y las tendencias de la época en relación con este tema, defiende la supresión del torno, apoya la campaña de las abogadas feministas como Victoria Kent y Clara Campoamor y Matilde Huici sobre la investigación de la paternidad de los hijos ilegítimos ${ }^{860}$, acepta el nodrizaje como un mal menor, propone la contratación de enfermeras puericultoras para el cuidado de los internos y un modelo ideal de Inclusa a imagen de las de otros países europeos, y admite que las diputaciones no tienen recursos suficientes para atender a todas las necesidades de las Inclusas. Concluye que la nodriza ideal es la propia madre

En España no se han opuesto los medios posibles al desarrollo alarmante de la mortalidad infantil

Si las líneas de mortalidad y natalidad marchan paralelas, el pueblo permanece estacionado en su vitalidad; si disminuye la de la mortalidad, se afianza; si se eleva, como en España ocurre, los pueblos llegan a desaparecer....

Las Inclusas son establecimientos llamados de beneficencia, verdaderos vertederos que recogen las inmundicias de la sociedad. En su origen, desde su creación en Roma por el pontífice Inocencio III, tenían una justificación tendiendo a evitar el infanticidio. Pero se han estancado, y hoy, a pesar de que en ellas pongan los médicos su ciencia y sus desvelos, valdría acaso más en bien de la infancia que no existieran.

En ningún país del mundo más que en España e Italia existen las Inclusas en esta forma de organización.

Leo unas estadísticas que demuestran que la mortalidad oscila de 70 a 80 por 100 a 19 del número global. La primera cifra la dan las Inclusas que tiene torno, la mínima las que lo han suprimido.

El término medio es de un 50 por 100, que es el ofrecido por la de Madrid y también por la de Valladolid...

Los niños alimentados con biberón en las inclusas se mueren todos...

Los que llegan de la Maternidad pudieran dar una solución al problema acogiendo a la madre con su hijo, sin ninguna limitación.

En España existe una ley de protección de la Infancia de 1904, muy bien hecha, pero incumplida en todas sus partes.

\footnotetext{
${ }^{860}$ A efectos legales la ley diferenciaba los hijos legítimos en naturales, cuando los padres podían casarse, y no naturales cuando no era posible: adulterinos, incestuosos sacrílegos e hijos de prostitutas, no permitiendo investigar la paternidad en éstos últimos, cuando el padre no podía casarse. LIZARRÁGA VIZCARRA I.: Libertad (1931), de María Martínez Sierra: La mujer española frente al Código Civil. Ilusión y compromiso: II Jornadas sobre María Lejarraga, Logroño 2002, p 35-8), p 40
} 
El torno, dice, es un receptáculo por el cual entra todo; es el secreto de las Inclusas y la hipocresía de la sociedad. Por el entran no sólo hijos sin padres, sino también legítimos. Para juzgar todo esto debe sustituirse el torno por una oficina receptora de información, con todo el debido secreto.

Alude con franco elogio a la campaña que, sintiendo la injusticia del código, están realizando Victoria Kent, Matilde Huici y Clara Campoamor. Defiende, a este respecto, la investigación de la paternidad.

Otras veces llegan niños enfermos ó moribundos.

Los niños se mueren por las condiciones de los edificios (oscuros, antihigiénicos, sórdidos, tan distintos de los extranjeros, llenos de luz y de alegría), por la alimentación defectuosa, la escasez de nodrizas, la falta de capacidad en éstas, la lactancia artificial, la dificultad de cuidar el régimen nutritivo. Lo menos que puede pedirse es que cada niño tenga una nodriza.

Otro aspecto del problema es el de las nodrizas externas, organización muy deficiente, pero desde luego un mal menor.

Una organización de observación y vigilancia de estos niños, podría tenerse gratuitamente con auxilio de los médicos de los pueblos.

El cuidado de los niños debía encomendarse a personas capacitadas. Para ello habrían de existir escuelas de puericultura en las más importantes capitales y en las Inclusas un servicio de enfermeras de niños.

En otros países las Inclusas no existen. En Francia entran en la "pouponier» los niños con sus madres, existiendo también los asilos para embarazadas y nodrizas. Las mujeres cobran un sueldo por alimentar durante tres meses a su propio hijo.

En Alemania, el tipo corriente es el «hogar del niño».

En Inglaterra, existe un modelo ideal. Los niños acogidos, el primer año lo pasan en el campo, volviendo al establecimiento modelo cuando no son prohijados.

En Suecia los tiene cuatro meses la madre y después los envía al campo.

Frente al problema, lo que hay que hacer en España es sencillamente -si la diputación no puede sostener las inclusas- cerrarlas o entregarlas al Estado para su transformación.

$\mathrm{Ha}$ de cumplirse radicalmente la protección a la infancia, y entre sus disposiciones, la de que una nodriza no pueda colocarse si su hijo no tiene más de seis meses y menos de diez. Debe llegarse a la supresión radical del torno en las inclusas.

La Diputación no puede dar lo que no tiene y en realidad el sostenimiento digno de las inclusas es superior a sus medios.

Se impone la reforma radical del edificio y cambio de personal.

El ideal -finalmente- es que las madres sean las nodrizas de sus propios hijos. ${ }^{861}$

Parece que la Diputación no cejó en sus buenos propósitos de mejorar las condiciones de vida de sus acogidos y sobre todo de rebajar la mortalidad de su Inclusa a niveles próximos a los de la población general, aunque, pese a los deseos expresados, se mantuvo muy alejada

\footnotetext{
${ }^{861}$ N.C.: Ayer en la Universidad. Conferencia del doctor Vidal Jordana, 3-04-1927, portada
} 
de una "Inclusa modelo". En 1933 en la sesión provincial del 18 de marzo se reconoce la labor de la Facultad de Medicina y se toma alguna medida, lejos de las propuestas del doctor Vidal

"El diputado delegado del Hospicio señor de los Cobos, propone mejorar los servicios en la Inclusa, en la que según dice, desde que está atendida por la Facultad de Medicina ha disminuido notablemente la mortalidad. Estima que la Diputación no debe regatear esfuerzos para llegar a tener una inclusa modelo, y atendiendo a las grandes ventajas que para la curación de gran número de enfermedades infantiles reportan las playas artificiales, propone la instalación, con sus correspondientes reflectores, provisionalmente, en un local de los que fueron comedores de maternidad reservada, y definitivamente en la galería del ropero general, una vez reparada.

La propuesta se aceptó por unanimidad, acordándose facultar al señor Cobos para que, de acuerdo con los médicos que crea oportuno, proceda a su realización ${ }^{\prime \prime 62}$

\section{Sustitución del torno de la In- clusa \\ Se facultó al señor Polanco para llevar a cabo esta sustitu- ción, ya que aportó anteceden- tes y forma en que lo han rea- Hzado otras Comporaclones pro- vinclales, quedando f a c ultado para realizar las obras y seña- lar el local donde se establezca la nueva ofleina de admislón de ingresos. \\ El señor Cuevas felicitó al se- ñor Polanco por haber tan rá- pidamente llevado a cabo la propuesta formulada por él a la Comisión gesbora.}

Imagen 3-60: Sustitución del torno. EI Norte de Castilla, viernes 15 de Mayo de 1936
En la sesión provincial del 14 de mayo de 1936 se aprobó la supresión del torno y su sustitución por una oficina de admisión ${ }^{863}$. El Hospicio y la Inclusa siguieron funcionando, con sus deficiencias y problemas, la mortalidad y las nodrizas. En 1945 se propone una modificación del reglamento, ya que seguía vigente el de 1927, en relación con el salario de las nodrizas internas y externas con el mismo propósito final de siempre, rebajar la mortandad y en este caso, además, promover la lactancia materna, mejorando también la remuneración de la madre cuando se queda a lactar a su hijo después del período obligatorio. Para entonces se habían rebajado los tiempos de lactancia y destete a 12 meses y 4 años respectivamente ${ }^{864}$ (ANEXO 9).

\footnotetext{
${ }^{862}$ N.C. 19- 03- 1933, p 3

${ }^{863}$ Se reúne la Comisión gestora de la Diputación provincial. N.C. 15- 05-1936, p 3

${ }^{864}$ Signatura: caja 7635, expediente 09. ADPVA
} 


\section{CONCLUSIONES}

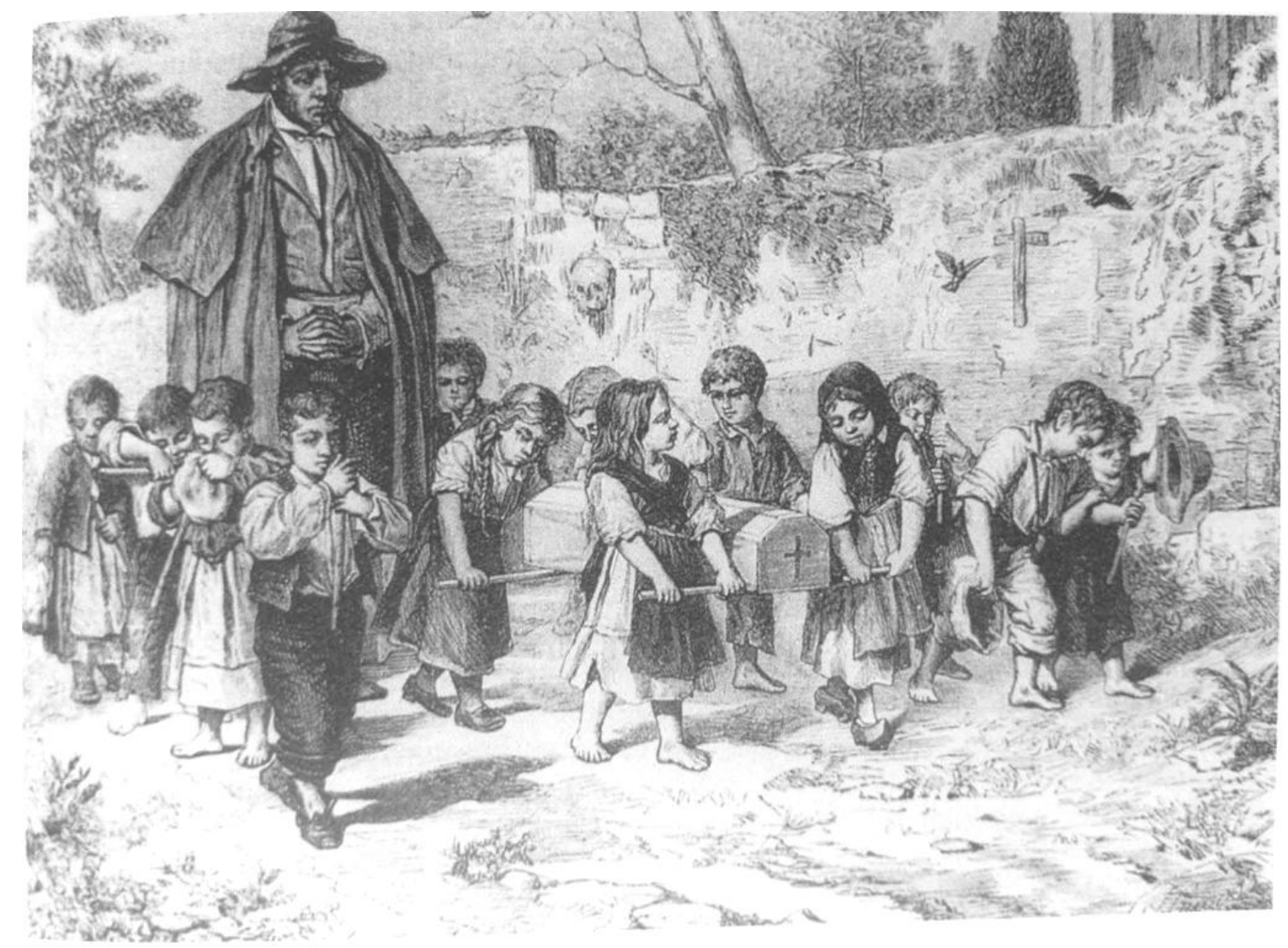

"Entierro de un párvulo", 1877.

Imagen 5: Entierro de un párvulo. 1887

Fuente: VV.AA. Valladolid un siglo de cuestión social (1840-1940). Valladolid. Grupo Pinciano. 1995, p 281 


\section{CONCLUSIONES}

La normativa legal que ha condicionado este trabajo nos ha hecho perder amplitud temporal, pero al mismo tiempo ha permitido ganar sin duda en profundidad, de manera que se ha realizado un análisis exhaustivo de la Inclusa Provincial de Valladolid en el intervalo 1900-13, ampliando hasta la tercera década en todo lo que la documentación ha permitido. Se compensa además con la novedad del material, no estudiado todavía.

Se ha vaciado la sección de Acogida de Menores en el Archivo de la Diputación Provincial de Valladolid para el periodo de consulta permitido. Sobre estas fuentes se ha realizado un análisis minucioso y consideramos que interesante, ya que puede facilitar consultas posteriores, además de ayudar al desarrollo del trabajo y aportar información.

Con todas las fuentes y medios, se ha conseguido obtener una visión amplia del tema en cuestión, si bien es cierto que se echa en falta información más personal, privada y cotidiana tanto de los niños, como sobre todo de las madres y de las nodrizas, las cuidadoras, mujeres de las que apenas hay unos pocos datos en los registros, como nombre y localidad. Es una información relevante porque el bienestar de los niños, su calidad de vida y sus circunstancias vitales estaban muy unidas y dependían de estas mujeres y de su realidad vital.

Muchas de las conclusiones a las que hemos llegado coinciden con las conocidas para otras inclusas, no en vano tenían un objetivo y una mentalidad común, pero dentro de ello cada una tenía sus particularidades. Este trabajo aporta conocimiento nuevo sobre la Inclusa de Valladolid, sin estudiar hasta ahora en el periodo que corresponde a los principios del siglo $X X$, lo que supone al mismo tiempo ampliar el que existe sobre las inclusas españolas, particularmente también para este tiempo. Además, se ha profundizado en temas poco estudiados o desde una perspectiva diferente, ampliando cuestiones menos tratadas como el destete y la dieta posterior o las causas específicas de la mortalidad infantil con los diagnósticos médicos actualizados. Se han tratado con profundidad cuestiones de identidad como el nombre y apellidos y enlazando con estas el bautizo. Otros aspectos del cuidado se han desarrollado en la medida, muy limitada, que la información ha permitido.

Son muchos los datos que se han analizado en este trabajo; sin perder de vista los objetivos iniciales, según se avanzaba en la investigación se iban planteando preguntas que no 
podían quedar sin respuesta, sobre todo en aquellos datos inéditos no conocidos. Intentaremos ofrecer una visión global lo más amplia y concreta posible.

La Inclusa o "Departamento de Lactancia" acogía niños de hasta 15 meses, el nombre por extensión se aplicaba así mismo al "de Destete" o "de Menores" de 5 años, conociéndose ambos también como Cuna. Debido a la mezcla de la información relativa a los dos departamentos, resulta difícil separar en ocasiones la que se refiere estrictamente a los lactantes; en cuestiones de interés, o cuando no ha sido posible separarlos se ha ampliado el análisis hasta los 5 años. El nombre de expósito se usaba en general para todos los incluseros.

El Hospicio Provincial de Valladolid, con la Inclusa, dependiente de la Diputación provincial, se ubicaba en el antiguo palacio de los Benavente, un edificio que describían como un caserón vetusto, sombrío y frío, con unas pésimas condiciones higiénicas e inapropiado para el uso que se le daba; las salas de niños eran poco luminosas, mal ventiladas, se quedaban pequeñas y no tenían zonas separadas para aislamiento. Aunque se realizaron obras continuas de reparación y ampliación, no llegaron a conseguir unas instalaciones adecuadas desde el punto de vista higiénico-sanitario, ni mucho menos una residencia confortable. Aparte de falta de previsión y algo de dejadez, el Hospicio sobre todo adolecía de falta de recursos; los presupuestos, siempre limitados y escasos de la Diputación, nunca dieron para cubrir suficientemente las necesidades ni del edificio ni de sus acogidos.

El personal para la atención directa de los asilados era muy escaso. Las Hijas de la Caridad, que pasaron de 17 a 27 en 30 años, eran las responsables del gobierno interior de todo el Hospicio y en particular de la Inclusa y la Maternidad, así como de las nodrizas. Su condición religiosa y su actitud condicionarían el sistema, para bien y para mal, y sería motivo de controversia, pero fueron una mano de obra barata y eficaz; cada monja cobraba la mitad que una nodriza de la Inclusa. Con dos médicos y un practicante, más dos ayudantes, un enfermero y una enfermera, que no eran profesionales titulados ni cualificados como los actuales, se atendía a toda la población asilada. La atención médica mejoró cuando la Diputación firmó un acuerdo con la Facultad de Medicina en 1922; se empezaron a ver resultados con una rebaja importante de la mortalidad a partir de 1927. Ya nos da una idea de la mortalidad del establecimiento el hecho de que entre el personal había un sepulturero. Las nodrizas, a pesar de ser imprescindibles, al igual que las demás mujeres de servicio, cobraban salarios muy inferiores al de los sirvientes masculinos. 
Resulta difícil conocer la población interna total del Hospicio en un momento concreto, debido al movimiento de niños que salían y entraban repetidas veces. Estimamos alrededor de 400-500 internos, por lo que no es de extrañar que se hablara de hacinamiento. Es más difícil valorar la población total de acogidos, internos y externos, de ser alrededor de 1.500 pasaron a la mitad, más del $70 \%$ eran menores de 5 años de la Inclusa. Con el tiempo fue disminuyendo el número de externos y aumentando el de internos. Aunque los datos variaban de unos años a otros, el 31 de diciembre de 1908 se encontraban internos 32 lactantes y 14 niños de destete y en los años cuarenta se refiere una capacidad en la Cuna para 66 lactantes y 56 destetes.

La media anual para el periodo 1900-13 fue de 425 ingresos efectivos en la Inclusa y aumentó en los años posteriores a 455. La mayoría ( $87 \%$ estimados) se encontraban en el 1o mes de vida y por lo menos un tercio podrían estar en su primer día de vida. Menos del $5 \%$ eran mayores de 1 año. El sexo no fue un factor relevante. Para hacernos una idea de la repercusión en la población general, en promedio para estos años, el 3’78\% de los niños nacidos en la provincia ingresaron en el primer año de vida. Un dato significativo para una cuestión con repercusiones personales y sociales importantes, reflejo de la situación social.

La mayoría de los usuarios de la Inclusa eran ilegítimos, alrededor del 80\%, para una provincia que tenía aproximadamente un $5 \%$ de ilegitimidad, ligeramente más alta que la media nacional. Entraban directamente cuando se exponían en los tornos o en cualquier otro lugar de la ciudad o la provincia o nacían en las maternidades del Hospicio o del Hospital. Los legítimos debían solicitar su admisión a la Diputación y demostrar pobreza e imposibilidad para lactarles y la Comisión provincial resolvía; también los encontramos echados al torno para evitar o agilizar los trámites. En situaciones de urgencia o desamparo, el Presidente o el Vicepresidente de la Comisión provincial o el Gobernador Civil ordenaban la admisión.

La extracción social podemos valorarla de forma indirecta a través de algunas notas del torno que habla de la falta de medios para criar al niño, incluso de pobreza extrema, y sobre todo de la ropa con la que se presentaban. Aunque llegaba algún niño con ropas que nos hacen pensar en una posición acomodada, la mayoría llevaban prendas viejas, muy usadas o simplemente trapos. Se confirma por tanto el uso de la Inclusa para el objetivo que señalaban sus reglamentos, recoger y criar a los niños ilegítimos, y a los pobres sin recursos y en la mayoría de los casos se combinaban las dos situaciones.

Se observa estacionalidad, con un mayor número de ingresos en los meses invernales, que fueron también de mayor natalidad general, y con mínimos en julio y agosto, los meses de menor natalidad y mayor mortalidad infantil general y de más actividad agrícola. 
La mayoría de los niños fueron echados al torno de la Inclusa (35'15\%), que hemos localizado en la esquina de la fachada principal junto a la Iglesia de San Nicolás; sitio ideal para procurar clandestinidad, discreto, sin paso y protegido por jardines y árboles. Quizás por eso, al estar muy preservado, en conjunto se le dio más uso diurno; las horas más frecuentadas fueron las siguientes al ocaso de $19 \mathrm{~h}$ a $23 \mathrm{~h}$ con otro pico durante la mañana de $9 \mathrm{~h}$ a $13 \mathrm{~h}$. Su funcionamiento era similar al de otras inclusas, con una hermana tornera siempre de guardia.

Más del $80 \%$ de los expósitos de la Inclusa se presentaron en el torno con una nota, son muchas para lo habitual en otras inclusas donde no solía llegar al $60 \%$. Su transcripción completa a los Libros de Exposiciones servía de medio de identificación en caso de reclamación del expósito. Las había de todo tipo y se han analizado extensamente en el trabajo por su interés. Todas ellas, incluso su ausencia, nos brindan información, desde un escueto "sin bautizar", tema que se toca repetidamente en muchas, al nombre o la filiación completa del niño, o la documentación necesaria para tramitar el ingreso. Las hay ingenuas, dramáticas, agradecidas o suplicantes, pidiendo buen trato, o justificando la exposición por imposibilidad de criar al niño, algunas muestran intención de recuperar al hijo o se utilizan a modo de recibo o resguardo, incluso ofrecen recompensas, aunque sean más veces espirituales que económicas. Especialmente dura, aunque refleja una situación aceptada entonces como normal, es la que escribe un hombre que parece pudiente y conocido de la Inclusa recomendando al hijo de la nodriza que tenía contratada en su casa para que le asignen pronto un ama de cría. Algunos niños presentaban otras señas que podrían servir de identificación como prendas características, collares de abalorios, evangelios, escapularios y medallas protectoras, sobre todo de la Virgen del Carmen y del Niño de Praga; incluso encontramos marcas físicas como quemaduras, marcas indelebles para identificarle sin lugar a duda.

La presentación de notas y objetos denota interés por el hijo, preocupación por bautizarle, intención de recuperarle o entregarle un recuerdo de su madre y su origen. En la mayoría de los casos serían un esfuerzo inútil, muy pocos retornaron con los padres, sólo el 8'15\% de los niños ingresados y un tercio lo haría después de permanecer varios años ingresados. Tenían más posibilidad los legítimos (55\%), pero algunos regresaban de nuevo a la Inclusa (3\%). Para recuperar al hijo tenían que identificarle con toda seguridad, demostrar buena conducta e indemnizar al asilo, lo que no solía hacerse por falta de recursos; para ahorrarse los gastos del traslado y agilizar los trámites, podían recoger al niño directamente de la nodriza. Muchos niños legítimos salieron y volvieron con la familia de forma fraudulenta. 
Por la vía oficial, a través de la Diputación, entraron en la Inclusa poco más del $24 \%$ de los niños, 1/3 de ellos por vía urgente; solían ser niños que habían quedado desamparados por enfermedad o muerte de los padres o abandonados. En esta población, como era de esperar, predominaban los hijos legítimos y de origen rural (83\%). Aunque también son mayoría los neonatos, hay muchos más niños mayores (siete veces más mayores de 1 año que por el torno) y un $10 \%$ más de varones; no obstante, no podemos afirmar que este dato indique una preferencia clara porque en ocasiones comprobamos que ingresaban todos los hermanos de la unidad familiar. Esta diferencia es más relevante en el grupo de ilegítimos que entraron por esta vía en el que los varones superan en un $15 \%$ a las niñas, muy por encima de la ratio por sexo en los nacimientos de la población general; se puede plantear, teniendo en cuenta que la tramitación llevaba un tiempo en que tenían que cuidar al hijo y pensar su cesión, que las madres solteras podrían tener más apego por las niñas.

La provincia de Valladolid contaba con otros dos tornos, o hijuelas, solo para la recepción de niños y traslado posterior a la Inclusa central, que se localizaban en las dos poblaciones más importantes después de la ciudad, Medina del Campo y Medina de Rioseco. El traslado lo hacían mujeres contratadas, probablemente por la Diputación, para atender estos tornos. A pesar de los tornos, muchos niños se echaban en los pueblos, en puertas o ventanas de casas de los vecinos, generalmente quienes les encontraban se encargaban de llevarles a la Inclusa de la capital, siempre eran mujeres. Sobre ellos, que representan un $14^{\prime} 27 \%$ del total de ingresos en la Inclusa, hay muy pocos datos registrados, casi en su totalidad eran de padres desconocidos y no hay diferencias por sexo; la mitad se recogieron en el torno de Medina del Campo y casi el $22 \%$ en el de Rioseco, el resto se repartió por la geografía provincial. Salvo en 5 localidades más pobladas, como Nava del Rey que tuvo más del $5 \%$ de exposiciones, en los demás pueblos no llegó a una por año

Se ha hecho un estudio pormenorizado sobre el lugar de origen de los niños de la Inclusa, que varió en función de la vía de ingreso. Resumiendo, para el total de los niños ingresados, excluyendo a los nacidos en las dos maternidades que necesariamente nacieron en la capital, predominó el origen rural (68'8\%) sobre el capitalino en valores absolutos, sin embargo, considerados los datos proporcionalmente, para una población equivalente saldría una ratio de 86 niños de la provincia por cada 100 de la capital. Los pueblos de origen se reparten por toda la geografía provincial con predominio de las comarcas del Sur-suroeste (Tierra de Medina y Tierra del Vino) con el 35'66\%, siguen la zona Norte de Tierra de Campos y el Centro (en torno al $25 \%$ ) y finalmente las comarcas del Sureste con poco más del $15 \%$. 
El Hospicio disponía de un departamento de Maternidad, que servía de refugio de embarazadas sin recursos económicos o que quisieran ocultarse, algunas mujeres repetían estancia. En él se garantizaba el anonimato total de las mujeres refugiadas, sobre todo de las que ingresaban en la sala Reservada o Secreta, para pensionistas distinguidas que podían ingresar en cualquier momento, pagaban más por su estancia y ni siquiera se registraban en los libros de la Maternidad. En la otra sala, la General, ingresaban a partir del séptimo mes de embarazo, o antes por indicación médica, las pensionistas de $2^{\underline{a}}$ y las gratuitas, realmente esto es un eufemismo porque estas refugiadas si no pagaban en moneda lo tenían que hacer en especie. El número de refugiadas fue muy variable en ambas salas de unos años a otros (de 70 a 111) y entre ellas comprobamos que también había mujeres casadas. Podían quedarse con el hijo, pero la mayoría lo dejaba en la Inclusa, solamente se han contado 10 niños que salieran con sus madres y 2 de ellos fueron depositados después en el torno. A cambio de su estancia, las gratuitas tenían que quedarse en la Inclusa como nodrizas tanto tiempo como el que habían permanecido en la Maternidad, aunque el hijo hubiera fallecido, pero solamente cobraban cuando lactaban a niños ajenos, no se remuneraba la lactancia del propio hijo. Si la mujer no quería lactar o se iba antes, tenía que pagar la parte correspondiente hasta saldar la deuda contraída según los días de estancia. No todas las refugiadas se quedaban.

En el período analizado, el $19^{\prime} 47 \%$ de los niños que ingresaron en la Inclusa nacieron en la Maternidad, la diferencia por sexo no es relevante, aunque sí para las muertes perinatales, los que aparecen registrados como niños muertos, con más del doble de varones. Todos fueron lactados por su madre hasta que salieron a crianza externa, pero no permanecieron más tiempo en la Inclusa que el resto de ingresados. A pesar del valor que se daba a la lactancia materna, no se mantenían los hijos de las refugiadas-nodrizas en la Inclusa con su madre, se quitó del reglamento una norma que decía que debían ser los primeros en salir, pero paradójicamente a partir de su retirada observamos una salida más precoz de estos infantes. En el folio de inscripción del niño se anotaba solamente el nombre, real o supuesto, de la refugiada, ningún dato más sobre ella, ni edad ni estado civil, ni procedencia.

Los nacidos en la Maternidad del Hospital provincial (6'75\% del total) tenían la misma consideración que los niños de la Inclusa, pero no sus madres. Por un lado, no les cubría la obligación de confidencialidad por lo que en los libros aparecen algunos datos personales. Son muy escasos, pero permiten acercarnos un poco a su perfil, que por extensión podemos aplicar a las refugiadas de la Inclusa. La mayoría eran solteras (84\%) con una edad media de 25 años y edades extremas de 16 y 41 . La mayor parte de los niños por tanto son ilegítimos, se daba tanta importancia a este hecho que en el caso de las viudas $\left(5^{\prime} 8 \%\right)$ se aseguraban de la 
legitimidad del niño antes de ponerle los apellidos, según el tiempo transcurrido desde el fallecimiento del marido. Un 10,2\% eran casadas y los hijos, aunque legítimos se admitían sin trámite, es probable que la condición de pobreza se hubiera justificado previamente. Por otra parte, estas mujeres no estaban obligadas a hacer de nodrizas y cuando lo hacían cobraban desde su entrada, pero no les asignaban a sus hijos; esto no parece hecho intencionalmente, sino que los niños ya tenían ama de cría porque ingresaban antes. No sabemos si luego entre las nodrizas se arreglaban porque en los libros, así como se anotaban los cambios de nodrizas externas, solo se registraba la primera de la Inclusa. En 1923 se amplió la obligación de lactar a las mujeres no casadas del Hospital por la necesidad de reclutar más nodrizas internas.

Al entrar, al niño se le asignaba un "atillo" (sic) con su ajuar completo, una nodriza interna y un número. Le colgaban del cuello el plomo de identificación que ya no podía ser retirado, se trata de una medalla con el número troquelado en una cara y en la otra a San José que hemos descubierto casualmente como era y aportamos imagen, pues no se conserva ninguno en el ADPVA ni se conocía. Pasaba a la Inclusa ya vestido con ropa del Hospicio y hasta que le bautizaban le colocaban en la sala de los no bautizados. Se menciona también una "sala de los colocados" que sospechamos sería para los que tenían asignada una nodriza externa. Les disponían en cunas numeradas y cuando no había suficientes colocaban dos bebés juntos, niño y niña para no confundirse. Aunque no hay datos concretos sobre la ocupación de la Inclusa, sabemos que aumentó en la segunda década estimándose la media por encima de 70 niños, cifra que justifica la denuncia sobre las malas condiciones higiénicas y el hacinamiento que en 1920 realizó el equipo médico del Hospicio.

Al ingresar, a cada asilado se le abría una hoja histórica en el Libro de Exposiciones del año; el número del folio y el año de exposición le identificaba. Más tarde se empezó a utilizar el número de filiación, una numeración indefinida e independiente del folio. Se emplearon los dos procedimientos de forma conjunta, pero además, existen dos series diferentes de números de filiación, por lo que hay niños con el mismo número, lo que pudo ser motivo de errores. Para un establecimiento tan complejo como el Hospicio, que atendía distintos departamentos separados administrativamente y mucha población, interna y externa, sería necesario un sistema de registro muy meticuloso. Toda la comunicación entre las distintas secciones del Hospicio y la oficina de dirección se hacía a través de papeletas oficiales y notas oficiosas y la información se repartía y repetía en libros diferentes. Un sistema complejo que favorecía la producción de errores al hacer la transcripción repetida de datos, con pérdidas o cambios. También es cierto, que podía permitir el control, en ocasiones el propio sistema 
detectaba los errores que en muchos casos eran involuntarios. Se han detectado otros que resultan muy sospechosos, como niños que prolongaban la crianza mucho más de lo previsto o legítimos que ingresaban por la oficina y no llegaban a la Inclusa.

La mayoría de los expósitos y todos los niños nacidos en la Maternidad se bautizaban en la capilla del Hospicio, había que imponerles un nombre y ésta era una de las cuestiones reglamentadas. En general, la Inclusa respetó las indicaciones de las notas del torno, en otras inclusas cambiaban el nombre. En algunas notas, incluso después de dar los apellidos, se decía que el niño era "de padres desconocidos" para que constará así en el Registro civil y no como ilegítimo; la ley además no permitía registrar el nombre de los padres sin su consentimiento.

Para los niños que llegaban sin nombre, el reglamento ordenaba poner el santo del día, costumbre muy arraigada que asignaba a los infantes un santo protector; sin embargo se comprueba, teniendo en cuenta la complejidad del santoral, que esto no siempre se cumplía. Otra cuestión era la asignación de apellidos; a pesar de la prohibición legal de 1870 de imponer aquellos que delataran la falta de filiación de los expósitos, la Inclusa siguió adjudicándoles el tradicional San José, en honor del que era su patrón desde la primera casa de Expósitos de Valladolid, y como la ley obligó a poner dos, porque uno solo también delataba al expósito, se añadió Prado, por la Virgen cuya imagen se encontraba en la parroquia de San Nicolás, a la que pertenecía el Hospicio. A partir de 1907 la Inclusa dejó de utilizar estos apellidos y empezó a adjudicar otros, sin criterios para su elección, salvo en los niños nacidos en la Maternidad, a los que dejaban los apellidos maternos, si la madre quería, permitiéndole elegir nombre. En Medina del Campo a los expósitos les adjudicaban los apellidos Ruiz y Barrientos, dos benefactores de aquella villa, en cambio en Rioseco utilizaron apellidos corrientes. En el resto de la provincia se daban también los dos casos y en algunos sitios usaban el toponímico, en ocasiones resaltando la ilegitimidad Matías Aparecido de Tiedra. En la provincia de Valladolid se utilizó muy poco el apellido Expósito, muy extendido en otras regiones. Además de no conocer sus apellidos familiares, muchos expósitos tampoco sabían su fecha de nacimiento porque en los libros solo se anotaba la de inscripción en el Registro Civil y la del bautismo.

La preocupación social por el Bautismo se refleja en las notas del torno que con frecuencia lo mencionan. La Inclusa atendía muy especialmente este aspecto, no en vano estaba al cuidado de una comunidad de religiosas, además, la ley obligaba a bautizar a los expósitos. Cuando los niños llegaban sin bautizar se investigaba su procedencia, solicitando información a parroquias y ayuntamientos. En caso de duda se hacía un bautizo subconditione. Los bautizos se celebraban en la Inclusa de una a tres veces por semana, sin una pauta fija. En 
general los niños no se bautizaban de forma inmediata, a veces se retrasaba hasta 8-11 días desde su ingreso. Los que ingresaban en mal estado eran bautizados de forma más inmediata y en ausencia del capellán recibían el agua de socorro. Se bautizaban en solitario o en grupos y tenían asignada una madrina, siempre mujer y durante años la misma, podría tratarse de la monja responsable de la capilla; de forma esporádica el director del Hospicio y su esposa apadrinaban algún niño, no parece que para los ahijados esto fuera una ventaja, los dos que encontramos fallecieron. También confirmaban a todos los niños que se encontraban ingresados el día señalado, incluso recién bautizados. La confirmación se celebraba en la parroquia de San Nicolás de Bari, pero no se registraba en los Libros oficiales.

La Inclusa estaba a cargo de las Hermanas de la Caridad, aunque el cuidado directo de los internos lo realizaban las nodrizas; una monja hacía guardia por la noche para comprobar que amamantaban a los niños. Hay muy escasa información de la sala de Destete, sus cuidadoras eran las llamadas "amas secas", sin leche o no aptas para lactar. Tenían muy pocas y se tuvieron que publicar anuncios en la prensa local solicitándolas.

La ropa, tanto de vestir como del hogar, y la mayoría del calzado, se confeccionaba en los talleres del Hospicio, incluso los colchones; también tenían telares pero su producción era insuficiente. A pesar de ello, o precisamente por eso, los hospicianos tenían fama de ir andrajosos, mal vestidos y calzados, las piezas de vestir se debían reparar casi indefinidamente, y no se podían dar de baja sin "orden escrita del director". Todos los niños debían vestir con la ropa reglamentaria. En el torno tenían dispuestas veinte envolturas completas, la ropa para vestir o envolver a los lactantes de pocos meses que constituía el "atillo" (sic) que se entregaba luego a la nodriza externa cuando se llevaba al niño y que debía devolver junto con el plomo si éste fallecía, "excepto la prenda que se emplee para la mortaja"; cuando las prendas no se devolvían, se descontaba su valor de los haberes del ama. No refieren los reglamentos la ropa que se utilizaba después, cuando el niño empezaba a andar, pero suponemos que el vestuario de los incluseros se ajustaría a los usos de la época y a partir de los seis meses, más o menos, se usaría el llamado vestido de corto. Tampoco dicen a qué edad se hacía el cambio a la ropa de los hospicianos mayores, que ya era similar a la de los adultos, pero parece que podría ser ya en la sala de destete.

Cada cuna y cama tenía dos juegos de ropa, de quita y pon, se mudaban mensualmente, o cuando fuese preciso. Las cunas se protegían con zaleas, o pellejos, empapadores de piel de carnero u oveja, que se sustituyeron por hules. Una de las cosas que 
se destacaba del departamento de menores era el olor a orines, a pesar de que los jergones se hacían con paja de maíz para poder cambiarla con cierta frecuencia.

La higiene de los asilados es un aspecto que en los reglamentos se mencionaba solamente de pasada, poco más que se debe lavar y peinar a los niños todos los días; acaso se daba por hecho (?). La falta de instalaciones adecuadas, la escasez de agua, el frío en los meses invernales, la escasez de personal y la falta de educación y conocimientos de las cuidadoras ayudaban muy poco; únase una mentalidad tolerante en la que el aseo y la higiene personal eran algo secundario y falta de presupuestos para completar un cuadro que debía ser desolador, dadas las continuas quejas que se hacían por distintos medios, incluida la prensa local, sobre el estado del edificio y de los hospicianos. La alta mortalidad de la Inclusa relacionada con problemas infecciosos es suficiente testimonio de las condiciones higiénicosanitarias del establecimiento. Al final de los años 20 la Diputación demostró más sensibilidad con este problema y más interés por mejorar la supervivencia de su población infantil.

El juego al aire libre podía ser un problema por falta de espacio adecuado, sobre todo para los más pequeños, pues en los patios del edificio se encontraban la vaquería y los talleres. Los juguetes no se contemplaban entre los gastos ordinarios del centro. En la ciudad se organizaban campañas todos los años por Reyes para regalar juguetes a los "hospicianitos".

Sorprende, desde nuestra perspectiva, tanta meticulosidad en los registros con cuestiones como la ropa y que, salvo contadísimas ocasiones, no se haga mención del estado en que llegaban los expósitos, ni siquiera en niños que fallecían de forma casi inmediata; puede ser de esas situaciones que a fuerza de repetirse pierden valor. Todos los niños pasaban una revisión médica al ingreso, pero no hay constancia de que se realizaran otros controles, ni siquiera antes de irse con las nodrizas pues se nota que algunos ya salían en muy mal estado. Los médicos, atendían a los niños de la Inclusa por indicación de la Hermana de la Caridad responsable del departamento, que entre otras funciones debía evitar que las nodrizas aplicaran remedios caseros, algo muy habitual en la época. La Inclusa disponía de incubadoras para el cuidado de los niños prematuros desde 1905, lo que no deja de resultar asombroso teniendo en cuenta su reciente descubrimiento y que su uso y comercialización todavía era controvertido, además de costoso. Al final de la década de los 20 , cuando se hizo cargo la facultad de Medicina, se compró "material de helioterapia artificial", que se había puesto de moda recientemente y se creó un solárium, siguiendo el ejemplo de otras inclusas como la de Barcelona, considerada modélica. 
No contamos con información para valorar cuestiones como el desarrollo psico-social de los niños internos, tan importante para el desarrollo personal, pero los pocos indicios que hay no son buenos, considerando el ambiente de internamiento existente no andaremos muy descaminados si valoramos su situación como la que se denomina hoy hospitalismo,' es decir de carencia afectiva. La realidad de los niños que vivían con las nodrizas, a pesar de encontrarse en un ambiente "familiar", tampoco siempre era positiva afectivamente; la devolución de los niños después de años de crianza son suficiente demostración. Cuestiones como la mortalidad y el déficit de crecimiento sabemos hoy que también pueden relacionarse con la falta de afectividad. En el aspecto educacional, los niños, a partir de 3 años, iban a la Escuela de párvulos, dirigida también por una Hermana de la Caridad.

En una época en que la lactancia artificial todavía no se había desarrollado y la lactancia natural era esencial para la supervivencia de los lactantes, la lactancia mercenaria convertida en un medio de supervivencia de muchas mujeres, estaba siendo duramente criticada desde distintos ámbitos médicos e intelectuales por los excesos, las malas prácticas y la doble moral que rodeaban al mundo del nodrizaje. En el caso de las inclusas era un necesidad; todas, incluida la de Valladolid, padecían el mismo problema, una escasez permanente de nodrizas, debido a las malas condiciones salariales y del régimen interno. La falta de nodrizas obligó a la Inclusa a rebajar sus exigencias, incluso en las condiciones para lactar; en los libros comprobamos que se admitieron mujeres que reunían solo condiciones "regulares". La Inclusa de Valladolid fue bastante tolerante, o práctica, admitió solteras porque eran la mayoría de las mujeres que se ofrecían y permitió, interesadamente, que ingresaran madres junto con su hijo. Esta era una práctica prohibida en las inclusas para evitar un efecto llamada, pero como estrategia para reclutar nodrizas resultaba eficaz puesto que, además de la posibilidad de evitar el abandono del propio hijo, se conseguía una nodriza para otros niños.

El número de nodrizas internas de la Inclusa osciló entre 20 y 30 en las tres primeras décadas, era claramente insuficiente pues encontramos mujeres criando a 4 niños a la vez. EI sistema que retenía a las refugiadas insolventes se convirtió en el método principal de reclutamiento de nodrizas, común en las inclusas, suponía realmente un "tributo de sangre" para las mujeres, sin embargo, tenía su cara positiva en que mejoraba las perspectivas de supervivencia de los niños al dotarles de lactancia natural y de cuidadoras y aumentaba la posibilidad, aunque realmente fuera muy remota, de que la madre se quedara con su hijo. En los catorce años revisados solamente 49 madres-nodriza (el 4'2\%.) recuperaron a sus hijos. 
La posibilidad de criar al propio hijo explica estancias prolongadas como alguna que hemos encontrado superior a dos años, aunque eran muy poco habituales. No hay un patrón fijo de comportamiento de estas madres-nodrizas. Algunas permanecieron en la Inclusa hasta que el niño falleció o salió a crianza externa, otras se fueron en cuanto saldaron su cuenta y otras siguieron internas aunque ya no estuviera su hijo. Las hay que solo lactaron a su hijo, las menos, pero las mujeres de estancias más largas resultaron enormemente productivas para la Inclusa, superando alguna incluso los 30 expósitos en poco más de un año. No todas las amas se quedaban hasta que los niños asignados salían de la Inclusa, por lo que algunos tenían que pasar por varias manos. Para las nodrizas lactar era un trabajo y un recurso económico.

Merece mención el tema de las nodrizas sifilíticas; no se tuvo en cuenta esta condición de la mujer a la hora de adjudicarle expósitos, las encontramos lactando a algún niño sifilítico, pero también a infantes sanos. Se suele decir en relación con este tema que las nodrizas rechazaban a los niños sifilíticos, pero en la Inclusa no lo podemos asegurar. Hemos comprobado que ninguno de los niños sin ama adjudicada en los libros falleció por esta causa, al menos en la Inclusa. Por otra parte, todos los niños que murieron por sífilis tuvieron una nodriza, según consta en su folio de inscripción, aunque podría tratarse de una mujer que le cuidara pero que no le amamantara y le alimentara con biberón. Solo en una memoria médica de 1920 se da a entender que algunas nodrizas rechazaban a los infecciosos, no se ha podido analizar ese año pero sabemos que el déficit de nodrizas se había intensificado.

Además del problema que pueden suponer los infecciosos y la alimentación simultánea de varios niños, comprobamos que todos los expósitos que se quedaron sin nodriza fallecieron por infecciones, lo que nos lleva al tema de la lactancia artificial como recurso utilizado a falta de amas de cría, con resultados catastróficos en todas las inclusas y una mortalidad casi del $100 \%$. No es de extrañar teniendo en cuenta las condiciones higiénicas existentes, solamente por utilizar el agua corriente de la Inclusa ya estaban condenados, pues el agua que se suministraba en la ciudad de Valladolid estaba altamente contaminada. Tenemos constancia del uso del biberón en la Inclusa, por las compras realizadas desde 1903 de harinas lacteadas, las primeras fórmulas artificiales, aunque se utilizaba principalmente la leche de la vaquería. A la sección del biberón de la Inclusa en los años 20 se le llamó La Gota de Leche, a semejanza de los consultorios que dispensaban leche esterilizada, porque disponía de sistemas de esterilización. Según el reglamento de 1927 las cuidadoras de esta sección eran las embarazadas de la sala general no pensionistas y las asiladas mayores que por sus defectos físicos no podían salir del Hospicio, naturalmente, supervisadas por una Hermana. Hemos 
comprobado que para ellas era un trabajo no remunerado. También podrían estar en esta sección las refugiadas gratuitas que después del parto no pudieran lactar.

En cuanto a la dieta del destete y lo que llamamos ahora alimentación complementaria, la introducción de otros alimentos diferentes de la leche, la única información que tenemos es la que nos proporcionan los libros de suministros, donde figuran compras de diferentes harinas, miel y azúcar para papillas, aunque no podemos decir exactamente a partir de qué edad se incluían todos estos productos en la dieta. Cuando pasaban a la sección de Destete, a los 15- 18 meses pasaban también a comer prácticamente igual que los mayores, variaban las cantidades; garbanzos, patatas, carne y tocino más leche, media taza en el desayuno y la merienda. No es de extrañar este proceso brusco de pasar de la leche a la comida adulta, que se hacía también en la población general, es probable que en la Inclusa se siguieran pautas similares, ya que existían costumbres muy arraigadas en relación con la alimentación de los niños. En la provincia de Valladolid las clases populares utilizaban para alimentar a los lactantes "pan esmigado con agua y azúcar" y sopas hechas a base de pan a las que daban distintos nombres: sopas de leche, que a pesar del nombre solían hacerse solo con agua; sopas de aceite, papillas con aceite agua y pan, o la "sopa boba", con aceite, agua y azúcar, todos son ingredientes que había en el Hospicio. Cuando empezaba la dentición les daban "trozos de pan para morder" y cuando ya tenían diente, comida de adultos, si hacía falta la masticaban antes; en algunos sitios el vino no faltaba, "vino para fortalecerles".

A partir de los 3 años todos los asilados comían igual y la leche ya no se incluía en la dieta. La alimentación, como casi todas las actividades del Hospicio, estaba reglamentada y las compras de provisiones se ajustaban a la normativa y, claro está, a los presupuestos. La dieta prescrita de todos los asilados era pobre, monótona e insuficiente y en la realidad pudo ser bastante peor en cuanto a cantidad y sobre todo a calidad, muchas veces debido a actuaciones fraudulentas en relación con los suministros. Estaba muy lejos de las recomendaciones actuales para una alimentación saludable, pero de hacerse según los reglamentos, podría ser mejor que la de muchos niños de la población general, como dirían en un artículo de la prensa local. No se incluían frutas ni verduras, solamente para los enfermos y en fechas celebradas. En cambio, hasta 1921, se llegaron a comprar más de 6.000 litros anuales de vino, que se consideraba un fortificante para niños y amas.

La crianza externa de los expósitos se consideraba una prioridad debido a la alta mortalidad de la Inclusa, que se relacionaba con la falta de nodrizas internas y el uso del biberón. El periodo de crianza remunerada duraba hasta los 5 años, generalmente, hasta los 
15 meses el periodo de lactancia y a partir de ahí el de destete, como en la Inclusa. Al finalizar la crianza, incluso antes, la mayoría de los expósitos regresaban al Hospicio y pasaban al departamento de Mayores. En cualquier momento las nodrizas podían solicitar quedarse con los niños sin percibir retribución, en condición de prohijado, o como también se escribe en los libros, en "3모 situación". Para todos los efectos, la Diputación mantenía la tutela legal del niño, podía retirárselo a los prohijantes, que también lo podían devolver, o incluso entregarlo a los padres. Es difícil saber exactamente cuántos niños fueron prohijados; da la impresión de que no siempre se registró, sobre todo en los libros de los primeros años. En el período consultado se encuentran solamente 238 prohijados (4\%); hay además 443 expósitos que consideramos de destino desconocido porque no se ha completado su historial. El prohijamiento sin duda suponía una ventaja tanto para los expósitos, si caían en buenas manos, como para la Inclusa que se liberaba de una carga económica y que en la práctica se desentendía del niño.

El tiempo de permanencia de los niños en la Inclusa hasta que salían por primera vez para crianza externa fue muy variable; para la mayoría inferior a un mes, el 68'14\% estuvo menos de 15 días, y en los últimos años se acortó aún más. Los reglamentos no definen los criterios de salida. Las estancias largas podrían estar en relación con un aspecto o un estado poco saludable de los niños; comprobamos que en más de un caso fueron rechazados por las criadoras por este motivo y también que no siempre se entregaban en buenas condiciones.

Los reglamentos eran más exigentes con las nodrizas externas que con las internas, sin embargo en la práctica, la carencia de mujeres obligaba también a relajar las exigencias, sobre todo la que, paradojicamente, les requería contar con medios económicos para mantener a los niños de destete. Aunque no se excluía a viudas y solteras se contrataron muy pocas, particularmente solteras; siempre se registraba el nombre del marido en los libros y al presentar la solicitud ambos debían acreditar buena conducta "moral política y social". Se preferían las nodrizas de los pueblos, que eran mayoría y cobraban más que las de la capital porque se suponía una crianza más saludable en el campo. También se pagaba mejor la lactancia que el destete; siendo los primeros meses de vida la época más crítica para los bebés y la falta de lactancia natural el riesgo más importante, a la criadora no solo se la pagaba por sus cuidados sino, sobre todo, por su leche.

Tenían que pasar un reconocimiento médico para valorar, solamente, sus condiciones para la lactancia. Si era apta en el mismo día le entregaban el expósito y para evitar fraudes se ocultaba su origen e identidad y se prohibía escoger niño, solamente se podía elegir su sexo, norma que se conseguía sortear en ocasiones. Una práctica prohibida, fruto de la miseria y la 
picaresca, que era común en las inclusas y que en esta nuestra también se constata, era depositar un hijo para luego sacarle y cobrar por su crianza. Solían ser niños legítimos que ingresaban por la oficina y salían el mismo día a su pueblo o a una localidad muy cercana; se necesitaría la complicidad de alguien del Hospicio pues la asignación de nodrizas se hacía en el establecimiento. Debido a las muchas situaciones irregulares de este tipo, se añadió la prohibición de mandar expósitos a poblaciones próximas a la suya de origen. La Inclusa no era tolerante en este sentido, si se admitía que un externo fuera criado por sus propios padres a cargo del Hospicio, se abría la veda a mucha necesidad y a la picaresca; la lista de candidatos y los gastos generados podrían ser interminables. Tampoco se toleraba la crianza externa de dos lactantes a la vez, por lo que no se permitía entregar expósito si la nodriza tenía un hijo; sí se consentía tenerlos de forma sucesiva, se han localizado amas que llegaron a criar 6 expósitos. En la práctica no se penalizaba la devolución precoz ni el fallecimiento de los niños, aunque se supone que se debían justificar y que se investigaban ambas situaciones; comprobamos que después de perder o devolver un expósito conseguían otro, incluso en el mismo día, como si fuera un intercambio; un motivo, no registrado habitualmente, era la enfermedad del niño.

Con el expósito se entregaba "el atillo" (sic) con un ajuar completo y una cartilla para controlar los pagos, con cupones para 15 meses de lactancia en los que las autoridades locales debían certificar el estado del niño. Si no se presentaba la cartilla junto con un certificado médico del niño no cobraban. A las nodrizas de la capital les exigían presentarse al cobro con el expósito. A pesar de no parecer mal sistema, no funcionaba y había muchas irregularidades.

Algunos expósitos pasaban por las manos de varias nodrizas, se han llegado a contar hasta 5 , pero más del $80 \%$ solo tuvieran una; esto no siempre significa que permanecieran con ella todo el tiempo de crianza, muchos eran devueltos a la Inclusa antes de tiempo. Un $14 \%$ tuvo dos amas, solían ser una de lactancia y otra de destete. El cambio de nodriza debía ser autorizado por el Hospicio, sin embargo con frecuencia las criadoras se saltaban esta norma y hacían intercambios entre ellas. Los niños devueltos anticipadamente eran reconocidos por el médico del establecimiento y de encontrarse en mal estado se debía investigar la causa.

El número de nodrizas fue variable en el tiempo y parece que dependía más de la oferta que de la necesidad que tenía la Inclusa; es lo que puede explicar la falta de amas que se declaró en 1915 y el descenso llamativo de las contratadas para destete. La razón, que el propio Hospicio reconoció, era la escasez de los salarios, y la competencia de las inclusas vecinas, que ante el mismo problema se adelantaron a Valladolid aumentándolas el sueldo. 
Los expósitos de la Inclusa de Valladolid salieron para crianza a más de 215 localidades, con una distribución muy desigual. Aunque se repartieron prácticamente por toda la geografía provincial, se concentraron principalmente $(75 \%)$ en el Sureste de la provincia y en las comarcas limítrofes de Burgos y especialmente de Segovia, provincia ésta que recibió en el periodo estudiado casi la mitad de los expósitos. Salvo estas zonas y la de Tiedra, al oeste, que también fue "receptora" de muchos incluseros, el resto de la provincia se comportó como "dadora" de niños y aportó pocas nodrizas. Esta distribución tiene mucha relación con la existencia de comisionados, intermediarios entre las nodrizas y la Inclusa para pagos y otras componendas, que por la escasa información que hay sobre ellos parece que controlaban el "mercado de expósitos". Uno de los que conocemos "llevaba" 22 nodrizas. Es probable que muchas de las irregularidades detectadas tengan que ver precisamente con estos hombres para la captación y retención de expósitos en sus zonas de influencia: niños destinados a localidades muy cercanas a la suya de origen, infantes que regresaban con sus padres de forma no reglamentaria, fallecimientos no comunicados para seguir cobrando la crianza o cambios de nodrizas no autorizados por el Hospicio. Para actuar impunemente, como parece que lo hacían, tenían que estar "compinchados" con alguien de dentro o con autoridades locales. Presentaban las cartillas con los certificados de vida de los expósitos y la autorización para el cobro. No sabemos qué tipo de "gratificación" percibían, pero reducían aún más el bajo salario de las nodrizas, por lo que estas mujeres debían tener mucha necesidad para prestarse a este negocio. Quizá no todos fueran deshonestos, pero su intervención no parece desinteresada.

Encontramos situaciones, sin explicar en los libros, que resultan cuando menos dudosas. Muchos fraudes y abandonos se podrían haber evitado estableciendo ayudas para madres necesitadas, simplemente pagándolas lo mismo que a las nodrizas. Podemos suponer que si la Diputación no se planteó esta opción fue por una cuestión económica y sobre todo por el temor a verse desbordados por la demanda, como sucedió en Oviedo.

No podemos cargar todas las tintas de las frecuentes malas prácticas con los expósitos sobre las nodrizas porque en definitiva los responsables de los niños eran la Inclusa y la Diputación. Las autoridades locales tenían que colaborar en la custodia de los incluseros; hay pruebas de que lo hacían, pero también de su dejadez en estas funciones que en la práctica podían comprometerles. Endurecer la normativa pudo mejorar el control, aunque no fue suficiente; en Valladolid, como en otras inclusas, faltó un sistema efectivo y cercano de vigilancia de expósitos y nodrizas, lo que se pone de manifiesto entre otras cosas en la falta de información sobre ellos. Los folios incompletos nos hacen pensar en expósitos "perdidos"; se 
daban situaciones tan surrealistas como ignorar el paradero de niños internos o que fueron reclamados por sus padres o descubrir que habían fallecido al cabo de los años.

La distancia y el número considerable de niños externos, difícil de calcular - expósitos en crianza, prohijados y los Mayores cedidos para compañía y para trabajar- son razones que lo explican, aún cuando no pueden servir de justificación. Los sistemas de registro y archivo disponibles y la dispersión de los hospicianos tampoco ayudaban, ni unos presupuestos limitados para tanta demanda asistencial. El problema principal es que queda en entredicho la obligada protección del menor y que el sistema establecido no podía asegurar su bienestar.

La altísima mortalidad de la infancia en España en las primeras décadas del siglo XX constituía una cuestión social prioritaria; la tremenda mortalidad de los expósitos, muy superior a la del resto de la población infantil, se convirtió en tema de preocupación política, económica y social, que llevó a cuestionar el sistema de las inclusas. A pesar de que en la Inclusa de Valladolid se tomaron algunas medidas no parece que fueran suficientes ni demasiado eficaces pues no se consiguieron resultados satisfactorios, solo al final de los años veinte parece que se abordó el problema de forma más efectiva.

A falta muchas veces de información directa suficiente, podemos considerar la mortalidad expósita como un indicador fiel y objetivo de las condiciones de vida, sobre todo higiénico- sanitarias y nutritivas de los expósitos. Es una cuestión que ha despertado desde el primer momento el interés de todos los estudiosos del tema expósito. En este trabajo se ha hecho un análisis pormenorizado de la mortalidad en la Inclusa Provincial de Valladolid y de sus causas en el período 1900-13, que es el que se ha podido consultar documentalmente a fondo, fuera de este intervalo la información aislada existente, además de ser muy escasa, es discordante y confusa, con datos difíciles de conciliar e incluso de comparar y en ocasiones poco creíbles. Para el análisis se han contado solamente a los niños que ingresaron vivos y a los pertenecientes al departamento de la Inclusa, menores de 5 años; se han excluido a los "nacidos muertos", que no llegaron a ser ingresos efectivos.

La mayoría de los estudios que existen sobre diferentes inclusas dan cifras sobre su mortalidad global y generalmente parece que se refieren solamente a la población interna en el establecimiento, no diferencian, o no dejan claro, si se incluyen también los niños en crianza externa. En este trabajo se estudian con detalle y se comparan las dos poblaciones, interna y externa, teniendo en cuenta que los externos también eran responsabilidad de la Inclusa y sus condiciones de partida y su historia de vida eran diferentes del resto de la población infantil. 
Resulta fácil contar la mortalidad global de la Inclusa Provincial de Valladolid, tantos niños como cruces hay en los libros, a simple vista se detecta su magnitud: el $74^{\prime} 06 \%$ de los niños que ingresaron en el período 1900-13 fallecieron antes de los 5 años, dentro o fuera del establecimiento; dato que podría ser aún más elevado teniendo en cuenta los registros de niños de destino desconocido (7'45\%). A esa cuarta parte de supervivientes de la Inclusa hay que restar otro $2^{\prime} 76 \%$ que falleció después de los 5 años ya en el departamento de Mayores.

El sexo no fue un factor relevante, pero sí la edad, de manera que la mayoría de los niños murieron en su primer año de vida ( $84^{\prime} 2 \%$ del total de fallecidos). Si empleamos indicadores similares a los demográficos, utilizando como referencia en lugar de los nacidos vivos el total de ingresos podemos establecer comparaciones con la población general. La mortalidad infantil (menores de 1 año) de la Inclusa fue, como corresponde a este tipo de establecimientos, muy superior a la de la población general, con una media para el intervalo $1901-13$ de $619{ }^{\prime} 3 \%$, frente al $238^{\prime} 2 \%$ o de la capital, el $201^{\prime} 5 \%$ o de la provincia y $162^{\prime} 5 \%$ nacional. Considerada de forma global para todo el intervalo (sin contar con 1900 porque no hay datos oficiales), la mortalidad expósita siguió la misma tendencia a disminuir de forma progresiva que la general, aunque bastante más discreta. Si el descenso para la provincia fue del $28^{\prime} 7 \%$ y para la capital del30'6\%, en la población de expósitos solo disminuyó el $12^{\prime} 3 \%$ y con una evolución desigual, con altibajos y variaciones anuales significativas En cuanto a la mortalidad global de la Inclusa, referida al total de los menores de 5 años, no se aprecian cambios, empezó con un 74’74\% en 1900 y disminuyó solamente hasta el 72'85\% en 1913.

Por tanto, podemos concluir, con los datos de la mortalidad infantil, que las posibilidades de sobrevivir más de 1 año para un niño nacido en la provincia de Valladolid en el intervalo $1901-13$ eran del $80 \%$, para uno de la capital del $76 \%$ y para un niño que ingresaba en la Inclusa provincial se reducían al 38\%. Para los menores de 5 años de la Inclusa las posibilidades de supervivencia no mejoraron y se mantuvieron por debajo de $30 \%$. Las mejoras que favorecieron la disminución de la mortalidad infantil de la población general no llegaron en la misma medida a la población de expósitos. Siendo los factores ambientales externos similares, tienen que ser factores intrínsecos a la Inclusa provincial y a su población de expósitos los que impidieron una evolución proporcional a la de la población general.

Conocida la mortalidad globa,I se distingue la que se produce dentro de la Inclusa $\left(54^{\prime} 63 \%\right.$ ) y la que acontece fuera con las nodrizas ( $\left.45^{\prime} 37 \%\right)$, la diferencia no llega a 10 puntos lo que significa que la mortalidad externa también fue muy alta. 
Si valoramos solo la mortalidad interior de la Inclusa, contando los fallecimientos de los internos sobre el total de ingresos vivos, sale una media para el periodo 1900-13 del $40^{\prime} 46 \%$. Hay pocos datos para comparar sobre esta época, valorando los referidos a algunos años de este intervalo de tiempo, resulta que la Inclusa de Valladolid tenía una tasa similar a la de Pontevedra ( $41^{\prime} 9 \%$ ) y menor que Barcelona, Oviedo y sobre todo Madrid (62"9\%). Es posible hacer una comparación más completa con la Inclusa de Pamplona, de la que disponemos de información anual muy detallada gracias a Arantzazu Uribe-Etxebarría. En los grupos de edad estudiados, Valladolid tiene una mortandad menor, 3 puntos para la mortalidad infantil y 9 para el grupo de 0 a 7 años. Considerando la mortalidad local de las dos capitales, vemos que no se correlacionan con las de sus inclusas ya que la de Pamplona fue notablemente más baja que la de Valladolid capital durante todo el periodo. La mortalidad de los expósitos internos, aunque influida por las condiciones locales, sobre todo relacionadas con la salubridad e higiene pública, parece que era una cuestión condicionada fundamentalmente por el funcionamiento de los propios asilos.

La mortalidad interna está en relación inversa con el número de niños que salían a crianza extena. Una conclusión determinante es que todos los lactantes que permanecieron siempre internos en la Inclusa fallecieron. No sabemos si no salieron porque murieron antes o murieron por no haber salido; este hecho por sí solo justifica la prioridad de la crianza externa.

El 34'34\% del total de ingresados en la Cuna fallecieron en ella sin haber llegado a salir nunca, de forma que comprobamos que cuanto más tiempo permanecían los niños internos en la Inclusa mayor era su riesgo de fallecer dentro, confirmándose los resultados para otras inclusas como la de Navarra. Sin embargo, si valoramos la mortalidad total, interna y externa en su conjunto, esta relación no es tan evidente, de manera que se ha podido también comprobar que los años de mayor proporción de salidas tempranas de la Inclusa, son los que tuvieron mayor mortalidad externa, llegando incluso a superar a la interna.

La mortalidad con las nodrizas externas resultó muy similar a la interna con un porcentaje medio del $33^{\prime} 35 \%$ sobre el total de ingresos anuales, como vemos muy similar a la de internos que no salieron. La mitad de los niños externos fallecieron con las nodrizas. Podríamos sumar además, parte del 10’05\% que fallecieron al regresar a la Inclusa, la mitad de ellos en el primer mes de retorno.

Esta mortalidad externa tan elevada comprobamos que está en relación con la mortalidad provincial, aunque muy por encima de ella. Puede decirse que la mortalidad 
externa refleja el ambiente de pobreza en el que se criaban la mayoría de los expósitos y confirma el nodrizaje como un medio de subsistencia, aunque muy limitado.

Ante estos datos cabe plantearse si merecía la pena a la Inclusa mandar a los niños con las nodrizas y la respuesta es doblemente afirmativa; por un lado, aunque vistas en conjunto las proporciones son similares, no hay que perder de vista que los lactantes que se quedaban internos estaban condenados a morir, con las nodrizas tenían más posibilidades de supervivencia, (un $46^{\prime} 86 \%$ que bajaba a $38^{\prime} 81 \%$ para los retornados). Por otro lado, por una cuestión logística y económica, la Inclusa no tenía capacidad para criar tantos internos ni para conseguir tantas amas para ellos y además, la crianza externa salía más barata.

La estacionalidad era un factor muy influyente en la mortalidad de la infancia y en sus causas; la Inclusa coincide con la población general en el incremento significativo de los meses veraniegos, julio y agosto especialmente (entre los dos 30'92\%). Existen algunas diferencias entre la población interna y externa. Entre los externos hay una mayor incidencia en el segundo semestre, coincidiendo con lo que Antonio Arbelo refiere para la población general. En la interna predomina la mortalidad entre junio y septiembre con una caída muy brusca después de julio y agosto, debido precisamente a la altísima mortalidad de estos dos meses, que eran también los de menos entradas; esto, unido a la salida temprana de la mayoría de los expósitos, supone que tendrían menos niños internos.

En cuanto a las causas de mortalidad en la Inclusa de Valladolid, solamente las conocemos para las defunciones internas, en las externas, salvo alguna excepción, no se han registrado en los libros, a pesar de que la normativa obligaba a enviar al Hospicio el certificado de defunción. Los cálculos se han hecho sobre el total de causas registradas en los Libros de Exposiciones que son legibles. Algunas son diagnósticos que actualmente están en desuso o son conceptualmente diferentes, por lo que se ha documentado su significado para entenderlos en el sentido con que en su momento se utilizaron. Dada la variedad de diagnósticos que aparecen, se han agrupado en categorías clínicas considerando también la nomenclatura utilizada por la Dirección General del Instituto Geográfico y Estadístico.

En la Inclusa de Valladolid para el periodo 1900-13 hay un claro predominio infeccioso (50'38\% de infecciones adquiridas) con las Infecciones Gastrointestinales como principal protagonista ( $28^{\prime} 62 \%$ de la mortandad total y $56^{\prime} 80 \%$ de la infecciosa), coincidiendo en esto con la población general aunque con un porcentaje más alto. En segundo lugar se sitúan las Enfermedades Nutricionales y Digestivas (18'53\%), que en la estadística nacional no llegan al 1\%. Éstas son dos categorías muy relacionadas con los aspectos higiénicos y alimentarios. La 
Sífilis fue la tercera causa $\left(15^{\prime} 72 \%\right)$, relacionada con la procedencia mayoritariamente ilegítima de los expósitos, mientras que en la estadística nacional tiene mínima representatividad llegando a desaparecer como categoria independiente en las listas de mortalidad, y el cuarto puesto lo ocupan las Infecciones Respiratorias (12'67\%). Comparando la mortalidad expósita con la general llaman la atención algunas diferencias muy significativas, aparte de la mencionada de la sífilis. La Debilidad congénita, relacionada con la prematuridad y el bajo peso al nacimiento, y los vicios de conformación (defectos congénitos) constituyen la 3a causa de mortalidad infantil general, sin embargo, en la Inclusa sorprendentemente no llega al 5\% del total y apenas se registran malformaciones, cuando por el tipo de población acogida y su origen toda la patología congénita y perinatal debería ser importante. Considero que se encuentran infravaloradas en la Inclusa y que podrían ser en muchos casos el problema subyacente, pero en los libros se registraba solamente el hecho final causante de la defunción. He tenido que agrupar las enfermedades consideradas clásicamente infantiles (sarampión, coqueluche, o tosferina, y escarlatina) para que tengan representatividad en la Inclusa porque su incidencia fue muy baja, en conjunto no llegan al $1 \%$ del total de procesos infecciosos. No se registró ningún caso de viruela dentro de la Inclusa en el período analizado, mientras que a nivel nacional causó más del triple de muertes en menores de 5 años que la sífilis; la razón de esta ausencia está en la vacunación de toda la población interna, prescrita por ley.

El patrón de esta mortalidad interna se relaciona por tanto con las condiciones de ingreso y de vida en la Inclusa, con un predominio claro de la mortalidad infantil (menores de1 año), relacionada a su vez con las condiciones maternas (sífilis y otros problemas congénitos representados insuficientemente) y con la mala calidad de los cuidados generales de los lactantes: alimentación deficiente y/o poco higiénica, nodrizas compartidas, lactancia artificial y malas condiciones higiénico-sanitarias, derivadas a su vez del propio internamiento, de la obligada convivencia con enfermos y de la falta de cuidados y de profesionales sanitarios, estando los niños a cargo de mujeres muchas veces poco saludables e ignorantes.

El de la mortalidad expósita fue un problema no resuelto en la Inclusa de Valladolid en las primeras décadas del siglo $\mathrm{XX}$, se mantuvo en tasas muy altas y superiores a la de la población general. La Diputación conocía la situación y no podemos decir que no existiera preocupación, sin embargo, parece puntual ya que en muchas de sus sesiones se planteó el problema pero no fue capaz de poner remedio. La solución requería intención, buena organización y una importante cantidad de recursos no siempre disponibles. 
La alimentación era sin duda un factor determinante, se reconoció siempre que el problema de la mortalidad se asociaba a la falta de nodrizas, sin embargo, no se supo o no se pudo resolver, ya que la solución pasaba por una lactancia artificial que por entonces suponía un riesgo mortal. El Nodrizaje fue un sistema con el que se intentó paliar el infortunio de unos con la miseria de otros, de ahí que no diera buenos resultados; las causas apuntan a un salario insuficiente en un ambiente social de pobreza, a las malas condiciones de las nodrizas internas para las que suponía "un tributo de sangre", pero sobre todo a un sistema que prácticamente se desentendía de los niños cuando salían fuera y que no fue capaz de establecer un procedimiento de control efectivo de niños y nodrizas externas y propició situaciones fraudulentas que rallaban el mercadeo y la explotación.

La Inclusa tenía además otros problemas, las condiciones higiénicas del edificio, la falta de bañeras y de un caudal de agua suficiente, el frío en los meses invernales y la escasez de personal al cuidado de los niños y en particular de profesionales sanitarios para tanta población a su cargo sumaban riesgos importantes. Aunque se nota que aumentó la sensibilización hacia los expósitos y sus condiciones de vida, en el periodo estudiado no se consiguió mejorar mucho la situación, ni dentro, donde la mortalidad no disminuyó suficientemente ni fuera porque tampoco disminuyeron de forma significativa ni el número de ingresos ni la mortandad de los acogidos. El aumento de profesionales, junto con otras medidas higiénicas y generales, finalmente dio sus frutos y consiguió rebajar la mortalidad de la Inclusa a partir de 1927 situándola próxima al 300\%. Parece que la Diputación no cejó en sus buenos propósitos de mejorar las condiciones de vida de sus acogidos y sobre todo de rebajar su mortalidad aunque se mantuvo muy alejada de ser una "Inclusa modelo".

En definitiva, la historia de los lactantes de la Inclusa Provincial de Valladolid, como la de los expósitos en general, no es ni más ni menos que un relato de miseria, económica y moral, en la que los niños son los protagonistas y las victimas principales, pero en la que el papel de las mujeres no es secundario; sus avatares de vida transcurrieron enlazados, madres que les abandonaron y nodrizas que les criaron y les volvieron a abandonar cuando consiguieron sobrevivir, mujeres que fueron causa y en ocasiones a su vez víctimas de la misma historia. Las Inclusas, pensadas para protegerles, no fueron capaces, no consiguieron proporcionarles los cuidados más básicos, como lo demuestra la elevada mortalidad que siguieron padeciendo en el sigo XX. 


\section{ANEXOS}

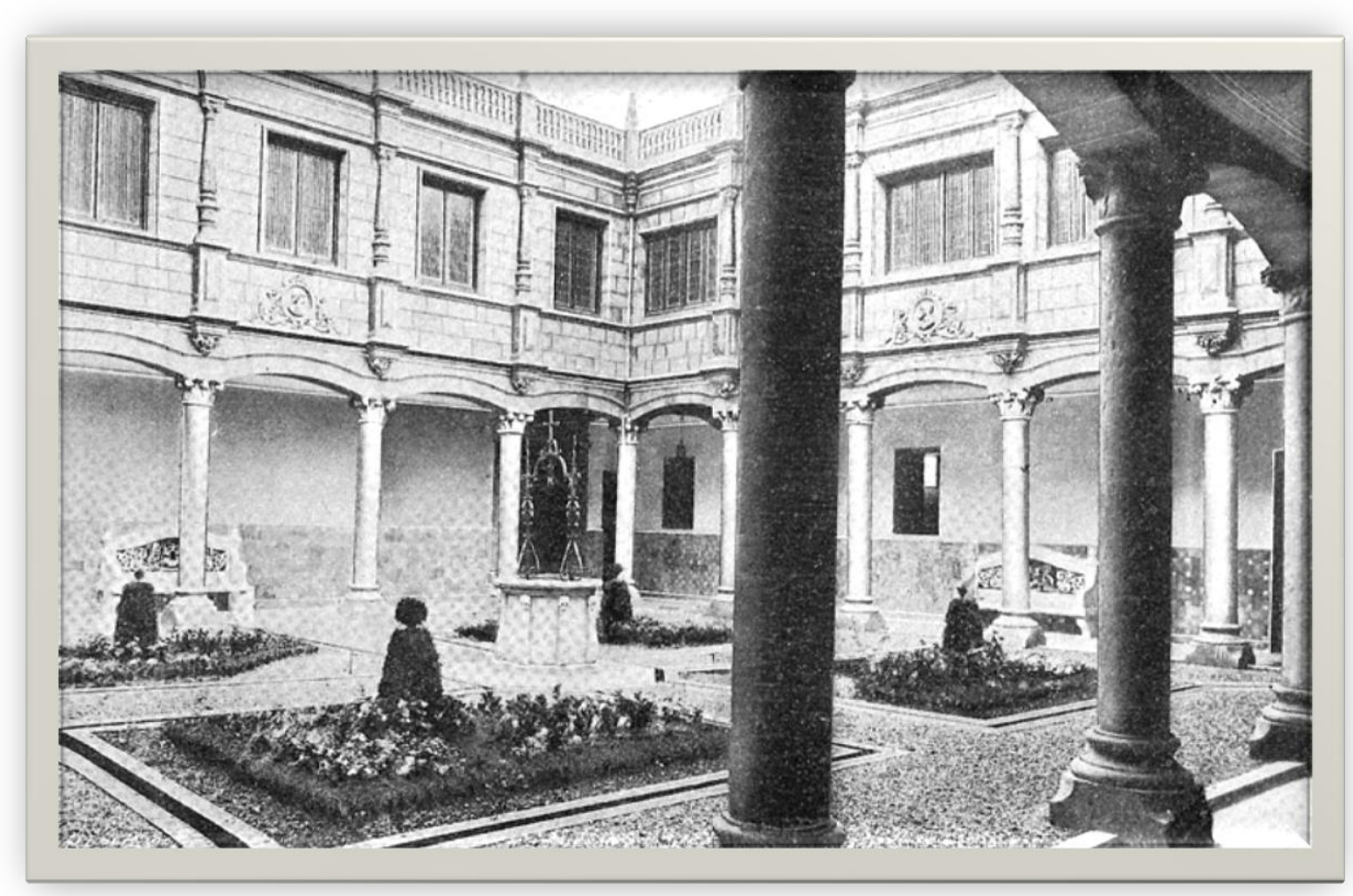

Imagen 6: Palacio de los condes de Benavente. Patio. Fuente: Colección Fundación Joaquín Díaz/ Libro Valladolid hace 100 años (va 1697) (s.a.) 


\section{ANEXO no 1}

Recién Nacidos para adopción en el Hospital Clínico Universitario de Valladolid en el período 1990- 2016

\begin{tabular}{|c|c|c|c|}
\hline AÑO & $\begin{array}{c}\text { RN } \\
\text { ADOPCIÓN }\end{array}$ & $\begin{array}{l}\text { № NACIDOS } \\
\text { en el Hospital }\end{array}$ & \% ADOPCIÓN \\
\hline 1990 & 4 & 1.546 & $0 ’ 26$ \\
\hline 1991 & 7 & 1.422 & $0^{\prime} 49$ \\
\hline 1992 & 4 & 1.489 & $0 ’ 27$ \\
\hline 1993 & 8 & 1.454 & $0 ’ 55$ \\
\hline 1994 & 3 & 1.427 & $0^{\prime} 21$ \\
\hline 1995 & 4 & 1.281 & $0 ’ 31$ \\
\hline 1996 & 6 & 1.229 & $0^{\prime} 49$ \\
\hline 1997 & 2 & 1.265 & $0^{\prime} 16$ \\
\hline 1998 & 3 & 1.142 & $0^{\prime} 26$ \\
\hline 1999 & 0 & 1.205 & $0^{\prime} 00$ \\
\hline 2000 & 1 & 1.219 & $0 \prime 08$ \\
\hline 2001 & 2 & 1.229 & $0 \prime 16$ \\
\hline 2002 & 0 & 1.270 & $00^{\prime} 00$ \\
\hline 2003 & 3 & 1.280 & $0^{\prime} 23$ \\
\hline 2004 & 2 & 1.363 & 0,15 \\
\hline 2005 & 1 & 1.432 & $0 \prime 07$ \\
\hline 2006 & 3 & 1.454 & $0 \prime 21$ \\
\hline 2007 & 2 & 1.445 & $0 \prime 14$ \\
\hline 2008 & 1 & 1.554 & $0 \prime 06$ \\
\hline 2009 & 2 & 1.458 & $0 \prime 14$ \\
\hline 2010 & 2 & 1.520 & $0 ’ 13$ \\
\hline 2011 & 0 & 1.392 & $0^{\prime} 00$ \\
\hline 2012 & 1 & 1.355 & $0 \prime 07$ \\
\hline 2013 & 9 & 1.273 & $0^{\prime} 71$ \\
\hline 2014 & 5 & 1.331 & 0,38 \\
\hline 2015 & 1 & 1.278 & $00^{\prime} 08$ \\
\hline 2016 & 0 & 1.226 & 0,00 \\
\hline TOTAL & 76 & 36.539 & $0 \prime 21 \%$ \\
\hline Promedio & $2^{\prime} 81$ & $1.353^{\prime} 29$ & \\
\hline
\end{tabular}




\section{ANEXO no 2}

\section{Informe sobre mejoras y necesidades del Hospicio Provincial (1906)}

[Signatura: caja 4872, expediente 43333. ADPVA.]

Excmo Sr.

Si preciso se hace para formar idea exacta de los distintos órdenes de la vida, establecer relación entre los mismos, comparando el estado actual de los asilados en este Establecimiento con el del anterior quinquenio, a primera vista se notará el mejoramiento de aquellos seres que al nacer son abandonados y puestos bajo la protección y amparo de esa Excma Corporación.

En efecto Sr, si grandes han sido los sacrificios y no menos el celo demostrados por la Excma Diputación para mejorar la suerte de esos desamparados, grandes han sido las recompensas obtenidas, tanto en lo que se refiere a la parte maternal como a la moral.

Así, debido indudablemente a la separación de la enseñanza de los párvulos de la de los adultos, se nota un adelanto; antes al ser entregados para su lactancia y destete a nodrizas que no tienen por lo general otro interés que percibir la cantidad con que son retribuidas, si bien no es edad para poder apreciar lo que significa la caricia maternal, al ser devueltos al Establecimiento por haber cumplido los cinco años se podía apreciar sin grandes esfuerzos, seres insensibles a todo sentimiento, que se aumentaba desde esta edad en adelante al notar la falta de las caricias de aquellos que estando en el indiscutible deber de prodigárselas, la necesidad, el vicio, la fatalidad u otras causa que no es pertinente entrar en su averiguación, hace que les abandonen.

A remediar en lo posible esta falta, con muy buen acuerdo encomendó esa Comisión la enseñanza de los párvulos a la Hermana de la Caridad, que aparte de sus reconocidas virtudes, por el sólo hecho de ser mujer, sabe dispensarles toda clase de caricias, despertarles su amor al prójimo, los beneficios que de él reciben, en una palabra, hacerles aparecer a la vida como satisfechos de su existencia y que no odien por acto instintivo a la sociedad en que viven, precisamente porque en sus primeros años les faltó lo que a los demás hijos, el ósculo maternal.

Para completar su educación, si bien es cierto que han desaparecido vicios y palabras que decían muy poco en favor de la cultura de los asilados y se nota entre ellos más unión y cariño, sería de indudables resultados prácticos, la estabilidad del Profesor de instrucción primaria, pues sujeta esta escuela a largas interinidades, triste es confesarlo, pudiera darse el caso que se la juzgase como un montón de niños que al azar se habían unido sin saber nada de nada; y en efecto se hace urgentísimo el nombramientos de Maestro propietario, pues en los dos meses que hace renunció el interino se conoce aquella necesidad. 
Necesario sería también tener un local destinado exclusivamente que no pudiéndoles corregir sus padres por sus malas inclinaciones y teniendo formado un concepto muy distinto de los que en sí son esta clase de Asilos, los recluyen para su corrección, pues aparte de hacer perder un tiempo necesario para los demás asilados, les inculcan ideas que parecen no son propias de la edad, al mismo tiempo que les hacen participes de sus malos sentimientos y peores inclinaciones, si bien este mal, ya que la separación es poco menos que imposible, se atenúan sus efectos con un poco más de vigilancia por parte de las personas encargadas de completar su educación.

Respecto a los niños de lactancia se hace más difícil su mejoramiento, teniendo en cuenta las concausas que anteceden a su ingreso.

En efecto, comparando el número de ingresos de niños de lactancia en esta Asilo con los de León, Zamora, Astorga, Salamanca, Palencia y Burgos, viene a ser proporcionalmente el mismo, no sucediendo esto por desgracia con relación al número de fallecimientos, pues si en las poblaciones citadas oscila entre el 45 al 49 por ciento, en este llega al 75, ¿causas que producen tal desproporción y medios para evitarla?

Difícil tarea, aparte de no ser de la competencia del que tiene el honor de dirigirse a V.S., es averiguar las causas que motivan tal número de fallecimientos, pero sí muy digno de tenerse en cuenta, por un lado las malas condiciones que anteceden a su exposición, pues generalmente ocurre que a las pocas horas de nacer es muy posible que sin recibir el primer calor de la madre, son expuestos y como derivación lógica fallezcan a consecuencia de falta de reacción; por otro lado, si se tiene en cuenta las enfermedades que adquieren por dentro del claustro materno (y que con facilidad propagan), queda reducida la mortalidad a un 50 por ciento y a remediar este mal deben dirigirse todos los esfuerzos, ya que en el veinticinco restante sus causas son inevitables.

En primer lugar hay que tener en cuenta que mientras en los Establecimientos de las poblaciones citadas el número de nodrizas internas no excede al de ocho, por ser éste el de niños, en éste cuando más ay veinte y épocas como la del verano que el número de niños pasa de sesenta, no pudiendo averiguar las causa que lo motivan pues la alimentación que se da a las internas y retribución que perciben las externas viene a ser la misma próximamente que en las poblaciones citadas, y únicamente al temor de que padezcan los asilados alguna enfermedad contagiosa, ó dispongan de más medios de vida por ser la población más rica, puede atribuirse tal causa.

En lo referente a la alimentación de los asilados mayores de doce años, teniendo en cuenta las múltiples obligaciones que sobre la diputación provincial pesan, puede decirse que en principio es buena, pero sería conveniente a fin de establecer algún estímulo, que a los niños que asisten a los talleres se les diera en el cocido carne diaria, y al mismo tiempo a las niñas para ayudar su desarrollo y evitar algún caso que tuberculosis se presenta.

Como medida reglamentaria, los asilados que a los quince años no hayan sido reclamados por sus familiares, deben ser emancipados, y de esta manera, el gasto que producen los cuarenta que hay de esta edad en adelante puede aplicarse en beneficio de los demás asilados; como medida económica establecer un número limitado de plazas para el ingreso de niños mayores de cinco años.

Respecto a las obras y mejorasen el edificio, muchas son las necesarias, permitiéndome indicar a la Comisión que V.S. preside la decoración y renovación del mobiliario de esta oficina.

Otra mejora es hacer u local para lavatorio de las niñas, pues el que hoy tienen, aparte de estar ruinoso, es oscuro, húmedo y frío, é imposible que en dicho local puedan asearse teniendo que hacerlo en un pasillo que da a la cocina y con facilidad el viento lleva a dicha dependencia lo que todos repugnan. 
Otra necesidad que se hace sentir, es la terminación de los talleres para los Maestros, así como teniendo en cuenta la ayuda que la Sra Superiora está dispuesta a hacer, terminar el pabellón para dormitorio de las niñas que lo tienen en la buhardilla, sin olvidar que urge un retejo general a todo el edificio puesto que hace más de veinte años que no se hace.

Tales son trazados a grandes rasgos las mejoras y necesidades que se hacen sentir y que el superior criterio de la dignísima comisión que preside sabrá suplir las deficiencias que en su exposición se noten

Dios gue. a V.S. m. a.

Valladolid 4 Enero de 1906

\section{El Director}

[firmado] Justo Esteban

Sr Vicepresidente de la Comisión provincial 


\section{AnEXo no 3}

\section{SALIDAS DE LA INCLUSA:}

MOMENTO EN QUE TIENE LUGAR LA PRIMERA SALIDA DESDE SU INGRESO PARA CRIANZA EXTERNA O PARA RETORNAR CON LA FAMILIA

\begin{tabular}{|c|c|c|c|c|c|}
\hline AÑO & $\begin{array}{c}\text { TOTAL } \\
\text { SALIDAS }\end{array}$ & $\begin{array}{l}\text { En su 10 } \\
\text { mes de } \\
\text { estancia }\end{array}$ & $\begin{array}{l}\text { En el 2o } \\
\text { mes de } \\
\text { estancia }\end{array}$ & $\begin{array}{c}\text { Después } \\
\text { del 20 mes } \\
\text { y hasta el } \\
\text { 60 mes }\end{array}$ & $\begin{array}{c}\text { Después } \\
\text { de } 6 \text { mes } \\
\text { de } \\
\text { estancia }\end{array}$ \\
\hline 1900 & 377 & 318 & 31 & 14 & 14 \\
\hline 1901 & 234 & 181 & 43 & 9 & 1 \\
\hline 1902 & 224 & 152 & 41 & 30 & 1 \\
\hline 1903 & 251 & 143 & 73 & 32 & 3 \\
\hline 1904 & 305 & 231 & 56 & 17 & 1 \\
\hline 1905 & 293 & 190 & 67 & 30 & 6 \\
\hline 1906 & 240 & 127 & 72 & 38 & 3 \\
\hline 1907 & 251 & 175 & 53 & 21 & 2 \\
\hline 1908 & 242 & 184 & 34 & 18 & 6 \\
\hline 1909 & 237 & 164 & 47 & 16 & 10 \\
\hline 1910 & 237 & 172 & 37 & 20 & 8 \\
\hline 1911 & 304 & 253 & 35 & 13 & 3 \\
\hline 1912 & 387 & 337 & 24 & 18 & 8 \\
\hline 1913 & 307 & 273 & 27 & 5 & 2 \\
\hline $\begin{array}{r}\text { TOTAL } \\
\text { SALIDAS }\end{array}$ & 3889 & 2900 & 640 & 281 & 68 \\
\hline PROMEDIOS & $277^{\prime} 9$ & $207^{\prime} 2$ & $45^{\prime} 7$ & $20^{\prime} 1$ & $4^{\prime} 9$ \\
\hline $\begin{array}{r}\text { \% SOBRE EL } \\
\text { TOTAL DE } \\
\text { INGRESOS }\end{array}$ & & 74 '57 & $16^{\prime} 46$ & 7'22 & $1^{\prime} 75$ \\
\hline
\end{tabular}




\section{Anexo no 4}

\section{DISTANCIAS ENTRE LA LOCALIDAD NATAL DE LOS EXPÓSITOS Y LA DE RESIDENCIA DE LA NODRIZA. 1905}

Distancia en línea recta (para evitar las variaciones que puedan haberse producido en el trazado de las carreteras) entre la localidad de origen de los expósitos que estuvieron como máximo dos días en la Inclusa y no tuvieron un ama de cría interna asignada y la localidad de la nodriza externa a la que se les entregó para crianza en el año 1905. Entre paréntesis en minúscula se completa el nombre de la localidad cuando existen varias posibles, en mayúsculas las iniciales de la provincia cuando no es Valladolid.

Sombreados en rosa cuando el expósito va a su misma localidad, en verde pueblos del entorno de Peñafiel y azul los que están distantes más de $10 \mathrm{~km}$

3 niños fueron a su misma localidad de origen, 9 niños fueron a pueblos separados del suyo de origen menos de $5 \mathrm{Km}, 18$ a una distancia entre 5 y $10 \mathrm{Km}$ y uno a $11 \mathrm{Km}$. Entre ellos, en 9 casos una de las localidades es Peñafiel y en otros dos pueblos de su entorno (a menos de 10 Km de Peñafiel)

Solamente 4 niños fueron a localidades distantes más de $15 \mathrm{Km}$

Distancias calculadas con la página web: http://www.distanciasentreciudades.com/ 


\begin{tabular}{|c|c|c|c|c|}
\hline $\begin{array}{l}\text { № fo } \\
\text { AÑo } \\
1905\end{array}$ & $\begin{array}{c}\text { Días de } \\
\text { estancia } \\
\text { en la } \\
\text { Inclusa }\end{array}$ & $\begin{array}{l}\text { Localidad de origen del } \\
\text { expósito }\end{array}$ & Localidad de la nodriza & $\begin{array}{c}\text { Km. de } \\
\text { distancia } \\
\text { (en línea } \\
\text { recta) }\end{array}$ \\
\hline 25 & 0 & PADILLA DE DUERO & PEÑAFIEL & $3 \prime 6$ \\
\hline 42 & 1 & TUDELA DE DUERO & TRASPINEDO & $9 ’ 3$ \\
\hline 43 & 0 & MORALES DE CAMPOS & VILLABRÁGIMA & $66^{\prime} 4$ \\
\hline 44 & 0 & VILLARMENTEROS & CASTRONUEVO (de Esgueva) & $2 \prime 6$ \\
\hline 46 & 0 & CASTRILLO DE DUERO & PEÑAFIEL & $9 \prime 5$ \\
\hline 47 & 0 & VILLANUEVA DE DUERO & PUENTEDUERO & $7{ }^{\prime} 1$ \\
\hline 48 & 1 & LA CISTERNIGA & VALLADOLID- capital & $5 \prime 9$ \\
\hline 50 & 0 & VALDEARCOS DE LA VEGA & MAMBRILLA DE CASTREJON (BU) & 6 \\
\hline 65 & 0 & VALLADOLID- capital & CABEZÓN & 11 \\
\hline 68 & 0 & VALLADOLID- capital & ALDEAMAYOR & $17^{\prime} 2$ \\
\hline 69 & 0 & SARDON DE DUERO & $\begin{array}{l}\text { VALCORBA } \\
\text { (Arroyo de) VALCORBA }\end{array}$ & $\begin{array}{l}9 \prime 6 \\
3 \prime 9\end{array}$ \\
\hline 70 & 0 & VALLADOLID- capital & ARROYO (de la Encomienda) & $6{ }^{\prime} 8$ \\
\hline 79 & 0 & FOMPEDRAZA & PEÑAFIEL & $7^{\prime} 2$ \\
\hline 84 & 0 & VALLADOLID- capital & LANGAYO & 45 \\
\hline 91 & 0 & ROALES & VEGA DE VILLALOBOS & $6{ }^{\prime} 8$ \\
\hline 96 & 0 & VILLABAÑEZ & VILLAVAQUERIZ & $6^{\prime} 2$ \\
\hline 109 & 0 & OLMOS DE PEÑAFIEL & CASTRILLO DE DUERO & $2 \prime 5$ \\
\hline 122 & 0 & BENAFARCES & VILLALONSO (ZA) & $2 ' 7$ \\
\hline 123 & 0 & PEÑAFIEL & PADILLA DE DUERO & $3^{\prime} 6$ \\
\hline 124 & 0 & PEÑAFIEL & CASTRILLO DE DUERO & $9 \prime 5$ \\
\hline 128 & 0 & SANTERVAS & VILLACARRALÓN & $5 ' 7$ \\
\hline 136 & 0 & BOCOS (de Duero) & PEÑAFIEL & $5 \prime 4$ \\
\hline 140 & 1 & SARDON DE DUERO & VALLADOLID- capital & 25 \\
\hline 141 & 0 & TORDESILLAS & VILLAVIEJA & $4^{\prime} 7$ \\
\hline 145 & 0 & VALLADOLID- capital & VALLADOLID- capital & $=$ \\
\hline 151 & 0 & VALLADOLID- capital & VILLARDEFRADES & 45 \\
\hline 154 & 2 & QUINTANILLA DE ABAJO & OLIVARES DE DUERO & 2 \\
\hline 162 & 0 & PEÑAFIEL & CASTRILLO DE DUERO & $9 \prime 5$ \\
\hline 166 & 0 & CANALEJAS DE PEÑAFIEL & FOMPEDRAZA & $2^{\prime} 8$ \\
\hline 169 & 0 & VALDEZATE (BU) & VALDEZATE (BU) & $=$ \\
\hline 170 & 0 & SIMANCAS & SIMANCAS & $=$ \\
\hline 172 & 0 & PEÑAFIEL & FOMPEDRAZA & $7^{\prime} 2$ \\
\hline 200 & 0 & COGECES DEL MONTE & BAHABON & $4^{\prime} 3$ \\
\hline 201 & 0 & BARRUELO & SAN CEBRIÁN DE MAZOTE & $6^{\prime} 6$ \\
\hline 213 & 1 & PEÑAFIEL & OLMOS DE PEÑAFIEL & $7 ’ 5$ \\
\hline
\end{tabular}




\section{ANEXO no 5}

Tablas con el número de nodrizas contratadas y sus salarios en el periodo 1900-1930

TABLA 3-27: NODRIZAS INTERNAS Y EXTERNAS CONTRATADAS ANUALMENTE POR LA INCLUSA DE VALLADOLID

\begin{tabular}{|c|c|c|c|c|c|c|c|c|c|c|c|c|c|}
\hline & & 1901 & 1902 & $03 / 04$ & 1905 & $06 / 08$ & $09 / 10$ & $11 / 12$ & 1913 & $14 / 15$ & 1923 & $\begin{array}{c}1925 / \\
1926 \\
\end{array}$ & $\begin{array}{c}1928 / \\
1929 \\
\end{array}$ \\
\hline \multirow{2}{*}{ INTERNAS } & LACTANCIA & 24 & 25 & 25 & 20 & 20 & 25 & 25 & 25 & 25 & 30 & - & - \\
\hline & DESTETE & - & - & - & - & - & - & - & - & 8 & 8 & $16 / 12$ & $8 / 9$ \\
\hline \multirow{2}{*}{ LACTANCIA } & PUEBLO & 365 & 240 & 200 & 185 & 225 & 225 & 225 & 300 & 300 & - & - & - \\
\hline & CAPITAL & 48 & 20 & 20 & 20 & 20 & 20 & 20 & 20 & 20 & - & - & - \\
\hline \multirow{2}{*}{ DESTETE } & PUEBLO & 500 & 416 & 350 & 300 & 300 & 300 & 250 & 250 & 250 & - & - & - \\
\hline & CAPITAL & 48 & 20 & 15 & 15 & 15 & 15 & 15 & 15 & 15 & - & - & - \\
\hline
\end{tabular}

Número de nodrizas contratadas por la inclusa de Valladolid, de lactancia y de destete, internas y externas, rurales y de la capital. Se recogen individualmente los años en que hay algún cambio y se mantienen agrupados los que tienen datos comunes. Tabla de elaboración propia a partir de los datos que ofrecen los Presupuestos generales de la Diputación. ADPVA. Hasta 1915 en los presupuestos se recogía el número de nodrizas, a partir de entonces solamente aparece el montante total destinado a esta partida sin dar el número de contrataciones previstas.

TABLA 3-29: SALARIO DE LAS NODRIZAS INTERNAS Y EXTERNAS DE LA INCLUSA DE VALLADOLID

\begin{tabular}{|c|c|c|c|c|c|c|c|c|c|c|c|c|c|}
\hline & & $\begin{array}{r}\text { REGL } \\
1889 \\
\end{array}$ & $\begin{array}{c}\text { PR } \\
1901\end{array}$ & $\begin{array}{c}\text { PR } \\
1904\end{array}$ & $\begin{array}{c}\text { PR } \\
08 / 12\end{array}$ & $\begin{array}{l}\text { REGL } \\
1910 \\
\end{array}$ & $\begin{array}{c}\text { PR } \\
1913\end{array}$ & $\begin{array}{c}\text { PR } \\
1914\end{array}$ & $\begin{array}{c}\text { PR } \\
1920\end{array}$ & $\begin{array}{c}\text { PR } \\
1923\end{array}$ & $\begin{array}{c}\text { PR } \\
1925 / \\
1926 \\
\end{array}$ & $\begin{array}{l}\text { REGL } \\
1927 \\
\end{array}$ & $\begin{array}{c}\text { PR } \\
1928 / \\
1930 \\
\end{array}$ \\
\hline \multirow{2}{*}{ INTERNAS } & LACTANC & $17^{\prime} 50$ & $17^{\prime} 50$ & 20 & 25 & - & 25 & 25 & 25 & 30 & 35 & $\begin{array}{c}35 / 45 \\
*\end{array}$ & $\begin{array}{c}35 / 45 \\
*\end{array}$ \\
\hline & DESTETE & - & - & - & - & - & - & $12^{\prime} 50$ & $12^{\prime} 50$ & $12^{\prime} 50$ & $15 / 20$ & 15 & $15 / 25$ \\
\hline \multirow{2}{*}{ LACTANCIA } & PUEBLO & $12^{\prime} 50$ & $12^{\prime} 50$ & - & - & \multirow{2}{*}{15} & 15 & 15 & 30 & - & 30 & 45 & 45 \\
\hline & CAPITAL & 11 & 10 & - & - & & 10 & 10 & 25 & - & 25 & 25 & 25 \\
\hline \multirow{2}{*}{ DESTETE } & PUEBLO & - & 8 & - & - & \multirow{2}{*}{$\begin{array}{l}7^{\prime} 50 / \\
6 * *\end{array}$} & 8 & 8 & 15 & - & 15 & 20 & 20 \\
\hline & CAPITAL & - & $6^{\prime} 50$ & - & - & & $6^{\prime} 50$ & $6^{\prime} 50$ & 10 & - & 10 & 15 & 15 \\
\hline
\end{tabular}

Salario de las nodrizas en pesetas/mes.

* Los dos datos de la fracción se corresponden con el número de niños que lacta la nodriza interna: en el numerador el salario cuando lacta 1 niño de la Inclusa (solo o + el suyo) / en el denominador cuando lacta 2 niños de la Inclusa (el suyo aparte en caso de que también lo esté criando).

** Los dos datos de la fracción se corresponden a distintos periodos de edad: desde $18 \mathrm{~m}$ a 48 meses /desde 48m hasta 72 meses del niño.

Tabla de elaboración propia a partir de los datos de los reglamentos del Hospicio (REGL) y de los Presupuestos generales de la Diputación (PR). ADPVA 


\title{
AnEXo no 6
}

\section{Año 1920 Memoria suscrita por los médicos del Hospicio, relativa a la alta mortalidad de niños en el Establecimiento}

\author{
(Signatura: caja 4025, expediente 37809. ADPVA)
}

"El coeficiente de mortalidad en los niños asilados es siempre elevadísimo, siendo objeto de preocupación y estudio de cuántos higienistas y sociólogos se dedican a estos humanitarios problemas.

La trágica estadística que tan justamente ha impresionado a esa Excma Corporación no es desgraciadamente una novedad; lejos de eso, nuestro Establecimiento benéfico, comparado en su mortalidad, con los similares de otras poblaciones de mayores elementos y recursos, es relativamente consoladora; en la memoria del Hospicio de Barcelona del año de 1917, cuya estadística tengo a la vista, se consigna la aterradora cifra de más de un $90 \%$ de mortalidad en su población infantil; mientras que en el mismo año tuvimos en el de Valladolid un 58\% solamente.

Sabido es que el débil organismo infantil, aun tratándose de los mimados de la fortuna, está mucho más expuesto a ser vencido por agentes morbosos que el del adulto, siendo víctima de sin número de enfermedades propias y exclusivas de la infancia, al extremo, de consagrar la patología una rama extensa a su estudio y constituyendo importante especialidad de la misma.

A estas causas ordinarias e inevitables de mortalidad infantil hay que agregar los propios y característicos de la internación en los Hospicios; en estos Establecimientos, arrojan la miseria y el vicio un verdadero detritus, piltrafas humanas con todo género de taras patológicas, muy especialmente tuberculosas y sifilíticas.

El niño recién nacido, sin haber reaccionado su débil organismo al amoroso calor de su madre y mal envuelto en miserables guiñapos, es llevado a la Inclusa y entregado a los cuidados de una nodriza, cuyo pecho ha de compartir con otros tres o cuatro compañeros de desdicha: la insuficiente alimentación del pecho, es complementada con leche de vaca, constituyéndose una lactancia mixta, en teoría, pues bien se comprende que en la práctica es una lactancia artificial, con gotas, muy pocas, de leche de mujer, y esto en el mejor caso, porque muy frecuentemente, sea por la carencia de nodrizas o bien por el riesgo de contagio, ha de instituirse desde el primer momento la lactancia artificial; la convivencia con una gran cantidad de niños en locales de medianas o francamente malas condiciones higiénicas, agregan nuevas dificultades a las escasas probabilidades de supervivencia de estas desgraciadas criaturas.

En tesis general, el niño tiene tantas más posibilidades de vida, cuanto que su alimentación sea:

Por lactancia materna

Id Id mercenaria

Id Id mixta

Id Id artificial.

Sentada esta base que los puericultores aceptan como axiomática, fácilmente se deduce el origen del aumento progresivo de mortalidad desde el año de 1915 al 18; obsérvese en la estadistica que mientras en el año de 1915 las lactancias externas eran 729, disminuyen progresivamente en los años 
sucesivos, hasta llegar en el 1918 a 367, existiendo una diferencia de 362 que quedan internados, pasando de la lactancia mercenaria unipersonal a la mixta o artificial y cambiando el aire de la aldea por el de la Inclusa.

Las causas de la disminución de la lactancia externa en estos últimos años pueden reducirse a una, la carestía de los artículos de primera necesidad, la nodriza externa con 15 pesetas mensuales que la abonan apenas si puede comprar el jabón necesario para el lavado de ropas; por otra parte las Diputaciones de la provincias limítrofes han aumentado la retribución a 25 pesetas mensuales, así se explica la falta de solicitud de niños de pecho y como lógica consecuencia el aumento de mortalidad en el Hospicio.

Justificadas o por lo menos explicadas las causas principales, origen de la mortalidad infantil, en esta y en todas las casas-cunas del mundo, así como también un aumento progresivo en estos últimos años; veamos los medios que pueden ponerse en práctica para mejorar en lo posible la situación de estos seres desvalidos e interesantes.

Teniendo en cuenta las bases sentadas anteriormente para explicar la mortalidad y fundados en las mismas; los medios que a nuestro juicio han de ponerse en práctica para salvar las vidas de algunos niños y que en su día puedan ser ciudadanos útiles a su patria, son los siguientes:

10. Favorecer por cuantos medios estén a su alcance la lactancia materna; a cuyo efecto debieran ponerse de acuerdo con las sociedades, juntas o instituciones de protección a la infancia, pues entendemos que es una labor social no privativa de las corporaciones oficiales dada la enorme importancia y complejidad del problema; debe estimularse a las madres lactantes con subsidios metálicos, alimentos, premios, \&, haciéndoles entender honrada y sinceramente el inminente peligro de muerte que sus hijos arrastran internándoles en la inclusa.

20. Estimular asimismo a las nodrizas internas y externas para aumentar en lo posible su número.

3‥ Higienizar los locales, hoy muy deficientes de la Inclusa, construyendo algún pabellón para diluir la población infantil y poder aislar a los enfermos contagiosos.

4․ Ya que el número de nodrizas ha de ser muy difícil, si no imposible, que esté en relación con el de niños, incrementar el de matronas o amas secas para que los meticulosos cuidados que el niño necesita puedan prestársele en mejores condiciones que en la actualidad

50. Aumento de un practicante: es de todo punto imposible que uno solo pueda atender a las curas, recetario, maternidad y llevar las estadísticas, gráficos de pesadas \&\&\&.

Por lo que se deduce de los datos estadísticos, la casi totalidad de las defunciones ocurre en niños de 0 a 3 años, haciéndose caso omiso por consiguiente de los departamentos ocupados por mayores de tres años.

Valladolid 12 de febrero de 1920

Firmado Evaristo Millán - Jerónimo Gavilán- Francisco Sisniega

La sesión provincial en sesión del 13 de Febrero acordó elevar esta Memoria a la Diputación proponiendo se fije en 30 pesetas la retribución a las nodrizas externas y 25 a las de la Capital y aceptar las conclusiones que en esta memoria se establecen". 


\section{Anexo no 7}

\section{Mortalidad en la Sala de Maternidad 1922}

(Signatura: caja 2449, expediente 30486. ADPVA)

\section{Carta de la Comisión Provincial dirigida a la Excma. Diputación. 29- 07- 1922}

\section{Excmo Sr}

Los departamentos de Maternidad e Inclusa que hoy existen en el Hospicio son pequeños y con defectos higiénicos.

En casi todas las Memorias que la Comisión provincial eleva a la Diputación en pleno se han dedicado algunas consideraciones sobre estos dos servicios encareciendo la urgencia de poner remedio a las deficiencias notadas ya en los locales, ya en el tratamiento de las acogidas y niños de la Inclusa.

La mortalidad de estos es aterradora en algunas épocas sin que disculpe esta mancha el hecho de que en todos los hospicios ocurre igual.

Nuestro deber es corregir las deficiencias buscando los medios de mejorar la situación de los pequeñuelos procurando a todo trance aminorar la mortalidad. Es una obligación que no solo demanda la ley si no el deber de humanidad.

En diferentes sesiones se ha tratado de este asunto importantísimo conviniendo todos en que tanto la Maternidad como la Inclusa necesitan una reorganización en los servicios, en el material y en los locales.

En los dos últimos semestres, el Diputado Sr Garrote propuso que para realizar este deseo estudiase la Comisión provincial la conveniencia de encomendar estos dos departamentos a la Facultad de Medicina en términos parecidos a los que hoy están pactados en el Hospital; y al hablar de las deficiencias que se notan como irremediables en el estado actual, no se refería a la competencia técnica del personal encargado de dichos departamentos sino a la falta de elementos científicos de que la Diputación no puede disponer, sobrándole en cambio a la Facultad de Medicina donde el Estado no regatea cuanto necesita en bien de la enseñanza y del progreso de la ciencia.

Como la Diputación encargó a esta Comisión provincial las gestiones que estimara precisas para que la propuesta se convirtiera en realidad, ha meditado sobre tan importante asunto y celebrado entrevistas con algunos Sres Profesores de la Facultad llegando al convencimiento de la necesidad y urgencia que existe de ir decididos a la reforma, encomendando a los Profesores de la Facultad la Maternidad e Inclusa del Hospicio en cuanto se refiere a la parte técnica conservando la Diputación, 
como lo hace en el Hospital, todas aquellas prerrogativas y derechos que le conceden las leyes en cuanto a la parte económico-administrativa.

No es posible en este escrito determinar los derechos y deberes que tanto de la Diputación como a la facultad han de asistirles con este cambio de régimen. Hay muchas cuestiones que analizar y muchos detalles que tener en cuenta para la implantación del nuevo sistema; pero todo puede estudiarse y resolverse reglamentándolo teniendo en cuenta los intereses creados y las necesidades que la práctica y la realidad nos enseñan.

En principio pues, esta Comisión entiende que sería conveniente una participación directa de la Facultad de Medicina en estos dos departamentos 10 Por la urgencia de mejorar los servicios que no ha conseguido la Diputación a pesar de sus buenos deseos, como lo demuestra la reciente adquisición del edificio de la Trinidad. 2o. Que la Facultad de Medicina teniendo como tiene cantidades que el Estado le entrega para mejorar la enseñanza, podrá dotar a estos dos departamentos de todo el material científico que sea preciso 3‥ Que por Real decreto de 18 de noviembre de 1902, la Diputación está obligada a facilitar a la Facultad todos los elementos de que disponga en sus establecimientos destinados a enfermería y 4‥ Que, de aceptarse este nuevo régimen ganarían los asilados y, económicamente, la Corporación.

En virtud de las anteriores consideraciones, la Comisión provincial que suscribe tiene el honor de proponer a la Excma Diputación acuerde

10. Que desde primero de octubre próximo se encarguen de la asistencia técnica de los departamentos de Maternidad e Inclusa los Sres Profesores de la Facultad de Medicina que tengan a su cargo estas enseñanzas cuya asistencia deberá prestarse gratuitamente.

2‥ Que para mejorar, ampliar y reorganizar cuanto se refiera a ambos departamentos se designe a una comisión mixta de Sres Diputados y Catedráticos para que proceda inmediatamente a redactar las bases de un contrato en el que se deslinden atribuciones, se declaren derechos y obligaciones de cada parte y aprobado éste por ambas entidades, se eleve al Excmo Sr Ministro de Instrucción pública para su Superior y definitiva aprobación.

Tal es la propuesta que someten a la deliberación y acuerdo de V.E. que como siempre acordará lo que más convenga a los intereses provinciales.

Valladolid 29 de julio de 1922

[firmado por los diputados de la Comisión provincial]

\section{A LA EXCMA. DIPUTACIÓN PROVINCIAL}




\section{Sesión provincial del 30 de Septiembre de 1922}

El Sr Vicepresidente dio cuenta que en el día de ayer en unión de los Sres Diputados Sres Escribano, Cabello y Garrote, se presentó en el Hospicio de los catedráticos de esta Facultad Sres Villa y Nogueras para presentarles al personal y Hermanas del establecimiento como Profesores encargados de la asistencia de la Maternidad e Inclusa conforme y en cumplimiento del acuerdo adoptado por esta Diputación. Que por el Sr Nogueras se indicó la conveniencia de que su visita fuera acompañada de los alumnos de la asignatura para que estudiasen los casos clínicos que en dicho departamento puedan presentarse. La Comisión acordó que desde luego se autorizara al Sr Nogueras para que realice cuanto interesa sin perjuicio de las bases que de acuerdo con la Facultad se han de establecer a cuyo efecto para este trabajo se designa por parte de la Diputación a Don Constancio Alonso, a Don Remigio Cabello y al Sr Vicepresidente de la Comisión provincial. También se acuerda dirigir oficio a referidos Sres Médicos para que desde primero de curso se encarguen de la asistencia de dichos departamentos, comunicándolo también al Sr decano.

Así mismo se acuerda oficiar a los Médicos provinciales del Hospicio para que cesen en la visita a dichos departamentos quedando a su cargo la de la asistencia a los niños y niñas que no pertenezcan a ninguno de los citados departamentos"

\section{Comisión provincial}

\section{Sesión del día 30 de Agosto de 1923}

Por el vocal Sr Rico se manifestó que tiene noticias que en la Inclusa hay una mortalidad alarmante y desea que se tomen las medidas necesarias para evitarlo; que tiene también noticia que los Médicos de la Facultad que se hicieron cargo de este departamento han estado fuera de Valladolid y es preciso que se les haga entender que tan importante servicio no puede quedar abandonado.

El Sr Garrote dice que en efecto ha estado fuera de Valladolid el Sr Nogueras, pero que ya está al frente de la Inclusa, que él ha tenido que encargarse de la asistencia de los niños y de acuerdo con el sr Pérez Torres y entendiendo la Comisión que no puede consentirse que ni un solo día pase sin hacerse la visita a dicho departamento y estimando de urgente necesidad que la Facultad, de acuerdo con la Diputación, formule las bases para la forma y modo en que aquella ha de encargarse de la asistencia médica; se acuerda recordar al Sr Decano de la Facultad de Medicina la conveniencia de designar los señores Profesores que han de entenderse con la Comisión de la Diputación, advirtiéndole que de no hacerlo en un plazo prudencial se entiende que desisten de prestar los servicios médicos que se les tenía encomendados" 


\title{
4. Respuesta del Decano Isidoro de la Villa, catedrático de Obstetricia. 18- 09- 1923
}

He recibido su atento oficio fecha 13 y tengo el gusto de manifestar que en lo referente a la maternidad el profesor encargado, precisamente el que abajo firma, se ha ocupado, de acuerdo con el Sr. Decano y la Comisión provincial, de elegir locales para mejorar el servicio actual, que no reúne ninguna de las condiciones necesarias. Además en reciente viaje por el extranjero ha adquirido material, sobre todo de esterilización, que falta en absoluto para la maternidad.

Atendiendo sin embargo su deseo, comunicaré al Sr Decano propietario, que ha de llegar dentro de unos días, su oficio e inmediatamente nos pondremos de acuerdo con la comisión nombrada por $V$. S. para remediar la mortalidad infantil"

\author{
DIOS guarde a V. S. muchos años \\ Valladolid 18 Septiembre de 1923 \\ El Decano actual \\ [firmado] Isidoro de la Villa
}

Sr. Vicepresidente de la Comisión provincial

\section{Comisión Provincial. Sesión del día 31 de marzo de 1924}

Se acordó insistir nuevamente cerca del Sr Decano de la Facultad para que designe la comisión que en unión de la Diputación acuerden las bases que han de determinar los servicios de Maternidad e Inclusa cuya parte técnica se encomienda a catedráticos de dicha Facultad"

[En la parte inferior del documento escrito a mano]

Cumplido el 1 Abril 


\section{ANEXO No 8}

\section{Carta de la Diputación Provincial dirigida a los directores del Hospital Provincial y del Hospicio. Septiembre 1923}

(Signatura: caja 4025, expediente 37809. ADPVA)

Acordado por la Diputación Provincial la unificación de las maternidades instaladas en el Hospicio y Hospital Provincial, se hace necesario unificar la reglamentación para el ingreso y estancia de las embarazadas que acudan á los referidos establecimientos.

Actualmente las gestantes que ingresan en el Hospicio adquieren el compromiso de lactar a los niños del establecimiento durante un tiempo igual al que han estado asiladas; y las que permanecen en el Hospital se ven libres de este compromiso, dándose el caso anómalo de causar estancias durante cinco o seis meses sin contraer el menor compromiso de lactancia, beneficio del que disfrutan sean o no de la provincia.

Como podrá verse por la adjunta relación que se acompaña, ha dado lugar este régimen abusivo y falto de equidad, a dos mil quinientos treinta y cinco estancias indebidas, que de haberse cumplido el reglamento, siendo este en la forma que abajo proponemos, hubiera permitido criar ocho niños más que se hubieran sustraído a la lactancia artificial de tan enorme mortalidad.

Es indudable que las modernas y humanitarias corrientes de protección a la mujer embarazada suprimen estos tributos de sangre prestando a la mujer ayuda económica durante los últimos meses de su embarazo; pero esto no puede ser misión exclusiva de la Diputación y sí del Estado, y en tanto esto no ocurra, debemos de procurar que los acuerdos de la Diputación se aproximen al ideal de justicia.

La espantosa mortalidad de la lactancia artificial, la explotación ejercida con muchos niños sometidos a la lactancia externa nos obligan a procurar los medios para que la Inclusa disponga del mayor número posible de amas de cría, y a este fin, hemos de establecer primeramente una diferencia entre las mujeres en gestación que pertenecen a otras provincias y las que son de Valladolid, o llevan dos años de residencia.

Otro grupo formarán las mujeres casadas que las necesidades económicas obliguen a ingresar en estos establecimientos benéficos.

Proponemos a esta Corporación que los preceptos reglamentarios de ingreso y estancia, bien sea en la maternidad del hospicio o en la del Hospital, sean redactadas en la forma que sigue:

Primero: No se precisará documentación de ninguna clase para el ingreso en la maternidad.

Segundo: Las embarazadas que no sean de la provincia de Valladolid y que no lleven dos años de residencia tendrán la obligación de lactar en la Inclusa tantos días como estancias hayan causado en la maternidad. 
Tercero: Las embarazadas de la provincia de Valladolid o con dos años de residencia en la mima, tendrán derecho a permanecer en la maternidad durante un mes, y los días que pasen de este plazo tendrán la obligación de lactar en la Inclusa tantas fechas como estancias hubieran causado más de ese mes.

Cuarto: Las embarazadas casadas podrán permanecer en la maternidad desde el séptimo mes de su embarazo, sin obligación de criar a ningún niño.

Palacio de la Diputación de Valladolid a 3 de agosto de 1923

Comisión Provincial

[Escrito a mano y firmado] Sesión 4 sepbre 1923

Aprobada, y que se comunique al Hospital a los efectos procedentes

[Escrito a mano]

Transcrito á los directores del Hospital y Hospicio el 7 Ag 


\section{Anexono 9}

Propuesta de modificación del Reglamento de 1927 en los artículos 331 y 334 sobre el salario de las nodrizas 5- 03- 1945 (Signatura: caja 7635, expediente 09. ADPVA)

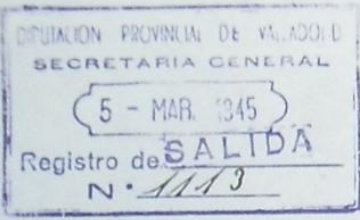

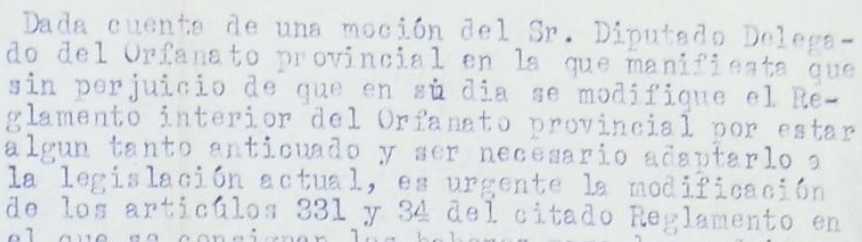
acogidaz en maternidad que a continución se expreasn:

Treinta y cinco ptas. mesuales a las que lactan su hijo y otro de la casa.

La misma cantidad si lacta a uno de la Inclusa y cuarenta y cinco ptas. sj lacta a dos de la Inolusa.

El Art. 334 se refiere a la crianze externa drrente la cual. na nojniza noroibe ouerenta y cinco ntag. mesma lossj la crianza fo en los puelrlos, veinticinco ptas. en la Capital, dumante el primels periodo ce lactencia cue ogmnende hasta los doce meses (on el Reglamento consta hasta los ifecicho mesos, noro la restricción de 18 a 12 mesez fus hechs posticriormente).

A partir de este tienpo perciben $2 u$ peas. las de los pueviug jo las ce la capital, hasta los 48 meses, on ol leglanchto cunsta nasta Lus 72 neses, siendo restringido posteriomante hasta 10348 meses.

Teniendo en ouenta la carestia de vida y la necesidad de fomentar la lactanc:a maternal Io gue lleva consigo a más de que la madre cumpla con un ceber natural y cristiano, la disminución de wortalida incantil, propone se remunere més dignamente a la madre, pregtandola una ayude economice más amplis lo cual.

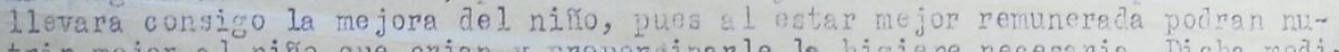
trir mejor al nifio que orian y proporqinarle la higiene necesaria. Dicha modieicesión vudieng zer ouno gigue:

a) la que lacte a su hijo solo 25 ptas. menavales.

b) " " " uno solo de la Inclusa 40 ptas. mensuales.

c) " " " al suyo J otro de la Incluse 60 ptes. mesuales.

oh) " " " dos de la Inclusa $7 / 5$ pesetas menauales.

d) " "la que lacte al provio y dos de la Inclusa 80 ptas. mensuales. e) " " tres de la Tnclusa 100 ptas. mensuales.

Para la lactancia externa 75 ptas. mensuales, ya sea en la capital, ya en 108 pueblos durante los 15 primeros meses à lactancia.

Las oue continuen con el niño lactado degpues de los 15 meses, nercibirar 50 ptas. hasta que el nifio cumpla la edad de 4 a fios.

Fin el caso a) ce las nolrizas interrs en este Centro ge entencera el teminado él tjempo obligatorio de estanciss ave oxige el Reglemento: Y la Lxena. Comisión Gestora en sesión del dia 10 de los corriontes, teniondo en cuents ? carestia de vida y la precjsión absoluta de acoptar con rapidez este aumanto. en evitación de las causas que pudieran ser peligiosas para la viáa do los nifos a ometidos a este regimen de alimetitación, acurás por unanimidad aceptar la propuesta, que se ponga en ejecución y que so lleve al ke blankto en la proxima modificación.

Lo que traslado a V. para su conocimiento y efectos.

Por Dios, Esnafia y su Revolucion Naojonal-Sindicalista.

Valladolid, 5 de Mnnzo तe 1945.

$$
\text { EL PRESTDENTE, }
$$
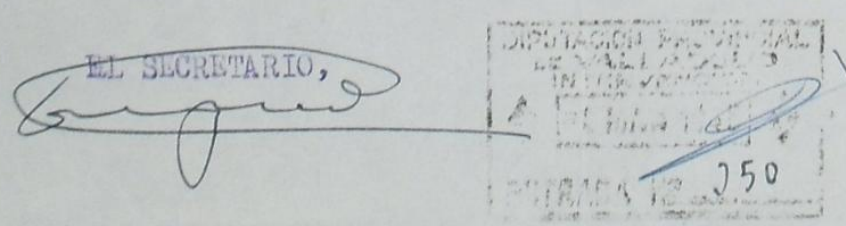

Sr. Intaryantor de fonitos nrowinoiales.

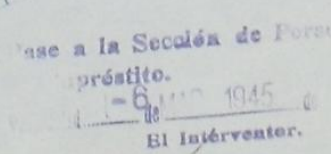

B1 injerveater. 


\section{Anexono 10}

\section{ENTREVISTA SOBRE LA CRIANZA DE LOS LACTANTES EN LAS PRIMERAS DÉCADAS DEL S. XX}

La entrevista va dirigida a personas nacidas antes del año 1933 (de 80 años o más) que puedan tener recuerdos vividos u oídos de su niñez. Se pueden incluir personas más jóvenes que puedan aportar datos que hayan escuchado a sus mayores. Queremos recoger todo lo que puedan recordar sobre la crianza de los niños de hasta 2-3 años en el período anterior a la Guerra Civil. Cuestiones sobre alimentación, vestido, higiene, juegos, estilo de vida, enfermedad, mortalidad infantil, amas de cría, abandono de niños y orfanato.

Valen recuerdos sobre ellos mismos, sus hermanos o su entorno o historias que hayan oído a sus padres o sus mayores.

La entrevista debe ser lo más fluida posible. No tiene por qué seguir un orden concreto. Se pueden contestar las preguntas sobre la marcha, dejando hablar al entrevistado, pero orientándole hacia los temas de interés.

No importa que no se contesten todas las preguntas, de lo que se trata es de recoger la mayor cantidad posible de información relevante y verídica, pero sin agobiar al entrevistado

Presentarse al comienzo y explicar la razón de la entrevista y el uso que se le va a dar. Garantizar que los datos personales son absolutamente confidenciales, que no se va hacer uso público de ellos y no se va a utilizar el nombre sin su consentimiento. Si así lo desea se pueden utilizar solo las siglas, el nombre de pila, o un seudónimo. El nombre se recoge en la entrevista por si fuera necesario volver a contactar para aclarar alguna cuestión.

Si se utiliza grabadora debe advertirse al entrevistado y pedir su consentimiento. Luego se debe transcribir la entrevista. Si no se graba se irán cogiendo notas rápidas procurando no cortar el hilo de la conversación, al finalizar la entrevista se pondrá por escrito todo lo que se recuerde y las impresiones recibidas.

Registrar como dudosos aquellos datos que se consideren como tal, bien porque el mismo entrevistado dude de lo que dice o porque según lo dice dudemos nosotros de su veracidad. Tener en cuenta para diferenciar, que puede ocurrir que mezclen recuerdos de su infancia y recuerdos de la crianza de sus propios hijos. 


\section{Nombre}

\section{QUEREMOS SABER:}

- Año de nacimiento

- Lugar de nacimiento

Provincia de

¿Se crió allí?

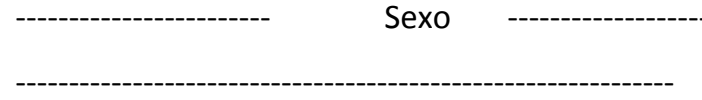

№ de hermanos en la familia

No: Dónde?

¿Quién atendió los partos de su madre?

¿Cuántos hijos tuvo su madre?

¿Se murió alguno de sus hermanos siendo niño?

Al nacimiento

a qué edad?

¿Recuerda por qué se murieron?

- $\quad$ № que ocupa en la serie de hermanos

¿Ayudó a criar a alguno de sus hermanos?

¿Ayudó de pequeño a sus padres, cómo?: a cuidar a sus hermanos, en las tareas de casa, en el campo, en el trabajo

- ¿ ¿En qué trabajaban sus padres?, tenían un negocio propio?, tenían tierras propias?

Si trabajaba la madre en qué?: en el campo, de asistenta en una casa, en una fábrica......

¿Sabían sus padres leer y/o escribir?

\section{Alimentación}

- ¿ ¿Todos los hermanos fueron criados al pecho por su madre?

¿Recuerda hasta qué edad?

¿Su madre dio el pecho a más de un hijo a la vez?

¿Y estando embarazada?

¿Necesitó nodriza para alguno? ¿Fue nodriza de algún niño?

- Si sus hermanos no tomaron pecho ¿Por qué? Y

Y ¿ ¿Con qué se criaron?

- ¿ ¿Recuerda si era lo habitual dar el pecho a los bebés? Y ¿Hasta cuándo?

¿Qué hacían las mujeres si nacía otro hijo, destetaban al primero, daban el pecho a los dos?

- ¿Cuándo se criaban al pecho los bebés, comían además otras cosas? ¿Cuáles? ¿Por qué?: La madre tenía poca leche, lo indicaba el médico, era costumbre...

- ¿Cuándo empezaban a tomar los bebés otros alimentos además del pecho? ¿Se daban alimentos de cuchara los primeros meses de vida? ¿Cuándo empezaban? ¿Se daba a los niños vino, anís?

¿Para qué?

¿Recuerda alguna otra cosa que ahora no se hace y le llame la atención?

- ¿Cuándo empezaron a tomar leche de origen animal sus hermanos?

¿Qué tipo de leche?

¿Por qué?

¿Se criaban bien los niños? ¿Tenían más problemas que los niños que tomaban pecho?

¿Tenían más problemas que los que comían alimentos de cuchara los primeros meses?

- Cuando la madre no podía lactar (enfermaba, moría, no tenía leche) ¿Cómo se alimentaba al niño? 
Ama de cría: familiar, vecina, ama contratada interna o en su domicilio

Se entregaba al hospicio

Se entregaba a alguna familia de parientes, amigos, vecinos o desconocidos

Se le daba leche animal ¿cuál?

Se daban otros alimentos ¿cuáles?

- ¿Usaban chupete los bebés?, ¿Cómo eran: se parecían a los de ahora?

- ¿Usaban biberones? ¿Cómo eran, se parecían a los actuales?

- ¿Cuándo comían con cuchara?

\section{Crianza}

- ¿ ¿Cuándo la madre tenía que trabajar, qué hacía con los bebés?

Los podía llevar con ella, los dejaba con parientes/ vecinos, al cuidado de los hermanos mayores, se quedaban solos ...

- ¿Qué pasaba con los bebés cuando fallecía alguno de los padres?

- ¿ ¿Era frecuente hacer tratos entre parientes/ vecinos para criar los hijos. Eran tratos de favor o remunerados?

- ¿ ¿Conoce algún caso de niño criado en el hospicio o con otra familia ajena a la suya? ¿Por qué ocurrió? ¿Lo entregaron en el hospicio o lo abandonaron? ¿Sabe cómo se crió en el hospicio, vivió en el hospicio o en algún pueblo con una nodriza? ¿Volvieron a saber algo del niño?. Volvió con su familia? Pensaban recoger al niño?

- ¿Le parece que se abandonaban muchos niños? ¿Qué pensaba la gente sobre ese tema?

- ¿ ¿Conoció algún caso de mujer que amamantara y criara un niño ajeno? ¿Era hijo de familiares, amigos, vecinos o desconocidos, o niños del orfanato?

- ¿Conoció alguna nodriza de niños del orfanato? ¿Le pagaban bien? ¿Criaba bien a los niños?: comida, ropa, trato ¿Alguien controlaba a la nodriza y a los niños? ¿Tenía hijos propios, los criaba igual, lactaba a los dos a la vez? ¿Qué pasó con el niño: lo devolvieron al orfanato, murió, lo prohijaron ¿Si lo devolvieron por qué?: fin contrato, no tenía leche, no podía criarle...

\section{$\underline{\text { Vestido }}$}

- ¿ ¿Recuerda cómo se vestía a los bebés? Se vestía igual a niños y niñas?
¿Y cuando los niños ya andaban? ¿Se diferenciaban con el color azul y el rosa? ¿Cómo eran los pañales?, hasta cuando los usaban?, cuando los quitaban, qué usaban?

- ¿ ¿Se ponía mucha ropa a los bebés, se les abrigaba mucho? 


\section{Aseo y cuidados}

- ¿A qué edad sacaban a los niños de la cuna para que empezaran a gatear?

¿Dónde pasaban más tiempo los lactantes grandecitos durante el día? En la cuna, les cargaba la madre, en sillitas, en el suelo...?

- ¿Se sacaba a los niños a la calle? Salían de paseo, al patio, a la puerta de casa ...?

¿Usaban cochecitos de paseo?

- ¿Recuerda cómo se aseaba a los bebés? ¿Dónde les bañaban?

¿Les bañaban a diario, cada semana, cada mes...?

- ¿Usaban algo para las irritaciones, eran frecuentes?

- ¿Les cambiaban mucho de ropa?

- ¿Cómo se cuidaba el cordón umbilical?, cómo se pinzaba, con qué, le aplicaban algo, tenían algún cuidado especial, qué hacían cuando se desprendía?

- Cómo se aliviaba a los lactantes cuando echaban los dientes?

\section{Sueño}

¿Qué hacían con los niños que dormían mal, y cuando lloraban mucho?: Les daban algo, algún remedio casero, iban al médico?

\section{Enfermedad y mortalidad}

- ¿Qué hacían cuando un niño enfermaba?: Se avisaba al médico, a alguna vecina que "sabía", a curanderos, se iba a algún consultorio, al hospital.

$\bigcirc \quad ¿$ Era frecuente ingresar a los niños?

- ¿Cómo se pagaba al médico? Tenían iguala, cuánto podía ser, resultaba caro?

- ¿Se compraban medicinas, se usaban remedios caseros?

- ¿Qué se hacía cuando el niño tenía fiebre, vómitos, diarrea?

- ¿Usaban mucho los purgantes? Aceite de ricino, otros?, Cuando, o para qué?

- ¿Qué usaban para aliviar los cólicos de los lactantes?

- ¿Cómo se curaban las heridas de los niños, recuerda qué utilizaban?

- ¿Recuerda algún remedio casero para niños?: para los dientes, los cólicos, heridas, dormir, engordarle

- ¿Les pusieron alguna vacuna?

- ¿Morían muchos niños pequeños?, se hacía un funeral diferente a los niños lactantes y a los que nacían muertos?. Qué pensaba la gente?

- ¿Le parece que los niños pequeños enfermaban y morían más que cuando crió a sus hijos?

- ¿Cuándo crió a sus hijos las cosas se hacían igual que lo que recuerda de pequeño, habían cambiado mucho? Aplicó lo que aprendió de sus padres o actuó de manera diferente 


\section{ANEXONo 11}

PLANO DE VALLADOLID. LOCALIZACIÓN DEL HOSPICIO PROVINCIAL

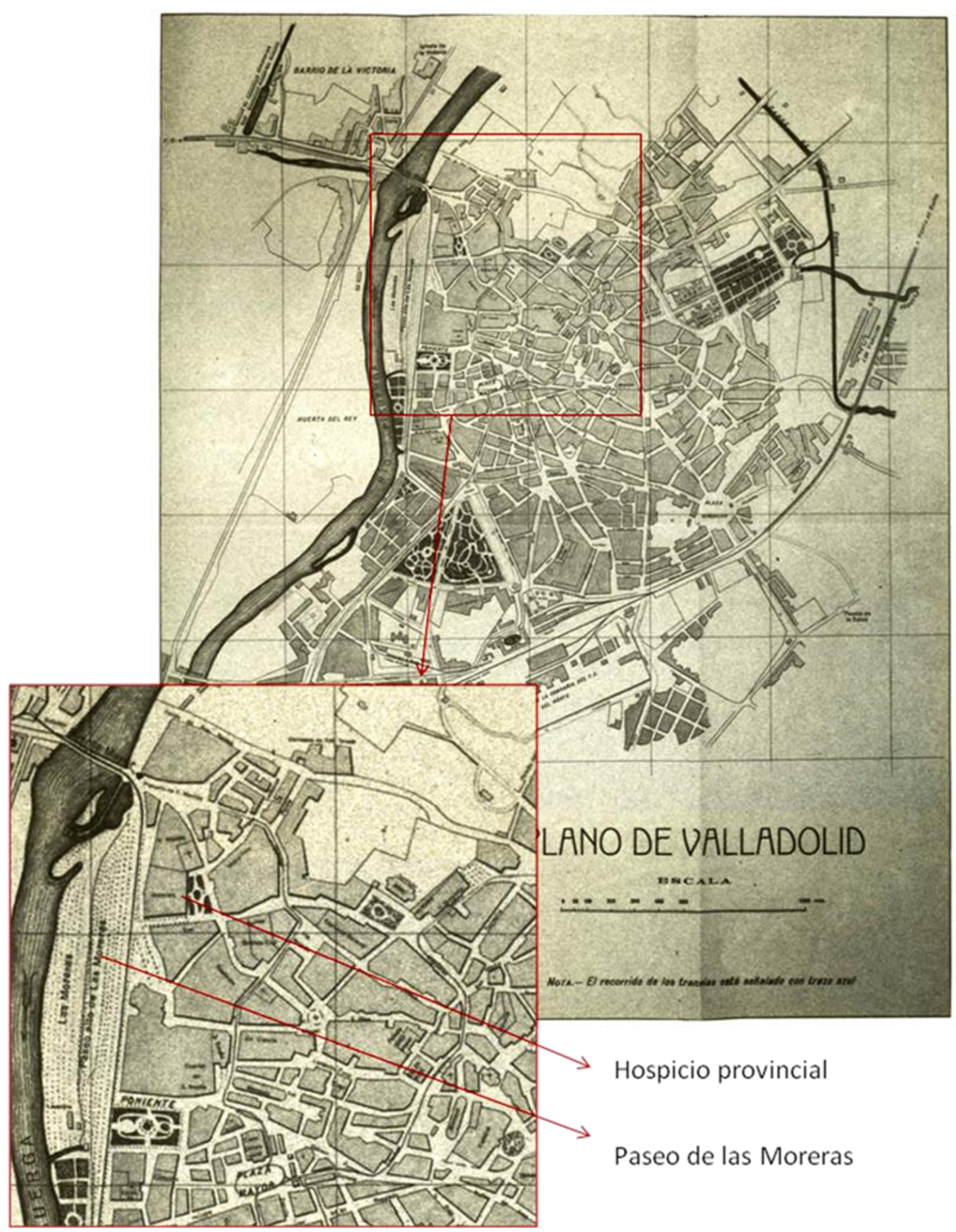

PLANO DE LA CIUDAD DE VALLADOLID. CASA SANTARÉN 1922 


\section{BIBLIOGRAFIA Y FUENTES}

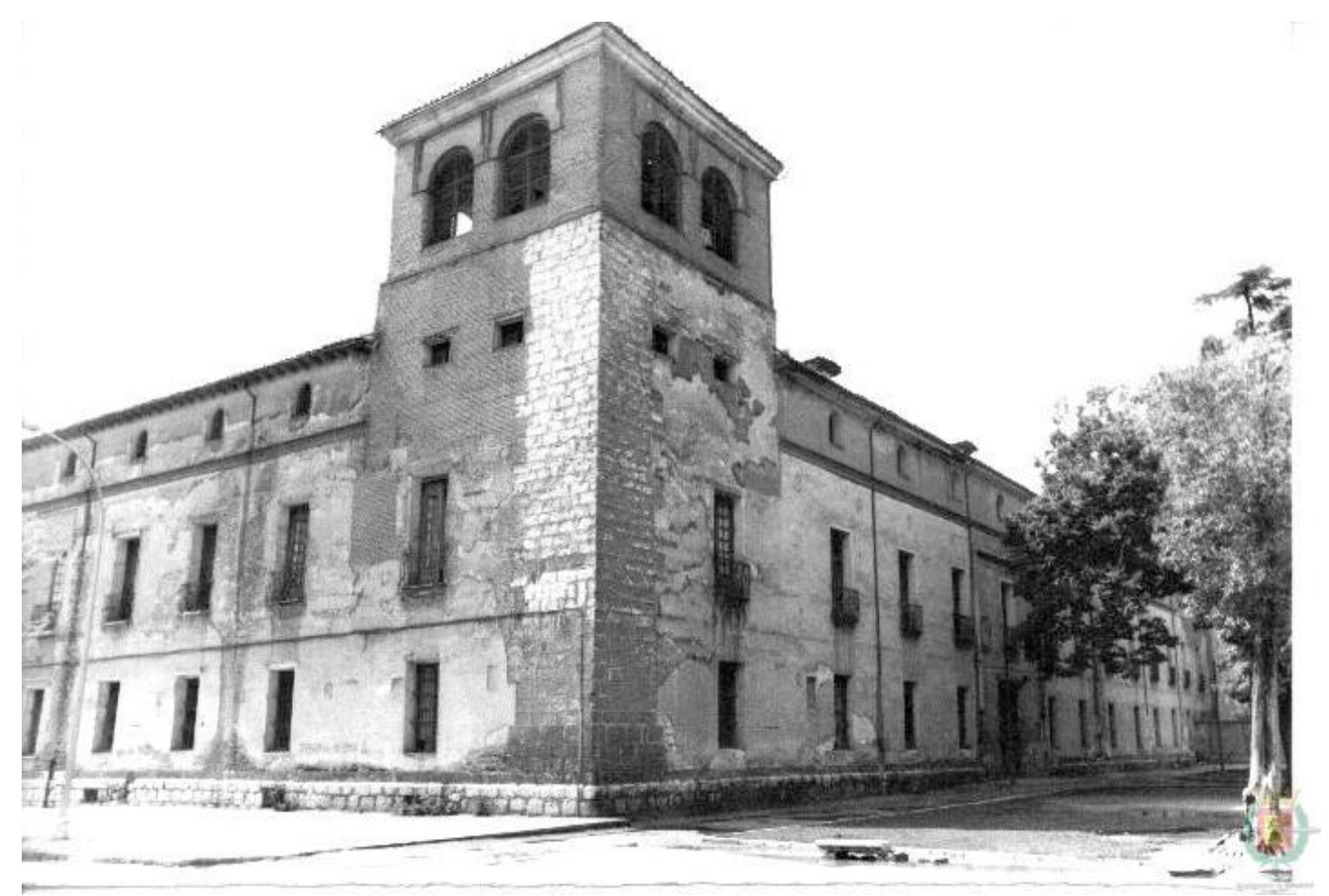

Imagen 7: Palacio de los Benavente, esquina san Quirce. Fuente: AMVA. Año 197? 


\section{BIBLIOGRAFIA y FUENTES}

\section{ARCHIVOS Y FUENTES DOCUMENTALES}

- $\quad$ Archivo de la Diputación Provincial de Valladolid (ADPVA):

- BUENO IGNACIO MARÍA: Memoria sobre la fundación del Hospicio Provincial de Valladolid, sus vicisitudes, estado actual, medios que podrían adoptarse para mejorar todas sus rentas, reivindicar todos sus derechos perdidos y aumentar los créditos con que hoy cuenta el mencionado establecimiento. Dedicada a la Excma. Diputación Provincial por D. Ignacio María Bueno, su Apoderado General para la liquidación y gestiones necesarias hasta lograr el cobro de toda clase de créditos pertenecientes á los establecimientos de Beneficencia Provincial. Año de 1871. Valladolid. Imprenta de Lucas Garrido 1874

- Presupuestos generales de ingresos y gastos de la Diputación Provincial de Valladolid;). Valladolid. Diputación Provincial. Imprenta del Hospicio Provincial (libros anuales para los ejercicios económicos desde 1901 hasta 1930

- Reglamento para el régimen interior del Hospicio Provincial de Valladolid. Diputación Provincial de Valladolid. Valladolid Imprenta y Encuadernación del Hospicio Provincial. 1927.

- Sección Acogida de menores: series

- Altas y bajas de menores acogidos:

- $\quad$ Libro defunciones 1908: Signatura: Caja 1225. Expediente 7757

- Defunciones 1913: Signatura: Caja 1201. Expediente 7672

- Correspondencia de menores acogidos:

- Signatura: Caja 2449. Expediente 30481

- Comunicaciones e informes de acogida de menores:

- Memoria. 1871: Signatura: Caja 307.Expediente 3668

- Niños ingresados en el Hospicio Provincial para su lactancia durante el año 1905: Signatura: Caja 4872. Expediente 43325

- Estado demostrativo del movimiento de acogidos del Hospicio Provincial. 1906: Signatura: Caja 4872. Expediente 43334

- Informe sobre necesidades y mejoras del Hospicio Provincial. 1906: Signatura: Caja 4872. Expediente 43333

- Memoria. 1908: Signatura: Caja 2449. Expediente 30483

- Estadística de la población existente en los servicios asistenciales. 1911: Signatura: Caja 1619. Expediente 12606

- Elaboración de pan. 1911: Signatura: Caja 2450. Expediente 30511

- Informe del número de acogidos entre 1914 y 1918: Signatura: Caja 4051. Expediente 38001

- Memoria suscrita por los médicos del Hospicio Provincial relativa a la mortalidad de niños del establecimiento. 1920 Signatura: Caja 4025. Expediente 37809

- Productos de vaquería del hospicio provincial. Julio- octubre. 1926: Signatura: Caja 2449. Expediente 30487

- Estadística demográfica sanitaria del Hospicio en el primer trimestre del año. 1932: Signatura: Caja 565. Expediente 5776

- Estadística demográfica sanitaria 1932-1934: Signatura: Caja 1619. Expediente 12607 
- Memoria estudio del orfanato provincial. 1944- 1948: Signatura: Caja 7593. Expediente 10

- Reglamento del Orfanato provincial. 1945: Signatura: Caja 7635. Expediente 9

- Mortalidad en la sala de maternidad. 1922: Signatura: Caja 2449. Expediente 30486

Expedientes personales de menores:

- Signatura: Caja 1277. Expediente 8225

- Signatura: Caja 1278. Expediente 8279

- Signatura: Caja 1279. Expediente 8310

- Signatura: Caja 1279. Expediente 8311

- Signatura: Caja 1279. Expediente 8312

- Signatura: Caja 1279. Expediente 8313

- Signatura: Caja 1281. Expediente 8416

- Signatura: Caja 1284. Expediente 8520

- Signatura: Caja 1284. Expediente 8522

- Signatura: Caja 1285. Expediente 8576

- Signatura: Caja 2199. Expediente 21740

- Signatura: Caja 2224. Expediente 24380

- $\quad$ Signatura: Caja 2224. Expediente 24386

- Signatura: Caja 2224. Expediente 24390

- Signatura: Caja 2224. Expediente 24392

- Signatura: Caja 2224. Expediente 24412

- Signatura: Caja 2224. Expediente 24417

- Signatura: Caja 2224. Expediente 24423

- Signatura: Caja 2224. Expediente 24442

- Signatura: Caja 5419. Expediente 53876

- Signatura: Caja 6594. Expediente 66378

- Libros de mayores acogidos:

- Libro 16 1906- 1911: Signatura: Caja 01869. Expediente 016474

- Libros de registro de amas de cría:

- Libro de cuentas corrientes con las amas externas. Lactancias:

○ año 1909: Signatura: Caja 689. Expediente 6752

- año 1910: Signatura: Caja 1158. Expediente 7486

- Justificantes de pago por crianza externa

- 1906: Signatura: Caja 2450. Expediente 30505

- 1907: Signatura: Caja 2450. Expediente 30506

- 1908: Signatura: Caja 2450. Expediente 30507

- 1909: Signatura: Caja 2450. Expediente 30508

- 1910: Signatura: Caja 2450. Expediente 30509

- 1911: Signatura: Caja 2450. Expediente 30510

- Registro especial de cartillas de lactancia y destete años 1910, 1911,1912, 1913:

- Signatura: Caja 755. Expediente 6866

- Signatura: Caja 1260. Expediente 7863

- Signatura: Caja 5745. Expediente 55375

- $\quad$ Libros de registro de entradas de menores acogidos:

- Años 1906 y 1907 1908: Signatura: Caja 1213. Expediente 7736

- Entradas y salidas de los niños de la inclusa años de 19091910 1911":

Signatura: Caja 409. Expediente 3979

- Inclusa niños dbre 1911 año 1912 año 1913 fin: Signatura: Caja 441. Expediente 4092

- Niños entradas en el año 1902: Signatura: Caja 1938. Expediente 16992 
- Niños entrada años 1907 1908: Signatura: Caja 1938. Expediente 16993

- Libros de Exposiciones:

○ Tomo I 1900: Signatura: Caja 1784. Expediente 16307

- Tomo II 1900: Signatura: Caja 1785. Expediente 16308

- Tomo I 1901: Signatura: Caja 1785. Expediente 16309

- Tomo II 1901: Signatura: Caja 1788. Expediente 16313

- Tomo I 1902: Signatura: Caja 1789. Expediente 16314

- Tomo II 1902: Signatura: Caja 1791. Expediente 16317

- Tomo I 1903: Signatura: Caja 1772. Expediente 16274

- Tomo II 1903: Signatura: Caja 1772. Expediente 16275

- Tomo I 1904: Signatura: Caja 1773. Expediente 16277

- Tomo II 1904: Signatura: Caja 1773. Expediente 16278

- Tomo I 1905: Signatura: Caja 1773. Expediente 16279

- Tomo II 1905: Signatura: Caja 1776. Expediente 16286

- Tomo I 1906: Signatura: Caja 1776. Expediente 16287

- Tomo II 1906: Signatura: Caja 1774. Expediente 16283

- Tomo I 1907: Signatura: Caja 1775. Expediente 16284

- Tomo II 1907: Signatura: Caja 1775. Expediente 16285

- Tomo I 1908: Signatura: Caja 1774. Expediente 16280

- Tomo II 1908: Signatura: Caja 1774. Expediente 16281

- Tomo I 1909: Signatura: Caja 1778. Expediente 16292

- Tomo II 1909: Signatura: Caja 1774. Expediente 16282

- Tomo I 1910: Signatura: Caja 1778. Expediente 16293

- Tomo II 1910: Signatura: Caja 1777. Expediente 16289

- Tomo I 1911: Signatura: Caja 1777. Expediente 16290

- Tomo II 1911: Signatura: Caja 1777. Expediente 16291

- Tomo I 1912: Signatura: Caja 1779. Expediente 16294

○ Tomo II 1912: Signatura: Caja 1779. Expediente 16295

- Tomo I 1913: Signatura: Caja 1765. Expediente 16242

- Tomo II 1913: Signatura: Caja 1765. Expediente 16243

- Libro: Signatura: Caja 409. Expediente 3979

- Libro: Signatura: Caja 1938. Expediente 16992

- Libro: Signatura: Caja 1938. Expediente 16993

- Defunciones Signatura: Caja 1213. Expediente 7736

- Libros de registro de salida de menores acogidos

- Libro: Signatura: Caja 709. Expediente 6787

- Libro: Signatura: Caja 756. Expediente 6868

- Libro: Signatura: Caja 762. Expediente 6882

- Libro: Signatura: Caja 761. Expediente 6880

- Libro: Signatura: Caja 715. Expediente 6803

- Libro: Signatura: Caja 1200. Expediente 7671

- Libro: Signatura: Caja 764. Expediente 6886

- Libro: Signatura: Caja849. Expediente 7029

- Libro: Signatura: Caja 1139. Expediente 7434

- Libro: Signatura: Caja 753. Expediente 6862

- Prohijamientos y adopciones de menores:

- $\quad$ Signatura: Caja 2449. Expediente 30489

- $\quad$ Signatura: Caja 2449. Expediente 30492

- Partes de movimiento de menores

- $\quad$ Registros de existencias de los centros de acogida de menores:

- Recibos:

○ Signatura: Caja 450. Expediente 4124

- Signatura: Caja 450. Expediente 4125

- Signatura: Caja 476. Expediente 4196

- Suministros: 
- Signatura: Caja 480. Expediente 4218

- Signatura: Caja 480. Expediente 4219

- 1902-03: Signatura: Caja 667. Expediente 6717

- Hospicio Provincial de Valladolid. Estadística general de gastos 1903, 1906: Signatura: Caja 1328. Expediente 10615

- Presupuesto Año 1909: Signatura: Caja 928. Expediente 7140

- Mensual de cuentas. Año de 1913 Oficina: Signatura: Caja 1260. Expediente 7864

- 1915 - Hospicio-Almacén: Signatura: Caja 667. Expediente 6718

- Libro de Certificaciones Año de 1918- 19: Signatura: Caja 6265. Expediente 61890

- Hospicio Provincial Registro de Certificaciones Año económico de 1919- 20: Signatura: Caja 1226. Expediente 7763

- Hospicio Provincial Registro de Certificaciones Año económico de 1921- 22: Signatura: Caja 920. Expediente 7115

- Hospicio Provincial Registro de Certificaciones Año económico de 1922- 23: Signatura: Caja 1333. Expediente 10650

- Hospicio Provincial Registro de Certificaciones Año económico de 1923- 24: Signatura: Caja 1328. Expediente 10614

- Hospicio Provincial Registro de Certificaciones Año económico de 1924 al 1925: Signatura: Caja 1328. Expediente 10613

- 1928: Signatura: Caja 441. Expediente 4091

- 1928: Signatura: Caja 1231. Expediente 7782

- Signatura: Caja 659. Expediente 6704

- Signatura: Caja 962. Expediente 7200

- Registros de maternidad de los centros de acogida de menores:

- Entradas Maternidad 1906, 907 y 1908: Signatura: Caja 929. Expediente 7142

- Hospicio Provincial Maternidad Año de 1863: Signatura: Caja 1228. Expediente 7771

- Archivo Histórico Municipal de Valladolid (AMVA):

- Subvención para el traslado de cadáveres desde los establecimientos de Beneficencia (1919) (signatura:CH255-24)

- Licencia de obras para ampliar instalaciones del Hospicio (1909) (signatura: 598-23)

- $\quad$ Licencia obras, pabellón en el Hospicio (1900) (signatura278-30)

- $\quad$ Obras en el Hospicio (1887-1892) (signatura: CH414-61)

- Recepción de aguas del Pisuerga y fontanero para el Hospicio (1886-87) (signatura: CH313-29)

- Obras para revocar la fachada y colocar canalones (1880) (signatura: CH322-46)

- Acometida de una alcantarilla a la noria de las Moreras (1882) (signatura: 51049- 28)

- Instituto de Puericultura (1864-1947) (signatura: 4301-2)

- $\quad$ Hemeroteca digital del diario El Norte de Castilla: 1895-1931

- Parroquia de San Nicolás de Bari:

- Libro noveno de los bautizados en el Hospicio de esta capital (24 diciembre 1895- 1 mayo 1919)

- Libro undécimo de los bautizados en el Hospicio de esta capital (2 mayo 1919- 17 agosto 1924)

- $\quad$ Libro duodécimo de los bautizados en el Hospicio de esta capital (18 agosto 1924- 31 diciembre 1929

- $\quad$ Libro de Difuntos XII (10- diciembre 1890- 26 septiembre 1920) 
- $\quad$ Libro de Difuntos XIII (1- octubre 1920- 21 agosto 1947)

- Biblioteca de Castilla y León-Biblioteca Pública de Valladolid: Hemeroteca del diario El Norte de Castilla, en microfilmado: 1 enero 1900- 31 diciembre 1920.

\section{Fuentes Orales}

- 63 entrevistas: 49 individuales y 14 grupales, personas nacidas antes de 1935 y criadas en Valladolid o provincias limítrofes.

\section{Fuentes Impresas y Bibliografia Especial}

- $\quad$ (17 de Junio. Publicada en 20) Ley mandando establecer desde luego, con el carácter de provisional, el registro civil en la Península é islas adyacentes, conforme al adjunto proyecto de ley. 1870

- $\quad$ AGAPITO Y REVILLA JUAN: Las calles de Valladolid. Noménclator histórico. Valladolid. Imprenta y Librería Casa Martín. 1937. Disponible en formato digital en la Biblioteca Digital de Castilla y León en: http://bibliotecadigital.jcyl.es/es/catalogo_imagenes/grupo.cmd?path=10065868

- $\quad$ ALONSO Y RUBIO FRANCISCO: Manual del arte de Obstetricia para uso de las matronas por el doctor D. Francisco Alonso y Rubio. Catedrático de Clínica de Obstetricia de la Facultad de Medicina en la Universidad Central. Madrid Imprenta Nacional. 1866

- $\quad$ ARRAZOLA LORENZO y col: Enciclopedia española de derecho y administración o Nuevo teatro universal de la legislación de España e Indias. Tomo VII. Madrid. Tipografía General de Antonio Rius y Rossell. 1848-1870

- $\quad$ BILBAO ANTONIO DE: Destrucción y conservación de los expósitos: idea de la perfección de este ramo de policía: modo breve de poblar la España y testamento. Antequera 1789. Disponible en: https://books.google.es/books/about/Destrucci\%C3\%B3n_y_conservaci\%C3\%B3n_de_los_exp.htm I?id=FqbInoiTj2sC\&redir_esc=y

- $\quad$ BUXÓ IZAGUIRRE POLIÓN: Enfermedades de los niños de pecho. Madrid. Morata, 1945

- Casa Provincial de Maternidad y Expósitos de Barcelona. Inclusa. Estudio demográfico- médico del quinquenio 1883 á 1887 por los doctores D. Juan de Rull y D. José Cabot. Barcelona Tipografía de la Casa provincial de Caridad. 1889

- $\quad$ CASAS DE BATISTA ROGELIO: Fare y D’Huc. Tratado elemental de las enfermedades de la mujer y del niño. Nueva edición notablemente reformada y adicionada con los adelantos más modernos é importantes de la especialidad, según las obras y trabajos de Churchill, Scanzoni, Bedford, Corral, Saura, Alonso, Henry Roger, Rilliet y Barthez, Bouchut, Fischer y Bricheteau y otros por Don Rogelio Casas de Batista. Doctor de la Universidad Central, Profesor clínico por oposición en la facultad de Medicina de la misma; condecorado con las cruces de primera y segunda clase de la Orden Civil de Beneficencia, por juicio contradictorio, etc., etc. Madrid. Carlos Bailly-Bailliere. 1870

- $\quad$ COVARRUBIAS SEBASTIÁN DE: Tesoro de la lengua castellana o española. Madrid. 1611

- Diccionario de la lengua castellana, en que se explica el verdadero sentido de las voces, su naturaleza y calidad, con las phrases o modos de hablar, los proverbios o refranes, y otras cosas convenientes al uso de la lengua [...]. Diccionario de Autoridades 1726- 1739. RAE. 
Diccionario de la lengua castellana por la Real Academia Española. RAE. Madrid: 13a edición 1899; 14a edición 1914; 15a edición 1925.

- Diccionario de Antonio de Nebrija. Salamanca. Impresor de la gramática castellana. 1495?

- El Financiero Hispano Americano. Extraordinario Valladolid. Año 1911. Disponible en la Biblioteca Digital de Castilla y León en:

http://bibliotecadigital.jcyl.es/es/catalogo_imagenes/grupo.cmd?path=10067831

- Enciclopedia Universal Ilustrada Europeo-Americana. Barcelona. José Espasa e hijos Editores. 19081925

- Estatutos que se han formado por la Real Junta de Hospicio para el Régimen, y Gobierno de la Casa de Misericordia, establecida en esta Ciudad de Valladolid, que ha de estar al cuidado de la Caritativa, y Piadosa Congregación de Nuestra señora de la Misericordia. Impreso en dicha ciudad en la Imprenta de la Viuda de D. Tomás de Santander. Valladolid 1785. Disponible en formato digital en la Biblioteca Digital de Castilla y León en:

http://bibliotecadigital.jcyl.es/i18n/consulta/registro.cmd?id=994

- GONZÁLEZ GARCÍA VALLADOLID CASIMIRO: Valladolid. Sus recuerdos y sus grandezas. Religión, Historia, Ciencias, Literatura, Industria, Comercio y Política. Valladolid. Imprenta de Juan Rodríguez Hernando. Tomo I, 1900. Tomo II, 1901. Tomo III, 1902. Disponibles en formato digital en la Biblioteca Digital de Castilla y León en:

http://bibliotecadigital.jcyl.es/es/consulta/resultados_ocr.cmd?buscar_cabecera=Buscar\&tipo=ele m\&id=15887\&forma=\&tipoResultados=BIB\&posicion=21

- $\quad$ Guía Anuario de Valladolid y su provincia. Valladolid, Santarén, 1922.

- Guía Anuario de Valladolid y su provincia. Valladolid, Santarén, 1927.

- Instituto Nacional de Estadística (INE). INEbase/Historia. Fondo documental. Disponible en: http://www.ine.es/inebaseweb/hist.do

- $\quad$ Anuarios Estadísticos de España de 1900 a 1930. Disponibles en:

http://www.ine.es/inebaseweb/libros.do?tntp $=25687$

- Censos de Población. Provincia de Valladolid

- Censo de 1900. Valladolid. Disponible en: http://www.ine.es/inebaseweb/pdfDispacher.do?td=69595\&ext=.pdf

- Censo de 1910. Valladolid. Disponible en: http://www.ine.es/inebaseweb/pdfDispacher.do?td=79830\&ext=.pdf

- Censo de 1920. Valladolid. Disponible en: http://www.ine.es/inebaseweb/pdfDispacher.do?td=85891\&ext=.pdf

- Censo de 1930. Valladolid. Disponible en: http://www.ine.es/inebaseweb/pdfDispacher.do?td=98574\&ext=.pdf

- Movimiento Natural de la Población. Siglo XX. Desde 1900 hasta 1930. Disponibles en: http://www.ine.es/inebaseweb/libros.do?tntp=205002

- Ley, mandando establecer desde luego, con el carácter de provisional, el Registro civil en la península é islas adyacentes, conforme al adjunto proyecto de ley (17 Junio 1870, publicada en 20). Disponible en: http://legishca.edu.umh.es/2015/08/16/1870-06-17-establecimiento-del-registrocivil/

- $\quad$ MARFAN Profesor y col.: Pediatría. Tomo I. Barcelona. Editorial Pubul. 1925

- MERINO ARROYO CARLOS, HERRERO, GÓMEZ GUILLERMO: La vida cotidiana en Valladolid a principios del siglo XX (Encuesta del ateneo 1901- 1902). Valladolid. Castilla Ediciones; 1999.

- Novísima Recopilación de las Leyes de España. Dividida en XII Libros. En que se reforma la Recopilación publicada por el señor Don Felipe II, en el año 1567, reimpresa últimamente en el de 1775: Y se incorporan las pragmáticas, cédulas, decretos, órdenes y resoluciones Reales, y otras 
providencias no recopiladas, y expedidas hasta el 1804. Mandada formar por el señor Don Carlos IV. Impresa en Madrid Año 1805.

Disponible en: http://fama2.us.es/fde/ocr/2006/novisimaRecopilacionT1.pdf

- Ordenanzas de la Real Casa de Misericordia de Valladolid. Ordenanzas para el Gobierno y Dirección de la Real Casa de Misericordia, y Expósitos de la Ciudad de Valladolid, dispuestas por el doctor don Juan Bautista Sacristán y Galiano, del Consejo de S. M. Inquisidor de Provincia, doctoral de su Santa Iglesia Catedral, director único, y juez conservador por S. M. de dichos establecimientos, y electo arzobispo de Santa Fe de Bogotá. Madrid, Imprenta de Don Josef del Collado. 1806. Disponible en formato digital en la Biblioteca Digital de Castilla y León en:

http://bibliotecadigital.jcyl.es/es/catalogo_imagenes/grupo.cmd?path=10066047\#search="Ordena nzas+para+el+gobierno+y+direcci\%C3\%B3n+de+la+Real+Casa+de+Misericordia+y+Exp\%C3\%B3sito s+de+la+ciudad+de+Valladolid\%2C"

- $\quad$ ORTEGA Y RUBIO JUAN: Historia de Valladolid (1881). Valladolid. Grupo Pinciano. Edición facsímil. 1991

- ORTEGA Y RUBIO JUAN: Los pueblos de la provincia de Valladolid. Tomo I y II. Valladolid. Palacio de la Diputación. Imprenta y Encuadernación del Hospicio Provincial. 1895. Disponible en formato digital en la Biblioteca Digital de Castilla y León en:

http://bibliotecadigital.jcyl.es/es/consulta/resultados_ocr.cmd?buscar_cabecera=Buscar\&tipo=ele $m \& i d=41 \&$ tipoResultados=BIB\&posicion=33\&forma=ficha

- Patronato de Niños Desamparados de Valladolid-Memoria-Circular. Valladolid: Tipografía y Casa editorial Cuesta, 1907. Copia digital. Biblioteca de Castilla y León. Valladolid: Junta de Castilla y León. Consejería de Cultura y Turismo, 2009-2010. Disponible en formato digital en la Biblioteca Digital de Castilla y León en:

http://bibliotecadigital.jcyl.es/i18n/catalogo_imagenes/grupo.cmd?path=10068372

- Presupuesto general de ingresos y gastos: Año 1924/1925-Valladolid (Provincia). Diputación Provincial. Valladolid.1925. Diputación Provincial. Imprenta del Hospicio Provincial. Disponible en formato digital en la Biblioteca Digital de Castilla y León:

http://bibliotecadigital.jcyl.es/es/consulta/registro.cmd?id=10000051262

- Presupuesto general de ingresos y gastos: Año 1928 - Valladolid (Provincia). Diputación Provincial. Valladolid.1928. Diputación Provincial. Imprenta del Hospicio Provincial Disponible en formato digital en la Biblioteca Digital de Castilla y León:

http://bibliotecadigital.jcyl.es/es/consulta/registro.cmd?id=10000051263

- RAMOS RAFAEL.: Puericultura: higiene, educación y alimentación en la primera infancia (del nacimiento a los tres años). Tomo I. Barcelona. s.e. 1941

- RAMOS RAFAEL: Puericultura: higiene, educación y alimentación en la segunda infancia (niños de tres a siete años). Tomo II". Salamanca s.e. 1938

- $\quad$ RAPIN D: Manual práctico de partos para uso de comadrones y parteras, por el Dr D. Rapín de la Universidad de Lausana. Traducido al español por el Dr. F. Corominas y Pedemonte. Barcelona. José Espasa editor s.a.

- Real Decreto de 24 de julio de 1889, texto de la edición del Código Civil mandada publicar en cumplimiento de la Ley de 26 de mayo último. Gaceta de Madrid de 25 de julio de 1889

- Reglamento de la Inclusa y Colegio de la Paz de Madrid. Madrid. Imprenta de D José María Alonso. 1849. Disponible en: http://babel.hathitrust.org/cgi/pt?id=ucm.5320308031;view=1up;seq=1

- Reglamento para el régimen interior del Hospicio Provincial de Valladolid. Hospicio Provincial de Valladolid. Imprenta de hijos de J. Pastor. Valladolid 1889. Disponible en formato digital en el Repositorio documental de la Universidad de Valladolid:

http://uvadoc.uva.es/bitstream/10324/3781/1/Leg.\%202-3\%20n\%C2\%BA\%20153.pdf

- Reglamento para el régimen interior del Hospicio Provincial de Valladolid. Diputación Provincial de Valladolid. Imprenta y Encuadernación del Hospicio Provincial. Valladolid 1910. Disponible en 
formato digital en la Biblioteca Digital de Castilla y León:

http://bibliotecadigital.jcyl.es/i18n/catalogo_imagenes/grupo.cmd?path=10067546

- $\quad$ Reglamento para el régimen interior del Hospicio Provincial de Valladolid. Diputación Provincial de Valladolid. Imprenta y Encuadernación del Hospicio Provincial. Valladolid 1927. Disponible en formato digital en la Biblioteca Digital de Castilla y León:

http://bibliotecadigital.jcyl.es/i18n/catalogo_imagenes/grupo.cmd?path=10067548

- $\quad$ Reglamento para la ejecución de las leyes de matrimonio y Registro civil. Gaceta de Madrid 14 de diciembre de 1870. Disponible en: $\quad$ http://legishca.edu.umh.es/2015/08/16/1870-12-13reglamento-para-la-ejecucion-de-las-leyes-de-matrimonio-y-registro-civil/

- $\quad$ ROMERO FRAILE EDUARDO: Mortalidad infantil de Valladolid. sus principales causas y medios de combatirla. Discurso del Académico electo Dr. Eduardo Romero y Frayle...el día 31 de enero de 1909. En: V.V.A.A. Valladolid un siglo de cuestión social (1840-1940). Valladolid. Grupo Pinciano. 1995, pp 261-301

- $\quad$ SALAZAR DE MENDOZA P.: Crónica de el gran Cardenal de España don Pedro Gonçalez de Mendoça, Arçobispo de la muy Santa Yglesia Primada de las Españas. Toledo, imprenta de doña María Ortiz de Sarauia. 1625. Copia digital disponible en Biblioteca Digital de Castilla y León: https://bibliotecadigital.jcyl.es/es/consulta/registro.cmd?id=13377

- $\quad$ SieRra y VAl SALVINO, MUÑOz EUgenio: Memoria de Higiene y estadística de la ciudad de Valladolid. 1896. En: V.V.A.A. Valladolid un siglo de cuestión social (1840-1940). Valladolid. Grupo Pinciano. 1995, pp 189-234

- $\quad$ SUÑER Y ORDÓÑEZ ENRIQUE: Enfermedades de la infancia (doctrina y clínica). Tomos I, II y III. Valladolid. Talleres Tipográficos Cuesta. 1a edición 1918 y 2a edic 1921.

- $\quad$ SUÑER Y ORDÓÑEZ ENRIQUE: Fisiología y clínica de la nutrición del lactante. Madrid. Ed. Fax, 1933?

- $\quad$ SUÑER Y ORDÓÑEZ ENRIQUE: La salud del niño (Puericultura fundamental). Madrid. Ed. Fax, 1920.

- $\quad$ VELASCO Y LLAMAS SAMUEL: Puericultura. Buenos Aires. Editorial Caymi. 1897

- $\quad$ VIDAL SOLARES FRANCISCO: Puericultura e higiene de la primera infancia. Barcelona. Luis Gili, 1915

\section{Bibliografia General}

- $\quad$ ALARCÓn MARQUEZ ARIAN J: Los expósitos de la Hijuela de Vera (1736- 1901). Trabajo Fin de Máster, Tutora Carmen González Canalejo. Almería. Universidad de Almería. 2013

- $\quad$ ALCALDE MARTín- CALERO CARLOS: Agregación de las obras Pías de Valladolid y su obispado a la Real casa de Misericordia, 1783 y 1805: La sección de Obras Pías del Archivo de la Diputación Provincial de Valladolid. En: Investigaciones históricas: época moderna y contemporánea, n. 20 Valladolid. Universidad de Valladolid, 2000, pp. 353-438

- $\quad$ ÁLVAREZ SANTALÓ LEÓN C: Marginación social y mentalidad en Andalucía occidental: Expósitos en Sevilla (1613-1910). Sevilla. Consejería de Cultura de la Junta de Andalucía, 1980

- $\quad$ ANTA MUÑOZ ANTONIO DE: La Diputación Provincial de Valladolid en el siglo XIX (1813-1874), Tesis doctoral defendida en el Departamento de Historia Moderna, Contemporánea, de América, Periodismo y Comunicación Audiovisual y Publicidad; Universidad de Valladolid, 2012.

- $\quad$ ARANA AMURRIO jOSÉ IgNACIO DE: Historia de la Inclusa de Madrid. Cuadernos de Historia de la Pediatría Española. 2012, № 4, dic, pp 20- 31

- $\quad$ ARBElo CURBElo ANTONIO: La mortalidad de la infancia en España 1901-1950. Madrid. Centro Superior de Investigaciones Científicas. Instituto Balnes de Sociología. Dirección General de Sanidad. 1962 
ARIÈS PHILIPPE: El Niño y la Vida Familiar en el Antiguo Régimen. Madrid. Taurus Ediciones.1987

ARIÈS PHILIPPE, DUBY GEORGES dir: Historia de la vida privada. 4 De la Europa Revolución Francesa a la Primera Guerra Mundial. Madrid. Taurus. 2001

- $\quad$ BANDURA ALBERT: Aprendizaje social y desarrollo de la personalidad. Madrid. Alianza. 1977

BANDURA ALBERT.: Teoría del aprendizaje social. Madrid. Espasa-Calpe. 1987

BABINI JOSÉ.: Historia de la Medicina. Barcelona. Gedisa.1980

BAKER JEFFREY P: The Incubator and the Medical Discovery of the Premature Infant. Journal of Perinatology 2000; no 5, pp 321-328.

- $\quad$ BARNESS LEWIS A: Brief history of infant nutrition and view to the future. Pediatrics, $\mathrm{n}$ - 88. 1991, pp 1054- 1056

BARÓ PAZOS JUAN: La codificación del derecho civil en España (1808-1889) Santander. Servicio de Publicaciones de la Universidad de Cantabria. 1992

- $\quad$ BIEDMA LÓPEZ ESTÍBALIZ: Aproximación al estudio de la Helioterapia. Revisión histórica. Medicina Naturista. 2007, vol. 1, no 2, pp 86- 100.

- $\quad$ BOEHN MAX VON, MORALES Ma LUZ: La moda. Historia del traje en Europa, no 9. Siglo XX: 19001920 Barcelona. Salvat. 1956.

BOIX BARRIOS JOSÉ: Manual de puericultura. Valencia. Librerías de F. García Muñoz, imp. 1941

- $\quad$ BORRÁS LLOP JOSÉ M: Historia de la Infancia en la España Contemporánea. 1834-1936. Madrid. Ministerio de Trabajo y Asuntos sociales, Fundación Germán Sánchez Ruipérez. 1996.

- $\quad$ BOSCH MARÍN JUAN: El niño español en el siglo XX. Discurso de recepción en la R.A.N. de Medicina. Madrid. Publicaciones "Al servicio de España y del niño español"; n. 109-112. Gráf. González. 1947

BOSWEL JOHN: L'abbandono dei bambini in Europa. s.l. Res Gestae. 2016

- BOUCHER FRANÇOIS: Historia del traje en occidente: desde la antigüedad a nuestros días. Barcelona. Montaner y Simón. 1967

- $\quad$ BUENDÍA MUÑOZ ALEJANDRO. y GARCÍA MORALES INMACULADA: La Enfermería en la Almería de los Siglos XVIII y XIX. Cuidados y cuidadores. Almería. Colegio de Enfermería de Almería. 2003.

- $\quad$ CABRÉ I PAIRET MONTSERRAT, ORTIZ GÓMEZ TERESA (edts): Sanadoras, matronas y médicas en Europa. Siglos XII-XX. Barcelona. Ed. Icaria. 2001.

- CABRERA ESPINOSA MANUEL: La lactancia como profesión. Una mirada al oficio de nodriza. IV Congreso Virtual sobre historia de las Mujeres. Jaén. Asociación de amigos del archivo histórico de Jaén. 2012, pp 1- 12

- $\quad$ CANO GONZÁLEZ RUFINO: La Diputación Provincial de Valladolid: campos de asistencia educativa y establecimientos dedicados a la infancia (1812-1900). Madrid. Tesis doctoral. Departamento de Historia de la Educación UNED. 1994

- CANO gONZÁlez RUfinO, REVUELTA GUERRERO CLARA: Educación y enseñanza en la Casa Hospicio de la Diputación Provincial de Valladolid (1723-1900). Badajoz. Ed. Abecedario. 2007

- $\quad$ CARANDELL LUIS: El Santoral de Luis Carandell. Madrid. Maeva ediciones. 1996

- $\quad$ CARASA SOTO PEDRO: Pobreza y asistencia social. Burgos. Caja de Ahorros Municipal de Burgos. 1992

- $\quad$ CARASA SOTO PEDRO, MARCOS DEL OLMO CONCEPCIÓN, MARTíNEZ FERRNÁNDEZ M, MARTíN DE LA GUARDIA RICARDO, PÉREZ SÁNCHEZ GUILLERMO: Alfonso XIII y la Segunda República. Editorial Gredos, 1991. Burgos. Caja de Ahorros Municipal de Burgos. 1992

CARBALLO BARRAL BORJA: La Beneficencia Municipal de Madrid en el cambio de siglo: el funcionamiento de las Casas de Socorro (1896-1915). En: Modernizar España 1898-1914. Madrid. Congreso Internacional de Dpto. Hạ Contemporánea de la UCM. 20-22 abril 2006. 
CARMONA-GONZÁLEZ INMACULADA, SAIZ-PUENTE Mạ SOLEDAD: El bautismo de urgencia, función tradicional de las matronas. Matronas Prof. 2009; no 10, 4, pp 14-19

- CASADO LOBATO CONCHA: La indumentaria tradicional en las comarcas leonesas. León Diputación de León. 1993

- COWEN PABLO: Nacimientos, partos y problemas de la primera infancia, fines del siglo XVIII, primeras décadas del Siglo XIX. En: MORENO JOSÉ LUIS, La política social antes de la política social. Caridad, beneficencia y política social en Buenos Aires, siglos XVII a XX.Buenos Aires. Trama editorial/Prometeo, 2000.

- CUSSÓ SEgURA XAVIER, GARRABOU SEGURA RAMÓN: La transición nutricional en la España contemporánea: Las variaciones en el consumo de pan, patatas y legumbres (1850-2000). Investigaciones de Historia Económica. 2007 invierno; no 7, pp 69 -100

- $\quad$ DEMERSON PAULA: La Inclusa de Madrid. Historia 16, 90. 1983, pp33-40

- $\quad$ EGIDO TEÓfANES: La Cofradía de San José y los niños expósitos de Valladolid (1540-1757). Revista de Estudios Josefinos. 1973, no 53-54, pp 232- 259

- $\quad$ ERIKSON ERIK H.: Infancia y sociedad. Buenos Aires. Horme-Paidós. 1983

- $\quad$ ERIKSON ERIK.H.: El ciclo vital completado. Barcelona. Ediciones Paidós Ibérica. 1985

- $\quad$ ESPÍN CÁNOVAS DIEGO: La Constitución de 1869 y la legislación civil española hasta 1874 Revista de estudios políticos, № 163, 1969, pp 117-13. Disponible en:

https://dialnet.unirioja.es/buscar/documentos?querysDismax.DOCUMENTAL_TODO=LA+CONSTIT UCI\%C3\%93N+DE+1869+Y+LA+LEGISLACI\%C3\%93N+CIVIL+ESPA\%C3\%910LA+HASTA+1874+

- $\quad$ ESPINA PÉREZ PEDRO: Historia de la Inclusa de Madrid. Vista a través de los artículos y trabajos históricos Años 1400- 2000. Madrid. Edita oficina del Defensor del Menor en la Comunidad de Madrid, 2005. Disponible en: http://www.biblioteca.org.ar/libros/200135.pdf

- $\quad$ FERNÁNDEZ ARUfe JOSEFA EUGENIA, OGANDO CANABAL OLGA: La economía de la provincia de Valladolid Almería. Fundación Cajamar. 2011.

- $\quad$ FERNÁNDEZ MARTIN LUIS: Construcción de nueva planta del antiguo teatro de Valladolid 16091610. Valladolid. Castilla: Estudios de literatura. 1995. № 20, pp 105-124

- $\quad$ FERNÁNDEZ PÉREZ ENRIQUE ANTONIO: El nombre y los apellidos. Su regulación en derecho español y comparado. Tesis doctoral, Derecho Civil. Sevilla. Universidad de Sevilla. 2015

- $\quad$ FLANDRIN JEAN L, MONTANARI MASSIMO: Historia de la Alimentación. Gijón. Ediciones Trea. 2004

- $\quad$ FLECHA GARCÍA CONSUELO: La educación de la mujer según las primeras doctoras en Medicina de la Universidad Española. Año 1882. Acta Hispanica ad Medicinae Scientiarumque Historiam Illustrandam. 1999, vol. 19, pp 241- 278

- $\quad$ FRAILE GIL JOSÉ MANUEL: Amas de cría, campesinas en la urbe. Revista de Folklore no 221. Valladolid. obra social y cultural de caja España. 1999, pp 147- 159

- $\quad$ FUENTE GALÁN Ma PRADO DE LA: La situación de las inclusas en el siglo XVIII. La encuesta de 1790. Chronica Nova. 1997, no 24, pp 61-78

- $\quad$ FUENTE NUÑEZ RUBÉN DE LA: Evolución histórica de Segovia. 1900- 1936. Tesis doctoral defendida en el Departamento de Historia Contemporánea, Universidad Complutense de Madrid, Madrid 2007.

- $\quad$ GANSO PÉREZ ANA ISABEL: Las parteras, un arte de mujeres para Mujeres. Una investigación sobre el Pasado. Tesis doctoral. Programa: Mujer y género en los estudios de humanidades. Departamento de Historia Antigua y Medieval. Facultad de Filosofía y Letras. Universidad de Valladolid. 2016

- $\quad$ GARCÍA ESTEBAN ARACELI: De los Centros de Acogida a las Instituciones Sanitarias. Evolución de la Política Socio-Sanitaria en la ciudad de Segovia: Siglos XV-XIX. Segovia. Diputación Provincial de Segovia. 2002 
GARCÍA GONZÁLEZ MARIANA: Hijas de la caridad. Precursoras de la Enfermería. En: Salud y enfermedad en los tiempos de las Cortes de Cádiz. Cádiz. Servicio de Publicaciones de la Universidad de Cádiz. Sílex ediciones S.L. 2013, pp 223-236

GOERLICH GISBERT FRANCISCO JOSÉ, PINILLA PALLEJÁ RAFAEL: Esperanza de vida en España a lo largo del siglo XX. Las tablas de mortalidad del Instituto Nacional de Estadística. Bilbao. Fundación BBVA. 2006

GÓMEZ URDÁÑEZ JOSÉ LUIS: La Real Casa de Misericordia de Zaragoza, cárcel de gitanas (1752 1763). En. GARCÍA FERNÁNDEZ MÁXIMO, SOBALER SECO Mạ DE LOS ANGELES coord. Estudios en homenaje al profesor Teófanes Egido. Valladolid. Edita Junta de Castilla y León. Consejería de Cultura y Turismo. 2004, pp 329- 344

GONZÁLEZ CANALEJO CARMEN: Asistencia sanitaria, género y cuestión social en Almería (18571930). Almería. Tesis doctoral. Departamento de Historia, Geografía, Historia del Arte y Sociología, Universidad de Almería. 2005

GONZÁlEZ CANALEJO CARMEN: Las Cuidadoras. Historia de las practicantas, matronas y enfermeras (1857-1936). Almería. Instituto de Estudios Almerienses. 2006

- $\quad$ GONZÁLEZ NÚÑEZ JOSÉ: La Historia Oculta de la Humanidad. Barcelona. Ars Médica. 2006

- $\quad$ GRANJEL MERCEDES: Mortalidad de expósitos y lactancia mercenaria en la alta Extremadura: 19151925. En: REHER SULLIVAN D. S. coord. Actas do III Congresso da ADEH (Associaçao Ibérica de Demografia Histórica), Braga 1993, vol. 3. 1996, págs. 303-330

- $\quad$ HARRIS MARTIN, ROSS ERIC B: Muerte, Sexo y Fecundidad. La regulación demográfica en las sociedades preindustriales y en desarrollo. Madrid: Alianza Universidad. 1991

- $\quad$ HERNÁNDEZ MARTÍN FRANCISCA: Las Hijas de la Caridad en la profesionalización de la Enfermería. Cultura de los Cuidados. 2006, no 20, pp 39- 49

HERNANDO GARRIDO JOSÉ LUIS: Los niños expósitos en tierras de Zamora durante el Antiguo Régimen. Revista de Folklore. Fundación Joaquín Díaz; 2912, edición digital no 364, pp 4 -16.

- $\quad$ JIMÉNEZ LÓPEZ ANTONIO R.: Vida y muerte en la Inclusa de Madrid en el primer año de posguerra. UNED. Espacio, Tiempo y Forma Serie V, Historia Contemporánea. № 25, 2013, pp 369- 386

- $\quad$ LERA de ISLA, ANGEL: Bautizos, bodas y entierros. Valladolid. Cuadernos Vallisoletanos. Ed. Caja de Ahorros, 1986

LIMÓN DELGADO ANTONIO, CASTELLONE HERRERO EULALIA: “El ciclo vital en España (encuesta del Ateneo de Madrid, 1901-1902) I. 2. Nacimiento: (alumbramiento, bautizo, hijos ilegítimos). Madrid. Ministerio de Cultura, Dirección General de Bellas Artes y Archivos. Edición Crítica. 1990

- $\quad$ LIZARRÁGA VIZCARRA ISABEL: Libertad (1931), de María Martínez Sierra: La mujer española frente al Código Civil. Logroño. Ilusión y compromiso: II Jornadas sobre María Lejarraga. 2002, pp 35-81

- LÓPEZ DE LETONA C: La pomada antioftálmica de la viuda Farnier. Archivos de la Sociedad Española de Oftalmología. № 6 - Junio 2000. Disponible en:

http://www.oftalmo.com/seo/archivos/articulo.php?idSolicitud=687\&numR=6\&mesR=6\&anioR=2 000\&idR=34

- $\quad$ LÓPEZ PIÑERO, JOSÉ MARÍA, BRINES SOlANES JUAN: Historia de la Pediatría. Valencia. Albatros. 2009.

- MARCOS DEL OLMO CONCEPCIÓN, SERRANO GARCÍA RAFAEL: Mujer y política en la España contemporánea (1868-1936). Valladolid .Universidad de Valladolid. Secretariado de Publicaciones e Intercambio Editorial. 2012

- MARCOS MARTín ALBERTO: De esclavos a señores. Estudios de Historia Moderna. Valladolid, Universidad de Valladolid, 1992

- $\quad$ MARTÍN DE LA GUARDIA RICARDO, PÉREZ LÓPEZ PABLO, PÉREZ SÁNCHEZ GUILLERMO: La sociedad vallisoletana a comienzos del siglo XX: Comportamientos ante el nacimiento, matrimonio $y$ muerte. Investigaciones históricas: Época moderna y contemporánea, no 9, 1989, pp 251- 286 
- MARTÍN DE UÑA JOAQUÍN: Valladolid, una ciudad contada. Valladolid. Ayuntamiento de Valladolid. 1999

- MARTÍN ESPINOSA NOELIA M, COBO CUENCA ANA I: La mortalidad infantil y sus causas en la inclusa de Toledo entre 1900-1910. Cultura de los Cuidados. 2013, Año XVII, 1ㅇ cuatrimestre, n. ${ }^{\circ} 35$; pp 55-62. Disponible en: http://dx.doi.org/10.7184/cuid.2013.35.05

- MARTín GONZÁLEZ JUAN JOSÉ: Monumentos civiles de la ciudad de Valladolid. Valladolid. Institución cultural Simancas. 2a edición. 1983

- $\quad$ MARTÍN JIMÉNEZ IGNACIO: La sociedad vallisoletana en los albores del siglo XX. Comportamientos ante los hitos vitales. Valladolid. Diputación provincial de Valladolid. 2004

- $\quad$ MARTÍNEZ-GÓMEZ SIMÓN LUIS M: Las instituciones de atención social al menor en la ciudad de Albacete. Albacete. Instituto de Estudios Albacetenses "Don Juan Manuel" de la Excma. Diputación de Albacete. 2002

- MARTÍNEZ VARGAS ANDRÉS: Historia de la pediatría en España. Madrid. s.e. 1946

- $\quad$ MAZA ZORRILLA ELENA: Valladolid: sus pobres y la respuesta institucional (1750- 1790). Valladolid. Universidad de Valladolid. 1985

- MAZA ZORRILLA ELENA: Pobreza y asistencia social en España, siglos XVI al XX. Aproximación histórica. Valladolid. Universidad de Valladolid. 1987

- MAZA ZORRILLA ELENA: Asistencia social en Castilla-León. Actas del Congreso Internacional CIII Madrid. 1990

- MAZA ZORRILLA ELENA: Pobreza, trabajo y sociabilidad (siglos XIX- XX). En: Valladolid Historia de una ciudad. Época Contemporánea. Valladolid. Congreso Internacional Ayuntamiento de Valladolid. 1999, pp 859- 888

- $\quad$ MAZA ZORRILLA ELENA: Pobreza y beneficencia en la España contemporánea (1808-1936). Barcelona. Ariel. 1999

- $\quad$ MCLAUGHLIN MARTIN M: Supervivientes y sustitutos. Hijos y padres del siglo IX al siglo XIII. En: DEMAUSE LLOYD: Historia de la infancia. Madrid. Edit. Alianza Universidad. 1982, pp 121- 205.

- MERINO ARROYO CARLOS, HERRERO GÓMEZ GUILLERMO: La vida cotidiana en Valladolid a principios del siglo XX (Encuesta del Ateneo 1901-1902). Valladolid. Castilla Ediciones. 1999

- $\quad$ MIGUEL AMANDO DE: La vida cotidiana de los españoles en el siglo XX. Barcelona. Editorial Planeta Historia y Sociedad. 2001

- $\quad$ MIRA CABALLOS ESTEBAN: Expósitos en Tierra de Barros en la Edad Moderna. Unos apuntes. Actas de las IV Jornadas de Almendralejo y Tierra de Barros. Almendralejo. Asociación Histórica de Almendralejo. 2013, pp. 361-376. Disponible en:

https://dialnet.unirioja.es/servlet/articulo?codigo=4573773

- MIRALles SANGRo MARIA TERESA: Pequeña historia del biberón. Madrid. Colegio oficial de Diplomados en Enfermería de Madrid. 2012

- MONTANARI MASSIMO: El hambre y la abundancia. Historia y cultura de la alimentación en Europa. Barcelona. Ed Crítica. 1993

- MONTESINOS VICENTE FERNANDO: Practicantes, Matronas y Cirujanos dentistas en la España Contemporánea (1855- 1932). Gerona. Tesis doctoral defendida en el Departamento de Geografía, Historia e Historia del Arte de la facultad de Letras de la Universidad de Gerona. 2011.

- MONTIEL PASTOR JOSÉ: Anar per tornar. La Casa Provincial de Maternitat i Expòsits de Barcelona com a centre d'una xarxa de re-distribució de la població infantil (1853-1936). XI Congrés d'Història de Barcelona - La ciutat en xarxa. Archivo Histórico de la Ciudad de Barcelona, Instituto de Cultura, Ayuntamiento de Barcelona, 2009

- MORAL TERESA DEL, BANCALARI EDUARDO: Evolución de la actitud frente al recién nacido prematuro. Bol Pediatr 2010; no 50, Supl. 1, pp 39-42 
MORALES ALVAREZ ÁNGEL: Casa Cuna de Ponferrada 1775-1937. Ponferrada. Instituto de Estudios Bercianos. 2001

- MORALES JOSÉ LUIS: El niño en la cultura española: (ante la medicina y otras ciencias; la historia, las letras, las artes y las costumbres). Tomo I: Biografías, obras beneficosociales, legislación. Madrid. s.e. 1960.

- MORALES JOSÉ LUIS: El niño en la cultura española: (ante la medicina y otras ciencias; la historia, las letras, las artes y las costumbres). Tomo II: El niño y las bellas artes (pintura, escultura y música), el niño y la literatura, ex-libri. Madrid. s.e. 1960.

- MORENO LÁZARO JAVIER: El nivel de vida en la España atrasada entre 1800 y 1936. El caso de Palencia. Investigaciones de Historia económica. 2006, no 4, invierno: p. 9 -50. Disponible en: http://ihe.aehe.net/numero.php?n=4

- MORENO LÁZARO JAVIER: La economía de Valladolid, 1830-2000. Una perspectiva histórica. Documentos de trabajo AEHE (Asociación española de Historia Económica). 2010, no 10, sept.

- MORENO LÁZARO JAVIER: Una perspectiva histórica. En: FERNÁNDEZ ARUFE JOSEFA EUGENIA, OGANDO CANABAL OLGA: La economía de la provincia de Valladolid. Almería. Fundación Cajamar. 2011, pp. $37-78$

- MUÑOZ LÓPEZ PILAR: Sangre, amor e interés. La familia en la España de la Restauración. Madrid. Marcial Pons Historia. Ediciones de la Universidad Autónoma de Madrid. 2001

MUÑOZ MUÑOZ M DOLORES: Recopilación legislativa sobre las Diputaciones Provinciales. Boletín del Instituto de Estudios Giennenses. 2013, no207 Enero-Junio, pp. 59-94

- $\quad$ NAVAS JUAN DE: Elementos del arte de partear. Madrid. Imprenta Real. 1795

- NEILA MUÑOZ CARLOS MARÍA: Etnohistoria del abandono. Los expósitos en los registros civiles (1871-1949). El caso de Trujillo (Cáceres). Trujillo. Asociación Cultural Coloquios Históricos de Extremadura, sept. 2011

- PAlOMARES IBÁÑEZ JeSÚS MARÍA: La Asistencia Social en Valladolid. El Hospicio de Pobres y la Real Casa de la Misericordia (1724- 1847). Valladolid. Servicio de publicaciones de la Diputación Provincial de Valladolid. 1975

- PASTRANA MORILla HelIOdORO: La Diputación Provincial de Valladolid 1875-1930. Política y Gestión. Valladolid. Diputación Provincial de Valladolid 1997, pp 208- 235

- PÉREZ MOREDA VICENTE: La infancia abandonada en España: (siglos XVI-XX). Discurso de ingreso en la Real Academia de la Historia (8 de mayo de 2005). Madrid. Real Academia de la Historia. 2005

- PÉREZ MOREDA VICENTE: La infancia abandonada en España: (siglos XVI-XX). Discurso de ingreso en la Real Academia de la Historia (8 de mayo de 2005). Separata. Madrid. Mensajeros de la Paz, no 14. 2005

- PLANESAS bigAS PERE: La hora oficial en España y sus cambios. Anuario del Observatorio Astronómico de Madrid para el año 2013 (IGN). Observatorio Astronómico Nacional. Instituto Geográfico Nacional-Ministerio de Fomento. 2013, pp 373-402. Disponible en: http://astronomia.ign.es/rknowsystheme/images/webAstro/paginas/documentos/Anuario/lahoraoficialenespana.pdf

PORRO FERNÁNDEZ CARLOS ANTONIO: "Notas sobre indumentaria infantil en Castilla y León". Revista de Folklore. №263. Año 2003, pp 96-108

- PROST ANTOINE, VICENTE GÉRARD.: Historia de la vida privada, 9, La vida privada en el siglo XX. Madrid. Taurus, 1991

- RECHE ANDRÉS JOSÉ: La Pediatría española a través de la revista "La Medicina de los niños, 19001936". Madrid. Departamento de Historia de la Medicina. Universidad Complutense. 1981

REVUELTA EUGERCIOS BÁRBARA ANA: Los usos de la inclusa de Madrid, mortalidad y retorno a principios del siglo XX (1890-1935). Tesis doctoral defendida en el Departamento de Historia Contemporánea, Universidad Complutense de Madrid, 2011. 
REVUELTA GUERRERO R CLARA, GALENDE MATEOS ÁGUEDA: La Prehistoria para el Tribunal de Niños de Valladolid (1904-1948). En: El largo camino hacia una educación inclusiva: la educación especial y social del siglo XIX a nuestros días: XV Coloquio de Historia de la Educación, PamplonaIruñea. 2009, vol. 2, pp 311-324

- $\quad$ ROBERTSON PRISCILA: El hogar como nido. La infancia de la clase media en la Europa del siglo XIX. En: DEMAUSE LLOYD: Historia de la infancia. Madrid. Edit. Alianza Universidad. 1982, p 449

- $\quad$ RODRÍGUEZ MARTÍN ANA MARÍA: Algunos aspectos relativos a la Inclusa de Pontevedra, 18721903. En: Revista de estudios provincial. Diputación de Pontevedra. 2001, núm. 16

- $\quad$ ROdRÍGUeZ MARTín ANA MARÍA: La Casa de Maternidad y Expósitos de Barcelona, 1872-1903. Barcelona. Tesis doctoral Departamento de Historia, Universidad de Barcelona, 2007

- RODRÍGUEZ MARTÍN ANA MARÍA: Una estrategia de supervivencia femenina: Las nodrizas sin retribución de la inclusa de Pontevedra, 1872-1903. En: Minius. Historia, Arte y Xerografía. 2007, núm. 15; pp 239-253

- $\quad$ RODRÍGUEZ MARTÍN ANA MARÍA: El destino de los niños de la Inclusa de Pontevedra, 1872-1903. Cuadernos de Estudios Gallegos, LV, 2008, no 121, enero-diciembre, pp. 353-388. Disponible en: http://estudiosgallegos.revistas.csic.es/index.php/estudiosgallegos/article/view/48/48

- $\quad$ RODRÍGUEZ MARTÍN ANA MARÍA: La participación femenina en la beneficencia española. La junta de damas de la casa de maternidad y expósitos de Barcelona, 1853-1903. Cuestiones de género: de la igualdad y la diferencia. 2014, no 9, pp. 134-157

- $\quad$ RODRÍGUEZ OCAÑA ESTEBAN: Rafael García-Duarte Salcedo y la consolidación de la Pediatría en la España del primer tercio del siglo XX. Cuadernos de Historia de la Pediatría española. 2012, no 3, pp 4-17

- $\quad$ RUIZ R: Apéndice y formulario del restaurador farmacéutico. Imprenta a cargo de Manuel Gil. 2a edición. Madrid 1851. Disponible en:

http://books.google.es/books?id=5BnrAAAAMAAJ\&pg=PA291\&lpg=PA291\&dq=pomada+de+la+viu da\&source=bl\&ots=MX68F2VuBT\&sig=NvOlty6gDogIWRzBt7YjWpMXLXc\&hl=es\&sa=X\&ei=CDgIVJjA MMfKObqngLAB\&sqi=2\&redir_esc=y\#v=onepage\&q=pomada\%20de\%20la\%20viuda\&f=false

- RUIZ GÓNZALEZ Ma DOLORES, MARTÍNEZ BARELLAS Ma ROSA, GONZÁlEZ CARRIÓN PILAR: Expectativas de la Enfermería de la Infancia. En RUIZ GÓNZALEZ Ma DOLORES y col: Enfermería del niño y el adolescente. Tomo I. Madrid Ediciones D.A.E. 2009, pp 16- 29

RUIZ RODRIGO CÁNDIDO, PALACIO LIS IRENE: Higienismo, Educación ambiental y previsión escolar (Antecedentes y prácticas de Prevención social en España (1900-1936). Valencia. Universidad de Valencia. 1999

- SÁNCHEZ FERNÁNDEZ LUIS VICENTE, COBO BARQUÍN JUAN CARLOS, HERNÁNDEZ MEJÍA RADHAMÉS: Marginación y pobreza desde la cuna: el niño expósito en el Concejo de Siero, Asturias (1800-1936). Revista de Demografía Histórica, 2013, no XXXI, II, pp 131-165

- $\quad$ SANTO TOMÁS PÉREZ MAGDALENA: Historia de la Enfermería. Enfermería Fundamental. Barcelona. Editorial Masson. 1995.

- $\quad$ SANTO TOMAS PEREZ MAgDALENA, VAL VALDIVIESO Ma ISABEL DEL, ROSA CUBO CRISTINA DE LA, DUEÑAS CEPEDA Ma JESUS: Oficios y saberes de mujeres. Valladolid. Universidad de Valladolid. 2002

- SANTO TOMÁS PÉREZ MAGDALENA: Las mujeres trabajadoras de la salud: de lo privado a lo público. Vivir siendo mujer a través de las historia. Ed. Universidad de Valladolid. 2005.

- $\quad$ SANTO TOMAS PEREZ MAgDALENA, VAL VALDIVIESO Ma ISABEL DEL y col: Vivir siendo mujer a través de la historia. Valladolid. Universidad de Valladolid. 2005

- $\quad$ SANZ GIMENO ALBERTO: Infancia, mortalidad y causas de muerte en España en el primer tercio del siglo XX (1906-1932). Reis: Revista Española de Investigaciones Sociológicas. 2001, no 95, pp 129154. 
SERRANO RUIZ-CALDERÓN MANUEL: El abandono de menores: su regulación en el ámbito penal. Madrid. Revista del Ministerio de Trabajo y Asuntos Sociales no 45. 2003. Disponible en:

http://www.empleo.gob.es/es/publica/pub_electronicas/destacadas/revista/numeros/45/estudio 2.pdf

SEVILLA BUJALANCE JUAN LUIS: Los niños expósitos y desamparados en nuestro Derecho histórico. Córdoba. Universidad de Córdoba, 2001.

SEVILLA BUJALANCE JUAN LUIS: El menor abandonado y su protección jurídica. Córdoba. Universidad de Córdoba. 2002

- $\quad$ SPIRA A., SCIPPA L. y col.: Hospitalism in the year 2000: The psychological development of children in a Romanian orphanage. La Psychiatrie de L'Enfant. 2000, vol. 43- 2, pp 587-646

- SPITZ RENÉ ARPAD: Hospitalism; an inquiry into the genesis of psychiatric conditions in early childhood. Psychoanal Study Child. 1945, no 1, pp 53-74

STERPELLONE LUCIANO: Historias curiosas de la Medicina. Usos y costumbres de la medicina desde la antigüedad hasta nuestros días. Barcelona. Ediciones Robinbook. 2009

- $\quad$ TESTÓN NÚÑEZ ISABEL, SÁNCHEZ RUBIO ROCIO, BLANCO CARRASCO JUAN PABLO: "Mi padre y mi madre me abandonaron, pero el Señor me acogió" expósitos y lactancia mercenaria en la Puebla de Guadalupe. En: GARCÍA FERNÁNDEZ MÁXIMO, SOBALER SECO Mã DE LOS ANGELES coord. Estudios en homenaje al profesor Teófanes Egido. Valladolid. Edita Junta de Castilla y León. Consejería de Cultura y Turismo. 2004, pp 381- 401.

- $\quad$ URIBE-ECHEVARRIA FLORES ARANTZAZU.: Marginalidad "protegida": mujeres y niños abandonados en Navarra 1890-1930. Bilbao. Servicio Editorial de la Universidad del País Vasco. 1996.

- $\quad$ URREA FERNÁNDEZ JESÚS: Arquitectura y nobleza: casas y palacios de Valladolid. Valladolid. Consorcio IV Centenario Ciudad de Valladolid. 1996

- $\quad$ VALLE RACERO JUAN Ignacio: El saber y la práctica de las matronas: desde los primeros manuales hasta 1957. Matronas Profesión. 2002, no 9, pp 28- 35

- VALVERDE LAMSFUS LOLA: Los Niños expósitos y sus nodrizas en el País Vasco: (siglos XVIII y XIX). San Sebastián. Vasconia Cuadernos de sección Historia-Geografía. 1990, no 17, pp 231-262. Disponible en: http://www.euskomedia.org/PDFAnlt/vasconia/vas17/17231362.pdf

- VALVERDE LAMSFUS LOLA: Legitimidad e ilegitimidad. Evolución de las modalidades de ingreso en la Inclusa de Pamplona, 1740-1934. En: Enfance abandonnée et société en Europe, XIVe- XXe siècle. Actes du colloque international de Rome (30- 31 enero 1987). Rome: Publications de l'École Française de Rome. 1991, vol. 140, no 1, pp 1169-1197. Disponible en: http://www.persee.fr/doc/efr_0000-0000_1991_act_140_1_4492

- VALVERDE LAMSFUS LOLA: Entre el deshonor y la miseria. Infancia abandonada en Guipúzcoa y Navarra, siglos XVIII y XIX. Bilbao. Servicio Editorial Universidad del País Vasco. 1994

- VARgas catalÁn nelson A: Historia de la Pediatría chilena. Crónica de una alegría. Santiago de Chile. Editorial Universitaria S.A. 2002, pp 451- 2. Disponible en:

http://books.google.es/books?id=eRC_uJ1i7fEC\&printsec=frontcover\&hl=es\&source=gbs_ge_sum mary_r\&cad=0\#v=onepage\&q\&f=false

- VIDAL GALACHE flORENTINA, VIDAL GALACHE BENICIA: Bordes y bastardos. Madrid. Compañía Literaria. 1995

- VIGARELlo GeORGES: Lo Sano y lo malsano: historia de las prácticas de la salud desde la Edad Media hasta nuestros días. Madrid. Abada Editores. 2006

- $\quad$ VILA-SAN-JUAN JOSÉ LUIS: La vida cotidiana en España durante la Dictadura de Primo de Rivera. Barcelona. Ed Argos Vergara. 1984

VOLTES MARÍA JOSÉ, VOLTES PEDRO: Madres y niños en la historia de España. Barcelona. Editorial Planeta de Agostini. 1997 


\section{Otros Recursos Electrónicos}

AEMet (Agencia Estatal de Meteorología) http://www.aemet.es/es/serviciosclimaticos/datosclimatologicos/valoresclimatologicos?l=2422\&k $=$ cle

- $\quad$ Archivo de la Diputación Provincial de Valladolid:

http://www.diputaciondevalladolid.es/extras/diputacion/personal-recursos-humanos//archivoprovincial/2013/bienestar-social-ah.pdf http://www.diputaciondevalladolid.es/extras/diputacion/personal-recursos-humanos//archivoprovincial/2013/bienestar-social-aa.pdf

- $\quad$ Archivo Municipal de Valladolid (AMVA). Fondo documental: http://www.valladolid.es/es/temas/hacemos/fondos-documentales-acceso-bases-datos/accesobases-datos-colecciones-documentales

- Biblioteca Digital de Castilla y León. Hemeroteca: http://bibliotecadigital.jcyl.es/bdtau/i18n/publicaciones/listar_cabeceras.cmd?destino=3D..\%2Fpu blicaciones\%2Flistar_numeros.cmd\&letra=3Dno\&destino_id=3Dbusq_idPublicacion\&analizadas=3 Dtrue $=0 \mathrm{D}=0$

- $\quad$ Biblioteca Nacional de España. Biblioteca Digital Hispánica: http://www.bne.es/es/Catalogos/BibliotecaDigitalHispanica/Inicio/index.html

- Biblioteca Nacional de España. Hemeroteca Digital: http://hemerotecadigital.bne.es/index.vm

- $\quad$ Biblioteca Virtual de Aragón. La Asociación, 15 de junio de 1886: http://bibliotecavirtual.aragon.es/bva/i18n/catalogo_imagenes/grupo.cmd?path=3704369

- Calculadora de distancias entre ciudades: http://www.distanciasentreciudades.com/

- Diario Pinciano. Disponible en:

http://hemerotecadigital.bne.es/results.vm?a=4524245\&t=\%2Bcreation\&l=600\&l=700\&s=0\&lang= es

- $\quad$ Diccionarios de la R.A.E., Nuevo Tesoro Lexicográfico: http://ntlle.rae.es/ntlle/SrvltGUIMenuNtlle?cmd=Lema\&sec=1.0.0.0.0.

- $\quad$ El Autonomista de Figueras, 3 de diciembre de 1905: http://www.bibgirona.cat/figueres/cgibin/Pandora/Autonomista\%20de\%20Figueras,\%20EI-

1905_12_03pagina\%20004?fn=commandselect;query=id:0000259980; command=show_pdf;texto= Autonomista\%20de\%20Figueras,\%20El\%20\%28Biblioteca\%20de\%20Figueres\%29\%2003-121905.\%20P\%C3\%A0gina\%204

- Fundación Europeana: http://www.europeana.eu/portal/usingeuropeana_search.html

- Hemeroteca digital de $A B C$ : http://hemeroteca.abc.es/

- Hemeroteca de El Mundo: http://www.elmundo.es/elmundo/hemeroteca/

- Hemeroteca digital de La Vanguardia: http://www.lavanguardia.com/hemeroteca

- Hemeroteca digital de La Voz de Galicia: http://www.lavozdegalicia.es/hemeroteca/

- $\quad$ Hemeroteca Municipal de Madrid: El Nuevo Mundo. 29 de diciembre de 1910: http://www.memoriademadrid.es/fondos/OTROS/Imp_24410_hem_nuevomundo_19101229.pdf

- Junta de Castilla y León. Regiones agronómicas 2015-2020. http://www.agronewscastillayleon.com/galeria/regiones-agronomicas-de-castilla-y-leon-20152020 
- La Farmacia Moderna. Año III, no 15:

http://bibliotecavirtual.ranf.com/es/catalogo_imagenes/grupo.cmd?path=3018245

- Mapa provincial de carreteras de Valladolid, con índice de pueblos. Diputación provincial de Valladolid:

http://www.diputaciondevalladolid.es/extras/MAPA_PROVINCIA_DE_VALLADOLID_carreteras_con _indice_de_pueblos.pdf

- Ministerio de agricultura, alimentación y medio ambiente, agua, Manual para Canarias. http://www.magrama.gob.es/es/ceneam/programas-de-educacion-ambiental/hogares-

verdes/manual_h_v_canarias_agua_tcm7-13481.pdf

- Museo del Traje. Centro de Investigación del Patrimonio etnológico:

http://museodeltraje.mcu.es/index.jsp

- $\quad$ Revista de Folklore. Fundación Joaquín Díaz:

http://www.funjdiaz.net/folklore/index_listado.php?an=2017

- Sociedad española de Oftalmología. N.o 6 - Junio 2000:

http://www.oftalmo.com/seo/archivos/maquetas/2/2E10A49A-FB92-B2A9-8B7C-

0000104CF3D2/articulo.html

\section{Fuentes Iconográficas}

- $\quad$ ADPVA: fotos sin datar

- Biblioteca de Castilla y León-Dibujos Palacio de los Condes de Benavente (Valladolid)-Dibujos http://bibliotecadigital.jcyl.es/es/consulta/registro.cmd?id=16755

- Biblioteca digital de Castilla y León:

http://bibliotecadigital.jcyl.es/es/estaticos/contenido.cmd?pagina=estaticos/inicio

- Campaspero. Las imágenes de nuestra vida. 1900- 1980. Gatón editores, s.l.. 2011

- DÍAZ JOAQUín: Álbum de Valladolid. Urueña. Editorial Castilla tradicional. 2010. Disponible en: http://www.cervantesvirtual.com/obra/album-de-valladolid/

- DÍAZ JOAQUÍN: Valladolid: hace 100 años. Urueña. Editorial Castilla tradicional. 2008. Disponible en: http://www.cervantesvirtual.com/obra/valladolid-hace-100-anos/

- El Financiero Hispano-Americano. Extraordinario Valladolid julio de 1911, pp 63 y ss. Imprenta de El Financiero 1911. Madrid. Copia digital. Valladolid: Junta de Castilla y León. Consejería de Cultura y Turismo: http://bibliotecadigital.jcyl.es/es/catalogo_imagenes/grupo.cmd?path=10067831

- Fundación Joaquín Díaz. Colección de Fotografías de Castilla y León: http://www.funjdiaz.net/basefotos1.php

- $\quad$ GARCÍA CHICO ESTEBAN: Valladolid: papeletas de historia y arte. Láminas LXXI y LXXII. Valladolid Gráficas Andrés Martín 1958. Copia digital en la Biblioteca Digital de Castilla y León. Disponible en: http://bibliotecadigital.jcyl.es/i18n/catalogo_imagenes/grupo.cmd?path=10067495

- Modelo de mes. Museo del Traje. http://museodeltraje.mcu.es/index.jsp?id=300\&ruta=7,77

- Valladolid 1929. Documental cinematográfico sobre Valladolid y provincia rodado en el año de la exposición iberoamericana de Sevilla / Con la colaboración de: Diputación de Valladolid, Caja España. Valladolid. El Norte de Castilla, 1995

- V.V.A.A. Valladolid un siglo de cuestión social (1840-1940). Valladolid. Grupo Pinciano. 1995 